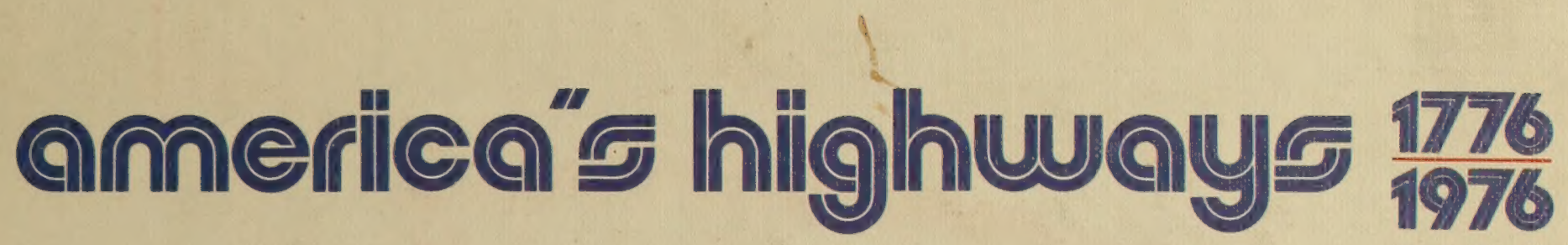

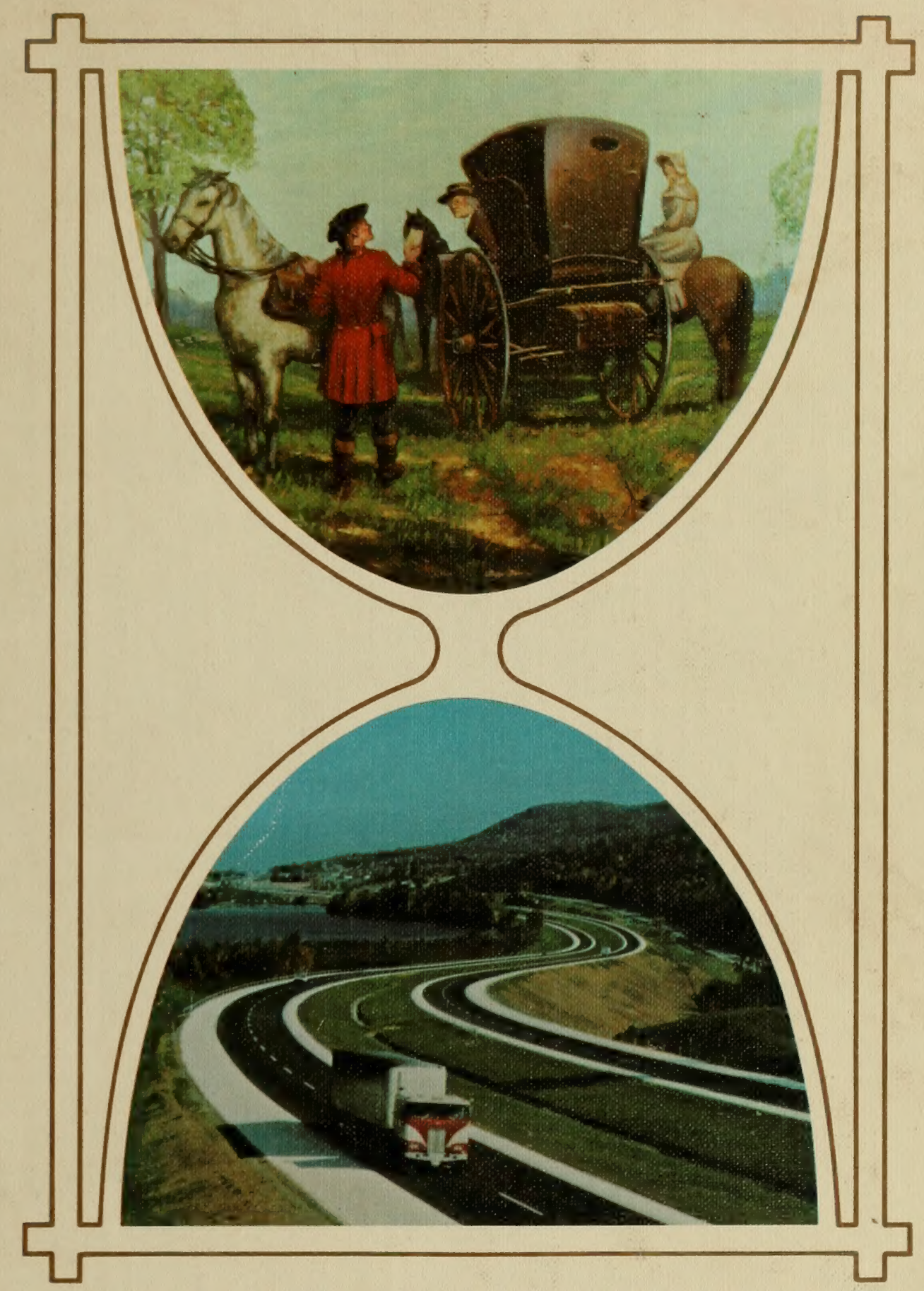

U.S. DEPARTMENT OF TRANSPORTATION Federal Highway Administration 


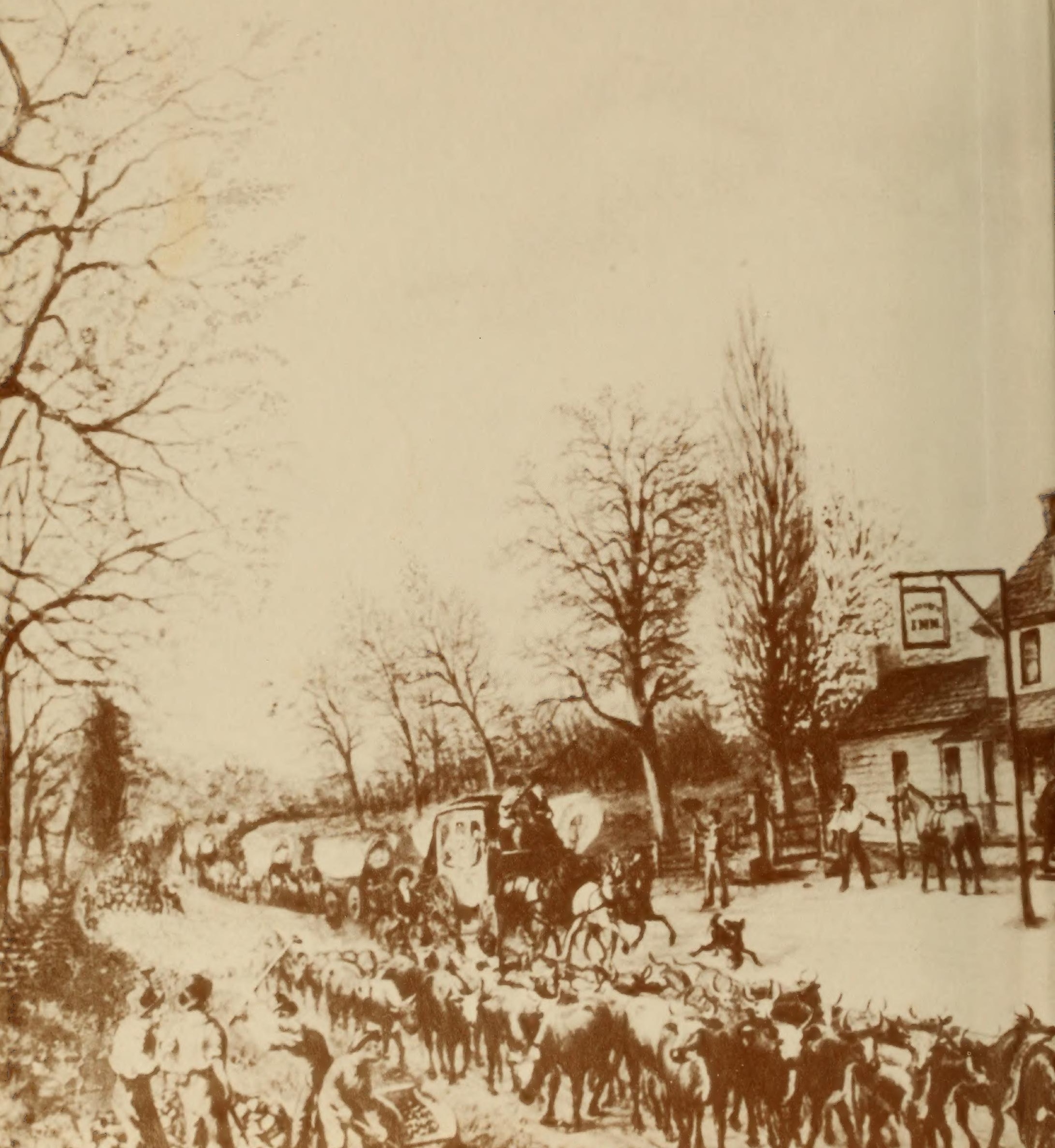




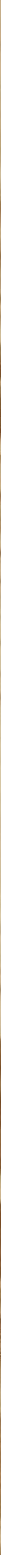





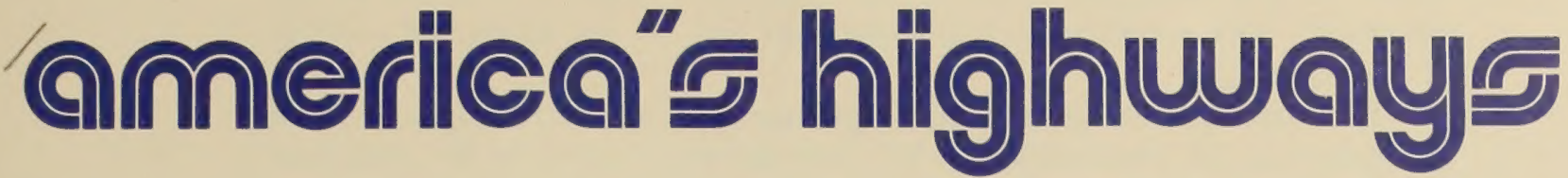

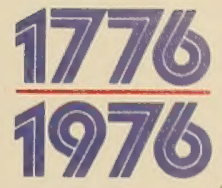

\section{A HISTORY OF THE FEDERAL-AID PROGRAM}

\section{U. S. Federal Highway Administration.}

\section{LICPARIES}

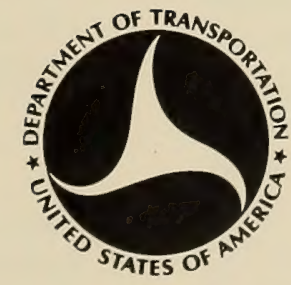

\section{U.S. DEPARTMENT OF TRANSPORTATION} Federal Highway Administration 


\section{Notice}

Where sources known to be covered by registered copyright have been quoted in this book, the name of the copyright owner is included in the reference. Any omissions are unintentional and do not affect the validity of the copyright.

The identification (in writing, in photographs, or in drawings) of items of equipment by trademarks or by manufacturer's name is for historical accuracy only and does not constitute an endorsement by the U.S. Government of the equipment or the manufacturer. 
This book has been written for a widely diversified audience-those interested in the general history of our Nation's highways and those whose interest might be more narrowly confined to matters relating to the technical aspects of highway transportation. It has been prepared in two parts-Part I deals with the broad subject of highway history from colonial days forward to the historic highway legislation of 1956 ; Part II deals separately and in some detail with the several areas of responsibility for administration, planning and research, design, construction and maintenance of highways and bridges, both foreign and domestic as authorized under the Federal highway legislation.

The reader will note the changing reference to the name of the Federal unit assigned responsibility for the administration of the Federal-aid highway program-the original Office of Road Inquiry, the Bureau of Public Roads, the Public Roads Administration, again the Bureau of Public Roads, and finally the Federal Highway Administration. These changes in organization title are chronicled in Chapter I, Part II which covers the program administration through the years.

Biographical information on a few key individuals has been included at the end of Part I and in selected chapters of Part II where each man's contribution is directly related. The numbers are purposely limited, and many hundreds of dedicated and competent individuals go unrecognized.

Many former and current employees have contributed text for or reviewed this book. The manu- scripts, in most instances, have been edited to make this book a reasonable length, but the original manuscripts are available in the U.S. Department of Transportation Library for future scholars to review. In addition to those listed below, many others assisted in the preparation of this book, in particular Mary Jo Burke and Verla R. Cook of the Department of Transportation Library, to assure a history as complete as possible.

$\begin{array}{ll}\text { Chauncey Aldrich } & \text { Henry H. Mahier } \\ \text { James A. Bloom } & \text { Martin F. Maloney } \\ \text { Frank L. Calhoun } & \text { E. J. Martin, Jr. } \\ \text { Carl A. Carpenter } & \text { Kennon Nakamura } \\ \text { William O. Comella } & \text { Barbara M. Neilson } \\ \text { Howard D. Correll } & \text { John D. O'Fallon } \\ \text { F. William Cron } & \text { S. Z. Phillips } \\ \text { Charles D. Curtiss } & \text { Charles W. Prisk } \\ \text { Phillip Darling } & \text { Joyce N. Ritter } \\ \text { Michael De Stephanis } & \text { Elizabeth Samson } \\ \text { Martin Deuterman } & \text { Gordon B. Sharpe } \\ \text { Thomas O. Edick } & \text { C. L. Shufflebarger } \\ \text { H. Dean Fravel } & \text { C. A. Steele } \\ \text { Robert B. Gair } & \text { Josephine C. Sweeney } \\ \text { A. F. Ghiglione } & \text { E. A. Swick } \\ \text { Willis Grafe } & \text { A. Taragin } \\ \text { E. H. Holmes } & \text { A. Clayson Taylor } \\ \text { John B. Kemp } & \text { William P. Walker } \\ \text { Ross W. Kruser } & \text { York Welborn } \\ \text { C. V. Kurylo } & \text { M. Susan Wiley } \\ \text { Lester P. Lamm } & \text { George M. Williams } \\ \text { D. W. Loutzenheiser } & \text { B. Dianne Williford }\end{array}$


The economic growth of the United States in the 200 years of its existence and the record of individual prosperity achieved by its people in that brief period of time are attributable to the success of the transportation system developed during that period-a system almost totally dependent on the Nation's highways.

This book has been written to record for posterity the story of highway development in the United States, beginning in the early years of the new Nation and expanding with the growing country as it moved into the undeveloped areas west of the original colonial States, and ultimately evolving into the Federal-aid highway program in which the State and Federal Governments have worked cooperatively and successfully for the past 60 years. It is a proud story and one that should be recorded.

The book will make available for future highway transportation officials a documentation of earlier decisions and experiences which, up to this time, have been available only in scattered writings or in the individual knowledge and recollections of many of those involved directly in the Federal-aid highway program during this period of development and whose experiences have not previously been recorded.

Our Nation will continue to grow and to progress, and our transportation system will contribute materially toward that objective.

\section{Norbert T. Tiemann}

Federal Highway Administrator 1976 


\section{Part One}

The Colonial Legacy

2 Early Turnpike Era

8

3 Early Federal Aid for Roads and Canals

4 The Age of Steam

28

5 The Good Roads Movement

6 Dawn of the Motor Age

7 The Beginning of Scientific Roadbuilding

64

8 The Drive for Federal Aid

Q Planning a Highway System

10 The Highway Boom

| Roads for National Defense

12 Events Leading to Enactment of the 1956 Federal-Aid Highway Act 


\section{Port Two}

Administration of the Federal-Aid Program

2 Finance and Economics

3 Planning

4 Research

5 Right-of-Way and Environment

354

6

Design

7 Bridges

8 Construction and Maintenance

9 Development of the Interstate Program

10

Construction in the Federal Domain

486

International Operations

Epilogue-The Success Story

Highway Related Legislation

Picture Credits 


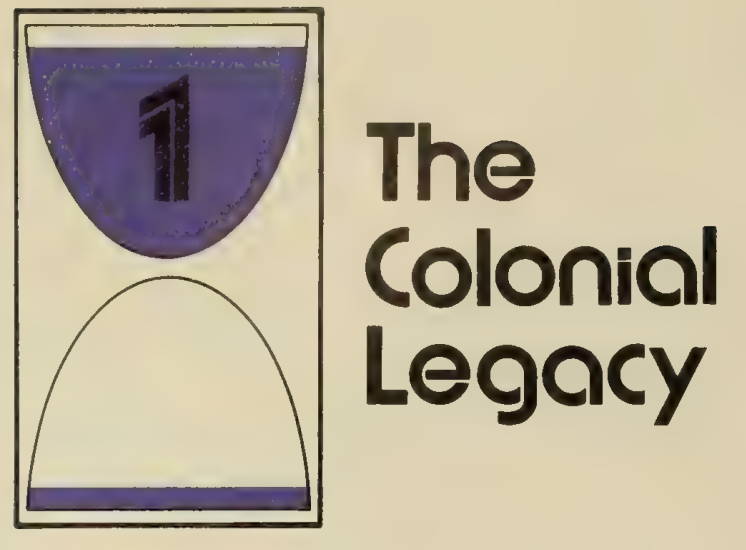

The Indian canoe.

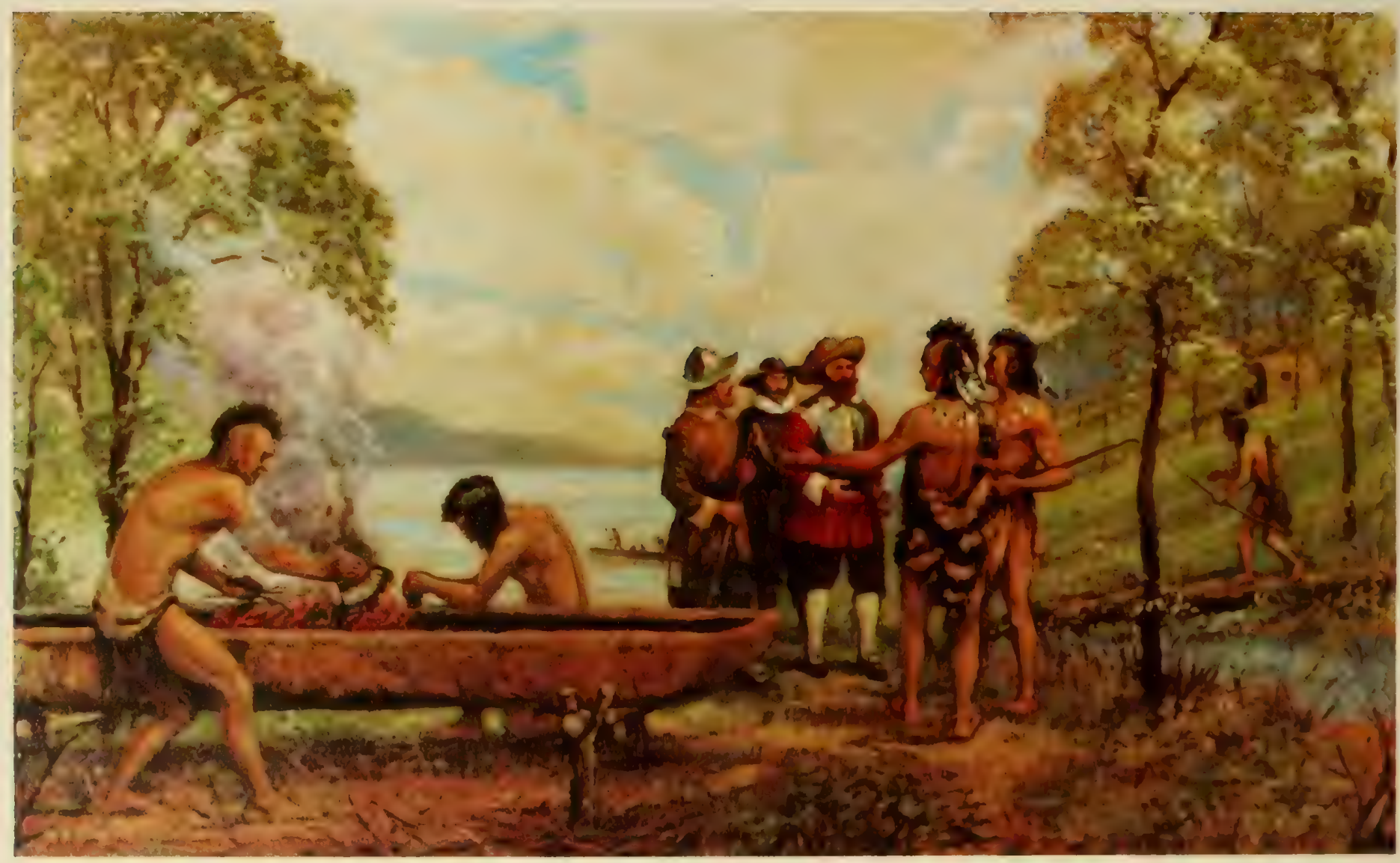




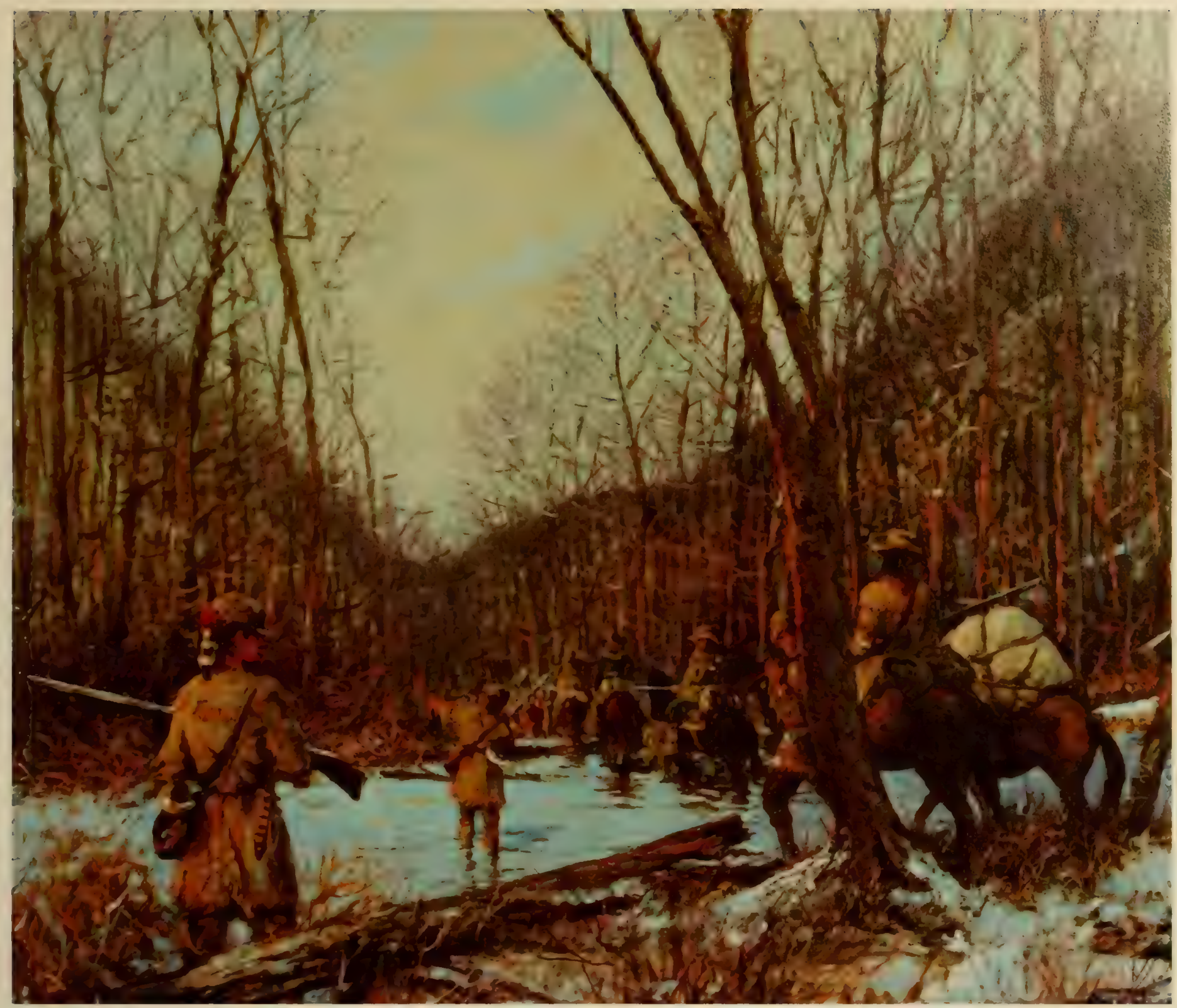

The Wilderness Road.

The young Nation that emerged from the War of Independence had a weak government and a primitive transportation system. The rivers and the sheltered coastal waters, such as Long Island Sound, Chesapeake Bay and Albemarle Sound, were the principal highways for travel and commerce. Extending back from these arteries were roads in various stages of development. A very few of these, near the largest cities, were "artificial roads," ditched and sometimes hardsurfaced with gravel or with "pounded stone." The rest were improved only to the extent of removing stumps and boulders and leveling the worst irregularities of the ground. Many of these roads were impassable for wheeled vehicles in winter or during the spring thaw. Trarelers crossed small streams by fording and the larger ones by ferries. Bridges were few and far between.

On the fringes of settlement, the "roads" were really only horsepaths, unsuitable for wheeled vehicles. The
Wilderness Road through Cumberland Gap, located by Daniel Boone in 1775 , was such a pack trail.*

General Braddock's military road, constructed in 1755 , was chopped out to a width of 12 feet-wide enough to pass the train of 150 Conestoga wagons in a single file-but by 1758 it had reverted to a trace through the forest. The other main transmountain road, the Pennsylvania Road, had been widened in 1758 during the French and Indian War to pass General John Forbes' wagon trains, but was otherwise unimproved.

* However, a Kentucky historian has called the Wilderness Road ". . a monument to the skill of Boone as a practical engineer and surveyor. It required a mind of far more than ordinary caliber to locate through more than two hundred miles of mountain wilderness a way of travel which, for a hundred years, has remained practically unchanged. ..." 1 


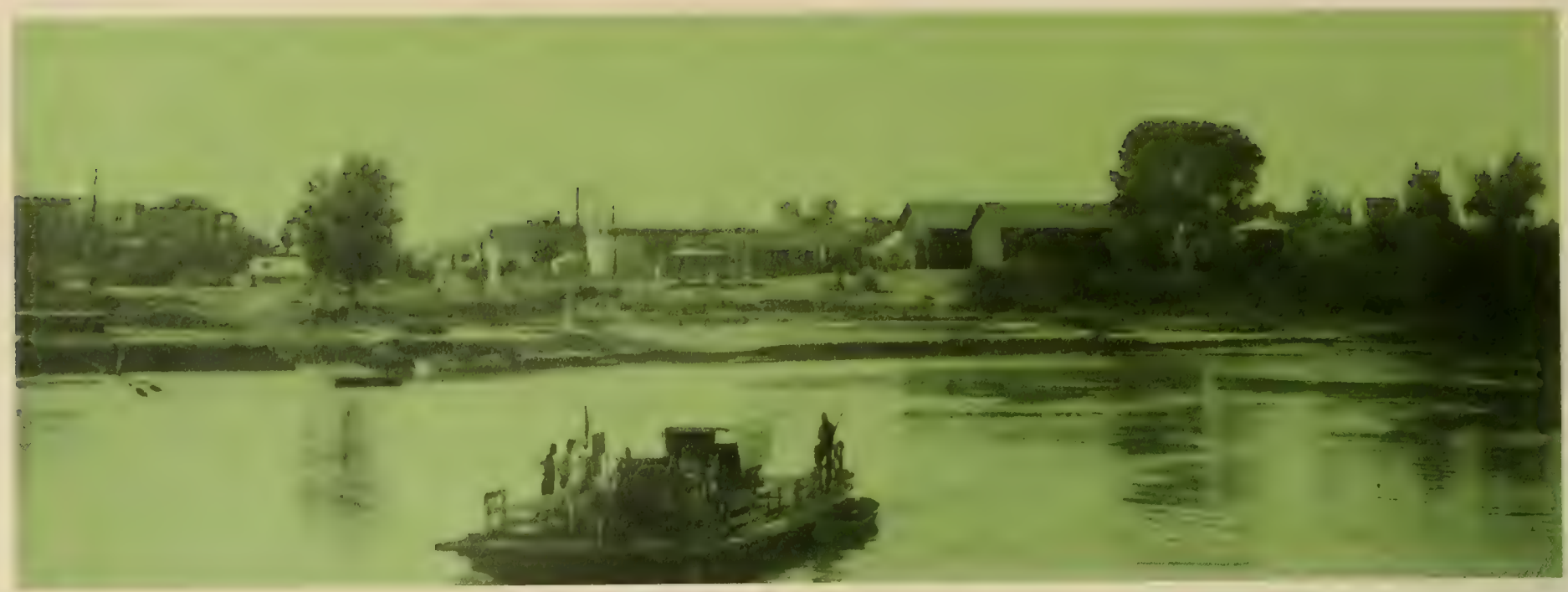

Cable ferry over the Colorado River. In the early days, this method was frequently used to cross rivers.

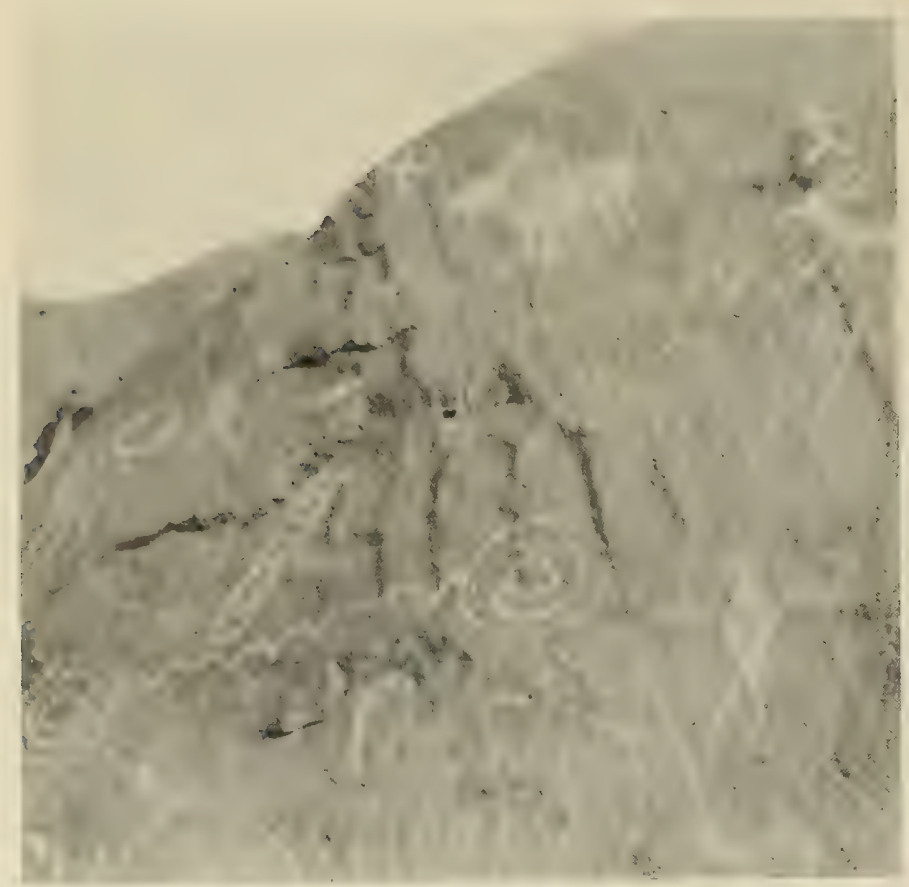

One of the first road signs in America-hieroglyphics on Basset rock, near Washington, Utah.

Winter travel over primitive trail.

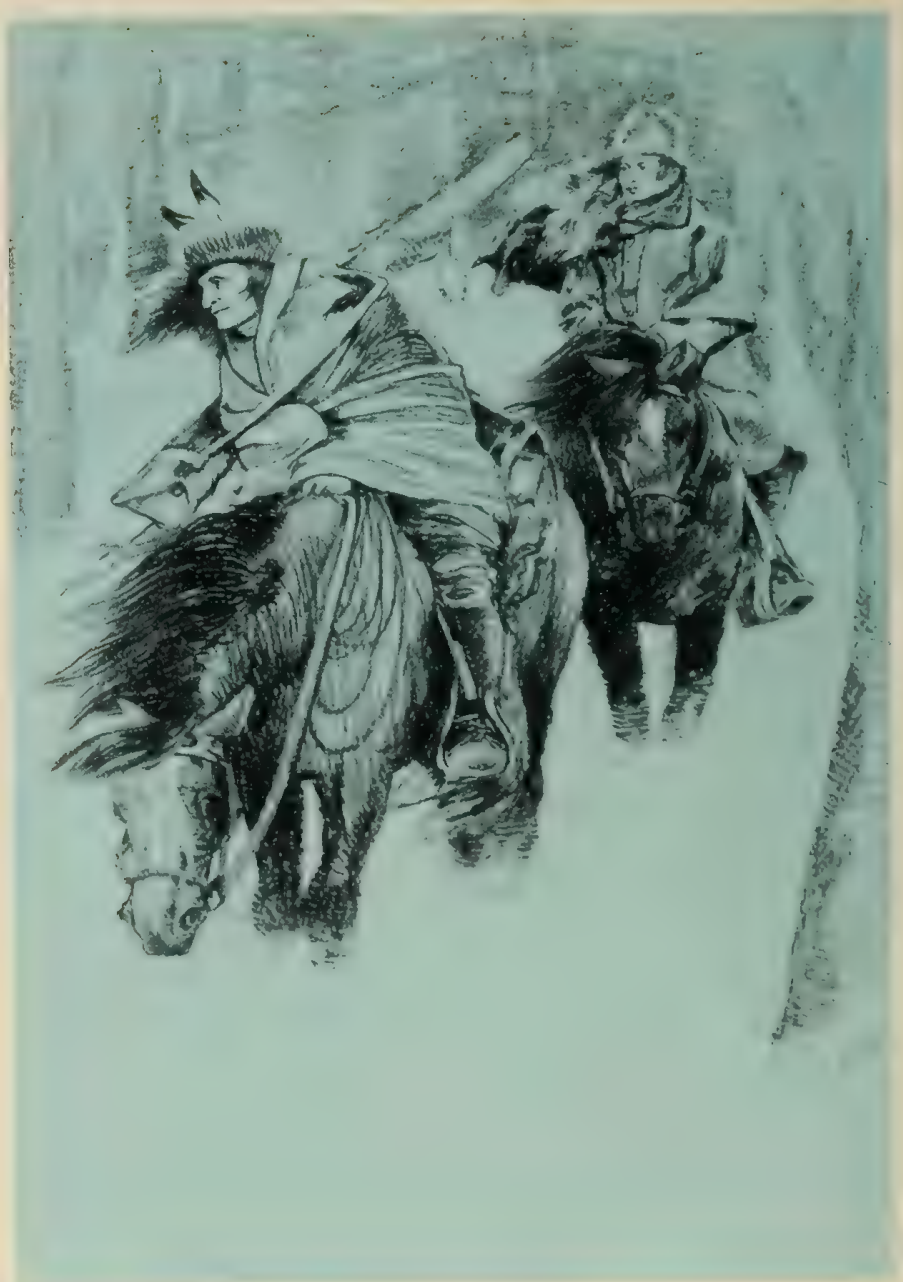




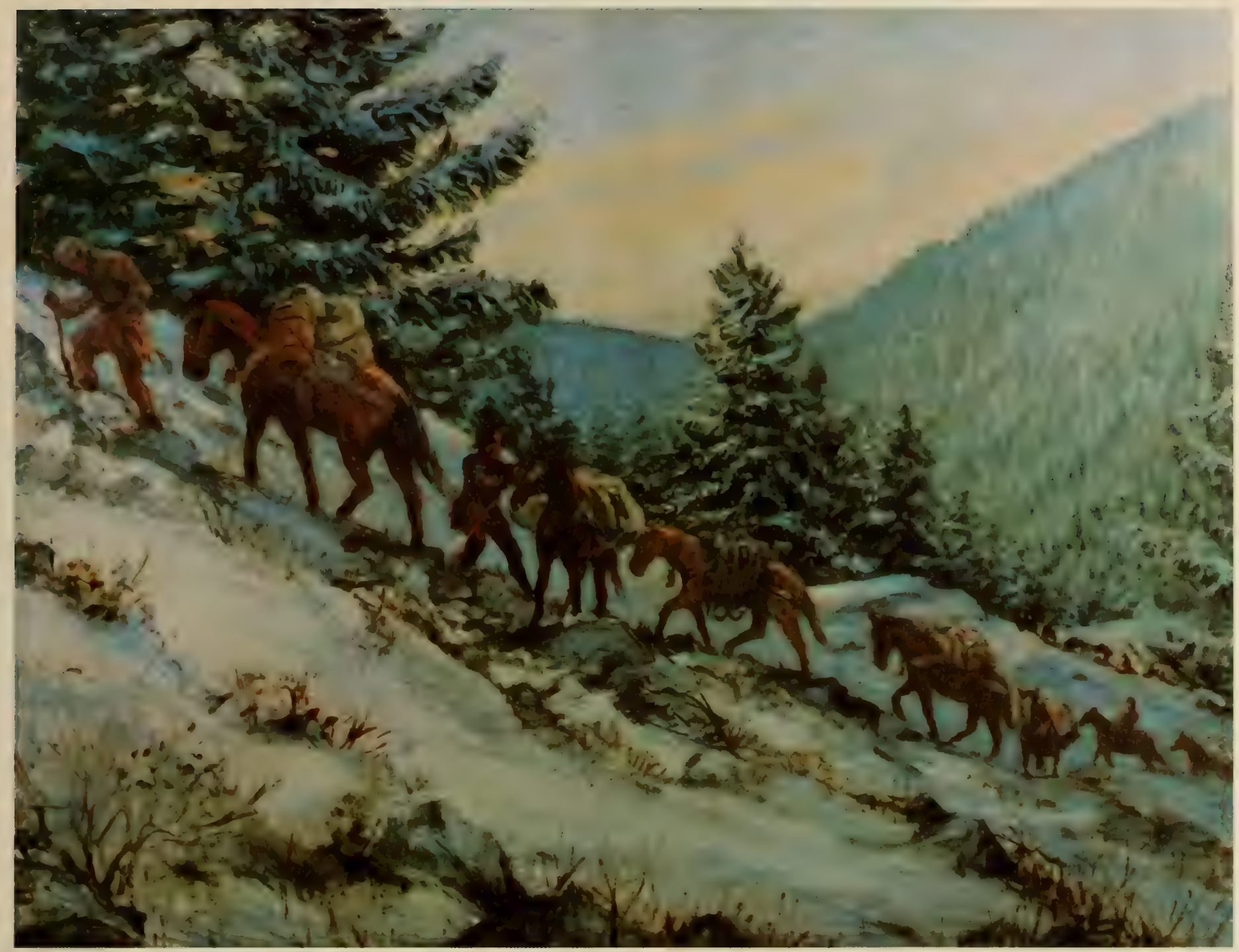

The Pennsylvania Road.

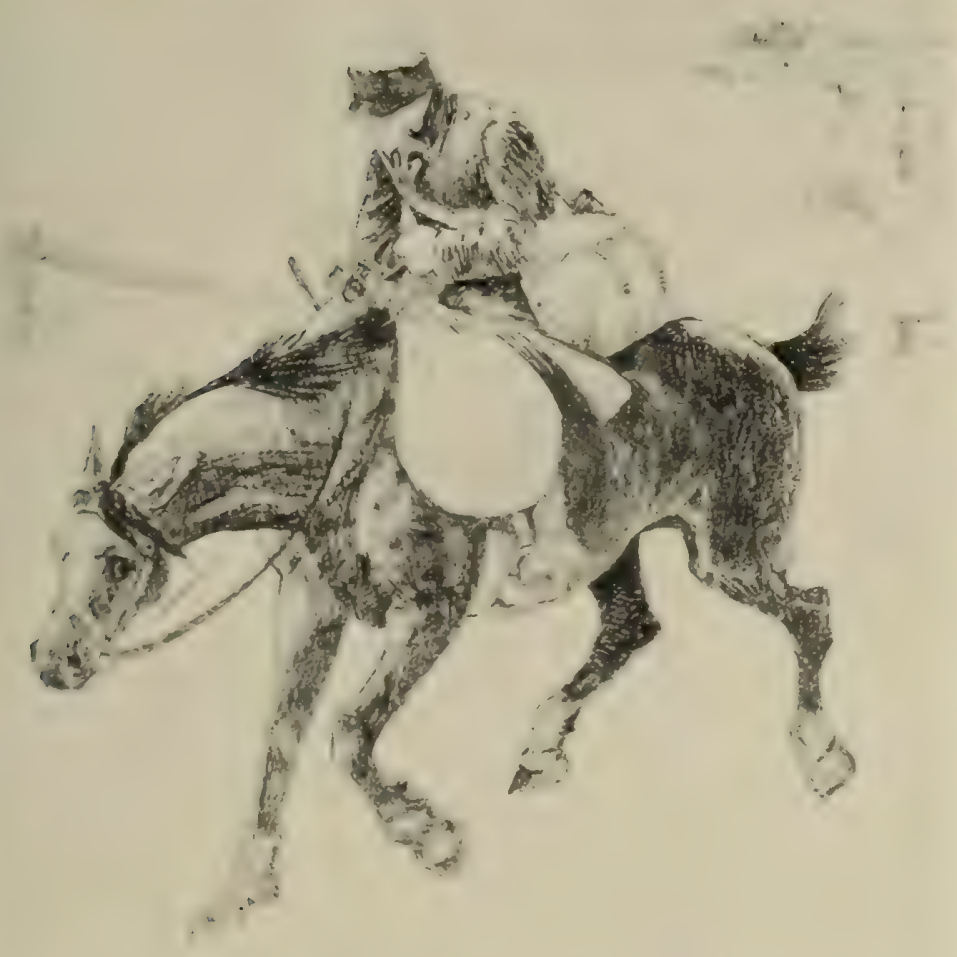




\section{Early Posial and Stagecoach Service}

Despite the primitive condition of the roads, a land postal service was operated by the colonial authorities between the principal cities of the eastern seaboard. In 1729, 4 weeks were required to send a letter from Boston to Williamsburg, Virginia. For the most part, the mail was carried on foot or by post riders on horseback who averaged about 4 miles per hour, with no night travel.

The mails were speeded up considerably during Benjamin Franklin's long tenure as Deputy and Associate Postmaster General, from 1737 to 1757 , and 1762 to 1773 . Within a year after his appointment, Franklin had so improved the service that a letter could be sent from Philadelphia to Boston and a reply returned in 3 weeks. After 1764, Franklin made the mails move day and night between Philadelphia and New York, and this fast service was later extended to Boston. ${ }^{2}$

As early as 1750 , there was a regular stage-wagon* service from Philadelphia to New York via Trenton and Brunswick. Just before the Revolution, passengers could travel by stage from Philadelphia to the Paulus Hook (now Jersey City) ferry in 2 days in

*A covered springless vehicle fitted with rigid wooden benches for carrying passengers. good weather, and public passenger stages were available for the journey from New York to Boston. ${ }^{3}$

\section{Local Authorities Responsible for Roads}

Under colonial laws patterned after those of the mother country, roadmaking and mending were responsibilities of the local governments - the towns in New England and the counties in other colonies. In the former, the elected town officers, among them a surveyor of highways, were charged with the upkeep of highways, private ways, causeways and bridges; and were authorized to remove obstructions from the highways, to dig for stone, gravel, clay or marl in any land not planted or enclosed, and to command the labor, on appointed days after public notice, of all persons over 16 years of age for work on the roads.4

In Virginia, the County Court, composed of eight or more gentleman inhabitants elected by the freeholders and approved by the Governor, was responsible for the condition of the roads and bridges. The court could contract for necessary road work or direct that it be performed gratis by the "tithable males" under the direction of the precinct surveyors, or foremen. Tithable persons were local residents over 16 years of age, whether free, slave, or indentured. Owners of two or more tithables could send them as substitutes in lieu of working in person. ${ }^{5}$

\section{The Flying Machine.}

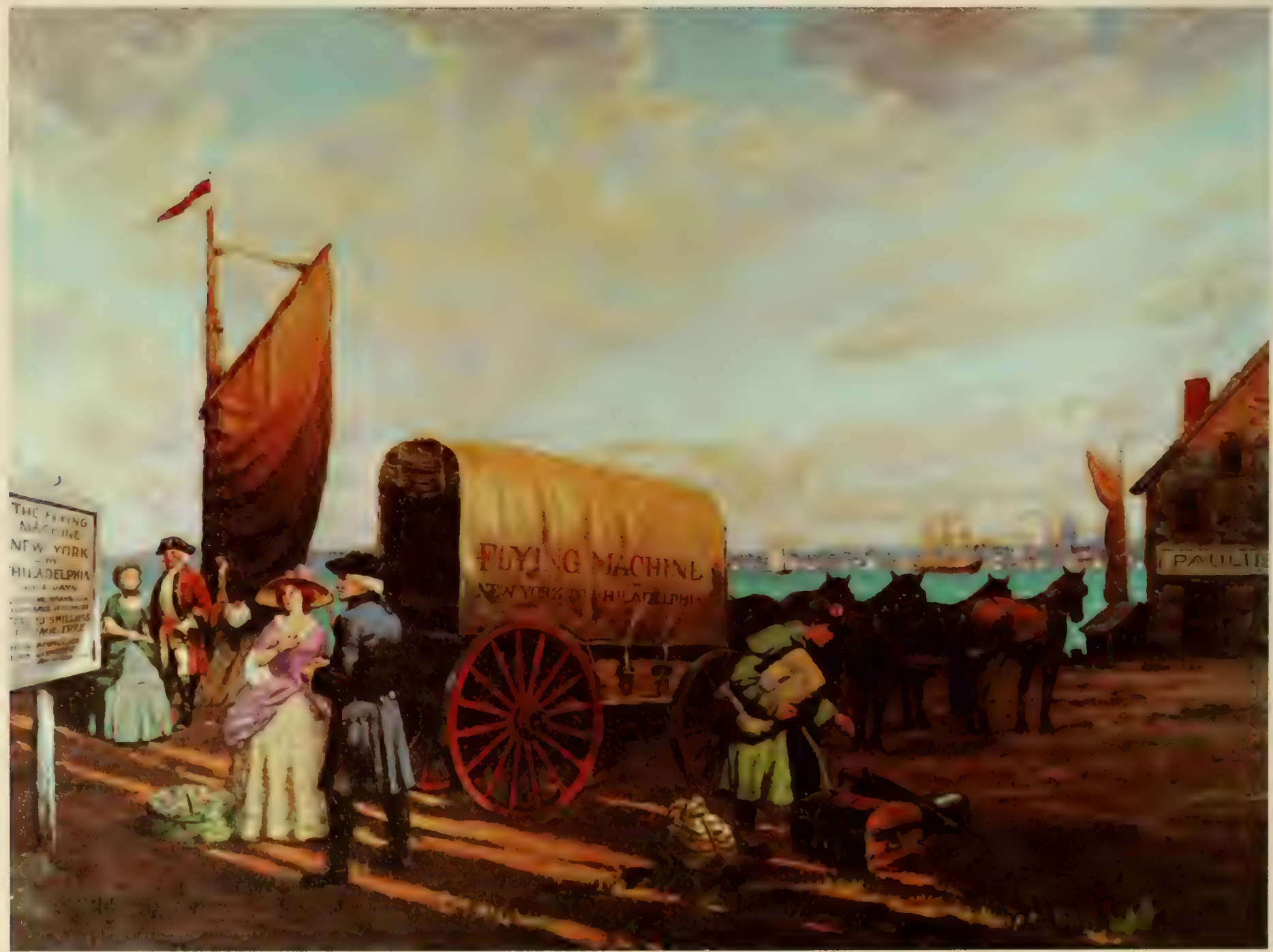




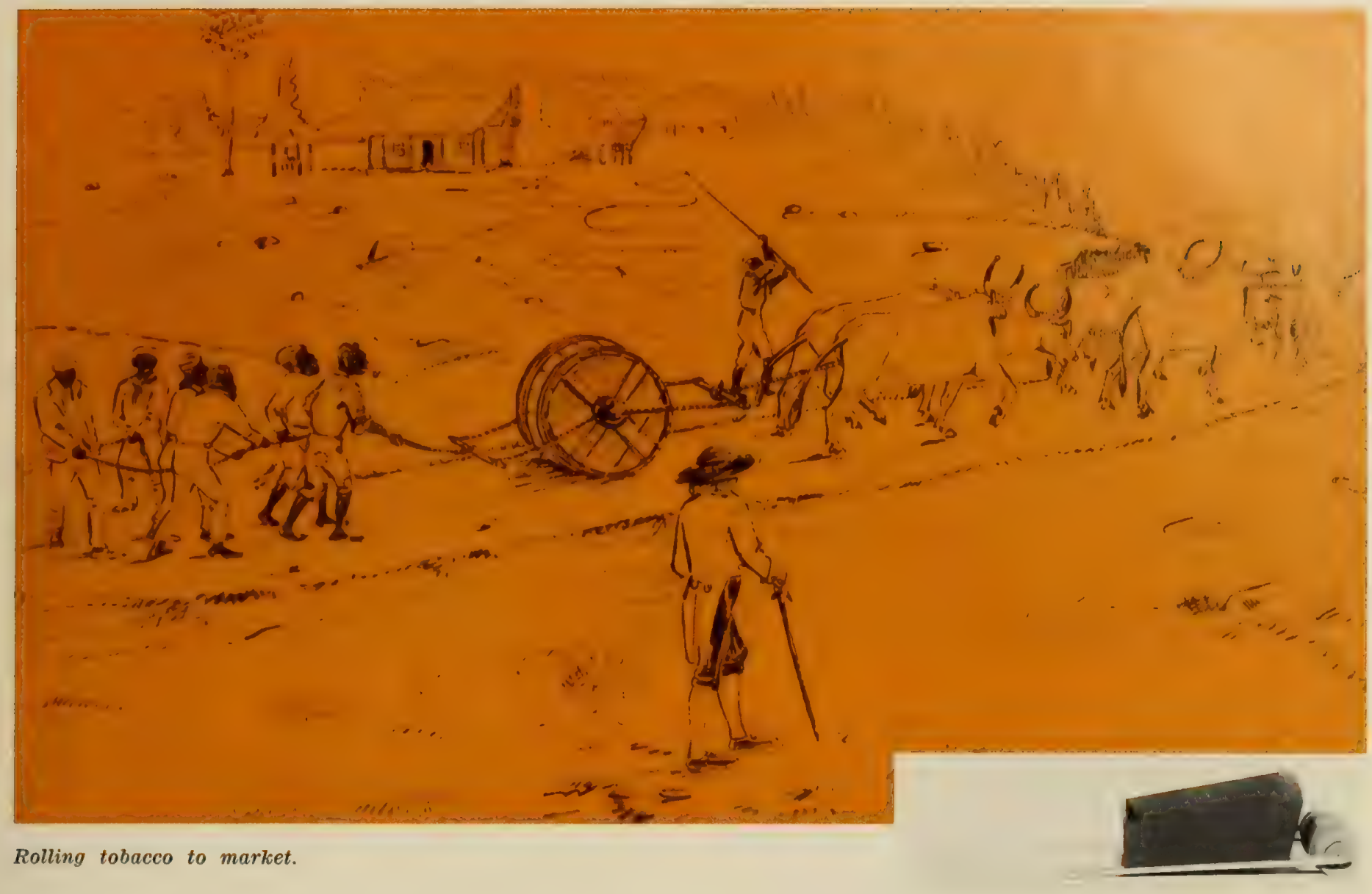

Model of Nantucket, Mass. fish cart. The barrel takes place of wheel and makes traction easier on sandy roads.

The other colonies had similar provisions for keeping their roads in repair, and all of them authorized the local authorities to require compulsory road service or its equivalent in cash. This "statute labor" was for years the principal resource available to local governments for road work in the colonies and later in the States, but other resources, such as private subscriptions, donations by public spirited citizens, assessments on adjacent property, or the proceeds of public lotteries, were occasionally available. ${ }^{6}$

There were hundreds of private ferries on the rivers. These ranged from canoes and small rowboats to flatbottomed barges capable of carrying a wagon or several cattle. The right to operate a ferry was obtained from the colonial legislature or the county by a grant or contract, under which the ferry owner was allowed to collect fixed fees in compensation for his services and the use of his property. Ferry proprietors were considered to be public carriers, responsible for the life and property of their passengers. ${ }^{7}$

The English practice, begun in 1663, of permitting the local authorities or private persons to raise money for roadbuilding and maintenance by charging user tolls did not spread to the colonies. Except for payment of ferry fees, a traveler could freely use the roads, such as they were, from Maine to Georgia.

\section{REFERENCES}

${ }^{1}$ Address by T. H. MacDonald, Chief, Bureau of Public Roads, in Washington, D.C., October 6, 1926.

${ }^{2}$ A. Rose, Historic American Highways-Public Roads of THE PAst (American Association of State Highway Officials, Washington, D.C., 1953) p. 32.

${ }^{3} I d$., p. 34.

"Id., p. 62.

${ }^{5}$ Id., p. 64.

${ }^{8} I d .$, p. 23.

${ }^{7} I d .$, p. 45. 


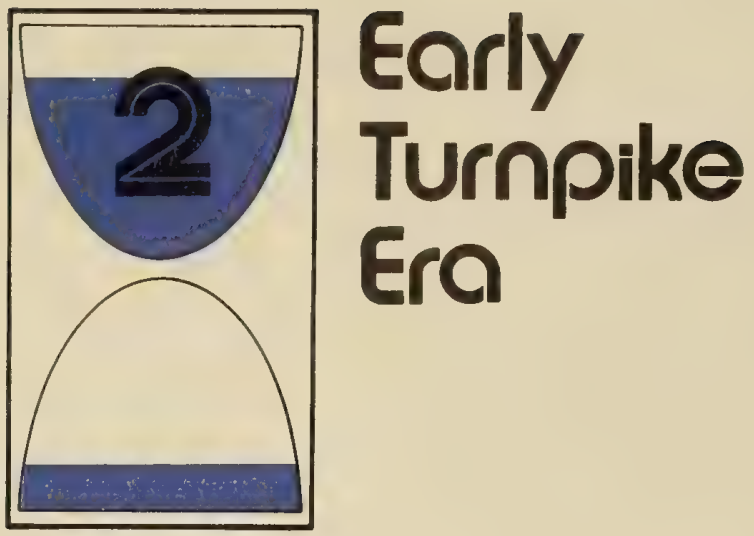

In all of the States, a long and severe depression followed independence. Recovery was hampered by the wretched condition of the roads, which had become practically impassable in many places from lack of maintenance during the war.

\section{Postwar Recovery Generates Increased Road Traffic}

Business began to pick up about 1787, and with the increase in trade came a rapid increase in road traffic, especially near the larger cities. The feeble efforts of the local authorities were not equal to keeping the roads in repair under this traffic, so there was widespread agitation for State assistance to help maintain the principal roads. The debt-burdened State governments met this challenge by appealing to private capital for the funds to build better highways. They chartered private turnpike* companies, conferring on them authority to build roads and charge tolls to the public for their use. The first of these companies, chartered by Virginia in 1785 , built a turnpike road from Alexandria, on the Potomac River, westward to the mountains near Berryville. However, the first to

* Originally, a "turnpike" was a long pole or pike which barred the traveler's way at each tollgate. After he paid the required toll, the pike was turned or swung out of the traveler's path." "Turnpike" eventually became a synonym for any highclass, stone-surfaced road. be completed for any considerable distance, and one of the most successful financially, was in Pennsylvania, between Philadelphia and Lancaster. ${ }^{2}$

\section{Transportation Plan Proposed for Pennsylvania}

In February 1791, The Society for Promoting the Improvement of Roads and Inland Navigation submitted to the Pennsylvania Legislature what may be the earliest statewide transportation plan in U.S. history. This plan proposed that the Legislature appoint a Board of Commissioners with power to decide the locations of the principal roads in the State and determine which should be improved by turnpike companies and which ought to be made or repaired at public cost. The board would then have the authority to advertise and award contracts to build and operate the turnpikes, and also to employ persons to repair those roads deemed unsuitable for turnpikes. Similarly, the board would have authority to contract for the construction and operation of toll canals or to make other navigation improvements at public expense. ${ }^{3}$

An important feature of the transportation plan was the voluntary relinquishment by the State for a stated number of years of its right to charter parallel competing facilities that would destroy or diminish the income or revenue of turnpikes or toll navigations already established. 


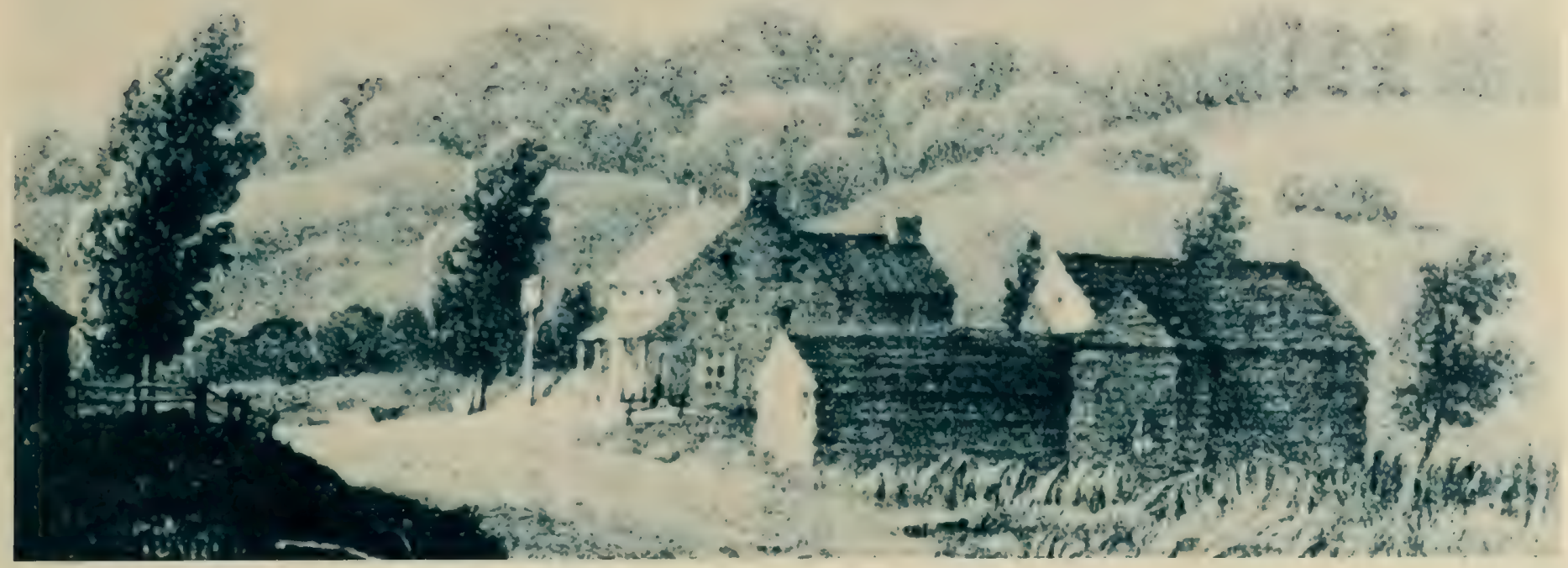

Wayside inn on Lancaster Road.

The Legislature was not ready, at that time, to confer such vast powers on an administrative body. However, it did announce its readiness to subsidize road and canal building in sparsely settled parts of the State with liberal appropriations of public money and to incorporate companies "for the gradual and progressive improvement of roads and waters where the tolls would be sufficient to recompense the subscribers or stockholders, and the charge would fall, according to justice, upon those who were to be benefitted, in proportion to the use they might make of such roads and waters." 4

Under this policy, the Legislature, in April 1791, appropriated 36,160 Pennsylvania pounds to be expended under the direction of the Governor and Council for some 68 road and navigation improvements scattered all over the state. ${ }^{5}$ Later, in April 1793, the Legislature authorized the Governor to incorporate the Conewago Canal Company to construct a lock canal around the Conewago Falls of the Susquehanna River at public expense, to be "opened as a public highway and for public use, forever ... free of toll, and any and every other charge whatsoever. ..." 6

In September 1791, the Legislature authorized the incorporation of the Schuylkill and Susquehanna Company to build a toll canal between those rivers. Two other acts in April 1792 established the Philadelphia and Lancaster Turnpike Road Company and the Delaware and Schuylkill Canal Navigation Company. Other turnpike and canal acts followed in later years, all modeled on the earlier ones.

The charters granted to the turnpike and canal companies under these acts were practically identicalin fact, both canals and turnpikes were considered to be "highways." Both were regulated transportation monopolies granted by specific acts of the State Legislature. These acts specified the termini and general route of the road or canal, set minimum engineering standards and conferred the right of eminent domain for taking necessary right-of-way and road materials.
Inn near Brandywine, $P a_{.}$, on Lancaster Road.

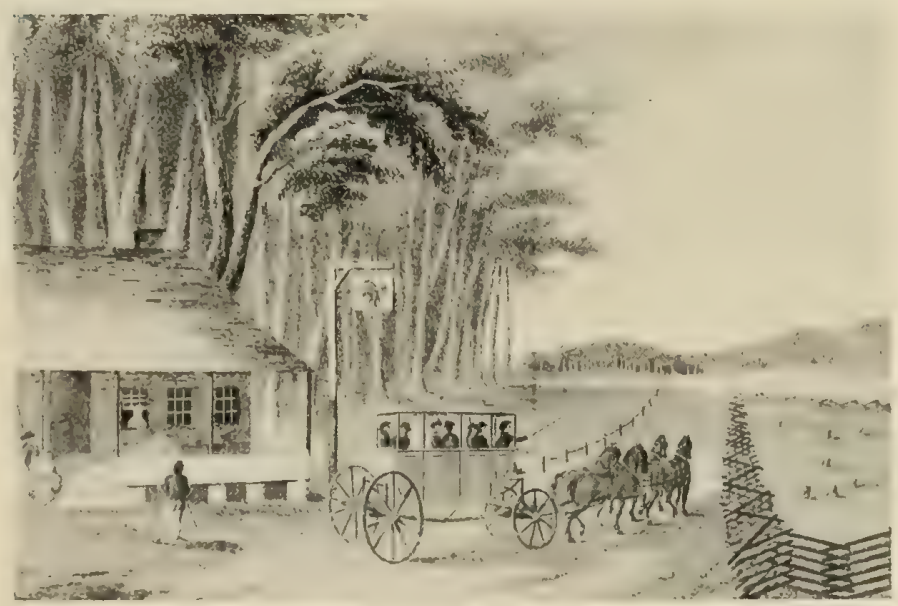

The companies were authorized to collect tolls at rates specified in the acts, but these rates were subject to renegotiation at intervals. The companies were required to keep their facilities in good order at all times. Turnpike acts set load limits and minimum tire widths for vehicles using the roads to protect the companies from destructive overloading by their patrons, especially during the spring thaw.

\section{The Lancaster Road-Prototype Turnpike}

The charter for the Philadelphia to Lancaster Road required that it be laid out 50 feet wide between fences, of which at least 21 feet "shall be made an artificial road, which shall be bedded with wood, stone, gravel, or any other hard substance, well compacted together, a sufficient depth to secure a solid foundation. to the same; and the said road shall be faced with gravel, or stone pounded, or other small hard substance, in such manner as to secure a firm, and, as near as the materials will admit, an even surface..." 7 The gradient was limited to an angle of 4 degrees with the horizon. (This is the equivalent of a grade of 7 percent.) 
The Company had no trouble selling its stock to eager investors at $\$ 300$ per share. "I have never seen men," an eyewitness wrote, "so wet with sweat in the harvest field as some were in the crowd today who subscribed to the turnpike road." 8 Construction began in February 1793, and was completed for the full length of 62 miles in a little under 3 years-a remarkable engineering achievement for the period. The cost was $\$ 465,000$, or an average of $\$ 7,500$ per mile. ${ }^{9}$

The Company collected tolls at 13 points along the road at rates varying from $21 / 2$ cents per vehicle-mile for stages and coaches drawn by 2 horses to 5 cents per mile for 4-horse freight wagons with 4-inch tires. Vehicles with wider tires could travel for lower rates, and $a$ horse and rider could travel 10 miles for 6 cents.

The Lancaster Pike did not return more than 2 percent of the invested capital for the first 5 years by the British Fleet. During the war, from 10 to 20 freight wagons arrived daily at Charleston, South Carolina, from cities as far away as Boston. ${ }^{12}$

\section{The Transmountain Roads}

The larger seaboard States from New York to North Carolina had extensive areas of western lands which they were anxious to settle and develop. Also, the seaport cities were eager for the trade such development would produce. There was, therefore, a strong sentiment to push good roads westward over the Allegheny Mountain barrier. Four main transmountain roads resulted.

After completion of the Lancaster Pike to Lancaster, the Pennsylvania Legislature granted charters for extending it westward to Pittsburgh. The State subsidized this "Pennsylvania Road" by subscribing to the stock of some of the companies.

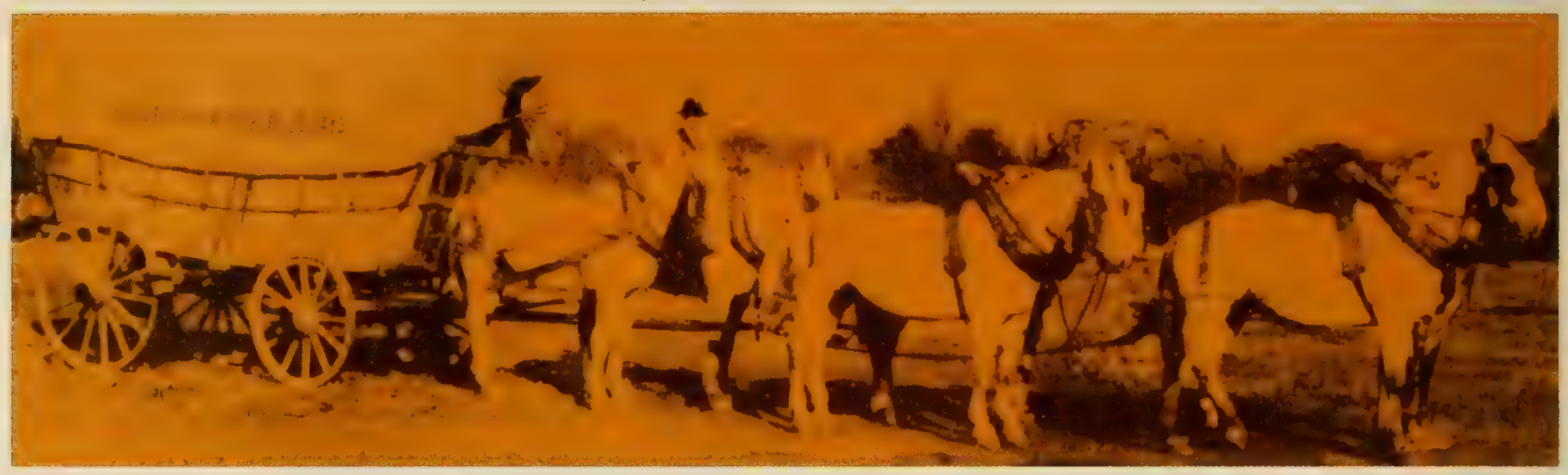

Conestoga wagon "Philadelphia to Pittsburg 20 days."

after it was opened, but, as the western part of the State developed, the profits rose until in some years they reached 15 percent, the maximum permitted by the charter.

\section{Rapid Spread of Toll Roads and Canals}

After 1800, most of the States adopted toll financing for main roads and canals, while retaining the old statute labor system for local improvements. By 1808, Connecticut had chartered 50 turnpike companies, which had completed 770 miles of roads. In New York, 67 companies, capitalized at over $\$ 5$ million, were chartered before 1807 to build 3,071 miles of turnpike roads, and 21 companies were chartered to build toll bridges. ${ }^{10}$ By 1828, Pennsylvania had 3,110 miles of turnpike roads, costing $\$ 8$ million. ${ }^{11}$

The turnpike companies at first concentrated their efforts on the main roads between cities where traffic was heaviest, and since most of these cities were along the Atlantic coast, the coastal highway (now U.S. Route 1) was the first to be improved over any considerable distance. The Delaware River Bridge Company built a substantial bridge at Trenton, N. J., in 1806, and by 1812 the New York-Philadelphia road was stone-surfaced the full distance between those cities. These, and improvements to the coastal highway in other States, came just in time to save the country from a severe transportation crisis during the War of 1812, when coastal shipping was blockaded

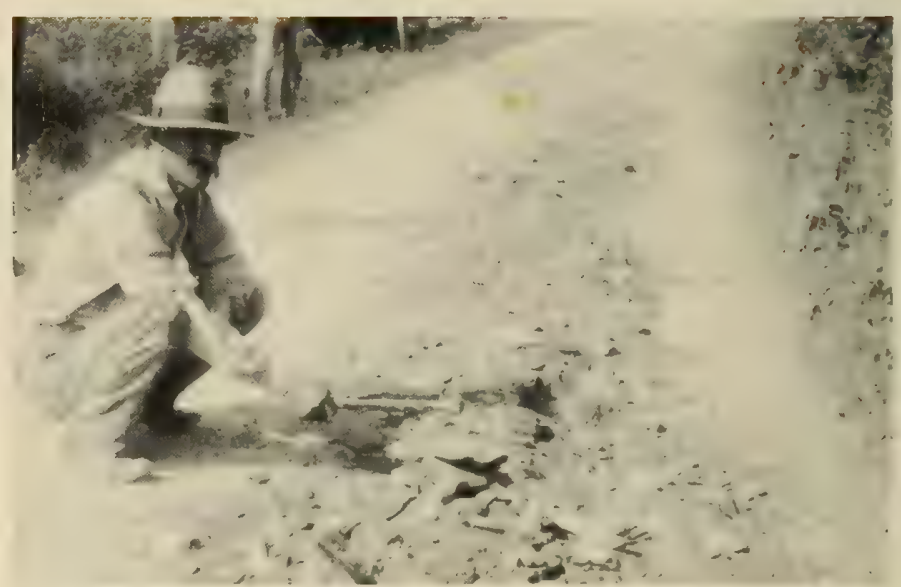

Primitive method of breaking stone on toll road.

In New York the turnpikes developed without State subsidies, and many of the turnpike roads were controlled by large landowners who sometimes were more interested in selling land than in providing transportation. However, by 1812 New York had a welldeveloped turnpike system extending from the Massachusetts boundary to Lake Erie.

Maryland chartered several turnpike companies in the 1820 's to connect Baltimore with the Cumberland Road (the National Road), then being built by the Federal Government with congressional appropria- 


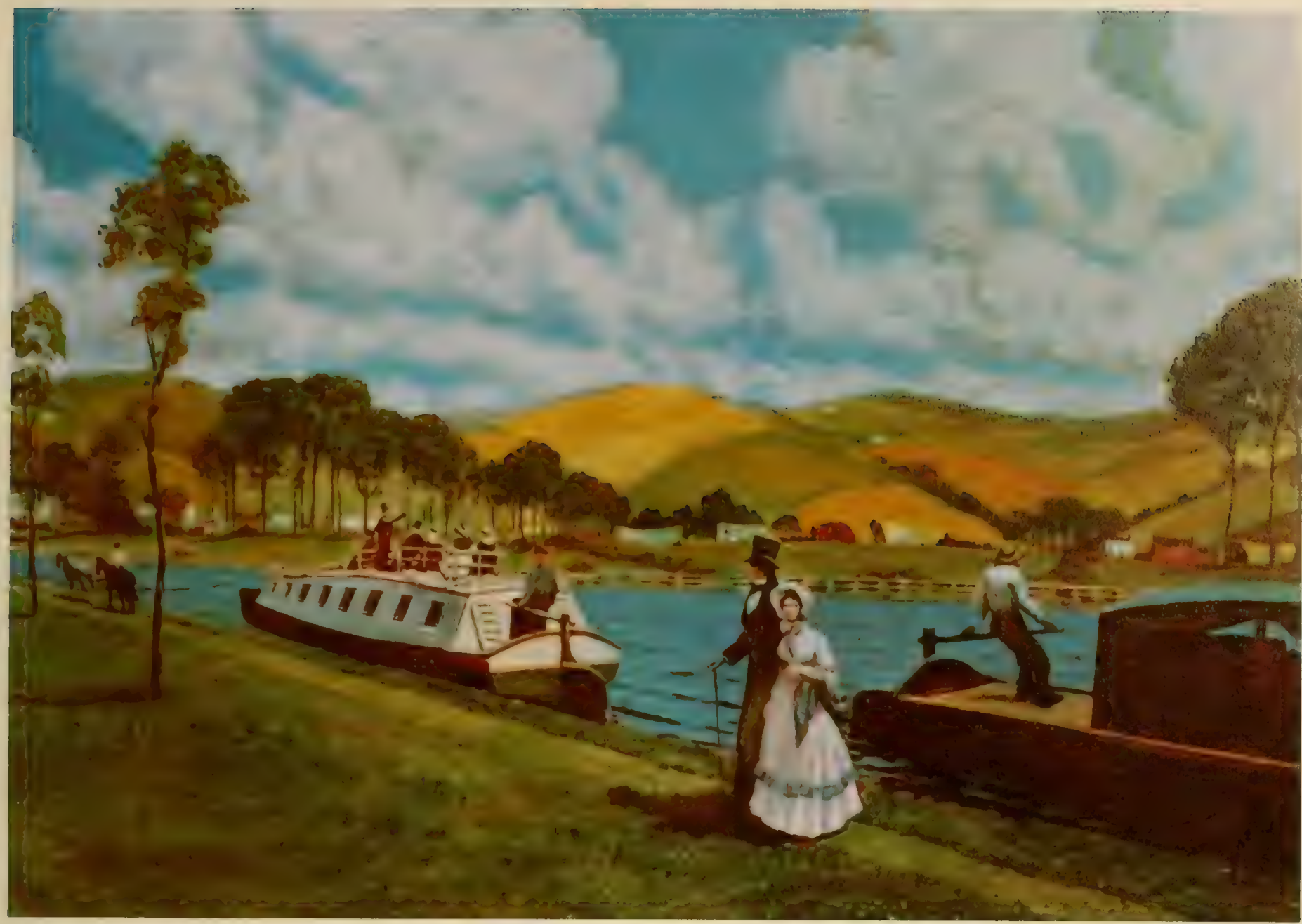

The Erie Canal.

tions; and was thus prepared to cash in on the Federal investment when the Cumberland Road reached the Ohio River.

Virginia incorporated the Northwestern Turnpike in 1831 as a State-owned enterprise, with the Governor as president of the board of directors, to build a turnpike road from Winchester to "some point on the Ohio River to be situated by the principal engineer." The principal engineer was Captain Claudius Crozet, formerly professor of engineering at West Point, and perhaps the ablest road engineer in America at this time. This road was completed to Parkersburg on the Ohio River in 1838 , at a cost of $\$ 400,000 .{ }^{13}$

The standards and costs of the many turnpikes varied widely. Some were graded and ditched, but unsurfaced. Most were surfaced with gravel or pounded stone. The pounded stone surface was very expensive because all stone had to be quarried and broken by hand labor.* After 1846 some roads were surfaced with wooden planks laid on heavy sills. Average construction costs for turnpikes varied between $\$ 550$ per mile to as high as $\$ 14,000$ per mile. ${ }^{14}$

The turnpike movement eventually spread into all the States, and by 1850 there were hundreds of companies operating thousands of miles of roads and

* The first practical mechanical stone crusher was patented by Eli Whitney Blake, in 1858. canals. These contributed tremendously to the States' internal development by opening new lands to settlement, by reducing the cost of haulage from the farms to the markets, and by stimulating the development of industries. Indeed, the construction of these privately financed public works was, itself, a major industry in the early 1800 's.

At first, only citizens of the United States were allowed to own road and canal stock, but this restriction was later waived to attract European investment capital. Some States subsidized turnpike and canal companies by tax exemptions and by purchasing shares in the ventures. The charter granted by Kentucky to the Ohio Canal Company, for example, not only authorized the Governor to subscribe for 1,000 shares on behalf of the State, but also extended the privilege to the United States Government and to five other States bordering on the Ohio River.

With certain notable exceptions, such as the Erie Canal, the profits on toll road and canal investments were modest at best. Most of the charters contained provisions for reducing tolls when profits reached a certain level, usually 12 or 15 percent per year. The Schuylkill and Susquehanna Navigation Company's charter required that when profits exceeded 15 percent per annum 1 percent of the same shall be reserved "for the establishment of schools, and the encouragement of the arts and sciences...."15 


\section{Roads and Canals Coexisfed}

Generally, toll roads and toll canals were not in direct competition with each other over the same or nearby routes, and could coexist as elements of an expanding transportation system. Because of their more restrictive grade lines, canals followed more indirect routes and were longer than turnpikes. Passing the boats through the locks was a slow and tedious business. Consequently, average canal speeds seldom exceeded 2 or 3 miles per hour, as compared to 4 to 6 miles per hour on stagecoaches. The coach lines, therefore, got most of the passengers and U.S. mail contracts, and the turnpike freighters retained the short-haul and the fast-freight business. On the other hand, one horse pulling a canal boat could move as much freight as eight 4-horse wagon teams on a road.* This made for a very low toll rate, so the canals got the heavy freight if the shipper bad a choice of carriers.

Only where a very large proportion of the total movement was through freight and the turnpikes and canals had common terminals did they come into direct and damaging competition. This happened when the Erie Canal was opened between Albany and Buffalo in 1825 and the Pennsylvania river-canal navigation system was opened between Philadelphia and Pittsburgh in 1834. In both cases, the heavy freight to and from the Great Lakes and the Ohio Valley switched to the canals and most of the wagon freighters went out of business, but the stagecoach lines continued to prosper. The toll roads consequently suffered a drastic decrease in their total income.

\section{Improved Engineering and Administrative Methods}

The toll roads were built by contractors, or by hired laborers supervised by trained roadbuilders. Their construction was thus a notable departure from the

* In 1807 Robert Fulton wrote, ". . . on a road of the best kind, four horses, and sometimes five, are necessary to transport only three tons. On a canal one horse will draw twentyfive tons, and thus perform the work of forty horses." 16 long-established feudal custom of building roads with inefficient statute labor directed by amateur supervisors. To meet the standards in their charters, the turnpike companies had to hire people with some understanding of civil engineering to lay the roads out; and, on the whole, the turnpike roads were well located, and well built.

The earlier turnpikes were paved according to the recommendations of J. P. M. Trésaguet, Director General of the French roads from 1775 to 1785 , with whose work educated Americans, such as Benjamin Franklin, were well acquainted. Trésaguet insisted on an adequate right-of-way for his roads and provided generous side ditches to carry away surface water that might otherwise stand on the road and soften it. On a crowned and rolled subgrade, his roadbuilders placed a layer of heavy foundation stones, laid on edge, with the interstices packed solidly with smaller stones rammed in place by hammering. Above this course, by hand, they placed successive layers of broken stone, course by course, compacted and filled so that the stones interlocked with each other. The top 3 inches were of hard, specially selected stone, broken with hammers to walnut-size at the quarry and hauled to the road to form the wearing course. ${ }^{17}$

The carriageways of Trésaguet's roads were 18 feet wide and about 10 inches thick. Most of the early American turnpikes were at least this wide, a common width being 20 feet. The Lancaster Pike was at least 24 feet throughout and in places even wider.

Trésaguet's greatest contribution to highway administration was his insistence on prompt and incessant maintenance of every mile of road by trained and adequately paid workmen. The system of maintenance he established made France's roads the best in the world for two generations.

After about 1820, the ideas of the Scotsman, John L. McAdam, who was responsible for the good roads around Bristol, England, dominated American roadbuilding. McAdam didn't believe in massive foundation courses-he asserted that the native soil, alone,

Laying stone foundation in Massachusetts. Although macadam roads were in use, as late as 1898 the Tresaguet roadbuilding method could be found.

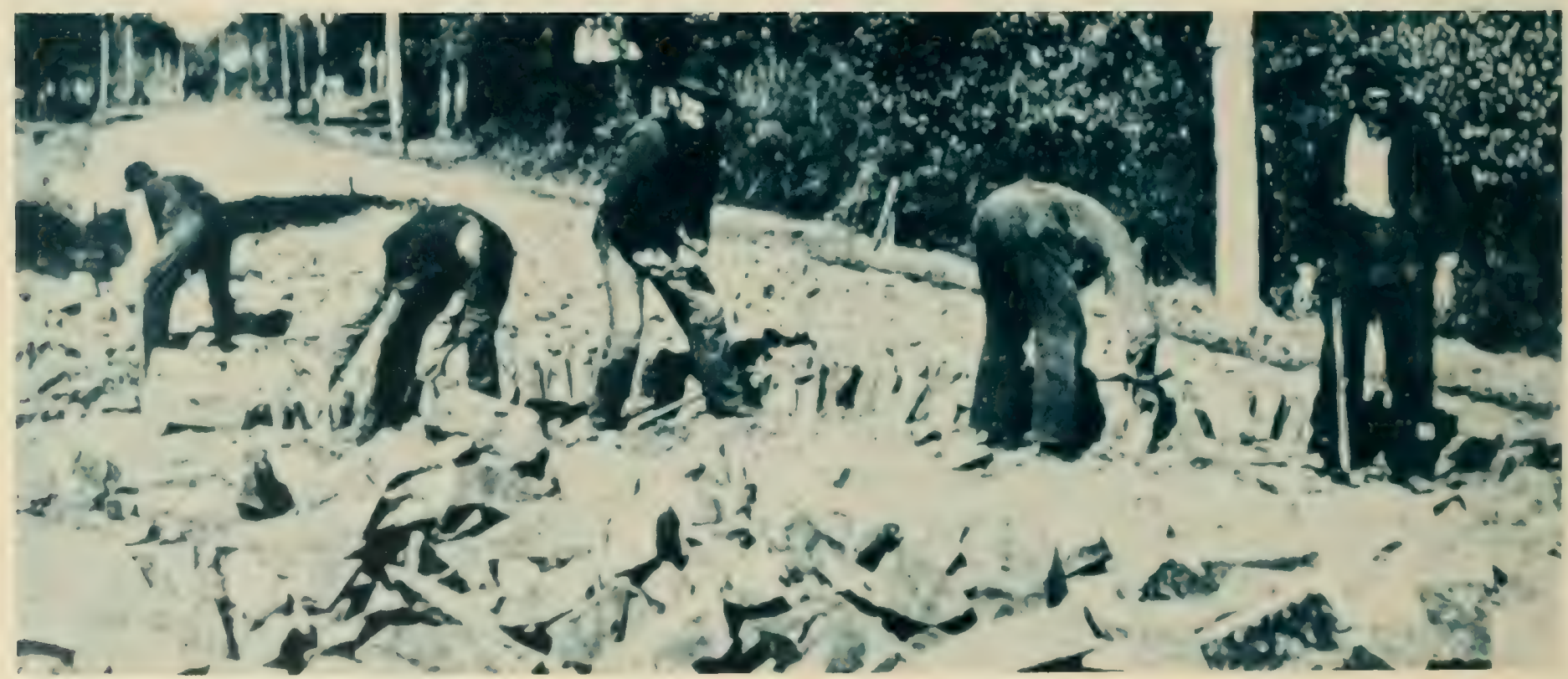




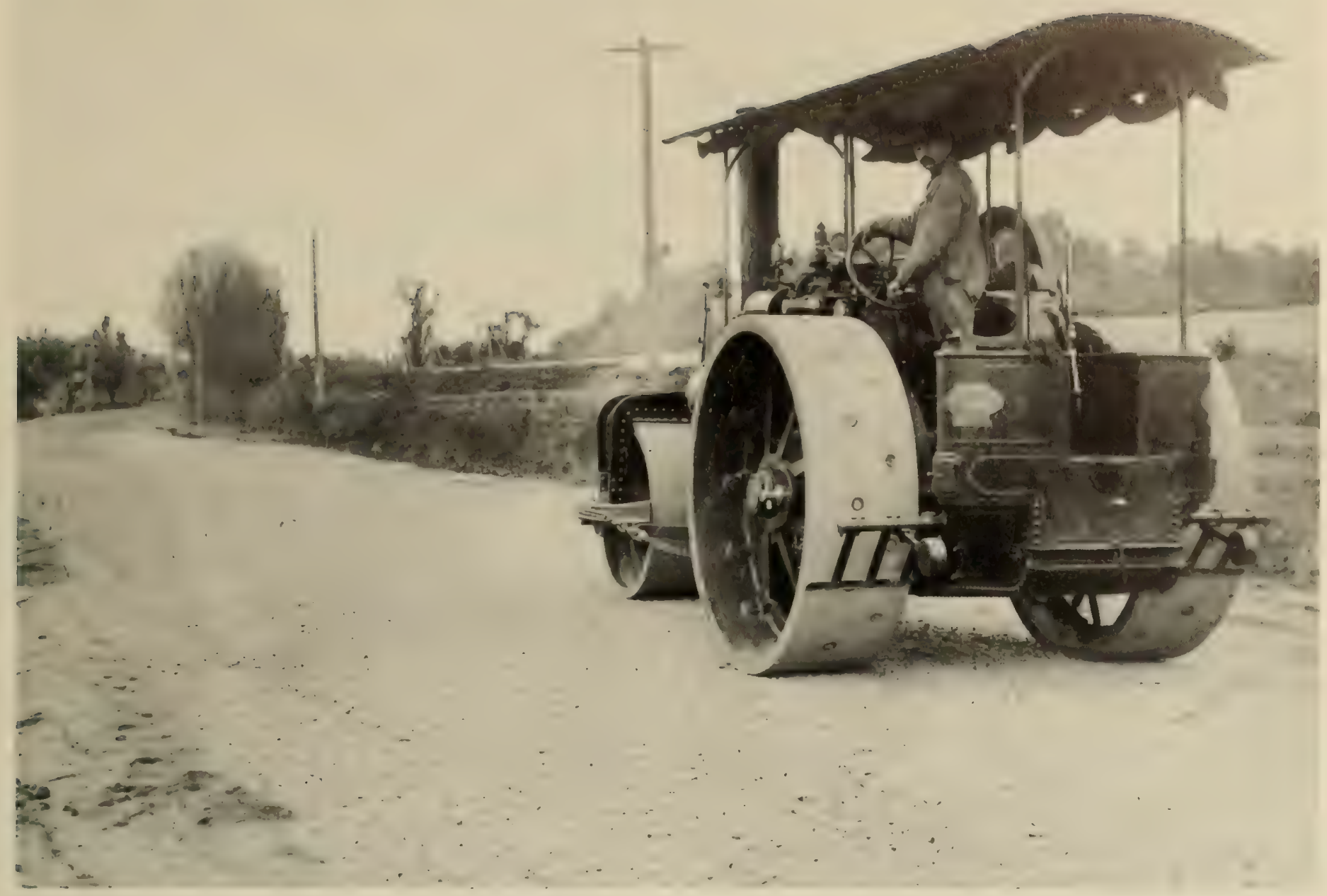

Rolling stone with steam roller near Westfield, Mass. in 1898.

was what supported the road and the traffic upon it and that the function of the road crust was only to protect the basement soil from wetting and abrasion. His roads, 6 to 10 inches thick, were made of angular broken stones, all passing a 2 -inch ring and packed by traffic until they interlocked into a dense mass. The first American road built according to McAdam's principles was the Boonsborough to Hagerstown Turnpike in Maryland, completed in $1822 .{ }^{18}$

McAdam was primarily an administrator, rather than an engineer. Like Trésaguet, he insisted on thorough and continuous maintenance. He also advocated payment of adequate salaries to attract good men who would make roadbuilding a career.

As might be expected, the administration of turnpikes varied widely from company to company, depending on the quality of the management, the amount of toll-paying traffic, and how well the roads were originally laid out and constructed. Many were underfinanced, and failures and reorganizations were frequent. The standard of maintenance was not always as high as it should have been, especially for those roads that were not making much money. But on the whole, the turnpikes were a vast improvement over both the miserable roads and tracks that preceded them and the equally bad local roads still under township control.

\section{Early Railroads Were Regarded as Public Highways}

In 1808 Benjamin Latrobe, the distinguished architect and civil engineer, and one of the designers of the U.S. Capitol, summarized the prospects of railroads as a national mode of transportation in these words :

... railroads are out of the question as to the carriage of common articles. Railroads leading from the coal mines to the margin of the James River, might answer their expense, or others from the marble quarries near Philadelphia to the Schuylkill. But these are the only instances, within my knowledge, in which they at present might be employed.

There is, however, a use for railroads as a temporary means to overcome the most difficult parts of artificial navigation; and for this they are invaluable. . . .

Latrobe's objection to railroads concerned the specialized iron-wheeled carriages required to travel on them; these were too expensive for the average farmer or shipper to own, and also unsuitable for operation on the common roads. Because of this restriction, only specialized roads hauling large quantities of bulk freight, such as coal, from a single source would be able to collect sufficient tolls from traffic to pay out their construction cost. 
At this time, there were no railroads in the United States and only a few in Europe. The carriages or wagons were pulled by horses. On a good railroad, one horse could pull four wagons of 2 tons each. ${ }^{20}$

England's first commercial railroad, opened in 1820 , was originally intended to be operated with horses. Even later when the Liverpool and Manchester Railroad was chartered in 1828 , it too was intended primarily to haul freight by horse power and included a provision in its charter that the owners could exact toll of all persons who might put vehicles on the road for transporting goods. However, this provision was required of few shippers because this railroad adopted steam propulsion a year later.

About the same time in Pennsylvania, the State built a railroad from Philadelphia to Columbia and licensed 20 different companies to run their horsedrawn cars over it. ${ }^{21}$ In Indiana, the chief engineer of the Madison and Indianapolis Railroad recommended in 1837 that the State furnish steam motive power for its railroads, "leaving the cars for the conveyance of freight and passengers to be furnished by individuals or companies, from whom the state will exact the proper toll for the use of the road, and for the motive power." 22

In their early days, railroads were regarded in the same light as tumpikes and canals, to be used by and for the benefit of the public. The theory that a railroad was private property to be used exclusively by the owners and with which they could do as they pleased, prevailed for only a very short time.

\section{Rapid Extension of Railroads in the United States}

In the United States, the first charters for commercial railroads were granted in 1827 to the Baltimore and Ohio Railroad to operate in Virginia, Maryland, and Pennsylvania, and to the Charleston and Hamburg Railroad for operation in South Carolina. Other States followed soon afterward, issuing charters for short railroads, few exceeding ' 100 miles in length. Up to the end of 1830 , only 41 miles of railroad were constructed. This increased to 918 miles by the end of 1835 and to 2,797 by 1840 . In $1856,18,400$ miles were in operation, and by 1860 railroads were being built at the rate of 5,000 miles per year, with 31,000 miles in operation. ${ }^{23}$

Steadily, this multitude of short lines was consolidated into more efficient systems by financial mergers and by standardization of gauges, so that long shipments were possible without changing railroads or cars.

Only a very few of the earliest railroads were planned for operation by animal power. After about 1835 practically all of the American railroads were made heavy enough to support steam engines, and, to accommodate the higher speeds possible with steam propulsion, were laid out with much less curvature and easier gradients than was customary for turnpike roads. At first, operating speeds were only about 8 to 10 miles per hour but these doubled by 1840 .

These higher speeds, plus the ability to haul large tonnages at low cost, gave the railroads a tremendous competitive edge over both the turnpikes and the canals. For topographic reasons, the railroads located their lines parallel or close to the previously established turnpikes and canals, thus, coming into direct competition with them for most of their length. This competition was ruinous to the freight wagon and stagecoach companies which eventually lost not only their passengers and freight, but also their mail contracts to the rails.

\section{Decline of the Turnpikes}

The National Pike, or Cumberland Road, had entered upon an era of great prosperity when the Baltimore and Ohio Railroad reached Cumberland, Maryland, in 1842. Eleven years later, when the railroad reached the Ohio River at Wheeling, the horse transportation companies went into bankruptcy. The same blight spread to the great Pennsylvania wagon road to the west when the Pennsylvania Railroad was completed to Pittsburgh in 1854. Roadside businesses, which depended on the road traffic, such as inns and stables, shriveled and dried up. With no revenue coming in, the turnpike companies stopped maintenance and the proud turnpikes became so rough that travelers refused to pay toll. ${ }^{24}$

\section{Milepost 10 miles west of Philadelphia on the old Lancaster} Turnpike.

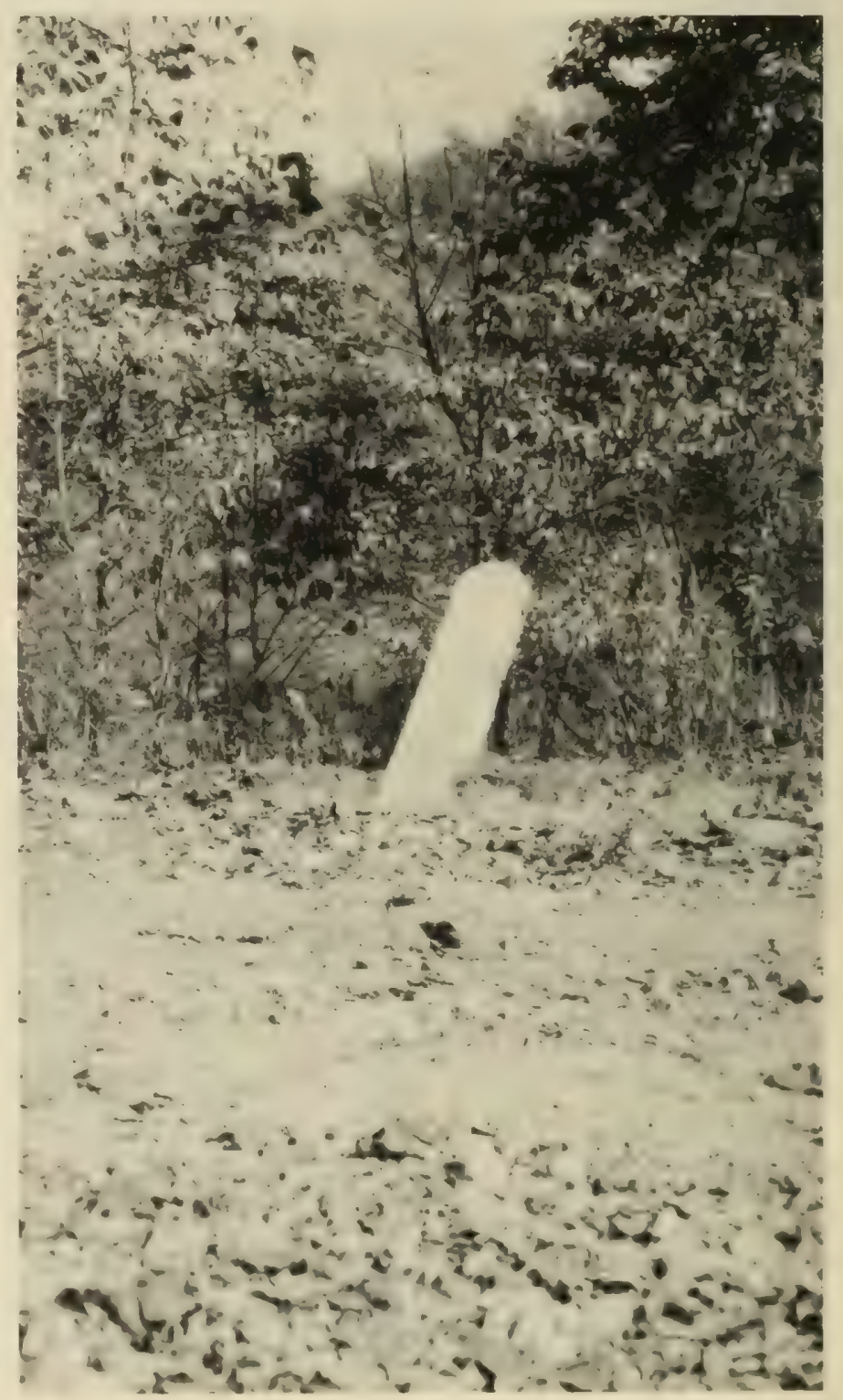


At the eastem end of the Pennsylvania Road, the Lancaster Turnpike, once the finest road in America, fell steadily into decay. In 1880 the company served notice on the township supervisors of its intent to abandon 17 miles of road. These sections were then "disturnpiked" and returned to public control. A little later, the company sold 35 miles of road to other companies for $\$ 40,000$, to be used, partly at least, for a railroad bed, and in 1899 the company sold all of its remaining interest in the turnpike for $\$ 10$ a share-one-thirtieth of what it sold for 100 years before. The Lancaster Turnpike Road Company was dissolved in February 1902.25

With variation in detail, hundreds of other turnpikes met the same fate as the Lancaster Pike, most of them eventually reverting to the local authorities for maintenance.

Paradoxically, as the older through turnpikes collapsed, new charters were being issued for feeder roads to the railroads. Thus, the number of new charters did not diminish greatly until about $1875^{26}$ Many of the newly chartered feeders enjoyed a measure of prosperity and maintained themselves until condemned or bought out by the States or local governments in the early 20 th century.

\section{REFERENCES}

${ }^{1}$ C. Borth, Mankind on the Move (Automotive Safety Foundation, Washington, D.C., 1969) p. 8.

"A. Rose, Historic American Highways-Public Roads of THE PAst (American Association of State Highway Officials, Washington, D.C., 1953) p. 37.
3A. Gallatin, Report of the Secretary on the Treasury on Roads and Canals, S. Doc. No. 250, 10th Cong., 1st Sess., p. $842(1808)$.

'Id., p. 843 .

${ }^{8} I d .$, pp. $863,864$.

${ }^{6} I d$. p. 851 .

${ }^{7} I d$., p. 895.

${ }^{8} \mathrm{~J}$. W. Brooks, A History of American Highways, Sect. 2, p. 5 (unpublished work in Department of Transportation Library).

${ }^{\circ}$ A. Gallatin, supra, note 3, p. 738.

${ }^{10} I d$., p. 737.

${ }^{11}$ G. R. Chatburn, Highways and Highway TrangportaTIoN (Thos. Y. Crowell, New York, 1923) p. 62.

${ }^{12}$ A. Rose, supra, note 2, pp. 46, 47.

${ }^{13} I d$., pp. 56, 57.

"A, Gallatin, supra, note 3, p. 737.

${ }^{15} I d$., p. 851.

${ }^{16} I d$., p. 918.

${ }^{17}$ A. Rose, supra, note 2, p. 40.

${ }^{18} I d .$, p. 53.

${ }^{10}$ A. Gallatin, supra, note 3, p. 917.

${ }^{20} I d$.

${ }^{21}$ G. R. ChatbunN, supra, note 11, pp. 101, 102.

${ }^{22} I d$., pp. 106, 107.

${ }^{23} I d$., p. 108.

${ }^{24}$ A. Rose, supra, note 2, p. 66.

${ }^{25}$ A. B. Hulbert, Historic Highways of America, Vol. 11 (Arthur H. Clark Co., Cleveland, 1904) pp. 91-96.

${ }^{28}$ A. Rose, supra, note 2, p. 72. 


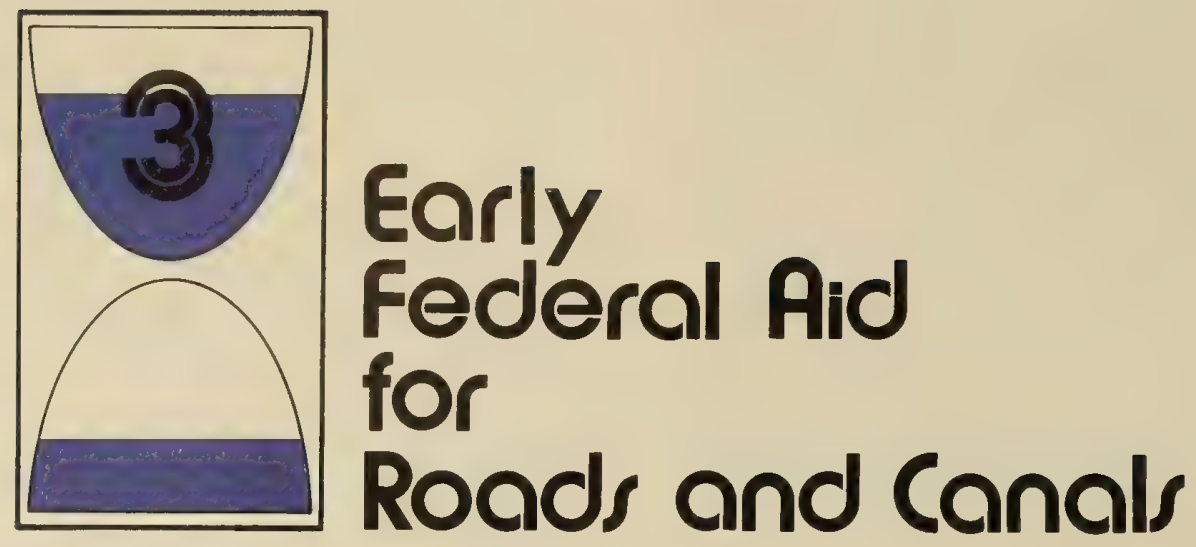

\section{Zane's Trace-First Federally Aided Road}

In March 1796, Colonel Ebenezer Zane, the founder of Wheeling, Virginia, petitioned Congress for permission to build a post road overland through the territory northwest of the Ohio River to the important river port of Limestone, Kentucky (now Maysville). Such a route, Zane said, would be 100 miles shorter than the windings of the Ohio River, on which 15 men with their boats were then engaged in transporting the mails, and would also be immune to interruption by floods, floating ice or low water. The road would afford far faster mail service while saving at least three-quarters of the $\$ 4,000$ annual cost of operating the mail route. Furthermore, the proposed road would provide a shorter and safer route for travelers both to and from the West.

As his only compensation for building the road, Zane asked that he be allowed to locate United States military bounty land warrants totaling three square miles where his road crossed the Muskingum, Hockhocking, and Scioto Rivers.

Colonel Zane's request was approved by Congress in the act of May 17, 1796, with the stipulation that Zane establish ferries upon the three rivers and operate them at rates of ferriage to be established by any two judges of the Northwest Territory. ${ }^{1}$

Zane's first road was no more than a pack trail, but as soon as it was finished, the Government established a mail route over it from Wheeling to Maysville and beyond to Lexington, Kentucky, and eventually Nashville, Tennessee. Zane's Trace played an important part in opening southeastern Ohio to settlement. It was also used by hundreds of flatboatmen returning on foot or horseback to Pittsburgh and upriver towns from downriver ports as far away as New Orleans.

By 1803, the road was chopped out wide enough for wagons to pass. The portion between Wheeling and Zanesville became a part of the National Road after 1825 , and the rest became an important turnpike in the 1830 's.

The grant to Zane appears to be the first instance of local road subsidy by the Federal Government, but it did not have much influence on Federal policy afterward. Furthermore, the aid extended was not particularly generous, since, in any event, Zane had the legal right as a Revolutionary War veteran to exchange his warrants (and any he might buy from other veterans) for public land. In reality, the act gave Zane only the right to locate his lands in advance of the general public and at strategic locations where he could later profit from their resale to settlers.

\section{Financing Roads in New States}

The lack of roads, and the resources to build them, was a serious impediment to the development of the lands north and west of the Ohio River. The United 


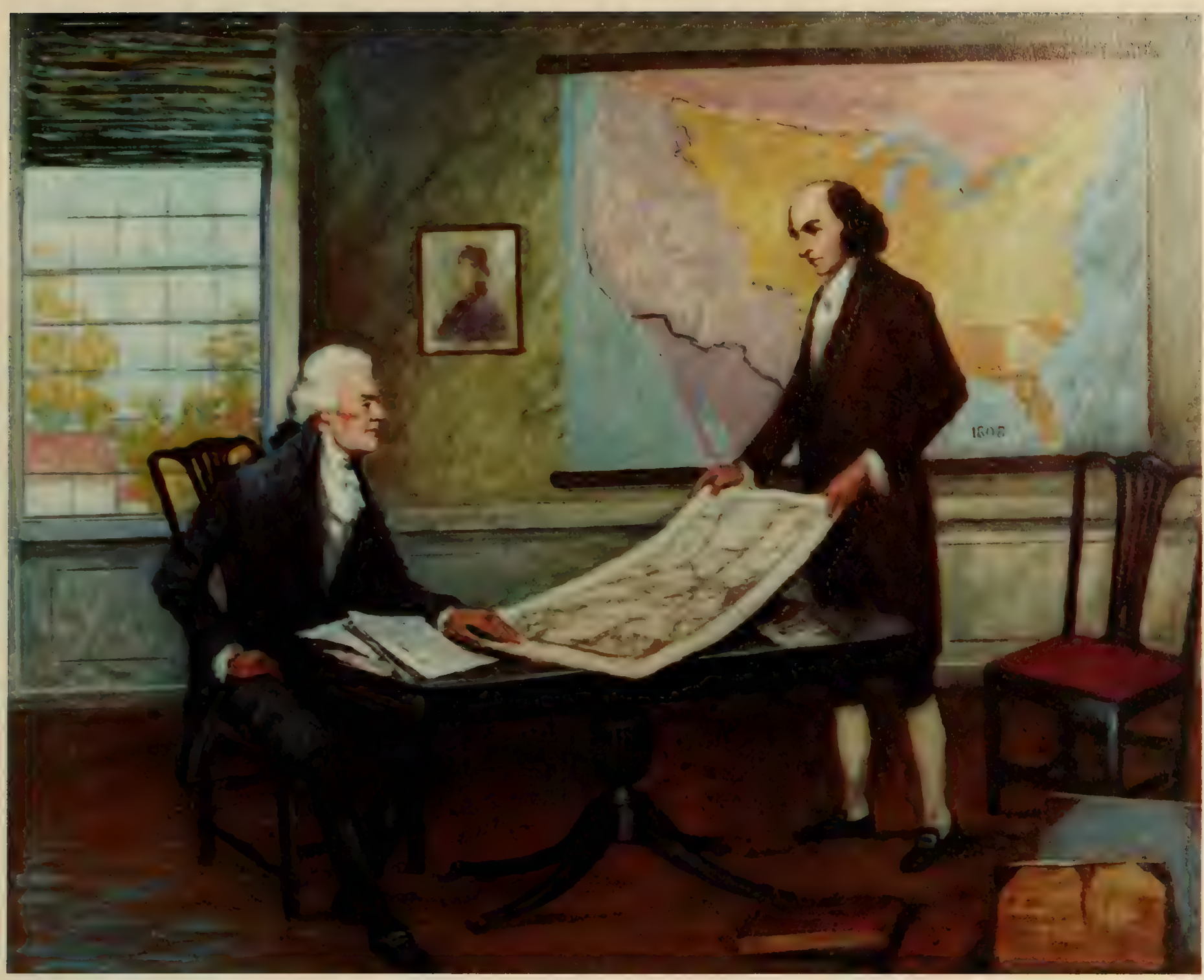

The Gallatin Report.

States Government owned practically all of the undeveloped land, the sale of which was its main source of revenue. What could be more logical than to set aside a portion of the revenues from the sale of public lands for building roads and canals, thus, promoting not only the development of the new territories, but land sales as well?

In 1801 Secretary of the Treasury Albert Gallatin, in a letter to Representative William B. Giles of Virginia, suggested that one-tenth of the net proceeds of public land sales be applied to the building of roads, but only with the consent of the States through which such roads might pass. ${ }^{2}$ This idea was incorporated in the Ohio Statehood Enabling Act of 1802, except that only 5 percent of the proceeds of land sales was to be set aside for roads. Ohio's constitutional convention modified the 5 -percent plan by insisting that three-fifths of the road money be spent on roads "within" the State and under the control of the Legislature. This change was accepted by Congress in 1803 by an act which established a " 2 percent fund" derived from the sale of public lands to be used under the direction of Congress for constructing roads "to and through" Ohio."
Following the Ohio precedent, Louisiana, Indiana, Mississippi, Illinois, Alabama, and Missouri, on their admission to statehood, were given 3 percent grants for roads, canals, levees, river improvements, and schools. Congress later granted an additional 2 percent to these States, except Indiana and Illinois, which, with Ohio, had already received the equivalent in expenditures on the National Road. The additional 2 percent funds were used by these States for railroads.

The remaining 24 States admitted between 1820 and 1910 received 5 percent grants, except Texas and West Virginia, in which the Federal Government had no lands. Of the 22 States that received grants, 9 were authorized to use them for public roads, canals, and internal improvements, and 13 for schools. ${ }^{4}$

\section{The First National Transportation Plan}

Secretary Gallatin, at the request of the U.S. Senate, made the first national inventory of transportation resources in 1807. Out of this study came his report on roads and canals in 1808 , a remarkably comprehensive and forward-looking document which, unfortunately, had little immediate effect on U.S. transportation policy. 
Gallatin clearly understood the vital role of transportation for increasing the wealth of nations. As he stated in his report:

It is sufficiently evident that, whenever the annual expense of transportation on a certain route, in its natural state, exceeds the interest on the capital employed in improving the communication, and the annual expense of transportation (exclusively of tolls), by the improved route, the difference is an annual additional income to the nation. Nor does in that case the general result vary, although the tolls may not have been fixed at a rate sufficient to pay to the undertakers the interest on the capital laid out. They, indeed, when that happens, lose; but the community is nevertheless benefited by the undertaking. The general gain is not confined to the difference between the expense of the transportation of those articles which had been formerly conveyed by that route, but many which were brought to market by other channels will then find a new and more advantageous direction; and those which on account of their distance or weight could not be transported in any manner whatever, will acquire a value, and become a clear addition to the national wealth.

Gallatin then went on to show that in developed countries, such as France and England, there is sufficient concentration of wealth and population that private capital will flow into undertakings, such as canals and turnpikes, offering only remote and moderate profit. By contrast, in underdeveloped countries, such as the United States, commerce will not support expensive roads and canals, except near a few seaport cities. Even these facilities will not be fully productive until they become integrated into larger networks which only the general government can finance and carry through.

Gallatin, therefore, proposed that Congress launch a great national program of roads, canals and inland navigations to be completed in 10 years and which he estimated would cost about $\$ 20$ million. To finance this program, he recommended annual appropriations of $\$ 2$ million, amounting to less than one-seventh of the Government's annual income and less than half of the fiscal surplus at that time. This modest invest- ment would, he said, not only stimulate internal development, but would also enhance the value of the yet unsold Federal lands by far more than the cost of the program, while contributing to the national defense. Lastly and most importantly, "Good roads and canals will shorten distances, facilitate commercial and personal intercourse, and unite, by a still more intimate community of interests, the most remote quarters of the United States. No other single operation, within the power of the Government, can more effectually tend to strengthen and perpetuate that Union which secures external independence, domestic peace, and internal liberty." 6

The works proposed by Gallatin were, first, a series of great canals along the Atlantic coast connecting the natural bays and estuaries into one continuous waterway for the carriage of heavy freight. Supplementing this waterway, there would be a light-duty turnpike from Maine to Georgia for passengers, mail and light goods hauling. The second part of the plan was to form communications between the four great Atlantic rivers and the Western rivers by river improvements, short canals and four heavy-duty freight turnpikes across the mountains. These would be supplemented by internal roads to Detroit, St. Louis and New Orleans. The third part was to open inland navigation between the Hudson River and the Great Lakes and the St. Lawrence River, plus a canal around the Niagara rapids to open the Great Lakes to sloop navigation as far as the extremities of Lake Michigan.

\section{The First National Plan For Financing Internal Improvements}

Gallatin's bold scheme was years ahead of its time and, further, it was proposed at a time when Congress was already divided by the Cumberland Road debate. It was shelved during the War of 1812. However, the plan had many friends in and out of Congress, chief of whom was John C. Calhoun, South Carolina.

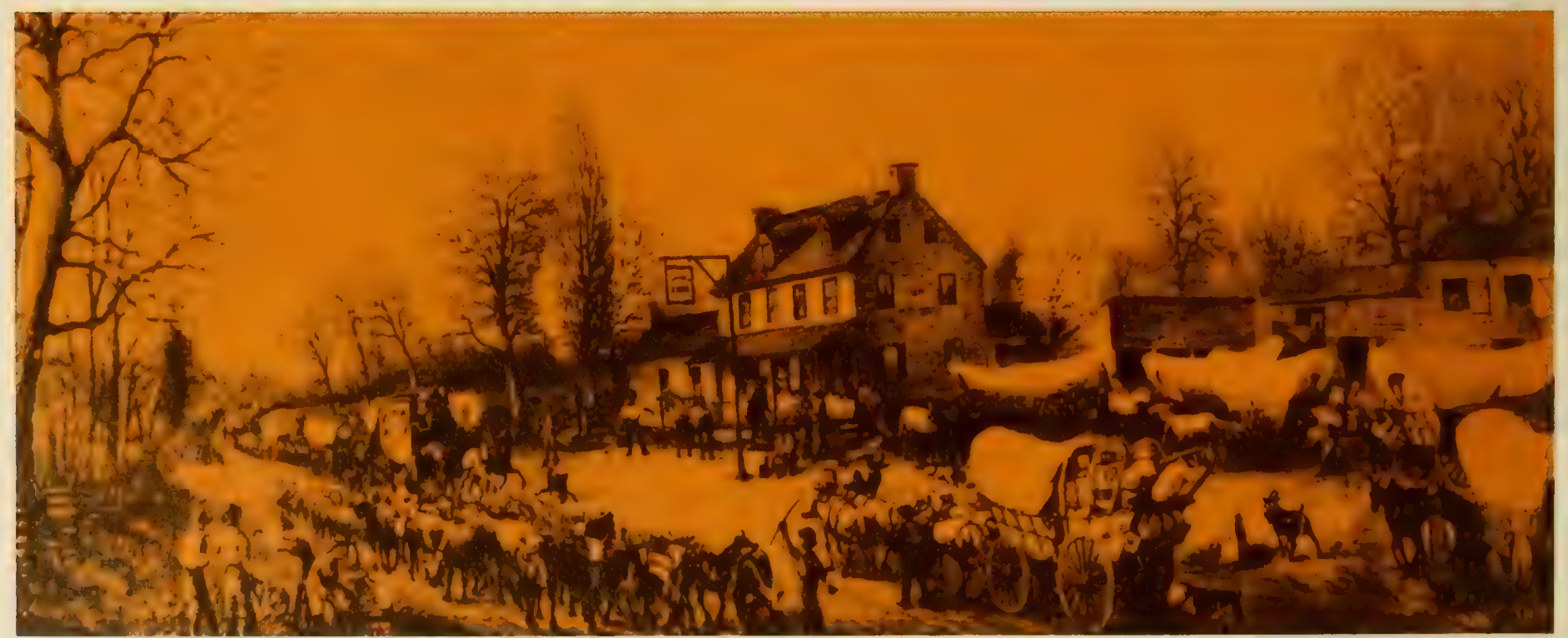

This scene at the Fairview Inn, near Baltimore, is typical of the heavy travel on the Cumberland Road. Heavily loaded freight wagons, herds of stock, stagecoaches, and buggies de- pended on the inns along the way for food and rest after long weary hours on the road. 


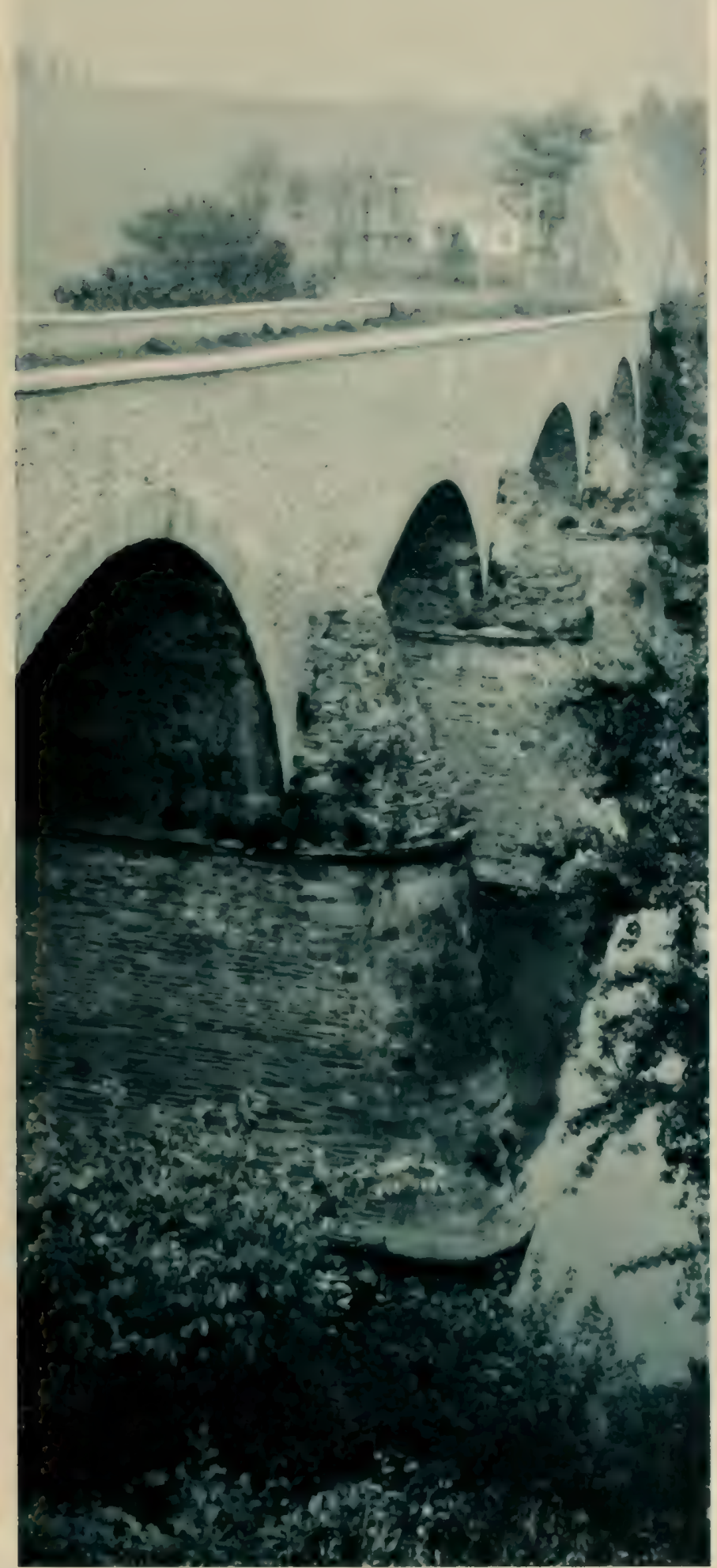

Bridge over the Monocacy River near Frederick, Maryland, built about 1810 by Baltimore bankers on the road connecting Baltimore with the old Cumberland Road.
In 1816 the question of chartering a second National Bank was before Congress. Calhoun introduced a bill providing that the bonus of $\$ 1.5$ million to be paid by the Bank for the new charter, plus the dividends on the Government's stock in the Bank for the next 20 years, be set apart as a permanent fund for internal improvements. This fund was to be apportioned among the States in proportion to their representation in the lower House of Congress, and the improvements were to be built by the Federal Government with the assent of the States in which they might be located. Since the annual dividends on the Government's $\$ 7$ million of stock were $\$ 560,000$, the bill would provide a 20 -year program of nearly $\$ 13$ million.

Urging adoption of this bill, Calhoun pointed to the need for roads for defense, but primarily to encourage commerce and cement political union :

If we look into the nature of wealth, we find that nothing can be more favorable to its growth than good roads and canals ... Many of the improvements contemplated are on too great a scale for the resources of the States or individuals; and many of such nature that the rival jealousy of the States, if left alone, might prevent.

Let us then bind the Republic together with a perfect system of roads and canals. Let us conquer space. It is thus the most distant parts of the Republic will be brought within a few days travel of the centre; it is thus a citizen of the West will read the news of Boston still most from the press. The mail and the press are the nerves of the body politic.?

Calhoun's bill was bitterly opposed in both the House and Senate, not only by the strict constitutionalists, but also by those who thought the money should be applied to tax relief and retirement of the war debt. Others said the States might refuse assent to the improvements or try to dictate their location for political expediency and, thus, defeat the purpose of the plan. Still others branded the bill as a scheme to mulct the wealthy States in which adequate roads and canals had already been built at great expense, for the benefit of the poor and improvident States.

In the end, however, the bill passed both the House and Senate by narrow margins, to be vetoed on March 3, 1817, by President Madison, who declared it to be an improper interpretation of the constitutional power of the General Government to regulate commerce and provide for the national defense. ${ }^{8}$ The motion to override the veto failed in the House, ending the first attempt to set up a continuing national plan for internal improvements. ${ }^{9}$

\section{The Cumberland Road}

On March 29, 1806, President Jefferson approved an act which directed that the President, with the advice and consent of the Senate, appoint three commissioners to lay out and build a road from the head of navigation on the Potomac River at Cumberland, Maryland, to a point on the Ohio River. ${ }^{10}$ The act set certain minimum standards for the proposed road and appropriated $\$ 30,000$ from the proceeds of Ohio land sales to finance the location of the road and to start construction. The debates attending the passage of this act exposed the bitter rivalries and jealousies 
between the eastern seaboard States over the development of the lands beyond the Ohio River.

The seaport cities in particular feared the advantage that a Government-financed road might give in competition for the western trade. Strict constructionists of the U.S. Constitution denied that the Federal Government had the authority to build roads at all, except possibly in the territories. Proponents of Federal roadbuilding on the other hand, asserted that authority to build roads was implied under the "general welfare" clause of the Constitution.

In the end, the issue was decided by those of both parties who felt strongly that the bonds between the East and the West should be strengthened in the interest of national unity, and the act passed the House by a narrow margin. At least one representative from every State voted in favor of the road.

President Jefferson lost no time in selecting the three commissioners and in applying to the legislatures of Maryland, Virginia, and Pennsylvania for permission to build the road within their boundaries. The first two States gave their assent without restriction, but Pennsylvania held back and conditioned its approval on the road's passing through the towns of Uniontown and Washington. ${ }^{11}$

It took the commissioners 4 years to select the route, and another 8 years to push the construction through from Cumberland to Wheeling, Virginia, the head of low-water navigation on the Ohio River. This road was 30 feet wide, with the central 20 feet paved by the Trésaguet method, that is, with several layers of small broken stone placed over a foundation of 7-inch stones. It was cleared 66 feet wide, ditched, and provided with drains and bridges. The cost, paid out of the Ohio 2 percent land fund, was about $\$ 1.75$ million, or an average of $\$ 14,000$ per mile.* 12

From the time the first section was opened in 1813 , the Cumberland Road came under heavy traffic, so heavy in fact, that the stone surface was worn away almost as fast as it was built. The commissioners were unable, with the funds available, to provide the systematic and continual maintenance required by broken stone roads; and they were without power to protect the road from the depredations of travelers and local residents.** Consequently, the condition of the road steadily deteriorated, despite efforts to repair the worst damage.

To provide a regular source of funds for maintenance, Congress in 1822 passed an act authorizing the collection of tolls from users of the road. President

\footnotetext{
* This cost included maintenance during the 8-year construction period.

** Freighters ripped up the shoulders by descending the steep hills with locked wheels. Local inhabitants fenced in parts of the right-of-way, dug into the banks, dragged logs over the road, and even stole broken stone from the road bed. ${ }^{13}$
}

Old Cumberland Road at Wills Creek just west of Cumberland, Md.

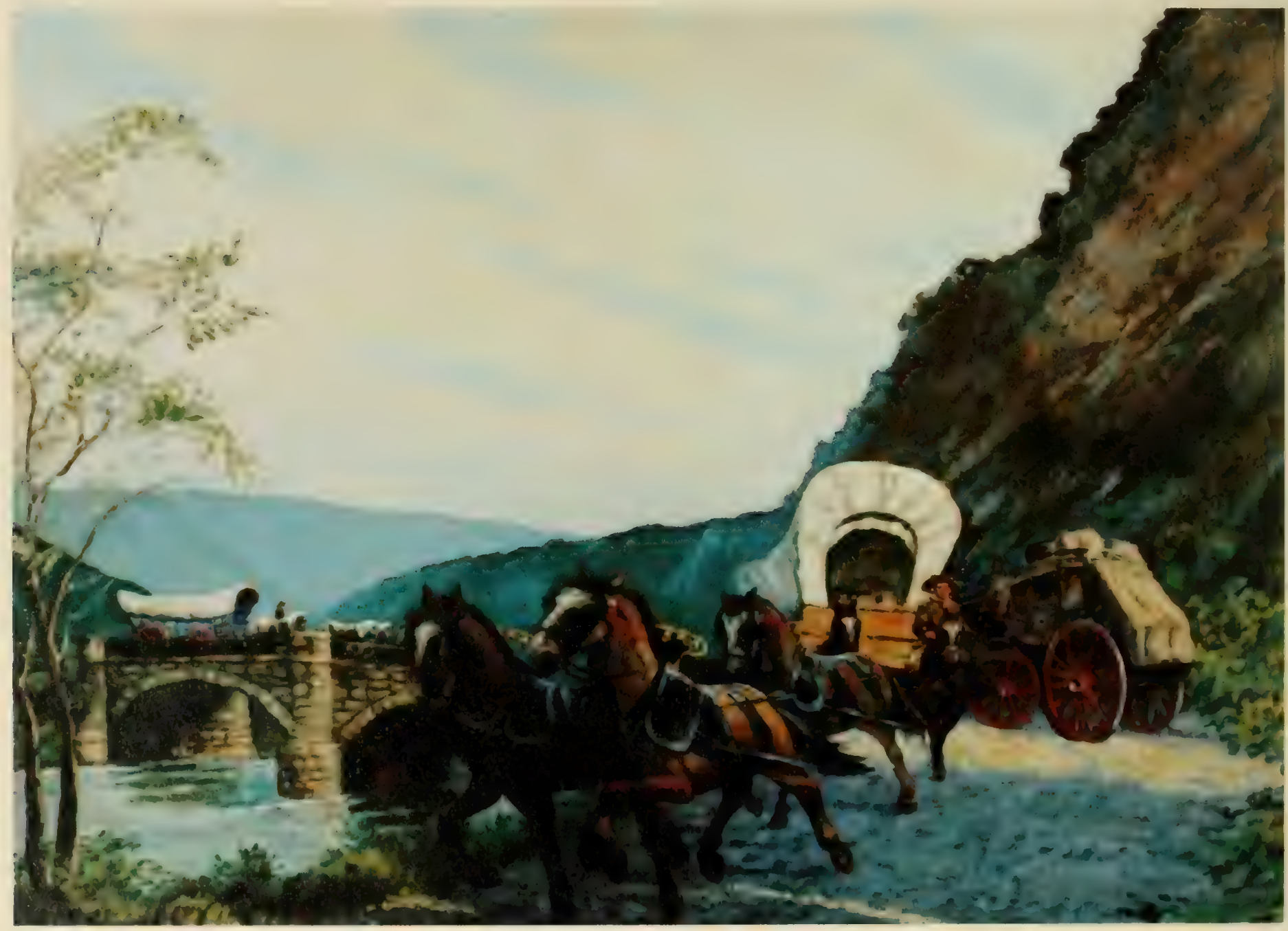




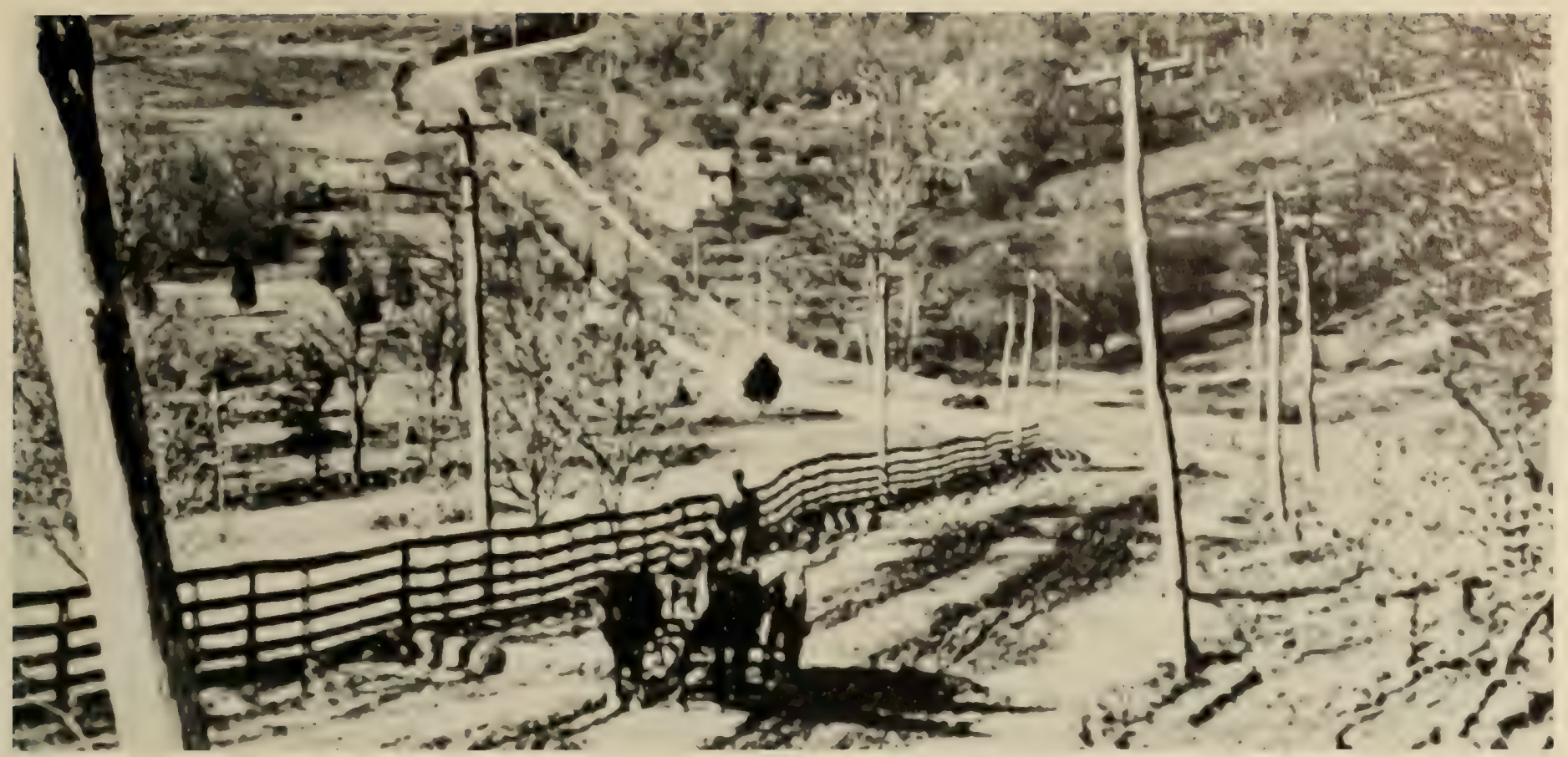

Old Cumberland Road approaching Chestnut Ridge Mountains in Pennsylvania about 1899.

Monroe retoed this act on the ground that it was an unwarranted extension of the power vested in Congress to make appropriations, "under which power, with the consent of the States through which the road passes, the work was originally commenced, and has so far been executed." ${ }^{4}$ Collection of tolls, the President said, implied a power of jurisdiction or sovereignty which was not granted to the Federal Government by the Constitution and could not be unilaterally conveyed by any State without a constitutional amendment. It was one thing to make appropriations for public improvements, but an entirely different thing to assume jurisdiction and sovereignty over the land whereon those improvements were made. ${ }^{15}$ This has been the Federal position on highway grants to the States down to the present day.

\section{Transfer to State Control}

In the 10 years following President Monroe's veto, Congress made occasional and niggardly appropriations for maintaining the Cumberland Road, but these were inadequate to preserve it under ever-increasing traffic.* The supporters of the road finally realized that there was little chance that a Congress bitterly divided over the issue of federally-financed internal improvements would ever make adequate provisions for keeping it in repair. State operation as a toll road seemed to be the only solution to the dilemma, and between 1831 and 1833, the Legislatures of Ohio, Pennsylvania, Maryland and Virginia agreed to accept and maintain their sections of the National Road.

\footnotetext{
* For the years 1823 to 1827 , a total of $\$ 55,000$ was appropriated for repairs, an average of only $\$ 88$ per mile per yearhardly enough to keep the ditches open. ${ }^{16}$ An idea of the traffic can be had from the fact that in 1822 one of the five commission houses at Wheeling unloaded 1,081 wagons, averaging 3,500 pounds of freight each, and the annual total freight bill from Baltimore to Wheeling was estimated at $\$ 390,000{ }^{17}$ In addition, hundreds of stagecoaches and private vehicles used the road daily. Nineteen thousand pigs were driven over the road in 1831, some in droves of 600 animals. ${ }^{18}$
}

Maryland and Pennsylvania, which had the oldest and worst-worn sections conditioned their acceptance upon the Government's first putting the road into a good state of repair and erecting toll gates. ${ }^{19}$

The Government spent nearly $\$ 800,000$ in 1833 , 1834 , and 1835 for repairing the road east of the Ohio River, the work being done under the supervision of the Army Corps of Engineers. This work was principally rebuilding the pavement according to $\mathrm{Mc}$ Adams' method, adding broken stone to replenish the wear of traffic. As soon as each section was reconstructed, the States assumed jurisdiction and maintenance. By the end of 1835 the National Road, from Cumberland to the Ohio-Indiana line, was national no longer.

\section{Westward Extension of the National Road}

As soon as the Cumberland Road reached the Ohio River, there was agitation to extend it westward through Ohio and the newly-admitted States of Indiana and Illinois. These States, like Ohio, had provisions in their acts of admission for setting aside 2 percent of the income from sales of public lands for road improvements.

In 1820 Congress appropriated $\$ 10,000$ for laying out a road between Wheeling and the left bank of the Mississippi River. However, the road did not officially get under way until 1825, when Congress made another appropriation to start construction and to extend the surveys to the permanent seat of government in Missouri, passing through the seats of government of Ohio, Indiana, and Illinois. ${ }^{20}$ Thereafter, the Government spent slightly over $\$ 4$ million to push the road as far west as Vandalia, then the capital of rllinois.

From Wheeling to Vandalia the road was laid out with Roman straightness in an 80-foot right-of-way, but except in eastern Ohio, it did not approach the high construction standard of the Cumberland Road east of the Ohio River. This was partly because of 


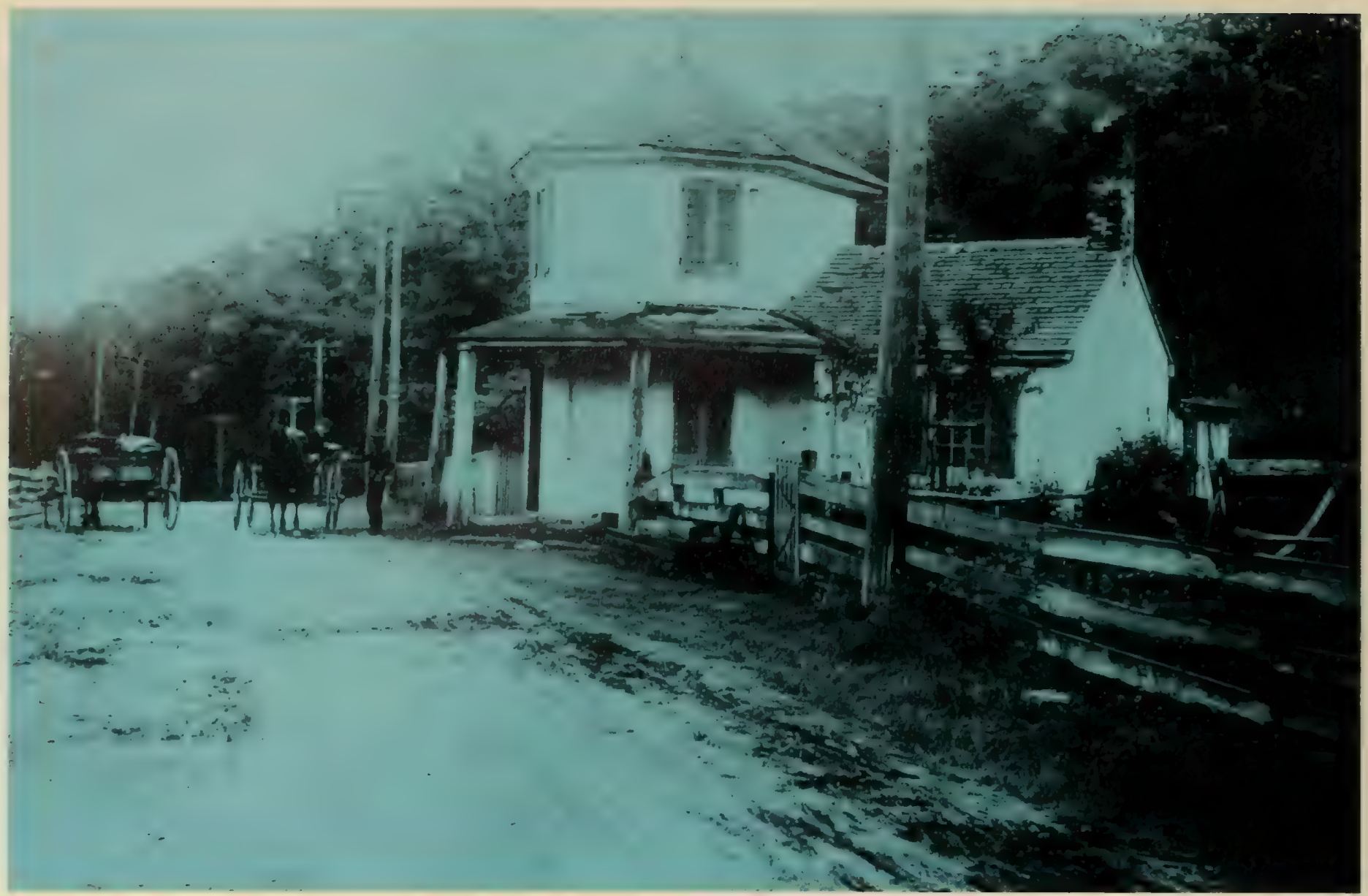

Old tollhouse on Cumberland Road near Frostburg, Md.

the scarcity of good roadbuilding stone, which had to be hauled long distances. In Indiana and Illinois the road was only a cleared and graded dirt track.

The annual appropriation bills continued to be bitterly opposed in Congress and passed by increasingly narrower margins. After 1832 there was sentiment in Congress to use the money appropriated for the National Road to build a railroad west from Columbus, Ohio, and an unsuccessful amendment to the appropriation bill for 1836 proposed to do just that. The last regular appropriation for the Road was in 1838, but construction continued until 1840 when the funds ran out. ${ }^{21}$

By its act of 1831, Ohio accepted the road as fast as it was completed by the Federal engineers and put it under toll. The road was never finished in Indiana and Illinois, and in 1848 Congress ceded to the former "all the rights and privileges of every kind belonging to the United States as connected with said road...." A similar act for Illinois was passed in 1856. In 1879 Congress granted Ohio the right to make the road free, "Provided, That this consent shall have no effect in respect to creating or recognizing any duty or liability whatever on the part of the United States." 22

The National Road never reached the Mississippi, but petered out in the Illinois prairies. Its ultimate demise could have been forecast in 1831 when Congress agreed to turn the eastern sections over to the States for operation and maintenance. The end was due not so much to the constitutional and sectional objections that had plagued the road from the beginning, as to the growing feeling in the country and in Congress that roads and canals were already obsolete for longdistance transportation. The day of the railroad was at hand.

\section{The Maysville Turnpike Veto}

The course of highway policy in the United States was profoundly influenced by two presidential vetoes. President Monroe's veto of Federal toll collections on the Cumberland Road has already been mentioned. President Jackson's veto on May 27, 1830, of turnpike stock subscriptions established national policy with respect to internal improvements of purely local character.

In January 1827, the Kentucky Legislature petitioned Congress to provide Federal aid for an artificial road from Maysville to Lexington, Kentucky. This would be an extension of the mail route leaving the National Road at Zanesville, Ohio, and following Zane's Trace to the Ohio River. In 1828 an appropriation bill in the U.S. Congress authorizing this road failed by only one vote in the Senate. ${ }^{23}$

The Legislature then incorporated the Maysville, Washington, Paris, and Lexington Turnpike Road Company to build the road, with the provision that 1,500 shares of stock be reserved for subscription by the U.S. Government. In a parallel action, Congress passed a bill authorizing the Secretary of the Treasury to subscribe to 1,500 shares in the Company in the name and for the use of the United States. ${ }^{24}$ 


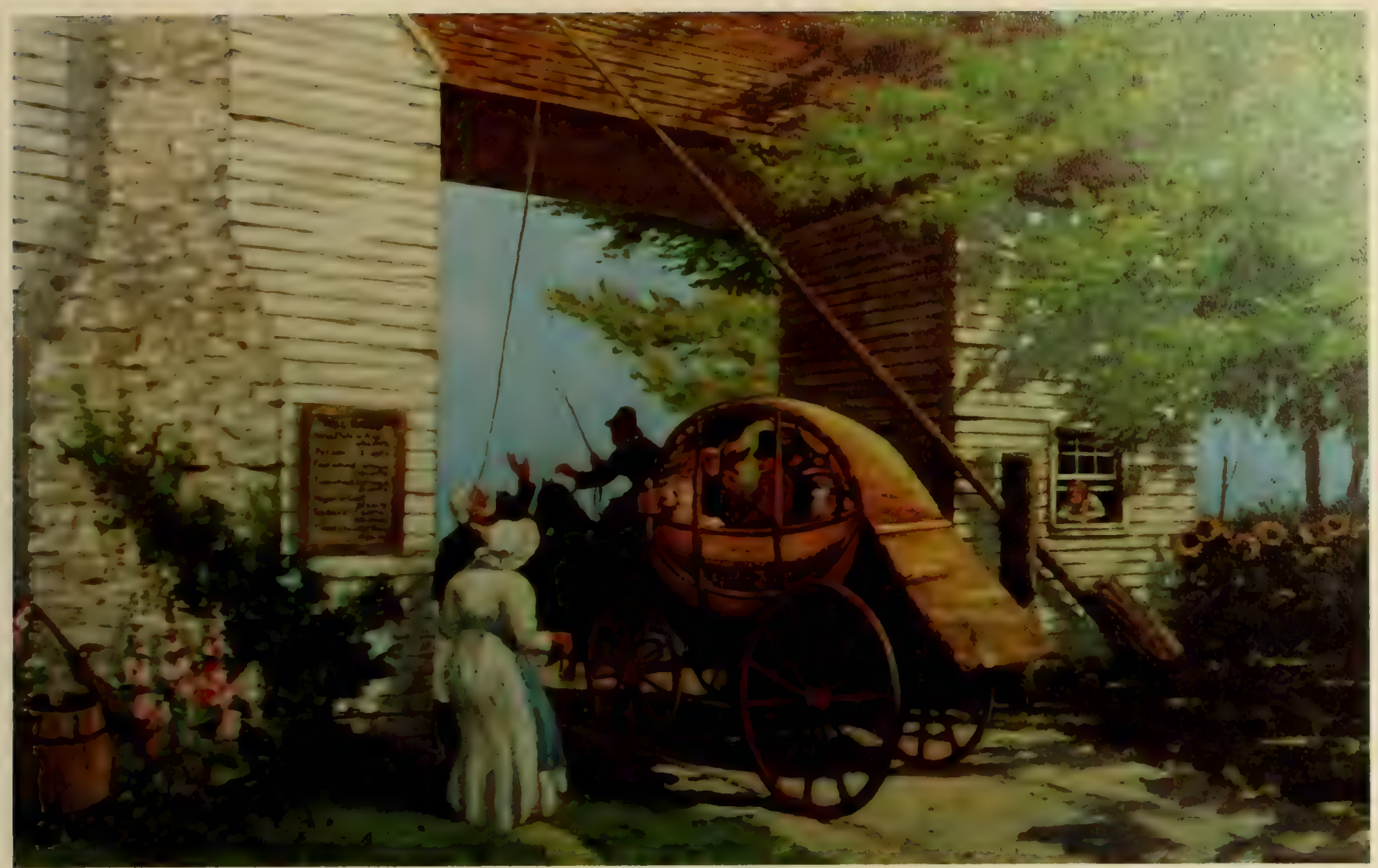

18s0-The Maysville Turnpike.

The President vetoed this bill on the ground that the proposed improvement was of purely local, and not national, importance.

It has no connection with any established system of improvements; it is exclusively within the limits of a State, starting at a point on the Ohio River and running out 60 miles to an interior town, and even as far as the : State is interested conferring partial instead of general advantages.

However, he went on,

What is properly national in its character or otherwise is an inquiry which is often extremely difficult of solution ...

If it be the wish of the people that the construction of roads and canals should be conducted by the Federal Government, it is not only highly expedient, but indispensably necessary, that a previous amendment to the Constitution, delegating the necessary power and defining and restricting its exercise with reference to the sovereignty of the States, should be made. . .

Jackson was not personally hostile to internal improvements; in fact, less than a year before in his first annual message to Congress he had recommended distributing the embarrassing annual surplus Federal revenue among the States to be used by them for internal improvements.

The Maysville Turnpike veto not only put an end to all thought of national aid to local road improvements, but it also forestalled any efforts that might be made to provide Federal aid to such genuinely national promotions as the Baltimore and Ohio Railroad. Over 20 years would pass before Congress would provide any significant subsidy for railroads.
The Maysville Turnpike was eventually completed with State and private funds. The road had long been a mail route, so the Government insisted it could run the mails over it without paying tolls. This question was settled by the courts in favor of the Turnpike Company in 1838; thereafter mail contractors paid the same fees as the general public. ${ }^{26}$

\section{The Michigan Road}

The first settlements in Indiana were along the Ohio River and the Wabash and White Rivers. By 1826 settlement had reached the southern limits of the Potowatomi Indian lands, which extended from the Wabash River to Lake Michigan. At this time the only overland communication with central Indiana was along a poor dirt wagon road from Indianapolis, the capital, to Madison on the Ohio River.

In October 1826, the U.S. Government concluded a treaty with the Potowatomi under which the Indians ceded a large area of northern Indiana and southern Michigan to the United States. Among other things this treaty provided that the State of Indiana should be given a strip of land 100 feet wide for a road commencing at Lake Michigan and extending to the Wabash River, plus a section (640 acres) of good land contiguous to every mile of the road, and in addition, a section of land for every mile the road was extended southward from the Wabash River. Congress, in March 1827, authorized Indiana to locate and build this "Michigan Road" in accordance with the treaty, from Lake Michigan to Indianapolis and southward to Madison, using funds from the sale of the designated Indian lands. ${ }^{27}$ 
From 1830, when the Legislature authorized construction to begin, until 1840, the sale of the Indian lands yielded $\$ 241,332$, with several hundred acres remaining to be sold. As noted earlier, Indiana also received grants from Congress under its Statehood Act from the proceeds of public land sales within the State. For a decade, these were the two principal sources of funds for wagon roads. When they were exhausted, Indiana, like its neighbors, turned to private financing and chartered plank road and turnpike companies to finish the job.

\section{Land Grants to the States for Wagon Roads}

The grant of Potowatomi lands to Indiana was not the first Federal land grant to a State for roads, or the last. The first significant Federal land grant was in February 1823 when Congress granted Ohio a 120foot right-of-way for a public road from the lower rapids of the Miami River of Lake Erie to the western boundary of the Western Reserve. To finance the road, Congress gave the State all the public lands for 1 mile on each side of the road, with the proviso that they could not be sold for less than $\$ 1.25$ per acre. ${ }^{28}$

Congress subsidized a toll turnpike from Columbus to Sandusky by another grant to Ohio in 1827 . This grant gave the State every alternate section of land abutting the west side of the road. ${ }^{29}$

The Maysville Turnpike veto put an end to further wagon road subsidies, other than the National Road, until the Civil War. Between 1863 and 1869, however, Congress made 10 separate grants of land to Michigan, Wisconsin, and Oregon for certain "military" wagon roads. These, with the previous grants to Indiana and Ohio, totaled $3,560,000$ acres, ${ }^{30}$ or about 5,500 square miles-an area somewhat larger than Connecticut.

\section{Federal Land Subsidies for Canals}

Prior to President Jackson's administration (18291837), Federal largesse extended not only to roads, but canal and river improvements as well. In March 1822, Congress granted Illinois a 180-foot right-ofway for a canal to connect the Illinois River and Lake Michigan. This act authorized the State to take construction materials from adjacent public lands and, in addition, granted Illinois one-half of the public lands in a strip 10 miles wide centered on the canal. In return, the State agreed that the canal would be "a public highway for the use of the Government of the United States, free from any toll or charge whatever, for any property of the United States, or any persons in their service." ${ }^{31}$

This Illinois River-Lake Michigan Canal grant was the first land subsidy voted by Congress for internal improvements, and became a precedent for the subsequent granting of immense tracts of the public domain.

An act of May 24, 1828, which, as a subsidy to canals, granted Ohio 500,000 acres to be selected from any available public lands within the State, became the precedent for the general act of September 4, 1841, granting 500,000 acres each to Ohio, Indiana, Illinois, Alabama, Missouri, Louisiana, Arkansas, and Michigan and to each public land State admitted there- after.* These grants were to be used for specified internal improvements, such as roads, railways, bridges, canals, river improvements, and draining of swamps. ${ }^{32}$

\section{Military Roads-The Natchez Trace}

Until the construction of the Cumberland Road and the Pennsylvania Road, the only outlets for the produce of the Ohio River Valley were by packhorse trains across the mountains or downriver in flatboats and rafts. At New Orleans the crews sold the vessels and their cargoes and either embarked by sea for eastern ports or returned overland by foot or horseback through the lands of the friendly Choctaw and Chickasaw Indians, to the Mero Settlements, now Nashville, Tennessee. From here, they could find their way to the upper valley by trails through central Kentucky to Zane's Trace and beyond.

In 1801 the Government negotiated agreements with the Choctaws and Chickasaws " to lay out, open, and make, a convenient wagon road through their land, between the settlements of Mero District (Nashville), in the State of Tennessee, and those of Natchez, in the Mississippi Territory.'" 33 Upon conclusion of these agreements, the Army began widening the old Indian trails, eight companies of infantry working south from Mero District and six companies northward from Natchez. This military road, later called the Natchez Trace, was completed in $1803 .^{34}$ Although it served a peaceful purpose to thousands of returning flatboatmen, this road was initially conceived with strategic military ends in view, in the event the United States should become embroiled with Spain over the port of New Orleans.

\section{The Jackson Military Road}

Following the War of 1812 , Congress authorized a more direct military road from Nashville to New Orleans, which would shorten the distance between those cities by 220 miles.

The First and Eighth Infantry Regiments began work on this road in June 1817, completing it in May 1820. Two congressional appropriations totaling $\$ 15,000$ were only a small part of the cost of this road. Over 75,800 man-days of labor were expended on it by the troops, and the total disbursement from military funds was well over $\$ 300,000$. For this, the Army cleared a right-of-way 40 feet wide through dense forest, graded an earth road 35 feet wide, built 20,000 feet of corduroy causeways, and over 35 substantial bridges from 60 to 200 feet long. By 1824 most of this road south of Columbus, Mississippi, was grown over and abandoned. ${ }^{35}$

\section{Military Roads on the Frontiers}

The Army built more than 100 other military wagon roads in the period from 1807 to 1880 , most of them in the territories. Their total length was well over 21,000 miles, and they cost at least $\$ 4$ million, not counting the labor of the troops. ${ }^{36}$ Some were built by the troops and some by hired labor.

* States admitted after 1889 received cash grants for educational and penal institutions instead of acreage. 


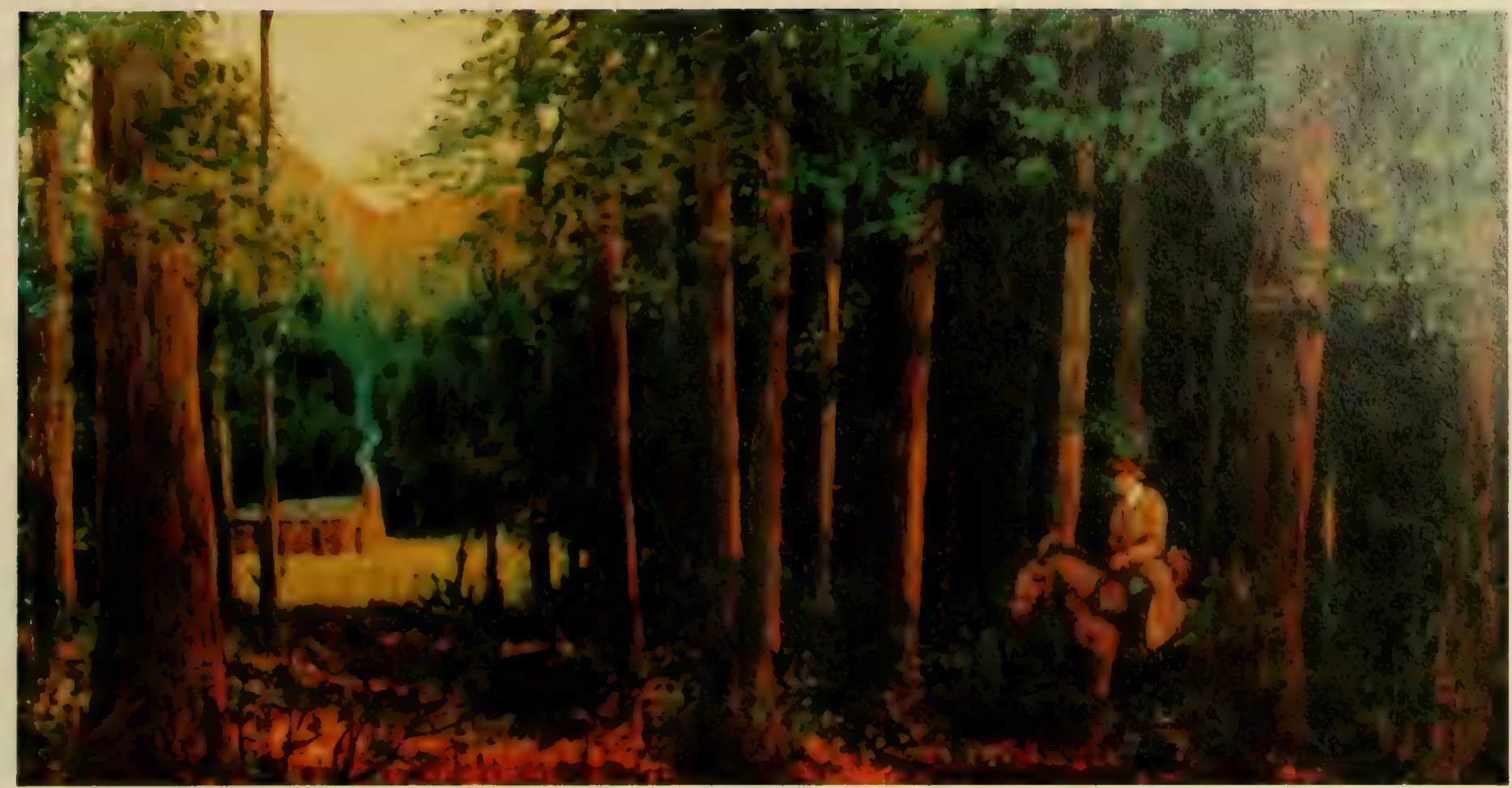

1809-The Natchez Trace.

1820-General Jackson's Military Road.

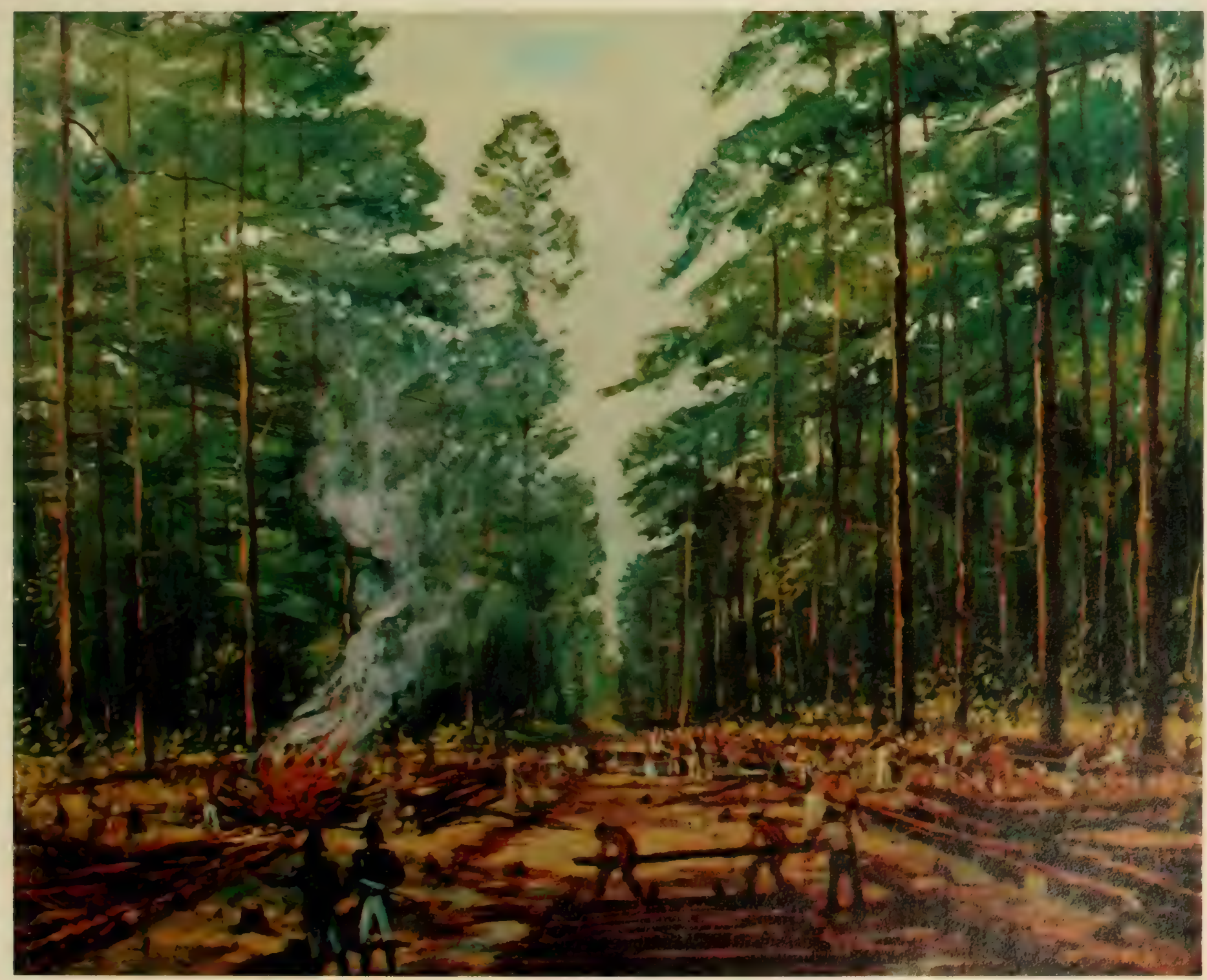




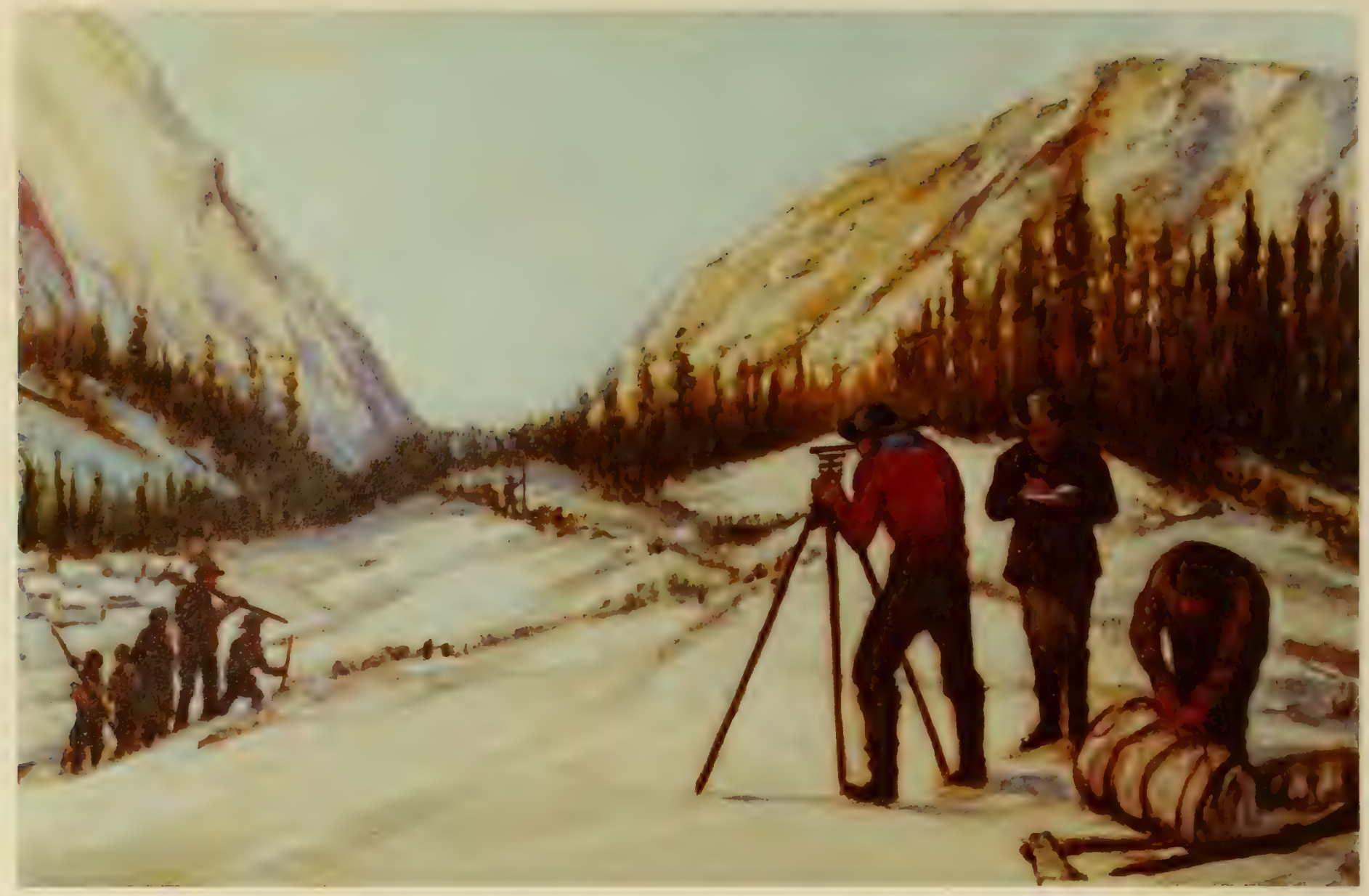

1862-The Mullan Road.

These roads were crude-mere wagon tracks across the prairies or traces chopped through the heavy timber of Florida or Wisconsin-but in the early years of settlement, they were often the only roads the settlers had. Among them were the famous Santa Fe Trail from Kansas City to Santa Fe, New Mexico, marked by the Army, following a route originally beaten by traders and trappers, and Colonel Cooke's Road from Santa Fe to San Diego, pioneered by the Army in 1846. The Army reopened the 400-mile Old Spanish Trail from Pensacola to St. Augustine, Florida, in 1824-1830. Military roads radiated like the spokes of a wheel from strategic Detroit toward Chicago, Grand Rapids, Saginaw and Cleveland, and in 1838 a 512-mile wagon road was made from $\mathrm{Ft}$. Snelling, Minnesota Territory, to Ft. Leavenworth in Kansas Territory.

One of the most remarkable of the military wagon roads was located and built by Lieutenant John Mullan in 1858 to 1862 from Fort Benton in Dakota Territory, the head of steamboat navigation on the
Missouri River, across the Rocky Mountains to Old Fort Walla Walla on the Columbia River. For 20 years afterward, this road was the only way open to emigrants into western Montana and northern Idaho. ${ }^{37}$

In the single year 1866 there passed over the Mullan Road 20,000 persons travelling back and forth, including 2,000 miners stampeding into Montana, 1,500 head of horses, 5,000 head of cattle, 6,000 mules loaded with freight, 83 wagons and $\$ 1$ million in money. ${ }^{38}$

During the overland migrations of the 1850 's and 1860 's, the Army improved and marked most of the pioneer wagon trails and used them to supply its garrisons. Between 1850 and 1869 some of these trails were transcontinental mail routes used by the Butterfield Overland Mail, the Pony Express, and other mail contractors.

After the Government divested itself of the National Road, military roads were practically the only Federal subsidies to local transportation. These were meager indeed, compared to the largesse that was distributed by Congress to the railroads. 


\section{REFERENCES}

${ }^{1}$ A. B. Hulbert, Histortc Hrghways of America, Vol. 11 (Arthur H. Clark, Co., Cleveland, 1904) pp. 157, 158.

${ }^{2}$ P. D. Jordon, The National Road (Bobbs-Merrill, Indianapolis, 1948) pp. 71, 72.

A. Rose, Historic anerican Highways-Public Roads of THE PAST (American Association of State Highway Officials, Washington, D.C., 1953) p. 66.

4 Office of Federal Coordinator of U.S. Transportation, Public aids to Transportation, aids to Railroads and ReLATEd SUBJECTS, Vol. II (GPO Washington, D.C., 1938) p. 7.

sA. Gallatin, Report of the Secretary of the Treasury on Roads and Canals, S. Doc. No. 250, 10th Cong., 1st Sess., p. 724 (1808).

' $Y d$., p. 725.

'Annals or Congress, 14th Cong., 2d Sess. (Gales and Seaton, Washington, D.C., 1854) pp. 851-854.

${ }^{8} I d .$, pp. 1061, 1062.

- Id.

${ }^{10}$ A. Rose, supra, note 3, p. 66.

${ }^{11}$ A. B. Hulbert, Historic Highways of America, Vol. 10 (Arthur H. Clark, Co., Cleveland, 1904) p. 26.

${ }^{12}$ Id., p. 54.

${ }^{13}$ P. D. Jordan, supra, note 2, p. 88.

${ }^{14}$ A. B. Hulbert, supra, note 11, pp. 58, 59.

${ }^{15} I d ., \mathrm{p} .59$.

${ }^{16} I d$., pp. 194-197.

${ }^{17}$ P. D. Jordan, supra, note 2, p. 217.
${ }^{18} I d$., p. 238.

${ }^{10} I d$., p. 170 ,

${ }^{20}$ A. B. HULBert, supra, note 11, p. 73 .

${ }^{21} I d$., p. 90 .

${ }^{22}$ P. D. JORDAN, supra, note 2, p. 175.

${ }^{23}$ A. Rose, supra, note 3, p. 57.

${ }^{24} I d$. p. 58.

${ }^{25}$ A. B. Hulbert, supra, note 1, pp. 171, 172.

${ }^{20}$ A. Rose, supra, note 3, p. 58.

${ }^{27}$ A. C. Rose, The Michigan Road, Road Butlders Newis, Vol. 38, No. 7, Aug. 1938, pp. 12-17.

${ }^{28}$ OFF, OF FED. Coordinator, supra, note 4 , p. 7.

${ }^{20} I d$.

${ }^{30} I d$, p. 8.

${ }^{31} I d$.

${ }^{32} I d$., p. 9.

${ }^{9}$ A. Rose, supra, note 3, pp. 44, 45.

${ }^{34} I d$., p. 44.

${ }^{35} I d .$, p. 51

${ }^{36}$ Military Roads. A Brief History of the Construction of Highways by the Military Establishment and a GazeTteer of the Military Roads in Continental United States (National Highway Users Conference, Washington, D.C., 1935) pp. 1-14.

${ }^{37}$ A. Rose, supra, note 3, pp. 80, 81 .

${ }^{98}$ R. E. HULt, Steamboats in the Timber (Binfords and Mart, Portland, 1952) App., p. 205. 

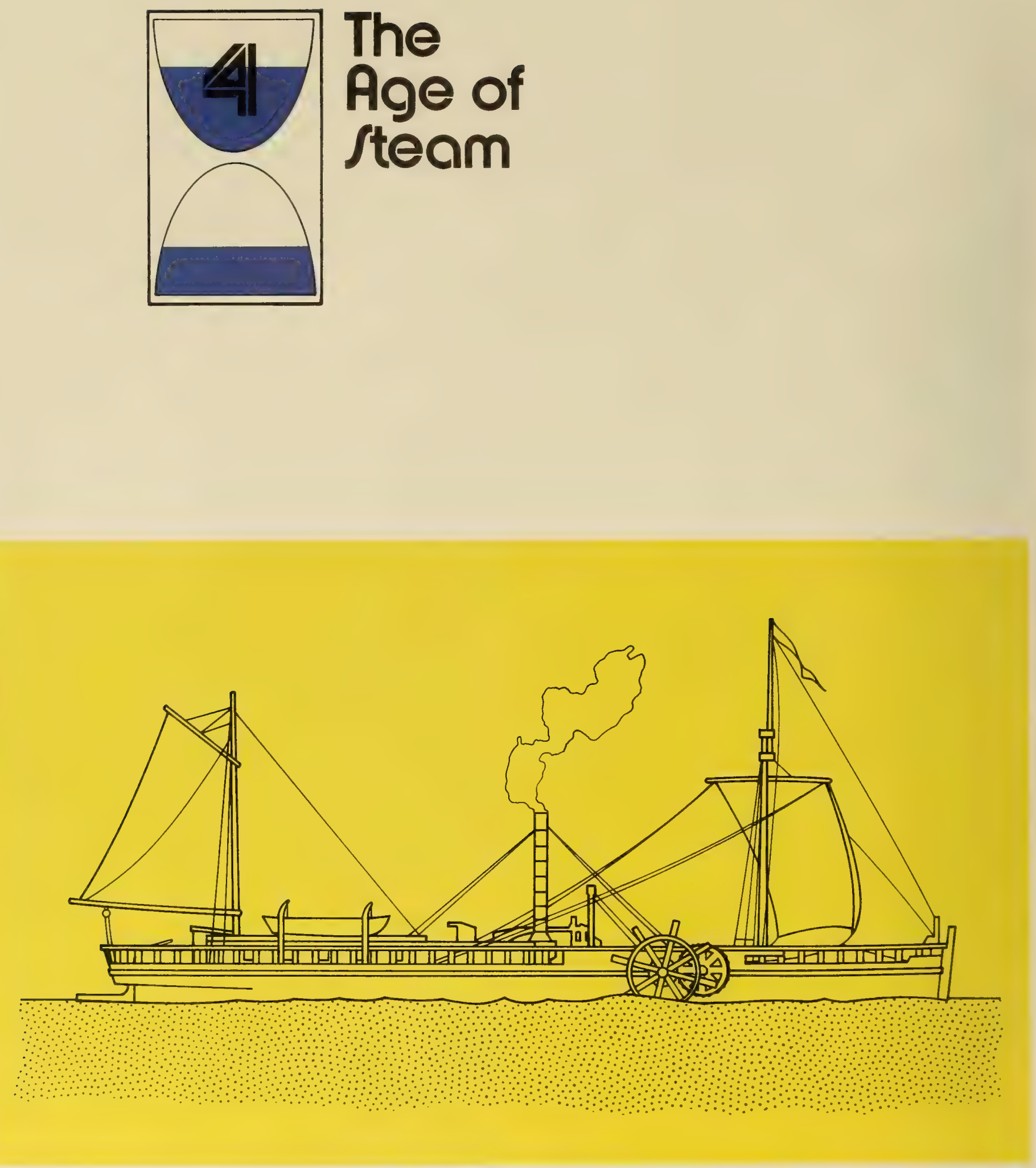

1807-Robert Fulton's CLERMONT 


\section{The Beginning of Steam Navigation}

The revolution of mechanical propulsion affected marine transport about a generation before it became apparent on land. In 178T, John Fitch established the first regular steamboat service in the United States on the Delaware River, between Philadelphia and Bordentown, 28 miles away. His ship, a stern wheeler, could make 8 miles per hour, but the machinery occupied so much space that little was left for cargoes and the ship was commercially unsuccessful. After running some 2,000 miles, she was laid up in 1790 and never used again. ${ }^{1}$

In 1807 Robert Fulton, with the backing of Robert R. Livingston, designed a steamboat with an economic ratio of power to capacity. This vessel was 133 feet long, with a beam of 13 feet, and weighed 100 tons. She was a sidewheeler, powered by an English Boulton and Watt engine of about 20 horsepower, and could make the 150-mile trip from New York to Albany in about 30 hours. From her maiden voyage in August 1807 , the Clermont was a commercial success. ${ }^{2}$

Henry Shreve had his own ideas about steamboat construction for river navigation. He knew that the western rivers were treacherous, filled with snags and shifting sandbars, and subject to tremendous fluctuations in water level. To successfully combat these hazards, a ship should have a very shallow draft and a very powerful engine. To implement these ideas, Shreve built his own steamboat, laying the keel in September 1815 at Wheeling, Virginia. Essentially, the Washington was a flatboat powered by steam, with the engine on the main deck and the boilers on another deck above. To get the extra power he needed, he operated the boilers well above atmospheric pressure. The two-cylinder engine could develop over 100 horsepower driving the ship's stern paddlewheel. ${ }^{3}$

The Washington broke all previous records for speed on the Mississippi and Ohio Rivers, and she was in fact the prototype for the great fleet that plied these rivers for the next 50 years. In the spring of 1817, Shreve took her from Louisville to New Orleans in 17 days, returning the 1,352 miles upstream against the current in 24 days. By 1860 , river steamers that could make the upstream voyage in less than 5 days were in regular service. ${ }^{4}$

\section{Steam Navigation Thrives}

After Fulton's successful demonstration that steam propulsion was practical, the steamboat industry prospered. Between 1807 and 1817, 131 vessels were built in the United States, and by 1832 there were 474 in operation. Some of these were ferries for transporting passengers, carriages and wagons across large rivers. In 1837, 158 steamboats were launched, and by 1846 , steamers were being built at a rate of 225 per year. ${ }^{5}$ By 1859 , there were more than 2,000 steamboats on the Mississippi River and its tributaries.

Steamboats were a major factor in opening the west for settlement. River villages became busy ports and then thriving cities, such as Memphis, St. Louis, Louisville and Cincinnati. Above all, New Orleans prospered on the river traffic, becoming the third busiest port in the United States, and in 1860 the value of products passing through her port exceeded $\$ 200$ million. ${ }^{6}$ Every overland trail to the Far West began at the head of steamboat navigation on some western river.

\section{Federal Assistance to Navigation}

The first Federal act for navigation improvement was passed in 1809. Thereafter, up to 1830 , Congress appropriated $\$ 2,867,000$ for subscriptions to canal stock and for such improvements as ports and piers and removal of river obstructions-slightly more than had been appropriated for the National Road. ${ }^{7}$ A large part of these appropriations was spent to remove hazards from the Ohio and Mississippi Rivers.

From 1830 onward, Congress appropriated generously for river and harbor improvements, many of them as completely within a single State as the Maysville Turnpike. In addition to improving the major rivers, the Great Lakes and the coastal ports, many creeks and inlets were made navigable, encouraging not only the flow of commerce but also the flow of Federal dollars into every congressional district.

\section{Railroad Expansion}

By 1850 the railroad had proved to the American people, and particularly to those who had money to invest, that it was far faster, cheaper and more adaptable to the country's transportation needs than either turnpikes or canals. As investment flowed in everincreasing amounts into railroads, the funds available for extending or even maintaining the old horsedrawn facilities became less and less and finally dried up altogether.

In the 1850 's railroad building escalated into a national frenzy. "The people were crazed with the idea of improvement; every town wanted to grow bigger and a railroad was an absolute necessity; scores of companies were formed with the intention of beginning construction, then deeding the improvement to some established line to operate. Many communities subscribed stock, others voted bonds, others paid for right-of-way by private subscription in order to secure a railroad. The result was often overbuilding, parallel lines, too many roads attempting to occupy the same territory, with the result that branch lines often never paid interest on the cost of construction." The fever even spread to Congress, which granted immense tracts of public land to subsidize railways.

With the possible exception of the Baltimore and Ohio, the Pennsylvania and a few others, the early railroads were local ventures, sometimes less than 20 miles long, each connecting a town to its neighbor or to the nearest river, lake, or seaport. In the West and South, many of the railroads were mere extensions of the river navigation systems. However, by 1860 most of the short lines were linked up into systems, a trend that was accelerated in the North and West with the general adoption of the $561 / 2$-inch "standard gauge."

\section{The First Railroad War}

When the Civil War began, about two-thirds of the railroad mileage was in the North. The railroad networks enabled both the Union and Confederate forces to shift men and supplies with a speed previously unknown in warfare. The North had an additional advantage in that it controlled the sea approaches to 


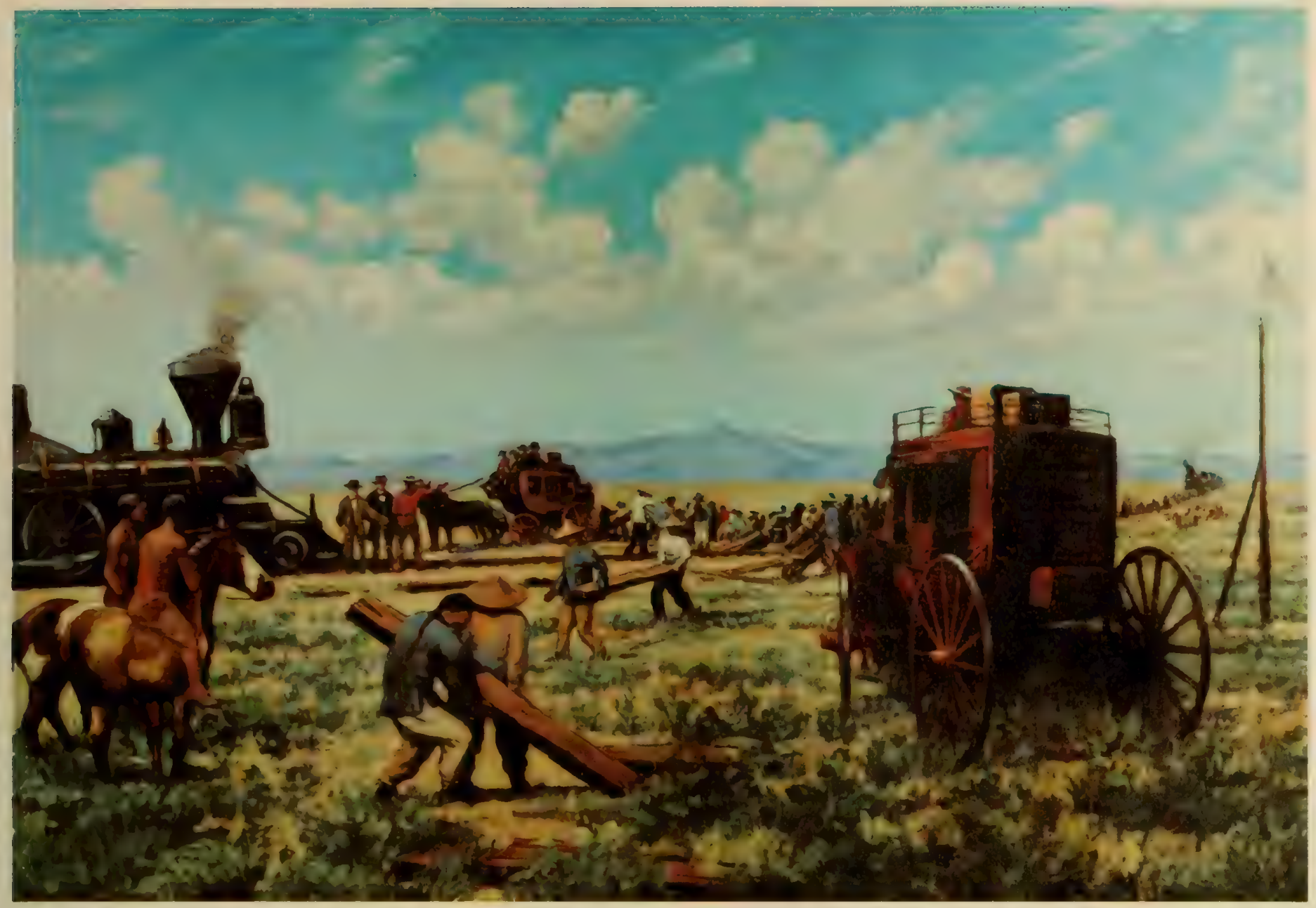

The Meeting of the Rails

Fierce and ruinous competition ensued among the shipowners, whose plight was compounded by the railroads because they began actively extending their lines as soon as hostilities were over. Short lines leading to river ports were extended inland linking up with others, and eventually connecting with each other to form parallel transportation systems which were able to capture the passengers of the steam packets and most of their profitable freight. The unregulated railroads cut freight rates below the cost of haulage on sections where they were in direct competition with water transportation, recouping these losses by charging higher rates on other parts of their systems. Another weapon of the railroads was their refusal to establish joint rail-water rates with the steamboat companies. ${ }^{10}$

Fighting back, the shipowners formed freight pools and organized common carrier packet lines controlling a number of boats. They instituted dependable scheduled service between the principal river ports. These measures slowed the drift to disaster but were unable to check it entirely. Water transportation on the Mississippi system reached its peak in 1889 , when over 28 million tons were carried. Thereafter, traffic declined, in spite of tremendous increases in the Nation's population and wealth, to about 19.5 million tons in 1906, and 16 million tons in 1916. Practically all of this was heavy bulk freight, such as coal, stone and gravel, carried in long barge tows. The romantic river packets were becoming things of the past. ${ }^{11}$

\section{Federal Subsidies to Railroads}

Early Federal subsidies to railroads had been in the form of surveys made at Government expense by civil engineers and officers of the U.S. Army and the remission of import duties on railroad iron.

The numerous turnpike and canal projects of the early 1880 's created a brisk demand for civil engineers and surveyors, yet the supply of such individuals in the United States was quite limited. The largest group was employed by the U.S. Army in its Corps of Engineers.*

In April 1824, Congress passed the General Survey Bill (4 Stat. 22), appropriating $\$ 30,000$ annually and authorizing the President to use a limited number of civil engineers and officers of the Corps of Engineers to prepare the necessary surveys, plans and estimates for "'such roads and canals as he may deem of national importance, in a commercial or military point of view, or necessary for the transportation of the public mail." "The employment of Government engineers was not limited to surveys ordered by law or by resolutions of Congress, but was interpreted by the President to apply also to "Surveys of a national or highly interesting commercial character, applied for by states or incorporated companies," "and when engineers could be conveniently spared from other work. ${ }^{12}$

* The first engineering school in this country was the United States Military Academy, founded in 1802. 
Although railways were not specifically mentioned in the Act, all of the 61 surveys made or proposed were for railways, and the amount spent on them was about $\$ 75,000 .^{13}$

Another early and very substantial Federal aid to railroads was the remission of import duties on railroad iron during the years 1830 to 1841 . The total duties remitted in this period-almost $\$ 6$ milliongave the infant railroad industry a much-needed boost at a critical time in its history at the expense of the infant iron industry.*14

By an act approved on July 7, 1838, Congress made all railroads "post routes" and, thus, eligible to carry the mails. Strictly speaking, this was not a subsidy,

* The remitted duty amounted to about $\$ 2,000$ per mile of track, or almost one-sixth of the total cost per mile. but it opened to the railroads a valuable source of income.

These early aids to railroads were a mere foretaste of what was to come in later years.

\section{The Railroad Land Grants}

In the early 19th century, it was almost an article of faith with the American people that national prosperity depended on the settlement of the western lands, practically all of which belonged to the Government. The Federal policy was to encourage settlement by removal of the Indians, favorable laws and cheap land prices. A logical extension of this policy was to encourage access to the lands by building first the National Road, and later, by subsidizing canals and railroads.

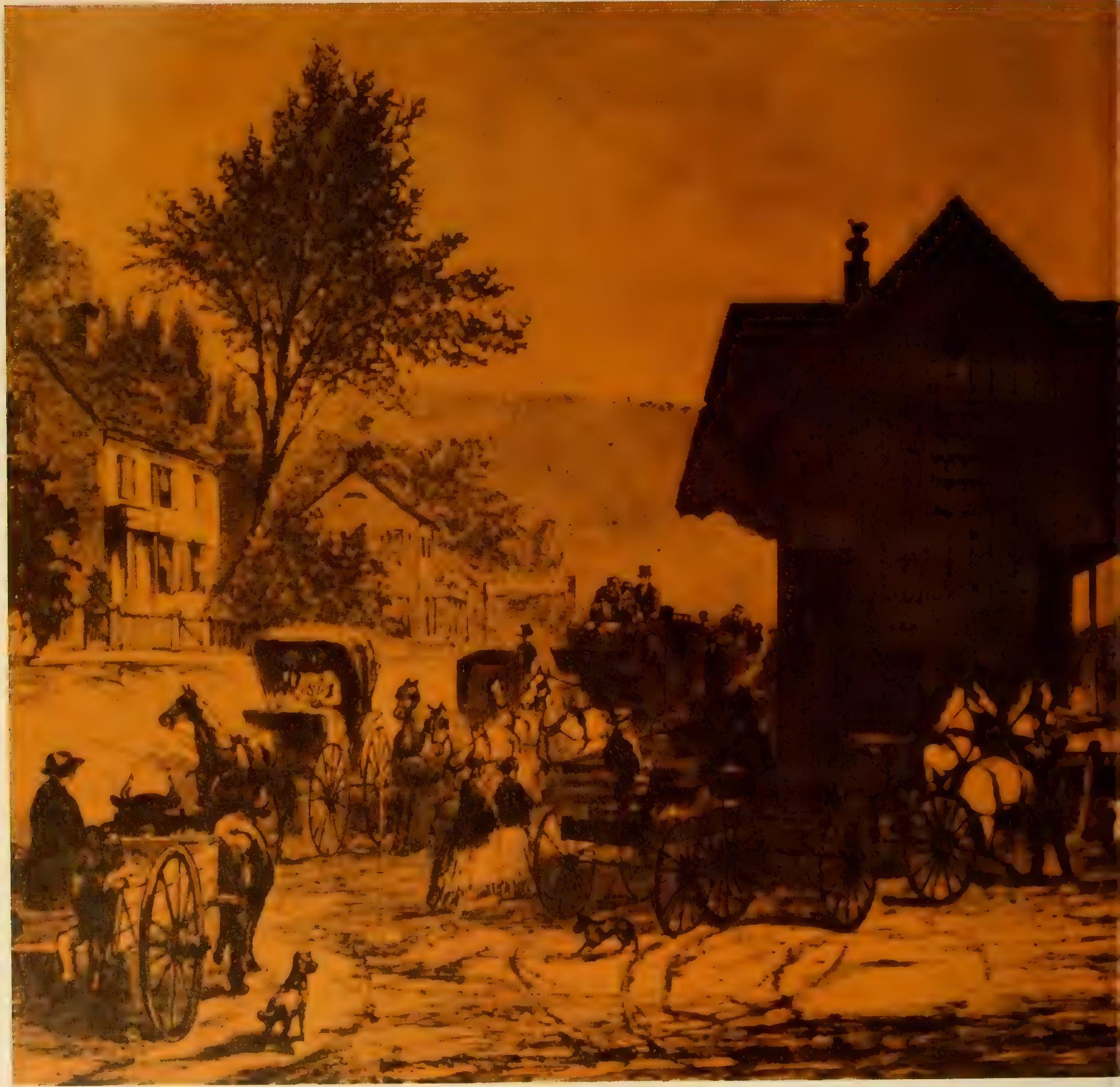


Although railways were not specifically mentioned in the Act, all of the 61 surveys made or proposed were for railways, af about $\$ 75,000 . .^{13}$

Another early an railroads was the $r e$ road iron during tl duties remitted in gave the infant rail at a critical time in infant iron industry

By an act approvi all railroads "post 1 the mails. Strictly

* The remitted duty

track, or almost one-si

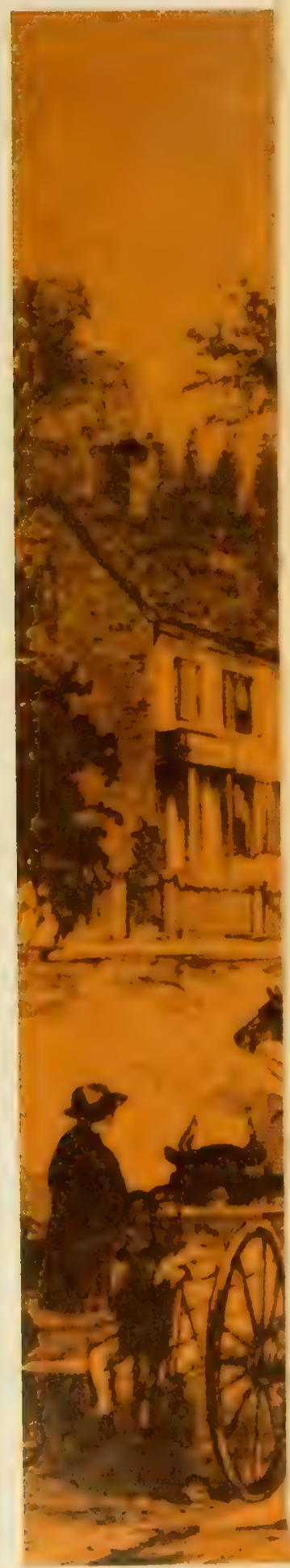

but it opened to the railroads a valuable source of income. 
Although railways were not specifically mentioned in about $\$ 75,0000^{13}$

Another early and very substantial Federal aid to railroads was the remission of import duties on railroad iron during the years 1830 to 1841 . The total duties remitted in this period-almost $\$ 6$ milliongave the infant railfoad industry a mach-nected bo the at a critical the in its history at the

By an act approved on July 7, 1838, Congress made
all railroads "post routes" and, thus, eligible to carry the mails. Strictly speaking, this was not a subsidy, * The remitted duty amounted to about $\$ 2,000$ per mile of but it were a mere foretaste

\section{The Railroad Land Grants}

In the early 19 th century, it was almost an article of faith with the American people that national prosperity depended on the settront the ands, practically all of ment. The Fef the In by removal of the lndians, foron of this policy was to (t) lands by building first the Tational Roal, and later, by subsidizing conals and railroads.
The first Federal land grants for railroads were and totaled 3,736,000 acres of land which the 1850 transferred to the Mlinois Central Railroad and the Mobile and Ohio Railroad. With these grants as precedent, Congress in the period 1850 to 1871 aided lond to nine oral sold by simitar grants of public western States* for * The Government eventually received a handsome return on its grants to the railroads. One of the conditions of these troops, mail, and freight at reduced rates. In other railroads, although not aided by land grants, voluntarily reduced their rates to compete for the Government business. and Government property in transporting the mails, troop. million and by the end of World War II were far above that
amount. ${ }^{\text {at }}$ Congress renounced all rate concessions in 1945.
The railway station was the meeting place for all-greeting
arrivals, farevells to those departing, and a good place to to arrivals, farevells to those departing, and a good place to
pick up the latest gossip by those who just came to wateh.

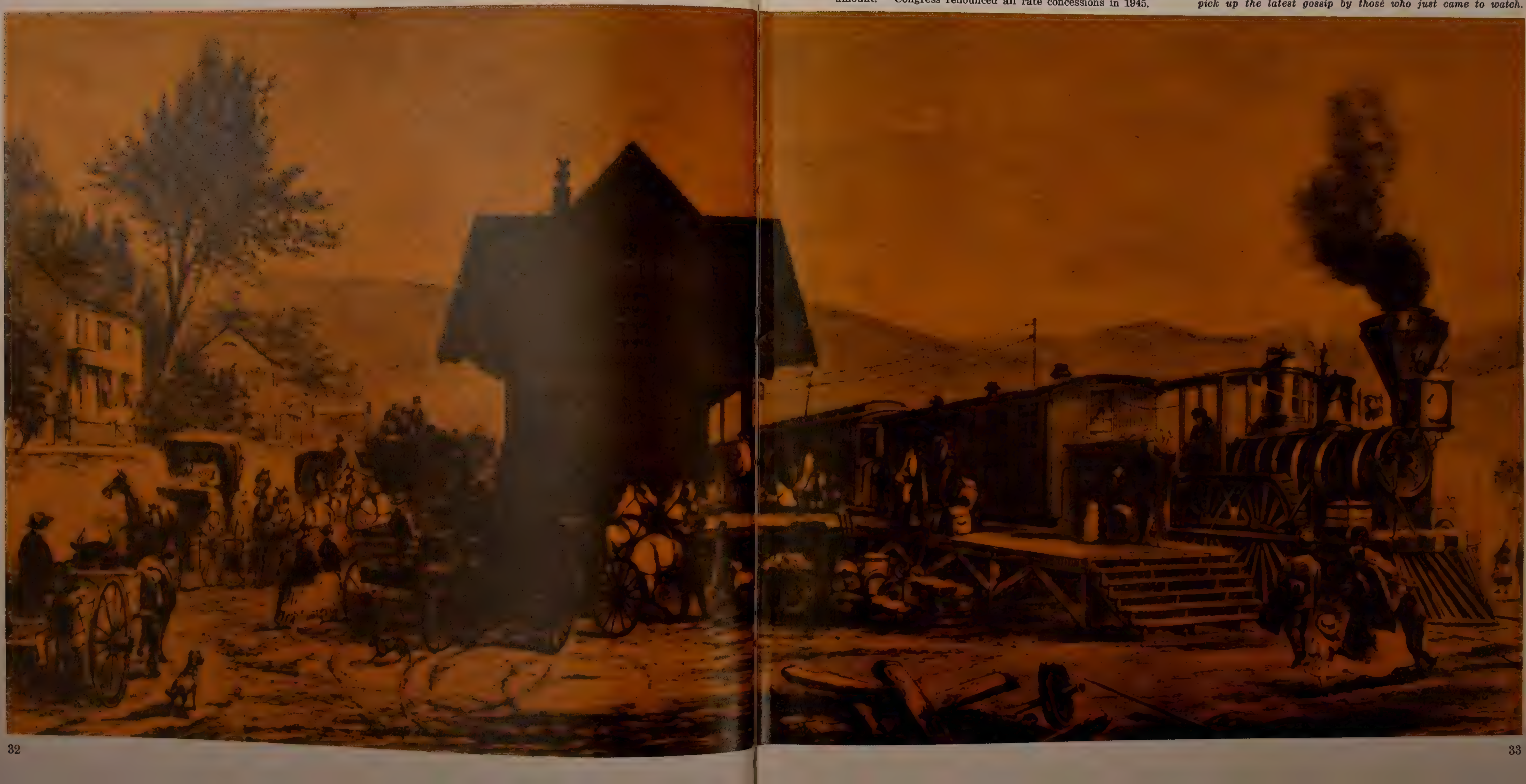




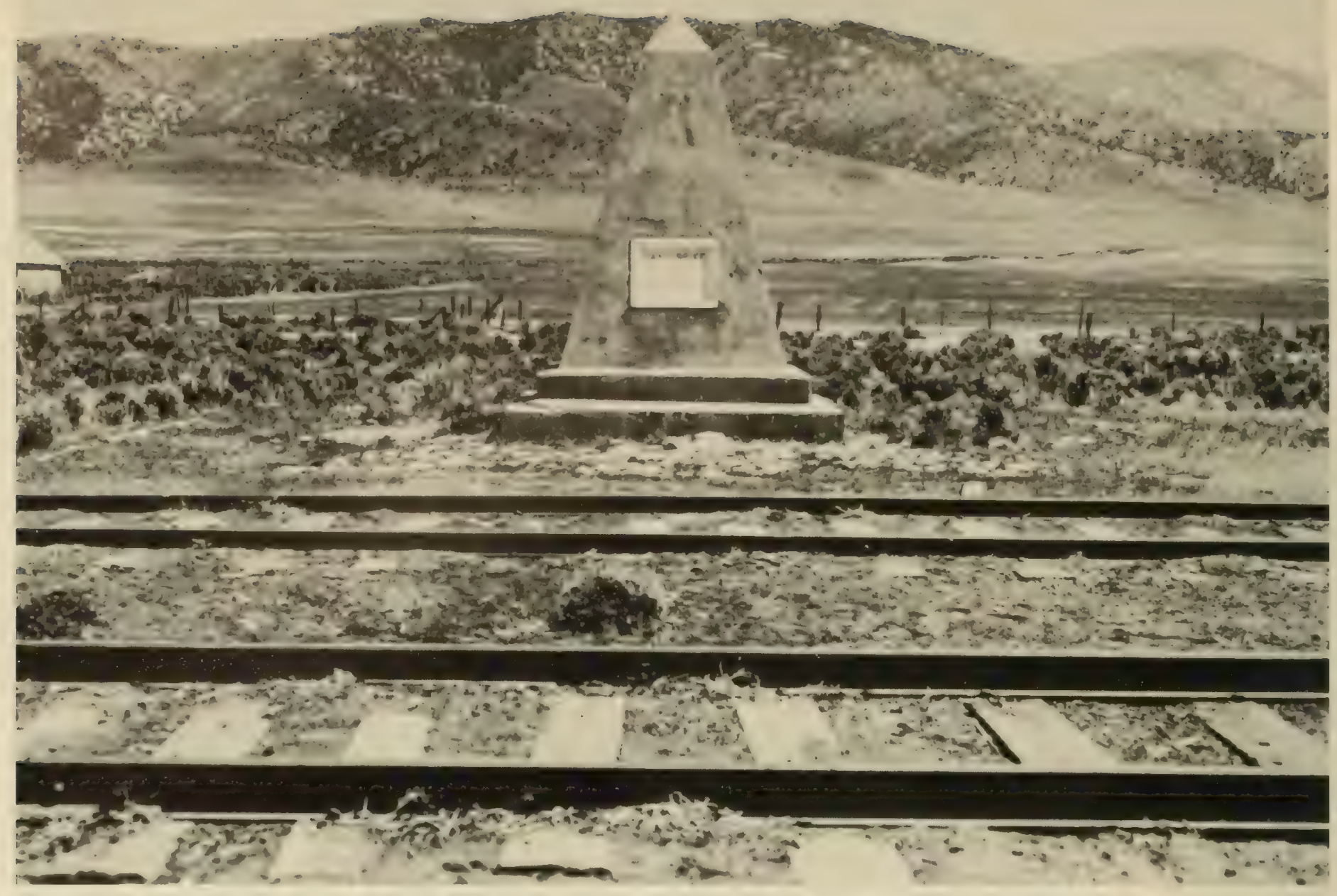

Monument commerating the last spike on the joining of the Central Pacific and Union Pacific railroads into the first transcontinental railway in this country.

a total of about $36,466,000$ acres. Even larger grants were to come in connection with the Pacific railroads. Eventually, Federal land grants to subsidize railroads amounted to 130.3 million acres, to which should be added 48.9 million acres of State land grants. ${ }^{16}$

\section{Railroads Dominate U.S. Transportation}

The northern States had such tremendous productive capacity that they were able to fight the Civil War and at the same time push a railroad across the western plains and mountains. This railroad, liberally aided by grants of public land and Government loans, was completed in 1869. Within the next 20 years, four other transcontinental railroads were completed, along with a north-south railroad through California, Oregon, and Washington Territory, and innumerable connectors, branches, and feeder lines all over the country. In 1887 alone, 12,878 miles of track were laid, and by 1900 there were 260,000 miles of railroad in the United States. ${ }^{17}$

These railroads opened up the country to settlement and development as it had never been opened before. They created the mass market that made the phenomenal industrial expansion of the 1880's, 1890's, and early 1900's possible, and which in turn, started the trend toward urbanization that continues to this day. 


\section{REFERENCES}

${ }^{1}$ R. Kirbi, S. Withington, A. Dariting \& F. Kingour, EngiNeERing IN History (McGraw-Hill, New York, 1956) p. 250.

${ }^{2} I d$., pp. 252, 253.

Id., p. 255.

' $I d$., p. 256.

${ }^{5}$ G. Chatburin, Highways and Highway Transportation (Thos. Y. Crowell, New York, 1923) p. 91.

' $I d$., p. 90.

${ }^{7} I d .$, p. 96.

${ }^{8} I d .$, p. 109.

- M. Whitenead, A Word From The National Grange, Good Roads, Vol. 1, No. 1, Jan. 1892, pp. 82, 83.

${ }^{20}$ Office of Federal Coordinator of U.S. Transportation, Public ards to Transportation, Public amd to Transporta-
TION BY WATER, Vol. III (GPO, Washington, D.C., 1939) pp. 16-18.

${ }^{11} I d$., p. 17.

${ }^{12}$ L. Hanex, A Congressional History of RaIlways in the United States (Reprint, Augustas M. Kelly, New York, 1968) p. 276.

" Office of Federal Coordinator of U.S. Transportation, Public aids to Transportation, Ards to Railroads and ReLAted SubJects, Vol. II (GPO, Washington, D.C., 1938) pp. 4,5 .

${ }^{11} I d ., \mathrm{p} .5$.

${ }^{15} I d$., p. 46.

${ }^{16} I d .$, pp. 11, 12, 32.

${ }^{17}$ B. Weisberger, The Life History of the United States, The Age of Steel and SteaM, Vol. 7 (Time, Inc., New York, 1964) p. 31. 


\section{Rural Roads in the Late 19th Century}

Railroad competition drove the long-distance wagon freighter and stagecoach companies out of business in the 1850 's and 1860 's, and traffic fell off to the point where toll road operation was unprofitable. Some of the turnpike companies were able to sell their roads to the counties for much less than they cost originally; but most of them simply surrendered their charters and ceased operation. Their facilities were then taken over by the local authorities and maintained as common roads. With the heavy through traffic gone, the more prosperous counties were able to maintain these roads in fairly good condition for local travel.* In the poorer counties, travel became more and more uncomfortable as the old turnpikes deteriorated from lack of care.

In the East, the old turnpikes were only a fraction of the mileage under county and township control. Most of the people lived along roads that were established in the early days of settlement through continued public use rather than by plan. These followed the boundaries between farms or occupied the lands least suited for agriculture, and, thus, were often winding and poorly located. Over the years, they had been improved by the county and township supervisors with what scanty funds they could raise from taxes, and practically everywhere, except in the wealthiest counties, these roads were maintained by statute labor.

The local road situation was somewhat different in the "public land States"-i.e., those States that had

* The stone surfaces of the original turnpikes were generally 18 or 20 feet wide. The local supervisors generally re plenished the stone only on the central 10 or 12 feet. $^{1}$

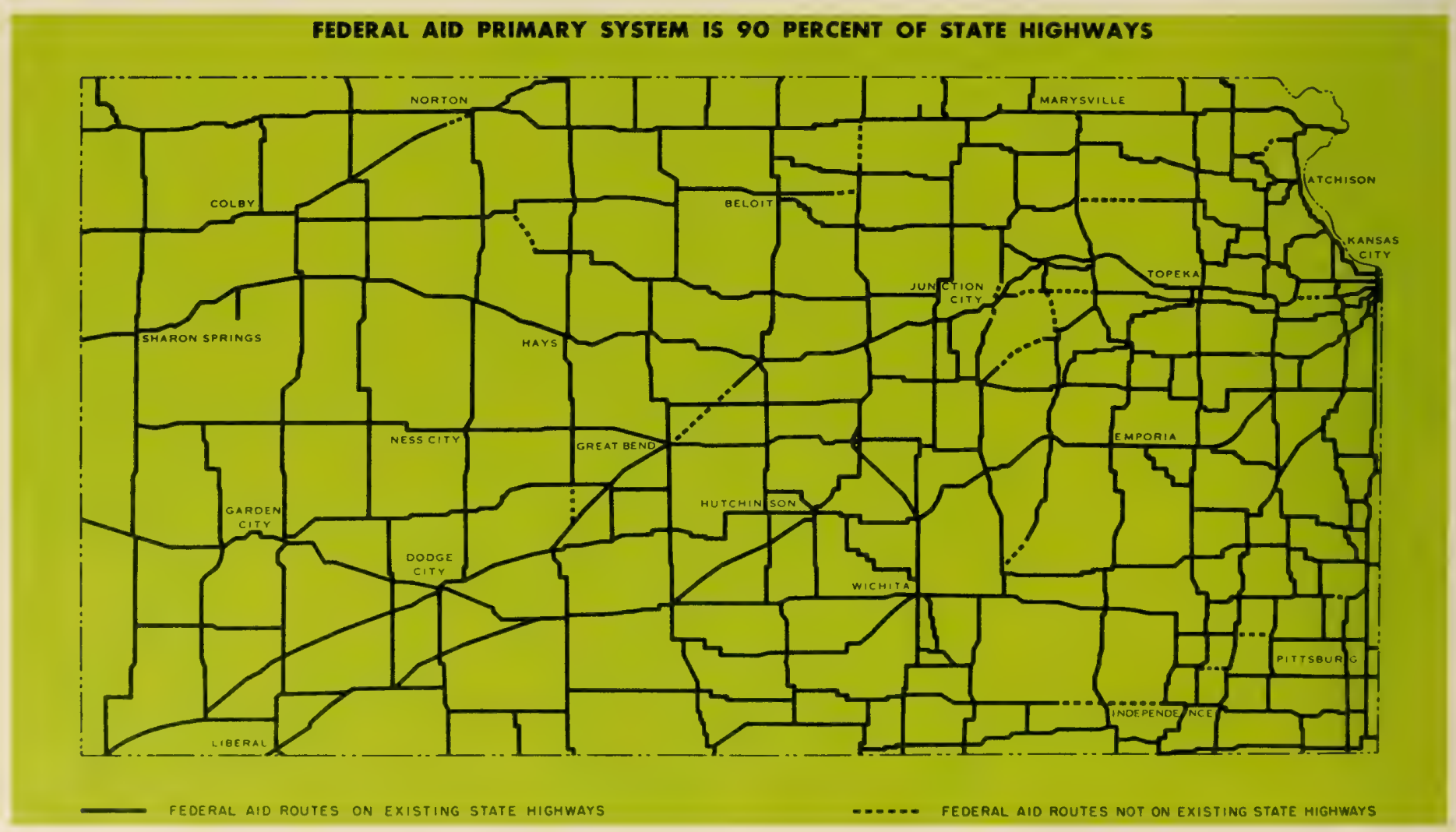

A 1948 map of Kansas showing State highways generally located

on a grid pattern, a carry over from the days when roads were built

on section lines and each owner donated land for the right-of-way. 
been formed from the public domain.* The lands in these States had been subdivided into rectangular townships and sections according to an ordinance of May 29, 1785. These land lines became the boundaries between farms and, thus, were the lines of least resistance for local roads. The customary right-of-way for these roads was one chain wide, or 66 feet, each property owner donating 33 feet on his side of the section line. As in the East, these roads were normally maintained by statute labor.

In the Great Plains and the Far West, this tendency to fix the local roads on the section lines was strengthened in July 1866 by an act in which Congress granted a free right-of-way for public roads over unreserved public lands. A number of counties took advantage of this act by declaring all section lines in the county to be public roads, thus, reserving the right-of-way before the lands became private property. The Legislature of Dakota Territory passed an act making all section lines public roads 66 feet wide, to the extent that it was physically possible to build roads on these lines. ${ }^{2}$

Section line roads were easy to build in level country, but in hilly country it was impossible to stay on the section lines and preserve a reasonable gradient.** The rectangular pattern imposed considerable indirect traffic on those whose destination was diagonal to the land grid. Nevertheless, hundreds of thousands of miles of these section line roads were built as the public land States were settled. Initially, these roads were mere wagon tracks, but over the years many of them were graded and ditched, and some were graveled. This work was aided tremendously by the introduction of blade graders after 1878. Some of these were pulled by 6 horses and in easy country, a mile of ditched earth road could be built in a single day.

The years between 1850 and 1900 have been called the "dark age of the rural road," yet in this period well over $11 / 2$ million miles of rural roads were built in the United States. It is true that, with insignificant exceptions, these roads were unimproved, or at best only ditched and graded, yet in the aggregate they represented a mighty public effort, particularly in the West where population was sparse and the people poor.

\section{The Financing of Rural Roads}

Until the early 1900 's, the main sources of local road funds were taxes on property, poll taxes and statute labor. In 1904 only 25 States had laws permitting counties, townships or road districts to issue bonds for road improvement, and in these the privilege was used sparingly and usually only to finance a particularly expensive purchase, such as a steel or concrete bridge. The total expenditures on rural roads from bond issues were only about $\$ 3.5$ million in $1904 .{ }^{4}$

Property taxes levied for road support varied widely from State to State and from county to county within the same State. As the Office of Public Roads (OPR) observed in 1904,

* All States except the Original Thirteen, and Maine, Vermont, Kentucky, Tennessee, West Virginia and Texas.

** In 1900 there were more roads having excessively steep grades in Iowa than in Switzerland.
Unquestionably the bitterest controversies in counties and townships in connection with the subject of road improvement are over proposed increases in the rates of property taxation for road purposes. It is common in many parts of the United States for uninformed though honestly-disposed citizens, to make a determined opposition to a very moderate and perfectly reasonable increase in the tax rate.

The average tax rate of all counties reporting to the OPR in 1904 was 25.7 cents per $\$ 100$ valuation, but this gives little idea of the tremendous variation between counties, some of which levied only 1.3 cents per $\$ 100$ valuation and some as much as $\$ 1.60$ per $\$ 100$ valuation. ${ }^{6}$ These taxes, together with poll taxes payable in cash, were by far the major source of funds for building and maintaining the country roads, yielding some $\$ 53.8$ million in 1904 . While this seems like a large sum, it amounted to very little when spread over 2.1 million miles of road.?

In 190411 States assessed an annual poll tax varying from $\$ 1$ to $\$ 5$ per person for upkeep of the roads. This tax could be paid in labor or in cash. In addition, 25 States retained the ancient statute labor sys-

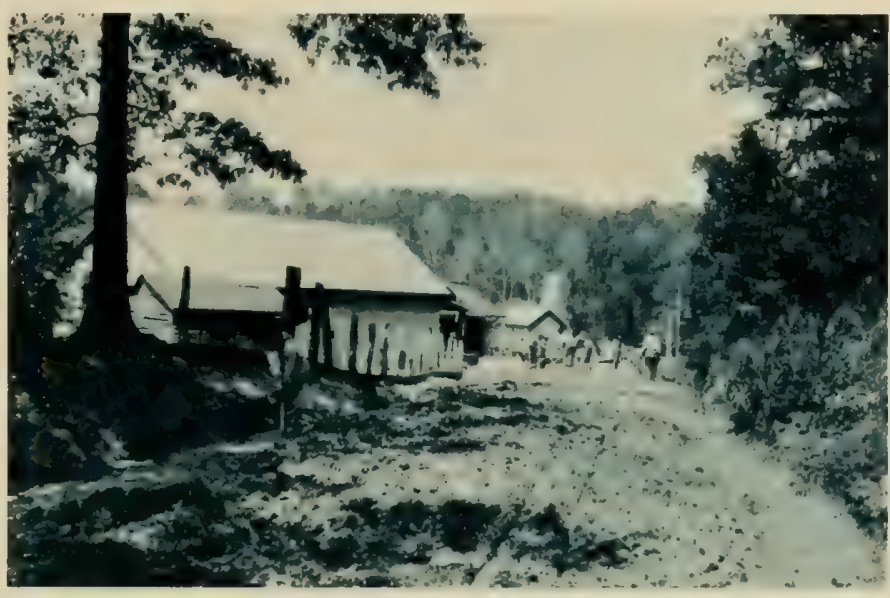

Working out the road tax on a gravel road. Ten days labor or $\$ 5$ tax was required by law in Alabama as late as 1918.

tem under which all able bodied male citizens of certain ages living along a road were required to work on its repair a stated number of days per year or pay the equivalent in cash.* Despite its inefficiency, the work rendered in 1904 by statute labor was valued by the OPR at $\$ 19.8$ million, and amounted to about onequarter of all rural road expenditures that year. ${ }^{9}$

Most of the rights-of-way for county and township roads were donated by their owners to the local authorities, and these donations represented a very considerable part of the original cost of these roads. Over the years, these rights-of-way came to some 10.4 million acres of land, valued in 1904 at about $\$ 342$ million. ${ }^{10}$ The roads themselves probably represented an investment of at least a billion dollars.

This large investment was, however, spread so thinly that very few rural residents enjoyed adequate road service. In the northern States, earth roads were quagmires during the spring thaw and became distressingly soft during rains at any time of year. Deep sand was a problem in many parts of the South.

* As late as 1889 no cash poll taxes or property taxes were levied for road purposes in Kentucky, South Carolina, Georgia, Alabama, Mississippi, Louisiana, New Mexico and Utah, and the rural roads in these States were built and maintained exclusively by statute labor. ${ }^{8}$ 


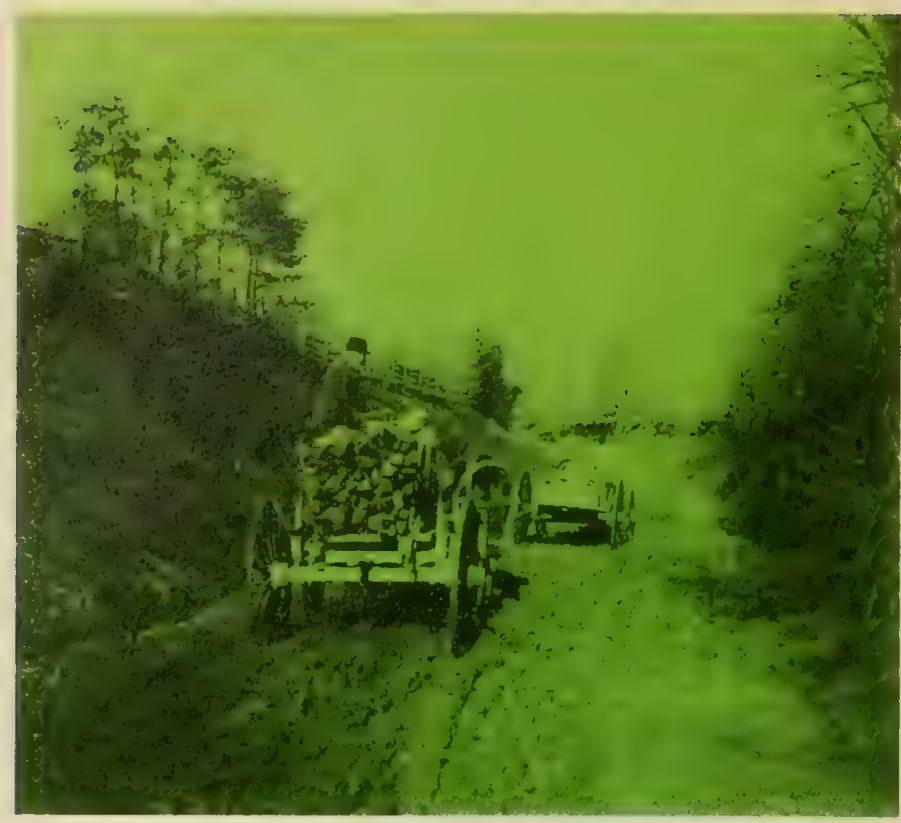

The Jefferson Memorial Road near

Charlottsville, Va., before improvement.
Either way-loose sand or deep mud-the loads a farmer could haul with his teams were only a fraction of what they would have been on a reasonably good road, and this difference was, in effect, a tax on everything the farmer bought or sold. The following account of one farmer's struggle with his local roads is typical of the era:

After the war I lived 9 miles north of Charlotte. The roads at times were so very bad that everybody was landlocked; the ladies could not go to church in winter; they hardly ever thought of going to town. The men went on horseback and sometimes it took a good thoroughbred to carry you there. . . . The first thing that impressed me with the importance of good roads occurred in 1867. It rained almost everyday for a month; the roads were horrible. I left home with two wagons, one with four horses and one with three, to go to Charlotte, only 9 miles away, for some fertilizer. I got a ton on one wagon and half a ton on the other, and when within a mile and a half of home on the return trip we stalled, and had to take the horses out and leave the wagons there all night. We went back after the wagons the next day and it took until nearly 11 o'clock to get them home. The merchant from whom I got the guano paid \$5 per ton freight on it from Baltimore to Charlotte. Considering everything, it cost me over twice as much to take the guano 9 miles from Charlotte to my home as it did to bring it from Baltimore to Charlotte on the railroad.11

The mud could be so sticky that a pair of oxen had difficulty getting these wheels, without a load, free.

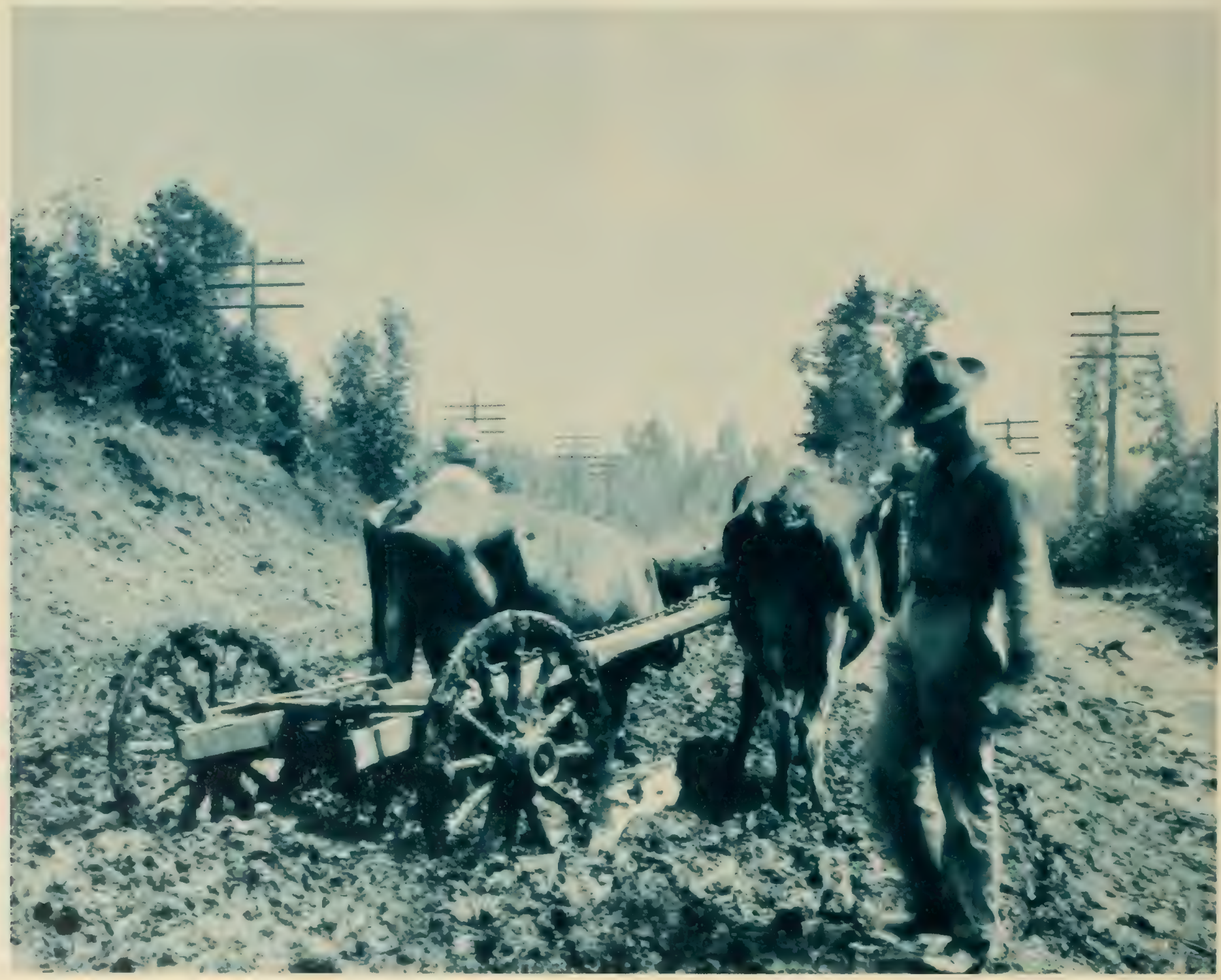



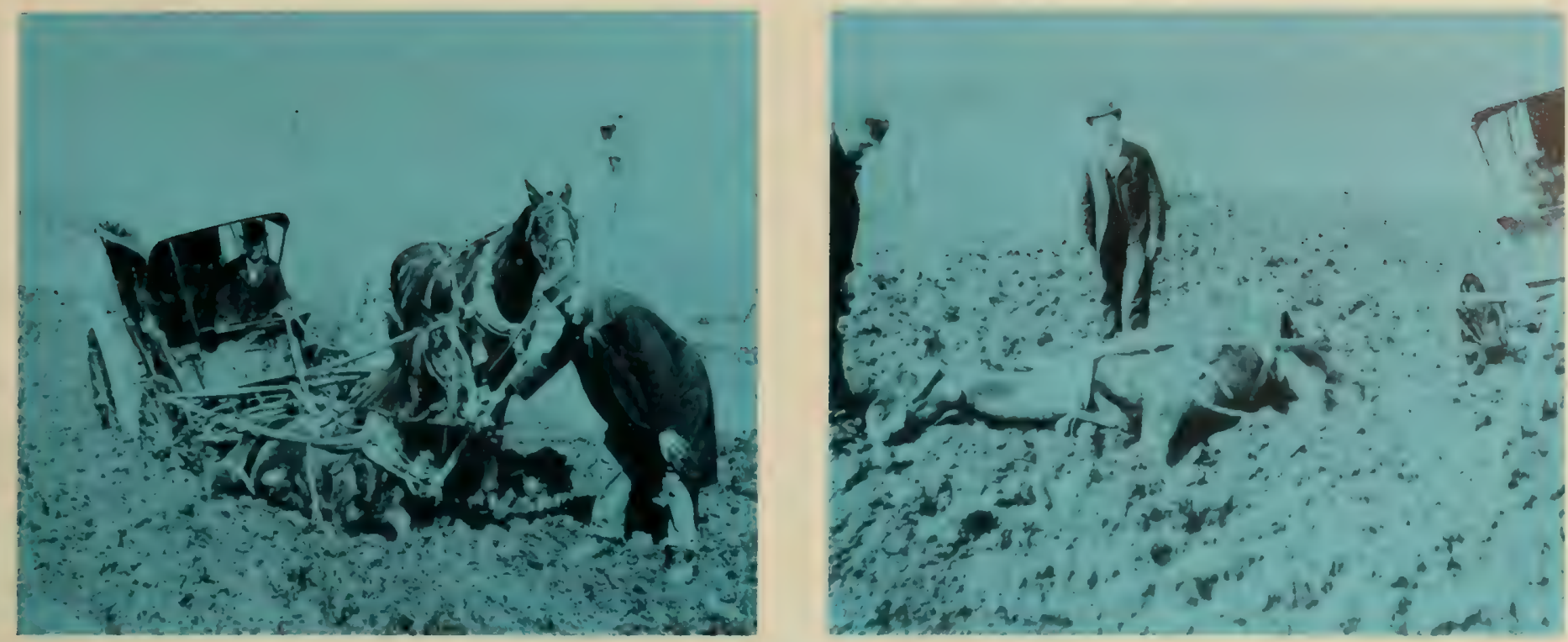

Although this appears to be an exaggerated condition of early roads, it was a common enough occurrence that the Good Roads magazine in May 1892 published the following guide on "What to do When A Horse Falls":

1. Jump down and hold the animal's head, to prevent his dashing it about to his own injury.

2. Loosen the check-rein (if you are so foolish as to use one) and the parts of the harness which fasten on the vehicle.

3. Back the carriage 80 as to get the shafts and traces clear.

4. Steady and support the horse's head, and excite and encourage him, with hand and voice, to rise.

5. When you have got him up pat and further encourage him, and see if he is wounded or otherwise injured.

6. Let him stand still a short time and recover himself, and then proceed gently and with greater caution than before.

The high cost of transport from the farms was also a tax on the people of the cities who were forced to pay higher prices for locally grown food and farm products. In 1901 fruit from California could be shipped to Raleigh, North Carolina, by rail for less than farmers living only 15 miles away could deliver their fruit to the Raleigh markets.

You see by this that the railroads enable the fruit growers of California to compete with the fruit growers of your own county towns. ... The way to successfully compete with these people is to build good roads so as to enable us to get to market at any time and carry a full load, thereby reducing cost of transportation. ... A bad road is a relentless tax assessor and a sure collector. ${ }^{12}$

\section{Transportation in the Cities}

According to the 1900 census, there were 161 cities of more than 25,000 inhabitants. Of these, 27 had populations in the 100,000 to 300,000 range and 11 had more than 300,000 people.

The ability to move goods freely from place to place was absolutely necessary to the prosperity of these cities. Industry, powered by steam, used great quantities of coal which had to be hauled over the streets from the docks and railroad yards to the factories and mills. Similarly, the hauling of raw materials and finished goods to and from the factories, warehouses, docks and railroads generated a tremendous volume of truck and dray traffic. Outside of the industrial areas, city dwellers depended on their streets for deliveries of coal, ice and groceries.

A typical 3-horse truck of the 1890's weighed 7,000 pounds empty and could carry a 10-ton pay load, and horsedrawn trucks and drays capable of hauling 18ton net loads were fairly common in large cities. These vehicles ran on steel tires which pulverized all but the hardest pavement surfaces. Consequently, the main streets of the large cities were built very heavily and surfaced with granite blocks or hard paving bricks.* The minor business streets and residential streets were commonly of macadam or gravel, and in the 1890 's many of these were made dust-free by asphalt surfacing. $* * 14$

For the most part, city dwellers enjoyed excellent local transportation. Even comparatively small cities had horsecar lines, some of which persisted into the early 1900's. About 1873 cable railways were introduced in the larger cities, but in the 1890's these, as well as most of the horsecar lines, were converted to electric propulsion. "By 1890 more than one hundred American cities had installed or were in the process of installing electric street railways." 16

Small towns on the peripheries of the large cities were tied to the cities by steam railroads and after about 1894, by electric interurban railroads as well. Frequent schedules on these railroads made it convenient for thousands of the more prosperous city workers to live in the suburbs and commute to work.

\section{The Financing of Urban Roads and Streets}

Concentrated populations, trade and industry built a fruitful base for property taxation in the cities. These taxes, supplemented by special assessments, provided the funds for thousands of miles of improved

* Broadway in New York City was surfaced with blocks of granite 10 inches thick laid on a 6-inch concrete base; and in Philadelphia pavements for important streets were made of 8-inch stone cubes laid on beds of gravel 15 inches deep. ${ }^{18}$ In the 1890 's these stone pavements were overlaid with asphalt to reduce noise and rolling resistance and to provide better footing for the horses.

** Asphalt paving was first used in New York and Philadelphia in 1871 and immediately became popular because of its smoothness, silence and ease of cleaning. By 1897 over 27.4 million square jards of asphalt were laid in American cities. ${ }^{15}$ 


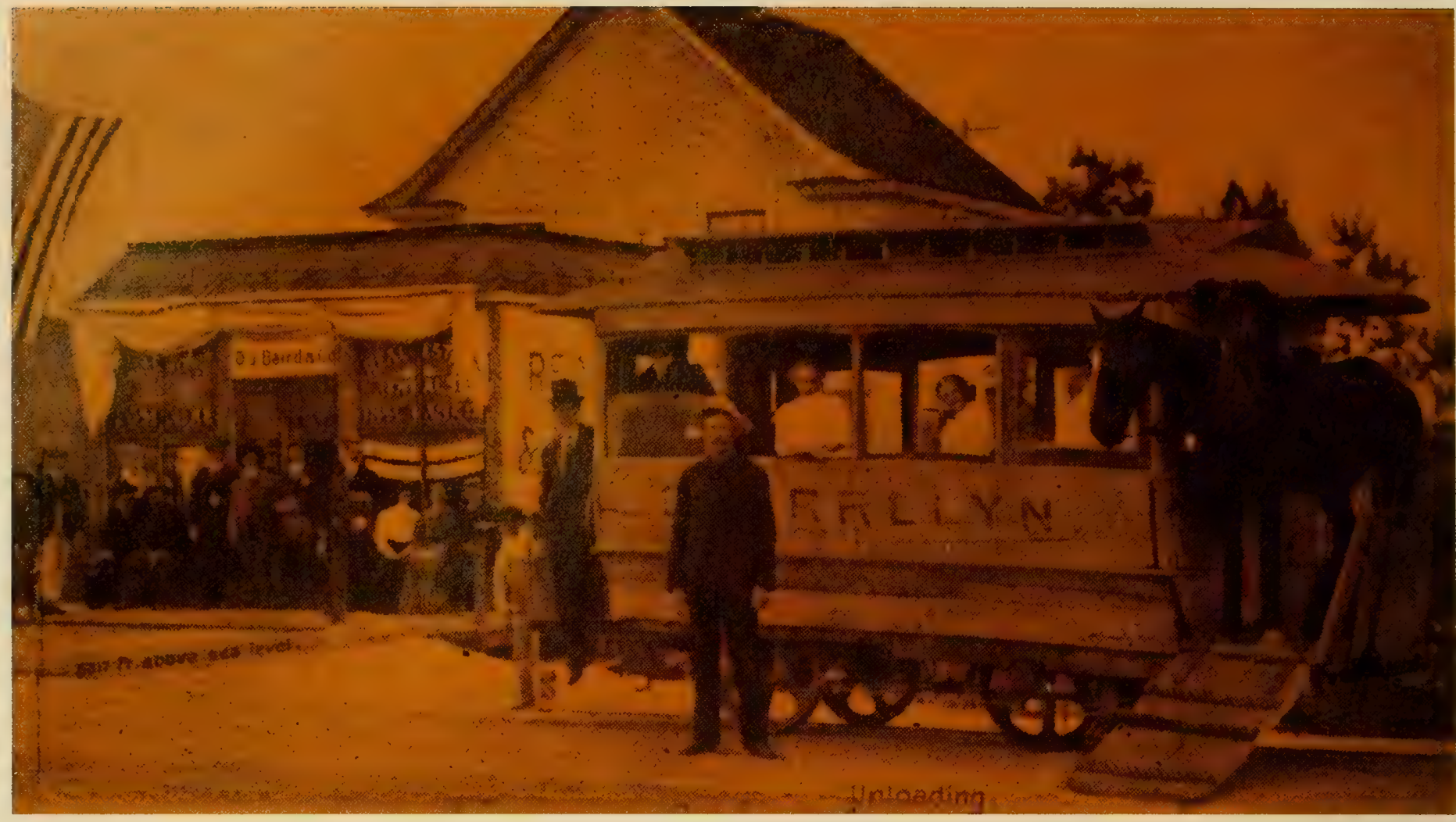

The Cherrelyn Horsecar was unique among horsecars of the day for the horse only pulled the car one way and was a nonpaying passenger on its return trip. It operated up and down the steep hill from downtown Englewood to Cherrelyn (Colorado), a distance of almost a mile, between 1883 and 1910. The horse, sometimes wearing a straw hat, riding on the special platform on the back of the car was a popular attraction for both tourists and residents. Today the old Cherrelyn is restored and is on display near the City Hall in Englewood.

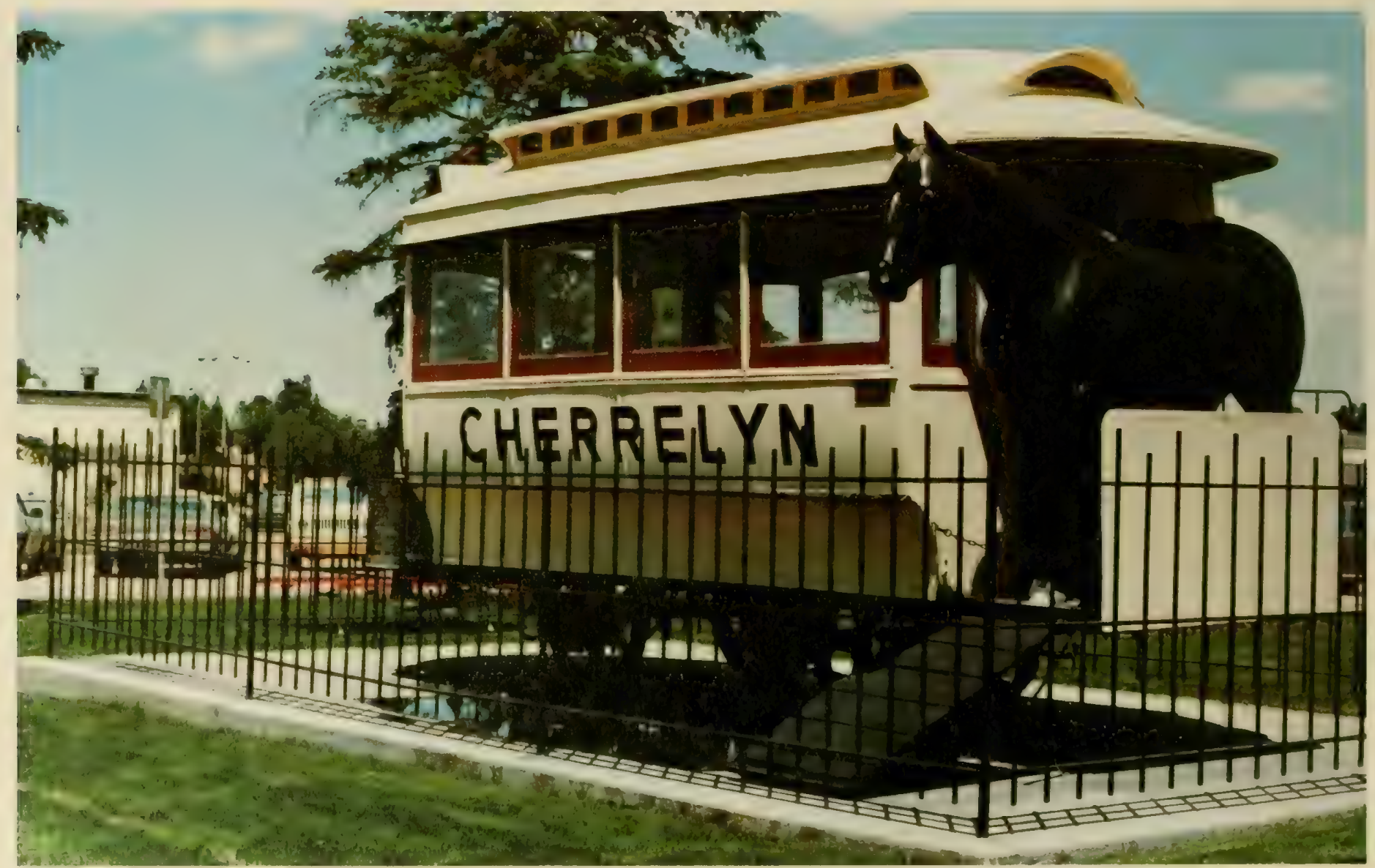




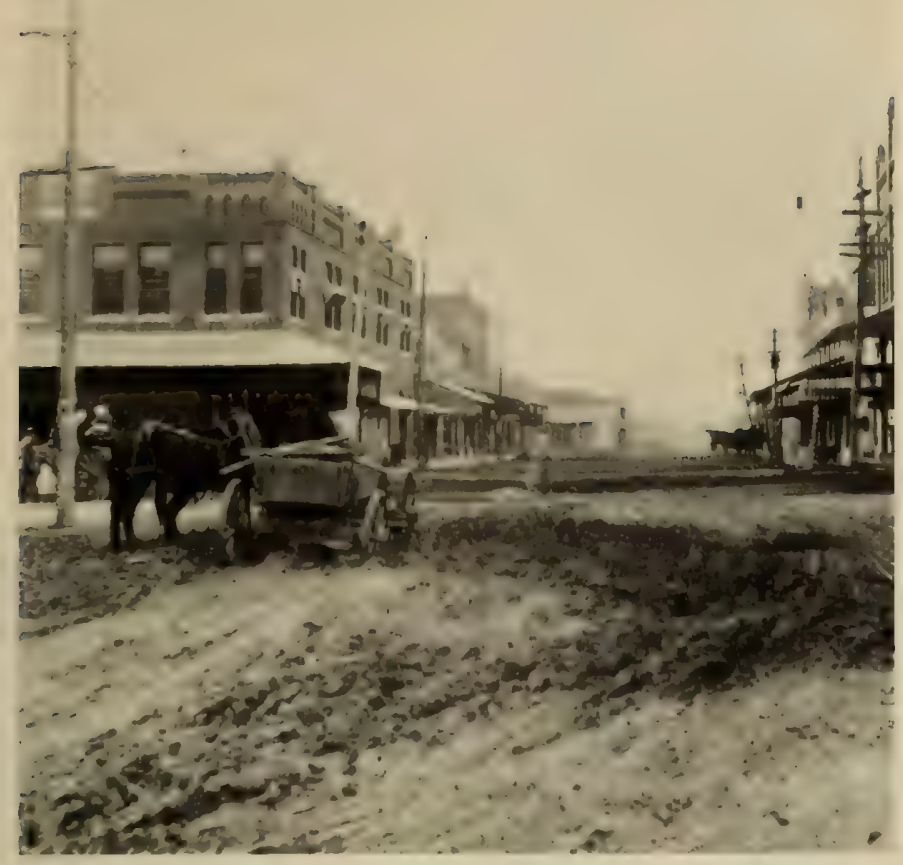

Even the streets of some towns were nearly as bad as the rural roads after a heavy rain.

streets, ${ }^{*}$ as well as sewers, water supplies, street lights, schools, parks and other municipal services far beyond the reach of the rural citizens.

Most city street improvements were financed by bond issues which were amortized out of general tax revenues. The cities for the most part avoided "payas-you-go" financing and did most of their original construction by contract.

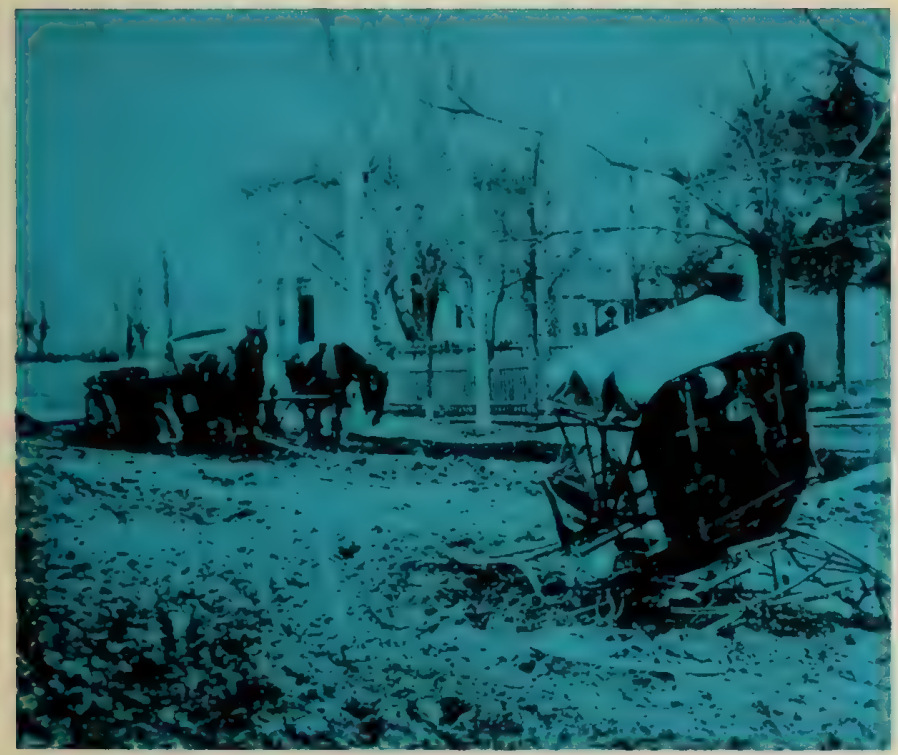

Broken and abandoned carriages vere the eyesore of the day.

* In 1907, the first year for which reliable figures are available, there were 47,000 miles of roads and streets in cities of 30,000 or more population, of which 20,646 were improved with some kind of surface better than dirt. These included 7,675 miles of heary-duty pavement; 4,161 miles with asphalt surfaces : 6,274 miles of macadam; and 2,536 miles of gravel, ${ }^{27}$
Practically all American cities enjoyed the right, conferred upon them by the State legislatures, to assess the cost of street improvements to the benefited property. This power greatly enlarged the financial resources available to the cities for improvements.*

City dwellers were exempt from the obligation to perform statute labor. Instead of relying on the obsolete and wasteful statute labor system, cities accomplished their street maintenance with paid labor under the supervision of civil engineers or, at the least, persons with some knowledge of roadbuilding, and paid for it out of general tax revenues.

\section{Beginning of the Good Roads Movement}

The great disparity between the cities and the rural areas in the quality of life was evident to everyone, but few city dwellers thought they had any obligation to do anything about it. They had taxed themselves to build their roads and streets, let the farmers do likewise, was the prevailing sentiment in the cities. Nevertheless, the impetus for road reform came from the cities and primarily from civic leaders who appreciated the economic burdens laid on city dwellers and farmers alike by the bad roads. These leaders realized and accepted the cold hard facts that good roads were impossible without adequate funds and that these could be obtained only by the taxation of urban, as well as rural, property.

In 1879 the General Assembly of North Carolina passed the "Mecklenburg Road Law" permitting that county to levy a road tax on all property in the county, including that in Charlotte, the principal city. The act was repealed the following year, but was re-enacted in 1885, and eventually most of the counties of the State elected to operate their roads under this law. By 1902 Mecklenburg was acknowledged to have the best roads in North Carolina, and its citizens were cheerfully paying the highest road taxes in the State: 35 cents per $\$ 100$ property valuation, plus $\$ 1.05$ on the poll..$^{19}$

The first State road convention was held in Iowa City, Iowa, in 1883, primarily to try to bring about some improvement in the deplorable condition of the rural roads. This convention recommended payment of road taxes in cash instead of labor, consolidation of road districts, letting road construction to responsible contractors, and, most importantly, authorizing county boards to levy a property tax to create a road fund. These recommendations were adopted by the Iowa Legislature in an act passed in 1884, but the reforms were made optional with the counties rather than mandatory. ${ }^{20}$

Other States adopted "good road laws" similar to North Carolina's and Iowa's, but the good roads move-

\footnotetext{
* The special assessment is an institution of American origin, first used in New York City in colonial times to finance streets and sewers. By 1893 all States and Territories had laws authorizing municipal corporations to assess the cost of physical improvements against benefited properties. Street railway companies were customarily assessed with the cost of paving between their tracks, and for a certain distance on each side. The right to make special assessments was rarely conferred on counties and townships, but in some States special road improvement districts were created by the legislature and given the power of assessment. ${ }^{18}$
} 


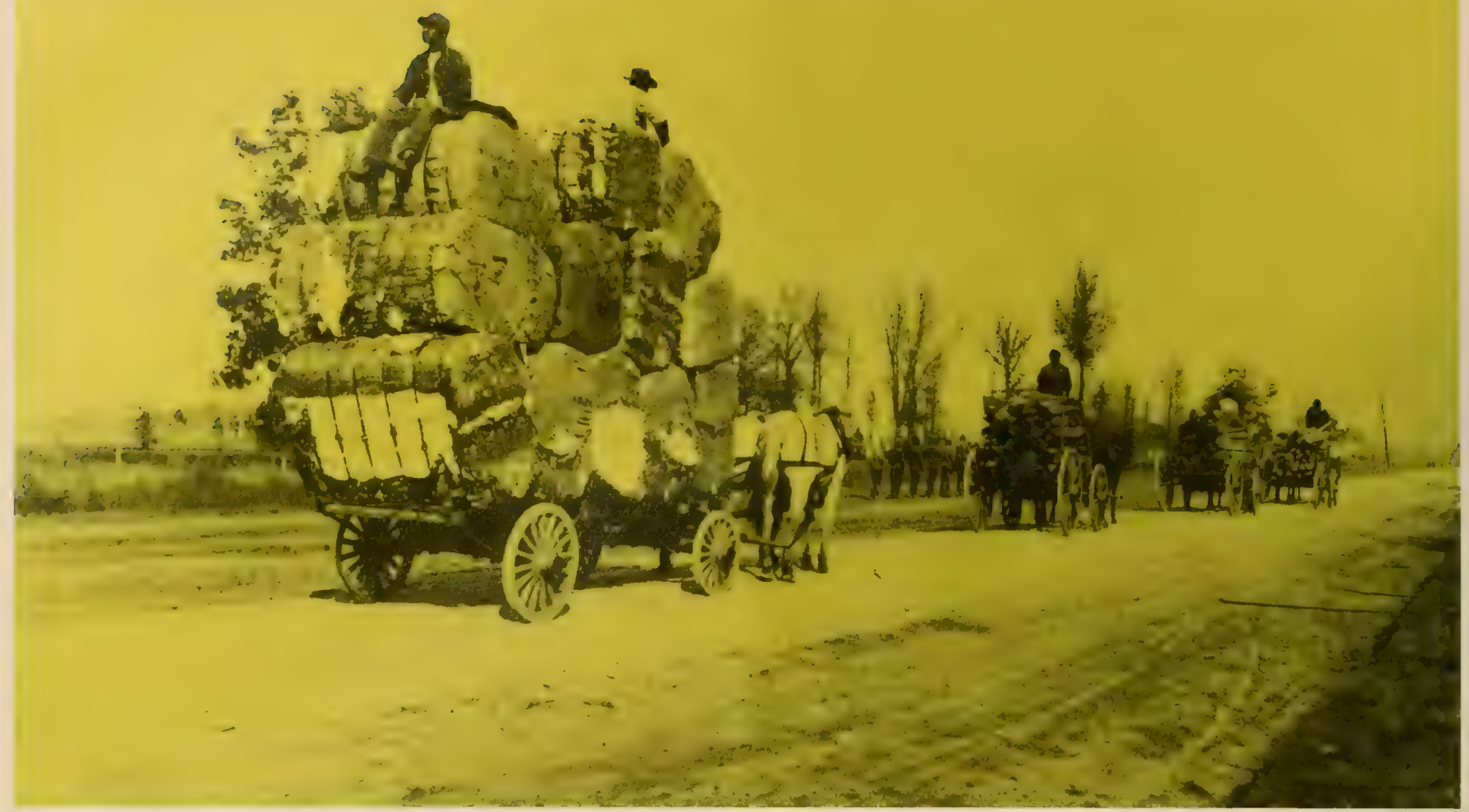

As a result of the Mecklenburg Road Law, loads such as this could be hauled by two mules on a macadamized road in any weather where formerly only two bales of cotton could be hauled on an earth road in fairly good weather.

ment did not really get underway until about 1890 when the organized bicyclists launched a national public relations campaign to whip up sentiment favorable to more and better roadbuilding.

\section{The Wheelmen and The Roads}

Bicycles became practical vehicles for personal transportation with the introduction of the "safety" design* in 1884 and the pneumatic tire in 1888. Almost overnight cycling became a national craze in the United States. "A frenzy seized upon the people and men and women of all stations were riding wheels; ardent cyclists were found in every city, village and hamlet." ${ }_{21}$

The wheelmen were not content to do their riding on the relatively smooth city streets, but fanned out into the country in all directions. They organized cross-country rallies, road races, weekend excursions. These activities brought the wheelmen into intimate contact with the miserable country roads, and they became vociferous advocates of road improvement.

All over the country, the bicyclists formed social organizations, or "wheel clubs," to promote cycling as a sport. Leading this movement nationally was the League of American Wheelmen, which had been organized in 1880 by consolidating a number of local "ordinary" bicycle clubs. Very early in its life the League perceived that cycling as a sport depended on good roads, and it transformed itself into a powerful propaganda and pressure group for promoting them.

\footnotetext{
* They were called "safety" bicycles because, unlike the "ordinary" bicycle with its high front wheel, the rider was less apt to be propelled over the handlebars if he hit an obstacle.
}

"Newspaper space was freely utilized; many papers making special and regular features of 'good roads'; pamphlets were published and distributed broadly, and a magazine was established." ${ }^{22}$ Appropriately, this magazine was titled Good Roads, and it was launched in 1892 under the energetic editorship of I. B. Potter, a New York City civil engineer and lawyer. Good Roads circulated far beyond the ranks of the wheelmen and was very influential in molding public opinion to accept the inevitable taxes that would be required to create good roads. Potter heaped ridicule on American roads by contrasting their sad condition with the fine roads of Europe, particularly those of France. He ran testimonials, praising good roads where they existed in the United States. He

\section{A leisure bicycle trip into the}

country about the turn of the century.

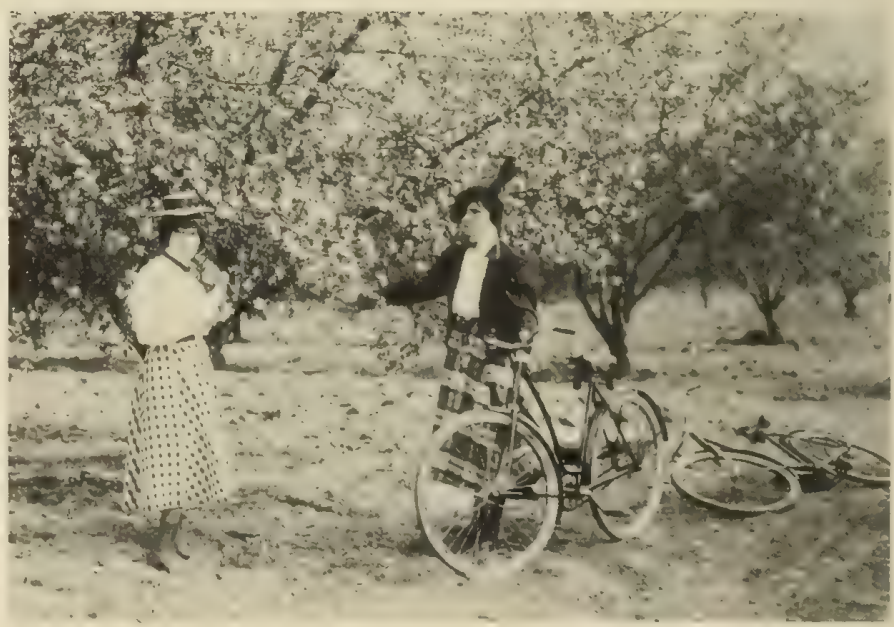


also published educational articles on the principles of good roadbuilding and the economic benefits of allweather roads. He used pictures of good and bad roads freely, thus, holding the reader's attention where words alone would have failed. Newspapers and national magazines reprinted these articles, affording them the widest distribution. ${ }^{23}$

A "Good Roads Association" was formed in Missouri in 1891, followed by similar organizations in other States. ${ }^{24}$ A national road conference, the first of its kind, was held in 1894 with representatives from 11 States. Resolutions passed at this conference urged the State legislatures to set up limited systems of State roads, and to create temporary highway commissions to recommend suitable legislation to implement good roads programs. ${ }^{25}$

\section{State Aid Spreads the Financial Burden}

In 1890 all the public roads in New Jersey outside of the cities were under township control and were built and maintained at township expense. Purely local traffic predominated on most of these roads, but some carried traffic from neighboring townships and even beyond, and on a few, teams could be counted from as many as 20 townships. By actual count, the New Jersey Road Improvement Association proved that the traffic on these main roads was intercounty rather than local, and it asserted that, in fairness, the counties and the State should shoulder part of the burden of building and maintaining them. The Association and the League of American Wheelmen put their support behind a State-aid bill in the Legislature which became law April 14, 1891. This law declared that "The expense of constructing permanently improved roads may reasonably be imposed, in due proportions, upon the State and upon the counties in which they are located." It left the initiation, planning and supervision of State-aided projects in the hands of the county officials, but reserved to the State, represented by the Board of Agriculture, the right to approve projects and to accept or reject contracts. Upon completion, the cost of the improvement was to be split three ways: one-tenth to be assessed to the property holders along the road, one-third to the State and the remainder to the county. The act appropriated $\$ 75,000$ as the State's share for the first year's operations. ${ }^{26}$

The State-aid act was challenged in the courts and upheld. The Board then approved petitions for State aid to three projects in Middlesex County totaling 10.55 miles which, when completed in December 1892 , became the first roads to be improved under the act. ${ }^{27}$

In 1894 the operation of the act was placed under a Commissioner of Public Roads appointed by the Governor for a 3-year term. New Jersey, thus, became the second State, after Massachusetts, to establish a State highway organization. For a number of years, however, the Commissioner of Public Roads had very little real authority over State-aided roads and none at all over other roads. Lacking the power to initiate projects, he could not insure that State-aided roads would link up into highways of any great continuous length, and after they were completed, he could not require that they be adequately maintained.

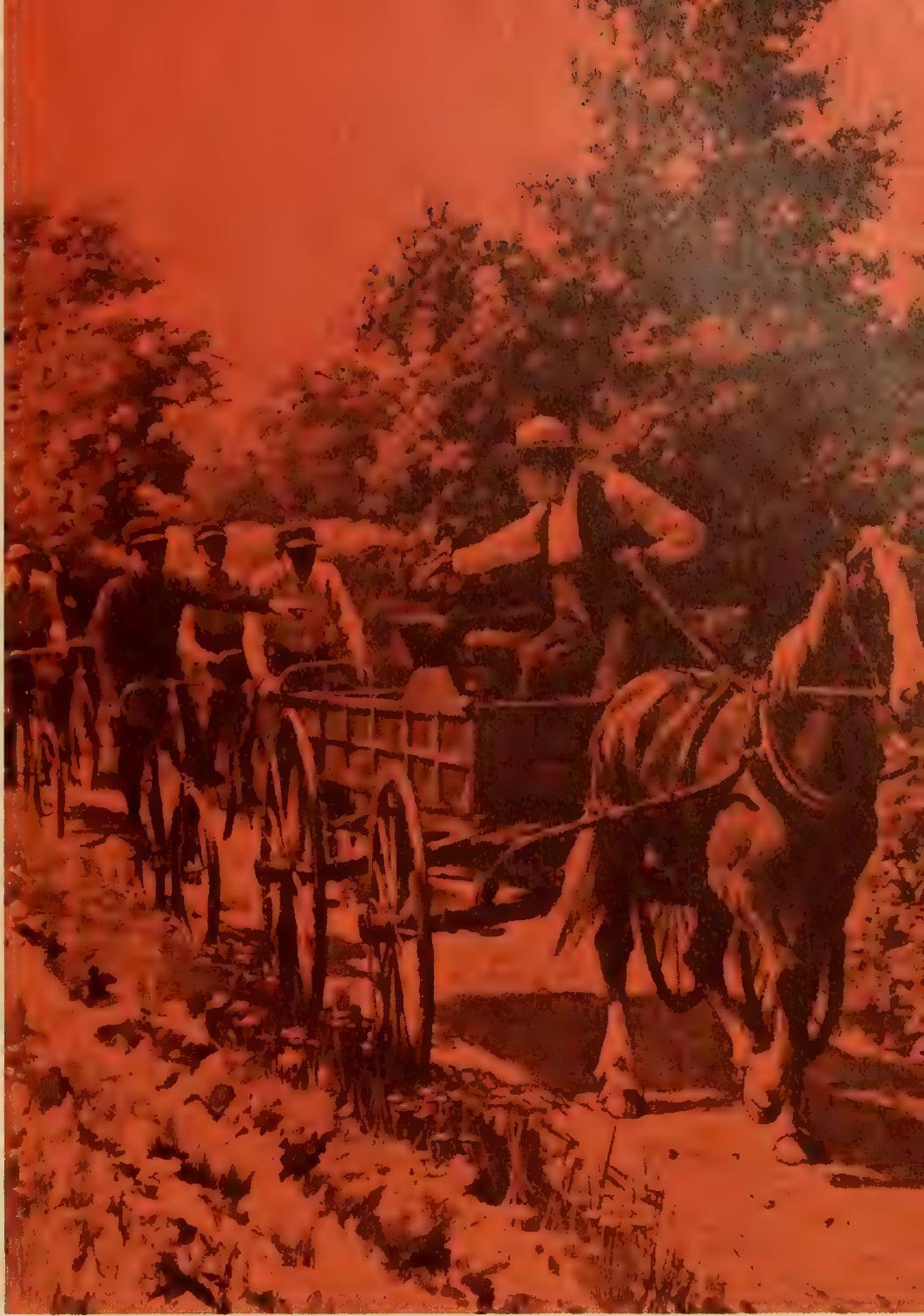

"The Right-of-Way"-bicyclists and horsecart vying for the road.

Nevertheless, the New Jersey State-Aid Act was a milestone in the history of highway administration in the United States, for it clearly stated the principle that highway improvement for the general good was an obligation of the State and county, as well as the people living along the highway. The act also imposed much-needed reforms in local road administration: it abolished the numerous road districts, along with the overseer method of road improvement, and required the township committees to adopt a systematic plan for improving the highways.

\section{The First State Highway Department}

Massachusetts approach State aid somewhat differently from New Jersey. The Legislature created a 3-man continuing commission and charged it with the building and control of a system of main highways connecting the municipalities of the Commonwealth. Originally, the counties were supposed to grade these roads, after which the Highway Commission would surface them. In 1894, the law was changed to require the Commission to shoulder the entire cost of construction, charging one-quarter of the expense back to the counties. ${ }^{28}$ At the same time, the Legislature appropriated $\$ 300,000$ to begin the operation of the Commonwealth Highway Plan, an amount that was afterward substantially increased from year to year. 
The Massachusetts plan was a tremendous improvement over the New Jersey State-aid law. First, it concentrated the limited State funds on a small mileage of the most important roads, thus, assuring that they could eventually be connected into a continuous network. The power to initiate projects remained with the local officials, but the Highway Commission had authority to approve or reject and also to make the surveys and plans and to award and inspect the construction contracts, thus, retaining control over standards. This control eventually led to establishing statewide standards for highways of various classes and also to setting standards for materials used in roads. Finally, the Massachusetts plan left the maintenance of the roads improved with State aid under the direct control of the Highway Commission, which could charge a part of the cost back to the local governments. ${ }^{29}$

The State-aid principle, in various forms, spread slowly to other States after New Jersey and Massachusetts had shown the way. In some States the aid consisted only of advice, which might be accepted or rejected by the local authorities; but in New York the State Highway Commission was given direct or indirect supervision over every public highway in the State. Four States helped only to the extent of putting convicts from the State penitentiary to work on the roads, while others authorized the employment of State and county convicts for road work and gave cash grants in addition. Illinois conducted a large stone-crushing operation with convicts and gave the stone to the counties free, except for the cost of hauling. Maryland, New Hampshire, New York, Washington and California required all State aid to be spent on trunkline road systems. ${ }^{30}$ The last States to enact some form of State aid were South Carolina, Texas and Indiana, all in 1917.

\section{Revival of the Federal Government's Interest in Roads}

As the Good Roads Movement gained momentum, its supporters began to put pressure on Congress to provide some kind of Federal assistance to highways. The proposed Chicago World's Fair, planned for 1893, seemed an auspicious occasion for a demonstration of Federal interest.

In July 1892, a Senate bill was introduced to create a National Highway Commission "for the purpose of general inquiry into the condition of highways in the United States, and means for their improvement, and especially the best method of securing a proper exhibit at the World's Columbian Exposition of approved appliances for road making, and of providing for public instruction in the art during the Exposition." ${ }_{31}$ Although introduced by Senator Charles F. Manderson of Nebraska, this bill was written by General Roy Stone, a prominent New York civil engineer and good roads booster. ${ }^{32}$

The Senate passed the National Highway Commission bill, but it was lost by adjournment of Congress and failed to become law. However, in the next session, Representatives Allan C. Durburow of Illinois* and Clarke Lewis of Mississippi introduced resolutions

\footnotetext{
* Mr. Durburow was Chairman of the Select Committee on the Columbian Exposition.
}

instructing the House Committee on Agriculture to incorporate a clause in the pending agricultural appropriation bill to authorize the Secretary of Agriculture to "make inquiry regarding public roads," and to "make investigations for a better system of roads."

The Agricultural Appropriation Act of 1893, as finally approved on March 3, appropriated $\$ 10,000$ to enable the Secretary "to make inquiries in regard to the systems of road management throughout the United States ... to make investigations in regard to the best method of road-making ... and to enable him to assist the agricultural college and experiment stations in disseminating information on this subject...."

\section{The U.S. Office of Road Inquiry}

Secretary J. Sterling Morton implemented this statute on October 3, 1893, by setting up the Office of Road Inquiry (ORI) within the Department of Agriculture. To head this office he appointed General Roy Stone as Special Agent and Engineer for Road Inquiry, but was careful to limit Stone's authority to investigating and disseminating information. He was specifically forbidden to seek to influence or control road policy in the States or counties or to promote or encourage schemes to furnish work to the unemployed or to convicts. "The Department is to furnish information, not to direct and formulate any system of organization, however efficient or desirable it may be." 33

With characteristic energy, Stone, whose entire staff consisted of himself and one clerk, sent letters of inquiry to the governors of the States and Territories, and their secretaries of state, the members of Congress, the State geologists and all the railroad presidents, soliciting information on highway laws, the locations of materials suitable for roadbuilding, and rail rates for hauling such materials. By the end of June 1894, the Office of Road Inquiry had issued nine bulletins on these subjects, some of which were already in their second printing ! $!^{34}$

In the following year the ORI produced nine more bulletins, three of which were the proceedings of national good roads conventions. The promoters of these meetings had no trouble getting able and influential men on their programs as speakers, including General Stone, and publication of their speeches at Government expense was an easy and cheap way to spread the gospel of good roads throughout the country.

Another major ORI project begun in 1894 was a large-scale Good Roads National Map of all the macadamized and gravel roads in the United States. For this, Stone sent a map of each county to the clerk or surveyor of that county, asking that it be returned with the existing roads laid down upon it. By June 1895 , he was able to compile statewide road maps for Pennsylvania, Indiana and New Jersey from these county maps, with those of other States in various stages of compilation. ${ }^{35}$

To round out a year of extraordinary activity, the ORI, with the help of the Division of Statistics of the Agriculture Department, compiled information on the cost of hauling farm products to market in 1,160 counties in the United States. These statistics showed that a farmer's average haul to market or shipping 
points ranged from 6.4 miles in the East to 23.3 miles in the Far West, with a national average of 12.1 miles. The average load for a 2 -horse team was a little over 2,000 pounds and the average cost of hauling was 25 cents per ton-mile. ${ }^{36}$ By comparison, the cost of hauling farm products by railroad was about $1 / 2$ cent per ton-mile at this time.

\section{The Object Lesson Road Program}

As yet, General Stone had not found a satisfactory way to assist the agricultural colleges and experiment stations to disseminate information on roadmaking. A solution to this problem came out of the experience of the State Highway Commission in implementing the Massachusetts State-aid law of 1893. The Legislature had appropriated $\$ 300,000$ with the provision that each county was to receive a "fair apportionment." The Commission decided to parcel the money out to 37 widely scattered projects, each about 1 mile long, on the theory that once the people had a taste of good roads, they would put pressure on the Legislature for a bigger future appropriation. Each project was located where it would eventually form a link in a continuous system of trunk roads between the principal cities. ${ }^{37}$

Stone proposed to apply the Massachusetts idea nationally by building short "object lesson roads" near or on the experimental farms of the various States. These would serve to instruct the roadmakers, to educate the visiting public and to improve the economic administration of the farms. ${ }^{38}$ This plan was satisfactory to James Wilson, the new Secretary of Agriculture, who preferred that the ORI emphasize the practical side of roadbuilding rather than the academic. However, the total annual budget of the Office of Road Inquiry was only $\$ 10,000$ at this time, so General Stone had to scrounge most of the cost of the first object lesson roads.

He began the scrounging by reducing his own office staff, using the money saved to hire practical roadbuilding experts, of whom the first was General E. G. Harrison of Asbury Park, New Jersey, a civil engineer who enjoyed a national reputation as a builder of macadam roads. Next, he talked the road equipment manufacturers into providing equipment free as a good will and promotion gesture. Finally, he got the experiment stations, the local road authorities and, in some cases, private individuals to put up the cash to pay for labor, materials, hauling and part of the wages of the machine operators.

The ORI's share of the cost of each project consisted only of the salary and travel expenses of the supervisory road expert, the expense of transporting the loaned equipment to and from the project and part of the wages of the equipment operators. However, the design, stakeout and supervision of construction were under the complete control of the ORI supervisor, "in order that the roads may be creditable to the Government when done." 39

The first object lesson road project was comparatively small, involving a cash outlay of only $\$ 321$ put up by the New Jersey Agricultural College and Experiment Station at New Brunswick. Under this project, General Harrison, in June 1897, placed 6 inches of trap rock macadam 8 feet wide on a 660 -foot section of the main road leading from the town to the

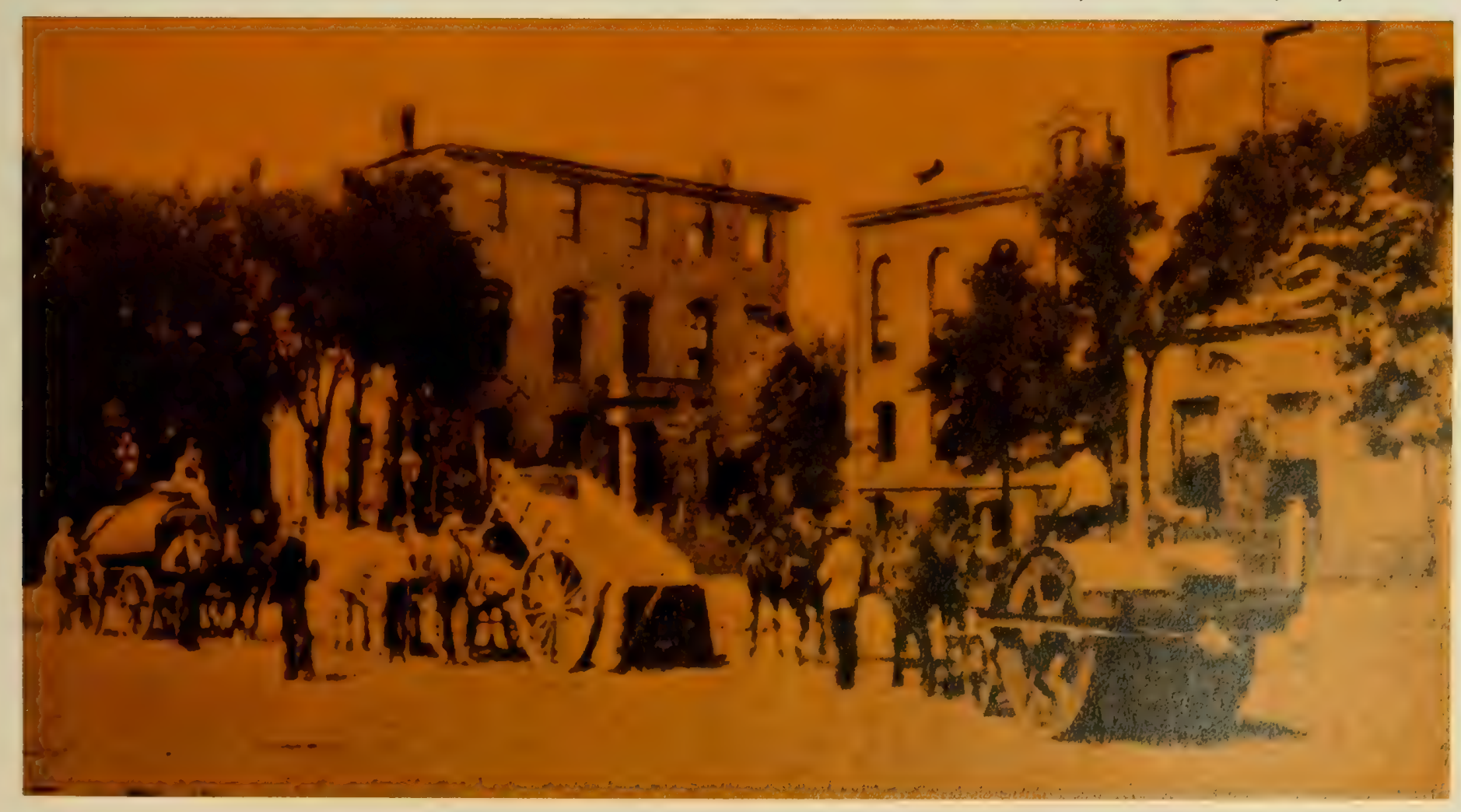

Building the first object lesson road near the New Jersey Agricultural College and Experiment Station, New Brunswick, N.J., in 189\%. 


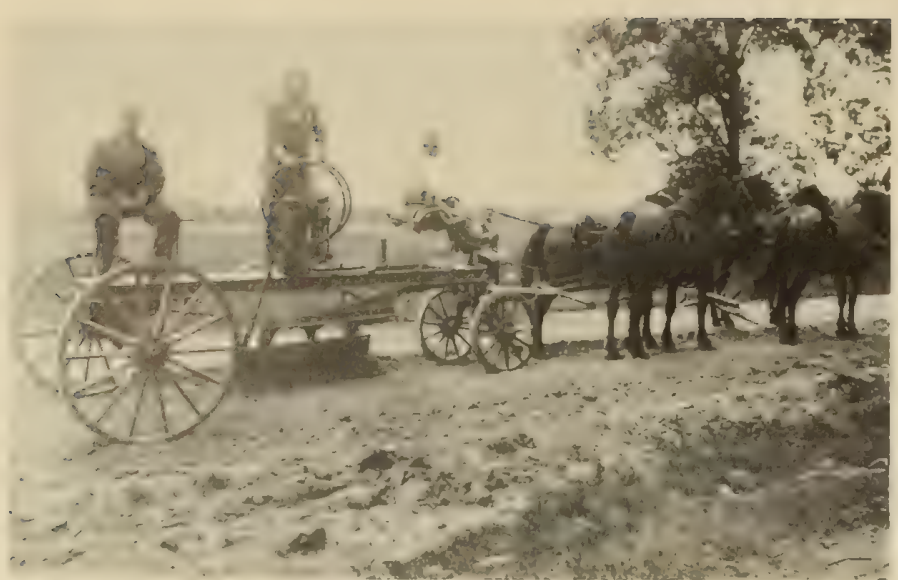

Working the road machine on a section

of the experimental road at Geneva, N.Y.

college farm. He then moved the equipment to Geneva, New York, where he built 11/2 miles of ruad connecting the city to the New York Agricultural Experiment Station. This road cost $\$ 9,046$ and was financed by contributions from the town of Geneva, the experiment station and three private individuals. After its completion, Harrison moved the equipment to Kingston, Rhode Island, where he completed a road for the Agricultural College of Rhode Island in 1898.40

These roads accomplished their intended purpose. They were a forceful demonstration of General Stone's "seeing is believing" philosophy of selling good roads to the public. They attracted hundreds of visitors, including many county road officials. They also attracted a deluge of requests for similar object lesson roads at other agricultural colleges which Stone was unable to fill because his funds had run out. In September 1897 he wrote:

The work now in hand will exhaust all the funds that can be spared from this year's appropriation, unless something additional is provided to meet the many urgent demands of the agricultural colleges and experiment stations for 'Government' roads.
If the manufacturers continue willing to furnish the machinery free, an expenditure by the Government of from $\$ 300$ to $\$ 500$ for each locality will be sufficient to call out enough local help to build from $\$ 2,000$ to $\$ 10,000$ worth of road at most of the 116 agricultural colleges and experiment stations, and any required number of outfits can be put in the field at once....4

\section{Educational Work of the Office of Road Inquiry}

General Stone and his deputy engineer, Maurice O. Eldridge, were indefatigable writers and speakers. In addition to writing or editing 20 published bulletins and 30 circulars on various aspects of the road problem, they accepted invitations to appear on the programs of several dozen good roads conventions and farmer's road institutes. The invitations were, in fact, far more numerous than the ORI could accept with its limited budget and force. General Stone was also an acknowledged expert on good roads legislation, and his advice was sought by several States, notably California, New York, Connecticut and Rhode Island, in framing their highway laws.

Following the outbreak of war with Spain, General Stone, in August 1898, was granted leave of absence from the ORI to serve with the Army. During the war he was a Brigadier General on the staff of General Nelson Miles. The war over, he resumed his duties in January 1899 , but resigned October 13,1899 , to return to New York, where he accepted the presidency of the National League for Good Roads, an organization he had helped to found in 1893 before his appointment to the Office of Road Inquiry.

\section{The Office of Public Road Inquiries}

While General Stone was on military duty, the Office of Road Inquiry was temporarily headed by Martin Dodge of Cleveland, Ohio, formerly President of the Ohio State Highway Commission. When Stone resigned in October 1899, the name of the agency was changed to the Office of Public Road Inquiries (OPRI) and Mr. Dodge was appointed as Director.

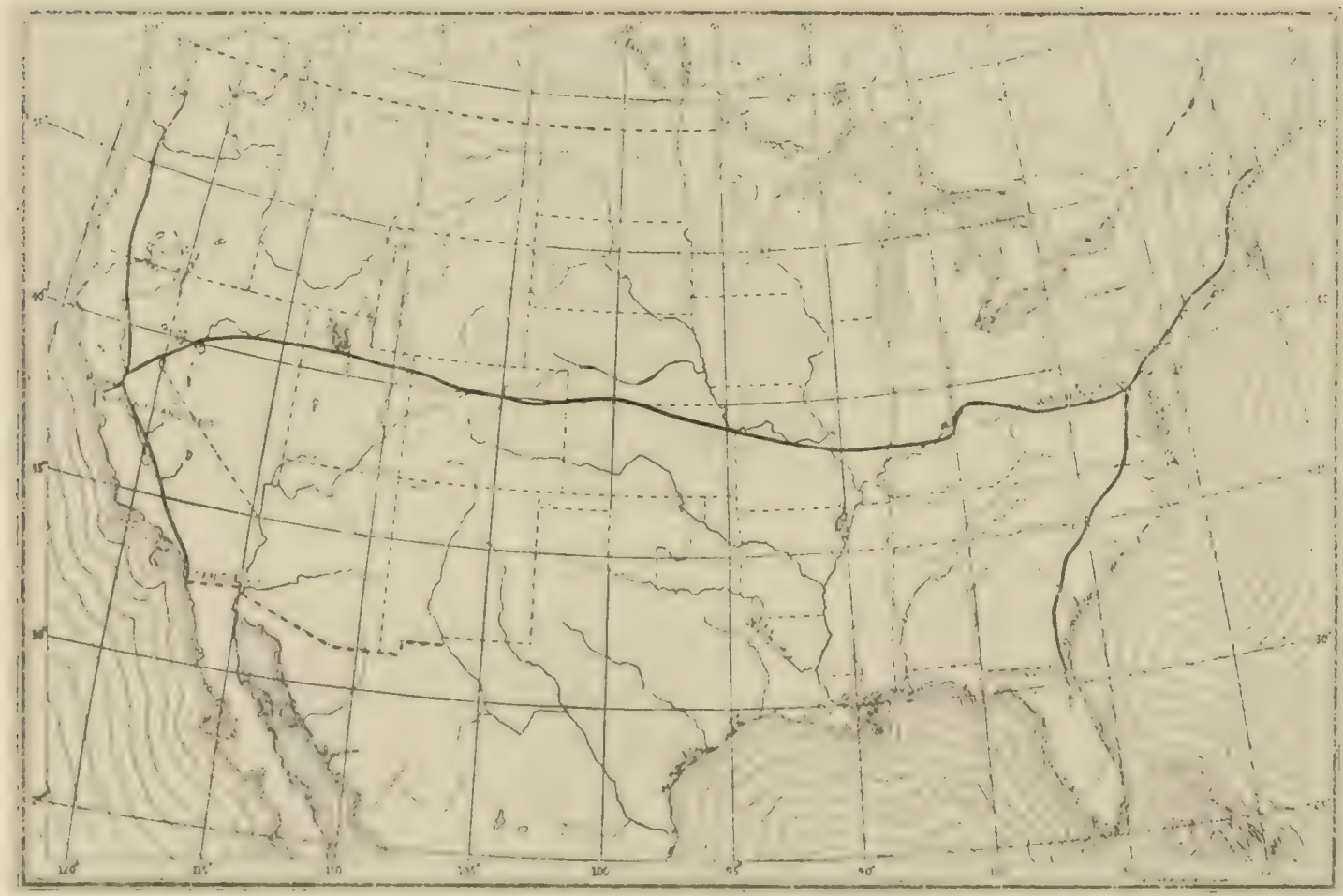

General Stone's plan for three great demonstration roads-from Portland, Maine, to Jacksonville, Fla., on the east coast; from Seattle, Wash., to San Diego, Calif., on the west coast; and from Washington, D.C., to San Francisco, Calif. 
About 1898 Martin Dodge advanced the idea of steel track wagon roads by exhibiting sections of steel track at the Trans-Mississippi Exposition at Omaha. The advantages were that steel track was less costly to install and maintain, more durable, and the power required to move a vehicle was only a small fraction of that needed over any other kind of road. This demonstration shows an 11-ton load being hauled by one horse on a steel track while it would take 20 horses to haul this load on an ordinary road of that day.

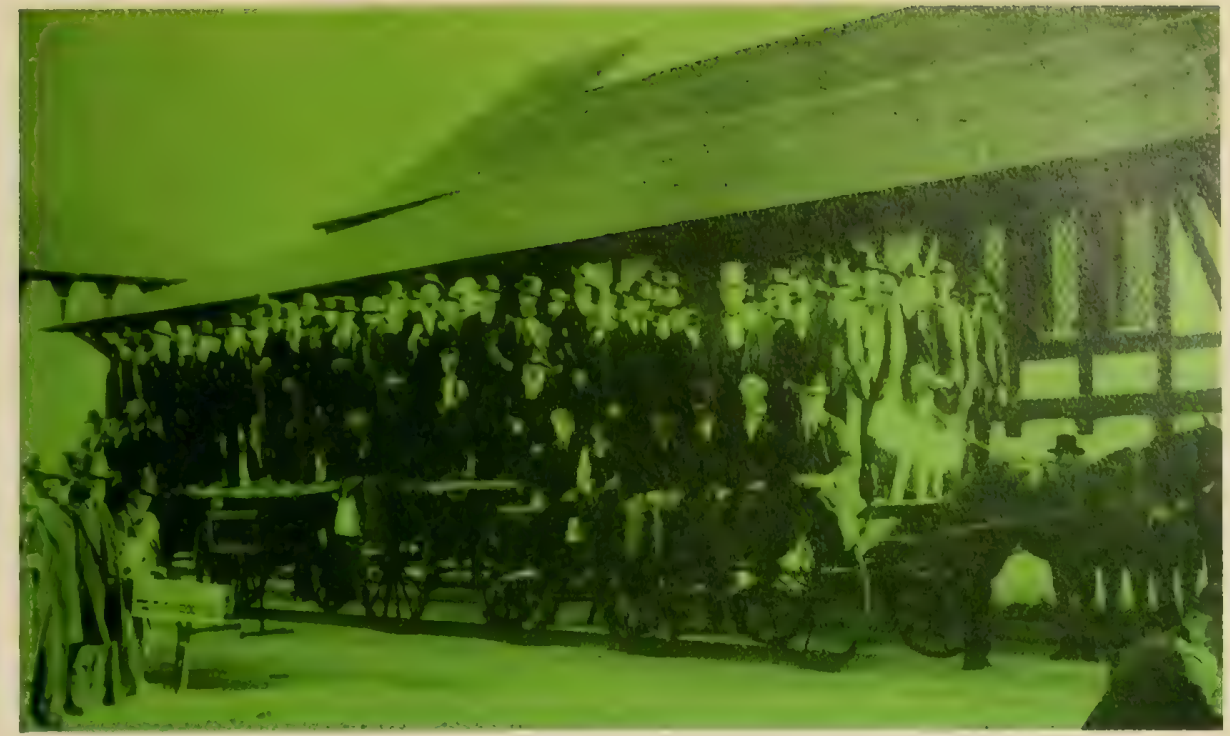

For 2 years, prior to General Stone's resignation, Congress had turned a deaf ear to his entreaties for more funds to expand the demonstration road program. When Mr. Dodge took office in 1899, the budget was still only $\$ 10,000$ per year, and for another 2 years he had no success in getting it increased. This resistance was due, in part at least, to fear on the part of some people that the OPRI was the entering wedge for national roads under Federal control. Seeking to allay this suspicion, Dodge wrote in his report for 1901:

It is proper just here to call attention to a misconception which appears to exist in the minds of some to the effect that increased appropriations for this work may lead to National aid. It should be distinctly understood that the work of this Office, like that of many other Divisions of the Department, is purely educational. In requesting an increased appropriation it was not the intention to shift the burden and responsibility of constructing improved roads from the States and counties to the General Government. Such a plan is not feasible, and even if it were, it would not be desirable, for there could be no surer way of postponing the building of good roads than by making them dependent upon National aid. Under such a system States and counties would wait for National aid and little or nothing would be done. ${ }^{42}$

Director Dodge's plea for more funds did not bear fruit until 1903 when Congress increased the OPRI's budget to $\$ 30,000$. In the meantime, to better keep in touch with local developments and economize on travel expense, Dodge divided the country into four "divisions," with a special agent in charge of each. To head the Eastern Division, he appointed Logan W. Page, a geologist who at the time was also Chief of the Bureau of Chemistry's Division of Tests. Page had been invited to Washington in 1900 to set up a materials laboratory in the Bureau of Chemistry of the Department of Agriculture and to conduct a study of road materials on a national scale. The other division heads were Professor J. A. Holmes of Chapel Hill, North Carolina, J. A. Stout of Menominee, Wisconsin, and James W. Abbott of Denver, Colorado.

All of the division agents, except Page, were parttime employees, and their available time was fully employed attending conventions, writing articles and collecting information on the progress of legislation. An idea of the duties of these agents can be gleaned from Dodge's summary of Special Agent Abbott's work for 1901. In addition to traveling more than 12,000 miles by railroad,

He attended and participated in the work of four very important conventions, at two of which he read papers. He has written several articles for publication in leading newspapers, and numerous interviews have been published giving accounts of his movements and work. He spent some time in consultation with the road committees of the Colorado legislature and assisted in framing a carefully prepared road law. He visited many places in Colorado, Utah, and California, and gave advice where it was desired regarding specific or general road improvement. Mr. Abbott visited, practically at his own expense, this Office and the highway departments of New York, Massachusetts, and California....

. He has, by personal interviews and private letters, brought the subject of road improvement to the attention of governors and other State officials, the editors of leading newspapers, professors in institutions of learning, presidents and managers of railroads, prominent civil and mining engineers, members of the legislatures, boards of county commissioners, road supervisors, the heads of leading industries, manufacturers of road machinery, besides a large number of influential private citizens. ${ }^{43}$

All this for $\$ 1,500$ per year! Obviously, Special Agent Abbott also had a private income to draw upon, as did the other division heads.

Until 1903 the OPRI had only one object lesson road construction team, which was managed by Special Agent and Road Expert E. G. Harrison until his death in February 1901. This team was shipped from place to place by rail on a prearranged schedule, building eight or nine roads per year, each $1 / 2$ to $11 / 2$ miles long. After a sufficient amount of road had been built at each location, a "good roads day" would be arranged, and the farmers of that and the adjacent counties would be invited to attend. Special Agent Harrison would lead the crowd-often as many as 500 persons-along the new construction, lecturing on the fundamentals of drainage, stone surfacing and road maintenance. Harrison would arrange for the lecture to be printed in the local newspaper. The following is a brief quote from one of these accounts:

'We are not here to build city streets, nor boulevards. Cities are able to pay for their expensive streets and know how to build them. But the U.S. is interested in 
the rural districts and wishes to help the farmers and others to get good roads. Therefore, the Department of Agriculture has established the Office of Road Inquiry, which is seeking to gather all the information possible about the construction and maintenance of good roads and to impart it gratis to the people. The government will not build your roads, but will place at your disposal all the information it has gained from experts, experiments and other sources. .

'Here we have not even built the best kind of macadam road. For that you must go to your cities and look at the boulevards. We have simply taken the material at hand and from it constructed the best road possible with the money we have. The boulders from which the stone is crushed were brought from the neighboring farms. They are of good quality and very hard. They consist of granite, trap, syenite, quartz, etc. This is much better than your soft limestone, or loose sandy, washed gravel.' ${ }^{44}$

After 1903, with a tripled budget, the OPRI was able to keep four demonstration teams in the field. Also, with Page's new laboratory in operation, the Government undertook to test the materials going into the object lesson roads without charge to the local cooperators, eliminating guesswork in this very important aspect of roadbuilding.

\section{The Good Roads Trains}

In 1893 there was only one national good roads organization in the United States and three or four local associations. Eight years later there were over 100 organizations promoting good roads, including six distinctly national road associations. In 1901 the most active and aggressive of these organizations was the National Good Roads Association (NGRA) which had been formed during the Chicago Good Roads Convention of 1900 , and was headed by Colonel William H. Moore of St. Louis as president and Colonel R. W. Richardson of Omaha as secretary. Like many other good roads organizations, the National Good Roads Association had no permanent membership list and depended for its support on donations from civic groups, manufacturers of road machinery, suppliers of road materials, wealthy individuals, the public at large and even the railroads.

Colonel Moore, the guiding spirit of the NGRA, was a skillful and persuasive promoter, with a wide acquaintanceship among influential people. In 1901 he conceived the idea of a traveling good roads show that would cover the country, educating the public on the advantages of improved highways, very much in the manner of the circuses and the popular Chautauqua shows. He persuaded the road machinery companies to help with this project by donating their latest models, along with trained operators, to run them. From the Illinois Central Railroad, he obtained the promise of an 11-car train free of charge, to transport the show from place to place. Finally, he approached Director Dodge to give Government sanction to the idea by providing a road expert to lecture on roads and supervise demonstrations of roadbuilding. Dodge was unable to help because his budget was already committed to other work; however, when the Associa-

The Southern Railway Good Roads Train with

some of the road experts during its fall trip in 1901.

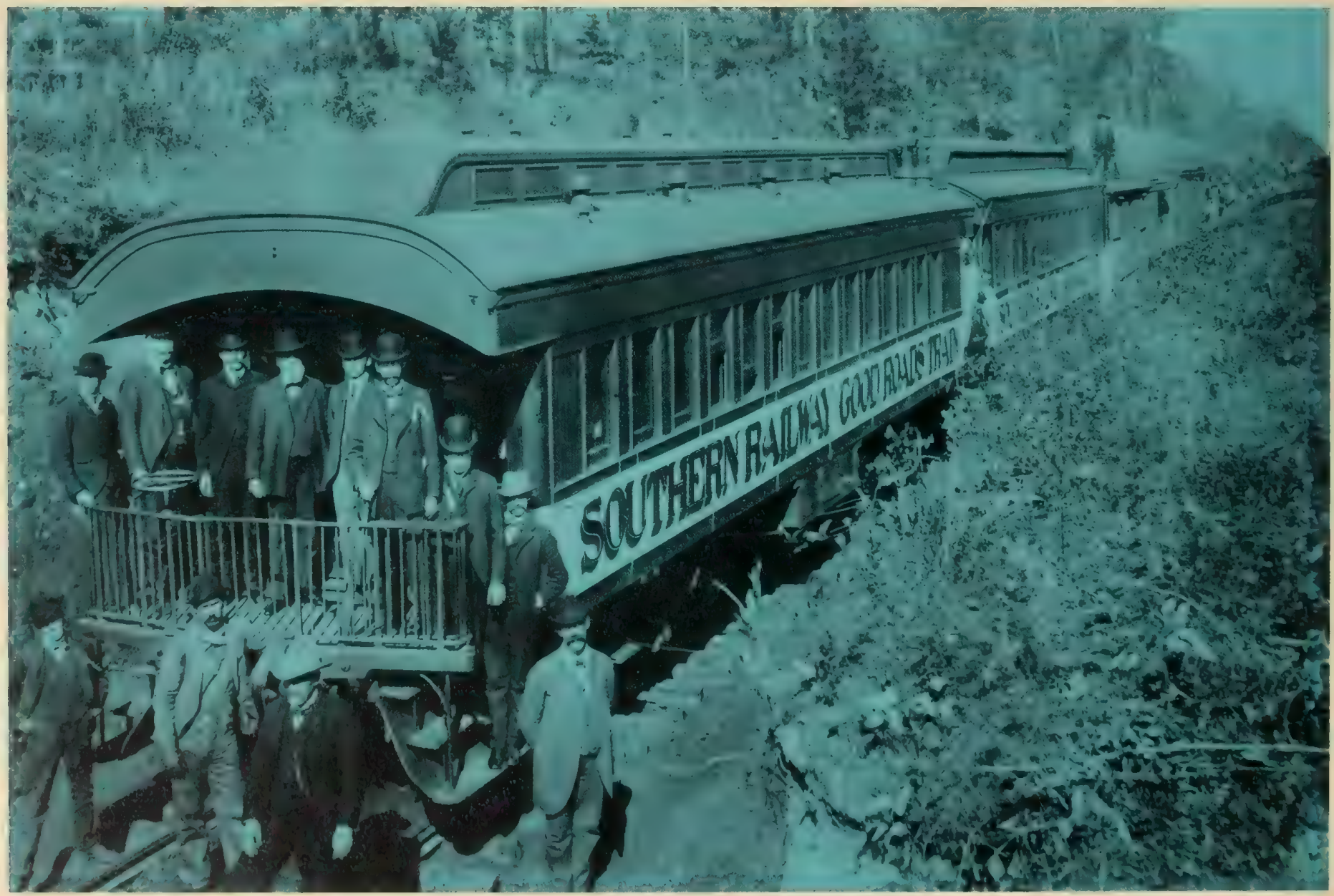


tion offered to pay the expert's salary and expenses, he agreed to participate and designated Special Agent Charles T. Harrison of New Jersey as the OPRI's representative.*

The Association mounted a high-powered publicity campaign to prepare the way for the "Good Roads Train." Advance agents organized local conventions and lined up donations of labor and materials for demonstration projects. The train, consisting of nine flat cars loaded with road machinery, and two sleeping cars for the operators, laborers, officials, road experts and press representatives, pulled out of Chicago early in April 1901, under the management and control of Colonel Richardson. Before returning in August, it stopped at 16 cities in five States, where the construction crew built sample roads of earth, stone or gravel varying in length from $1 / 2$ mile to $11 / 2$ miles. Director Dodge, who went along on the first trip from Chicago to New Orleans, expressed his enthusiasm for the project in this glowing account:

About 20 miles of earth, stone, and gravel roads were built and 15 large and enthusiastic conventions were held. The numbers attending these conventions and witnessing the work were very large, in nearly every instance more than a thousand persons and in some cases 2,000 persons being present. Among the attendants were leading eitizens and officials, including governors, mayors, Congressmen, members of legislatures, judges of the county court, and road officials. This was undoubtedly the most successful campaign ever waged for good roads, and the expedition has been of great service to the cause, and especially to the people of the Mississippi Valley. ${ }^{45}$

- Charles T. Harrison replaced E. G. Harrison who died February 6, 1901.
At this time the steam railroads were among the strongest supporters of good roads. Secure in their position as the backbone of the American transportation system, they were anxious to extend their tributary traffic areas and also to overcome some of the widespread hostility engendered by their high-handed methods of dealing with the public. The economic aspect of the railway interest in roads was aptly expressed by an official of the Southern Railroad in 1902:

\begin{abstract}
.. They [the Southern Railroad] now handle the products of from 2 to 5 miles on each side of their tracks. In the winter season they can not get the products that are any farther away. If you had improved roads, they would be able to serve the country 20 to 30 miles from their tracks. .. . If you are a shipper, you know that at some seasons of the year it is hard to get cars; that every railroad in the United States suffers from a lack of cars and locomotives, and that the industries of almost every community suffer on this account. This is because the traffic on all railroads is so greatly congested within a few months of the year. It is not divided over the twelve months as it ought to be. If there were good roads leading to every railroad station in the United States, the railroads would be able to get along with half the cars they now need. ... ${ }^{46}$
\end{abstract}

The Illinois Central Railroad "expedition" was so successful that Colonel Moore had little difficulty lining up others. One left Chicago on the Lake Shore and Michigan Southern Railroad for Buffalo, where it was placed on exhibit on the grounds of the PanAmerican Exposition during the International Good Roads Congress during September 1901. ${ }^{47}$

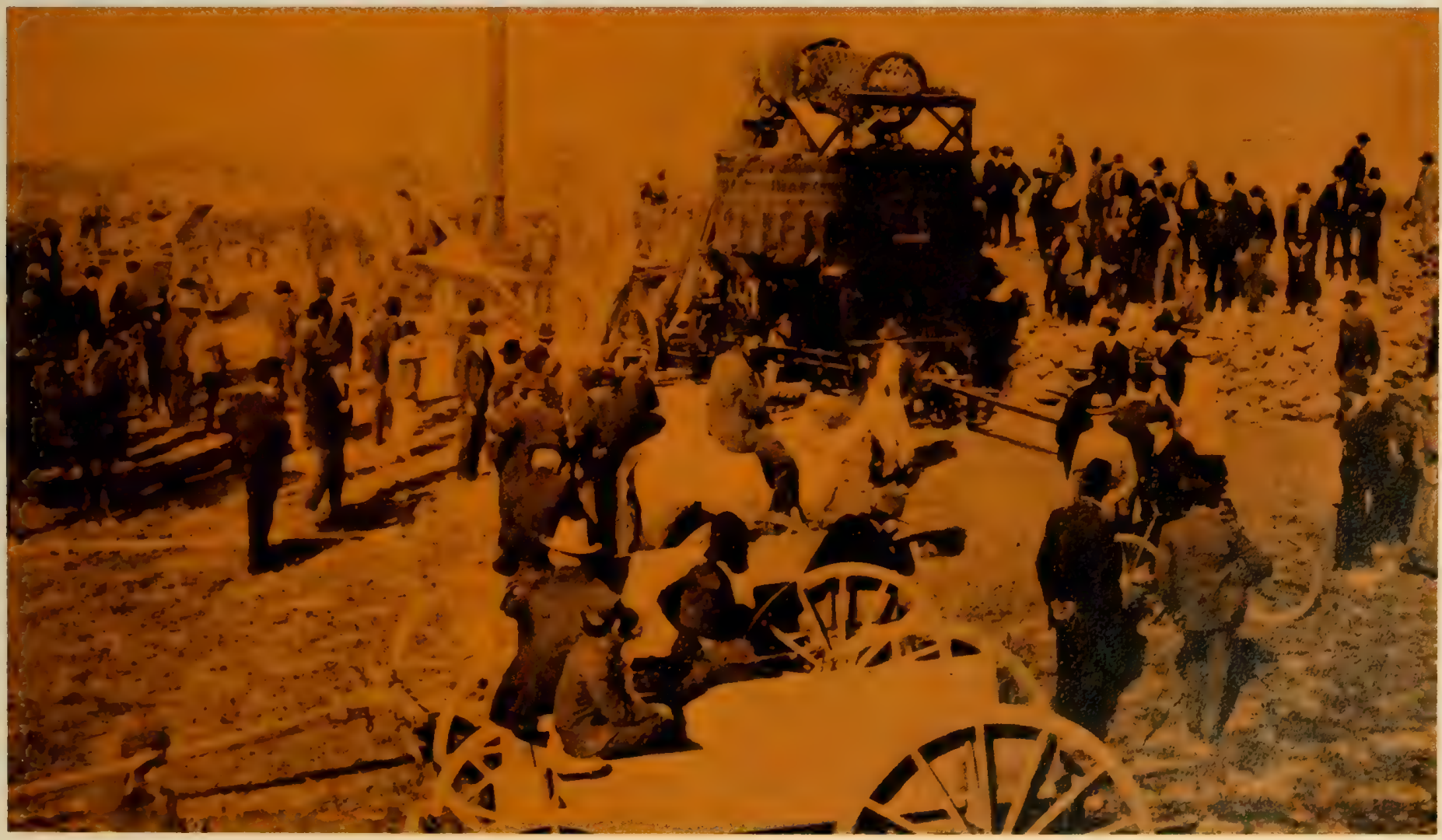


The most elaborate expedition of all was sponsored jointly by the Southern Railroad and the NGRA and cost the railroad over $\$ 80,000$. It left Alexandria, Virginia, on October 29, 1901, and was on the road for 5 months, traveling 4,037 miles and demonstrating at 18 good roads conventions. Welcoming this train to Lynchburg, U.S. Senator J. W. Daniel of Virginia said :

An itinerant college on wheels has come among us. It brings its professors and its equipment with it. It is known as the 'good roads train' of the Southern Railway system. This college does not teach out of books, nor solely by word of mouth. It teaches by the greater power of example. If you will just watch its operation you will see a new good road grow over an old and bad road at the magic touch of titanic machinery, and while an orator talks of road building it will set his words to the music of practical accomplishment. ${ }^{48}$

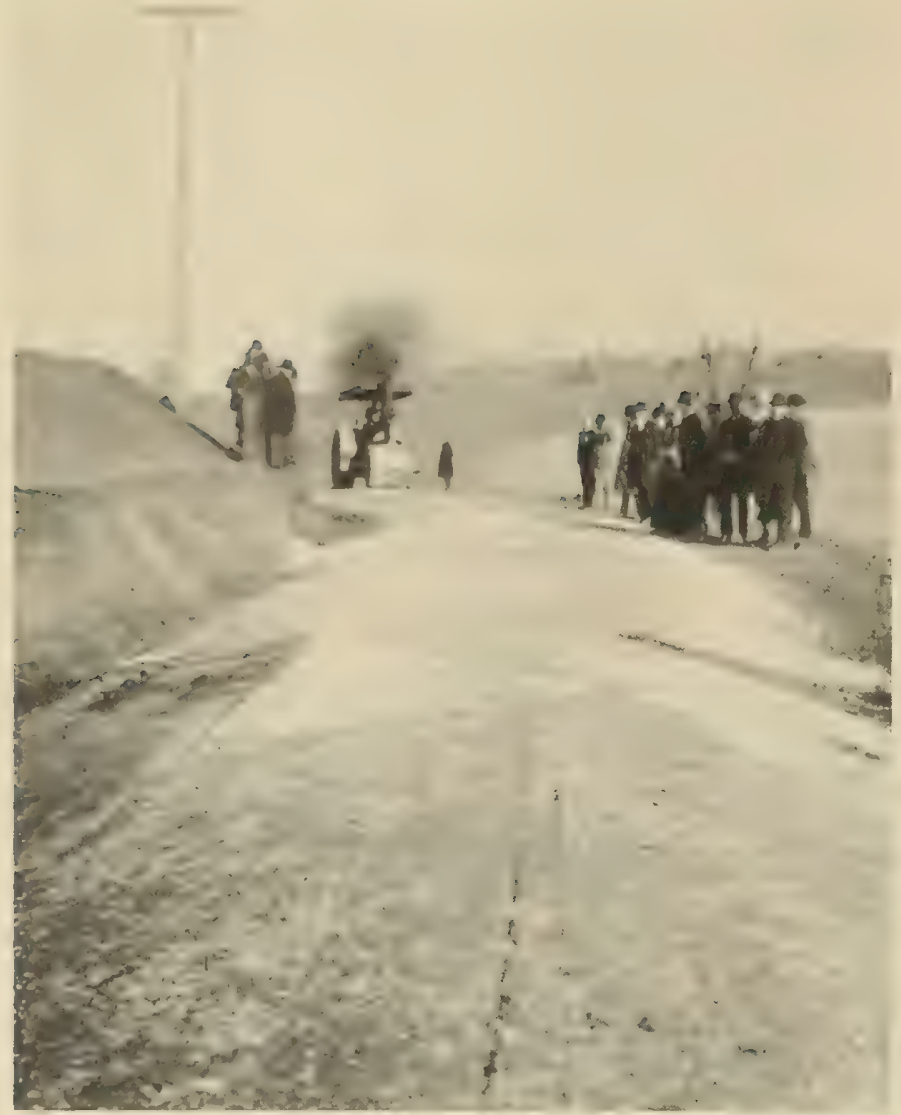

A steam roller in operation on a demonstration

macadam pavement near Greenville, Tenn., in 1901.

The Pere Marquette Railroad and the Michigan Good Roads Association sponsored a Good Roads Train for the summer of 1902-the only train which did not have at least one of Dodge's road experts aboard. The last of the Good Roads Trains left St. Paul on the Great Northern Railroad, September 8, 1903, for an expedition through Minnesota, the Dakotas, Montana, and beyond to the Pacific Coast.

\section{The First National Road Inventory}

One of the most ambitious tasks undertaken by the OPRI during Director Dodge's administration was an inventory of all the roads in the United States outside of the cities. The information for this enumeration was obtained in 1904 from questionnaires sent to the county authorities or from "voluntary correspondents"
When the automobile arrived, many miles of rural road were similar to this one along Bishop Creek in California.

appointed by the OPRI. The investigators, headed by Assistant Director M. O. Eldridge, went far beyond merely tabulating road mileage. They investigated taxation and sources of revenue, road laws and total expenditures in every county of every State. Road mileage was subdivided according to surface type. The information was so voluminous that over 2 years were required to tabulate it and issue the report, which did not appear until May 1907.99

The OPRI study showed that there were $2,151,570$ miles of rural public roads in the United States in 1904 , plus 1,598 miles of stone-surfaced toll roads.* Of the public roads, only 153,662 miles had any kind of surfacing.** The expenditures on roads in 1904 were $\$ 79.77$ million of which only $\$ 2.6$ million was contributed by the States in the form of State aid. ${ }^{52}$

\section{Office of Public Roads Achieves Permanent Status}

From its beginning in 1893 as the ORI, the Office of Public Road Inquiries had been a temporary organization set up by the Secretary of Agriculture to perform a job mandated by Congress, namely, to collect and disseminate information about good roads. Apparently, Congress did not contemplate originally that this would become a permanent function of the Government, but the work was continued from year to year by a short paragraph in the annual Agriculture appropriation bill. In 1903 and again in 1904

* By comparison, there were 213,904 miles of railroads in the United States in $1904 .^{50}$

** This mileage was distributed as follows:

Surfacing Type (Miles)

Earth Gravel Stone Shells, etc. Total Sand-Clay

\begin{tabular}{lrrrrr}
$\begin{array}{l}\text { Eastern and } \\
\text { Southeastern }\end{array}$ & & & & & \\
States & 580,850 & 24,627 & 21,240 & 3,091 & 629,808 \\
$\begin{array}{l}\text { Texas } \\
\text { Public Land }\end{array}$ & 119,281 & 167 & 1,909 & 52 & 121,409 \\
States & $1,297,777$ & 83,439 & 15,473 & 3,664 & $1,400,353$ \\
\hline & $1,997,908$ & 108,233 & 38,622 & 6,807 & $2,151,570$
\end{tabular}

In addition to the above, there were 1,101 miles of stonesurfaced toll roads in Pennsylvania and 497 miles of toll roads in Maryland. 51 


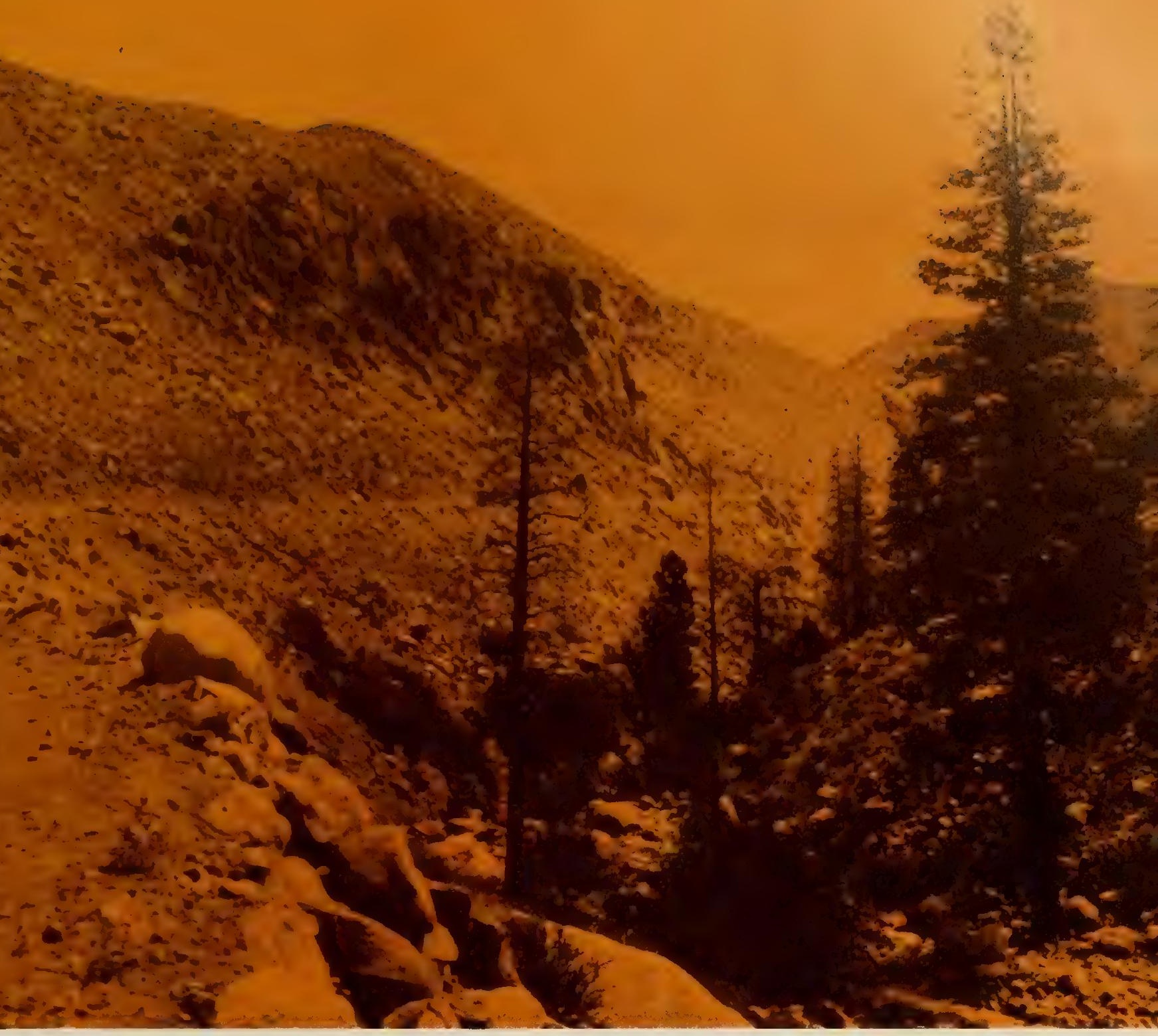

A plank road between El Centro, Calif., and Yuma, Ariz.

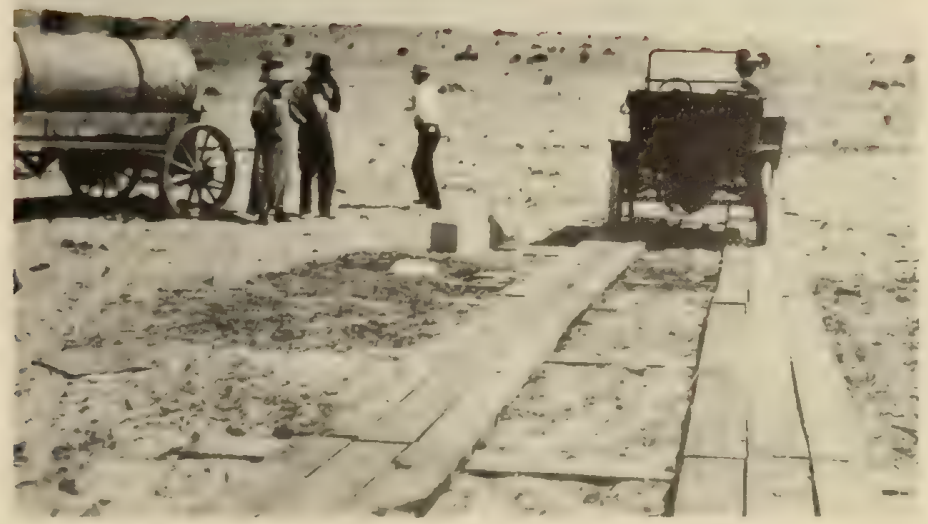




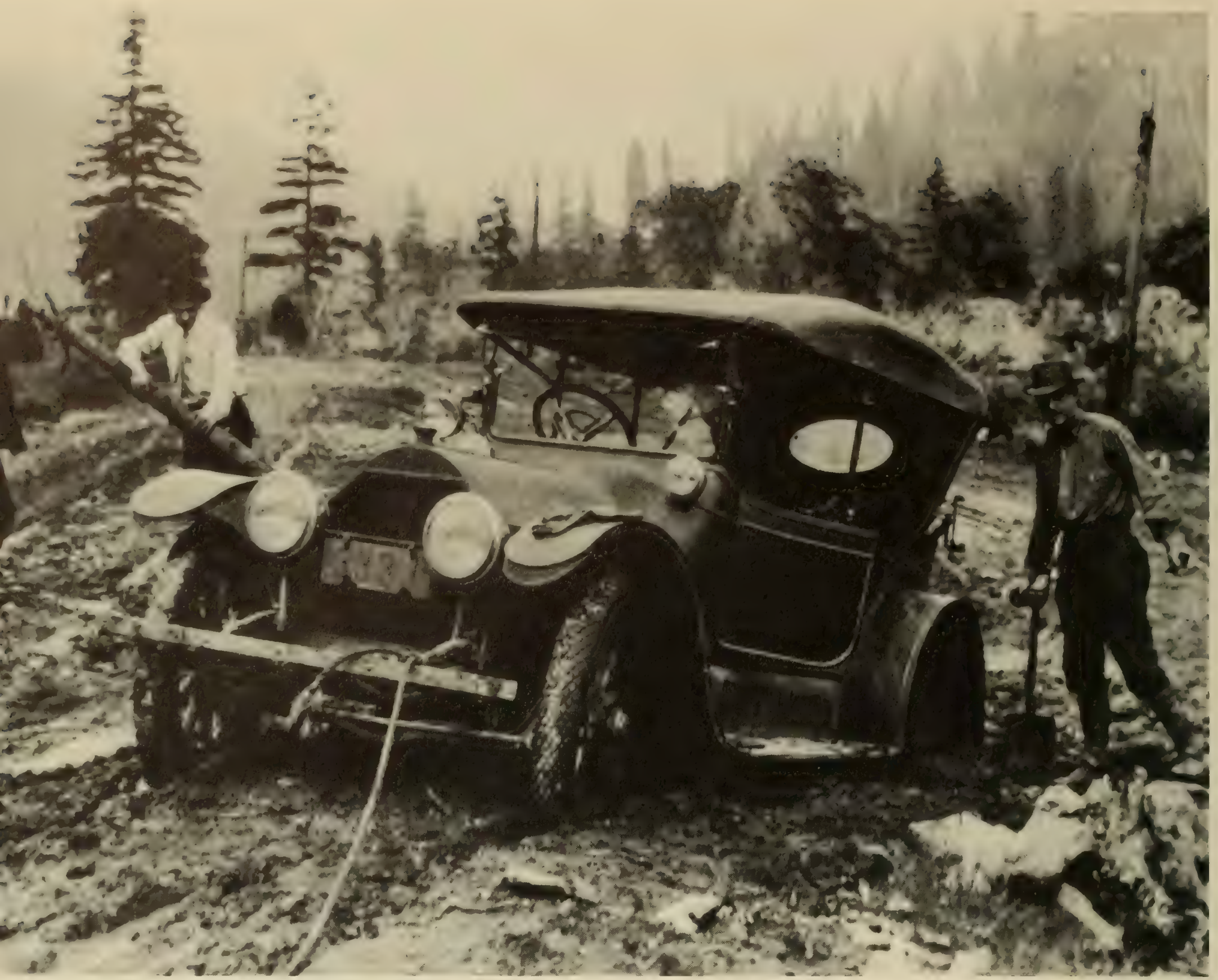

stuck in the mud in Sacramento Canyon.

Director Dodge recommended that his office be transformed into a Division of the Department "with a statutory roll of officers and employees."

The work of this Office appears to be no longer of tentative character. Year after year it has assumed increased importance and wider scope, and there is now a general demand coming up from all sections of the country that it be made a permanent feature of the work of this Department. It appears fitting, therefore, that it be given a more definite legal status, thereby adding dignity and stability to this branch of the Department's work...

Congress eventually heeded this plea, and in the Agriculture Appropriation Act of March 3, 1905 (33 Stat. 882), it merged the Division of Tests of the Bureau of Chemistry with the Office of Public Road Inquiries to form the Office of Public Roads. The new agency had a statutory roll, headed by a Director, "who shall be a scientist and have charge of all scientific and technical work," at a salary of $\$ 2,500$ per year. The Act also provided for a Chief of Records, an Instrument Maker and 6 clerks, and boosted the total annual appropriation for the office's work to $\$ 50,000$.

The requirement that the Director should be a scientist prevented Martin Dodge, a lawyer, from succeeding to the directorship of the new Office of Public Roads, and Logan Waller Page was appointed instead.

Director Page assumed the helm of the Office of Public Roads at a momentous time in the history of land transportation. To his predecessors "good roads" meant wagon roads, constructed according to the timetested methods of Trésaguet, Telford and McAdam and designed for horsedrawn steel-tired traffic traveling 6 to 8 miles per hour. In 1905 the shape of things to come was dimly foreshadowed by scarcely 78,000 automobiles, most of which were confined to the cities. Ten years later 2.33 million autos were raising clouds of dust on the country roads, and by 1918 this number had increased to 5.55 million. The motor age had arrived, and with it a new kind of highway, designed specifically for motor vehicles, would evolve. Director Page would preside over the early stages of this evolution. 


\section{REFERENCES}

${ }^{1} \mathrm{~J}$. OWEN, The Controverted Questions in Road Construction, Transactions, Vol. 28 (American Society of Civil Engineers, New York, 1893) p. 111.

${ }^{2} 43$ U.S.C. Section 218 (1964).

'M. O. EldRIDGe, Good RoAds For FARMers, Farmers' Bulletin No. 95 (Office of Public Roads, Washington, D.C., 1900) p. 9.

'M. O. Eldridge, Public Road Mileage, Revenues and Expenditures, In the United States In 1904, Bulletin No. 32 (Office of Public Roads, Washington, D.C., 1907) p. 16.

s Id., p. 18.

- Id.

${ }^{1} I d .$, p. 16.

Id., p. 20.

I $d_{\text {., }}$ p. 16.

${ }^{10} I d$., p. 14.

"S. AtexANDER, History of Good Road Making in Mecklenburg County, Proceedings of the North Carolina Good Roads Convention, Bulletin No. 24 (Bureau of Public Roads, Washington, D.C., 1903) pp. 22, 23.

12 T. PARKER, Good Roads and Their Relation to the Farmer, Proceedings of the North Carolina Good Roads Convention, Bulletin No. 24 (Bureau of Public Roads, Washington, D.C., 1903) p. 27.

${ }^{13}$ W. Gillespie, a Mandal of the Principles and Practice of Road Making (A. S. Barnes and Co., New York, 1871) pp. $221,227$.

"A. Blanchard \& A. Fletcher (eds.), american Highway Exgtideer's Handbook, 1st ed. (Wiley, New York, 1919) p. 467.

${ }^{15}$ G. Trusson, Asphalt and Asphalt Pavements, TransacTross, Vol. 38 (American Society of Civil Engineers, New York, 1897) pp. 224, 234.

${ }^{16} \mathbf{R}$. Kirby, S. Withington, A. Darling \& F. Killgour, Engineering in History (McGraw-Hill, New York, 1956) p. 396.

${ }^{27}$ OfFice of Federal Coordinator of U.S. Transportation, Public aids to Transportation, Public Aids to Motor Vehicle Transportation, Vol. IV (GPO, Washington, D.C., 1940) p. 6 .

${ }^{18} \mathrm{~L}$. VAN ORNum, Theory and Practice of Special Assessments, Transactions, Vol. 38 (American Seciety of Civil Engineers, New York, 1897) pp. 336-361.

"J. Holmes, Roadbuilding in North Carolina, Proceedings of the North Carolina Good Roads Convention, Bulletin No. 24 (Bureau of Public Roads, Washington, D.C., 1903) pp. 66,67 .

${ }^{20}$ H. Trumbower, Roads, Encrclopedia of the Soctal Sciences, Vol. 13 (MacMillan, New York, 1948) pp. 406, 407.

${ }^{21}$ G. Chatburi, Highways and Highway Transportation (Thos. Y. Crowell, New York, 1923) p. 128.
${ }^{22}$ Id., pp. 128, 129.

${ }^{2} I d$., p. 129.

${ }^{24}$ W. H. MOORE, Response to Address of Welcome, ProceEDings of the North Carouina Good Roads Convention, Bulletin No. 24 (Bureau of Public Roads, Washington, D.C., 1903) p. 12.

${ }^{25}$ H. TRUMBower, supra, note 20, p. 407.

${ }^{20} \mathrm{~L}$. PAGE, Progress and Present Status of the Good Roads Movement in the United States, Yearbook of The Department of Agriculture, 1910 (GPO, Washington, D.C., 1911) p. 270.

${ }^{27}$ A. Rose, Historic American Highways-Public Roads of THE PAST (American Association of State Highway Officials, Washington, D.C., 1953) pp. 94, 95.

${ }^{28} \mathrm{G}$. Chatburn, supra, note 21 , pp. 150, 151.

${ }^{29}$ M. EldDridge, G. ClARK \& A. LUEdre, State Highway Management, Control and Procedure, Public Roads, Vol. 1, No. 9, Jan. 1919, p. 60.

${ }^{30}$ L. PAGE, supra, note 26, pp. 273, 274.

${ }^{31} 23$ Cong. Rec. 6846 (1892).

${ }^{32}$ G. Chatburn, supra, note 21, p. 133.

${ }^{3}$ Buread of Public Roads Annuat Report, 1893, Letter From Secretary Morton to General Roy Stone, Oct. 3, 1893, p. 586.

${ }^{34}$ Bureau of Public Roads Annual Report, 1894, p. 217.

${ }^{85}$ Bureau of Public Roads Annual Report, 1895, p. 198.

${ }^{86}$ Id., p. 197.

${ }^{\mathrm{s}}$ G. PERKINS, State Highways in Massachusetts, YEARBOOK of The Department of Agriculture, 1894 (GPO, Washington, D.C., 1895) pp. 508, 509.

${ }^{38} \mathrm{BPR}$, supra, note 35 , p. 198.

${ }^{39}$ Bureau of Public Roads Annual Report, 1897, p. 174.

${ }^{40}$ U.S. Department of Agriculture, Yearbook of The DeP.ARTMENT OF Agriculture, 1897 (GPO, Washington, D.C., 1898) pp. 376-379.

${ }^{41}$ BPR, supra, note 39 , p. 174.

${ }^{42}$ Bureau of Public fioads Annuat Report, 1901, p. 251.

${ }^{43}$ Id., p. 238.

"Gen. Harrison Tells How the Road Was Built, THe RoAD MaKer, Vol. 1, No. 3, (Port Huron, Mich.) p. 6.

${ }^{45}$ BPR, supra, note 42, p. 243.

${ }^{48}$ M. A. HAYS, Interest of Railways in Road Improvement, Proceedings of the North Carolina Good Roads Convention, Bulletin No. 24 (Bureau of Public Roads, Washington, D.C., 1903) pp. 15, 16.

${ }^{47}$ Bureau of Public Roads Annual Report, 1902, p. 309.

${ }^{48}$ Bureau of Public Roads Annual Report, 1903, p. 337.

${ }^{49} \mathrm{M}$. O. ELDRIDGE, supra, note 4, pp. 5-7.

${ }^{50} I d$., p. 11.

${ }^{51} I d$., pp. 8, 9.

${ }^{52} I d$.

${ }^{53}$ BPR, supra, note 48 , p. 347. 


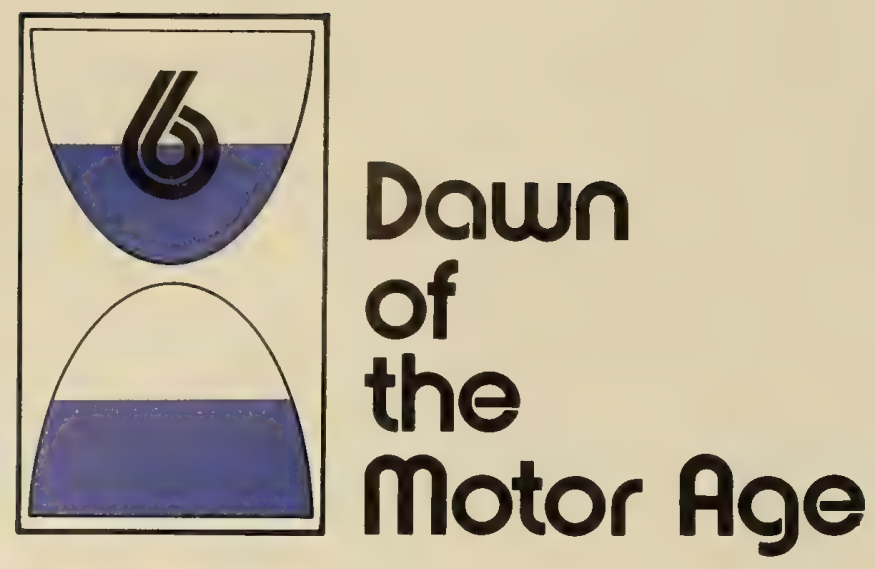

\section{The Early Automobiles}

In 1900 there were about 8,000 automobiles in the United States, practically all concentrated in the major cities. ${ }^{1}$ Probably half of these were electric-motor driven, silent and dependable, but limited by their lead-acid batteries to an operating radius of 25 to 30 miles. Since dependable pneumatic tires did not become available until 1897, practically all of these electrics ran on solid rubber tires, and most of them were European-made.

In the late 1890 's, the Stanley brothers of Newton, Massachusetts, perfected the European steam car into a reliable American vehicle with a greater driving range than the electric. By 1900 their steamers had driven the European models from the American market and two factories were producing cars under the Stanley patents. ${ }^{2}$

Karl Friedrich Benz of Mannheim, Germany, built the first reliable internal combustion engine automobile-a three-wheeler-in 1885. This extraordinary vehicle had electric ignition, water cooling system, a differential gear and surface carburetor-all Benz inventions. Later Benz invented the fixed front axle with steerable stub axles and in 1899 the gear box for changing speeds. ${ }^{3}$ In 1893 he exhibited a four-wheel vehicle which incorporated most of these advanced mechanical ideas at the Chicago World Fair. This machine, which incorporated in rudimentary form, practically all of the essential features of the modern automobile, was the inspiration for many others produced by American inventors in the following decade.

The total production of U.S.-made automobiles for the year 1900 was 4,192 machines, of which 1,575 were electrics, 1,681 were steamers and 936 were gasoline engine-driven. ${ }^{4}$ These, along with the European imports, were individually handcrafted and correspondingly expensive, costing from $\$ 3,000$ to $\$ 12,000$ each at a time when industrial and farm laborers were paid $\$ 1$ for a 10 -hour day.

\section{Auto Manufacturers Tap Mass Market}

These early automobiles were large, heavy and clumsy, partly from a paucity of engineering knowledge on how to compute the stresses in their various parts and partly from lack of strong light materials for their manufacture. About 1906 vanadium alloy steel, developed in Europe, became available in the United States, and by using it and other alloys, Henry Ford of Detroit, Michigan, was able to redesign his big, heavy touring car into a much lighter and smaller 


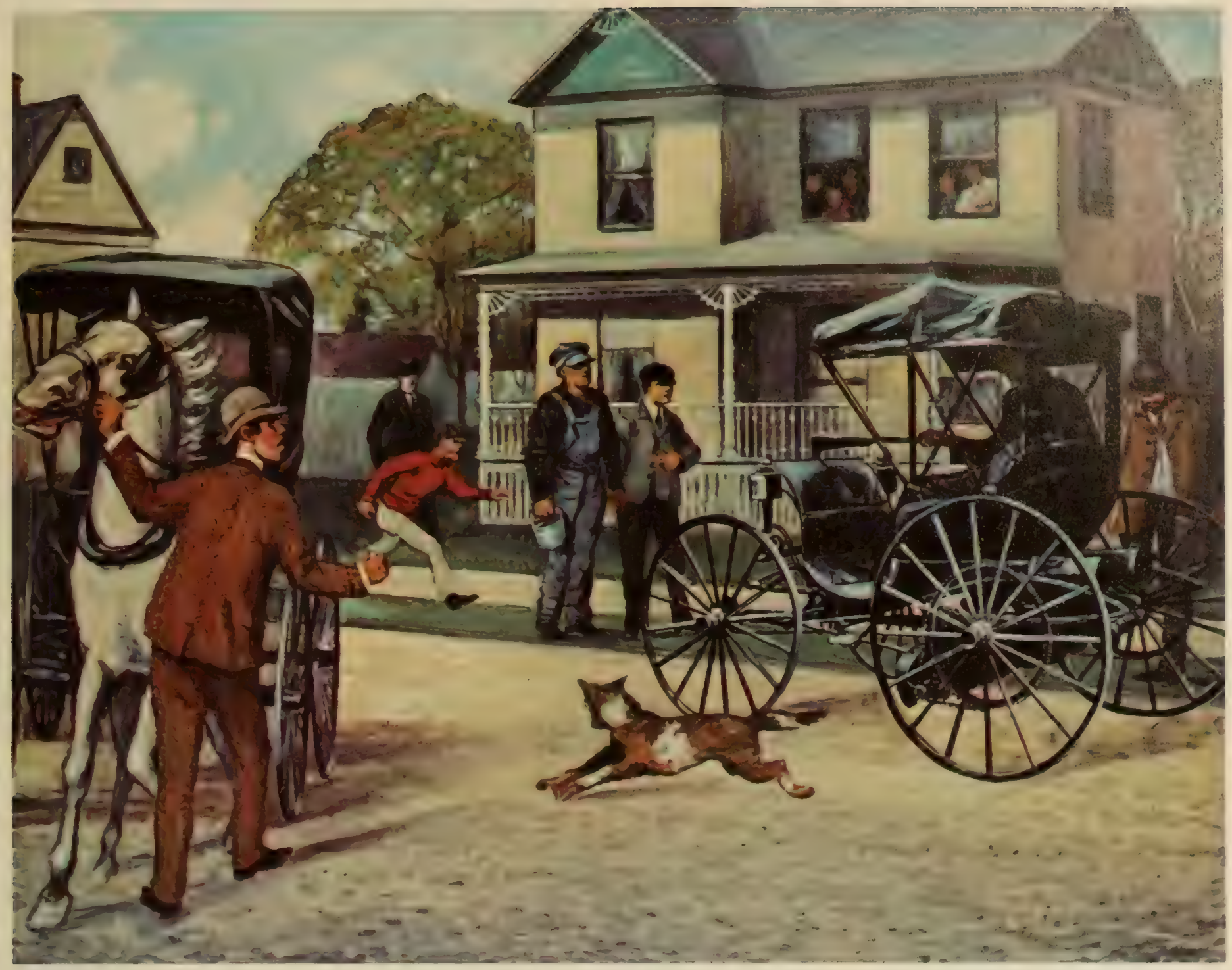

An early American automobile built around 1898.

vehicle - the famous Model T. At the same time, he tooled up to mass-produce components for this one vehicle and designed a moving assembly line on which to put the components together into cars.*

By thus redesigning the vehicle and standardizing the production process, Ford was able to increase production from 1,599 units in 1905 to 8,729 units in 1906 and 14,887 units in 1907 , at the same time reducing prices. These lower prices, in turn, opened the door to a huge mass market. As sales increased, Ford was able to realize further economies of scale in manufacturing, and still further reductions in cost, until by 1917 he was selling cars for less than $\$ 600$ apiece. $^{7}$

As Ford's competitors adopted his methods in a rush to catch up with him, the automotive industry turned out an ever-increasing flood of vehicles at lower

* Henry Ford did not invent mass-production, nor was he the first to apply it to auto making. The French made interchangeable parts for musket locks before 1785, and the Colt Armory at Hartford, Connecticut, was mass-producing firearms before the Civil War. Ford's contribution was in organizing manufacturing into a smooth coordinated process, eliminating wasted time and effort, and continuously applying technology to increase productivity.
A 1907 Columbia built by the Electric Vehicle Co. in Hartford, Conn. However, this is not an electric car. The auto manufacturers of that period numbered in the thousands, but often a manufacturer built no more than a dozen or so cars.

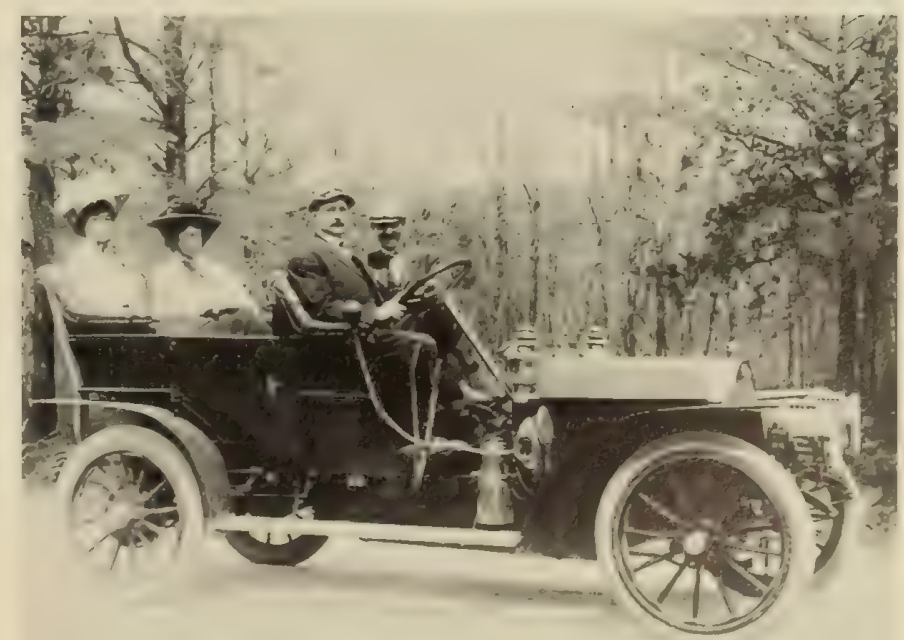


and lower prices.* To an increasing extent, the owners of these vehicles began using them on the country roads, as well as the city streets, bringing about a rural road crisis that began to be seriously felt by about 1910 .

\section{Competitive Auto Racing Spurs Vehicle Development}

Some of the pre-1900 autos were used as for-hire cabs in the cities, but most were owned by wealthy people who used them for personal convenience and as pleasure vehicles. In Europe, where there were many miles of smooth macadam roads, road racing by wealthy owner-drivers was a popular sport. Backed by motor car manufacturers and tire makers, road racing eventually became big business there, and contributed a great deal to the rapid improvement of motor design and mechanical reliability, which, in turn, gave Europe undisputed leadership of the motor car industry up to the outbreak of the war in Europe in 1914.

As the Wheelmen had done before them, the American motorists organized themselves into clubs for social enjoyment of their hobby and to protect themselves from restrictive legislation. The Automobile Club of America, one of the oldest of these social clubs, organized a road race, which was run on April 14, 1900, between Springfield and Babylon, Long Island. A 5 -horsepower electric car won this 50-mile event in the surprisingly good time of 2 hours $31 / 2$ minutes, followed by a steamer ( 2 hours 18 minutes) and a gasoline car (2 hours 30 minutes). ${ }^{9}$ However, road racing never became popular in the United States, partly because of hostile laws, but mostly for lack of sufficient mileage of reasonably motorable roads.*

"Toot ' $n$ ' be darned." A common problem when horsedrawn vehicles and automobiles mixed on narrow roads.

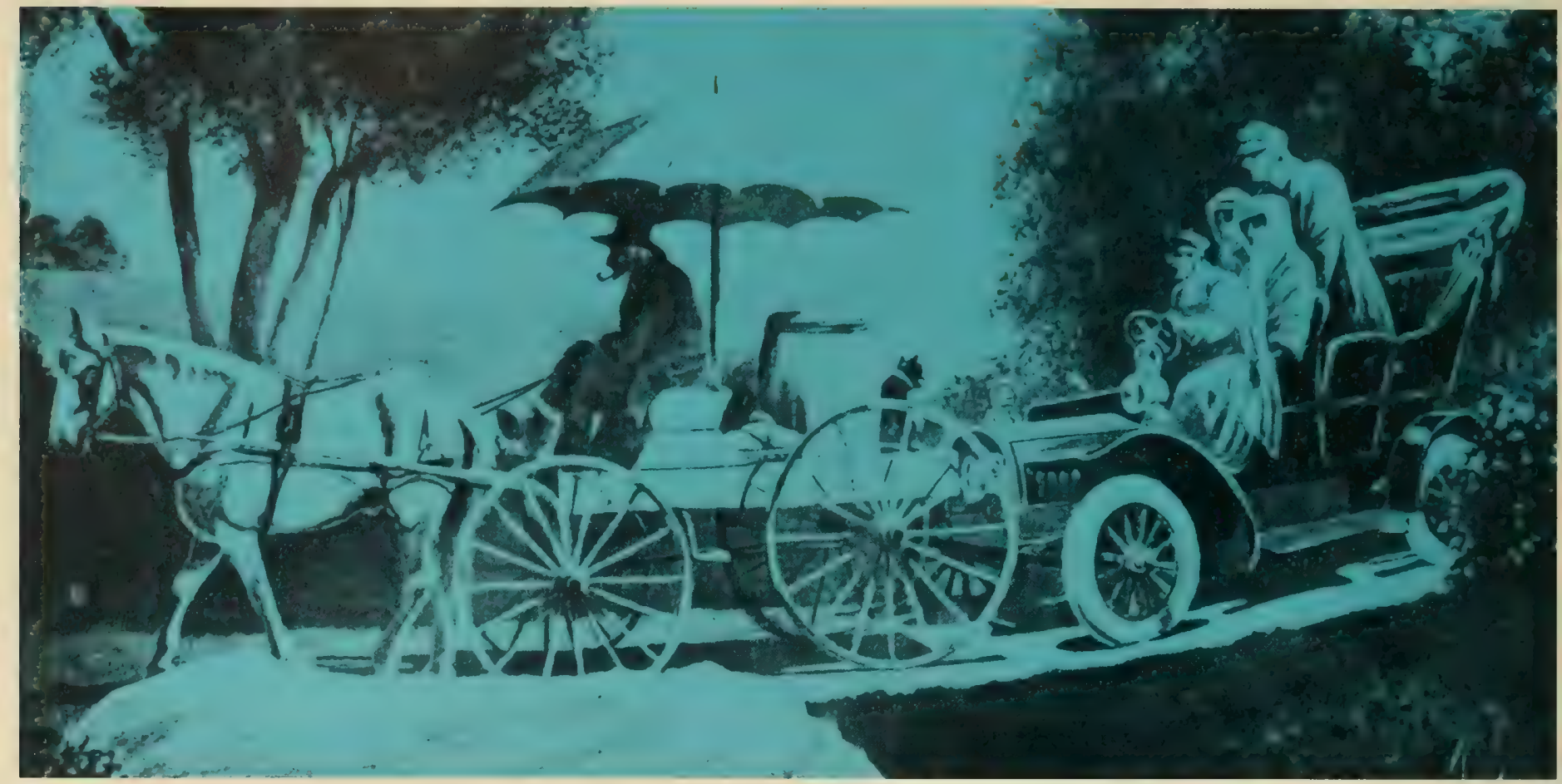

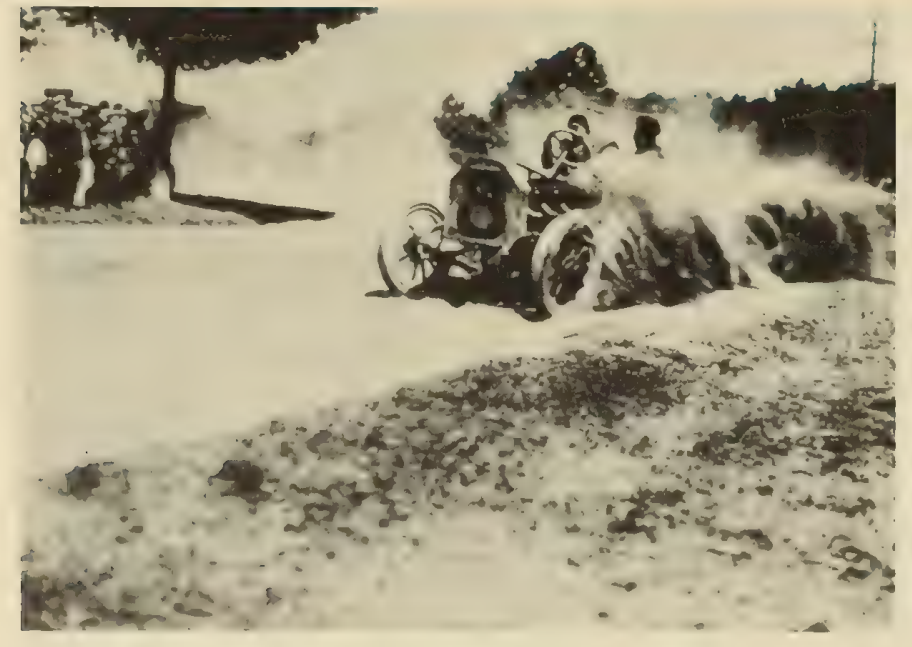

* Annual production of U.S.-made motor vehicles was 25,000 in $1905,187,000$ in 1910 and 969,930 in $1915 .^{8}$ The average new motor vehicle price in the United States in 1916 was about $\$ 605$.
Harry Grant driving a 60- $h p$

Berliet at Lowell, Mass, Sept. \%, 1908.

Grant came in second.

* In 1906 a group of racing enthusiasts, headed by William K. Vanderbilt, Jr., organized the Long Island Motor Parkway Company, which built a motor road on private right-of-way as a race course for the Vanderbilt Cup. The first unit of this parkway, opened October 10, 1908, was 11 miles long, paved with reinforced concrete, and was one of the first roads in the world to have superelevated or banked curves. When completed in 1910, this road was 45 miles long, and when not used for racing, it was opened to pleasure vehicles as a toll road. ${ }^{10}$ The European counterpart of the Long Island Motor Parkway was the Avus, begun in 1913 but not completed until 1919. This was a divided highway 6 miles long laid out on an absolutely straight line from Charlottenburg to Berlin, Germany, with no grade crossings and limited access to the traffic lanes. ${ }^{12}$ In 1909 Carl G. Fisher built a $2 \frac{1}{2}$-mile oval racing speedway at Indianapolis, Indiana. ${ }^{13}$ 
The Automobile Ventures Into the Country

In the early 1900 's a motor trip for any considerable distance into the country was an uncertain undertaking. To run out of fuel was disastrous and might entail a walk of several miles to the nearest hardware or paint store. Mechanical service was practically unobtainable; blowouts and tire punctures were frequent and not easy to repair. Dust was a major nuisance in dry weather. Most embarrassing of all, there were no comfort stations, and tourists were dependent on private kindness or the more secluded portions of the right-of-way for sanitary accommodations.

The automobile, to the dismay of road officials, was unexpectedly damaging to macadam and gravel roads. According to Director Page:

. The driving wheels of motor cars moving at high rates of speed exert a powerful tractive force on the road surface, which displaces the materials composing the surface. The result is that the finer particles and dust are thrown into the air to be carried off by cross currents of air. The rubber tire of the automobile does not wear any appreciable amount of dust from the rock fragments, and consequently, the loss of rock dust is a permanent loss to the road. Under these conditions, the road soon ravels, making travel difficult and allowing water to make its way to the earth subgrade or foundation. ${ }^{\text {Is }}$

The initial reaction to this destruction of the rural roads was a clamor to bar automobiles from the highways or severely limit their speed. Fortunately, calmer counsels prevailed, and some observers, such as the editor of American Highways magazine, actually viewed dusting as a blessing in disguise :

However, the motors are unquestionably here to stay and are going to play an important and very useful part in the lives of coming generations, and instead of trying to bar them off the roadways or misusing their owners, highway commissioners should attack the problems they present and should solve them as they have former problems. It is rather fortunate than otherwise that the motors have appeared on the scene before roadbuilding in the better sense engaged public attention. Had their advent been postponed until the country had built up a complete system of roads a tremendous expense would have been incurred for tearing up the old material and relaying it. ${ }^{25}$

It was, perhaps, inevitable that the early motorists should come into conflict with the farmers. Despite the fact that most surfaced rural roads built after 1900 had been made possible by State aid, paid for largely by city people or by urban support for county bond issues, many rural residents looked upon the motorists as intruders. This feeling was exacerbated by a minority of the motorists who used the roads for racing, often with mufflers cut out, frightening livestock and teams and raising clouds of dust. Some of the farmers countered by refusing to yield for overtaking, forcing motorists to creep along behind them for miles. It was even alleged that some farmers buried spikes and glass in the roads to puncture tender tires.

This division between farmers and urban motorists affected the solidarity of the Good Roads Movement, and was not finally resolved until the farmers themselves became motorists along with everyone else, and motoring ceased to be regarded as a rich man's pastime. The final burying of the hatchet came with the enactment of the Federal Aid Road Act of 1916.

\section{The Problems of Automobile Registration and Regula- fory Laws}

In the early years of this century, pleasure driving was restricted by a host of State and local laws and ordinances, as well as by the condition of the roads and other hardships. New York was the first State to require registration of motor vehicles, and in 1901, the first year a fee was charged, this State collected nearly $\$ 1,000$ from its motorists. ${ }^{16}$ The New York law was primarily a measure for legal control rather than for revenue, but in later years New York and other States collected sizable amounts of money in registration fees.*

As other States began charging registration fees, problems of reciprocity between the States arose to plague motorists. New York, the leader in the registration movement, allowed any vehicle to use its roads, provided that vehicle was registered in its own State, and provided that State granted the same privilege to cars registered in New York. At this time, New York had full reciprocity with 15 other States but not with New Jersey. As a result, thousands of New Yorkers who had summer homes on the Jersey coast had to register their machines for the full year in both States. ${ }^{18}$ A similar relation existed with Massachusetts and 17 other States which did not grant full reciprocity.

Lack of reciprocity was a serious hindrance not only to pleasure travel, but also to interstate commerce which was just beginning to use the roads again after a lapse of 60 years. As the secretary of state of New York said in 1911:

... It seems to be a failure to recognize the importance of the automobile, when a tourist is confronted by the necessity of carrying with him on a tour throughout the States the license of each State he enters. . . The automobile gives opportunities of seeing the country which the people have never had to such an extent before. It leads to many small interesting places which even the railroad with its great facilities has not been able to make sufficiently accessible. It enables the people to know their country better. It brings people into closer contact. Especially is this true of the commercial vehicle. Trips from New York to Philadelphia are very frequent. It surely will not be conducive to the growth of this phase of the industry and to business generally if a merchant in Philadelphia, desiring to carry goods to New York City, will have to have his machine registered in Pennsylvania, New Jersey and New York and to pay a fee in each State. ....

In many States, registration fees were not the only imposts on motor vehicle owners. Some cities and villages required the motorist to pay a "wheel tax" of $\$ 10$ to $\$ 20$ per year for the privilege of driving on their streets. A number of States collected a personal property tax on the vehicle in addition to the registration fee.

After he had solved the registration and tax problems, other hazards confronted the motorist when he ventured beyond the limits of his own city. The individual municipalities had their own ordinances regulating speeds, parking, the use of bells, horns and

* In the first 10 months of 1911, 35 States collected a total of $\$ 3,746,938$ in registration fees and operator license fees from 516,977 owners of motor vehicles. The amounts collected ranged from $\$ 986$ in Utah (442 owners and 51 operators) to $\$ 882,975$ in New York ( 81,665 owners and 33,485 operators)..7 


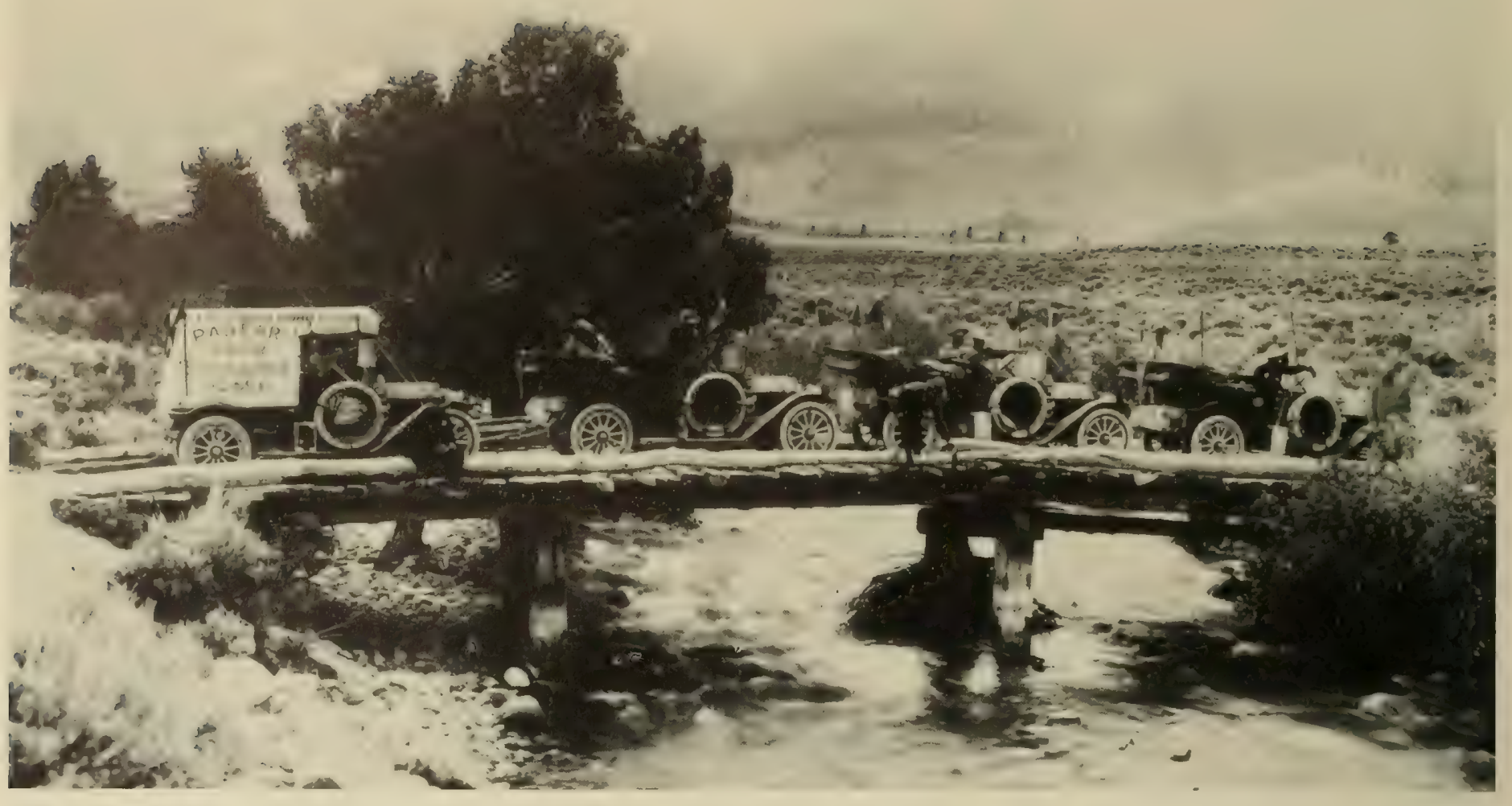

The Pasear was the name given to a combination of three highways in California: El Camino Real or the Royal Highway; El Camino Sierra or the Mountain Highway; and $\mathrm{El}$ Camino Capital or the Capital Highway. These roads form a 1,500-mile scenic circuit from San Francisco to Los Angeles, to Lake Tahoe, and back to San Francisco. In 1912 the advocates of the Pasear urged that the roads be improved for motor travel in time for the Panama-Pacific Exposition to be held at San Franciscu in 1915. These scenes along the El Camino Sierra are a prelude to the rugged beauty to be found on the Pasear. 
2. 245

d. $x+x^{3}$

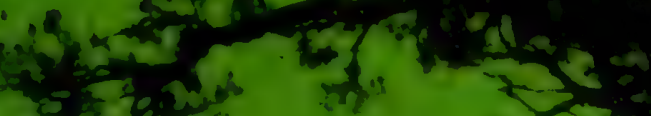

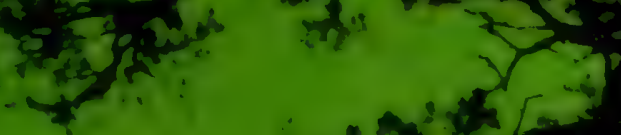

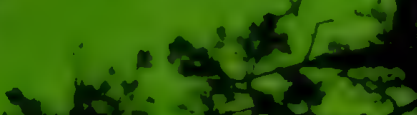

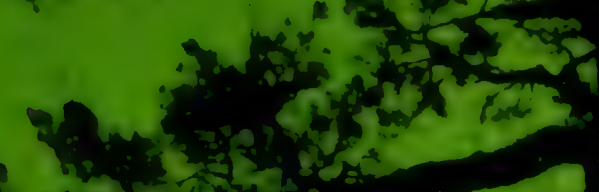

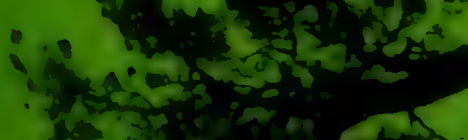

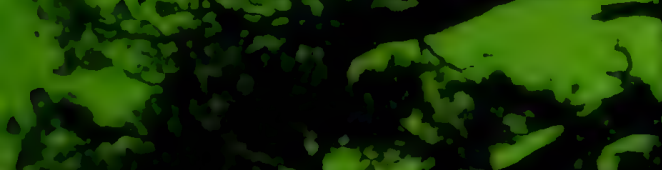

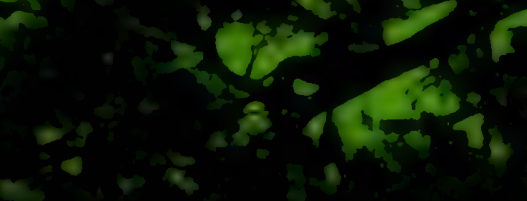

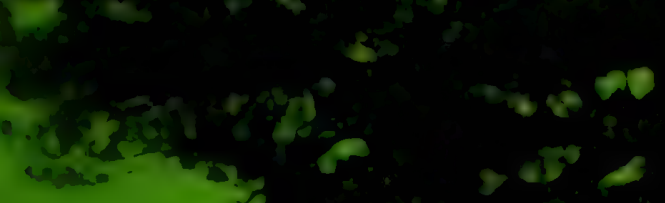

$x^{2}+x^{2}+x^{2}$

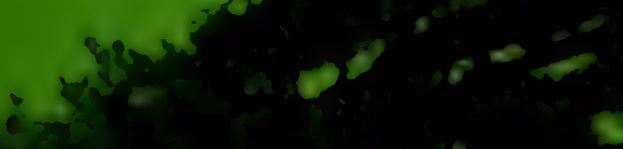

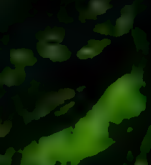

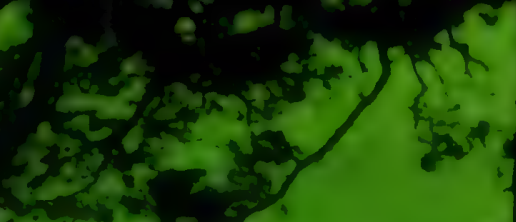

$\int_{3}$

$\therefore i$

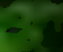

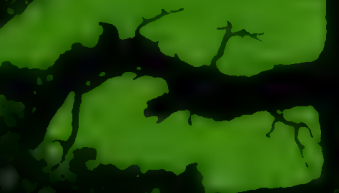

at:

$2 \sin ^{2}$

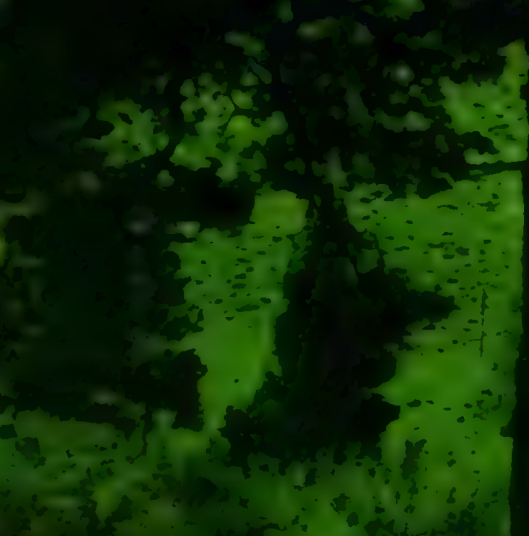

$6 x^{2}$

$x^{2}-1-t^{2}+e^{4}$ $-\infty$ tes

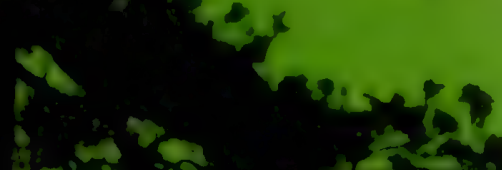

40 की

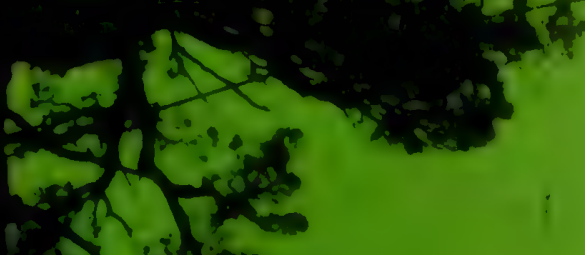

fos this

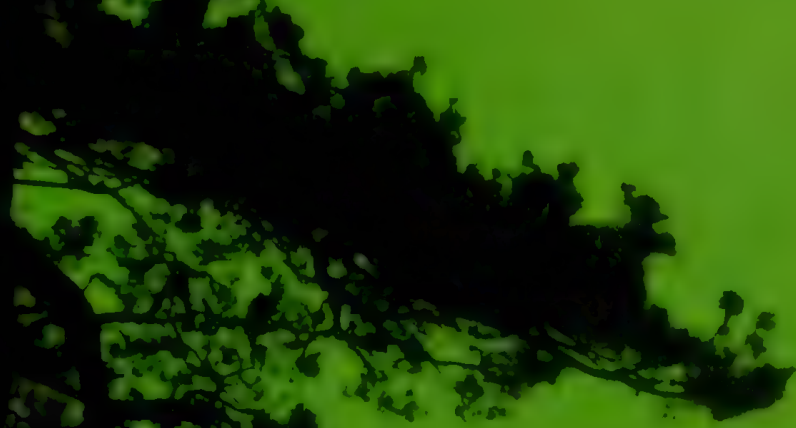

- $x^{3}+b^{5}-34$

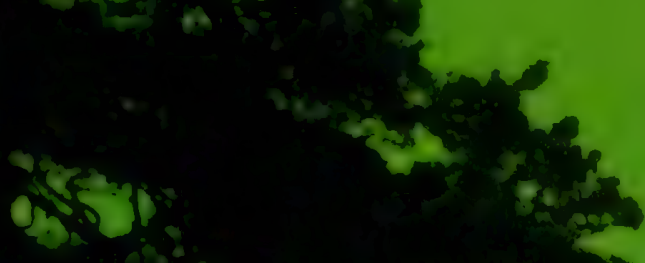

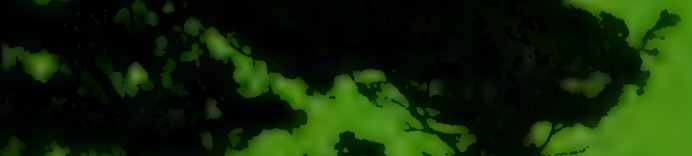

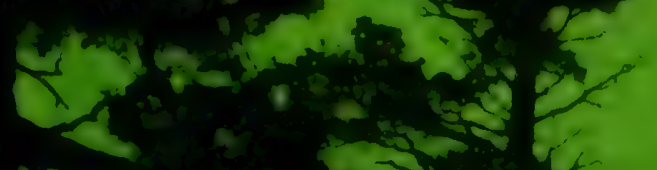

(2)

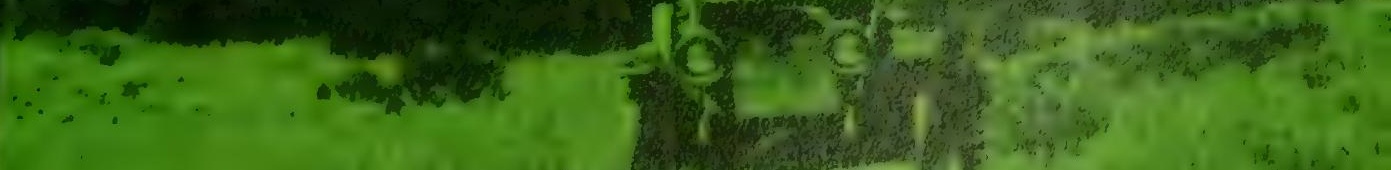

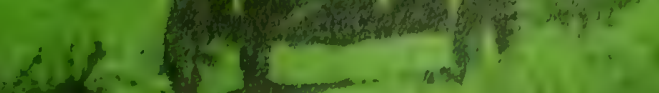

$\operatorname{lin}_{1}+2$

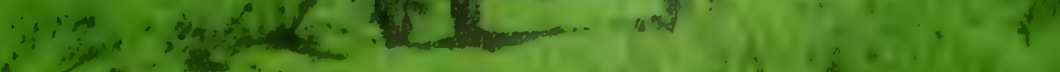




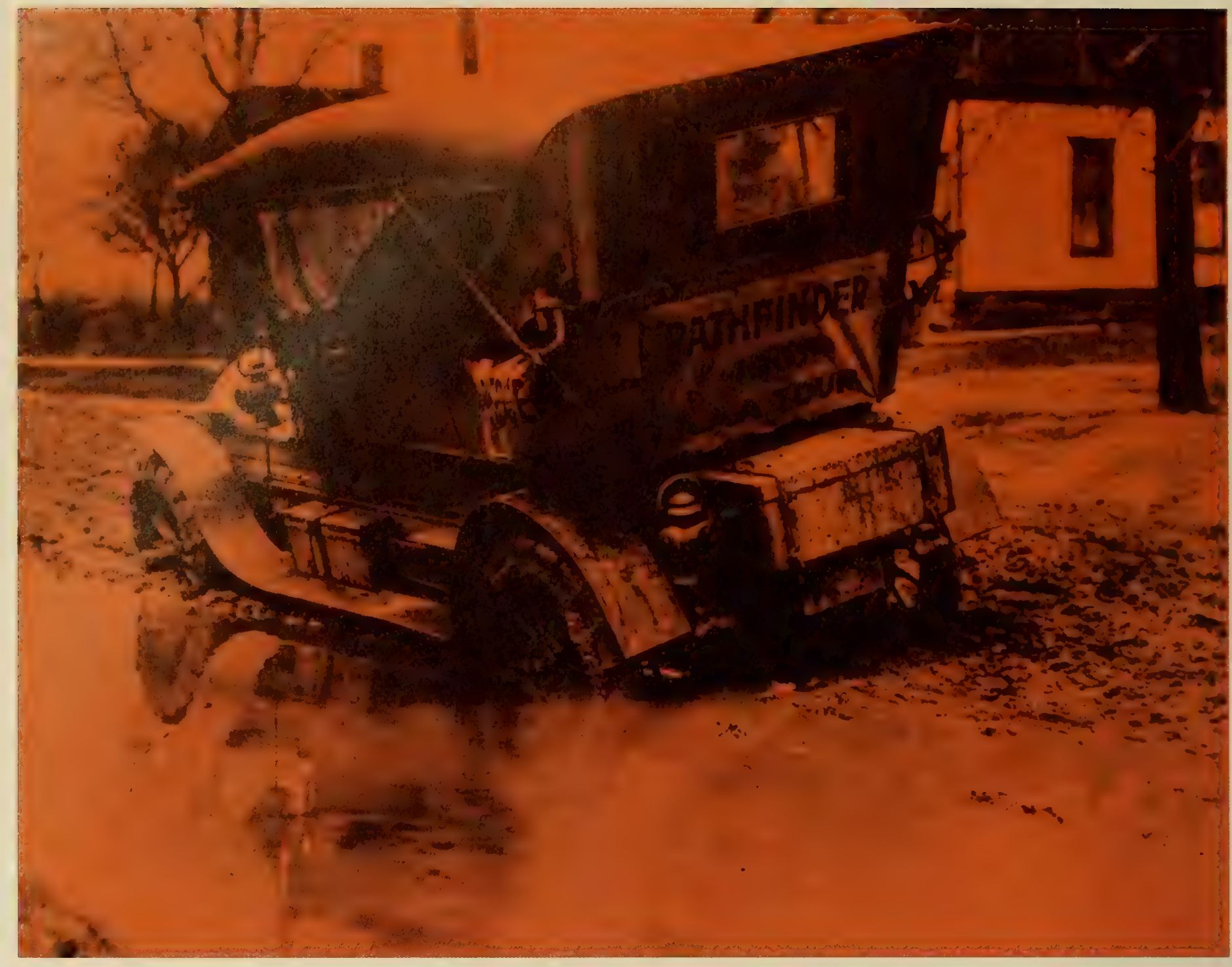

One of the challenges of the early AAA tours.

gongs, the making of unnecessary exhaust noise and the emission of noxious gas, smoke or steam, and they could impose fines for violations. These regulations varied widely from city to city and, especially in the smaller municipalities, were often enforced in a discriminatory way. The operation of "speed traps" by local peace officers was a widespread abuse in rural communities, with the fines going into the local treasury or the pocket of the police justice or magistrate.*

The widespread variations in traffic regulations, and especially in registration requirements, laid a severe burden on motorists and also on automobile manufacturers who regarded them as obstacles to vehicle ownership and the expansion of the market for automobiles. Combating restrictive legislation was a principal reason for the organization of both the American Automobile Association in 1902** and the

* The speed trap racket was so bad in New York prior to 1910 that the Legislature passed an act that year requiring all fines imposed for violations of the motor vehicle laws to be turned over to the State treasurer. This reduced the fines collected from motorists to a mere trickle. ${ }^{20}$

** A number of State and local automobile clubs banded together to form the American Automobile Association, which rapidly became the national voice of the automobile owners and a powerful lobby for good roads.
National Automobile Chamber of Commerce in 1913.* These and other organizations backed a bill in the 60 th Congress that would have required Federal registration for all vehicles. They also worked diligently to standardize the motor vehicle laws in all the States. Eventually, both goals were achieved without Federal intervention, as shall be seen.

\section{The Motor Pathfinders}

Up to 1903 no automobile had crossed the United States under its own power, and most people who knew anything about American roads, especially those of the Rocky Mountain and Great Plains States, thought such a trip impossible. Dr. H. Nelson Jackson, of Burlington, Vermont, thought otherwise, and he burned with the urge to be the first person to travel from coast to coast by motor. On May 23, 1903, he left San Francisco, in secrecy, with his chauffeur Sewell K. Crocker, in a 20 -horsepower Winton touring car. Sixty-three days later, the two pathfinders rolled into New York after averaging 90 miles per day in 44 days actual running time, despite terrible weather. ${ }^{21}$

A year after Doctor Jackson's feat, a group of motor enthusiasts conceived the idea of a mass motor tour or

\footnotetext{
* Now the Motor Vehicles Manufacturers Association.
} 
"pilgrimage" from the major eastern cities to the Louisiana Purchase Centennial Exposition in St. Louis. The logistics for such an expedition at this time were formidable. There were no through routes, no reliable road maps, no way of knowing the condition of the roads in advance, no road signs or route markers. Between major cities, getting repairs for a breakdown, or even fuel, was an uncertain business. The promoters of the tour enlisted the aid of the automobile clubs along the way who agreed to select and map the best roads in their areas and mark them with confetti at the critical cross roads so the out-of-State motorists wouldn't get lost. The trip was planned in 100 -mile stages, and each entrant was provided with marked maps showing the assembly points, the selected routes, and points along the way where repairs, fuel, lodging and meals might be obtained. Finally, the promoters persuaded the American Automobile Association (AAA) to supervise the affair through a set of committees. ${ }^{22}$

Fifteen cars left New York City July 25, 1904. At Albany they were joined by a contingent from New England led by Charles J. Glidden, the most experienced motorist in America, who, with Mrs. Glidden, had already logged 17,782 miles in 17 countries in his English Napier. The tour continued through Buffalo,
Cleveland, Toledo, South Bend and Chicago to St. Louis, losing a fow machines enroute from mechanical failure, but picking up new entrants at the principal cities. Of 108 machines registered for the tour, 70 reached starting points and only 58 of these reached St. Louis. The Boston entrants covered 1,264 miles in 17 days, an average of 70 miles per day of hard driving. ${ }^{23}$ Unlike Dr. Jackson, who had shunned publicity, the St. Louis World Fair Motor Caravan carried reporters from the Nation's principal newspapers and was attended by enormous ballyhoo, which focused on the execrable condition of most of the roads encountered by the hardy pathfinders.

Upon arrival in St. Louis, Charles Glidden announced that he was presenting a trophy to the American Automobile Association on which would be engraved the name of the owner-driver of the car making the best record on a carefully organized long distance tour such as the one just completed. This reliability contest would be an annual affair, supervised by the AAA, which would draw up the rules for the contest and retain ownership of the trophy.

The first Glidden Tour of 34 participants left New York City July 11, 1905, on an 870-mile junket through New England. Thereafter, the Tour was held annually until $1910 .^{24}$

The Ohio Mud Hen during a cross country trip in 1911 about to cross the Gila River in Arizona with the aid of a couple of mules.

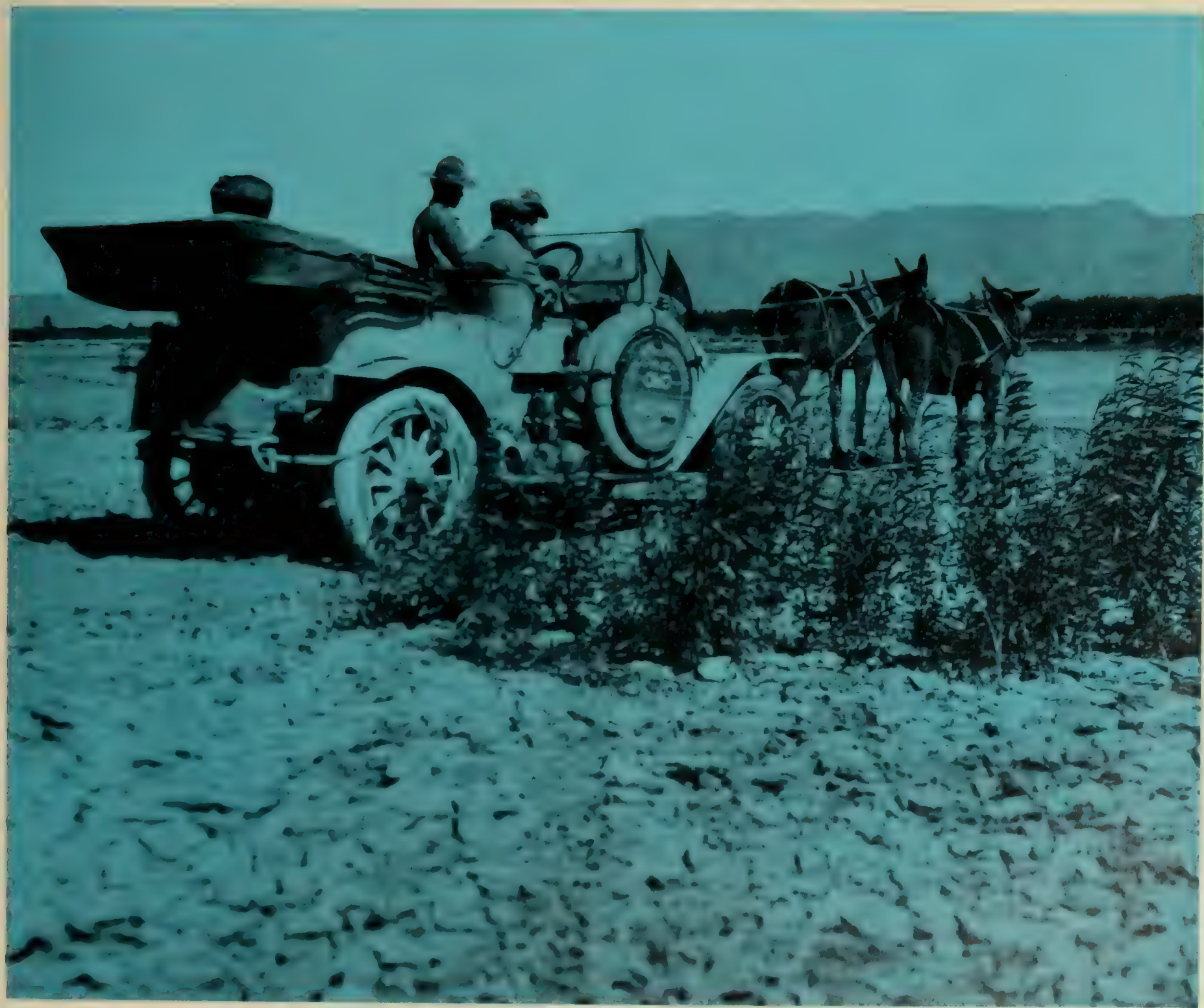




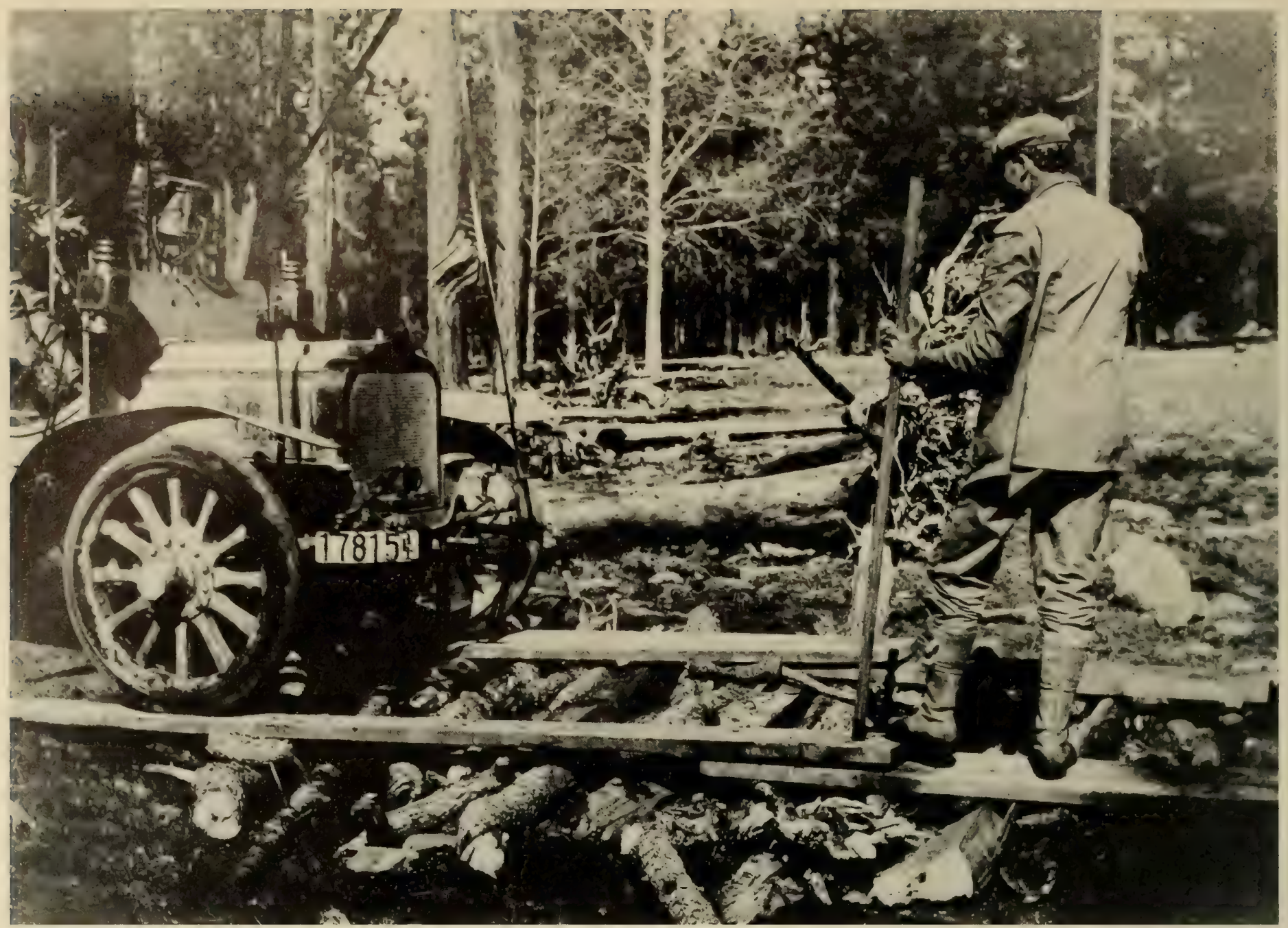

The Pioneer Freighter bridging a swampy area on the north side of the White Mountains in Arizona.

The Jackson-Crocker transcontinental trip had been a daring stunt, like crossing the Atlantic in a rowboat, with no underlying purpose other than to show that it could be done. The St. Louis tour was a similar challenge on a larger scale. The competition for the Glidden Cup, however, had a more serious objectiveto focus national attention on the difficulty of traveling any considerable distance on the common roadsand it was remarkably effective in meeting this objective. The Glidden Tours showed conclusively that motor cars were mechanically capable of traveling long distances if the roads were reasonably good, and they fueled a rising demand from motorists for motorable long-distance roads, even a coast-to-coast highway.* Many people thought the States and counties would never be able to provide such highways, and they seriously advocated that the Federal Government build and operate national highways.

The Pioneer Freighter, a gasoline-powered motor truck made by the Saurer Motor Car Company, made two memorable cross country trips in 1911. This 37 horsepower vehicle weighed 3 tons and carried a load of $31 / 2$ tons of lumber for bridging creeks and soft places, plus supplies of fuel and camp equipment. The expedition was in the charge of $\mathrm{A}$. L. Westgard of the Touring Club of America, who had also been commissioned a Special Agent of the Office of Public Roads by Director Page.

The first trip of the Pioneer Freighter began March 4, 1911, at Denver, Colorado, and proceeded via Santa $\mathrm{Fe}$ and Phoenix to Los Angeles. This trip traversed 1,450 miles in 66 days, of which 53 days were consumed in actual travel. The average speed was 3.26 miles per hour-about as fast as a man could walk. The machine was shipped to Pueblo, Colorado, by rail, leaving there under its own power June 12, 1911, and ending in New York City in July 1911. The full significance of these trips would be felt a few years later, when the United States began mobilizing for World War I. ${ }^{26}$

\footnotetext{
* In 1907 a group of promoters proposed a toll road from New York to Boston to be built on a 150 -foot fenced right-ofway with two one-way 25-foot roadways and entrances every 6 or 7 miles. They estimated that traffic would be 250 cars per day each way and planned to charge each one a toll of 5 cents per mile. ${ }^{25}$
} 


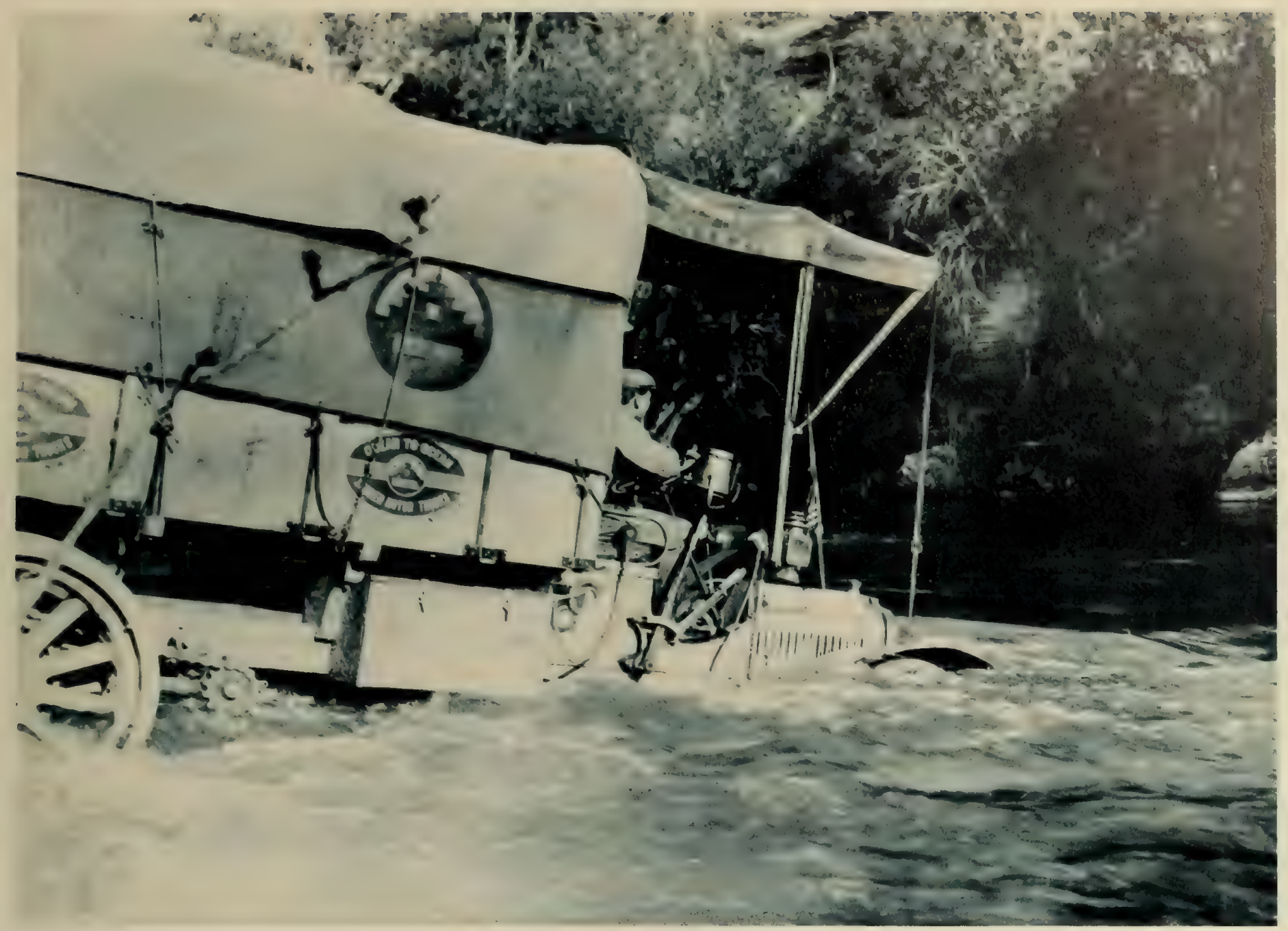

The Pioneer Freighter fording a river near Ft. A pache, Ariz.

\section{REFERENCES}

${ }^{1} 1971$ AUtomobile Facts and Figures (Automobile Manufacturers Association, Detroit, 1971) p. 18.

${ }^{2}$ C. Borth, Mankind on the Move (Automotive Safety Foundation, Washington, D.C., 1969) p. 171.

'R. Kirby, S. Withington, A. Darling \& F, Ktugour, EngiNEERing In Histoky (McGraw-Hill, New York, 1956) pp. 406, 407.

' Supra, note 1, p. 3.

- A. Rose, Historic American Highways-Public Roads of THE PAST (American Association of State Highway Officials, Washington, D.C. 1953) p. 102.

-A. Butstall, a History of Mechanical Engineering (M.I.T. Press, Cambridge, 1965) p. 224.

${ }^{\top}$ A. Rose, supra, note 5, p. 103.

'Supra, note 1, p. 3.

A. Rose, supra, note 5, pp. 101, 102.

${ }^{10} I d$., p. 106.

${ }^{2}$ H. Kelly, Toll Roads, Public Roads, Vol. 12, No. 1, Mar. 1931 , p. 4.

23 C. Tunnard \& B. Pushkarev, Man-Made America: Chaos or Control? (Yale University Press, New Haven, 1963) p. 163.
${ }^{13}$ A. Rose, supra, note 5, p. 103.

${ }^{14}$ L. Page, Roads, Paths and Bridges (Sturgis and Walton, Co., New York, 1912) p. 216.

${ }^{15}$ Editorial, American Highways, Vol, 2, No. 8, Jan. 1908 (American Highways Publishing Co., Grand Rapids, Mich.) p. 239.

${ }^{16}$ A. Rose, supra, note 5, p. 102.

${ }^{17}$ E. Lazansky, A Model State Motor Vehicle Law, Papers, Addresses and Resolutions Before the American Road Congress (Richmond, Va., Nov. 1911), (Waverly Press, Baltimore, 1912) p. 151.

${ }^{18} I d .$, pp. 153, 154

${ }^{19}$ Id.

${ }^{20} I d .$, p. 157.

${ }^{21}$ A. Rose, supra, note 5, pp. 102, 103.

${ }^{22}$ C. Вовтн, supra, note 2, pp. 178-183.

${ }^{23} I d$.

${ }^{24}$ A. Rose, supra, note 5, p. 103.

${ }^{25}$ Plan Great Auto Boulevard, American Highways, Vol. 1, No. 10, Mar. 1970 (American Highways Publishing Co., Grand Rapids, Mich.) pp. 278, 279.

${ }^{28}$ A. Rose, supra, note 5, p. 107. 


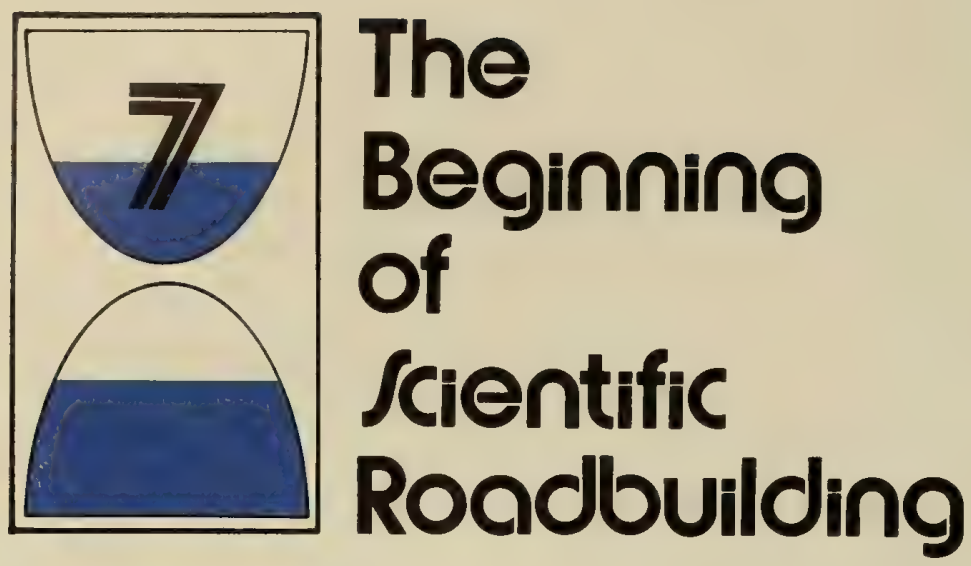

The appointment of Logan Waller Page as Director of the Office of Public Roads brought a new type of leader-the scientifically trained civil servant-into the highway movement. In 1893 , when only 23 years of age, Page was appointed director of the road materials laboratory of the Lawrence Scientific School of Harvard University and also geologist and testing engineer of the Massachusetts State Highway Commission. At this time, although standard practice in France, the laboratory testing of road materials was unknown in the United States. Page enrolled in the French Laboratory of Bridges and Roads where he learned the French methods, introducing them later into his Massachusetts laboratory. ${ }^{1}$ After 7 years of distinguished work for the Commission, Page was invited to Washington in 1900 to set up a road materials laboratory in the Bureau of Chemistry of the Department of Agriculture. ${ }^{2}$ This laboratory tested thousands of specimens for the OPRI under the object lesson road program, and Page was instrumental in establishing testing laboratories in some of the States. In the reorganization of 1905 , Page's laboratory became the Division of Tests of the Office of Public Roads and eventually one of the world's famous physical research organizations.

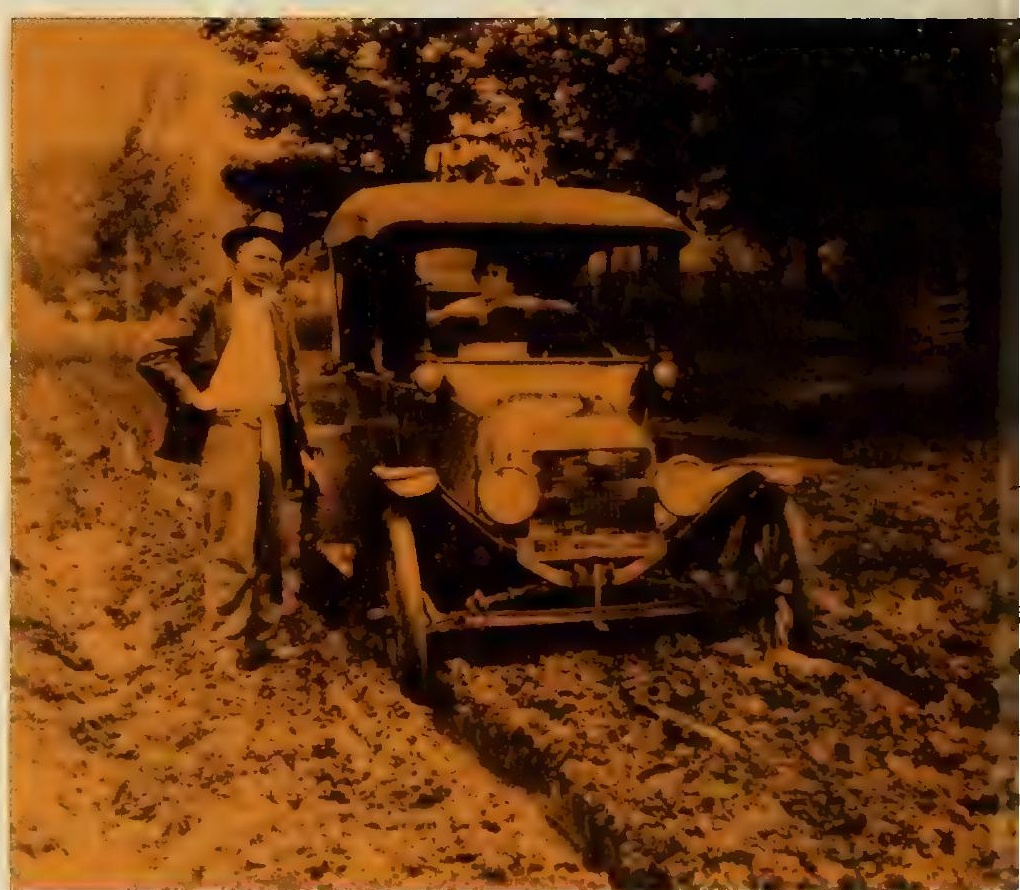

The Jefferson Highway near

DeQueen, Arkansas, before improvement. 


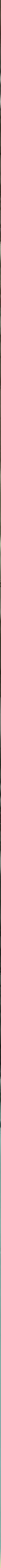

The Jefferson Highway after improvement as a gravel road.

\section{Expansion of the Object Lesson Road Program}

When Page became director of the Office of Public Roads (OPR) in 1905, only 14 States had highway departments, and 5 of these were less than 6 months old.* The mileage of roads under State control was very small, and State expenditures, mostly in the form of aid to the counties and townships, were only about 3 percent of total road expenditures in the United States. ${ }^{* *}$

It was as evident to Director Page as it had been to his predecessors that the main effort for improving the rural roads would have to be directed to the counties and townships. Up to this time, the OPR's most popular work with the local governments had been the object lesson roads, and already ample evidence of their effectiveness was beginning to accumulate. This evidence was summarized by Director Dodge in 1904:

\footnotetext{
* Massachusetts (organized 1893), New Jersey (1894), Connecticut (1895), Rhode Island (1896), New York (1898), Vermont (1898), Pennsylvania (1903), Ohio (1904), Iowa (1904), Illinois (1905), Michigan (1905), Minnesota (1905), New Hampshire (1905), Washington (1905). ${ }^{3}$

** In 1904 total road expenditure, including the estimated value of statute labor, was $\$ 79.77$ million, of which $\$ 2.6$ million was State aid."
}

a section of good road built as an object lesson under the direction of the United States Government in any community has the effect of awakening much greater interest than such a road constructed by the local authorities. That the people desire instruction by the building of object lesson roads and are willing to bear the expense incident thereto is fully proved by the requests received for cooperation, the number being far more than we are able to comply with. That the results are almost uniformly satisfactory and frequently beyond the most sanguine expectation is demonstrated by reference to the letters embodied in this report from representative citizens in the sections where the roads were built and by personal investigations by representatives of this Office. In some instances the object lesson resulted in the slow but steady improvement of the common roads; in a few cases the results were the inauguration of extensive systems of road building. In practically every instance some measure of progress resulted from the object lesson. It would seem to be conservative to estimate that an average of at least 10 miles of improved highways are constructed as a result of the building of each of these roads. ...

Page, whose budget had been increased to $\$ 50,000$, decided to expand the object lesson road program and change its emphasis away from macadam construction to a wider use of local materials, particularly the most abundant of all-earth, clay and sand. As he wrote in 1909: 
... Experience has shown that our earth roads can, in general, be very much improved by proper construction and systematic maintenance at a cost well within the reach of almost any community. Furthermore, these improved earth roads serve as the best possible foundation for further improvements with a hard surface as means become available. ...

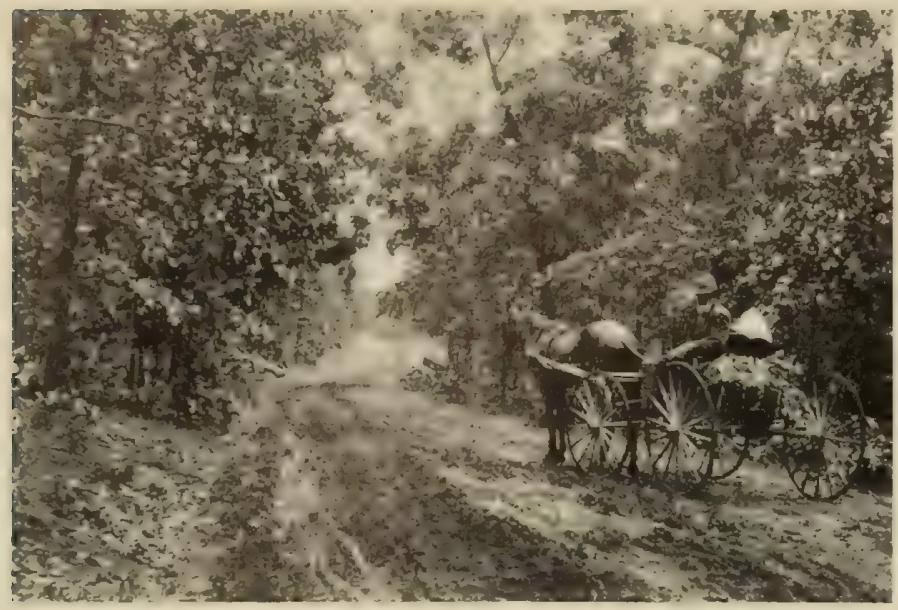

Post road in Lauderdale County,

Alabama. Small hump in distance is chert

which will be cut and used for surfacing.

The concept of stage construction, enunciated by Page in the above quotation, became one of the guiding principles of Federal road policy for the next 50 years.

During 1908, 1909 and 1910, the OPR supervised the construction of 1,300 miles of earth roads and 440 miles of sand-clay roads.* Inevitably, object lesson roads to demonstrate the use of local materials became, in some respects, experimental roads as well. The OPR's Road Expert, W. L. Spoon, who was handling the object lesson road work in the southern States, thought that clay might be made into a suitable road surfacing material by burning or roasting it in place on the road. A small experimental project was set up the summer of 1904 near Clarksdale, Mississippi, in which 300 feet of clay "gumbo" road was burned by wood and bark fires until the clay was nonplastic. The resulting surface compared favorably to gravel and cost only one-fourth as much. ${ }^{8}$

The OPR also cooperated in the construction of experimental sand-clay roads in Iowa, Kansas and Nebraska to determine whether sand-clay was suitable for areas with cold climates and deep frost penetration.

\section{Experimental Roads Expand Knowledge of Road- building}

These experiments were not the first in which the Office had been involved. In 1898, the Office of Public Road Inquiries had built short steel trackway roads at the Trans-Mississippi Exposition at Omaha and at Ames, Iowa, and St. Anthony Park, Minnesota. These

* Mileage based on an assumed average width of 15 feet. Sand-clay roads were ancestral to our modern soil stabilizations and were first used extensively in Richland County, South Carolina, in 1889, from where they spread through the South in the 1890 's.

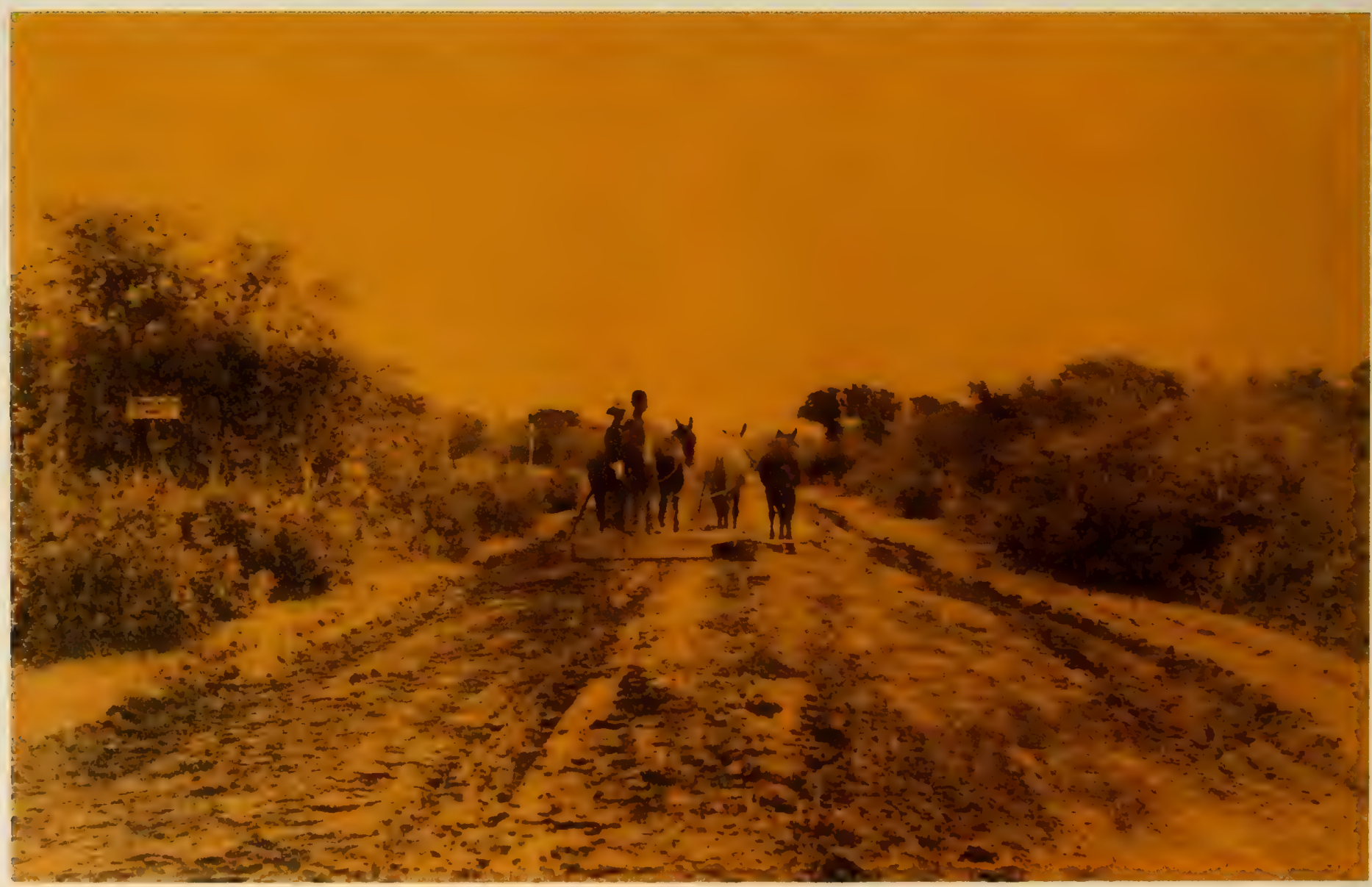


proved to be impractical. Another experimental trackway road, this one of bricks, was built on the Department of Agriculture grounds in Washington in 1900. The most important of these early experiments, however, was the oil treatment of a 4,650-foot section of the Queens Chapel Road in the District of Columbia.

In 1900 the automobile was not a significant cause of road dusting, and road oiling was practically unknown outside of Los Angeles County, California, where 6 miles of road were oiled in 1898 to lay the dust "which, churned beneath the wheels of yearly increasing travel during the long dry season in that region, had become a most serious nuisance." "The Queens Chapel Road had a surface of sandy clay and loam. This was shaped up and sprinkled with oil delivered by an ordinary water-sprinkling wagon.

The ordinary sprinkling wagon was found quite satisfactory, especially as the weather was warm, so that the oil ran quite fast enough to be gradually taken up by the surface and not so fast that it would flow into the side ditches, as would have been the case had the required amount been applied at once. ${ }^{10}$

The oil used for this experiment was "that which is left of crude petroleum after such volatile substances as naptha, kerosene, benzine and gasoline have been extracted." The results of the treatment appeared to be good, but the OPRI elected to reserve judgment on its ultimate effectiveness:

This road was treated several weeks ago, and so far as we are now able to judge the new system is a success as a dust layer. We believe that where roads have so much traffic and dust as to require the use of the sprinkling cart in dry weather, the residue oil, or roadbed oil, as it is called by dealers, could be used very effectively and economically. The fact that it settles the dust and kills weeds was first recognized and utilized by the West Jersey and Seashore Railroad. It is now being applied annually to about thirty of the leading railroads throughout the country, and its use is being gradually extended to the ordinary country roads. It is claimed by some that the application of crude oil will make a surface impervious to water, and consequently comparatively free from frost and mud. If this be the case, oil will supersede gravel and stone in the improvement of country roads. The test of time alone can settle this very much disputed question."

Out of these early experiments there gradually evolved a new program, the object of which was not so much to demonstrate good construction practice as to acquire new knowledge and experience.

In 1908 the OPR began a study to determine whether blast furnace slag could be made into a suitable road aggregate by mixing it with lime, limestone, tar or asphaltic road oil. This investigation had an immense economic potential, since about 20 million tons of slag were produced annually in the United States, most of which had no commercial value.

Between 1908 and 1916, the OPR supervised or participated in the construction of several dozen experimental roads, ranging from earth-oil mixtures to portland cement concrete and paving brick. These were inspected periodically and their service evaluated and correlated with the laboratory records of the materials that went into them. Eventually the OPR engineers drew up specifications for each type of construction based on their experiences with these experimental roads and the numerous object lesson roads. These specifications were published in bulletins, some of which went into five editions, and were widely used

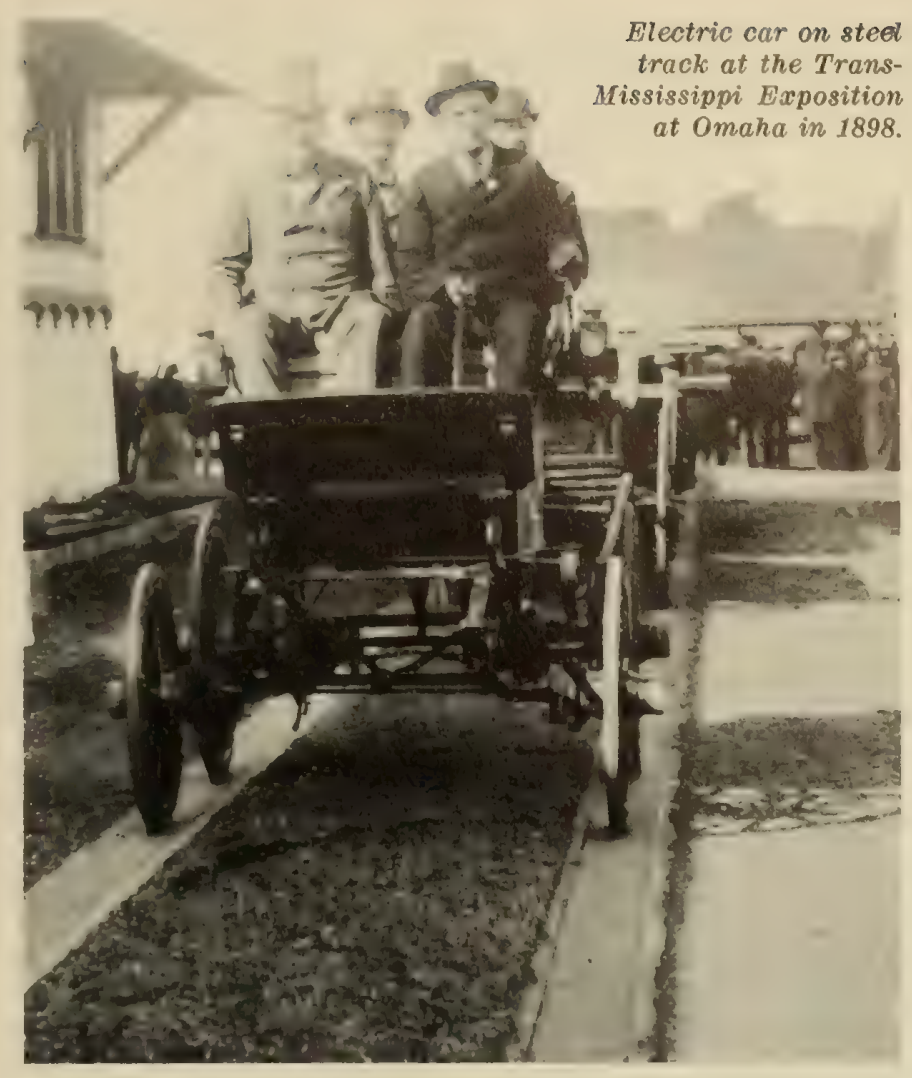

by counties, States and engineering colleges as references. In particular, the OPR's specifications for bituminous road binders became the standards for the industry and were adopted by most of the State highway commissions.

\section{The Dust Nuisance and Road Preservation}

The light duty macadam and gravel roads constructed during the Good Roads Movement served their purpose very well until appreciable numbers of automobiles began to use them.* Many engineers, Page among them, were convinced that the solution to this troublesome problem lay in using something other than stone dust or clay as a binder for stone and gravel roads. Hot-laid asphalt paving had been used on city streets in Europe and the United States since the early 1870 's, but was considered far too expensive for country roads. However, liquid materials containing bitumen cement, such as petroleum, coke-oven tar and water-gas tar, were plentiful and cheap and seemed promising as dust layers.

An opportunity to test these materials came in 1905 when the Madison County Roads Association and the city engineer of Jackson, Tennessee, sought the OPR's cooperation in experiments to determine the value of coal tar and petroleum oils for building dustless roads. Page agreed to participate by supplying expert supervision and the facilities of the OPR laboratory. The Tennessee experiments were moderately successful, and 3 years later, in 1908, the tar and residual petroleum oil (asphalt) treatments were pronounced "on the whole very satisfactory," but the crude oil treatment had disappeared, leaving the roads as dusty as ever. ${ }^{13}$

\footnotetext{
* In 1900 there were 8,000 automobiles in the United States. By 1905 there were 77,400 autos and 1,400 trucks. By 1910 motor vehicles had multiplied six times, to 468,500 , and by 1915 the total was $2,491,000{ }^{12}$
} 


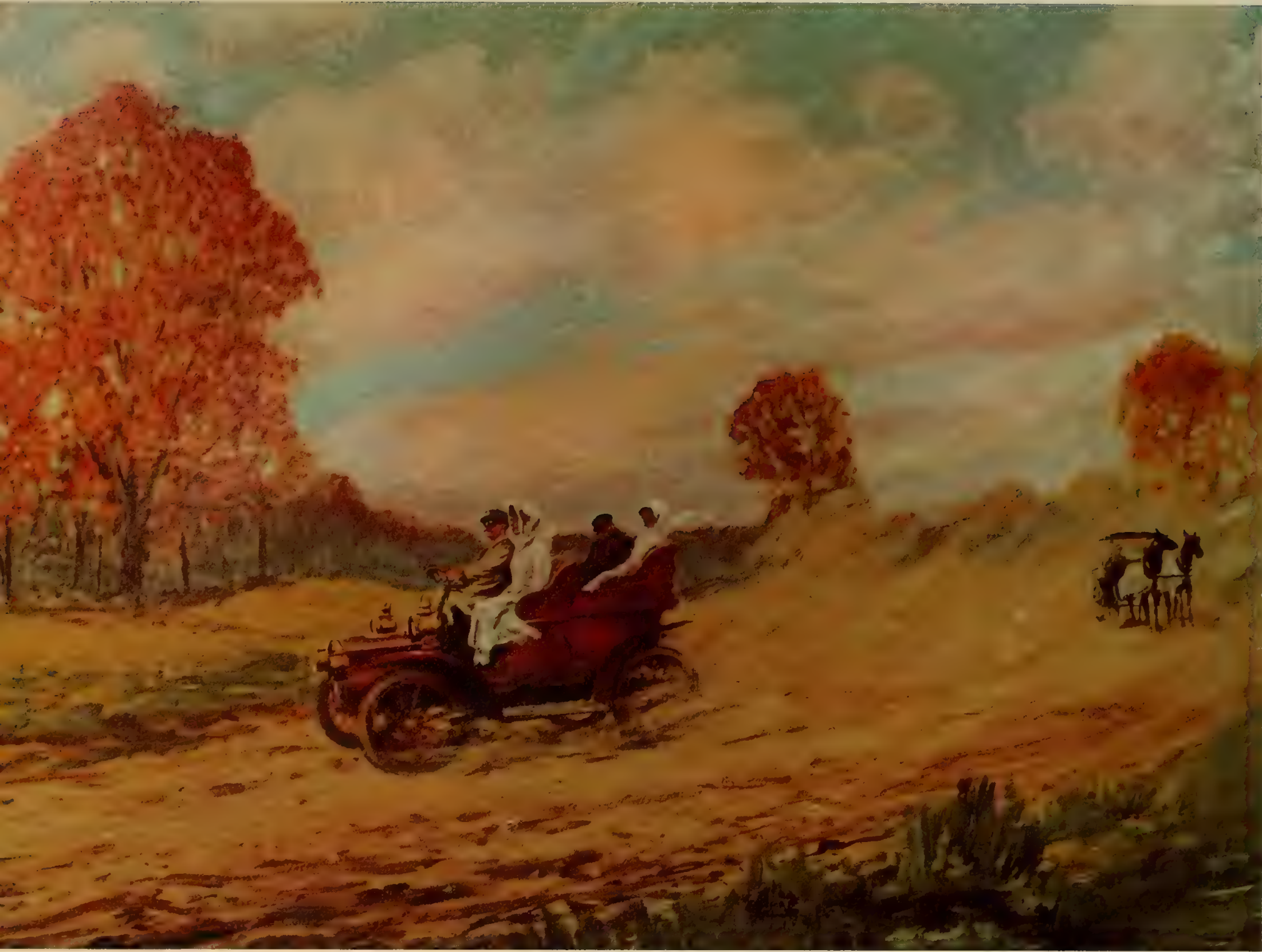

The dust nuisance.

In the summer of 1907 , the OPR joined with the Massachusetts Highway Commission to make experimental application of water-gas tar and coal tar on the main New York to Boston highway and also cooperated with Warren County and Bowling Green, Kentucky, to investigate the fitness of rock asphalt as a binder for macadam.

These projects all pointed to the need for a more systematic knowledge of bituminous products and methods for using them. To get some of this knowledge, the OPR arranged a cooperative research project with Cornell University at Ithaca, N.Y., to test the relative value, under practically uniform conditions, of different bituminous road binders applied by different methods. As its contribution to the project, the OPR added two chemists to its laboratory staff and stepped up its testing and research on asphalts and tars.

The field tests showed that both the penetration method and the mixing method of making bituminous macadam surfaces gave good results. The laboratory studies were especially fruitful:
Through its laboratory work the Office has been able to offer valuable advice in regard to specifications for bituminous road binders and in many instances to frame such specifications upon the request of various public bodies.

Many worthless road preparations have been and are at present being manufactured and sold to the public through ignorance on the part of both producer and consumer with regard to the requisite characteristics of sucb materials to meet local conditions. These materials are sold under trade names, and as a rule carry no valid guarantee of quality. Specifications for such materials are therefore needed for the protection of the public.... Some manufacturers have already followed the work of the Office along this line, and are either manufacturing materials in accordance with specifications of the Office or stand ready to do so upon request. ${ }^{14}$

In succeeding years the dust abatement program was enlarged, until by 1916, the OPR was involved in experiments on 28 roads in 11 States and the District of Columbia. Gradually, the emphasis shifted from "dust prevention" to "road preservation," and the building up of tar or asphalt wearing courses over macadam, slag or gravel bases. This led to the general adoption of bituminous surfaces wherever automobiles were an appreciable portion of the total traffic. 


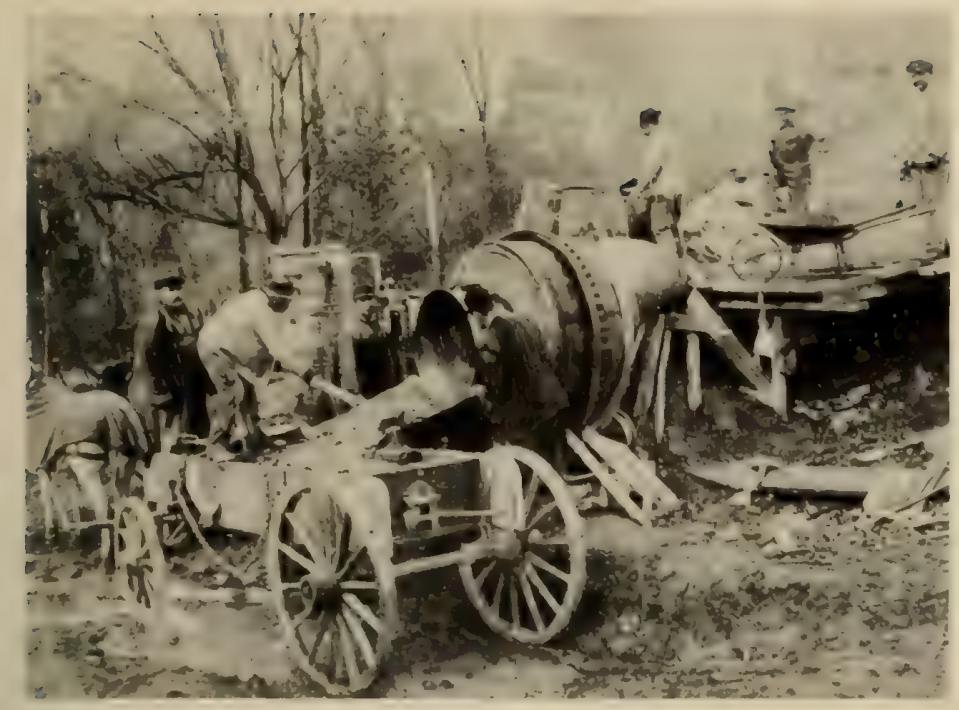

In 1909 the science of producing

portland cement concrete was in its

infancy. This early rotary mixer was used

at Cornell University in Ithaca, New York.
The Office of Public Roads' dust prevention and experimental roads programs were the training grounds for the small group of highway engineers and physical scientists who later laid the foundations of soil engineering and pavement design.

\section{Dragging the Dirt Roads}

Dirt roads will not stand up under traffic unless they are shaped and kept free of ruts so that water will shed quickly and not soak in and soften the roadbed. Even before the Civil War, some township supervisors were smoothing their roads by dragging them with "a stick of timber, shod with iron, and attached to its tongue or neap obliquely, so that it is drawn over the road 'quartering,' and throws all obstructions to one side." 15

About 1905, D. Ward King, of Maitland, Missouri, improved on this simple device by splitting the timber lengthwise and positioning the two halves, one ahead of the other, to make a rigid platform. A typical King drag was made from an 8-inch log split down the middle; the two halves were held about 3 feet

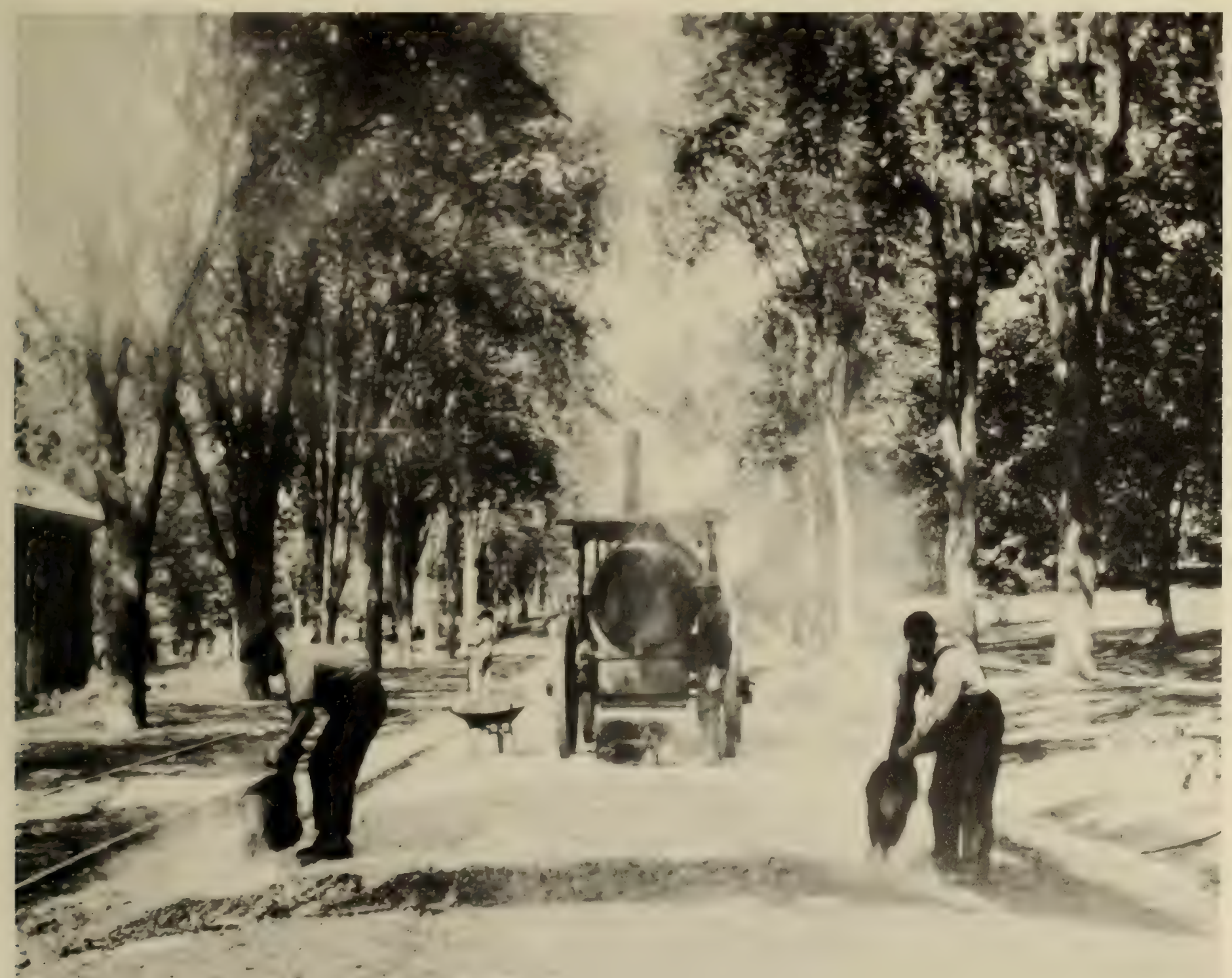




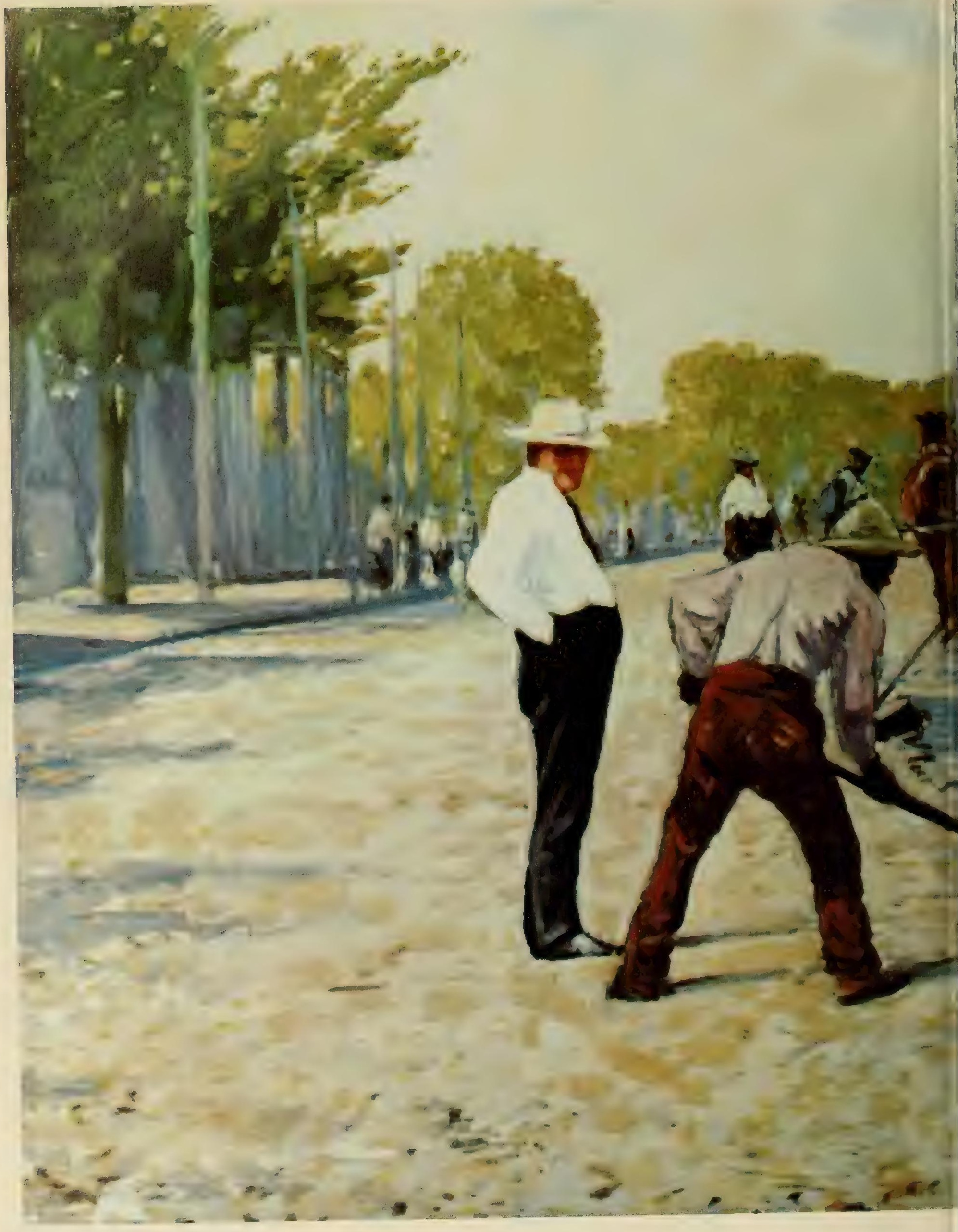

Coal tar and crude oil experiments. 


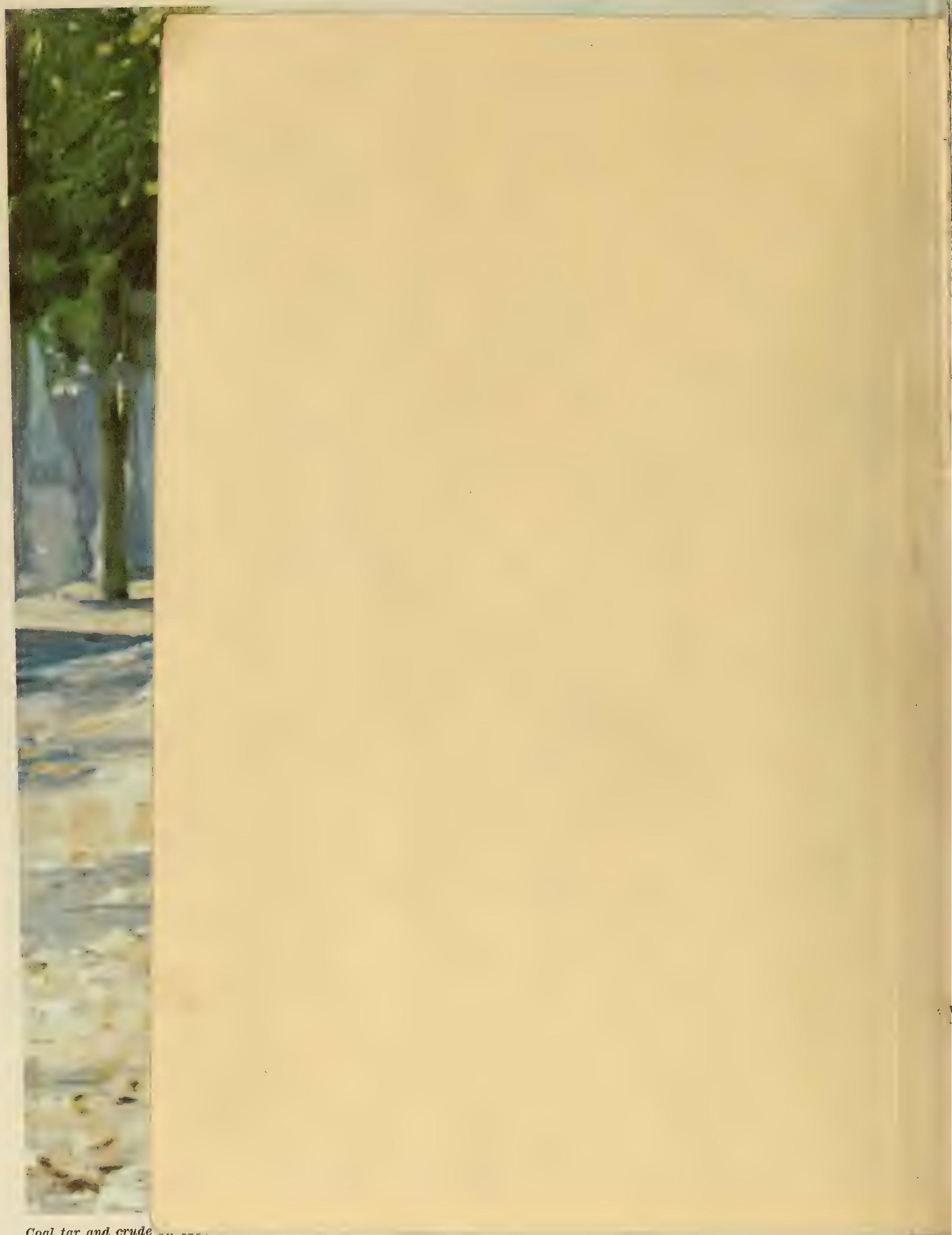

Coal tar and crude ....... 


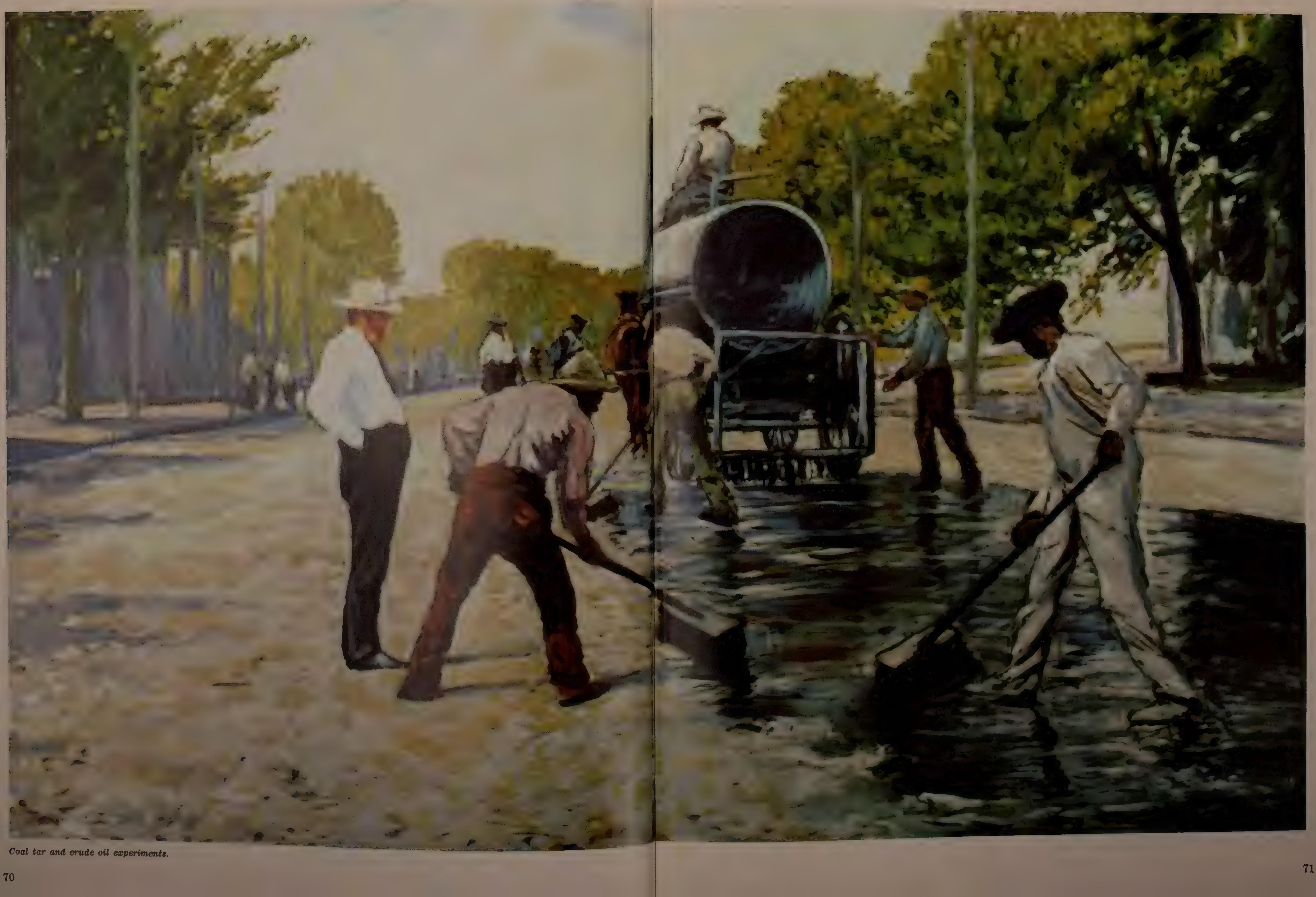




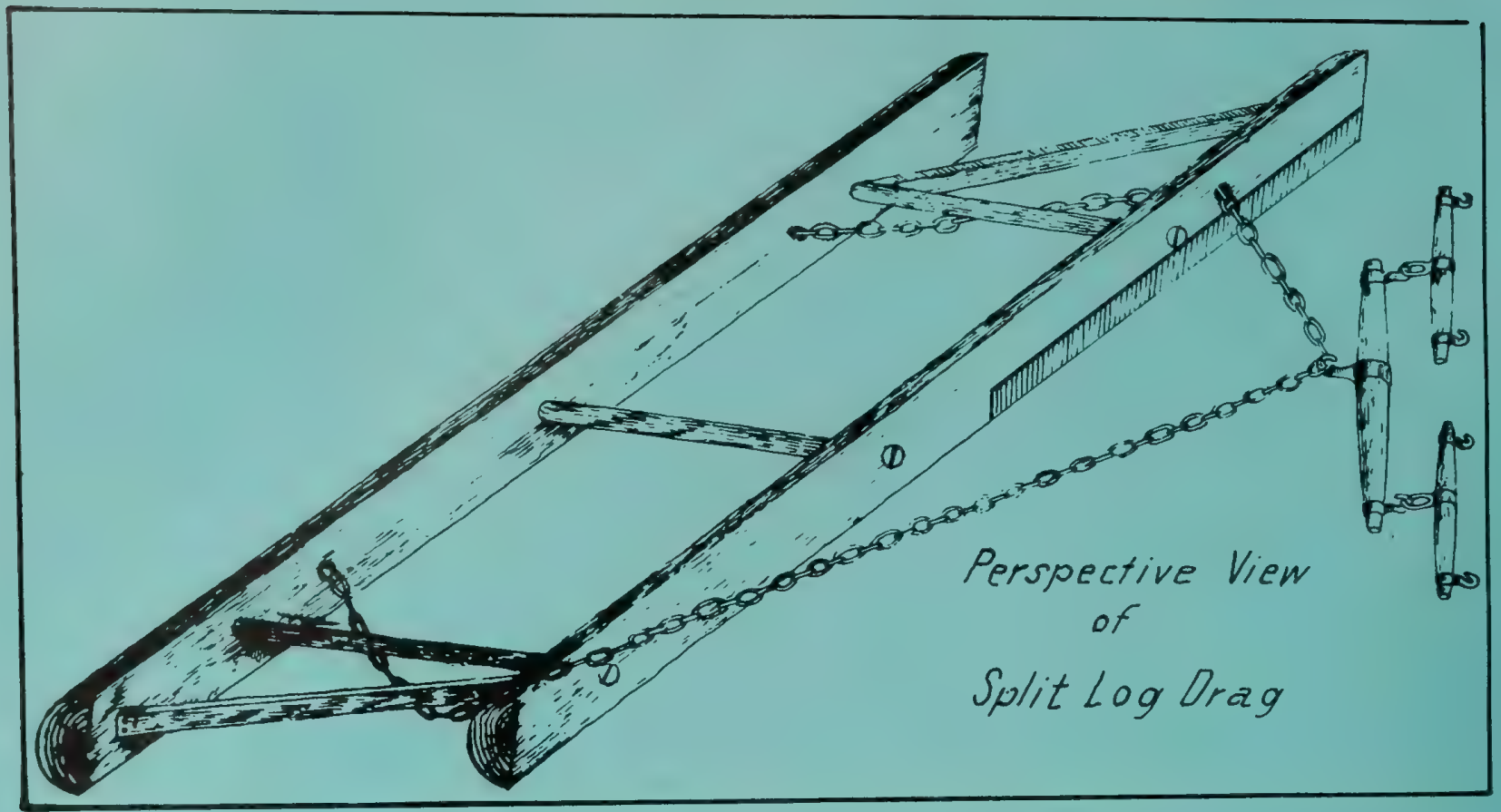

apart by struts and the lower edge of the front log was shod with a $1 / 4$-inch steel cutting plate. A hitching chain attached to the front log could be adjusted so that the drag would move earth to either side of the road as the device was pulled behind a team. This drag could be made on the farm for about $\$ 2 .{ }^{16}$

The King split-log drag was a surprisingly effective maintenance machine. After a little instruction and practice, an average farmer could easily drag 6 to 8 miles of road per day and could keep a well-graded dirt road in good shape for light traffic for as little as $\$ 8$ per mile per year. The appearance of the King drag coincided with Director Page's decision to place greater emphasis on earth and sand-clay roads in the object lesson road program, so Page decided to promote dragging as well. In 1906 he had King write a manual on how to make and use the split-log drag. This was published by the Department of Agriculture as a Farmer's Bulletin, and thousands of copies were distributed. The OPR assigned experts to deliver lectures and make demonstrations in the use of the drag. A number of States passed "King Drag Laws" authorizing the township supervisors to contract with abutting farmers to drag the public roads. ${ }^{17}$

This activity, in a few years, brought about a remarkable improvement in the condition of the country dirt roads and brought home to the local supervisors, as nothing else had before, the importance of prompt and intelligent maintenance.

\section{Experimental Maintenance}

In 1911 the French roads were not only the best in the world, but were also the best maintained. Maintenance was strongly centralized and closely supervised; every road was divided into short segments of a few kilometers, each the full-time responsibility of a paid patrolman who lived nearby, usually within walking distance. Page wanted to try out the French system under American conditions, and in 1911 at his recommendation, the Secretary of Agriculture contracted with Alexandria County, Virginia, for a 2-year experimental maintenance project to include 8 miles of earth roads. Under this contract, the county supervisors agreed to shape up the roads and put them in good condition, after which the OPR hired a local farmer as a patrolman to maintain the roads under OPR supervision. The patrolman was paid $\$ 60$ per month plus an extra $\$ 1$ per day whenever he used his team for dragging.

The roads selected for the experiment-Columbia Pike and the Mount Vernon Road-were among the heaviest-traveled in the county, ${ }^{*}$ yet the patrolman kept them in first-class condition most of the time at a cost of $\$ 95.77$ per mile per year. ${ }^{18}$ This, however, was far more than the average rural county was spending to maintain its roads. In the final analysis, this experiment demonstrated not so much the efficiency of the patrol system as the desirability of more durable surfaces for all but the very lightesttrafficked roads.

\section{The Washington-Atlanta Maintenance Demonstration Road}

The Alexandria County experiment was the beginning of a major effort by the OPR to raise maintenance standards in the counties. By 1912, a decade of promotion by the good roads associations, the motorists, and the Office of Public Roads and others had trebled the funds available annually for roadbuilding. Hundreds of counties had issued bonds to finance road

* One section near Fort Myer carried 173 wagons and 96 cavalry horses per day, plus a few runabouts. 
programs, and about half of the States had State-aid programs, some of which were financed by State bond issues.* Roads were improved with borrowed money faster than the supervisors could arrange to take care of them, and in this emergency, the counties turned to the OPR for advice and assistance.

To meet this demand, Page set up a Division of Maintenance in the OPR under Edwin W. James which embarked on an ambitious program of instruction and demonstration. James' engineers studied the details of State maintenance in States that had effective highway departments and also in selected counties, some with good maintenance programs and some with poor ones. They also persuaded a number of strategically located counties with new bond-financed roads to introduce adequate maintenance on one selected demonstration road in each county, the work to be under OPR supervision.

The capstone of the maintenance program was a mammoth demonstration road, involving 49 counties in Virginia, the Carolinas and Georgia, the purpose of which, in Page's words, was "conducting an object lesson in road maintenance on a sufficient scale to at-

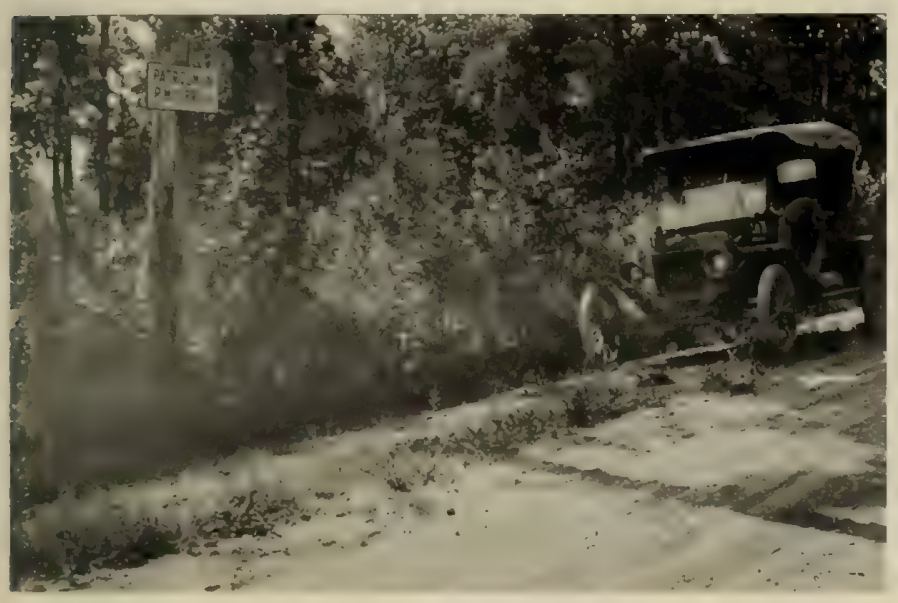

Knowing who is responsible for the condition of the road and appealing to the pride of the patrolman.

tract general attention, and at the same time render the largest amount of assistance at the least relative cost to the Office of Public Roads . . ." ${ }^{20}$ Under the plan adopted for this "Washington-Atlanta Highway," a continuous route between these cities was traced over existing county roads, the combined length of which was 1,038 miles. The participating counties agreed first to put the selected roads in good condition and then to accept the supervision of an engineer assigned by the OPR who would approve all maintenance expenditures.

The work began in the spring of 1914 with only 723 miles under the cooperative plan and three experienced engineers detailed by the OPR to supervise the work. The experiment continued until 1917 when the OPR had to withdraw its engineers for more urgent work. The success of the maintenance plan was at-

* There were $\$ 229.44$ million of local road and bridge bonds and $\$ 115.32$ million of State bonds outstanding on January 1 , $1915 .{ }^{19}$ Many of the roads financed by county bond issues were improved to make them eligible as free rural mail delivery routes.

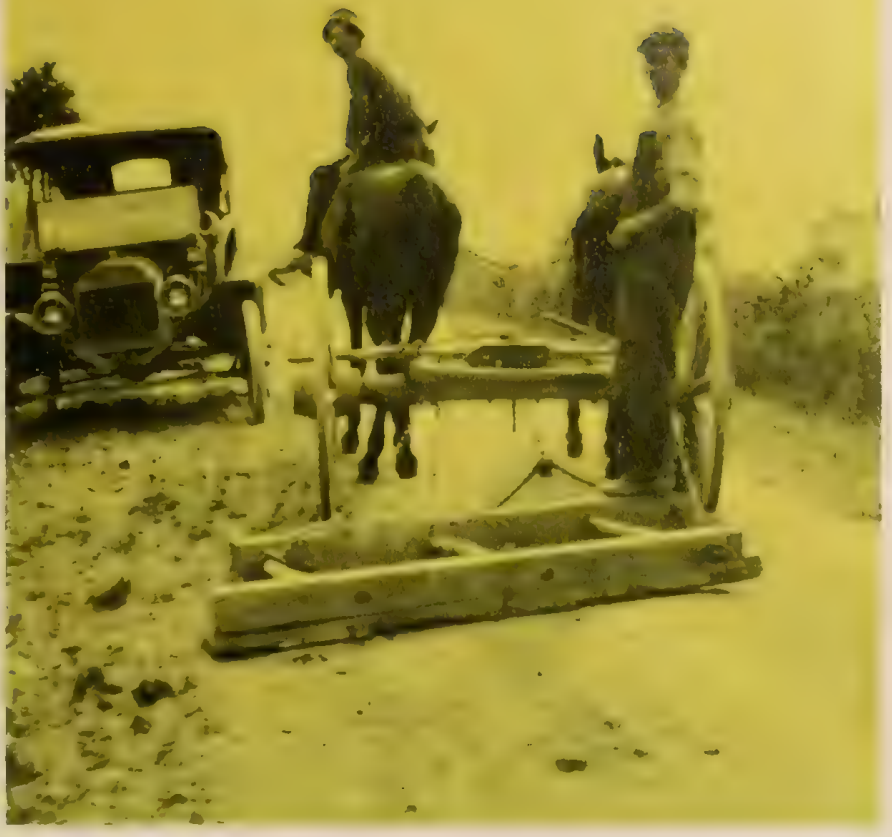

Removing the ridge with a drag after a cultivator has loosened the material.

tested by the fact that, from March 1915 through June 1916, a total of 876 miles of road had been under OPR supervision and "had not been closed to traffic at any point, even in the winter months," ${ }^{21}$ and by the adoption of the OPR maintenance methods by many other counties not on the Washington-Atlanta route.

Among these last was a group of 13 counties in North Carolina which joined with the State Highway Commission in 1916 to petition for OPR supervision over a proposed Central Highway from Morehead City to Statesville, about 338 miles. The OPR assigned two engineers to this project until the United States' entry into the European war made it necessary to withdraw them.

\section{The Problems of Road Management}

The OPR's four road construction demonstration teams could fill only a fraction of the requests for object lesson roads. However, in many cases what was needed was not so much a demonstration road as good advice from a road expert. After 1904 Page began detailing experienced engineers, upon request, as consultants to counties to get them started properly on their road programs. These assignments, each lasting from 2 days to a week, covered every conceivable aspect of road engineering and management and occupied most of the time of the OPR special agents.

In time, Page and his aides came to realize that advising the counties on specific road problems did little to improve the overall competence of road management. Therefore, in 1908, the OPR began a more comprehensive approach which is best described in Page's own words: 
As an example of this work, San Joaquin County, Cal., may be mentioned. At the request of the proper authorities an engineer was detailed to make a comprehensive study of all conditions affecting the highways of that county. About three months were required for this work, during which time his salary was paid by the Government and his local expenses by the community. The final report, besides containing a full and detailed description of the existing conditions, embodied also detailed recommendations for a system of improvements in road administration, construction, and maintenance within the reach of the people and which they have since adopted. A bond issue of about $\$ 1,800,000$ was voted to provide the necessary revenues, and a system of roads is now under construction which will place San Joaquin County among the foremost counties of the State in the matter of transportation facilities. ${ }^{23}$ extraordinary in U.S. highway history, lasted until December 1913. "The officials of Bennington County were so pleased with the results of this object-lesson supervision that they have since employed an engineer to take charge of the road work of the county." ${ }_{23}$

\section{The Shortage of Highway Engineers}

The Bennington County experience pointed up one of the most serious problems of this period-the general lack of engineering expertise at the county level. Some critics asserted that, because of this lack, from

County patrolmen in New Yorle were responsible for 2 to 8 miles of road and were paid $\$ 3$ per day in 1914 .

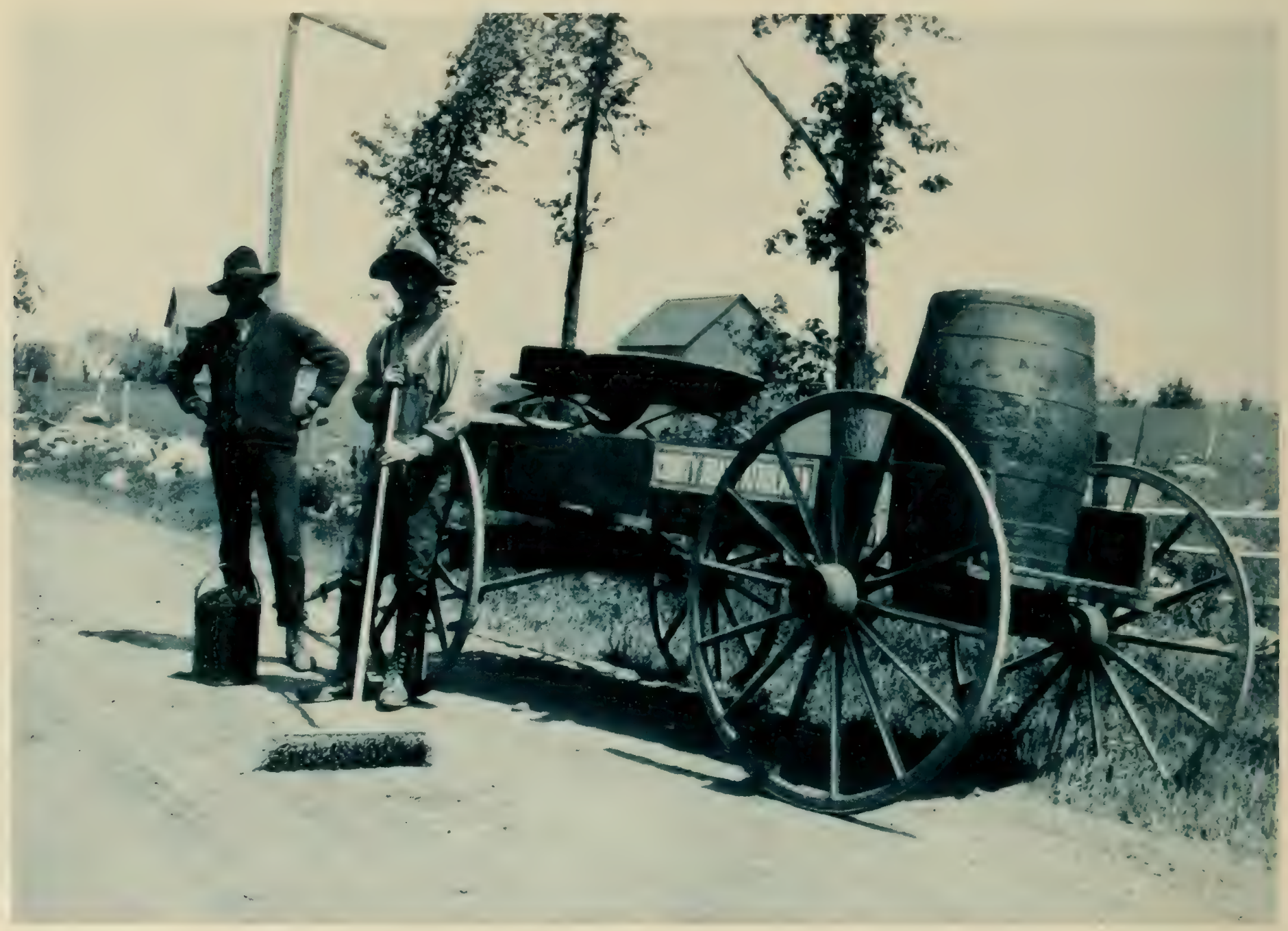

The "model systems" program was an instant success. By assigning as many engineers as he could spare from other work, Page in 10 years was able to assist 144 counties in 28 States to reorganize and modernize their road operations. Most of these counties sold bonds to finance a start on the programs recommended by the OPR advisers.

Bennington County, Vermont, carried the model system idea one step further. In 1912,69 of the 74 road officials of the county, with the approval of the State Highway Commissioner, petitioned the OPR to detail an engineer for 1 year to supervise all road work in the county and its townships. Page assigned an engineer in 1913, who was in effect the County Engineer, in direct charge of all road work carried on in the county. This arrangement, one of the most one-quarter to one-third of all the money spent on the country roads was wasted. Most of this waste came about because the roads were originally poorly located or poorly drained, and these errors were perpetuated when the roads were later upgraded. Repeatedly, in its bulletins and expert advice, the OPR urged that the old locations be revised to reduce grades and unnecessary curvature, and to improve drainage before expensive bond-financed surfacing was undertaken. Such improvement required engineering study and advice.

Many, perhaps most, counties thought they were too poor to afford an engineer. Others didn't really want one for fear he might lead them into expensive road schemes that would raise taxes. Still others clung to the ancient tradition of amateur supervision of in- 
efficient statute labor. Those counties that wanted to hire engineers had difficulty finding them, since the supply of civil engineers with highway training was exceedingly small.

The shortage was so serious that Director Dodge in 1903 had recommended that Congress establish in Washington, in connection with the Office of Public Road Inquiries, a National School for Roadbuilding, similar to the famous School of Bridges and Roads which had trained French road engineers since 1747. This institution, as envisioned by Dodge, would be ". . . a post-graduate school, where graduates in civil engineering from the land-grant colleges could secure a thorough course in theoretical and practical road building. .... The American school of road building should include a series of lectures by experts of this Office, and some practical work in the road-material laboratory and in connection with the object-lesson road work of the Office in different parts of the country." 24 Most of the students would be employees of the States, counties and cities who would return to these agencies after completing their training.

This school was never established, but after he became Director, Page obtained Department approval for a training program under which a limited number of young civil engineering graduates, after taking competitive examinations, were appointed to the position of civil engineer student in the OPR, at a salary of $\$ 600$ per year. These young men learned practical roadbuilding in the field with the OPR's object lesson road teams. They received instruction in testing road materials in the laboratory and were detailed as assistants in the OPR's other activities to learn by doing. After 1 year in the training program, they were eligible for promotion to junior highway engineer without further examination. ${ }^{25}$

Despite the small compensation, the OPR had no trouble recruiting all the civil engineer students it needed. Over a period of 10 years, some 70 engineers were hired, of whom about 36 resigned within a year of completing their training to accept positions with colleges, counties and State highway departments. Page accepted these losses philosophically:

. . the engineers after a few years' training in the office are in great demand for State and county work. The practice of permitting these engineers to resign is detrimental in one sense to the service, in that the office is constantly losing some of its best men, but the benefits derived by the various States and counties through the distribution of trained men to all sections of the country are so great as to be a vindication of the wisdom of this project. $^{23}$

Page also realized that his ability to expand the Federal good roads effort would depend on attracting additional experienced engineers to his staff. His first acquisition was Arthur N. Johnson, the able highway engineer of the Maryland Roads Commission.* Johnson agreed to take over the supervision of the OPR's far flung field operations. Later, Page got Edwin W. James, who had supervised road work in the Philippines, to transfer to the OPR from the War Depart-

* Johnson resigned 2 years later to become chief engineer of the Illinois Highway Department, and he subsequently became one of the most distinguished American highway engineers and one of the founders of the science of traffic analysis. ment. However, in the long run, the major source of recruitment for the OPR's permanent force of engineers was the civil engineer student training program. Page's foresight was forcefully demonstrated 12 years later when the trainees he had selected for this program became the backbone of the Bureau of Public Roads organization for administering the immense Federal-aid appropriations.

Director Page's interest in the education and training of engineers went far beyond his own organization. In 1909 he had the OPR survey the status of highway engineering instruction in all the technical schools and colleges in the United States, and he furnished advisors to help the schools set up practical courses in highway design and construction. The OPR aided a number of schools to set up first-class testing laboratories, and whenever its agents and engineers could be spared from other work, they were detailed to lecture on highway engineering in the colleges.

\section{Federal Roads on Federal Lands}

Since the two agencies were in the same department of the Government, it was natural for the Forest Service to turn to the Office of Public Roads for help with its road problems, and the OPR was furnishing occasional advice on forest trails as early as $1905 .^{27}$

However, it was not until 1913 that a formal arrangement was made for the OPR to handle road work in the national forests. ${ }^{*}$ Congress in 1912 had required that 10 percent of the revenues from the national forests should be spent to construct roads and trails within these forests. ${ }^{29} \mathrm{By}$ the end of fiscal year $1912, \$ 210,925$ had accumulated in the forest road fund, and the Forest Service found that it needed expert advice on where and how to spend the money. The Chief Forester asked Director Page to assign highway engineers to inspect all the existing roads and to recommend how these should be improved and where others should be built. The OPR then assigned five engineers to this work, one for each of five forest districts.

About this time, the Secretary of the Interior also asked for assistance to help with the planning of roads in the national parks. Page responded by placing an engineer and a field survey party in Yosemite National Park during the summer of 1914 and promised to begin work in five other parks as soon as he could find the engineers.**

To handle this sudden increase in workload, Director Page set up a Division of National Park and Forest Roads within the OPR and assigned responsibility for the Division to T. Warren Allen. The work in

* In 1910 the OPR, at the request of the Crater Lake Highway Commission, a private body, assigned a road expert to supervise the construction of a road through the Crater Lake National Forest to the Crater Lake National Park and to plan a system of roads and trails for the Park. This road was financed by county funds and private subscriptions and was not actually Forest Service work. ${ }^{28}$

**At this time, there was no National Park Service; each park superintendent reported directly to the Secretary of the Interior and did his own road work, except for Yellowstone where the roads were built by the Corps of Engineers. In 1914 there were 12 national parks. 
federally owned areas built up so rapidly that, by 1916, the OPR was maintaining 160 miles of road, constructing 170 miles and making surveys and plans for yet another 477 miles-a total program that was spread over 12 States and Alaska, and which exceeded the programs of a number of State highway departments. This far-flung program would soon receive a major boost from Congress in the Federal Aid Road Act of 1916.

\section{Publicity Adds Momentum to the Good Roads Move- ment}

Most of the OPR's engineers were as much at home on the lecture platform as in the field or the laboratory. The special agents spent most of their time on such work, and they and the Washington Office staff were in great demand as speakers at road conventions and meetings of trade associations and professional groups. Director Page supplied lecturers only upon invitation and then only upon assurance that the meeting had been properly advertised and that the attendance would justify the expense. He was never able to satisfy the demand, even though he doubled and then trebled the number of men assigned to the work. In 1906 the OPR engineers gave about 100 lectures in 14 States. By 1912, 27 lecturers were giving 1,139 lectures which were heard by 208,472 persons in 37 States. ${ }^{30}$

To reach even more people, Page, in 1907, launched an information campaign directed at the rural population. Twenty-five hundred county newspapers cooperated by publishing short practical articles on road construction and maintenance written by the OPR staff. Through this program, Page estimated that he could reach up to 10 million people a year. ${ }^{31}{ }^{32}$

Important as it was, the OPR publicity was only a small part of a nationwide outpouring of good roads propaganda. The magazine, Good Roads, founded by the League of American Wheelmen, was still the leading publication in the good roads field, but it had many competitors. In 1908 the American Automobile Association (AAA) launched the American Motorist to speak for the rapidly increasing number of automobile owners. Hardly a month passed without an article on good roads appearing in the influential Saturday Evening Post or in Harper's Magazine, and between 1910 and 1915 , it is safe to say that no national issue received greater coverage in the country and city newspapers.

\section{Show Business in the Road Business}

In 1908 Congress authorized a Government exhibit at the Alaska-Yukon-Pacific Exposition and specifically provided that the Office of Public Roads should be represented. For its part of the exhibit, the OPR prepared a series of scale models, complete with miniature machinery, showing every aspect of roadbuilding. These were supplemented with a handbook, a series of moving pictures and stereopticon slides and a lecture on roads.

The Seattle exhibit of 1909 was so successful that the OPR made up several others like it which were shown at national expositions and fairs in 1910. These boosted the demand still further, so Page arranged to transfer a professional model maker from the Smith- sonian Institution to augment the OPR's effort. The models were loaned to various State fairs and expositions, which agreed to cover the cost of installation and transportation. The exhibits were accompanied by an OPR road expert to show the slides ard give lectures. Between 1910 and 1917, the exhibits were shown at over 100 places and were seen by some $21 / 2$ million people.

In 1911 the Pennsylvania Railroad offered to provide a "Road Improvement Train" to carry the OPR exhibit throughout the State of Pennsylvania, and arrangements were made with the State Highway Department and the Pennsylvania State College to sponsor the tour. The train consisted of an exhibit car, a lecture car and two flat cars carrying full-sized crushers, rollers, graders and even split-log drags. The train stopped at 165 places during its 2 -month tour. The crowds were so large in the larger towns that the lectures had to be held in court houses and opera houses. Over 53,000 people saw the exhibits and heard the lectures. ${ }^{33}$

Not to be outdone by the Pennsylvania Railroad, the Southern and five other eastern and midwestern railroads petitioned the OPR to outfit Road Improvement Trains for them, and these took to the road in 1911 and 1912, carrying the good roads gospel to some 163,000 people in 650 towns. The last Good Roads Train in American history toured the State of Iowa in 1916.

\section{The American Highway Association}

By 1910 there were literally scores of organizations in the United States devoted to the promotion of good roads. A few of these were strong, effective, and national in scope. The American Automobile Association founded by the motorists in 1902 and the American Road Makers, bringing together State engineers, road contractors and road machinery manufacturers, were in this category. However, many of the good roads associations were primarily pressure groups whose purpose was to get improved roads by influencing legislation. Most of these had no dues-paying members but depended on commercial interests-railroads, materials producers, automobile manufacturers-for financial support.

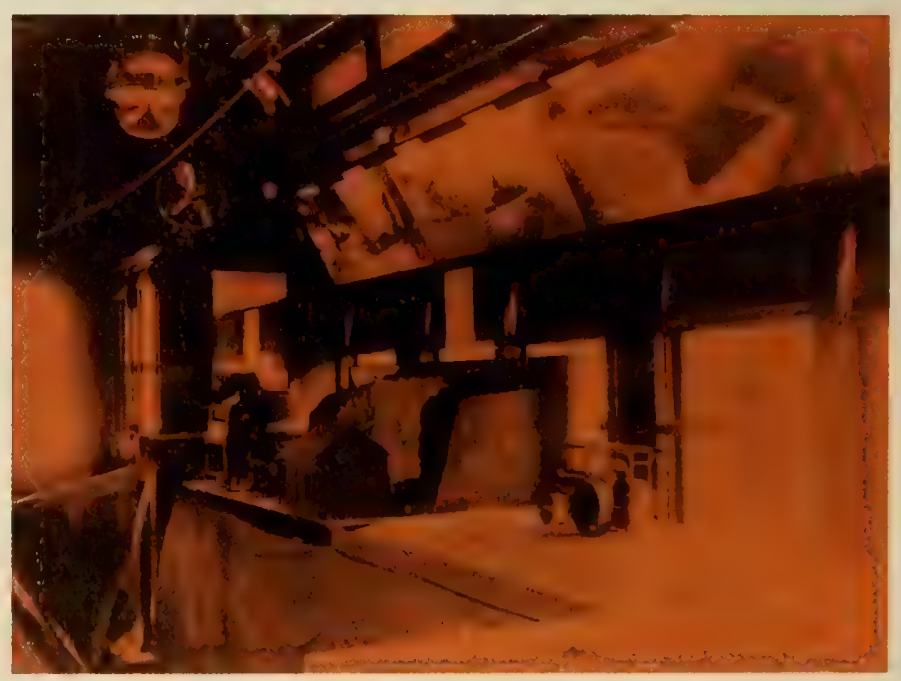

The interior of the exhibit car of the Road Improvement Train. 


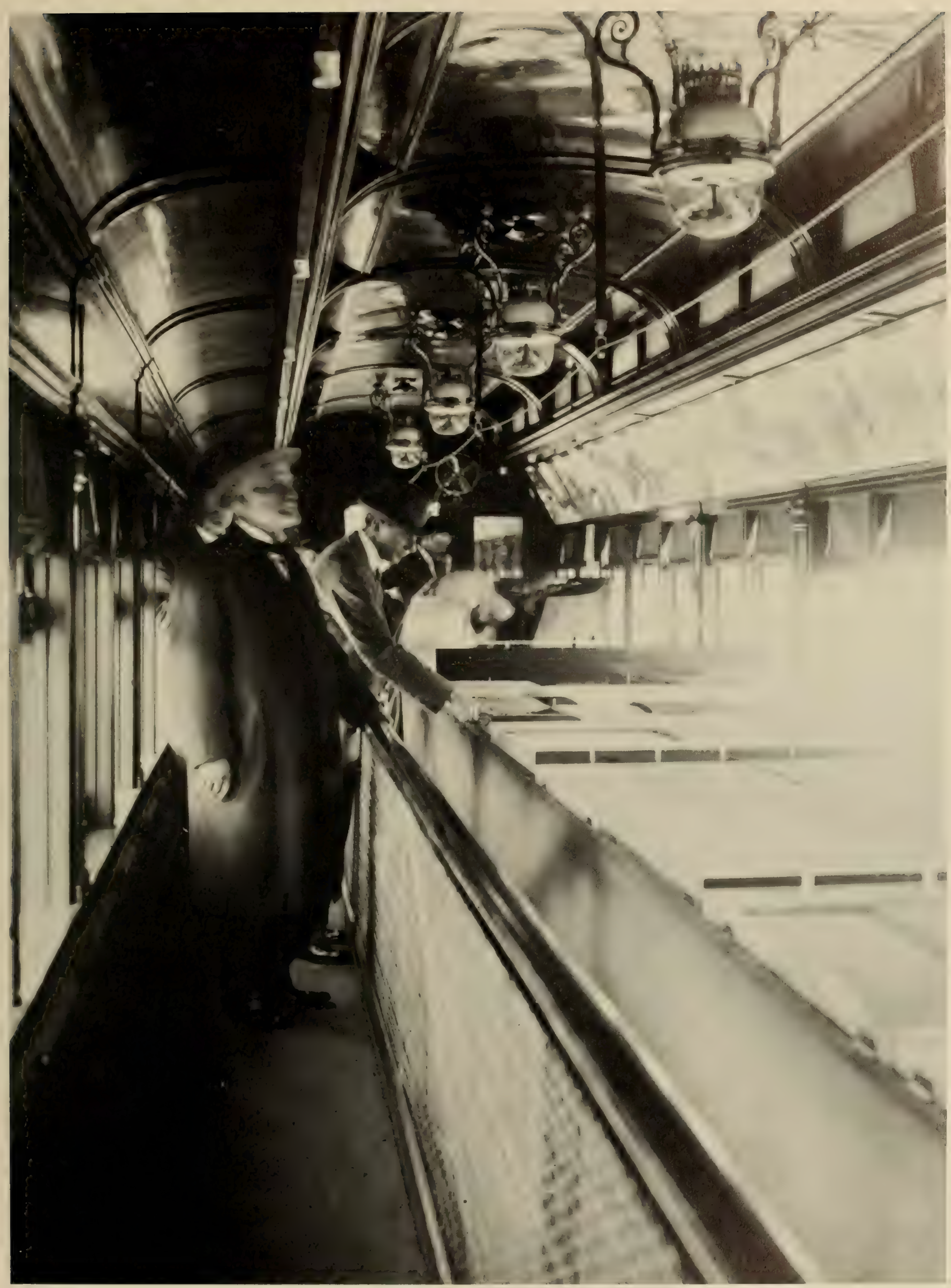

Secretary of Agriculture Wilson and L. W. Page visiting the Road Improvement Train October 4, 1911. 
Page continued his predecessors' policy of furnishing speakers for the annual conventions of the larger good roads associations, but he also saw a need for a larger, permanent umbrella-type organization to encompass the entire Good Roads Movement. In 1910 at Page's invitation, the officials of some 30 State and interstate organizations, including highway departments, railroads, good roads associations, and others, met in Washington and formed the American Association for Highway Improvement, electing Page as its first president, along with a prestigious board of directors.

This Association sponsored the First American Road Congress at Richmond, Virginia, in 1911 which passed strong resolutions recommending $:^{34}$

- That Congress extend financial aid to the States to encourage them to build and maintain good roads.

- That no appropriation for road construction should ever be made without proper provision for maintenance afterward.

- That all States provide for State supervision of main highways through a State highway department, and that liberal financial assistance be given through State aid in the building and maintenance of such roads.

- That the work of construction and maintenance of all public highways of any locality or State should be under the direction of experienced highway engineers.
- That all the States enact laws providing for the employment of prison labor for the improvement of public highways.

- That, for safety of the public, all vehicles be required to display a lighted lamp at night, visible at least 200 feet ahead, and a red light visible from the rear.

- That the use of the muffler cut-out and the unnecessary use of horns and bells be forbidden in thickly settled sections.

- That slow-moving trafic be required to drive to the right so that faster vehicles may pass.

- That uniform speed regulations be adopted by all States, and the local authorities in cities, villages, and towns be prohibited from fixing local speed regulations.

- That officials responsible for bridges be required to inspect them periodically and post safe weight limits.

- That all roads be systematically placarded by sign boards giving directions and distances to towns and cities.

These resolutions were a complete and unambiguous statement of the principles that were to guide the American highway movement for the next 5 years.

In 1912 the Association shortened its name to American Highway Association and joined with the American Automobile Association to sponsor the Second

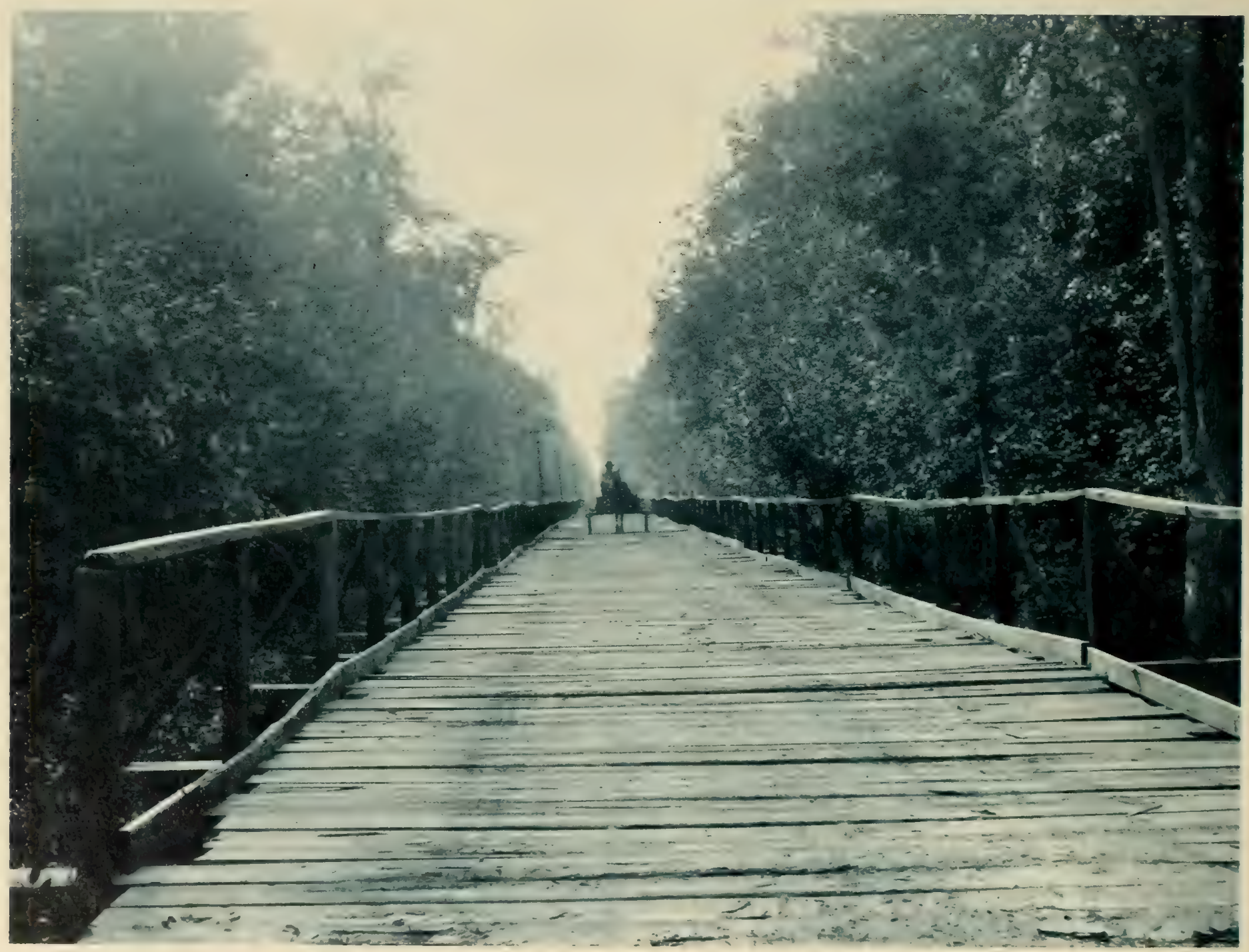


American Road Congress. The Third and Fourth American Road Congresses followed in 1913 and 1914.

A number of State highway commissioners and chief engineers assumed very active roles in the American Highway Association, but most of the State men felt a need for an organization more specifically tailored to their needs. Such an organization, with membership restricted to the chief officials of the State highway departments and their staffs, was proposed by Virginia's Commissioner of Highways, George P. Coleman, in January 1914. Page endorsed the idea, although he had hoped the State officials would organize within the framework of the American Highway Association, and in March 1914 he wrote to Mr. Coleman :

It has become increasingly apparent to me during the past few years that some medium should be provided for bringing the heads of the various State Highway Departments and of this office into closer touch, for the consideration of questions of mutual interest. Some sort of organization is, to my mind, highly desirable, but I think the best results can only be obtained by limiting the membership strictly to official heads of departments and their immediate staff, thus making the organization strictly official and enabling full and frank consideration of questions, particularly those of a technical character untrammeled by commercialism or popular prejudices. ${ }^{25}$

With Page's blessing, the formation of the new body was assured, and in December 1914 the American Association of State Highway Officials was organized "for the purpose of providing mutual cooperation and assistance to the State highway departments and the several States and the Federal Government, as well as for the discussion of legislative, economic and technical subjects pertaining to the administration of such departments." ${ }_{36}$

One of the first acts of the newly formed association was to instruct the executive committee to prepare, for the consideration of Congress, a bill authorizing Federal aid to highways.

A plank bridge in South Carolina a half mile long and too narrow for two teams of horses to pass.

\section{REFERENCES}

${ }^{1}$ L. PAGE, The Selection of Materials for Macadam Roads, Proceedings of the Thipd American Road Congress (Detroit, Mich., Sept.-Oct. 1913), (Waverly Press, Baltimore, 1914) p. 170.

${ }^{2}$ Buread of Public Roads Annual Report, 1919, pp. 34, 35.

AASHO-The FIRST FIFTY YEARs, 1914-1964 (American Association of State Highway Officials, Washington, D.C., 1965) pp. 322-330.

4M. Eldridge, Public-Road Mileage, Revenues and Expenditures IN the United States IN 1904, Bulletin No. 32 (Office of Public Roads, Washington, D.C., 1907) pp. 16-18.

${ }^{8}$ Bureau of Public Roads Annual Report, 1904, pp. 442, 443.

- Bureau of Public Roads annual Report, 1909, p. 7.

'A. Rose, Historic american Highways-Public Roads of THE Past (American Association of State Highway Officials, Washington, D.C., 1953) p. 92.

${ }^{8}$ Butreau of Public Roads annual Report, 1905, pp. 427, 428.

A. Rose, supra, note 7, p. 101.

${ }^{10}$ Bureau of Public Roads Annual Report, 1900, p. 287.

"Id.

121971 AUTomobire Facts And Figures (Automobile Manufacturer's Association, Detroit, 1971) p. 18.

"Office of Public Roads, Progress Reports of Experiments With Dust Preventives, Circular No. 89 (U.S. Dept. of Agriculture, Washington, D.C., 1908) p. 26.

"Bureau of Public Roads Annuat Report, 1910, pp. 785, 786.

${ }^{18}$ W. Gullespie, a Mandal of the Principles and Practice of Road-Making (A. S. Barnes, New York, 1871) p. 191.

${ }^{18}$ Office of Public Roads, The Road Drag and How It Is UsED, Farmers' Bulletin 597 (U.S. Dept. of Agriculture, Washington, D.C., 1914) p. 5.

${ }^{17}$ Kansas King Drag Bill, American Highways, Vol. 1, No. 10, Mar. 1907, p. 277.

${ }^{13}$ Bureau of Public Roads annual Report, 1913, p. 9.

${ }^{10}$ Office of Public Roads, Public Road Miteage and ReveNuES IN the UNited States, 1914, Bulletin No. 390 (U.S. Dept. of Agriculture, Washington, D.C., Jan. 12, 1917) p. 3.

${ }^{20}$ Bureau of Public Roads Annual Report, 1914, p. 6.

${ }^{2}$ Bureau of Public Roads annual Report, 1916, p. 4.

${ }^{22}$ BPR, supra, note 6, p. 27.

${ }^{2}$ BPR, supra, note 20, p. 4.

24 Bureau of Public Roads annuat Report, 1903, p. 332.

${ }^{25}$ BPR, supra, note 8, pp. 434, 435.

* Bureau of Public Roads annual Report, 1911, p. 28.

${ }^{27}$ BPR, supra, note 8, p. 434.

${ }^{29}$ BPR, supra, note 26 , pp. $25,26$.

${ }^{29}$ Agricultural Appropriation Act of 1912 (37 Stat 288).

${ }^{80}$ Bureat of Public Roads Annual Report, 1912, pp. 33, 34.

${ }^{31}$ Bureau of Public Roads annual Report, 1907, pp. 22, 27.

${ }^{82}$ Buteau of Public Roads annuat Report, 1908, p. 6.

${ }^{3}$ BPR, supra, note 26, p. 42.

${ }^{34}$ American Assoctation for Highway Improvement, Papers, Addresses, and Resolutions Before the American Road Congress (Richmond, Va., Nov, 1911) (Waverly Press, Baltimore, 1912) pp. 187-190.

${ }^{35}$ Supra, note 3, p. 50.

${ }^{a}$ Id. p. 52. 


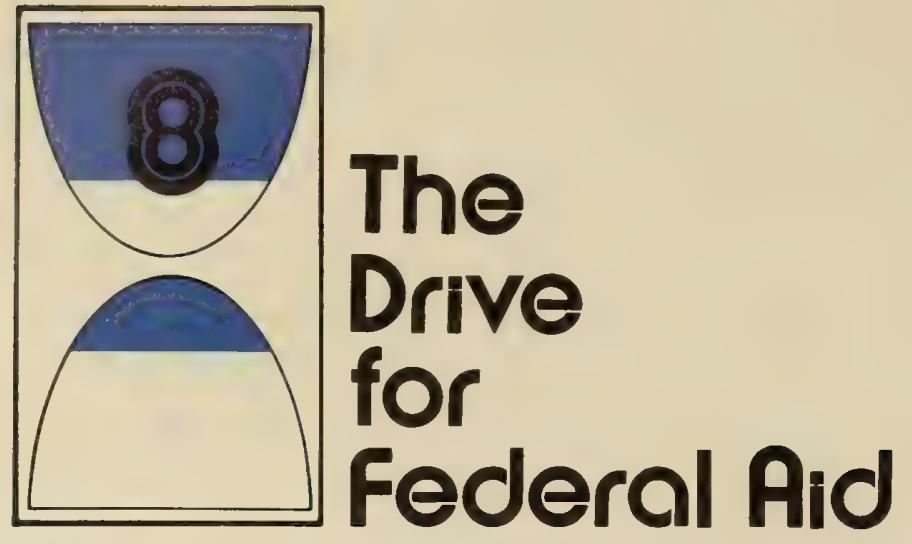

\section{Rural Free Delivery of U.S. Mail-A Powerful Force for Road Improvement}

It is hard for rural residents today to realize the isolation in which most farmers lived in the 19th century. There were then no rural mail delivery, no telephones. One had to go to town, perhaps 4 or 5 miles away, to get a newspaper. If the roads were bad, as they usually were in winter and spring, the rural schools and churches might be only a third filled, and even neighbors might have difficulty communicating with each other.

One of the strongest arguments of the good roads advocates of the 1890's was that good roads would reduce this isolation, and particularly, would make it practical for the Government to deliver mail to the farms, as some European countries had been doing for decades. In 1893, largely through the influence of the State Granges of the Patrons of Husbandry, Congress appropriated $\$ 10,000$ for an experimental program of rural mail delivery. After some foot dragging by the Postmaster General, who thought the idea impractical, the Post Office Department established the first experimental rural delivery routes from Charlestown, Halltown and Uvilla, West Virginia, on October 1, 1896, and by July 1897, 44 routes were in operation. Congress increased the appropriation to $\$ 50,000$ in 1898 , and thereafter the free delivery system grew rapidly until, by 1903 , there were 8,600 carriers traveling 200,000 miles per day and reaching almost 5 million people. ${ }^{1}$

The Department made it a rule that rural delivery would be established only along reasonably good roads and that the carrier need not go out on his route unless the roads were in fit condition for travel. These requirements marshaled public opinion on the side of those who wanted better roads, and hundreds of counties undertook substantial road improvements to get rural delivery. In Texas, for example, 100 fords were replaced by bridges in 1901 and 1902 .

Under a 1906 agreement between the Postmaster General and the Secretary of Agriculture, a locality desiring a rural mail route could petition the Office of Public Roads for an engineer inspector to examine the route and recommend whatever was necessary to make it suitable for carrying the mail. It was then up to the local officials to make the improvements, but sometimes the inspector, if requested, might assume temporary supervision of the work as an object lesson in roadbuilding. Director Page, thus, hoped to greatly extend the OPR's educational work:

As the chief aim and purpose of this office is to bring about a general and uniform improvement of the country roads throughout the United States, a cooperative plan such as the one described above offers the best possible means of achieving positive results in furtherance of that purpose. By this means correct methods of road building and road maintenance will be introduced into practically every section of the United States. ${ }^{2}$ 
Important as these efforts were, they did not satisfy the skyrocketing demand for rural delivery service. Congress was generous with funds to operate and extend the free delivery system-in fact, it consistently appropriated more than the Post Office Department asked for-but the problem was really one of roads on which to carry the mails and not one of financing the postal service. This was realized by Congressman Walter P. Brownlow of Tennessee, who in 1903 introduced a bill that would provide $\$ 20$ million annually in Federal aid to States or counties for the building of post roads. The grants would have to be for specific roads, and the State or county applying for aid would have to agree to pay one-half of their costs. Plans and specifications for the aided roads would be drawn by the Federal Government to insure adequate standards, but the contracts for the work could be let and supervised by the State or county. ${ }^{3}$

Brownlow's bill did not become law, but thereafter, for 13 years, bills for some form of national aid to roads were introduced in every session of Congress. One of these, introduced in 1912 by Representative Dorsey W. Shackleford of Missouri, would authorize the spending of $\$ 25$ million per year out of the Federal fiscal surplus to improve and maintain rural free delivery routes. The aid would be distributed to the counties at the rate of $\$ 15$ for each mile of graded earth road, $\$ 20$ for each mile of gravel road, and $\$ 25$ for each mile of macadam, provided the counties had spent a like amount on these roads in the preceding year.* The sliding scale would be an inducement to the local authorities to upgrade their roads. ${ }^{4}$ Shackleford argued that this aid would actually save the Government money in the long run by reducing the

* In 1912 there were $1,200,000$ miles of rural delivery routes in the United States, most of them over dirt roads. cost of rural delivery which was then losing $\$ 28$ million per year. ${ }^{5}$

The Shackleford bill passed the House but was lost in the Senate. However, in the same session an experimental appropriation was added to the Post Office Department Appropriation Bill (37 Stat 551) to be spent by the Secretary of Agriculture, in cooperation with the Postmaster General, to improve the condition of certain selected post roads, and thereafter, to determine "the increase in the territory which could be served by each carrier as a result of such improvement, the possible increase of the number of delivery days in each year, the amount required in excess of local expenditures for the proper maintenance of such roads, and the relative saving to the Government in the operation of the Rural Delivery Service and to the local inhabitants in the transportation of their products by reason of such improvement. ..."

The Act also required that the State or local government receiving aid should put up two-thirds of the total cost and that the Secretary and the Postmaster General should report back to Congress within 1 year the results of their operation and also their recommendations, pro or con, on a general plan of national aid for the improvement of postal roads.

This was a very large assignment for both Departments and one that was to test their negotiating skills to the utmost. Unfortunately, Congress failed to provide either agency with administrative funds to carry out the Act, so they had to secure the necessary engineers and postal inspectors by cutting down on other activities.

Another more important provision of the same Act authorized the appointment of a joint committee of five Senators and five Representatives to make an inquiry into the whole matter of Federal aid to highways and to report back to Congress at the earliest possible date.

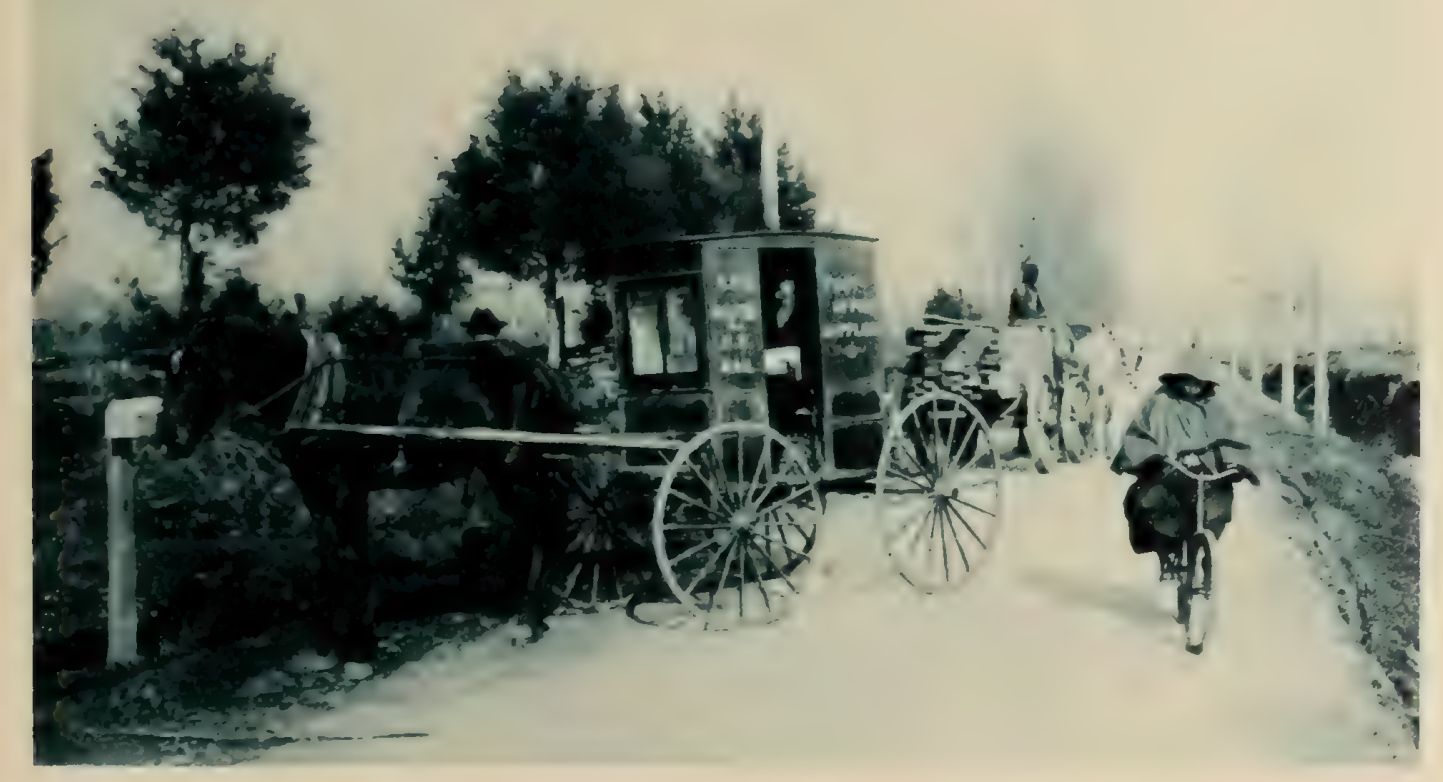

Traffic on an improved post road in Tennessee in 1903. 


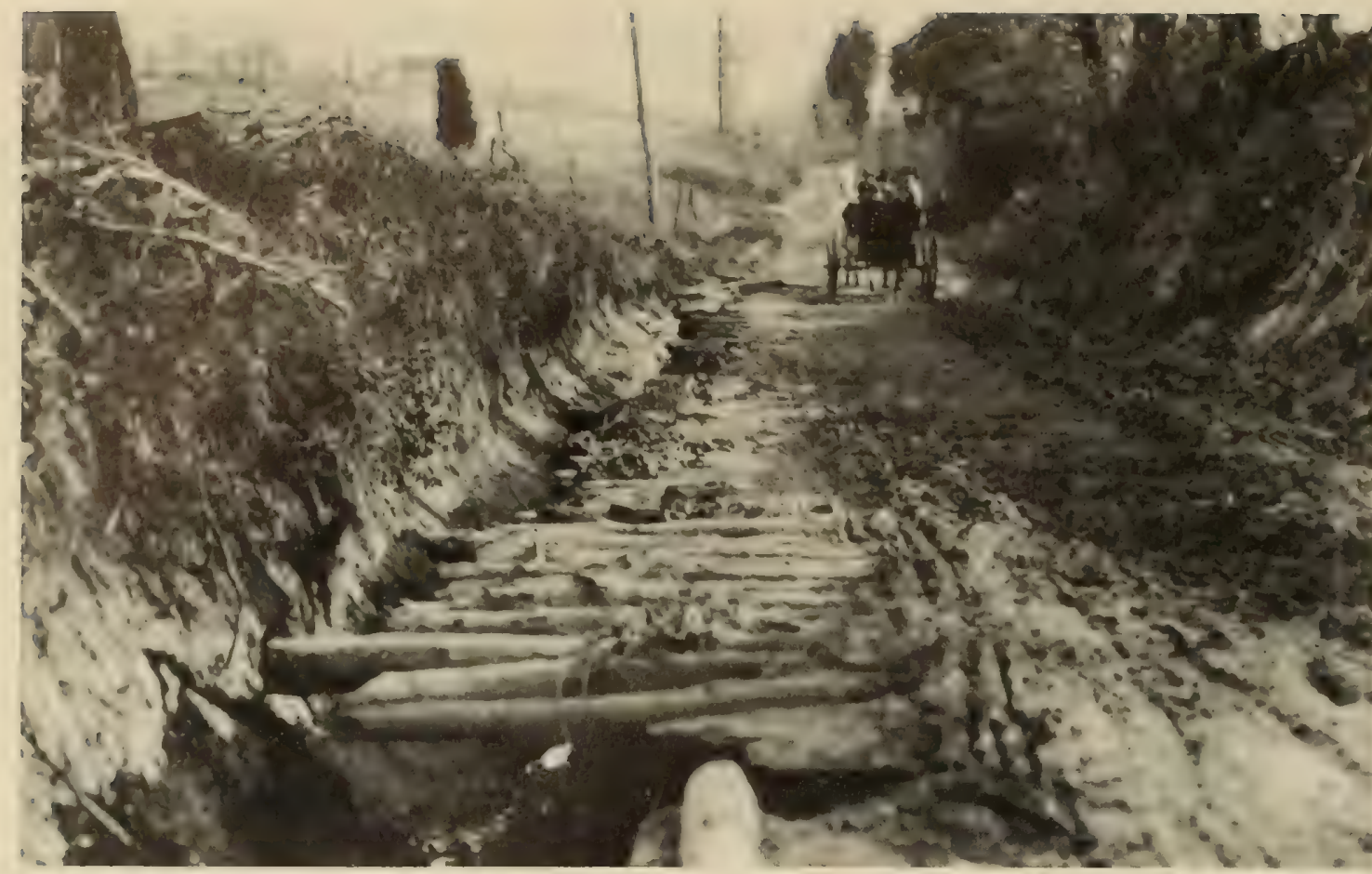

An earth road near Stafford, Va. that was repaired with pine poles about 1912.

\section{The Complexities of Federal-State-County Cooperation}

In order to treat all States equally, and also to get information representative of all parts of the country, the two Departments divided the $\$ 500,000$ appropriation equally among the 48 States. They then, in a joint letter, notified each governor of the apportionment and asked that he designate about 50 miles of road within his State on which rural delivery was or might be established as an experimental post road. Five governors did not even hother to reply to this request; six refused to participate; and 28 indicated that they were unable to comply for lack of legal powers or because of conflicting State statutes. Two States, Georgia and South Carolina, declined to participate because of Federal statutes requiring an 8hour work day and the Executive Order of May 18, 1905, barring the employment of convict labor on Government work. In the end, only Alabama, Iowa, and Oregon agreed to designate post roads and accept the Federal subsidy. ${ }^{6}$

By this time, nearly 7 months had passed and no projects were underway, so the two Departments tried a different approach. They decided to select from two to eight locations representative of conditions in various sections of the country and to concentrate the available funds on a few roads in these localities. This plan produced the desired result, and eventually agreements were made for 17 post road projects totaling 457 miles, located in 13 States and 28 counties, but not without practical and legal difficulties. One county in Virginia figured that it could build roads more economically by doing its own work with convicts or by free labor working 10 or 11 hours per day than by accepting the Federal subsidy, and the county canceled its agreement. The original idea of appointing a trustee in each county to hold the funds for each post road, subject to disbursement by a Federal engineer, had to be dropped in some States because of conflict with State laws. The most serious objections came from Minnesota which protested the 8-hour clause in the agreements and appealed the matter to the Attorney General of the United States, who ruled that the work contemplated under the post road program was, after all, not public work of the United States, within the meaning of the statutes, and, therefore, neither the 8-hour law or the prohibition on use of convict labor would apply. ${ }^{7}$

The Secretary of Agriculture turned the supervision of the post road program over to the Office of Public Roads, and Page in turn assigned responsibility to E. W. James, who detailed an engineer to each project to lay out the road, supervise construction, and approve expenditures. Cooperation with the counties was not easy. Unlike Bennington County, Vermont, which had petitioned the OPR to assign an engineer, the cooperating post road counties had surrendered their control over the joint road funds unwillingly and only to get the Federal subsidy. The Secretary and the Postmaster General described some of the difficulties in these words:

From correspondence and from the attitude of the local officials in many places it appears that there is a disposition frequently to avoid the obvious requirements of the present act with respect to Government control over the expenditure of joint funds. The allotments have been looked upon not infrequently in the light of a gratuity, the idea of the post road has been lost sight of, and the question has been frequently raised in the field as to why the Government would not give the money to the counties and let them spend it. ...

Fiscal procedure in the States and counties, if possible, should be provided for in local statutes, written with Federal aid in mind. The longest delays, the most unsatisfactory conferences, and the most troublesome routine in the execution of the present projects have arisen because the Federal aid and supervision of local funds was not thought of when the fiscal regulations of the States and counties were made.

We find that many States incorporate into their State road laws certain details of design and methods of construction which, in any general distribution of national aid, would at once act as checks on supervision by the National Government. . . . 
The first post road to be completed was opened to traffic in 1914. It was a dirt road, extending $141 / 2$ miles west from Florence, Alabama, to Waterloo. The program, with congressional extensions, dragged on for four more years, until the last post road, in Dubuque County, Iowa, was opened in 1918. From the start, this program was a very considerable burden on the Office of Public Roads, yet in carrying it out, the OPR learned valuable lessons which Director Page was able to pass on a few years later to the framers of the Federal Aid Road Act of 1916. The most important of these recommendations was that Federal aid should be dispensed only through the 48 States, avoiding the complexities of dealing with the Nation's more than 3,000 counties.

It is worth noting that the post road program of 1912 to 1918 was the Office of Public Roads' first involvement with the Federal policy of inducing social change in the States by means of the public works programs. Later legislation conditioned Federal grants for roads on State compliance with the 8-hour law, the prohibition of convict labor, the use of hand labor methods, the payment of minimum wages, and numerous other requirements that were primarily social.

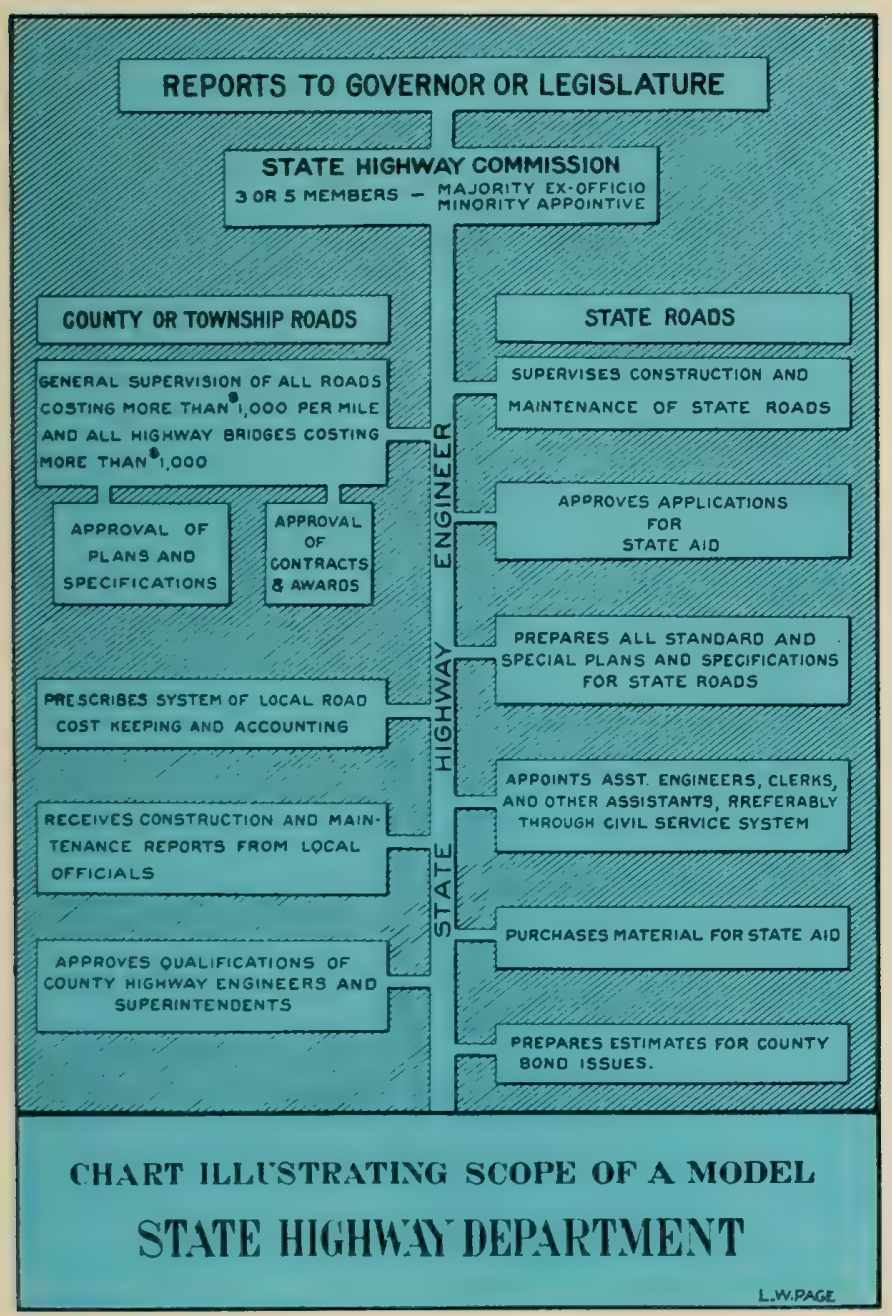

Although the date is not known, it can be assumed that Director Page made up this model of a state highway department about the time that he made his recommendation on the 1916 Federal Aid Road Act.

\section{The Lincoln Highway}

The Glidden Tours and the exploits of the Pioneer Freighter inspired a growing interest in motorable long-distance roads among the rapidly increasing class of automobile owners. In 1912 Carl G. Fisher, builder of the Indianapolis Speedway, conceived the idea of a "coast-to-coast rock highway" as a way to dramatize the need for interstate roads. He was able to get support for this idea from some of the foremost leaders of the automotive and allied industries, and in July 1913, Fisher and his supporters formed the Lincoln Highway Association to carry out the scheme and collect public subscriptions to pay for it. The Association then selected what they considered the most direct route across the mid-United States beginning at New York and proceeding by way of Philadelphia, Chicago, Omaha, Cheyenne, and Salt Lake City to San Francisco, a total distance of about 3,150 miles. ${ }^{9}$

The Association recruited members in all of the towns along the route, and, with thoroughgoing efficiency, appointed able and influential local citizens as "consuls" to promote the improvement of the various sections of the route. The result was a rich harvest of local and national publicity and sizable cash contributions as well.

The Lincoln Highway Association collected millions of dollars from the public, but its officers had no illusions that they would ever be able to get enough to build the highway from this source. Their primary purpose was to educate the public to the need for better roads and build political support for national aid to good roads. As a vehicle for this educational campaign, they adopted Roy Stone's tried and tested technique of object lesson roads. The funds donated to the Association were used to finance "seedling miles" distributed throughout the length of the route. The first of these, begun October 1914, near the village of Malta, Illinois, was a cement concrete pavement, and many of the others were of similar high types suitable for heavy traffic.

The Lincoln Highway inspired a tremendous amount of argument both for and against longdistance roads. The rural interests generally were against them, claiming that the Nation would be drained of funds to build a few "peacock alleys" for the enjoyment of wealthy tourists. Urban spokesmen said the country had been too long in bondage to the medieval English concept that roads were the responsibility of the smallest and weakest units of government, namely, the road districts, townships, and counties, and that the Federal Government should assume responsibility for "national routes."

Among the most active of the national roads advocates was the National Highways Association, an organization its enemies claimed was dominated by the road machinery, road materials, and portland cement interests. This Association published a map showing a recommended 50,000-mile system of national roads extending from coast to coast and from Canada to the Gulf, which it claimed should be the responsibility of the Federal Government to build and maintain.*10 Such a system, proponents claimed,

* This idea was 30 years ahead of its time and was not realized until the Interstate System was authorized in 1944. 


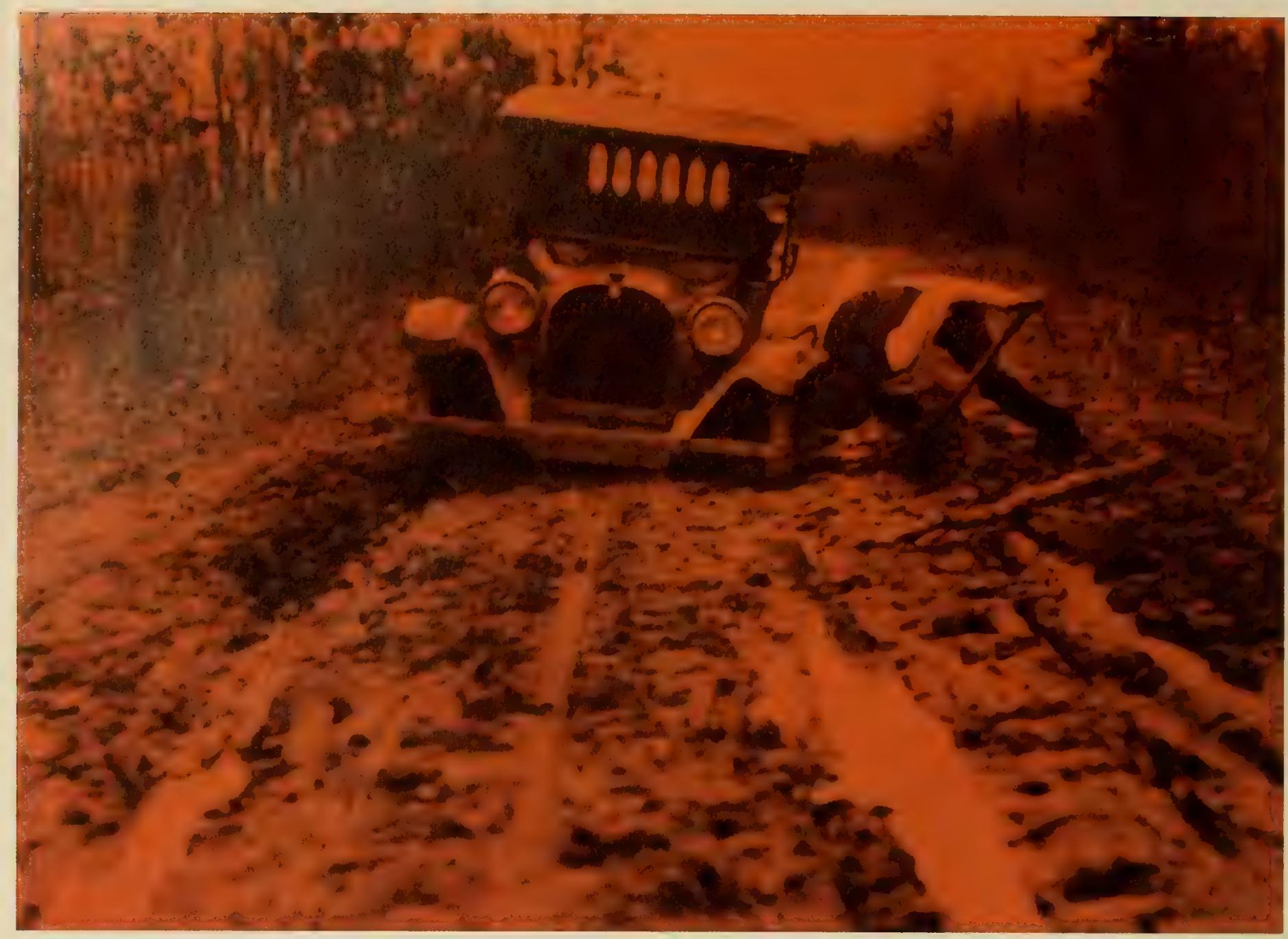

With the spring thaw, roads such as this one in Michigan

about 1916 annually became impassable because of the mud.

would not lay any additional expense on the States and counties but, rather, would relieve them of the cost of keeping up their heaviest trafficked roads, leaving more of the local funds to spend on the local roads.

The American Automobile Association took a strong position in favor of Federal aid and against dissipating the Federal funds in driblets over the more than 2 million miles of local roads:

\begin{abstract}
we advocate the main roads to be built first, and those are the two fundamental principles that this Association is working for: that the government should aid, and that the government money should be spent only on the main thoroughfares and should not be dissipated by trying to spend it on $2,000,000$ miles of road . . we believe that this work should not of necessity be done by the government, but that the State highway officials, in cooperation with the government, should agree on the roads, the plans, and the specifications, and on the various features of the contract. ${ }^{11}$
\end{abstract}

\section{The Evolution of a National Policy on Federal Aid}

When the Post Office Appropriation Act of 1912 was passed, it was already apparent to most Congressmen that some form of Federal aid to roads was inevitable. The real questions before Congress were how much the aid should be and the form in which it should be granted. The experimental post road appropriation and the congressional joint committee were measures designed to get some answers to these questions, but in the end, the inevitable Federal-aid bill was hammered out on the anvil of political compromise.

The legislators appointed to the Joint Committee on Federal Aid in the Construction of Post Roads represented all shades of opinion from extreme national road advocates to local road supporters. The Committee held hearings and drew heavily on the files of the State Department and the Office of Public Roads for information on the economic and social importance of roads and how they were administered in the United States and the advanced countries of Europe. They learned, for example, that in the United States the average haul for farm products to market or to the nearest railroad station was 9 miles; and the average cost of hauling over the existing country roads was 21 cents per ton-mile. By comparison, it cost French farmers only 8 cents per tonmile to haul farm products over their macadam roads. The difference, or 13 cents per ton-mile, was in effect a financial burden laid on American producers and consumers alike by bad roads, a "mud tax" that was costing the country $\$ 504$ million annually. At 6 percent, this loss represented the interest on $\$ 8.4$ billion, which, according to some economists, might profitably be spent annually to improve the roads instead of the niggardly $\$ 204$ million spent in $1912 .{ }^{12}$ 
The Committee received testimony on the effect of bad roads on the education of rural children, the quality of rural life, and migration of young people from the farms to the cities; and on the value of farm land, the labor of horses, and the wear and tear on wagons and draft gear, and the motorization of farm transportation. They sent inquiries to people in all walks of life in all parts of the country, and of 10,000 replies, 97 percent were in favor of some form of Federal aid.

The Joint Committee's work stretched out far longer than Congress had anticipated and was not completed when the 63d Congress convened in 1914. This did not discourage the proponents of Federal aid, who poured a steady stream of bills into the legislative hopper in the first session. In all, 10 bills were introduced in the Senate and 39 in the House. These bills covered the whole spectrum of thinking on the Federal-aid question. At one extreme was Alabama Senator John H. Bankhead's bill to set up a National Bureau of Highways in Washington to spend $\$ 25$ million per year on a national highway system. At the other end was a bill by Senator Hoke Smith of Georgia to classify all the rural mail routes according to the type of surfacing and then pay each State $\$ 60$ annually for each mile of Class A (macadam) road, $\$ 30$ per mile for Class B (gravel), and $\$ 15$ per mile for Class C (earth), as "rental" for the use of the roads to carry the U.S. mail. A novel plan offered by Senator Jonathan Bourne, Jr., of Oregon would apportion $\$ 1$ billion among the States according to four factors. Under this complicated plan, the Federal Government would lend part of the money to the States at 4 percent interest and the remainder would be a subsidy for State roads. This was to be accomplished by the issuance of both State and Federal Government bonds over a long period of time.
Through this welter of different Federal-aid plans there ran a thin thread of agreement on three matters:

- The amount of Federal aid should be from $\$ 20$ to $\$ 25$ million annually.

- The aid should be apportioned among the States according to some formula. (The most popular formula was one-third of the funds according to population, one-third according to geographic area, and one-third according to the mileage of post roads.)

- The aid should be matched by State contributions, with 50-50 the most favored ratio.

Eventually the House passed a modified version of the "ABC Rental Plan" offered by Representative Shackleford of Missouri, but this bill was lost in the Senate reportedly because of the opposition of the American Automobile Association and big city interests. ${ }^{13}$

In support of his plan to subsidize the lesser rural roads, Shackleford used an argument that would have repercussions for years afterward in the design of highways. He asserted that there are two types of roads: "touring roads" and "business roads," and that the two are somehow incompatible in the same system of highways. In 1913, at the Third American Road Congress he said:

It can not be doubted that an overwhelming majority of the people want federal road legislation; but, unfortunately, they radically differ in opinion as to what such legislation should provide. They are divided into two general classes, which for the purposes of this discussion may be designated as the 'touring-roads' class and the 'business-roads' class. The 'touring-roads' class is marching under a banner upon which is inscribed in letters of gold: 'See America first.' The 'business-roads' class is marshaling its forces under a flag which bears the legend: 'Cheaper transportation and lower cost of living.' ...

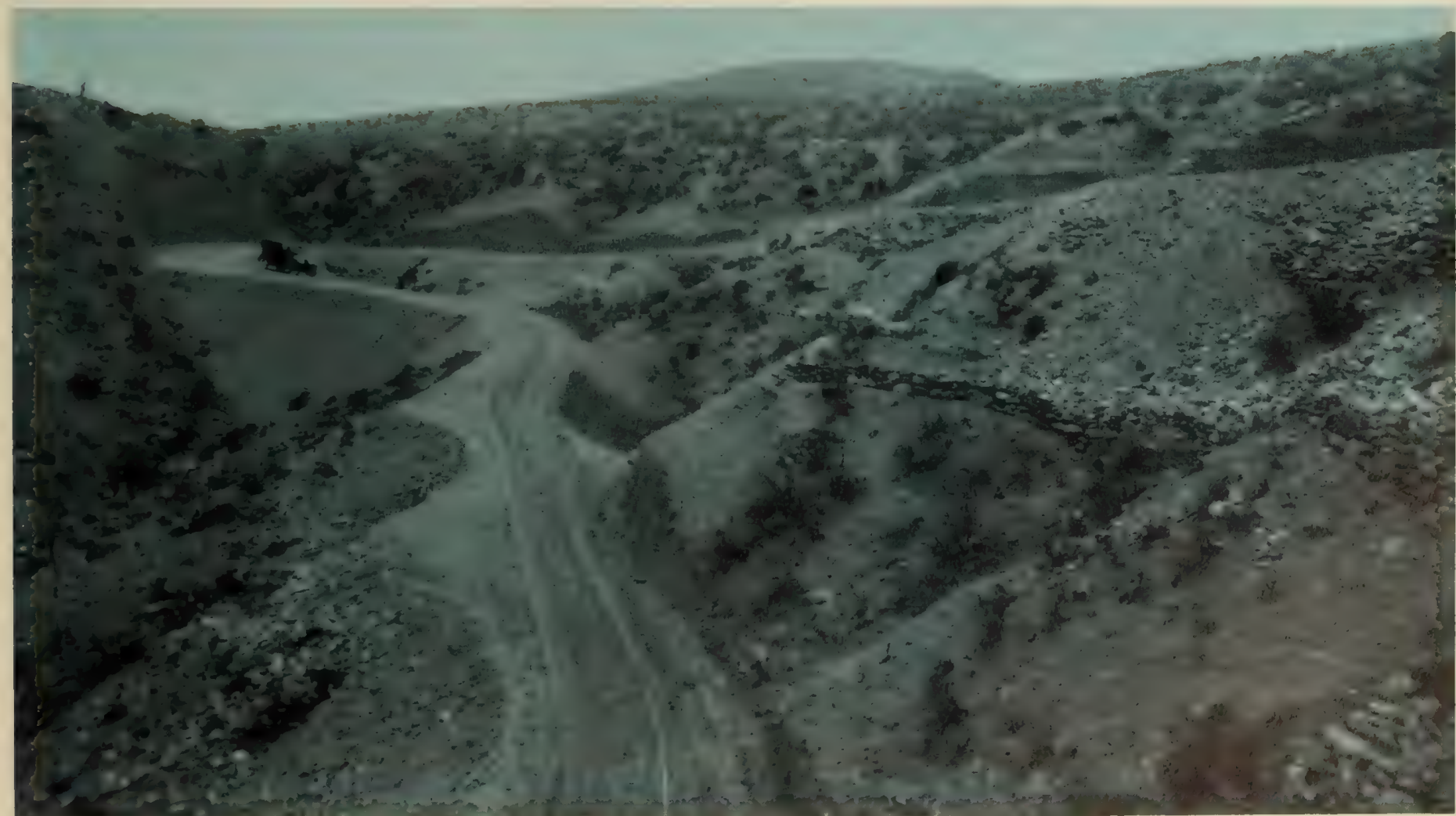


The 'touring-roads' class demands that the United States shall limit its road activities to the construction and maintenance of a few 'ocean-to-ocean' and 'acrosscountry' highways of great perfection and then leave the rest of the people to build their own roads or do without, as they may choose.

The 'business-roads' class believes that in dealing with roads we must keep in mind their functions and the relation which they bear to the general transportation system of the country; that, as the harbor is the terminus of the river and the railroad, so, for practical purposes, the railway station is the terminus for roads; that neither freight nor passengers will ever be carried long distances over roads as cheaply as they could be over railways, and that it is an idle dream to imagine that auto trucks and automobiles will take the place of railways in the long-distance movement of freight or passengers; that the proper function of roads is not to connect antipodal oceans nor the distant capitals of far-away States, but to make easy communication between the farms on one hand and the towns and railway stations on the other, to the end that the farmer may market his crops at less expense and the town dweller may get farm products more easily at less cost. They therefore favor a general system of roads radiating from the towns and railway stations out among the farms. ${ }^{14}$

In later years, in a different context, and in somewhat different form, Shackleford's arguments would be used to oppose parkways, highway beautification and long-distance freeways.

In their report of January 21, 1915, the members agreed unanimously on the need and desirability of Federal aid and its constitutionality, but not on any specific policy for Congress to follow in granting such aid. The Committee failed to come to grips with the question of how much aid should be granted, other than to counsel that Federal aid should be undertaken in a large way rather than a small, haphazard way. They warned that small contributions spread over a large mileage would create a "pork barrel" that would dissipate the Federal funds without any permanent upgrading of the roads. The Committee also came out against centralization of control over the road program in Washington.

Prophetically, the Committee declared, "We believe that permanent highways will result in very considerable adoption of auto-truck hauling in preference to rail transportation where the distance is within a half day's run." 15

\section{Federal Aid Becomes A Reality}

Among the first bills introduced into the 64th Congress in January 1916 was Representative Shackleford's H.R. 7617, providing that "the Secretary of Agriculture, on behalf of the United States, shall, in certain cases, aid the States in the construction and maintenance of rural post roads." This bill proposed to appropriate $\$ 25$ million annually, out of which each State would receive at least $\$ 65,000$. The remainder would be apportioned one-half in proportion to population and one-half in proportion to the mileage of rural free delivery (RFD) and star post routes. The locations and standards of the aided roads were to be agreed upon between the Secretary of Agriculture and the States, and earth, sand-clay, and other low cost surfaces would be eligible for the subsidy, as well as higher types, and the Federal share of the cost would be not less than 30 percent nor more than 50 percent. To receive Federal aid after 1920, each State would have to have a State highway department to administer the Federal funds. Finally, the construction and maintenance of the aided roads would remain under State control.

Other good roads bills were introduced in the 64th Congress, but Shackleford's H.R. 7617 attracted the most support. Its author had been cochairman of the Joint Congressional Committee, and he was now chairman of the newly formed House Committee on Roads. He had come to realize that compromise between the long-distance roads and local roads advocates would be necessary to pass any Federal-aid bill. His new bill had the support of the American Association of State Highway Officials, the Secretary of Agriculture, the Postmaster General, and the Office of Public Roads, all of whom opposed the ABC rental plan so dear to Shackleford's heart.

When the Shackleford bill reached the floor of the House, there was no opposition to it on constitutional grounds, and almost everybody was satisfied that ownership and responsibility for roads should remain with the State and local governments. There was also general agreement that the Government should deal only with States through a highway department. Debate revolved almost entirely about the formula for apportioning the funds among the States, and the exclusion of places of more than 2,500 population from the benefits of the act.*

Opponents of the bill claimed that the apportionment formula gave the wealthier States, which contributed most of the Federal revenues, less than their fair share of the post road benefits, and they were particularly bitter that the cities, which contributed a very large share of the revenue in all States, got nothing at all from the bill. The rural road advocates replied that the wealthy States and the cities had already received more than their fair share of the national income in other forms, such as expensive post offices and public buildings, harbor improvements, veterans' pensions (one-third of the pensioners lived in six eastern States, practically none in the south) and, most of all, in shelter of their industries behind a high protective tariff.

Despite the opposition, the Shackleford Bill, with some changes, passed the House by a good margin and was carried unanimously in the Senate. It became law July 11, 1916.

The principal changes in the bill were to reduce the funding and change the apportionment factors to onethird according to area, one-third according to population, and one-third according to post road mileage. The Secretary of Agriculture was allowed to take 3 percent off the top of all appropriations for administration. No Federal aid was to be apportioned to any State until its legislature had assented to the provisions of the Act, but after that, the Secretary would pay one-half of the actual cost of any approved project, including the cost of bridges and culverts, up to $\$ 10,000$ per mile. After completion of the aided road, it would be the duty of the State to properly maintain it, and if this were not done, the Secretary could refuse to approve further Federal aid in that State until the road was restored to good condition.

* The debate on the Federal-aid bill comprises some $\mathbf{3 0 0}$ pages of The Congressional Record, Vol. 53, 1916. 
Congress realized that it would take some time for the States to enact suitable legislation assenting to the Federal Act, to raise matching funds and train personnel for an expanded road program. The Congress, in order to provide time, allowed States with unexpended funds at the close of the fiscal year one additional fiscal year to obligate funds and, for those States that did not have a State highway department, the appropriation would be available until the close of the third fiscal year following the fiscal year for which it was apportioned. The legislators may also have remembered how long it took the Secretary of Agriculture and the Postmaster General to implement the much smaller post road program of 1912. At any rate, they appropriated only $\$ 5$ million for fiscal year 1917 , the first year of the new program, but at the same time, they provided for increasing the amount by $\$ 5$ million annually up to a maximum of $\$ 25$ million in 1921.* Thus, although the amount initially available was not large, Congress, by appropriating for 5 years in advance, made it possible for the States to plan ahead and build up an orderly program. This wise policy has continued down to the present.

\section{Launching the Federal-Aid Program}

The Federal Aid Road Act of 1916 placed an immense additional responsibility on Logan Waller Page and the Office of Public Roads and Rural Engineering,** to whom Secretary of Agriculture Houston delegated the administration of the Act. First, they had to apportion the appropriated funds among the 48 States, and this required that the Postmaster General certify the mileage of rural delivery and star routes in each State. The apportionment was published July 21, 1916, just 10 days after President Wilson signed the Act.

Page and the Department solicitor then drafted tentative regulations for carrying out the provisions of the Act, and invited the heads of all the State highway departments to a conference in Washington to discuss them. The draft regulations did not satisfy everyone, particularly the provisions denying Federal participation in the cost of right-of-way and the cost of making preliminary surveys and plans. However, most of the suggestions made by the State officials were incorporated in the final draft, and the regulations were issued September 1, 1916.

The harmonious cooperation between the Federal and State officials in drafting these regulations was a good omen for the eventual success of the Federal-aid program. Their work was so well done that the regulations were not greatly changed for years afterward, even though the Act itself was very considerably amended.

* In addition to providing $\$ 75$ million for Federal aid to post roads, Congress appropriated $\$ 10$ million for roads and trails in national forests to be spent at the rate of $\$ 1$ million per year beginning in 1917 under the supervision of the Secretary of Agriculture.

** On July 1, 1915, the Department's work on farm drainage, irrigation and farm architecture was merged with the work on roads under a new Office of Public Roads and Rural Engineering (OPRRE) with Logan Waller Page as Director. The working force under Page after the merger was 450 persons, of whom 288 were from the rolls of the old OPR and 162 from other agencies. ${ }^{18}$
The Act gave the State highway departments the authority to initiate projects subject to approval of the plans, specifications and estimates by the Secretary. To provide prompt inspection and approval of projects, Page decentralized the OPRRE into ten regional districts, each in charge of an experienced highway engineer. At the same time, he had men at work, in cooperation with the States, preparing standard forms for plans and specifications, and in February 1917 he convened a conference of State testing engineers in Washington to recommend to the States standard specifications and methods of testing road materials.

The OPRRE's administrative diligence was matched by that of those States which already had adequate highway departments. By July 1917, Page's district engineers had received applications from 26 States for Federal aid in the construction of 949 miles of road estimated to cost $\$ 5.43$ million, the Federal share of which amounted to about $\$ 2.43$ million, or less than half of the funds appropriated by Congress for fiscal year 1917. Of these projects, 188 miles, with a Federal share of $\$ 846,152$, had been approved. ${ }^{17}$

\section{Standards for Federally Aided Roads}

Representative Shackleford's original bill, which much amended eventually became the Federal Aid Road Act, provided that Federal aid might be used for earth and sand-clay roads, as well as for higher types, ". . . one of the purposes of this Act being to encourage and promote the improvement of a general system of roads leading from cities, towns and railway stations into the adjacent farming communities." "18 This specific language was eliminated while the bill was under consideration in Congress. Instead, the Secretary of Agriculture was given the power to review and approve State proposals, including road types and standards, subject to the limitation that approved projects should be "substantial in character."

The poorer States of the South and West regarded this limitation with considerable apprehension, fearing that the Secretary might require macadam, concrete or other high types of surfacing for Federal approval. This apprehension may have been reinforced by the fact that the first Federal-aid project approved was a 20 -foot concrete road in California. To allay this widespread fear, Secretary Houston, in February 1917, issued a specific statement to the public:

"This department, which is charged with the administration of the Federal Aid Road Act, has placed absolutely no restrictions, either direct or implied, upon the kinds of highways to be constructed. States may submit for approval any kind of road, even an earth road, and approval will be given if the construction be substantial in character, suitable for traffic needs, and meets the terms of the Federal act. To give State legislators and highway officials the impression that this department favors only costly types of road or discriminates in favor of any particular material, results not only in spreading misinformation, but in placing barriers in the way of States which wish to avail themselves of Federal aid in road construction.' ${ }^{19}$

This announcement apparently had the desired effect. As of January 1918, 80 percent of the 2,849 miles submitted for Federal-aid approval were for gravel, sand-clay or graded earth roads. 


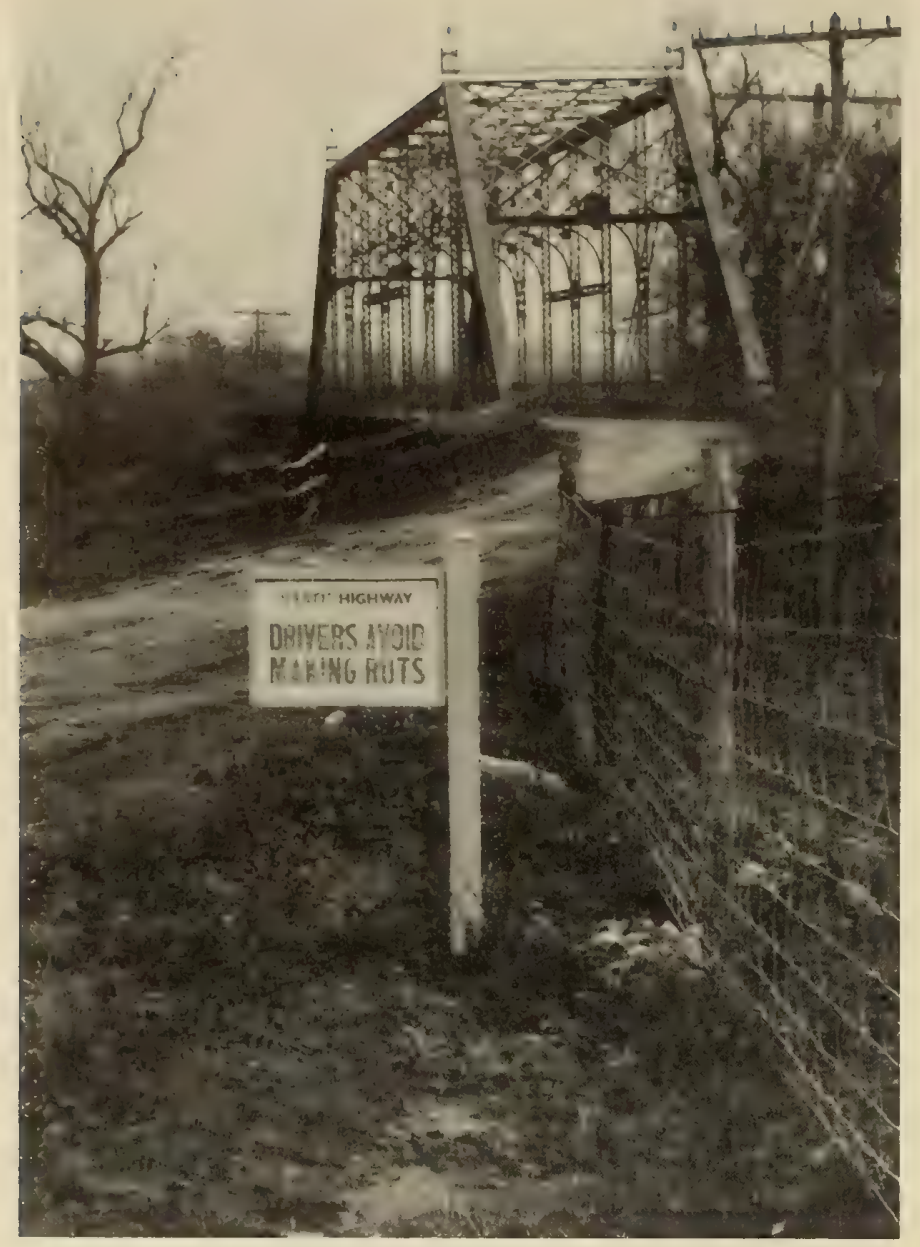

A caution sign to drivers to preserve

the low type State highway.
The Federal-aid regulations of 1916 contained one rather unusual provision:

Unless otherwise specifically stipulated in the project agreement, bridges, viaducts and under-passes shall have clear width of roadway of not less than 16 feet, and clear head room of not less than 14 feet for a width of 8 feet at the center. ${ }^{20}$

This was one of the few occasions on which the Federal Government chose to set standards for roads. In the years following, the Government let the States set standards by agreement among themselves through the American Association of State Highway Officials and then made adherence to these standards a condition for receiving Federal aid. Thus, strictly speaking, there have never been "national standards" for roads in the United States, such as were established by the governments of France and other European countries.

\section{The Road Census of 1914}

The Office of Public Road Inquiries made the first national road inventory in 1904, canvassing not only road mileage, but also revenues and expenditures for construction and maintenance. This information, such as it was, was obtained entirely by correspondence, and before the inventory was over, some 60,000 printed forms and letters were sent out and received by the OPRI. The information was far from complete, and some was of questionable accuracy. In some instances, the county road officials refused to supply the information unless paid for their services, and in such cases, it became necessary to secure the information through postmasters, attorneys, physicians or other private citizens.

The roads in many counties and townships have never been measured, surveyed or recorded, and in such cases it became necessary to secure an estimate of the mileage from persons best informed on this subject in the counties. In some instances no permanent records appeared to have been kept of collections or expenditures of road funds, and in others the records are kept in such manner as to confuse rather than enlighten one in search of information. ${ }^{21}$

Tollgate in Ambrose County near Lynchburg, $\nabla a$. The sign warns that there is a fine of \$10. for exceeding the speed limit of 6 m.p.h.

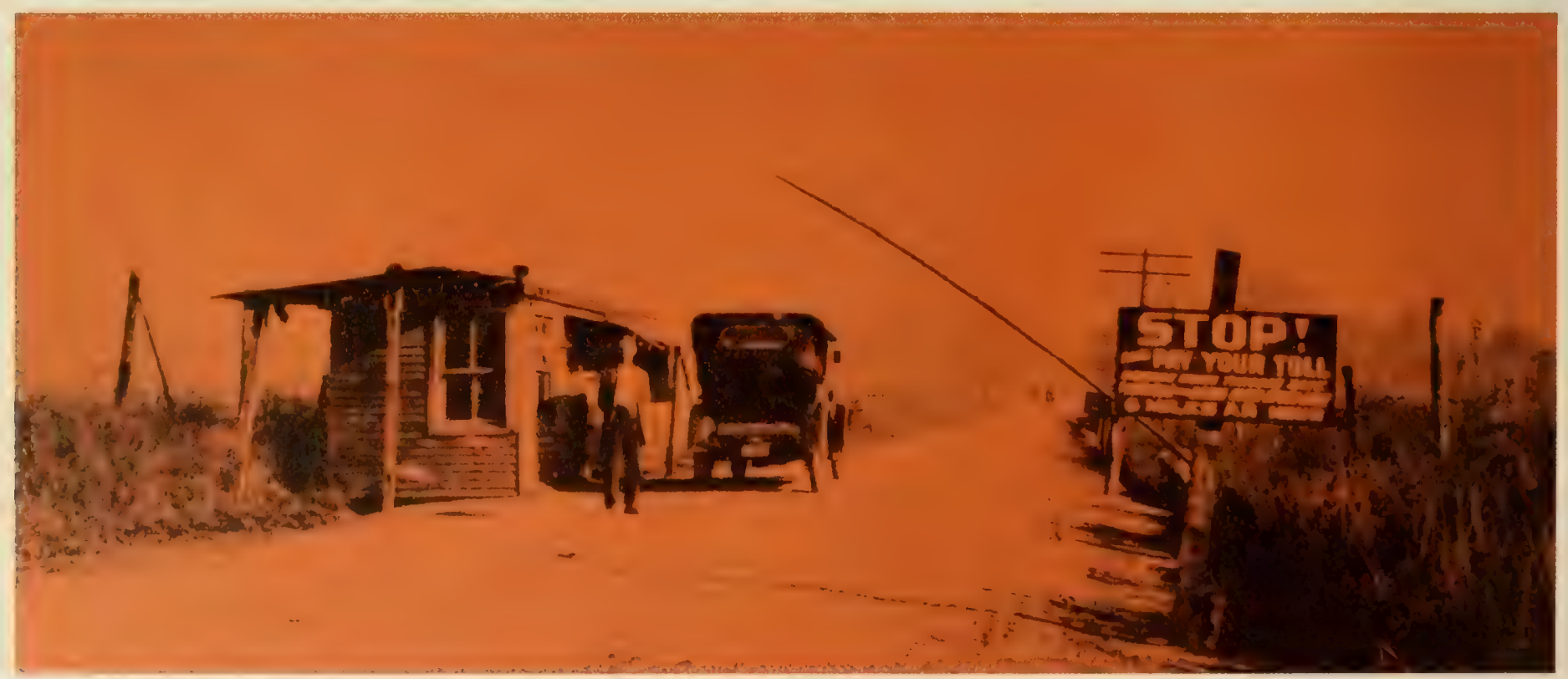


In 1909 , the OPR made another inventory by mail, canvassing only the mileage of various types of road surfaces.

By 1914, well over half of the States had highway departments, and Page persuaded these departments to help with the road census by supplying "collaborators" who would collect the information in their States and forward it to OPR. In those States that did not supply collaborators, the OPR collected the information directly from the local authorities, or from local and State road associations, chambers of commerce, automobile clubs, postmasters and private citizens. Apparently, in these States the quality of recordkeeping had improved but little since 1904 :

Highway accounting systems and methods, especially in the local subdivisions of States, are, in general, far from satisfactory. In many places the records were found to be so indefinite or so incomplete that the most careful investigation failed to determine even the bare total of what funds had been expended on roads and bridges during the previous years. At times the memory of some official or employee seemed a better guide than the permanent existing records.

Lack of definite data and records by the local subdivisions is even more pronounced as to road mileage. Hundreds of instances were discovered where the local officials could give no more than a rough estimate, as maps had not been prepared or measurement of the roads been made. ${ }^{22}$
Despite these shortcomings, the census of 1914 , taken as a whole, was the most accurate and comprehensive inventory of American roads and road finances made up to that time. The most striking finding was an enormous increase in the total annual expenditures on roads and bridges, from $\$ 79.62$ million in 1904 to $\$ 240.26$ million in 1914 , a large part of which was derived from the sale of bonds.*

The mileage summary showed that the country's network of rural roads, that is, those outside incorporated cities and towns, had grown from 2,151,379 miles in 1904 to $2,445,760$ miles in 1914. Roads surfaced with sand-clay, gravel, macadam or substances other than plain dirt had increased from 153,530 miles in 1904 to 257,291 miles in 1914 but were still only 10.5 percent of the total mileage. Of the surfaced mileage, 32,180 miles, or 12.5 percent, were of dust-free types, such as bituminous macadam, brick or concrete. These, with a few thousand more miles added in 1915 and 1916, would soon be put to the supreme test of wartime traffic.

* About $\$ 21.0$ million of road and bridge bonds had been issued in the 10 years preceding 1904 in five States. ${ }^{28}$ In 1914, the total of State and local bridge and road bonds outstanding was $\$ 344.76$ million, distributed through 42 States. Of this amount, $\$ 115.32$ million were State bonds issued by New York ( $\$ 65$ million) and 10 other States. ${ }^{24}$

\section{REFERENCES}

${ }^{1}$ A. Machen, Rural Free Delivery of Mails, Proceedings, North Carolina Good Roads Convention, Bulletin No. 24 (Office of Public Road Inquiries, Washington, D.C., 1903) p. 51.

"Bureau of Public Roads Annual Report, 1906, p. 23.

'M. Dodge, Our National Policy, Proceedings, National Good Roads Convention Held At St. Louts, Mo, Bulletin No. 26 (Office of Public Road Inquiries, Washington, D.C., $1903)$ p. 20.

'Address by Hon. Wm, P. Borland, Procendings, Thtrd American ROAD CoNGress, (American Highway Association, Washington, D.C., 1914) p. 76.

' 64 Cong. Rec. 1353 (1916).

- Joint Report of The Progress of Post Road ImproveMENT, H. Doc. 204, 63d Cong., 1st Sess., pp. 4, 5.

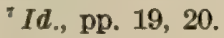

${ }^{8} I d$., p. 13.

-A. Rose, Historic American Highways-Public Roads of THE PAst (American Association of State Highway Officials, Washington, D.C., 1953) p. 109.

${ }^{10}$ D. Shackleford, Federal Road Legislation, Proceedings, Third American Road Congress (American Highway Association, Washington, D.C., 1914) pp. 59, 60.

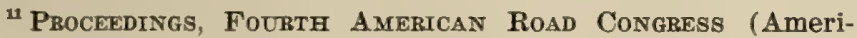
can Highway Association, Washington, D.C., 1915) pp. 26, 27.
${ }^{12}$ Federal Aid To Good Roads, H. Doc. 1510, 63d Cong., 3d Sess., pp. 15-17.

${ }^{13}$ D. Shackleford, supra, note 10 , p. 63.

${ }^{14} I d$., pp. 56, 57.

${ }^{15} \mathrm{H}$. Doc., supra, note 12, p. 15.

${ }^{16}$ Bureau of Public Roads Annual Report, 1915, p. 1.

${ }^{17}$ Bureau of Public Roads Annual Report, 1917, p. 3.

${ }^{18}$ H. R. 7617, 64th Cong., 1st Sess., Jan. 6, 1916.

19 J. Pennybacker \& L. BoYkin, Federal Aid to Highways, Yearbook of The Department of Agriculture, 1917 (GPO, Washington, D.C., 1918) p. 135.

${ }^{20}$ U.S. Department of Agriculture, Rules and Regutations of The Secretary of Agriculture For Carrying OUt The Federal Aid Road Act, Circular No. 65 (GPO, Washington, D.C., 1916) p. 10.

${ }^{21}$ M. Eildridge, Public-Road Mileage, Revenues and Expenditures In The United States In 1904, Bulletin No, 32 (Office of Public Roads, Washington, D.C., 1907) p. 7.

${ }^{22}$ Office of Public Roads and Rural Engineering, Public Road Mileage and Revenues In The United States, 1914 A Summary, Bulletin No. 390 (U.S. Dept. of Agriculture, Washington, D.C., 1917) p. 2.

${ }^{23}$ M. ELDRIDGE, supra, note 21, p. 18.

${ }^{24}$ OPRRE, supra, note 22, pp. $3,8$. 


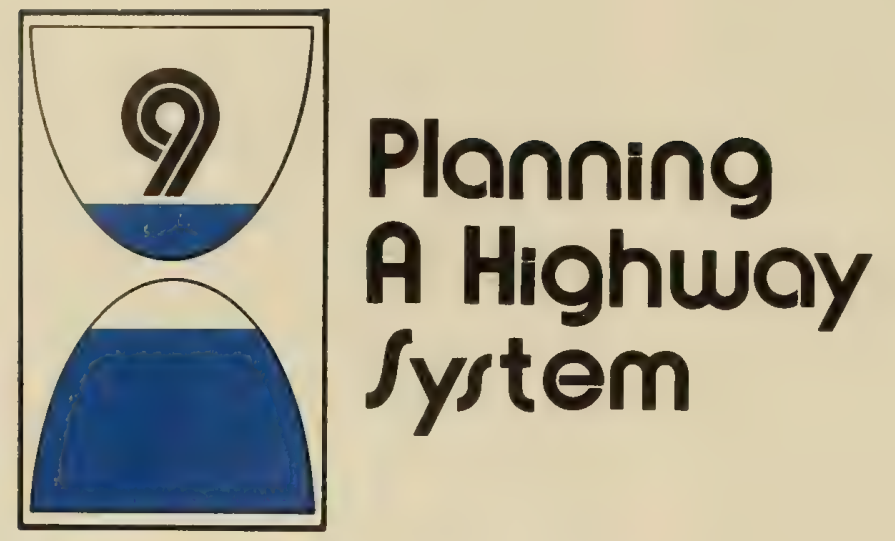

\section{The Clouds of War}

The United States was only slightly prepared for hostilities when war was declared against Germany April 6, 1917. The total strength of the Army was less than 200,000 men, and most of these were recent enlistments in the early stages of training. Perhaps half a dozen regiments stationed in the Canal Zone and on the Mexican border were at war strength; the rest of the Regular Army was scattered all over the country in battalion-sized garrisons. Some industries had tooled up to produce munitions for the Allies, and America was making large shipments of food to Europe; but these were only token efforts compared to those that would be required to fight a full-scale war.

Within a week of the Declaration of War, President Wilson created the Council of National Defense, consisting of the Secretaries of War, the Navy, Agriculture, the Interior, Commerce, and Labor, along with an unpaid Advisory Council of industrialists, labor leaders, financiers, and prominent citizens from all walks of life. Boards and committees functioning under the authority of the National Council eventually supervised every aspect of the war effort, including regulation of the national economy.

On May 17, 1917, Congress imposed Selective Service, and the United States set out to build an army of a million men. This national Army was to be trained in 16 huge cantonments, each as large as a good-sized city, complete with railroad tracks and terminals, sewers, waterworks, streets, roads, and housing for 22,000 men. First, however, it was necessary to train the officers who would train the men; and for this job the Army built 12 officer training camps at existing military posts. All of this construction went on at such a pace that the 12 officer training camps and 9 of the 16 cantonments were completed by June 14, 1917-just 30 days after the program was started. ${ }^{1}$

A drastic industrial expansion paralleled the military mobilization. Steel mills were expanded. The capacity of portland cement mills was increased to meet the spiraling demand triggered by an immense construction program. Brand new shipyards were built in eastern ports to build steel and concrete ships to replace the dozens sunk each month by German U-boats; and at Sparrows Point, Maryland, Bethlehem Steel built a city to house its shipyard workers, complete with sewerage, water, and streets.

\section{Breakdown of a Lopsided Transportation System}

The railroads were as unprepared for war as the rest of the country-perhaps more so. For a decade they had been under effective Government regulation, and to preserve competition they had been prohibited from pooling freight or from merging parallel competing lines, even where such mergers would have 
resulted in more efficient systems. The years 1913 and 1914 were a period of sluggish business activity during which the earnings of the railroads had been low and their dividends small. They had had difficulty borrowing money for equipment and improvement of terminals, and some authorities estimated that the American railroads as a whole were 5,000 locomotives short of the number needed to handle traffic in normal times, especially during the fall harvest.

At the low point of the 1914 recession, the railroads had about 400,000 idle cars. In 1915 traffic began to pick up under the stimulation of war orders from the Allies, and by September 1916, cars were beginning to be scarce. When the United States entered the war, there was a nationwide shortage of about 148,000 cars. $^{2}$

Foreseeing trouble ahead, the railway executives met in Washington on April 11, 1917, and "voluntarily agreed to merge their 'individual and competitive activities to produce a maximum of national transportation efficiency.'" 3 They created the Railroads' War Board, a committee of five top executives, to coordinate the operations of the mainline railroads and draw up rules for conservation of motive power, joint use of terminals, and the use of embargoes against shipments to areas already choked with loaded cars. The board eliminated unnecessary or competing passenger trains and luxury services. They organized an educational campaign among shippers to promote better utilization of cars* and quicker loading and unloading. By September 1917, these efforts had reduced the car shortage to about $34,000 \mathrm{cars}$, and the railroads had moved 16 percent more freight than in the corresponding period of 1916, which itself had been a record year.

Despite the efforts of the Railroads' War Board, the transportation picture became darker as the fall harvest of 1917 approached, and creeping paralysis began to spread over the railroad system. Coastal ships that normally carried coal from Chesapeake Bay ports to New England were diverted to transAtlantic service, throwing an extra load on the rails. Ancient locomotives that had been continued in service far beyond their normal lifespan began to break down. Traditionally underpaid track labor left the railroads for the warplants, and track maintenance declined to a dangerous level. However, the major bottlenecks appeared at the terminals, which for dense traffic lines, fixed the ultimate limit of the traffic that could be handled. In the words of one executive, "Its terminals are the heart of a transportation system. If the terminals are inadequate to handle the traffic currently, then congestion follows, traffic is set

* It was estimated that in 1916 an average carload of lessthan-carload package freight was only 7 tons, whereas the capacity of a properly loaded car was several times that amount. ${ }^{4}$

The importance of streets and highways in shipping goods was demonstrated during the war as increasing numbers of trucks carried commercial or military supplies. Below, army trucks wait for a load of tires.

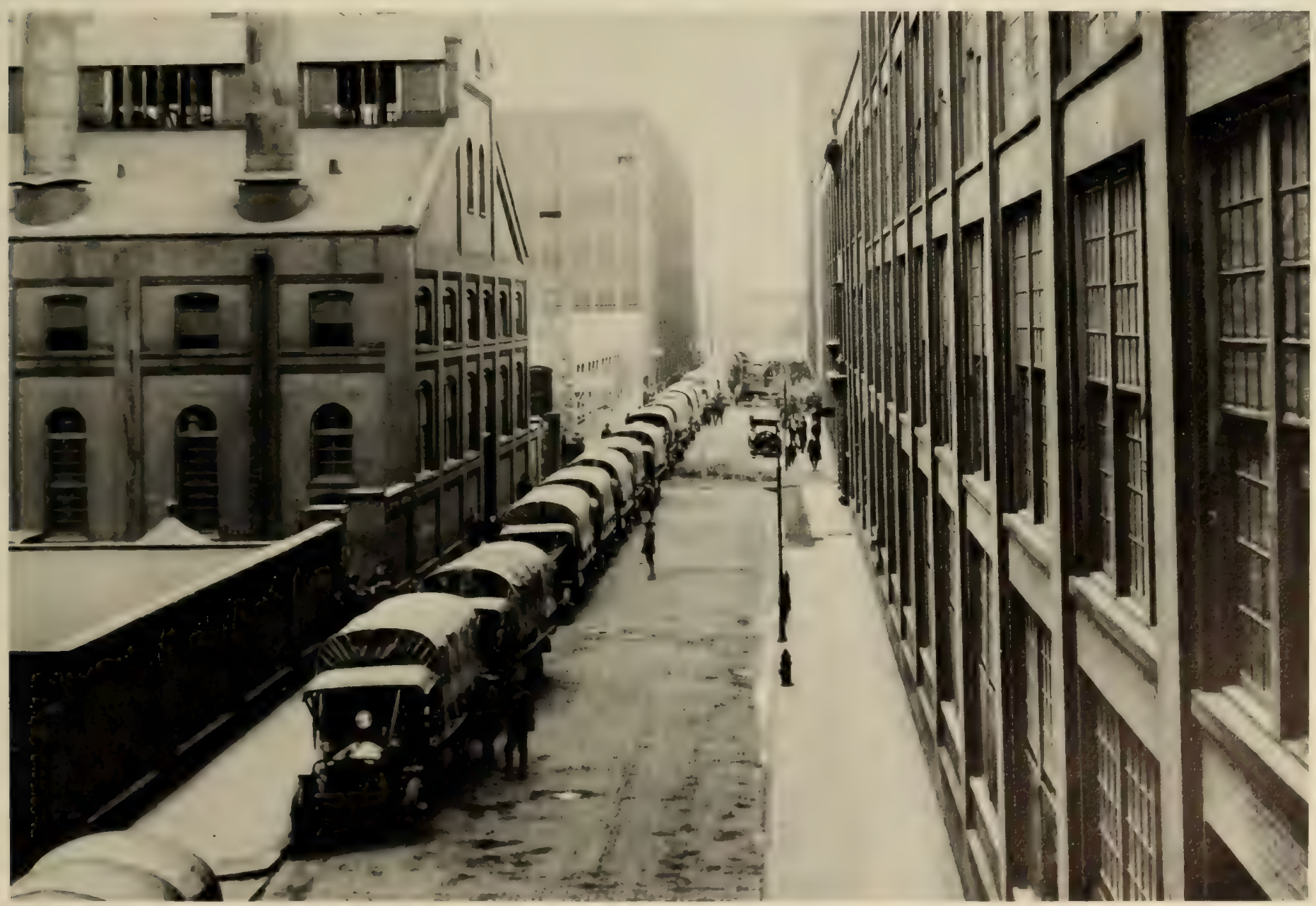




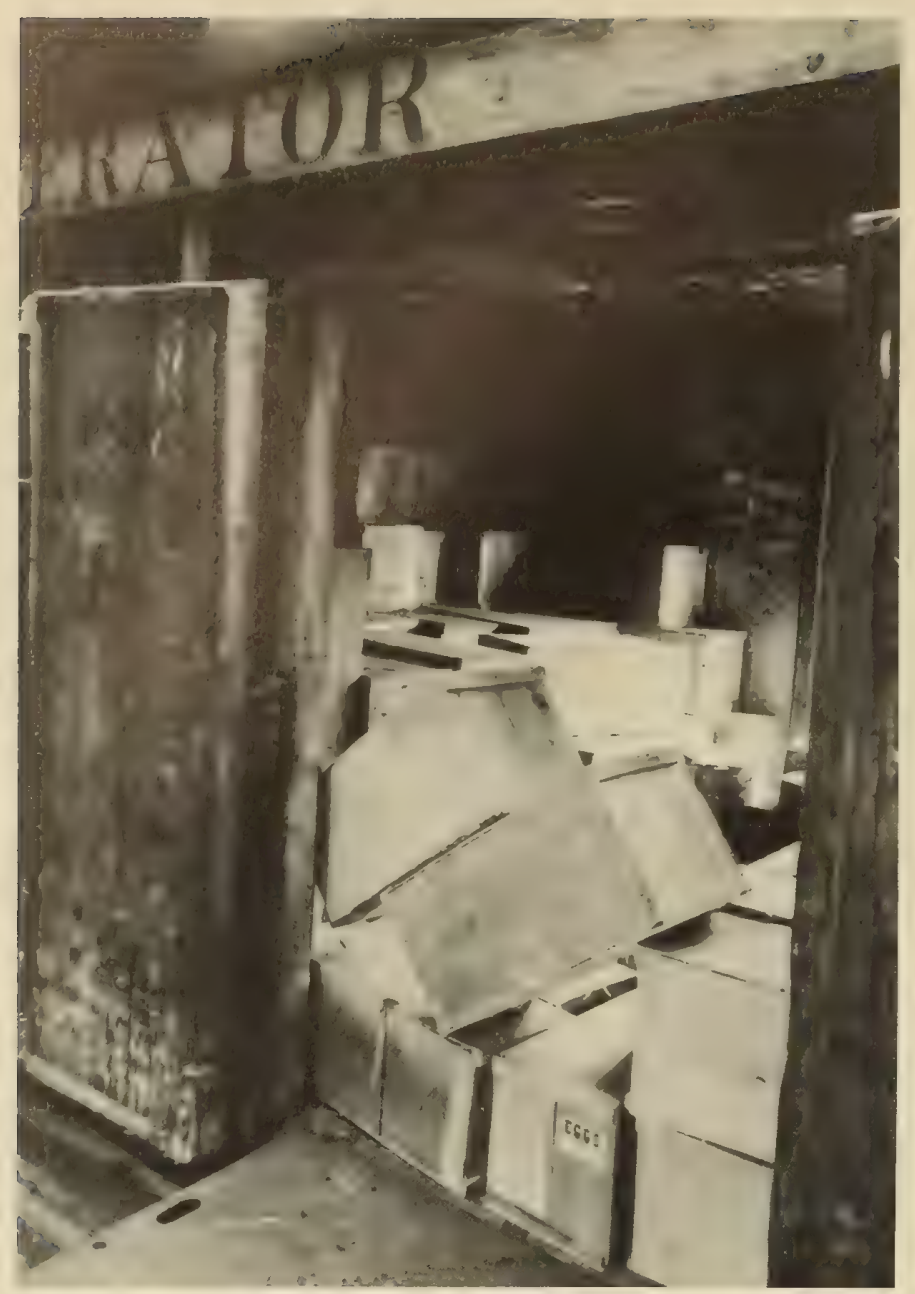

The poor loading of railroad cars added to the general inability of the railroad system to handle all the transportation needs of the war years.

off between terminals, the arteries become clogged, and the system fails to perform its functions properly." 5

The terminal tieups came about from a variety of causes. Due to shortage of ships, export freight accumulated in the North Atlantic terminals. Contractors for cantonments and shipyards ordered materials forwarded far in advance of their ability to receive and unload them. (At one time over 5,000 carloads of wooden piling were tied up in the $\mathrm{Hog}$ Island shipyard waiting to be unloaded.) Feverish demand for materials to keep industry going led manufacturers to purchase raw materials from unusual markets in excessive quantities, with the result that arrivals were badly bunched and unloading was slow and difficult.

In many terminals antiquated business procedures were a principal cause of congestion. Older cities such as New York had an inadequate number of team tracks where freight could be unloaded directly from the cars into drays and trucks. Most freight consigned to lower Manhattan, even in carload lots, was unloaded at freight depots and stored there until picked up by the consignee, who was notified by mail of the shipment's arrival. Due to congestion in the mails, the notice might take 3 days to reach the consignee who then had 48 hours in which to pick up the goods.
Indescribable traffic congestion prevailed around the freight houses. Some trucks stood in line for hours or even days to pick up a few boxes of freight. One count at a Manhattan depot showed 100 drays standing in line at 7 a.m. waiting for loads. Unloading from the freight cars was often haphazard, so that a truck driver might have difficulty finding his consignment and then even more trouble getting it to the loading dock.

With freight piling up in the stations, the railroads set off incoming cars in the freight yards, and when these also filled up, on any available empty siding at small towns approaching the city. As these, too, became filled, the congestion spread outward as much as 30 or, in extreme cases, 50 miles from the city. Eventually, the railroads were forced to embargo further shipments to that city until some of the congestion cleared up.

Toward the end of the war the railroads, then under Government operation, cleared up much of the terminal congestion by instituting "store-door delivery." Under this system, cities were divided into zones. Freight consigned to addresses in these zones was unloaded from the cars into specified areas on the loading docks, where it was picked up by registered trucks and delivered direct to the consignee without prior notice. If the consignee was not ready to accept the shipment, it was taken immediately to a public warehouse and stored at the consignee's expense. By eliminating the free storage at the depot, this system broke the bottleneck in a few weeks. Store-door delivery also reduced the enormously inefficient waste of trucks and labor waiting for loads at the freight stations.

Unable to get long-haul freight into the cities, the railroads refused to accept short-haul shipments such as milk and produce from the surrounding country, and the food distribution system began to suffer. A few farmers who owned trucks began to drive them into the city with loads of vegetables instead of to the nearest railroad station. At the other end, wholesalers and even retailers began to send their own trucks out into the country for loads of produce. The cost per mile was more than for rail shipment, but the delay was less and terminal costs were eliminated at both ends, so they at least broke even on the business.

\section{Birth of the Trucking Industry}

Practically every large business in the cities had a few trucks for drayage and deliveries, and by 1917 most of these were power driven.* When the city terminals began to choke up, some consignees had their shipments sent to outlying towns and sent their trucks there to receive them, at the same time carrying outgoing shipments. Soon, hundreds of trucks were being used in this way, and the radius of operation was constantly increasing.

Akron, Ohio, tied up with a package freight embargo, broke the embargo by truck hauls to 14 outlying shipping points within a radius of 20 miles. A New York drug firm started making weekly deliveries to Boston in its own trucks. Cleveland manu-

* In 1917 there were 391,000 motor trucks registered in the United States, most of them used in the cities. 
facturers bought motor trucks and started a motor freight service to bring castings from foundries 20 to 30 miles away. An Akron tire manufacturer found it feasible to deliver to Detroit and Boston by truck, and a new household moving business began operating between Chicago and Milwaukee. Some shippers used trucks for the first part of a haul that would have required two rail carriers, avoiding the transfer between railroads. In June 1917, nine new trucks were driven from Hartford, Wisconsin, to Baltimore1,200 miles-under their own power because the manufacturer couldn't get railroad cars; and in Connecticut, when the railroads embargoed certain classes of freight, truck transport made it possible to keep factories open. ${ }^{6}$

By August 1917, car shortages and embargoes had diverted so much traffic to trucks that the highways began to show signs of distress. Pennsylvania, New York, New Jersey, and New England had fairly good networks of bituminous macadam roads; but these were of light construction, seldom more than 7 or 8 inches thick, and also were in many places only 14 to 16 feet wide. At this time all trucks ran on solid rubber tires, and since there were no laws against overloading, many were loaded to the full capacity of their engines. Within a few months maintenance costs began to soar, as the thin road crusts wore out and broke through. The States and counties were unable to get railroad cars to haul stone and bituminous material, and they increased over-the-road hauling with their own trucks, throwing a further load on the highways. The Connecticut Legislature made an emergency appropriation of $\$ 6.5$ million just to keep the main highways passable for traffic. Massachusetts spent $\$ 2$ million on maintenance of State highways alone and $\$ 1.25$ million for resurfacing and strengthening trunk routes. Other States were faced with similar huge expenditures at a time of rapidly escalating costs and labor shortage.

\section{The Plight of the Highway Contractors}

The large highway bond issues of 1915 and 1916 , plus the prospect of sizable road expenditures under the 1916 Federal Aid Road Act, led many experienced and inexperienced contractors into the road business. With the outbreak of war, they immediately began to encounter difficulties in getting materials, especially steel, and in retaining labor on the job. Within a few months material costs advanced 20 to 30 percent and wages of common labor went up to $\$ 2.50$ and even $\$ 3.00$ per day. Railroad car shortages made deliveries of stone and asphalt uncertain. Large numbers of contractors were forced out of business, and others, having completed their contracts, refused to bid for new work.

The virtual collapse of the highway construction industry created a desperate situation for States and counties struggling to keep the roads open in the face of ever-increasing numbers of heavy trucks and devastating losses of personnel to war industry and the Army. What made the job particularly heartbreaking was the sentiment openly expressed in some seg ments of the war effort hierarchy that roadbuilding was nonessential work that should be discontinued for the duration of the emergency.

As the summer of 1917 advanced, a coal famine began to develop in the industrial eastern States because of the shortage of railway cars. Production of munitions was beginning to be affected when the Priority Board of the Council of National Defense issued Priority Order No. 2, to be effective November 1, 1917, prohibiting the use of open top cars other than flat cars for shipping supplies, other than coal, for construction, maintenance and repair of public and private highways, streets, and sidewalks or for theaters and other places of amusement. ${ }^{7}$ This peremptory order, issued without public hearings or other advance warning, struck the States "like a bolt from the blue," at a particularly bad time. It caught them with many miles of new road graded but not surfaced with winter approaching. Despite the fact that trucking had already released thousands of cars for war purposes and the roads in the vicinity of cantonments and ports of embarkation were being pounded to pieces by truck traffic, the Priority Board refused to recede from its position, and road work

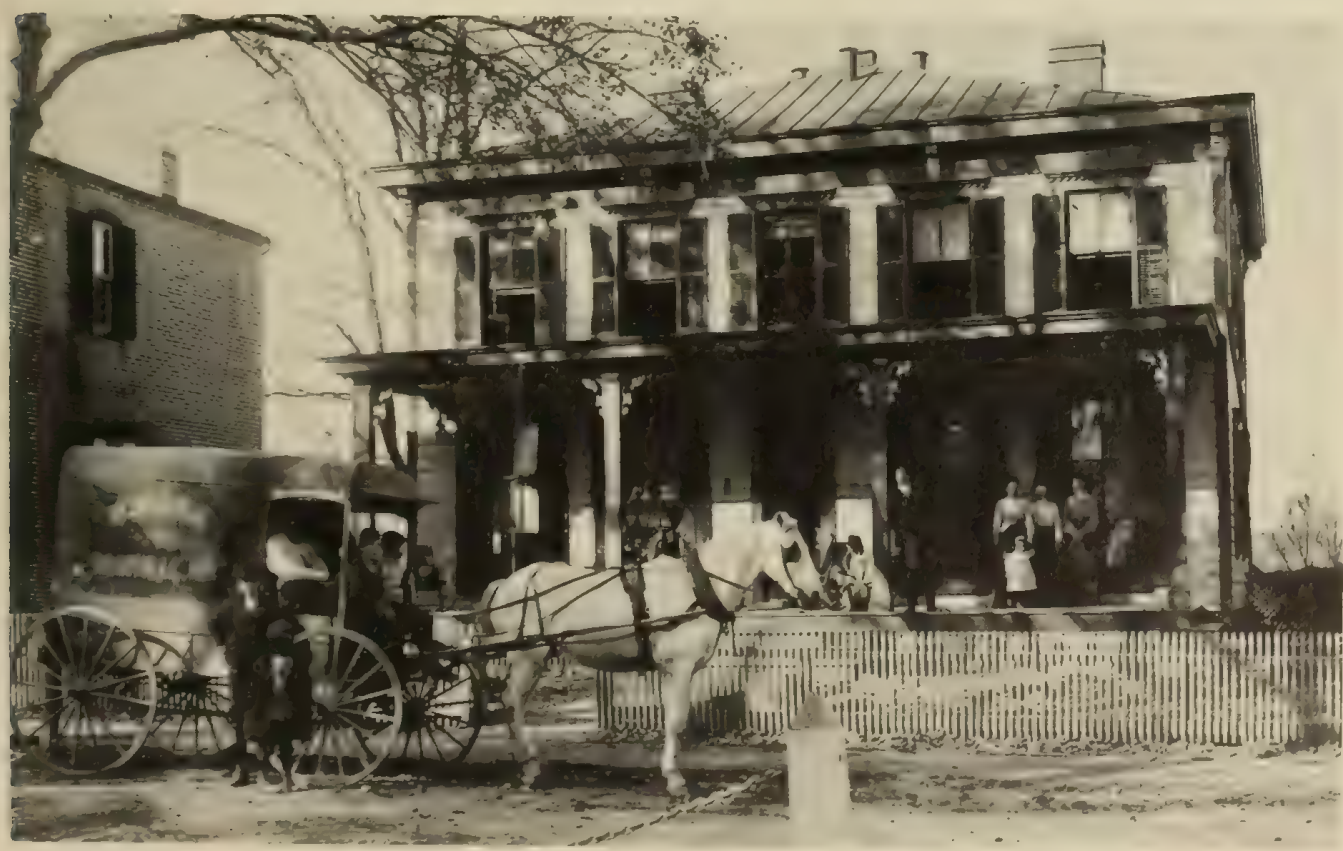

At the turn of the 20th century, the Hicks Company in Rockville, Md., was making local deliveries of dry goods. This was a forerunner of the scene on $a$ much larger scale during World War I when local deliveries for all kinds of goods became $a$ demand with the advent of motorized delivery trucks. 


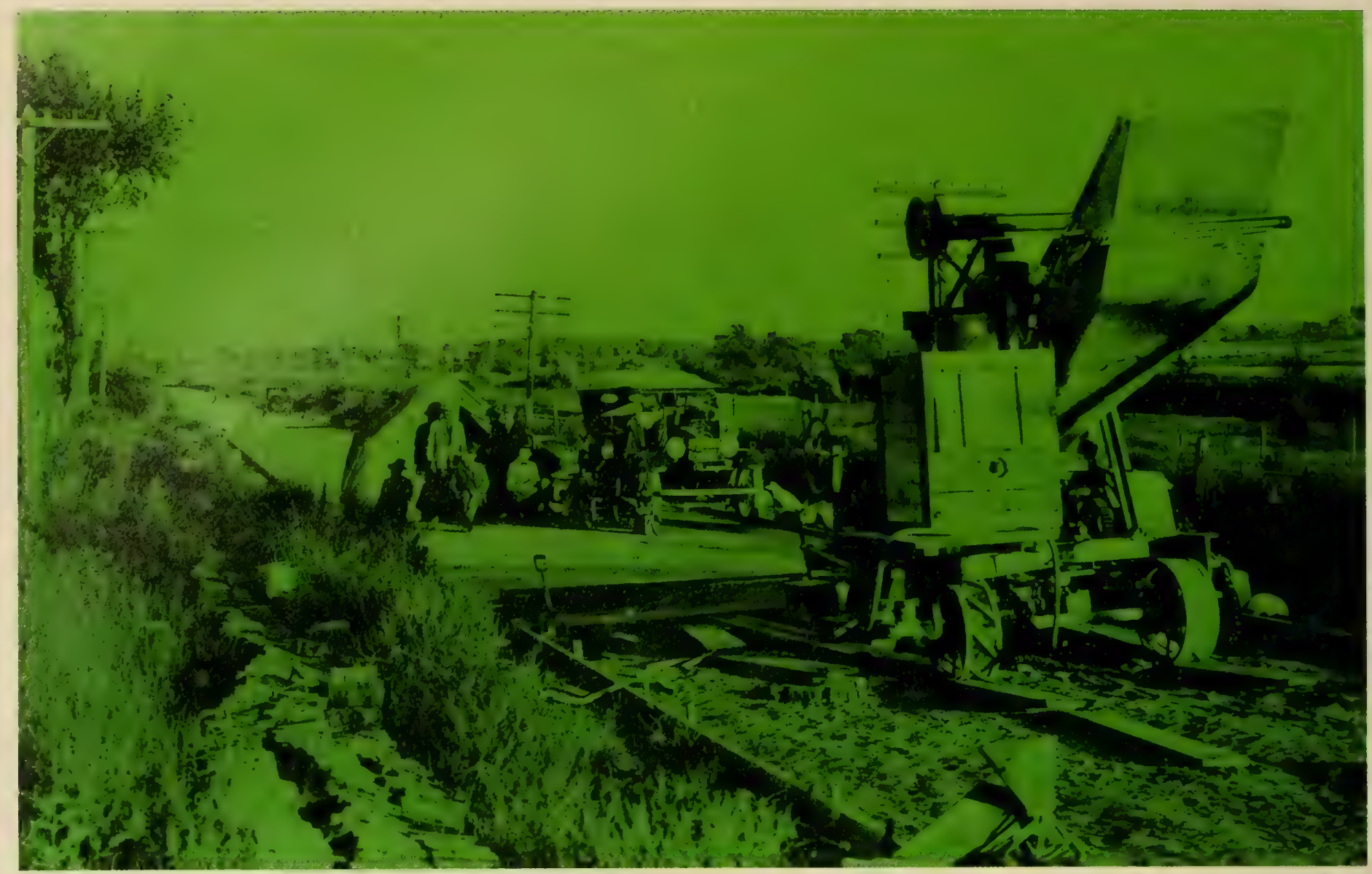

State highway officials on inspection tour of 1917 construction project

in Michigan. Such projects were soon forced to stop when involvement in the war caused shortage of materials and manpower.

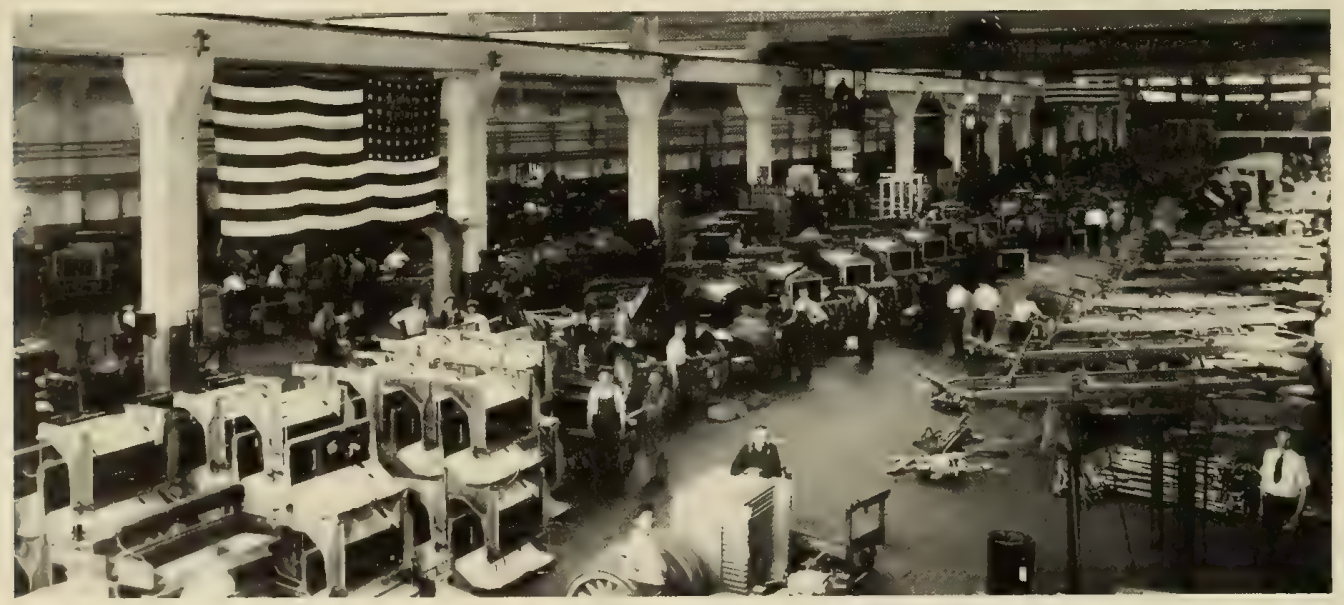

Truck assembily increased to meet the war needs.

and road materials production that was dependent on rail transportation ground to a stop.

As a direct result of the widespread protests over Priority Order No. 2, the National Council set up a Highway Transport Committee in Washington to represent the highway and highway transport interests, and appointed Roy D. Chapin, President of the Hudson Motor Company, as chairman. This Committee began its work November 29, 1917.

\section{The National Military Truck Routes}

The experience of the Allies had shown that enormous numbers of trucks would be needed in France to support military operations. The War Production Board decided to standardize truck designs to simplify parts supply and increase production, and they induced the motor industry to design two vehicles on which to concentrate production for the duration of the war. Class A trucks were to have a capacity of 3 tons and a speed of 14 miles per hour, while Class B trucks would carry 5 tons at 12 miles per hour. The Army placed an order for 30,000 of these trucks in September 1917.

Several months before the Highway Transport Committee was organized, Chapin advanced the idea that trucks destined for France could be driven from 


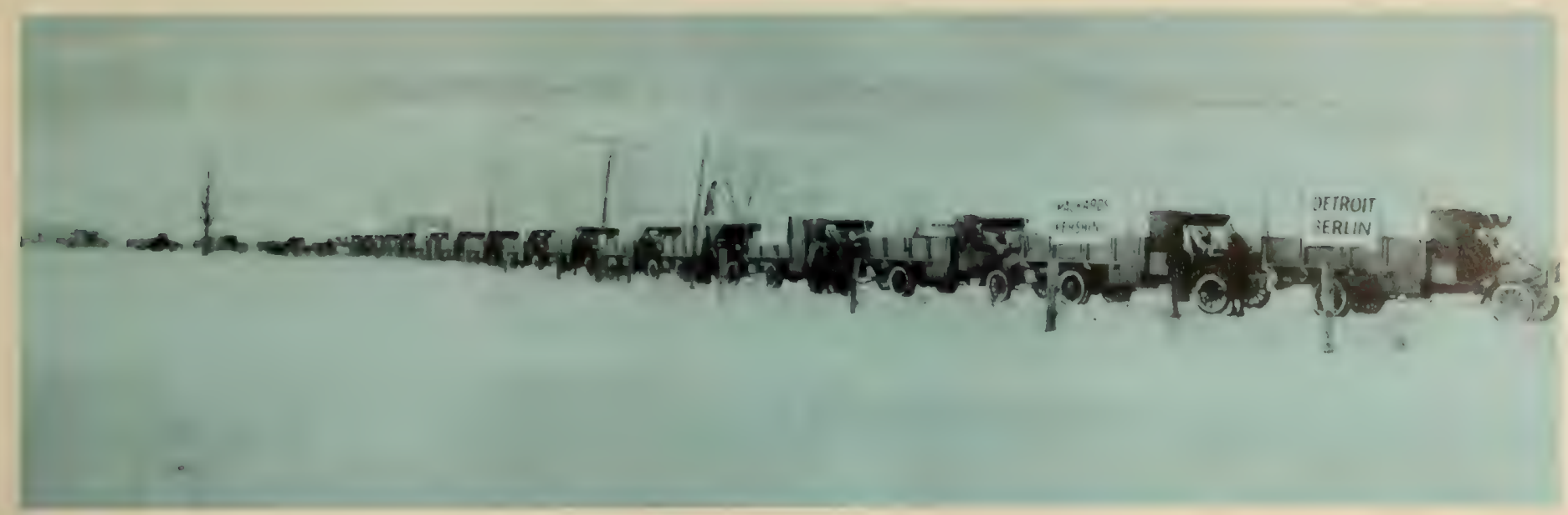

A caravan of trucks from Detroit headed for eastern seaports and the war.

the factories to the ports of embarkation, and he obtained the Army's approval for an experimental convoy. On November 22, 1917, a trail-blazing party consisting of representatives of the Ohio Highway Department, the Army, the Lincoln Highway Association, and the OPRRE left Toledo enroute to the East Coast. The route they selected crossed Ohio via Toledo and Akron to East Palestine, where the Pennsylvania Highway Department picked it up, continuing on to Pittsburgh and across the Allegheny Mountains to Harrisburg, Lancaster, and Philadelphia. This became the main military truck route. Later, other truck routes were designated by Ohio, West Virginia, Pennsylvania, and Maryland over the Old National Road, and by Ohio, Pennsylvania, and New York via Cleveland, Erie, Buffalo, and Albany to New York City.

In December the Quartermaster General announced that, in order to relieve the squeeze on railroad cars, the trucks would be driven overland to the Atlantic Coast under their own power. ${ }^{8}$ The first Army truck convoy left Toledo early in December 1917, at the beginning of one of the most severe winters in recent U.S. history. Three weeks later, on January 3, 1918, 29 of the 30 vehicles that began the trip rolled into Baltimore. ${ }^{9}$ This grueling trip was testimony to the durability of the war-model trucks and the endurance of the drivers, but most of all, to the superb maintenance efforts of the Pennsylvania Highway Department, which, as a result of careful preplanning, had kept the road open over the Alleghenies in the face of blizzards that left drifts 3 to 6 feet deep. In some places the crews worked around the clock to keep the road open. Teams and drags broke a track through the drifts, followed by horsedrawn road machines and homemade plows mounted on trucks. ${ }^{10}$ Altogether, 7 trucks and plows, 22 road machines, 20 drags, 105 teams, 3 tractors, and 200 men were thrown into this massive and successful maintenance effort. ${ }^{11}$

Military vehicles were not the only ones to use the truck roads. Because they were kept free of snow throughout the winter, they attracted large numbers of private trucks and automobiles. In Ohio this traffic was particularly heavy :

With the congested condition of the railroads and their inability to promptly handle supplies that were needed in almost every community, it became necessary after opening up main arteries for travel to open up the lateral

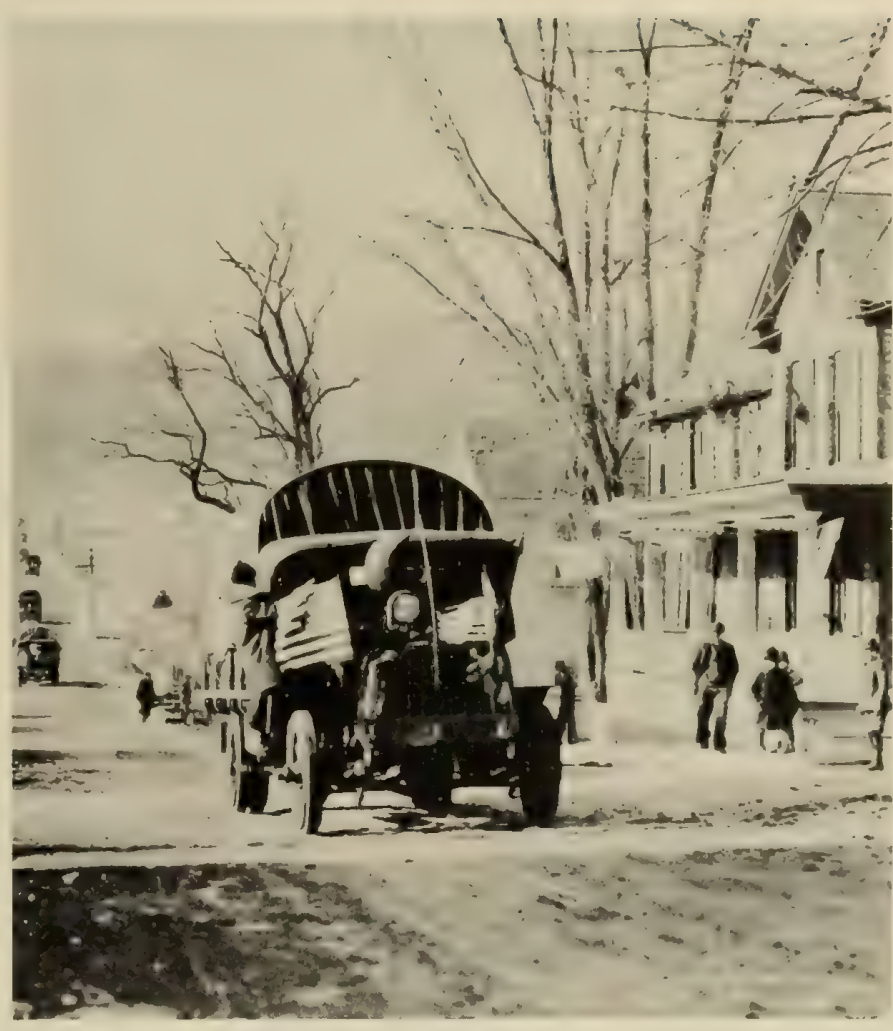

McConnellsburg, Pa., and other similar towns and villages vitnessed the industrial might of the Nation as caravans of trucks rolled through on the way "over there."

roads in order to reach the possible outlet to and from markets and villages. The amount of traffic these highways must sustain is apparent. The truck traffic was practically constant with all additional vehicles conceivable using many of the roads ... Not only did truck and automobile traffic greatly increase, but burdens were placed upon them clearly in excess of what any ordinary road would be expected to carry. This great increase in traffic was, of necessity, confined largely to such roads as had been prepared by the removal of snow drifts, etc. ${ }^{12}$

In the months following the first convoy, the Army sent the remaining 30,000 trucks east via the truck routes, each loaded with 3 tons or more of spare parts and munitions. This operation released 17,250 railroad cars for other work, but the cost per ton-mile was high, even without considering the efforts of the States and counties to keep the roads open. From a historical viewpoint, the main accomplishment of the 
Snowplows played an important role in keeping the military truck routes open.

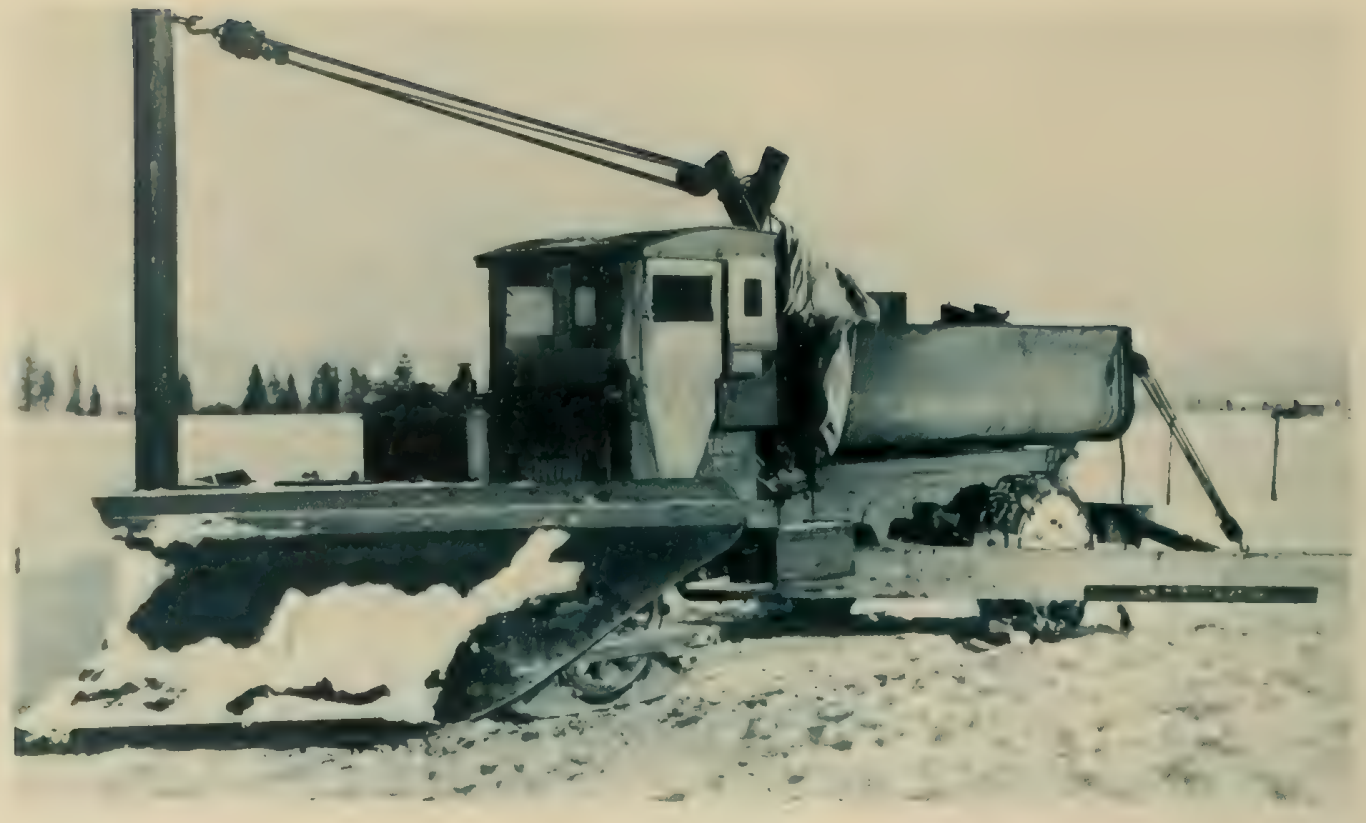

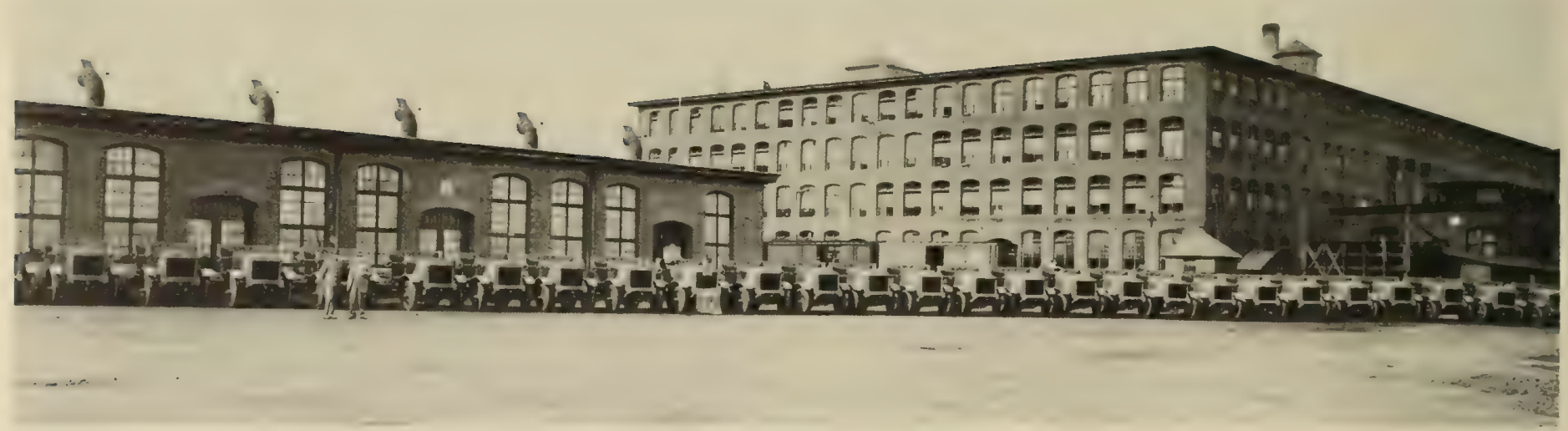

Trucks were steadily being built for war duty, but highway officials

were hard pressed to get funds or materials to maintain the roads damaged by the trucks.

truck routes was to demonstrate that it was possible to keep long stretches of highway open to traffic through a severe winter and that dependable longdistance interstate travel on the highways was desirable and even necessary.

\section{The Highway Departments Call for a National War Policy for Roads}

When the annual meeting of the American Association of State Highway Officials (AASHO) opened at Richmond, Virginia, December 4, 1917, the problem uppermost in the minds of the delegates was how to carry on and keep the roads open in the face of what many of them perceived to be a hostile policy by the Government toward highway transportation. Priority Order No. 2 was only the latest action hampering their efforts. The War Industries Board had assumed control over all supplies of cement, brick, steel, stone, and gravel and was giving the highest priorities for these materials to defense installations and the railroads. The Fuel Administration controlled the supply of fuel oil, and to make more fuel available, it restricted the production of asphalt. No bond issues exceeding $\$ 100,000$ could be made without the assent of the Capital Issues Committee, a war organi- zation that was particularly hostile to highways. Clearing a project through these war agencies was a matter of weeks and even months since there was very little cooperation between them.

To make things easier for the Government, AASHO called upon all the States to designate the essential war roads and estimate the amounts of materials and rail transportation that would be needed for their construction and maintenance during the coming year. These programs would then clear through the Executive Committee of AASHO and in due course be presented to the Priority Board and to the Highway Transport Committee of the National Council, of which Director Page of the OPRRE was a member. ${ }^{13}$ The delegates also passed a resolution,

That the American Association of State Highway Officials request the United States Government to formulate and promulgate, as soon as possible, a definite policy for road and street construction and maintenance, and that it is requested that said policy contain a statement that freight cars shall be furnished next spring for the transportation of the necessary materials for the construction and maintenance of streets and roads of economic or military value. ${ }^{14}$

There was a note of urgency in this resolution, for the State officials knew that the spring breakup was 
only a few months away. Throughout the winter the roads, once cleared of snow, could carry heavy trucks because they were frozen solid, but every highway engineer and maintenance superintendent knew what could be expected after the spring thaw began.

The Department of Agriculture immediately endorsed the AASHO plan and asked all States to submit their priority programs as soon as possible.

\section{Government Seizure of the Railroads}

To avert complete paralysis, the Government seized all the mainline steam railroads on December 26, 1917, and set up a Federal Railroad Administration to operate them. This was not so much a reflection on the work of the Railroads' War Board as an admission that only a Government agency could suspend the operation of the antitrust laws and the onerous regulations of the Interstate Commerce Commission, designed to foster competition, and force the various war agencies to resolve their conflicting demands for transportation. "The government can ignore the antitrust laws, force the various war-supply departments to accept what transportation is given them, eliminate the problems of credit and capital for future construction, and settle beyond dispute the demands of labor." 15

The Railroad Administration organized the seized lines into three huge systems-the Eastern Railroads, Southern Railroads, and Western Railroads, pooling equipment and terminals. Since the Government now had direct control over all railroad cars, the Priority Board suspended the operation of Priority Order No. 2, and on February 6, 1918, Director General of Railroads McAdoo assured AASHO that "The United
States Railroad Administration will cooperate with the Secretary of Agriculture by transporting materials for construction of national highways designated by it as a military or economic necessity, when the equipment is available and not needed to move supplies for the army, navy, shipping board, or other governmental activities." 16

\section{The Quagmires of Spring}

In 1917 very few States had load limit laws to protect their highways. Michigan had just passed a law requiring reduced loads during the spring thaw. A 1913 Pennsylvania law permitted gross vehicle loads of 24,000 pounds, not to exceed 750 pounds per inch width of tire, and a few eastern States had similar laws. But these laws were not enforced strictly and apparently not at all against military vehicles. Prophetically, the Engineering NewsRecord warned of the coming debacle and urged engineering societies and the press to prepare the public for it: "The universal cry for a more complete use of the roads in order to relieve the railroads of their abnormal burdens will probably be utilized as an excuse to evade or even violate intentionally not only statute law [on vehicle loading], but the law of reason." 17

With the arrival of spring, the predicted destruction occurred on an unprecedented scale. In Delaware a single truck with a gross load of 11 tons broke up a light macadam road from end to end in one trip. In New York bituminous macadam roads that had given good service for 5 to 10 years broke up and became impassable under truck traffic averaging only 30 heavy vehicles per day. Roads that cost $\$ 11,000$

This Fairfax County, Va., road, macadam surfaced with bituminous materials, shows the effect of truck traffic in 1918.

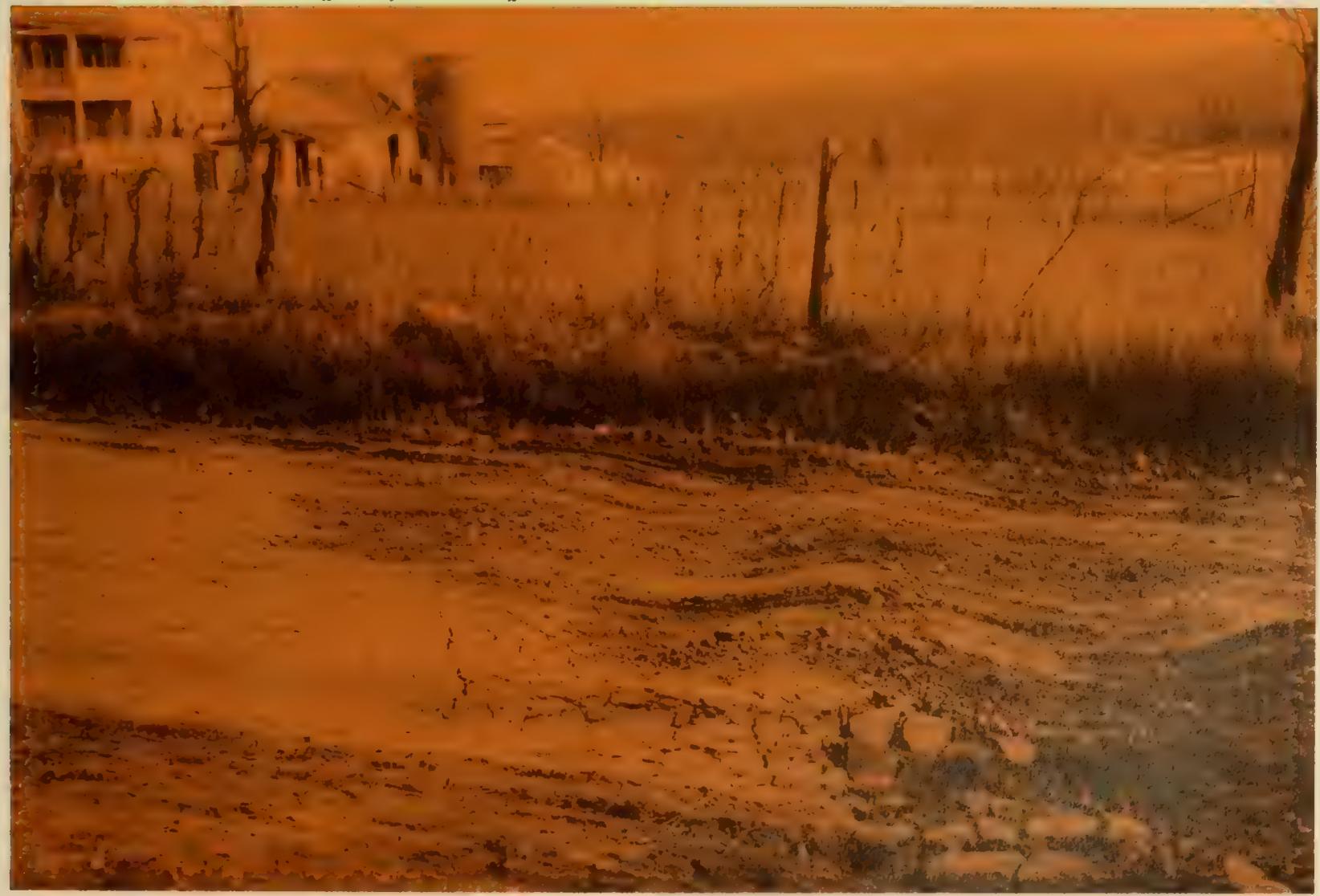


per mile to build in 1912 were destroyed so completely that the State estimated it would cost $\$ 32,000$ per mile to repair them at inflated 1918 costs. In New Jersey the "heavy truck would break through the crust, and immediately upon being extricated would be followed by others, until there was formed a veritable quagmire." 18

Supposedly higher types of pavement, such as cement concrete and brick on concrete bases, also failed, principally because the extremely thin 4-inch and 5-inch slabs failed to bridge the soft spots in the subgrade. However, in Wayne County, Michigan, which for a number of years had been using progressively thicker concrete pavements, 8- and 9-inch slabs stood up remarkably well under some of the heaviest trucking in the Nation.

In normal times the States and counties would have closed their roads to save them from destruction, but in time of war this was unthinkable. It was also impracticable to force the truckers to lighten their loads enough to provide any real relief. The highway departments handled the emergency as best they could. Those that were able to get railroad cars hauled in immense quantities of stone and gravel. Others, such as Massachusetts, used nearby supplies of poor quality gravel and soft stone rather than wait for railroad cars to haul in better materials:

While the roads would not wear as long, we felt that in these times as this work could be done without closing them so they could still be used by the traffic, and as four carloads of bitumen would be sufficient to construct a mile of road which would require 40 carloads of cement or from 70 to 80 carloads of imported stone or gravel, that this would save rail shipments and thereby help the general traffic situation. ${ }^{19}$

In this emergency the States, despite the AASHO priority road program, were still having difficulties getting railroad cars, asphalt and road materials for maintenance. To get things moving faster, the Secretary of Agriculture, at Director Page's suggestion, invited the Army, the War Production Board, the Fuel Administration, the Railroad Administration, and the Capital Issues Committee to name representatives to meet with Page in a council to coordinate the Government's highway activities. At its first meeting June 8, 1918, this United States Highway Council elected Mr. Page as chairman, and thereafter until it dissolved on November 13, 1918, the Council passed on over 7,300 applications for highway financing, railway cars or materials. By acting as a clearinghouse for the industry, the Council drastically shortened the time required for project approvals, approving 95 percent of the asphalt applied for, 50 percent of the crushed stone, and 45 percent of the open top cars, but only 12 percent of the steel and 15 percent of the highway financing. ${ }^{20}$

With so much destruction occurring in such a short time, primarily as a result of national defense needs, it was inevitable that there should be appeals to Congress to pay for the damage. Representative John G. Cooper of Ohio introduced a bill "to aid the States in the maintenance, repair, and reconstruction of roads subjected to extraordinary wear by reason of the use of such roads by the Government of the United States." This bill never emerged from committee, probably because its essential purpose was accomplished by other legislation.

\section{Amazing Growih of Truck Transportation}

The production of trucks was not greatly restricted during the war, and in fact was encouraged. Throughout 1918 the truck factories turned out about 19,000 units per month, and at the end of 1918 there were about 525,000 nonmilitary trucks of all sizes registered in the United States. This was an increase of 199,000 over 1917.21

In spite of war restrictions on fuel and the generally poor condition of the roads, for-hire trucking thrived in an atmosphere unclouded by Government regulation and surcharged by intense competition. The heavy demand for trucking was not due solely to the failure of the railroads and their embargoes on short-haul package freight. Shippers were becoming aware that for short hauls, trucks could greatly shorten delivery time. This was dramatically illustrated early in the war when a disastrous fire occurred in Salem, Massachusetts. Using trucks to bring tents to shelter the victims, the National Guard was able to complete the trip from Framingham, 42 miles away, in only 3 hours. Due mostly to terminal delays, this shipment would have taken 2 days by rail. ${ }^{22}$

Trucking also saved drayage charges at both ends of the shipment, and these, even in normal times, were often more than the railroad freight charges. Also, shippers soon found that boxing and crating could often be omitted without increasing breakage. Thus, although the cost of truck hauling was 12 to 25 cents per ton-mile, this was no greater than the total doorto-door cost of rail shipment for short haul trips.*

Despite the intense and unregulated competition, a number of reliable motor carriers established regular service between the principal cities. Beginning in November 1917, the Beam Fletcher Corporation operated twenty-two 5-ton White trucks between Philadelphia and New York carrying 400 tons per day. ${ }^{25}$ Early in 1918 the Liberty Highway Company began a motor express business between Toledo and Detroit with daily runs of a 5-ton, four-wheel-drive Walter truck pulling three 5-ton trailers. The running time was $71 / 2$ to 9 hours one way, depending on the weather and the condition of a 12-mile stretch of unsurfaced dirt road on the main route between these cities. (If the road was bad, the driver might have to pull his trailers through the 12-mile gap one at a time.) ${ }^{26}$

In Maryland, the Farmers' Cooperative Association of Harford County obtained a franchise to operate a motor express on the Baltimore-Bel Air Road to haul milk and produce to Baltimore, returning with empty milk cans and package express for the farmers. ${ }^{27}$ And in Alabama the Civic Association of Birmingham averted a coal famine by contracting with the Jenkins Motor Company to haul 200 tons of coal per day direct from the mines to consumers. ${ }^{28}$

\footnotetext{
* In normal times the terminal charges for rail freight were 15 to 45 cents per ton, depending on the commodity and the terminal. Once loaded on cars, mainline railroads could haul freight for only $2 \frac{1}{2}$ mills per ton-mile, and even lowtraffic branch lines could haul for 2 or 3 cents per ton-mile. In 1916, the Pennsylvania Railroad's average system operating cost was 4.3 mills per ton-mile, including terminal charges. ${ }^{23}$ Railroad men estimated that an average railroad car traveled about 25 miles per day, spending 12 hours in terminals for every hour of movement between terminals. ${ }^{24}$
} 


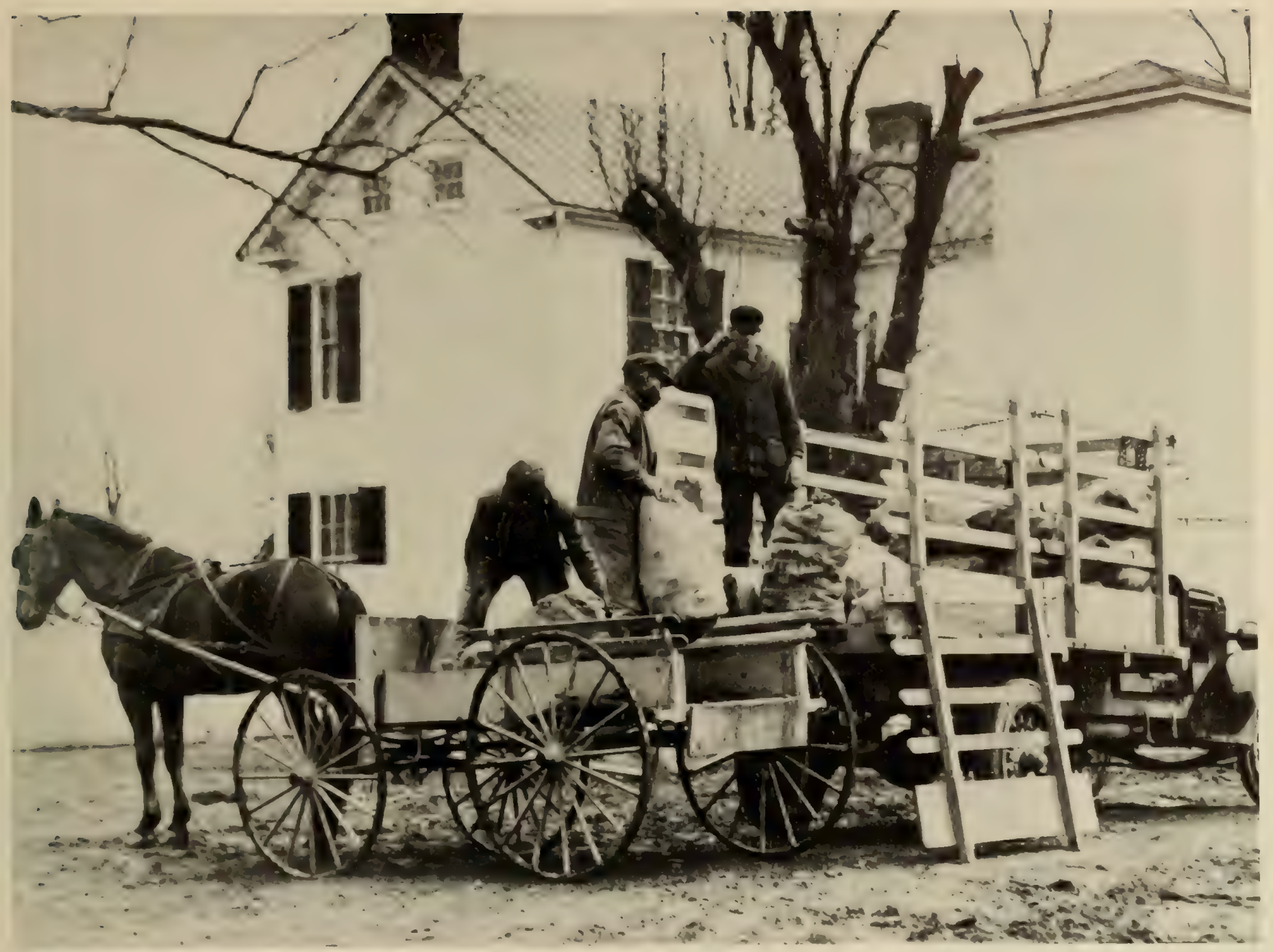

Trucks also played an important role in civilian life by making short haul runs faster and cheaper than could the overburdened trains.

Even greater tonnages, in the aggregate, were hauled by business and industry in company-owned vehicles. In 1917 and 1918, the Goodyear Tire and Rubber Company ran its trucks on schedule from Akron to Chicago and even Boston, carrying relief drivers and running day and night. By the spring of 1918, the White Motor Company of Cleveland was sending most of its new trucks to the East under their own power over the "Liberty Highway," a route through central New York which the White Company drivers had pioneered to avoid the massive breakups on the Army truck routes. After 1 year of truck deliveries, the Otis Elevator Company found that it had saved $\$ 100,000$ in the cost of boxing and crating for truck shipments as compared to rail shipment, as well as a great deal of paper work. Where 6 days to 6 weeks had been required for rail delivery, the company trucks needed only 24 hours and delivered the goods in better condition. Because of the shorter delivery time, less capital was tied up in goods in transit. ${ }^{28}$

These and similar experiences by hundreds of other shippers permanently changed the shipping habits of American industry. In a matter of a few months, the railroads lost millions of tons of freight business by default-business they were destined never to recover.

\section{Fresh Vegetables by Mail}

The Post Office Department began rural mail delivery by automobile in 1915, and by 1917 a considerable number of the 43,562 rural routes were motorized, but of these, only 288 emanated from the 50 largest cities.* 30

In July 1916, Congress authorized the Postmaster General to conduct experiments in three or more communities to determine "the most practical means of extending the operations of the parcel post in the direction of promoting the marketing of farm products and furthering direct transactions between producers and consumers." 33

By the time the Government established the first experimental routes, war had been declared, and the pinch on railroad cars for short-haul shipments was already being felt. Although the service was not cheap $(1 / 2$ cent per pound for hauls averaging 50

* The dispatch of rural mail by automobile began July 1 , 1915, at Quarryville, Pennsylvania. The rehicles were required to be of at least 80 cubic feet capacity and able to carry 800 pounds of mail. ${ }^{31}$ In 1915 carriers serving motor vehicle routes that were at least 50 miles long, 6 days per week, received $\$ 1,800$ per year. Carriers serving horsedrawn vehicle routes at least 24 miles long received $\$ 1,200$ per year. All carriers were required to furnish their own transportation. ${ }^{22}$ 
miles), it was enthusiastically received by farmers along the routes and widely praised in the press. Herbert Hoover, the Federal Food Administrator, hailed the service as a means for saving food, 50 percent of which was rotting in the field for lack of transportation. Others pointed out that rural express would relieve draft animals from transportation duty, releasing land devoted to growing animal fodder for the raising of human food. Still others envisioned public food markets in the cities, supplied direct from the fields by parcel post. And, of course, the service would enable farmers to devote more time to raising food and less time to taking it to market. ${ }^{34}$

The Government established eight routes, mostly in the Washington-Baltimore-Philadelphia area, and operated them with 19 Government-owned 1-ton trucks. The Department kept precise records of all direct and indirect expenses, including Department overhead and depreciation on the vehicles. For the 6 months ending May 31, 1918, the Postmaster General reported to Congress that only one route, between Philadelphia and Atlantic City, had lost money and that the operation as a whole had grossed $\$ 152,217$ in 6 months against total expenses of $\$ 29,100$, for net earnings of $\$ 123,118 .^{35}$

Projecting these enormous profits on a theoretical nationwide rural express network of 10,000 miles, the Postmaster General estimated gross revenues of $\$ 80$ million per year, with a surplus of about $\$ 40$ million per year above all operating and Departmental expenses. This surplus, he recommended, might well be spent to improve the roads of the network to a high standard to reduce vehicle operating costs and ensure reliable daily service. Such roads should be of concrete or brick, at least 16 feet wide and 9 inches thick, and would cost about $\$ 20,000$ per mile, or $\$ 200$ million for the network. ${ }^{36}$

Earlier in the $2 d$ session of the 65th Congress, Senator Claude A. Swanson of Virginia had introduced a bill that would permit the Postmaster General to establish a Federal network of motor express routes and to devote one-half of the gross revenues from these routes to improve them for motor truck operation. Despite the statistical support of the Postmaster General's optimistic report, this bill failed in committee. Congress, instead, included an item of $\$ 300,000$ in the Post Office appropriation for fiscal year 1919 to be used by the Postmaster General for experiments in motor truck delivery in the vicinity of large cities "... to promote the conservation of food products and to facilitate the collection and delivery thereof from producer to consumer, and the delivery of articles necessary in the production of such food products." ${ }^{37}$

This was July 1918. By the time the Postmaster General came back to Congress with his next report, the war had ended and conditions had radically changed. Private enterprises such as the Farmers' Cooperative Association of Harford County had moved into the transportation vacuum the Government hoped to fill and were doing the job for much less than the fourth class mail rate. The motor route service did not materially increase new postal business, and the service was made to show a profit only by diverting fourth class mail to the Department's trucks that would otherwise have gone by train. ${ }^{38}$

\section{Post Roads Versus Through Roads}

The first impact of the war on the Office of Public Roads and Rural Engineering was a loss of men, some in key positions, who volunteered for military service.* When the Secretary of War requested engineers to plan and supervise the building of roads for the Army cantonments, Director Page assigned 18 experienced men to this work for periods of a year or more. Page also assigned engineers to map the Army truck routes and channeled most of his laboratory's efforts into war work.

What personnel remained after these losses and assignments were concentrated on the Federal-aid program. Although severely crippled by manpower shortages, the States continued to submit Federal-aid projects for approval throughout the war. By July 1918 , the OPRRE had approved 572 projects, totaling 6,249 miles in length, estimated to cost $\$ 42.28$ million, of which $\$ 16.05$ million was Federal aid. However, only five projects, totaling 17.6 miles, had actually been completed.

The Federal Aid Road Act provided that the Federal funds could be spent only in the construction of "rural post roads," defined as "any public road over which the United States mails now are or may hereafter be transported, excluding every street and road in a place having a population, as shown by the latest available Federal census, of two thousand five hundred or more, except that portion of any such street or road along which the houses average more than two hundred feet apart." The Act also provided that the Secretary of Agriculture and the State highway departments "shall agree upon the roads to be constructed and the character and method of construction."

The Secretary, acting through the OPRRE, at the outset of the program tried to eliminate haphazard roadbuilding by asking each State to submit an overall plan or scheme showing where the State proposed to spend its share of the 5-year Federal appropriation. This wise requirement forced the States that did not already have established highway systems to begin classifying their highways and setting up systems. This kind of planning and the organization and strengthening of the several State highway departments were the principal accomplishments of the first 2 years of the Federal-aid program. ${ }^{39}$

Very early in the program the States began to have difficulty scheduling improvements to their major system roads that would also follow the rural post routes. In keeping with good system planning, the State trunkline roads were laid out along comparatively direct lines between county seats and major cities. The post routes, on the other hand, meandered through the country to enable the carriers to serve the greatest number of patrons with the least travel. The Attorney General held that to prove the post road requirement would "require the submission of evidence to show that the mails are actually carried over the road proposed to be improved or that there is a reasonable prospect that this will be done." 40

* Of 187 male employees on the rolls when war was declared, 52 or 28 percent had entered the military service b5 June 1918. When the war ended, 79 were in the service. 
The OPRRE made as liberal an interpretation as possible and ruled that the direct route could be followed as long as it also substantially followed post routes with gaps of only a mile or two in length.

Yet even with this liberalized interpretation, some of the western States found the post road clause an impossible hurdle to clear. In most of them, the main highways most in need of improvement ran through sparsely populated prairies, deserts, and mountains where there was no prospect of rural post routes being needed or established for decades. Nevada, a State as large as all of New England, had only four rural routes.

The industrialized eastern States were also denied the full benefits of Federal aid by the provision in the Act limiting Federal participation to 50 percent of the cost up to a maximum of $\$ 10,000$ per mile. Many of the eastern States were beginning to build heavier and wider pavements and these, with wartime inflation, were costing $\$ 40,000$ to $\$ 50,000$ per mile.

The States expressed their dissatisfaction with these provisions of the Act at the Richmond meeting of AASHO in December 1917, but the Administration, preoccupied with conducting the war, was unwilling to ask Congress for corrective legislation.

\section{The Rift in the Good Roads Movement}

The battle for Federal aid in the 64th Congress had been a contest between the proponents of long-distance improved highways and those who wanted only to get the farmer out of the mud. Neither side was really satisfied with the compromise embodied in the 1916 Federal Aid Road Act, and neither side approved wholly of the OPRRE's efforts to administer the Act. The post road clause was the major concession in the law for the local roads people, and the OPRRE very obviously was sympathetic to the State highway departments' efforts to eliminate compliance with it as a requirement for Federal aid.

The long-distance highway boosters regarded the OPRRE's efforts to get the States to designate highway systems as inadequate to ever produce a national road system. In a number of States the systems were so extensive that it would take decades of Federal aid at the most optimistic rate of appropriation to bring them up to an acceptable interstate standard. And even with the benevolent intervention of the OPRRE, it was difficult to get the States to coordinate their systems with their neighbor States. The States were primarily interested in State systems, not national systems.

Before the war was over, the national road advocates decided to cut loose from Federal aid and pressure Congress for a national system under Federal control. They supported the Postmaster General's motor express route proposal as a step in the right direction. And in October 1918, Senator George E. Chamberlain of Oregon introduced a bill "to provide for taking over, improvement, relocation, construction, and maintenance of a system of National highways and State highways, designed to facilitate the movement of troops, equipment, munitions, and supplies, and to promote the general welfare of the people of the United States." "41 This bill was buried in the
Committee on Military Affairs, but it showed which way some winds were blowing.

In October 1918, the influential Engineering NewsRecord, which had formerly favored Federal aid, came out for a national highway system, declaring that the Federal-aid projects already approved by the OPRRE were so scattered that there was no hope that they could ever be connected into a workable national system.42 The editor declared that "The Federal road administration has too long been in a subordinate capacity, lost in a department-that of Agriculture-whose main interests are foreign to road work," and went on to recommend that an autonomous commission similar to the Interstate Commerce Commission be set up to build and operate national highways. $^{43}$

\section{The Postwar Highway Drive Begins}

With the end of the war in sight, practically all of the States began preparations for a postwar road program. The highway atmosphere in late 1918 was entirely different from what it had been before the war. In Pennsylvania, where a bond issue for State highways had been defeated by 40,000 votes in 1913 , an even bigger issue for $\$ 50$ million carried by 180,000 votes in November 1918.44 Illinois proposed a $\$ 60$ million bond issue to pay for a carefully selected 4,800-mile system of trunk highways, and it carried by a large majority. ${ }^{45}$

In November 1918, Secretary of Agriculture Houston warned that the unexpended balances from the 1916 Federal-aid act would be inadequate to carry on an effective postwar road program in view of the enormous damage the country's roads had sustained during the war, and the need for more and stronger roads. He recommended larger appropriations from the Federal treasury.

The postwar road program was the main theme of the Joint Highway Congress sponsored by the American Association of State Highway Officials and the Highway Industries Association and scheduled to be held at Chicago, December 11 and 12, 1918.

The Congress opened under a pall of sadness cast by the sudden death of Logan Waller Page, Director of the Bureau of Public Roads, ${ }^{*}$ and the foremost highway engineer of the United States. Page had died of a heart attack the night of December 9, 1918, during a meeting of the executive committee of AASHO, to the dismay of the State highway forces who had been counting on him to lead the drive for an expanded postwar Federal-aid program. Page had brought to the meeting a Federal-aid bill that had been drafted by the Administration and had the support of AASHO. It provided for re-wording the post road clause of the Federal Aid Road Act of 1916, for authorizing 50 percent Federal participation in the cost of roads with no upper limit and for increasing appropriations by a total of $\$ 450$ million over a 4-year period. Those favoring the continuation of Federal aid planned to seek the endorsement of the Joint Highway Congress for the Page bill.

\footnotetext{
* On July 1, 1918, the Office of Public Roads and Rural Engineering had been elevated to the status of a bureau in the Department of Agriculture.
} 
On the other side, the principal spokesman for national highways was Editor E. J. Mehren of the Engineering News-Record. He outlined a plan for a national highway system of 50,000 miles consisting of five east-west routes and ten north-south routes, which would include about 2 percent of all U.S. roads. This system would give every State at least one through north-south route and one through east-west route and would cost about $\$ 1.25$ billion. With congressional appropriations of $\$ 100$ million per year, it would take $121 / 2$ years to complete. Mehren recommended that Congress set up a Federal Highway Commission to build, maintain, and operate the system. ${ }^{46}$

Still another plan was unveiled by James I. Blakslee, Fourth Assistant Postmaster General, for a Postal Motor Express System of 15,000 miles costing about $\$ 450$ million which, he claimed, if authorized by Congress, would pay for itself out of surplus postal revenues.

The Joint Highway Congress, dominated by the American Automobile Association, the National Automobile Chamber of Commerce, representatives of the emerging trucking industry, and other urban interests, passed a resolution favoring the Mehren plan for a national system. The outnumbered AASHO delegates then met in separate session, endorsed the Page bill and went on record as having "favored the making of all expenditures under the Federal-aid plan, the routes in the Federal system being selected by the various states and connected at the state lines by the Federal department in cases where connections are not made by the adjoining states." 47

\section{Unsuccessful Attempt in Congress to Extend Federal Aid for 3 Years}

The Page bill, sponsored by Senator Swanson of Virginia, was one of six highway measures introduced when Congress convened in December 1918. One of these, also sponsored by Swanson, would authorize the Postmaster General to set aside one-half of the net proceeds from the operation of motor parcel post for the improvement of a system of Federal motor express routes. Another, by Senator Reed Smoot of Utah, would establish a National Academy of Highway and Bridge Engineering in Washington. The others were Federal-aid bills similar to the Page bill providing for augmentation of the funds provided in the original Federal Aid Road Act for fiscal years 1920 and 1921 and an extension of Federal aid through fiscal year 1924.

This last authority was important, for it would insure the continuation of the policy of Federal assistance and enable the States to plan an orderly program. It was, however, opposed by those who were against Federal aid to highways, and they were successful in confining the funds authorized to fiscal years 1919,1920 , and 1921 and reducing the total amount to $\$ 200$ million. In addition, the rural road advocates imposed a limit of $\$ 20,000$ per mile on Federal participation.

In this form, the road legislation was added as a rider to the Post Office Appropriation Bill for 1920 (40 Stat 1252), along with another provision authorizing the Secretary of War to transfer to the Secre- tary of Agriculture "all available war material, equipment, and supplies not needed for the purposes of the War Department, but suitable for use in the improvement of highways, and that the same be distributed among the highway departments of the several states to be used on roads constructed in whole or in part by Federal aid...."

When this measure reached the floor of the House, the $\$ 200$ million appropriation encountered only token resistance. Congress clearly felt some obligation to help repair the damage inflicted on the State roads by war traffic. "The interstate character of traffic, as well as its excessive volume, render inequitable the placing of the cost burden on individual States." 48 Also, there was consensus that public improvements would be needed to stimulate business and provide employment for returning veterans. Senator Swanson urged road improvements as a weapon for gaining a place for the United States in world markets. Good roads he said would save American producers $\$ 700$ million annually and enable them to undersell foreign competitors.

The bill proposed that the term "rural post road" be construed to mean "any public road a major portion of which is now used, or can be used, or forms a connecting link not to exceed ten miles in length of any road or roads now or hereafter used for the transportation of the United States mails." Unexpectedly, this clause aroused considerable opposition from the floor, and Senator Charles S. Thomas of Colorado declared that the bill "commits the United States to the improvement of every cattle trail, every cow path, and every right of way in the United States." Senator James W. Wadsworth, Jr., of New York said, "I am convinced that any road that can be made suitable for carrying mail includes any and every road in the United States." 49 This, of course, was exactly the effect desired by the Administration when it proposed the amendment. The new post road definition ended the pretense that Federal aid for highways rested even in part on Congress' constitutional power to establish a postal system. The feeble opposition was unable to change the bill, and it became law on February $28,1919$.

Only a few days before the passage of the Post Office Appropriation Bill Senator Charles E. Townsend of Michigan introduced his own highway bill to establish a Federal Highway Commission of seven members, each to be paid $\$ 10,000$ per year, with power to establish a Federal highway system of not less than two trunkline roads in each State, suitably connected to the trunklines of adjacent States and counties. This bill, although lost by adjournment, was an omen of the coming battle over Federal aid in the 66th Congress. ${ }^{50}$

\section{Thomas H. MacDonald Selected to Head Bureau of Public Roads}

While the Page bill was working its way through Congress, the Secretary of Agriculture was trying to fill the vacant position of Director of the Bureau of Public Roads. This was not an easy task, partly because of the prestige the position had acquired under Page and partly because of the meager salary of $\$ 4,500$ Congress had allowed for the job, which was 


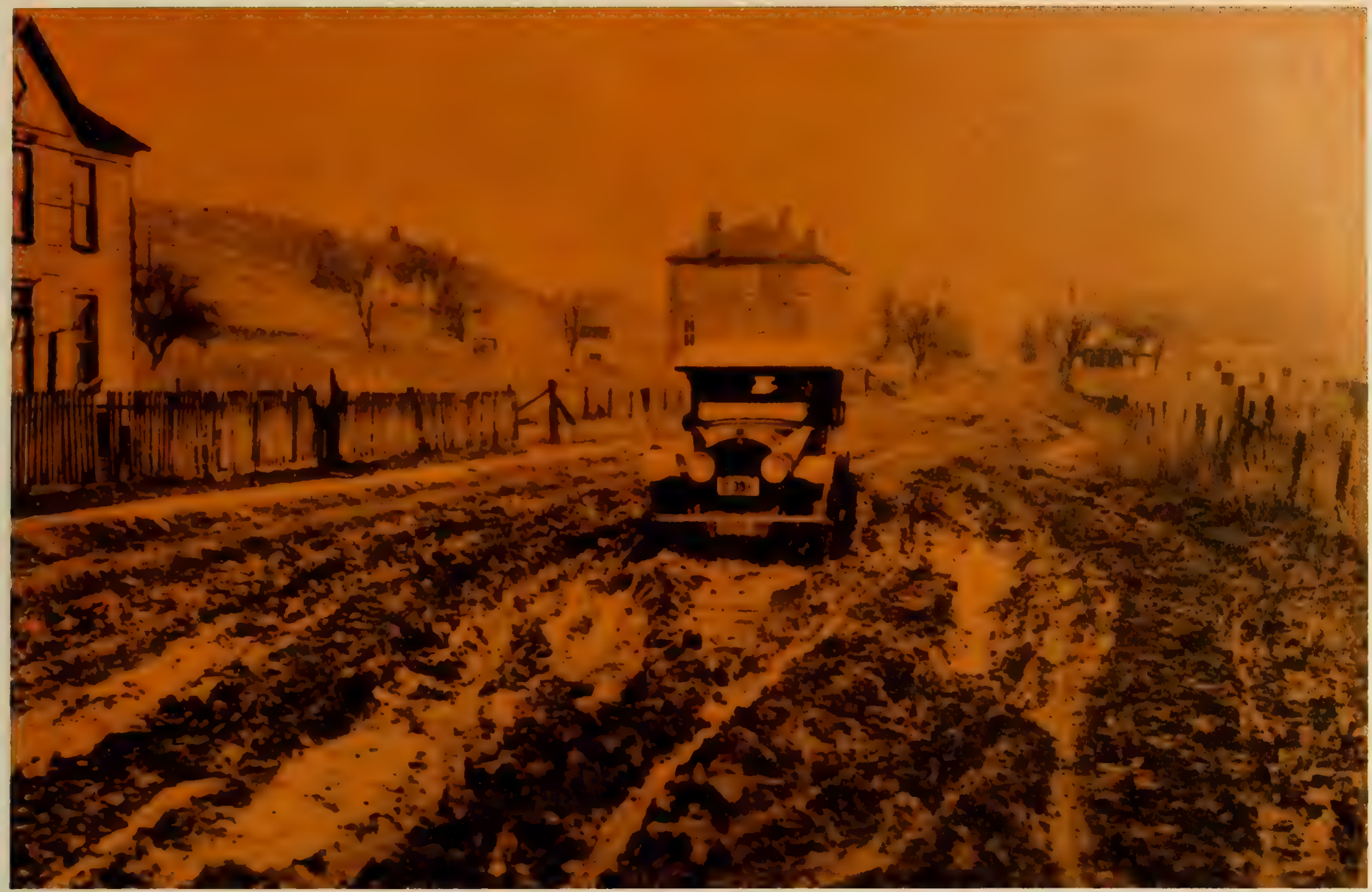

With roadbuilding severely limited during the war and a slow postwar start, many roads were still a quagmire each spring.

far below the compensation of many State highway executives. The American Association of State Highway Officials had recommended Thomas H. MacDonald, Chief Engineer of the Iowa State Highway Commission for the position, and MacDonald was willing to accept if more adequate compensation could be provided.

When nearly 4 months had passed without filling the position, the highway departments began to get restless, and some suggested that the hiatus in direction was affecting the work of the Bureau and delaying project approvals. This was denied, and on April 1, 1919, MacDonald was appointed "engineer in immediate charge of the work under the Federal aid road act" pending a reexamination by Congress of the Director's compensation. ${ }^{51}$ On July 1, 1919, he was appointed to fill the vacant directorship, with the title of Chief of Bureau, at a salary of $\$ 6,000$ per year.

\section{Highway Building Gets Off to a Slow Start}

Less than half a million dollars of the funds authorized by the Federal Aid Road Act had been paid out to the States when the war ended in November 1918. This left $\$ 29.5$ million available for fiscal year 1919 , to which Congress added another $\$ 50$ million in the Post Office Appropriation Bill. After deducting 3 percent for BPR Administration, about $\$ 77$ million were available to the States for their 1919 programs. ${ }^{52}$

Large as this sum seemed, it was only a small part of the funds voted for roads in 1919. Besides the
$\$ 110$ million already authorized in Pennsylvania and Illinois, Michigan, California, Oregon, South Dakota, Utah, Wyoming, and Nevada authorized another $\$ 114.8$ million worth of bonds, and bond issues carried in dozens of counties, some for very large sums.* ${ }^{53}$ Without counting the cities, which were also preparing large street programs, the funds available for new construction in 1919 were well over $\$ 400$ million..$^{55}$ This was about five times the amount spent under State supervision in 1918 for new construction.

For a variety of reasons, the States were slow getting started on their 1919 programs. Many did not have plans ready, and in some States, the bond funds and Federal-aid matching money did not become available until the construction season was well advanced. Early in the year there was a shortage of trained highway engineers.** There was also a shortage of contractors and construction equipment.

* For example, on July 1, 1919, St. Louis County, Minnesota, approved $\$ 7.5$ million of road bonds by a 9 to 1 margin. This was the largest sum ever authorized for roads in any county of the United States up to that time. About the same time the Dallas County, Texas, voters approved an issue of $\$ 6.5$ million for road and bridge bonds. In both of these States, the counties were required to match Federal-aid funds rather than the State. ${ }^{54}$

**At this time about one-fifth of all the trained highway engineers were still in the Army. The French Government had requested the United States to reconstruct the roads worn out by American military operations, and to do this the Army kept the engineer troops overseas the best part of the summer of 1919. 
By the time road construction began to gain some momentum, the annual movement of coal from the mines to markets had begun and open top railroad cars, which had been plentiful in the spring, became scarce once again. This cut into the supplies of construction materials, and many contractors were unable to complete their contracts before winter set in. When the season ended, no more than half of the 1919 road program had been realized, and only $\$ 2.7$ million of the available Federal aid had been earned by the States.

The failure of the States to measure up to public expectations was widely criticized. In defense, A. R. Hirst, President of the American Association of State Highway Officials, said,

Never, I believe, since the days of early railroad development have the American people been so determined to change instantly their means of transport and not even then were they so willing to pay the cost, provided they could get the results.

What are the results they are now demanding and what are some of the problems that grow from these demands?

They are expecting the States which had no highway organizations three or even two years ago, which had done no preliminary work and in some of which hardly a mile of modern rural highway had ever been built, to create an organization full sprung from the earth (like our imaginary defensive and aggressive army was to spring) and to build instantly hundreds of miles of modern roads costing millions upon millions of dollars. In the older States in the highway game, better prepared with organizations and contractors, and with some knowledge of materials and construction conditions, they are asking us to double, triple, or quadruple our annual output of roads. ${ }^{56}$

\section{The Debacle of 1920}

Shutting their eyes to the obvious impossibility of performance, some States announced 1920 road programs that were even larger than those for 1919. Additional bond issues, plus the Federal aid authorized for fiscal year 1920 had, according to BPR estimates, boosted the road funds available to the States and counties to at least $\$ 663$ million. A few sober voices warned of trouble ahead and advised the States to revise their programs downward to a realistic level or risk loss of public confidence. ${ }^{57}$ Others predicted that the highway program would put unbearable strains on the national economy which was already suffering from shortages of every kind. In particular, they said the competition for labor might lead to an agricultural disaster if the farmers could not get their crops planted and harvested.

Despite the warnings, the States began advertising road projects on a massive scale early in 1920, so as to be ready for construction as soon as the weather permitted in the spring. Very soon the market for road contracts was saturated; and as contractors became loaded, bids fell off and bid prices escalated alarmingly. High-type roads that had cost $\$ 20,000$ per mile before the war, and which went for $\$ 40,000$ per mile in 1919 , went up to $\$ 49,000$ and even higher. In Pennsylvania bids ranged from $\$ 52,500$ to $\$ 91,500$ per mile for concrete roads.

In March 1919, the State Auditor of Ohio asked the Highway Department to hold up contract awards pending a readjustment of economic conditions after
13 contracts for 44 miles of highway were offered with only two bids received. In May, the New York State Highway Department withdrew all highway projects not already awarded to contract "until the situation shows a decided change for the better." Also in May, the Minnesota Commissioner of Highways ordered the counties to stop letting new work and concentrate on finishing projects already under contract.

Bond interest rates began to rise early in 1920. In April the City of Pittsburgh received no bids for a proposed issue of $41 / 2$ percent improvement bonds. California was unable to sell its highway bonds because State law fixed interest at not over $4 \frac{1}{2}$ percent and prohibited the sale of State bonds below par. While the legislature wrestled with the problem, all construction and even advance planning came to a stop.

With the opening of the construction season, other troubles developed in abundance. Contractors who had taken contracts anticipating delivery of equipment in the spring sat idle waiting for the equipment. (The road equipment producers were themselves having labor and materials problems and were far behind on their orders.) Open top railway cars became scarce early in the season because of construction demand, and not enough cars were available for hauling coal, causing localized coal famines. Because of coal shortage, some of the portland cement mills reduced production, causing a shortage of cement, with contractors scrambling wildly for the available supplies at soaring prices.

The cement shortage was particularly serious to the industrial eastern and north central States, which had suffered the most damage from heavy trucking during the war. They were convinced that only concrete pavements or brick surfaces on concrete bases could stand up to heavy truck traffic, and they were also dominated by the idea that their main roads should be of "permanent construction" that would "outlive the bonds."

Delaware and Rhode Island, unable to get portland cement, changed their designs to bituminous concrete to utilize asphalt, which was still in reasonably good supply. Wisconsin, which had planned a 400-mile cement concrete road program, cut back to 200 miles.

To add to the States' and contractors' difficulties, the Interstate Commerce Commission in June 1920, gave the coal industry priority on open top cars, shutting down scores of road projects at the height of the construction season.

To keep going and to appease the public demand for highway construction, some States resorted to methods that would never have been countenanced in normal times. Some let contracts on a cost-pluspercentage, or cost-plus-a-fixed fee basis. Others set up force-account or day-labor organizations to do their own work. Temporary surfaces were laid on many projects in the expectation of better conditions in 1921 under which to do the final paving. ${ }^{58}$

When the construction season ended in December 1920 , not more than one-quarter of the anticipated program had been realized, and in some States, the accomplishment was less than 20 percent. However, it was possible to salvage some consolation from what appeared to be a massive failure. 
First, the Federal-aid program had done much better than in any previous year with total payments to the States of about $\$ 35.44$ million as compared to only $\$ 4.66$ million in the previous 3 years. ${ }^{59}$

Then, curtailed construction programs allowed the States to put more engineers on preparing surveys and plans for future work. Because of this enforced breathing spell, the States were able to get the unprecedented number of 1,286 projects, totaling 10,826 miles, ready for contract-twice as many as in all the previous years of the Federal-aid program. The estimated total cost of these projects was $\$ 197.6$ million, with a Federal share of $\$ 85.9$ million. This, according to Chief MacDonald, was a very desirable accomplishment:

\begin{abstract}
... it has been fortunate for the future stability of the roadbuilding program that because of the limitations imposed there has been sufficient time to get the necessary engineering work done much more thoroughly than would have been possible had we gone hastily into a heavy construction program. ${ }^{\circ}$
\end{abstract}

And finally, there was a rather general feeling that the slowdown would benefit everyone in the long run by taking the inflationary heat off labor rates and materials prices. The inability to get work under contract would almost certainly allow construction prices to stabilize so that the same funds would later buy more roads and bridges.

In the perspective of later events, the most significant development of 1919 and 1920 was a tremendous expansion of the highway construction business and the manufacture of road machinery. Encouraged by the prospect of a huge postwar highway program, literally hundreds of new contractors entered the highway field, and the old ones that had survived the war greatly expanded their capacity. Under the stimulus of high labor rates and acute labor shortage, the construction industry began an astounding mechanization which not only arrested the inflation in road prices, but in a few years brought them down to relatively low levels.

\section{Federal Aid In Kind-The War Surplus Equipment}

At the end of the war, the United States Government was the largest owner of motor trucks in the world, by a wide margin, and most of these vehicles were surplus to the peacetime needs of the Army. To the motor industry, this huge surplus of vehicles was a threat hanging over the postwar truck market. The highway people, on the other hand, looked upon these vehicles as a possible way to replace the vehicles worn out during the war.

Congress resolved the dilemma in four acts authorizing and directing the Secretary of War to transfer to the Secretary of Agriculture all vehicles, construction equipment, and supplies not needed by the military but suitable for use in improving the highways for distribution among the State highway departments. The only conditions imposed were that the States must request the equipment, pay transportation charges from where it was stored, and agree not to resell it.

In June 1919, the Bureau of Public Roads, acting for the Secretary, allocated 20,519 motor trucks to the

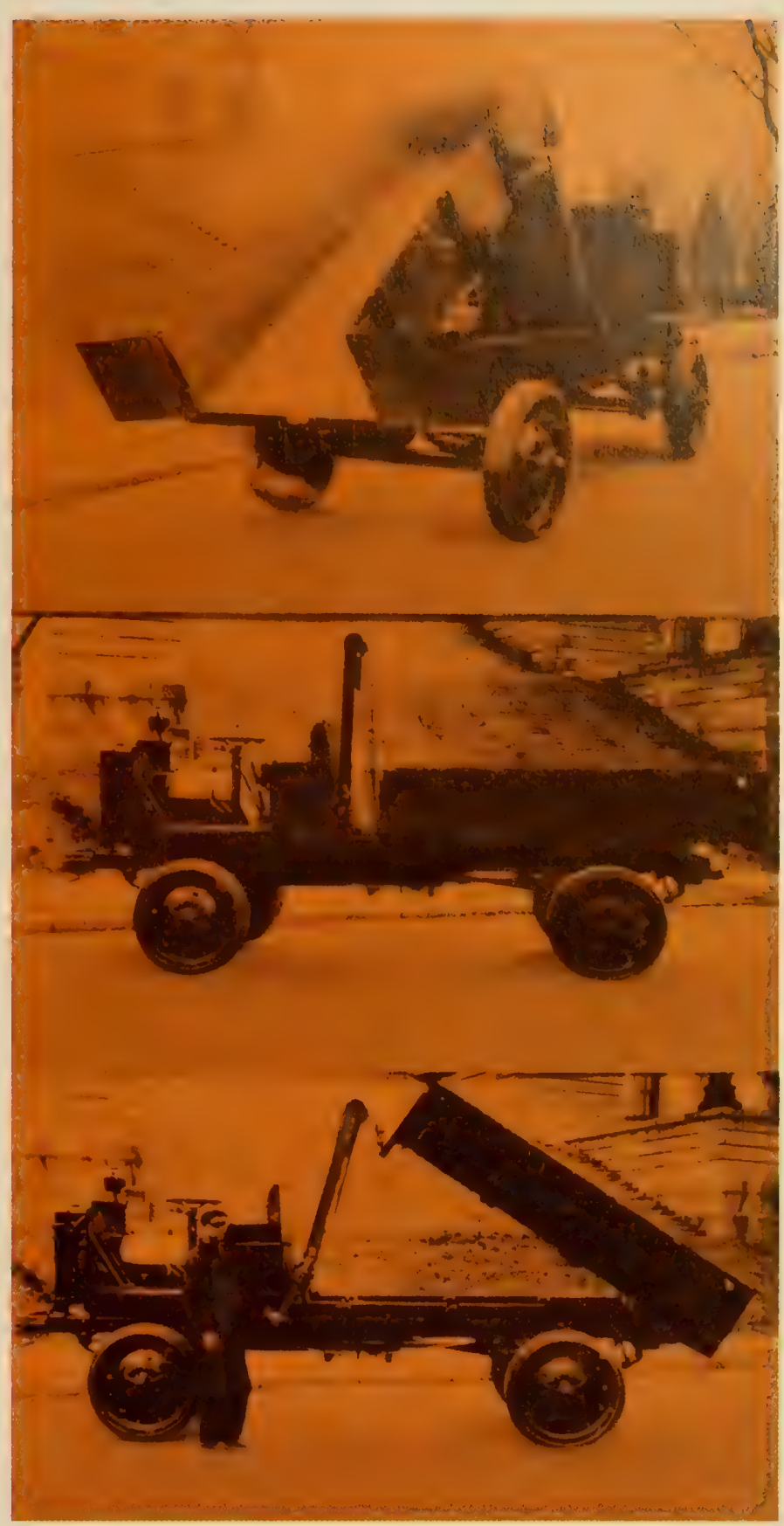

This 2-ton Army ordinance truck was converted into a dump truck for highway construction use.

States; and by the end of July, a third of these had been delivered to them. By October 1920, a total of 22,719 surplus vehicles had been delivered. This windfall was a tremendous boost to the maintenance efforts of the States and counties, for it enabled them to haul stone and gravel for repairs when railway cars were unobtainable.

By 1921 the flow of war surplus to the States had become a broad stream, including not only motor trucks, "Fords," and autos, but shop equipment, spare parts, and construction equipment of all kinds from hand shovels to steam shovels. Over 20,000 tons of explosives worth $\$ 10$ million were distributed and enthusiastically applied to highway construction and quarry operations. One construction superintendent declared "The results of TNT in rock blasting are so far superior to those of any other explosive that we 
have found that an experienced powderman who has once used TNT can hardly be induced to use anything else." 61

The massive distribution was substantially completed in 1925 by which time equipment and supplies worth $\$ 215$ million had been given to the States and the BPR had retained for its own use equipment worth another $\$ 7.8$ million. ${ }^{62}$

\section{The Defects of the Federal-Aid Program Exposed}

The Federal-aid forces suffered serious defections in April 1919, when a group of national road advocates formed the Federal Highway Council.63 One of the organizers of this group was highly respected Henry G. Shirley, Chief Engineer of the Maryland State Roads Commission and one of the founders of AASHO. The avowed purpose of the Council was to get Congress to set up a system of national highways under Federal control such as that proposed by the Townsend bill. The backing for such a system came principally from the eastern and north central States that had suffered the most from wartime traffic. Most of these States had well-defined, limited State highway systems and strong highway departments; and they had for years concentrated much of their money on main intercity highways which were under the direct control of and maintained by the State. In these States Federal aid had been applied to the through routes with good effect.

The situation was quite different in 17 southern, prairie, and western States in which the counties were still the basic political units for building and maintaining roads. These States had created weak highway departments or commissions to receive and distribute the Federal-aid funds and had given them some powers to approve or disapprove standards, but these departments generally lacked the power to initiate projects and so to place the funds where they were most needed. Even worse, the legislatures of some States had directed that the Federal funds must be subapportioned among the counties according to a formula similar to the Federal-aid formula ( $1 / 3 \mathrm{ac}-$ cording to area, $1 / 3$ according to population, and $1 / 3$ according to post road mileage). This split the limited amount of the State's apportionment into fragments, each too small for a satisfactory project, a process that, according to Henry Shirley, would result in these States being "spotted with and not linked by Federally constructed highways." ${ }^{64}$ In one southern State a sparsely populated county got only $\$ 4,000$ of Federal aid in one year for its portion of the State highway system. At this rate, according to Shirley, it would take 100 years to complete one road across the county even though this road might also be an important link between important cities in adjoining States.

Minnesota and Kansas were prohibited by their constitutions from engaging in works of internal improvement, and some southern States were legally unable to incur bonded debt. In these and a number

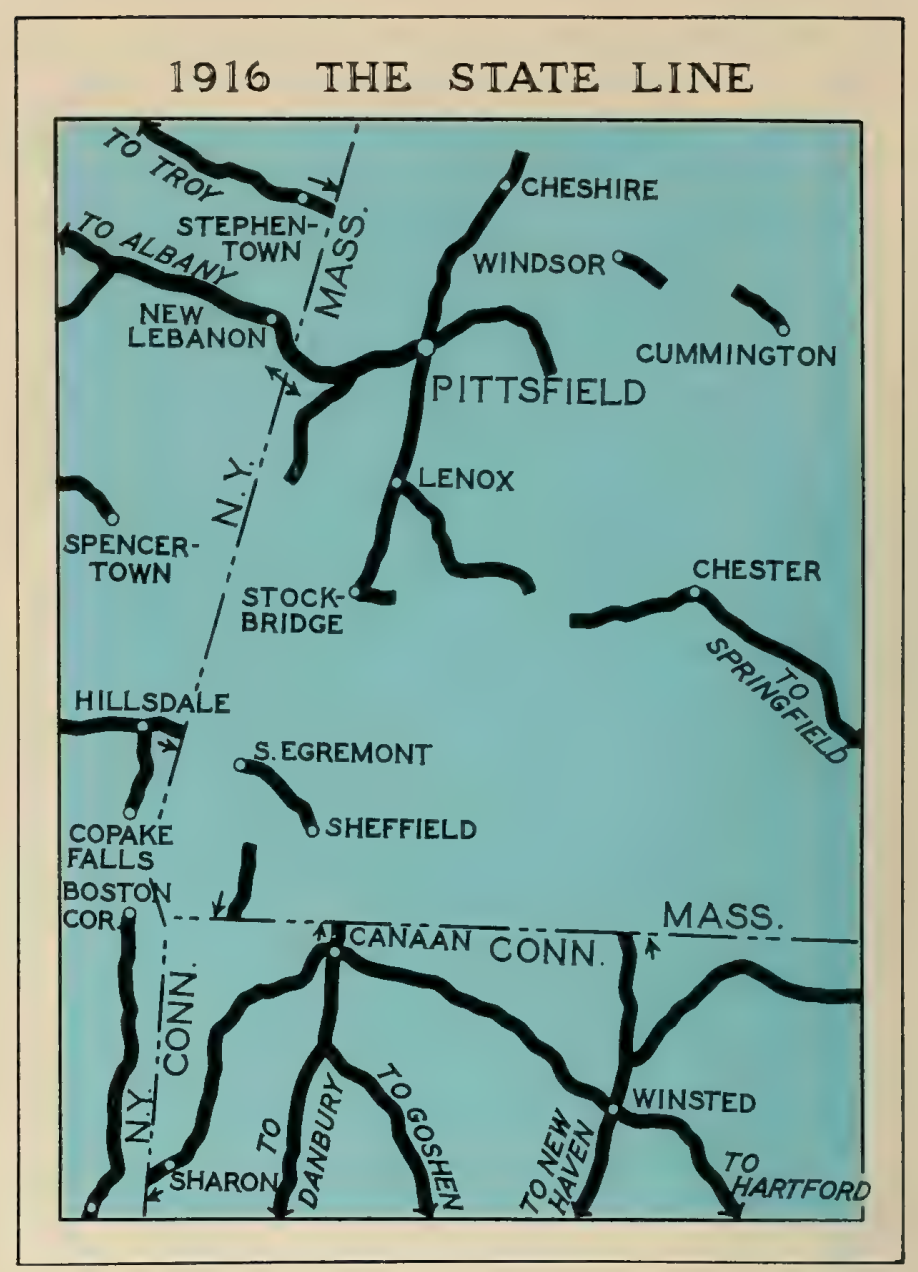

A drawback of the 1916 Federal Air Road Act was that federally aided roads need not have been connected.

of other States, the counties were required to put up all or part of the matching funds for Federal aid and also to pay for maintaining the roads afterward. This policy, according to the director of the American Automobile Association's Good Roads Board, resulted in giving good ". . . roads in rich counties and in pauperizing poor counties." ${ }_{65}$ Another result was that the completed roads in the poor counties were often poorly maintained and there was little the State highway departments could do about it other than threaten to withhold future Federal-aid funds.

To establish eligibility for Federal aid, the Secretary of Agriculture had required all States to designate State systems of main roads on which the Federal funds would be spent. These systems totaled 214,000 miles, or 8 percent of all U.S. roads. However, for individual States, the system mileage varied from less than 5 percent up to as much as 15 percent of the total existing mileage; and in some of the latter States the systems were so diffuse that it would take years to improve them, and even then they would not provide reasonably direct routes to important places in neighboring States.

Critics of Federal aid also liked to point out that, according to the official reports of the Bureau of Public Roads, three-quarters of the road mileage improved with Federal aid had low- or intermediate- 
type surfaces such as earth, sand-clay, gravel, or macadam which were incapable of carrying heavy truck traffic without excessive maintenance, and were, therefore, unsuitable as long-distance national roads. (However, the same reports showed that 65 percent of the funds were spent for high-type roads such as concrete and brick.)

Chief MacDonald was well aware of these shortcomings when he assumed office in 1919. He appreciated the need for a connected system of interstate highways, but he did not believe that a separate national system under a Federal commission or department was the way to achieve it. Such a system, he thought, would eventually absorb a very large part of the funds Congress was willing to vote for roads and, thus, weaken Federal aid to the States. MacDonald also questioned the assumption that longdistance highways were necessary for national defense, and in June 1920, he wrote:

There is no support for the assumption that long transcontinental roads will be needed for military defense, a transcontinental road which merely crosses the continent is of little military value. What is needed is a series of roads connecting all important depots, mobilization, and industrial centers, which, as thus connected, may give us a transcontinental route eventually; but the transcontinental feature is of secondary importance. ${ }^{68}$

The real need, in his mind, was to strengthen the State highway departments by giving them full control over both the Federal-aid matching funds and the maintenance of Federal-aid highways. In time, he believed long-distance highways would come into existence as the States improved their trunk highways, provided they could be persuaded to agree on a restricted mileage of interstate roads on which to concentrate the Federal-aid funds. The immediate problem was to bring about such an agreement and, thus, blunt the arguments of the national road advocates.

\section{The BPR Begins National System Studies}

MacDonald's handling of this problem was typical of his approach to many later ones. First, he obtained the support of the State highway departments by persuading Secretary Houston to set up a FederalAid Advisory Committee of six members recommended by the Executive Board of AASHO, of which MacDonald himself was a member. ${ }^{67}$ The members of the Advisory Board were from all parts of the country, and they all favored limited State road systems under the complete control of strong highway departments.

MacDonald then asked the War Plans Division of the Army General Staff and the Corps of Engineers to cooperate with the BPR to select those highways that were of national strategic or military importance; and when the military accepted this invitation, he supplied them with maps of all the States* on which the BPR had plotted the tentative road systems submitted by the States and also all of the approved Federal-aid projects. ${ }^{68 * *}$

* These base maps were prepared to a scale of approximately 8 miles to the inch by the Geological Survey. When that agency's appropriation was exhausted, MacDonald placed five of its cartographers on the BPR payroll to finish the job.
These preparations completed, MacDonald announced in March 1920, that the BPR, with support of the Advisory Committee was going to make a nationwide survey of the roads of the country and a classification of all highways in respect to their importance and character of service. ${ }^{69}$ This was necessary, he said, because the rate of improvement of the public roads is much slower than the public is demanding; yet,

There must come a realization that only a percentage of the resources demanded for increasing the rate of road production can be provided for this purpose, and so the production of roads must be studied and programs determined the same as for any large industrial undertaking, and in order that the roads which meet the greatest economic needs will receive first consideration. ${ }^{70}$

The survey, MacDonald said, would enable the Bureau and the States to segregate the roads into systems according to their national, State, county, or local importance, determine their needs for improvement, and allocate the costs of improvement and maintenance between the systems.

Meantime, the States were approaching a serious financial situation. Under the Bankhead Act of 1916 and the Post Office Appropriation Act of 1919, Congress had provided funds for Federal aid only through fiscal year 1921. When the $2 d$ session of the 66th Congress opened in January 1920, Senator Chamberlain of Oregon introduced an Administration bill backed by AASHO which would have provided $\$ 100$ million per year for Federal aid in fiscal years 1921, 1922,1923 , and 1924, with the provision that the money be concentrated on an adequate national highway system selected by the States and connected at the State lines. Senator Townsend also introduced his proposal for a Federal highway commission and a national highway system.

In committee, a measure known as the Sells bill, which provided funds for only fiscal year 1922, was substituted for the Chamberlain bill and was then passed by the House by a margin of almost 8 to 1 . However, it failed narrowly in the Senate, and Congress adjourned without passing a highway bill. MacDonald warned of hardship ahead for the States:

The fact that a new apportionment of funds was not made in January 1921, made it impossible for the States to maintain an unbroken continuity of policy and administration in respect to Federal-aid work, and this condition has resulted in an unprecedented number of withdrawals, cancellations, and modifications of existing projects as the States have endeavored to adjust their programs to a reduced rate of expenditure. This condition has emphasized the fact that in so large and important a national policy as Federal aid implies, the action of the Federal Government should as nearly as possible be uniform, consistent, and prompt. The probable cost of administering Federal aid in the several States will no doubt be appreciably increased, owing to the fact that the States do not yet know whether Federal aid will be continued, under what conditions it will be continued, or what appropriation is likely to be made, so that it is practically impossible for them to make any definite plans with respect to the administration or financing of future work or to conduct the necessary studies preparatory to filing applications for additional aid. ${ }^{71}$

** Apparently the Post Office Department was not asked to participate in these studies even though at the time (March 1920) the Postmaster General was still engaged in experiments with motor parcel post and motor truck transportation of fourth class mail. 


\section{A New Charter For Federal Aid}

Although the appropriation for 1922 was lost, the supporters of the Sells bill interpreted the lopsided vote in the House as a substantial endorsement for Federal aid. The Engineering News-Record, recognizing the "overwhelming sentiment" in favor of Federal aid, withdrew its support of the Townsend bill and urged all the highway factions to get together on a compromise measure. ${ }^{72}$

The Federal-aid people, under MacDonald's leadership, were eager to compromise, and in April 1921, the Executive Committee of AASHO met in Washington to draft a bill that would retain the essential principles of the 1916 Federal Aid Road Act and correct its weaknesses. To win the support of the national highway system advocates, this bill provided that each State must designate a State highway system, including not more than 7 percent of all roads in the State on which all the Federal funds must be spent. Three-sevenths of this system must be roads "interstate in character" and up to 60 percent of the Federal funds could be spent on this fraction. The bill also provided that State funds must be used to match the Federal money and that all construction and maintenance must be performed under the direct supervision of the State highway department. The State must agree to properly maintain all federally aided roads, and where the Secretary of Agriculture has found the maintenance to be inadequate, he may, after 60 days' notice, restore the road to a proper condition of maintenance and charge the cost to the State's apportionment of Federal funds and also withhold further Federal aid until the State refunds the money so spent. The authors got Representative Cassius Dowell of Iowa to introduce this bill when the 67th Congress convened in April 1921. ${ }^{73}$

Senator Townsend was also inclined to compromise, and he rewrote his bill to provide that a "post roads and federal highway commission" should select an "interstate highway system," and set standards but that the system be built, maintained, and operated by the States with Federal aid. His bill proposed an appropriation of $\$ 200$ million for a 2-year program. ${ }^{74}$

A few States, for one reason or another, were unable to spend all the Federal aid previously apportioned to them by the 1916 Act, and to keep them from losing the money, Senator Lawrence C. Phipps of Colorado introduced a bill extending the time limit for States to use these funds by 1 additional year for a total of 2 fiscal years beyond the fiscal year the funds were made available. This bill passed the Senate unanimously; but when it reached the House, the Committee on Roads added the Dowell bill with its limiting 7 percent system and 60 percent fund expenditure as an amendment, and in this form it was passed by the House with a thumping majority.

Eventually, after a long, hot summer of hearings and conferences, the Phipps-Dowell and Townsend bills were merged and passed with an appropriation of $\$ 75$ million as the Federal Highway Act of November $9,1921$.

This Act ended, or at least submerged, the feud between the local and long-distance road advocates by concentrating the Federal-aid funds on limited interconnected systems and by requiring that the paved surface of the interstate roads should be not less than 18 feet wide. It greatly strengthened the State highway departments, especially in their maintenance function, and it permanently laid to rest the idea of a national highway system under Federal control. However, much to the disappointment of the States, the appropriation was for only 1 year (fiscal year 1922), and, thus, it failed to provide the continuity so urgently needed for program planning.*

\section{The Federal-Aid Highway System}

The selection and approval of the "7-percent system" of roads mandated by the Federal Highway Act was the largest and most important task ever assigned to the Bureau of Public Roads. In anticipation of the passage of the Act, Chief MacDonald asked each highway department to certify the total mileage of public roads in its State. These mileages totaled $2,859,575$ miles, which fixed the maximum extent of the Federal-aid system at 200,170 miles.

Immediately upon passage of the Act, MacDonald requested the States to submit tentative system recommendations. At the same time, he assigned a BPR task force, under Edwin W. James, the job of devising an equitable method for testing the systems submitted by the States.

This group obtained from the Bureau of the Census its latest figures, by counties, for population, value of agricultural products, value of mineral products, value of forest products, and value of manufactured products. Calling the State population 100, they calculated a population index for each county. In the same manner they calculated county indices for the four significant production factors. Finally, by adding all these together and dividing by five they obtained a composite index for each county.

Then, according to James:

We adopted squares as emblems of the indices. When these squares, blackened in, were put into their appropriate counties on a clean map, we had a series of emblems through which diagrammetric routes could be laid out. Routes through the heaviest emblems were routes through the generally wealthiest and all around most important county areas. Road locations could be made catching obvious local control points along these diagrammatic lines, and you had a selection from best to poorest almost staring you in the face. ${ }^{75}$

By October 1922, tentative system maps had been received from all but nine States. Most of the routes in these systems followed existing roads, and they agreed remarkably well with the BPR task force's studies. Surprisingly, the largest deviations from what appeared to be the best interstate routes occurred in States such as New York and Massachusetts where a large percentage of the principal roads was already improved. In these States there was "a natural disposition to designate other roads of less importance as the Federal-aid highway system for the State." 76 These and other differences were smoothed

\footnotetext{
* Congress remedied this by appropriating a total of $\$ 190$ million in Federal aid for fiscal years 1923, 1924, and 1925 in the Post Office Appropriation Act of June 19, 1922 (42 Stat 660 ).
} 
out in conferences between the BPR and the individual States and by regional conferences between the States to coordinate across State boundaries. The first inter-State conference at Troy, New York, resulted in completely coordinated primary systems for New England, New York, and New Jersey.

System selection and highway correlation were somewhat different in the west where population was scattered, road distances great, and financial resources very limited. "The designation of a system of roads in such States adequate at once to serve local requirements and at the same time correlate satisfactorily with the roads of adjoining States demands very careful adjustments in order to keep the mileage, the resources, and the service value of the roads properly balanced and economically justified." 77 In a few of the larger western States, three-sevenths of the total Federal-aid mileage was insufficient to make all of the connections to interstate roads in adjoining States, and some of the secondary Federal-aid mileage had to be used for this purpose.

The huge job of designating and approving all of the 48 State systems and correlating them across State lines was completed November 1,1923 , the work published by the Bureau of Public Roads in the form of a national map of the Federal-Aid Highway System. Because many States designated less than 7 percent of their total mileage on the Federal-aid system, the roads shown on this map totaled only 168,881 miles, or 5.9 percent of all U.S. roads. However, almost immediately, the system began growing and it has been growing ever since.* By July 1923, Maryland, Delaware, and Rhode Island had completed their original systems to a satisfactory standard and had been granted increases by the Secretary.

The Bureau of Public Roads estimated that for the country as a whole at least 90 percent of the population resided not more than 10 miles from a Federalaid road, and in a few States, this figure was as high as 97 or 99 percent. The BPR estimated that at least 94 percent of the cities of 5,000 or more population were directly on the system. ${ }^{78}$

The Federal Highway Act concentrated a sizable amount of money on a limited mileage of roads, resulting in the rapid improvement of interstate routes. Fiscal year 1922 was a banner year in which nearly 14,000 miles of the Federal-aid system were improved. By July 1925, 46,486 miles, or over one-quarter of the system, had been brought up to a reasonably travelable standard.

However, the production of motor vehicles increased at an even more rapid rate. From 1916 to 1921 registrations increased at about 1.4 million per year. From 1921 to 1925 the rate increased to about 2.37 million per year, and in 1925 the total number of motor vehicles of all types registered was 19.95 million. ${ }^{79} 80$

* The Federal Highway Act provided that whenever a State had finished improving its entire original 7 percent system, the State, with the approval of the Secretary of Agriculture, could add additional increments. The Emergency Relief and Construction Act of 1932 modified this to provide that increments of 1 percent of total State road mileage could be added to the Federal-aid system whenever 90 percent of the original system plus all subsequent increments had been improved.
With the increase in vehicle ownership, there came an immense increase in travel and tourism, and cross country motoring rapidly became the major recreational activity of millions of Americans.

\section{The End of the Trails}

The cross country wagon trails of the prerailroad era were a romantic episode in American history. These trails furnished the emigrants one essential service that outweighed all others-the assurance that if the traveler followed the trail, he would eventually arrive at his destination and not become lost.

When the Lincoln Highway Association was organized in 1913, this assurance was lacking for anyone so rash as to attempt a long overland trip, for the roads were almost completely unsigned and there were few reliable maps. Few residents along a road could give the traveler reliable information on the condition of the roads in the next county or even beyond a distance of 10 miles in their own county. By selecting and mapping the best roads over the most direct routes and by encouraging the local officials to improve them and the local auto clubs to mark them, the Lincoln Highway Association provided services of real value to motorists. The American Automobile Association augmented these services by publishing its famous "Blue Books," advising tourists of the accommodations to be found along the route. In 1915 Lewis Stubbs of St. Joseph, Missouri, proposed marking auto trails by painting colored bands around utility poles, and the Automobile Club of St. Joseph marked a considerable mileage of the Pikes Peak Ocean-to-Ocean Highway, the "Appian Way of America," in this manner. ${ }^{81}$

The National Old Trails Association formed in 1913 was dedicated to preserving and improving the old Cumberland Road and the old Santa Fe Trail as a transcontinental route. In 1915 Carl Fisher was instrumental in organizing the Dixie Highway, a network of parallel roads extending from the Straits of Mackinac to Miami, Florida. Between 1914 and 1916 community boosters put together the Yellowstone Trail, under the slogan "A good road from Plymouth Rock to Puget Sound," with the Pikes Peak Oceanto-Ocean Highway following in $1916 .{ }^{82}$

Because they were marked and advertised, these pioneer auto trails became channels for the rising tide of tourist traffic. After World War I, competing auto trails burgeoned in scores. In the absence of an official marking system, these trails provided a useful service to motorists, even though they were established in large part to promote the commercial interests of their sponsors. But within a few years, the movement got out of hand as more and more trails were organized. By 1924 there were at least 250 marked trails sponsored by 100 or more separate organizations, each with a headquarters and issuing maps and promotional material and collecting funds. Some of these routes were interstate in character, some of only local significance. Some routes were promoted to further roadbuilding by arousing public opinion, some were purely scenic, and some existed only to provide salaries for their organizers. ${ }^{83}$ 
The trail organizations were highly competitive and their efforts were uncoordinated, resulting in numerous overlaps.

For example, 70 percent of one trail overlapped other marked routes and one trail overlapped as many as 11 others. One road carried eight different trail markers for a considerable distance. Many trails had alternate sections, compounding the confusion, and one had alternates following three separate roads, all with the same name. Most routes followed their financial support and it was impossible to integrate many of them into any logical highway system. ${ }^{84}$

The pressure of the trail associations for the improvement of their trails made sensible programing by the State highway departments almost impossible. The situation finally became so bad that in 1924 the American Association of State Highway Officials approved a resolution calling on the Secretary of Agriculture to name a board of BPR and State engineers to formulate a numbering and marking system of interstate character for the principal highways of the United States. In response to this resolution, the Secretary appointed a Joint Board of 21 State highway engineers and 3 BPR engineers under the chairmanship of Chief MacDonald with E. W. James as secretary.

Early in its work the Joint Board decided to confine the numbered routes to actual existing roads in the Federal-aid system, but to disregard the state of improvement of any road as a factor in putting it on the system. The Board pointedly avoided holding public hearings to avoid placing itself in the position of arbiter between competing trails.

The Joint Board sponsored six regional meetings at which each highway department had an opportunity to designate its most important routes and coordinate across State lines with its neighbors. When these recommendations were consolidated on a single map, they added up to a system of 81,096 miles, or 2.8 percent of the total existing road mileage. The Board then went over the State recommendations eliminating routes of doubtful interstate importance and finally arrived at a "skeleton system" of 50,137 miles which it submitted to the individual States for approval.

By this time the work of the Board had begun to attract popular attention and, to use the expression of the president of AASHO, "the Infernal regions began popping." Every community of any size wanted to be on a numbered route, just as a generation earlier every town thought it a matter of life and death to be on a railroad. Under the influence of local pressure the skeleton system was fleshed out to 75,884 miles. This was the system that was recommended by the Joint Board to the Secretary of Agriculture in its final report and approved by him. The Secretary sent the report to AASHO recommending that the Association "take such necessary steps as might be feasible under their respective State laws to put the plan into operation." 85

At its annual meeting in October 1925, AASHO delegated to its Executive Committee authority to make minor changes in the system recommended by the Joint Board "as appeared necessary or desirable." Immediately, requests for changes began to come in from the States, most of them inspired by the trail associations. The Executive Board acted on 142 such requests and approved additions which boosted the total system mileage to 96,626 miles. This system was approved by ballot of the States on November 11, 1926, and was immediately put into effect by all the States and marked with the familiar black and white shield markers which for almost 50 years have guided American motorists.

What became of the private trails? They were replaced by one or more U.S. numbered routes and, one by one, the trail associations, their work done, went out of business. However, for years afterward and even today, sections of road in many States continued to be called "Lincoln Highway," "Yellowstone Trail," "Dixie Highway," etc.

\section{REFERENCES}

${ }^{1}$ Engineers At Washington Rush Work On Army Oamps But There Is Much Delay, EngINEERING News-ReCord, Vol. 78, No. 12, June 21, 1917, p. 619.

${ }^{2} \mathrm{C}$. UpHAM, Car Shortage and Its Relation to Highroay Work, Engineering News-Record, Vol. 79, No. 24, Dec. 13, 1917, p. 1099.

'Making Existing Facilities Do The Work-The Railroads' Problem, Engineering News-Record, Vol. 80, No. 1, Jan. 3, 1918, p. 4.

"Transportation Needs-Rail, Water, Highway, ENGINEERING News-Record, Vol. 80, No. 16, Apr. 18, 1918, p. 779.

${ }^{5}$ The Immediate Needs of the Railroads, EnaINEEring News-Record, Vol. 81, No. 4, Jul. 25, 1918, p. 166.

${ }^{6}$ Build Roads!, EngineERING News-Record, Vol. 79, No. 3, Jul. 19, 1917, p. 98.

'Priority Order to Halt Road Construction, EngINeERING News-REcord, Vol. 79, No. 18, Nov. 1, 1917, p. 855.

${ }^{8}$ Short Stretches vs. Through Routes, Engrneering NewsRECORD, Vol. 79, No. 25, Dec. 20, 1917, p. 1137.

- The First Motor Truck Convoy, EngINeERING NewsRECORD, Vol. 80, No. 1, Jan. 3, 1918, p. 3.

${ }^{10}$ Pennsylvania Keeps Roads Open For Motor Truck Convoy, Engineering News-Record, Vol. 80, No. 9, Feb. 28, 1918, p. 408.

${ }^{11} \mathrm{G}$. BILES, Clearing Roads for Army Transport, PubLIC Roads, Vol. 1, No. 1, May 1918, p. 13.

${ }^{12} \mathrm{C}$. Cowen, How Ohio Handles Important Roads Broken Down By Huge Traffic, Public Roads, Vol. 1, Nos. 6-8, Dec. 1918 , p. 26.

${ }^{13}$ Action By The State Highway officials, ENaINEERING News-ReCoRd, Vol. 79, No. 24, Dec. 13, 1917, p. 1087.

${ }^{14}$ Secretary Houston Will Urge Vital Road Work, ENGINEERING News-RECORD, Vol. 80, No. 3, Jan. 17, 1918, p. 140.

${ }^{15}$ Government Operation And What It Means, Engrneering News-ReCoRd, Vol. 80, No. 1, Jan. 3, 1918, p. 5.

${ }^{16}$ McAdoo Will Aid In Transporting Road Materials, ENGINEERING News-ReCoRd, Vol. 80, No. 8, Feb. 21, 1918, p. 381.

${ }^{17}$ What Most Highway Departments Will Face In The Near Future, Engineering News-Record, Vol. 80, No. 15, Apr. 11, 1918 , p. 693.

${ }^{18} \mathrm{~W}$. Thоmpson, New Jersey, One of The Great Sufferers, Plans To Meet Needs of The Future, Public Roads, Vol. 1, No. 2, Jun. 1918, p. 21.

${ }^{10} \mathrm{~W}$. SoHIER, Massachusetts Sees The Solution In Limits Upon Capacity And Loads of Trueks, Public Roads, Vol. 1, No. 2, Jun. 1918, p. 13.

${ }^{20}$ Bureau of Public Roads Annual Report, 1919, p. 5.

${ }^{21}$ Truck Facts For 1927 (National Automobile Chamber of Commerce, New York, 1927) p. 10.

${ }^{22}$ Carrying Your Terminal Facilities With You, Engrneering News-Record, Vol. 79, No. 24, Dec. 13, 1917, p. 1985.

${ }^{23}$ Motor Trucks Needed To Supplement, Not Compete, With Highways, Engineering News-Record, Vol. 82, No. 3, Jan. 16, 1919 , p. 120.

${ }^{24} \mathrm{~J}$. WALLACE, Unit Operation Of Terminal Zones Urged, Engineering News-Record, Vol. 80, No. 16, Apr. 18, 1918, p. 779 . 
${ }^{25}$ Industry's Use of Highways And Motor Trucks To Re lieve Freight Congestion, Engineering News-Record, Vol. 79, No. 22, Nov. 29, 1917, p. 1033.

${ }^{20}$ Developing Freight Routes on Highways With Motor Trucks and Trailers, EngINeEring News-Record, Vol. 81, No. 2, Jul. 11, 1918, p. 106.

${ }^{27}$ Highway Carries Twelve Times As Much Local Freight As Railroad, Engineering News-Recond, Vol. 81, No. 5, Aug. 1, 1918, p. 224.

${ }^{28}$ Contract Let For Motor-Truck Transportation of Coal, Engineering News-Record, Vol. 81, No. 24, Oct. 3, 1918, p. 647.

${ }^{7}$ Comparison of Short-Haul Truck And Rail Shipments, ENgineering News-Record, Vol. 82, No. 19, May 8, 1919, pp. 903, 904.

${ }^{20}$ H. Doc. 159, 65th Cong., 1st Sess., p. 2.

${ }^{31}$ Editorial, American Motorist, Vol. 7, No. 4, Jul. 1915, p. 436.

Joint Resolution Making Appropriations for the Post Office Department for Fiscal Year 1916 (38 Stat 1227).

39 Stat 424.

"Regional Highway Transport Directors Meet, ENGINEERine News-Record, Vol. 81, No. 13, Sept. 26, 1918, p. 599.

${ }^{25}$ Report Shows Results of Motor Parcel Post Service, Engineering News-RecoRd, Vol. 81, No. 2, Jul. 11, 1918, pp. 90-91.

Id., pp. 90-92.

" 40 Stat 753

${ }^{38}$ Cong. Rec. 65th Cong., 3d Sess., Vol. 57, App., p. 386.

"P. Wilson, Operations of Bureau of Public Roads Under the Federal Aid Road Act, PUBLIC RoAds, Vol. 1, No. 10, Feb. 1919 , p. 22.

${ }^{40}$ S. R. 666, 65th Cong., 3d Sess., p. 3.

"Cong. Rec. 65th Cong., 2d Sess., Vol. 56, pp. 11, 311.

Wanted-A Connected National Highway System, ENaINEERING News-Record, Vol. 81, No. 14, Oct. 3, 1918, p. 608.

"Post-War Highway Drive Begins, Enginenaing NewsRecord, Vol. 81, No. 20, Nov. 14, 1918, pp. 878, 879.

" Report of The State Highway Department of PennSTLVANIA, 1917-1920 (J. L. L. Kuhn, Harrisburg, 1922) p. 15.

${ }^{4}$ Second Administrative Report of The Directors of DePartments For The Year JuLY 1, 1918-June 30, 1919 (Illinois State Journal Co., Springfield, 1919) p. 204.

${ }^{*}$ E. Merren, A Suggested National Highway Policy and Plan, Engineering News-Record, Vol, 81, No, 25, Dec. 19, 1918, p. $1115,1116$.

${ }^{17}$ National Highway System Gets Strong Backing, ENGINEering News-Record, Vol. 81, No. 25, Dec. 19, 1918, p. 1108.

${ }^{4}$ S. R., supra, note 40 , p. 10.

57 CoNg. REC. 2427 (1919).

${ }^{50} I d$., p. 3635.

${ }^{\circ}$ New Roads Official Named, Public Roads, Vol, 1, No. 11, Mar. 1919, p. 3.

BPR, supra, note 20 , p. 8.

A. Anderson, State Highway Mileages And Expenditures in the Year 1918, Public Roads, Vol. 2, No. 15, Jul. 1919, p. 3.

* Largest County Bond Issue, Public Roads, Vol. 2, No. 15. Jul. 1919, p. 7. suthorized Road Bond Issues Total Nearly $\$ 500,000,000$ Engineering News-Record, Vol. 84, No. 4, Jan. 22, 1920, p. 202.

${ }^{3}$ A. Hinst, The American Highway Problem, PUBLIC Roads, Vol. 2, No. 20, Dec. 1919, p. 6.

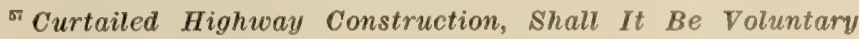
or Enforced?, ENGiNeERING NEWs-Record, Vol. 84, No. 10, Mar. 4, 1920, p. 451.

${ }^{*}$ P. Sargent, The President's Address, Public Roads, Vol. 3, No. 32, Dec. 1920 , p. 6.

${ }^{59}$ Bureau of Public Roads Annual Report, 1920, p. 5.

"T. MacDonalD, Federal-Aid Accomplishments, PuBlic Roads, Vol. 3, No. 32, Dec. 1920, p. 14.

${ }^{61}$ L. Smith, TNT A Success In Road Work, Public Roads Vol. 3, No. 31, Nov. 1920, p. 13.

${ }^{62}$ Bureau of Public Roads Annual Report, 1925, p. 28.

"Federal Highway Council Formed, Engtneering NewsRECORD, Vol. 82, No. 16, Apr. 17, 1919, p. 790.

${ }^{*}$ Why Federal Aid Will Not Build A National Highway System, Engineering News-Record, Vol. 84, No. 7, Feb. 12, 1920 , p. 336.

${ }^{65}$ M. Eldridge, Federal Highway Appropriations, EngineerING News-Record, Vol. 86, No. 6, Feb. 10, 1921, p. 272.

${ }^{66}$ T. MACDoNALd, Four Years of Road Building Under The Federal-Aid Act, Public Roads, Vol. 3, No. 26, Jun. 1920, p. 13.

${ }^{\text {a }}$ BPR, supra, note 20, p. 34.

BPR, supra, note 59 , p. 7.

${ }^{\circ}$ Highway Classification Undertaken by Bureau of Public Roads, Engineering News-Record, Vol. 84, No. 13, Mar. 25, 1920 , p. 635

${ }^{10} I d$.

${ }^{71}$ Bureau of Public Roads Annual Report, 1921, pp. 6, 7.

${ }^{72}$ Getting Together On Highway Policy, Engineering NewsRecokd, Vol. 86, No. 13, Mar. 31, 1921, p. 534.

${ }^{73}$ State Officials Confer On Highway Policies, EngINeErING News-Record, Vol. 86, No. 16, Apr. 21, 1921, p. 696.

"Revised Townsend Road Bill Introduced, ENGINEERING News-Record, Vol. 86, No. 18, May 5, 1921, p. 783.

${ }^{75}$ Letter from E. W. James to F. W. Cron, Feb. 21, 1967, (Original in the Department of Transportation Library, Washington, D.C.)

${ }^{76}$ Bureau of Public Roads Annual Report, 1922, p. 3.

${ }^{77} Y d$.

${ }^{78}$ Bureau of Public Roads Annual Report, 1923, p. 3.

${ }^{79}$ Motor Vehicle Registration 15,092,177, Public Roads, Vol. 5, No. 2, Apr. 1924, p. 16.

${ }^{80}$ Motor Vehicle Registrations, Revenue And Gasoline Taxes For The Year 1925, Public Roads, Vol. 7, No. 2, Apr. 1926, p. 50 .

${ }^{81}$ Ask A.A.A. Recognition for Pike's Peak Route, AMERICAN Motorist, Vol. 7, No. 4, Apr. 1915, p. 232

${ }^{82}$ V. Stevenson, American Hrghways, Vol. 1, (Winship Publishing Co., New York, 1919) pp. 13-17.

${ }^{83}$ E. JAMES, Making And Unmaking A System of Marked Routes, American Highways, Oct. 1933, p. 16

${ }^{84}$ F. CRon, Touring By Numbers-Why and How, PUBLIC Works, Feb. 1968, p. 80.

${ }^{85}$ E. JAMES, Marking Our Highway System, AMERICAN HighwaYs, Oct. 1931, p. 19. 


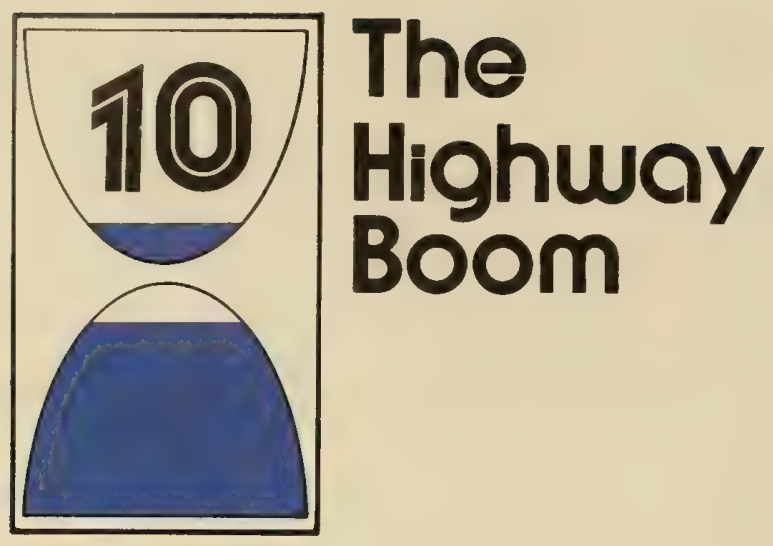

". . . but each separate project [new road] is to some community a new opportunity, a means of bettering, in some respects, the economic and social status of the community, and together they form the linles which, eventually united, will constitute a new means of transportation. ..."

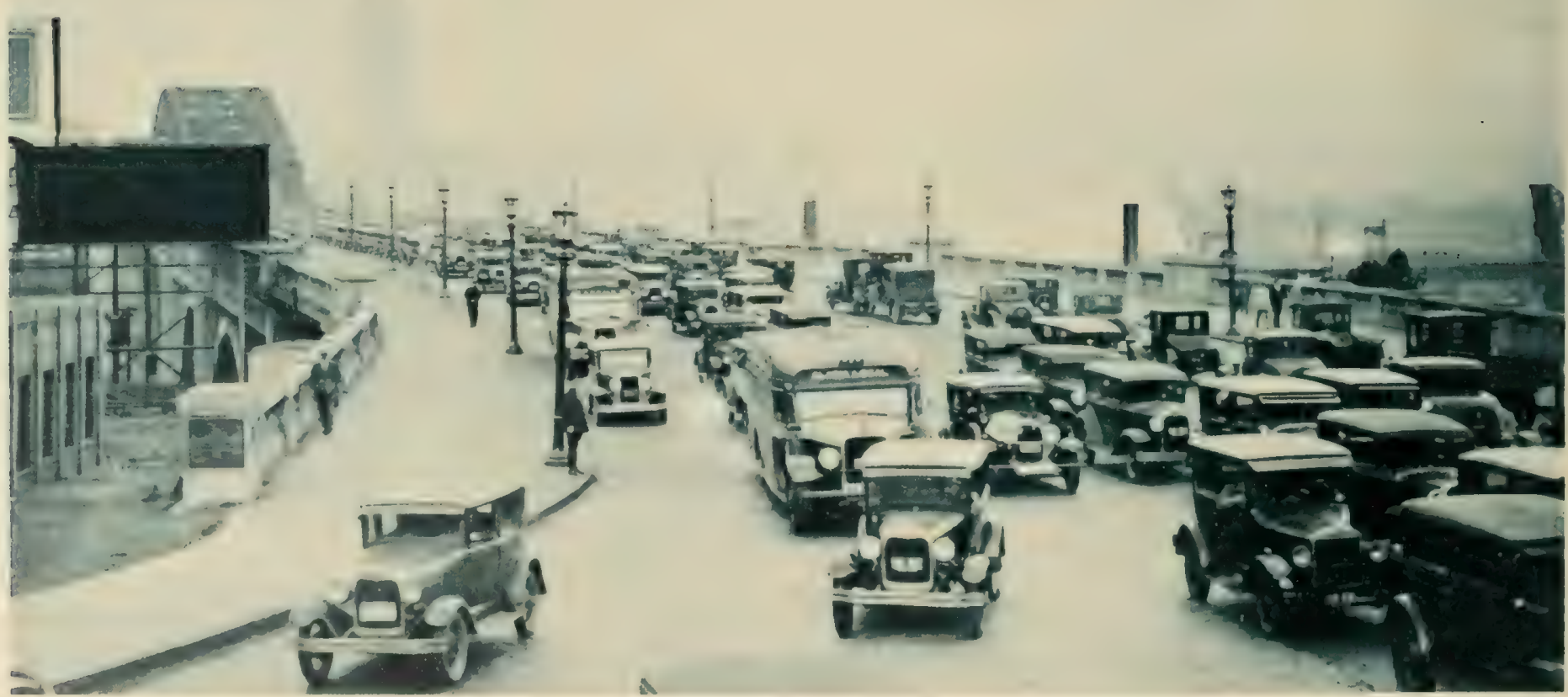


The Beginning of a Sustained Highway Program

The Federal Highway Act of 1921 increased the limit of Federal participation in road costs to $\$ 20,000$ per mile, a change that had been urged by the eastern and northern States to compensate for the wartime inflation in the cost of the higher types of road pavements. When Congress again considered the financing of the Federal-aid program in April 1922, this limit became a bone of contention. Rural interests wanted the limit cut back to as low as $\$ 4,000$ per mile to force the States to use the less expensive construction types and, thus, more rapidly provide some kind of improvement for the entire Federal-aid system, and particularly its less heavily traveled parts. Eventually, a compromise was reached on a limit $\$ 16,250$ per mile for projects funded in fiscal year 1923, falling to $\$ 15,000$ per mile in 1924 and thereafter.*

This was only a minor setback for Federal aid. Much more important was Congress resumption of the desirable practice of authorizing aid funds several years in advance by authorizing appropriations of $\$ 50$ million, $\$ 65$ million, and $\$ 75$ million for fiscal years 1923, 1924 and 1925. Since most State legislatures met biennially, this advance notice of Congress intent was of the utmost importance to the States in planning their own matching appropriations and budgets.

This removal of uncertainty in the Federal-aid program coincided with a drop in wages and a lowering of price levels for construction materials. The State highway departments, profiting from their past mistakes and added experience, had developed much more effective construction organizations and procedures, and these were matched by a stronger and more efficient construction industry. The result was the completion of 10,247 miles of construction at a cost of $\$ 189$ million-31/2 times as much as had been accomplished since the Federal-aid program began-in the single fiscal year of 1922. To Chief MacDonald the mere recital of statistics could not possibly convey an adequate idea of what was accomplished. In 1922 he wrote:

But merely to say that this year has added 10,000 miles to the previously existing mileage conveys no adequate sense of the far-reaching effects of the work that is being done. The 10,000 miles completed represent something more than the equivalent of three transcontinental roads. They are not transcontinental roads. They are not even connected roads, though as the work continues they will be connected; but each separate project is to some community a new opportunity, a means of bettering, in some respects, the economic and social status of the community, and together they form the links which, erentually united, will constitute a new means of transportation, no less important to the country as a whole than that offered by the railroads. ${ }^{1}$

\section{Roadbuilding by Stages}

The 1922 record was possible mainly because at least two-thirds of the work was of low type, such as graded earth, sand-clay and gravel, and this in turn came about because the BPR adopted a stage con-

* The participation limit on cost per mile was raised to $\$ 25,000$ in 1930 and eliminated altogether in 1934. struction policy in the early years of the Federal-aid program:

In many instances it has he'en found advisable to grade and drain a road and delay an "xpensive pavenent until a later time. This policy will be continued under the same conditions: that is, when the volume of traffic at the time of the original construction is not large enough to require any lenter surface than can lo built of selected soil; sand-clay, or gravel, when financial considerations require that the expense of a pavement be deferred, and when, as in the light of past experience it has often been found advisable, a delay to allow the subgrade to become stable is believed to be necessary. In such cases the plan will be, as it has been in the past, to so design and construct the grades and drainage structures and whatever temporary surfacing that is applied, that any additions or subsequent improvements can be made without loss of prior investment. ${ }^{2}$

Most of the stage construction projects were in the West, the Prairie States and the South where traffic was light and roadbuilding was least advanced. The intention to build by stages was set forth in the project agreement, or contract between the Government and the State, and only a portion of the Federal share of the cost of the project was paid upon completion of the first stage; the rest was held back until the final stage was finished. As traffic increased, the State upgraded the initial construction with better surfaces, but these second stage projects did not become an appreciable part of the total Federal-aid program until about 1926, when 11 percent of all mileage improved was second stage. By 1933, however, 55 percent of the mileage was in this category.

The basic concept of stage construction was good, but it failed to take into account the enormous increase in vehicle ownership and road traffic that would occur during the 1920 's, or the rapid evolution in highway engineering. In the 5 years or so that elapsed between original and second stage construction, many States changed their ideas as to what were adequate or desirable standards. Instead of following the original plan for the second stage, they upgraded it, and in many instances made minor relocations to eliminate sharp curves.* Thus, the stage construction, or "wait and see" approach, resulted in abandoning some of the original construction, but also avoided premature investment in high-type work that would later have proved inadequate.

The stage construction policy accomplished its purpose which was to give the poorest portions of the Federal-aid system a modest improvement as soon as possible. This philosophy was well expressed by Chief MacDonald in his annual report for 1926 :

An exactly similar policy was followed by the builders of the railroads, whose first object was to 'get the traffic through, leaving until a later date the perfecting processes of ballasting, banking of curves, etc. It is the only satisfactory method of dealing with the conditions existing in many of the Southern, Middle Western, and Western States in which there are thousands of miles of main road still entirely devoid of any improvement whatever. $^{3}$

However, not everyone agreed with this policy, and some influential critics asserted that the Federal aid was being frittered away in low-grade work that would never handle the traffic. They pointed to the original Federal Aid Road Act of 1916 which re-

* By fiscal year 1933 these minor relocations had shortened the original locations by 237 miles or about 1.1 percent. 
quired that "The Secretary of Agriculture shall approve only such projects as may be substantial in character." To these critics MacDonald replied:

In interpreting the word 'substantial' the Secretary has taken cognizance of the fact that an improvement which is substantial for one density and kind of traffic may not be substantial for another. It has been recognized that the types of roads which it is desirable to construct in New York, Massachusetts and Pennsylvania are not suitable or necessary for Nevada, Idaho, and the Dakotas... the decision as to the type of road which the Secretary will approve for a given locality has been based in every case upon the traffic which is using the existing road and which it is estimated will use the improved road. The result is that the Secretary has approvel roads of all types and widths, from graded earth roads to concrete, brick, or bituminous concrete, narrow as well as wide; but the essential point is that in each case the decision has been based upon the best engineering judgment of the Federal Government and the several State highway departments, which between them employ the most highly capable highway engineers in the country. ${ }^{4}$

The 1916 Act permitted spending Federal-aid funds on practically any rural post road. Director Page and, later, Chief MacDonald tried to focus the aid on the main intercity and intercounty roads, but inevitably, because of the realities of local politics, a number of roads of only local importance were improved. These failed to pass the test for inclusion in the 7 percent system, but the States, under their contracts with the Government, were still obliged to maintain them. To relieve the States of this burden, the Government permitted them to pay back the Federal share of the cost of these roads and then turn them back to the counties for maintenance. This process began in 1924 and by 1933, 1,526 miles had been relinquished.

Stage construction was little used by the eastern and northern States. Their federal-aid mileage was already largely improved with dustless pavement, thousands of miles of which had been severely damaged by trucking during the war. Their problem was to reinforce their roads to carry heavy motor trucks, and for this they chose concrete or brick pavements, not only because of their generally excellent service during the war, but also because they were considered "permanent" and, therefore, suitable for bond financing. With a few notable exceptions, these costly new pavements were laid within the existing rights-ofway, and, thus, perpetuated the faults of poor alinement and grade that existed in the old roads.

\section{Getting the Traffic Through and Paying the Highway Bill}

Within 5 years of the debacles of 1920 and 1921, the States had increased their capacity for roadbuilding to the point where they were able to obligate $\$ 100$ million of Federal aid per year.* By 1929 they had improved 90 percent of the Federal-aid system, or about 170,000 miles, to some degree, at least, by adequate grading and drainage. A little less than half of this mileage, some 79,000 miles, was improved with Federal aid and State matching funds; the rest with State and local funds alone. ${ }^{5}$

This record was made possible not only by improved organization and management, but also by a rapid increase in the highway revenues of all the States. The increase was accompanied by a shifting of much of the highway tax burden from real property to the road user.

In 1921 there were 10.5 million motor vehicles registered in the United States, and the owners of these vehicles paid $\$ 122.5$ million to the States in road-user taxes.** This was about one-third of the total State expenditures for construction. The rest came from Federal aid and general State revenues.

* From fiscal year 1925 to fiscal year 1929, the regular Federal-aid appropriations were $\$ 75$ million per year, so this rate of obligation was possible only because of the unused backlog of appropriations from earlier years. This backlog was used up in 1928.

** The gasoline tax, first imposed by Oregon in 1919, was still a minor source of revenue in 1921, amounting to only $\$ 5.4$ million. By 1929 fuel taxes were $\$ 430.2$ million, or 56 percent of all revenues from road users.

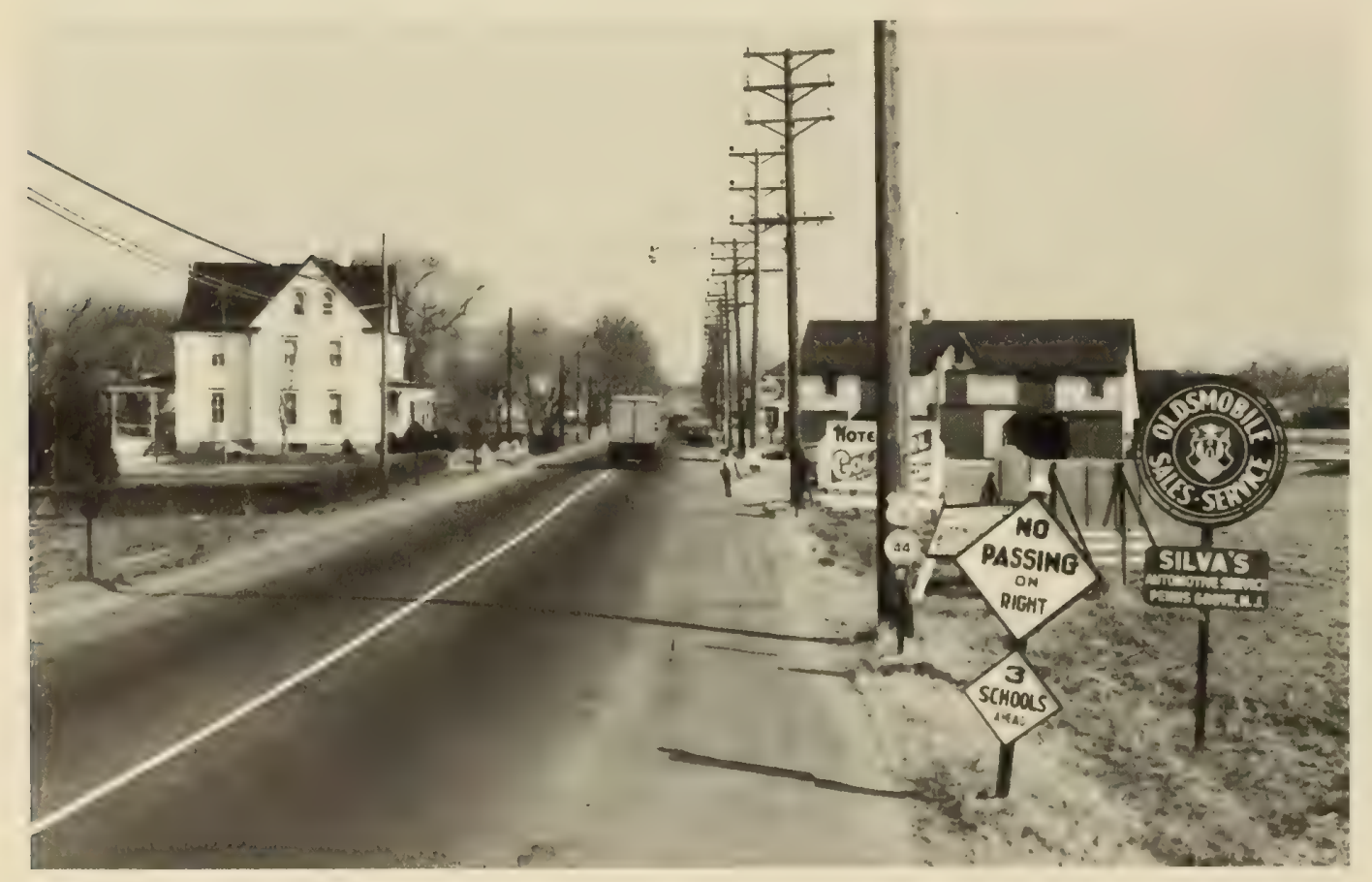

With more and more cars being sold, the automotive industry favorably affected the national economy by requiring more materials and services for the traveler and his car. 
By 1929 the number of vehicles had increased $2 \frac{1}{2}$ times, to 26.5 million, but State highway revenues had increased over 6 times, to $\$ 763.4$ million, and the percentage of the highway burden carried by road users had risen to over 99 percent. Actually, when Federal aid is considered, the road users paid about $\$ 81$ million more than the cost of building and maintaining the State highways. Some of this excess was spent for nonhighway purposes, but most of it was distributed as aid to the counties and townships. ${ }^{6}$

\section{Impact of the Motor Vehicle}

The period from 1921 to 1929 was one of rising prosperity, paced by the automobile industry which not only increased its production astonishingly, but also improved the vehicles while reducing prices. In the early 1920 's the industry introduced installment sales on a large scale and strengthened the secondhand car market. As a huge mass market for automobiles burgeoned, sales increased from 1.6 million units in 1921 to 4.0 million in 1923 and 5.3 million in 1929, valued at $\$ 3.4$ billion. Motor vehicle manufacture became a major industry which, in 1929, employed 471,000 people.

Automobiles affected the national economy in innumerable ways. They greatly expanded the market for steel, glass, rubber and fuel. Thousands of garages and service stations sprang up along the new roads to care for the motorists' needs. Auto touring had its impact on the travel business, spreading tens of millions of dollars throughout the country. New automobile factories, garages, tourist facilities and the large road and street programs helped to fuel the already imposing construction and business boom of the twenties.

The proliferation of motor vehicles also had its dark side. As millions of new drivers took to the roads, traffic accidents increased by leaps and bounds, their cost reaching nearly $\$ 1.3$ billion by 1929 . Highway fatalities more than tripled, from 10,723 in 1918 to 31,215 in 1929.7

On the streets of the larger cities, traffic congestion became unbearable. Police and city engineers tried frantically to keep traffic moving by instituting oneway street schemes, by developing automatic traffic signals and by assigning the right-of-way to arterial traffic with the innovative stop sign. One of the simplest and most effective measures for expediting traffic movement was by cutting back curb corners at intersections from the customary 4- or 5-foot radius to 12 or even 15 feet. This permitted vehicles to make right turns without swinging into the adjoining lane and greatly smoothed traffic flow.

With the increase in traffic and highway-related business, long "string towns" developed along the approaches to every city, and advertising signs by the thousands proclaimed the virtues of innumerable products and services to growing captive audiences. Because of these roadside activities, new highways became congested and dangerous within a few years of opening, creating demands for by-passes.

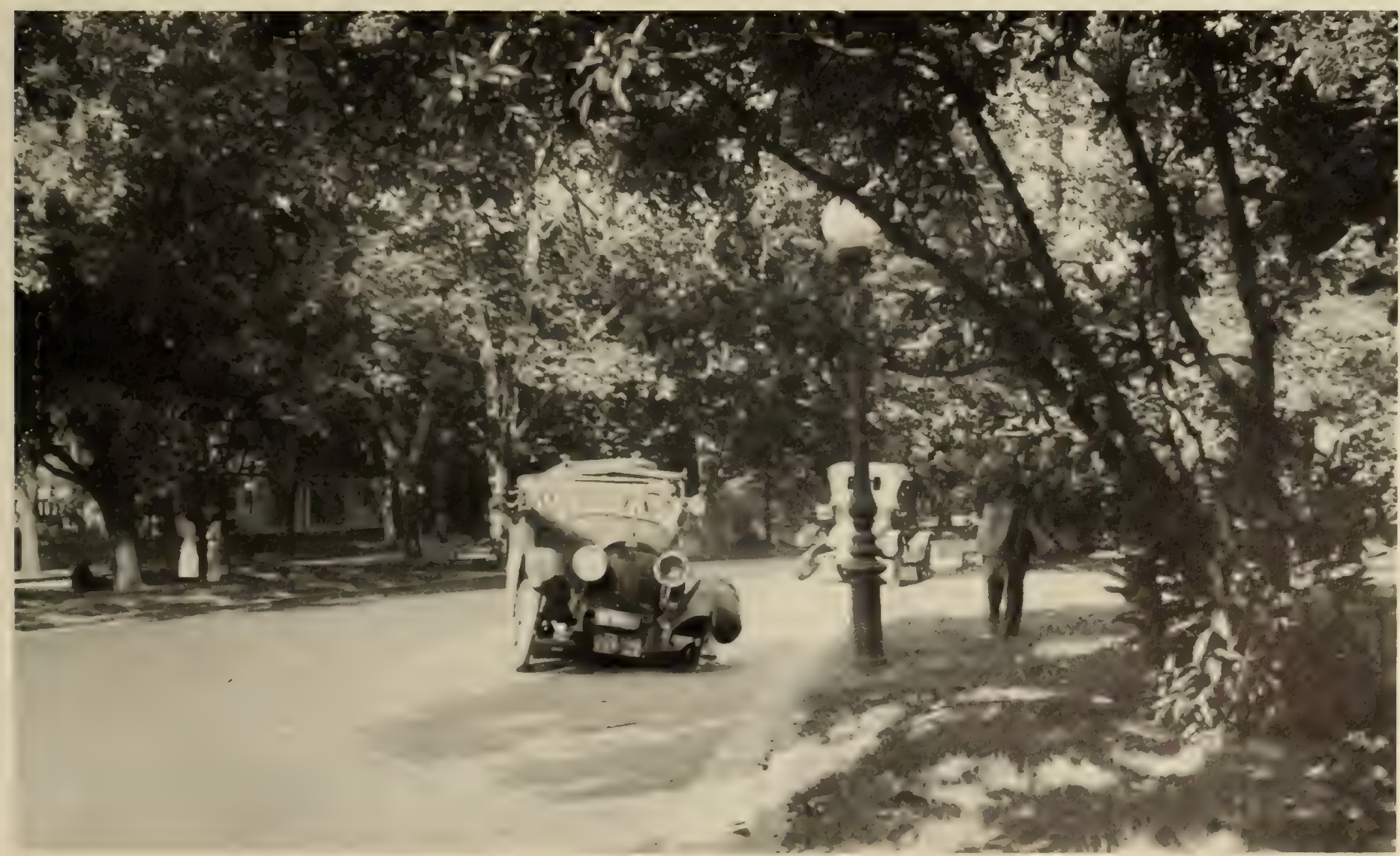




\section{The Private Toll Bridge Menace}

As interstate roads were completed and connected with each other, the growing stream of traffic attracted another class of highway parasite-the private toll bridge promoter. By 1928, private bridges were becoming a serious threat to the free use of the highways. In 1928 alone, Congress granted 75 franchises for private toll bridges over interstate waters and the States issued many others. Most of these were stock promotion projects, giving favored cliques a strangle hold for years on key sites on the main highway arteries on terms inadequate to protect the public interest.

Chief MacDonald spoke out against this trend at the 1928 AASHO meeting:

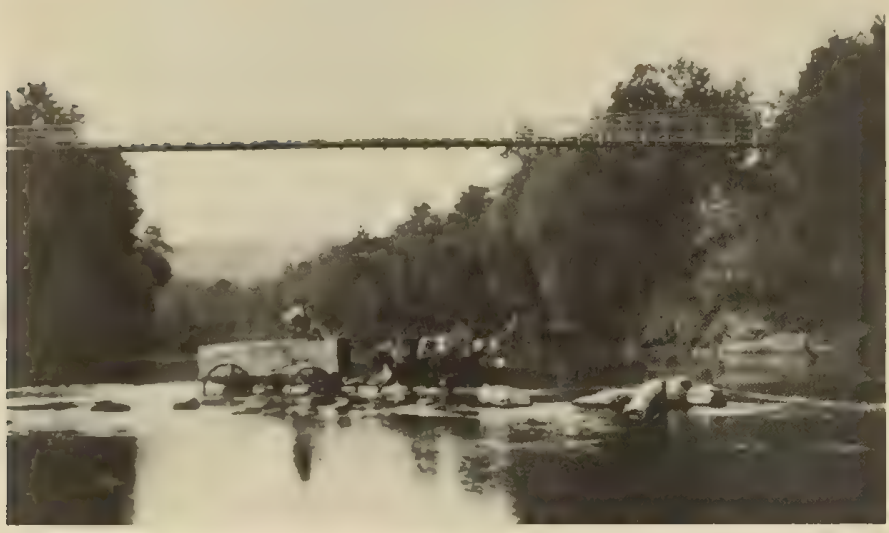

Private toll-bridge interests are becoming bolder and obstructing the public's business. They are attempting to defeat legislation unfavorable to themselves and are obstructing the efforts of highway departments to carry on State projects.

$$
\text { * * * * * * }
$$

There is much confusion in the public mind on this question. In all sincerity many have endorsed the private toll bridge franchise on the theory that it is desirable to have bridges, and if the public funds are not sufficient or available, rather than do without, it is better to grant a toll franchise to private interests. This is not the issue ... The real question is the very simple one of whether it is sound public policy to grant the right to collect a private profit from the user of the highway. The answer ought to be a vigorous and authoritative 'No.' There is no place on the public highway today for the privately owned toll bridge. ${ }^{8}$

MacDonald was not against toll bridges as such, but he thought they should be owned and operated by the State or other public authority and freed from toll as soon as the bonds were paid off. This type of financing had been provided for by Congress in an act approved March 3, 1927, which permitted Federalaid funds to be used on publicly owned toll bridges on the Federal-aid system. Such financing had also been adopted by the Port of New York Authority for four monumental and costly bridges, including the immense George Washington Bridge over the Hudson River.

Farmers in Paneytown, Ark., ford stream to avoid the fee on a private toll bridge.

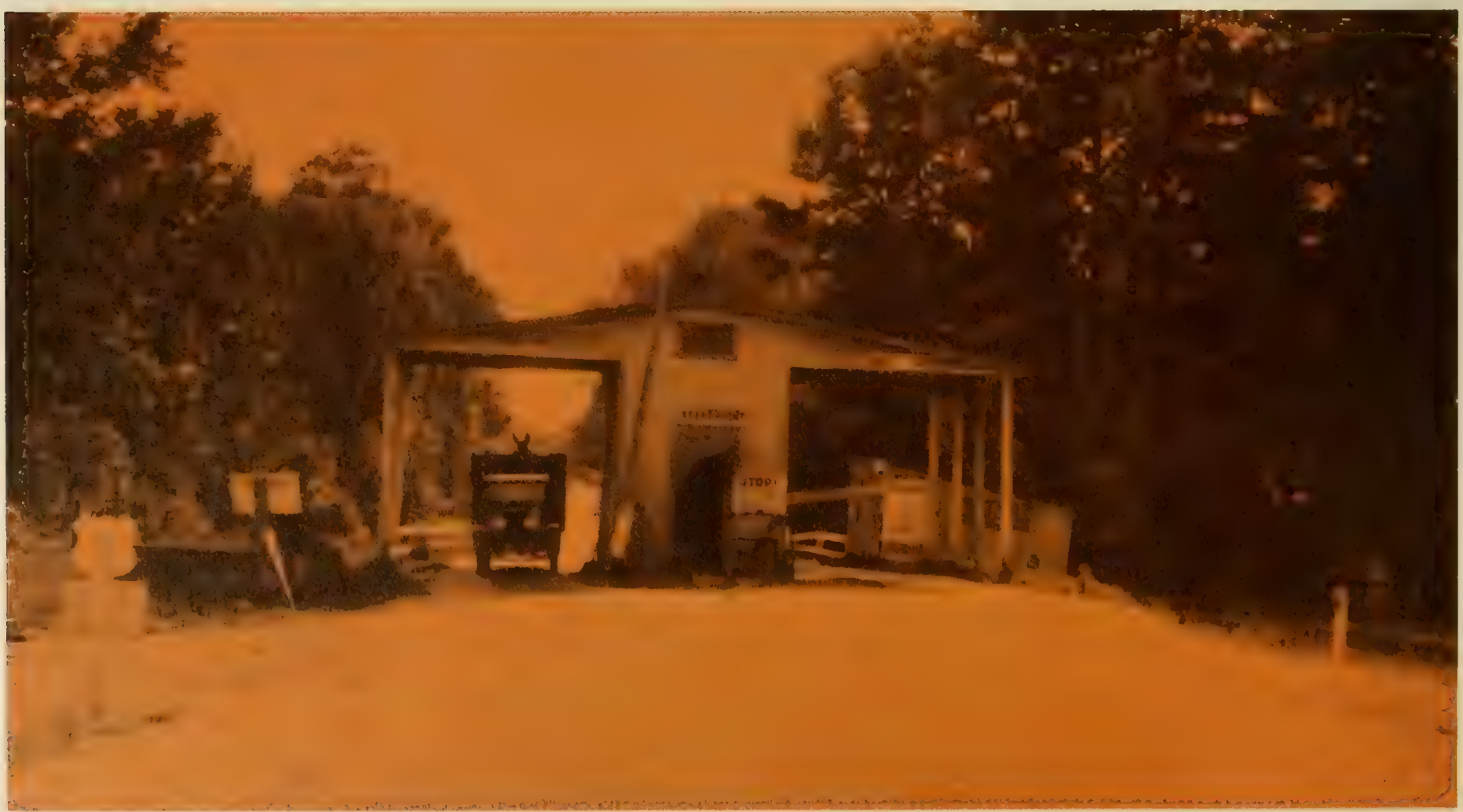


Chief MacDonald also warned of another threat to free highways in the possible resurgence of the private toll road, for which the Italian autostrade were the current models. These roads had been built in the early 1920's on private rights-of-way, with limited access, and were for automobiles only. The bonds were guaranteed by the Italian government. MacDonald said :

The motor road on a closed right of way takes on the characteristies of a railroad. A highwas cannot be so transformed and continue to serve in a universal way....

If de luxe service roadways to a limited extent are needed on private rights of way their development should be, undertaken by the existing railways, not in competition with them. Much harm without compensating benefits will otherwise result. Once let franchises be granted to private interests with the necessary power of eminent domain, and inconceivable harm would result to the financial structure of the railways in that area.

\section{Railroads Versus Highways}

The steam railroads experienced a remarkable recovery from the postwar doldrums in 1921.* Even so, their net operating revenue for that year returned them only 3 percent on their investment-not enough to cover fixed charges. ${ }^{10}$ Some railroad executives blamed the failure to make a better showing on truck competition, which, they claimed was "subsidized" by the free use of public highways paid for, in part at least, by the railroads' own property taxes. Some railroads mounted a publicity campaign to protest the "unfairness" of this subsidized competition, and their arguments were given some substance by President Harding's December 1922 address to Congress in which he said that motor haulage would be wasteful if burdened with its proper share of the highway cost. ${ }^{11}$

However, there were realists in the railroad industry who realized that trucks and improved highways had come to stay and that the railroads would have to accommodate them. One executive said flatly that low-volume unprofitable branch railroads should be replaced by truck lines and that trucks could help the railroads by collecting and delivering carload freight for long hauls. ${ }^{12}$ In the east a number of railroads made determined efforts to reclaim the short-haul business from the trucks, but these efforts were only partly successful. Practically all hauls under 30 miles were gone for good, but the railroads were able to get back a good part of the over-70-mile business, at least temporarily.

For the electric railroads, highway competition was disastrous and eventually fatal. In the early 1920's, few States regulated buses as common carriers, and bus and stage lines sprang up by the hundreds, competing fiercely with each other for business.** These

* The Government returned the railroads to their owners in 1920 .

** There was a short-lived parallel trend in the cities where unregulated "jitneys" made huge inroads into street railroad revenues with their flexible routings and cut-rate fares. The usual fare was 5 cents, or "one jitney" in current slang, hence the name. Jitneys were clearly in violation of the traction companies' charters and were eventually outlawed by most cities, along with competing intracity buslines. operated over most of the roads radiating out from the cities, reaching hundreds of rural families who were not served by the electric railroads. However, many buses ran in direct competition with the interurban lines on parallel roads, carrying both passengers and express.

By 1923 interurban buslines were operating pneumatic-tired vehicles that would carry 30 passengers and some even 60 passengers in relative comfort at fares of about 4 cents per mile, which closely approximated the rates charged by steam and electric railroads. For the convenience of both passengers and buslines, the business interests in many cities, small as well as large, organized terminal associations to provide waiting rooms and other terminal facilities for the convenience of the public. ${ }^{13}$ Through competition between themselves and financial mergers, the buslines rapidly became formidable competitors of both the steam and electric railroad lines for passenger traffic, and by 1930 most of them were placed under State regulation as common carriers.

Buses were not the only competitors for passenger traffic. Rapidly increasing motor car ownership was equally damaging to the railroads, and by the end of the 1930's, most of the electric railroads were in receivership. So rapid was the obsolescence and decline of this form of transportation that some of these were only 20 years old when they ceased operation.

\section{Heavy Trucks Shake the Foundations of Highway Engineering}

Up to 1917 , the main problems of highway engineers were financial, not technological. Roadbuilding was an established art practiced essentially according to the precepts laid down by Trésaguet, Telford and McAdam more than a century earlier. The principal innovation, and perhaps the earliest application of research to roadbuilding, was the successful development of bituminous surfaces in the early 1900's to combat dusting. The roads built prior to World War I were narrow and thin, but they were adequate for automobiles and farm vehicles.

This feeling of technological well-being came to an abrupt end in the spring of 1918 with the widespread failure of roads of all types under heavy trucking. Prevost Hubbard, the BPR's chief chemist and expert on bituminous pavements described the disaster as follows:

\begin{abstract}
Hundreds of miles of roads failed under the heavy motor-truck traffic within a comparatively few weeks or months. Roads with bituminous surfaces, bituminous macadam roads, and bituminous concrete roads all failed alike, together with other types used in State and county work. These failures were not only sudden but complete, and almost overnight an excellent surface might hecome impassable... A very large proportion of the failures have been characterized by an almost simultaneous destruction of the entire road structure, and not merely the disintegration of the wearing course or pavement proper. ${ }^{14}$
\end{abstract}

Director Page made the investigation of these massive failures his first order of business for 1918. He sent the OPRRE experts into every part of the country to investigate and report. Highway Engineer J. L. Harrison found two kinds of failure in Illinois 


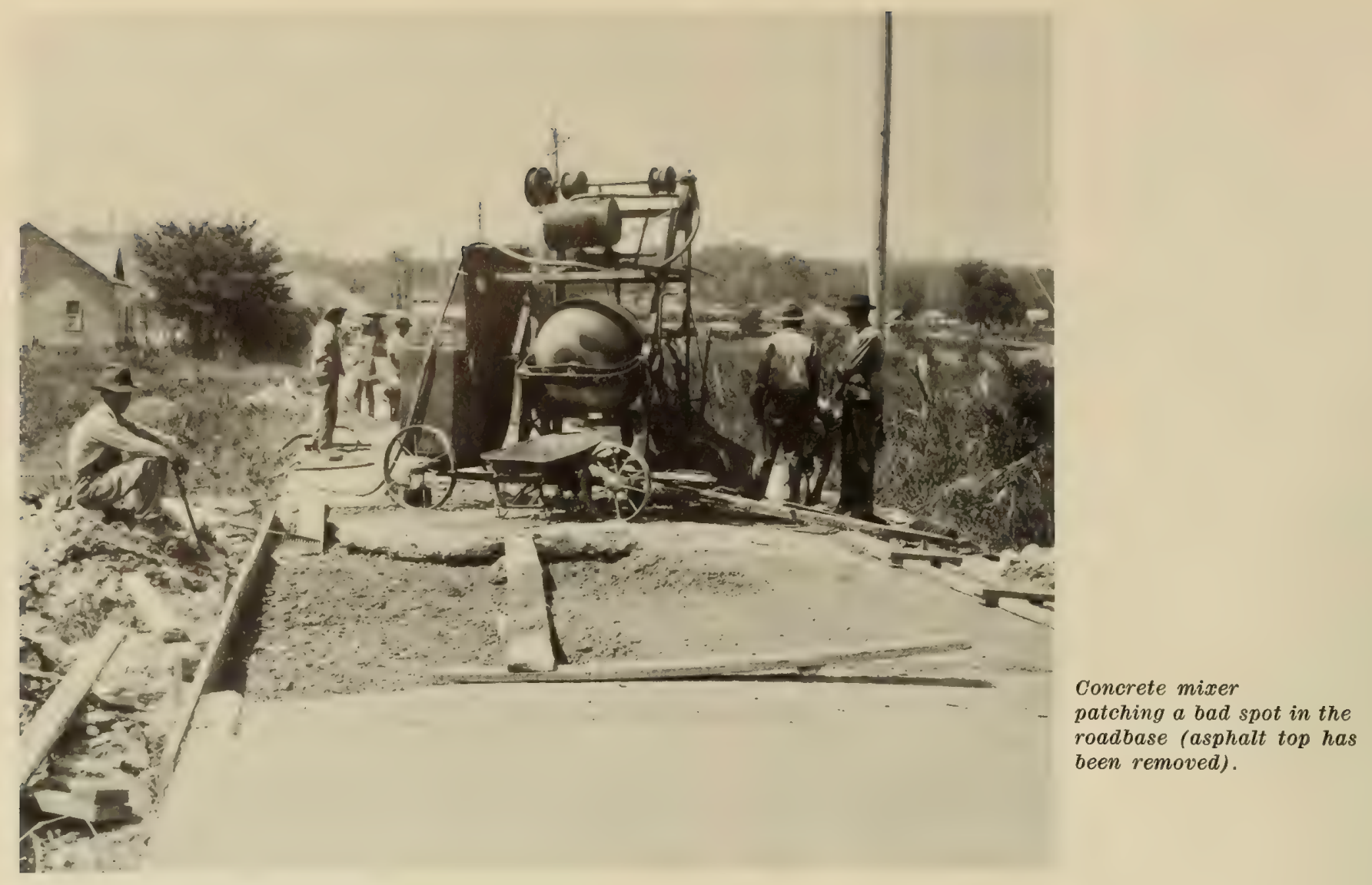

and Ohio. One was failure of the base due to overloading of a frost-softened subgrade, such as Hubbard described, resulting in sudden and complete failure. The other was internal failure of macadam bases due to pressures high enough to crush the stone particles. Harrison found failure by internal crushing in macadam bases as thick as 18 inches near Chicago. In Wayne County, Michigan, he found that thin concrete pavements had broken up so badly that they had to be resurfaced, but that those which were made 7 or 8 inches thick had withstood heavy trucking with little damage.

Albert T. Goldbeck and F. H. Jackson of the OPRRE's Division of Tests found that brick roads on concrete bases in Ohio, Illinois, and Indiana had stood up well except where the underlying earth foundation had become softened due to poor soil or poor drainage.

All investigators agreed that pavements on sandy, well-drained soils had given much better service than those on clay soils, especially at places where drainage was poor because of inadequate ditches.

The most significant observation of all was by Harrison who noted that hundreds of pavement failures were obviously due to moisture softening clay soils, yet the shoulders had adequate slope and drainage was excellent. Some failures were on low fills where there was no possibility that surface water could have penetrated to the subgrade. Harrison concluded that these failures were caused by "nongravitational water," that is, water held in the soil by capillary attraction. Not only would such soils not drain by gravity; they would actually take up more water from below by capillary action due to their fine pore structure. He also declared that any theory of design (such as McAdam's) that held that soils under a pavement could be kept dry by an impervious covering was fallacious, and therefore only soils that do not lose their strength when wet, such as gravels and sands, should be used there.

\section{How to Manage the Behemoth}

The widespread destruction of the roads by trucking inspired angry demands for limits on the weight of vehicles, and for crushing taxes on trucks to make them "pay their fair share" of the maintenance bill. However, the more thoughtful leaders, such as Delaware's influential chief highway engineer Charles Upham, warned that the motor truck was not just a wartime phenomenon, but would be around for years after the war was over. ". . . the motor truck," he said, "which has been developed during abnormal times has shown that it has solved an economic problem, and this solution assures us that ... the heavy truck will be utilized for transporting freight and express within expanding limits. Therefore, ... we must build and maintain in such a way that our roads will withstand, as permanently as possible, the demands of the future heavy truck traffic." 15

Upham's viewpoint was shared by most of the State highway department heads, but none of them had a clear idea of how truck traffic might develop or how to deal with it. However, they agreed completely that legal limits must be placed on the weight of the vehicle and its load, and that without such limits there would be no way to protect the rural roads from destruction. There was a general consensus that the 5-ton capacity truck was the largest that should be allowed on the rural roads, although about 15 percent of the trucks then in existence were of greater ca- 


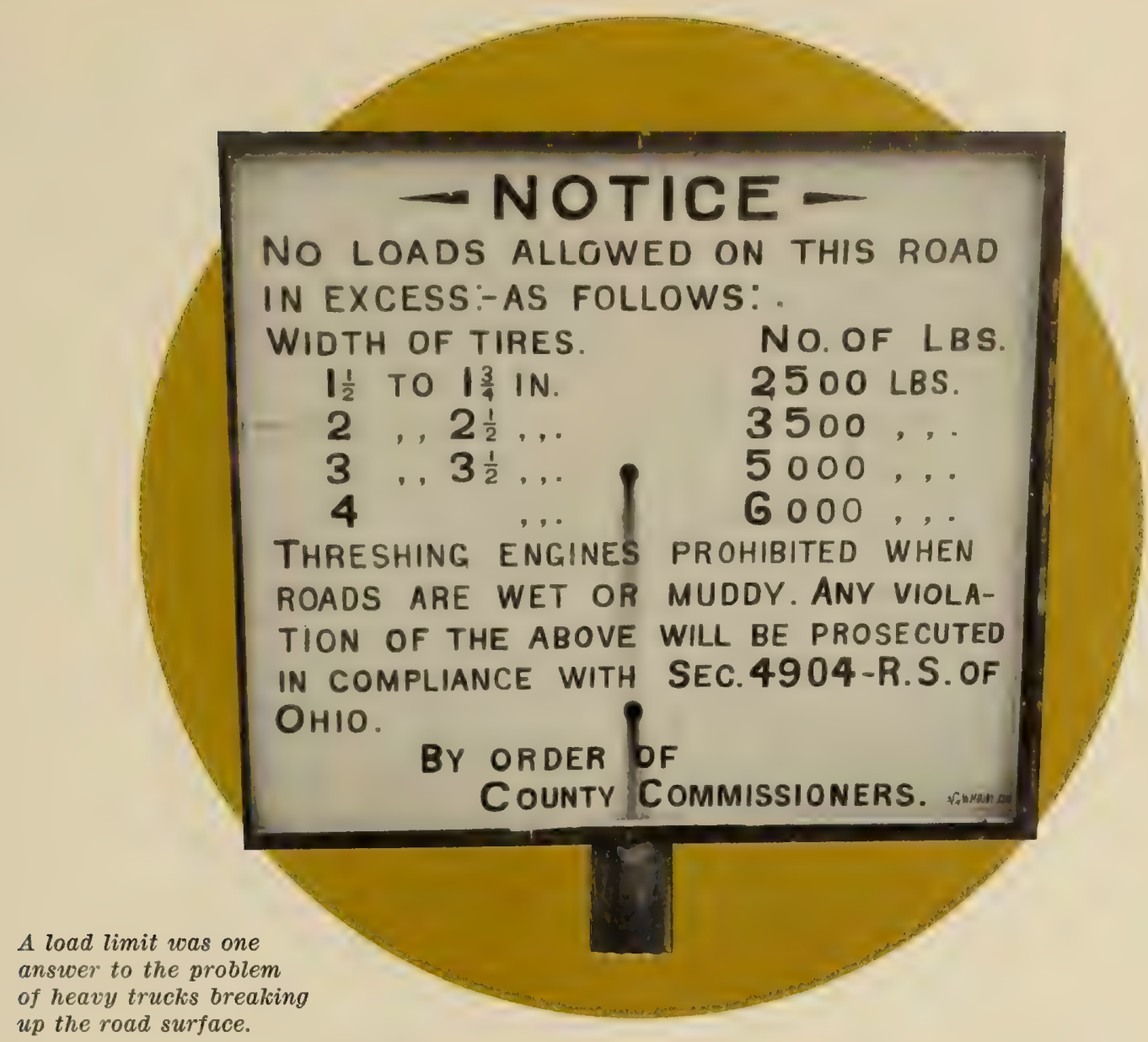

pacity than that.* A few States had already set weight limits that would permit net loads up to about 7 tons and were planning to strengthen their roads to carry these loads.**

Spokesmen for the infant trucking industry urged the States not to strangle trucking by imposing unrealistically low weight limits. George Pride, President of the Heavy Haulage Company of New York City, spoke out against the 3-ton limit advocated by several States, which, he said, would increase hauling costs by 20 percent, as compared to hauling in 5-ton or larger trucks.

\begin{abstract}
... either directly or indirectly, the ultimate consumer pays the cost of all transportation of the commodities he uses. If the cost of transportation is lessened by the motor truck, he gets the benefit of the decrease; or, conrersely, if it should be increased by unduly restrictive legislation, he would be penalized to the extent of the added expense.
\end{abstract}

Pride recommended that gross loads of 28,000 pounds on four wheels be permitted and also that

* For example, in 1917 there were 55,401 trucks registered in New York, of which 8,895 , or 14 percent, were of 6 or more tons capacity. Of these, 3,319 could carry 10 tons or more. ${ }^{16}$

** The limit in New Jersey was 30,000 pounds gross. Maryland permitted 7 -ton trucks to operate but imposed a license tax of $\$ 500$ on them, compared to $\$ 60$ for a 3-ton truck. Connecticut restricted gross loads to 25,000 pounds on four wheels. tests be made by an impartial committee to ascertain the real damage caused by trucks to the roads. He also warned:

Whatever may be the immediate limit placed upon the motor truck, it is my judgment that it must not be considered final. We are on the eve of vast developments, and requirements of the future will demand greater weights, better and different types of road beds, reduced grades, etc. ${ }^{18}$

In April 1918, the Engineering News-Record declared that the economic and engineering problems brought on by trucking should be faced squarely and not postponed:

... highways have never been investigated with the thoroughness that is necessary to prove their right to rank with the railroad or the waterway as a transportation agency .... We are faced at the outset, then with the question whether it will pay to build better and costlier roads than any yet contemplated; whether it will pay to adopt the trailer idea ... or whether the pneumatic tire, now being developed by at least one company for the heaviest loads, will not in the end prove the solution. ${ }^{19}$

As long as the country was at war, little could be done on engineering and economic investigations. However, the truck problem received a high place on the agenda for the Joint Highway Congress held in Chicago in December 1918. By resolution, that body not only recommended a thorough investigation of motor truck regulations and limitations, but also urged the States to undertake experiments on different types of pavements to develop basic engineering knowledge. The Congress, which was dominated 
by urban and industrial interests, also recommended that gross loads of 14 tons be permitted on the highways provided the load per inch width of tire did not exceed 800 pounds.*

\section{Launching a National Highway Research Program}

The matter was brought to a head in August 1919 by Thomas R. Agg, Testing Engineer of the Iowa State Highway Commission, who wrote in an article for Public Roads magazine :**

During the past 10 years, the transition from horsedrawn to motor traffic has been so nearly complete that horse drawn-traffic can no longer be considered a controlling factor in highway design; yet practically all of the basic principles of highway construction were evolved for horse-drawn traffic. These have been modified from time to time as experience has indicated defects, but for the most part local conditions have been so large a factor that types and designs which have been satisfactory in

* The 800-pound figure was recommended by tire manufacturers as the maximum economic loading for solid truck tires. Heavier loads would, they said, cause crushing of the rubber and premature failure by fatigue. At this time the widest tire manufactured was 14 inches, so the maximum load that could economically be carried by a two-wheel axle was 22,400 pounds. $^{20}$

** Public Roads was an official publication of the U.S. Department of Agriculture. It had been launched in May 1918, by Logan Waller Page as a vehicle for exchange among the States of information on methods for financing, building, and maintaining roads. By 1919, Public Roads was an important voice for the highway engineering profession and also, in effect, the journal of AASHO, which did not have its own publication, American Highways, until 1922 one State have proven entirely unsatisfactory in another. ...

It seems imperative that investigation in the field of highway engineering be prosecuted with the utmost vigor during the next few years, else it will be found that much of the money expended for highway improvement has not secured highways of the maximum serviceability because the design and the requirements for materials were based on unsound theories or inadequate tests. ${ }^{23}$

Agg then urged that the Bureau of Public Roads take the lead in a national program of highway research:

The bureau has already done a large amount of research work in this field and has trained investigators for carrying on the work and for passing on projects submitted for action ... But most important of all, the bureau is in close touch with the highway work in the various States and is in a position to judge as to the problems most imperative of solution and to secure the assistance of the State highway departments in those problems requiring the actual construction of surfaces or structures. ${ }^{22}$

In a companion article, A. R. Hirst, President of AASHO, not only endorsed Agg's proposal but pledged AASHO's support "for this very great and necessary work."

I agree thoroughly with Mr. Agg in his statements that the present facilities for highway engineering investigations are not adequate to meet the situation, or to develop the theories upon which the future science of highway engineering should be based.

It is to my mind certain that unless the United States Bureau of Public Roads builds up a good and extensive organization to prosecute these inquiries, that nothing of value can or will be done by any other existing organization. ${ }^{23}$

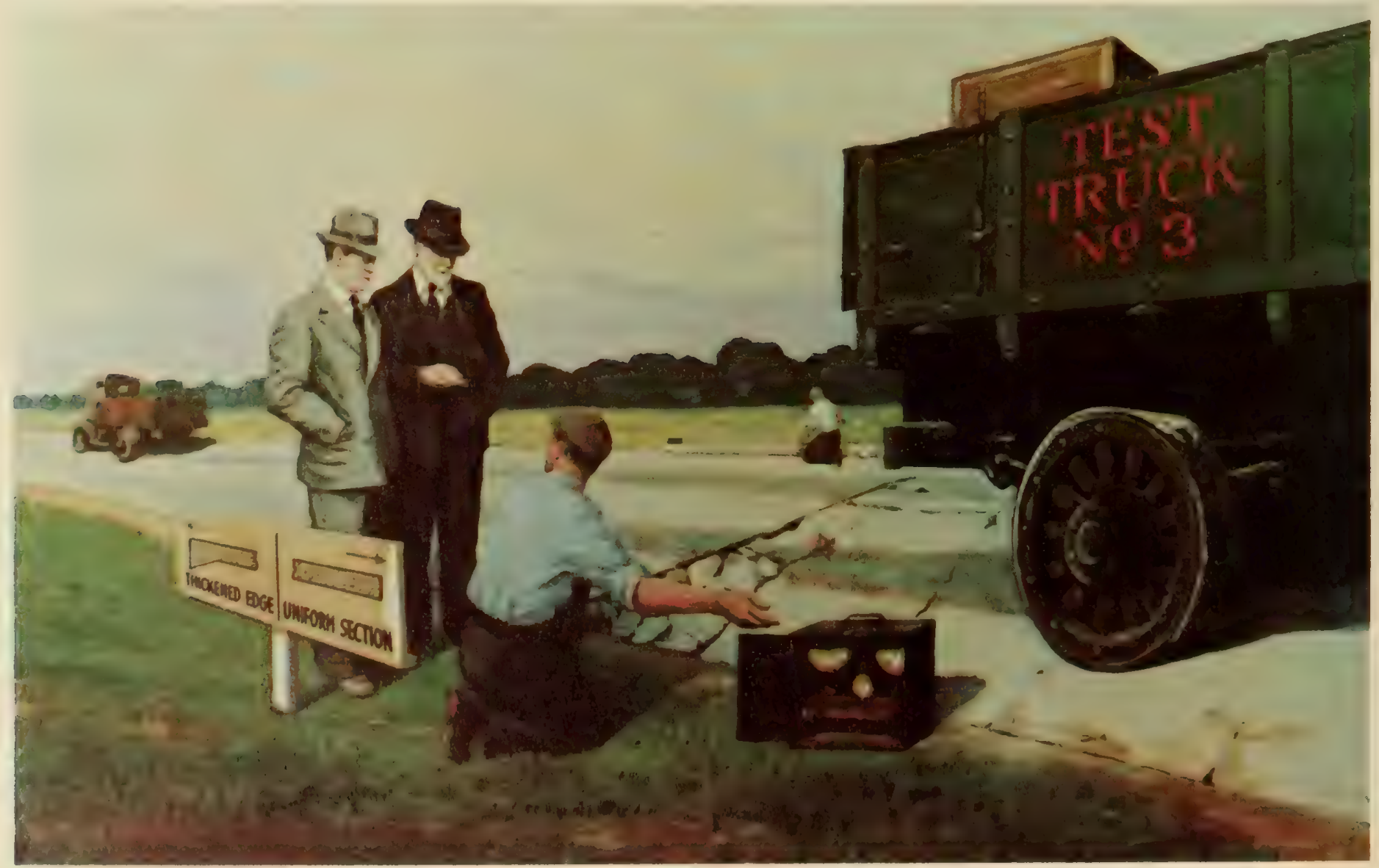


Agg's and Hirst's appeal set the stage for a series of events that resulted in the formation on November 11, 1920, of the National Advisory Board on Highway Research, under the auspices of the National Research Council of the National Academy of Sciences. This Advisory Board was conceived as a means of bringing together in a coordinated national research program all the various agencies and organizations involved in highway transportation and highway research. The organization of the Board was completed July 1921 with the appointment of Dr. W. K. Hatt of Purdue University as Executive Director.

As his first job, Director Hatt prepared a list of 19 "fundamental questions in highway transport," which, he said, could not be answered without data that then were unavailable. A few of these questions, listed below, illustrate the extent of the current ignorance of fundamental highway problems:24

- What is the economical highway track unit for each of the several situations, e.g., intercity, farm to market?

- What is the cost of transport arising from the vehicle and from the road?

- What type of road paving should be selected for a specific transport unit?

- How should the design of the road and paving be modified to meet changing conditions of subgrade, climate, etc.? How shall subsoils be improved?

- What sum of money is the locating engineer justified in spending to avoid increase in distance, curvature, rise and fall, maximum grade, maximum curve?

- What is the capacity of a road of given width as expressed in vehicles per hour, ton-miles per year, etc.? What is the appropriate unit for expressing traffic for various purposes?

- How can the volumetric changes in roads be overcome?

- What is the economic life of various types of roads?

- What police regulations should control the use of roads?

- What principles should govern the selection of a system of roads in its various parts, as influenced by interstate, intrastate, county or local traffic?

- To what extent do social betterment, military use, i.e., social value, and other imponderables enter into highway policy?

- How shall safety be ensured on the roads?

Hatt posed these questions at a meeting of educators and industrial leaders held at the University of Maryland in August 1921 and urged "a mobilization of the efforts, of research agencies in a comprehensive program," adding that the National Research Council would be glad to coordinate the research but would not engage in research directly. ${ }^{25}$

At this time the Bureau of Public Roads was the only research organization that was prepared to immediately begin work on a large-scale research pro- gram, and, in fact, it was already working on some aspects of the program. The BPR had 13 major studies underway in the field of physical research and its research budget was about one-third of the total national expenditure on highway research.* Chief MacDonald took the lead in the national program by expanding the BPR's in-house activities and also by entering into cooperative research agreements with State highway departments and universities.

\section{The Fruits of Research}

Throughout the 1920's, with two notable exceptions, the brunt of the research effort fell upon the Bureau, primarily because it had the only large assured income available for the costly studies that were required.**

For about 5 years, the investigators concentrated mainly on soil and pavement research to provide immediately usable information to guide the vast paving programs that were already underway. As a result of these studies, all States stopped using thin, that is, 4- and 5-inch pavements and they rapidly adopted a 20 -foot minimum width for main road pavements.*** One of the major fruits of the research program was a rational method of analysis proposed in 1925 by Professor H. M. Westergaard of the University of Illinois, which removed much of the guesswork from slab design.

Out of the BPR soils investigations there came a practical system for classifying soils into eight groups based on physical properties that could be measured by simple laboratory tests. This was a tremendous step forward, for it enabled the researchers to relate pavement performance to measurable soil properties and, ultimately, to predict in advance of construction the type and depth of pavement that might be required for any field condition.

* In 1920, 22 State highway departments spent about $\$ 175,000$ on research and 21 colleges and universities about $\$ 150,000$. In addition, the BPR spent about $\$ 150,000$. $^{26}$

** The two exceptions were the Bates Experimental Road, financed by the Illinois Division of Highways, and the Pittsburg, California, Test Track built by the Columbia Steel Company with private funds.

The Federal Highway Act of 1921 authorized the Secretary of Agriculture to deduct up to $2 \frac{1}{2}$ percent of all Federal-aid appropriations for administering Federal aid "and for carrying on necessary highway research and investigational studies independently or in cooperation with the State highway departments and other research agencies..." From 1922 to 1932 the sums so set aside amounted to $\$ 1.87$ million per year, of which probably one-half went into research. By contrast, the States were unable to use Federal-aid funds for research, because the Government's policy was to approve the use of these funds only for construction.

*** The Bates and Pittsburg Tests showed that narrower pavements channeled traffic near the edges and caused ex cessive corner and edge breakage. In 1928 the AASHO recommended in its first published road standards that the minimum width of one traffic lane be 10 feet. Other considerations, such as safety and freedom of maneuver at higher speeds, also entered into this recommendation. AASHO also recommended a minimum thickness of 6 inches for concrete parements and the strengthening of all unsupported pavement edges in its 1928 standards. ${ }^{27}$ 


\section{Highway Planning Begins}

In 1920 the Bureau of Public Roads began a series of "transportation surveys" in cooperation with the States, and in a few instances, with counties and cities as well. In all, there were 16 investigations extending over a period of 16 years. Twenty States were involved at various times with the BPR in the studies.

The first surveys were essentially traffic censuses to help the cooperating States select their 7-percent Federal-aid systems. Gradually, the studies became more and more research-oriented, and by 1925 the BPR and the States were looking into every aspect of highway transportation: the ownership of motor vehicles; the seasonal, monthly and daily variations in traffic; the types of vehicles using the roads; the origin and destination of cargoes; the size and weight of trucks and the kinds of tires they ran on, and whether they were overloaded. In the later studies, they examined driver behavior-the average speeds of drivers traveling freely on the highway and their observance of traffic laws, such as those prohibiting passing on hills and curves.

In Maine, the researchers discovered a historical relationship between vehicle ownership, population and traffic. By projecting historical trends ahead, they were able to make fair estimates of traffic 5 years in the future. From these predictions, the investigators placed the highways in priority groups according to traffic density, the amount of future truck traffic, and need for improvement. Finally, they suggested improving the deficient mileage to an adequate standard for the 5-year future traffic, financing the improvements with either a bond issue or an increase in the gasoline tax. ${ }^{23}$ Following the Maine study, this

Maryland State Roads Commission testing laboratory.

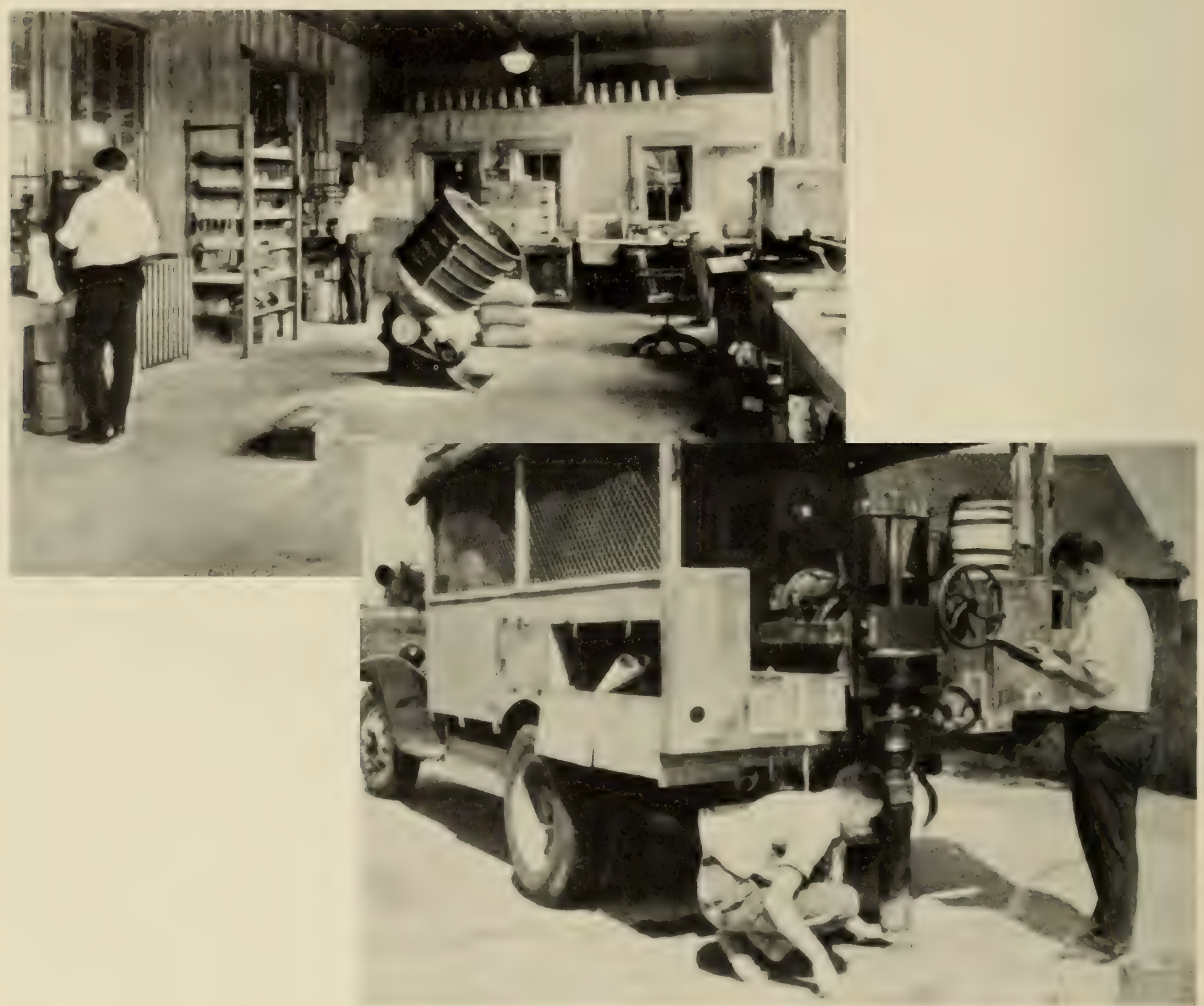

Core drilling outfit taking test cores. 
kind of analysis was applied with increasing sophistication and accuracy in other States. A major improvement was the substitution of gasoline consumption for population increase as an indicator of future traffic growth.

The Cleveland Regional Area Traffic Survey of 1927 brought all levels of government-Federal, State, county and city-together for the first time in a concerted study of the traffic problem in a single metropolitan region. The BPR which paid half of the cost of the survey, agreed to participate only on condition that the study be areawide without respect to political boundaries and that it lead to a general highway plan for the region. The study actually resulted in a 10year improvement plan costing $\$ 63$ million - a budget well within the capability of the region. The report of the survey ended with a note of caution which was to be a guidepost to future planners:

Traffic conditions, however, are constantly changing, and the recurrence of present conditions can be prevented only by careful and far-sighted planning based on a definite knowledge of these changing highway and traffic conditions. Proper highway planning must be a continuous process, based on a continuing series of facts in order that the constantly increasing traffic demands may be foreseen and met with improvements as required. ${ }^{20}$

\section{The Highway Boom Continues}

A decade of unprecedented national prosperity ended in 1929, although signs of a slowdown had appeared earlier. The building industry, which had been in slow decline for 2 years, went into a slump early in 1929. By late summer the building-related industries-steel, cement, lumber-were curtailing production. Automobile sales began falling, but the industry, in a runaway boom, produced $5,337,087$ vehicles, a record not to be equaled for 20 years. $^{30}$

After the stock market collapse of October 1929, deflation gained momentum as factory after factory reduced production. With a huge unsold backlog of 1929 cars hanging over the market, the auto industry cut back to 3.36 million units in $1930,2.38$ million in 1931, and 1.33 million in 1932 and laid off thousands of workers. ${ }^{31}$ Nationally, unemployment increased from 1.5 million in 1929 to 12 million in 1932 as the gross national product dropped from its 1929 high of $\$ 104$ billion to $\$ 58.5$ billion in 1932 .

Throughout this massive deflation, roadbuilding held up much better than other kinds of manufacturing. During the "Roaring Twenties," the States built up their roadbuilding capability to the point where they could obligate $\$ 100$ million of Federal aid per year. This rate exceeded Congress authorizations and was possible only because of the backlog of unexpended funds from the early years of the program. By 1928 this backlog was exhausted and the States began to cut back their programs to fit the authorizations, which were only $\$ 75$ million per year. The slowdown became apparent in fiscal year 1929, when the completed Federal-aid mileage that year (initial construction plus stage construction) fell to 9,386 miles from its 1928 level of 10,174 miles, and it carried on into fiscal year $1930 .^{32}$

After the 1929 crash, Congress, at the President's request, sought to bolster the sagging economy by authorizing large sums for public works, including highways. The authorization of April 4, 1930 (46 Stat 141) increased the regular Federal aid for fiscal year 1931 by $\$ 50$ million, to a total of $\$ 125$ million, and authorized \$125 million per year for 1932 and 1933. The Secretary of Agriculture apportioned the new 1931 funds immediately and also made the 1932 apportionments available for use in September 1930, instead of December, as in the past. This action made $\$ 175$ million of Federal funds immediately available, which was more than many States were able to match, principally because their legislatures were not in session to make the matching appropriations and would not meet until January 1931, or later.

Congress met this situation by appropriating $\$ 80$ million to be apportioned among the States in the same manner as Federal aid and to be used to match the regular Federal-aid apportionments. These funds were really advances to the States, not grants, and were to be repaid by deduction from the regular Federal-aid apportionments over a period of 5 years. Further, Congress required that all of these emergency funds be obligated by September 1, 1931.*

The States responded to this stimulus with commendable promptness. By June 30, 1931, they obligated $\$ 55$ million of the emergency money and by August the entire amount, along with most of the regular Federal aid. Completed initial and stage construction jumped to 11,033 miles, and in 1932 it went far beyond that, to 15,997 miles.

In a small way, this highway construction helped to stabilize employment, particularly winter employment for farmers who had been hard hit by severe drought in 1930. Chief MacDonald reported that the early authorizations and the emergency loans had boosted employment on Federal-aid highway projects from 30,944 men in January 1931 to 155,466 in July 1931, while the total of all Federal and State highway employment that month was 385,349 men. ${ }^{33}$ However, the stimulation was short-lived and by July 1932, total highway employment was only 305,372 persons. ${ }^{34}$

\section{Diversion of Highway Revenues-A Thorny Issue}

In the early years of the Depression, there was a precipitous drop in the collections from income and property taxes. Personal income was down and destitution was widespread. Millions of people lost their life savings in the stock market crash and the wave of bank failures that followed. Drought and low agricultural prices wiped out tens of thousands of farmers who lost their farms by foreclosures and tax sales. The resulting shortfall of revenue was felt with particular acuteness by the counties and townships which had traditionally depended on property taxation for the support of schools and local roads.

Surprisingly, road-user revenues were remarkably stable. Motor vehicle registrations increased slightly in 1930 as compared to 1929 , reaching the peak of an

* Emergency Construction Act of December 20, 1930 (46 Stat 1030). The Hayden-Cartwright Act of June 18, 1934, converted these loans into outright grants. 
uninterrupted rising trend extending back to the invention of the automobile.* To millions of owners, the automobile was no longer a luxury but a necessity of daily existence, and sometimes gasoline came ahead of food and clothing in the family budget. The 1931 receipts from vehicle registrations and fees were only 6.7 percent below 1929, and in 1932 the yield dropped another 1.9 percent. These were insignificant losses compared to the massive deficiencies in other public revenues. The shrinkage of $\$ 26.9$ million per year in revenue from registrations and fees was more than made up by a whopping $\$ 55.5$ million increase in the annual yield of the fuel tax which, with registrations, gave the States an annual highway revenue in addition to Federal aid of $\$ 807$ million in $1932 .{ }^{36}$

This huge revenue was an irresistible magnet to hard-pressed legislatures. In the words of one commentator, ". . . the motor tax has become a big red apple within easy reach, viewed with slavering lips by every agency of government." ${ }^{37}$ In 1932, 16 States "diverted" $\$ 82.8$ million of road-user revenue to nonhighway purposes, over one-half of this by New York. Diversions increased to $\$ 145$ million in 1933 and $\$ 164$ million in 1934; and in the decade from 1930 to 1939 they totaled the huge sum of $\$ 1.25$ billion. ${ }^{38}$

Diversion of highway funds to nonhighway purposes began before the Depression but did not become a real detriment to the highway improvement program until about 1930. In 1916 six States diverted their entire receipts from motor-vehicle fees-some $\$ 700,000$ - to nonhighway purposes. When the gasoline tax became popular, diversions increased, until by 1924 they were about $\$ 10.7$ million nationwide. By this time, motorists, the automotive industries, and the good roads supporters began to be alarmed by the trend. In 1928 they had enough influence in Kansas and Missouri to push through constitutional amendments prohibiting diversion of highway revenues.

Its opponents argued that diversion was unfair because it saddled one class of taxpayers-the motorists-with more than their fair share of the general expenses of government. The author of Oregon's pioneering gasoline tax law said, "We might as well tax sugar to build roads as to tax gasoline to run the government." " 39 In particular, diversion penalized lower income families, hundreds of thousands of whom were totally dependent on automobiles and buses to get to work and back again.**

However, the most telling argument against diversion was that it was self-defeating as a means of fighting unemployment. In $1932 \mathrm{~J}$. L. Harrison of the BPR traced the employment generated by the construction of reinforced concrete pavement and found that ultimately 80 to 90 percent of the total

* Registration peaked at 26,523,779 vehicles in 1930 . From 1921 to 1926 registrations had increased at a rate of about 16 percent per year, but for the years 1927 to 1929 , this rate dropped to about 6 percent per year. From 1931 to 1934 registrations were 24 to 25 million per year. ${ }^{36}$

** About 1940 a study by the Department of Commerce showed that half of all car-owning families had a weekly income of $\$ 30$ or less, three-fourths had less than $\$ 40$ per week and 90 percent less than $\$ 60$ per week. ${ }^{40}$ expenditure was laid out for labor and that only oneseventh of this labor was direct employment at the road site. In other words, for every person employed directly on the job, seven others were indirectly employed making cement, aggregates, and machinery and in transporting these products through the economy. ${ }^{41}$ Dollars, therefore, were much more effective when used to build roads than when used for direct relief or a dole.

This argument was not lost on the Congress, which not only greatly increased authorizations for roads, but also declared in the Hayden-Cartwright Act of June 18, 1934:

Since it is unfair and unjust to tax motor-vehicle transportation unless the proceeds of such taxation are applied to the construction, improvement or maintenance of highways, after June 30,1935, Federal aid for highway construction shall be extended only to those States that use at least the amounts now provided by law for such purposes in each State from State motor vehicle registration fees, licenses, gasoline taxes, and other special taxes on motor-vehicle owners and operators ...

Only two States lost Federal money because of this Act, but it put a brake on further diversions, while the antidiversionists marshaled public opinion for a series of constitutional amendments that, along with an improving economic climate, eventually brought the problem under control. By 1942, 14 States had such amendments.*

\section{Priming the Pump}

As the national economy continued to decline, Congress applied another stimulus in the Emergency Relief and Construction Act of July 21, 1932. This Act appropriated $\$ 120$ million for advances to the States to match Federal-aid funds with the proviso that the funds should be obligated before July 1, 1933. The advances were to be repaid by deduction from regular Federal-aid apportionments over a period of 10 years.**

In a number of States, this assistance was sorely needed. Many had over extended themselves during the business boom by huge bond issues secured by the State's highway revenues.*** By 1927 bond interest and repayments were an appreciable part of the highway budget in many States, amounting to $\$ 48$ million nationwide; and by 1932 this figure had risen to $\$ 90$ million. ${ }^{45}$ As had been predicted by opponents of bond financing, these payments became a heavy burden, cutting into the funds available for maintenance

* The Federal Government did not practice what it preached. Until 1956, it treated excise taxes on motor vehicles and fuels as general revenues not connected in any way with grants to the States for highways. From 1918 through 1930 the Federal Government collected $\$ 1.17$ billion in excise taxes and from 1933 through 1936 another $\$ 1.08$ billion. ${ }^{42}$

** These advances were converted to grants by the HaydenCartwright Act of June 18, 1934.

*** Illinois had pioneered this method of placing the highway burden on the road users in its $\$ 60$ million bond issue of $1919{ }^{43}$ In 1923 , the Legislature, against the opposition of business and financial interests, approved the issue of an additional $\$ 100$ million of highway bonds." 
and even for matching Federal aid.* State funds were further depleted by increased allocations of highway revenues to counties to meet the charges on their own highway bonds and to replace shriveling property taxes, by payments to the financially beleaguered cities and by diversion to nonhighway purposes, principally schools and relief.

The road contracts financed with Emergency Relief and Construction funds were the first to contain predetermined minimum wages for skilled and unskilled labor. Congress insisted on these determinations to protect labor from wage pressure and arrest further deflation in wage rates. These contracts set the pattern for other road work, and in a short time, minimum wages became standard provisions in all public works contracts.

With the change of administrations in 1933, the Government suspended regular Federal-aid authorizations and embarked on a massive program of emergency public works. The National Industrial Recovery Act of June 16, 1933 provided $\$ 400$ million in grants to the States without the requirement that they be matched by State funds and instituted some notable changes in Federal road policy. For the first time, Federal funds could be spent on urban streets that were extensions of the Federal-aid highway system to and through municipalities and on "secondary and feeder roads" that were not on the Federal-aid system.**

To spread the work, Congress limited employment to 30 hours per week per worker, prohibited convict labor, and required that hand labor methods be used "wherever consistent with sound economy and public advantage." The States were required to predetermine fair wage rates and to give employment preference to veterans.

Congress continued the emergency program by appropriating $\$ 200$ million for unmatched grants to the States in the 1934 Hayden-Cartwright Act and, a year later, $\$ 200$ million for highways and $\$ 200$ million for eliminating hazards at railroad grade crossings in the Emergency Relief Appropriation Act of April 8, 1935. These grants, with the National Industrial Recovery Act grant, pumped a billion dollars into highway construction between 1933 and 1938enough to assure the continuation of highway building at boom levels. Altogether, the emergency funds financed over 54,000 miles of road improvements on the Federal-aid system, urban extensions and secondary feeder roads, plus the elimination of nearly 3,000 railroad grade crossings. ${ }^{47}$

Of equal or greater importance in the reckoning of the Administration, the emergency program provided the equivalent of 162,000 full-time jobs per year at the job site during the depths of the Depression.***

* To redeem its certificates of indebtedness, the Louisiana Highway Commission laid off half of its maintenance employees January 1933, replacing them with relief workers. ${ }^{40}$

** The Secretary of Agriculture channeled one-quarter of the funds into urban extensions and one-quarter of the remainder into feeder roads.

*:* Actual employment fluctuated seasonally from about 70,000 in the winter months to as high as 336,000 in summer. ${ }^{48}$
Indirect employment generated by the program was well over 480,000 full-time jobs.*

\section{The Broadening of Federal Highway Policy}

The emergency funding for 1933, 1934 and 1935 had channeled Federal money into urban areas and into secondary farm-to-market roads not on the Federal-aid system. These emergency measures became permanent Federal policy in the 1934 HaydenCartwright Act, which also abolished the limit on Federal payment per mile of road. In this Act, Congress resumed its practice of authorizing Federal-aid funds 2 years in advance, and also the requirement that Federal funds be matched by the States.**

This return to established Federal-aid principles locked the rather considerable Federal-aid authorizations into the 1936, 1937 and subsequent budgets and also provoked a bitter attack on Federal aid from the President. On November 27, 1937, President Roosevelt sent a message to Congress protesting that Congress practice of advance authorizations "ties the hands of the Executive" and the Budget Director and should be abandoned. The President's message seemed merely to antagonize the Congress and strengthened its support for Federal aid. Senator Carl Hayden, the principal defender of Federal aid stated publicly that tying the hands of the Executive in the use of road funds was "exactly what the Congress intended to do." He continued,

'Although the President transmitted with his message the draft of a bill to change the system and repeal much of the basic highway law, there was not one Senator or one member of the House of Representatives who would even introduce the bill, and the system has continued to operate just as it is now functioning. ${ }^{50}$

The Hayden-Cartwright Act permitted the States to use Federal-aid funds for plans, surveys and engineering investigations for future work, and this authority was broadened in the Agricultural Appropriations Act of June 16, 1936 to include economic investigations as well. The States could use up to $11 / 2$ percent of their matched Federal aid for these activities. This money provided the stimulus and the means for statewide highway planning surveys in every State similar to the BPR's cooperative transportation studies of the preceding decade. In a few

* BPR studies of a decade of highway expenditures showed that, nationwide, 24.4 percent of the total highway cost was for direct labor at the job site, 50.3 percent was for indirect labor for producing materials and equipment used on the job, and the remainder reached workers in other industries stimulated by the highway investments. For high-type surfaces, direct labor on the job was only 18 percent of the total cost, but for grading work, it went as high as 43 percent of the cost. The BPR concluded, "Where hand labor is permitted to replace modern equipment the amount of improvement obtained with a given expenditure is materially reduced, and the benefit to indirect or industrial labor in cities becomes almost negligible." 49

** The States were required to match the Federal funds dollar for dollar except for those States in which more than 5 percent of the total area was nontaxable public domain or Indian lands, where the Federal share was larger. In $\mathrm{Ne}$ vada, where such lands were over 80 percent of the State's total area, Federal aid was about 90 percent of the total project cost. 
years, all of the States developed strong planning and research organizations which joined with the Bureau and the universities in the first comprehensive investigation of national highway problems. This national study led directly to Congress authorization in 1944 of a system of "interregional highways" within the Federal-aid system.

In these two Acts Congress not only continued its traditional support for roads in the national forests, ${ }^{*}$ but also appropriated funds for roads in Indian reservations, national parks, and unreserved lands of the public domain, and for "parkways to give access to national parks, and national monuments, or to become connecting sections of a national parkway plan ..."

\section{Obsolescence Overtakes the Highways}

After 1921 the States concentrated their efforts on improving the 7 percent Federal-aid system into a travelable national network. As traffic became heavier in volume and faster, the States improved the highways to keep pace. They widened pavements first to 18 feet as required by the Federal Highway Act of 1921 and then to 20 feet. Some States banked the curves of old roads to make them safer and flattened the cut slopes for greater visibility. The highway departments of the public land States smoothed thousands of right angle turns with flatter curves. For the most part, these improvements were accomplished by the maintenance forces or by small contracts with State funds. But in 1929, for the first time the BPR began to approve Federal aid for "reconstruction" of roads previously improved with Federal-aid funds. By June 1930, nearly 21 miles in five States had been reconstructed, and this mileage increased rapidly in succeeding years.

The roads in the eastern and northern States, where the Federal-aid mileage had been reinforced after World War I with concrete or brick pavements, were still far from worn out by 1930 but were obsolete in alinement, grade and width, resulting in thousands of miles being rebuilt during the 1930's. In many cases the States made entirely new locations, relinquishing the old roads to the local authorities.

As could be expected, there was no lack of criticism for these abandonments because when the roads were originally paved, it is doubtful that a relocation policy would have been possible. To begin with, in the early 1920 's, property holders would have considered it extravagant to jettison the old road and its improvements. The crying need was for durable surfacing, and most everyone thought the available funds should be spent on this rather than right-of-way and now grading. Then, too, diverting the road from its old course would have been bitterly resisted by landowners along the route, with possibly years of delay in getting the program started. For most of them, the roads were already good enough in alinement and width.

* From 1917 through fiscal year 1933, Congress appropriated $\$ 122$ million for forest highways, most of which was administered directly by the Bureau of Public Roads.
Long distance travel by road had not developed and was not foreseen. For the local movements from one town to its immediate neighbors the indirection of the old roads was not a disadvantage, but an advantage. Motor vehicles were incapable of high speed and were legally restricted to very low speeds. The desire for the present high speed had not been born in a populace still tied to its home places and regarding 30 miles an hour as a breakneck pace. The improved curvature obtainable by slightly cutting the corners of the existing rights-ofway was all that was believed to be needed, and all that could reasonably be foreseen as required in the future. ${ }^{5 x}$

By 1934 the Federal-aid system, including authorized additions, mostly in national forests and public land areas, comprised 207,231 miles; and 96 percent of it had received some kind of improvement.* But the improved sections varied widely in adequacy for traffic and in safety for road users. In Chief MacDonald's words,

\begin{abstract}
Moreover, in the effort to extend surfaced mileage the presence of defects in alignment and the generally lower standards of the earlier work had been tolerated. Bridges inherited from a much earlier period had been held in service though in many cases it was necessary to post them for limited loads and their narrow widths prohibited the safe passing of vehicles on them. Thousands of railroad grade crossings had been allowed to remain, each in some degree hazardous. All these known defects had been tolerated to advance more rapidly the first essential task of smoothing and strengthening the road surfaces to get a growing traffic through. ${ }^{52}$
\end{abstract}

The improvements eased the worst bottlenecks temporarily, but for many thousands of miles, it was impossible to build a really adequate road on the existing locations. The roads were simply too crooked and the rights-of-way too narrow to permit upgrading to modern standards. More and more, the States began to build new roads on new locations for high speed traffic, relinquishing the old ones to the counties for maintenance.

The locators of these new roads and the Bureau of Public Roads' engineers who approved them held a philosophy of location that was best expressed in 1920 by Delaware's influential chief engineer, Charles M. Upham:

In giving consideration to alignment roads may be divided into two classes, roads located within parks, and intended as scenic roads and used mainly by sightseers and tourists, and roads that can be considered as commercial and industrial roads, which would be located within and between business centers, towns and cities...

In considering the alignment of commercial roads, or direct routes, it must always be remembered that a straight line is the shortest distance between two points, and from a commercial standpoint the shortest way is not only the most direct, but with other things equal, is the most economical; therefore, it seems to be practically conceded that ideally aligned commercial roads are those that are laid in absolutely straight lines.

Where there are costly infuences entering the problem that make it impossible or impracticable to follow the straight line, then the alignment should approach the straight line, and become a compromise of line, grade, and cost of construction. ${ }^{63}$

This dogma dominated highway engineering in the United States for half a century, leaving a legacy of thousands of miles of absolutely straight monotonous highway.

* Of the improved mileage, almost 80,000 miles had been accomplished by the States without Federal aid. 


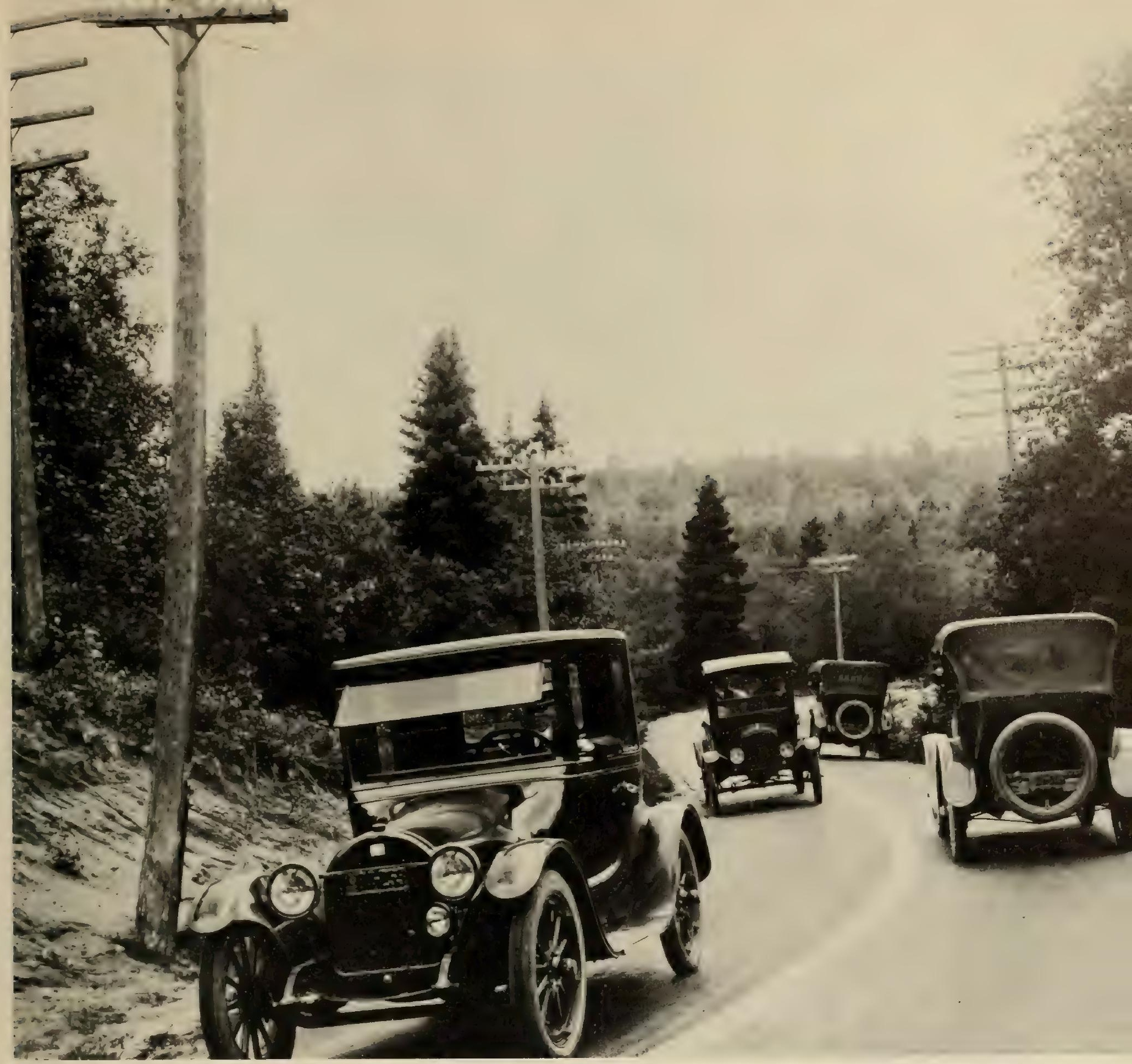

The first centerline on a rural State highway was painted between Marquette and Ishpeming, Mich., in 1917.

\section{Highway Safety Becomes a Serious National Problem}

Aside from Upham's arguments, there were two main justifications for straight highways. Having no curves, they were thought to be less hazardous to drive and also practically immune to obsolescence, since a straight road can be driven at the maximum speed of which an automobile is capable. This last argument was important at a time when speed records were falling almost every year at the Indianapolis Speedway and many engineers were predicting stock car speeds of 70 or even 80 miles per hour.

The safety argument was even more persuasive. Throughout the 1920's highway fatalities kept pace with the growth of the vehicle fleet and by 1924 had reached almost 20,000 per year. ${ }^{54}$ Recognizing that the problem was national in scope, Secretary of Commerce Herbert Hoover convened the First National Conference on Street and Highway Safety in Washington in December 1924. Here, for the first time, representatives of State highway and motor vehicle commissions, police, insurance companies, the steam and electric railroads, safety councils and chambers of commerce, labor unions, women's clubs, automobile associations, automotive manufacturers, and truck and bus operators met in one place to discuss means of abating what was already a national scandal.

Committees appointed 6 months in advance reported wide differences in traffic regulations from State to State and city to city. They found "an almost total lack of systematic effort to secure accurate and complete data regard such [traffic] accidents, their types 
and causes, and methods of prevention." Twenty States made no attempt to collect accident statistics. Only 8 States required that accidents resulting in personal injury be reported to the commissioner of motor vehicles or similar centralized authority, and 38 required railroads and common carriers to report highway accidents. ${ }^{55}$

The Committee on Traffic Control reported that high road crowns, a carryover from the earlier days of horsedrawn traffic, caused the "currents of traffic" to hug the middle of the road instead of keeping to the right. Hand signals to warn others of the intentions of drivers were not standardized, causing confusion and hazard. The Committee concluded that it was impossible to fix any safe speed limit but that traveling at a speed of over 35 miles an hour should be considered unreasonable and evidence of reckless driving. The Committee doubted the feasibility of imposing minimum speed limits on heavily traveled highways, even though failure to follow the prevailing speed was a recognized cause of accidents. ${ }^{56}$

The Committee on Construction and Engineering brought in a long list of inadequacies in the highways and recommended that no paved road or street should be less than 18 feet wide, or any bridge less than 22 feet wide. Rural highways should be provided with emergency off-road stopping places at intervals not exceeding 300 feet, and stopping on the traveled way should then be prohibited. Grades for primary highways should be 6 percent or less but might go up to 9 percent in the mountains; the minimum curve radius should be 300 feet, and a 300-foot sight distance should be provided everywhere on main highways. For safety, high crowns should be reduced and curves superelevated and widened. ${ }^{57}$ A white centerline stripe should be painted on the pavement to indicate no-passing danger sections such as curves and hilltops, and signs warning of hazards such as curves and railroad crossings should be uniform throughout the United States. ${ }^{58}$ Noting that 10 percent of all fatalities were at railroad grade crossings, the Committee recommended that a priority program be set up to eliminate the most dangerous crossings first. ${ }^{59}$

The Committee on the Motor Vehicle reported that a vehicle speed governor would be desirable but that as yet a practical one had not been devised. The most urgent safety problem facing the industry was the design of headlights that would adequately illuminate the road ahead without blinding oncoming drivers. Illumination engineers had worked out combinations of lenses and mirrors, but these compromises were difficult to keep in adjustment and were far from satisfactory.* Another difficult problem was providing adequate vision for the driver. The Committee thought that "Some device for cleaning the windshield from rain and snow, that can be conveniently operated by the driver should be available..." and also that "All windshields should be designed so that they can be opened to allow clear vision in case circumstances make it impossible to

* This problem was not adequately resolved until the introduction of sealed beam headlights about 20 years later. keep the windshield clean." 60 This Committee also thought that vehicles should be so designed that the accelerator could not be easily confused with the brake pedal and all vehicles should have brakes capable of stopping the vehicle in 50 feet from a speed of 20 miles per hour. ${ }^{61}$

The Conference approved and recommended the adoption by legislative, administrative, technical and educational bodies of a wide range of measures "which, if carried out even in part, will effect an immediate reduction in the accident toll." It also recommended that the States, as the sovereign political units closest to the problem, take the lead by passing adequate motor vehicle laws and setting up suitable machinery for administering them and for policing the highways, registering vehicles and licensing drivers. To the Federal Government, the Conference assigned the role of encouragement, assembly and distribution of information, and the development and use of good practices, leaving the achievement of uniformity to the voluntary action of the various States. Under legislative principles the Conference declared,

There is in the opinion of the Conference, a tendency to include far too much detail in legislation. This not only divides responsibility but also hinders progress toward uniformity. Laws should be so drafted as to include only those features which must be authorized by legislation, leaving the great mass of detalled regulations to be prescribed by the responsible officials whose orders should, within the limits fixed by statute, have the effect of law.

There should be a minimum of restrictive laws and regulations, for the history of transportation shows that restrictive measures written without regard to economic needs have always proved a failure. ${ }^{62}$

For lack of reliable statistics, the Conference was unable to come to any formal conclusion as to the causes of highway accidents. However, there is little doubt that most of the delegates agreed with Secretary Hoover when he said,

It is impossible to put the whole blame for the deplorable conditions upon any particular individuals or any particular classes of traffic. If we were to analyze the facts presented to the conference as to the causes of this enormous death roll (sic) and injury we would find that incompetence, carelessness, and recklessness are the largest contributors to this ghastly toll. We would find in a lesser degree the lack of preventive measures. We would find a considerable contribution from confusion over the regulations in force. We would find also that prevention of accidents is in part involved in large problems of difficult solution in the planning of our cities, the construction of highways, and generally the handling of these new traffic problems that have been thrown upon cities and country wholly unplanned for such use. ${ }^{63}$

Secretary Hoover called another conference for March 1926. During the interim between this and the first conference, a special committee drew up a model "Uniform Vehicle Code" covering the registration and titling of vehicles, the licensing of drivers and the operation of vehicles on the highways, which incorporated the best features of the numerous and varied State laws then on the statute books. The second conference approved this code, recommending it to the State legislatures as the basis for uniform motor vehicle legislation. ${ }^{64}$ 


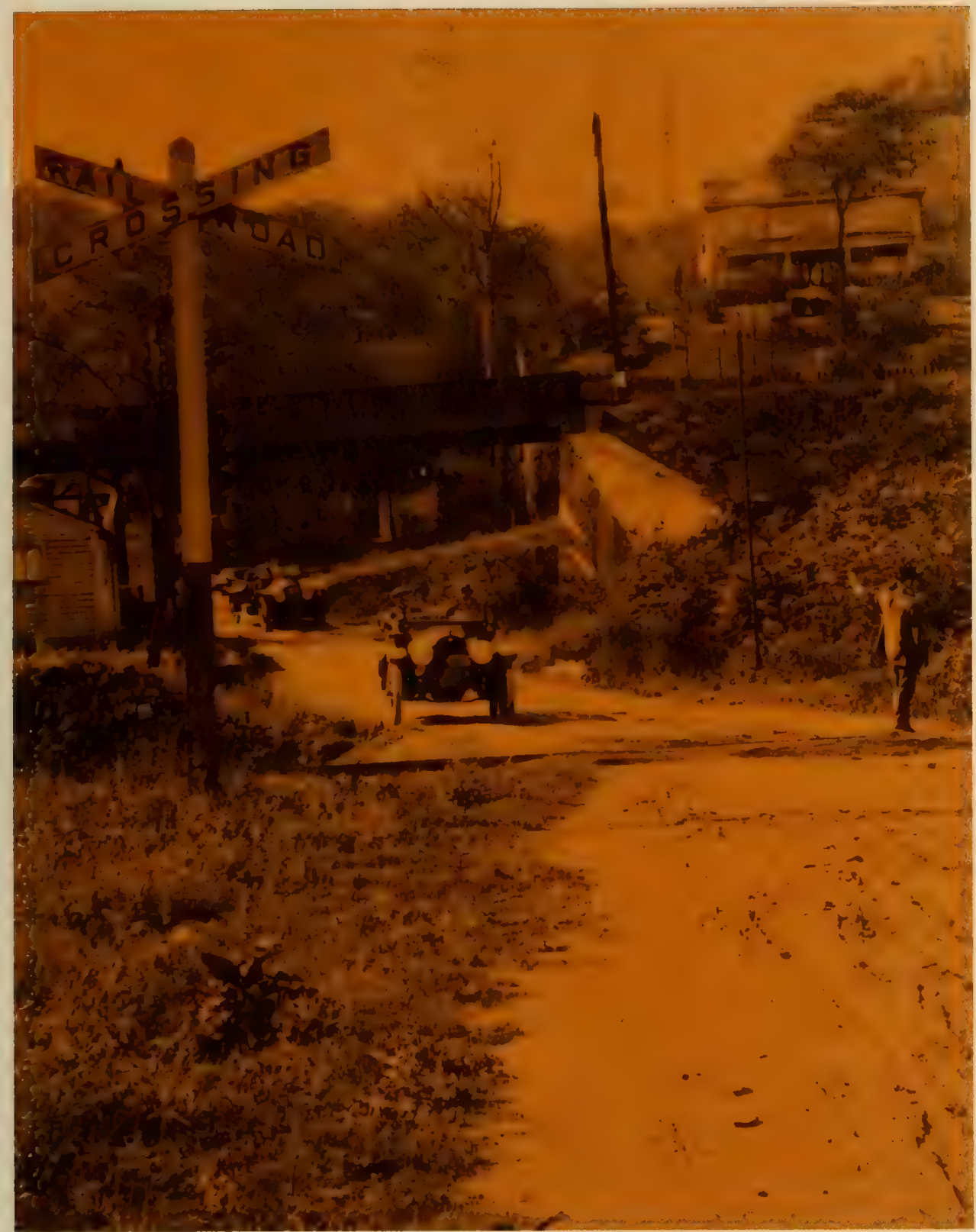

Highway-railroad grade crossings such as the one at left were common hazards for automobile traffic up to the 19s0's.

A year of study by another committee of the second conference disclosed that ascertaining the causes of accidents was far more difficult than had once been supposed. . It was not sufficient to ascribe most of the accident problem to human incompetence, carelessness and recklessness. Even if adequate accident records were available, this committee thought a sustained program of research by a central organization, national in scope, would be needed to get to the roots of the problem. ${ }^{65}$

The Conference agreed, and as a result of its recommendation, the Highway Research Board (HRB) organized a "Committee on Causes and Prevention of Highway Accidents," in May 1927 to coordinate accident research nationwide.* The HRB played a major part in subsequent efforts to reduce the accident toll.

* The first act of the Committee was to request the BPR to compile an index of published articles on highway safety and the allied subjects of highway design, town planning and traffic control. The BPR librarians found that no fewer than 2,400 items on these subjects had appeared in American and European journals for the years 1923 to 1927 - certain proof of the intense worldwide concern over the problem ${ }^{* 6}$

\section{The First Large Highway Safety Program}

The Bureau of Public Roads and the State highway departments recognized that the obsolescence of the highway system was one of the contributing causes of the high accident toll, but they were not willing to accept all or even a very large part of the responsibility :

One matter that confronts highway officials which is of great present importance and which will be of much concern in the future is the eradication of those conditions that are now or may be conducive to accident, injury, and death. A prominent part of the effort to be made to correct conditions will be the elimination of highway-railroad grade crossings ... The separation of opposing streams of traffic on the most heavily traveled highways seems also to be essential. The greatly increased speed of motor-vehicle travel requires a general increase in sight distances and the elimination of obstructions to view at intersections. Occasional sharp curves and steep grades on highways that, in general, invite the driver to speed must not be tolerated. Provision for pedestrian travel senarate from that portion of the highway used by vehicles must be made wherever the amount of pedestrian travel justifies it. 
The need for corrective measures in these directions is definitely recognized and will be cared for as rapidly as available funds will permit. But this alone does not give assurance of a complete solution of our highway-accident problem, since it must be recognized that such accidents are due, in large measure, not to faults in the highways, but to weaknesses of the drivers of vehicles.

Congress response to the highway accident problem was to provide increased appropriations for highways, and particularly for the elimination of grade crossings and other hazards to highway traffic. A considerable part of the $\$ 400$ million granted to the States under the National Industrial Recovery Act and the additional $\$ 200$ million of emergency grants under the Hayden-Cartwright Act went into safety improvements. Congress provided another $\$ 200$ million for a major attack on grade crossing hazards in the Emergency Relief Appropriation Act of 1935 , and a further $\$ 190$ million in the regular Federal-aid authorizations for fiscal years 1938 through 1943. All of these funds were outright grants and did not have to be matched by the States.*

This huge safety program reached its peak in fiscal years 1937 and 1938 when the States eliminated over 1,800 grade crossings and reconstructed over 300 existing grade separation structures at crossings. In addition, this program provided for the installation of train-activated protective devices at grade crossings with a high of nearly 1,200 devices installed in 1940 .

* The Federal-aid authorization of June 16, 1936 required that grade crossings be eliminated or adequately protected on all future projects financed by Federal aid. This made grade crossing protection a permanent part of the Federal highway program.
However, the grade crossing campaign had its critics who claimed that far too much money was being spent to solve a very small part of the total problem.

\section{Signing for Safety}

Before World War I, most States were using signs to warn road users of danger ahead, particularly railroad crossings, and the railroads themselves were required to post warning signs at all public road crossings. Most States agreed that danger signs "should be conspicuous and easily and quickly read, and therefore concise; should specify the character of danger to be guarded against and should be located at such distance from the danger point as to give ample time to be acted upon." ${ }^{68}$ However, agreement ceased with these principles, and the signs themselves were of an infinite variety of shapes, sizes and colors.

In 1922 the Mississippi Valley Association of State Highway Officials recommended that its members use distinctive standard shapes for warning signs-the circle for railroad crossings, the octagon for stop, and the diamond for caution. The American Association of State Highway Officials (AASHO) adopted these shapes in 1924 and also the standard colors yellow for caution signs and red for stop signs, and in 1927 AASHO published the first Uniform Manual for Highway Signs. This included not only danger and regulatory signs, but also the famous black and white shield for routes on the U.S.-numbered highway system. ${ }^{69}$

Meantime the American Engineering Council was making a survey of sign practices in all American cities of over 50,000 population. The Council's 1929

With additional financing by Congress, highway-railroad grade crossings were either eliminated or made safer with the addition of train activated warning systems.

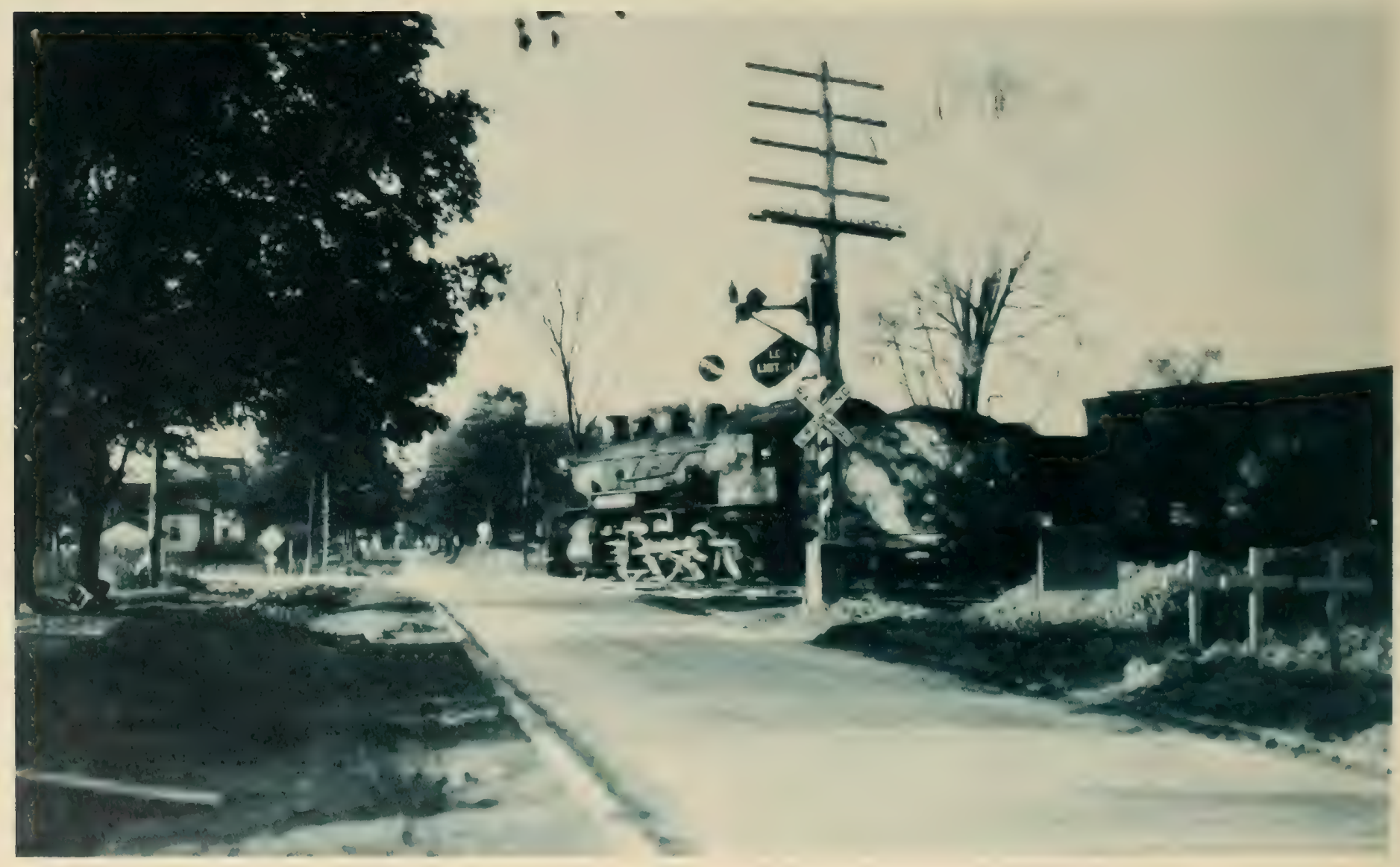




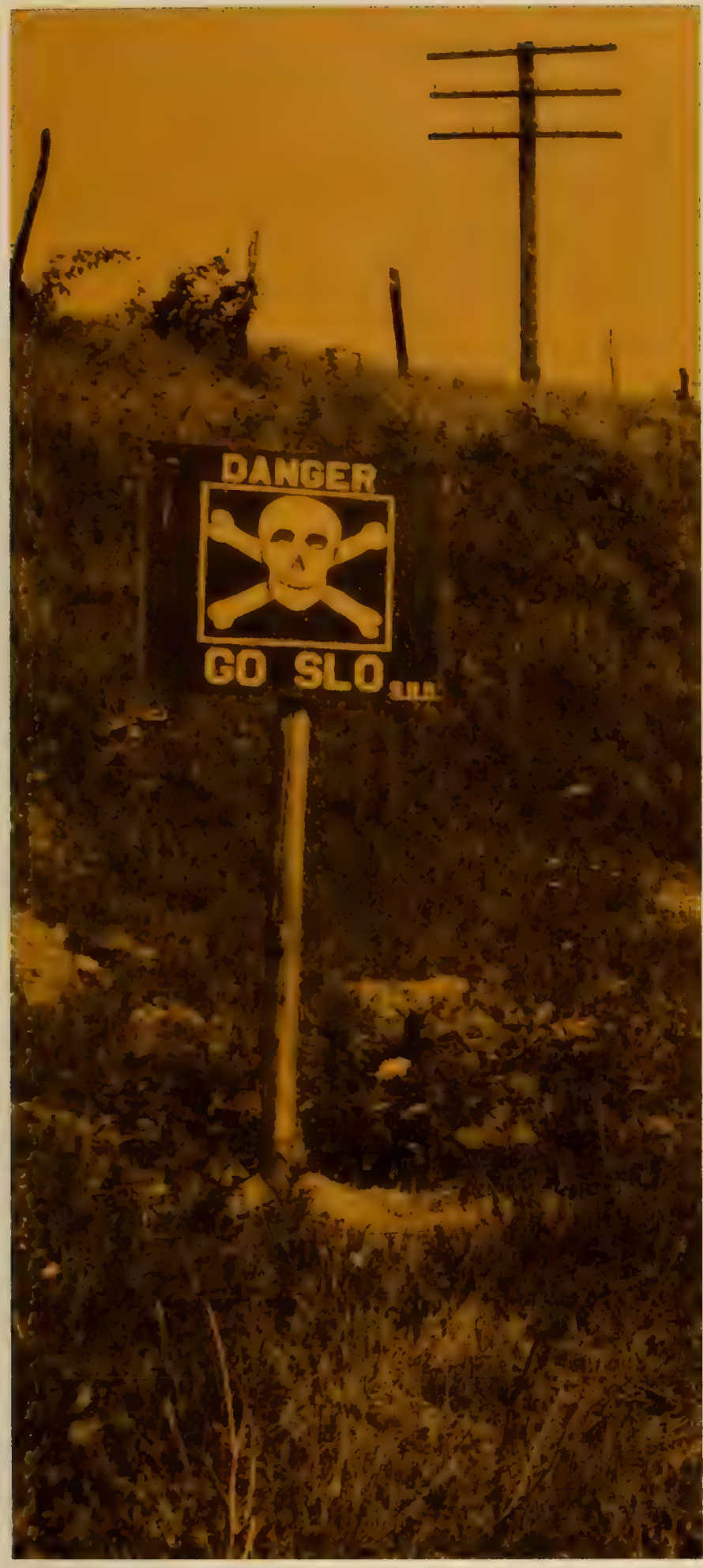

report was adopted by the Third National Conference on Street and Highway Safety in 1930. It was in effect a manual of the best practices of the time, including much of the practices embodied in AASHO's manual. Recognizing that there could not be different standard practices for signing in rural and urban areas, AASHO and the National Conference organized a Joint Committee on Uniform Traffic Control Devices* in 1931, which in 1935 brought out a new

* The Joint Committee now consists of members from AASHO, the Institute of Traffic Engineers, The National Committee on Uniform Traffic Laws and Ordinances, The National Association of Counties and The National League of Cities.
Until 1924, there was no national agreement as to uniform road signs; thus, from region to region there were an infinite variety.

manual for national use. This manual, periodically revised to keep pace with traffic developments, has been a powerful force for uniformity and traffic safety in the United States.

\section{The Consequences of Speed}

In the early days of the automobile, legal speed limits were set far below the speeds of which most motor vehicles were capable.* Horsedrawn vehicles were numerous on the highways, and teams might bolt if they were approached or passed at high speed. High speeds aggravated the dust nuisance and accelerated the destruction of macadam surfaces. Roads were narrow-generally less than 16 feet wide-and often flanked by deep ditches so that other vehicles could be passed safely only at low speed. Finally, the vehicles, and especially their tires, were of uncertain reliability; blowouts and loss of steering control were fairly frequent, and these could be disastrous at speeds greater than 25 miles per hour.

All of these factors changed as motor vehicle ownership increased. Animal-drawn traffic decreased and became numerically and politically unimportant. Bituminization solved the dusting problem, and vehicles and tires became more reliable. Drivers, feeling safer and more comfortable, increased their speeds and were able to exert enough political pressure to have speed limits raised also.

With heavier traffic and higher speeds, it became dangerous to drive in the middle of the road, and the States began painting centerlines on the pavements to channelize traffic in lanes.** At 40 miles per hour,

* In 1918 the legal limit in South Carolina was 15 miles per hour and five States had limits of 20 m.p.h. The limit in most States was 25 to 30 m.p.h., but in Kansas 40 m.p.h. was permissible. Eight States had no speed limit.

In 1928, only Massachusetts still had a 20-mile per hour limit, and in 32 States the limits were 35 to 40 miles per hour. Four permitted 45-mile per hour speeds. ${ }^{70}$

** In 1920 Marquette County, Michigan, began painting white centerlines on curves. These lines were hand-painted with whitewash and lasted only a month on the road, but were effective for keeping drivers on their own side of the road. $^{71}$

About 1925 it became general practice to build concrete highways with a center joint to control longitudinal cracking. This joint became a visible line separating the two lanes of traffic and served the same purpose as a painted stripe. 
these lanes appeared uncomfortably narrow to most motorists, especially when passing trucks. The lane lines also caused trucks to run closer to the shoulder where they caused increased breakage of slab edges and corners. To provide greater safety and reduce edge damage, the State highway departments built wider pavements, and they also made new roads straighter. These improvements along with mechanical advances in vehicles, such as more powerful engines and four-wheel brakes, in turn encouraged even higher road speeds.

Thus, after 1918, highway design followed a spiral of cause and effect, resulting in higher and higher speeds and wider and wider pavements. The motivating force behind this spiral was the driving speed preferences of the great mass of vehicle operators, and the public authorities were never able for very long to impose or enforce speed limits that this great mass of operators believed to be unreasonably low.*

\section{Balanced Design for Safety}

In the 1920's and 1930's, it was good engineering practice to locate new highways as much as possible in long straight lines or "tangents." When it became necessary to change direction, the locator laid out a circular curve, the radius of which he selected to fit the ground with the least construction cost but which could not be less than a certain minimum fixed by department policy.** In practice, locators made the curves flatter than this minimum when it was cheaper to do so, but with little consistency. Motorists driving these roads were expected to adjust their speeds to the varying radii; and on the sharper curves safe speeds might be considerably lower than the posted speed limit.

In their increasing concern for highway safety, many highway engineers worried about this inconsistency between speed limits and safe speeds on curves. One of these was Joseph Barnett of the BPR, and in 1935 he proposed that all new rural roads be designed according to an "assumed design speed." This, he said, should be "the maximum reasonably uniform speed which would be adopted by the faster driving group of vehicle operators, once clear of urban areas." " 44 All features of geometric design-curve radii, sight distance, superelevation, even gradientsshould then be made consistent with the chosen design speed so that a motorist traveling at that speed would not have to slow down to round any of the curves or ascend any of the hills.***

Barnett's "balanced design" concept became a permanent feature of American design policy with its

\footnotetext{
* In 1933, Maryland studies showed that in 40-mile per hour speed zones the average speed of all traffic was 37 m.p.h., and 87 percent of the drivers were traveling less than 45 miles per hour. Only a minuscule fraction were traveling as fast as 60 m.p.h. The Maryland authorities construed these findings as good public acceptance of the posted limit. ${ }^{72}$

** In 1912, the minimum radius in New York was 200 feet, but it was considered good practice to use 300 - or 400 -foot radil for curves on steep grades or at the foot of such grades. ${ }^{73}$

*** This idea was developed concurrently by the German highway engineers in their designs for the Reichsautobahnen.
}

adoption by the American Association of State Highway Officials in 1938. In its Policy on Highway Classification, AASHO declared,

A principal factor affecting the choice of a design speed is the character of the terrain. In general, rolling terrain will justify a higher design speed than mountainous country since the cost of constructing almost every highway detail will be less. An important highway carrying a large volume of traffic may justify a higher design speed than a less important highway in similar topography due to the fact that the increased expenditure for right of way and construction will be offset by the savings in vehicle operation, highway maintenance, and other operating costs. ${ }^{75}$

The essential data needed to implement the balanced design concept came from a series of research studies on driver reactions, curve dynamics and vehicle capabilities which began in the middle 1920's. By 1936 the fruits of this research were so abundantly available that AASHO appointed a special high-level committee of senior State design engineers to review the available information on highway design, bring it up to date and publish the results in usable form. Chief MacDonald assigned a small task force of BPR experts to work under this committee. Between 1937 and 1944 this Special Committee on Administrative Design Policy summarized and published all that was known about motor highway design in seven "policies." In 1954 the Committee combined these policies into a single manual which, with later revisions, is still the final authority in the United States on rural highway design. ${ }^{76}$

\section{The Parkway-A New Idea In Highways}

In 1907, the New York Legislature created the Bronx River Commission and authorized it to preserve the waters of the Bronx River from the pollution of encroaching trash dumps and land fills. The Commissioners acquired broad strips of land on both sides of the river, then built a highway through the resulting elongated park. They planned this parkway as a four-lane, low-speed recreational road connecting the public parks of northern New York City with city reservoirs in Westchester County.

Originally Herman Merkel, the consulting landscape architect, recommended that the parkway be planned as two widely separated one-way roads at different levels with a wide belt of undisturbed land between them-a very advanced concept for the year 1917. He was, however, overruled by the Commission, and only two short divided sections were built. ${ }^{77} *$

In practically every respect, the Bronx Parkway was different from other highways of its time. It had an unlimited right-of-way, and this relieved the builders from the need to confine their construction within a narrow band of fixed width. Furthermore, this right-of-way was also parkland which insulated the roadway from the adjoining street and highway

\footnotetext{
* This unfortunate result was probably caused by a popular engineering misconception that was not dispelled until the 1930 's. E. W. James, Chief of Design of the BPR, stated in 1929 that, "Two 20-foot pavements segregating traffic, with a parking between, are not adequate. Apparently two 30-foot pavements are needed to equal a single 40 -foot pavement in capacity." 78
} 
systems and made it possible to limit access to it to a fow places. All grade intersections were eliminated and trucks were excluded.

The parkway's designers laid it out as a series of long curves connected by short tangents-not so much to make the road intentionally crooked as to follow the sinuosities of the river valley, and thus reduce the depth of the cuts and fills. They laid the grade line to fit the ground closely and varied and rounded the slopes with unusual freedom to blend into the adjacent land forms.*

The construction methods were no less revolutionary than the design. Instead of clearing everything back to the right-of-way line, the Bronx River Parkway builders saved all trees not actually within construction limits. They saved the precious topsoil, and later spread it over the finished slopes of the parkway as a seedbed for grass and plants to arrest erosion. The landscape plan was informal, blending the parkway slopes into the adjacent forest and fields.

\section{Rapid Spread of Parkways in the New York Metro- politan Area}

The Bronx River Parkway was opened to traffic in 1923. It was so popular with the people of Westchester County that they got the Legislature to set up the Westchester County Park Commission with authority to build more parkways. This Commission approached parkways from a somewhat different angle. The Bronx River Parkway had been primarily an environmental cleanup project and pleasure drive. The Westchester County Parkways, on the other hand, were deliberately planned as suburban commuting arteries by locating them through the corridors between the existing steam and electric railroads that radiated out into the county from New York City. Thus, the parkways not only moved commuters into the city, but also made additional areas of the county available for development. The consequent large increases in taxable values were more than enough to finance the very considerable costs of the parkway program. Because of the high class residential character of Westchester County, the Commissioners were careful to retain for the new parkways the high esthetic standards that had been established on the Bronx River Parkway, as well as the wide right-of-way and access control features. Their principal change in policy was to flatten curvature somewhat to permit higher operating speeds.

Commuter and recreational parkways spread rapidly throughout the New York metropolitan area and, to some extent, in and near Washington, D.C., but did not become popular elsewhere.***

- At this time, other highways were designed with uniform slopes, usually $1 \frac{1}{2}$ or 2 horizontal to 1 vertical, for economy of excavation and to stay within the narrow rights-of-way. Contractors prided themselves on dressing these slopes accurately and smoothly for a neat and workmanlike appearance.

* One reason for this lack of popularity was their high cost. The Bronx River Parkway cost \$15 million for 15 miles, which included the parkland and measures to reclaim it from blight. The Mount Vernon Memorial Highway, the first parkway in the Washington area and opened to traffic in 1932 , cost $\$ 500,000$ per mile.
Influence of the Parkway Concept on Highway Design

Parkways, designed and operated essentially as commuter arteries, were tangible challenges to the dogma expressed by Upham that there are two kinds of highways-scenic and commercial. Here were highways that were essentially commercial, transporting workers to and from their offices, and also scenic or at least attractive. The fallacy of the old position was aptly expressed in 1932 by a distinguished committee of architects, engineers and planners:

\begin{abstract}
Highways traverse varied landscapes and should differ accordingly. However, we regard as unsound the common idea that they may be classified as scenic and commercial and that the appearance of the latter is of minor consequence. Scenery does not consist only of spectacular views. All outdoors is scenery of one kind or another. Therefore, wherever the rural character of the landscape has not been violated, a highway is scenic.

Classification according to assumed use is no more valid. When a tourist comes to San Francisco, or a citizen leaves and enters on a holiday, the Bay Shore Highway is a pleasure road; and when a resident of Eureka is called by his affairs to Crescent City, the Redwood Highway becomes a business road. Differing localities and circumstances may suggest different kinds of beauty, but every highway should be beautiful, with the kind of beauty appropriate to it. ${ }^{70}$
\end{abstract}

The principles of parkway design-the wide parklike right-of-way, control of access, elimination of grade crossings with other highways, fitting of the alinement and grade to the natural contours of the ground without using excessive cuts and fills, shaping and rounding slopes to merge them into the adjacent natural land forms, restoring natural vegetation to protect parkway surfaces from erosion, and preserving a high standard of architectural excellence for bridges and other structures-were all developed and proved out in practice before 1926. Yet these principles were almost totally ignored by the designers of other highways, which were laid out with long tangents and rollercoaster grade lines within narrow rights-of-way, with little effort to protect their steep side slopes from erosion. On these highways practically the only concession to pleasing appearance was the occasional planting of trees on the right-of-way.*

The first application of parkway principles to ordinary highways-on a very limited scale-came in 1933. The regulations for administering the National Industrial Recovery Act grants made it clear that the work done under these grants should include landscaping on a reasonably extensive mileage of roads. The States then programed 1,500 miles of roadside improvement projects costing about $\$ 2.22$ million. These were mostly on main highways near cities and towns where they would provide employment and also serve as demonstrations of what could be accomplished to beautify roads.

This program, although clumsily carried out in many localities, was an immediate public relations success. It inspired strong public support for landscaping and roadside improvement, something that had been lacking up to that time. Of equal importance, it focused the attention of the State highway

* The Amendment of May 21, 1928 (45 Stat 683) authorized the use of Federal-aid funds for planting shade trees along highways. 
departments on the enormous annual maintenance cost of correcting the damage caused by the erosion of unprotected slopes and ditches, and got them started on a long-overdue program of erosion control and correction.

The pilot beautification program also spotlighted the inadequacy of the prevailing 60 -foot rights-ofway. For hundreds of miles of road, the State had to purchase additional right-of-way or obtain slope easements from property owners to provide room to repair erosion damage and to regrade the cuts and fills with flatter slopes and wider ditches. Only then could grass and protective vegetation be established to prevent future erosion. This experience led to the general adoption of wider rights-of-way for new highways, so that by 1940, 100 feet was practically a standard for main roads.

The Secretary of Agriculture's regulations for programing the $\$ 200$ million of emergency road funds authorized by the Hayden-Cartwright Act of 1934 required the States to use not less than 1 percent of their apportionments for the improvement of roadsides. By 1936, 5,000 miles of roadsides had been improved with emergency funds and with Federal aid, and most State highway departments were incorporating improved roadside design in their new projects. The BPR was able to report in 1936 :

Provision is being made within State highway department organizations for an improved technical approach to the various roadside problems, and more effective methods of handling the work are being used as experience is accumulated. Only a few years ago highways were completed with little thought of the appearance of the finished roadside, and attempts were made at socalled beautification under conditions already bad and often with overemphasis on some particular kind of planting. Far better results have been produced since roadside improvement has been regarded as an integral part of highway improvement to be provided for in planning rather than as an afterthought following construction. ${ }^{80}$
In recognition of the increasing importance of the roadsides in highway planning, the Bureau of Public Roads established a landscape section in its Washington Office and urged the States to set up similar positions to plan and direct the roadside work.*

Congress gave a further impetus to roadside improvement in the Federal-Aid Highway Act of 1938 by authorizing landscaping and roadside development with regular Federal-aid funds and also "such sanitary and other facilities as may be deemed reasonably necessary to provide for the suitable accommodation of the public ..." within the right-of-way or publicly controlled adjacent areas. This encouraged the States to build rest areas along the main highways, a policy that had been pioneered in the early 1930 's by the Ohio Department of Highways.

Erosion control, landscaping and rest areas brought commercial highways and parkways much closer together in the 1930's but the full merging of the design philosophies behind them was still 30 years away.

* The landscape planning for the Mount Vernon Memorial Highway was done in 1929 by Wilbur H. Simonson, who came to the Bureau from the Westchester County Parkways. Subsequently, as the BPR's chief landscape architect, Simonson played a decisive part in the movement for improved roadsides in the United States.

Pittsylvania Wayside Rest Area built in 1985 on Rt. 29 near Alta Vista, Va.

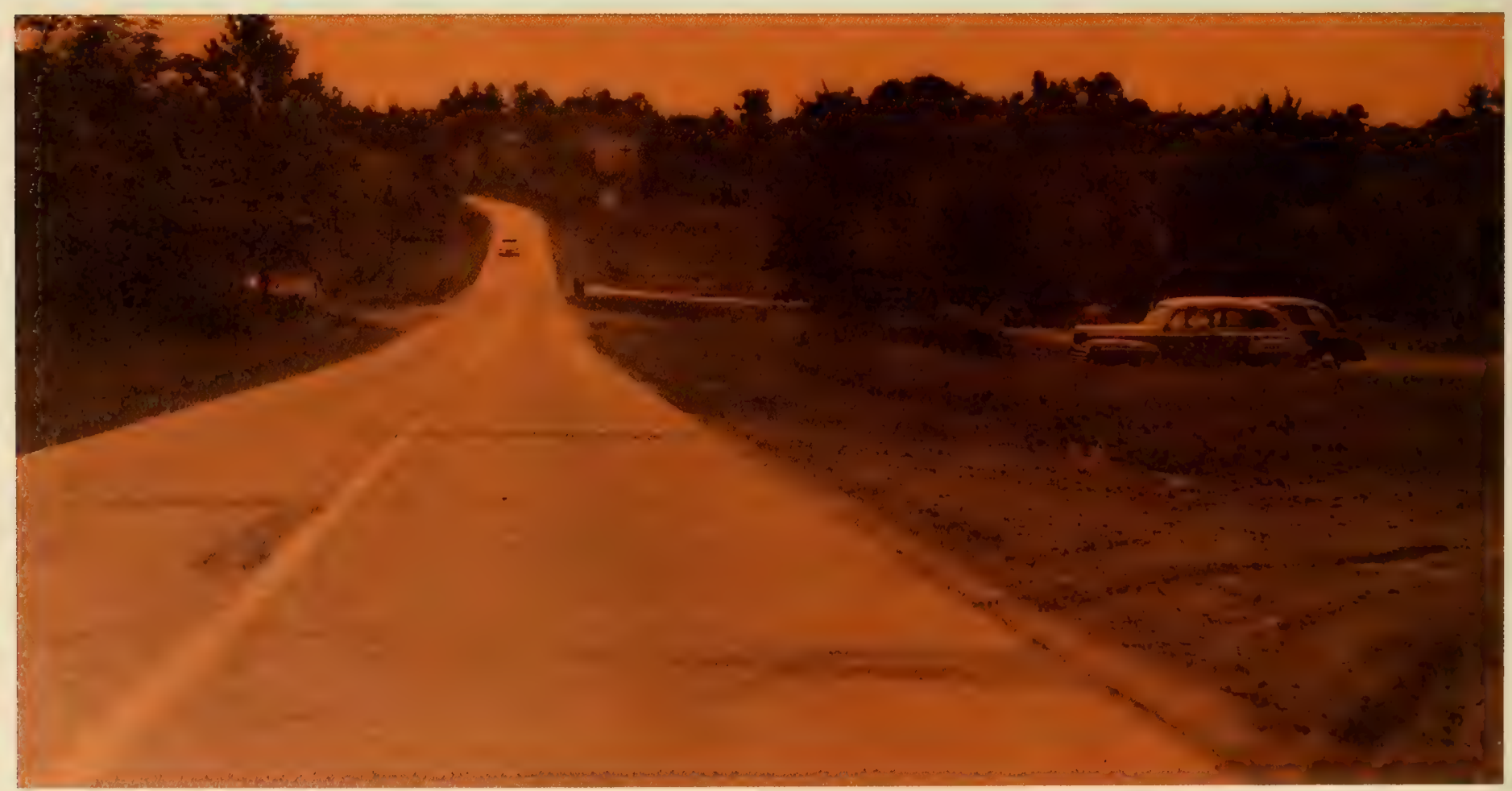




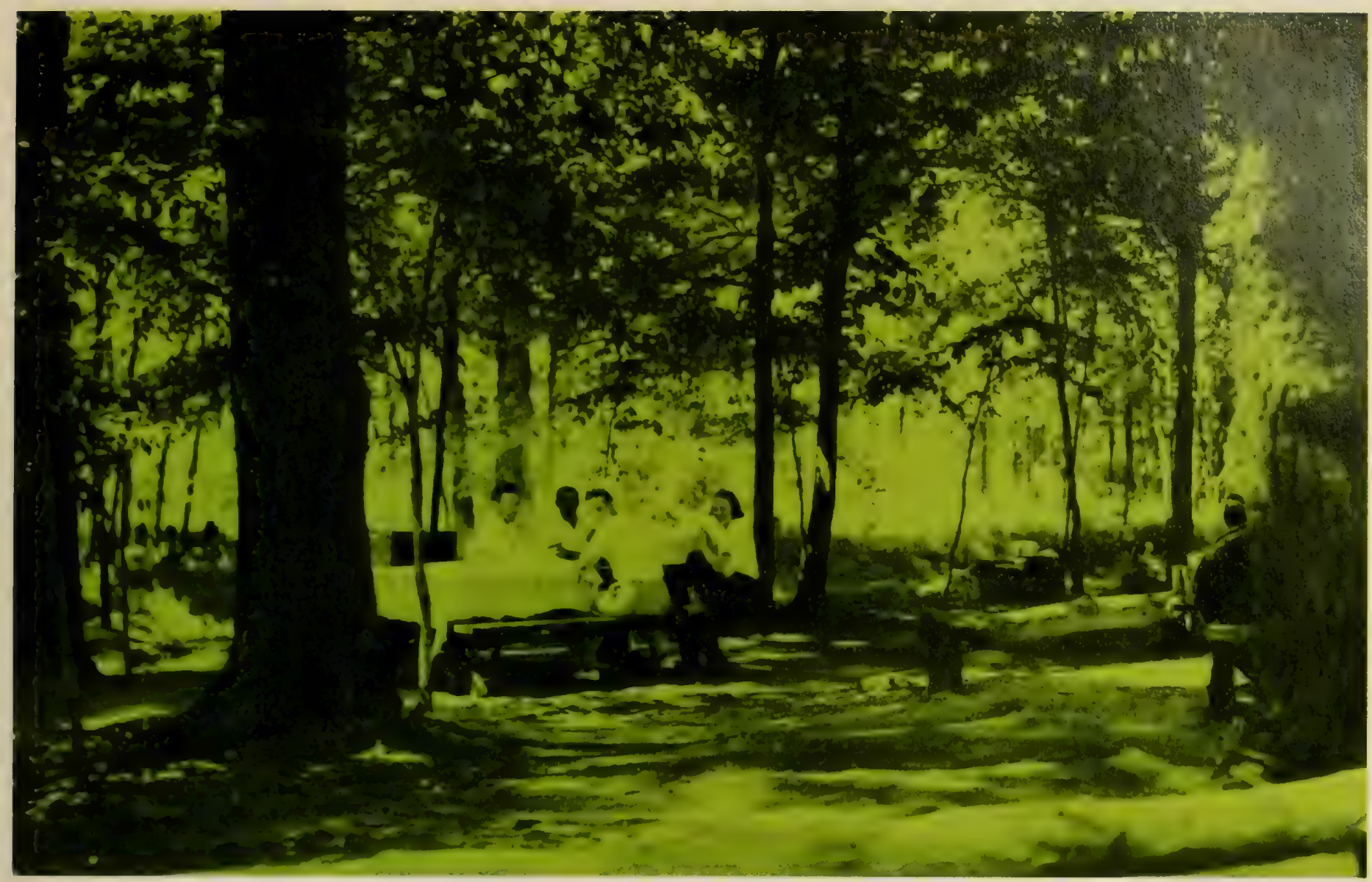

$A$ roadside park in Connecticut, 1938.

\section{The Return of the Toll Road}

Landscaping and erosion control were not the only reasons for adopting wider rights-of-way. By the mid-1920's, the main roads near and between large cities were getting seriously congested. The easiest way to relieve this congestion was to add another lane, and several State highway departments did this extensively, despite a growing realization that threelane roads might increase the possibility of head-on collisions. By the middle thirties, three-lane roads were practically obsolete, but hundreds of miles of highways had been widened to four lanes, especially in Cook County, Illinois, and Wayne County, Michigan.

However, these too proved to be dangerous, and many highway administrators began to believe that the only safe way to build multilane highways was to completely separate the opposing lanes of traffic, as had been done for years on city boulevards. In 1929, Milwaukee County, Wisconsin, rebuilt a part of the Blue Mound Road as a "split-slab highway" with "neutral ground" between the opposing lanes of traffic, leaving the remainder with an undivided four-lane pavement. After this road was opened to traffic, the commissioners were pleasantly surprised to observe that the divided part of this highway was able to carry more traffic at 10 to 20 miles per hour greater speed than the undivided part. ${ }^{81}$

Despite their superior safety characteristics, acceptance of divided or "dual" highways was slow, and by
1937 there were only 1,200 miles of nonurban divided highway in the United States.* 82

In that year, Chief MacDonald reported:

The large volumes of traffic that now flow between densely populated localities have created a demand for wide, multiple-lane highways, built according to the highest standards of grade and alinement, with opposing traffic separated by a center parkway, bypassing all cities, with structures separating streams of traffic at all highway and rail crossings, and with access from side roads permitted only at carefully selected points. Such highways offer great savings in time and in vehicleoperating costs to commercial vehicles, and to the drivers of private vehicles they offer freedom from dangers of the highway and from other vehicles as nearly complete as it is possible to attain.

That large volumes of traffic would flow constantly over such highways between densely populated localities there is no doubt-a traffic large enough to justify the high cost of such improvement with reasonable assumptions as to the value of the savings in fuel and time and those resulting from greater safety and freedom of travel. However it is not readily apparent how any large mileage of such highways might be financed. ${ }^{84}$

* The prejudice against divided highways stemmed in part from the assumption that they were not "flexible" enough to accommodate changes in the direction of traffic load.

In 1922, the Lincoln Highway Association assembled a panel of the most eminent highway engineers and professors in the United States to recommend the "ideal section" for heavy traffic highways. This panel recommended an undivided four-lane concrete pavement 40 feet wide on a 100 -foot right-of-way to carry 15,000 autos and 5,000 trucks per 24 hour day at a speed of 35 miles per hour. ${ }^{83}$ 
The Federal Highway Act of 1921, by concentrating Federal-aid funds on a limited mileage of the principal highways, had temporarily quieted demands for interstate highways under Federal control.

As congestion increased in the 1930's, these demands were renewed, and they were not long in reaching Congress. Here, there was talk of authorizing the collection of tolls to finance Federal "super highways" between the principal cities-a possibility that had been considered for some time by the BPR but had been discouraged because of the large volumes of traffic required to support the high cost of such facilities.

Early in 1937, President Roosevelt summoned Chief MacDonald to the White House and handed him a map of the United States on which he had drawn three east-west routes from coast to coast and three routes traversing the country from north to south. The President asked MacDonald to get started at once on a study of the feasibility of constructing the six routes as toll roads. ${ }^{85}$

The basic information for such a far-reaching study was already in the files of the BPR and the State highway departments: the product of the economic and traffic studies begun in 1920. Therefore, when Congress ordered a similar study in the Federal-Aid Highway Act of 1938, the work was already well advanced, and the BPR task force was able to finish the report to Congress by A pril 1939.

From their national traffic map the BPR analysts selected six transcontinental routes totaling 14,336 miles that would satisfy most of the demand for longdistance travel. After making estimates of traffic, the analysts found that only 3,346 miles-those within the influence of the major cities-would need more than two traffic lanes, and of these, only 547 miles would meet as much as 70 percent of their annual cost from tolls by the year 1960. Only one section of 172 miles, from Philadelphia to New Haven, would break even by that date.

The BPR had shown that toll financing was impractical. Nevertheless, the report pointed out, there was an urgent need for "a special, tentatively defined system of direct interregional highways, with all necessary connections through and around cities, designed to meet the requirements of the national defense in time of war and the needs of a growing peacetime traffic of longer range," and also a need to upgrade the existing Federal-aid highways and the secondary and feeder roads. ${ }^{86}$

The Bureau selected a 26,700-mile system of main interregional highways which would connect all of the major population centers, and which the report recommended should be built as free public highways on wide rights-of-way, access controlled, and without grade crossings. The report went on to observe that in the past, the major obstacles to building needed highways, especially in urban areas, had been "the inadequacy of available funds and the overpowering legal obstacles that stand in the way of obtaining essential rights-of-way." ${ }^{87}$ Archaic laws in most States limited the lands that could be acquired or taken for highways to the bare essentials of present needs without adequate allowance for future expansion and also limited the States' rights to deny access to abutting property owners in order to preserve a road's traffic capacity. These difficulties were compounded by the Government's policy of denying Federal-aid participation in right-of-way costs and the usual practice of State legislatures of providing for land acquisition in the same acts that authorized construction, so that the land was seldom available when needed.

The report recommended that Congress create a Federal Land Authority to buy and hold lands for interregional highways in advance of need in those States without constitutional authority to do so. Such lands would then be leased to the States when needed on terms that would repay the Government's investment in 50 years. Finally, in an appendix, the report discussed the possibility of recovering all or a part of the cost of interregional highways by the resale of land acquired in excess of the amount needed for the actual construction and protection of the highways. This proposal was enthusiastically approved by the President who remarked in transmitting the report to Congress :

Under the exercise of the principle of 'excess-taking' of land, the Government, which puts up the cost of the highway, buys a wide strip on each side of the highway itself, uses it for the rental of concessions and sells it off over a period of years to home builders and others who wish to live near a main artery of travel. Thus the Government gets the unearned increment and reimburses itself in large part for the building of the road. ${ }^{88}$

This suggestion was condemned in and out of Congress as a socialistic scheme to transfer the cost of providing deluxe highways from those most benefited to the already heavily burdened landowner.

The Bureau of Public Roads' adverse report took some of the steam out of the toll road movement, but by no means all. In December 1939, under pressure from the toll road people, eight North Atlantic States set up a committee of State highway engineers to make a more comprehensive study of the interregional route from Washington, D.C., to Boston which, the BPR report had admitted, had a marginal possibility of success as a toll road. This committee studied the 405-mile route and estimated that an adequate super highway to handle the traffic would cost $\$ 253$ million, and recommended that some of the Federal strategic highway funds be used for further studies. ${ }^{89}$ This suggestion and the report itself were buried in the gathering mobilization for war.

\section{The Pennsylvania Turnpike}

While the BPR was working on the toll road study, the State of Pennsylvania was perfecting its plans for a modern high-speed highway through the Allegheny Mountains on the right-of-way of the abandoned South Penn Railroad. In January 1936, the Legislature requested the State highway department to survey the old railroad route and report on the cost of converting it into a highway. A year later, the department reported that a highway was feasible, but would cost $\$ 50$ to $\$ 60$ million, much more than could be financed out of the highway budget in any reasonable period.

The Legislature then created the Pennsylvania Turnpike Commission and authorized it to acquire 
the South Penn right-of-way and build on it a toll road to which adjoining property would have no rights of access. The Legislature was careful to stipulate that the bonds issued by the Commission would not be backed by the credit of the State. This stipulation made the bonds practically unsaleable in the depressed securities market. The project came to a standstill until the summer of 1938, when the Public Works Administration, to stimulate employment, made an outright grant of $\$ 26.1$ million to the State, with the proviso that construction be completed by June 1940 - an almost impossible deadline. At the same time, the Reconstruction Finance Corporation purchased $\$ 35$ million of the Commission's bonds to complete the turnpike financing.

The Commission let the first grading contracts in November 1938, and thereafter pushed the construction at top speed, day and night with 155 contractors and thousands of men and machines. The 160-mile turnpike was opened to traffic without fanfare on October 1, 1940.

The Pennsylvania Turnpike was the prototype of the modern high-speed heavy-duty Interstate highway. It incorporated the most advanced practice of German and American design engineers on highway grades and curvature and was hailed by many as the safest highway in the world. It had 12-foot traffic lanes, two in each direction, separated by a 10-foot median strip. The right-of-way was 200 feet wide. The steepest grade was 3 percent, as compared to 8 and 9 percent on the nearby Lincoln Highway, and the total climb going over the mountains was only one-third as much as on the Lincoln Highway. For trucks the saving in transit time between Philadelphia and Pittsburgh was 5 to 6 hours, a saving sufficient to insure the financial success of the turnpike.

\section{Toll Parkways}

While the Pennsylvania Turnpike was under construction, the Connecticut highway department was completing a modern landscaped parkway connecting with Westchester County's Hutchinson River Parkway at the New York State boundary and extending 37 miles to the Housatonic River. This road was planned partly to serve commuters and partly to ease traffic pressure on the congested Boston Post Road. From its opening in June 1938, the Merritt Parkway attracted large volumes of traffic, and within a year, it was carrying 18,800 passenger cars per day. (Commercial traffic was excluded.) Searching for a source of funds with which to extend the parkway northward to Hartford, the Legislature decided to tap this huge flow of traffic, and in June 1939, it imposed a toll for use of the road. The Parkway was amazingly profitable to the State. In its first 35 weeks of operation, 3.4 million motorists, most of whom could have used the Boston Post Road free, cheerfully paid a 10-cent toll to use the parkway's uncongested deluxe facilities. In its first 6 months, the Merritt Parkway grossed $\$ 320,644$, for a net operating revenue of $\$ 280,000{ }^{90}$

Westchester County, heavily in debt for its own parkways and suffering from tax shrinkages, was not slow to notice the revenue pouring into the Connecticut toll booth at Greenwich, just east of the State line. In August 1939, the County Board of Supervisors imposed a 10-cent toll on the Hutchinson River Parkway which in 6 months grossed $\$ 279,000$. However, the bonanza was of short duration, for an order from the New York Court of Appeals forced the county to stop collecting the toll and refund what had already been collected. The court held that, although built entirely with county funds, the Westchester parkways had by use and custom become arteries of the State highway system on which by State law the collection of tolls was prohibited. ${ }^{91}$

\section{The Federal Highways}

In most of the western States, national forest highways occupied a strategic position in the State road system. In 1920 the Bureau of Public Roads reported:

Due to the fact that the forest areas lie along the mountain summits, they contain the passes through which the important trunk highways must cross the mountain ranges, and as a consequence many forest road projects are links in important State and national highways. Within the forests are 15,000 miles of roads which form connecting links for State and county highway systems. ${ }^{02}$

In 1912, Congress set aside 10 percent of the receipts from the national forests as a "10-percent fund" for financing forest highways, and with this money, the Forest Service and the Office of Public Roads made a feeble beginning on the enormous task of building the most urgently needed highway connections. ${ }^{*}$ This work received a much-needed boost from the Federal Aid Road Act of 1916 which appropriated $\$ 10$ million for forest roads for the years 1917 to 1926; and further financial support from the Post Office Appropriation Act of 1919 which provided $\$ 3$ million each for fiscal years 1919, 1920 and 1921 .

To spend these funds, the Bureau of Public Roads rapidly built up an engineering and construction organization equivalent to that of an average State highway department, but scattered over hundreds of thousands of square miles of forests. The roads it built in the early twenties were narrow and steep but reasonably adequate for the traffic.** Much of the construction, especially in the solid rock sections, was done by station contracts under which a "station gang" of cooperative laborers contracted to excavate a 100-foot section of road:

These men attack the ledge in various ways. Sometimes they use the deep 'coyote hole,' burrowing 30 feet into the rock with a tunnel large enough to permit a stooping man to enter with a wheelbarrow. Sometimes the hole is smaller, 8 or 10 feet in depth and less than a foot in diameter. Such a hole is known as a 'boot jack.' One 'coyote hole' on the Cooks-Collins Road in Washington brought down 2,000 yards of rock with 1,700 pounds of black powder. ${ }^{\text {29 }}$

The BPR also used modern construction equipment such as steam shovels and trucks, much of it war surplus from Army stocks, as well as millions of pounds of surplus TNT explosive in building these early forest highways.

\footnotetext{
* From 1912 to 1920 the 10-percent fund provided $\$ 2,322,225$ for forest roads. ${ }^{\text {e3 }}$

** The typical forest highway of this period had a 12-foot
} gravel surface and an overall graded width of 16 feet. 
When the States selected the 7 percent systems required by the Federal Highway Act of 1921, they included over 8,000 miles of forest highways. These roads were either entirely within the national forests or were necessary to the surrounding communities for access to and use of the forests. There were also about 5,400 miles of public roads within the national forests, but not on the Federal-aid system. These last and the roads on the Federal-aid routes the Secretary of Agriculture grouped into a forest highway system on which one-half of the forest highway appropriations were to be spent.* The Secretary concentrated 70 percent of these funds on approximately 1,000 miles of main Federal-aid routes lying entirely within the forests in order to keep pace with the improvement by the States of the adjoining portions of these routes. ${ }^{96}$

This policy complemented the policy of stage construction that was being followed by most of the western and southern States. To insure early completion of some kind of improvement on the principal primary routes, the Government coordinated not only the scheduling of improvements with the adjoining States, but also adopted comparable construction standards. As traffic increased, these standards were upgraded :

\begin{abstract}
Meanwhile, as the traffic increases standards of construction are being constantly raised. Grades and curvature are being reduced and widths increased, and projects constructed originally as unsurfaced earth roads are being surfaced..$^{97}$
\end{abstract}

Through the 1920's and 1930's, Congress authorized about one-tenth as much for forest highways as for Federal aid to the States.** This was applied where it was most needed to keep up with traffic, mostly for second- and third-stage construction or reconstruction, so that by 1939, two-thirds of the annual program was rebuilding or upgrading previous work. Even this did not keep up with demand, and a number of States and even counties supplied "cooperative funds" to supplement the Federal apportionments for roads of particular interest to them. Some State highway departments spent their own funds to blacktop forest highways carrying heavy through traffic. Eventually the main highways through the national forests were taken over by the States, rebuilt, and incorporated into their own highway systems.

\section{Roads in the National Parks}

Before the creation of the National Park Service in 1916, each national park superintendent reported directly to the Secretary of the Interior; each had his

* The original forest highway system as finally approved by the Secretary in 1926 comprised 13,459 miles of which 11,271 miles were in Alaska and 11 western States and 2,188 miles in 17 eastern and southern States. ${ }^{95}$ In addition, there were thousands of miles of trails and logging roads not in the forest highway system, but necessary for the protection and use of the forests. One-half of the forest highway appropriations went to these "forest development roads."

** Forest highway appropriations for fiscal years 1917 to 1941 were $\$ 108.5$ million. Federal aid in the same period was $\$ 1.1$ billion. Forest highways also received a share of the emergency relief funds provided by Congress during the New Deal. own road budget, and made his own arrangements for laying out and maintaining roads.* There was no overall plan for developing the national parks and making them accessible to the public, but in the annual appropriations to the Interior Department, Congress might include amounts for specific roads in certain parks, generally those with strong local political support.

In 1924 Congress gave the Secretary of the Interior general authorization to construct, reconstruct and improve roads and trails in the national parks and appropriated $\$ 2.5$ million each for fiscal years 1924 , 1925, 1926 and 1927 for such roads. In the same Act, Congress directed the Secretary of Agriculture to turn over 5 percent of the war-surplus road equipment and supplies to the Secretary of the Interior for use in park road construction. ${ }^{98}$

This act gave the Secretary the means to plan ahead, and in 1925 he had the National Park Service (NPS) prepare a 5-year plan of road improvements in 17 national parks and monuments, totaling some 1,510 miles. Since the NPS had a very small engineering staff, Director Stephen Mather arranged with Chief MacDonald, in 1926, for the BPR to handle the engineering and construction for this program on a reimburseable basis.**

Under this agreement, which, with some changes is still in effect, the NPS and the BPR built some of the most scenic and spectacular highways in North America, one of which was described thus by Chief MacDonald in his annual report for 1927:

One of the most interesting of the national-park projects is the work on the Transmountain Highway in Glacier National Park. Here is a road in which practically every conceivable obstacle has been met and overcome. The 16-foot roadway is being literally hewn out of the solid rock of the Garden Wall in order to reach and cross the Continental Divide.

By 1931 only one-fifth of the 5-year program was finished, yet already some roads were in need of rebuilding to higher standards. Furthermore, the National Park Service had acquired the Colonial National Historical Park and the Shenandoah and Great Smoky Mountains Parks in the East and had begun road programs in all of them that were ultimately to run into the millions of dollars. In January 1931, Congress authorized (46 Stat 1053) the Secretary of the Interior to build approach roads, not exceeding 60 miles long from the park gateway of isolated national parks to the "nearest convenient 7 percentum road" and required that $\$ 1.5$ million of the annual park road authorizations be spent on such roads. And in 1933 President Roosevelt, by executive order, transferred to the NPS 64 military parks, national cemeteries, historical areas and national monuments that had formerly been in the charge of the War Department or the Department of Agriculture. Most of these areas had roads in need of modernizing.

\footnotetext{
* However, for many years roadwork in Yellowstone National Park was handled by the Army Corps of Engineers.

** This informal arrangement was legitimized by Congress in the Agricultural Appropriation Act of 1928 which authorized the Secretary of Agriculture to perform engineering services for other agencies of the Government in connection with roads.
} 
To meet all these demands, the NPS in effect jettisoned its original 5-year plan and embarked on a looser, but much larger, road program tailored to larger authorizations. Between 1930 and 1933, Congress tripled the annual park road authorizations. In 1934 and 1935, the Administration allocated $\$ 18.3$ million of emergency relief funds for park roads and parkways. ${ }^{100 *}$ With these funds the NPS and BPR greatly expanded their efforts, and in the single year of 1936, they completed 204 miles of park roads and 142 miles of approach roads. ${ }^{101}$ By 1941, when the war put an end to roadwork in the parks, 1,781 miles of park roads and 255 miles of access roads had been completed at a cost of about $\$ 87$ million. ${ }^{102}$

To some extent, roads in the national parks were demonstration roads for the embryonic State highway landscaping and erosion control programs of the 1930 's. For years before environmental design became popular, the National Park Service had employed landscape architects, naturalists and foresters to advise on the location and construction of its roads. Because of this advice, damage to the landscape from roadbuilding was much less in the parks than on State highways or even on roads in the adjacent national forests constructed by the BPR. Furthermore, the park roads were highly visible models of what could be accomplished by good slope grading and landscaping to blend a highway into its natural surroundings and control erosion damage.

\section{The National Parkways}

In May 1928 Congress instructed the Secretary of Agriculture to build a highway from Washington to Mount Vernon as a memorial to President Washington and to have it finished in time for the bicentennial of the first president's birth in 1932. The BPR, acting for the Secretary, selected a scenic location along the shore of the Potomac River and designed a landscaped four-lane undivided highway in the style of the Westchester County parkways. No effort was spared to make this the most modern and beautiful highway in the United States:

Every possible effort is being put forth... to make this road one of the most attractive in North America. The alignment as designed is a succession of long, easy curves; the grades rise and fall gently with the natural roll of the hills; the cut and fill banks will be cut to flat slopes and rounded so as to merge with the natural topograph; and the bridges . . . will be graceful flat arches faced with native stone. ${ }^{103}$

The BPR finished the Mount Vernon Memorial Highway on schedule, at a cost considerably above the $\$ 4.5$ million originally provided by Congress. In 1930 it became the first unit of the George Washington Memorial Parkway authorized by the CapperCramton Act (46 Stat 482).

The George Washington and other later Federal parkways in the Washington metropolitan area became commuter arteries in the same manner as the Westchester County parkways. The Blue Ridge and

* \$16.0 million from the National Industrial Recovery Act and \$2.3 million from the Hayden-Cartwright Act of 1934 . In addition the Civilian Conservation Corps spent tens of millions in the national parks improving minor roads and trails.
Natchez Trace Parkways, however, developed along quite different lines and much closer to the original Bronx River recreational road concept.

These parkways were begun as emergency relief projects without specific authorization by Congress. After they were well started, Congress recognized them as national parkways in acts providing for their administration and maintenance by the National Park Service. When originally planned in the 1930 's, these parkways were conceived as modern motor roads with extremely wide rights-of-way-actually elongated parks sited to provide scenic views for the motorists and recreational opportunities at selected places along the way.* Thus they became not merely cross-country highways, but recreational destinations in themselves similar to the national parks and monuments.

The BPR as construction agent for the NPS let the first contract for the Blue Ridge Parkway in February 1936, and by the end of 1939, 305 miles were completed or in various stages of construction and 140 miles of continuous paved parkway were open to traffic, attracting 300,000 visitors that year. ${ }^{104}$ The Natchez Trace Parkway developed much more slowly and by 1939 only 36 miles were completed.

Most of the Federal highways were in the national forests, the national parks or the national parkways, but there were others. In the West, considerable mileages of local roads in Indian reservations remained under Federal control after the States took over the main primaries and secondaries. Some of the larger military reservations contained well over 100 miles of roads maintained by the Army or Navy.** Over the years, the Government added steadily to its road inventory so that now almost 7 percent of the rural road mileage is under Federal control.***

\section{The First Foreign-Aid Program}

A land route connecting the countries of the Americas has been a dream of visionaries going back to Spanish times. These early schemes did not involve the United States until May 1928 when Congress, by joint resolution, requested the President to explore the possibility of an international highway at the forthcoming Pan American Highway Congress scheduled to meet in Rio de Janeiro in August 1929. $\uparrow$ In March 1929, Congress authorized the appropriation of $\$ 50,000$ to enable the Secretary of State to coop-

* The rights-of-way, including all access rights, were purchased by the States and transferred to the Federal Government. They averaged 125 acres per mile, but varied in width from 400 feet in tight places to as much as $1 / 2$ mile at special park sites.

** In World War II an average cantonment for 30,000 men required 18 miles of primary roads, 7 miles of secondaries and 3 miles of local roads. ${ }^{105}$

*** In 1973, 215,747 miles of rural road were under Federal control as compared to a total national rural mileage of $3,175,654$ miles. $^{100}$

† Congress was responding to a previous resolution of the Sixth International Conference of American States calling for the construction of a highway connecting North, Central and South America. ${ }^{107}$ 
erate with other governments of the Pan American Union in reconnaissance surveys to develop the facts.

These surveys began in June 1930 in cooperation with the governments of Panama, Costa Rica, Nicaragua, Honduras and Guatemala under the general direction of $\mathrm{E}$. W. James of the BPR. In the course of the next 3 years, the engineers of the BPR and of the Central American republics covered 900 miles on foot or horseback through dense jungles and rugged mountains to make the ground reconnaissance. They were greatly aided by aerial photographs of the most promising routes made by the U.S. Army Air Corps from its bases in the Canal Zone - one of the earliest extensive uses of aerial photographic methods for highway location in unexplored country.

In January 1934, the Bureau of Public Roads reported to the Secretary of State that of the 3,250 miles of the route from the U.S. border to Panama City, 1,265 miles were already passable for motor vehicles the year round and 1,000 more were passable in the dry season and that it was entirely practicable to build a motor road over the remainder. ${ }^{108}$

Congress appropriated $\$ 1.075$ million in June 1934 to start construction of the Inter-American Highway in cooperation with the countries through which it would pass. The BPR then worked out cooperative agreements with Panama, Honduras and Guatemala to build three large bridges. Under these agreements, the United States furnished the plans and engineering supervision, the steel and cement, and some of the heavy equipment, while the cooperating countries supplied labor and local materials. ${ }^{109}$

The assistance provided by Congress was little more than seed money to induce the Central American republics to improve their highway organizations and to step up their own construction efforts. This purpose was largely accomplished. On work for which the United States provided $\$ 680,000$ up to 1938 , the cooperating countries provided $\$ 710,0000^{110}$

More importantly, the BPR made a determined effort to train engineers to carry on the work:

In each country where cooperative work has been conducted, a Bureau engineer has been placed in charge as resident engineer. All other positions have been filled with local engineers, most of whom have been trained in the United States. It has been the policy to aid each country in developing its own highway engineers capable of carrying on future highway programs according to the most modern standards. ${ }^{111}$

In 1938 Congress authorized the President to provide technical assistance to countries of the Pan American Union for planning and building roads. Venezuela, Colombia and Ecuador requested such assistance, whereupon BPR engineers were assigned as advisers to those countries in 1939. And in May 1939 the Export-Import Bank requested the Secretary of Agriculture to assign highway engineers to assist the Bank in evaluating applications for highway loans in Central and South America. This request was filled by assigning experienced BPR engineers to the Bank. These small tentative efforts provided valuable experience for the huge foreign highway-aid program carried on by the BPR after World War II.

Throughout the 1930's, work proceeded in a rather leisurely manner on the Inter-American Highway, limited largely by the financial abilities of the cooperating countries. It required the stimulus of war to get the program really moving-a stimulus that was soon to be applied.

\section{REFERENCES}

${ }^{1}$ Bureau of Public Roads Annual Report, 1922, pp. 4, 5.

${ }^{2} I d$., p. 7.

${ }^{3}$ Bureau of Public Roads Annual Report, 1926, p. 2.

${ }^{4}$ T. MacDonald, Four Years of Road Building Under the Federal-Aid Act, Public Roads, Vol. 3, No. 26, June 1920, pp. 10-12.

${ }_{5}^{5}$ Bureau of Public Roads Annual Report, 1929, p. 3.

${ }^{\circ}$ Offrce of Federal Coordinator For U.S. Transportation, Public aids To Transportation, Public aids To Motor Vehicle Transportation, Vol. IV (GPO, Washington, D.C., 1940) pp. 9, 67, 76.

'ACCIDENT FACTs, 1934 (National Safety Council, Chicago, 1934) p. 32.

${ }^{8}$ T. MACDONALD, The Freedom of the Road, AMERICAN Highways, Vol. VIII, No. 1, Jan. 1929, pp. 6, 7.

${ }^{\ominus} I d$., pp. 7, 8.

${ }^{10}$ Railroad Revival, Engineering News-Record, Vol. 88, No. 1, Jan. 5, 1922, p. 4.

${ }^{11}$ An Industrial Message to Congress, Engrneering NewsRECORD, Vol. 89, No. 24, Dec. 14, 1922, p. 1006.

${ }^{12} \mathrm{~W}$. LXFORD, Urges Co-operation Between Railroads and Motor Trucks, Engineering News-RecoRD, Vol. 89, No. 22, Nov. 30, 1922, p. 933.

${ }^{13} \mathrm{G}$. Chatburn, Highways and Highway Transportation (Thomas Crowell Co., New York, 1923) pp. 429-432.

${ }^{14} \mathrm{P}$. Hubbard, Efficiency of Bituminous Surfaces And Pavements Under Motor Truck Traffie, Public Roads, Vol, 1, No. 10, Feb. 1919, p. 25.

${ }^{15} \mathrm{C}$. UpHaM, Solution of the Growing Problem May be Found in Cooperative Action, Public Roads, Vol, 1, No. 2, Jun. 1918, p. 16.

${ }^{10} \mathrm{E}$. Dufrey, New York Advocates Placing Reasonable Limit Upon Total Load of Motor Trucks, PUBLIC RoAds, Vol. 1, No. 2, Jun. 1918, p. 7.

${ }^{17}$ G. PrIDE, Limitations To Be Placed On Trucks From User's Viewpoint, Engineering News-RECORD, Vol. 81, No. 22, Nov. 28, 1918, p. 969.

${ }^{18} I d .$, p. 970.

${ }^{19}$ Highway Transportation Problem Needs Study, ENGINEERING News-ReCoRD, Vol. 80, No. 17, Apr. 25, 1918, pp. 798, 799 .

${ }^{20}$ Ideas and Actions: A History of The Highway ReSEARCH BOARD, 1920-1970, (Highway Research Board, Washington, D.C., 1970) p. 7.

${ }^{21} \mathrm{~T}$. AGG, Comprehensive Investigations In Highway Engineering Needed, Public Roads, Vol. 2, Nos. 16-17, Aug.-Sept. 1919, p. 35.

${ }^{22} I d$., p. 36 .

${ }^{23} I d$.

${ }^{24}$ Ideas AND ACtions, supra, note 20, pp. 185, 186.

${ }^{25} I d$.

${ }^{28}$ Id., pp. 9, 181.

${ }^{27}$ Standards Approved by the American Association Of State Highway Officials During the Year 1928, American Higfiways, Vol. 7, No. 4, Oct. 1928, p. 21.

${ }^{28} \mathrm{~J}$. MCKaY, The Maine Transportation Survey, PUBLIC Roads, Vol. 6, No. 3, May 1925, pp. 45-48, 67, 68.

${ }^{29}$ A Study of Highway Traffic in the Cleveland Regional Area, Public Roads, Vol. 9, No. 7, Sept. 1928, p. 152.

${ }^{30} 1971$ Automobile Facts and Figures (Automobile Manufacturer's Association, Detroit, 1971) p. 3.

${ }^{31} I d$.

${ }^{32}$ Bureau of Public Roads Annual Report, 1930, p. 4.

${ }^{33}$ Bureau of Public Roads annual Report, 1932, p. 2.

${ }^{34}$ Bureau of Public Roads Annual Report, 1933, p. 3.

${ }^{35}$ Motor Vehicle Registrations and Receipts, PUBLIC Roads, Vol. 12, No. 1, Mar. 1931, p. 19; Vol. 13, No. 2, Apr. 1932, p. 39 ; Vol. 14, No. 3, May 1933, p. 54 ; Vol. 15, No. 7, Sept. 1934, p. 178; Vol. 16, No. 5, Jul. 1935 , pp. $90,91$.

${ }^{36} I d$. 
${ }^{37}$ Diversion-An Analysis of the Practice of Applying Motor Vehicle Impost Collections To Other Than Highway Purposes (National Highway Users Conference, Washington, D.C., Jan. 1936) p. 10.

${ }^{2} I d .$, p. 22.

${ }^{3} I d$., p. 8.

${ }^{10}$ Dedication of Special Highway Revenues To Highway Purposes (National Highway Users Conference, Washington, D.C., Aug. 1941) p. 9.

${ }^{41}$ J. HARRISON, Where The Highway Dollar Goes, PUBLIC RoaDs, Vol. 13, No. 2, Apr. 1932, p. 21.

"OFf. of Federal Coordinator, supra, note 6, pp. 53, 54

${ }^{43} \mathrm{G}$. ChatbuRN, supra, note 13, p. 330.

"Road Location by Legislature, ENGINEERING News-Record, Vol. 90, No. 25, Jun. 21, 1923, p. 1070

${ }^{45}$ Supra, note 35.

"Louisiana Highway Forces To Be Cut on Jan. 1, EngrNEERING NeWS-RECoRd, Vol, 109, No. 19, Nov. 10, 1932, p. 572.

${ }^{17}$ Bureau of Public Roads annual Reports, 1934-1944.

48 Bureau of Public Roads annual Report, 1936, p. 6.

49 Id. p. 63 .

${ }^{3}$ Save The Federal aid Highway Principle-The Story of What It Is, How It Operates and The attacks againgt Ir (National Highway Users Conference, Washington, D.C., Mar. 1942) p. 31

"Toll Roads and Free Roads, H. Doc. 272, 76th Cong., 1st Sess., p. 107.

T. MacDonald, Federal Aid From The National Viewpoint, The History and Accomplishments of Twenty-Five Years of Federal aid For Highways (American Association of State Highway Officials, Washington, D.C., Nov. 28, 1944) p. 29 .

"C. UpHaM, The Alignment, Grade, Width, And Thickness In Design of Road Surfaces, Public Roads, Vol. 2, Nos. 2122, Jan.-Feb. 1920, p. 25.

"Accident Facts, 1927 (National Safety Council, Chicago, 1928) p. 6.

* Report of The Committee ON Statistics (National Conference on Street and Highway Safety, Washington, D.C., Nov. 3, 1924) pp. 7, 21, 26, 27.

${ }^{36}$ Report of The Committee ON Traffic Control (National Conference on Street and Highway Safety, Washington, D.C., Nov. 3, 1924) pp. 9, 10, 14.

${ }^{6}$ Report of The Committee ON Construction and EngiNEerivg (National Conference on Street and Highway Safety, Washington, D.C., Nov. 3, 1924) pp. 5-7, 12 .

Id I., p. 23

sa., p. 15.

${ }^{e 0}$ Report of The Commitee ON Motor Vehrcles (National Conference on Street and Highway Safety, Washington, D.C. Nov. 3, 1924) pp. 9, 14.

${ }^{a 1} I d$., p. 12.

${ }^{62}$ Report of The First National Conference ON Street and Highway Safety, Washington, D.C., Dec. 15-16, 1924, p. 15.

\&d., pp. 9,10

a Report of The Second National Conference ON Street and Highway Safety, Washington, D.C., Mar. 23-25, 1926, p. 15.

${ }^{c 5}$ Id., pp. 19

A. Fletcher, Report of the Committee on Cause and Prevention of Highway Accidents, Proceedings, 7TH ANNuar. MeEtrivg, Vol. 7, (Highway Research Board, Washington, D.C., 1928) pp, 43, 44

${ }^{\sigma}$ BPR, supra, note 48 , p. 10.

- MARK Brooke, Sidewalks, Curbs, Gutters and Highway Signs, AMERICAN HigHWAY ENGINEER's HANDBOOK, A. H Blanchard, ed. (Wiley, New York, 1919) p. 1393.

A. E. Johnson, A Story of Road Signing, AASHO-THE FrRst FifTY YEARS, 1914-1964, (American Association of State Highway Officials, Washington, D.C., 1965) pp. 130, 131.

${ }^{10}$ A. Bruce, Effect of Increased Speed of Vehicles on the Design of Highways, Public Roads, Vol, 10, No. 1, Mar. 1929, p. 11.

${ }^{7} \mathrm{~K}$. SAWYER, Line Controls Country Roads Traffic, EngINEERING NEWs-RECORD, Vol. 85 , No. 18 , Oct. 28,1920 , p. 833.
${ }^{72}$ A. Johnson, Notes on Trafic Speeds, Proceedinas, 13th Annual Meeting (Highway Research Board, Washington, D.C., 1934) p. 353

${ }^{73}$ W. Harger \& E. Bonney, HandBook For Highway EngiNEERs (McGraw-Hill, New York, 1919) p. 33.

${ }^{4} \mathrm{~J}$. BARNeT, Safe Side Friction Factors and Superelevation Design, Proceedings, 16th Annual Meeting, Vol, 16 (Highway Research Board, Washington, D.C., 1936) p. 75.

${ }^{75}$ A Policy on Highway Classification, Approved September 16, 1938, Policies ON Geomerric Design (American Association of State Highway Officials, Washington, D.C., 1950) p. 8 .

${ }^{76}$ A Policy On Geometric Design of Rural Highways (American Association of State Highway Officials, Washington, D.C., 1954)

${ }^{77}$ G. D. Clarke, The Parkway Idert, The Highway and The Landscape, W. B. Snow, ed. (Rutgers Univ. Press, New Brunswick, N.J., 1959) pp. 39, 40.

${ }^{78}$ E. JAMES, Parkway Features of Interest to the Highway Engineer, Public Roads, Vol. 10, No, 2, Apr. 1929, p. 22.

${ }^{79}$ I. F. MORRow, Report of the Section on Architecture of the Commonwealth Club of California, THE CoMMonWealtH, Vol. 8, No. 46, Nov. 15, 1932, p. 245.

${ }^{80} \mathrm{BPR}$, supra, note 48, p. 11.

${ }^{81}$ Editorial, Engineming News-Record, Vol. 103, No. 20, Nov. 14, 1929, p. 757.

${ }^{82}$ B. Marsh, Discussion on Design Research, Proceedrngs, 17th Annual Meeting, Vol, 17 (Highway Research Board, Washington, D.C., 1938) p. 253.

${ }^{8} \mathrm{~W}$. Tномpson, Design Features of Lincoln Highway "Ideal Section," Engineering News-Record, Vol. 88, No. 24, Jun. 15, 1922, p. 982.

${ }^{84}$ Bureau of Public Roads Annual Report, 1937, p. 4.

${ }^{85}$ As related in January 1974 by $\mathrm{E}$. H. Holmes of the BPR, a member of the task force that prepared the Interregional Highway Report.

${ }^{86} \mathrm{H}$. Doc. 272, supra, note 51, p. 4.

${ }^{87} I d$., p. 114.

${ }^{88} I d$., pp. VII, VIII.

${ }^{89}$ Boston-Washington Super Highway, Engineering NewsRECORD, Vol. 126, Apr. 10, 1941, pp. 550, 524

${ }^{*}$ Tolls on Merritt Parkway Paid By $31 / 2$ Million Cars, Engineering News-Record, Vol. 124, No. 11, Mar. 14, 1940, p. 360

${ }^{91}$ Toll Collection Void on Western Parkway, ENGINEERTNG News-ReCoRd, Vol. 124, No. 10, Mar. 7, 1940, p. 353.

${ }^{92}$ Bureau of Public Roads Annual Report, 1920, p. 20.

${ }^{23}$ L. Hewes, Federal Road Building in the National Forests of the West, Public Roads, Vol. 3, No. 26, Jun. 1920, pp. 15 $25,26$.

${ }^{9} I d .$, p. 26.

${ }^{95}$ BPR, supra, note 3, p. 30.

${ }^{98} I d$.

${ }^{n 7} I d .$, p. 31.

${ }^{93}$ Authorization of Road Construction in National Parks (43 Stat 90).

${ }^{93}$ Bureau of Public Roads Annual Report, 1927, p. 32.

${ }^{100}$ Bureau of Public Roads Annual Report, 1935, p. 51.

${ }^{101} \mathrm{BPR}$, supra, note 48, pp. 58, 61.

${ }^{102}$ Bureau of Public Roads Annual Report, 1941, pp. 71, 72.

${ }^{103}$ BPR, supra, note 5, p. 42.

${ }^{104}$ History of the Blue Ridge Parkway Project, Typescript of unknown authorship, dated April 2, 1940, in the files of the National Park Service, Denver, Colorado.

${ }^{105}$ Road Builders Annual Meeting Centers on War Restrictions, ENGineEring News-Record, Vol. 128, No. 11, Mar. 12 , 1942, p. 393

${ }^{106}$ Federal Highway Administration, Highway Statistics, 1973 (Department of Transportation, Washington, D.C., 1974) p. 210

${ }^{107} \mathrm{BPR}$, supra, note 5 , pp. 42, 43 .

${ }^{108}$ Proposed Inter-A merican Highway-Report Prepared By The Department of Agriculture Transmitted To The Secretary of State, S. Doc. 224, 73d Cong., 2d Sess., p. 13.

${ }^{109}$ Bureau of Public Roads anndal Report, 1934, p. 53.

${ }^{110}$ Bureau of Public Roads Annual Report, 1938, p. 63.

${ }^{111} I d$. 


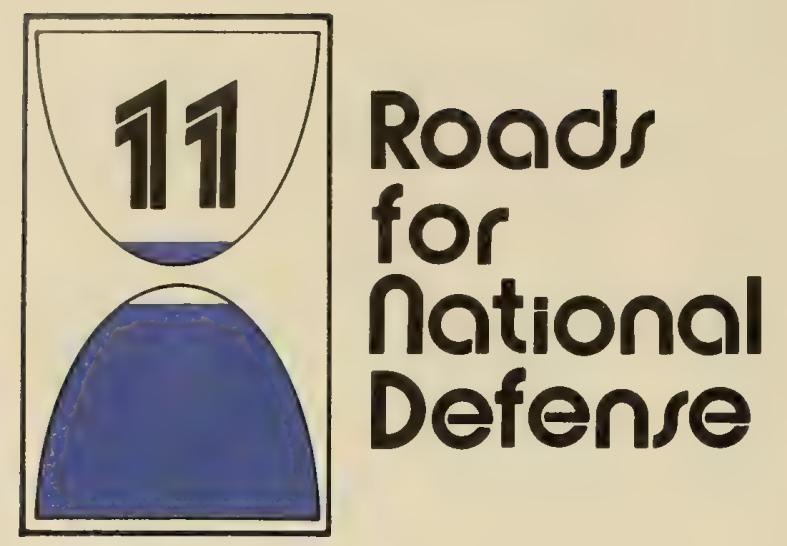

\section{The Pershing Map}

Shortly before the passage of the Federal Highway Act of 1921, Chief MacDonald asked the War Plans Division of the Army General Staff to designate the most important roads for national defense, and he supplied maps on which to show these roads. In 1922 the Army produced the "Pershing Map," showing for the first time the main roads of prime importance in time of war. For the most part, these coincided with the principal roads selected by the States for their 7 percent systems, and, in fact, the War Department's general position was that a system of highways that was adequate to serve the industrial and commercial demands of the Nation would adequately serve the military requirements also.* All of the routes on the Pershing Map were incorporated into the Federal-aid system.

In 1935 the BPR and the War Department restudied the military highway needs to establish priorities for improvement. These priorities were then passed on to the States for use in planning their own highway programs. These needs were a principal factor in selecting the 26,700-mile system of interregional highways recommended by the BPR in its 1939 report, Toll Roads and Free Roads.

* In 1921 General Pershing had testified before Congress that what the United States needed for defense was not wide transcontinental superhighways, but a network of good roads blanketing the country.
In the postwar years, the United States had allowed its military forces to sink into the same unprepared condition that had prevailed before World War I. The rude awakening came in 1939 when the Germans seized Czechoslovakia and prepared to invade Poland. In August 1939, Congress hastily appropriated $\$ 2$ billion for defense, and the country began rearming.

The War Department again reviewed its strategic highway map, adding more routes which brought the total up to some 74,600 miles, of which 29,000 miles were considered of immediate importance to the defense effort. The Public Roads Administration (PRA) (successor to the BPR in a governmental reorganization plan) and the State highway departments immediately began an inventory of the strategic network roads which disclosed that thousands of miles of the network failed to meet adequate standards for either military or civilian traffic. Worst of all, the survey revealed that there were 2,400 bridges that were unable to safely sustain the $\mathrm{H}-15$ loading of the American Association of State Highway Officials, which was then the standard for bridges on the Federal-aid system.*

\footnotetext{
* Since 1935 the Army had designed military equipment to stay within the limits of AASHO bridge loadings. Bridges designed for $\mathrm{H}-15$ loading would readily carry all classes of military equipment except 50 -ton tanks. These could safely pass under special speed and spacing restrictions.
} 


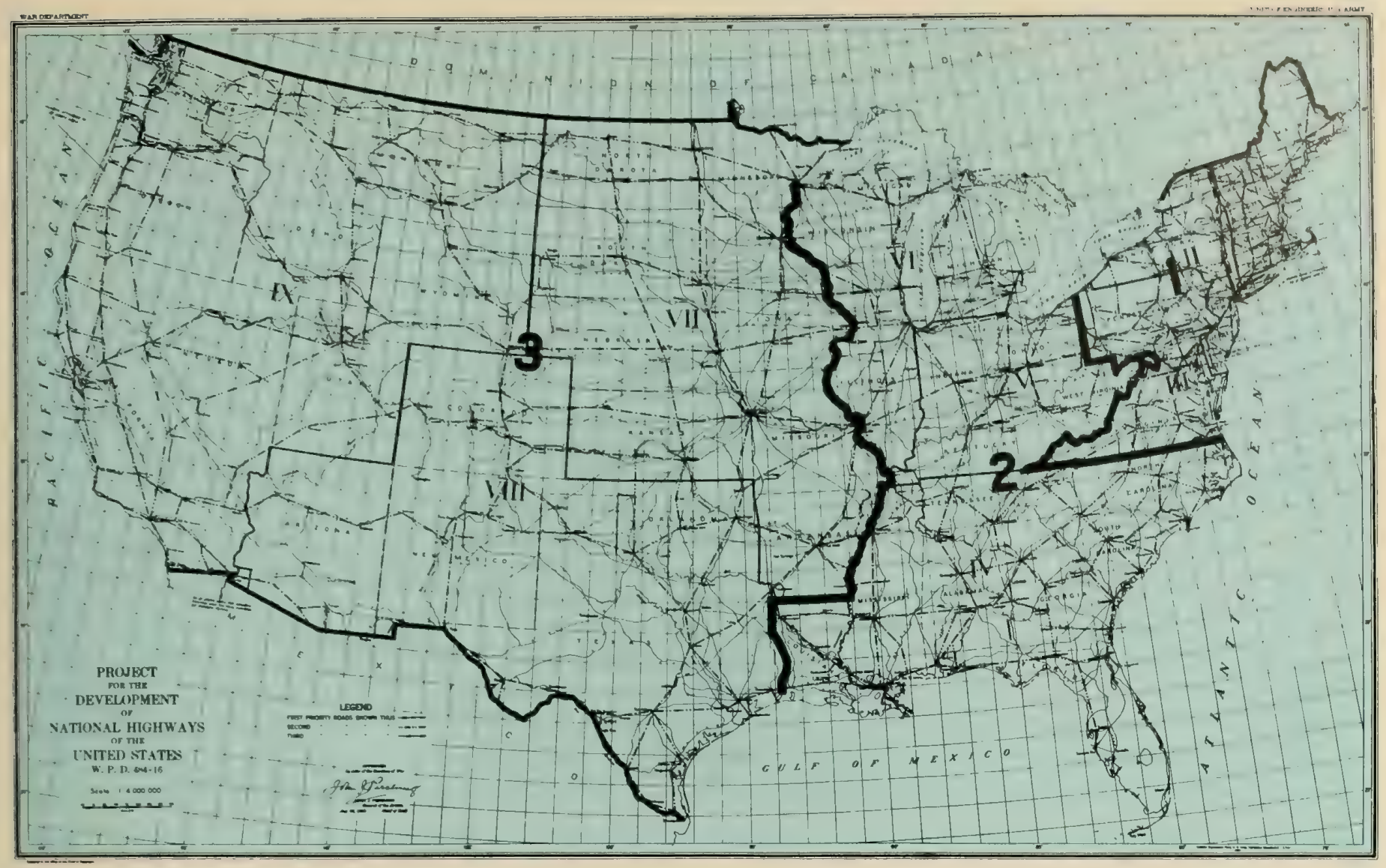

The 1922 "Pershing Map."

The PRA estimated that it would cost $\$ 202$ million to remedy these deficiencies, yet Congress had made no appropriations specifically for public roads outside of Federal reservations as a part of the defense buildup. However, the need for such roads increased rapidly as the Army and Navy began enlarging existing posts and laying out new camps and airfields, many of them in areas served only by county and local roads. The Government placed some defense establishments, such as powder works, in remote areas almost devoid of roads. And mobilization placed abnormal strains on the State highway systems to move men and materials to new or enlarged factories.

The stalemate in the European war ended in April 1940 with the German invasion of Denmark, and by the end of June, the Germans were in firm control of Western Europe. Frantically, the United States began mobilizing for war. Between June and September 1940 , Congress appropriated $\$ 11.55$ billion for military housing, armaments, munitions, shipyards and a twoocean navy. On September 16, 1940, Congress enacted the first peacetime draft.

The Administration asked the States and counties to step up work on the strategic network and on access roads to defense installations, but with little success. Many of the defense access roads were not on the Federal-aid or State highway systems and were thus ineligible for improvement with Federal or State funds. The counties were impoverished and unable to take on the added burden of providing for vastly increased volumes of defense traffic. The Federal-aid secondary and feeder road funds for fiscal years 1940

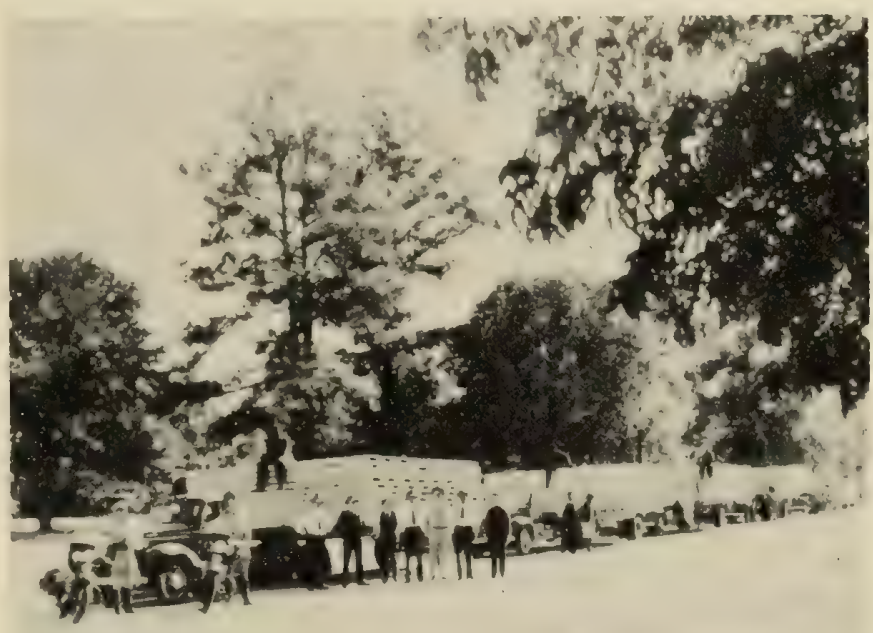

With WW II approaching, access roads had to be built for new military posts being established. This fleet of trucks carrying tent platforms was going to Camp Shelby, Miss., where a tent city was built to quarter 50,000 recruits. 
and 1941, drastically cut by Congress, were hopelessly inadequate for the job.

The only agency with sizable Federal funds that could be used quickly to build access roads was the Work Projects Administration, which was still getting about $\$ 65$ million per month for unemployment work relief. Wherever possible the WPA's efforts were channeled into defense projects. The requirement that sponsors contribute 25 percent of the project cost was waived and the nonlabor cost limit on projects was raised from $\$ 20,000$ to $\$ 100,000$ to permit the purchase of more materials and the use of machinery. ${ }^{1}$ For about 5 critical months in the summer and fall of 1940 the WPA kept traffic moving and averted paralysis at dozens of defense installations. These roads were mostly upgraded local roads and not really planned to meet installation needs, but they filled the gap until Congress provided funds for more adequate roads.

Meanwhile Commissioner MacDonald tried to persuade the States to concentrate their funds on the most urgent needs of the strategic highway system. $\mathrm{He}$ had no direct legislative authority to do this but relied on his powers of persuasion and the authority conferred in the original Federal Aid Road Act of 1916 to approve or disapprove projects. In August 1940 MacDonald rejected the Oklahoma highway department's entire $\$ 5$ million Federal-aid program because it was scattered throughout the State with little regard for strategic needs. ${ }^{2}$ A month later Congress, in the Federal Highway Act of 1940, gave the Commissioner of Public Roads specific authority to give priority to defense highways in approving Federalaid projects. In an even more drastic departure from traditional Federal-aid policies, Congress also authorized the Federal Works Administrator to initiate defense projects urgently requested by the Secretary of War or Secretary of the Navy and to charge the cost of these projects to the Federal-aid apportionments of the States in which they were situated.

This Act was not popular with the States, who viewed it as an attempt to make them pay for road costs that were primarily the responsibility of the national government. It provided no money for urgently needed access roads to defense establishments and, in the face of increasing civilian highway needs, actually reduced the Federal aid authorized for fiscal years 1942 and 1943. Nevertheless, most of them voluntarily concentrated a large part of their funds and other resources on the strategic network and such access roads as were on the Federal-aid system, and they also provided engineering assistance to counties for access roads not on the Federal-aid system. By October 1941, the combined Federal-aid programs of the States totaled 11,271 miles, of which 2,884 miles were on the strategic network and 197 miles were access roads. Over 40 percent of the total funds programed were directed particularly to meeting defense needs. ${ }^{3}$

\section{The PRA Report on Defense Highway Needs}

On June 21, 1940, President Roosevelt requested John M. Carmody, the Federal Works Administrator,

to have the Public Roads Administration ... make a survey of our highway facilities from the viewpoint of national defense and advise me as to any steps that appear necessary.

I suggest that particular attention be paid to the strength of bridges, the width of strategic roads, adequacy of ingress and egress from urban centers, and the servicing of existing and proposed Army, Navy and Air bases." "

The PRA's report of February 1, 1941, Highways For the National Defense, disclosed an urgent need for the improvement or construction of 1,500 miles of roads entirely within military reservations and 2,830 miles of access roads to serve 192 military establishments. The estimated cost of the access roads was $\$ 220$ million. The report noted that there were 2,436 substandard bridges in the strategic network and 14,000 miles of surfaces incapable of supporting 9,000 pound wheel loads in all weather. To eliminate these deficiencies would cost $\$ 458$ million. The PRA recommended immediate appropriation of $\$ 150$ million for access roads and at least $\$ 100$ million to remedy critical deficiencies in the strategic network, the latter to be apportioned according to the traditional Federalaid formula.

There was no immediate action on the PRA report, and it was not until June 2, 1941, that the President asked Congress to provide funds for defense highways. After extensive hearings in both Houses, Congress passed a defense highway bill which provided $\$ 150$ million for access roads and $\$ 125$ million to correct critical deficiencies in the strategic network to be apportioned among the States according to the Federalaid formula.

The President vetoed this bill because of the mandatory apportionment of the strategic highway funds among the States, which, he said prevented the Administration from placing the funds where they were most needed. The veto did not escape criticism. The Engineering News-Record observed that the President had in the past made repeated attacks on the apportionment of Federal-aid funds among the States. The veto, it declared, "is a step toward complete Federal control over Federal contributions to state highway work, which appears to be the President's objective."

Congress bent a little but did not entirely accede to the President's wishes. Three months after the veto, it passed a practically identical bill, with the strategic highway funds scaled down to $\$ 50$ million of which half were to be apportioned according to the Federalaid formula and half could be allocated anywhere on the network at the discretion of the Federal Works Administrator. The matching ratio on these funds was to be 75 Federal to 25 State. The $\$ 150$ million of access road funds in the bill did not have to be matched, but initiation of projects was left to the Government rather than the States.* The President signed this bill November 19, 1941.

\section{War Traffic Pounds the Highways}

The Defense Highway Act cleared the way for a tremendous highway effort. In October 1941, the PRA began construction of a vast network of express highways in Arlington County, Virginia, to funnel 50,000 workers into the huge Pentagon Building under

* Congress authorized the appropriation of an additional $\$ 100$ million for defense access roads in 1942 and $a$ further $\$ 25$ million in 1944 . 


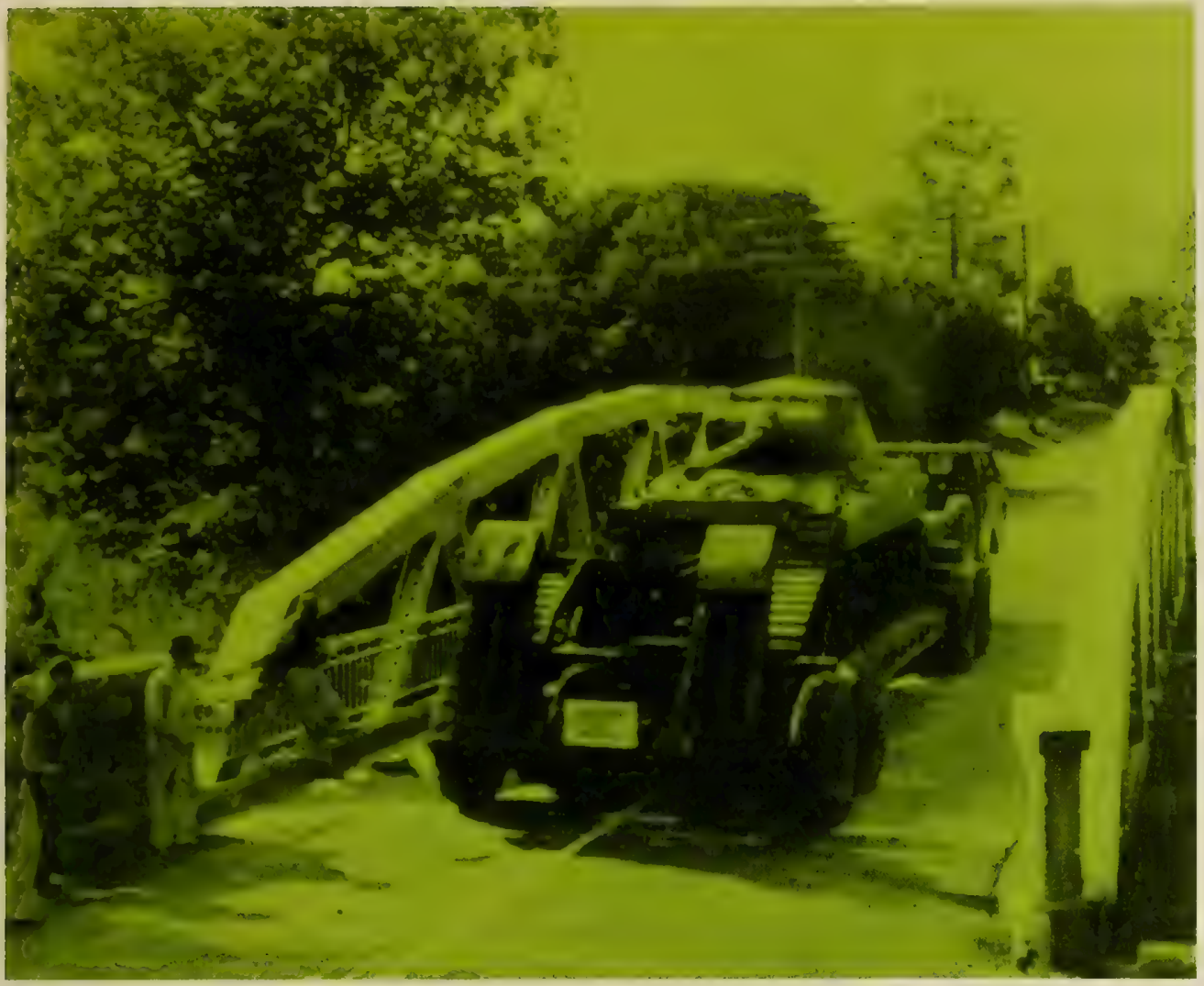

This bridge on U.S. Route 30 in Pennsylvania could carry only infrequent loads such as the 152,000pound tank transporter and tank. construction by the War Department. In 1942 alone, the PRA approved 600 access road projects costing over $\$ 200$ million. Some of these projects were very large indeed. In Michigan the highway department began work on a $\$ 12$ million limited access expressway connecting Detroit to the River Rouge defense industry complex and the Ford Willow Run bomber plant.

After the official entry of the United States into the war in December 1941, packs of German submarines began preying on the coastal sealanes, and by May 1942, they were sinking oil tankers at such a rate as to cause acute fuel shortages in the east. The Office of Defense Transportation diverted railroad tank cars normally used to serve inland States to East Coast destinations, hoping that the trucking industry would fill the transportation gap. However, this plan ran into a stubborn obstacle-the size and weight laws of the States.

For years organizations such as the National Highway Users Conference, the trucking associations, and the automobile manufacturers had been trying to get the States to enact uniform size and weight laws so that trucks could pass readily across State lines. Before World War I there had been bills in Congress proposing national registration of vehicles and Federal size and weight laws, but in the end the Government left this field of regulation to the States. The result was diversity, not to say chaos. In 1941 five States still limited wheel loads according to the width of tire-a holdover from the days of solid rubber tires, which had long since disappeared from the highways. Texas and Louisiana imposed the absurd limit of 7,000 pounds on "payloads." In Kentucky the gross load limit of a four-wheel vehicle on pneumatic tires was 18,000 pounds and in six other States, it was 20,000 pounds. At the same time, other States per- mitted gross loads as high as 36,000 pounds on four wheels. In the neighboring States of North and South Dakota the difference in permissible gross loading was 12,000 pounds. The permissible gross load on one axle-a more significant measure of stresses imposed on roads-varied from 12,000 pounds in Alabama and Mississippi to 22,400 pounds in Rhode Island and New York, and even 24,640 pounds in the District of Columbia. ${ }^{6}$

In January 1942 a bill was introduced in Congress giving the Interstate Commerce Commission the power to set uniform truck weights and sizes as a war measure. ${ }^{7}$ Thereafter, a number of States raised their load limits. The PRA and AASHO drew up a provisional Uniform Code of Weights, Heights and Lengths of Motor Vehicles which permitted axle loads of 18,000 pounds and gross loads on four wheels of 30,000 pounds, and up to 40,000 pounds on trucks of three or more axles. This code was put into effect in all States in May 1942, in some by the legislature and in others by proclamation of the Governor, under the auspices of the Council of State Governments.

Despite the liberal limits, widespread violations of the code began almost immediately. When some States began enforcing the new limit, the truckers appealed to the legislature or the governors or even congressmen to suspend the penalties for overloading. Appeals to the Office of Defense Transportation (ODT) to stop overloading at the source fell on deaf ears. The controversy came to a head in Colorado when Charles D. Vail, who was State Highway Engineer and also head of the State Patrol began cracking down on the overloaders, most of whom were petroleum haulers. He had two reasons for this. One was to enforce the law and prevent wholesale damage to the State's highways. The other was fear that if the 


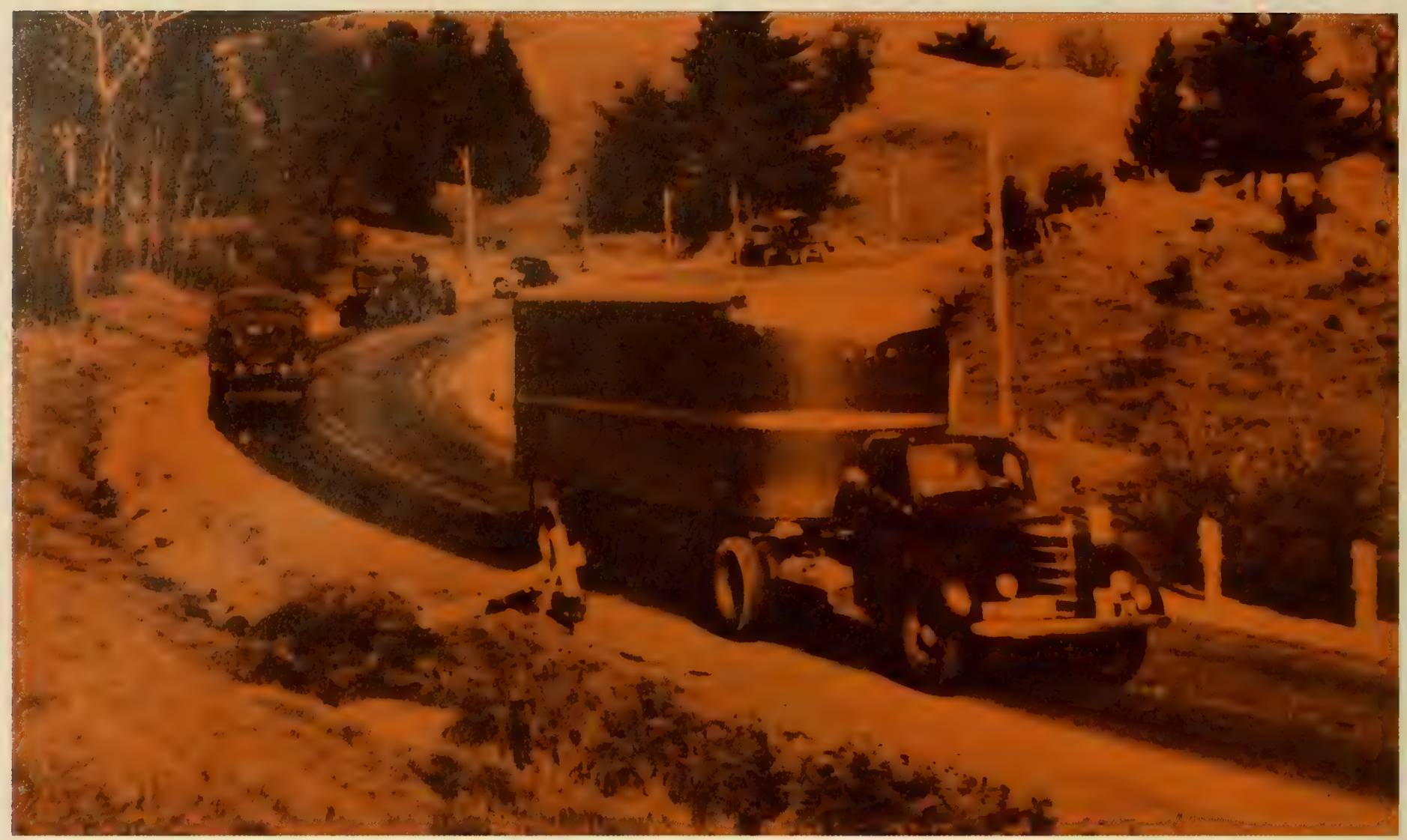

Because of the necessity to transport war materials, commercial and military trucks were allowed to carry overloaded cargo at the expense of the Nation's roads.

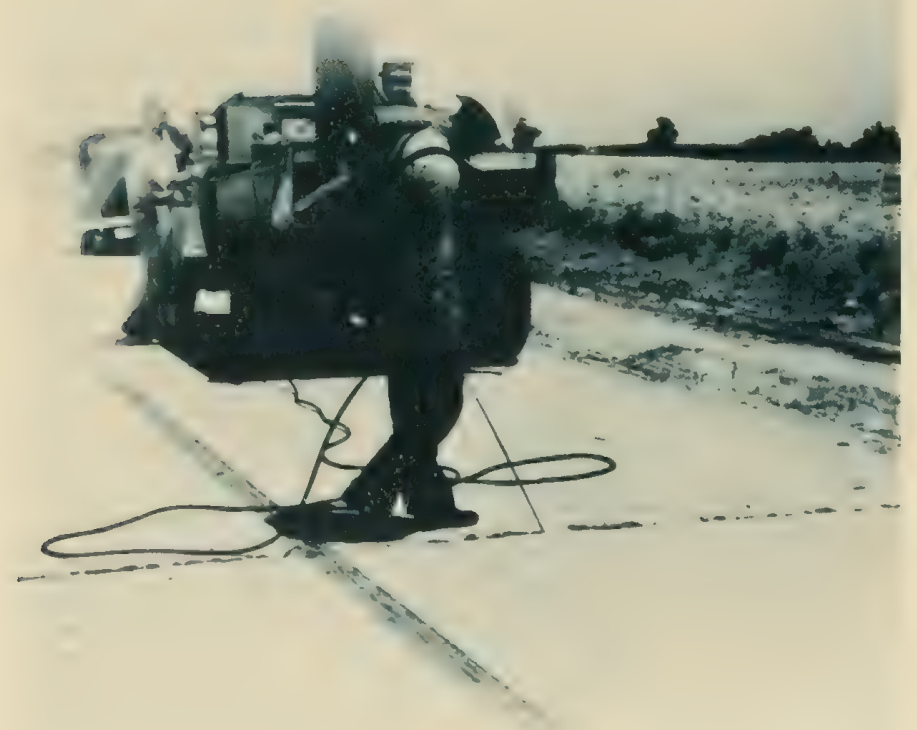

With materials rationed, only minor maintenance, such as patching the cracks in the surface, was performed. law were not enforced the overloads would become the plateau for a new round of weight-increase demands by the truckers after the war that would lead to the eventual rebuilding of the entire State highway system. ${ }^{8}$

In March 1943, ODT complained to the Governor that Colorado's rigid enforcement was causing bottlenecks in motor freight movements throughout the Rocky Mountain area and was making it impossible for operators to use their most efficient equipment.* ODT suggested that Colorado issue free overload permits to allow the truckers to run regularly with overloads for the duration of the emergency. Vail countered with a plan to issue permits for a nominal fee for small overloads, but with fees increasing steeply for serious overloads. This, Vail said, would permit nominal overloads up to a certain point but would make it unprofitable to operate with dangerously destructive overloads.

The Defense Transportation Coordinator then appealed directly to Governor Vivian to "liberalize" Colorado's enforcement of the Uniform Code, and in September 1943, the Governor by proclamation and executive order set aside the State's regulatory laws as they might apply to the transportation of materials necessary for the war effort and specifically authorized the continued operation of overlength and overweight equipment without payment of any fees.

\footnotetext{
* By this time, the truck manufacturing industry, which was going full force to keep up with wartime demands, was producing trucks in quantity which, when fully loaded, considerably exceeded the 18,000-pound axle load of the emergency code.
} 
This victory for the truckers was widely publicized, and it seriously crippled enforcement of the code in other States. In the words of the PRA, "On high military authority, roads were pronounced expendable." 9

Although the highway administrators, including Commissioner MacDonald, were deeply worried about overloading, the rest of the country was more concerned about critical shortages of fuel, rubber, manpower and vehicles, and overloading was widely tolerated as a way to conserve all four. One highway administrator commented, "Unwise publicity has conditioned public opinion to the point where even arrests made of the most flagrant violators of trucking codes are considered obstructive of interstate war transportation plans." 10

\section{The End of the Highway Boom}

The great highway boom that began in 1921 and continued unabated through the Great Depression, came to an end in the complexities and frustrations of mobilization and war. Fiscal year 1941 was the peak year for the Federal-aid program with 12,936 miles of roads of all classes completed; thereafter completed mileage fell to 10,178 miles in fiscal year 1942, and 8,445 miles in 1943.11 After 1942 practically all new work related directly to national defense. The diminishing Federal-aid funds were used to solve traffic problems in areas congested by war activities.* The forest highway funds went into mineral access and timber access roads to provide raw materials for the war effort.

The highway departments were feeling the pinch of scarcities even before Pearl Harbor. In June 1941, the Office of Defense Mobilization imposed materials priorities for all kinds of construction, ranging from A-1 for access roads to military installations and defense plants to $\mathbf{A}-\mathbf{1 0}$ on materials needed for maintenance repairs to Federal-aid highways. Materials for bridges, tunnels and shoulders for roads on the strategic network rated an A-2 priority if on primary highways or A-7 if on secondaries. By April 1942, it required a priority of $\mathbf{A}-3$ or better to get steel of any kind, and at least $\mathbf{A}-1$ to get track-laying tractors or other construction machinery. Only 15 percent of the total U.S. production of construction equipment was going to the domestic market-the rest went to equip Army and Navy engineer troops or as lendlease to European allies. ${ }^{12}$

In April 1942, the Petroleum Coordinator for War limited the use of asphalt and tar in the 17 Atlantic Seaboard States to projects certified by the PRA as necessary to the successful prosecution of the war. This order was extended to the Rocky Mountains in July. The PRA channeled most of the available asphalt and tar into maintenance "since it is important that the condition of war transport arteries not be allowed to deteriorate." 13

To get around the steel shortage, the States changed their designs. Ohio began using wooden bridges on secondary highways. Arch culverts requiring no steel

\footnotetext{
* There were no regular Federal-aid authorizations for fiscal years 1944 and 1945.
}

were substituted for reinforced concrete box culverts; steel reinforcing was omitted from concrete pavements.

Acute manpower shortages began to appear in certain categories of employees. In Michigan 40 percent of the draftsmen left the State highway department for the Army or other employment, along with 25 percent of the designers and 27 percent of the inspectors. The Pennsylvania highway department's engineering staff dropped from 2,728 persons to 2,069 in 8 months. ${ }^{14}$ Utah experienced such a serious loss of mechanics that it became difficult to keep its equipment running.

Contractors became scarce as bid prices advanced. In Kansas some contractors asked to be released from their road contracts in order to bid on defense work.

In the face of these difficulties, the States curtailed operations drastically. In April 1942, the War Production Board issued an order stopping all construction not essential to the war effort. Pennsylvania canceled its $\$ 50$ million construction program. Indiana rescinded all bridge contracts and North Carolina abandoned all contracts already let except $\$ 3,145,000$ of high priority defense access projects. By the end of 1943, State work was down to bare bones maintenance and a diminishing number of defense access projects.

The maintenance was actually insufficient to keep up with the increasing needs. Periodic resurfacing and strengthening, so necessary to preserve the integrity of pavements, was greatly reduced and reconstruction practically eliminated. The result was the rapid advance of decrepitude accompanied by soaring maintenance outlays as the State highway departments struggled to keep the ever-weakening highway plant in operation.

\section{Rationing Highway Service}

After the outbreak of war, the Government prohibited the manufacture of automobiles and the auto manufacturers converted their plants to arsenals for the production of tanks, aircraft engines and ordnance. The number of new cars produced dropped from $3,779,682$ in 1941 to 222,862 in 1942 and only 139 and 610 in 1943 and 1944. ${ }^{15}$ The few new cars available in 1942 were strictly rationed.

An acute shortage of rubber developed very early in the war and continued until the United States created its own supplies of synthetic rubber. The War Production Board rationed tires and recapping rubber to extend the dwindling supplies, but this did nothing to conserve the huge inventory of tires on the national fleet of 34.4 million vehicles. In July 1942, the President asked the States to reduce highway speed limits to 35 miles per hour, primarily to conserve rubber, but also to save fuel and engine wear.* Subsequent speed studies by the PRA in 15 States disclosed fairly good public acceptance of the reduced

\footnotetext{
* It had been common knowledge for 20 years that high speed operation greatly shortened tire life. In 1942 and 1943, investigations by the PRA and the Iowa Engineering Experiment Station demonstrated that the life expectancy of tires driven on concrete pavements at 65 miles per hour was only 18,700 miles, but that if the speed were held to 35 miles per hour or less, identical tires had a life of 56,500 miles. $^{16}$
} 
limit. The observers noted average speeds of 37 miles per hour for cars and 36 miles per hour for trucks, but 23 percent of the drivers continued to drive over 40 miles per hour. ${ }^{17}$

By April 1942, fuel shortages were so severe in the eastern States that the Government imposed gasoline rationing, and by November 1942, rationing was imposed nationwide. This greatly diminished "nonessential" travel, but the volume of essential travel was still huge.

The mobilization of $1940-41$ had shown in a startling way how dependent the United States had become on its highways for its very existence. Studies in Michigan showed that 13 percent of the defense plants received all of their materials by highway. Most of the remaining plants received at least 50 percent of their materials by highway and more than half of their outgoing products left that way. In February 1942, Commissioner MacDonald announced that only a small fraction of the 10 million workers required to man the defense plants could possibly be accommodated by the existing rail and bus transit facilities, and all the rest would have to move in private automobiles. $^{18}$ Another study in Kansas showed that 81 percent of the employees of a large aircraft factory lived more than 5 miles from the plant and 17 percent more than 10 miles away. Only 5 percent of the plant workers used public transportation; 93 percent depended on private automobiles. ${ }^{19}$

In the early years of the defense effort, it was generally understood that it would take time to build new highways or enlarge the old ones and that in the meantime it would be necessary to greatly improve the utilization of the existing highway and mass transit plants. To promote this utilization, the Secretary of War, in December 1940, appointed a Highway Traffic Advisory Committee composed of Commissioner MacDonald of the PRA and the presidents of AASHO, the International Association of Chiefs of Police and the American Association of Motor Vehicle
Administrators. The Secretary also asked that each State Governor appoint a State Highway Traffic Advisory Committee, and this was done early in 1941. The several committees then concentrated on local action plans to organize transportation at warplants so as to eliminate the need for costly road improvements.

Widespread staggered working hour programs reduced traffic peaks by 10 to 15 percent and also increased the utilization of buses and streetcars. In Atlanta a staggered hour plan had the effect of adding 90 buses to the city's fleet of 455 . Intense group riding campaigns resulted in hundreds of carpools and increased average car occupancy from two or less to 3.8 , and in some cases even 4.2 occupants per car. Walking to work was encouraged as patriotic exercise, but the committees found that few workmen would walk if the one-way distance was more than 2 miles. ${ }^{20}$

\section{Shrinkage of Highway Revenues}

Rationing reduced not only nonessential travel, but highway revenues as well. Although nearly three million trucks and buses were produced during the 4 war years, total vehicle registration dropped by over 1.4 million as wear and tear took their normal toll, and thousands of owners laid up their cars for the duration.

The eastern States were the first to feel the financial pinch. By August 1942, Maryland gas tax collections were running $\$ 250,000$ per month behind 1941. Iowa revenues dropped 33 percent in June 1942 as compared to the same month in 1941. The Public Roads Administration reported that following nationwide gasoline rationing, highway traffic dropped 35 to 40 percent below corresponding levels for 1941 .

In some States this loss of revenue was not particularly serious since there were no capital improvement programs underway requiring large expenditures. The diminished revenues were sufficient to take

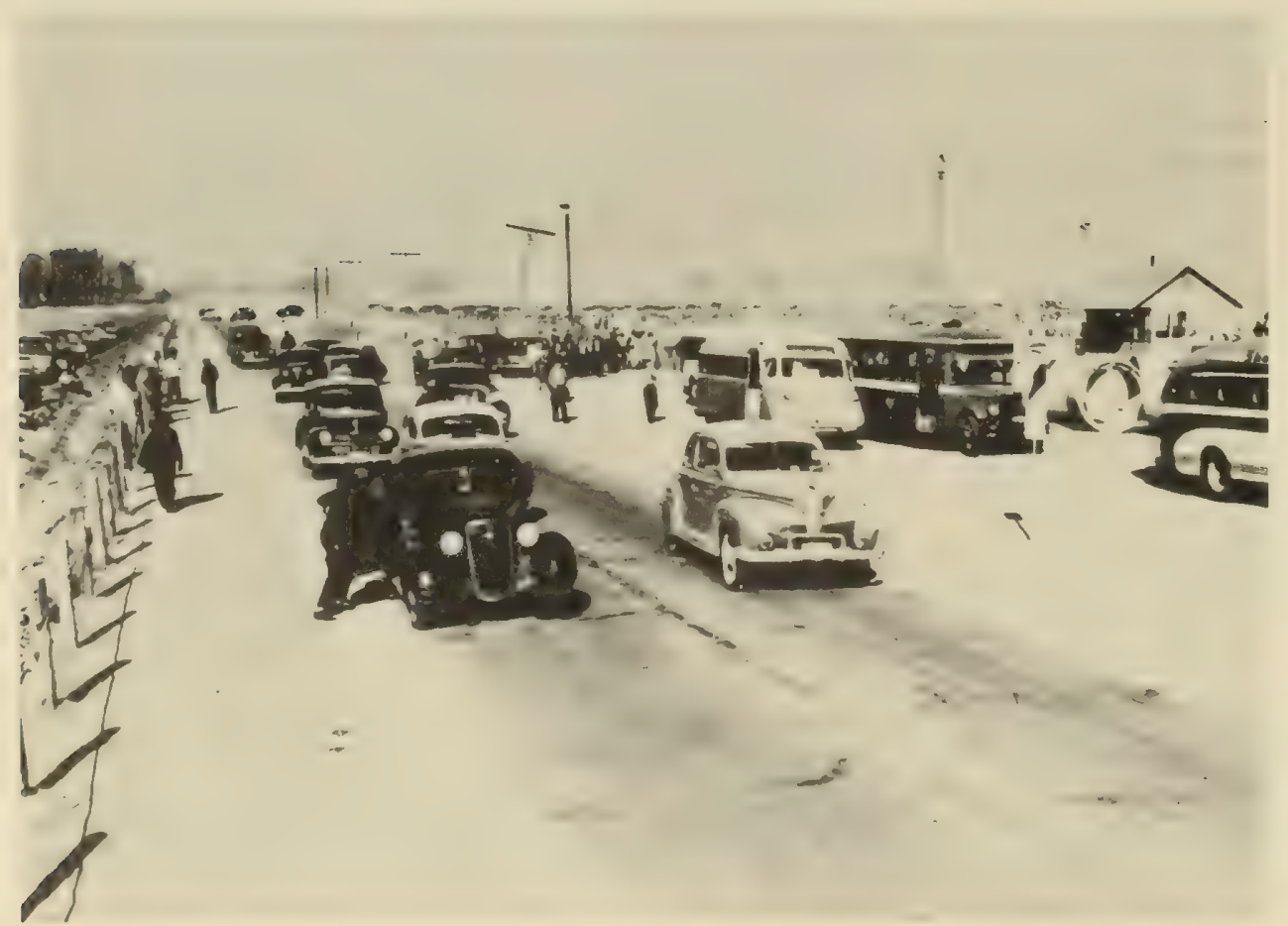

Even with the rationing of gas and automotive parts, workers at the Willow Run bomber plant in Michigan depended on private cars to go to and from work. 


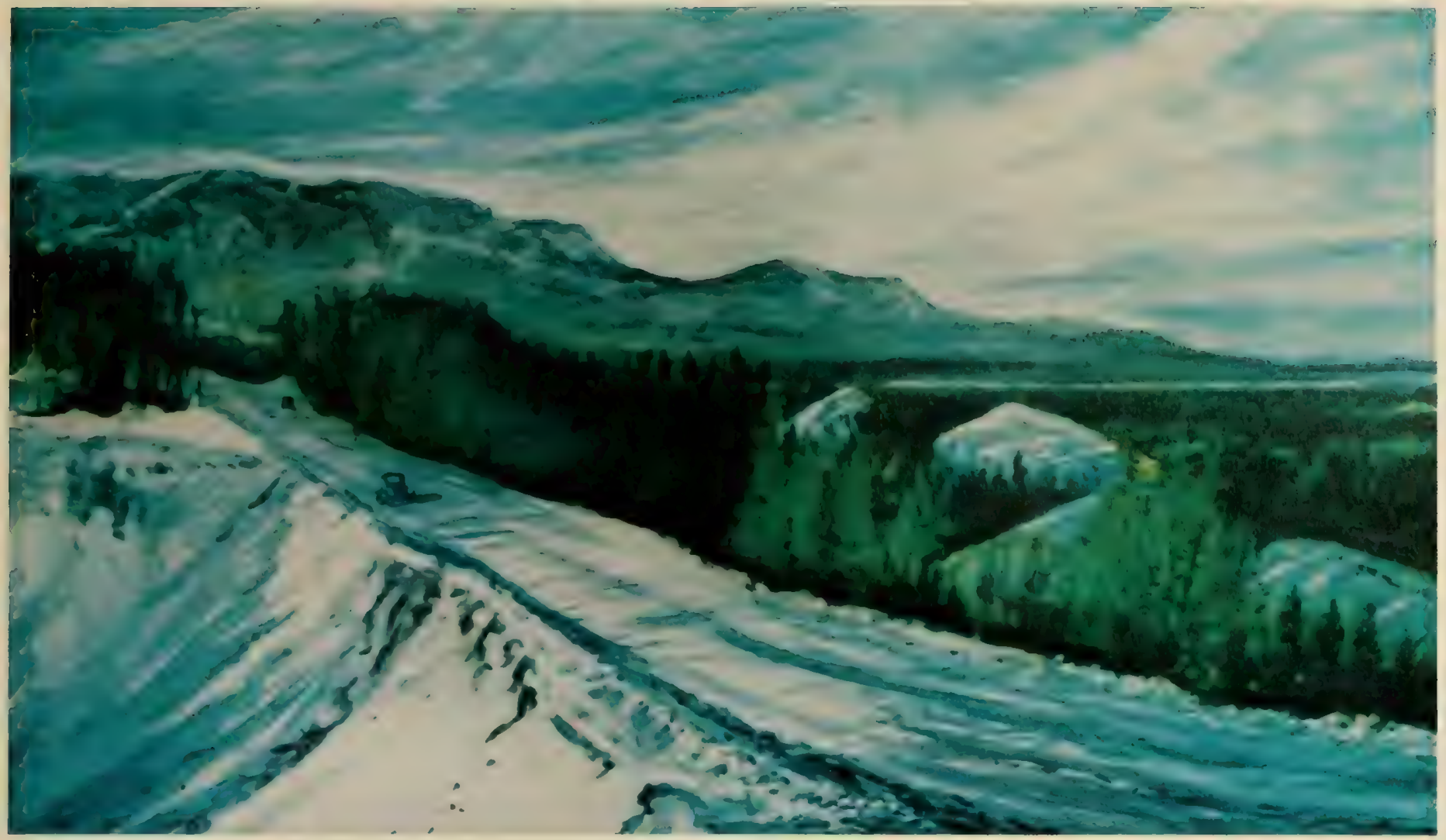

By October 1943, the Alaska Highway was ready to serve as an overland route, maintaining the U.S. link with Alaska.

care of bond service and maintenance. But other States, particularly those that had become accustomed to diverting large amounts of highway revenue to nonhighway purposes, underwent severe financial embarrassment. Highway officials and road user organizations that had preached for years against diversion viewed the predicament of these States with considerable relish, best express by the Engineering NewsRecord, a long-time foe of the diversionists.

Where reserved for highway purposes these declining funds are still relatively proportionate to requirements. But in those States where legislatures have made diversions to the general fund, relief, the school system or oyster propagation, the present decline in revenues has brought retribution that is harsh as it is just. The legislatures that avoided finding money for relief or for their school systems must now find money to keep their roads from going to pieces. ${ }^{21}$

Amidst the gloom of war, the shortages of everything and the wartime restrictions there was one piece of cheerful news. Motor vehicle traffic accidents dropped materially in 1942, not only in number but in the rate per 100 million vehicle miles of travel.* This was due to a combination of factors-reduced exposure, lower speeds and, probably, greater emphasis on safety as a contribution to the war effort.

\section{Defense Road to Alaska}

After the Pacific Fleet was crippled at Pearl Harbor, it seemed possible that the United States might be cut off from Alaska except by air. The U.S.-

* The fatalities in 1941 were 39,969 with a rate of 12,0 fatalities per 100 million vehicle miles. In 1942, deaths dropped to 28,309 total, or 10.6 per 100 million vehicle miles. Fatalities remained below the 1941 level until 1957.22
Canadian Permanent Joint Board on Defense recommended that a military road be built through Canada to Alaska, and the United States offered to build it. By mid-March 1942, the two countries agreed that Canada would supply the right-of-way and waive customs duties and the United States would build and maintain the road during the war and for 6 months afterward. The 1,400-mile plus route from Dawson Creek, British Columbia, to Big Delta, Alaska, was intended primarily to connect and supply a chain of strategic military airfields and provide an all-weather overland supply route to Alaska. As soon as the agreement with Canada was negotiated, the War Department requested the help of the PRA for locating and building the road.

Within a week of the agreement, U.S. engineer troops began cutting a pioneer road through the Canadian wilderness. During the season of 1942, the Army placed seven regiments on the project and, with the assistance of PRA location engineers and contractors, pushed the pioneer road through the entire distance to Big Delta. Meanwhile, the PRA was working as rapidly as possible on reconnaissance, survey, and plan preparation for the proposed allweather road. In addition the PRA was busy mobilizing engineers, contractors and equipment for the huge job.

Time did not permit the usual procedure of preparing plans and specifications, advertising for bids and letting contracts. Instead, the PRA engaged four engineering firms as management contractors. These firms recruited American and Canadian construction contractors for the work, and by the summer of 1942, in a period of only 3 or 4 months, 52 contractors and 7,000 construction workers were mobilized in working 
camps along the route, widening, surfacing and building sections of the Army's pioneer road. ${ }^{3}$ On November 20,1942, 7 months and 17 days from start of work, a crude but motorable road was opened to truck traffic the entire distance to Big Delta. ${ }^{24}$

By the summer of 1943 the PRA had doubled the construction force and concentrated on further widening and improving the pioneer road as well as building new sections and some permanent bridges. At the peak of operations in September 1943, there were 1,850 PRA employees and 14,100 civilian employees of 81 contractors working with over 11,000 pieces of construction equipment on the job. As with the pioneer road, the bulk of the construction of the 1,420 miles of final highway was largely completed in a 4-month period at a final cost of $\$ 130.6$ million. ${ }^{25}$ On October 31, 1943, the PRA phased out its work on the all-weather truck route and turned the project over to the Army for maintenance. ${ }^{26}$

\section{The Trans-Isthmian Highway}

For years after completion of the Panama Canal, the only land link between the Atlantic and Pacific ends of the Canal was the efficient Panama Railroad, wholly owned by the United States Government. In 1939 the Army, concerned about the possibility of the railroad's being knocked out by bombing or sabotage, recommended construction of a modern truck highway across the isthmus, and the State Department then negotiated a treaty under which the United States agreed to build the road from Colon across Panamanian territory to Madden Dam, and Panama agreed to supply the right-of-way.* Construction of the highway was assigned to the Public Roads Administration and the grading work was largely completed during the 1941 dry season.

When war was declared in December 1941, the Army urgently requested the PRA to finish the paving on a crash schedule extending into the wet season and also to accelerate work on a section of the InterAmerican Highway extending from Chorrera to the strategic Rio Hato airfield. For both jobs the War Production Board assigned A-1 priorities. Despite the wettest dry season in years, the PRA and the Panamanian Government completed the 72 miles of concrete pavement and 42 bridges and opened both projects by July 1, 1942.

\section{War Work on the Inter-American Highway}

In December 1941, Congress authorized appropriations of $\$ 20$ million as aid to the six Central American republics for the construction of the Inter-American Highway from the Mexico-Guatemala border to the Canal Zone. To be eligible for the aid, each country agreed to complete its part of the highway and to pay one-third of the cost. These assurances were received from the six countries by April 1942, and each with the help of the PRA developed a 4-year construction plan to push the road to completion.

* There was already a heavy duty highway from Madden Dam to the city of Panama built by the United States in 1931 as a construction access road to Madden Dam.
As shipping losses to submarines mounted in early 1942, the Army became apprehensive that the United States might be cut off from the Panama Canal, and the General Staff decided to open a pioneer road through the remaining gaps in the Inter-American Highway, using military funds. The standards adopted by the Army for the pioneer road were much inferior to those agreed upon between PRA and the cooperating countries, but the Army agreed to follow the route chosen for the Inter-American Highway as closely as possible.

By mid-July 1942, the Chief of Engineers had assigned a staff to proceed with the pioneer road project. Contracts were made with the governments of Guatemala and El Salvador to complete the pioneer road in their respective countries using U.S. furnished equipment and with three American road contractors for the remainder. The PRA continued its work in Costa Rica and Panama and maintained engineering advisors to other countries where PRA assistance was requested.

The work began in Guatemala in November 1942, but ran into trouble almost immediately. The General Staff gave the Inter-American project a very low priority in its global schedule. Equipment and supplies essential for military operations elsewhere were grudgingly and sparingly committed to the pioneer road project. Stringent shipping restrictions also delayed the arrival of essential supplies. Finally, in October 1943, the Army decided the pioneer road was no longer strategically significant, withdrew the staff to other duties, and closed the project. The PRA continued construction on the project in Costa Rica. A short time later the PRA engineers returned to their technical assistance efforts in the countries working on their 4-year construction programs.

\section{Postwar Planning}

The Defense Highway Act of 1941 provided a small sum, \$10 million, for postwar planning, and MacDonald was able to channel most of this, with the State matching funds, into projects on the interregional system proposed in the BPR's toll road report of 1939.* However, actual planning proceeded rather slowly due to scarcity of engineers and planners, even though some States took extraordinary measures to overcome the manpower shortage by hiring high school students and older men and women for routine work. Urban expressways, such as the Bayshore Freeway in San Francisco and the WashingtonBaltimore Expressway, predominated in most of this planning, but New York began studies for a superhighway system that would traverse the entire State from the New Jersey border to Lake Erie. Indiana made plans for rebuilding 60 percent of its antiquated State highway system on which the pavements were less than 20 feet wide.

The Pennsylvania Turnpike, opened late in 1940, had grossed \$2.6 million in its first 11 months of operation-enough to pay all expenses with a good

\footnotetext{
* Congress provided another $\$ 50$ million for planning in the
} Act of July 13, 1943 ( 57 Stat 560). 
margin for bond payment.*27 Undoubtedly, the successful experience of this toll road had much to do with 1941 legislation in Florida, Illinois, Maine, Maryland and New York creating independent authorities to sell bonds and build toll roads. Similar bills in Missouri, New Jersey, Oklahoma and Wisconsin were defeated by narrow margins. ${ }^{29}$

The Pennsylvania experience seemed to prove that the motoring public wanted wide, high-speed highways at a much faster rate than they were being provided by the States and was willing to pay a stiff extra charge to obtain them. Nevertheless, the Government persisted in its opposition to toll roads, and on April 14, 1941, President Roosevelt appointed a National Interregional Highway Committee of prominent highway engineers and planners, "to investigate the need for a limited system of national highways to improve the facilities now available for interregional transportation, and to advise the Federal Works Administrator as to the desirable character of such improvements, and the possibility of utilizing some of the manpower and industrial capacity expected to be available at the end of the war." 30 Commissioner MacDonald of the PRA, who was also chairman of the new committee, provided it with a working staff of the men who had been most closely identified with traffic research during the two previous decades.
Meanwhile, schemes for national superhighways were being proposed in and out of Congress. In October 1941, the chairman of the Missouri Highway Commission called for a comprehensive plan for a system of postwar limited access highways. The plans for these, he said, should be prepared immediately so that they would be ready when normal times returned. ${ }^{31} \mathrm{~A}$ bill introduced into Congress in October 1942, would authorize a 25,000-mile network of 14 strategic routes costing $\$ 10$ billion. $^{32}$ Finally, in July 1943, Congress instructed the Commissioner of Public Roads "to make a survey of the need for a system of express highways throughout the United States" and report his findings to the President and Congress within 6 months.

\section{The Interregional Highway Report}

Much of the work for the report on express highways requested by Congress had already been done by the PRA and the President's National Interregional Highway Committee. The PRA task force of experts assigned to work with the Committee analyzed at least six possible combinations of interregional routes to arrive at the recommended "optimum" system of 33,920 miles. This system included 4,470 miles within cities and 29,450 miles of rural highways. It comprised a little over 1 percent of the total street and

* While the financial experience of the turnpike was good, its accident experience was bad-worse than that of the Pennsylvania highway system as a whole. In less than a year after opening, the Commission imposed a 60 mile per hour speed limit to curb reckless speeding. ${ }^{28}$

The experience of the Pennsylvania Turnpike seemed to indicate that people wanted high-speed highways and were willing to pay extra for them.

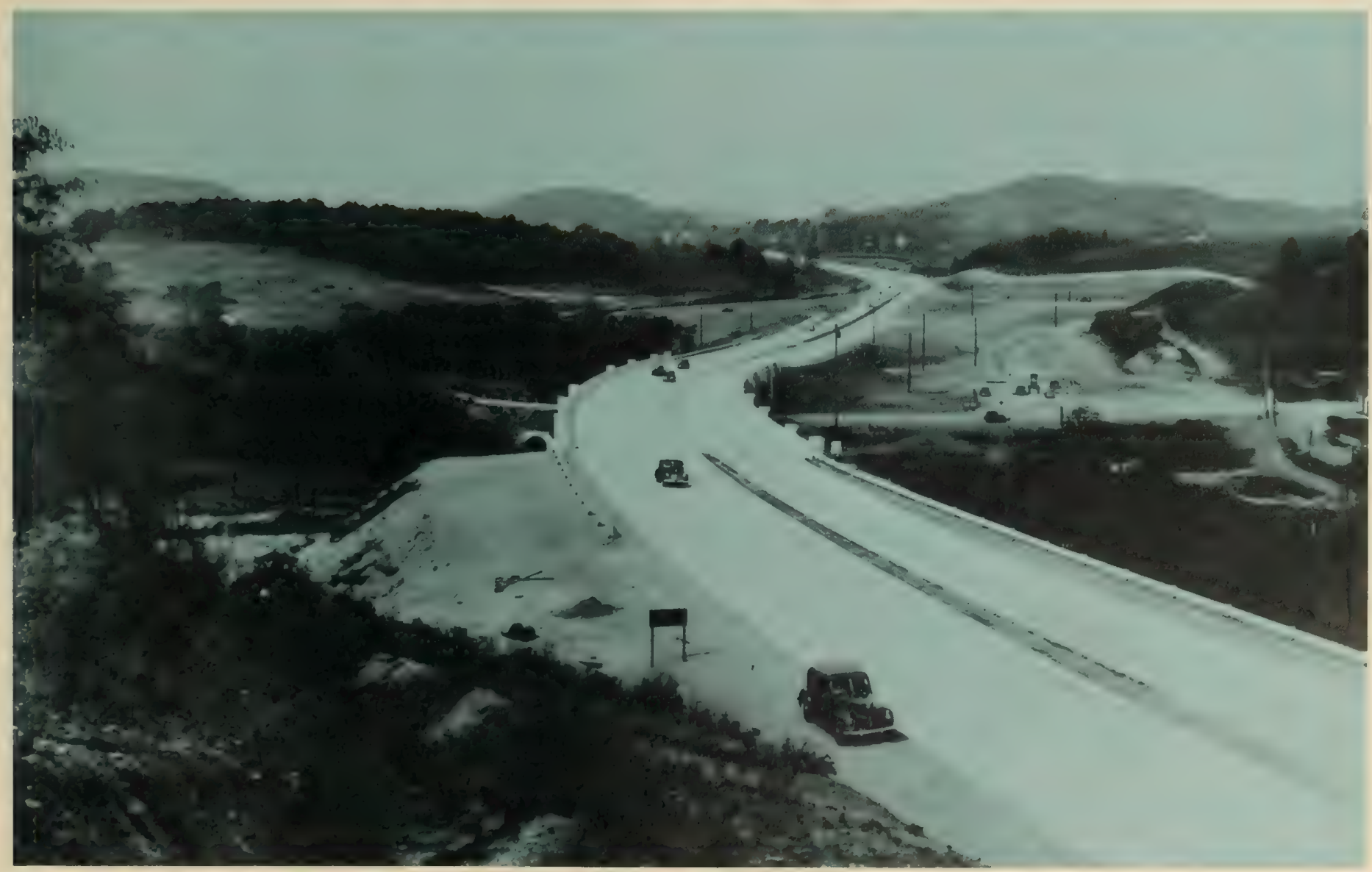


highway mileage of the United States, yet the experts estimated that it would carry 20 percent of all vehicle miles of travel. It would directly connect all cities of 300,000 population and reach 59 of the 62 cities of 100,000 to 300,000 population.

The Committee found, as had the BPR in its 1939 report Toll Roads and Free Roads, that very little of the estimated traffic on the optimum system would be long-distance interregional traffic. Most of the traffic, and all of the high-density traffic, would occur within "zones of influence" around the cities, varying in radius from 35 miles for the largest cities to 6 miles for the small ones. Of the recommended system, 8,141 miles would fall within these zones of influence, and this mileage would include practically all of the highways and city streets expected to carry more than 10,000 vehicles per day. Of the remaining 25,779 miles, 20,300 would probably carry less than 3,000 vehicles per day, and thus require only 2-lane pavements. $^{33}$

Because most of the traffic was shown by the State and PRA traffic studies to have origins or destinations within the cities, particularly their central business districts, the Committee concluded that there was little need for bypasses.* The interregional routes, therefore, would have to penetrate into the cities, where they would exert a tremendous influence in shaping city growth. They should, therefore, be planned in close cooperation with the city governments and planning authorities:

The immediate inference ... is that the creation of such ample and efficacious traffic facilities as the improvement of the interregional routes would supply, will exert a powerful force tending to shape the future development of the city.

It is highly important that this force be so applied as to promote a desirable urban development. If designed to do this, the new facilities will speed such a development and grow in usefulness with the passage of time.

The Committee recommended standards for the interregional highways but declined to estimate the probable total cost of the system. "Moreover," they went on to say, "the usefulness and validity of an estimate of the total cost of a construction program that must inevitably extend over a period of perhaps 20 years and be affected by unpredictable changes in the general economy, in the habits and desires of the people, in the character of vehicles, and in other circumstances, would still be highly questionable." ${ }^{36}$

However, the Committee did recommend that construction of the system be prosecuted at a rate of about $\$ 500$ million per year in the rural sections and $\$ 250$ million per year in the urban sections-a rate that would provide about 145,100 man-years of direct employment, and 323,400 man-years of indirect employment per year.

One of President Roosevelt's strongly held convictions was that some of the increase in land values created by new highways should be recouped by the Government and used to pay for the highways. The Interregional Highway Committee avoided this tick-

* The studies showed that only 4 to 6 percent of traffic entering the largest cities was bypassable and only 20 percent for the smaller cities and 50 percent for the smallest villages." lish matter in their report, but the President brought it up in his message transmitting the report to Congress, as he had in his message on the 1939 toll road report. "After all," he wrote, "why should the hazard of engineering give one private citizen an enormous profit? If there is to be an unearned profit, why should it not accrue to the Government-State, Federal or both?" 37

\section{The New Highway Charter}

There were already a number of postwar highway proposals before the 78th Congress when it received the interregional highway report. One of these bills would set up a Rural Local Roads Administration independent of the PRA through which the counties could receive Federal aid without going through the States. The bill would give this agency $\$ 1.125$ billion to begin operations. ${ }^{38}$ Senate Bill No. 971 , backed by AASHO, would provide $\$ 1$ billion annually for 3 years divided equally between the Federal-aid system, urban extensions, and secondary feeder roads and would increase the Federal share of the cost to 75 percent. This bill would also create an interregional highway system. ${ }^{39}$

The perennial toll road bill, with added features, would establish an independent commission with authority to issue $\$ 10$ billion in U.S. bonds to pay for a toll system of 8-lane military superhighways and for airports, with dams and powerplants to furnish light for the entire system..$^{40}$

Another proposal would authorize an 18,000-mile system of free superhighways - three east-west from coast to coast and six north-south from border to border-with a system of airports, each 2 miles square, at the 18 intersections. Still another would authorize a defense highway across the United States to connect the Alcan Highway with the Inter-American Highway.

Fantastic as some of them were, these bills showed that there was still an insistent demand from an important segment of the public for long-distance through highways. This demand was coupled with a rising insistence that more attention be given to the strictly rural roads and an awakening interest in civil aviation.

The postwar highway bill that was finally enacted in 1944 after 9 months of congressional wrangling fell below the expectations of the Administration and the States, but was still the largest in history. It authorized Federal aid at the rate of $\$ 500$ million per year for the three first postwar years, divided $\$ 225$ million to the Federal-aid highway system, \$125 million for urban extensions and $\$ 150$ million for the principal secondary and feeder roads. These last were required to be spent on a secondary highway system selected by the State highway departments in cooperation with the local road officials and the PRA, but without any mileage or percentage limits. Congress authorized participation with Federal funds up to one-third of the cost of right-of-way, but specifically rejected the President's suggestion for taking excess right-of-way for purpose of recoupment. Finally, the Act authorized a 40,000-mile National System of Interstate Highways but provided no funds specifically for its construction. 
The Federal-Aid Highway Act of 1944 preserved all of the essential features of the Federal-State relationship that had been built up over the preceding years, while liberalizing Federal assistance in some areas, notably right-of-way. In passing it, Congress again beat off efforts by the toll road and superhighway extremists to impose a national system of trunk highways under Federal control on the country. The National System of Interstate Highways was intended to satisfy the demand for long-distance highways, but without strong funding, it could not possibly achieve this purpose in any reasonable time, as events in the next 12 years would demonstrate.

\section{REFERENCES}

${ }^{2}$ WPA Mobilization For Defense Starts, ENGINEERING NEWSRECORD, Vol. 124, No. 24, Jun. 13, 1940, p. 829.

${ }^{2} P R A$ Demands Defense Priority For Federal-Aid Work, Engrineering News-Record, Vol. 125, No. 10, Sept. 5, 1940, p. 307 .

${ }^{3}$ Hrghway Needs of the National Defense, H. Doc. 249, 81st Cong., 1st Sess., p. 66.

'Id., p. 56.

${ }^{5}$ Editorial, Engineering News-Record, Vol, 127, No. 23, Dec. 4, 1941, p. 785.

-H. H. Kelly, The Problem of Motor Vehicle Regulation, Public Roads, Vol. 13, No. 10, Dec. 1932, pp. 167, 168.

${ }^{7}$ Legislation to Raise Truck Weight Protested, ENGINEERING News-ReCord, Vol. 128, No. 4, Jan. 22, 1942, p. 155.

${ }^{8}$ C. VAIL, Regulation of Truck Transportation-A Challenge to Highway Departments, Convention Group MeetingsPaPers AND Discussions (American Association of State Highway Officials, Washington, D.C., 1943) pp. 10-15.

${ }^{\circ} \mathrm{H}$. Doc., supra, note 3, p. 63.

${ }^{10} \mathrm{~F}$. N. BARKER, The Development of Uniformity in State Regulations of Size and Weight of Vehicles, Convention Group Meetings-Papers and Discussions (American Association of State Highway Officials, Washington, D.C., 1943) p. 128.

II Bureau of Public Roads Anndal Report, 1943, p. 25.

${ }^{13}$ Construction Machinery Purchases to be Placed on A-1 Priority Basis by WPB, ENGINeERING News-Record, Vol. 128, No. 16, Apr. 16,1942 , p. 581.

${ }^{13}$ Bureau of Public Roads Annual Report, 1942, p. 43.

"War Cuts Into Personnel of Highway Departments, ENGINEERINg News-Record, Vol. 129, Sept. 10, 1942, p. 339.

${ }^{15} 1971$ Automotive Facts and Figures (Automobile Manufacturer's Association, Inc., Detroit, 1973) p. 3.
${ }^{16}$ Tire Wear and Costs, Public Roads, Vol. 24, No. 9, JulySept., 1946, p. 248.

${ }^{17}$ J. T. Thompson, Wartime Highway Transportation Problems, Convention Group Meetings, ST. Lours, Mo., Dec. 7, 8, 9, 1942 (American Association of State Highway Officials, Washington, D.C., 1943) pp. 114-124.

${ }^{18}$ Transport in War Period Dominates Atlantic States Highway Meeting, Engineering News-Record, Vol. 128, No. 10, Mar. 5, 1942, p. 368.

${ }^{19}$ Thompson, supra, note 17, pp. 114-124.

${ }^{20} I d$.

${ }^{21}$ Gas Tax Diversion Backfires, Engineering News-Record, Vol. 129, No. 13, Sept. 24, 1942, p. 410.

${ }^{22}$ Accident Facts-1973 (National Safety Council, Chicago, $1973)$ p. 59.

${ }^{23} \mathrm{BPR}$, supra, note 11 , pp. 29,30 .

${ }^{24}$ Alcan Highway Officially Opened-Trucks Go North, Engtneering News-Record, Vol. 129, No. 22, Nov. 26, 1942, p. 740 .

${ }^{25}$ R. E. Royali, Construction of the Alaska Highway (Public Roads Administration, Washington, D.C., 1945) pp. $69,77$.

${ }^{26}$ The Alaska Highway, $H$. Rept. 1705, 79th Cong., $2 d$ Sess., p. 26.

${ }^{27}$ Pennsylvania Turnpike Earns \$2,600,000, EngINEeRiNG News-RecoRd, Vol. 127, No. 12, Sept. 18, 1941, p. 398.

${ }^{28}$ Transport in War Period Dominates Atlantic States Highway Meeting, Engineering News-Record, Vol. 128, No. 10, Mar. 5, 1942, p. 369.

${ }^{20}$ Brief News, Engineering News-Record, Vol. 127, No. 14, Oct. 2, 1941, p. 464 .

${ }^{30}$ Interregional Highways, H. Doc. 379, 78th Con., $2 d$ Sess., p. III.

${ }^{31}$ Programming Highway Construction to Meet Post-Defense Needs, Engineering News-Record, Vol. 127, No. 19, Nov. 6, 1941, p. 649.

${ }^{32}$ Nation's Highway Departments Make Plans to Meet Present, Post War Needs, Engineering News-Record, Vol, 129, No. 15, Oct. 8,1942, p. 465.

${ }^{33}$ H. Doc., supra, note 30, pp. $43-45$.

${ }^{34} I d$., p. 60.

${ }^{3 \pi} I d$., p. 55.

${ }^{36} I d$, p. 114.

${ }^{37} I d$., p. V.

${ }^{38}$ New Local Highway Agency Proposed in Congress, EngINeERing News-Record, Vol. 131, No. 21, Nov. 18, 1943, p. 727.

${ }^{39}$ Three Billion Dollars Asked For Postwar Highway Projects, Engineering News-Record, Vol. 131, No. 5, Jul. 29, 1943, p. 179.

${ }^{40}$ Several Laws of Engineering Interest Enacted by $2 d$ Session, 78th Congress, EngINeERING News-Record, Vol. 133, No. 1, Jul. 6, 1944, p. 3. 


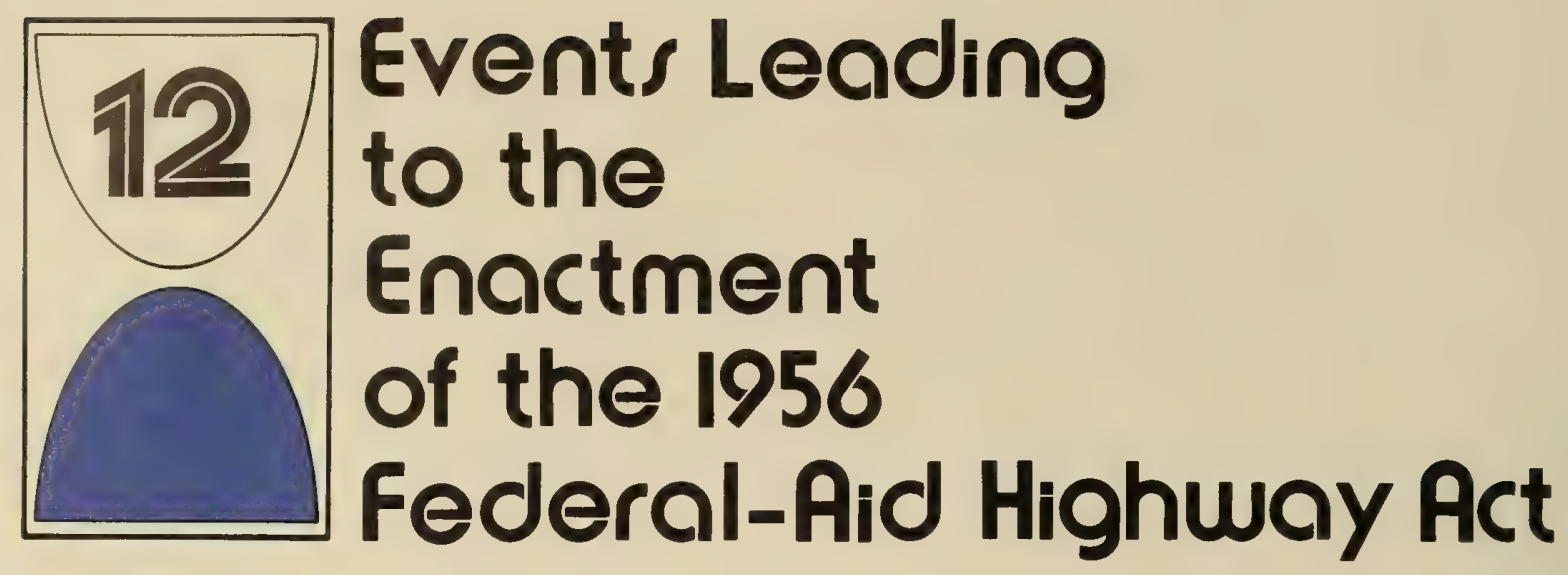

\section{Rapid Recovery of Motor Traffic to Prewar Levels}

After the surrender of Japan, the American economy shifted from war to peace with remarkable speed. Huge wartime savings, some $\$ 44$ billion, created an insatiable market for housing and for all kinds of goods, including new automobiles to replace the decrepit vehicles that had survived the war. Automobile production jumped from a mere 69,532 in 1945 to over 2.1 million in 1946, 3.5 million in 1947 and 3.9 million in $1948 .{ }^{1}$

Reflecting this vast increase in vehicle production, registrations increased 22 percent, from the wartime low of 30.6 million vehicles to 37.4 million vehicles in 1947. (In this period trucks increased by 34 percent.) With the end of rationing and emergency speed controls, highway travel reached its prewar peak in 1946 and began a steady climb of about 6 percent per year that was to continue for decades. ${ }^{2}$

The Nation's highways were in poor shape to receive this traffic. Most of the deficiencies disclosed in the 1941 survey of the strategic network still existed in 1946. Under wartime restrictions, the States could do little to remedy them, and, in fact, because of widespread operation of overloaded trucks and reduced maintenance, the State highway systems were in worse shape structurally after the war than before.

\section{The Urban Traffic Problem}

In and near the cities, hundreds of miles of highways were functionally obsolete because of narrow pavements, ribbon development and insufficient capacity. In the 1920's and 1930's, migration of the more affluent inhabitants to outlying suburban areas created expansive thinly spread residential communities surrounding the major cities. This movement to the suburbs, which began in the days of the steam and electric railroads, was greatly accelerated by the private automobile. As the street and highway networks expanded, more and more people found it convenient to live in the suburbs and drive to and from work, but the convenience decreased rapidly as the highways became congested with ever-increasing volumes of vehicles.

The city, county and State highway authorities tried to keep up with the traffic increase, first by widening streets and highways and then by providing special high-capacity roads such as parkways and expressways, commonly financed by bond issues.* These special facilities expanded the radius of suburban development and attracted so much more traffic that they too became seriously congested.

\footnotetext{
* In the prewar period, the outstanding examples of such deluxe facilities were the Westchester County Parkways and the Long Island State Parkway System. The latter, begun in 1925, by 1947 had expanded into a 158-mile network of commuter arteries tying western Long Island to downtown New York. ${ }^{3}$ In the west, the Arroyo Seco Parkway between Los Angeles and Pasadena, opened in 1940, was a dramatic demonstration of what could be done to move large volumes of traffic to and from the suburbs.
} 


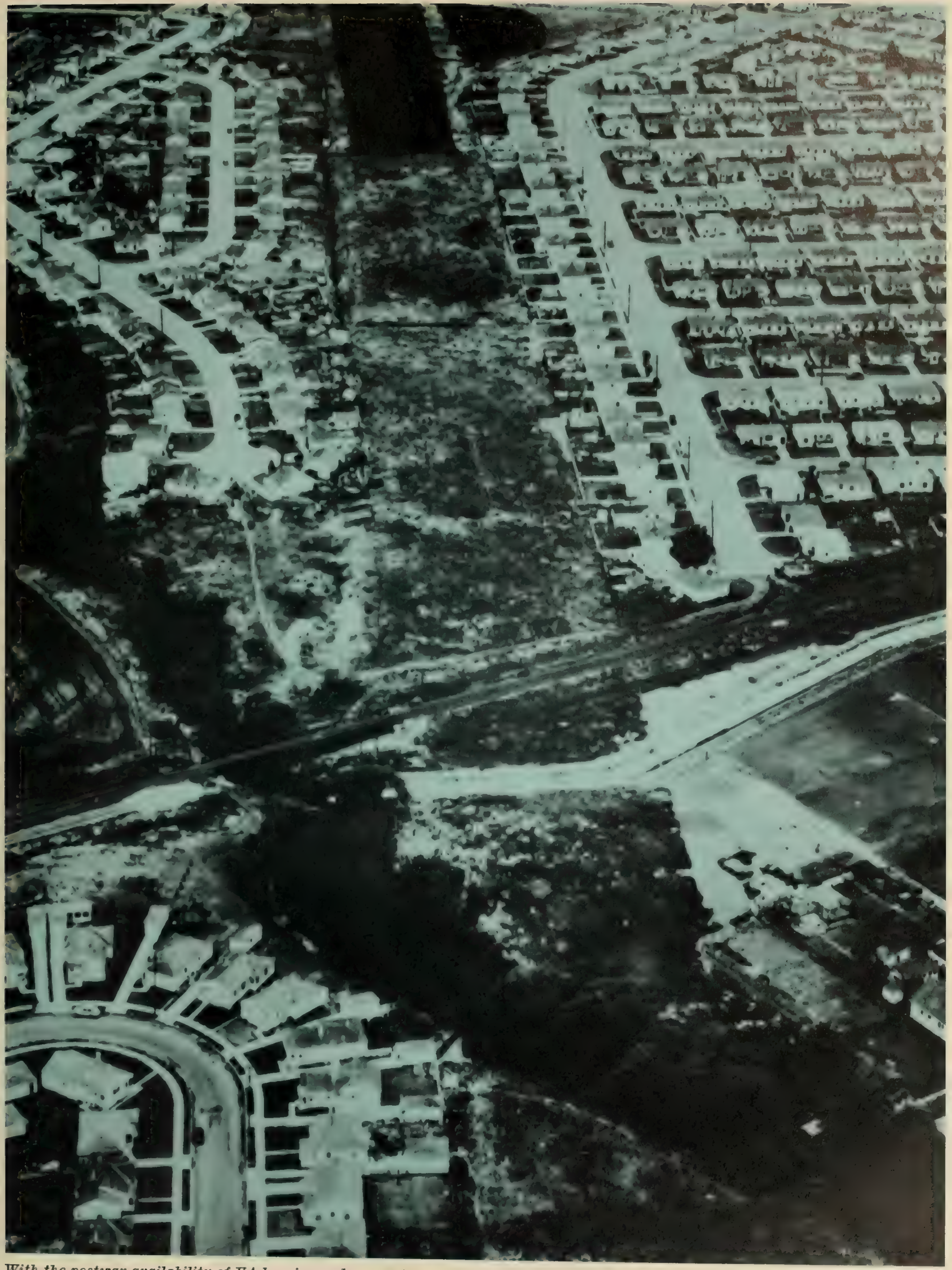

With the postwar availability of $\nabla A$ housing and new automobiles, people began to move from the city to outlying suburban areas. Highway authorities tried to keep pace with the commuters, but the day was at hand for the rush-hour traffic jam. 


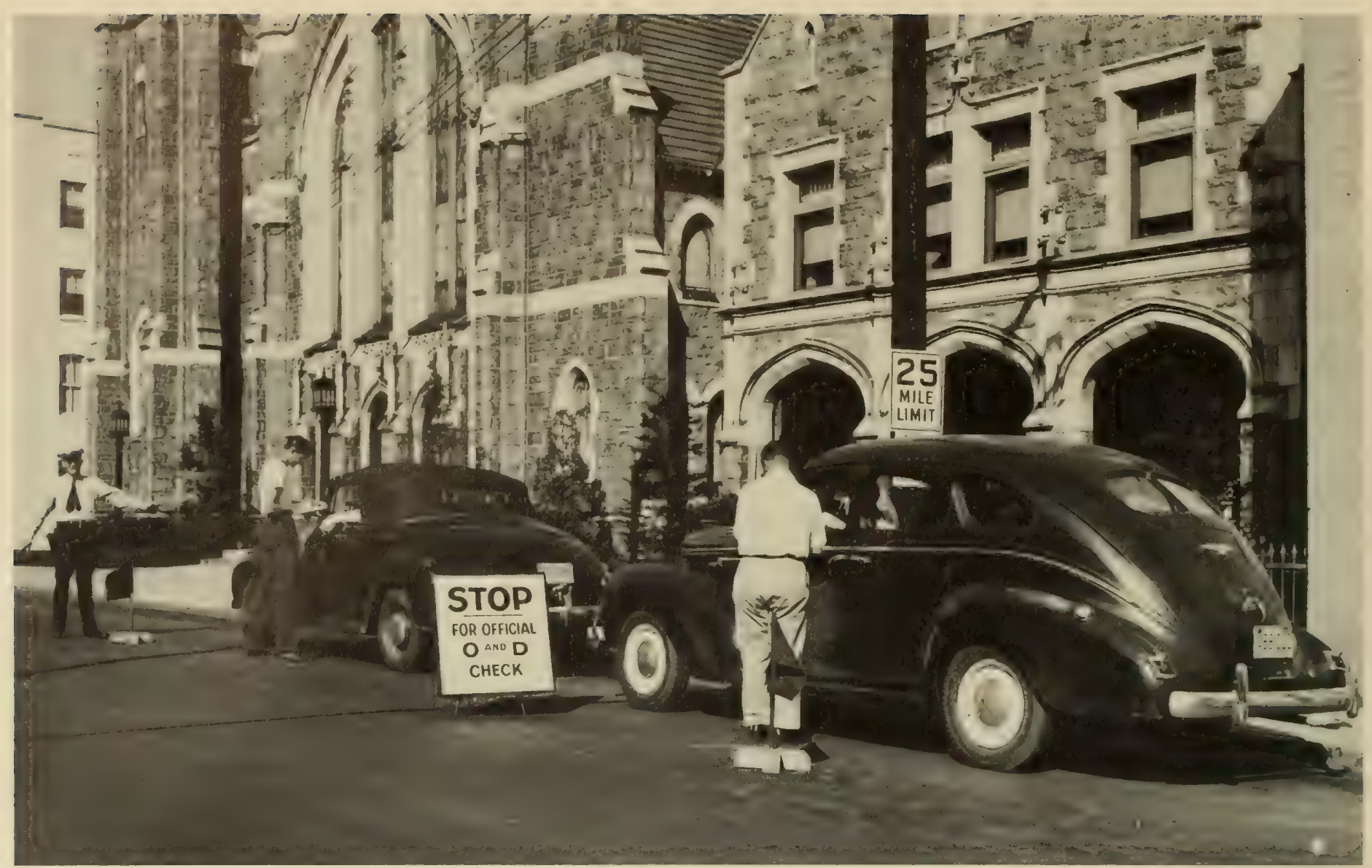

An "origin-and-destination" survey.

Before the war was over, many of the State highway departments became involved with the large cities and urban counties in the planning of costly schemes for expanding highway capacities. Most of the Federal aid provided by Congress for postwar planning went into urban highways.

\section{Federal Aid for Urban Highways}

In its early days, the Federal-aid program applied strictly to rural roads, "excluding every street and road in a place having a population, as shown by the latest available Federal census, of two thousand five hundred or more, ..." 4 This exclusion was suspended in the Emergency Relief and Construction Act of 1932 and the National Industrial Recovery Act of 1933, and abolished altogether in the Hayden-Cartwright Act of 1934. Thereafter, the States enlarged their Federal-aid systems to include extensions of Federalaid routes into and through municipalities and even new routes wholly within urban areas, but the main interest of the State highway departments was in the rural highway systems outside the cities.

Congress changed all this in 1944 by specifically earmarking $\$ 125$ million annually for the first 3 postwar years for roads in urban areas. These funds were to be apportioned to the States in the ratio that their urban populations (cities of 5,000 or more inhabitants) bore to the national urban population. In the same Act, Congress established the National System of Interstate Highways and required that its routes should be selected by the States within the cities as well as between them. Thus, the FederalAid Highway Act of 1944 brought the State highway departments, and also the Public Roads Administra- tion (PRA), actively into the field of city and regional transportation planning beside the city and county officials.*

\section{Urban Traffic Studies}

Before they could designate the urban Interstate System arteries with confidence, the planners needed to know a great deal more than they already knew about the movements of traffic within cities and between cities and their suburbs:

Traffic within an urban area is more complex than on rural roads. Traffic volumes are larger, and arteries are much more numerous. Parallel streets offer many alternate routes of travel, and it is not possible to tell from observing traffic volumes alone where the drivers really want to go. Drivers often travel considerable distances out of their way to use exceptionally attractive routes, or to avoid congested or unattractive routes. Examples of this have been noted in numerous cities and originand-destination surveys have shown that the facts were sometimes quite different from assumptions made by engineers with long familiarity with the local situation.?

The old techniques that had been developed in previous years during the cooperative State-BPR traffic surveys and the statewide highway planning surveys, such as driver interviews and postcard questionnaires, were too costly, too cumbersome or not sufficiently accurate. The planners needed a better

* The Bureau of Public Roads (BPR) had pioneered in urban traffic studies in the Cook County Transportation Survey of 1924, the first comprehensive study of traffic in an urban region including a large city ${ }^{5}$ and in the Cleveland Regional Area Traffic Survey of 1927. The latter was the first concerted study by all levels of government of the traffic problems of a single metropolitan region. 
method of estimating future traffic flows, and they found it in the "origin-and-destination survey," a sampling technique developed in 1944 by the PRA with the help of the Bureau of the Census. ${ }^{8}$ The origin-destination surveys were made by interviewing a sample of the urban population at their homes and obtaining from each family in the sample detailed information on the travel habits of its members. Samples varied from as small as 1 dwelling unit in 30 to as high as 1 in 3 , but averaged about 1 in 10 .

During 1944 and 1945 the State highway departments and local officials, with the help of the PRA, analyzed the needs of 30 large metropolitan areas and 135 cities of 50,000 or less population.

By providing the means to estimate the traffic volumes that will use any specific route, these studies serve to evaluate the merits of proposals advanced by different groups within an urban area, and to bring together the various local agencies in the support of a single plan. Availability of the facts often permits harmonizing the views of differing factions, each of whose proposals, in the absence of facts, is of necessity based on opinions."

\section{A Larger Share of the Highway Dollar for Non-Federal- Aid System Roads}

As statewide traffic increased, so did gasoline tax revenues, and inevitably there was political pressure to distribute some of this revenue to the counties as State aid for their roads. In many States a considerable part of the State-collected road-user revenues was redistributed to the counties, and often in greater amounts than was generated within a specific county.* As the State contributions increased, most counties reduced their own support for local roads (the revenues being derived mostly from property taxation) so that by 1947 local governments were carrying only about 40 percent of the cost of construction and maintenance where 20 years before they had carried over 80 percent. ${ }^{11 * *}$

The National Industrial Recovery Act of 1933 and the Hayden-Cartwright Act of 1934 had provided emergency funds that could be spent on "secondary or feeder" roads off the Federal-aid system "to be agreed upon by the State highway departments and the Secretary of Agriculture." Although not required by the legislation, the Secretary, through the Bureau of Public Roads, insisted that these funds be spent on connected road systems in each State as a condition for his agreement. ${ }^{12}$ The States then, in selecting systems, for the most part, selected the roads carrying the most traffic, but not necessarily those most desired by the local officials. These systems totaled about 138,500 miles, and on them about $\$ 245$ million of emergency relief and regular Federal-aid funds were spent by the States in the period from 1934 to 1943.

Nevertheless, there was widespread dissatisfaction with the county roads among rural residents, accompanied by an unwillingness to increase taxes to im-

* In 1944 it was estimated that nationally, about 61 percent of road-user revenues was going to the State highway departments, about 26 percent to the counties and cities for their roads and streets, and the rest to nonhighway uses..$^{10}$

** In Delaware, North Carolina, West Virginia and Virginia (except for two counties), the highway departments are responsible for all roads outside of municipalities because the local governments succeeded in shifting the entire road burden to the State. prove them. This feeling led to increased political pressure on the State governments for a larger share of road-user taxes and also pressure on Congress for direct Federal aid to the counties. In 1943 Senator A. T. Stewart of Tennessee introduced a bill to set up a Rural Local Roads Administration with $\$ 1.1$ billion in Federal funds to be distributed among the counties without going through the State highway departments. ${ }^{13}$ This bill never emerged from committee, but its supporters were able to include a very generous measure of assistance for local rural roads in the Federal-Aid Highway Act of 1944.

\section{The Federal-Aid Secondary Road System}

The 1944 Act authorized the appropriation of $\$ 150$ million in each of the first 3 postwar years for projects on the "principal secondary and feeder roads" but required that the funds be spent on "a system of such roads selected by the State highway departments in cooperation with the county supervisors, county commissioners, or other appropriate local road officials, and the Commissioner of Public Roads." The money was to be apportioned to the States one-third according to State area, one-third according to rural population and one-third according to the mileage of rural mail delivery and star routes, and the Federal share of any project was limited to 50 percent.

Congress imposed no mileage or percentage limits on the secondary system, and it soon became apparent to the State highway departments that their previously selected secondary systems were not nearly large enough to satisfy the local authorities. However, the PRA arbitrarily set guidelines for selecting routes which had the effect of limiting the mileage. First, these guidelines required that the State Federal-Aid Primary System and the selected Secondary System be integrated to form continuous networks. Second, the PRA limited the mileage it would approve to a system not larger than could be constructed and maintained with the funds that "might reasonably be expected to be provided" according to past performance in the area.*

The system approved by the Commissioner of Public Roads in June 1946 totaled 217,073 miles, but this was just a beginning, as tens of thousands of miles of additional routes were then still under review. According to the PRA, "No route is approved without first assessing its importance by reference to the records made in the planning surveys showing locations of farms, schools, churches, and business establishments, type of existing road improvement, general population distribution, and the amount of traffic." 14 By June 1947 the Secondary System had increased to 350,809 miles and by 1948 to 377,622 miles. It reached 502,676 miles in 1955 .

\section{The States Select Interstate System Routes}

By the 1944 Act, Congress had limited the National System of Interstate Highways to 40,000 miles and had also provided that the routes should be selected

* Planning for the Federal-Aid Secondary Systems had the beneficial effect of forcing the States to reexamine and update their Primary Systems. Nationwide, about 40 percent of the Federal-aid secondary routes were already under State control or were immediately taken over by the States. The rest remained under local control. 
by joint action of the State highway departments of each State and the adjoining States. All routes so selected were automatically to become part of the Federal-Aid Primary System without regard to previous mileage limits on that System.*

In February 1945 the PRA requested each State to submit recommendations for the Interstate System routes within its boundaries. When these recommendations were all in, they totaled 45,070 milesconsiderably over the legal limit and far above the 33,920 miles recommended by the Interregional Highway Committee. ${ }^{16}$ Two thousand miles were circumferential or distributing routes around the large cities. The PRA decided to defer consideration of these to a later date and concentrate on getting the States to agree on the main routes between the cities.

After weeding out the routes with the weakest justifications and adding a small mileage requested by the War Department, the PRA came up with a total of 37,324 miles for the main routes. In March 1946 the PRA sent each of the States a map showing this tentative integrated system and asked for their concurrence. The first State to concur was Nebraska, and by June 1946 acceptances had been received from 37 States. ${ }^{17}$

It required a year for the PRA and the remaining 11 States to iron out their differences, but agreement

* The Federal-aid system (later the Primary System) was limited to 7 percent of each State's total highway mileage by the 1921 Act. Congress, in 1932, allowed 1 percent increments to be added as a State improved 90 percent of the entire Federal-aid system in that State. ${ }^{15}$ was finally reached on a 37,681-mile System, including 2,882 miles of urban thoroughfares. Some 2,319 miles were reserved for urban circumferential and distributing routes, to be selected later. The Federal Works Administrator approved this System on August 2, $1947 .{ }^{18}$

\section{Interstate System Standards Adopted}

While the States were selecting the Interstate routes, the PRA asked the American Association of State Highway Officials to propose standards to control the location and design of the Interstate highways. "There was no thought of requiring that every mile of the system be built according to a rigid pattern but it was believed essential that there be a high degree of uniformity where conditions as to traffic, population density, topography, and other factors are similar." 19

AASHO's Committee on Planning and Design Policies had been formed in 1937 to review and evaluate the immense amount of research and operational information on highways that had accumulated since the 1920 's.* Between 1938 and 1944 the Committee summarized the existing knowledge of geometric design and good design practice in seven "Policies" which were adopted by the Association and became, in effect, the national design policies for highways. Because of this prior work, the Committee was able

* Thomas H. MacDonald was chairman of this powerful committee from its inception until 1944. The Committee's working staff of design experts was supplied by the BPR (and PRA) and functioned under Joseph Barnett, who was also secretary of the Committee.

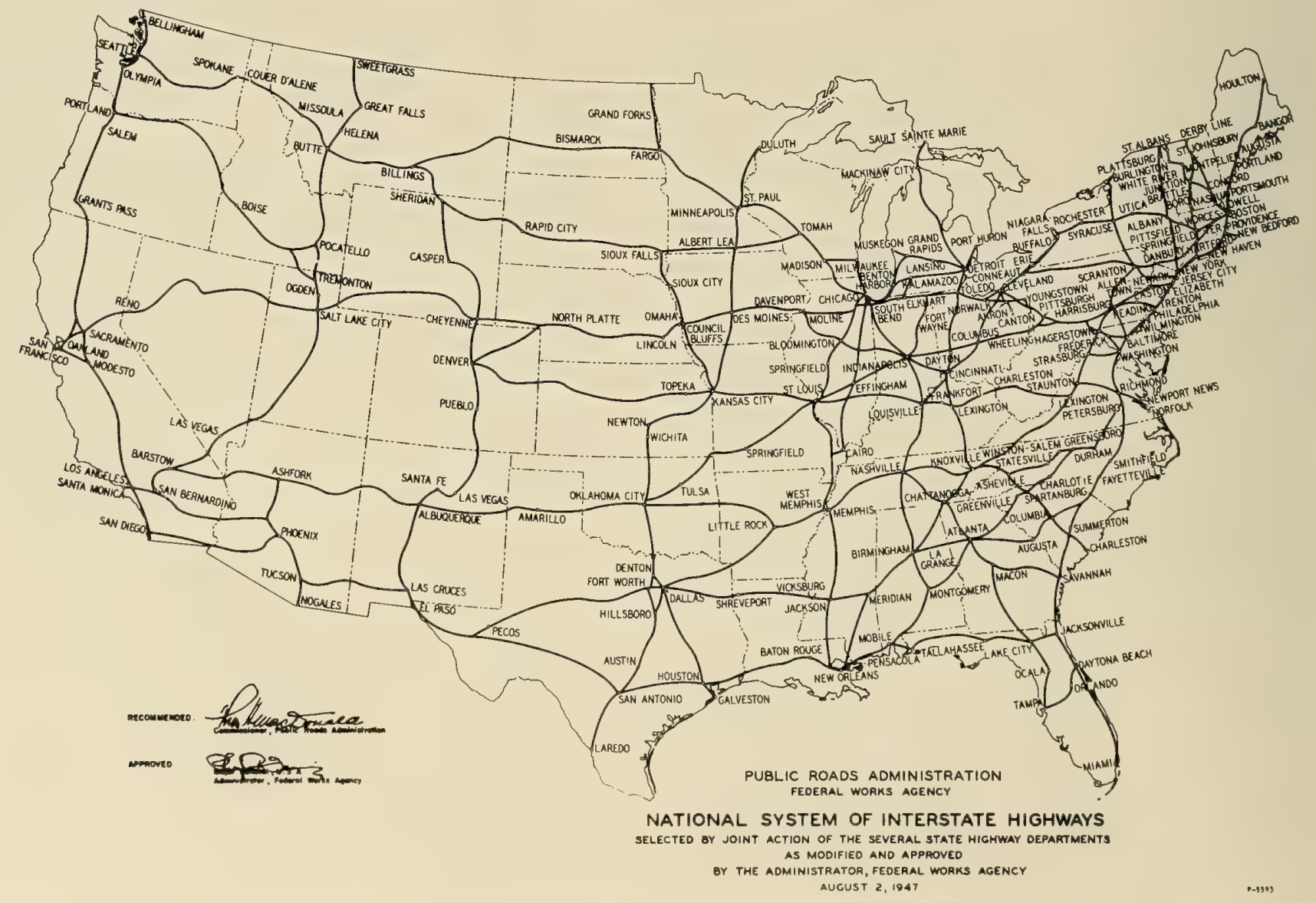


to recommend standards for the Interstate System by June 1945, and these were adopted by AASHO and approved by the Federal Works Administrator in August 1945.*

Of necessity, the Interstate standards were a compromise. A few States thought they were inadequate, pointing to the provision permitting three-lane highways for traffic volumes intermediate between those requiring a two-lane highway and those requiring a four-lane divided highway. Some criticized the weak provisions permitting grade crossings with railroads and other highways for low-traffic sections of the Interstate System. In these respects, the standards fell far below those for existing parkways and turnpikes which had been held up to the public by many people as the ideal for the Interstate System.

To get wide acceptance of the standards, the Committee equivocated on other elements of design by setting up "minimum" and "desirable" levels of design. Thus, for level country, a State could elect to

*When the 1956 Federal-Aid Highway Act specifically called for adoption of uniform design standards for the Interstate System, these earlier standards were the basis for the new standards, permitting completion of the work in 2 to 3 months. use either a 60 - or 70-mile per hour design speed. For right-of-way, the "desirable" width for divided highways was 250 feet, but in a pinch the State could get by with the "minimum" of 150 feet.

\section{Control of Access Recommended but Not Required for Interstate System}

The most important deficiency in the standards concerned a matter over which AASHO had no control and little influence with the States. This was the control of access to the highway from abutting property. Two decades of experience had shown that new highways invariably attracted ribbon development by commercial enterprises catering to the traffic on the highway. Movements to and from these businesses disrupted the traffic stream on the highway and greatly increased accidents. Eventually, the ability of the highway to carry traffic was reduced far below its original capacity by the roadside activity. At the same time the cost of future widening was made prohibitive. Gradually, highway administrators began to realize that the only way to protect the capacity of the highway was to deny or restrict access to the road from the adjacent private property. This growing realization ran counter to the most deeply ingrained

The lack of access control prevented free-flowing movement on this four-lane, undivided bypass of U.S. 101 in California.

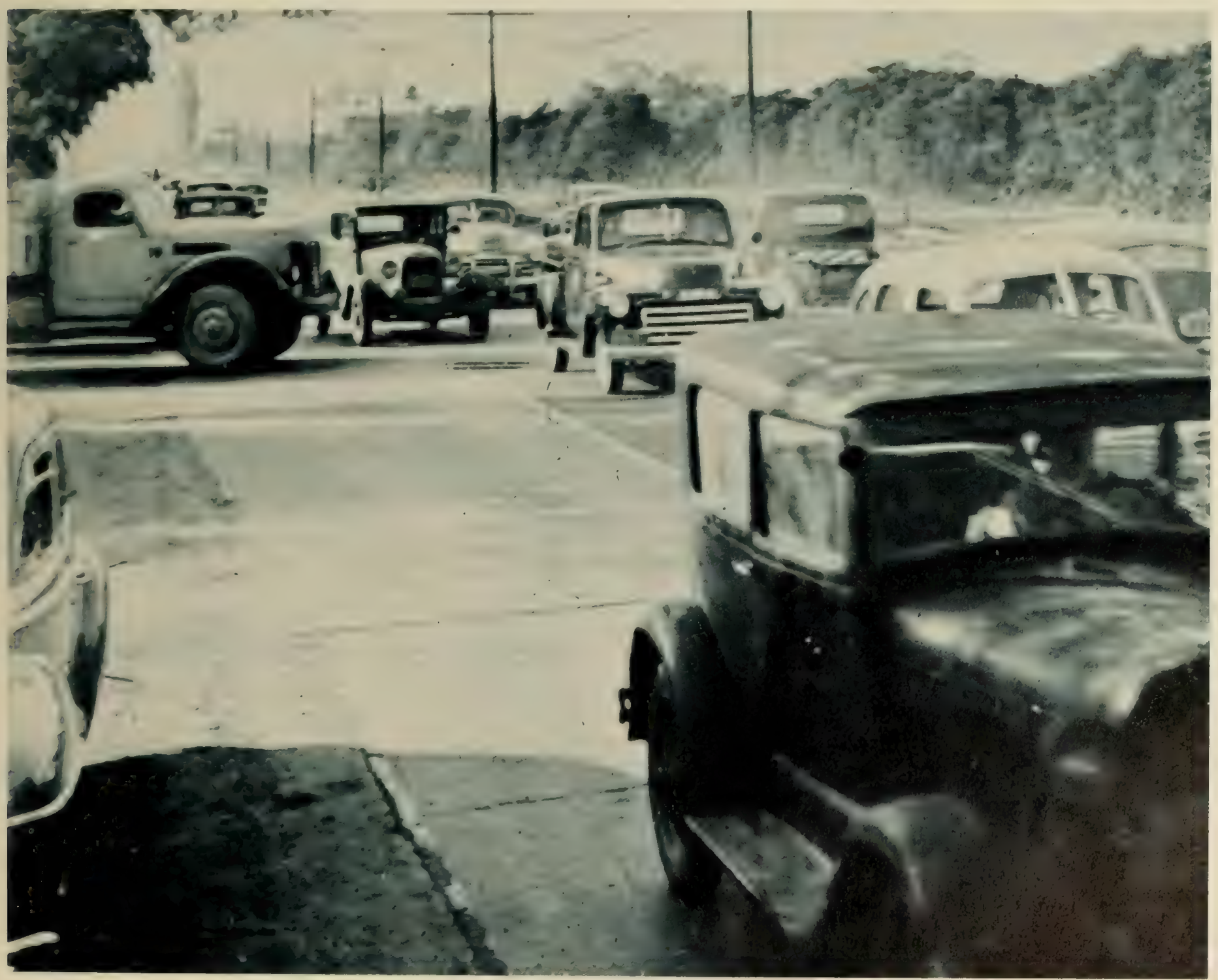


traditions of English common law and also most American statute law, which granted to abutters the very rights highway administrators now sought to take away.

The Bronx River Parkway Commission acquired a broad expanse of parkland along each side of the parkway road. This practice effectively controlled access to the road while avoiding the question of the loss of access rights to abutting property owners. However, there was some doubt as to whether this was really sufficient, and the Westchester County Parkway Commission made it their practice to purchase access rights and specifically mention them in the deeds. ${ }^{20}$ The Pennsylvania Legislature in the act creating the Turnpike Commission gave the Commission the power to acquire access rights, by eminent domain, if necessary. However, very few State legislatures conferred such rights on their highway commissions. By 1945 only 17 States had laws permitting the control of access to State highways.

The Committee on Planning and Design Policies skirted this ticklish question by saying,

Where State laws permit, control of access shall be obtained on all new locations and on all old locations wherever economically possible. . . In those States which do not have legal permission to acquire control of access, additional right-of-way should be obtained adequate for the building of frontage roads connecting with controlled access points, if and when necessary. ${ }^{21}$

\section{Slow Start of the Postwar Highway Program}

When the war ended, the States were well prepared with plans for the largest highway program in history. On the shelf ready to go were plans for $\$ 590$ million worth of road improvements, and plans for another $\$ 2.5$ billion worth of work were well advanced. A total of about $\$ 624$ million in Federal aid was available from prewar and postwar authorizations, and most of the States had ample matching funds saved up during the war. $^{22}$ Most highway departments anticipated some difficulty in obtaining trained engineers and building contractors, but this did not seem at first to be a great obstacle.

On October 2, 1945, Congress, by concurrent resolution, declared that the war emergency had been relieved to such an extent that the postwar road program authorized by the Federal-Aid Highway Act of 1944 could proceed. About the same time most of the wartime restrictions on road building were lifted. Eager to launch the postwar program as soon as possible, and urged on by the PRA, the State highway departments advertised hundreds of jobs during the winter of $1945-46$, some of them for very large bridges or urban expressways.

The result was, in some respects, a repetition of the 1920 experience. During World War II the inflation in road construction prices had been held to about 6 percent per year by price controls, and after 1943, by scarcity of work. A number of contractors had gone out of business, and those remaining were short of serviceable equipment and labor. The increased offerings of the State highway departments in 1945 and 1946 quickly saturated the available capacity of the construction industry and prices began to rise. At the same time materials scarcities developed, particularly in steel and lumber, which were in great demand for housing. The general uncertainty in prices and supplies resulted in higher bids, and by the end of 1946, the prices of highway structures had risen 24 percent over the 1945 level. Concrete pavement was up 12 percent. ${ }^{23}$

The States began rejecting the low bids that were far above preliminary estimates in an attempt to stem the tide of advancing prices. By the end of fiscal year 1946, only 1,958 contracts for $\$ 298$ million of construction had been awarded-less than a third of earlier expectations. Twenty-two percent of all low bids received had been rejected as too high. ${ }^{24}$ In some States, rejections ran as high as 30 percent of the low bids received.

This policy of rejecting low bids was ineffective, largely because the country was in the early stages of a building boom fueled not only by the State road programs, but also by large city expressway schemes, a huge increase in housing, and construction for industrial reconversion.

In August 1946, the Director of War Mobilization and Reconversion restricted highway construction to ease competition with the housing program for scarce materials. This restriction was lifted in October except for structural steel, but it had its effect along with rising prices in reducing State contract awards. Prices in 1947 reached a level 45 percent above 1945 prices and nearly double the prewar level. Unwilling to admit that prices had risen permanently to a new plateau, the States rejected 18 percent of all low bids received in fiscal year 1947.

Despite these difficulties, the States made a much better showing in 1947 than 1946, awarding contracts for 47,163 miles of road estimated to cost $\$ 817.7$ million. Most of these were for rural primary or rural secondary roads and for simple projects such as repaving which did not require right-of-way or expensive plans.

The situation was quite different in the urban areas where most of the projects were arterial street widenings, new expressways or large bridges. Some of these schemes were very large indeed and required the acquisition and demolition of hundreds of buildings and the relocation of many families at a time when it was almost impossible to find other housing for them.

The State highway departments, usually in cooperation with the large cities or urban counties, started over a score of expensive expressway projects in 1947, each expected to cost in the millions. New York began clearing the way for the $\$ 34$ million CrossBronx Expressway and the equally expensive Brooklyn-Queens Expressway. Massachusetts began the Northern Circumferential Highway around the Boston metropolitan area, while Michigan launched the John C. Lodge Expressway and the Edsel Ford Expressway in Detroit, each expected to cost over $\$ 6$ million per mile. In Chicago work began on the Congress Street Expressway, an eight-lane depressed freeway designed to accommodate 4,000 vehicles per hour in each direction, and estimated to cost $\$ 69$ million. Expressways in Denver, Dallas, Fort Worth, Los Angeles, Oakland, Jacksonville, Miami, Cleveland, San Francisco, and Pittsburgh added to the huge total.

The shortages of contractors, labor, materials and equipment persisted through 1947, 1948, and into 1949. 


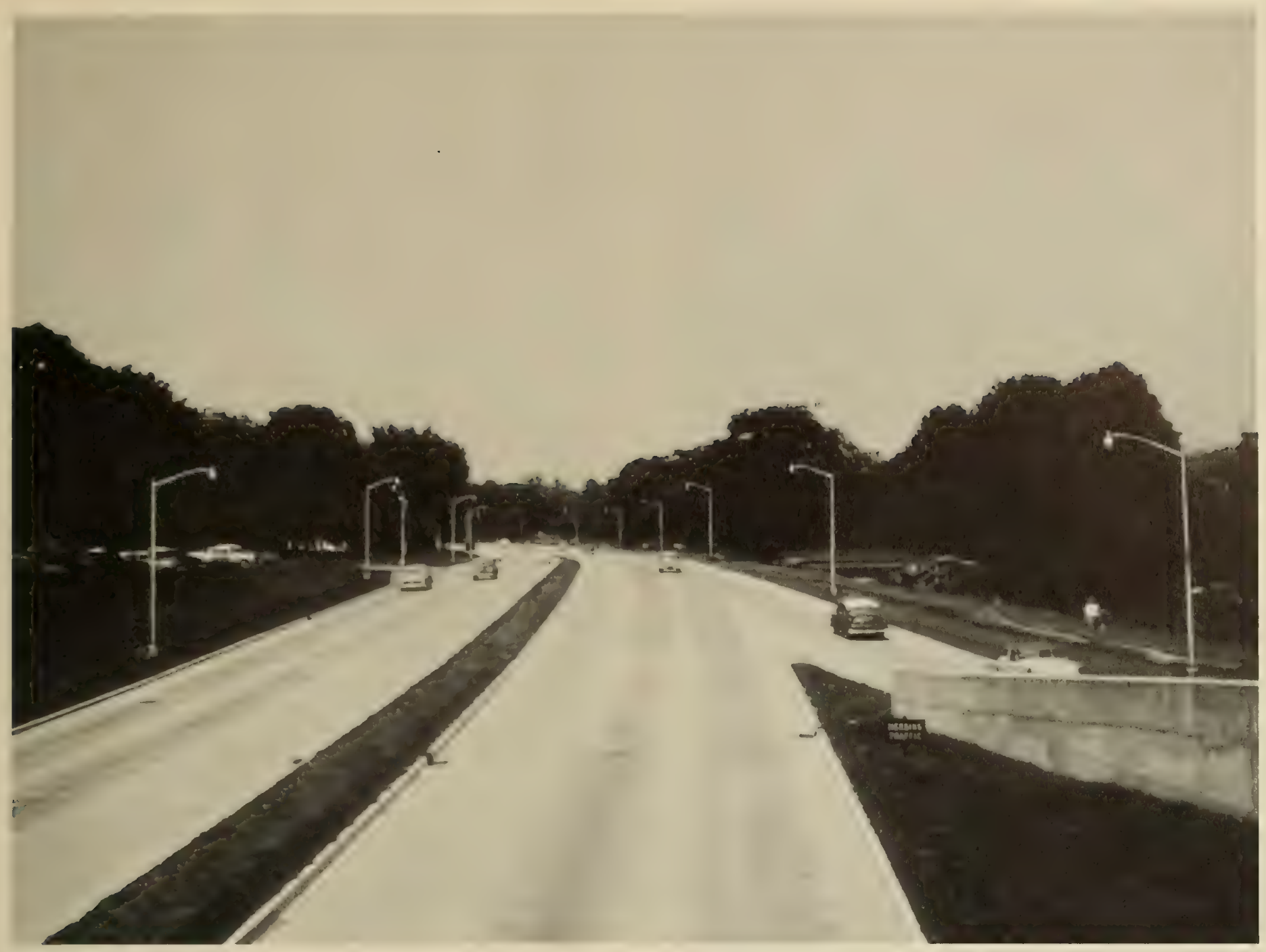

The Bronx River Parkway with controlled access and extensive parkland along each side.

In addition, a severe shortage of highway engineers developed in 1946 and became worse as the highway departments expanded their programs. Most States had failed to raise their pay scales to keep in step with the inflation, and as a result, many engineers did not return to State service after the war or left for other employment in industry.

Struggling against these handicaps and the continuing high prices, the States were able to obligate only 36 percent of their Federal-aid authorizations in fiscal year 1946, 62 percent in 1947, and 79 percent in 1948. It was necessary for Congress to extend the availability of the postwar authorizations by 1 year, and the unused backlog was so large that Congress made no authorization for fiscal year 1949 and reduced the authorizations for 1950 and 1951.

\section{The Local Rural Road Problem}

Aithough slow, there was improvement, and in 1949 the annual mileage of completed roads had reached the 1937 level of 21,000 miles, including about 14,000 miles of farm-to-market roads. But this did not satisfy the extreme rural road advocates.

The dissatisfaction in the counties found expression in two bills before Congress which would set up a
Rural Roads Division in the Public Roads Administration with authority to dispense $\$ 100$ to $\$ 200$ million annually to the counties and local political subdivisions without going through the State highway departments. ${ }^{25}$ There was also some rural sentiment for doing away with all system restrictions on rural roads so that their benefits could be more widely distributed among the rural population.

In testifying before the Senate Subcommittee on Roads on these bills, Commissioner MacDonald asserted that the proposed legislation would entail a "vast amount of costly supervision" on the part of the PRA to insure that the aided roads received proper maintenance. Rural roads, he said, were necessarily of light construction and required efficient and continuous maintenance to preserve their integrity. Past experience had shown that maintenance was the very aspect of road management in which the counties were weakest. Approval of the bills, according to MacDonald, would greatly dilute and weaken the fundamentally sound rural road program already in operation. ${ }^{26}$ In May 1949, the Subcommittee requested Commissioner MacDonald to make a study of the rural road problem and report back to the Subcommittee by January 1950. 


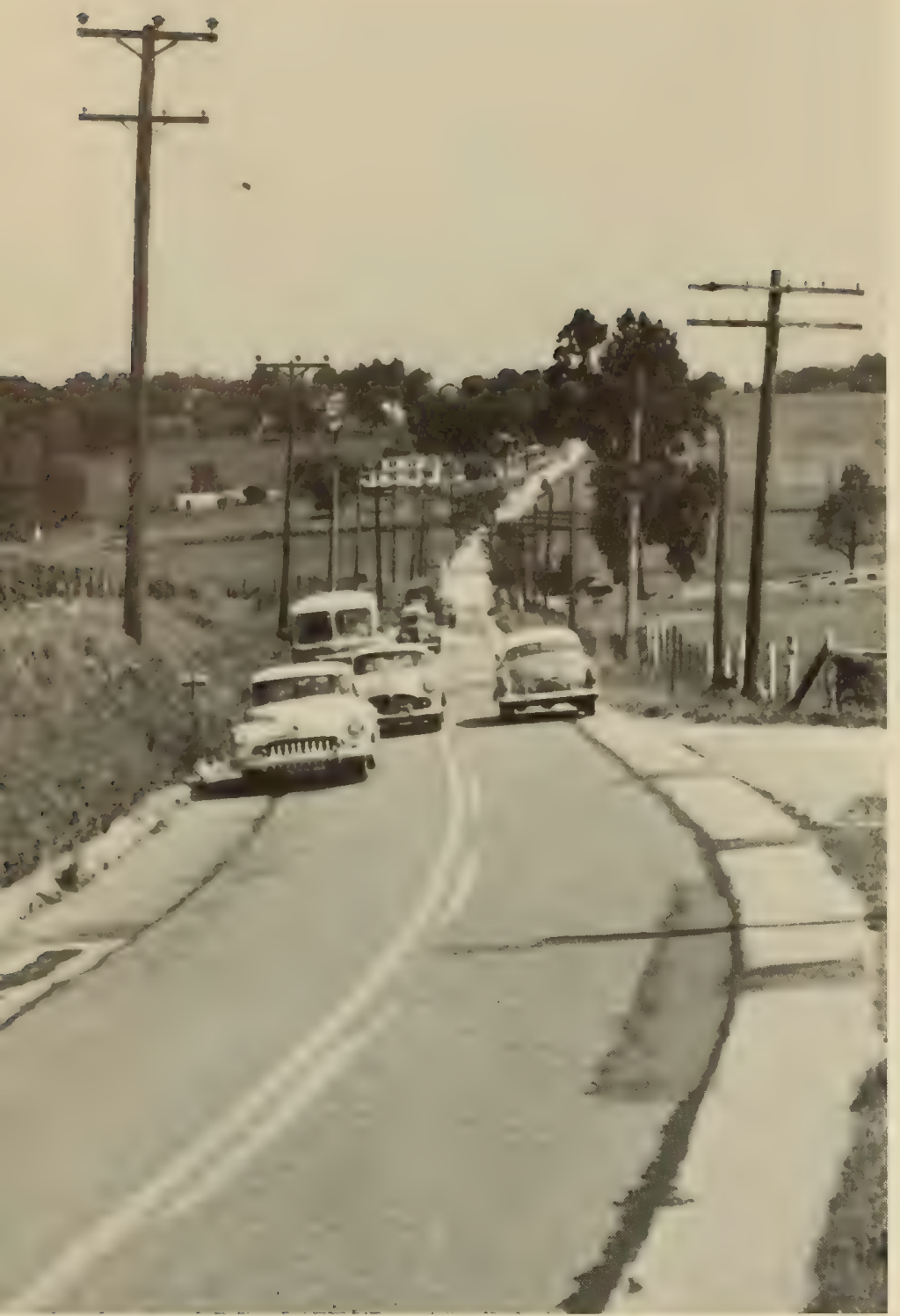

The PRA's study, made with the help of the Board of County Consultants* and the State highway departments, did little to assuage the feelings of the extreme ruralists. The survey disclosed that of the 2.5 million miles of local roads in the United States in 1949, 323,000 miles were already on the FederalAid Secondary System. Another 100,000 miles carrying at least 100 vehicles per day could and should be transferred to the Federal-Aid Secondary System. ${ }^{27}$ Another 400,000 miles was described as "wholly nonessential." To bring the remaining 1.8 million miles up to acceptable standards and provide adequate maintenance over a 20-year period would cost the local governments about $\$ 894$ million per year. Since the local units were already spending $\$ 835$ million per year on roads, the PRA concluded "It is apparent that a relatively small addition, with efficient management, applied to a planned program would be sufficient to accomplish the satisfactory improvement of local roads in a period of 20 years." ${ }^{28}$

The report concluded that what local roads needed was not so much more money as improved administration. Federal cooperation and participation, the PRA thought, could best be achieved through coordination at the State level.

\footnotetext{
* In 1946 the Federal Works Administrator appointed a Board of County Consultants consisting of 10 county officials from the PRA's 10 geographical administrative areas to advise the PRA on the secondary road program.
}

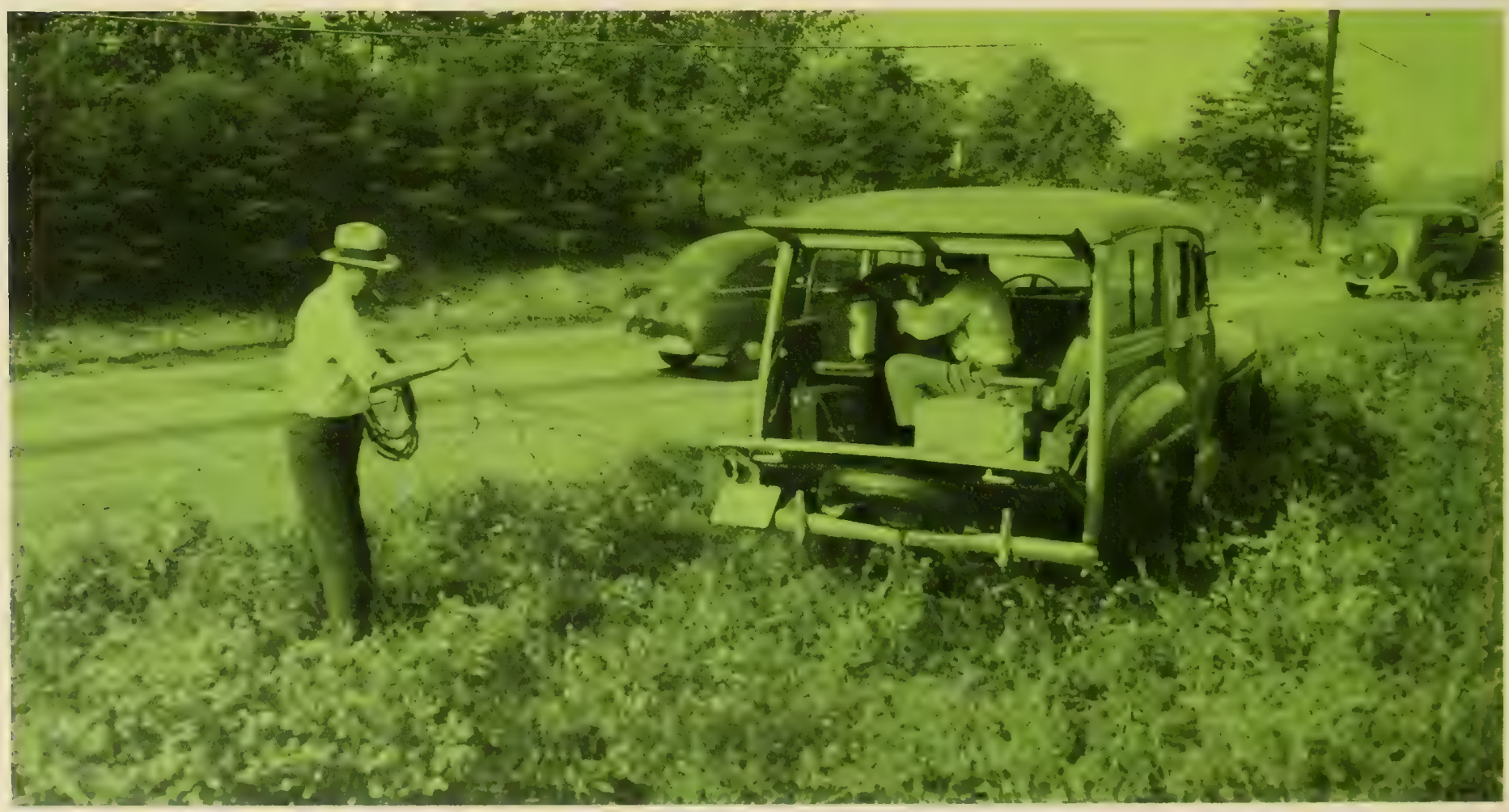

$B P R$ "Driver Behavior" studies to measure speed, spacing, and lateral vehicle placement on the road, 1945. 
Highway Needs Versus Financial Resources

In the early 1920's some economists and even engineers predicted that the market for motor cars would become saturated. As the number of motor vehicles stabilized, road mileage and the need for road improvement would also stabilize. Eventually, the highway system would reach a state of "maturity" at which time there would be a diminishing need for capital expenditures, and most of the highway revenues would be used for maintenance.

This prediction was never realized. Instead, as national income increased, the automobile market expanded even more. The manufacturers were able to spend large sums on research, and they greatly improved the performance and reliability of motor vehicles. After World War I, motor trucks, which previously had operated only in cities, took to the highways and rapidly increased in numbers, size and speed.

As already noted, the highway administrators responded to this ever-increasing and continually changing vehicle population first, by upgrading the old wagon roads, and then by building improved new roads tailored to the motor vehicle. Finally, they invented new types of roads such as parkways and expressways to move huge volumes of traffic at high speeds. As the roads improved, the annual usage per vehicle increased, so that highway traffic built up faster than vehicle registrations in a self-reinforcing spiral. The highway system never reached maturity. The need for capital expenditures did not diminish, but increased enormously.

By the middle 1940 's, most States had accepted as a virtual certainty that their road systems would never be completed. They realized that they would have to plan highway improvements far into the future and establish a policy that would recognize future needs and provide for them:

Establishment of a highway policy that will result in adequate highway service in the future requires determination of the proper size and cost of systems of the different classes of highways needed. There must be an equitable plan for distribution of costs among highway users and general taxpayers, allocation of authority and financial responsibility among levels of government, and regulation of highway use to protect users and to obtain maximum service. Each element is so interrelated with others that complete facts on present conditions and most up-to-date results of transportation research are essential to develop an over-all analysis of highway needs to serve the interests of all in an equitable manner. ${ }^{29}$

In 1947, the California Legislature created a joint fact-finding committee from both houses to study the highway needs of the State "and to recommend a policy and means of putting that policy into action." The Michigan Good Roads Federation undertook a similar statewide needs analysis. Other States followed, and by 1950, 13 had published needs reports, and others were working on the complex studies for such reports.

The legislative and other fact-finding committees depended on their State highway departments, assisted by the BPR, to supply the factual information for their studies. Most of this factual material came from the tremendous bank of economic and traffic data assembled by the statewide planning surveys begun in the middle 1930's. There was also a large amount of research information on driver behavior and the vehicle-carrying capacity of urban streets and rural roads that had been assembled before and after the war by the BPR, the States and the Highway Research Board's Committee on Highway Capacity.

The compilation of future needs was simple in principle, but laborious in practice. First, the analysts had to forecast the traffic that might be expected in a future year and then assign the future traffic to the various roads in the several systems. Then, knowing the present condition of these roads and the desirable standards to handle the forecasted traffic, they could compile a list of "deficiencies." Finally, they would compute the future cost of the construction needed to overcome these deficiencies. The sum of these costs was the estimate of needs for the particular year studied.

These predictions of future needs were necessarily painted with a broad brush. First, they depended on the continuation of past population, economic, vehicle registration, and traffic trends. And then there was considerable difference of opinion among the States as to what the standards should be to accommodate the future traffic. Nevertheless, there was a broad general agreement that the past trends would continue or even be exceeded and that the AASHO standards would be adequate or at least tolerable. The needs estimates were widely accepted as being well within the accuracy required for long-range financial plans and also for arousing popular support for the increased taxes and highway imposts that would be required to realize those plans.

It is safe to say that most of the State legislatures were astounded and dismayed by the size of the back$\log$ of needs as shown by the needs studies. The California legislative committee found that it would cost $\$ 1.7$ billion over a 10 -year period to bring the State's roads up to a reasonable standard. The cost in Washington was estimated at $\$ 509$ million and in Oregon at $\$ 468$ million. $^{31}$ The Michigan committee found needs that would cost $\$ 1.75$ billion to remedy. ${ }^{32}$ Connecticut, one of the smallest States in area, found needs exceeding $\$ 400$ million, and in Massachusetts the needs exceeded $\$ 700$ million. $^{33}$

In 1950 AASHO made its own needs study and asserted that what was needed nationally to catch up with highway needs was a $\$ 4$ billion annual program for 15 years ( $\$ 1$ billion for maintenance, $\$ 2.5$ billion for construction and $\$ 500$ million for interest, amortization and administration). ${ }^{34}$ About the same time the Congressional Joint Committee on the Economic Report set the immediate national road needs at $\$ 41$ billion. ${ }^{35}$

The reaction to the disclosure of these massive needs varied from State to State. The California Legislature immediately increased the gasoline tax by $11 / 2$ cents per gallon and radically amended the highway laws to speed up right-of-way acquisition and permit acquisition of land in advance of actual need to forestall speculative increases in land prices. Michigan raised its 3 -cent gasoline tax to 5 cents per gallon and added 2 cents to the diesel fuel tax which, along with a hefty increase in the truck weight tax, raised an additional $\$ 135$ million annually. ${ }^{36}$ Other States looked to Congress to make up the difference between 
what they needed and what they could raise without pain with their current tax policies. Still others thought the solution was to get the Federal Government to withdraw from the taxing of fuel so that the States, without lowering the total tax, could use the Federal 2 cents per gallon for their own needs.

But most States decided on some form of credit financing to close at least a part of the gap. The Massachusetts Legislature authorized a $\$ 100$ million bond issue backed by road-user revenues to improve the main highways and began looking into toll financing for some highways. ${ }^{37}$ By a two-to-one vote, the voters of North Carolina approved a $\$ 200$ million bond issue for rural roads. The bonds, backed by the faith and credit of the State, sold to yield an effective interest rate of only 1.52 percent. ${ }^{38} *$

* By comparison North Carolina sold its road bonds in 1920 to produce an effective interest rate of 5 percent.

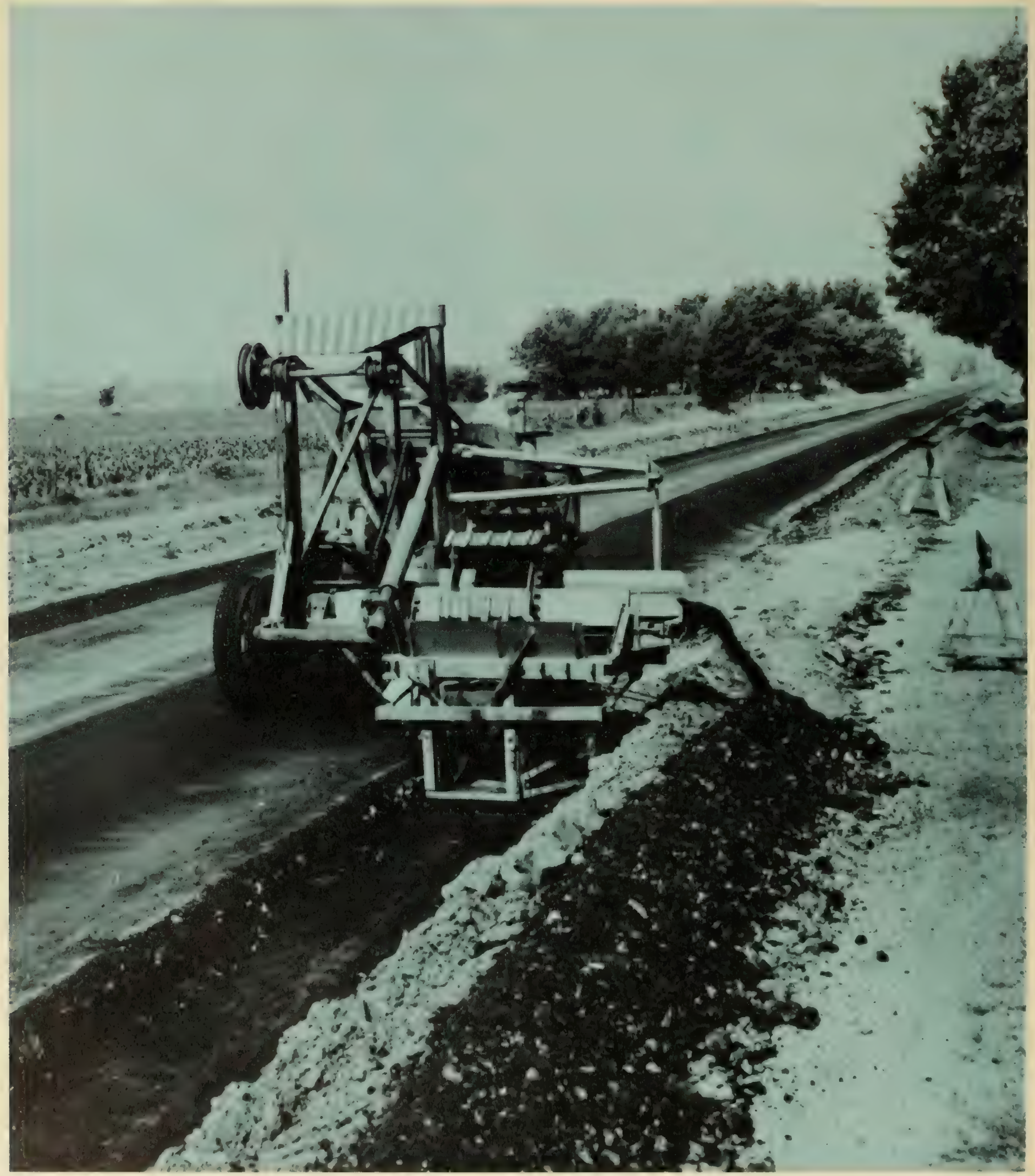

Traffic was concentrated around the cities, but the need to upgrade rural roads also demanded that limited funds be spread across the State, resulting in pavement widening projects such as this. 
In New York, Governor Thomas E. Dewey, despairing of ever completing the Thruway System from diversion-depleted current revenues, authorized a study of revenue bond financing backed by tolls. When this study showed that tolls alone would not carry the project, the Legislature created the New York Thruway Authority and empowered it to sell $\$ 500$ million in bonds backed by the State's credit. ${ }^{39}$

Some State legislatures decided to wring as much as possible of the needed revenue from road users in the form of tolls on the theory that "every dollar that can be obtained from private sources to extend existing toll highways will mean a dollar of regular highway income released to match federal aid for highway building in some other part of the state." 40 Other States, notably New Jersey, switched from payas-you-go financing to revenue bonds backed by tolls to build their most expensive and heavily traveled arteries. Between 1950 and 1954, the legislatures of 19 States created independent toll road authorities or authorized their State highway departments to build toll roads.

The Federal-Aid Highway Act of 1950 permitted the States to borrow funds in the bond market against future Federal-aid apportionments. However, this authority did not make any new money available to the States or enhance their credit or change their own constitutional debt limits; and further, Congress carefully disclaimed any obligation to provide the future Federal-aid funds that might be used to redeem the bonds. Consequently, only a few States availed themselves of the privilege, and these for comparatively small amounts.

\section{The Financial Dilemma of the State Highway Depart- ments}

The prices bid for highway construction peaked in late 1948 and then stabilized at about twice the prewar level. Highway maintenance costs also doubled because of the war and postwar inflation. This put the State highway departments in a double price squeeze at a time when highway traffic, and particularly truck traffic, was increasing alarmingly.* As the States put increasingly more of their income into maintenance, the money left for new construction, including Federal-aid matching, became less. The purchasing power of this remainder was only half that of the prewar period, yet the increased traffic demanded much heavier, wider and costlier roads than the prewar models.

Traffic growth was not uniform but was concentrated most heavily in the industrial States and, to a large extent, on a very small mileage near and between the large cities. Yet it was politically impossible for the highway departments to concentrate their funds on this small mileage. Their programs were designed to distribute highway work rather evenly over their States, and in a situation where all roads needed some improvement, it was not possible to deny

\footnotetext{
* In the 4 years from 1947 to 1950 , registrations of privately owned rehicles increased by 11.2 million units- to a total of 48.60 million. $^{41}$ Annual vehicle miles of travel by passenger automobiles increased by 21 percent and by trucks 37 percent. In 1950 , about 48 percent of the travel was in urban places, the rest on the rural roads. ${ }^{42}$
}

some areas in order to build a few miles of costly superhighways near the cities.

Practically all of the States agreed that the most troublesome congestion was on the selected Interstate System routes. These had long been the most important traffic arteries and were now the oldest and most obsolete. Most of the highway departments made a determined effort to upgrade these old roads, and through fiscal year 1948 they channeled about 22 percent of their postwar primary and urban Federal aid and matching money, amounting to $\$ 384$ million, into interstate projects. These totaled over 2,000 miles, including 800 bridges and grade separations, but this was a mere drop in the bucket compared to the obvious needs.

\section{Congress Orders Reevaluation of Defense Highway Needs}

As the States struggled to keep up with continual traffic increases, Western Europe was approaching economic collapse, and relations with the Soviet Union were deteriorating to a state of "cold war." In 1947 Congress acted to provide massive military and economic aid for Turkey and Greece to help them resist Communist aggression. In April 1948 Congress approved the $\$ 17$ billion Marshall Plan to rebuild Europe. In June 1948 the Soviets blockaded Berlin, and the United States responded with a massive airlift to break the blockade.

In the tense atmosphere of these events, Congress became more conscious of the growing inadequacy of the country's highways, and particularly the Interstate System to sustain a possible remobilization. It added a provision to the Federal-Aid Highway Act of 1948 requiring the Commissioner of Public Roads to study the needs or potential needs of the Interstate System for national defense in cooperation with the Secretary of Defense, the State highway departments and the National Security Resources Board and report back to Congress not later than April 1, 1949.

The study began with a detailed inventory which disclosed an amazing diversity of geometric standards, widths and types of pavements, and dimensions and strengths of bridges among the 37,800 miles of existing roads in the System. The average age of the road surfaces was 12 years and 13 percent were more than 20 years old and nearing the end of their useful lives. In the rural sections, 6,000 miles had surfaces less than 20 feet wide and only 4,147 miles had more than two lanes. On 6,273 miles, the shoulders were less than 4 feet wide. There were 1,262 grade crossings with main line railroads and another 785 with branch lines and spur tracks. Of the 12,048 bridges on the System, only 677 were found to be below AASHO's H 15 capacity, but there were many more of inadequate width, including 52 one-way bridges less than 18 feet wide. Of the existing bridges, 1,245, aggregating 29 miles in length, were of wooden construction. ${ }^{43}$

The PRA and the States measured the traffic using each section of the System and estimated the cost of upgrading each section to handle this traffic according to the standards proposed by AASHO for Interstate highways. They found that many sections would have to be completely relocated to meet the design speed, sight distance and gradient requirements and 
that the relocations would shorten the total length of the system by about 641 miles. All together, the investigators found that it would take an investment of $\$ 11.3$ billion at 1948 prices to bring the Interstate System up to an acceptable standard to handle 1948 traffic. To meet this need in a 20 -year period would require an investment of at least $\$ 500$ million per year, according to the PRA's report.

However, the report stated that the needs of the national defense would require a "substantially more rapid improvement," and it pointed out that tremendous benefits to the civilian economy would flow from a faster rate of modernization. Rather than stretch out the work over 20 years, the PRA suggested credit financing with appropriations sufficient to amortize the bonds in 20 years. To this end, the report recommended that Congress consider permitting the States to borrow capital now to complete their sections of the Interstate System and use their future Federal-aid apportionments to repay the borrowings. To further promote rapid completion, the report suggested that Congress increase the Federal share of the cost of Interstate projects and also earmark funds specifically for the Interstate System. These earmarked funds should be apportioned so that the improvement of the System would proceed at about the same rate in all the States. ${ }^{44}$

In March 1950 Representative William M. Whittington of Mississippi introduced a bill to increase Federal aid for fiscal years 1952 and 1953 to $\$ 570$ million per year, of which $\$ 70$ million would be earmarked for the Interstate System, to be matched 75 percent Federal to 25 percent State. Whittington's bill would also increase Federal participation in rightof-way costs to 50 percent and permit the States to use future Interstate apportionments to repay loans incurred to finance Interstate projects. This bill had the support of AASHO, except that AASHO had asked for $\$ 210$ million for the Interstate instead of the paltry $\$ 70$ million. ${ }^{45}$

Not all the State highway people were behind AASHO in this support. Led by the influential chief engineer of the Pennsylvania State highway department, the Association of Highway Officials of the North Atlantic States (AHONAS) passed a resolution opposing any further increase in Federal aid to the States, any further earmarking of funds for particular Federal-aid systems and any increase in the Federal share of projects. Increase in the Federal share would, AHONAS asserted, lead inevitably to more Federal control and intervention in State affairs. ${ }^{46}$

Other bills in the $2 d$ session of the 81 st Congress would have boosted Federal aid to $\$ 870$ million annually with $\$ 100$ million going directly to counties and townships. In the end, despite the continued unsettled conditions in Europe and the outbreak of war in Korea in June 1950, Congress left the road program substantially unchanged except for an increase of $\$ 50$ million to restore the $1946-48$ level of $\$ 500$ million per year. There was no increase in the Federal matching share or any earmarking of funds for the Interstate System. The only important changes were raising Federal participation in rightof-way costs to 50 percent and the granting of permission for the States to use future Federal-aid apportionments to retire the principal of bonds issued to finance improvements on the Primary System, including the Interstate System.

Nearly 2 years passed before Congress took any further action on the PRA recommendations. The Federal-Aid Highway Act of 1952 increased Federal support for the Primary and Secondary Systems to $\$ 550$ million each for fiscal years 1954 and 1955 and also authorized $\$ 25$ million for each of these years for the Interstate System. This token amount was to be apportioned according to the original Federalaid formula and matched $50-50$ by State funds.

Two years later in the Federal-Aid Highway Act of 1954, Congress increased the whole Federal-aid program to $\$ 875$ million per year, earmarking $\$ 175$ million in fiscal years 1956 and 1957 for the Interstate System and increasing the Federal share to 60 percent on Interstate projects.

The reluctance of Congress to provide adequate funding for the Interstate System can be explained in part by a rising sentiment against the principle of Federal aid, and voiced by the 1953 Governors Conference which recommended that there be no further increases in aid, and that the Federal Government withdraw from the taxation of motor fuel. ${ }^{47}$ However, the best excuse for congressional inaction was a strong indication from a number of States that they were well on the way to removing their worst traffic bottlenecks by building roads without Federal assistance.

\section{The Second Toll Road Era}

The Pennsylvania Turnpike operated at a loss during the war years despite increased traffic. In 1944, 1.04 million vehicles used the turnpike and paid $\$ 1.78$ million in tolls, yet the Authority lost $\$ 500,000$ and had to draw on the reserve built up in 1940, 1941 and 1942.48

After the war, traffic increased rapidly, and this, with increased toll rates, quickly restored profitable operation. By 1948 the turnpike's net operating revenue was $\$ 5.6$ million per year. With the financial security of its original investment assured, the Pennsylvania Legislature authorized the Turnpike Commission to extend the turnpike 100 miles east to Philadelphia at an estimated construction cost of $\$ 75$ million and 60 miles west to the Ohio State line for about $\$ 55$ million. ${ }^{49}$ The Commission had no trouble selling its bonds to eager investors.

Meanwhile Maine was pushing plans for a toll road to be built a few miles inland from U.S. Route 1 between the New Hampshire border and Portland. This road was expected to attract most of the summer traffic bound from New York and New England to the Maine resorts and thus take some of the pressure off congested Route 1. The Legislature thought this traffic would not mind paying a small toll to avoid the congestion on the old road.

As soon as wartime restrictions were lifted, the Maine Turnpike Authority sold $\$ 15$ million of revenue bonds to finance the 47 -mile road and began construction. Although the bonds were secured only by the future earnings of the turnpike, they sold readily at a net interest rate of only 2.64 percent. When the turnpike was opened in 1947 , traffic exceeded estimates, and after some initial difficulties, the road operated in the black on a toll of about $1 \frac{1}{2}$ cents per mile. ${ }^{50}$ 


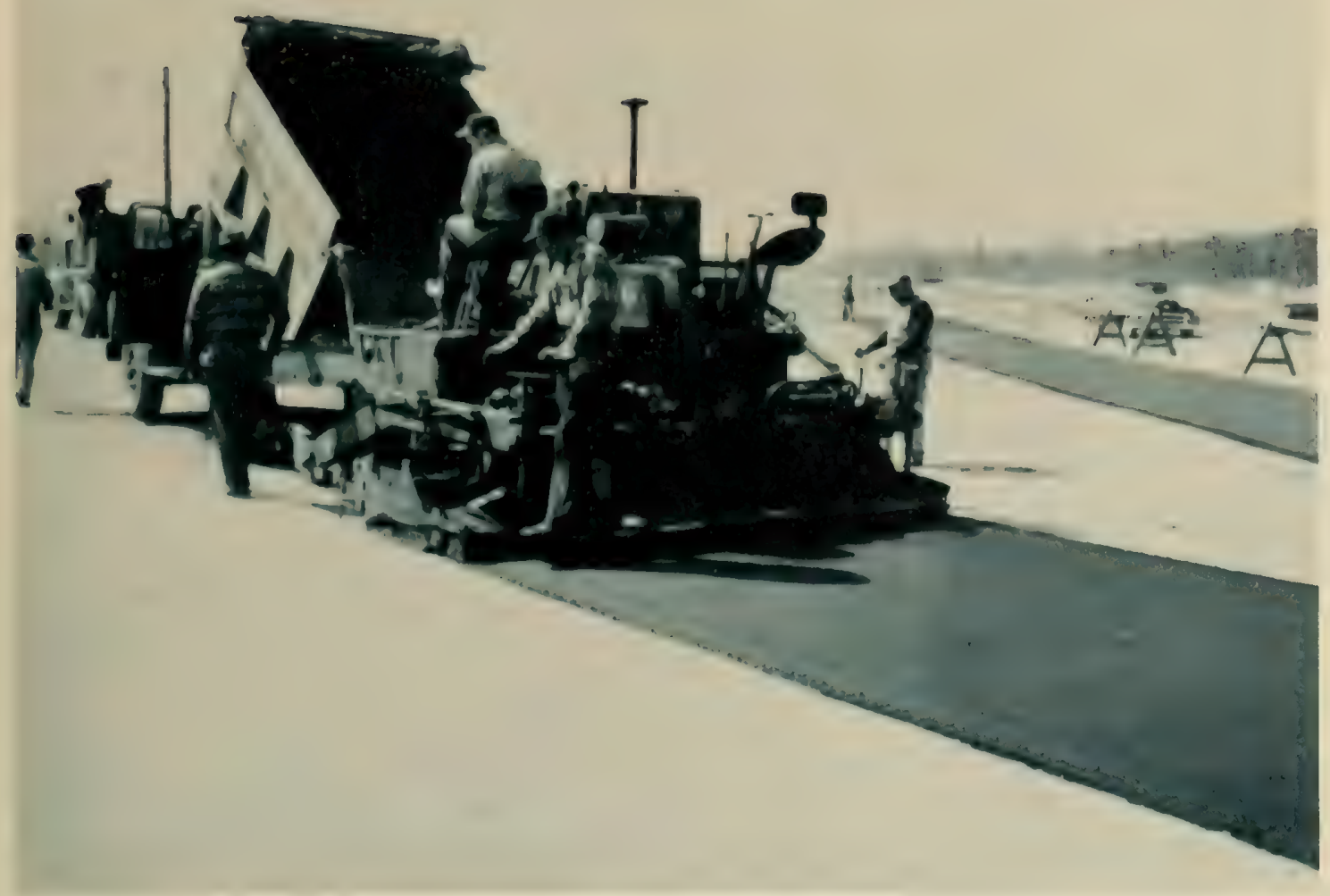

Building the New Jersey Turnpike.

With the completion by Massachusetts of a free expressway to the New Hampshire line and the opening of the Maine Turnpike, traffic congestion became intolerable on New Hampshire's 15-mile portion of U.S. Route 1. Unable to obtain an increase in the gas tax from the Legislature to finance major improvements for the old winding road, the Highway Commission asked for authority to build a toll road financed by State bonds. The bonds, backed by the faith and credit of the State, sold for a net interest rate of only 1.58 percent. The toll road, built in only 1 year, opened to traffic in 1950 and was enormously profitable from the outset-so much so that the Legislature decided to build two more toll roads in other parts of the State.

In 1945 the New Jersey Legislature authorized a system of free expressways and parkways to relieve congestion in the densely settled New York-Philadelphia corridor. The system was started in 1946, but in a few years it became evident that highway revenues were insufficient to complete the system in any reasonable time. The Legislature then set up the New Jersey Turnpike Authority in 1949 to build the principal artery between the George Washington Bridge and the Delaware River, a distance of 117 miles. By-passing the New York bond houses, the Authority sold its revenue bonds to a consortium of 53 insurance companies in February 1950. It then embarked on a round-the-clock construction program that finished the $\$ 285$ million toll road in less than 3 years.

From the opening of the first section in 1952, the turnpike was a resounding success and by 1953 was returning six times the operating expenses for a net operating revenue of $\$ 18.2$ million per year. Traffic was 22 million vehicles during 1953 of which only about 12 percent were trucks and buses.

In 1947 the New York Legislature authorized Westchester County to collect a 10-cent toll on the Hutchinson River and Sawmill River Parkways provided the county reimbursed the Federal Government for the $\$ 2.15$ million of Federal-aid funds spent on these parkways.*

\section{The Toll Road Bandwagon Begins to Roll}

The Pennsylvania, Maine, New Hampshire and New Jersey Turnpikes showed rather conclusively that the public was impatient with obsolete, congested highways and was willing to pay handsomely for modern freeways.** Other States, equally short of capital funds, began to consider credit financing schemes backed by tolls. Oklahoma in 1953 completed the 88-mile Turner Turnpike between Oklahoma City and Tulsa. New York, which had started its thruway as a free expressway, switched to toll financing in 1954 to accelerate construction. And West Virginia completed a 2-lane toll road from Charleston to Princeton in 1954. Colorado built the 17-mile Denver-Boulder Turnpike in 1952.

* The Hayden-Cartwright Act of 1934 authorized the expenditure of Federal-aid funds on "such main parkways as may be designated by the State and approved by the Secretary of Agriculture as part of the Federal-aid highway system."

** In 1953 the average State gasoline tax was about 5 to 6 cents per gallon, and the Federal tax was 2 cents per gallon. Thus, the States and the Government were collecting $1 / 2$ cent per mile for providing and maintaining the public highways. On top of this the toll roads collected about $1 \frac{1}{2}$ cents per mile in tolls so turnpikes cost their users about four times as much as free roads. There were, of course, offsetting economies in time, operating costs, and distance savings which made the turnpikes attractive. 


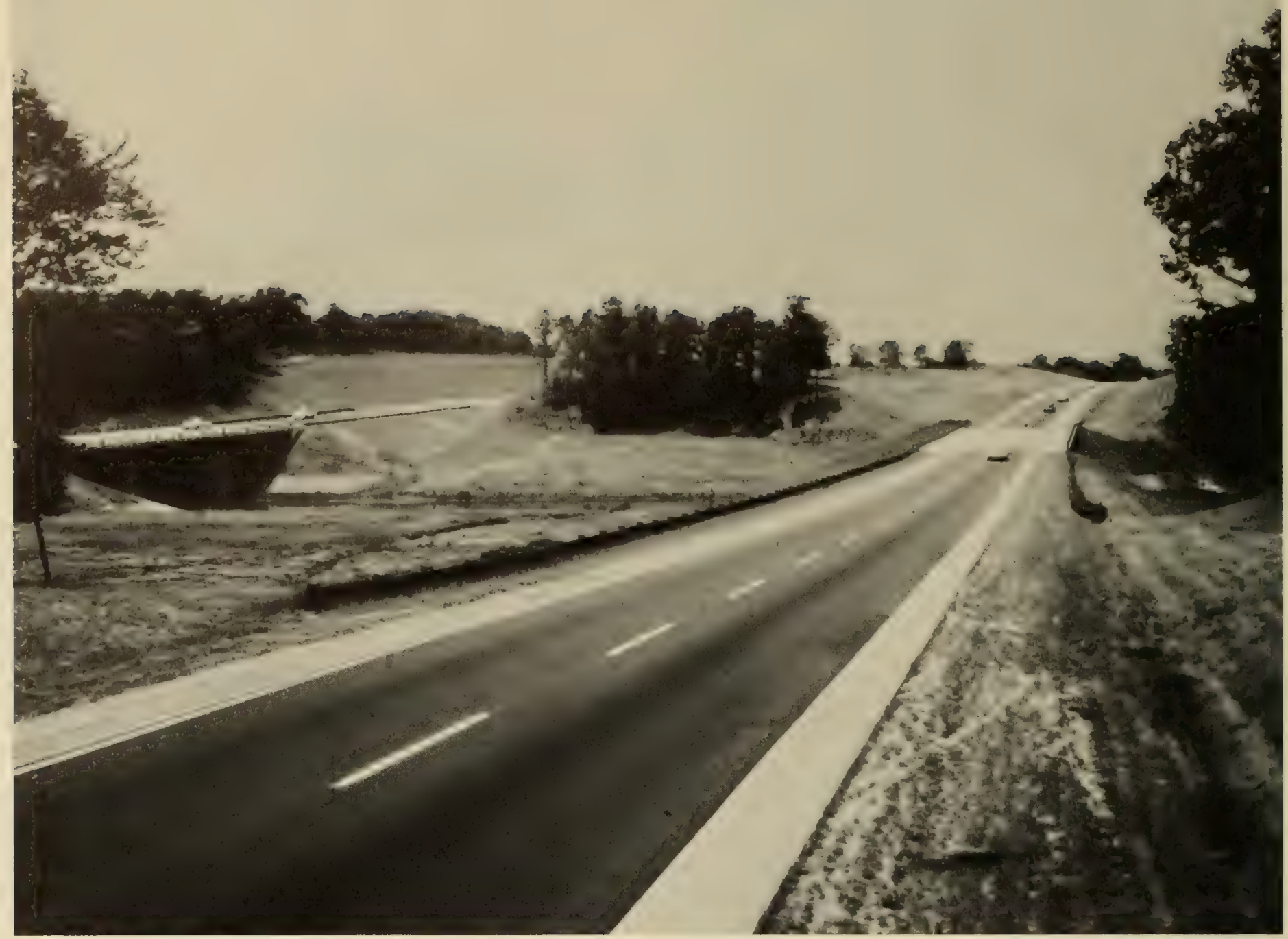

New Jersey's Garden State Parkway, one of the early examples of excellent design for high-speed, access-controlled roads.

Toll road authorities were created in Connecticut, Indiana, Illinois, Ohio, Kansas, Kentucky, Florida, Georgia, Louisiana, Massachusetts, Michigan, North Carolina, Rhode Island, Texas and Virginia. By the end of 1954, these authorities had 1,382 miles of toll roads under construction at costs estimated to total $\$ 2.3$ billion, and they were making plans and studies for 3,314 additional miles estimated to cost $\$ 3.75$ billion. The 1,239 miles of toll roads already completed as of January 1955 represented an investment of $\$ 1.55$ billion. ${ }^{51}$

With few exceptions, these toll roads followed the routes selected by the PRA and the States for the Interstate System, and they represented the heaviest trafficked portions of that System outside the cities. At the height of the toll road boom, the turnpike authorities were investing their funds in interstate highways at about three times the rate of the State highway departments.

It is not an exaggeration to say that most of the motoring public first learned the safety and comfort of driving on access controlled roads on the turnpikes.
The toll roads provided the example that later led to mandatory control of access on the Interstate System. The toll roads were high-speed divided highways with wide rights-of-way. Their geometric standards equaled or bettered AASHO's "desirable" standards for the Interstate System. In addition, the turnpike authorities spent considerable sums to provide amenities for their users-rest areas, landscaping, built-in safety features. A few, notably New Jersey's Garden State Parkway and portions of the New York Thruway, were planned with the two roadways totally independent of and largely concealed from each other-an advanced technique of highway design pioneered by the PRA and the National Park Service on the Baltimore-Washington Parkway. Most toll roads, however, were built in the monotonous tradition of long tangents that had dominated highway engineering for decades. Nevertheless, the toll roads, as a class, set a high standard of excellence that was hard for the State highway departments with their limited budgets to match. They provided highly visible yardsticks by which to measure the glaring inadequacies of the public highways and whetted the public appetite for better free roads. 


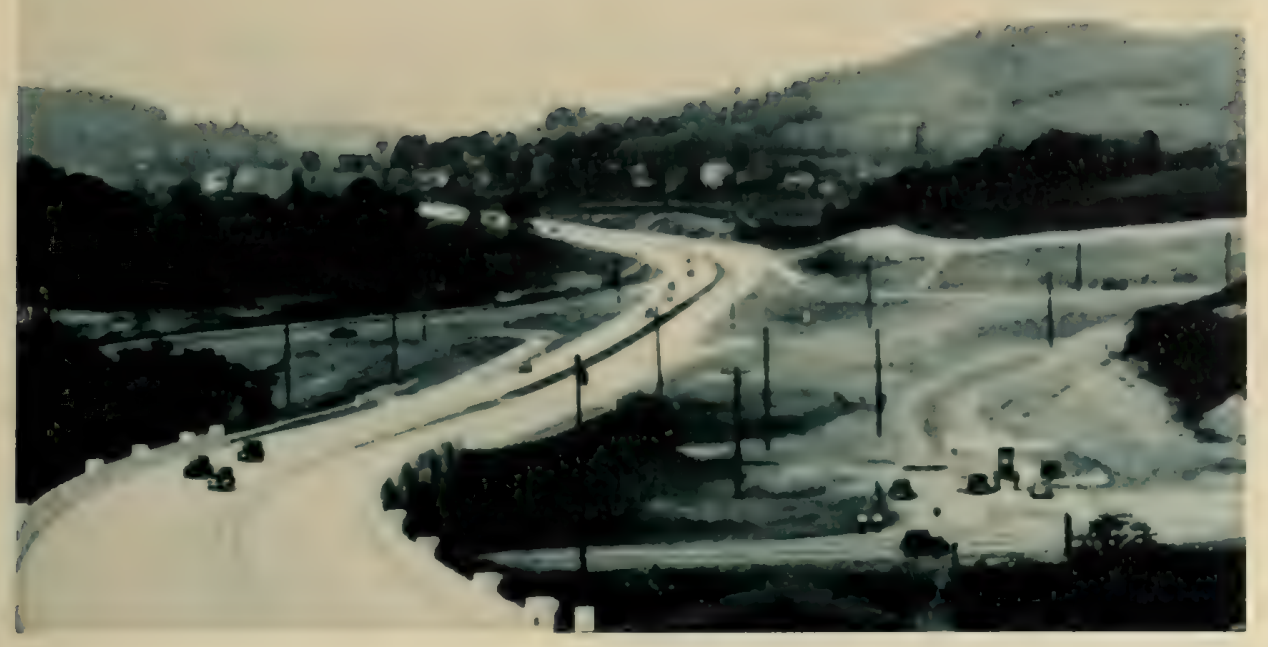

With the great success of many of the early turnpiles, their excess capital was used to build and support less profitable roads, appearing to establish a never ending requirement for tolls.

\section{Tolls Forever}

The feasibility of the original Pennsylvania Turnpike was assured by Federal grants of $\$ 29.5$ million which greatly reduced the part of its cost that would have to be financed by revenue bonds and recovered in tolls from the road users. The success of the turnpike convinced many proponents of toll roads in and out of Congress that the much-needed improvement of the main interstate highways could be achieved by Federal subsidy of toll roads, especially those with marginal revenue potential, or even by a system of federally owned toll roads. A bill was introduced in the 80th Congress to permit the use of Federal funds on toll roads, along with the perennial bill to authorize transcontinental Federal toll expressways. ${ }^{52}$

These proposals were opposed by the PRA and a long list of organizations representing highway users. The PRA's argument was that toll roads were wasteful and solved only a part of the problem. To reduce the cost of collecting tolls, the access points had to be spaced far apart, denying the use of the road to local and short haul traffic.* The States or counties would have to build duplicating parallel free roads to handle this local traffic at greater total expense than it would take to build a free expressway originally.

By 1948 business was so good on the Pennsylvania Turnpike that toll collections were running far ahead of the requirements for retiring the bonds. When the Legislature authorized the 100-mile extension east to the Delaware River, the Turnpike Commission merged the financing of this extension with that of the original toll road by floating new bonds, part of which were used to pay off the original bond issue. Later other extensions were all financially tied together so that revenue from the profitable sections of the system supported the weaker sections.

This pattern of financing, long used by the Port of New York Authority, ${ }^{* *}$ was copied in other States.

* On the Maine Turnpike the distance between access points averaged 11 miles.

** Tolls on the Port of New York Authority's enormously profitable Holland Tunnel were set at a rate far higher than was necessary to retire the bonds, and the extra income was used to finance other undertakings.
Connecticut placed the income from the Merritt and Wilbur Cross Parkways and the Charter Oak Bridge in a revolving fund to support the bonds for a new toll expressway from Greenwich to Killingly. Maine applied the income from its first turnpike to finance a northern extension to Augusta.

This trend alarmed many State highway administrators who foresaw a situation of perpetual tolls on their main highways. In 1950 the Deputy Director of the New York Department of Public Works warned that the proliferation of toll roads would stifle free transportation and injure the national welfare. ${ }^{53}$ The Engineering News-Record cautioned against the danger that toll authorities would perpetuate themselves long after the original excuse for their existance (shortage of funds) has passed. "As a result, the publicly owned toll highway of today can become just as pernicious an evil as the privately owned toll road of a century or more ago." 54

\section{Congress Sets National Policy on Toll Roads}

In 1954 the New York Thruway Authority and the New Jersey Highway Authority agreed to connect the thruway and the Garden State Parkway at the State line. However, trucks were prohibited on the parkway, which meant that southbound trucks on the thruway would have to exit at the State line and continue their journey on the public roads. Critics of toll roads pointed to this decision as one of many examples of uncoordinated regional planning by the toll authorities. The connection, they said, should have been made to the New Jersey Turnpike instead of the parkway, and the decision as to where to connect should have been made by the State highway authorities in Albany and Trenton rather than by the toll road authorities. ${ }^{55}$

There was also widespread criticism of allowing the toll roads to preempt the Interstate highway locations and thus condemn the free roads in those locations to a generation of inadequacy.

The Bureau of Public Roads had played a decisive role in coordinating the regional planning of the Federal-aid system by the States. However, the BPR had no influence with the toll authorities since they had not received any Federal funds. One of the 
reasons advanced by proponents of Federal aid for toll roads was that such aid would give the Government some control over them-at least to the extent of requiring that the roads be freed of tolls after the bonds were paid off.

The 83d Congress (1953-1954) considered the thorny problem of Federal aid for toll roads but left it unsettled by directing the Secretary of Commerce to make a study and report his recommendations to the next Congress. This report, Progress and Feasibility of Toll Roads and Their Relation to the Federal-Aid Program submitted to the 84th Congress in 1955, showed that on January 1, 1955, there were 1,239 miles of completed "arterial toll roads" in the United States, plus 1,382 miles under construction and an additional 3,314 miles authorized. ${ }^{56}$ Many hundreds of miles in the third category had not been studied, and their possibilities for revenue bond financing were unknown.

The BPR analyzed all highways, toll or free, that were not already adequately improved for future traffic up to the year 1984 or definitely scheduled for such improvement. The analysts found that about 6,900 miles of heavy-traffic roads were feasible for revenue bond financing, and of these, 6,700 miles were on the Interstate System routes. ${ }^{57}$ Whether there could be additional self-supporting toll roads, therefore, would depend upon the policies of the Federal Government and the States in the use of public funds to improve the Interstate System. "Assurance of public funds to provide reasonably early completion of the system would soon spell the end of revenue-bond financing of roads in the system. Continuation of the present inadequate allocation of funds to this system, however, can only serve to increase the mileage that would be potentially feasible as tool roads." 58

The report then went on to describe the inadequate local service given by toll roads and the resulting need for parallel free highways. "Thus, even though a toll road may be readily self-liquidating, it can never relieve some public agency from the responsibility of continuing to provide local service... On the other hand, a properly located and designed free road can serve both the through and local traffic." 59

The Secretary recommended that there be no Federal support or encouragement of new toll roads but that Congress permit the integration of existing toll roads into the System where they followed Interstate routes and met Interstate standards and where there were available reasonably satisfactory alternate free roads. No toll roads should be permitted on any other Federal-aid system.

Congress incorporated these recommendations in the new law, and also authorized the use of Federal funds on approach roads connecting acceptable toll roads to the free portions of the Interstate System. This last was conditioned on the State's agreement to free the benefited section of toll road after retirement of the original bonds.

\section{New Leadership for the Bureau of Public Roads}

When Commissioner MacDonald reached the statutory retirement age in 1951, only a handful of the oldest employees could remember a time when he had not been in charge of the Bureau of Public Roads. The Bureau's budget had increased from \$69 million in fiscal year 1919, when he assumed control over what was then a minor bureau in the Department of Agriculture, to $\$ 485$ million in 1951 -about half of the Commerce Department's total budget. In those 32 years, MacDonald had supervised the spending of over $\$ 6.6$ billion of Federal aid and forest highway funds without a hint of impropriety, although not without controversy at times. He had served under six Presidents and up to that time had the longest continuous tenure of any important policymaking officer of the Government.

Under "the Chief," as he was known for most of his career, the Bureau of Public Roads had grown from a small but capable and dedicated group of road experts to the most prestigious highway organization in the world.

When the Korean emergency developed into a national crisis, President Truman recognized the confidence MacDonald enjoyed with the Congress and with the State highway departments by persuading MacDonald to continue as Commissioner for the remainder of his Administration.

Commissioner MacDonald retired in March 1953. In his farewell remarks to the press, he emphasized the importance of continuing the traditional FederalState partnership:

'first, it is a workable plan to accomplish a continuing program that involves both local and national services; second, it sets a pattern in harmony with the concepts of federal government.'

The original Federal Highway Act of 1916, he said, 'recognized the sovereignty of the states and the authority retained by the states to initiate projects. All through the legislation since then, the same mechanism of checks and balances has been maintained evenly so that the states and the federal government both have to agree before they can accomplish a positive program.' ${ }^{60}$

Freed from the inhibitions of his office, MacDonald went on to state that the Federal gasoline tax revenue should be returned to the States as Federal aid, and that "it is time to give serious consideration to a charge for use of what we may call extra facilities such as controlled access express highways."

President Eisenhower appointed Francis V. duPont as Commissioner in April 1953. A civil engineer, duPont had been chairman of the Delaware Highway Commission for 23 years and was thoroughly familiar with Federal and State road policies. In announcing his appointment, Secretary of Commerce Sinclair Weeks made a point of also declaring that the administration had no intention of recommending that the Government retire from the taxation of gasoline as had been so loudly demanded by the 1953 Governors Conference. He also said that there were no plans to make any serious changes in the Bureau of Public Roads or its functions.

Mr. duPont assumed control over the Bureau with the expressed intention of making changes slowly, and then only after a complete review of its operations. In his first appearance before the House Subcommittee on Roads he suggested few changes in national policy. Toll roads, he said, were economically feasible at only a very few locations and would not solve the overall road finance problem. Congress, he recommended, should accelerate a solution to the vexing truck size and weight problem not by threats, but 
by hints that Congress would act if the States and industry did not. $\mathrm{He}$ thought the Federal-aid apportionment formula should be changed to give greater weight to the population factor. ${ }^{61}$

\section{The Drive for More Federal Aid}

The Korean emergency coupled with the continuing steady increase in vehicle registrations imposed new strains on the highways. Freight carried by highways increased by one-third in a single year, from 107 billion ton-miles in 1949 to 142 billion ton-miles in $1950{ }^{62}$ The traffic increases affected all classes of highways but were felt most acutely on the Interstate System, a number of sections of which were carrying over 50,000 vehicles per day.

Contractors were plentiful, and construction prices reasonably stable; still, the States were barely able to keep up with traffic, especially in the cities. Some States, with BPR approval, adopted a stage construction policy for urban expressways, building them in little pieces to "provide immediate relief at the most seriously congested points, with a view to subsequent construction of an entire facility. ${ }^{63}$

The real problem with all the States was a shortage of funds. Nearly all of them had increased their gasoline taxes and registration fees, but these increases barely offset the inflation in maintenance and construction costs. In their straitened circumstances, State resentment focused on the Federal gasoline tax which had originally been imposed by Congress as an emergency revenue measure but had been continued after the war and which was yielding about $\$ 1$ billion annually. Some State governors also pointed to the Federal excise taxes on automobiles, trucks, tires, oils and greases which yielded another billion dollars to the Government. Since Federal aid to the States was currently only half a billion dollars, this in the eyes of the governors was diversion of road-user funds on a massive scale-the very practice penalized by the 1934 Hayden-Cartwright Act when indulged in by the States.
The congressional road committees held exhaustive hearings in 1953 in preparation for the 83d Congress biennial highway bill.

The legislation that emerged in 1954, without acknowledging any tie between Federal-aid appropriations and the Federal gasoline tax, boosted the appropriations 50 percent above any previous level, to $\$ 875$ million for fiscal years 1956 and 1957 , including $\$ 175$ million specifically earmarked for the Interstate System and increased the Federal share on Interstate projects to 60 percent. Congress also requested a comprehensive study of the costs of completing the several systems of highways in the Statesto be completed along with a new toll road study.

The House Subcommittee on Roads had argued the merits of toll financing, but in the end, Congress avoided the toll road problem in drafting the final version of the Federal-Aid Highway Act of 1954 except to ask for a study and to allow Connecticut the right to charge tolls on its proposed expressway from Greenwich to Killingly after repayment of the Federal funds previously expended on the road.

In the 1954 Act, Congress, for the first time, relaxed some of the Government's tight control over the spending of Federal-aid funds. For secondary road projects under the Secondary Road Plan, as it came to be known, the BPR was required to approve only system changes and programing of funds and to inspect and accept completed projects. By agreement between the State and the BPR, all other details of planning, contracting and building secondary roads could be handled by the State without detailed Federal supervision. This relieved the BPR of much tedious detail and enabled it to concentrate available personnel on primary and Interstate projects.

\section{The Grand Plan}

Before the Secretary could prepare either the toll road study or the highway cost study requested by Congress, President Eisenhower announced his own plan for bridging the gap between highway construction and highway needs. Choosing the annual confer-

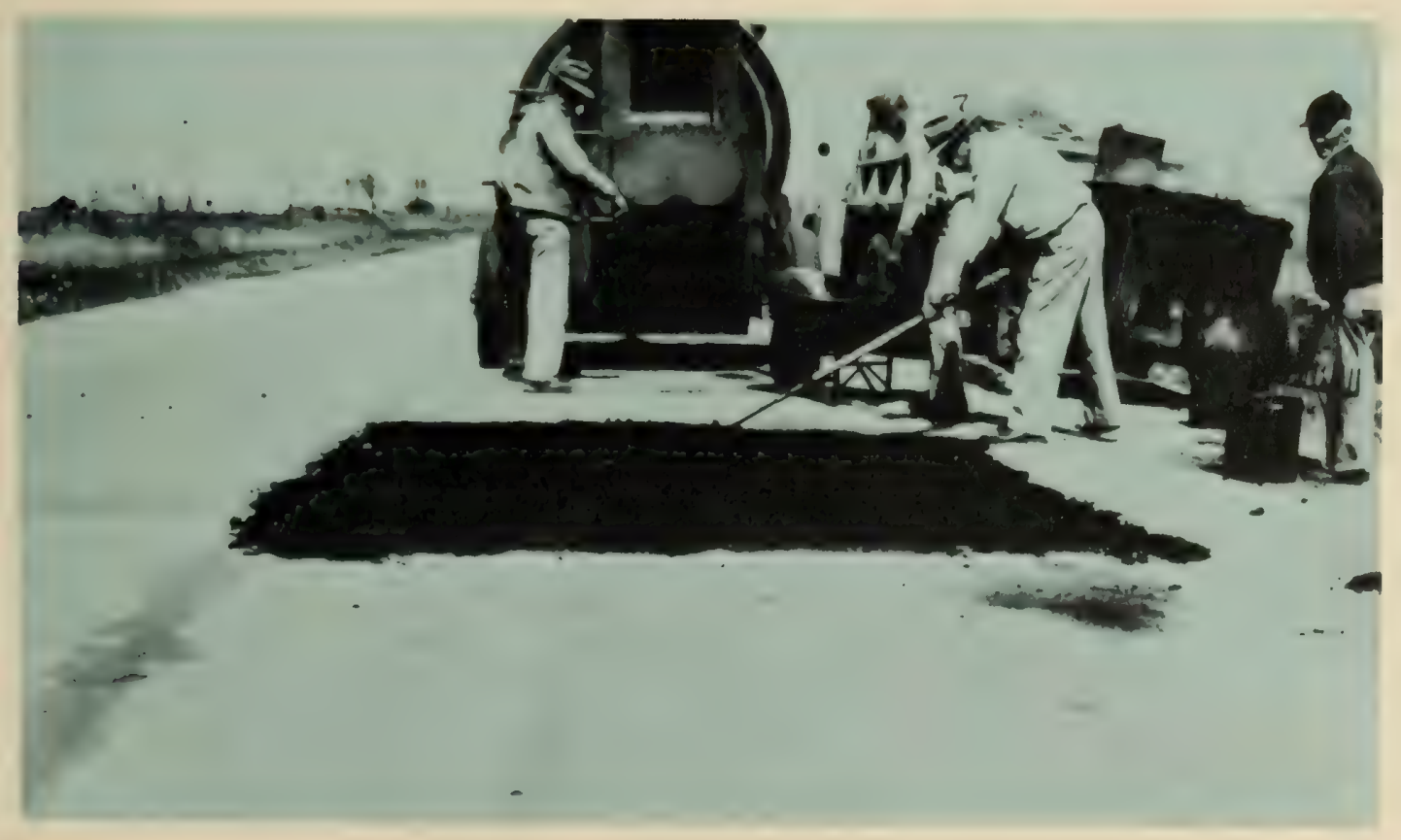

Inflation and shortage of funds during the Korean emergency made even simple. maintenance difficult for the States. 
ence of State Governors as his forum, the President asked the governors for their cooperation and help to work out the details of " "... a grand plan for a properly articulated system that solves the problems of speedy, safe, transcontinental travel-intercity communication-access highways-and farm-to-market movement-metropolitan area congestion-bottlenecks-and parking." " 64 To overcome the accumulated deficiencies, he called for spending $\$ 5$ billion per year for 10 years, in addition to normal expenditures. ${ }^{65} *$

The President's bold plan was well received. The conference appointed a Governors Highway Committee to advise the President, particularly in the matter of financing the program. The conference also refrained from further attempts to get the Federal Government to retire from gasoline taxation.

At this time, the President did not have a detailed blueprint for his Grand Plan, and he realized that a great deal of study would be needed before a definite plan could be presented to Congress for action. $\mathrm{He}$ appointed a Federal Interagency Committee to study highway policy within the Government and also asked General Lucius D. Clay, who had served as military governor of Germany, to head up an advisory committee of prominent citizens to determine the needs and recommend a financing plan. The Clay Committee, as it was thereafter known, held hearings and enlisted the help of AASHO and outstanding experts from public agencies, the highway industry and highway user groups.

The best estimate of needs came from AASHO which, with the help of the BPR, had updated its estimate of the needs of the Federal-aid systems in 1953. That estimate was $\$ 35$ billion to make the 673,137-mile Federal-aid system adequate for 1953 traffic. Projecting the needs ahead to 1964 and adding an allowance for other roads not on any Federalaid system, AASHO and the Committee arrived at a figure of $\$ 101$ billion for the total capital needs that would have to be met by $1964 . * *$ The Committee estimated that the existing sources of revenue would produce only $\$ 47$ billion to meet these needs, leaving a financial gap of about $\$ 54$ billion. ${ }^{68}$

\section{The Clay Committee Report}

In December 1954 the Governors Conference Special Highway Committee*** submitted a report recommending that the Government assume the entire financial responsibility for the Interstate System and that Congress continue its 50-50 support for the remaining Federal-aid systems so long as the Govern-

* In calendar year 1953, these normal expenditures amounted to $\$ 3.5$ billion for State-administered highways, $\$ 1.2$ billion for local roads and $\$ 1.2$ billion for urban highways and streets-a total of $\$ 5.9$ billion. ${ }^{68}$

** The BPR's study ordered by Congress in 1954 showed that the total of the needs to reach adequacy of all highways by 1964 was $\$ 126.1$ billion (\$100.8 billion for construction, $\$ 19.4$ billion for maintenance and $\$ 5.9$ billion for administration) ${ }^{67}$

*** This Committee was composed of Governor Walter J. Kohler, Jr., of Wisconsin, Chairman, and Governors Frank $J$. Lausche (Ohio), Howard Pyle (Arizona), John Lodge (Connecticut), Lawrence W. Wetherby (Kentucky), Paul Patterson (Oregon), Allan Shivers (Texas), and Robert $F$. Kennon of Louisiana, Chairman of the 1954 Governors Conference, ex officio. ${ }^{6}$ ment continued to levy excise taxes on motor fuels, lubricants and motor vehicles. The States and local governments, the report continued, should pay for the remaining costs, amounting to about 70 percent of the total program. ${ }^{70}$

The Clay Committee agreed substantially with the governors in this division of the financial burden, but recommended that the States pay 5 percent of the cost of the Interstate System. To finance the Federal share, which they estimated at $\$ 31$ billion, ${ }^{*}$ the Committee recommended that Congress create a Federal Highway Corporation with authority to issue $\$ 20$ billion in 32-year bonds, paying the interest and amortization charges out of the future income from the Federal taxes on fuel and lubricants. The Committee estimated that the cost of the Interstate System financed by this method plus the cost of the regular Federal-aid authorizations continued at the current rate would about equal the yield of the fuel and lubricating oil taxes, projected without increase in rates to $1987 .{ }^{72}$

President Eisenhower received the Clay Committee report, A 10-Year National Highway Program, in January 1955. A few months earlier he had asked for and received from Congress a $\$ 6$ billion increase in the national debt limit to cover deficits incurred in the Administration's antirecession program. The President, therefore, welcomed the Clay proposal to finance most of the road program outside the budget, and he included it as a major feature of the Administration's highway bill which he sent to Congress in March 1955.

Meanwhile, Senator Albert Gore of Tennessee, Chairman of the Senate Subcommittee on Roads, was holding hearings on his own highway bill-an expanded version of the traditional biennial Federal-aid authorization providing $\$ 1.6$ billion annually of Federal funds which the States would be required to match with $\$ 1.27$ billion.

Both the President's bill and the Gore bill came under strong attack in the committee hearings. Former Commissioner duPont testified that the old payas-you-go system was too little, too late to meet present needs: that it would take 32 years to complete the Interstate System at the rate proposed by Senator Gore. ${ }^{73 * *}$ The new Commissioner of Public Roads, Charles D. Curtiss, said that according to a poll of the State highway departments, only 19 States would be able to match the Federal funds proposed in the Gore bill, but 43 would be able to match the smaller amount in the Administration's bill. ${ }^{74}$ Senator Harry F. Byrd, Jr., of Virginia, chairman of the powerful Senate Finance Committee denounced the Administration's plan as a scheme to evade the debt limit and remove the highway program from the control of

* This total was divided as follows: $\$ 25$ billion for the Interstate System, including essential urban arterial connections; $\$ 3.15$ billion for the remainder of the Primary System; $\$ 750$ million for the Federal-aid Urban System, $\$ 2.10$ billion for the Federal-Aid Secondary System and $\$ 225$ million for forest highways. ${ }^{\text {"1 }}$

** Mr. duPont resigned as Commissioner of Public Roads in December 1954 in order to give his full attention to promoting the President's highway program. Charles D. Curtiss, a longtime career engineer who had served 11 years as deputy commissioner, was appointed to the vacancy January 14, 1955. 
Congress. Asserting that it would cost $\$ 12$ billion in bond interest, Senator Dennis Chavez of New Mexico called the Administration's bill a "bankers bill" rather than a road bill. Rural interests branded the Administration's proposal to pledge all Federal gasoline tax revenue above $\$ 622$ million per year to back the Federal Highway Corporation's bonds as a 32-year straitjacket for rural highways.

The Engineering News-Record came out strongly for the Administration bill, and particularly for the 10-year limit on completion of the Interstate System. "The real crux of the matter rests in the fact that we need a whole new system of highways just as soon as we can get it, and no adequate pay-as-you-go plan has yet been seriously proposed to assure that result." 75 Proponents of pay-as-you-go financing, the article continued prophetically, were gambling that there would be no inflation in the 30 years or more it would take to build the Interstate System from current revenues.

\section{Defeat of the President's Plan}

Tossing the President's Grand Plan aside, the Senate passed the Gore bill, somewhat modified, by 60 votes to 31. As passed, the bill provided $\$ 13.2$ billion of Federal aid over a 5-year period, financed in part by a 1-cent boost in the Federal gasoline tax. State matching would be $\$ 4.8$ billion in the 5-year period, or $\$ 960$ million per year.

The House Subcommittee on Roads chaired by Congressman George H. Fallon brought out a measure that was somewhere between the Gore bill and the Administration bill. It provided $\$ 24$ billion of Federal aid over a 12-year period, with increases in Federal fuel and rubber taxes to provide the additional revenue. The Fallon bill and the Administration bill came before the House in the last days of the session, but both went down to defeat--a stunning setback for the supporters of the President's Grand Plan.

\section{A New Highway Bill}

Although the President's plan had been defeated, there was still tremendous popular support for an accelerated highway program when the 84th Congress returned for the $2 \mathrm{~d}$ session. The Administration jettisoned the Federal Highway Corporation and endorsed the pay-as-you-go principle. The House Subcommittee on Roads then undertook to put together a new road bill, while the Ways and Means Committee studied the financial aspects of the program. Eventually, the Senate Subcommittee on Roads and the Senate Finance Committee also became involved with the highway bill. The legislation drafted by these four committees contained some notable departures from previous highway policy.

The most radical innovation was the earmarking of Federal highway-user revenues for Federal highway aid. Congress accomplished this by creating a Highway Trust Fund and appropriating into it the proceeds of all Federal taxes on motor fuel, tires and tread rubber and a portion of certain other excise taxes such as those on automobiles, trucks and buses.

Another innovation, sought by organized labor, was a provision that the Davis-Bacon Act of 1935 should apply to all contracts for the Interstate System. This
Act, passed during the Depression, required that the Secretary of Labor determine the prevailing wage rates paid for similar work in the area where the proposed Federal project was to be built. These rates were then set forth in the contract and became the minimum rates for that job. The purpose of the Act when originally passed was to give local workers a chance to compete for jobs on Federal projects without lowering their wages to match those of cheap imported labor. However, its detractors said the Act was applied during the Roosevelt Administration to force prevailing wages in outlying rural areas up to the level of those won by unions in the big cities.

Heretofore, the Davis-Bacon Act had applied only to the Federal Government's own contracts. Those contracts entered into by the States for Federal-aid work were subject only to the regulations the BPR had made pursuant to the original Federal Aid Road Act of 1916. These left the predetermination of job labor rates up to the States, whose labor laws, according to the Engineering News-Record, were "as heterogeneous as their liquor laws." 76

Introduction of Federal wage-fixing into the Federal-aid program was bitterly resisted by AASHO, the Associated General Contractors and the American Roadbuilders' Association who claimed that the DavisBacon Act had the potential of boosting highway construction costs 15 to 40 percent. Inevitably, they said, contracts for other Federal-aid and State work, not covered by the Davis-Bacon Act, would be drawn into its orbit, and there would be a general inflation of wages in the highway construction industry. Spokesmen for labor asserted that since the proposed matching rate for the Interstate System was 90 percent Federal and 10 percent State funds, the real employer was the Federal Government, and, therefore, its laws should apply. In the end, the Davis-Bacon Act became the price for labor's support of the highway program, and it was incorporated in the final bill.

The third innovation proposed by the legislators was to treat the Interstate System as a single huge project, comparable to an irrigation or flood control scheme, and provide in one authorization for its inception and completion. Previously, Congress had viewed Federal aid as an open-ended program of assistance to the States that would continue forever at a pace determined from time to time as circumstances might dictate. In hard times highway construction was stepped up to "prime the pump," and at other times cut back to balance the budget. Now the committees proposed that a limited national system of special highways be built within a fixed time period of 13 years. In concept, this scheme was practically identical to that of the Pacific Railroads 100 years previously, and for its time, was on about the same scale.

This single huge project concept affected the apportionment of the Federal funds among the States. When Congress earmarked funds for the Interstate System in 1954, it changed the apportionment factor to give more of the money to the more populous States.* The framers of the new bill provided that

* According to this formula, half of the funds were to be apportioned in the ratio of each State's population to the total national population; the other half was to be divided according to the classic Federal-aid formula of 1916. 
this formula should be continued for fiscal years 1957, 1958 , and 1959, but that thereafter the apportionments should be made according to the relative "need" of each State to assure completing the entire Interstate System at the same time. Needs would be determined by a series of cost estimates to be submitted to Congress by the Secretary of Commerce and the States at dates set forth in legislation. The first of these estimates was due not later than January 12, 1958, and would be used for apportioning authorizations for fiscal years 1960, 1961, and 1962. The total amount authorized for the Interstate System was $\$ 25$ billion through fiscal year 1969 .

The compromise bill developed by these committees contained other departures from previous highway policy, as well as features from both the 1955 Gore bill and the Administration's original proposal. The compromise bill, the Federal-Aid Highway Act and the Highway Revenue Act of 1956 was passed overwhelmingly by both the Senate and the House and was signed into law by President Eisenhower on June 29, 1956. 


\section{REFERENCES}

${ }^{1} 1970$ Automobte Facts and Figures (Automobile Manufacturers Association, Detroit, 1970) p. 3.

${ }^{2}$ Bureau of Public Roads, Highway Statistics, 1951 (U.S. Dep't. of Commerce, Washington, D.C., 1953) p. 29.

${ }^{3} \mathrm{~S}$. M. Shapro, The Long Island State Parkway System, Convention Group Meetings, New York City, September 24-26, 1947 (AASHO, Washington, D.C., 1947) pp. 112-117.

40 Stat 1200 .

${ }^{8} \mathrm{~J}$. G. MCKAY, The Cook County Transportation Survey, Public Roads, Vol. 7, No. 1, Mar. 1926, pp. 1-6.

'A Study of Highway Trafic in the Cleveland Regional Area, Public Roads, Vol. 9, No. 7, Sept. 1928, pp. 129-138.

${ }^{7}$ Bureau of Public Roads annual Report, 1946, p. 34.

${ }^{8} \mathrm{~J}$. T. LYNCH, Traffic Planning Studies in American Cities, Public Roads, Vol. 24, No. 6, Oct., Nov., Dec. 1945, pp. 168, 169.

'Bureau of Public Roads Annual Report, 1945, p. 12.

${ }^{10}$ Federal Highway adinistration, Highway Statistics SUMMARY To 1965, (U.S. Dept. of Transportation, Washington, D.C., 1967) p. 85.

${ }^{11}$ Burgau of Public Roads, The Local Rural Road ProbLEM (Dep't. of Commerce, Washington, D.C., 1950) p. 31.

${ }^{12} \mathrm{BPR}$, supra, note 9, p. 9.

${ }^{13}$ New Local Highway Agency Proposed in Congress, EngtNeEring News-Record, Vol. 131, No. 21, Nov. 18, 1943, p. 727.

${ }^{13}$ BPR, supra, note 7, p. 13.

${ }^{25}$ Title 23, U.S. Code, "Highways," RePort of the CoMMitTtee on Public Works, H. Doc. 1938, 85th Cong., 2d Sess., pp. $15,16$.

${ }^{18}$ BPR, supra, note 7 , p. 9 .

${ }^{27} \mathrm{BPR}$, supra, note 7, p. 11.

${ }^{18}$ Bureau of Public Roads annual Report, 1947, pp. 5, 7.

${ }^{10} \mathrm{BPR}$, supra, note 9 , p. 8 .

${ }^{20}$ A History of the Interstate System, AASHO-THE FIRST FIFTY Years, 1914-1964 (American Association of State Highway Officials, Washington, D.C., 1965) p. 184.

${ }^{\mathrm{A}}$ A Policy on Design Standards for the National System of Interstate Highways, Policies on Geometric Highway Design (American Association of State Highway Officials, Washington, D.C., 1950) pp. 1, 2.

${ }^{22}$ BPR, supra, note 7, p. 4.

${ }^{23}$ Bureau of Public Roads, Highway Statistics, 1949 (U.S. Dep't. of Commerce, Washington, D.C., 1951) p. 112.

" $\mathrm{BPR}$, supra, note $7, \mathrm{p} .5$.

${ }^{25}$ Federal Aid to Local Roads Opposed at Senate Hearing, EngtNemering News-Record, Vol, 142, No. 19, May 12, 1949, p. 51 .

${ }^{23}$ Editorial, ENgINeERING News-Record, Vol. 142, No. 23, Jun. 9, 1949, p. 47.

${ }^{27} \mathrm{BPR}$, supra, note 11, pp. 5, 6, 24.

${ }^{23}$ Id., p. 30.

${ }^{20} \mathrm{BPR}$, supra, note 18 , p. 41.

${ }^{30} I d$.

${ }^{31}$ C. Shatn, State Highway Needs and Finances, CommitteE Proceedrngs, Convention Group Meetings, Papers and Discussions (American Association of State Highway Officials, Washington, D.C. 1948) pp. 84, 85 .

${ }^{32} \mathrm{H}$. WARD, The Financial Aspects of the Engineering Analysis, 'Highway Needs of Michigan', Committee Proceedrngs, Convention Group Meetings, Papers and Discussions, (American Association of State Highway Officials, Washington, D.C., 1948) p. 63.

${ }^{23}$ Study Toll Roads, Engineering News-Record, Vol. 142, No. 11, Mar. 17, 1949, p. 65.

${ }^{34}$ Money, Aggressiveness, Legislation Needed For Road Progress, ARBA Told, Engineming News-Record, Vol. 144, No. 11, Mar. 16, 1950, p. 25.

${ }^{25}$ Transportation-Roadbuilding Lags, ENGineEring NewsRECORD, Vol. 144, No. 12, Mar. 23, 1950, p. 108.

${ }^{*}$ States Seek Methods to Raise Funds for Highway Construction and Repair, Evgriseering News-Record, Vol. 146, No. 20 , May 17, 1951, p. 27.
${ }^{37}$ Massachusetts Roads Scheduled Swiftly, ENGINEERING News-Record, Vol. 144, No. 4, Jan. 26, 1950, p. 21.

${ }^{38}$ Bright Spot for Roads, Engineering News-Record, Vol. 144, No. 15, Apr. 13, 1950, p. 17.

${ }^{39}$ New York OK's Thruway Authority, Engineering NewsReCord, Vol. 144, No. 13, Mar. 30, 1950, p. 19.

${ }^{40} \mathrm{~V}$. Boughton, Toll Highway Construction to Reach Peak in 1954, Engineering News-Record, Vol. 152, No. 1, Jan. 7, 1954, p. 31.

42 1955 Automobile Facts and Frgures (Automobile Manufacturers Association, Detroit, 1955) p. 21.

${ }^{42}$ Bureau of Public Roads, Highway Statistics Summarx, 1955 (U.S. Dep't of Commerce, Washington, D.C., 1957) p. 72.

${ }^{43}$ Highway Needs of The National Defense, H. Doc. 249, 81st Cong., 1st Sess., pp. 10-23.

${ }^{44} I d .$, pp. 3, 4.

${ }^{15}$ Road-Aid Bill Contains New Item For Interstate System, Engineering News-Record, Vol. 144, No. 10, Mar, 9, 1950, p. 17.

${ }^{48}$ Road Officials Hit Federal-Aid Boost, Engineering NewsRECORD, Vol. 144, No. 10, Mar. 9, 1950, p. 21.

${ }^{47}$ AASHO, supra, note 20, p. 185.

${ }^{48}$ Pennsylvania Turnpike Continues at a Loss, EngINEERING News-ReCoRd, Vol. 134, No. 8, Feb. 22, 1945, p. 53.

49 Announce Extension Route of Pennsylvania Turnpike, Engineering News-Record, Vol. 142, No. 3, Jan. 20, 1949, p. 63.

${ }^{50}$ Progress and Feasibility of Toll Roads and Their RElation To The Federal-Aid Program, H. Doc. 139, 84th Cong., 1st Sess., pp. 6-8.

${ }^{51} I d$., pp. 11-14.

${ }^{52}$ Perspective-Controversy Over Toll Roads, ENGINEERING News-Record, Vol. 138, No. 17, Apr. 24, 1947, p. 10.

${ }^{53}$ Supra, note 46, p. 21.

${ }^{54}$ Toll Road Policy Needs Restudy, EngIneERING NeWSRECORD, Vol. 144, No. 13, Mar. 30, 1950, p. 26.

${ }^{55}$ Editorial, Engineering News-Record, Vol. 153, No. 1, Jul. 1, 1954, p. 96.

${ }^{56} \mathrm{H}$. Doc., supra, note 50, p. 14.

${ }^{57} I$ d., p. 23.

${ }^{58} I d$., p. 24.

${ }^{59} I d$., p. 26.

${ }^{60}$ MacDonald Retires as Commissioner of Public Roads, F. V. duPont Takes Over, ENGINeEring News-ReCond, Vol. 150, No. 14, Apr. 2, 1953, pp. 52-54.

${ }^{61}$ Changes in Federal Highway Policies to Await Administration's Studies, Engineering News-Record, Vol. 150, No. 17, Apr. 23, 1953, pp. 21, 22.

${ }^{62}$ Bureau of Public Roads Annual Report, 1951, p. 1.

${ }^{63} I d .$, p. 7.

${ }^{6}$ Bureau of Public Roads Annuat Report, 1954, p. 3.

${ }^{65}$ President Starts Ball Rolling for Bigger Highway Program, Engineering News-Record, Vol. 153, No. 4, Jul. 22, 1954, pp. 21,88 .

${ }^{68}$ Bureau of Public Roads, Hrghway Statistics, 1953 (U.S. Dep't of Commerce, Washington, D.C., 1954) pp. 61, 90, 94.

${ }^{67}$ NeEds of The Highway Systems, 1955-84, H. Doc. 120 , 84th Cong., 1st Sess., p. 19.

${ }^{68}$ Highway Problem is How to Raise \$50 Billion, ENGINEERING News-Record, Vol. 153, No. 16, Oct. 14, 1954, p. 21.

${ }^{69}$ AASHO, supra, note 20, p. 185.

${ }^{70}$ President Gets Governors' Highway Report, ENGINEERING NEws-RECoRd, Vol. 153, No. 24, Dec. 9, 1954, p. 23.

${ }^{71} \mathrm{H}$. Doc., supra, note 67, p. 21.

${ }^{72}$ AASHO, supra, note 20, p. 186.

${ }^{73}$ Battle Joined Over Rival Highway Plans, ENGINEERING News-Record, Vol. 154, No. 8, Feb. 24, 1955, p. 23.

${ }^{74}$ Highway Hopes Dim, Engineering News-Record, Vol. 154, No. 16, Apr. 21, 1955, p. 26.

${ }^{75}$ Editorial, Engtneerivg News-Recond, Vol. 154, No. 9, Mar. 3,1955 , p. 84 .

${ }^{76}$ The Davis-Bacon Highway Compromise, ENGINEERING News-RecoRd, Vol. 157, No. 1, Jul. 5, 1956, pp. 180-182. 


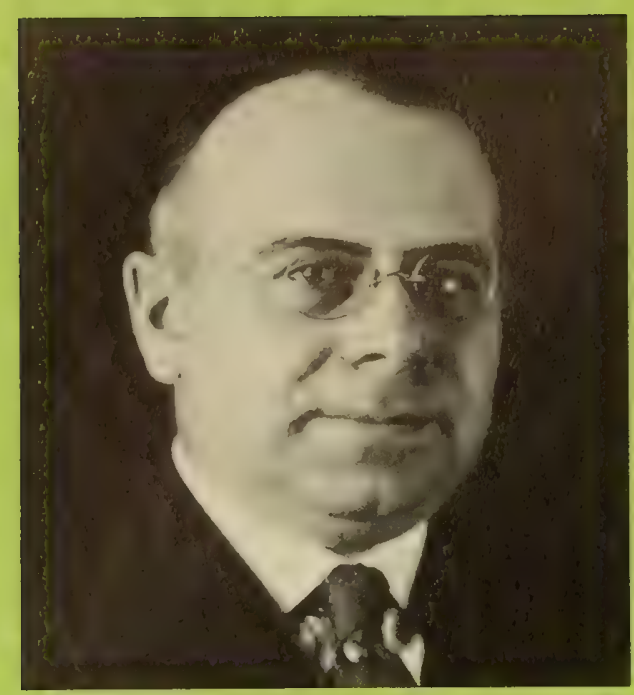

\begin{abstract}
"Rugged integrity" . . "Honesty" . . "Fairness" . . "Inspirational" ... "Sound, far-sighted leadership" ... "Dedicated public servant" and more were the expressions used by many who knew Thomas Harris MacDonald at the time of his retirement as Commissioner, Bureau of Public Roads. He had been head of the Bureau from 1919 to 1953, and during these years of his leadership, this Nation expanded its roadways from a scant $1 / 4$ of a million miles, of which very little was hard surfaced, to $3 \frac{1}{2}$ million miles of hard-surfaced, efficient, interstate roads; the Federal-State partnership in roadbuilding was developed and refined; the Alaska Highway was built and the Pan American Highway was well underway; and many of his staff worked with other countries in developing their roads and further training their engineers. Under MacDonald, the Bureau of Public Roads grew to become a center of highway research with worldwide influence.
\end{abstract}

Mr. MacDonald was born in Leadville, Colorado, on July 23, 1881, and moved with his family to Iowa in 1884. He studied at Iowa State College and received his bachelor's degree in civil engineering in 1904. While at Iowa State, he developed an interest in highway engineering and, under the supervision of Dean Anson Marston, an early good roads proponent, did his undergraduate thesis on the highway needs of farmers and the force required to pull a wagon over different types of roads.

In 1904, the year MacDonald graduated, the Iowa Legislature designated the State College as a Commission to perform studies on highways and methods for their improvement. He took a position as an Assistant Professor of Civil Engineering and was placed in charge of road investigations. By 1907, at the age of 26 , he was appointed State Highway Engineer, and in 1913, with the creation of a three-man State Highway Commission, he was appointed chief engineer. During his tenure with the Iowa State Highway Commission, Iowa became one of the first States in the Midwest to have a statewide system of main roads, with about one-third of the designated 6,400-mile network permanently graded, drained, and provided with bridges. MacDonald also developed plans for the hard surfacing of the roads. His success in improving the difficult Iowa roads attracted national attention among highway. officials and the fledgling automobile industry. He became a leader among the highway officials of the 'teens and took an active part with the American Association of State Highway Officials (AASHO) in their efforts to secure Federal-aid highway legislation. This strong tie with AASHO and the various State highway officials was to remain constant throughout his professional life.

Then in 1919, Thomas MacDonald was called to Washington to serve as Chief of the Bureau of Public Roads, a position he was to hold through seven different presidents. President Wilson made his selection based upon the unanimous recommendations of the American Association of State Highway Officials. Though MacDonald's title changed over the course of the years, this original designation of "Chief" became synonymous with the man. It ceased to be just a title, but rather became a personal designation, applied with affection and admiration by an ever-widening circle of people around the world that included everyone with even the slightest interest in roads.

When the Chief took office, the 1916 Federal-Aid Road Act had been passed, but a program had not had a chance to get underway. Meanwhile, the first World War had ended, and the roads lay devastated by the effect of traffic, particularly that of heavy trucks and the inability to provide sufficient maintenance during the war effort. In addition, cooperation between BPR, the States, and Congress was needed to prepare the 1921 Federal Highway Act, which was intended to strengthen the 1916 Act. In general, in 1919, man's maximum range of daily movement was still only 10 miles, and much work needed to be done. 
By March 1953 when the Chief retired, millions of miles of hardsurfaced, efficient, connected roads were built, and the building of the National System of Interstate and Defense Highways was about to begin. But the real importance of his work, as one of his close friends and associates, Pyke Johnson, former President of the Automotive Safety Foundation, expressed in 1957, was that it allowed "... the vast transportation revolution" to take "place in the lives of all of us.

It is enough to note, perhaps, that as of today all but 22 million of our people live in urban or metropolitan areas. Isolation no longer is an important factor in our lives."

In the 34 years that the Chief served, a list of his career milestones reads like the history of the movement for better roads in this country and around the world. A list of only a very few of these would include:

- Sponsored the organization of the Highway and Highway Transport Education Committee (later to become a part of the Highway Research Board), 1920.

- Led in defeating the "Townsend Plan" which called for a very limited system of national highways to be built and maintained by the Federal Government and instead argued for the continuation of the Federal-aid plan but restricted to a larger Federal-aid highway system to be selected by the States, themselves. This became the Federal Highway Act of 1921.

- Chairman, Joint Board of Interstate Highways, 1924.

- Sponsored the organization of the Pan American Highway Congress, 1924.

- Sponsored first President's Highway Safety Conference, 1945.

- Sponsored creation of the official U.S. Interregional Highway Commission, 1946.

- Served as a member of the Official Commission on the Alaska Highway. Later, he was charged with the responsibility of building this road.

- Throughout his term of office, he served as a member of the Executive Committee, American Association of State Highway Officials and took an active part in all of its deliberations on the part of the Federal Government.

For his work, he received most of the honors that can be bestowed by individuals, associations, and organizations interested in highway work within the United States. He was awarded an honorary degree in engineering from Iowa State College in 1929, and received the Marston Medal for Achievement in Engineering in 1939. He received the Medal of Merit for outstanding service during World War II. He received the George Bartlett Award in 1931, was designated an honorary member of the American Society of Civil Engineers in the late 1940's, and received the Award of Merit of the Highway Research Board in 1950. These are but a few of the honors conferred upon the Chief in his own country. In the international field, his advice was sought, and given, all over the world. He was awarded the Cross of the Legion of Honor from the French Government, the honor of Knight of the First Class, Order of St. Olav, given by the King of Norway, as well as numerous other important recognitions by foreign governments. All of these and the many more awards he received attest to his excellent work and the respect held for him by those interested in the betterment of the highways.

The Chief's 49 years of active service in the betterment of our highways, first for Iowa and then for the Nation, were motivated by a belief in the importance of sound transportation and the role of highways in the overall picture. Herbert S. Fairbank, a close friend and a great name in the roads effort in his own right, discussed MacDonald's views of transportation

as something much more than the 'service' it is generally held to be, more even than the essential link between supply and demand, or production and consumption, and actually as, in itself, one of the most potent of the creative forces that have shaped and will continue to shape this and all other countries in almost every aspect-in their economy, of course, but also in the spread and concentrations of their population and industry, the location, size, form and character of their cities, and the degree of development of their every natural resource. 
In discussing the effect of roads as a part of this creative force, MacDonald believed, according to Fairbank, that roads allowed the population to disperse throughout the country and away from the rivers and main rail lines. It served as a great unifying force between the "hayseed" and the "city slicker" with "freer and more frequent contacts of the two which the automobile and good roads facilitated." There was a greater urban orientation produced in this country as the small towns, "long the centers of their tiny rural areas promptly became the mere satellites of larger nearby cities...." The cities were also able to reach out more as people were able to move further from downtown and finally to the suburbs as the principal roads radiating out of the city were improved. Good roads were an important link in the creative force that is transportation that started from the waterways, to the railways, to roadways, and on to the airways.

A continuing theme throughout the Chief's years with the Bureau of Public Roads was the importance of the principle of Federal-State cooperation in the framework of our form of government. Pyke Johnson describes this belief as "the continued achievement of an engineering job of the magnitude of our highway program [that] must rest upon the essential premise that here we are dealing with the lives of people. That being so, the people finally must make their choice. The Federal Government cannot successfully dictate to the States. It must continue to act in cooperation with them and initiation of undertakings must remain with the States."

MacDonald was able to achieve the essential close cooperation with the States because he never forgot his first position as a State highway engineer and because of his active participation in AASHO. Thus, he was and remained fully acquainted with the views and sensitivities of State highway officials in respect to the Federal legislation and the Bureau. But he was also aware of the shortcomings of the various State highway departments. According to Fairbank, MacDonald

interpreted literally the requirement of the Federal-Aid Act that each State must have 'a highway department adequate in the opinion of the Secretary... to cooperate with the Federal Bureau.' He was unceasing, though without fanfare, in his efforts to bring about an elevation of the standards of engineering and administrative proficiency of all the State highway departments. This was done as occasion offered, through letters to our division and district offices or directly to the highway departments concerned. But he made effective use of personal contacts with the State highway officials at meetings of the AASHO and other gatherings. He made it a point to become personally acquainted as quickly as possible with the heads and principal officers of the departments of all the States when they took office after each political turnover, the frequency of which he deeply deplored.

In recognition of the sensitivity of State officials, if he could, he preferred working through the AASHO committees in developing standards and thereby avoiding the appearance of a Bureau crusade.

In developing standards, the Chief felt that research and factfinding must play a very important role, but the research that he stressed had to be of a nature calculated to yield results promptly applicable in the Bureau's administrative or engineering practice. Thus, he strongly supported the undertaking of soil studies, pioneered by the Bureau, and the impact and circular track studies done to test the wear on pavements by wheels equipped with various kinds of tires. He gave enthusiastic support of statewide traffic studies that were carried out in cooperation with various State highway departments and which were later expanded and augmented by economic and financial studies. When research expenditures occasionally came under question by Congress or the senior Executive Department, he was able to ward off this challenge by pointing to the important results derived from this aspect of the Bureau's work.

To many, MacDonald was the embodiment of official rectitude, and a stout defender of the independence of the State highway departments, as well as the Bureau, from political interference. For the sake of this independence, he was quite willing to have the Bureau remain a subordinate branch of an Executive Department. He believed that this system would sufficiently interpose a screen between executive action 
and the pressures of self-seeking interests. However, at the same time, as Fairbank wrote, "He was quick to oppose and resent any tendency of the superior administrative agency to interfere in the executive or administrative policies of the Bureau." For the most part, because of the respect he commanded from all the Department heads under whom he served, he was remarkably free of any such interference.

In the actual day-to-day administration of the Bureau, the Chief could not be considered one of the great leaders of management science. He directed the Bureau mainly through individual conferences with a relatively few men in whom he reposed confidence and through memos often produced as a result of these individual conferences. Fairbank mentioned MacDonald's administrative style:

Conferences with all the division heads jointly were rare almost to the point of total absence of occurvence. In his last years in Washington he may have been persuaded that the idea of regular 'staff' meetings might be worthy of trial, but after a few such 'trials,' his interest in the idea (never very keen) simply evaporated. ... Mr. MacDonald was averse to the employment of most of the devices now so highly esteemed by so-called 'management consultants.' He had no interest in 'Suggestion Boxes,' or the offering of pecuniary rewards for employee suggestions. If there was overlapping of the responsibilities of the several divisions of the organization or lack of clarification of the definition of individual or organic duties, he didn't worry much about it. As he seemed to have little or no concern about his own salary, he expected a similar avoidance of anything like a request for a raise on the part of every employee. Nothing would more certainly result in the consignment of any member of the organization to the MacDonald doghouse than to be caught agitating for an increase in pay. To paraphrase Lord Nelson's famous order the simple rule was: The Bureau expects that every man this day will do his duty. And by and large, by golly, they did. The Bureau enjoyed an esprit de corps that many a 'scientifically managed' organization of these days couldn't purchase with all the so-called incentives and rewards that the ingenuity of the doctors of management science can devise.

As head of the Bureau, Mr. MacDonald was called upon to participate as a speaker on many occasions, be it at a congressional hearing, a seminar, or an after dinner speech. Yet in 34 years of public speaking, the Chief never developed a reputation for an eloquent style, and it seems for good reason. Yet at all these occasions, though his style was not eloquent, it was, more importantly, effective. Again, as Mr. Fairbank commented,

His public speeches, especially those before the AASHO were so heavily factual and dry as to impose a serious burden upon the attentiveness of the audience. These speeches he almost always wrote himself; and he often turned from his written text to interpolate remarks which seemed unnecessary and which usually caused both the speaker and the audience to lose the thread of what he had been saying. But when all this has been said the fact remains that he somehow left his hearers in both public and private audiences with a sense of his mastery of whatever the matter was that was under discussion. He was outstandingly effective in his relations with Congressional Committees and individual Congressmen and Senators, often by patient repetition of his recommendations and views converting to their support those who initially opposed or even ridiculed them.

The Chief retired from the Bureau of Public Roads in July 1951, but at the request of President Truman stayed on as interim head until March 31, 1953, when Francis V. duPont assumed the position. In his retirement, however, the Chief continued to work for better roads and general transportation improvement from his new position as distinguished research engineer of the Transportation Institute of Texas A \& M College. He saw new challenges in filling the gaps that existed in the knowledge about transportation. Then, on April 7, 1957, the Chief quietly passed away.

His old friend, Pyke Johnson, gave a close, personal look at the man, Thomas H. MacDonald, in an article he wrote at the time of the Chief's death.

A quiet and modest man, a man of few intimates, a man who found solace in Bertrand Russell, Dr. Toynbee, Erle Stanley Gardner, and A. Conan Doyle, with few writers in between; a husband, a father, a chef, a photographer, a top engineer and administrator, a statesman who built an enduring monument to himself not so much in roads and bridges as in the lives of people.

Few knew him. But those few knew him as one of the men of history, who with their associates, have profoundly affected the course of modern life.

Thomas H. MacDonald-The Chief. 


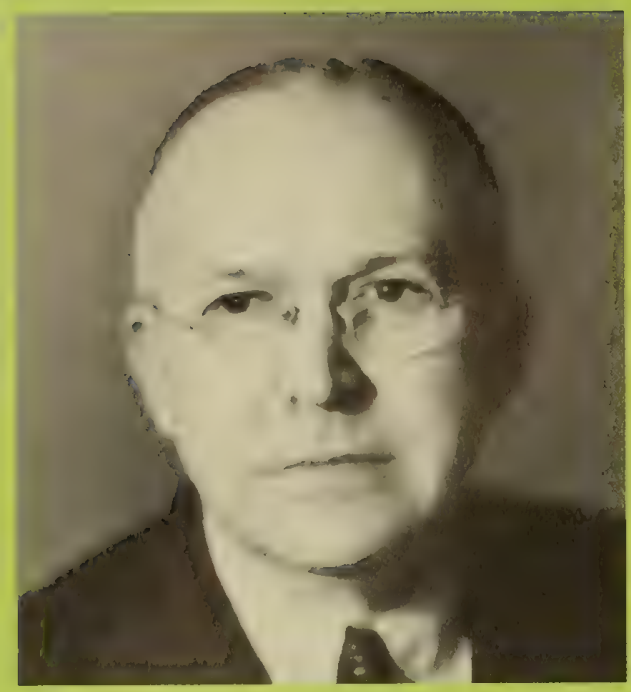

Shortly after Francis V. duPont succeeded Thomas H. MacDonald as Commissioner of Public Roads in 1953, he called on Deputy Commissioner for Research Fairbank to describe the Bureau's research program. Fairbank assembled his Division Chiefs to meet the new Commissioner and to permit each to explain his part in the research effort. Each Division Chief, having grown up in the Bureau during the 34-year tenure of Mr. MacDonald, must have approached this meeting with the new Commissioner with considerable trepidation, and so perhaps did Fairbank. But the tension initially felt in the atmosphere as the meeting convened was soon broken when duPont asked "Mr. Fairbank, does the Bureau engage in fundamental or practical research?" and Fairbank replied, "Oh, practical research-by all means, practical research," and duPont responded, "That's good to hear, for there's no point in doing research if the results can't be applied."

In reality the Bureau's research program went far beyond the usual narrow definition of practical research. Fairbank was constantly looking ahead and exploring how best to meet the needs of the future as he and his associates envisioned them. Yet he constantly demanded that the product of this exploratory work be suitable for practical application. If any program ever faced the need to anticipate and prepare for practical problems resulting from rapidly changing conditions, it was the highway program. And more than anyone else, it was Fairbank whose clear vision and firm hand produced the basic facts needed to guide the policies and determine the programs and methods to keep abreast or ahead of new and changing demands that others did not foresee. While the research was practical, the application of the results was fundamental to the success of the program.

Fairbank's career spanned virtually the entire development of the modern highway system, from the earliest days of the sand-clay road to the authorization of the Interstate System, and in all stages he took a personal hand. Graduating with a civil engineering degree from Cornell University in 1910, he joined the staff of the then-Office of Public Roads as a student engineer, one of the earliest of the Bureau's trainees, and was assigned to the Road Improvement Train.

Carrying road construction equipment on flat cars and exhibits and lectures in the coaches, the purpose of the train was to encourage the use of local materials and labor to improve access from farms to the freight stations. The road was conceived as a benefit to the farmer and the railroad alike. So in this period Fairbank became a "lecturer," and as he said, could deliver his lecture in his sleep as the train stopped at one small town after another through the south and west.

As the next step in his training, Fairbank built object lesson roads to demonstrate rather than just to describe the roadbuilding technique. One assignment was on Martha's Vineyard, where the technique involved mixing appropriate amounts of sand and clay, a process later achieving wide acceptance in other sections of the country. By virtue of his innate reserve and dignity, Fairbank was not one to whom a nickname would ordinarily be applied, but here he had one. The young engineer and the road he was constructing attracted much interest among a colony of deaf-mutes on the island, who identified him by pointing with a forefinger three times in quick succession, the second and third pointings each being some six inches below the one that preceded. His name in sign language was "3 Buttons," reflective of a fashionable blue blazer with large pearl buttons he wore when not on duty.

Following his early training and engineering assignments and service as an officer in the Chemical Warfare Service in 1918 and 1919, he was named Editor of Public Roads, the Bureau's Journal of Highway Research. This was a particularly fitting assignment, for in those days and for many years thereafter, the editor was expected to be not only a competent handler of the language but also an able appraiser of the technical soundness of the reports submitted for publication. Since at 
that time research was virtually all related to physical research, and largely to soils, and since Fairbank was far and away the finest writer in the Bureau's history, he was eminently qualified on both counts. Whether the breadth and depth of his ability were recognized by Chief MacDonald at the time or whether these qualities emerged as he gained experience, Fairbank was nonetheless steadily accepting broader responsibilities and became increasingly valuable to the Chief in the policy area. The expanded responsibilities were formally recognized in 1927 when he was made Chief of the new Division of Information, a position he held until 1943 when he was named Deputy Commissioner for Research, another new position and the one he held until his retirement. In each case, the title reflected the expanding responsibilities that had been given him by Chief MacDonald, and, in effect, simply provided a formal definition of his area of concern.

In these positions Fairbank's influence was broad indeed, though seldom was his contribution to knowledge and practice identifiable as his. $\mathrm{He}$ consistently urged others to carry on investigative work and saw to it that resources necessary to its conduct were provided. $\mathrm{He}$ insisted on thoroughness and accuracy in experiment, in analysis and in writing. An excellent writer himself, an ability no doubt developed through extensive reading, he demanded high quality on the part of others in all forms of writing. Careful indeed must be the drafter of a letter for his signature, for the words not only must mean exactly what was intended, but could not be construed to mean anything else. A well-worn eraser and an equally well-worn dictionary were always on his desk-two items, incidentally, that his successor preserved as graphic reminders to himself and others of what it takes to be a good writer.

It was in his perception of the needs of the future and his organization of research to prepare to meet them that he made his outstanding, though generally anonymous, contributions. While he built roads to link the farm and the railroad, he early foresaw the linkage of roads themselves into systems. While roads were being designed for static wheel loads, and much research was being carried on to this end, he was urging and organizing investigations to study the effect of impact and dynamic loading. While the geometrics of the road were being designed for the characteristics of individual vehicles, he was supporting research in the geometry of mixed traffic. In the area of economics, even before benefit-cost comparisons of specific projects were generally accepted, he had encouraged investigation of how economic analysis might be applied to the design of systems. And even before that idea became accepted, he was writing that social, environmental and land use factors might assume more importance than user costs and benefits. While intercity and rural highway problems still occupied nearly the full attention of highway officials, it was Fairbank who foresaw the problems of highways in urban areas, problems that have since developed but could have been avoided had his early warnings been heeded. In short, when an idea's time finally came, when it became generally accepted, the Bureau, thanks to Fairbank, generally was ready.

Certain areas were distinctly identifiable as Fairbank's, however. The Bureau library, one of the most complete highway transportation libraries in the world, bore his stamp. Likewise, an exhibit section to which he gave his personal touch produced many instructive and promotional exhibits for display throughout the country. A series of paintings depicting "Highways of History" were produced in the 1930's, and they were reassembled for a Bicentennial exhibit. A well-equipped photo laboratory, staffed with skilled photographers, produced slides and movies describing the results of research. Unfortunately, in the name of good administration and economy, these functions were lost to the Bureau as they were taken over by one or another "parent" organization as the Bureau moved from one to another in successive reorganizations, and their effectiveness as an arm of research was largely lost.

Of the many areas of his broad interest, the one most distinctly identifiable as Fairbank's was the highway planning surveys. The breadth and depth of this activity is described elsewhere, so suffice it to say that for perhaps a year before the first field work was started in 1935, Fairbank had personally overseen the preparation of forms and manuals 
of instruction for every phase of the program. So clearly did he perceive not only the need for data, but the detail in which they should be collected and recorded, that only minimal changes were required as the procedures were introduced into field operations. Of course, as new equipment came on the scene, as mapmaking and reproduction processes advanced and statistical science developed, the early manuals and procedures were correspondingly updated, but the basic format never was changed.

While the facts assembled in the surveys eventually formed the base of planning and programing of all State highway departments, no use of the data was more effective or significant than their use, under Fairbank's direction and guidance, in forming national highway policy. As the author, again anonymously, of Toll Roads and Free Roads and Interregional Highways and subsequently in directing the organization of planning data for the Clay Committee and the Committees of Congress, Fairbank saw the realization of his 1934 vision in the authorization of the National System of Interstate Highways in 1944 and the start of its construction under the 1956 Act. He himself must have regarded the conception, birth and maturity of highway planning as his prime contribution, for in his own words appearing in Who's Who in America he accorded that function more prominence than any other of the many national and international contributions he listed.

Two other areas distinctly bore Fairbank's mark. One was research in highway economics and finance, an area in which it was particularly difficult to interest State highway officials and administrators. He pushed hard to develop research programs in this area, setting up a new division in his Office of Research for the purpose, and organizing and serving as Chairman of the Department of Economics, Finance, and Administration of the Highway Research Board.

Another area to which Fairbank gave personal and identifiable attention was the broad problem of deterioration of road surfaces brought about by the great increase in heavy axle loads. He early believed that failure of road surfaces was caused as much by the high frequency of heavy loads still within the legal limits as by the illegal loads. $\mathrm{He}$ believed that frequently repeated load applications caused fatigue and failure in concrete and organized university research projects to test and eventually to substantiate this concept.

To discover the effect of fatigue was one thing, but to convince others of its importance was another. As an illustration, Fairbank resorted to the eraser on his desk. While he would describe the research and portray the results before a group, he would show them he could bend the eraser double without its cracking. But, as he continued to talk, he would continue to flex the eraser not to a 180-degree bend, but only perhaps 45 to 60 degrees, and before long a crack would appear and soon the eraser would break in half, indeed a graphic analogy even if perhaps not convincing to a highway engineer that the phenomenon would apply to a concrete slab. Incidentally, Fairbank would later use each half of the eraser for its intended purpose-revising the first drafts of his writings.

Acceptance of the theory was of little value, however, unless the phenomenon could be quantified, and here the Highway Transport Committee of the American Association of State Highway Officials entered the picture, organizing, through the Highway Research Board, the first of a series of full-scale road tests, using an existing recently constructed concrete road in Maryland. As chairman of the Committee and as head of research in Public Roads, Fairbank entered strenuously into the conduct of that test and the analysis of its results, the details of which are described elsewhere in this history. Peculiarities in the rate of deterioration of different sections of the test road led to the discovery of a serious lack of uniformity of the specified subbase and, in turn, led Fairbank to insist on trenching both sides of the road for its entire length in an effort to explain the variations in performance, an example of his thoroughness as a researcher. Finally, while the next in the series of tests was being prepared, he personally oversaw the development of motion picture and exhibit material to be shown 
before State legislatures and other groups to promote the concept of coordination between highway design and traffic regulation and the need for strict adherences to load limits.

The series of tests culminated in the AASHO Road Test in Mllinois where the statistically designed experiment produced the data that permitted the development of performance equations that showed, with great precision, the effect of frequency of application as well as the magnitude of axle loads. Thus, his concept was completely validated and, after his departure from the scene, quantified to permit its application in highway design. It was the product of practical research of fundamental importance, however it may have been defined.

Fairbank accepted the almost invariable success of his efforts with modesty, almost as though he had but a small part in them, so it was unfortunate that he took so deeply to heart what he regarded as a failure, one which in his mind overshadowed all his contributions. As he saw it, he failed to stop the proliferation of toll roads in the early 1950 's. Along with Chief MacDonald, he opposed the toll road not simply as a matter of Federal-aid law and policy, but on principle. $\mathrm{He}$ wrote and spoke against toll financing, emphasizing that the toll roads with their widely spaced access points offered only limited and specialized service and that the short trips, overwhelming in number, must still be accommodated on the existing or expanded systems. $\mathrm{He}$ saw duplication of facilities in individual corridors to accommodate both long and short trips, dual charges for toll road users and revenues going to interest payments rather than to mileage or maintenance of road.

Never wavering on principle, he could not accept the political reality that the quality of road - the freeway - that he had so long and strongly advocated could not then be produced by "conventional" financing. As he saw it, he went down fighting. But it is ironic that it probably was the rapid proliferation of the toll roads more than any other single factor that convinced the American public that it wanted, and could have, the very thing Fairbank had so long advocated. He did not live to see the near completion of the Interstate System, so he could not know that the battle he thought he'd lost was but a temporary setback, that the magnificent system he had envisioned as much as 40 years earlier would become a reality, and in the minds of many, his monument.

Along the way he received many awards. Almost automatically he received the Bartlett Award and the Crum Award, and when the MacDonald Award was established by AASHO, Fairbank, then in retirement, became the first recipient.

The recognition he would have most appreciated, however, came after his death when the research laboratory at Langley, Virginia, was named in his honor the Herbert S. Fairbank Research Station. It can be hoped that within its bounds there will always be the talent, resources, and time to carry on research with the thoroughness he always imposed on himself in his own work.

An educated man, Fairbank was a lover of literature, a scholar, an engineer, totally honest, dignified, modest, retiring, friendly-all these terms fit. Never married, he lived in Baltimore, in later years with his sister to whom he was devoted, and commuted daily the 40 miles each way to Washington.

He was a genuinely friendly man, but he had few close friends, and he found it difficult to get on casual or familiar terms with his associates. Much as did the British, he referred to people generally by their surnames, and one whom he eventually called by his first name felt honored indeed. Likewise, he was always referred to as Fairbank or Mr. Fairbank, and relatively few felt comfortable in referring to him as Fairbank in his presence. To a few friends outside the Bureau, mostly in Baltimore, he was known as Herb. Yet despite this reserve, he was a better friend to some in need than perhaps they realized.

Totally dedicated to the organization and to his profession, he had few outside interests. Each year he took his vacation (he, like the British, called it his holiday) with his sister, often spending time in Vermont's Green Mountains and occasionally taking a trip abroad. It 
was on their last holiday in Italy that he contracted an illness that was never diagnosed and from which he never fully recovered, and ultimately it led to his retirement.

His leadership was by example, and none who worked with him could fail to try to follow. He encouraged the younger members of his staff to take the initiative and gave them responsibility as rapidly as they could accept it. He saw to it that their contributions were recognized and, to the extent possible, rewarded. He never thought of his subordinates as working for him, but with him, and referred to them as his colleagues. But his closest colleagues would probably be more accurately defined as disciples.

What kind of man was he? He was a gentleman, in the truest sense of the word. He was a man for his time. 
This involved a return to Washington, consultations with the Department of State and the Office of the President, and the final result of Turner's efforts was the assignment of the Naval Headquarters compound in Manila, the Sea Frontier, to the agencies for housing and headquarters offices. Once staffed, Turner turned his attention to procuring steel and equipment, employing a Filipino staff for training, and preparing plans for the bridge replacement program. As rapidly as the Philippine Bureau of Public Works could be staffed and reorganized to accept responsibility for the work, it was shifted to them. Once again he demonstrated innovation and ingenuity by refitting a naval landing craft, an LCI, first as a survey ship to reach remote islands and later as a floating school for training Filipino engineers in highway techniques throughout the archipelago. In 1949, he was transferred, temporarily, to the American Embassy to coordinate all the rehabilitation programs of the nine U.S. Government agencies. His thoughtfulness, his courtesy, his consideration for others, and the high regard in which he was held by the Philippine Government made the assignment a highly successful one. His contribution to the Philippines was recognized by that Government's making him a member of the Legion of Honor (Officer Grade) in 1951.

Turner returned to the United States in 1950 to become assistant to the Commissioner, Thomas H. MacDonald. In this capacity he coordinated the work on the Inter-American Highway and the many foreign missions engaged in highway activities in Ethiopia, Turkey, the Philippines, Liberia and many others, as well as taking on many special assignments. Here he brought into play his tremendous capacity for work - a 14- to 18-hour day was not unusual for him-and his extraordinary memory for detail. He had the ability to retain in his mind everything that he read and recall it months later.

In 1954, President Eisenhower appointed the President's Advisory Committee on the National Highway Program, and Turner was appointed Executive Secretary for the Committee. At that time, the highway program was at a crossroads with many influential voices seeking to establish a National System of Toll Highways. One of the responsibilities of this Committee was to recommend whether to make the system, so obviously needed, toll or free. Turner worked unceasingly to place before the Committee all aspects of the problem, and it was largely due to his influence upon the Committee members that the decision was to recommend a National System of Interstate and Defense Highways to be financed in part by Federal excise taxes on automotive equipment, parts and fuel set up in a Trust Fund and in part by matching funds supplied by the States. Upon conclusion of the Committee report, Turner worked in liaison with the several congressional committees to convince them of the soundness of the recommendations and the need for the program. More than any other single individual, he may be said to be the "Father" of the Interstate Highway System. During his contacts with these committees, he again exhibited endless patience, sound reasoning and disregard of personal acclaim that had always distinguished his career.

About this time, a highly placed departmental official came into office who obviously had been directed to liquidate the highway organization or to severely diminish its activities and influence. As he worked closely with Turner, it became obvious also that his viewpoint was changing, and he became one of the strongest advocates of the organization and its responsibilities. Later he told one of his staff, "I decided that if an organization could produce a man like Frank Turner, there had to be some good in it, and I'd better take a real close look at it before I made any changes."

From 1957 to 1967, Turner served as Deputy Commissioner and Chief Engineer for Public Roads, and upon his shoulders fell the major responsibility for implementation of the legislation that had established the Interstate Highway System and provided for its funding. The difficulties and complexities of this challenge are discussed in other places in this history but the experience that he had gained in drafting the original legislation that had established the program stood in good 
stead in discussing the problems that arose as the program progressed with the interested congressional committees and leaders and in resolving individual problems as they presented themselves.

Turner never lost his interest in and enthusiasm for the role of the United States in technical assistance in highways for foreign countries. He was a member of the U.S. Delegation to the 5th Pan-American Highway Conference in Lima, Peru, in 1951, to the Extraordinary Session in Mexico City in 1952, and to the 6th Conference in Caracas, Venezuela, in 1954. He was the Chief of the U.S. Delegation at the 10th Pan-American Highway Congress in Montevideo, Uruguay, in 1967, the 11th Pan-American Highway Congress in Quito, Ecuador, in 1971, and Chief of the U.S. Highway Exchange Delegation to the Soviet Union in 1961. His contributions and his leadership in the field of transportation were attested by silver and gold meritorious awards by the Department of Commerce in 1954 and 1956; by the Thomas $\mathrm{H}$. MacDonald Award of the American Association of State Highway Officials in 1962; by the George S. Bartlett Award of the American Road Builders' Association in 1965; by the Gold Medal Award for Outstanding Achievement from the Department of Transportation in 1970; by the Special Secretarial Medal and Award in 1972; by the Roy W. Crum Award of the Highway Research Board in 1969; by the Neil J. Curry Award for Leadership in Highway Transportation in 1970 of the Highway Users Federation; and by the James Laurie prize for leadership in highway transportation of the American Society of Civil Engineers in 1971. He received recognition from the Engineering News-Record as the Construction Man of the Year in 1967 and 1970, and the World Highway Man of the Year by the International Road Federation, presented by Emperor Haile Selassie in Addis Ababa in 1969. Of unusual interest is the fact that he was selected as a Distinguished Alumnus by two universities-Texas A \& M University where he was graduated in 1929, and the University of Texas at Arlington where he took his first 2 years when it was a Junior College. In 1974, he was elected an Honorary Life Member of the American Society of Civil Engineers.

On February 27, 1967, his appointment as Director of Public Roads was confirmed by the United States Senate and he served in that capacity until February 24, 1969, when he was confirmed by unanimous consent by the Senate as Federal Highway Administrator. He served with distinction in this capacity until his retirement on June 30, 1972.

Frank Turner's entire career was marked by his professional ability, his sincerity, integrity, modesty, charm and love of his fellow man. During the most pressing technical problems, he could and did take time out to concern himself with whether the wife of a member of his staff had enough doors in her newly assigned house to make her happy. His calmness under pressure was remarkable; no one ever saw him excited, flustered or angry. Although basically a serious man, he possesses a puckish wit that springs forth when least expected. From a rather monotonous, hesitant public speaker in his younger days, he became an urbane, accomplished and witty after dinner speaker. His world has been centered around his family, his work, and his church. The American people owe an undying vote of gratitude to Francis Cutler Turner for his lifetime of dedicated public service, his strong unerring leadership, and his determination to obtain a dollar's worth of road for every dollar of tax money spent. 


\section{Joseph Barneft}

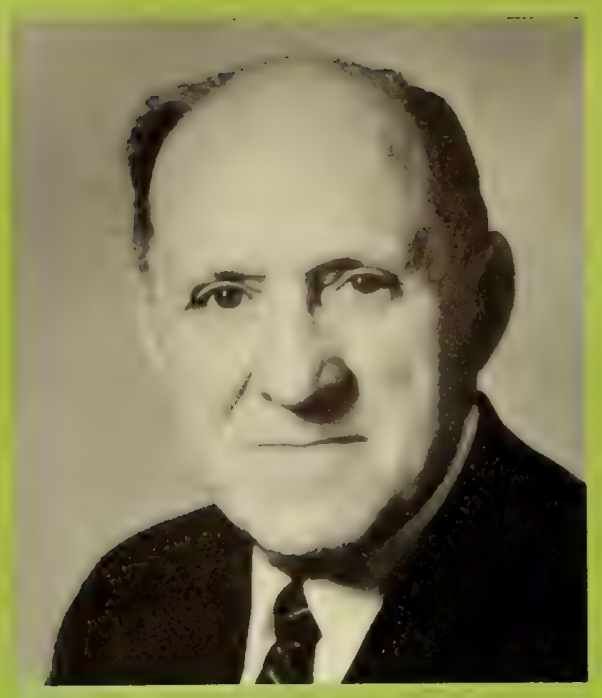

The belief that highways should be pleasing to the eye and compatible with the environment was a new idea when a foresighted engineer named Joseph Barnett joined the Bureau of Public Roads in 1933. By the time he retired 33 years later as Deputy Director for Engineering, Barnett had made good visual design a hallmark of American highways. His dedication to his work, his forceful pursuit of engineering principles and his extensive and lucid technical publications played a key role in the development of today's highway policies. He was a pioneer in the standardization of geometric design - design of the visible features of a road; he advocated, long before it was fashionable, a balanced transportation system to eliminate urban traffic congestion; and he developed the principles of controlled access in modern highway construction.

Barnett was born January 1, 1897, on the lower east side of Manhattan and attended public schools. At the age of 16 he received a scholarship to Cooper Union Institute and graduated with a B.S. in civil engineering at 19. After serving a year as an ensign in the U.S. Navy, he worked for consulting firms in the field of structural design and building construction and with the city of New York in the area of city transit design.

In 1925 he went to work for the Westchester County Park Commission, taking part in the pioneering development of the first parkways and expressways in the New York metropolitan area. He moved from squad leader in structural design to chief of the Engineering Design Division. In these assignments he obtained unique experience in highway flowing alinement, parkway amenities, free traffic operation and controlled highway access which were to become the key features of Interstate highway design in years to come.

Barnett joined the Bureau of Public Roads (BPR) as Senior Highway Engineer, Division of Design, where his engineering experience was put to use in a series of special assignments. During the first 2 years, he directed the design of the George Washington Memorial Parkway on the Virginia side of the Potomac River from Memorial Bridge to Great Falls.

Barnett is remembered by his colleagues as having a tremendous sense of purpose and a terrific power of concentration. By the mid1930 's he was applying himself to a new idea in highway constructionstandardization of design.

He first brought order into the design of guardrail types then available and set standards for adequacy and use of the types subsequently developed. He then organized a countrywide study of speed-radiussuperelevation on existing highway curves. Analysis of the data led to a new standard for superelevation design in relation to vehicle speed and the friction factors.

Knowing that better highway designs resulted from spiral or transition curves, Barnett worked out a set of practical spiral curve design tables that could be used by field survey engineers with calculations no more involved than those required for simple radii curves. His curve design manual, Transition Curves for Highways, was first published in 1938. It has been reprinted several times, translated into Spanish, recomputed to the metric system, and is still used extensively both here and abroad by highway design professionals.

Bamett was named Secretary of the Committee on Planning and Design Policies of the American Association of State Highway Officials (AASHO) from its inception in 1937 until his retirement at the end of 1966. This Committee profoundly influenced the design of safe and efficient highways. The scope of the series of AASHO standards, policies, and guides developed by the Committee attest to Barnett's leadership and unique qualifications for the innovative development work. Collectively these writings showed his attributes in several forms: analyses of the subject item to derive major design principles; details 
and values in a form for direct use by designers; clear, simply-worded texts; sound judgment in practical control and guide values; and advice for flexible, thoughtful applications to produce better designs. As each separate subject was completed, it was adopted and published by AASHO and accepted by BPR for use on Federal-aid highway projects. The first seven subject brochures established the concepts of highway design and were combined into one publication in 1950 entitled Poticies on Geometric Highway Design. Subsequent expansions in 1954 and 1965 entitled A Policy on Geometric Design of Rural Highways, popularly known as "The Blue Book," have been put into use on highway programs of all agencies, including those in foreign countries. A second major work produced by the Committee was A Policy on Arterial Highways in Urban Areas, published in 1957 and known as "The Red Book." The advent of the Interstate System opened other new areas, and the 1956 Interstate standards were prepared based on the Committee's earlier work. These policies on highway design matters have been widely accepted by engineers in governmental and private practice.

Between 1941 and 1943, Barnett headed a special BPR design team that rapidly developed contract plans for the main roads, interchanges and highway structures made necessary by the construction of the Pentagon building in Arlington, Virginia. The roads and bridges around the Pentagon were designed and constructed in less than 2 years. This interconnected system of freeways provided flexible connections to the building, the three Potomac River bridges and several Virginia arterials. They served through and local traffic needs well until the steadily increasing traffic volume of the 1960's overtaxed them.

On February 14, 1950, Barnett was presented the Commerce Department's Silver Medal Award for outstanding contributions to the development of urban roads, including the design of the Pentagon road network.

After completing this task, Barnett, always a hard worker, was given the responsibility of establishing an Urban Roads Branch to administer highway construction in urban areas under provisions of the 1944 Federal-Aid Highway Act. This was a new, open field inasmuch as most State highway departments only had rural programs. Barnett spearheaded the Federal assistance to establish State urban divisions and to advise them on the planning, location and design of urban expressways and other arterials. In this context, he addressed engineering groups, joined in conferences on specific route problems, prepared papers, and directed the development of design policies and guides.

In his key Federal position, Barnett was also busy at this time developing and applying the principles of controlled access which he had absorbed during his Westchester County experience. The early parkways demonstrated the multiple advantages of controlled access, not only in the safety and efficiency of traffic operations, but also in the opportunities for developing esthetic facilities well-fitted to their surroundings. Barnett stressed controlled access as a practical tool to relieve urban congestion at a time when rush hour traffic jams were becoming a common city experience.

In 1954 Barnett was assigned broader administrative responsibilities as Assistant Deputy Commissioner for the Division of Engineering. He was sent to Istanbul and Ankara, Turkey, to advise that country on the feasibility of a bridge across the Bosporus and an arterial highway system for Istanbul.

In 1961 he was made Deputy Director for Engineering, a principal decisionmaker on Federal-aid policy relating to engineering matters (which included the eligibility of proposed work for Federal-aid funds), the policy application on special problems, and conclusions on specific highway section design features. He received the Gold Medal for Distinguished Federal Service in 1963 from the Department of Commerce.

At the request of the International Bank for Reconstruction and Development (World Bank), he headed a mission to Japan to study and report on the feasibility of extending the Tokyo Expressway from Haneda to Yokohama. 
Barnett was a sensitive man with a dry wit who "liked to call a spade a spade."

Even after retirement in December 1966, Barnett remained active as a consultant on urban highways. He joined in the general debate on mass transit development in urban areas. His 1970 paper on "Express Bus Mass Transit" presented a review of the various forms of transit and outlined a practical concept for improving service through expanded facilities.

He belonged to the Tau Beta Pi honorary engineering society and was an active member of the American Society for Civil Engineers. $\mathrm{He}$ received the ASCE Arthur M. Wellington Prize in 1949. Upon his retirement he was awarded a citation by AASHO.

Until his death in Roslyn, New York, on September 30, 1973, he believed that better highways can and should be produced through the design process. His philosophy was that clear principles and guides should be formulated; however, their application should not be by rote, but by thoughtful adaptation to the specific conditions.

"A complete highway incorporates not only safety, utility and economy," he once wrote, "but beauty as well." 


\section{HIGHWAY ADMINISTRATORS}

\section{General Roy Stone 1893-1899}

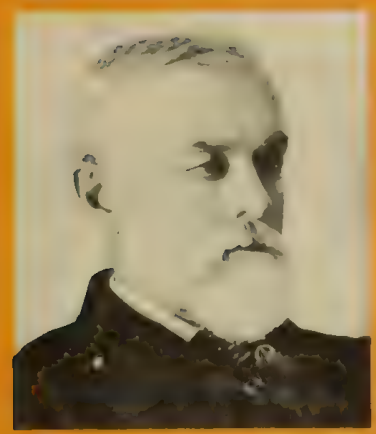

On October 3, 1893, Secretary of Agriculture J. Stexling Morton instituted the Office of Road Inquiry and appointed General Roy Stone, formerly secretary for the National League of Good Roads, as Special Agent and Engineer for Road Inquiry.

Earlier in 1893, the Office had been authorized by a statute enacted by the 52d Congress and approved March 3, 1893, by President Benjamin Harrison.

The statute read in part:

To enable the Secretary of Agriculture to make inquiries in regard to the systems of road management throughout the United States, to make investigations in regard to the best methods of road-making, and to enable him to assist the agricultural college and experiment stations in disseminating information on this subject.

General Stone was a professional civil and mechanical engineer; a military hero who distinguished himself in the Civil War and again in the Spanish-American War; an astute organizer; and the architect of many State-aid laws for U.S. roads.

He proposed the first parcel post, the first rural free delivery service and postal savings banks.

\section{Martin Dodge 1899-1905}

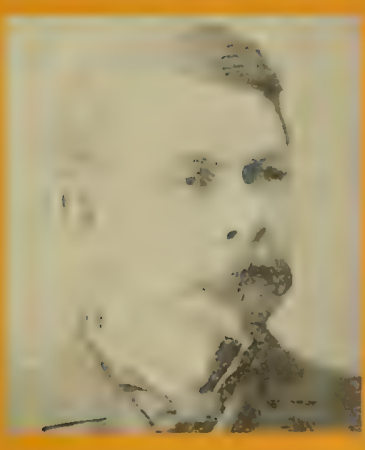

Martin Dodge was appointed Interim Director of the Office of Road Inquiry in August 1898 when his predecessor, General Roy Stone, vacated the office to serve in the Spanish-American War. General Stone resumed his duties as Director on January 31, 1899. He resigned on October 23, 1899, and Martin Dodge was reappointed and served until 1905.

Mr. Dodge was a zealous roadbuilder and an advocate of free roads in the United States. As a member of the Ohio State Roads Commission, he was the leading exponent of the first brick surfaced rural road in this country.

The road was laid on the Wooster Pike near Cleveland. Four miles of brick pavement were built in the fall of 1893 at a cost of $\$ 16,000$ per mile.

During Mr. Dodge's tenure, he established an information office to furnish advice about roadbuilding techniques to State and local officials and recommended a postgraduate school for civil engineer graduates to receive advance roadbuilding training, which became a reality in 1905 .

\section{Logan Waller Page 1905-1918}

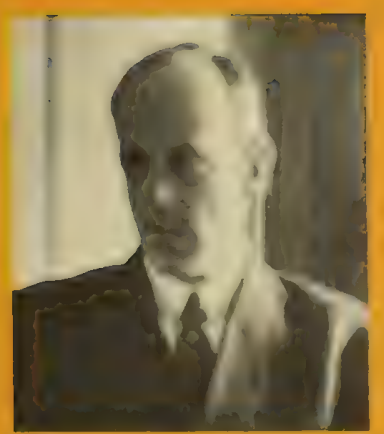

Logan Waller Page in 1905 became the first Director of the newly created Office of Public Roads. The Congress had passed an act that consolidated the Office of Public Road Inquiries and the Division of Tests of the Bureau of Chemistry.

Five years earlier, Mr. Page, a renowned geologist with the Massachusetts State Highway Commission, accepted the position of Chief of the Division of Tests in Washington.

As Laboratory Chief, his responsibilities included a study of roadbuilding on a national scale. As a geologist in Massachusetts he had conducted the first extensive investigation of roadbuilding materials in America.

Then as the Director of the Office of Public Roarls, he began a series of investigations which won international acclaim for the laboratories he directed. 
Mr. Page introduced a scientific movement in roadbuilding that won enthusiastic national public support. He initiated "a petrographic study" of roadbuilding materials; wrote the first comprehensive report on the elements of roadbuilding rocks; and improved French rocktesting machines whereby physical tests of roadbuilding rocks became a routine procedure.

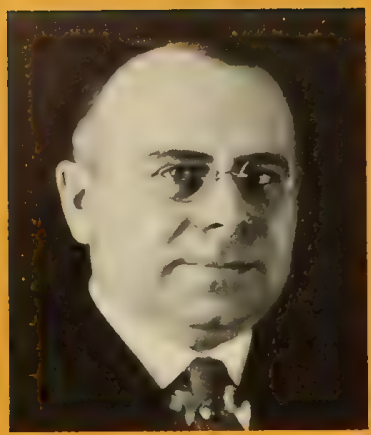

\section{Thomas H. MacDonald 1919-1953}

The good roads and highways Americans travel and enjoy today are a monument to Thomas H. MacDonald who for 34 years served as Chief of the Bureau of Public Roads and Commissioner of the Public Roads Administration.

Affectionately he was known as "Chief" by all who knew and worked with him.

When Chief MacDonald came to Washington in 1919, the office he was to head was still in its infancy. The Bureau had direct supervision over highway engineering activities and expenditures of Federal-aid funds.

The country had scarcely a quarter million miles of public roads when Chief MacDonald took office--and very little of that mileage was hard-surfaced. Few bridges were adequate to carry heavy truck traffic. Chief MacDonald in 34 years put together an integrated system of $31 / 2$ million miles of hard-surfaced highways which crisscrossed America.

Chief MacDonald personally directed the major steps in construction of the Alaska Highway. He also supervised fund expenditures to aid the countries of Central America in building the Inter-American Highway.

\section{Francis V. du Pont 1953-1955}

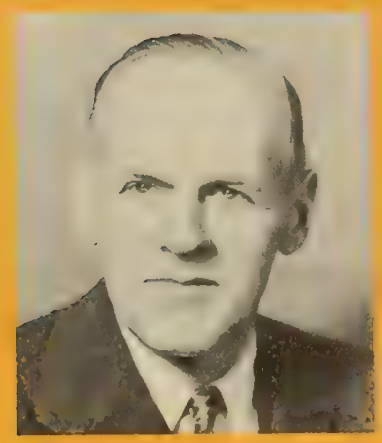

Francis V. duPont was connected with the development of highways in America since the early twenties.

He was appointed Commissioner of the Bureau of Public Roads in 1953 and while serving as Commissioner, advanced a highway program that led to legislation under which the Interstate Highway System was constructed.

Mr. duPont was the son of T. Coleman duPont who was the president of the giant chemical firm that bears that name in Wilmington, Delaware.

From 1922 through 1949, he was a member of the Delaware State Highway Commission. He also served as chairman of the Commission.

Mr. duPont played a major role in the development of the financing, engineering and the initial construction of the Delaware Memorial Bridge. When it was opened to traffic on July 1, 1951, it was the fifth longest suspension span in the world.

He had major accomplishments in the private, State and Federal sectors.

Mr. duPont resigned his Federal post on January 1, 1956. During his tenure as Commissioner, he was credited with stimulating interest in and getting the Interstate System underway. 


\section{Charles Dwight (Cap) Curtiss 1956}

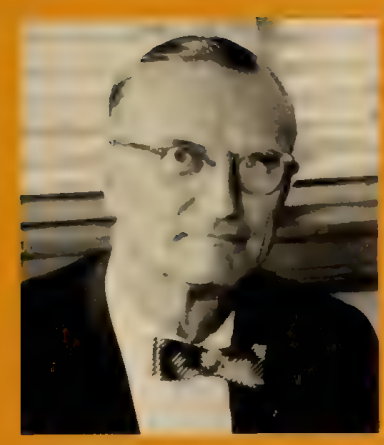

Charles Dwight (Cap) Curtiss grew up with the Bureau of Publie Roads and the American highway system.

The name "Cap" came from Mr. Curtiss' service as a captain with the U.S. Army Corps of Engineers during World War I in France.

Following the war, Cap Curtiss joined the Bureau of Public Roads and began a 38 -year public service career.

Along with others in the Bureau who were destined to give this $\mathrm{Na}$ tion a new concept in transportation at both the State and national levels, Cap Curtiss aided materially in the formulation of the policies and procedures of the amendments and expansions of the Federal-Aid Highway Act of 1916.

When he became Commissioner in 1956, plans for an enlarged and greatly expanded highway program reached out to every corner of the Nation.

With the signing of the Federal-Aid Highway Act of 1956 by President Eisenhower, it became Cap Curtiss' responsibility to put into immediate operation the authorization of the largest public works program ever undertaken on a State-Federal cooperative basis.

\section{John Anthony Volpe 1956-1957}

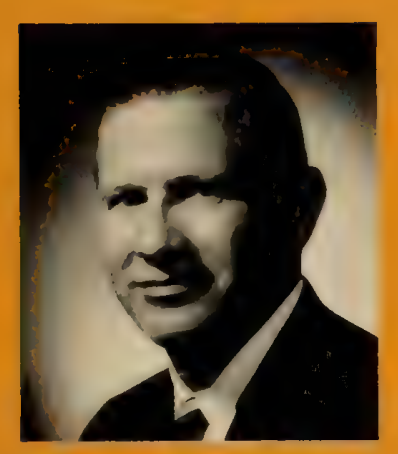

John Anthony Volpe, who was to become the Nation's second Secretary of Transportation, agreed to serve as interim Federal Highway Administrator from October 1956 to February 1957, pending confirmation by the U.S. Senate of Bertram D. Tallamy as Administrator.

Prior to his appointment as Administrator, Mr. Volpe had served nearly 4 years as the Massachusetts Commissioner of Public Works.

His personal history reflects the success story of the self-made man.

In 1933 he cashed a $\$ 300$ insurance policy and borrowed $\$ 500$ to begin a construction firm that was parlayed into a multimillion dollar organization.

The Volpe firm established a national reputation for construction excellence.

Mr. Volpe was elected Governor of Massachusetts in 1960, lost in 1962, and won a second term in 1964. He then was reelected in 1966 for the first 4-year term in the State's history.

$\mathrm{He}$ was serving his third term when President Nixon swore him in on January 20, 1969, as the second Secretary of Transportation.

In $1973 \mathrm{John}$ Volpe was appointed Ambassador to Italy, realizing his lifelong ambition.

\section{Bertram D. Tallamy 1957-1961}

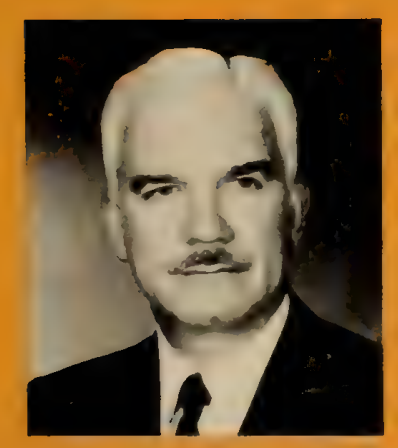

Bertram D. Tallamy was an advocate of esthetic design in the Interstate System.

In administering the Interstate System, Mr. Tallamy wanted it fashioned after the New York Thruway, which in 1957 was generally regarded as one of the most magnificent highways ever constructed.

He wanted motorists to see the country, to enjoy the scenery, and above all to avoid monotony. All these things, he said, could be accomplished with an added safety factor without adding to the cost.

Mr. Tallamy also was in favor of regulated outdoor advertising along the Interstate System.

The first Senate-confirmed Federal Highway Administrator was born and bred to the engineering and construction fields. Both his father and grandfather were general contractors. 
His early construction training was with a firm that specialized in the fields of waterworks, dams, sewage treatment plants, roads and bridges,

From the early thirties, he progressed through various posts to where he was appointed Superintendent of Public Works for New York State in October 1948.

In 1950 he became Chairman of the New York State Thruway Authority. Overall construction costs for New York State in 1954 reached $\$ 928.5$ million.

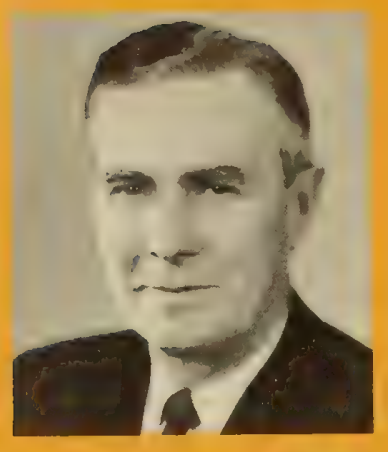

\section{Rex Marion Whitton 1961-1966}

When Rex Marion Whitton retired as Federal Highway Administrator on December 30, 1966, he left behind a career of public service that almost spanned the entire history of modern highway construction in the United States.

He had completed more than 46 years of continuous highway work, of which 40 were spent in his native State of Missouri.

Mr. Whitton rose through the ranks, from a member of a highway survey crew in 1920 to Chief Engineer for the State of Missouri in 1951.

Other posts held by Mr. Whitton included that of assistant resident engineer, resident engineer, chief of survey party, plans designer, assistant district engineer, district engineer, and engineer of maintenance.

During his tenure as Federal Highway Administrator, the Bureau of Public Roads was revised to increase operational efficiency and instill new confidence.

In 1960 he was named one of the top 10 public works men of the year by the American Public Works Association in cooperation with Kiwanis International.

He also was president of the American Association of State Highway Officials (AASHO) 1955-56.

\section{Lowell K. Bridwell 1967-1969}

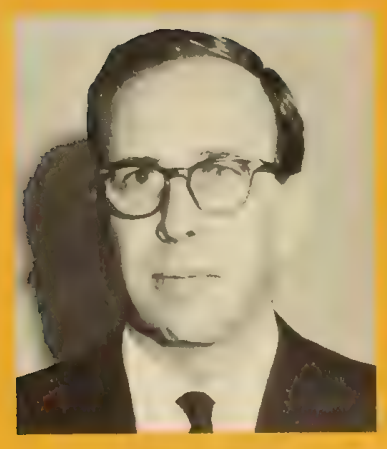

Lowell K. Bridwell, former journalist, acquired a reputation through the years as an authority on highway transportation.

Mr. Bridwell made his first impact on the highway program as a journalist.

A correspondent for the Associated Press and the Ohio State Journal from 1946 to 1950, he became associated with Scripps-Howard Newspapers in 1950. He joined the Washington Bureau of Scripps-Howard in 1958 as their top writer on highways.

From this vantage point he set up close liaison with both government and industry. He became well-known as an individual who was exceptionally well versed in the technical aspects of highway administration, finance and construction.

As a representative for Scripps-Howard, Mr. Bridwell participated in many local and national highway meetings. These included numerous conclaves of State highway officials as well as leading trade associations.

He assumed the helm of an expanded and reoriented Federal Highway Administration in 1967 in the new U.S. Department of Transportation.

Mr. Bridwell was responsible for administering a $\$ 4.4$ billion highway program. This figure dwarfed everything else in the Department of Transportation's $\$ 6.6$ billion budget. 


\section{Francis C. Turner 1969-1972}

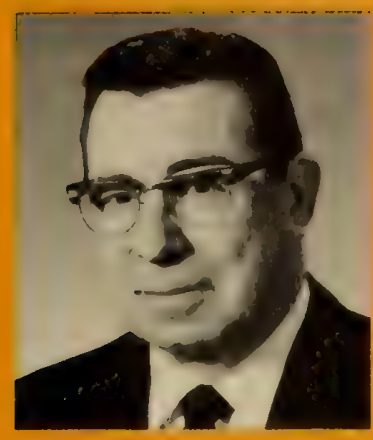

Francis C. Turner, during his lifelong career with the Bureau of Public Roads, won national and international acclaim for his contributions to both national and international highway programs.

He joined the Bureau of Public Roads in 1929 as a junior highway engineer and began a steady rise through the ranks.

Fourteen years later he had acquired such stature that he was detailed (1943-1946) to Alaska as adviser on maintenance of the Alaska Highway.

In the next 4 years $(1946-1950)$ he served with distinction as coordinator of the entire Philippine Rehabilitation Program.

Subsequent to this assignment, he held several top positions with the Bureau of Public Roads: Deputy Commissioner, Chief Engineer, Assistant Federal Highway Administrator, and Director of the Bureau of Public Roads. Furthermore, he was a member of the task force that set up the Department of Transportation.

He was named Federal Highway Administrator on February 24, 1969.

During his tenure as Federal Highway Administrator, new attention was given to the environment, accelerated concern was focused on highway safety, and increased emphasis was placed on the quality of life for people affected by highway construction.

\section{Norbert T. Tiemann 1973-}

Norbert T. Tiemann, former Governor of Nebraska, is the current Federal Highway Administrator.

Governor Tiemann's term as Nebraska's Chief Executive, from 1967 to 1971, included several major accomplishments on behalf of his State. Among these were:

- First broad reorganization of the Department of Roads.

- First revenue bonds for highway construction.

- Closing of the Omaha Gap on Interstate 80.

- Established the first 20-year plan for construction of a comprehensive expressway-freeway system.

- First mandatory driver examination.

- First motor-vehicle inspection program.

After completing his term as Governor, he served as Vice President for Corporate Finance of First Mid-America, Inc., an investment banking firm in Lincoln.

In his position as Administrator, he was involved in the obligation of $\$ 7.8$ billion in Federal-aid highway funds in fiscal year 1975-the largest amount in the history of the Federal-State highway program.

Other accomplishments have included the close planning liaison between FHWA and the Urban Mass Transportation Administration and the conclusion of an agreement with Iran for FHWA personnel to advise and assist that country in building a modern highway network. 


\section{Editor's note}

In Part I of the history of the Federal interest in the Nation's highways, the period from the colonial days to enactment of the Federal-Aid Highway Act of 1956 has been developed in a broad chronological format of events. As a result, there is a mixing of diverse elements, such as financial support, construction practices, research and many others that contributed to the continuity of highway development as we know it today. The advent of the 1956 FederalAid Highway Act was a turning point in highway financing, program magnitude, and administration complexity. For this reason, Part I stops at the 1956 Federal-Aid Highway Act.

During the years since the Federal Aid Road Act of 1916, specialized knowledge and skills were required to cope with the expanding program. The program became more complex with each piece of highway legislation in response to the need for broader measures in transportation, the desires of the public it serves, and the interaction of the highway program with other programs to serve the needs of a growing Nation. Technology became so sophisticated that, to keep pace with the demands, the program developed special areas of concern. In recognition of this situation, Part II has been assembled according to each major specialization and its contribution to the overall program.

The chapters of Part II cover separately one particular aspect of the program, including a chapter devoted to the development of the Interstate System. The authors for these chapters are recognized authorities, and their decisions as to what has proven significant in their individual fields of expertise has been left largely unchanged. 


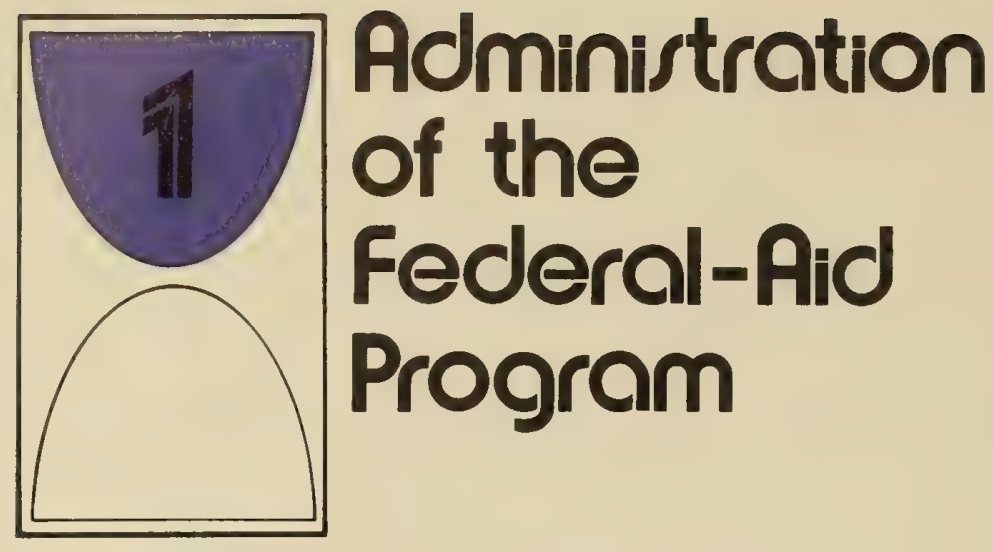

\section{Early Federal Government Inferest in Roads}

The first Federal financial aid specifically for the construction of roads in the States was incorporated into the Ohio Statehood Enabling Act in 1802 which provided that 5 percent of the proceeds of the sale of public (Federal) lands in Ohio was to be set aside for roads. Upon the insistence of the State of Ohio, the Act was amended in 1803 to provide that 3 percent of the funds would be available for roads within the State and 2 percent of the funds would be used under the direction of Congress for constructing roads to and through Ohio. ${ }^{1}$

This form of Federal assistance was later extended to all the States that had public lands when they were admitted to statehood, but the purposes for which the funds could be used were broadened to include canals, levees, river improvements, and schools.

In 1806 an act authorized the Federal Government to lay out and build the famous Cumberland Roadfrom the head of navigation on the Potomac River at Cumberland, Maryland, to a point on the Ohio River-provided that permission should first be secured from the Legislatures of Maryland, Virginia, and Pennsylvania to build the road within their boundaries. Funding was to be from the Ohio 2 percent fund.

The debate in Congress before the Cumberland Road Act was approved, centered on the constitutional issue of whether or not the Federal Government had the authority to build roads at all, except possibly in the territories. The Act was finally passed without resolving the constitutional issue.
Because the Cumberland Road deteriorated badly as a result of heavy traffic and lack of funds for maintenance, Congress, in 1822, passed a bill authorizing the Federal Government to collect tolls to be used for maintenance. This bill was vetoed by President Monroe on the constitutional grounds that it was an unwarranted extension of the power vested in Congress to make appropriations. Collection of tolls, the President said, implied a power of jurisdiction or sovereignty which was not granted to the Federal Government by the Constitution and could not be unilaterally conveyed by any State without a constitional amendment. He felt ". . . that it was one thing to make appropriations for public improvements, but an entirely different thing to assume jurisdiction and sovereignty over the land whereon those improvement were made."' President Monroe's position has continued to be the Federal position on highway matters to the present day.

During the next 9 years, the Cumberland Road continued to deteriorate despite a few meager Federal appropriations for maintenance, and it was finally recognized that the only solution was State operation as a toll road. ${ }^{3}$ In 1831 and 1832 the Legislatures of Ohio, Pennsylvania, Maryland and Virginia agreed to accept and maintain their sections of the Cumberland Road. ${ }^{4}$

The Federal Government attempted to extend the Cumberland (National) Road westward to the Mississippi River. In 1820 Congress appropriated $\$ 10,000$ to locate the road, and subsequent periodic appropriations were made for construction which ultimately totaled about $\$ 5$ million. The Ohio Legisla- 
and the creation of highway departments and commissions. It also began to put pressure on Congress to provide some form of Federal assistance for highways.

The first State to actually create a State Highway Commission was Massachusetts in 1892. The Commission was given the authority to establish a State road system, and beginning in 1894, the Legislature appropriated the first funds for actual construction. The need for State aid in financing road construction had been recognized as early as 1891 when New Jersey enacted the first State-aid road program in the Nation. However, it was designed simply to help the counties finance their programs, and its administration was placed under the State's Department of Agriculture. It wasn't until 1894 that New Jersey placed the program under a Commission of Highways.

\section{The Office of Road Inquiry is Created}

In 1892, the Senate passed a bill entitled the National Highway Commission Law, but Congress adjourned before it was enacted into law. Then, in the Agriculture Appropriation Act for 1894, enacted March 3, 1893, an item for $\$ 10,000$ was included to enable the Secretary "to make inquiries in reoard to the systems of road management throughout the United States... to make investigations in regard to the best method of roadmaking... and to enable him to assist the agricultural college and experiment stations in disseminating information on this subject...." To carry out the work directed by Congress, the Secretary created the Office of Road Inquiry, the small beginning from which the world's largest highway program was to develop.

When the Federal interest in roads was reinstituted in 1893 , the appropriation was made to the Department of Agriculture because the recognized problem was in the rural areas - there were not enough adequate roads for the farmers to get their produce to the railroad terminals and even nearby towns. The cities and larger towns were considered to be adequately satisfying their own internal road needs.

The creation of the Office did not represent the reinitiation of Federal financial assistance for the construction of roads in the States, since Congress provided only $\$ 10,000$ for each of the first 3 years and then dropped the appropriation to $\$ 8,000$ for each of the next 4 years. Rather, it was distinctly an educational and promotional effort, but it did represent a renewal of Federal recognition of the importance of highways in the Nation's economic and social future.

For several years the work of the Office of Road Inquiry consisted almost wholly of collecting and disseminating road information through publications, lectures, and consultations. In 1896, a new program was administratively added. Short stretches of road were constructed as object lesson roads through contributed labor and materials and borrowed equipment. The only Federal cost was usually the salary and expenses of a road expert from the Office of Road Inquiry who designed and supervised the work.

Despite efforts to get increased appropriations to expand the object lesson roads, additional funds were not provided-probably because of some congressional concern that construction of roads by the Office of Road Inquiry might be the opening wedge for rein- stitution of national roads under Federal control. It was not until 1901 that the appropriation level was increased. From then on, additional increases followed almost every year, until 1912 when the appropriation was over $\$ 160,000$.

During the years between 1897 and 1912, the Office broadened its activities to include experimental use of new materials in the construction of short sections of experimental roads; free tests of road materials sent in by private citizens from all over the country; provision of onsite assistance to State and county highway authorities, ranging from solving specific problems in construction or maintenance to encouraging enactment of road laws and helping in the organization of highway commissions or departments; institution of a training program for student highway engineers; provision of specialized assistance in problems concerning bridges, culverts and drainage in general; and of considerable significance, in 1909, launching into the area of economic research and statistical investigations, ${ }^{9}$ the forerunner to the sophisticated and extensive programs of today.

Some accomplishments had been achieved by 1912 through the joint efforts of the States, counties and townships combined with the leadership of the Office of Public Roads and the many good roads associations and similar special interest groups. In 1912 the expenditures by the States for road work totaled approximately $\$ 43$ million, and it was estimated another $\$ 100$ million was spent by counties and townships. ${ }^{10}$

A new need was gaining recognition-interconnecting roads at the local, State and national level. Few States had either the authority or the necessary funds to plan an interconnected system within their own boundaries, and each operated independently of its neighboring States. A road location in one State which was advantageous to that State for topographic, economic, or geographic reasons might not fit the situation just across the State line, so there was no assurance that a road would not simply end at the State line or some local terminus.

The landscaped median on I-19 provides a pleasant exit from Tucson, Ariz., and an effective headlight screen on the curve.

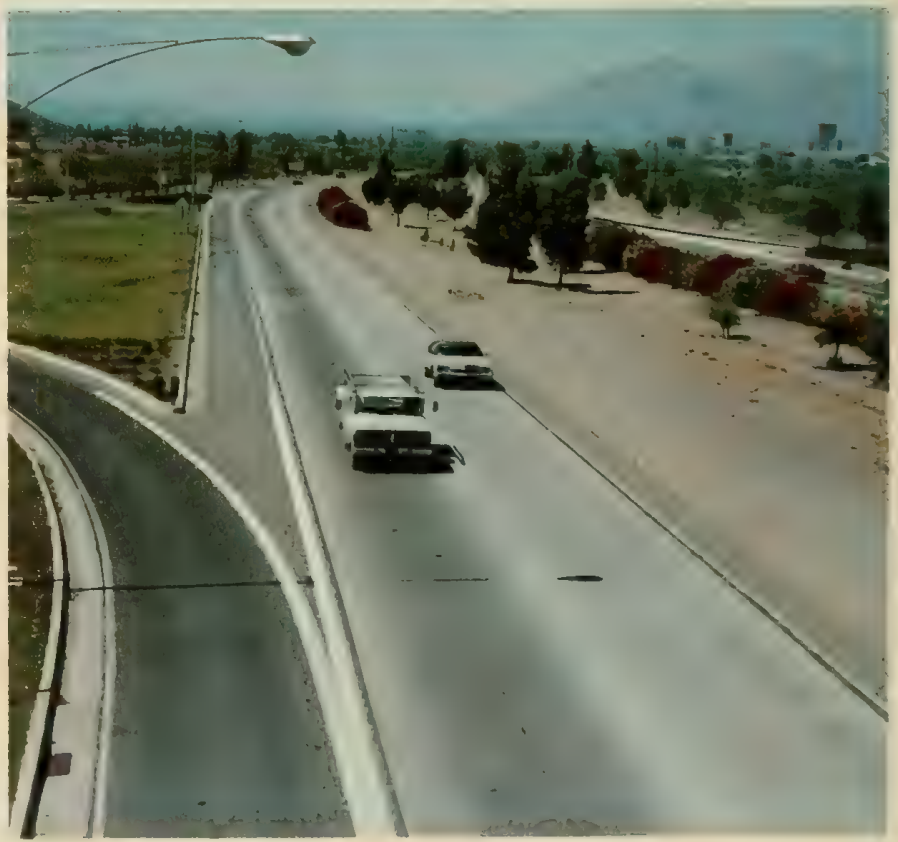




\section{Federal Aid for the Construction of Rural Post Roads}

The enormity of the road problems and their national character gradually developed a recognition that Federal aid was the only solution. Groups, such as the National Good Roads Association, the American Road Builders, and the American Highway Association, were leaders in efforts to secure necessary legislation. As a result, during the first 6 months of the session of Congress which began in December 1911, over 60 bills were introduced providing for some form of direct aid by the national government. ${ }^{11}$ This concern led to the inclusion in the Post Office Appropriation Act for fiscal year 1913 of an appropriation of $\$ 500,000$ to be expended by the Secretary of Agriculture, in cooperation with the Postmaster General, to aid in the improvement of post roads (roads which would be used by the Post Office in the delivery of mail) in rural areas. It provided "That the State or the local subdivision thereof in which such improvement is made under this provision shall furnish double the amount of money for the improvement of the be made under the supervision of the Secreary of road or roads so selected. Such improvement shall Agriculture." The Act also provided for a Joint Congressional Committee ". . . to make inquiry into the subject of Federal aid in the construction of post roads and report at the earliest practicable date. . . ."

Among its other provisions, the 1913 Act also specifically directed the Joint Committee to consider the problem of maintenance of the roads constructed, no doubt remembering the disastrous experiences of the past Federal efforts, and particularly the National Road.

The significant features of the Act were:

- It was a direct appropriation with authorization to proceed. There was no authorization in advance of an appropriation.

- The Act authorized the Secretary of Agriculture and the Postmaster General to determine where the funds should be used. It did not specify how the funds were to be spread among the States.
- The matching principle was established by prescribing that project costs be financed on a twothirds State, one-third Federal basis.

- The funds were available until expended.

No specific portion of the funds was made available for the costs of administering the program by the Office of Public Roads.

In the administration of the program launched by the 1913 appropriation the principle of "apportion" ment" was born. The $\$ 500,000$ was allocated by making available $\$ 10,000$ to each State (to be matched by at least $\$ 20,000$ State and local funds), and $\$ 20,000$ was reserved by the Office of Public Roads to supervise and administer the program. ${ }^{12}$ However, only 13 States and 28 counties participated, and approximately 455 miles of road were built. ${ }^{13} 14$

While the Federal financial interest in other than demonstration and experimental roads was rekindled by this measure, the appropriation was made to the Post Office Department even though the work was to be administered by the Department of Agriculture. Congress was still concerned with the constitutional issue of Federal money going into construction of roads wholly within individual States. The national character of mail delivery provided a satisfactory rationalization, hence, the appropriation was made to the Post Office Department.

The Joint Committee made its final report on Federal aid in the construction of post roads on January 21, 1915. The report offered no particular plan for Federal aid in the cost of constructing roads but did strongly recommend such aid. Furthermore, it pointed out that a Federal-aid highway program would accomplish several objectives of the Constitution, namely, to establish post roads, regulate commerce, provide for the common defense, and promote the general welfare. ${ }^{15}$

During the congressional hearings which followed the submission of the report, there was much debate but not too much opposition to the principle of appro-

Federal involvement in roadbuilding was justified in 1912 because of the national character of rural free delivery of the mail.

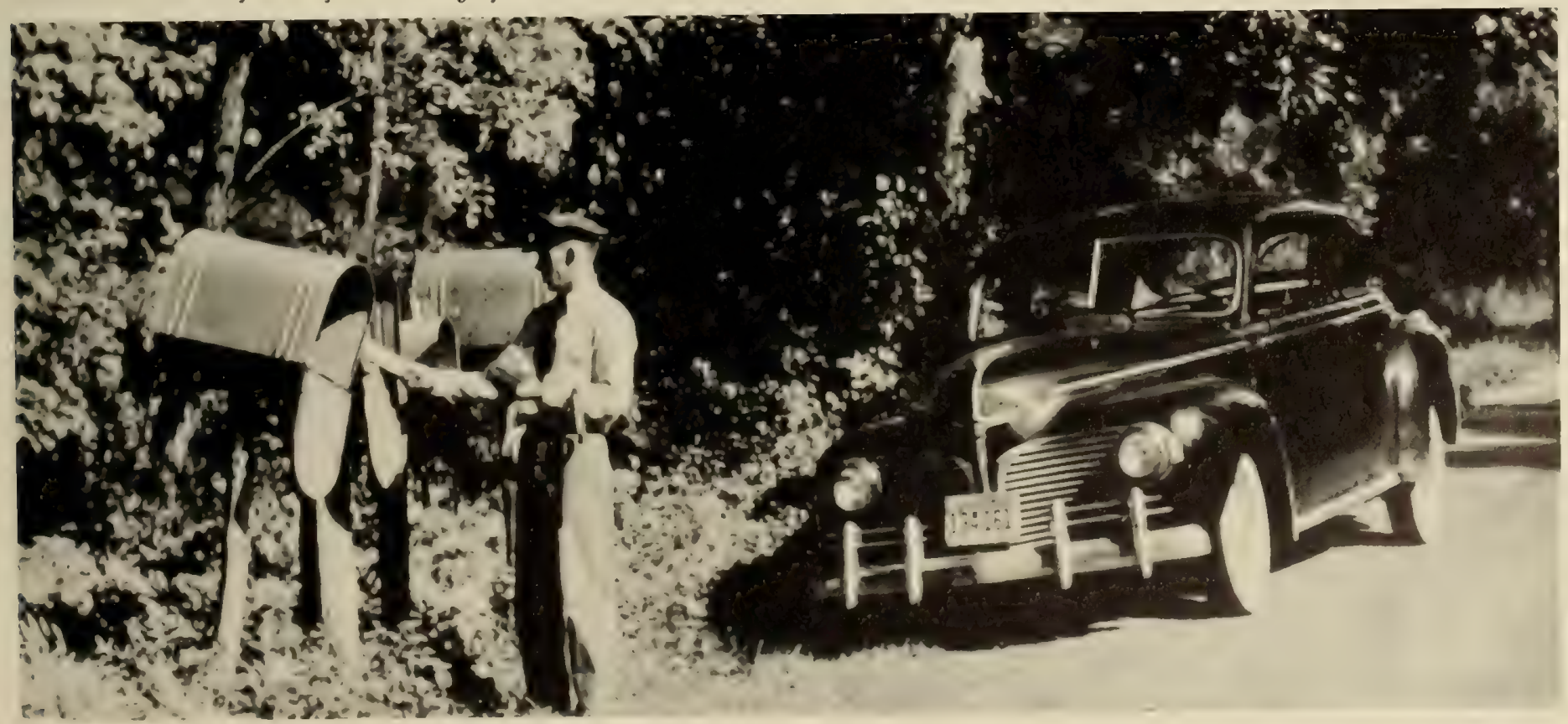


priating Federal funds for the development of highways. The main issue was how such funds should be administered, and there were three viewpoints: (1) Those who favored total Federal funding and control - a system of national highways built, owned and operated by the Federal Government (which again brought up the constitutional issue); (2) those who favored that the Federal money be turned over to the States or directly to some 3,000 counties in the country to spend as they saw fit (at the time there were still 17 States which had no State agencies with highway responsibilities; and (3) those who favored a cooperative Federal-State relationship, with the States retaining jurisdiction over the highways and having responsibility for carrying out the work under general Federal approval.

The concept of a cooperative Federal-State program was finally adopted in the enactment of the Federal Aid Road Act of 1916.

\section{The Evolution of the Federal-Aid Program}

The 4-page Federal Aid Road Act of 1916 was a simple document entitled "An Act To provide that the United States shall aid the States in the construction of rural post roads, and for other purposes." From this basic concept of building rural post roads, as the Nation has grown and prospered, so too the concept of roadbuilding has grown in terms of responsibilities to the economy, social and cultural needs, protection of the environment and national resources, and even to international relations.

The State highway officials had already joined together in 1914 to form the American Association of State Highway Officials (AASHO) to provide mutual cooperation and assistance to the Federal Government on legislative, economic and technical subjects relating to highways. First on the organization's agenda was to direct the executive committee to draft a bill authorizing Federal participation in the construction of highways. Logan Waller Page, the Director of the Office of Public Roads and Rural Engineering, worked directly with AASHO on the draft, drawing considerably, no doubt, on the experience gained during the construction of the rural post roads a few years before. The cooperative spirit was already evident when the Federal Aid Road Act was signed into law on July 11, 1916.

\section{The Federal Aid Road Act of 1916}

The basic philosophies of the Federal-State relationship in the administration of the Federal-aid program were established by the 1916 Act, and they have remained intact to the present time. These included:

- Participation of any State in the program is permissive, not mandatory.

- If a State elects to participate, it must satisfy the requirements and comply with the provisions of the legislation and its implementing rules and regulations.

- The authority and responsibility for initiation of proposed projects, their character, and method of construction is reserved to the States; Federal participation is dependent upon project approval by the Federal authority.

- The State highway department, or its equivalent, with proper legal authority to carry out its functions shall represent the State in its administration of the program in cooperation with the Federal Government (as distinguished from the individual local governmental subdivisions).

- While not specifically stated in the legislation, the absence of any provisions to the contrary made it abundantly clear that the States retain full and absolute ownership of the roads constructed or improved with participation of Federal-aid funds. The States also retain responsibility for their use and operation, with the proviso that they must be free from tolls of all kinds.

This philosophy was to be sustained in the 1973 Federal-Aid Highway Act which restated the intent of Congress as follows:

The authorization of the appropriation of Federal funds or their availability for expenditure under this chapter shall in no way infringe on the sovereign rights of the States to determine which projects shall be federally financed. The provisions of this chapter provide for a federally assisted State program.

The 1916 Act appropriated the following sum for Federal participation in the construction of rural post roads :

Fiscal Year
1917
1918
1919
1920
1921

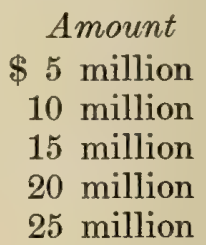

In addition, the Act appropriated $\$ 10$ million for construction of roads and trails within or partly within national forests for the fiscal years 1917 through 1926 at the rate of $\$ 1$ million per year. This action established the basic policy for providing for the development of main roads serving federally owned lands, reservations or areas. Regrettably, the Act permitted a wide dispersion of Federal funds, with the result that there was no assurance that a connected system of major roads would ever be achieved.

The Act also established principles upon which following legislation would build. These were:

- Multiyear authorizations

- Leadtime apportionment of funds

- Apportionment by a fixed formula

- Extended availability of funds for expenditure (1 year after the year for which funds were appropriated)

- Definition of type of roads for which funds could be used

- A limitation on funds that could be used by the States for engineering and contingencies

- Permanent responsibility was placed with the States for adequate maintenance of completed projects (the penalty being that the State had 4 months to repair the road or lose all further road project approvals in the State until the road was repaired)

Minnesota State highway 61 along the rocky shorcline of Lake Superior. The view from the highway allows the traveler to experience the beauty of the lake and the Superior National Forest. 


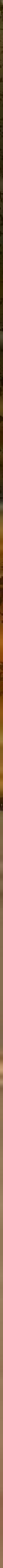


- The costs of Federal administration of the program were provided for by reservation of 3 percent of the appropriated funds for this purpose

The legislators used foresight, too, in establishing in the Act the basic roles of the States and the Federal Government in project procedures. The Act first defined the term "construction" and then outlined these procedures:

- When proposed projects were approved by the Federal agency, the State highway department was responsible for the preparation of plans, specifications and estimates (PS\&E) for review and approval by the Federal agency.

- Upon Federal approval of the plans, specifications and estimates, the applicable Federal funds were "obligated" and reserved for future payment to the State.

- The construction work and labor in each State was to be done in accordance with its laws and under the direct supervision of the State highway department, subject to the inspection and approval of the Federal agency and in accordance with the rules and regulations established under the authority of the legislation.

- Reimbursements to the States for the Federal share of State expenditures for projects could be made as work progressed subject to its approval by the Federal agency.

- Upon completion of any project in compliance with the plans and specifications, final reimbursement of the Federal share of the project costs was to be made upon approval of the Federal agency.

Other provisions of the 1916 Act included:

- Funds were appropriated with authorization to proceed.

- The matching ratio of State funds to Federal funds was 50 percent.

Most of the basic philosophies, principles, policies, procedures, and controls established in the 1916 Act still exist today.

Before work could be started under the 1916 Act, many problems had to be resolved to establish the radically new Federal-State partnership. Eleven States did not have highway departments within the meaning of the law and required legislation to create them. In many others, some legislation was necessary. In some States, the highway departments could not exercise the necessary direct supervision. In others, State and local funds were not available to match the Federal funds, nor could adequate maintenance assurance be given. All the States had to assent to the provisions of the 1916 Act through their legislatures or temporarily through their Governors if they wished to participate. In spite of all these problems, by June 30, 1917, all States but one* had a highway department and had agreed to the requirements and terms of the Act. ${ }^{16}$

Recognizing that some States would not have agencies empowered to carry out the provisions of the Act, Congress provided that the availability of the Federal

* Indiana's highway commission later was challenged on its constitutionality which postponed its participation until 1919. funds to those particular States could be extended for an additional 2 years. This gave those States not having a State highway department both the incentive and the time to take the necessary legislative or administrative action to establish one. A "forfeiture" feature provided that any funds not expended by the end of their availability would be reapportioned among all the States. Obviously, it was advantageous for the States to create State highway departments if they did not already have them.

The rules and regulations for carrying out the Federal Aid Road Act were issued by the Secretary of Agriculture on September 1, 1916. "In them he designated the Office of Public Roads and Rural Engineering as his representative in the administration of all [sections] of the act except Section 8, which applied to roads in national forests." Section 8 was assigned to the Forest Service for apportionment of funds and the selection of projects, although surveying and construction work on the forest roads was to be performed under the supervision of the Office of Public Roads and Rural Engineering (OPRRE)..$^{18}$

Implementation of the 1916 Act had just gotten well underway when the United States entered World War I in April 1917. The war curtailed road construction but did not bring it to a complete halt. Efforts were made to limit construction of roads to those needed for military purposes or war industry.

By the end of the war, roads had deteriorated from inadequate maintenance and heavy traffic, and an accelerated program was necessary. It was also believed that there would be extensive unemployment as a result of demobilization of the Armed Forces and war industry. Congress responded by including in the Post Office Appropriation Act for 1920 an appropriation of $\$ 200$ million for additional Federal aid under the Federal Aid Road Act of 1916. Of this amount, $\$ 50$ million was available immediately for fiscal year 1919 and $\$ 75$ million for each of the fiscal years 1920 and 1927. The Act also provided an additional $\$ 9$ million for forest roads at the rate of $\$ 3$ million for each of the fiscal years 1919, 1920 and 1921. An additional Federal subsidy to the road program was included by the transfer of surplus war materials and

Hoist and dump body, built by the Washington State Highway Department, are mounted on a $1 \frac{1}{2}$-ton Kelly Springfield truck which was WW I Army surplus. Equipment such as this aided the accelerated postwar highway program.

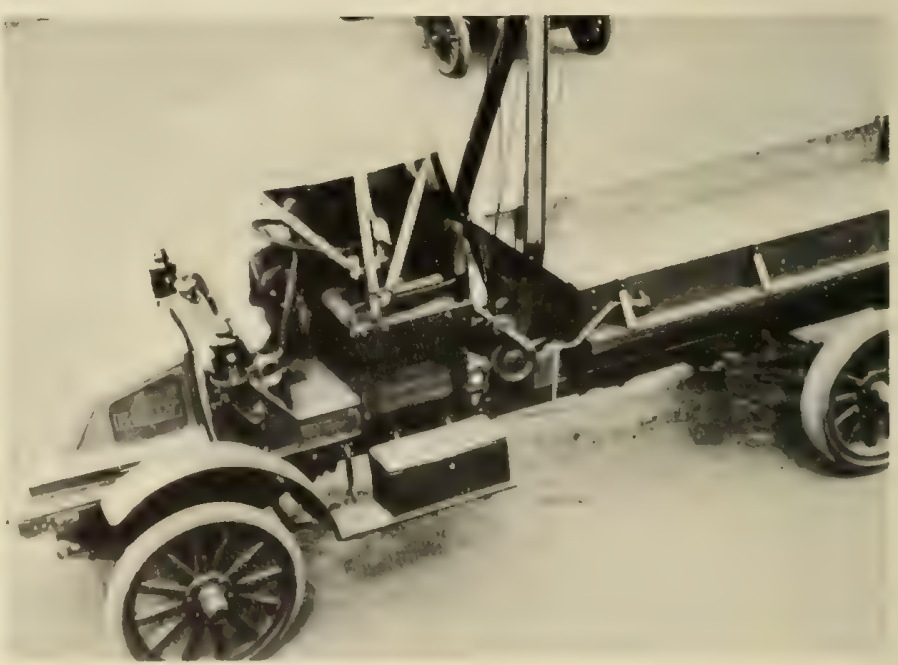


equipment to the Secretary of Agriculture for distribution to the State highway departments for use on Federal-aid roads. The Secretary was authorized to retain 10 percent of the material for the Department's use. The value of the surplus materials turned over to the States totaled $\$ 139$ million by July 1, 1922, when the distribution was essentially completed. ${ }^{19}$

The transfer of surplus war equipment played a major role in launching the postwar construction. Many States were able to continue highway construction and maintenance during that time only because they received the surplus equipment. ${ }^{20}$

\section{The Federal Highway Act of 1921}

The appropriations for Federal aid for roads extended only through fiscal year 1921. Consequently, Congress, in 1921, had to make a decision whether or not to continue the program, and this provided a chance to reevaluate the entire concept. There was considerable debate as to whether the Federal Government should construct a system of national highways directly or continue with the Federal-State cooperative plan. Again, the constitutional issue was raised.

Controversy also developed about what type of roads should be built with Federal-aid funds. One position was that the funds should be used for interstate highways which would serve as main lines for the State and county road networks. The other position was that the most important roads for the welfare of the country were the local roads connecting the farmer with his market and that, therefore, those should be built before the interstate roads which seemed to serve mostly the tourists.

These issues were decided in the 1921 Act. The Federal aid concept in a Federal-State cooperative program was reaffirmed.

The "character of road" issue was resolved by a most important new requirement-that Federal-aid funds should be expended only upon a federally approved, State selected system of main connecting interstate (primary) and intercounty (secondary) rural roads, limited to 7 percent of a State's total road mileage. The 7 percent limitation was based on a concept that the system should be limted to a mileage which could be constructed in a reasonable period of time. Once the State had provided for the construction and maintenance of highways equal to 7 percent, then mileage could be added to either system as funds became available and with the approval of the Secretary of Agriculture. The Act further provided that not more than three-sevenths of the total mileage could be used for the primary system, thus, a balanced program was assured. No more than 60 percent of any State's Federal-aid apportionment could be spent on the primary system, except with the approval of the Secretary, thus, establishing the principle of categorical funding (using Federal-aid funds only for specific purposes or programs).

Another new requirement in the 1921 Act was that when the States were preparing their design standards and specifications for highway projects, they should take into consideration the durability of the type of surface and kinds of materials that would best suit each locality and that would adequately meet the existing and the "probable character and extent of the

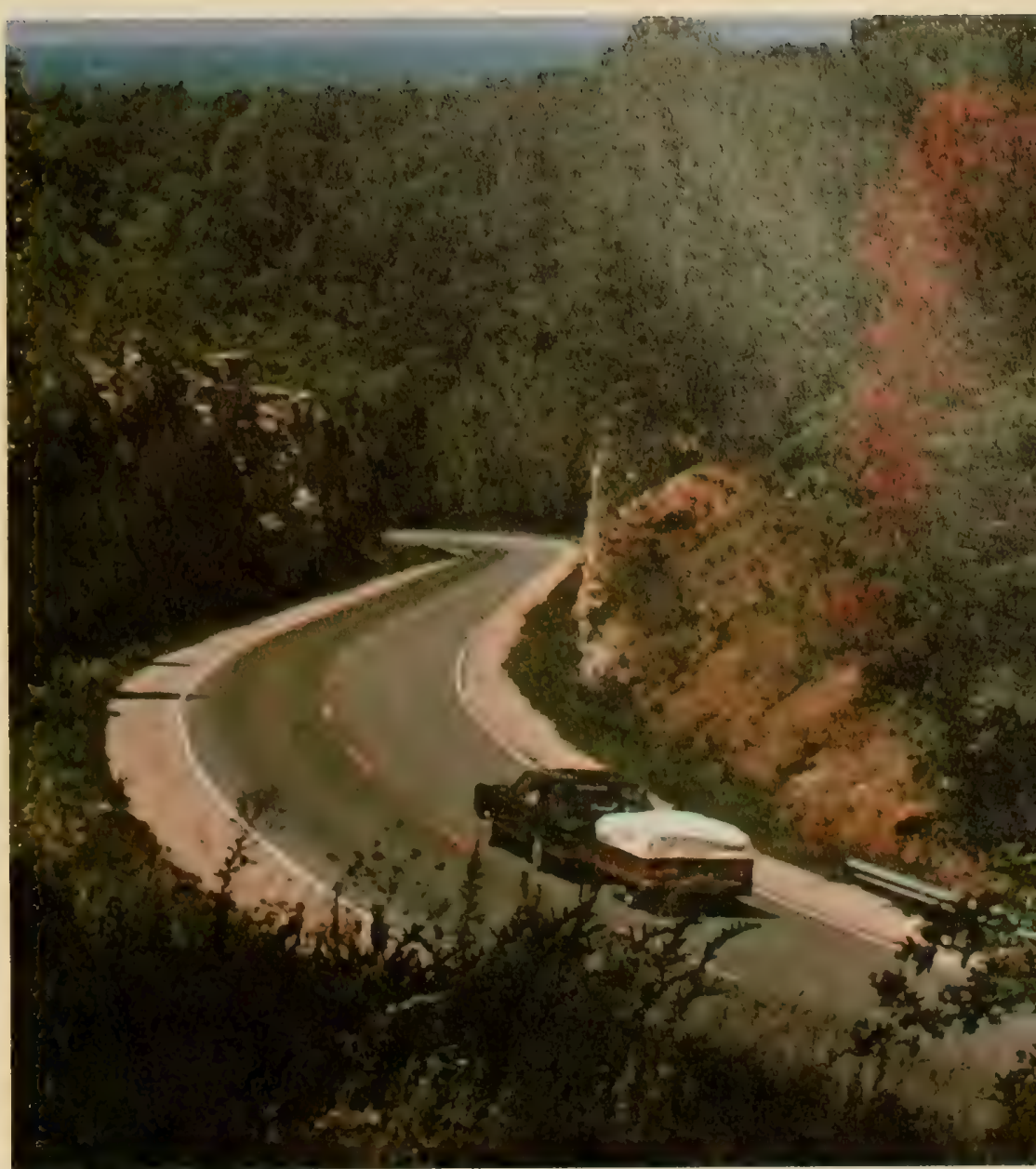

Section of Missouri route 79 south of Hannibal in "Mark Twain" country. The gorge had become a dump but was reclaimed for the new road site. Scenic turnouts allow the traveler to enjoy the rustic beauty of the area.

future traffic," subject to the approval of the Federal agency. This was apparently addressed, in part to those States that had been concerned about the meaning of a provision of the 1916 Act that " . . . the Secretary of Agriculture shall approve only such projects as may be substantial in character. ..."

The 1921 Act strengthened several other provisions of the 1916 Act by:

- Broadening the requirement for a State highway department, or equivalent, to require that such organization be suitably equipped and organized to administer the program to the satisfaction of the Federal agency.

- Providing that the State must have already made provisions for the State's share of funds required each year for construction, reconstruction and maintenance of all Federal-aid highways within the State and that these funds must be under the direct control of the State highway department before any project submitted by a State could be approved by the Secretary.

- Liberalizing the 50 percent Federal-State matching funds by increasing the Federal share of project costs, on a sliding scale computed by formula, in those States having large Federal public land areas.

- Amending the availability of funds for expenditure to provide that funds would be available for expenditure until the end of the second fiscal 
year following the fiscal year for which they were appropriated.

- Authorizing the Secretary of Agriculture to proceed to place any road in a proper state of maintenance if any State failed to do so within 90 days after having been notified to do it and to charge the costs of such work against the Federal funds allotted to that State. Furthermore, it stipulated that no other propects would be approved until the State reimbursed the Federal Government for the costs of the repairs and that the money paid would be reapportioned among all the States for construction of roads. The Secretary, then, could approve further projects submitted by that State.

- Providing that funds deducted for costs of administration could be used for highway research and investigational studies independently or in cooperation with the State highway departments and other agencies.

The Federal Highway Act of 1921, as it amended and supplemented the 1916 Act, constituted the remainder of the basic philosophies, principles, policies, procedures and controls which still exist for the program.

The appropriations in the 1921 Act provided funds for forest roads and trails in the amount of $\$ 5$ million for fiscal year 1922 and $\$ 10$ million for fiscal year 1923, but it appropriated Federal-aid system funds only for fiscal year 1922 in the amount of $\$ 75$ million.

\section{Contract Authority}

However, when the Post Office Appropriation Act for 1923 was approved June 19, 1922, it contained provisions amending the Federal Aid Road Act of 1916 to provide for the continuance of the highway program through fiscal years 1923, 1924, and 1925. Important new language was used in the Act-instead of providing appropriations for the 3 years, it stated "...there is hereby authorized to be appropriated, ... the following additional sums. ..."

This language meant that it was still necessary to go through the appropriation process by further legislation. The actual funding of the authorization then became a matter for consideration later by the appropriations committees. In this instance the "authorized to be appropriated" language was used in an Appropriation Act-however, the following additional provision was included regarding the funds for fiscal year 1923 :

Provided, That the Secretary of Agriculture shall act upon projects submitted to him under his apportionment of this authorization and his approval of any such project shall be deemed a contractual obligation of the Federal Government for the payment of its proportional contribution thereto.

The principle thus established is commonly called "contract authority," which meant that the full sum of money authorized in the Act could be obligated before any legislation had been passed to provide liquidating cash to pay the amounts claimed by the States.
The impact of this change in the method of authorizing and funding the Federal-aid highway program was vast because:

- It was essential that the States be provided ample time to prepare to participate in the program.

- It was not reasonable to expect the States to proceed with preparatory work and costs without assurance from the Federal Government that the apportionments would be funded.

- It was essential that Federal funds be available for prompt payment of State claims for reimbursement.

- It was not efficient money management to appropriate the full program funds for a 2- or 3-year period awaiting annual apportionment and an additional 5 or more years before a given fiscal year's need for actual reimbursement. Under this system, large sums would be tied up awaiting eventual disbursement.

- It was assurance of the continuity of the program because the program was then dependent only upon obtaining future authorizations.

\section{The Federal-State Relationship}

When Federal assistance for the development of highways was first considered, there was no "model program" to copy. While Congress must be given the final credit, many of the pioneer leaders in the emerging State highway departments, highway industries and associations, and the Office of Public Roads in the Department of Agriculture all played a major part in developing the legislation. Among all major Federal assistance programs, the Federal-aid highway program has been one of the most successful in its effectiveness, efficiency and its cooperative administration by the Federal Government and the States.

The very limited role of the Office of Road Inquiry, when it was created in 1893 , was strictly spelled out in Secretary of Agriculture J. Sterling Morton's letter appointing General Roy Stone, a prominent New York civil engineer and Secretary of the League of National Roads, to the position of Special Agent and Engineer for Road Inquiry. The Secretary cautioned: "The Department is to furnish information, not to direct and formulate any system of organization, however efficient or desirable it may be. Any such effort on its part would soon make it subject to hostile criticism. ..." 21

While the role of the Federal Government was to be greatly strengthened and broadened both by legislation and the personal policy of future highway administrators, the underlying philosophy behind the original directive has survived.

Of great significance in the shaping of the FederalState relationship in the administration of the Federalaid highway program was the appointment of Thomas H. MacDonald as the Chief of the Bureau of Public Roads on May 3, 1919. At the time of his appointment, Mr. MacDonald was the Chief Engineer of the Iowa State Highway Commission and had been a member (since 1915) of the Executive Committee of AASHO which was created late in 1914. It was on the recommendation of State highway officials that Mr. MacDonald was selected to succeed Logan Waller Page who died unexpectedly in December 1918. 
Mr. MacDonald, known throughout his career with the Bureau as "the Chief," was largely responsible for the development and success of the Federal-aid highway program and, so important to that success, the building of a cooperative Federal-State relationship founded on mutual respect. The American Association of State Highway Officials (AASHO) declared in 1964 its view of Mr. MacDonald's role as follows:

There were spokesmen for both plans* and they were articulate. It was in no small part due to Mr. Mac'Lonald's efforts that the Federal-aid program was the one that was adopted. It was his contention that such a program would encourage development of highway technology and the creation of a great network of highways throughout the Nation, instead of a few Federal routes and some spiderweb highway systems within the individual States. The results prove that contention was correct.

He felt that without the encouragement and stabilizing influence of Federal-aid, some of the States would have a difficult time dereloping adequate and competent Highway Departments and effective highway programs.

It was his belief that the States must retain the initiative in administering the Federal-aid highway programs, and that the Bureau of Public Roads should make such checks as necessary to protect the Federal interest. ${ }^{22}$

During his entire administration of the Bureau (1919-1953), Mr. MacDonald, clearly ran the organiza-

* "National" highways vs. federally assisted, State administered program.

Washington, D.C., was as popular with tourists at the turn of the century as it is today.
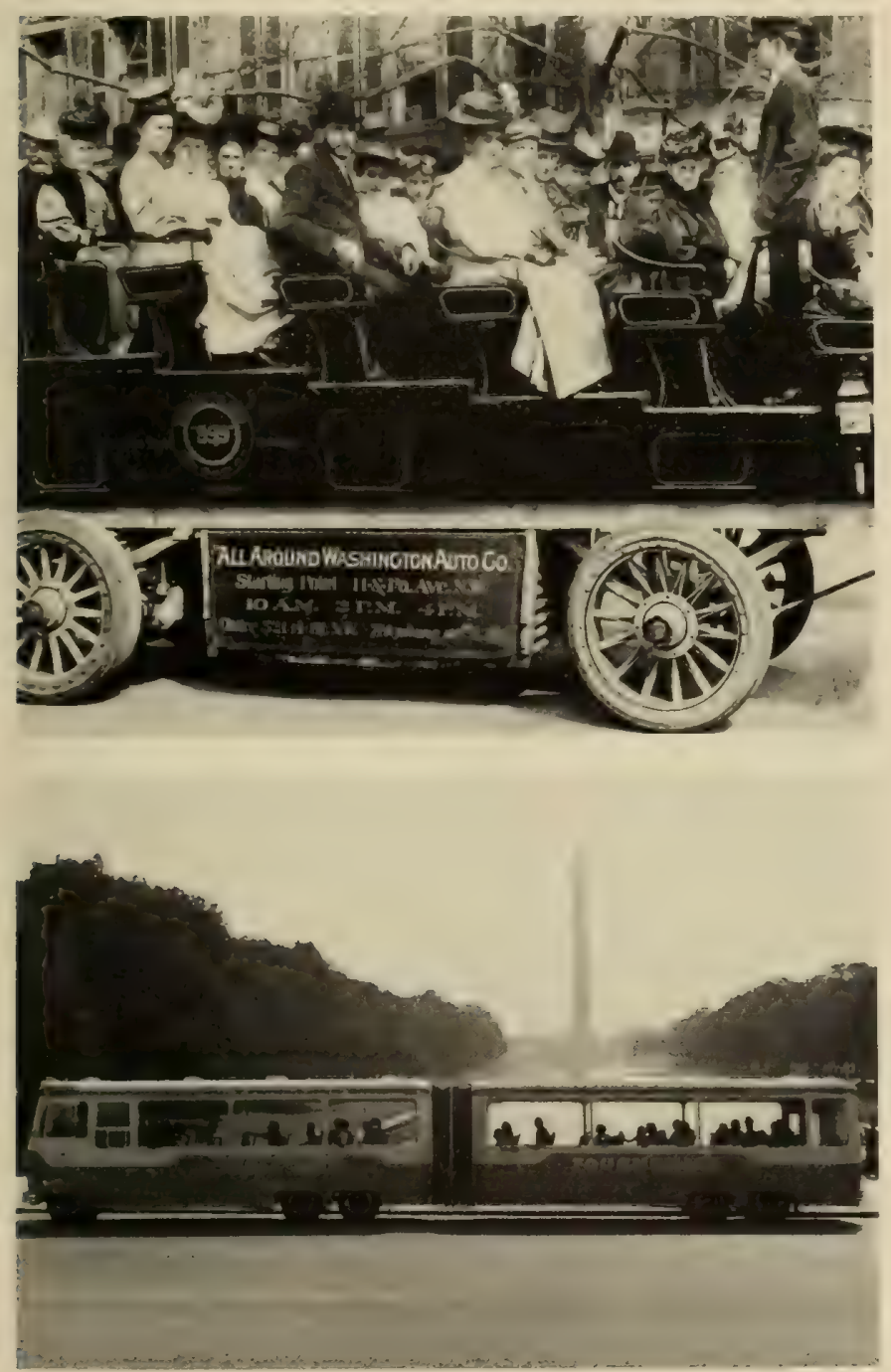

tion. There was never any question who was "Chief." He did not believe in staff meetings or internal group decisionmaking. He discussed policies and problems normally on a one-to-one basis with a very small group of his most trusted assistants, but in the end, he made the policy and he made the decisions.

In his external relationships, Mr. MacDonald was a strong believer in committee or group action. He did everything possible to strengthen the policymaking role of the American Association of State Highway Officials and its numerous technical committees. Similarly, he supported the organization, cooperation and interaction of other special interest and professional groups who were interested in or affected by the Nation's highway program.*

There was no paradox in Mr. MacDonald's diametrically different approach to internal and external administration of the highway program. He could control the Federal internal policies-and this extended beyond him through the Federal department level to the pertinent congressional committees. On the other hand, the external elements of the total highway industry and interests were so widespread and diverse that independent and singular views could well lead to chaos, inaction and conflict. His solution was organized group policy and decisionmaking, intercommunication, interaction, compromise, all toward common goals.

Mr. MacDonald's administrative skill, his strong sense of direction, his dedication, and his long tenure in office-spanning 34 years-permitted the basic Federal-State working relations to become fully established and to demonstrate their worth. During his tenure, agency personnel were well-trained in the MacDonald philosophy that the Bureau should maintain as low a profile as possible while quietly maintaining a role of encouragement, leadership and protection of the national interest.

Reflecting on the pioneers on the State side of the Federal-State relationship, major personal contributions were made by many individuals over the years. G. P. Coleman, Highway Commissioner for the State of Virginia, was perhaps the individual who played the most important part in the actual creation of AASHO in 1914.

Mr. Coleman, in turn, singled out A. G. Batchelder, Executive Secretary to the American Automobile Association, for special credit. Mr. Coleman also gave much credit to the assistance of some 16 other heads of State highway departments or commissions for the creation of AASHO. In any event, the creation of the American Association of State Highway Officials was a "cornerstone" upon which the successful FederalState relationship was to be built.

Over the years there have been a great many outstanding and influential heads of the various State highway departments and commissions who played

* These included, but were not limited to: The American Road Builders' Association, Associated General Contractors, Automotive Safety Foundation, National Highway Uscrs Conference, National Safety Council, American Trucking Association, National Association of County Engineers, American Public Works Association, American Municipal Association, Institute of Traffic Engineers, and the Highway Research Board which played a very special role in highway development. 
major roles in strengthening $\mathrm{AASHO}$ and in shaping the Federal-aid highway program. These men are too numerous to cite individually, but collectively, much of the success of the Federal-State relationship must be attributed to their wisdom and leadership.

\section{The Interaction of AASHO and BPR}

Since the framers of the 1916 Act agreed that the key to a successful Federal-State relationship in the administration of the Federal-aid highway program at the policy level, at least, was interaction and cooperation of the Federal Government with a "federation" of the States, the appropriate instrument to accomplish this was the American Association of State Highway Officials.

The Bureau of Public Roads became a "member department" of AASHO in 1919 and, through Mr. MacDonald, a member of the Executive Committee. By the terms of the AASHO revised Constitution, the Federal Highway Administrator became an ex officio member of the Executive Committee in 1957.*23 During this long period of time, cooperative effort toward common goals has been the basis of the relationship between the Federal agency and AASHO with each organization fully respecting the right of the other to hold individual viewpoints.

The fact that in $1923 \mathrm{AASHO}$ located its headquarters office in Washington in the charge of an Executive Secretary, who traditionally has been a strong and capable representative of all the States, provided both BPR and AASHO with the opportunity for effective day-to-day communication.

The principal interaction between AASHO and the Bureau at the Washington level has been in the areas of proposed legislation; interpretation of the effects of legislation on the States and plans for its implementation; assurance of a viable AASHO committee structure; the agenda for the annual AASHO and regional AASHO meetings; joint consideration of relationships with the many other national associations that have been involved in, or have an interest in, the highway program; and other subjects of mutual interest that are best handled on a national basis rather than with the individual States.

Following the extensive hearings which preceded enactment of the 1944 Federal-Aid Highway Act, congressional highway leaders requested that in the future the States develop their policy statements on highway legislation jointly through the AASHO mechanism as a basis for testimony by an AASHO spokesman rather than appear individually to present State viewpoints. This policy continues, though upon rare occasions a State has asked permission from a congressional committee to appear individually. ${ }^{24}$

A very extensive and highly important area of interaction and cooperation between AASHO and the Bureau has been in the establishment and activities of the various committees of AASHO. At the top of the AASHO committee structure, as defined in the 1914 Constitution, was the Executive Committee which

\footnotetext{
* To carry out the broader requirements of new legislation and the impetus of cluaned social values, A ASHO officially changed its name to the American Association of State High way and Transportation Officials (AASHTO) in 1973. The reconstitution of AASHO resulted in the Secretary of Transportation's designation as the Federal member.
}

was responsible for legislative matters of a national character. In addition, the Constitution provided for a Finance Committee, a Committee on Tests and Investigations for evaluating various kinds of materials, and a Committee on Standards for establishing methods of construction and maintenance. Eventually, as circumstances required, other standing committees were formed, some with working subcommittees. Special committees and joint committees have been established whenever the need for such committees became apparent.

The AASHO committee system, supported by BPR personnel, has been a strong factor in the successful and invaluable contributions made to improving highway administrative and engineering technology. For many years, BPR staff members chaired many of the AASHO committees and served as secretaries on many others. Later the policy was changed to name State officials as chairmen and BPR officials as secretaries when such practice was mutually beneficial to the highway program.

Through refinement of the state-of-the-art in all aspects of highway engineering and administrationwhich, in turn, insured continual improvement in the quality, effectiveness, and efficiency of program implementation-the committee activities of AASHO have proven to be the Association's greatest strength.

\section{BPR and the Highway Research Board}

The need for a national program of highway research was recognized in 1919. It was envisioned as a national program of highway research that would be coordinated by the National Research Council (of the National Academy of Sciences) with participation by such organizations as AASHO, BPR, the engineering colleges and experiment stations, municipal testing laboratories, manufacturers' research departments and associations, commercial laboratories, technical societies, and consulting engineers. ${ }^{25}$ When the National Advisory Board on Highway Research* was established in 1920, its purpose was "To prepare a comprehensive national program for highway research; to assist existing organizations to coordinate their activities therein; and to collect and distribute information of completed and current research." ${ }^{26}$

From the very beginning, the Board was organized into a series of committees headed by an Executive Director. Under the Board's bylaws, ex officio members were designated from the Bureau of Public Roads and the National Research Council Division of Engineering. In 1945 the Executive Secretary of AASHO was also made an ex officio member of the Highway Research Board (HRB).

During the early years, the Board was supported largely by the BPR, both in terms of dollars and in staff effort. During the first year, BPR, through a contractual agreement, supplied $\$ 12,000$ of the total $\$ 14,500$ budget and continued financial support averaging about 62 percent of the total operational budget for the first 24 years. Many of the States had no legal authority to make funds available to the HRB unless the funds were to be used for research projects within their own States. ${ }^{27}$ Gradually this problem

\footnotetext{
* The name of the organization was changed to the Highway Research Board in January 1925 and to Transportation Research Board in March 1974.
} 
was resolved, and since 1945 the BPR's support of the HRB's operational budget has averaged about 14 percent and that from the State highway departments about 60 percent. The balance has come from industry and cooperating organizations and associations. ${ }^{28}$ Incidentally, the operational budget of the HRB does not include the cost of the actual research activities the HRB may administer-such funds are provided separately for specific projects by the BPR, the States, and, as appropirate, private industry on a project-by-project basis.

Among the various regular ongoing programs of HRB, the committee activities have been the most important. Committees have been organized within subject matter areas and can be created or terminated as needs dictate. The membership of the committees have always included technical specialists from BPR and the States; often these specialists have been selected to serve as either the committee chairman or secretary. Membership on the committees has also included specialists from universities and colleges, technical and professional associations, and the private sector in the wide scope of the highway industry. By 1926 six committees had been formed on economic theory of highway improvement, structural design of roads, character and use of road materials, highway traffic analysis, highway finance, and maintenance.

Since 1922 the Board has held annual meetings. These meetings have provided a forum for the presentation of technical and administrative research papers and have presented an invaluable opportunity to all segments of the industry interested in highway research to assemble and exchange information on the latest research developments. Attendance at the an- nual meetings has shown an almost continuous increase from the 30 who attended the first meeting in 1922 to a level that approaches 3,500 today. From the beginning until 1962, the technical papers presented at the HRB annual meetings were published in the HRB Proceedings. Other HRB publications have served over the years to distribute research information.

A highway Research Information Service (HRIS) was instituted in 1930 for a broader means of research exchange. At one point the Director of HRB, Roy W. Crum (1928-1951), said he had always felt that HRB was an educational institution and that "The end product of our work is usable technical information, but it will be of no value to anyone unless it is learned and put to use by the technical man." 29 In addition, HRB has produced Highway Research Abstracts, HRB Bibliography, Annual Report, and many other publications on highway and transportation research, which effectively carries out its mission "to collect and distribute information."

In 1945, the HRB inaugurated the Highway Research Correlation Service (HRCS) which greatly strengthened its role in implementing the concept upon which it was created. The method of operation of the HRCS was "for a staff of competent engineers and other technologists who can work in the various areas of interest, travel about the country, and find out the things we need to know about facilities, personnel, and needed information. They will carry information from one State to another, or to other research agencies. In the progress of this work they will gather for dissemination much valuable and

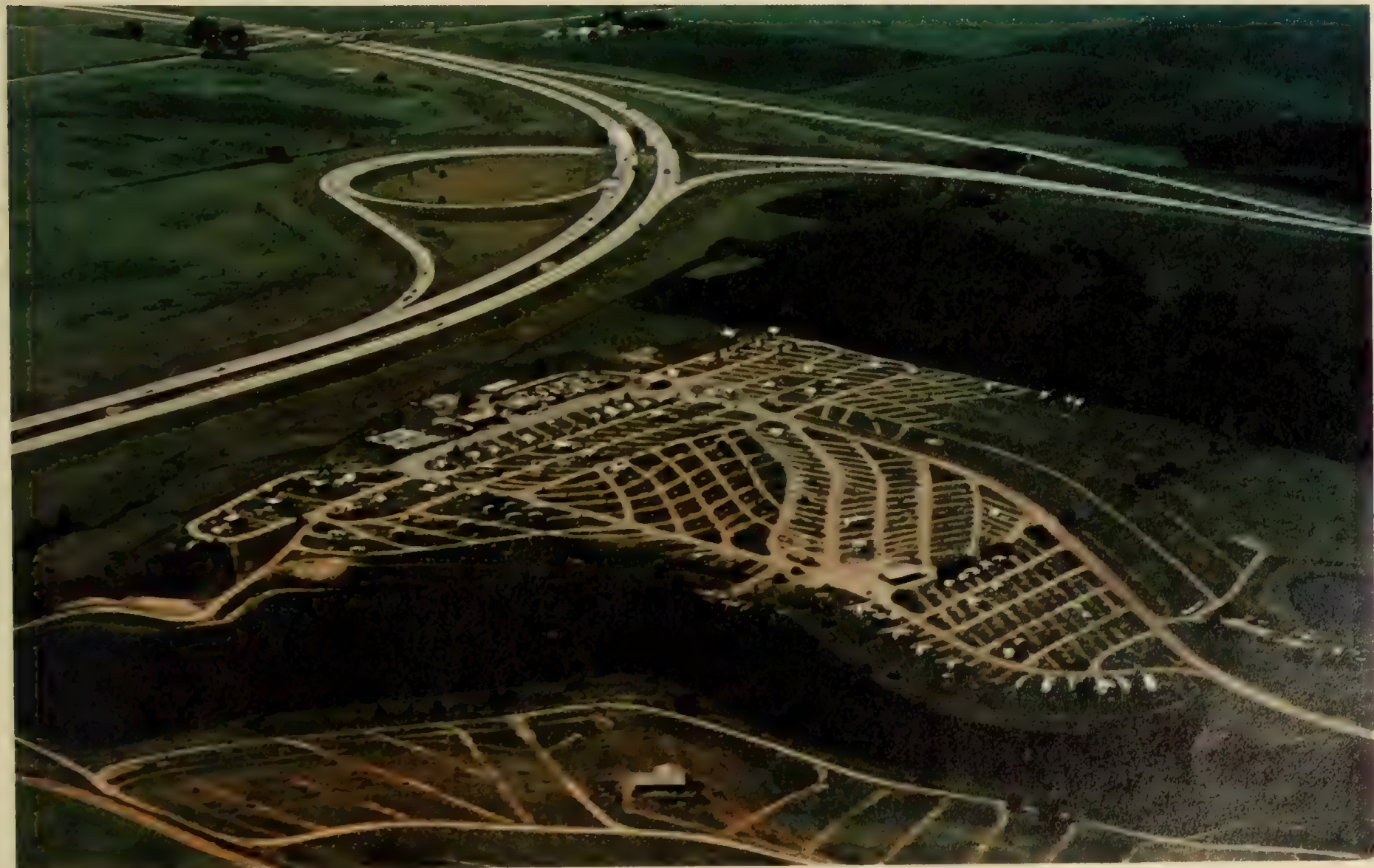


usable information. ${ }^{30}$ Meanwhile, it had been determined that the States could use a portion of their 11/2 percent Federal-aid planning apportionments for participation in the HRCS so long as State matching funds were also provided. The timing of the creation of the HRCS coincided with the initiation of the greatly expanded postwar Federal-aid highway program. This permitted the growth of HRB at a time when it was needed most to keep pace with the needs of the highway program.

In 1962 the National Cooperative Highway Research Program (NCHRP) was established through which a national program of highway research could be developed jointly by the States (through AASHO), the BPR and the HRB, under a plan of pooled financing by the States and BPR. This program came soon after the initiation of the Interstate program when many new problems were beginning to emerge.

Between 1964 and 1967, the HRB initiated an automated Highway Research Information Service (HRIS). Items selected for HRIS processing fell into two general categories, research-in-progress reports and abstracts of published research articles or reports. The program was extended to include foreign research-in-progress and foreign language research reports through cooperative exchange agreements arranged with international organizations and other nations. Presently, from computer storage, HRIS provides abstracts of published works and summaries of ongoing research projects in response to specific inquiries.

A research library was initiated in 1946. Today, it plays a very important role in not only providing the specialized professional library services the TRB requires for its activities, but it also maintains an awareness of the subject content of other libraries and other institutions that may possess material of TRB interest. Copies of all TRB publications are also maintained by the library.

\section{Current Status of the Federal-State Relationship}

The unique Federal-State partnership in the Federal-aid highway program still exists despite the constrictions placed upon it by the changing climate in which the highway program must be administered.

When one speaks today about the Federal side of the Federal-State relationship in the administration of the Federal-aid highway program, actually the Federal Highway Administration is no longer the only Federal agency involved. Many other Federal agencies are now legally involved in the program, e.g., the Environmental Protection Agency; the Departments of the Interior, Commerce, Labor, Housing and Urban Development, and Justice; the Occupational Safety and Health Administration; the Office of Economic Opportunity; the Urban Mass Transportation Administration; the National Highway Traffic Safety Administration; the Corps of Engineers; and a number of Federal councils, commissions, and boards.

Somewhat the same situation exists when one speaks about the State side of the Federal-State relationship. Many of the provisions of recent Federal (and some State) legislation require the States to coordinate with their local subdivisions and State and regional plan- ning groups and commissions. In some program categories, project initiation is vested with the local subdivisions.

The increasing complexity of Federal highway legislation and other interrelated and interacting Federal legislation obviously have had an inevitable impact on the administration of the Federal-aid program. The early procedures were strikingly simple by comparison with today's requirements. The problem then was the extensive centralization of final authority at the Federal level in Washington. Over the years this problem was gradually corrected by decentralization, but intricate programs and project processing requirements were substituted by other important, but sometimes conflicting, programs, making accomplishments tediously slow.

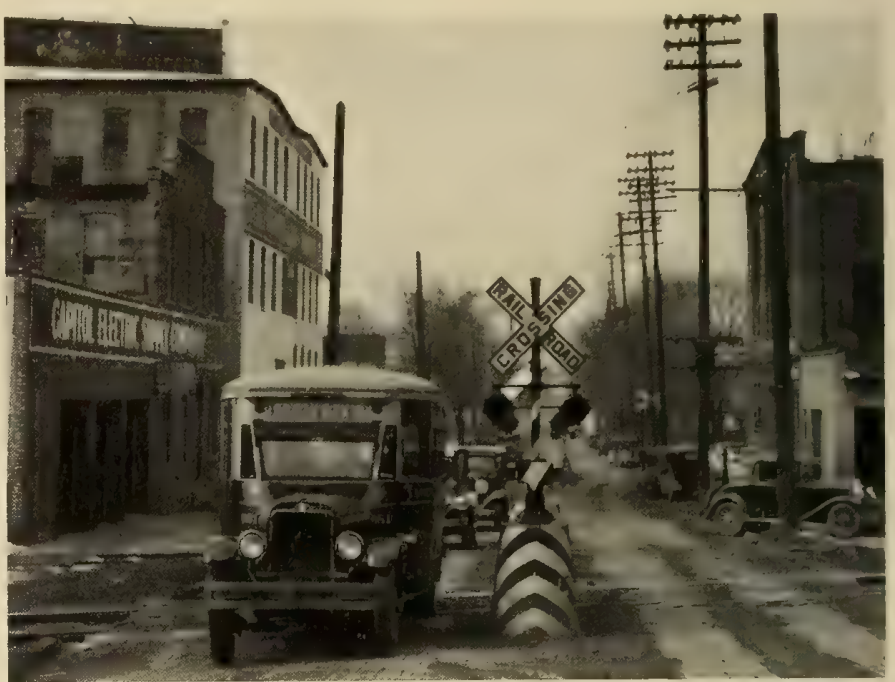

Lansing, Mich., street scene about 1930. Note the brick pavement, railroad warning device and the municipal bus.

\section{Legislative Developments*}

Many additions and changes in the Federal-aid highway program evolved through continuing Federal legislation after 1921. Most of these have increased the effectiveness of the program but have resulted in more complex procedures for administering the program.

During the Depression years larger regular authorizations and special appropriations were made to provide employment opportunities, and special regulations were necessary to insure that this purpose was achieved. For the first time, Federal-aid funds were made available for extensions to the Federal-aid system into and through municipalities and also for secondary feeder roads.

In $1934,1 \frac{1}{2}$ percent of apportioned funds were made eligible for surveys, planning, and engineering investigations. Later this was broadened to include highway research and statewide highway planning surveys. Special funds were provided for the elimination of hazardous railroad grade crossings.

In 1944 the Federal-aid system was expanded to include a secondary system of farm-to-market roads and an urban program of extensions of primary routes in urban areas of 5,000 population or more. In addition a 40,000-mile National System of Interstate

* This section is a very brief summary of the legislation to identify major trends. Many of these points are discussed in more detail later in this and other chapters. 


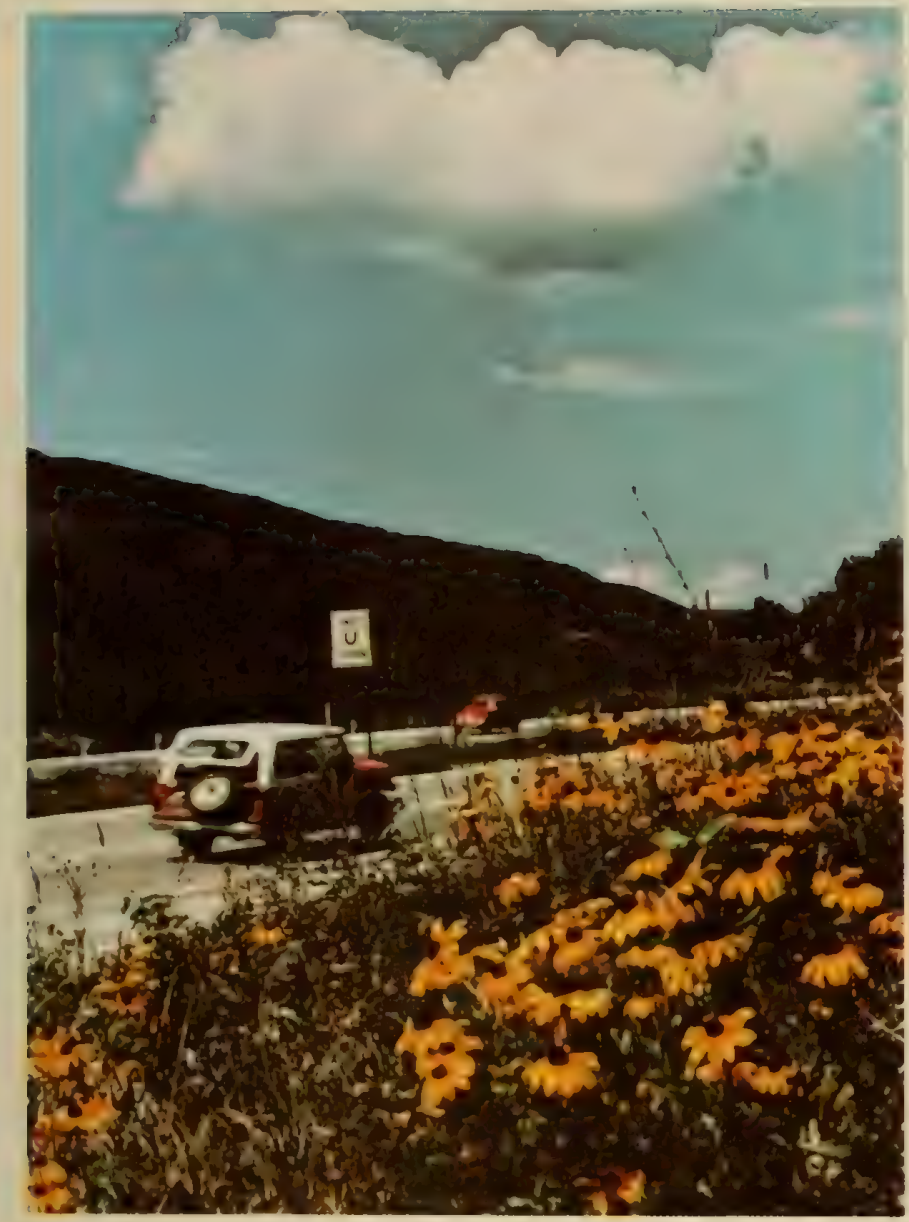

The 1965 Highway Beautification Act gave new emphasis to programs of landscaping and scenic enhancement on Federal-aid highways.

Highways was called for but no funds were provided for its construction. The 1944 legislation also permitted the use of Federal-aid funds for acquiring highway rights-of-way.

By 1950 highways were being planned or built on more new locations. To allay fears of community economic depressions, legislation was enacted which required States to hold local public hearings with respect to any proposed project that would bypass any city or town.

The Interstate System routes in each State were approved in 1947 , but it was not until the 1952 legislation that specific funding was authorized for Interstate construction, and then, only in token amounts.

Congress provided substantial long-term funding in 1956 to complete the National System of Interstate and Defense Highways. The funding authorizations in the 1956 Act were increased from $\$ 175$ million to $\$ 2.2$ billion per year for fiscal year 1957 with additional sums for other years. To finance the program, Congress established the Highway Trust Fund. The 1956 Act planned for the completion of the Interstate System in 16 years, thus, accelerating construction work in all States. It increased administrative requirements by providing for utility relocations, establishing vehicle size and weight limits on Interstate highways, providing for archaeological and paleontological salvage, and applying the provisions of the Davis-Bacon Act of prevailing wage rates to Interstate construction projects.
The tremendous expansion of the Federal-aid highway program by the 1956 Act, together with its new provisions and added complexity, made necessary an intensive effort by the Bureau of Public Roads and the States (through AASHO) to simplify, standardize, and expedite procedures. Of most importance was a complete reorganization by Public Roads, together with an increased decentralization of responsibility and authority to its field offices. The basic separate Federal-State roles were not changed by the 1956 Act, but additional and more complex project steps had to be introduced to satisfy the new legislative provisions.

The highway acts and other interacting legislation after 1956 provided further program expansion, particularly for the basic Federal-aid systems, and injected more refinements, additions, and controls into the program which complicated the Federal-State relationship and introduced new procedures. One such requirement in 1962 was the continuing, comprehensive, cooperative transportation planning process (known as the $3 \mathrm{C}$ process) that required States and local communities to develop cooperatively long-range highway plans and programs in urban areas of more than 50,000 population and to properly coordinate them with the programs for other forms of transportation. Another requirement in the 1962 Federal-Aid Highway Act was that the State highway departments furnish satisfactory assurance that advisory assistance was provided for families displaced by Federal-aid highway construction. It also provided that limited amounts of Federal-aid funds could be used to defray the costs of relocating families and businesses. This program was broadened later and culminated in the Uniform Relocation Assistance and Real Property Acquisition Policies Act of 1970 making relocation assistance applicable in all federal assisted programs.

In 1965 an amendment to the 1956 Highway Act prescribed measures to be taken to slow the rate of traffic accidents. These endeavors led ultimately to the enactment of the Highway Safety Act of 1966 and the TOPICS program (Traffic Operations Program to Increase Capacity and Safety) in 1968. The Highway Beautification Act of 1965 established two new programs on control of junkyards and landscaping and scenic enhancement and expanded the scope of the outdoor advertising control program.

Equal employment opportunity provisions were required to be included in the advertised specifications for contracts on Federal-aid projects in 1968.

Legislation in 1970 established a program for economic growth centers designed to revitalize rural and small urban areas, a new urban highway system, and a bridge replacement program for safety improvements to bridges considered structually deficient and functionally obsolete. In addition, there were new requirements for construction of replacement housing, noise standards to be developed and requirements resulting from the Clear Air Act.

By 1973 the requirements of highway legislation and other legislation having a direct bearing on the highway program were so complex that establishing procedures to be sure the requirements were being carried out was a monstrous task. Many new programs often had separate funding which meant sep- 


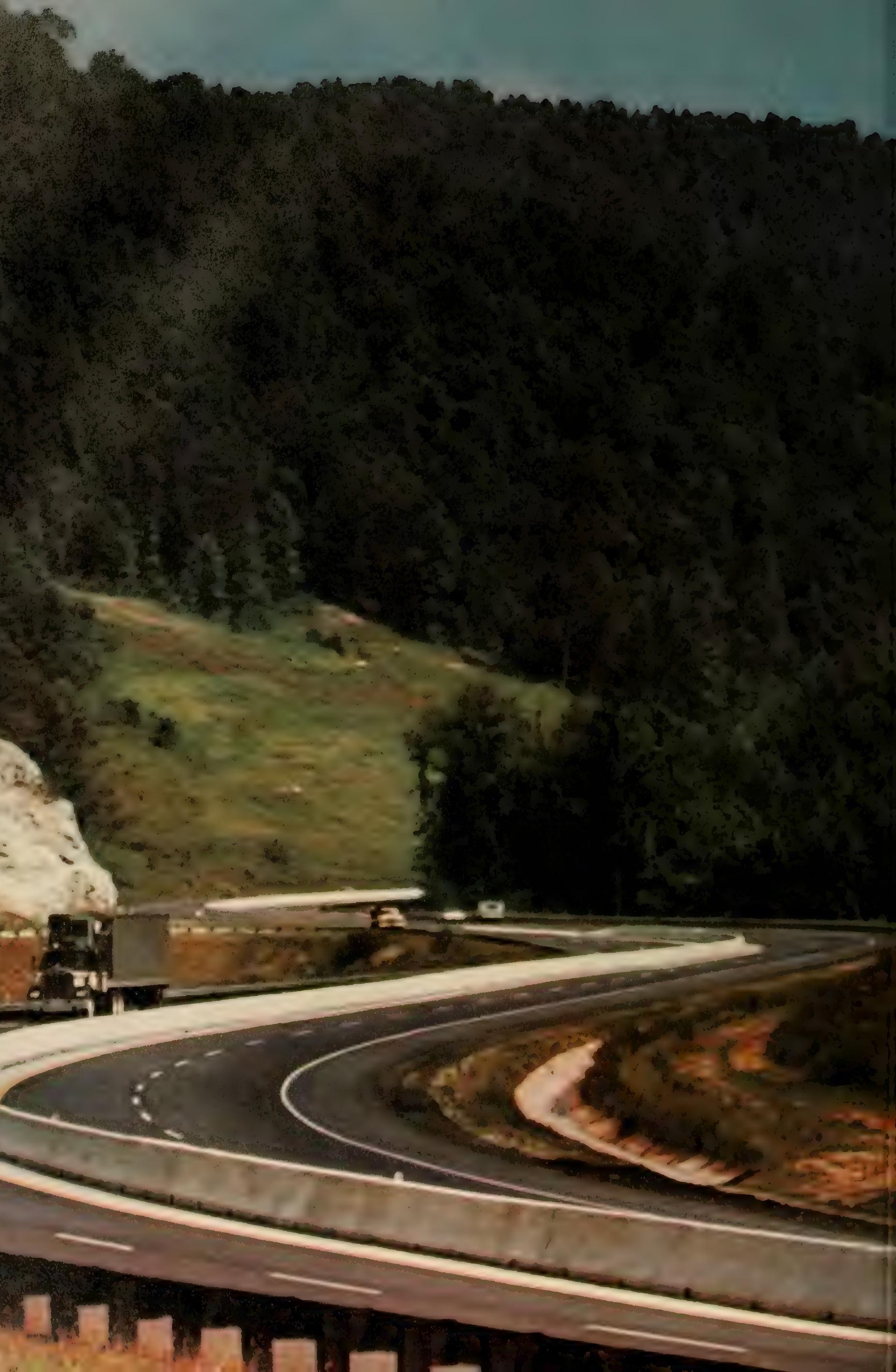


arate budgeting procedures, as well as separate reporting and accounting procedures. The States and the FHWA were inundated with statistics.

But in 1973 major highway legislation was enacted which established more new programs: (1) Safety construction-a separate program for safer roads, roadside obstacles, high-hazard locations, and pavemen markings; (2) priority primary routes-high traffic routes on the Primary System which connected to the Interstate System; and (3) urban high density - high traffic routes in urbanized areas which connected to Interstate routes. Furthermore, highway projects on Interstate and Urban Systems could be traded for transit projects. In addition, bicycle and pedestrian paths could be constructed along highways, curb ramps for the handicapped were required, and special provisions were included to encourage carpooling.

In 1974 requirements for transporting the elderly and handicapped were enacted, along with enforced higher limitations on sizes and weights of trucks and buses and a national speed limit of 55 m.p.h. Funding was also permitted for road improvements not on a Federal-aid system for the first time since 1921.

It would normally be expected that such a large and complex program would require a large and complex organization to manage the program. This is not the case in the highway program, primarily for three reasons. The first is the unique Federal-State partnership which has already been discussed. The second reason is that as the program has grown, more responsibilities and authority have been decentralized to the FHWA field offices which work closely with the State highway departments. The third reason is that, since 1893, the Federal agency responsible for administering the highway program has had a strong interest in training and initiated its first formal training program in 1905. Since then, the organization has kept pace with the program by revising and updating its training program as new requirements arose.

\section{Management of the Federal-Aid Program}

\section{The Federal Agency}

To comprehend the management of such a large Federal-aid program, it is necessary first to understand the Federal agency charged with the responsibility for administering the Federal interest in the Nation's principal highway programs for more than 80 years.

The original agency was established in the Department of Agriculture in October 1893 by Secretary J. Sterling Morton as a result of the $\$ 10,000$ appropriation in the Department's Appropriation Act. It is believed that the original Office of Road Inquiry consisted of the Special Agent and Engineer for Road Inquiry, General Roy Stone, and one secretary.

The Agriculture Appropriation Act for fiscal year 1897 added authority to investigate the best kinds of

Concern for safety characterizes today's Fefleral-aid programs. This new section of U.S. 25 replaces a steep, winding two-lane route built in 1929 near Greenville, S.C. Now the highway has a maximum of 6 precnt grade and concrete median barriers between opposing traffic lanes where necessary. roadmaking materials in the several States. Through cooperation with the Division of Tests in the Bureau of Chemistry (Department of Agriculture), a laboratory was established by the Office of Public Road Inquiries in 1900 where any citizen interested in the construction of public highways could have road materials tested free of charge. The Appropriation Act for 1902 put this testing work directly under the Office of Public Road Inquiries by giving it an appropriation for the investigation of the chemical and physical character of road materials. Furthermore, by 1901 the idea of field representation had been established with the country divided into four segments with a part-time special agent for each division. This field representation over the years has been of great benefit by supporting the Federal-State relationship, and as the Federal-aid program expanded, the necessary interaction at the operational level was greatly enhanced.

In 1905 the agency's name changed again to the Office of Public Roads and, by law, it was permitted to retain 10 employees. To carry out its major functions, the work was organized into three divisions: Highways, Laboratory Tests and Investigations, and Information. It is significant that a program of hiring student engineers (at $\$ 600$ per year) was initiated in 1905 with the express purpose of training them for career highway engineer positions in the Office of Public Roads and in the State highway departments.

During 1911 part-time Special Agents were appointed for each State to improve the collection and reporting of information.

By then the Federal agency had already undergone three name changes and there were others to come. Since the identity of the Federal agency responsible for the Federal-aid highway program becomes rather obscure when the program becomes so complex and interrelated with other Federal agencies, the following table is a chronological listing:

\begin{tabular}{|c|c|c|c|}
\hline $\begin{array}{l}\text { Date of } \\
\text { Creation }\end{array}$ & $\begin{array}{c}\text { Organization } \\
\text { Title }\end{array}$ & $\begin{array}{c}\text { Parent } \\
\text { Organization }\end{array}$ & $\begin{array}{c}\text { Title of } \\
\text { Top } \\
\text { Executive }\end{array}$ \\
\hline Oct. 3,1893 & $\begin{array}{l}\text { Office of Road } \\
\text { Inquiry }\end{array}$ & $\begin{array}{l}\text { Dept. of } \\
\text { Agriculture }\end{array}$ & $\begin{array}{l}\text { Special } \\
\text { Agent and } \\
\text { Engineer } \\
\text { (1897 } \\
\text { became } \\
\text { Director) }\end{array}$ \\
\hline FY 1899 & $\begin{array}{l}\text { Office of } \\
\text { Public Road } \\
\text { Inquiries }\end{array}$ & $\begin{array}{l}\text { Dept. of } \\
\text { Agriculture }\end{array}$ & Director \\
\hline July 1, 1905 & $\begin{array}{l}\text { Office of } \\
\text { Public } \\
\text { Roads }\end{array}$ & $\begin{array}{l}\text { Dept. of } \\
\text { Agrieulture }\end{array}$ & Director \\
\hline July 1, 1915 & $\begin{array}{l}\text { Office of } \\
\text { Public } \\
\text { Roads and } \\
\text { Rural } \\
\text { Engineering }\end{array}$ & $\begin{array}{l}\text { Dept. of } \\
\text { Agriculture }\end{array}$ & Director \\
\hline July 1, 1918 & $\begin{array}{c}\text { Bureau of } \\
\text { Public } \\
\text { Roads }\end{array}$ & $\begin{array}{l}\text { Dept. of } \\
\text { Agriculture }\end{array}$ & $\begin{array}{c}\text { Director } \\
\text { (1919 } \\
\text { became } \\
\text { Chief) }\end{array}$ \\
\hline July 1, 1939 & $\begin{array}{l}\text { Public Roads } \\
\text { Administra- } \\
\text { tion }\end{array}$ & $\begin{array}{l}\text { Federal Works } \\
\text { Agency }\end{array}$ & $\begin{array}{l}\text { Commis- } \\
\text { sioner }\end{array}$ \\
\hline
\end{tabular}




\begin{tabular}{|c|c|c|c|}
\hline $\begin{array}{l}\text { Date of } \\
\text { Creation }\end{array}$ & $\begin{array}{c}\text { Organization } \\
\text { Title }\end{array}$ & $\begin{array}{c}\text { Parent } \\
\text { Organization }\end{array}$ & $\begin{array}{l}\text { Title of } \\
\text { Top } \\
\text { Exccutirc }\end{array}$ \\
\hline July 1, 1949 & $\begin{array}{l}\text { Bureau of } \\
\text { Public } \\
\text { Roads }\end{array}$ & $\begin{array}{l}\text { General } \\
\text { Services } \\
\text { Admin- } \\
\text { istration }\end{array}$ & $\begin{array}{l}\text { Commis- } \\
\text { sioner }\end{array}$ \\
\hline Aug. 20, 1949 & $\begin{array}{l}\text { Bureau of } \\
\text { Public } \\
\text { Roads }\end{array}$ & $\begin{array}{l}\text { Dept. of } \\
\text { Commerce }\end{array}$ & $\begin{array}{l}\text { Commis- } \\
\text { sioner } \\
\text { (1956 } \\
\text { became } \\
\text { Federal } \\
\text { Highway } \\
\text { Admin- } \\
\text { istrator*) }\end{array}$ \\
\hline Apr. 1, 1967 & $\begin{array}{l}\text { Federal High- } \\
\text { way Admin- } \\
\text { istration }\end{array}$ & $\begin{array}{l}\text { Dept. of } \\
\text { Transpor- } \\
\text { tation }\end{array}$ & $\begin{array}{l}\text { Admin- } \\
\text { istrator }\end{array}$ \\
\hline
\end{tabular}

*This was a new position above the Commissioner's position on a level with an Assistant Secretary of Commerce. The position of Commissioner was retained until 1961.

Following the enactment of the Federal Aid Road Act on July 11, 1916, with its initiation of the cooperative Federal-aid highway program, the Office of Public Roads and Rural Engineering (OPRRE) created a formal field organization. The field work was organized into 10 districts, each headed by a District Engineer. At the Washington headquarters level, all of the existing divisions were grouped into two branches-the Engineering Branch and the Management and Economics Branch-headed by a Chief Engineer and a Chief of Management, respectively. In addition, two General Inspectors, independent of the branches, reported directly to the Director of OPRRE. This reorganization in fiscal year 1917 established the firist formal field structure of the OPRRE with delegated operating responsibility and authority.

Because of the large amount of forest road work in the West and the passage of the 1921 Federal Highway Act enlarging the Federal-aid program, a western regional office under a Deputy Chief Engineer, Dr. L. I. Hewes, was created in 1921 to supervise the work in the 11 western States and to dispose of a large number of routine matters without reference to Washington. In effect, the Western Headquarters, as it was called, was an extension of the Washington Office located in San Francisco. This permitted more efficient communication on matters needing the Secretary's approval and reduced travel costs.

Another organizational change made in 1921 to help meet the demands of the accelerating program, was to divide the Engineering Branch in Washington into a Division of Design to handle all applications and steps preliminary to the execution of the Project Agreement, including the review and approval of the plans, specifications and estimates (PS\&E), and a Division of Construction to monitor the construction work in progress, to check construction estimates (reimbursement claims) submitted by the States, and to monitor the maintenance of roads after construction. A Division of Control was also established to include all program and project accounting, budget activities, fiscal accounting, payrolling, purchasing, and equipment and supplies. By June 30, 1922, the staff of BPR had reached a total of 784, representing 297 in Washington and 487 in the field.
In fiscal year 1925 an office was established in Hawaii under the jurisdiction of the Western Headquarters and in fiscal year 1930, because of the reconnaissance survey proposed for the Inter-American Highway, an office was set up in Panama. Later division offices were established in each of the Central American countries. As of April 1930, the BPR had a total permanent staff of 976 persons, of whom 461 were engineers. ${ }^{31}$

An Eastern Parks and Forests District was created in January 1934 to handle all forest and park work east of the Rocky Mountains together with miscellaneous direct Federal construction work in the East for other Federal agencies.

The Federal-Aid Highway Act of 1944 authorized a greatly expanded postwar highway program providing authorizations for fiscal years 1946,1947 and 1948 at the unprecedented level of $\$ 500$ million per year, plus $\$ 25$ million per year for forest highways. Recognizing that a considerably larger staff and extensive decentralization would be necessary in the field, a major reorganization of the Public Roads Administration was initiated July 1, 1945.

In July 1953 a further decentralization move was taken to delegate approval authority to the lowest practicable level, thereby eliminating or reducing the duplication of checking and reviewing project documents at the successive layers of organization. This delegation went to the BPR District Engineer in each State for final approval of plans, specifications and estimates.

The Inter-American Highway which today is complete except for the segment in the Darien Gap between Panama and Colombia.

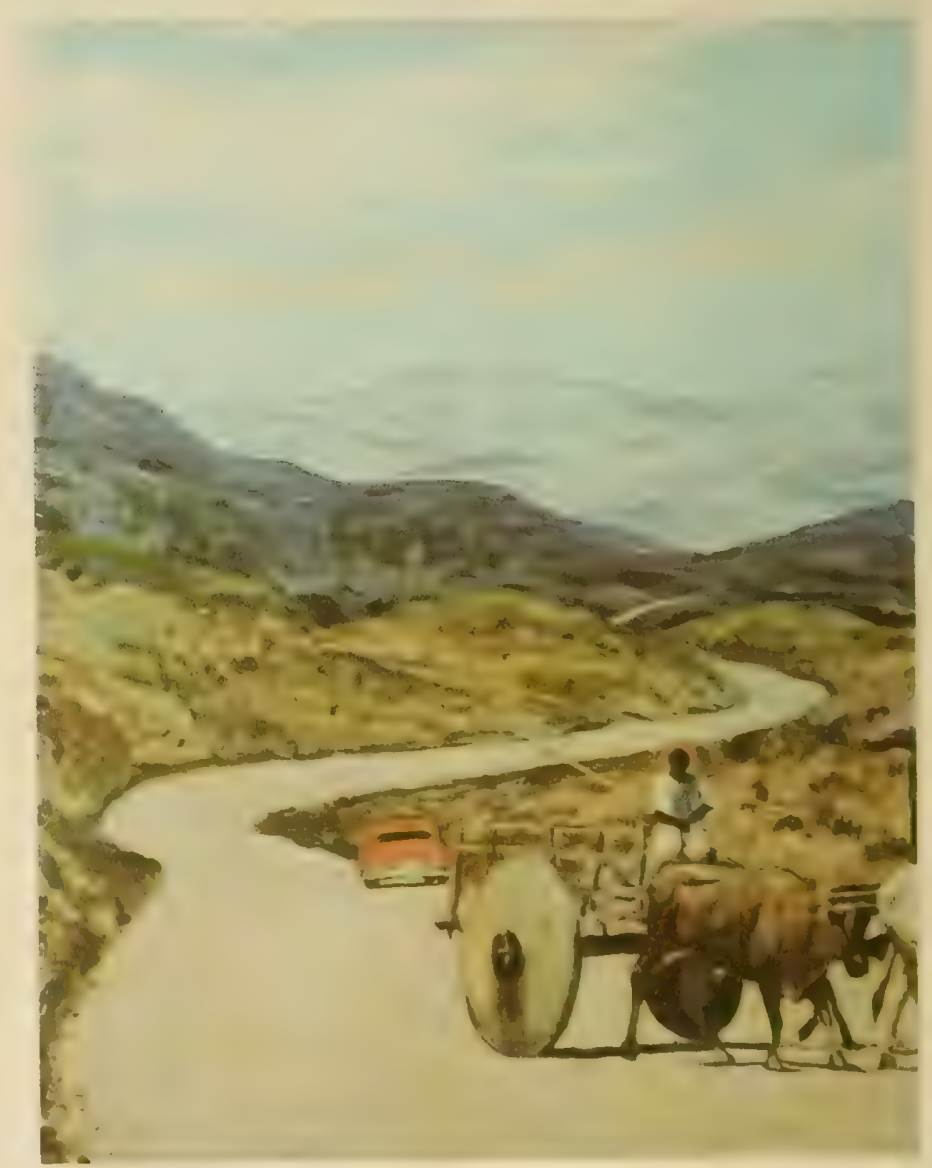




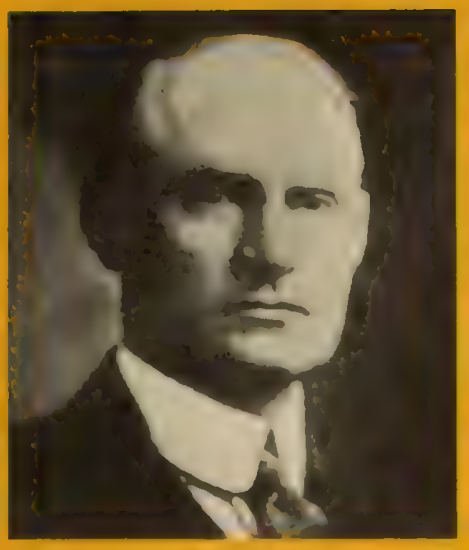

It wasn't idle flattery when the Engineering News-Record roforred to Maurice Owen Eldridge as an "engineer and road expert" in announcing his death on April 28, 1951, at age 77. The announcement further stated Mr. Eldridge, who was called "M.O." had retired in 1946 after 52 years as a roadbuilder.

"Road expert" was the official title given to key staff members of the Office of Road inquiry in its early days. Few were as well-qualified to hold it as M.O. Eldridge.

He was proficient in many fields: roadbuilding, road research, highway economics, highway finance and taxation, highway safety, promotion of good roads, and program administration. He was a well-known lecturer, an author and editor of reports, articles, and technical papers.

Eldridge was a man of broad vision, strong convictions, great zeal, dedication, and dogged determination. These good qualities sometimes got him into trouble with his superiors, but subsequent events nearly always vindicated him.

His dream of good roads was based on good common sense and sound economics. He not only lived to see it come true, but was an active participant in its fulfillment.

Basically, his dream was that the Federal Government and the States would join together in a cooperative program of road improvement. This dream became a reality with the enactment of the Federal Aid Road Act on July 11, 1916.

Eldridge was an active participant in developing rules and regulations for implementing the new program and in preparing much of the background information which eventually led to the passage of the Federal Highway Act of 1921.

M.O. Eldridge was born July 3, 1873 , on a farm near Lenoir, Tenn. Many anecdotes are told about Eldridge, some verifiable, some not.

He went to a $\log$ schoolhouse where the seats were made by splitting logs in two and the flat sides were used as seats and backs. His teacher was a Baptist preacher named Pope who believed that, in addition to being taught such classical subjects as Greek and geometry, his students should be taught manual dexterity. He showed them how to make their own compasses and to use poke and other berries from the nearby woods to color designs they had traced. Eldridge's interest in drawing and drafting got him his first job in 1894 with the Office of Road Inquiry in Washington, D.C.

While attending the University of Tennessee, Eldridge's talents came to the attention of University President Charles W. Dabney who shortly became the Secretary of Agriculture. The Department of Agriculture was a small organization and when a man was wanted to draw some maps, Secretary Dabney knew the right individual to get and that is how M.O. Eldridge began his roadbuilding career at a princely salary of $\$ 60$ a month.

Returning to Washington from a trip to Tennessee, M.O. was looking pensively out the train window at the drab, sodden countryside on a rainy November day in 1902, when the train stopped at Jonesboro in eastern Tennessee. He saw an acquaintance, Congressman W. P. Brownlow, board the train. They got into a conversation with another passenger, District Judge Hal Haines, who joined them on the train at Bristol.

The subject of conversation turned to the deplorable condition of the roads; inspiration was the view outside the train windows.

What could be done to improve them? Eldridge pointed out that most rural and small-town residents took such paralyzing road conditions for granted, not knowing how to go about improving them. But, said Eldridge, improvement was possible, and, in his opinion, the Federal Government should not only take the initiative in showing the people how to build good roads, it should cooperate with them in doing it. 
He cited as an example an operation in New Jersey under which the State cooperated with counties and local units in financing and building "mainline" intercity roads.

Both Representative Brownlow and Judge Haines agreed with Eldridge's position. The Congressman then directed Eldridge to draft a bill that would incorporate his ideas and Representative Brownlow would introduce it.

So M.O. Eldridge went back to his Government desk, outlined the plan to his chief, Martin Dodge, who approved. They rewrote the New Jersey law to fit the national situation. Mr. Brownlow introduced the bill and thus was sown the idea of Federal-aid roads.

The speech was made in January 1903 and was printed in the Congressional Record. It attracted a lot of attention and found supporters, but not in the Administration. The leaders in the Congress were against it. The Administration was against it. James Wilson, then Secretary of Agriculture, was against it.

Then one day a telegram was delivered to the Roads Office for Eldridge. It was signed by $\mathbf{A}$. R. Shattuck who requested Eldridge to come to New York to see him.

Shattuck was an executive of an organization that had just come into existence-a forerunner of the American Automobile Association. This organization believed in the idea of Federal aid for good roads. And it wanted to help the idea along. What could it do?

Eldridge suggested the greatest need was to educate the public. Eldridge was provided $\$ 10,000$ a year for publicity. He said he couldn't do anything through the Roads Office but something might be accomplished outside.

The arrangement was made. Eldridge hired an office, a publicity man and a stenographer.

The major promotion campaign was to have a million copies of the Brownlow speech printed at cost by the Government Printing Office, as can be done in such cases. These were mailed out under Government frank by friendly congressmen to a million people. On a single day a solid carload of mail went out of Washington.

It was a thorough campaign. The people responded and Congressmen were showered with questions on good roads from their constituents.

Questions arose on who was responsible for this campaign.

Finally, it was found out that M.O. Eldridge was responsible. $\mathrm{He}$ was called in on the carpet and summarily dismissed from service.

He was a sacrifice for this early advocacy of a policy that a dozen years later became a national enthusiasm in the passage of the 1916 Act.

Eldridge's friends in Congress went to bat for him and they succeeded in getting him reinstated - at a reduced salary and loss of his rank as second in command in the office.

Eldridge might have directed the office, but he had pushed a right idea before its time.

When the United States entered World War I, Eldridge and the entire staff of the Office of Public Roads and Rural Engineering were diverted from peacetime activities to supporting the war effort.

For example, he and Prevost Hubbard of the Office staff served as Public Roads representatives on a subcommittee of the United States Highway Council which reviewed 7,307 applications for approval of road construction projects between June 18 and December 31, 1918.

M.O. received many commendations for the work he did.

One of his assignments with the Office of Public Road Inquiries was to construct experimental and demonstration roads, using locally available materials. Ernest F. Acheson, member of Congress from Pennsylvania, wrote on February 1, 1901, concerning a demonstration road built under Eldridge's direction in Washington County, Pennsylvania:

I wish to say that the experiments made. . last fall under the direction of Mr. Eldridge awakened a deep interest among the farmers, and has done a great deal to promote the cause of good roads.... 
In 1919 he joined the Washington staff of the American Automobile Association. He served in many capacities, including editor of the Association magazine, American Motorist; Director of Roards, AAA Good Roads Board; and subsequently, Executive Chairman of the Association.

Leaving the AAA in 1925, Eldridge joined the staff of the District of Columbia government to become the first Director of Traffic for the City of Washington. At the time of his retirement on December 31, 1946, he was the Assistant Director of the D.C. Department of Vehicles and Traffic.

Eldridge was a prolific writer. Mention of only a few of his efforts will indicate the breadth of his interests in highway matters.

For the 1899 Yearbook of the U.S. Department of Agriculture he wrote on the "Progress of Road Building in the United States." To Historic Highways of America, volume 15, entitled "The Future of Road-Making in America, A Symposium by Archer Butler Hulbert and Others," published in 1905, he contributed Chapter III on "Good Roads for Farmers."

He provided two articles for the Third Annual Edition (1922) of the Highways Green Book, published by the American Automobile Association. These related to "Highway Financing and Taxation" and "Accident Prevention Suggestions." Part II of the 1925 Proceedings of the National Safety Council contains a paper by him on "Traffic Control Systems." Also, the 1935-36 Convention Proceedings of the American Road Association includes a paper he prepared on "Should Pedestrian Traffic Be Regulated?" 


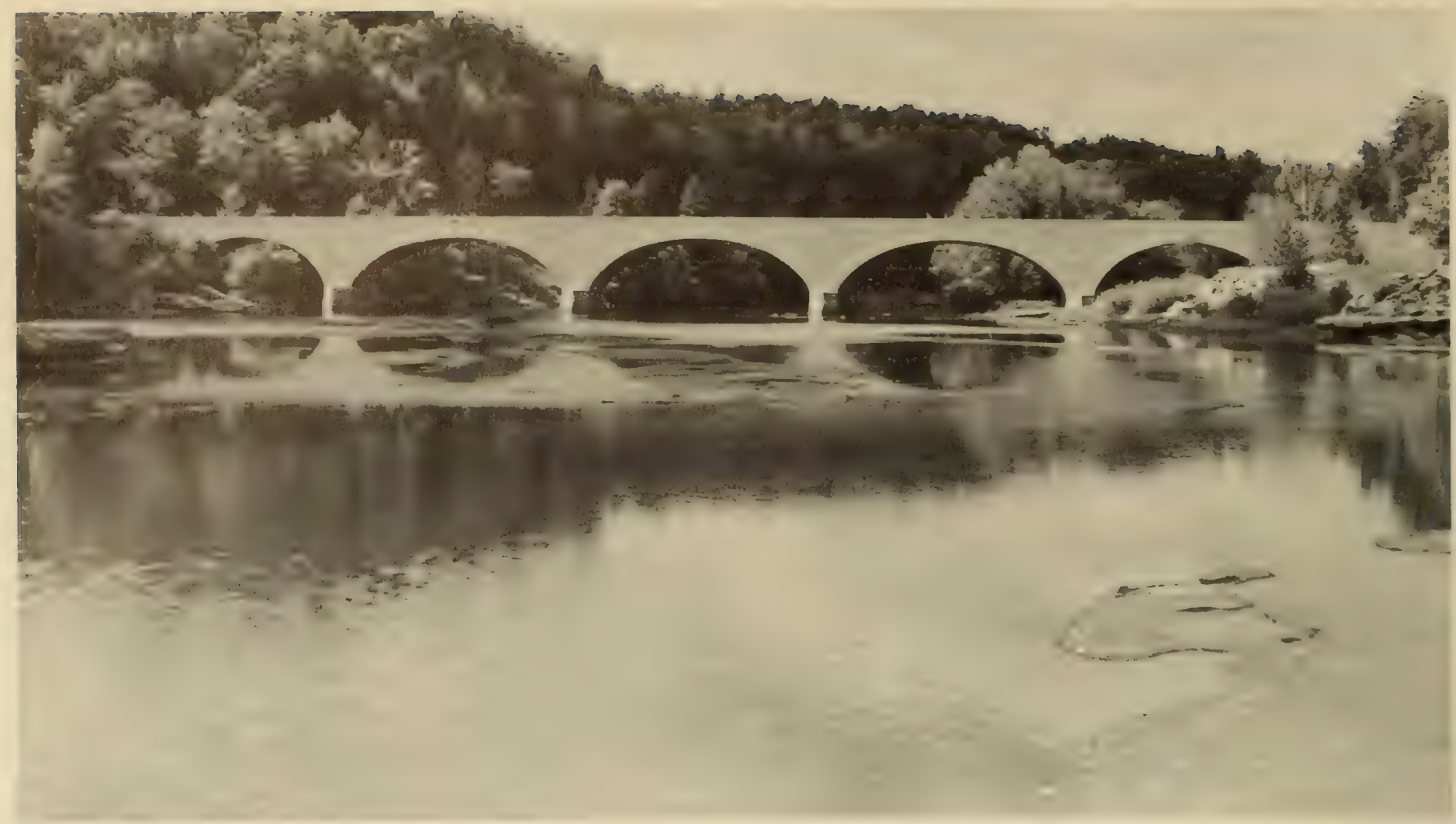

The Edward $M$. Gatliff Memorial Bridge is on Kentucky route 90 at Cumberland Falls, Ky. It was completed in1954 to replace a ferry crossing operation. The stone facing was obtained from a local quarry.

Early in 1955 it seemed apparent that Congress would soon enact legislation which would provide funding authorizations for the construction of the Interstate System which had been designated in 1947. The contemplated workload and manpower needs for such a program were staggering. Since an adequate supply of qualified engineers was not then available to administer the program, a task force was appointed to study the problem and develop recommendations. As a result of the studies, the field structure again was reorganized and further redelegation of responsibilities and authorities was given to the field offices. This decentralization to the field was the most important and beneficial change made by BPR in its administration of the highway program since the creation of the first operating field offices in 1917. The total BPR employment as of June 30, 1956, totaled 3,646 , a reduction from the postwar peak of 4,239 as of June 30,1949 .

In June 1957 a very important functional addition was made in the Washington headquarters by the creation of a Project Examination Division in the Office of Administration. The new division initiated a broad internal and external management audit program in BPR designed to ensure compliance with program policies and procedures as well as to monitor program effectiveness and integrity at both the Federal and State levels.

In December 1961, as a result of a consultant's study of the program's management and operations undertaken in 1960, an Office of Planning was established as a separate unit. Previously this function was combined with research. The separate office greatly strengthened the planning function in BPR and speeded the implementation of the $3 \mathrm{C}$ planning process when it became a requirement in the 1962 Federal-Aid Highway Act. By now the total full-time employment of BPR was 4,521, including 206 temporary employees and 188 stationed in foreign countries.

During the next several years broadening program responsibilities and functions were to make rather frequent reorganizations of the Washington headquarters necessary. For example, a reorganization in 1962 created an Office of Right-of-Way and Location to assume functions formerly a responsibility of the engineering staff. A very significant change in terms of program development was the creation of an Office of Audits and Investigations by transferring the Project Examination Division and the external audit functions of the Finance Division from the Office of Administration.

It became necessary to add certain specialists to the organization over the years as the requirements of the various highway acts and other legislation affecting the highway program were enacted by Congress, and the Bureau became something more than just an engineering organization to oversee the construction of highways. These specialists included economists, landscape architects, real estate appraisers, behavioral scientists, planners, historians, ecologists, contract specialists, safety experts, and civil rights specialists. By December 31, 1966, total employment was 4,839, including temporary employees and 157 persons in foreign countries.

The Department of Transportation Act enacted October 15, 1966, consolidated more than 30 transportation agenices or functions that had been scattered throughout the Government. At its inception, the Department encompassed more than 90,000 employees and an annual budget of approximately $\$ 6$ billion, 
the bulk of it being $\$ 4$ billion of highway programs. ${ }^{32}$ The purpose of the Act was:

The Congress therefore finds that the establishment of a Department of Transportation is necessary in the public interest and to assure the coordinated, effective administration of the transportation programs of the Federal Government; to facilitate the development and improvement of coordinated transportation service. . .

On April 1, 1967, the Bureau of Public Roads became a bureau within the Federal Highway Administration (FHWA) in the new Department. Other functions transferred to FHIVA were the regulatory motor carrier safety functions from the Interstate Commerce Commission and the highway safety and the traffic and motor vehicle safety functions created by congressional legislation in 1966 from the Department of Commerce. The other organizational elements of the new Department of Transportation (DOT) were the Federal Aviation Administration, Federal Railroad Administration, U.S. Coast Guard, and the St. Lawrence Seaway Development Corporation. The Urban Mass Transportation Administration was transferred to the Department from the Department of Housing and Urban Development on July 1, 1968.

As of December 31, 1967, the end of the first calendar year following creation of the new FHWA, its employment (including the three bureaus-Public Roads, Motor Carrier Safety, and the National Highway Safety Bureau) totaled 5,366, including temporary employees and 140 persons in foreign countries.

In March 1970 the National Highway Safety Bureau was separated from the Federal Highway Administration to become the seventh DOT operating administration and was renamed the National Highway Traffic Safety Administration. All of the Safety Bureau's functions went with it except that responsibility for specified highway-oriented safety standards assigned to the Federal Highway Administration.

With the separation of the National Highway Safety Bureau, FHIVA again was reorganized. The reorganization that became effective August 10, 1970, abolished the "Bureau of Public Roads" as an identifiable separate organizational component of FHWA. Instead of the former bureau structure, FHWA was divided into six new components made up of Planning, Research and Development, Right-of-Way and Environment, Engineering and Traffic Operations, Motor Carrier and Highway Safety, and Administration, each to be headed by an Associate Administrator. Staff offices directly responsible to the Administrator were the Offices of Chief Counsel, Program Review and Investigations, Public Affairs, and Civil Rights, each headed by a Director. In 1971, the National Highway Institute was added as the fifth staff office.

From August 1970 to March 1975, there were continual minor organizational changes in the Federal Highway Administration to keep abreast of the everbroadening scope of FHWA's programs and responsibilities. However, the total employment of FHWA as of December 31, 1974, was 5,134, including temporary employees and 39 persons in foreign countries and 28 persons in territories of the United States. Comparing the 1974 employment level with the 784 employees in June 1922 when the Federal-aid highway program was just getting underway and the growth of a program from $\$ 80$ million at that time to over $\$ 6$ billion in 1974, the current level of staffing is remarkable in terms of efficient program administration.

\section{The Operational System}

In order to proceed with the implementation of the program provided by the Federal Aid Road Act of 1916, much had to be done at both the State and Federal levels. As mentioned earlier, the States had to enact legislation to satisfy the administrative requirements of organization, authorities, methods of financing the new Federal-aid matching requirements and future maintenance responsibilities, and the administrative and financial relationships with the States' local governmental subdivisions.

At the Federal level, the small Office of Public Roads and Rural Engineering (OPRRE) had to develop the implementing rules and regulations required by the $A$ ct and develop the necessary plan and organization for its role in administering the program, not only in the Washington Headquarters, but also at the field level in all the States.

The initial project procedures that were established under the Federal rules and regulations for the administration of the Federal-aid program were relatively simple and direct. These procedures included:

- A Project Statement or application was submitted to the OPRRE District Engineer describing the location, nature and estimated cost of the work. Upon review and an onsite inspection by the District Engineer, he forwarded the Project Statement with his recommendations to Washington for review by the Engineering Branch of the OPRRE and the approval by the Secretary of Agriculture.

- Upon approval, the State was authorized to proceed with the preparation of detailed plans, specifications and estimates (PS\&E). The District Engineer reviewed the PS\&E and made another onsite inspection with "plans in hand," and forwarded everything with his recommendations to Washington for final review and approval.

- A Project Agreement was prepared for signature, first by the authorized State official and then by the Secretary of Agriculture, which represented the contractual agreement between the State and Federal Government. The Project Agreement established the maximum amount of the Federal participation and the State's responsibility for adequate maintenance of the completed project. When this document was executed, the State was free to proceed with construction.

- Direct supervision of the construction was the responsibility of the State. However, a staff member of the OPRRE District Office made monthly inspections and reported his evaluation of the work to Washington. These reports were used as the basis for approval of requests for progress payments to the State. Progress payments could not exceed the Federal share of the cost of the work and materials actually put in place in accordance with the plans and specifications.

- Upon completion of the project, the OPRRE District Engineer made a final onsite inspection 
and prepared a detailed final inspection report for the Washington office. The final payment of the remaining Federal share of the project costs was contingent upon the final acceptance of the work by the District Engineer.

- Maintenance, the State's responsibility with no Federal funding, was monitored by the ORPPE District Engineer's staff through annual inspections and reports to the Washington office. At the local level, deficiencies were discussed and corrective action was normally initiated promptly by the State.

The project costs not eligible for Federal participation were:

- Administrative costs of maintaining the State highway department and its staff, except those direct costs involved in providing the engineering supervision of the work after construction was initiated by contract or the actual costs of construction by force account (costs of labor, equipment, materials and overhead).

- Cost of surveys and preparing the plans, specifications and estimates.

- Costs of advertising projects for construction by contract.

- Costs of necessary right-of-way related damage costs.

- Costs incurred as a result of acceptance of other than the lowest bid unless the acceptance of a higher bid was justified and concurred in by the Federal agency.

- Costs of work not included in the approved PS\&E or changes that were not approved by the Federal agency.

- Engineering inspection and contingency costs in excess of 10 percent of project estimate.

- Costs in excess of the amount provided for in the Project Agreement.

After enactment of the Federal Highway Act of 1921, two significant changes were made in the rules and regulations: (1) Because the States were required in 1921 to designate a limited State highway system of main roads, Project Statements submitted by a State for proposed construction thereafter were limited to routes or sections of routes that were a part of the approved system and (2) when the PS\&E for an approved project was recommended for approval by the local Federal District Engineer, the State was authorized to proceed immediately with initiating the steps leading to construction.

In addition to selecting their Federal-aid systems, each State was required to prepare an annual program of those specific highway improvements it wished to undertake with available Federal assistance during the year and their costs. This measure was required to assure an orderly development of projects.

Another step not mentioned in the foregoing was the requirement that if a project was to be built on a new location, rather than an improvement of an existing road, the State would have to study alternative locations to decide the best route and the most economical type of road to construct. In the early days of the program, this step did not come up too often because the major portion of the work was the improvement of existing roads. However, the location of a new road was another item needing Federal approval before the project could be designed. The project design might also have several alternative designs in order that the most economical and serviceable product could be obtained.

These procedures were relatively simple and remained so until the 1950 's. The separate roles of the States and the Federal Government in the step-by-step project procedures that were thus established set the basic pattern for the cooperative administration of the Federal-aid program. For many years thereafter an evolutionary period existed during which the States and Bureau of Public Roads (BPR) were continuously developing methods and ways to improve, simplify and expedite the movement of projects through the various steps. Some of the more important efforts and actions taken were:

- The authority of the States to proceed with construction upon recommendation of the District Engineer was extended to include subsequent major revision of the plans, even when the changes would require additional Federal-aid funds.

- Arrangements for "sectionalizing" projects were developed to give the States wide latitude in placing work under contract by sections and completing sections independently of each other. At the same time, the number of Project Statements and Project Agreements was substantially reduced.

- Project Agreements were prepared in Washington for the signature of the Secretary before they were sent to the State for signature to expedite subsequent Federal payments.

- A separate division was established in the BPR Washington office to handle the review and approval of Federal-aid payment vouchers; a minimum voucher amount of $\$ 1,000$ was established; and, to avoid sending vouchers back to the States for correction of small errors, a practice was adopted using a 5 percent retent or withholding to cover as many of these errors as possible.

- The principle of using stage construction on Federal-aid construction was adopted, e.g., approval of a project for grading and drainage only, with deferral of paving until a later time when justified.

To assure uniform quality of the roads and to speed up the detailed work, both at the State level and the Federal level, some standardization was needed:

- Standard specifications and format were developed by most States, eliminating the need for the development and submission of individual specifications for each project.

- Standards were developed jointly between State and BPR engineers for uniform methods of sampling, testing and reporting on road materials, and the standards were published in a department bulletin.

- Through AASHO committee action, minimum design standards were developed for various classes of roads and structures.

- Standard forms of various types were developed and approved for use, such as bid forms incor- 


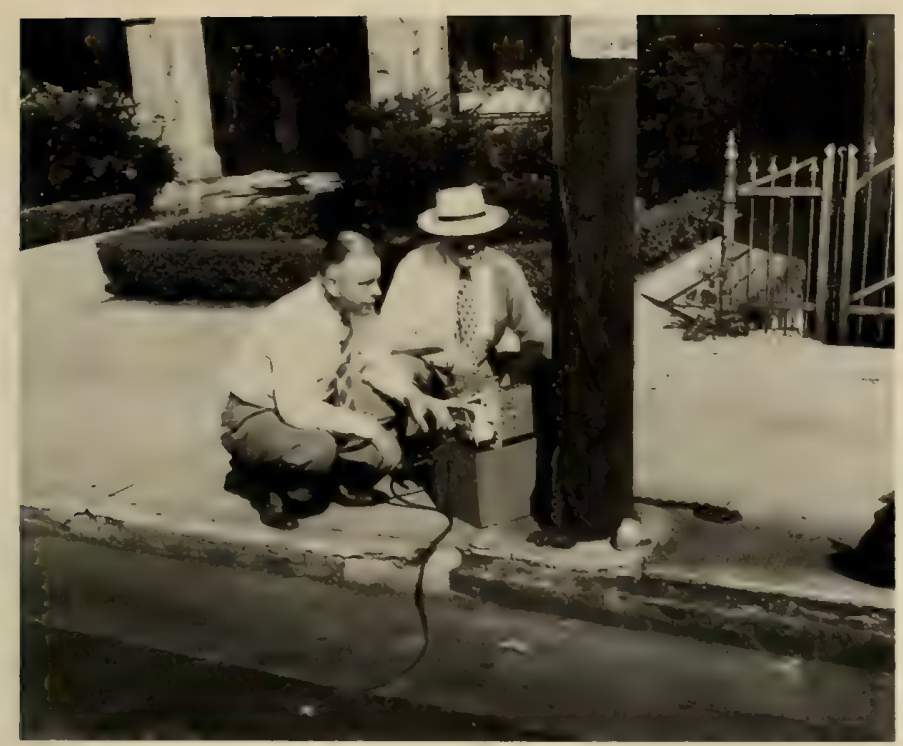

BPR officials examining a traffic counter in the late 1940's. Traffic volume is often a factor in determining highway needs.

porating required general provisions, contract forms, performance and payment bonds, contractor qualification forms, Project Agreement forms, etc.

While the basic principle of State initiation and Federal review and approval remained intact, the continuing enactment over the years of new highway legislation with new programs and new provisions inevitably led to increasingly complex step-by-step project procedures to a degree that never could have been imagined in 1921 .

With the passage of the 1956 Federal-Aid Highway Act came new procedural requirements which were inserted into their logical sequence of project steps to obtain Federal approvals.

The first of these was the requirement to hold public hearings, originally called for in the 1950 Federal-Aid Highway Act for highway projects bypassing a city or town, but later extended to all Federal-aid projects to be responsive to the goals and objectives of the local community. The term "public hearings" is always used in the plural because, although at first it was required only at the corridor or location stage, for many years it was administratively determined that a second public hearing was necessary at the design stage. In recent years a more flexible approach permits the requirement for public participation to be met in whatever way is considered most suitable in a specific situation.

Another procedural change resulted from a provision in the 1956 Highway Act that permitted Federal reimbursement for costs of relocating public or private utilities. Accommodation of utilities within the rightof-way is permitted as long as they do not hamper the safe flow of traffic.

The 1956 Act also required that the Davis-Bacon Act of 1935 would apply to Interstate projects. This involved the preparation and Federal approval of minimum labor wage rates to be paid to contractor construction employees on an individual project basis. The minimum rate is established by the U.S. Department of Labor and varies by geographic area. Later, the 1968 Act required extension of the Davis-Bacon coverage to all Federal-aid highway projects.
By 1962 highway projects in cities were numerous and concern for the integration of the highway with other modes of transportation, with the growth of the cities, and the potential needs of the future came to the fore. Federal assistance for planning had been available since 1934 , but in 1962 , legislation required that after July 1965 all Federal-aid highway projects within urban areas of more than 50,000 population must be based on the results of a continuing, comprehensive, cooperative transportation planning process. Planning was extended further in 1968 by the Intergovernmental Cooperation Act which, as implemented by the Bureau of the Budget BOB, ${ }^{*}$ in Circular A-95, Notification Procedure, required that all proposed highway projects be submitted to State and areawide clearinghouse agencies for review and comments. The aim was to insure that all Federal and federally assisted projects were coordinated with the development plans of other public agencies. Thus, two general procedures were added to the already growing requirements before any physical work could begin on a highway project.

Another emerging social concern in 1962 was the plight of those persons required to move because of highway construction. At first the States were required to provide counseling for those whose property or dwelling place was taken, but in 1968 limited financial reimbursement was authorized. In 1970 the Uniform Relocation Assistance and Real Property Acquisition Policies Act was passed to protect the displaced people, and Federal review and approval were required before right-of-way could be taken on any Federal-aid project.

Over the years concern had been developing for preserving our social, cultural and historical heritage. As early as 1956, Federal funds could be used for archeological paleontological salvage. However, in 1966 the Department of Transportation Act mandated protection of parklands, historic sites and other public conservation lands. Although this provision does not apply in the vast majority of highway projects, where taking these types of lands is contemplated, it results in considerable extension of preconstruction planning and review time.

Since about 1965 not only the number of categorical highway programs have increased, but also the highway-related considerations involved in carrying out highway programs. As a direct consequence of the Nation's changing social values and quality of life standards, Congress enacted legislation responsive to the increasing demands of those adversely affected by highway locations. Much of this legislation necessarily had an impact upon the highway program and the complexity of its administration. Some of the pertinent legislation included:

\section{Civil Rights Acts of 1964 and 1968}

Highway Beautification Act of 1965

National Environmental Policy Act of 1969

Uniform Relocation Assistance and Real Property

Acquisition Policies Act of 1970

Clean Air and Noise Control Acts of 1970

Equal Employment Opportunity Act of 1972

* Now known as the Office of Management and Budget (OMB). 


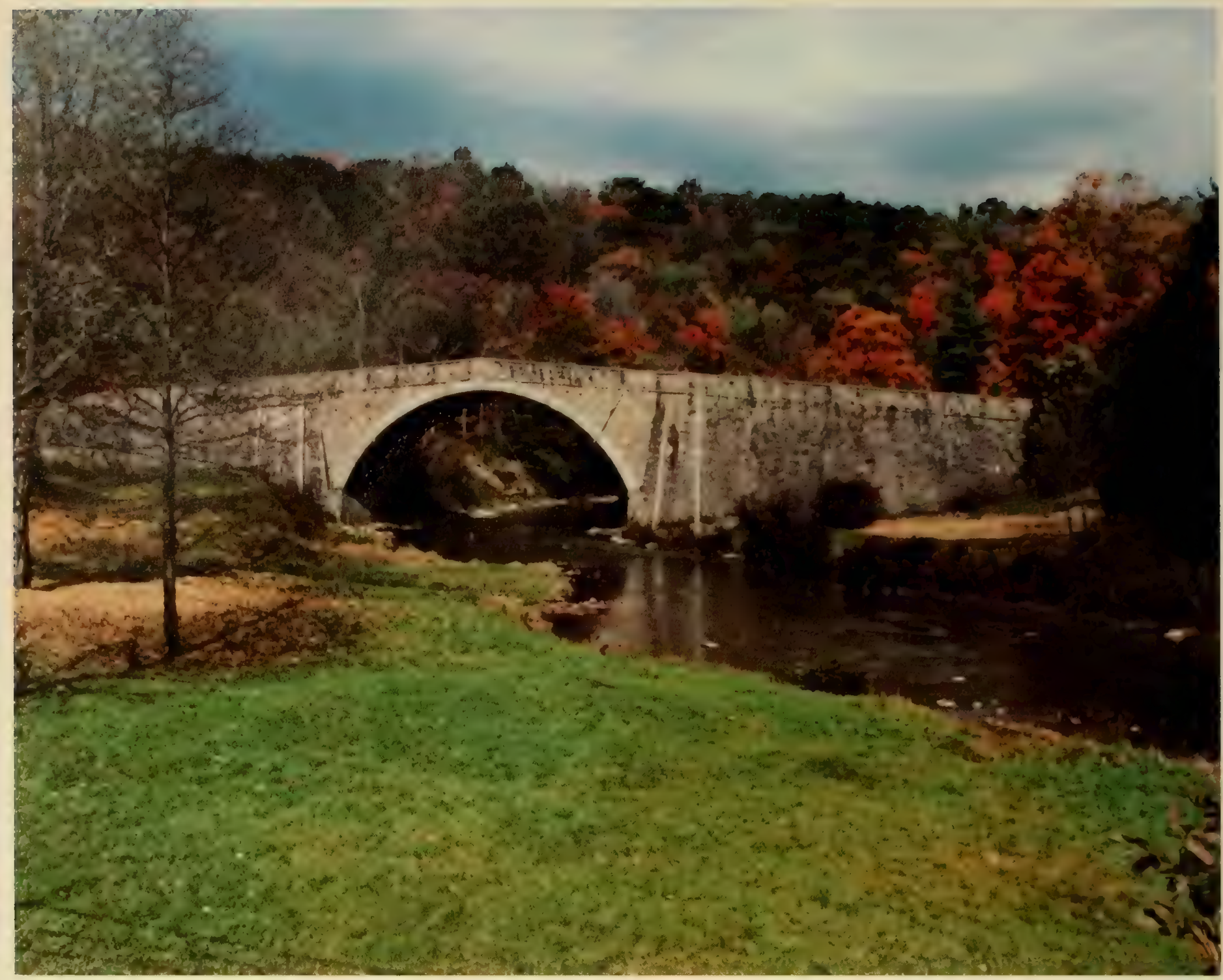

The Casselman River Bridge, built in 1813 on the National Road near Grantsville, Md., has been preserved as a historic site.

When the 1964 Civil Rights Act was passed, it prohibited discrimination on the grounds of race, color, creed or national origin under any program or activity receiving Federal financial assistance. (In 1973 the Highway Act added, for the first time, prohibition of sex discrimination.) The 1964 Civil Rights Act and Executive Order 11246, promulgated in 1965 , led to the eventual establishment of a formal civil rights and equal employment opportunity (EEO) program within FHWA. The development of this program was slowed by the fragmentation of internal and external concerns. In the beginning, the internal concerns were assigned to the Office of Administration and the external concerns to the Office of Audits and Investigations.

Two important factors contributed to the advancement of the agency's civil rights and equal opportunity program. Congress enacted, as part of the Federal-Aid Highway Act of 1968, the requirement that States submit assurances that employment and training in connection with proposed Federal-aid projects would be provided without regard to race, creed, or national origin. This legislation was followed in January 1969 by civil rights and equal opportunity hearings held by the Subcommittee on Roads of the Public Works Committee of the Senate. As a result of these hearings, the Senate Subcommittee made several recommendations. Foremost among these recommendations was that the Federal Highway Administration should assume leadership in showing to all levels of the agency and the States the importance attached to equal employment opportunity efforts.

In response, FHWA took three important steps. First, the Administrator appointed a Special Assistant for Equal Opportunity in March 1969. Second, he created the Office of Civil Rights in June with responsibility for both internal and external concerns. Third, he elevated the former Special Assistant to Director of the new Office of Civil Rights.

The newly established Office began monitoring FHWA's own internal employment practices and established and maintained minority group statistics. The initial operations of the Office were strengthened by the issuance of Executive Order 11478 in 1971 which served as the basis for the development of affirmative action plans and procedures for processing discrimination complaints and EEO counseling activities. This led to the formation in 1972 of an Internal Division with a system for self-evaluation. 


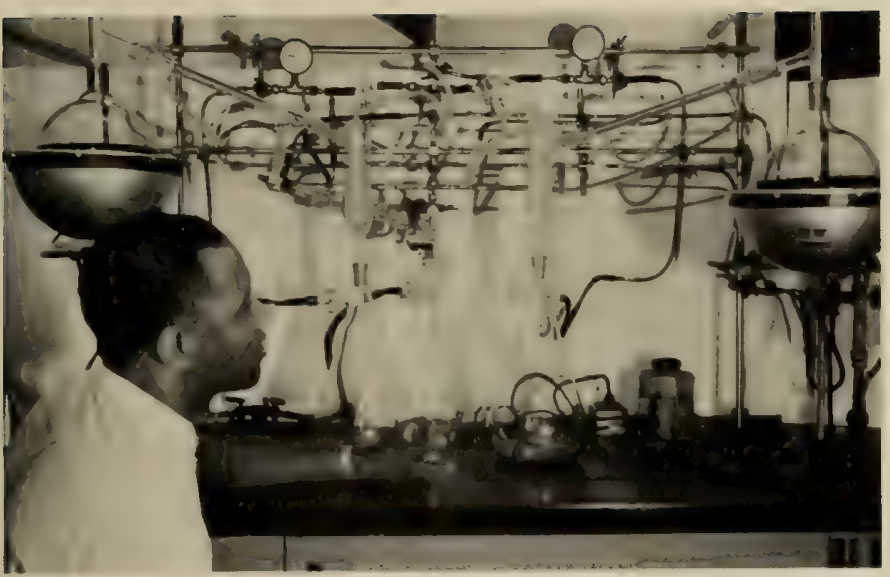

To study the behavior of asphalt in service, an FHWA analyst is using a racuum distillation technique to remove the bulk of the solvent from solutions of asphalts extracted from pavements.

The FHWA Federal Women's Program was established in 1971 . In the early part of 1974 , the SpanishSpeaking Program was established to deal with the employment concerns and problems of Hispanics employed by the FHWA.

Meanwhile two major changes in the EEO civil rights program took place. First, the 1970 FederalAid Highway Act gave the agency authority to add on-the-job training aimed at furthering equal employment opportunity. Goals were set for specified numbers of persons to receive training on selected construction projects, and supportive services for on-the-job training were provided the following year. Second, the Department of Transportation published rules and regulations in 1970 to implement Title VI of the Civil Rights Act of 1964 prohibiting discrimination based on race, color, or national origin in federally assisted programs.

Because of FHWA's highly decentralized organizational approach, most of FHWA's EEO responsibilities are carried out at the field level. The Headquarters develops overall policy and monitors the results through review of reports of Title VI and Title VIII (Fair Housing) activities, contract compliance, special programs (minority business enterprise, summer youth opportunity program, on-the-job training, and supportive services), and the internal employment practices of FHWA offices. The FHWA Headquarters and field EEO staffs also make onsite Federal-aid project reviews and onsite reviews of State highway agencies.

In FHWA's direct construction program, directives were issued specifying that a clause be included in all contracts requiring contractors to take affirmative action to recruit and employ the disadvantaged, including minorities and women, and to achieve positive equal employment opportunity results on construction projects. These directives were followed by additional procedures for monitoring and evaluating the contractors ${ }^{6}$ compilance with EEO.

In June 1973, a directive to implement the Minority Business Enterprise Program was issued. This directive requires that, where feasible, direct Federal projects shall be set aside for contract negotiation and subsequent award to a minority-owned firm under the requirements of section 8 (a) of the Small Business Act of 1958 (P.L. 85-536). The FHWA field and Headquarters offices have taken the initiative to implement this program to develop minority contractors with the capability to perform highway construction or perform highway research studies.

Since 1899 when the River and Harbor Act was passed requiring permits to build bridges over navigable waters, coordination, consultation or receipt of permits from other agencies has been required for highway projects as the result of various legislation. In 1958 the Fish and Wildlife Coordination Act was passed, in 1966 the Historic Preservation Act, and in 1968 the Wild and Scenic River Act. Since then many new acts and requirements have emerged, such as:

Federal Water Pollution Control Amendment of 1972

\section{Coastal Zone Management Act of 1972}

Marine Protection, Research and Sanctuaries1972

\section{Endangered Species Act of 1973}

Archeological and Historic Preservation Act of 1974

As their titles imply, these requirements protect navigable waterways, marine and animal wildlife, the physical environment, air and water pollution impacts, floodplains, etc. This is not a complete list, but it does indicate the extent of Federal safeguards against undesirable impacts. Compliance with these new legislative requirements is very time consuming and may take up to 18 months to accomplish. This is one of the reasons why it takes much longer now from conception of a highway project until it is completed and open to traffic. It should be pointed out that all of these specific coordination and permit requirements are in addition to the basic environmental impact evaluations required for all highway projects since 1970 .

As may be presumed, the Federal-aid highway program has not been without its legal complications which ultimately have wound up in courts of law. For example, a legal issue arose out of the Federal Water Pollution Control Act of 1972. Section 404 of the Act provided that permits from the Army Corps of Engineers would be required for dredge and fill activities in navigable waters. A District Court order in March 1975 interpreted the term "navigable waters" as meaning all waters of the United States and thus subject to the Corps of Engineers jurisdiction in regard to the need for section 404 permits. Since almost all highway projects touch some body of water in the expanded sense, this could conceivably include a need for a permit for a highway crossing wetlands or even a stream. Congressional hearings have been held to alleviate this problem, but to date no satisfactory solution has emerged.

As a result of the enactment in 1969 of the National Environmental Policy Act and related provisions contained in the 1970 Highway Act, each proposed highway project must be evaluated to determine its impact on the environment. The States were first required to develop and use an approved process to assure that 
adequate consideration was being given to possible social, economic and environmental effects of proposed highway projects. Guidelines were issued by FHWA, and the States developed Action Plans that document the process for assessing the environmental impacts. The Action Plan explains how social, economic, and environmental factors are identified and studied, how the assistance of a wide range of professional skills is obtained and utilized, and how interested groups and citizens are involved or can participate in the highway development process.

As an integral part of the location study process, the State highway department, in consultation with the FHWA Division Engineer, must first determine whether the highway project will be a major action requiring an evaluation of its potential environmental impact. For those projects found to be major under established criteria, a study will be conducted to see if the environmental impact is significant. If it is determined that a significant impact may occur, then a draft environmental impact statement (EIS) is prepared prior to corridor public hearings. The draft is distributed for comments to interested State and Federal agencies. After comments from the reviewing agencies and from the public hearings are available, a final version of the EIS is prepared and made available to the general public. The final statement insures that appropriate consideration has been given to the views expressed and to the anticipated effects. Only after the final EIS is approved can the route locations be approved. If it is found during the environmental evaluation that there is no significant impact, a negative declaration is prepared to document this conclusion.

In the beginning a major issue arose as to whether or not the States could prepare environmental impact statements under Federal supervision. At first the Second Circuit Court of Appeals said no, that it was the responsibility of the Federal Highway Adminstration to prepare the EIS's. Later this was changed by act of Congress to permit the States to prepare the EIS's under the guidance and supervision of the involved Federal agency.

Highway system statutory management requirements that do not involve Federal funding have expanded also since 1956. Initially, as already mentioned, the States were only required to properly maintain federally assisted projects. Since 1956 the States are also required to enforce maximum weight and width limits for vehicles operating on the Interstate System and to certify annually to FHIV $\mathrm{A}$ that they are doing so. In January 1975 a provision was added to highway law effecting a nationwide maximum speed limit of 55 m.p.h. for all public highways, and the States must certify annually that they are enforcing this speed limit. In addition, all States are required to have an approved highway safety program designed to reduce the frequency and severity of traffic accidents

A tranquil spot for fishing-one of over 100 lakes in the "Chain 0 Lakes" along I-80 in Vebraska. These lakes resulted from borrow pits, used during the highwall construction. They have since been developed into water oriented recreation areas and wildlife sanctuaries. and which must meet certain Federal performance criteria. Inventories of accident locations, bridge structural conditions and railroad-highway crossings are required to assure funding of highway priority needs. Each State must have a schedule for updating traffic signs, signals and pavement markings to meet uniform standards.

As the Federal Highway Administration turned its attention to the administration of the foregoing requirements, the States progressively assumed effective design and construction responsibility without close Federal supervision. This is the significant result of the successful Federal-State partnership.

\section{The Secondary Road Plan}

Legislation enacted in 1954 permitted the first major change since 1916 in the basic Federal-State roles in project procedures through the initiation of The Secondary Road Plan. Under the Plan, any State could request the Bureau of Public Roads to relinquish most of its engineering and administrative review and approval responsibilities for secondary road system projects by accepting a certification by the State that the projects had been designed and constructed in accordance with State standards and procedures established for general application to all projects on the Secondary System. To qualify for this procedure, a State had to submit its Secondary Road Plan for review and approval by BPR. The BPR review and concurrence actions under the Plan were limited to system changes, programs of proposed projects, program changes, project agreement, a final inspection, and a fiscal review and audit of voucher claims. All the States adopted this greatly simplified plan, although one State has since dropped it.

The philosophy behind the Secondary Road Plan was to let the States assume more independent responsibility and to permit the BPR staff to devote its principal efforts to the more nationally significant Primary System, including the National System of Interstate Highways which, it was anticipated, would soon be authorized funds. Secondary projects accounted for 30 percent of all Federal-aid projects administered by the BPR in 1954 prior to enactment of legislation permitting the Secondary Road Plan.

\section{Certification Acceptance}

The Secondary Road Plan not withstanding, by the 1970 's a growing sentiment was developing among the State highway administrators, FHWA officials, and the involved congressional committees that something had to be done to reduce the complexity and red tape that was rapidly growing in the administration of the Federal-aid highway program. At the same time, however, support for the protection of social values was becoming stronger and much more vocal. As it gained momentum, considerable anti-highway sentiment arose. The many additional controls, requirements, considerations and clearances added to the administration of the highway program in response to the public demands were inescapable.

Congress reflected its definite awareness of the problems by including in the 1973 Highway Act a new procedure called Certification Acceptance, an effort 


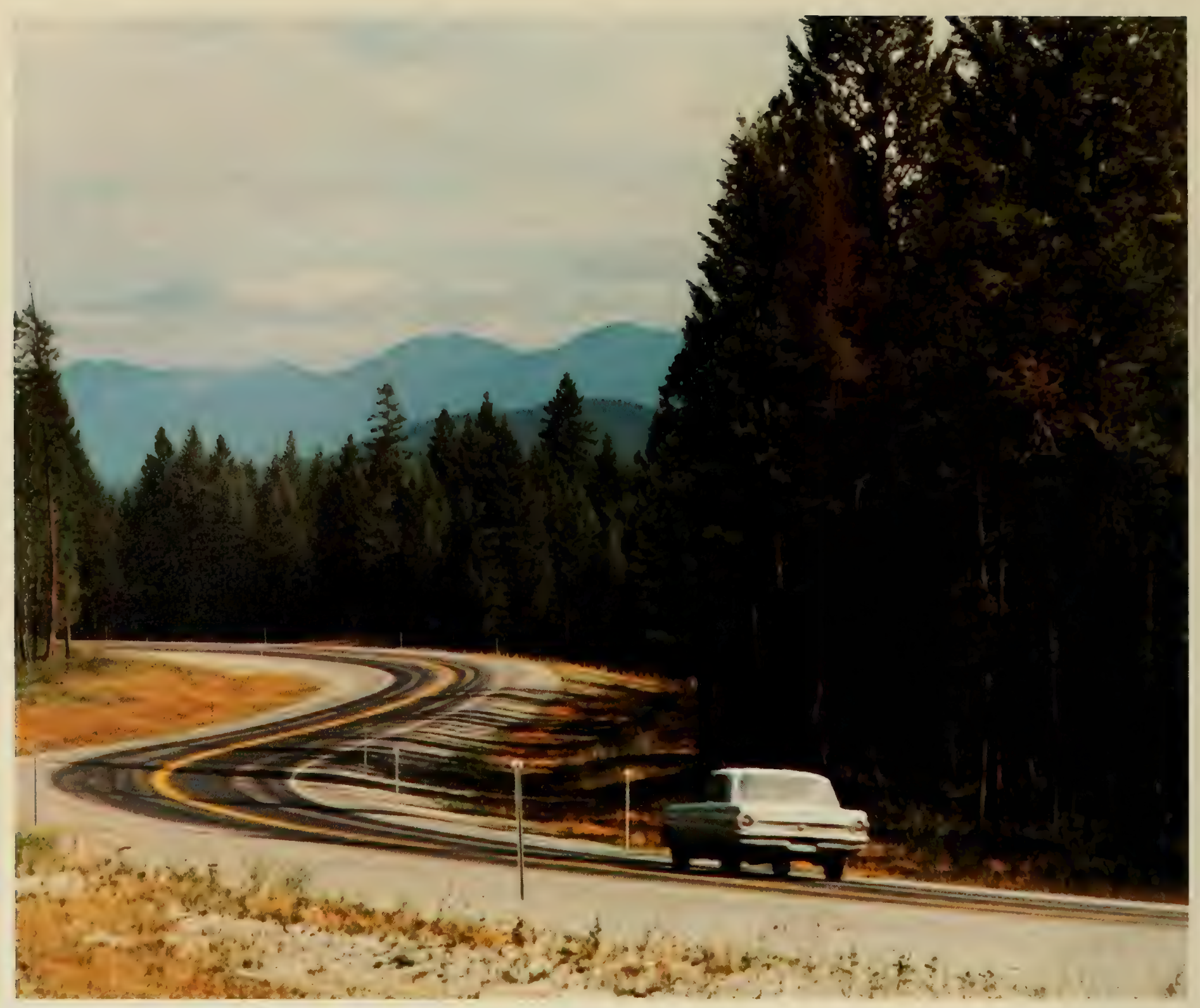

A secondary road project through the mountains of northwestern Montana.

to reduce FHWA monitoring of projects by extending the Secondary Road Plan concept to all projects on Federal-aid systems except the Interstate System.

The Certification Acceptance procedures superseded the highly successful Secondary Road Plan, but unfortunately, it did not succeed very well. The success of the Secondary Road Plan lay in the fact that the State was certifying that ". . . the plans, design, and construction for such projects are in accord with the standards and procedures of such State applicable to projects in this category ..." [italics supplied] which the Federal Government (Secretary of Commerce) had approved. The Certification Acceptance procedure required the State to certify that ". . . such projects will be carried out in accordance with State laws, regulations, directives, and standards establishing requirements at least equivalent to those contained in, or issued pursuant to, [title 23]." [Italics supplied.] Thus, Federal program demands and complexities still governed. It also prescribed that the new optional procedure would not affect or discharge any responsibility or obligation of the FHWA under any Federal law outside of title 23, U.S. Code, such as the environmental impact statements, right-of-way acquisition methods, relocation assistance, minimum wage rates, etc. None of the complexities were eliminated since the States had to have requirements equivalent to Federal laws. Because the secondary road system now came under the Certification Acceptance procedure, more work actually was generated. As a result, States did not elect to use Certification Acceptance procedures.

Congress then took another look at the situation, and in the 1976 Highway Act, the Certification Acceptance section of title 23, U.S. Code, was amended by striking out ". . . establishing requirements at least equivalent to those contained in, or issued pursuant to, this title" and substituting ". . . which will accomplish the policies and objectives contained in or issued pursuant to this title." In addition, the Act reinstated the Secondary Road Plan.

It is too soon to know just how or to what extent the amended Certification Acceptance procedure will be accepted by the States. However, the States and FHWA are continuing to work together to reduce paperwork, needless duplication, and unnecessary delays in administering the highway program, giving full recognition to the capabilities of State organiza- 
tions and the limited need for detailed Federal involvement.

The operational system or technical administration of the physical program is only half of the story of the management of the Federal-aid highway program. Since the Federal agency is responsible for protecting the Federal Government's investment in the highway program, the other half is concerned with the financial management of funds and the accounting for expenditures. This, too, involves very complex procedures that are not independent of the operational system procedures.

\section{Financial Management}

The system that has evolved over the years for authorizations, apportionments among the States, and the overall funding of the Federal-aid highway program has been prescribed largely by the Federal legislation. While it was developmental in the sense that its concepts were developed in bits and pieces, the basic rules or principles were established early in the history of Federal-aid legislation. The one major new element was the creation of the Highway Trust Fund in 1956.

The ground rules used in the legislative and financial administration of the program comprise the steps, principles, authorities, and limitations that must be followed in administering, or managing, the Federalaid highway funds that are made available by congressional legislation. The system is integrally related to the operational system; i.e., the technical administration of the physical program.

The system for the financial administration of the Federal-aid highway program is unique in relation to

\section{CONGRESSIONAL PROCEDURES (SIMPLIFIED, TYPICAL PROCESS)}

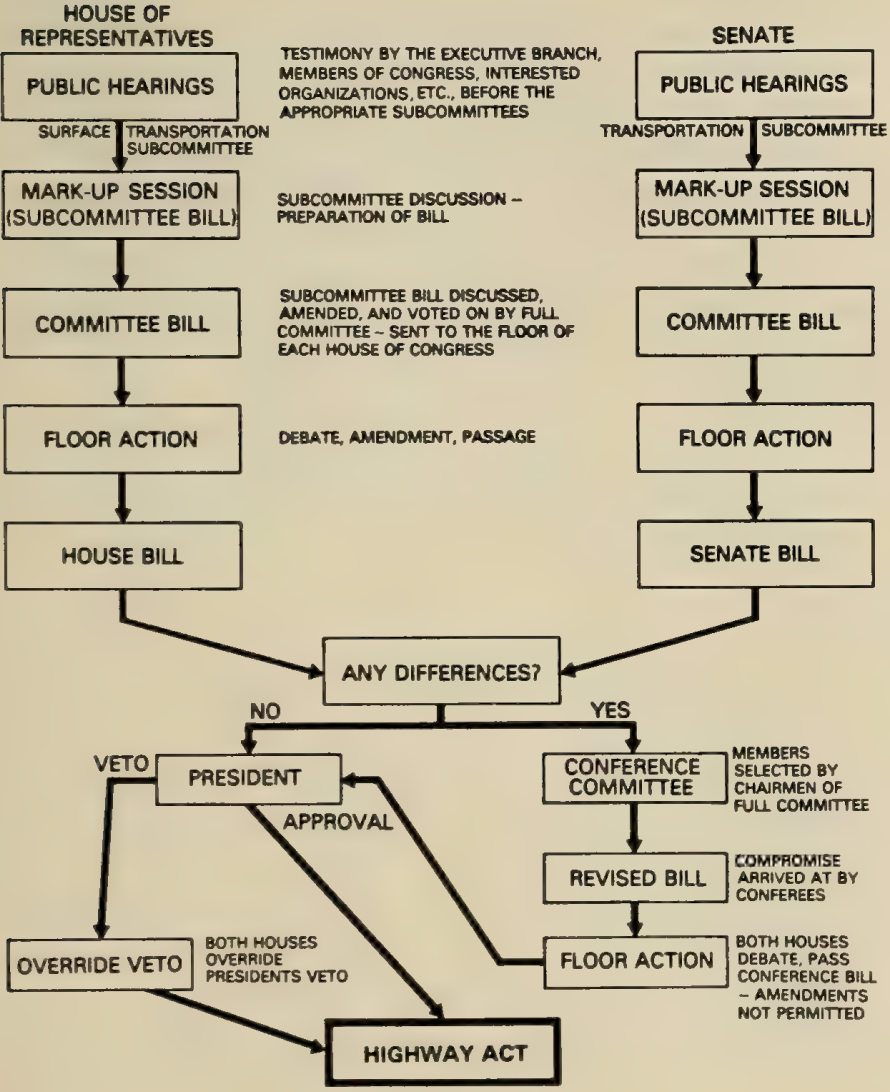

most other Federal assistance programs in that it has recognized that the States must know what to expect from the Federal Government with a substantial leadtime to provide for their own adequate legal, fiancial, and administrative planning.

The legislative process has not changed much over the years. The Administration submits its proposed program to Congress and individual members of Congress may also submit bills. Extensive committee hearings are held, and eventually the House and Senate committees develop and report out proposed bills for consideration by the whole Congress. Differences are resolved by conference committee made up of members of both Houses. After final approval by both the House and the Senate, the bill is sent to the President for signature which constitutes enactment.

Traditionally, the Administration has submitted its proposed highway legislation to Congress shortly after the first of each even-numbered year. This was an endeavor on the part of Congress to assist the States in their planning for participation in the program, since most State legislatures convene on a biennial basis in the odd-numbered years. Thus the coming availability of Federal funds to the States was known in advance so that the State legislatures could provide their highway moneys, including the State matching funds and the advance funds which the States needed to first pay highway contractors and which would be later reimbursed from the Federal Government.

The committee hearings usually have been initiated in Congress in the spring, and the highway act is usually enacted any time from early summer to the end of the year. Over the years, there have been exceptions to this timing, but the pattern has been fairly consistent.

When the 1916 and 1921 Highway Acts were passed, they appropriated funds for the new highway program. This appropriated money had specific limitations as to amount, purpose, and duration. In addition, these Acts specified that a percentage of the appropriation was to be set aside for administering the program and for research. It also specified how the money was to be apportioned, or divided, among the States based on a prescribed formula in the law. By appropriating the funds, Congress provided budget authority which allowed the Bureau to incur obligations (a commitment by the Bureau to pay out the money).

After a State received its certificate of apportionment from BPR telling it how much money the Federal Government was committing for its use, the State was free to go ahead with obligations for work to be performed. When the Project Agreement had been executed and signed by the Secretary of Agriculture, the Secretary notified the Treasury Department, and the money was thus reserved for payment of the State's voucher when received and approved by the Bureau of Public Roads.

The Post Office Appropriation Act for fiscal year 1923 did not appropriate any funds directly because it only "authorized [sums] to be appropriated." This was the beginning of contract authority for the Federal-aid highway program which permitted obligations of the full authorized amounts before any legislation had been passed to provide liquidating cash to pay the 
amounts on the vouchers. When the appropriations committees met to consider the estimated total of funds that would be required during the coming year to pay the claims submitted by the States, they had simply to evaluate the accuracy of the estimate and provide the money in the legislation that the Federal Government had already made a legal commitment to pay.

Subsequent to 1923, the Federal-aid highway legislation generally contained some or all of the following: (1) Permission to start new or to revise existing programs; (2) permission for specific project demonstrations or requests for reports; and (3) funding for the highway operations programs.

The dollar amounts in these acts have always been provided for specific fiscal years. These amounts were usually apportioned or divided among the States by a formula established by law. The apportionments had to be made at least 6 months before the fiscal year for which they were authorized and were available for obligation for a period of 2 years after the end of the fiscal year for which authorized, at which time they lapsed. Therefore, sums apportioned were usually available for obligation for a minimum of $31 / 2$ years. What had been authorized, apportioned, and made available was the authority to incur obligations on behalf of the U.S. Government. No cash had yet exchanged hands.

Not all funds were apportioned, however. Some funds are not governed by a legislatively mandated apportionment formula. In these cases, the sums are divided among the States at the discretion of the Secretary of the department or, as in the case of emergency relief moneys, sums of money are triggered by events. These discretionary or administrative divisions are called allocations, as compared to the statutory formula divisions or apportionments.

Although funds were authorized for specific Federalaid systems and programs, it was recognized that the apportionment formulas, equitable as they may be, would not always provide funds in the relative proportions that States required them. Therefore, Congress provided flexibility in the use of apportionments by permitting transfers between funding categories.

From 1923 to 1956 there were no significant changes in the basic system of legal and financial administration of the program. Some new categories of funds were created and special apportionment formulas were prescribed for specific funds, but the basic system remained intact.

When the 1956 Federal-Aid Highway Act was passed, it became title I of a two-part piece of legislation, the second part, title II, being the Highway Revenue Act of 1956. Title II created the Highway Trust Fund from which Federal-aid highway appropriations were to be drawn as well as the BPR administrative and research funding. The Highway Revenue Act also provided for the revenue sources to support the Fund.

Prior to the 1956 Act, all appropriations for the Federal-aid highway program came from the General Fund of the Treasury. Although Federal taxes on motor fuels and automotive products were in existence, there was no relationship between the level of revenues obtained from these excises and the level of funding for the highway program. The Highway Revenue Act increased some of the previously existing highway user taxes, established a number of new ones, and provided that most of the revenues would. be credited to the Highway Trust Fund and dedicated solely to the financing of the Federal-aid highway program.

The change in the method of financing the Federalaid highway program was dictated primarily by the legislative decision contained in title I to provide authorizations for the completion of the National System of Interstate and Defense Highways by June 30, 1972. Title I provided Interstate authorizations for fiscal years 1956 through 1969 totaling almost $\$ 25$ billion. In addition, the Act greatly increased the level of authorizations for the regular primary, secondary and urban programs. The creation of the Highway Trust Fund made it possible for the public to accept the increased and new highway user taxes by placing the program on a wholly user-supported, pay-as-you-go basis.

Other significant changes made by the 1956 Act in the system of financial administration applicable only to the Interstate System were:

- The Federal share of the cost was 90 percent plus a computed increase for the public lands States to a total not to exceed 95 percent.

- The apportionments of authorizations to the States, beginning with fiscal year 1960, were to be made ". . on a date as far in advance of the beginning of the fiscal year for which authorized as practicable but in no case more than eighteen months prior to the beginning of the fiscal year for which authorized."

- Beginning with the authorization for fiscal year 1960 , the apportionment to the States was prescribed to be ". . . in the ratio which the estimated cost of completing the Interstate System in each State ... bears to the sum of the estimated cost of completing the Interstate System in all of the States." The cost estimates were to be prepared at frequent intervals to assure that no State was given more than was required to complete the System within that State and ideally to assure the completion of the System in all States at an approximately uniform rate.

- The States were authorized to proceed with the construction and completion of Interstate projects beyond the total of their currently available Federal apportionments, but they could not expect reimbursement for the Federal share of costs of these projects until the State was apportioned additional Interstate funds.

- If the Interstate apportionments were unobligated at the end of the second fiscal year after the fiscal year for which they were authorized, the apportionments would be reapportioned to all the other States and become a part of the new obligational authority for that particular year with the same availability.

In addition to the creation of the Highway Trust Fund and its sources of revenue, the Highway Revenue Act of 1956 also prescribed how the Fund should be 


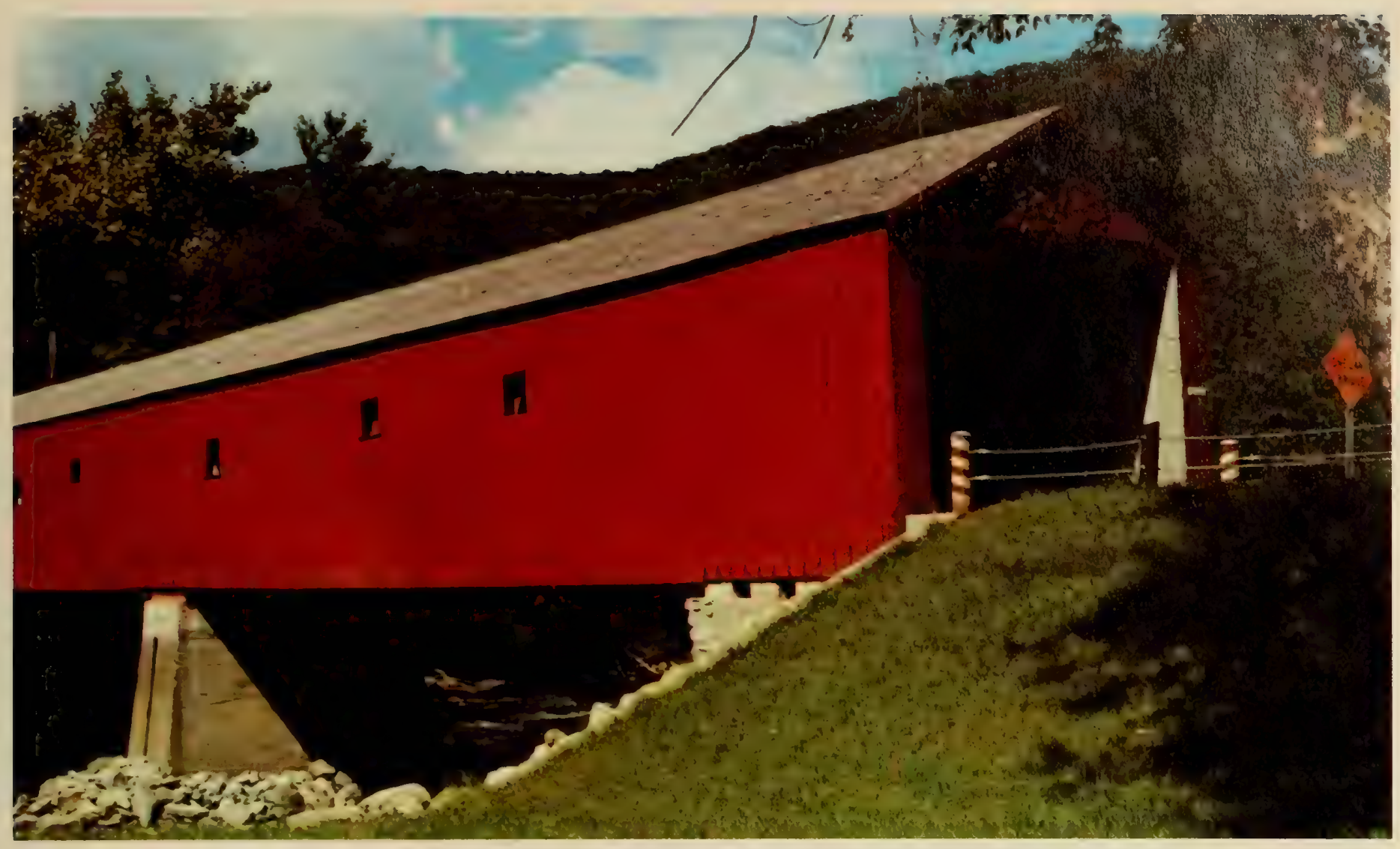

A charming relic of another age. Although an orthotropic steel deck for structural safety is concealed by careful design, this covered bridge at West Cornwalk, Conn., makes the motorist a bit nostalgic.

managed by the Secretary of the Treasury. The most significant features were:

- Repayable advances from the General Fund to the Highway Trust Fund were authorized to be made as might be needed to meet expenditure demands on the Trust Fund in excess of available balances during a fiscal year. However, this feature was suspended by the next one.

- Before the apportionment of the Interstate authorizations for any fiscal year, the Secretary of the Treasury had to determine that anticipated revenues to be credited to the Trust Fund by the end of the fiscal year would be adequate to meet the expenditure requirements. If deficits were projected, then the Interstate apportionment had to be reduced to meet anticipated revenues. This feature placed the program on a "pay-as-you-go" basis by permitting apportionments to be made only to the extent that revenues would be available to reimburse obligations and by prohibiting the Trust Fund from entering into a deficit condition.

The provision in the 1956 Act for short-term loan provisions from the General Fund of the Treasury was in effect nullified by the pay-as-you-go requirement added to the Act before final passage.

However, in 1958 the United States found itself in the grip of an extended economic recession, and one way to hasten recovery seemed to be through an acceleration of the Federal-aid highway program. For this and other reasons, the 1958 Highway Act increased the annual Interstate authorizations. It also set aside the pay-as-you-go provision of the 1956 Act for 2 years and directed apportionment to the States of the full amounts, but these provisions were not matched by a commensurate provision for the necessary additional revenue.

The effect of the 1958 Act was that the Federal-aid program annual expenditures exceeded annual Trust Fund revenue, making it necessary for the BPR to institute reimbursement planning. This was a new procedure establishing a limitation on the total dollar amount of Federal-aid project obligations that could be incurred in a given year, regardless of the unobligated balance of apportionments that were available to the States. This new program control was to insure that obligations incurred by the States did not exceed the amounts that could be subsequently paid from currently available Highway Trust Fund revenues when work was done and the States claimed reimbursement for the Federal share.

In 1961 the pay-as-you-go principle was reinstated.

The Highway Trust Fund is not a physical depository in which its dedicated revenues are actually deposited. It exists only in the accounting records of the U.S. Treasury. Estimated Trust Fund revenues are transferred by an accounting transaction from the General Fund to the Trust Fund early in each month and then adjusted later on the basis of the actual tax receipts.

It is important to recognize that even though the Highway Trust Fund was created specifically to finance the Federal-aid highway program, the revenues that accrue to the Trust Fund cannot be used to pay any of the costs of the highway program until they are made available for expenditure by enactment of appropriations acts by Congress as was the case before the creation of the Trust Fund. The budget 
estimates for appropriations from the Highway Trust Fund must be confined to the estimated availability by the end of the fiscal year of sufficient revenues in the Fund to finance the appropriations.

With a few exceptions, the Federal Government does not pay for the entire cost of Federal-aid highway projects. Originally the States were required to match the Federal funds on a $50 / 50$ basis, except in States with large areas of public lands where there have been statutory increases in the Federal share. In 1973 the matching basis was revised for most projects, other than Interstate, to be funded on a 70 percent Federal/30 percent State basis. The Interstate System has been funded 90/10 since the 1956 Act, again with an increased Federal share in public lands States.

Although the Federal share of a project's cost was established by law, there were periods when this provision was waived or temporarily suspended. In 1932, to aid in fighting the Depression, Congress authorized $\$ 120$ million which could be used to provide the State share of a project's cost. This advance of funds, or suspension of the matching requirements, was to be repaid over a 10-year period beginning with fiscal year 1938 by deductions from regular apportionments. There were several other acts authorizing additional funds during the Depression.

In 1958, again to fight a recession, additional authorizations for the Primary and Secondary Systems and their urban extensions were enacted. The Federal share for these supplemental funds was raised but a separate authorization was also made to assist the States in providing matching funds. The amounts used to increase the Federal share had to be repaid from future apportionments.

The latest example of increasing the Federal share occurred in 1975, and a recession was again the reason for it. In this instance, all matching was waived for a 6-month period in 1975 with the proviso that the State share be repaid by January 1, 1977. This repayment provision was extended by the 1976 Act to provide for a staggered repayment to be completed by January 1, 1979.

The Office of Management and Budget (OMB) of the Executive Office of the President has authority to establish obligational limitations for the highway program and to specify the maximum amount of obligations to be incurred in a given fiscal year. The OMB limitation also may specify the rate at which obligations can be permitted to be incurred.

The OMB limitation on obligations does not apply to any particular fiscal year's apportionment, but rather applies to the sum of all obligations within a particular fiscal year. Because of the multiyear availability of funds, if funds for a fiscal year are not obligated in that fiscal year, they are still available until they lapse according to the law.

The highway program, like other Federal programs, is subject to overriding national concerns, such as the rising rate of inflation which has led to controls being placed on highway spending. From fiscal year 1966 through fiscal year 1975, the Office of Management and Budget, through authority delegated to it by the President, regulated the rate at which Federal-aid highway funds were obligated in a given time period. It must be stressed that limitation on obligations, or impoundment, of highway program funds is somewhat different from impoundments for other Federal programs since there is no refusal to spend funds, only a slowing down in the rate at which funds may be spent.

The appropriations acts usually contain the wording "not otherwise provided" because not all of the highway programs are reimbursed from the Highway Trust Fund. For example, until the 1970 Highway Act, the forest highways and public lands highway programs were not funded from the Trust Fund, but had separate funding authorizations from the General Fund. There are still numerous safety and other highway-related programs with separate funding accounts, some with contract authority and some that must await each annual appropriations act for budget authority to spend money. Thus, the appropriations acts provide liquidating cash with which to reimburse the States under the normal Federal-aid highway programs, provide budget authority for certain other programs, and may provide limitations on obligations equivalent to previous Executive Branch impoundments for specific programs.

Although most Federal-aid highway programs obtain their budget authority in the form of contract authority rather than through appropriations acts, in recent years Congress has made several major changes. The one that may have the most impact on the highway program was enactment of the Congressional Budget and Impoundment Control Act of 1974 (Public Law 93-344) which was an effort to gain budgetary control over "backdoor spending," spending not subject to year-to-year congressional or executive scrutiny. The contract authority exercised by the Federal Highway Administration is considered a form of "backdoor spending." The Budget Act requires that future Federal-aid highway acts contain provisions limiting new budget authority to the estimated amount provided in appropriations acts, and this was first done in the 1976 Federal-Aid Highway Act.

This requirement would seem to negate all contract authority, but Congress, recognizing that some programs require advance knowledge of the size of future Federal funding commitments, permitted several exceptions. One of these exceptions relates to programs whose new budget authority is derived from trust funds, 90 percent or more of whose receipts are user related taxes. ${ }^{33}$ The Highway Trust Fund, which is wholly supported by user taxes, meets the requirement, but its life term has been limited by law since 1956. Its term has been extended numerous times, the latest, in 1976, extended the Fund to September 30, 1979. Should the Trust Fund be terminated, or its uses or revenue altered so that it no longer meets the exception requirements, the highway program would have to obtain its budget authority through appropriations acts as other Federal agencies do. Of course, the appropriations acts could provide for multiyear funding, but this would be in opposition to the principle of annual review of expenditures.

The Federal-Aid Highway Act of 1976 has made other changes in the legal and financial management 
of the highway program. Some of the more important points are:

- Apportionments and allocations are now available for obligation for a total of 4 years. Interstate apportionments are made 1 year in advance of the beginning of the fiscal year for which they are authorized and remain available until 2 years after that fiscal year ends. Non-Interstate apportionments are made on the first day of the fiscal year for which authorized and remain available until 3 years after that fiscal year ends.

- In the future there will be greater flexibility in the expenditure of highway funds, such as substitution of programs and transfer of funds.

- Some highway programs were consolidated, but instead of reducing the number of separate funding accounts, several new ones were added.

In summary, the legal and financial management cycle can be considered to begin with the authorizing legislation. These acts set the upper limits on Federal commitments which can be incurred for Federal-aid highways. Deductions from the authorized levels are then made for administration of the program and urban transportation planning, with additional amounts earmarked for other planning and research activities. These normally amount to about 4 or 5 percent of the authorizations.

The remaining amounts are then apportioned or allocated (divided) among the States. Apportionments and allocations are considered "new obligational authority" and, when added to the unobligated balances of previous apportionments and allocations, constitute the total amount of obligational authority available to

\section{FINANCIAL PROCEDURES}

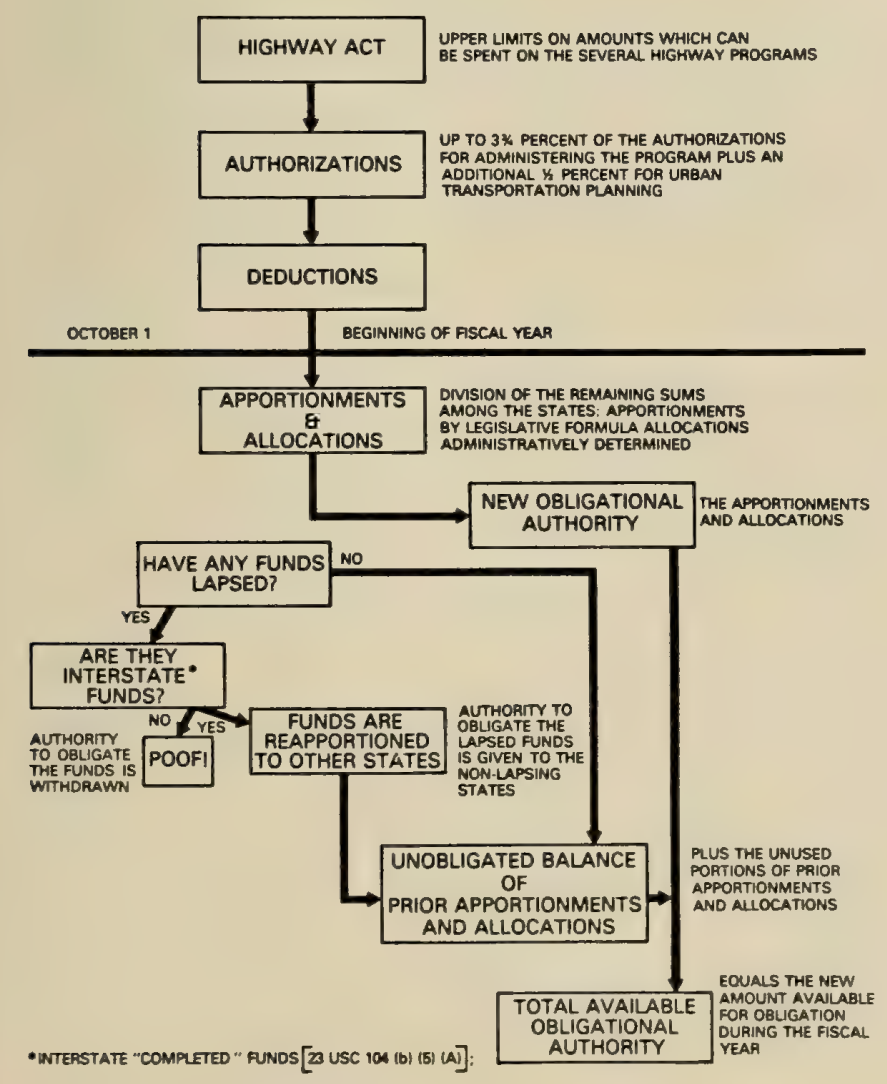

the States. This is not money, but authority to incur obligations.

Apportionments are available for obligation for a total period of 4 years.

The States may obligate funds subject to the availability of apportionments and allocations and to any limitations on obligations which may have been imposed for that fiscal year. These limitations regulate the rate of obligations by imposing a maximum amount on obligations which can be incurred during a given fiscal year.

Once funds are obligated and a project is underway, progress payments may be made to the States for completed work. This liquidating cash is appropriated annually by Congress and is derived from revenues accruing to the Highway Trust Fund.

The final step in the legal and financial administration of the Federal-aid highway program is reimbursement to the States for the Federal share of the cost of approved projects or programs.

Initially the States, or their local governmental subdivisions, finance the costs of Federal-aid projects. After authorization by the Division Administrator, work can proceed on a Federal-aid project. Once the Project Agreement has been executed between the State and FHWA, the State can submit progress vouchers claiming reimbursement for the Federal share of costs of work satisfactorily completed and for materials stockpiled for use on the project.

After the project has been completed and final FHWA acceptance has been issued by the Division Administrator, the State submits a final voucher for the project. The final voucher summarizes the final

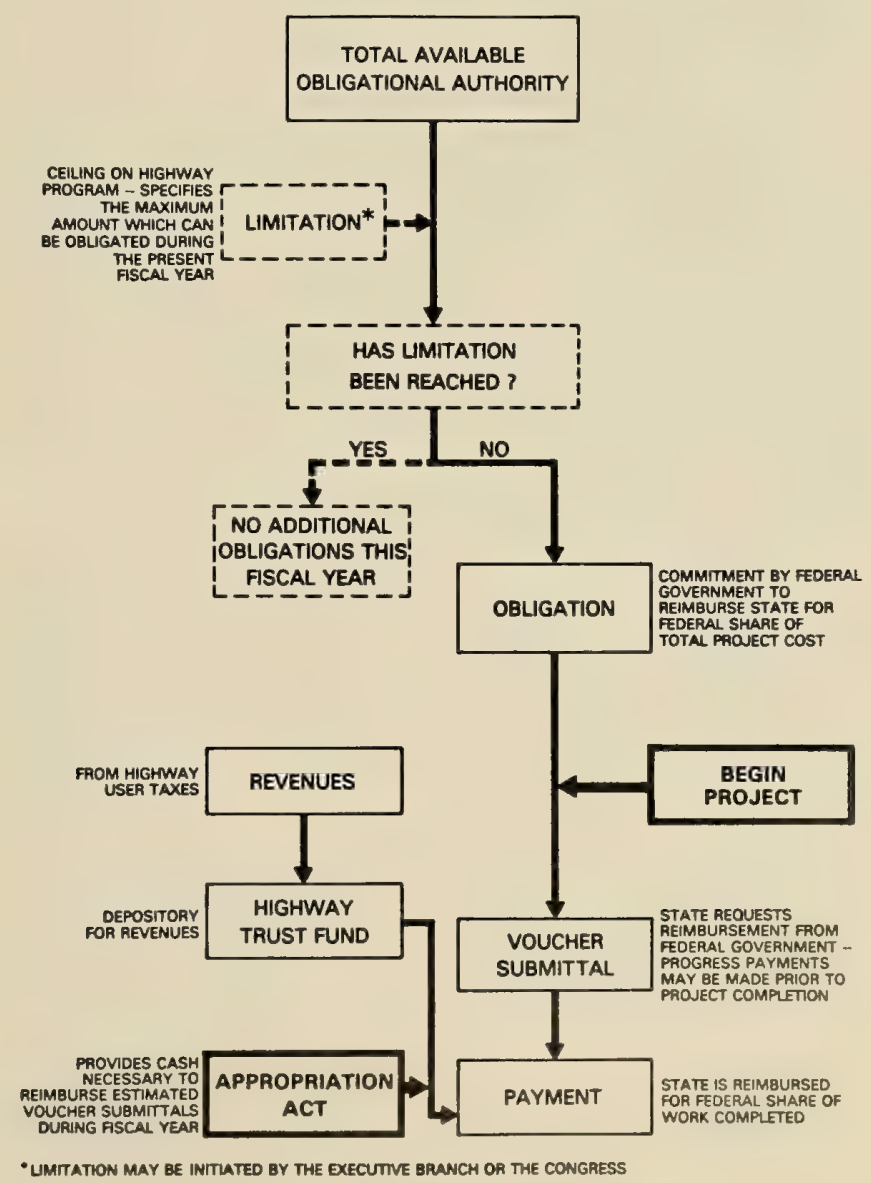


project costs in accordance with the contract, change orders, extra work orders and the project agreement.

Final vouchers are subject to a complete fiscal and engineering and right-of-way review. A number of projects are subjected to in-depth engineering and fiscal audit by FHWA to insure the integrity of the State's project administration and documentation.

In 1921 when Chief MacDonald was organizing the Bureau for the basic Federal-aid highway program, he included a Division of Control responsible for program and project accounting, budget activities, fiscal accounting, payroll, purchasing, and equipment and supplies.

The accounting activity was the only functional element that was specifically created by law. Until 1921 the Bureau had kept program and fiscal records, but the function was fragmented and treated as a routine clerical operation. Congress, recognizing that administration of the Federal-aid highway program would require detailed accounting records, directed in the 1921 Act that an accounting division be established. This later was to become the Finance Division and the Program Analysis Division in the Bureau. Over the years, the function has progressed from a routine bookkeeping operation to a very professional financial management organization.

Because of the need to maintain very detailed financial and project records, a records section was established in 1921 with the primitive data processing equipment of the day - a tabulating machine, a key punch and a sorter. As the data processing technology and equipment developed and became more sophisticated, the increased data processing capability became one of the primary tools in the administration of the highway program and made it possible to cope with the program without a corresponding growth in the staffing requirements.

The finance function in the Bureau extended beyond the Bureau's internal financial management operations to the development of the financial management operation in the States. The American Association of State Highway Officials created a Subcommittee on Uniform Accounting in 1926 to assist the States in developing a uniform system of highway accounting, but little progress was made because of the diversity among the States. By 1936 BPR had joined in this effort, but no formal procedures were established before World War II suspended operations of the AASHO Subcommittee.

It was not until 1955 that the AASHO Executive Committee directed that work resume on a uniform accounting system and that a uniform accounting manual be developed. Between 1957 and 1960 a uniform accounting manual was developed, and today virtually all the States have adopted the principles of this manual.

After the passage of the 1956 Highway Act, it became evident that the State highway departments would need assistance in modernizing their accounting systems and the Bureau of Public Roads would have to improve its own internal accounting system. In 1959 , a special staff was created to develop and implement a cooperative financial management improvement program with the States and to strengthen the Bureau's accounting operations.
The cooperative financial management improvement program with the States focused its immediate attention on the modernization of the State highway departments' accounting systems, particularly in the areas of establishing reimbursement claims and substantiating them, and in providing advice to the States. This program was called "current billing." Current billing is a concept whereby the States were encouraged to centralize their financial operations and relate all highway construction costs to projects through project cost accounting techniques. To achieve this, it was necessary to revise their accounting procedures, install sophisticated data processing systems, and make some organizational changes. An important feature of current billing was the computer-produced tabulation of costs supporting the billing voucher to the Bureau for reimbursement of the Federal share. All 50 States, Puerto Rico, and the District of Columbia have implemented current billing procedures.

The adoption of current billing enabled the Bureau auditors to change their audit techniques. Formerly, it was necessary to audit the transactions of each project due to the lack of adequate centralized cost accounting techniques. This resulted in portions of claims being prepared from other than the States' accounting records, costs being omitted, variations in cost methods and controls from project to project, and similar peculiarities in the States' accounting systems. As a result of the improvements made under the current billing concept, the auditors were able to concentrate their reviews on the States' procedures and controls, thus substantially eliminating the time-consuming examination of project documentation.

Under the authority and direction of the Budget and Accounting Act of 1950, the U.S. General Accounting Office $(\mathrm{GAO})$, an administrative support tool of the Congress, initiated comprehensive managementtype audits of the departments and agencies in the Executive Branch. These audits were designed to evaluate for Congress the administration and effectiveness of agency operations and programs. The provisions of the Act also encouraged the agencies and departments to initiate their own internal audit or review programs. As a result of these review efforts, the GAO approved FHWA's accounting systems and procedures in 1967, one of the few to receive GAO's approval up to that time.

Of course, the financial operation includes cost accounting, but the information necessary for this function is so complex that early in the highway program, a special division was created to maintain the data on project obligations on a nationwide project-byproject basis.

Program analysis is the continuous maintenance of the official records of the current status of all Federalaid and other FHWA program authorizations together with the current status, cost, and physical characteristics of each project authorized for financing. Over and beyond this generalization, it also includes the determination of the apportionments of authorizations (and obligational limitations) which are made available to the individual States; the control and maintenance of the record of transfers of funds between apportionments; the determination of the maximum percentage of Federal participation on Federal aid, emergency relief and other special categories of 
funds; the monitorship of the interrelationship of obligations and disbursements and the development of data to control the rate of obligations within the limit of funds available in the Highway Trust Fund; the maintenance of the official project obligation records; and the management, at all levels, with interpretations and evaluations, of program progress by States, by funds, by limitations, by highway systems, by classes of projects, etc.

The records for the program analysis function are maintained by computer. Before the days of the electronic and digital computers, the scope of the information for each project was necessarily quite limited in comparison with the current data that is maintained. However, because of the sophistication and flexibility of modern computers, a vast amount of data is collected, stored in the computer and used on a day-to-day basis to monitor the progress of the program and insure compliance with all legal and administrative requirements.

The total program is implemented through individual projects throughout the 50 States, the District of Columbia, Puerto Rico and the American territories. There are nearly 40 categories of funds or programs for which records must be kept separately. The total number of active projects at any given time is approximately 30,000 . For each project the physical characteristics and fiscal data must be maintained on a current basis.

This record information is not one-time datarather, much of it is "fluid" and changes to reflect current status as the projects progress through the project steps from initial authorization to final completion.

An innovative feature of the system is the method used to obtain the computer input data. A "shuttle form" is used. When a project first enters the system at the obligation stage, a form is completed by the FHWA field division office reporting all the currently available project data, and it is sent to Washington. The data is recorded in the system and a printout confirming form is sent back to the field, reflecting the data which has been recorded. The field office holds the form until the next action, change or addition takes place at which time the form is pulled, the changes or additions are indicated on the form, and it is again sent to Washington. The new data is recorded and another printout is sent back to the field for verification and storage until the next change in status occurs. This "shuttle system" continues until the project is finally completed. Each month a summary printout reflecting the basic project data for all projects in the State is sent to each FHWA division office. This system eliminates the need for duplicate project records.

The program analysis work and the mass of detail stored in the computer are vital to the effective administration of the highway program. A case in point is the need for the operating records for budget purposes. The FHWA budget office not only serves FHWA, but serves indirectly as a budget office for all the States since it must accurately provide the budget estimates for liquidating cash for all Federalaid highway programs. This is a unique budget responsibility, especially in view of the complex pro- cedures used for the financial administration of the Federal-aid highway program.

The key to the economic and effective operation of FHWA's budget office is the use of program, fiscal and personnel records which must be maintained by other offices. Following World War II, the budget process, content and format prescribed by the Bureau of the Budget became more detailed and sophisticated. The preparation of the various budget schedules, especially for "personal services," became very timeconsuming and required extensive compilation and analysis. At the time, the Public Roads Administration was already using automatic data processing (ADP) equipment to prepare its payroll and to maintain its employment and personnel records. Since the bulk of the source data required for budget purposes already existed in the ADP records in raw form, the budget office decided in 1947 to develop an $\mathrm{ADP}$ system which would use the same records, but supplemented with the additional data required for budget purposes. The system proved to be remarkably effective and provided practically any data or personal services which might be required with accurate statistics to support the budget statements and schedules. Significantly, no additional staffing was required in the operating offices to do the minimal amount of additional coding that was required, and the budget office today, although responsible for an annual budget of over $\$ 6$ billion, operates with a total staff of 11 people.

\section{Auditing}

Within the Federal Highway Administration, external audit is concerned with the means and methods used by the States to administer the Federal assistance program. The ultimate objective is to ensure FHWA management that (1) financial operations of the States are properly conducted; (2) that financial reports and claims are presented fairly; and (3) that the States are otherwise complying with applicable law, regulations and administrative requirements.

Internal audit is concerned with an intensive performance-compliance-effectiveness program audit of an organizational unit of FHWA or, perhaps, of a functional program phase through all levels of the organization. The internal audit is a management-type activity designed to evaluate operational effectiveness, and it normally involves review of some State records and files and discussions with State officials as a necessary part of the evaluation of FHWA's own program administration.

A third functional area, investigations and special inquiry, became a part of the audit complex in more recent years and is concerned with investigations of allegations of irregularities, fraud, bribery, collusion, impropriety, etc., involving employees of FHWA, the States, their political subdivisions, contractors or others dealing with funds for FHWA administered programs.

From the inception of the Federal-aid program until 1953 , the audit activities of the Bureau were confined to the external audit of State claims for reimbursement, normally at the final voucher stage. These audits were made after the engineering staff (and later also, the right-of-way specialist) had reviewed the physical aspects of the work and accepted the completed project as having been built in accordance 
with the approved plans and specifications. Following the passage of the 1956 Highway Act, financial audit was also made of the costs of any railroad or utility changes that were involved in the project. This audit was made at the accounting offices of the railroad and utility companies.

As the size of the Federal-aid program, and the resulting audit workload, increased over the years, the organizational arrangement for accomplishing the audit necessarily changed. Originally all external audit was performed by auditors attached to the Washington headquarters, and they traveled out of Washington to make the audits. In the next evolutionary stage, the very small group of auditors were headquartered at various geographically strategic locations in the field to reduce travel costs-however, they still reported to the Washington headquarters. At the next stage, at least one auditor was placed in each regional office. At the end of World War II, as a part of the major reorganization for the greatly expanded postwar highway program, the audit function was decentralized to the district offices which were established in each State. During this evolutionary period, there was no significant change in the concept or form of the audit.

The external financial audit program experienced many progressive changes over the years to keep the Bureau's audit program consistent iwth the latest and most sophisticated audit concepts and procedures as they were developed.

It was not until 1954 that the Reoional Enioneers, for the first time, were delegated authority to approve payment of final construction vouchers, and those only if they did not include any costs for rights-of-way or railroad or utility work. This was a significant step because it involved making the final evaluation and decision on audit findings.

In 1961 the current billing and concurrent audit procedure was developed and authorized. This concept permitted those States using electronic data processing equipment to make a single consolidated monthly claim for reimbursement of the Federal share of all project earnings. Under this procedure, BPR auditors utilized a "system audit" or concurrent audit concept in lieu of a voucher and record audit. It constituted an audit of the State's total accounting system, including the flow of source data and the State's own auditing processes rather than an audit of individual projects. Under the new system, the final audit was essentially complete when the final voucher was received and only a minimum of additional review was required.

In 1968 operational auditing was initiated to further supplant the traditional audit procedures. Operational auditing is a continuing and comprehensive audit of the administrative, accounting, and operational procedures and controls employed by the State in the administration of the Federal-aid program. It allowed the auditor to express an opinion on costs claimed as representations of the system rather than having to use claims as the medium through which audits were conducted.

In 1971 a single audit concept was authorized where the State agreed to perform an independent audit of the Federal program. The FHWA auditors reviewed and accepted the State-performed audits.
In 1974, as a condition of receiving funds, the States were asked to perform an internal financial audit of all Federal-related activities at least biennially. If the reports and work papers were available for review, if audit standards under which the work was done were adequate, and if they otherwise met Federal requirements, FHWA auditors were directed to use and rely on it in lieu of Federal audits.

The professional development and continuous improvement of the external financial audit activities of FHWA were possible only because the States' financial management and audit activities kept pace with FHWA's objectives. This required a great deal of Federal-State cooperation and responsive professional leadership on both sides.

As mentioned earlier, the Budget and Accounting Act of 1950 encouraged the establishment of internal audit programs in the agencies and departments. Accordingly, in $1953 \mathrm{BPR}$ established an internal review office in the Audits and Accounts Division of the Washington headquarters.

At first the new internal review activities were mainly confined to the administrative areas of program management, but the office provided a staff capability to evaluate and recommend action on the General Accounting Office comprehensive audit reports of elements of the highway program.

Following enactment of the 1956 Federal-Aid Highway Act, the internal review program was broadened and a project examination office was created in 1957, which included the internal review functions.

The new project examination office was given broad and independent responsibility to review program and project administration at all levels of the Bureau and in the State highway departments. The reviews were to be made by four-man teams consisting of a professional investigator who was in charge of the team, an engineer, a right-of-way specialist, and a fiscal or administrative auditor. An intensive and highly selective recruiting effort was put forth to obtain wellqualified professional civil and criminal investigators, a skill until then not utilized in BPR. The emphasis on investigative talent was two fold: (1) It was anticipated that the large sums of money that would be involved in the construction of the Interstate System, in combination with the greatly expanded highway program in general, would require close vigilance to prevent scattered incidents of irregularities, collusion, bribery, etc.; and (2) it was believed that professional investigators would be particularly skilled in the planning and conduct of investigative reviews, while the subject matter specialists would provide the required program evaluation and compliance expertise.

The creation of the project examination office proved most timely. Problems of irregularities involving highway department employees, contractors, and others did in fact develop and, in many instances, were first identified by the project examination reviews. Unfavorable publicity which followed these incidents resulted in congressional interest and the creation in 1959 of a Special Investigative Subcommittee on the Federal-Aid Highway Program under the House Public Works Committee. The Subcommittee was under the chairmanship of the Honorable John A. Blatnik of Minnesota and became commonly known as the Blatnik Committee. $\mathrm{A}$ well-qualified and ex- 


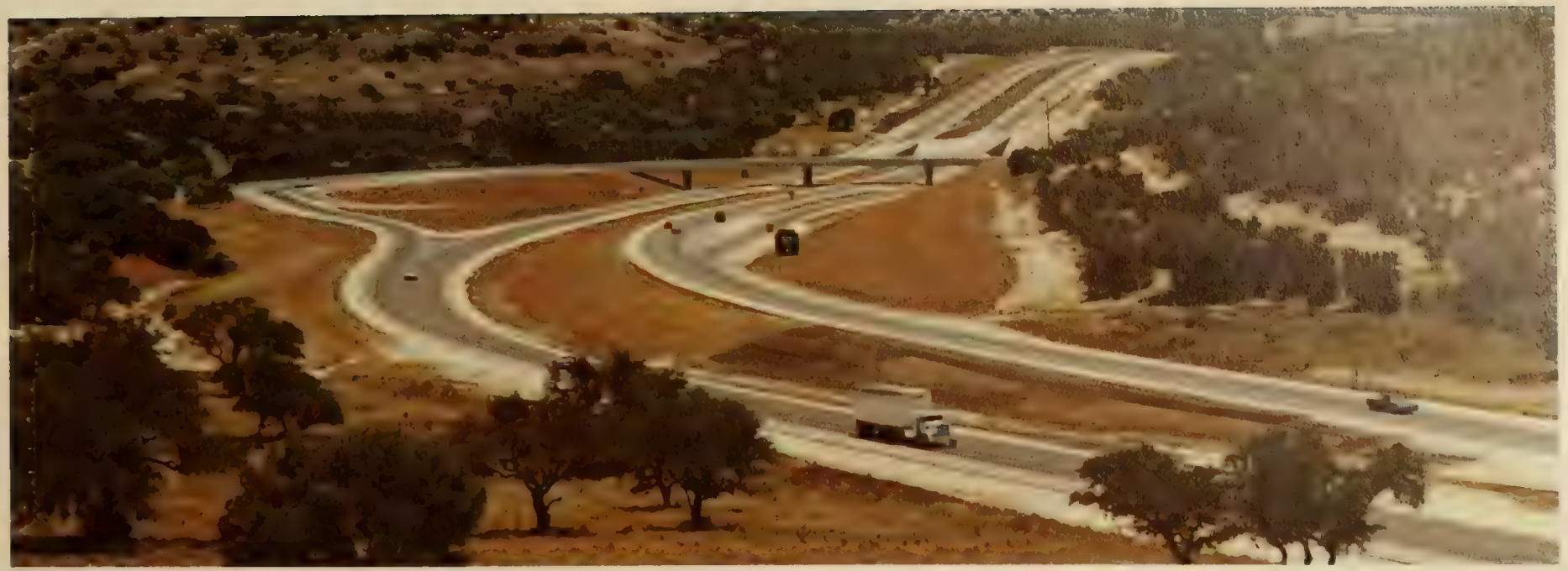

Interstate 10 through the rugfed Texas hill country uest of Kerrille blends with the terrain because care has bern taken to preserve the natural vegetation and to make the highway and interchange design compatible with their surroundings.

perienced investigative staff was employed by the Blatnik Committee. In the ensuing months and years, the Committee became very active in terms of both investigations and public hearings.

To augment the limited resources of the project examination office and the efforts of the Blatnik Committee staff, an active effort of encouragement, persuasion and professional guidance was initiated by the Bureau to get the States to initiate their own programs of internal review and investigation. The leadership in AASHO actively supported this effort with the result that many States instituted their own internal review processes.

In 1962, as an administrative action designed to strengthen the independence of BPR's internal and external audit and investigative programs, a new office was established with its Director reporting directly to the Federal Highway Administrator. This change separated the audit and accounting functions which had been organizationally combined since the creation of an accounting section. The responsibility for the financial audit of State reimbursement vouchers remained at the field level while the headquarters office provided technical direction, leadership, and guidance in all financial audit activities. In 1971 the internal audit function was absorbed into a centralized departmental internal audit office.

\section{Training}

A key to the successful administration of the Federal-aid highway program has been the outstanding people in most of the top positions in the organization and a strong supporting staff with a remarkably low employee turnover rate - recently running at an annual rate of 11 percent, about half that of the Federal Government as a whole. ${ }^{34}$ Part of the reason for this was that the program itself attracted bright young engineers but also because the Bureau offered specialized training.

A strong interest in training dates back to 1893 when the Office of Road Inquiry was established. One of the primary purposes of that organization was education, but mainly in the external sense. This included encouraging the colleges and universities to teach highway engineering since, at that time, there were few academically trained highway engineers.
In the Annual Report for fiscal year 1903, Director Martin Dodge recommended the establishment in the Office of Public Road Inquiries of a post-graduate national school of roadbuilding similar to the L'Ecole Nationale des Ponts et Chaussees that was established in Paris in 1747. No action was taken on this recommendation, although the idea resurfaced many times in later years.

In 1905 the Office of Public Roads (OPR) initiated its first formal internal training program. Graduates of engineering colleges were appointed after a competitive civil service examination to the position of civil engineering student at a salary of $\$ 600$ per year. A course of instruction included experience in the construction of object lesson or experimental roads, instruction in the office routine, laboratory work and theoretical instruction through lectures and reading assignments. After completing the year's training, the students were promoted to the position of junior highway engineer in OPR at $\$ 900$ per year. This program continued until 1916 with the number of appointees ranging from 4 to 10 per year. ${ }^{35}$ During the period of this first engineer training program, a total of 78 students were appointed. ${ }^{36}$

In 1921 the engineer training program was reinstituted. The emphasis in this program was quality recruitment. Most students were recruited during their junior year of college and placed on a production cost study. They were evaluated for future employment and, if they met the desired standards, were appointed to a junior engineer position after graduation. They were then given a 2 - to 3 -year period of training throughout the country in production cost studies, equipment development and design, and economic studies. The program was gradually phased out by 1936 because of economic conditions. During the span of this second training program, approximately 150 college graduates were appointed. ${ }^{37}$ A high percentage of these men ultimately moved into key positions in the Bureau, the most notable of whom was Francis C. Turner who became the Federal Highway Administrator in 1969 .

At the end of World Was II, the Junior Engineer Training Program was reactivated and administered by a professional training officer. For the first time, 
Public Roads had a specific organizational unit responsible for training.

The new Junior Engineer Training Program was planned to provide 3 years' training in rotational assignments in different parts of the country and to give the trainees the best possible foundation for a career in Public Roads. Subject to satisfactory performance, the trainees received a scheduled promotion during training and a promotion upon graduation and a regular assignment. Recruiting was directed toward graduating seniors in colleges and universities, but highway engineers within Public Roads could be selected for entry into the program.

The Highway Engineer Training Program (HETP), as it is now called, has continued without interruption since 1946. Recruitment started modestly with an annual quota of approximately 15; from 1949 through 1956 , the annual recruitment averaged about 33 per year. Following enactment of the Federal-Aid Highway Act of 1956 with its greatly expanded program, 76 individuals were enrolled in 1957 and 170 in 1958.

In 1961 a master's 18-month training program was added to provide a training vehicle for approximately 10 candidates with master's degrees per year. This program was directed toward development of a quality source of individuals for positions in research, planning and structures. From 1961 to 1972 , the recruitment for both programs averaged about 75 new trainees per year. Since then the average has been about 60 trainees per year in both programs.

From 1946 through 1974, a total of approximately 1,600 individuals have entered the Highway Engineer Training Program. Approximately 85 percent of all graduates have remained with the organization. A number of these graduates have reached key positions in the FHWA organization: six of nine Regional Administrators are HETP graduates; two of six Associate Administrators; and 33 of 52 Division Administrators. The FHWA Executive Director, Lester P. Lamm, was a 1960 graduate.

To insure that the program would continue to be responsive to the needs of the Bureau and the career development of its engineers, there have been periodic searching reviews of the entire program. Two other major management efforts have contributed to the effectiveness of the HETP in providing engineering manpower consistent with the Bureau's projected needs. The first of these occurred in 1961 when a task force was named to conduct a manpower utilization study on field engineers. Engineering manpower needsnumbers and skills-were projected 10 years into the future. In 1974 a similar task force conducted a complete manpower utilization study of the entire organization and projected FHWA's personnel needs and skills over the next 10 to 15 years. The annual recruiting quotas for the HETP have been based largely on the two studies.

Until 1953 formal inservice training was limited to the Highway Engineer Training Program. In that year, inservice training was formalized and greatly expanded. Field enigneers were encouraged to attend courses and conferences held in the Washington headquarters. Then in 1955 an annual comprehensive inservice and outservice agencywide training program was initiated to assess training needs on a priority basis.
With enactment of the Government Employees Training Act of 1958, an active outservice training program began. The Act not only authorized the use of agency funds for training in Government and nonGovernment facilities, but it prescribed that all agencies must establish, operate and maintain a program and plans for the training of their employees. The two major new areas of training which were opened up as a result of this Act were: (1) Full-time or parttime enrollment in colleges and universities; and (2) attendance at meetings, conferences, seminars, etc., that would contribute to improved performance of the employees' duties and responsibilities.

The Bureau immediately initiated an extensive Full-Time Graduate Study Program. Over a period of approximately 18 years, 240 employees have enrolled in full-time graduate study.

As the program has grown both in size and into disciplines other than engineering, the Bureau has added several other professional career intern programs structured basically on the format established for the successful Highway Engineer Training Program. The procedures were the same, that is, to employ outstanding college and university graduates and to provide rotational training assignments during a formal training curriculum. Other employee career development programs have also been instituted for employees in all grade levels.

These programs have included formal curriculums for management specialists (1960), right-of-way officers (1962), auditors (1964), civil rights specialists (1969), and a national upward mobility program for administrative and professional type positions (1974). Other areas of career development have included executive development, environmental specialists, and motor carrier safety investigators. As a part of FHWA's equal employment opportunity action plan, an upward mobility education program was begun in 1973 to assist lower grade employees to attend courses so that they may be qualified to compete for better positions.

Obviously, the strong emphasis on training within FHWA has influenced the economical staffing of the Federal agency that administers the Federal-aid highway program. Congress saw the validity of this philosophy and, in the 1970 Highway Act, authorized the creation of a National Highway Institute (NHI) with the express purpose to "... develop and administer, in cooperation with the State highway departments, training programs of instruction for Federal Highway Administration and State and local highway department employees engaged or to be engaged in Federal-aid highway work."

The NHI is not a physical faciilty, such as a school with classrooms, but is an administrative organizational element. Its operating costs are funded from FHWA's regular appropriation for administrative expenses, which tends to limit the amount of direct training that the Institute can undertake.

The Institute has established itself as a significant source of training in the highway field. During fiscal year 1974, the NHI sponsored 10 separate courses and workshops at various locations throughout the United States, involving about 5,500 State, local, and FHWA 
personnel. In most instances, the workshops and courses were developed and conducted by universities and training consultants under contracts funded and supervised by the NHI.

Under the terms of the 1970 Act, the States may use up to $1 / 2$ percent of their apportioned Federal funds for highway purposes (except Interstate funds) for education and training of State and local highway department employees with two conditions: (1) The States may not pay more than 70 percent of the costs of tuition and direct educational expenses from this fund, which leaves the States to provide at least 30 percent of the costs; and (2) no Federal funds can be used for travel, subsistence, or salaries of the employees being trained.

One of the major efforts of the Institute has been to encourage the States to take advantage of this optional program to broaden their own training programs. Since this Federal financial assistance is not an independent source of funds-it is highway construction funds being used for training purposes- the States have been slow to take advantage of this opportunity. Presently, approximately 20 States are programing a portion of their eligible Federal funds for training and educational activities.

However, the NHI program for fellowship and scholarship awards to FHWA, State, and local employees has been very successful. Currently, the Institute is awarding approximately 40 annual fellowships in highway transportation research and education and 40 in highway safety at $\$ 5,000$ each, and about 50 scholarships are awarded annually in highway technology at $\$ 2,500$ each.

At the time the Institute was established, it was assigned the responsibility for administering FHWA's ongoing orientation and training programs for foreign highway officials and engineers, which had been handled by the Foreign Projects Division along with its foreign construction program. The activities arranged by the Institute for the foreign groups range in duration and depth from a 1-day meeting with selected officials to a year or more of academic study at a university offering the type of highway-related curriculum desired. In fiscal year 1974, the NHI arranged programs for a total of 763 foreign officials and engineers from 56 different countries.

The NHI also serves as a clearinghouse of useful information related to training and education of highway employees. It seeks to assist the States in identifying particular types of training and maintains a referral service of training aids.

To give direction to the extensive training effort of FHWA, the Administrator has moved lately toward establishing national training goals, or areas of training emphasis, for managers throughout the FHWA. While these national training goals are pointed toward the development of FHWA employees, they also have implications for State highway and transportation officials in two ways. In one instance, the FHWA employees will be using their new knowledges and skills to assist the States with their highway and transportation missions. In the other instance, the State officials will be invited to make use of courses developed to achieve the FHWA's national training goals.
Training has been one of the key elements to the successful administration of the Federal-aid highway program throughout the years. It will most likely continue to be a main support of the greatest public works program in the world.

\section{REFERENCES}

${ }^{2}$ A. Hurbert, Historic Higmways of America, The CumberLAND RoAD, Vol. 10 (Arthur H. Clark Co., Cleveland, 1904) p. 19.

${ }^{2} I d$, pp. 57-61.

${ }^{3} I d$., p. 64 .

${ }^{4} I d .$, p. 199.

${ }^{5} I d$., pp. $73,86,92$.

${ }^{6} \mathrm{P}$. Jordan, The National Road (Bobbs-Merrill Co., Indianapolis, 1948) p. 175.

${ }^{7} 43$ U.S.C., Sec. 218 (1964).

${ }^{8}$ M. O. Eldridge, Progress of Road Building in the United States, Yearbook of the Department of Agriculiture, 1899 (GPO, Washington, D.C., 1900) pp. 374, 375.

${ }^{\circ} \mathrm{W}$. Holt, Service MoNographs of the United States (Governaext, The Bureau of Public Ronds, No. 26 (Johns Hopkins Press, Baltimore, 1923) pp. 7-13.

${ }^{10} I d$., p. 13.

${ }^{11}$ Hearing on S.J. Res. 106 Before the Comm, on Agriculture and Forestry United States Senate, 62d Cong., 2d Sess., p. 5 (1912).

${ }^{12}$ Joint Report of the Progress of Post-Road Improvement, H. Doc. 204, 63d Cong., 1st Sess., p. 3.

${ }^{13}$ Bureau of Public Roads Anjual Report, 1914, p. 4.

${ }^{14}$ Bureau of Public Roads Annual Report, 1916, p. 2

${ }^{15}$ Federal Aid to Good Roads, H. Doc. 1510, 63d Cong., 3d Sess., p. 14.

${ }^{16} \mathrm{~W}$. HoLt, supra, note 9, pp. 19, 20.

${ }^{17}$ AASHO-The First Fifty YeARS, 1914-1964 (American Association of State Highway Officials, Washington, D.C., 1965) p. 239.

${ }^{18}$ W. HoLT, supra, note 9, p. 19.

${ }^{19} I d$., pp. 22-24.

${ }^{20}$ C. Borth, Mankind On The Move (Automotive Safety Foundation, Washington, D.C., 1969) p. 199.

${ }^{21}$ Bureau of Public Roads Annual Report, 1893, p. 586.

${ }^{22}$ A. E. Johnson, History of the Origin, Development and operation of the American Association of State Highway Officials, AASHO-The First FifTy Years, 1914-1964 (American Association of State Highway Officials, Washington, D.C., $1965)$ pp. $52,53$.

${ }^{23}$ Supra, note 17 , pp. $5,6$.

${ }^{24}$ A. Johnson, supra, note 22, p. 56.

${ }^{25}$ Ideas and Actrons: A History of the Highway Research BOARD, 1920-1970 (Highway Research Board, Washington, D.C., 1971) p. 133.

${ }^{26} \mathrm{Id}$., p. 105.

${ }^{27} I d$., pp. 25, 135.

${ }^{28} I d$., p. 136.

${ }^{29} I d$., p. 53.

${ }^{30} I d .$, pp. 57,58 .

${ }^{31} \mathrm{P}$. Wilson, Organization of the Bureau of Public Roads (file copy of article prepared for U.S. Daily, Apr. 1930).

${ }^{32}$ Dept, of Transportation, The United States Department of Transportation-Its Organization and Functions (GPO, Washington, D.C., 1967) p. 1.

${ }^{33}$ P.L. 93-344, Sec. 401 (d) (1) (B)).

${ }^{34}$ Federat. Highway Administration, Manpower Utilization STUdY-1974 (Dept. of Transportation, Washington, D.C., 1974) p. VI 4 .

${ }^{35}$ W. HoLT, supra, note 9, p. 12.

${ }^{36}$ Bureau of Pubicic Roads, Report ON the Junior Engineer Training Program-July 1, 1946 to OCtober 1, 1955 (Dept. of Commerce, Washington, D.C., 1955) p. 1.

${ }^{37} I d$. 


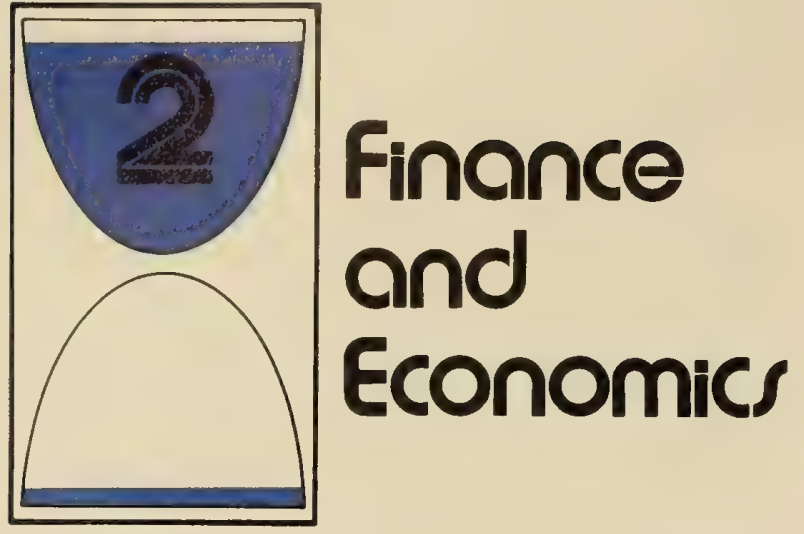

During the early days of the Republic, road management was amateur in most rural areas, and little money changed hands. The "statutory labor system" prevailed in most States. Under this arrangement, a "poll" or per-capita tax was usually levied. The rural citizen could pay it in cash or work it out either by laboring on the road himself or by hiring a substitute. If he provided a team and wagon, his credit for work done went up.

On the other hand, the average town or city dweller was not his own boss. Unlike the farmer, he could not arrange to set his own work aside to work a specified number of days on the road. Consequently, in most municipalities, the residents were taxed for the improvement, maintenance, and management of streets through property taxes, poll levies, or some other form of local tax. In the downtown areas of some of the larger places, businesses were taxed or they contributed voluntarily to the more highly improved streets.

During most of the 19th century, the chief source of funds for financing city and town streets was some form of real estate tax, which fell into three major classes:

- Property taxes levied against all real property for general purposes, the proceeds going into the general funds, from which appropriations were made for highway and other purposes.

- Property taxes levied against all real property specifically for street purposes.

- Special assessments of many kinds levied against specific parcels of real property for street purposes.

In many places, taxes were also imposed on various types of personal property, a portion or all of the proceeds being applied to street purposes.
The level of total annual expenditures on rural roads by all governmental agencies seldom, if ever, exceeded $\$ 75$ million before 1904. By far the largest portion of this money came from property taxes, although a considerable amount also came from poll and "labor" taxes.

The so-called labor taxes were those imposts adopted to replace the requirement of a labor contribution. Actual labor contributions remained important in the building and upkeep of rural roads in some sections of the country for a long time. In 1914, 18 States reported considerable use of statutory labor. Although only four States, all in the South, reported the use of convict labor, it is known to have been more prevalent than this. The practice is still in use in a few areas today, but the cost of such labor is not eligible for Federal-aid reimbursement, although it can be used in the case of emergency construction following a disaster without disqualifying the entire project.

At the beginning of the automobile era, the street networks of the incorporated places in the United States were in a much higher state of development than were the rural roads. It has been estimated that in 1906, when annual expenditures on rural roads were at the $\$ 75$ million level, expenditures on city and village streets were averaging about $\$ 300$ million per year. Borrowing to finance large construction projects of all kinds, seldom resorted to in rural areas at that time, was a common practice in cities, especially in the larger ones.

For highway purposes, borrowing in anticipation of future tax revenue was a local practice at first, but in 1893 Massachusetts became the first State government to contract debt to finance highways, although the territory of Idaho issued wagon road bonds as 


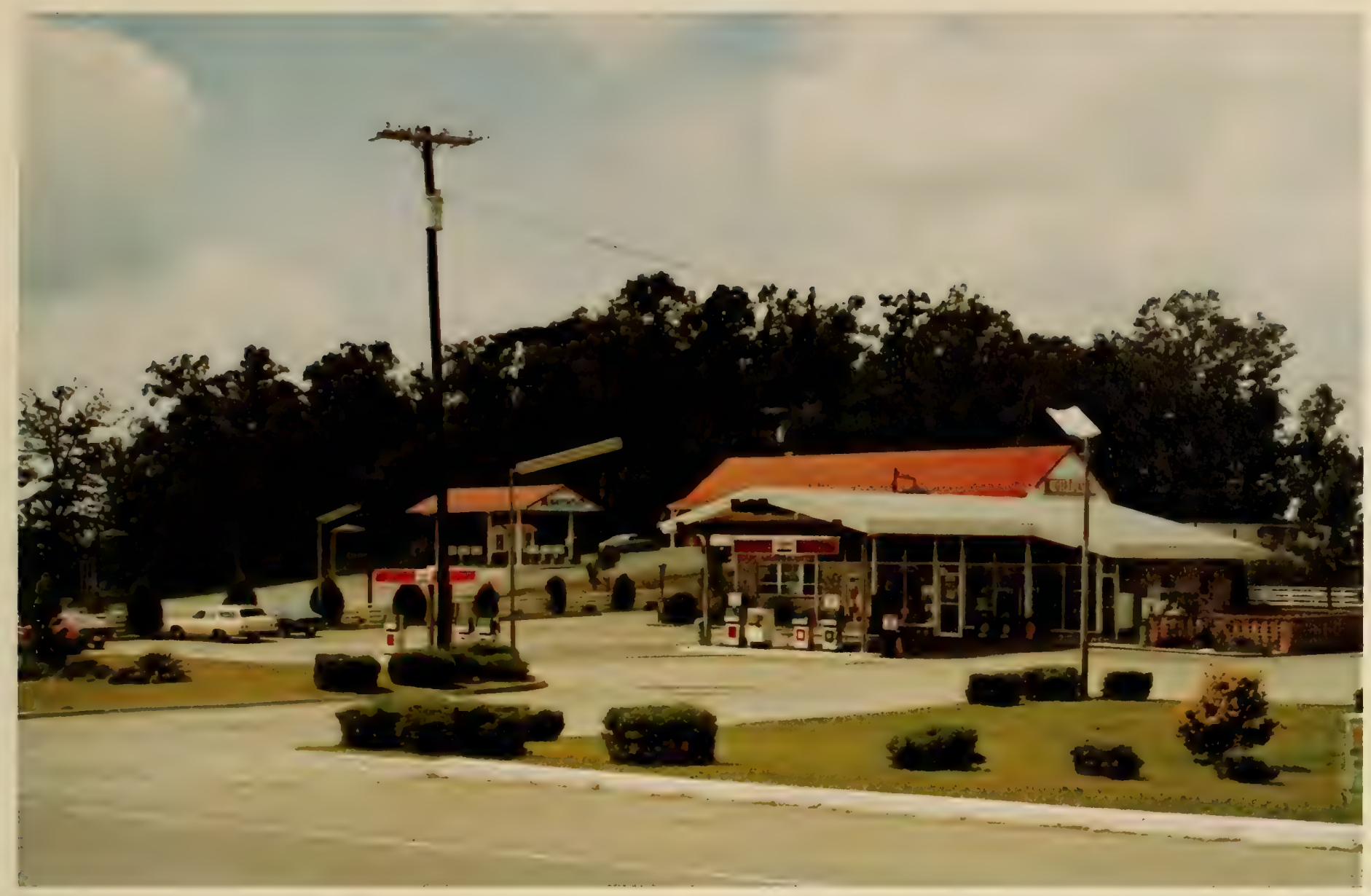

The gas station represents the major source of highway financial income today. Will it be able to support future highway construction and maintenance?

early as 1890. Other States, notably New York, California, Maryland, and Connecticut, soon followed the lead of Massachusetts, and State borrowing began a long period of steady increase.

Before 1914, county and local road bonds were concentrated in a relatively few States, exceeding $\$ 10$ million in only seven: Ohio, Texas, Pennsylvania, Indiana, California, New Jersey, and Tennessee.

\section{State Aid for Roadbuilding}

State participation in the financing of road construction was an accomplished fact before the motor vehicle became a practical means of transportation. It began with a law enacted in New Jersey in 1891 providing for the appointment of Township Committees to inspect the roads in their townships annually and to develop a systematic improvement plan for them. The committees were empowered to employ engineers or other competent persons as consultants and to prepare plans and estimates. The financing plan obligated the State to pay one-third of the cost of improvements; adjacent property owners, onetenth; and the county in which the improvement was made, the remaining 57 percent. To the county belonged the responsibility for road maintenance.

Middlesex County, the first to take advantage of the new plan, borrowed some $\$ 50,000$ to $\$ 60,000$ to pay the cost of three projects totaling nearly 11 miles. On December 27, 1892, the State paid its share of the construction cost, almost $\$ 21,000$, "the first money paid by the State of New Jersey for improved roadways." 1

The State aid idea caught on rapidly, and, by the close of 1917, all 48 States had enacted such laws, though the patterns of aid varied widely from State to State, some at first providing only advice to the localities.

With the spread of State aid came the development of State highway systems. The first such system was established in Massachusetts in 1893 and the last in Mississippi in 1924. In the early days, State laws granted varying degrees of State control over these systems: Some States had none at all; others had full responsibility for them.

The highway-user tax, which was to become the great provider for large-scale highway development in this country, appeared inconspicuously, first in New York in 1901 with a registration fee of $\$ 1.00$ per vehicle for regulatory purposes. In 1906, New Jersey established an annual license fee classified on the basis of vehicle horsepower. The rate was $\$ 3.00$ for vehicles of less than $30 \mathrm{HP}$ and $\$ 5.00$ for those of 30 or more. The next year, Connecticut provided for a more steeply graduated scale of charges.

Thus, the user charge was in existence at the beginning of this century but not exploited as a source of significant amounts of revenue for highways. Its role as part of a system of motor-vehicle imposts dedicated to furnishing a consistent, dependable flow of revenue for long-term highway financing was not foreseen at this stage of highway development. 


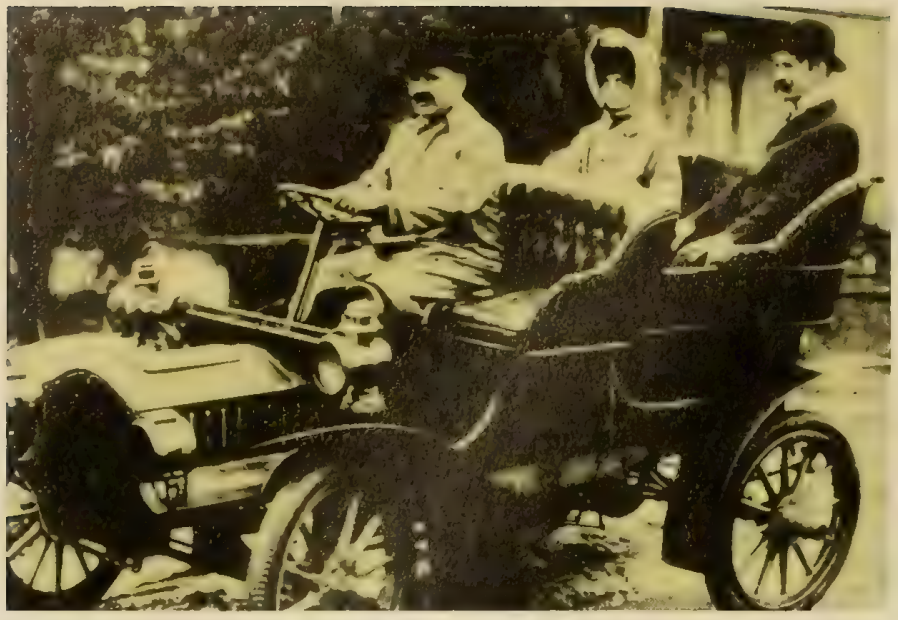

The highway-user tax derived from the registration of vehicles, in this case a 1905 cadillac.

\section{An Experiment in Federal Aid}

The growing demand for highway improvement was reflected in the more than 60 bills introduced in the Congress in 1912 providing for some form of Federal aid for this purpose. ${ }^{2}$ Activities leading toward development of a plan for nationwide Federal aid for highways first bore fruit in 1912, when Congress, in passing the Post Office Appropriations Act, took two steps: (1) It created an investigating committee to study the feasibility of providing Federal aid for improving rural post roads, and (2) it appropriated $\$ 500,000$ to aid the immediate building of such roads.

The Postmaster General and the Secretary of Agriculture were to administer the program jointly, and they were directed to select and improve certain roads for mail delivery. The States and their subdivisions were to pay two-thirds of the cost of the improvements and the Federal Government, one-third. The $\$ 500,000$ in Federal funds for immediate construction was supplemented with $\$ 1.3$ million of State and local funds.

Although the funds were provided through the Post Office Appropriation Act, direct responsibility for operating the program was assigned to the Office of Public Roads. For want of a better basis, the funds were apportioned equally among the States,

Early use of trucks was limited to local industry because of poor road conditions and few interconnecting roads.

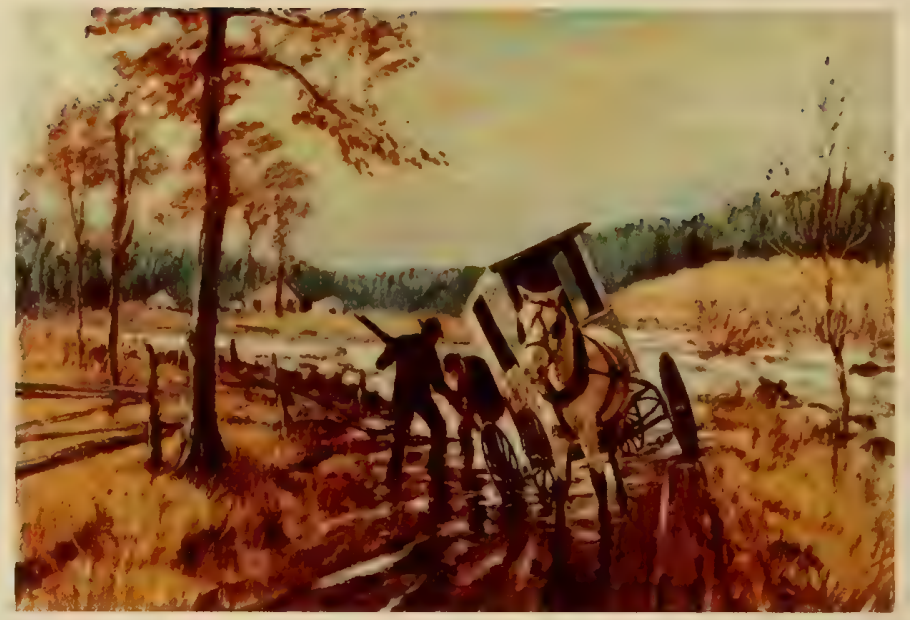

The Federal effort to improve rural post roads was rather disappointing since only 13 States participated in the project.

about $\$ 10,000$ to each. This approach failed miserably. Some States refused outright to participate, some were unable to do so because of constitutional and other limitations, and others simply did not respond to the offer.

The Public Roads officials, together with cooperative State and local officials, then selected projects that they believed to be representative in such characteristics as topography, soil condition, and climate. The first project to be built under this Act extended for about 30 miles from Florence to Waterloo in Lauderdale County, Alabama. A total of 455 miles of road located in the 13 States that elected to take advantage of the program were improved under this arrangement, successfully demonstrating the possibilities of a Federal-State cooperative road improvement program.

\section{The Federal Aid Road Act of 1916}

Two years before the landmark Federal Aid Road Act of 1916, revenue for rural roads and bridges had risen from $\$ 80$ million in 1904 to $\$ 240$ million, a threefold increase.* The number of motor vehicles

\footnotetext{
* In 1904 the Office of Public Roads began a policy of obtaining road mileage and revenue data at 5-year intervals. In 1904 the data were published in Bulletin No. 32 of the U.S. Department of Agriculture. The data for the third such investigation (1914) are presented in HIGHWAY STATISTICS: SUMMARY TO 1965, issued by the Bureau of Public Roads in 1967, which is the general source of the financial and motor vehicle data in this chapter.
}

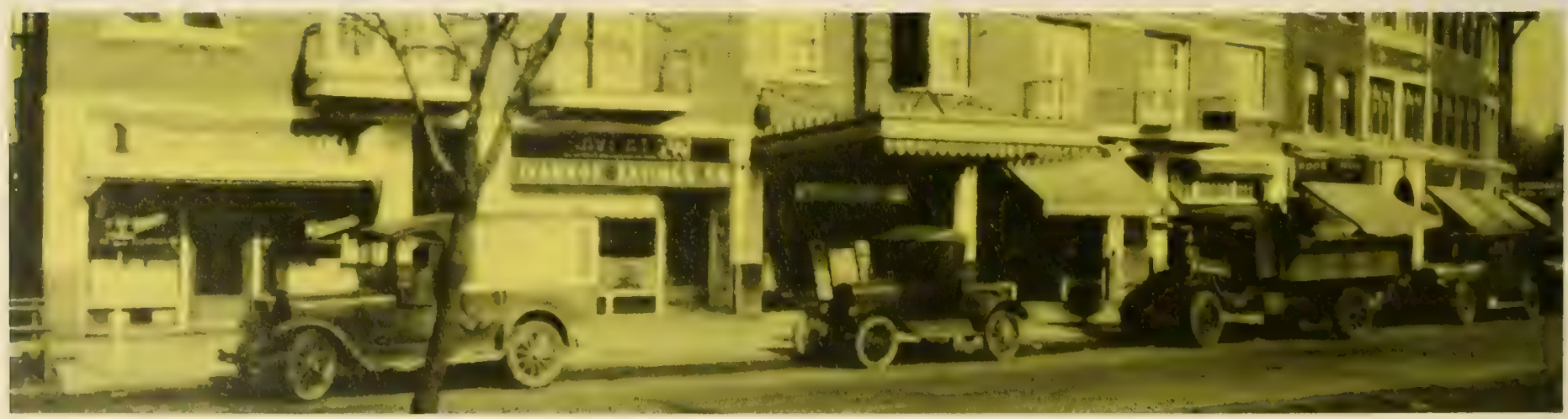


registered had increased from 55,000 in 1904 to nearly 2 million in $1914 .{ }^{3}$ But this increase is not as great as it appears to be, since it represents a larger number of States requiring vehicle registration in the later year-47 as compared with only 13 in 1904. Imposts on motor vehicles, rapidly growing in importance as a source of State income for highways, provided $\$ 12$ million of the $\$ 75$ million spent by the States for that purpose.

Of the almost 2.5 million miles of rural roads in 1914 , only 257,000 were surfaced and a mere 14,000 miles had a high type of surface:

$\begin{array}{lr}\text { Bituminous } & 10,500 \text { miles } \\ \text { Brick } & 1,600 \text { miles } \\ \text { Concrete } & 2,300 \text { miles }\end{array}$

By 1916, 3.4 million autos were registered and 1 truck for every 14 autos. Roads were not equipped to meet the needs of this growing vehicle population. Probably because of the poor condition of most rural roads and their discontinuity, the use of trucks was limited almost entirely to cities and their close-in suburbs. Although trucks were beginning to be used for intercity transportation, this use was not yet economically significant and was largely restricted to the household moving industry.

Yet the potential of trucking was recognized; and farmers, railroads, and others joined the ranks of the auto owners and wheelmen (bicyclists) who were dissatisfied with the progress being made and who were pressing for better roads. One of their loudest complaints was about the lack of completed intercounty and interstate improved routes.

County and local authorities tended to improve those roads that were the objects of the greatest local pressure or were best suited to the needs of the local economy in narrow terms, with little regard for the requirements of the traffic going to and from other jurisdictions. Nor did the States usually make a serious effort to gear their road improvements to those of adjoining States.

A step forward in progress toward connected road systems, the Federal Aid Road Act of 1916 contained some of the most important principles still in effect today. The Act reserved to the States the right to initiate projects and determine their characteristics and to perform the work directly or by contract. Completed projects were to be federally inspected and approved for reimbursement to the extent of 50 percent of the funds expended, not to exceed $\$ 10,000$ a mile. The policy of the United States Government favoring a tax-supported highway system was expressed in a provision that "All roads constructed under the provision of this Act shall be free from tolls of all kinds."

While the Act itself did not require that Federal aid be spent upon designated-system routes, the Bureau of Public Roads requested that each State highway department designate a limited system to which it would confine its Federal aid. Maintenance was made a State and local responsibility.

In recognition of the longer time span required for financing large capital improvements, funds were appropriated for a 5-year program and were apportioned among the States according to a formula based on area, population, and post road mileage. Thus, the eligibility of roads for improvement with Federal-aid money, adopted from the earlier post road Act, carried forward the justification of Federal aid on the basis of the use of roads for carrying. the mail, although the provision was so broad as to enable almost any rural road to qualify.

\section{World War I and Its Aftermath}

At the end of 1917, all 48 States had formed highway departments adequate to meet the requirements of the 1916 Act, and 26 States had submitted for approval 92 projects involving 948 miles of road, expected to cost about $\$ 5$ million. With United States' participation late in World War I came general economic dislocations because of the draining of manpower and materials to the war effort. By the 1918 fiscal year, all Federal-aid work was limited to projects essential to that effort. Even so, the required projects were such that the amonut of Federal-aid construction completed and under agreement continued to grow.

Following the Armistice on November 11, 1918, the public began to clamor for a speedup in the regular Federal-aid program. In 1919, Congress increased the appropriation for the period 1916-1921 from $\$ 75$ million to $\$ 200$ million. In spite of the handicaps of shortages and high costs of materials and labor, strikes, and unrest, the work accomplished during fiscal year 1920 exceeded by 25 percent all work done previously under the Federal Aid Road Act.

During the year, a survey was launched to obtain data needed to establish a classified system of highways. At the same time, Federal officials were cooperating with the War Department in selecting a system of highways of military importance.

Before the First World War, the military establishment exhibited little interest in trucks and truck transportation. In 1911 the Army began experimenting with their use. In 1912 it tried out trucks of 11 different makes in a cross-country operation from Washington, D.C., to Atlanta, Georgia, and thence to a camp near Sparta, Wisconsin. Only one vehicle, an all-wheel drive truck, finished the journey. The resulting Army report approved the use of trucks for field and supply purposes, but nothing came of it.

By this time, the Office of Public Roads had become interested in the possibilities of overland truck transportation. In 1911, the agency participated in the first coast-to-coast journey made by a truck by designating the driver as a special agent of the Office of Public Roads. Although the trip was accomplished in two entirely separate operations, it reached both coasts and demonstrated that trucks could negotiate the nearly impassable roads and rugged terrain.

World War I was the first "motorized" war, and thousands of trucks were built by American factories for military use. In 1919 a convoy of 20 Army trucks was sent from Washington, D.C., to San Francisco to further demonstrate the capability of such vehicles for wartime transportation. It took 56 days to complete the trip. One of the officers making the journey was Captain Dwight D. Eisenhower, who became greatly impressed with the possibilities of highway transportation. 
One of the significant roles of highways in freight movement has been to serve "as extenders and connectors for other transportation modes." One highway extension of rail service, now called "piggyback," began in a primitive form in the 19th century when circus wagons and wagons carrying farm produce and livestock were transported on flatcars, starting and finishing their journeys on their own wheels.

As now used, the term piggyback service means transporting cargo by both rail and highway, in or on highway trailers and principally in van-sized containers. Beginning in the 1920's and extending into the 1930 's, extensive experimenting with piggyback service was carried on in an effort to increase the use of motor vehicles in moving freight by overcoming the limitations imposed by poor roads in disconnected systems. Conditions of the time did not support the effort, and it was left to the future.

\section{Uncerfainty and Crisis in the States}

Failure of the Congress to enact a new highway bill before January 1921 precipitated a major financial crisis in most States. Having no assurance that a Federal-aid highway bill would be passed, the States had to cut back severely on work underway and contemplated. Contracts in progress were modified or canceled. Requests for bid proposals were withdrawn. Clearly a capital program of this magnitude required the regular commitment of funds over the relatively long period from planning to the completion of construction.

The States, seeking new ways to bolster their revenues, had begun to look to the motor vehicle as a potentially productive source. As motor vehicles became more numerous on the highways and their damaging effects on lightly constructed road surfaces became evident during the war period of 1917-1918, the practice of graduating registration fees with the weight or capacity of the vehicle grew until it had spread to all States. By 1917 all States required motor vehicles to be registered at fees averaging a little more than $\$ 7.00$ per vehicle.

In 1919 the State of Oregon levied the first tax on the sale of fuel for motor vehicles. The tax was adopted by other States because it proved at least a rough measure of highway use, was relatively painless to the taxpayer, and easy for the State to administer. But in 1921 this tax, which later became the prime revenue producer for highways, brought in only $\$ 5$ million, compared with $\$ 116$ million for registration fees.

\section{AASHO Recommendations}

Shortcomings of the 1916 Act began to be evident by 1919 , and the annual report of the Bureau of Public Roads for the 1920 fiscal year contained recommendations made by the American Association of State Highway Officials for modifying some of the financial provisions of the law:

- Federal appropriations should be at least $\$ 100$ million a year in order to carry out the program.

- The Federal-State 50-50 matching ratio should be modified to increase the Federal share in States where more than 10 percent of the area was public lands.

- The application of Federal aid should be restricted to those roads that would expedite completion of a national highway system.

- Federal appropriations for forest roads should be continued for 10 years at the level of $\$ 10$ million a year.

The Federal Highway Act of 1921 provided for only a 1-year continuation of the cooperative FederalState financing plan by appropriating $\$ 75$ million for the 1922 fiscal year. But the next year, Congress began the practice of authorizing Federal aid for succeeding periods of 2 or 3 years. These funds were then apportioned to the States in accordance with

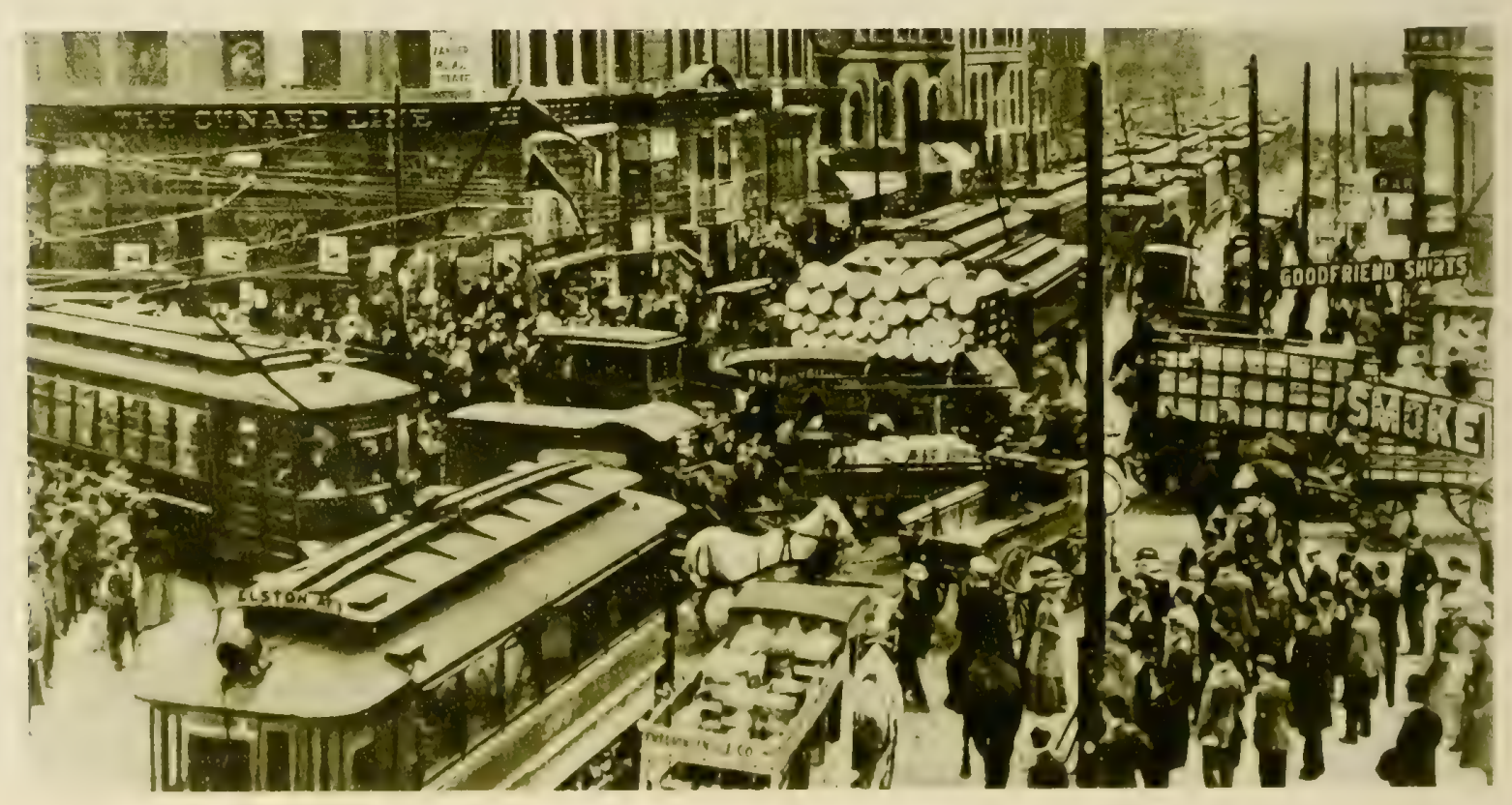


the previously existing formula with two modifications: one for small States and the other for the large public land States.

For small States, which were receiving virtually meaningless amounts of aid (for example, less than $\$ 25,000$ apiece for Delaware, New Hampshire, Rhode Island, and Vermont in 1917), a floor of at least onehalf of 1 percent of the total apportionment was established. For the large western States, whose extensive areas of untaxable federally owned land put them at a serious disadvantage, the remedy was to increase the Federal share of highway funds above 50 percent in proportion to the ratio of public lands to the total area of the State. The areas within national forests, parks, and monuments were excluded from the calculation.

To insure that Federal funds would be spent on roads of more than strictly local importance, the Act required that all Federal-aid funds be expended on a primary system of highways limited to 7 percent of the State's total highway mileage on November 9, 1921. This interconnected system included two classes of highways: (1) Primary or interstate highways, comprising $3 / 7$ of the system, and (2) secondary or intercounty highways, comprising the remainder. No more than 60 percent of the funds apportioned were to be expended on the primary or interstate highways.

City residents began to benefit from the highway improvement program long before the expenditure of Federal-aid highway funds on municipal streets was authorized. By focusing attention upon the improvement of intercity and interstate routes, the creation of the Federal-aid primary system under the 1921 Act stimulated more travel over greater distances. than had been possible before.

Urban automobile owners began to venture beyond the city limits on "joy rides," and commercial and intercity trucking developed. On the other hand, although farm-to-market trucking of agricultural com- modities became common in many areas, the horse and wagon was still an important factor in such movements.

\section{Highways a Local Program}

The highway program was still essentially a local one in 1921, financed largely from property taxes and general-fund revenues and concentrated on county and local roads. If the work-relief expenditures of the thirties are excluded, the estimated capital outlay of $\$ 337$ million for county and local roads in 1921 was not equaled until the early fifties. At the same time, almost three-fourths (\$771 million) of the more than $\$ 1$ billion of total current revenue (i.e., exclusive of bond proceeds) available for road and street purposes was obtained from county and local sources. The Federal and State governments furnished the remaining $\$ 285$ million, of which $\$ 123$ million (43 percent) came from State imposts on motor vehicles.

Bond proceeds of $\$ 353$ million increased the current (exclusive of bond receipts) highway funds available by about one-third. The county and rural local governments borrowed about 57 percent of this sum (\$202 million) and the States the remainder. Borrowing by municipalities was not reported.

\section{Increasing Role of Credit Financing}

It was common practice to issue highway bonds secured by a general pledge of the taxing power of the issuing authority. These general obligation or full faith bonds are still predominant among the obligations issued to finance toll-free capital projects.

As the revenue potential of highway-user taxes came to be realized, the practice of issuing State highway bonds gathered momentum. Those highway administrators who advocated credit financing contended, with much justification, that the savings to highway users brought about by acceleration of the road-improvement program would more than compensate for the interest charges on the bond issues.

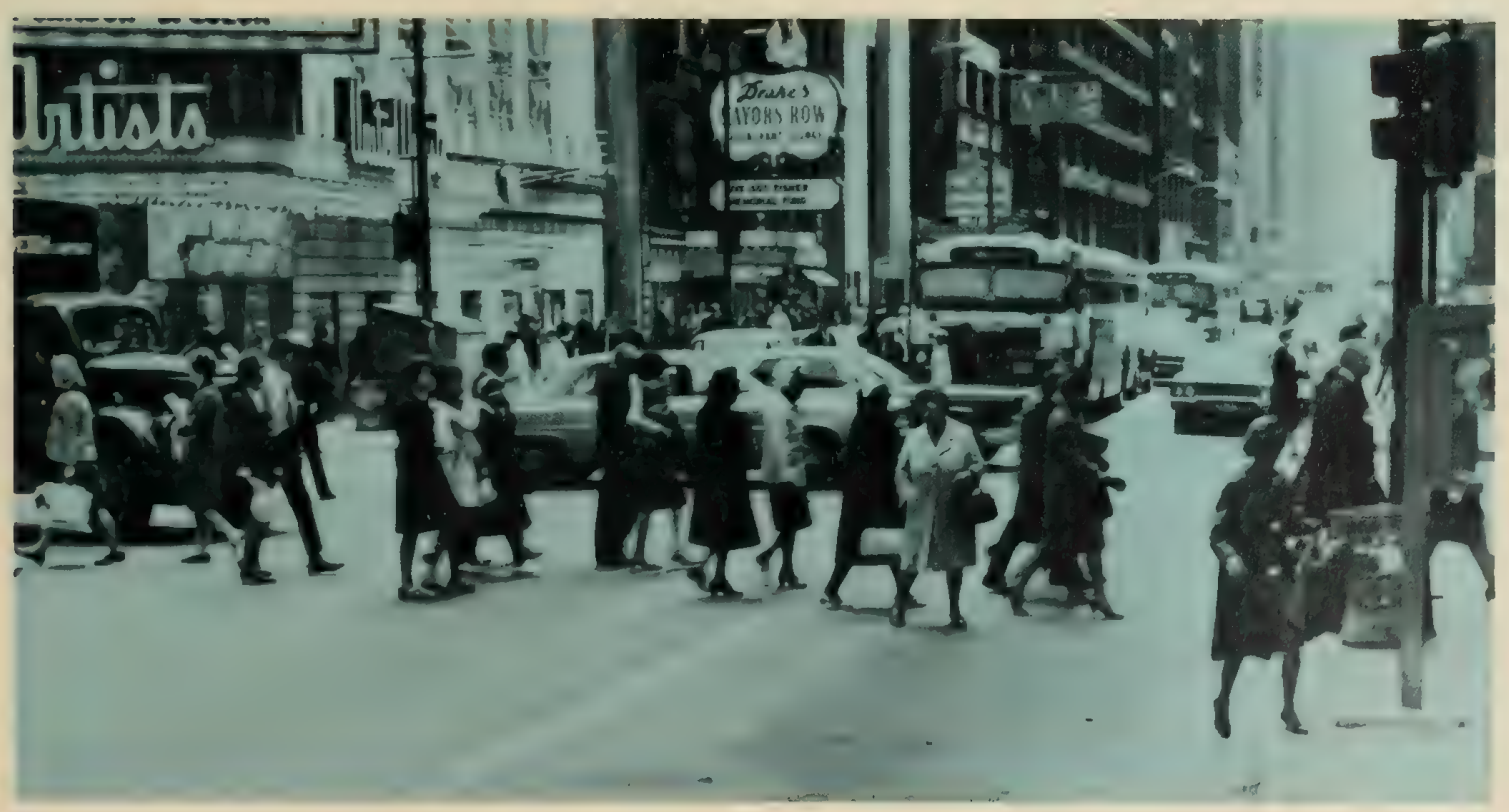




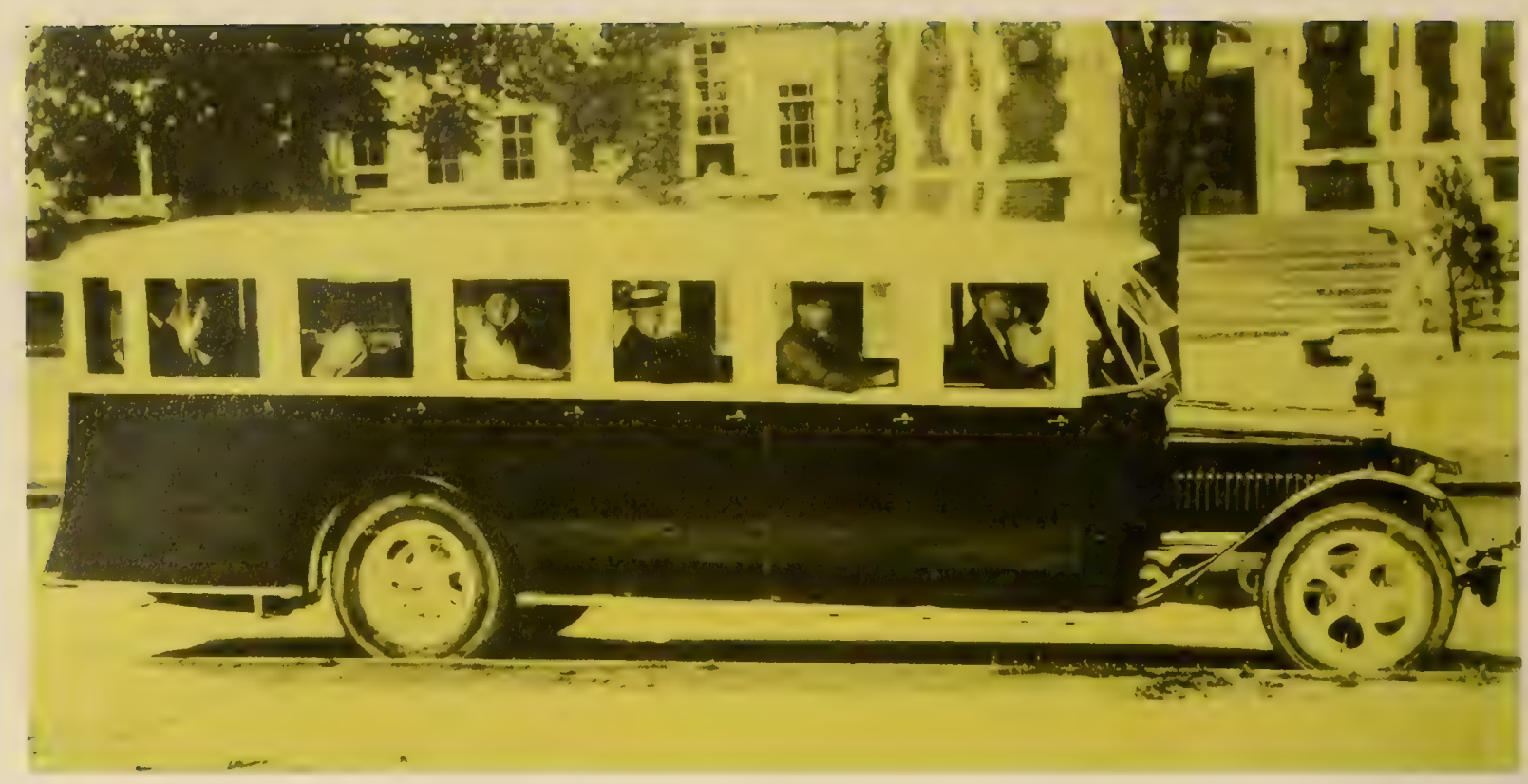

A 1922 deluxe coach manufactured by the Superior Motor Coach Body Company.

During the period from 1921 to 1930 , bond proceeds contributed from 25 to 40 percent of all State construction funds. This was the first great period of accelerated bond financing. Illinois, for example, authorized bond issues totaling $\$ 160$ million; Missouri, $\$ 135$ million; and North Carolina, $\$ 115$ million. In these States, and others with similar programs, bond issues formed the bulk of highway construction funds during the decade.

A number of States that did not or, because of constitutional limitations, could not issue bonds did not hesitate to make use of the borrowing power of the counties, townships, and road districts. These units in numerous States either borrowed to build roads that later became State highways or supplied bond proceeds to the State highway departments.

Beginning in the 1920's, many States undertook to reimburse the counties for these contributions to State highway systems. These obligations usually took one of two forms: (1) An agreement between the State and its local governments whereby the State would reimburse the local governments in annual amounts for costs incurred initially in building roads that later become part of the State systems or (2) an agreement whereby the State would pay to its counties an annual amount equal to the interest and principal on local highway bonds issued for such purposes. The security for this type of obligation was somewhat obscure except when the State had funded or refunded the obligation from the proceeds of its own bond issues.

The practice of transferring funds between levels of government complicates the pattern of highway finance in other ways. The States not only provide financial aid to counties and cities, but they spend money directly on county roads and city streets. There are also arrangements whereby one unit of government performs certain services (maintenance, for example) for another and is reimbursed for the cost of the services.
Most of the Federal expenditures for highways in 1921 were, of course, in the form of aid to the States, amounting to $\$ 78$ million. The States also received $\$ 33$ million from county and local rural governments and transferred $\$ 22$ million to them-a net increase of $\$ 11$ million in State funds and a corresponding decrease in the county and local funds available for expenditure on roads.

The Federal Highway Act of 1921 confirmed the Federal Government's policy against tolls on federally aided facilities expressed in the 1916 Act. But large bridges and other crossing facilities, because of their semi-monopoly position and their costliness, had long been widely accepted as suitable for toll-revenue financing. The use of revenue bonds payable solely from the earnings of the facility (tolls) began with the Port of New York Authority bond issues in 1926.

In 1927 Federal policy with respect to tolls was modified by the Oldfield Act (now 23 U.S.C. 129(a)), which allowed the States or their instrumentalities to use Federal funds to construct or acquire toll bridges, provided that net revenues would be applied to the capital costs of the facility or the retirement of its debt and provided that the facility would be toll free upon retirement of its outstanding indebtedness. This Act had the effect of discouraging the construction of privately owned facilities and did not lead to any significant amount of toll bridge construction.

\section{From War to Depression}

The period following passage of the Federal Highway Act of 1921 was one of considerable accomplishment, as improvements on the designated Federal-aid system moved forward. Annual Federal authorizations remained at $\$ 75$ million through 1930 and the onset of the Great Depression.

Total expenditure for highways by all levels of government grew rapidly, reaching $\$ 2.5$ billion by 1930. State income for highway purposes had risen steadily since 1920 . The yield of State motor fuel 
taxes constituted only 3 percent of State and local imposts on motor vehicles in 1921. By 1926 they totaled $\$ 188$ million, which was 40 percent of user-tax collections, though still well below the $\$ 258$ million received from registration fees.

In 1929, the first year in which all the States and the District of Columbia levied the motor fuel tax, its yield exceeded that of registration fees. By 1931 it produced $\$ 538$ million, nearly three times the 1926 yield and close to twice the income from registration fees of $\$ 298$ million.

In 1923, when 37 States imposed a motor fuel tax, the average rate was under 2 cents a gallon. In 1929 it averaged approximately 3.7 cents.

A new fee was added to the user-tax family in the twenties. Vehicle-operator and chauffeur licensing began in most States in the early part of the decade. In 1925 the States obtained nearly $\$ 10$ million from this fee, which is not considered a prime source of revenue for road purposes.

As the decade of the thirties opened, the Depression triggered by the 1929 stock market crash was beginning to be felt in highway financing, but there was a delayed response to economic conditions so that, for a time, the pattern of highway finance continued very much as it had before. The Federal-aid program had been moving forward at a rapid rate. Federal aid for highways of $\$ 273$ million in 1931 was nearly three times the 1921 figure. Together, Federal and State funds were providing half of all current income available for roads and streets. The equivalent of most of the Federal-aid funds received by the States was passed on to the counties and local governments. Only $\$ 50$ million of these funds was spent by the States themselves.

State taxes on motor vehicles and their use were now a major element in the tax structure. Totaling $\$ 848$ million in 1931, they were 93 percent of all State revenue for highways obtained from State sources. They provided nearly seven times their 1921 yield and constituted about 36 percent of the total of $\$ 2.3$ billion available in that year for highway and street expenditure by all levels of government. State bond proceeds added another $\$ 351$ million to the available State funds.

On the expenditure side, the total by all levels of government began to decline sharply in 1930 until it reached a low level of about $\$ 1.7$ billion in 1933 . Although declining, State current expenditures (excluding debt retirement) of $\$ 1$ billion in 1931 were still more than $21 / 2$ times their 1921 level. On the income side, on the other hand, average State registration fees and related imposts began to decline only slightly after 1931, largely because of the adoption of graduated fee schedules lowering the rates for certain types of vehicles, notably passenger cars and light trucks.

For county and local roads, expenditures from regular highway funds had reached $\$ 700$ million in 1930 , nearly $\$ 100$ million more than they were in 1921 . Expenditures for city and village streets showed much greater growth, rising from $\$ 337$ million to a high point (if Federal work-relief expenditures are omitted) of about $\$ 800$ million. Taken together, these
1930 expenditures by the counties and localities, rural and urban, were more than 11/2 times their 1921 level.

During the 10-year period since 1921, a change in emphasis had taken place in the financing of local roads and streets. In 1930 the counties and local rural units of government were spending more to maintain and administer their roads and to pay interest on the debt incurred for highways than they were spending for new construction. Expenditure for construction by the urban governments exceeded those of the rural governments by close to $\$ 200$ million, a foretaste of the effects of the great population movement to the cities.

\section{Failure of the Property Tax}

Motor vehicle imposts were relatively unaffected by the Depression. The major problem in highway finance arose from the failure of the property tax to fulfill its customary role in support of the highway function, which had been a major recipient of property tax income in most States. The municipalities were almost totally dependent on the property tax for road and street funds, and the counties and local rural governments only a little less so.

As income from farming and other sources declined, unemployment soared, and prices (especially farm prices)- skidded downward, taxpayers began to default on their mortgage and tax payments. Delinquency rates rose rapidly, and mortgage foreclosures and tax sales became common.

State laws were enacted providing for increased leniency toward tax delinquents. Limits were placed on tax rates, the levy of taxes on property for certain purposes was sometimes forbidden, and homeowner and other exemptions were introduced.

Laying a new stone block surface at East $23 d$ and Broadway in New York City in the late 1920's.

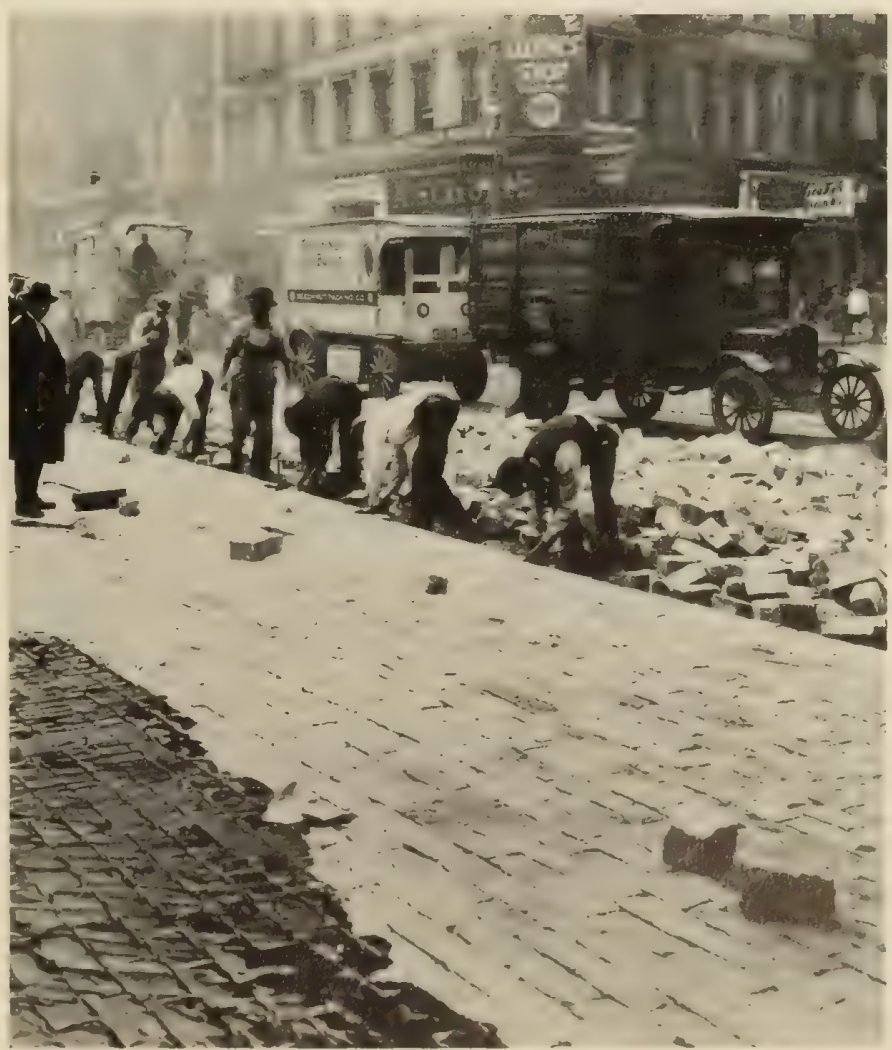




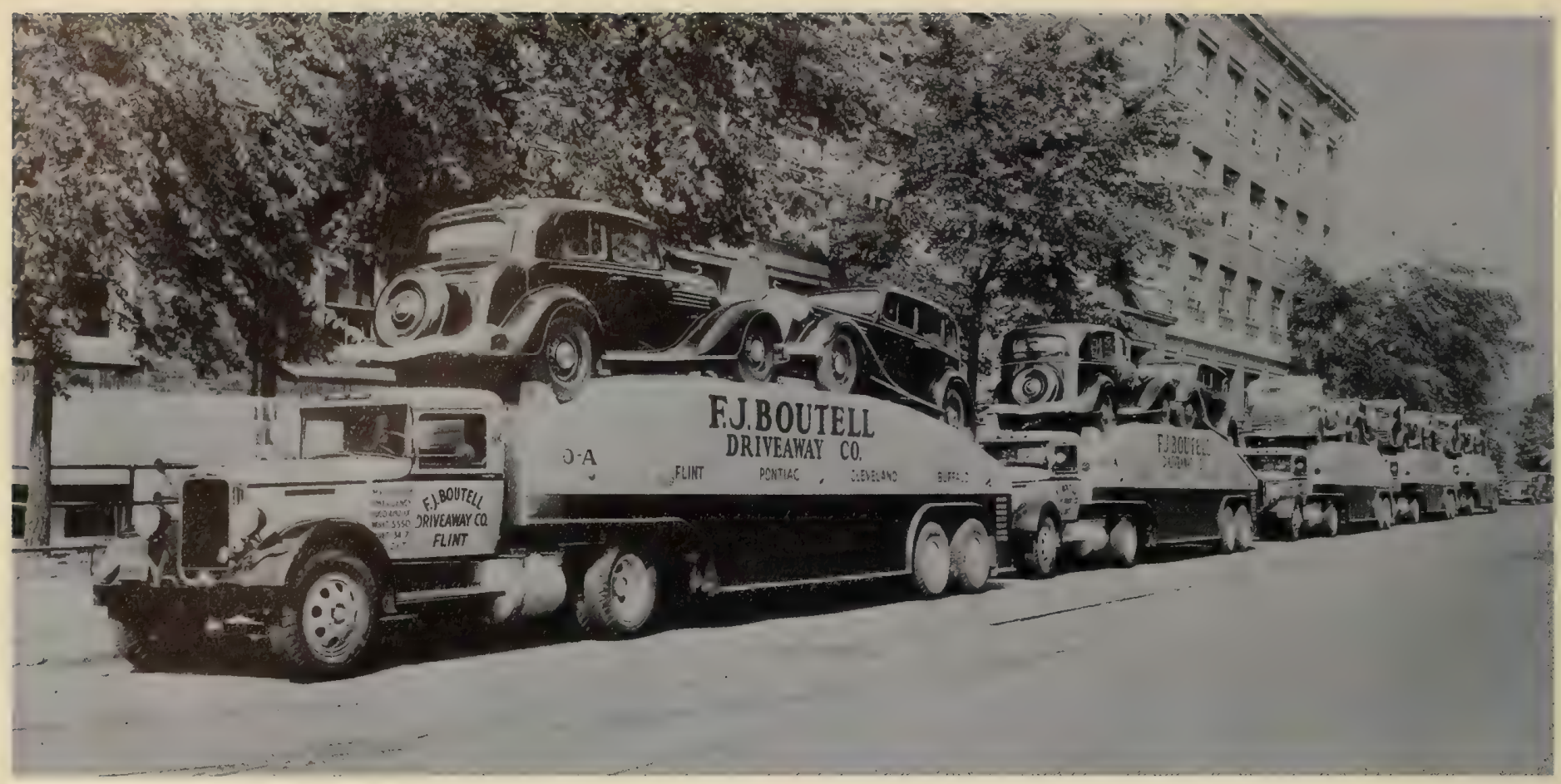

Much automobile travel was evident in the 1930's despite the Depression, thus, the need for new autos to replace old ones.

In 1931, the States faced difficulty in matching their Federal-aid apportionments. To ease the effects of the Depression, annual Federal highway authorizations were increased to $\$ 205$ million in 1931 , reduced somewhat to $\$ 125$ million in 1932 , and increased again to $\$ 229$ million in 1933 . But the lack of matching funds was only partly the result of these large increases above the $\$ 75$ million a year previously authorized. Nor did it arise from declining State revenues from motor vehicle imposts, since these revenues declined very little at any time during the Depression. Rather, it stemmed from the large sums used by the States to replace local revenues from property taxes in financing local roads and city and village streets. Moreover, substantial amounts were diverted from highways to meet the rising demand for expenditures for other purposes.

Many States took action to provide tax relief by reducing or eliminating property taxes as a source of revenue for highways. In four States (Delaware, North Carolina, Virginia, and West Virginia), responsibility for administering and financing all county and local rural roads was transferred to the States, except that in Virginia the counties were allowed the option of retaining control of their highways. Following the transfers, local property taxes for highways were customarily reserved for servicing debt already outstanding and sometimes for bridge construction.

Indiana was representative of States that left secondary and local roads under local control but provided for the transfer of State motor-vehicle user taxes to the local jurisdictions for the support of roads. In these States, imposition of property taxes for highways was usually forbidden except for bond service. Most of the remaining States adopted a middle course, transferring some roads from local to State responsibility or providing increased State aid for secondary or local roads.

\section{Emergency Federal Aid}

In an act passed on December 30, 1930, Congress advanced $\$ 80$ million to the States for matching regular Federal-aid apportionments. As conditions worsened, the Emergency Relief and Construction Act of 1932 made a further advance of $\$ 120$ million. It also provided for 1-percent additions to the Federal-aid highway systems that were originally limited by the Federal Highway Act of 1921 to 7 percent of total State highway mileage, as these systems were completed according to standards acceptable to the Bureau of Public Roads.

Unemployment grew to crisis proportions, and Congress was forced to turn from the regular Federalaid program to other types of financing, emphasizing projects that would provide for as much direct labor as possible. Thus, the regular Federal-aid authorizations were replaced with emergency appropriations. The Federal Government made available a total of $\$ 1$ billion of such funds for the fiscal years 1934-1936, far more than ever before for a like period of time.

The National Industrial Recovery Act of 1933, while not primarily a highway bill, included several provisions affecting the financing of highways. The President was authorized to make grants of not less than $\$ 400$ million to State highway departments to provide for the emergency construction of highways. The use of these funds did not carry with it the customary restrictions on the use of Federal-aid highway funds. The funds were to be available without matching by the States. They could be used for projects on the urban extensions of Federal-aid system routes; for paying as much as 100 percent of the costs of preliminary engineering; for projects associated with highway safety, such as building footpaths or eliminating highway-railroad grade crossings; and for construction on secondary and feeder roads off the Federal-aid system. 
Seven-eighths of these emergency funds were to be apportioned according to the regular Federal-aid formula and the remainder on the basis of population alone. The Act did not specify how the funds were to be allocated to the highway systems. An administrative decision was made to allocate about 50 percent to the rural Federal-aid system, 25 percent to its urban extensions, and 25 percent to secondary and feeder roads.

Some $\$ 95$ million of the authorized $\$ 400$ million went to highway projects on secondary or feeder roads not then on the approved system of Federal-aid highways but which were either part of State highway systems or important local highways leading to shipping points on roads that would permit the extension of existing transportation facilities. This was the first major Federal action directed towards secondary or farm-to-market roads. ${ }^{4}$

The Hayden-Cartwright Act of 1934 authorized a highway appropriation of $\$ 200$ million to be apportioned to the States immediately according to the revised formula of the National Industrial Recovery Act. No less than 25 percent of the apportionment to any State was to be applied to secondary or feeder roads.

The States were relieved from repayment through deductions from future Federal-aid apportionments previously advanced for emergency unemployment relief. Matching by the States was not required, and the money could be used to pay for such preconstruction expenses as surveys and the preparation of plans.

The effect of the 1934 Act was to incorporate as a matter of continuing Federal-aid highway policy the provisions for using Federal funds to improve secondary and feeder roads and to eliminate such traffic hazards as railroad-highway grade crossings. The Act also provided for withholding sums up to onethird of their subsequent Federal-aid highway apportionments from States using motor-vehicle revenue for nonhighway purposes, except in those instances provided for by State laws in force at the time the Hayden-Cartwright Act was passed. This was the genesis of many State so-called "antidiversion" amendments.

State governments have often dedicated income from particular sources to particular purposes. This practice, which is embodied in State constitutions and statutes, has the effect of removing "earmarked" revenues from the regular annual or biennial review of the legislature. Carried to an extreme, it allows no flexibility in applying income to the governmental services determined to be necessary at any given time, so that a case could be-and was-made for the point of view that the special commitment of funds to highway purposes had no valid significance-that all governmental revenues should be general revenues and all expenses should be defrayed out of general funds.

While it was generally acknowledged that the nonhighway purposes to which highway-user revenues had been directed were, for the most part, essential functions for which money must be obtained from some source, nevertheless the antidiversionists pointed to the fact that the State highway-user tax schedules had been predicated on the concept that in paying these taxes the highway user was contributing his due share to the support of the highway system. Highway-user taxes being measured by the requirements for highway expenditures, the product of these taxes, it was argued, should be used for the purpose that determines their magnitude.

Historically, the highway function in this country had always partaken of the nature of a public utility, with aspects both of a private-enterprise and a governmental activity. Before the coming of the motor vehicle, local taxpayers could not meet the demand for land transportation over long distances, and it was left to private capital to provide these facilities. For a while, the pricing mechanism was tolls, and the user-tax principle was partially developed during the period of the early toll roads. These roads were soon put out of business by the railroads, roads once more becoming a local governmental function. Highwayuser taxes, then, could with justification be linked to the benefits received from the service to which they were dedicated, inasmuch as they provided an indirect pricing of the benefits of highway use.

With the development of the road-user tax structure and its growing importance as a source of highway funds during the 1930's, a number of States followed the lead of New Mexico, the first State to issue general obligation bonds secured by a specific pledge of road-user tax revenue. Bonds backed by this type of security proved to be a more attractive investment than bonds secured by the general taxing power of the State.

Although no regular Federal-aid authorizations were made for the fiscal years 1934 or 1935 , Federal funds continued to be authorized for forest highways (begun in 1917) and public lands highways (begun in 1931). Other highway funds not administered by the Bureau of Public Roads were made available through the National Park Service, the Forest Service, and the Bureau of Indian Affairs. Allocations for Indian reservation roads were made for the first time in 1933.

Although 1934 was a mid-Depression year, the indicators of highway use were on the upswing. Motor vehicle registrations were already close to full recovery.

Present patterns of automobile use were fairly well established at that time. More automobile trips were made for earning a living than for any other purpose, and most auto trips were within a radius of less than 10 miles from home. Average annual automobile travel was generally least in the rural agricultural areas and highest in middle-sized cities.

As motor vehicle ownership increased and private automobile travel became more convenient and dependable, other available passenger service began to dwindle and, in some cases, essentially disappear. Among the casualties-mainly after 1930-were the electric interurbans, local railroad passenger service, and local commuter bus and trolley service. By the late 1930 's, many communities were left with no public passenger transportation service at all. 


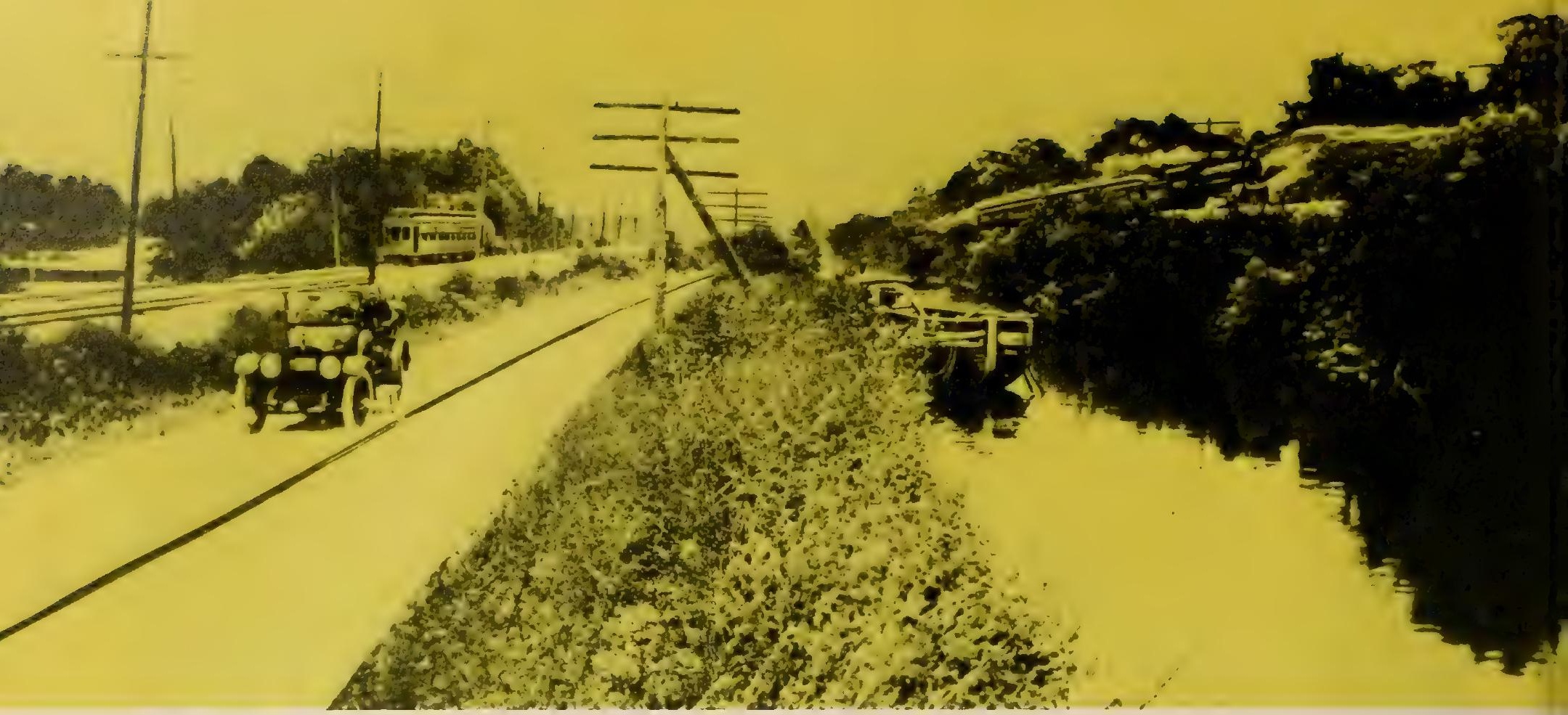

Moving people and goods: the trolley line, the highway, the canal, and the railroad. By late 1930's, the trolley lines and the canals had become casualties of the transport war between highways and railroads.

The transportation of goods by highway, on the other hand, was becoming increasingly important economically, so much so that by the late 1930's the railroads, beginning to view intercity truck transportation as a competitive threat, called for a study of truck taxation. In 1936, the first year such calculations were attempted by the Bureau of Public Roads, the average truck was estimated to have been driven about 10,000 miles a year, and total travel of all trucks was estimated at 41 billion vehicle-miles.

Special fees and taxes had begun to be levied in connection with registration fees on for-hire carriers of persons and property. By the mid-thirties, such imposts were in effect generally in the States, although they were not great revenue producers. Their importance lay in their usefulness as a means of regulation and of applying concepts of equity to the tax schedules.

The 1933 low point of $\$ 1.7$ billion in total expenditures for highways was followed by an erratic increase, which peaked at almost $\$ 2.7$ billion in 1938 . Then the Federal emergency funds began to run out. But the expenditures from funds normally available for highways continued a gradual upward trend until World War II stringencies began to force a reduction. Federal work-relief expenditures, although continued through 1942, reached a maximum in 1938, when the amount spent on county and local rural roads reached $\$ 389$ million and on city and village streets, $\$ 367$ million.

The late 1930 's saw what may be said to be the beginning of the modern toll road movement with the construction of the Pennsylvania Turnpike from 1937 to 1939. The State turned to this method of financing because of insufficient funds to improve existing roads to adequate standards. But the turnpike was not financed as a wholly self-supporting facility. Federal Public Works Administration grants totaling \$295 million were supplemented by $\$ 40.8$ million of bonds sold to the Reconstruction Finance Corporation. The turnpike suffered badly because of wartime restrictions in the 1940's, and it operated at a loss most of the time until the end of the war.

Although the total governmental debt for highways included such large revenue bond issues as those for the Pennsylvania Turnpike, the San Francisco Bay Bridge, and the Port of New York Authority's bridge and tunnel program, the period of the 1930's produced slightly diminished State highway borrowing. The dominance of Federal-aid funds during this period of depression and recovery reduced the relative contribution of bond proceeds to about 20 percent of the funds used to finance highways. But the reliance on borrowing shifted from the local governments to the State. In 1926 State highway bond issues exceeded those of county and rural local governments for the first time and, with several exceptions, have annually dominated the highway bond market.

The Federal Government's anti-toll policy was once again written into the statutes with the passage in 1937 of a law authorizing Federal-aid funds to be used for freeing toll bridges on the Federal-aid system. It authorized the payment of Federal money up to 50 percent of the cost of labor and materials actually used in the construction of any toll bridge built after 1927 on the Federal-aid system. In return, the recipients had to agree to remove the tolls.

At the close of the 1930 's, highways had not fully recovered from the effects of the Depression. World War II was raging, and the possibility of an end to United States neutrality was on the horizon. 
Highway Development During World War II

The Federal Highway Act of 1940 became law more than a year before the Pearl Harbor incident made the United States an active belligerent. The Act provided that, on request of the Secretaries of War and Navy or the head of any other official national defense agency and by order of the Federal Works Administrator, Federal-aid highway funds previously authorized could be used, without matching, to pay for preliminary engineering and for supervising the construction of projects essential to the national defense.

The decade of the 1940 's was marked by two contrasting developments: (1) The cessation of normal highway construction during World War II followed by (2) accelerated construction expenditure accompanied by an increase in borrowing for highway purposes after the war. At the outset, the Nation was entering a period of wartime economic boom that hastened what might otherwise have been a long, slow pull out of the Depression. But the boom found materials, equipment, and labor for normal civilian purposes in short supply.

In 1941, 78,000 miles of highway were designated as the strategic network developed in cooperation with the War Department and used in selecting highpriority projects for construction. Approximately 20 percent of the mileage in this network was found to be seriously inadequate, and the proportion was found to be even higher on other essential roads, such as those providing access to war industries, ammunition depots, and military establishments.

The Defense Highway Act of 1941 appropriated funds for construction on the strategic network, to be apportioned according to the standard formula but with State participation limited to not more than 25 percent of the project cost. Funds were authorized, without apportionment, for projects on access roads, these funds to be available with or without State matching and usable for purchasing right-of-way and for off-street parking.

Policy for the conservation of critical materials called for (1) deferring all nonessential highway construction that would consume large amounts of such materials; (2) substituting less critical materials, where possible; and (3) deferring construction through maintenance operations. These practices plus the inability of governments to stretch the available resources in materials and manpower to cover routine maintenance added to the large volume of unmet highway needs that had been accumulating since the early 1930's.

Highway expenditures, which had not yet returned to their pre-Depression level, again began to decline. County and local governments, both rural and urban, were receiving from 45 to 47 percent less from their own sources than they had in 1930. Though in 1941 State-collected highway revenues were 36 percent above their 1931 level and the States had stepped up their aid to rural local governments, still the funds available for local roads were substantially below the 1931 figure. Construction expenditures for county and rural local roads reached a low point of $\$ 72$ million in 1944.
In 1943 and 1944, total expenditures on city and village streets reached their lowest level (\$321 million) since 1920. The principal cause was the war-imposed curtailment of construction, which totaled only $\$ 71$ million in 1943. Expenditures at the Federal and State levels also declined until the close of World War II.

The 1943 Highway Act amending the Defense Highway Act of 1941 served as a bridge between wartime and postwar programs. It extended the emergency funding programs of the 1941 Act and amended the definition of construction in order to continue the use of Federal-aid highway funds for the purchase of right-of-way. It also broadened the provisions related to reimbursing the States and other governments for road damage resulting from national defense and other war-related activities.

Executive Order 8989 of December 18, 1941, created the Office of Defense Transport (ODT) as a wartime agency to assure continued essential operations and maximum use of domestic transport facilities for the successful prosecution of the war. The ODT's Highway Transport Division, supervising motor transportation, pursued the objective of the order through issuance of orders governing full loading, delivery schedules, and interchange of freight. It also pressed for allocations of fuel, tires, and other critical items in short supply to enable domestic truck transportation to perform its service.

\section{Postwar Problems}

When the war ended in 1945 , highway agencies entered the postwar period under conditions of great difficulty. It had become apparent that during the period preceding the war, insufficient effort was put into the construction and maintenance of roads and streets to insure that the quality and condition of the highway plant would keep pace with the demands of traffic. The agencies were therefore faced with the necessity of a widespread modernization and reconditioning of highway facilities, both rural and urban. The problem was complicated by the fact that construction and maintenance costs, which rose very materially during the war period, become inflated with the general rise in prices that followed.

The Federal Government's grand plan of attack on postwar highway problems was embodied in the Federal-Aid Highway Act of 1944, which added some important new provisions:

- A new National System of Interstate Highways, not to exceed 40,000 miles in length, was authorized.

- A specific system of secondary Federal-aid highways, not limited in size, was provided for.

- Recognition was given for the first time to a system of urban extensions of rural Federal-aid highways.

- Authorizations were made by systems in a $45-30$ 25 ratio for primary, secondary, and urban (ABC) systems for each of 3 successive years. No funds were specifically authorized for the Interstate System.

The apportionment formula adopted for the Primary System was continued, giving equal weight to the 


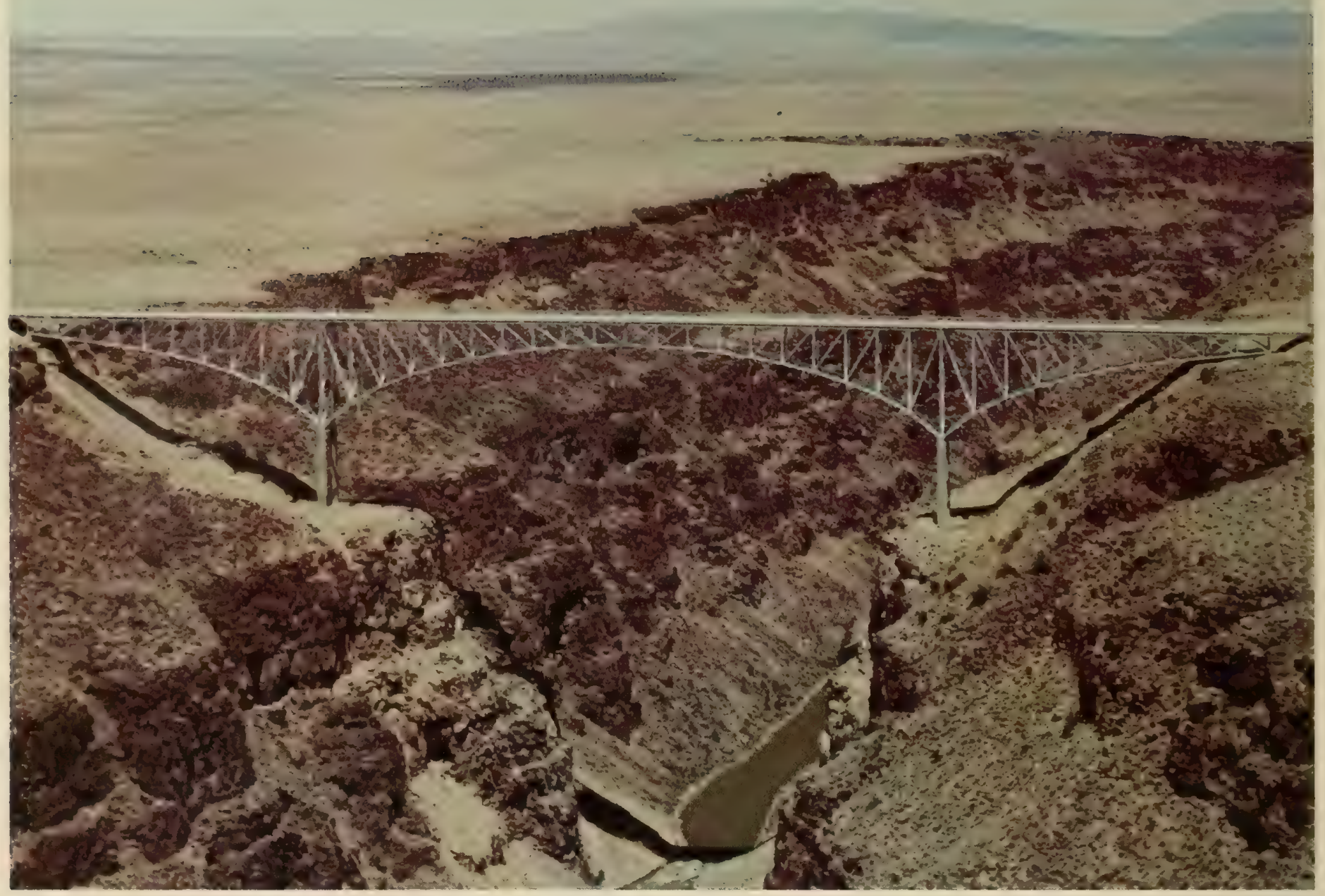

three factors of population, area, and post road mileage. The formula adopted for the Secondary System was the same except that rural instead of total population was used. The urban apportionment was based on the sole factor of population of municipalities and other urban areas of 5,000 or more.

The Act added to the law a provision authorizing the States to use 10 percent of apportioned Federal funds without matching to eliminate hazards of highway-railway crossings on the Federal-aid systems. The railroads were to contribute 10 percent of the construction cost of those projects benefiting them.

\section{Postwar Taxation for Highways}

During the 1940 's, the States strove to improve their revenue positions by increasing the tax rates on motor fuel. In 1947, 8 States raised their rates, and the average rate for all States rose from 4.16 to 4.25 cents a gallon. During 1949, 13 States increased their rates, bringing the average State rate to 4.52 cents.

Regardless of what originally precipitated the adoption of user taxes, no carefully worked out theory preceded their adoption. The theoretical foundation was built after the tax framework was erected. The structure of highway taxes was an evolution brought about over a long time by balancing the demands of conflicting interests with the necessities for the development and support of highways.
The Rio Grande Gorge Bridge, located near Taos, N. Mex. carries the highway over the Rio Grande 650 feet below. Originally, Federal aid was limited to $\$ 10,000$ per mile for bridges under 20 feet and 50 percent of the cost for bridges over 20 feet. Because bridges are so costly to build, many are financed through bonds or as toll facilities.

Part of the pressure that led to the development of a more organized body of highway tax theory during this period was produced by a changed attitude on the part of the railroad industry. The industry had been a supporter of highway development in the beginning, viewing road improvements as a means of providing better feeders to their lines. At that time they paid taxes without complaint. But as highways encouraged long-distance freight movement by truck, they began to realize that they were facing serious competition. Fearful of the results of growing diversion of traffic, they became active critics of both the operating and the business practices of highway carriers and of the extent to which such carriers paid taxes to support the government expenditures made in their behalf, i.e., the extent of the public subsidy of the motor carrier industry.

The framework of highway tax theory is founded on the principle that taxation for the support of highways should be assessed in proportion to benefits received. There had been nearly universal acceptance 
of the concept that the provision of highway facilities serves three major interests finding a parallel in three principal sources of highway revenue:

- The interest of access to land and improvements, a service indispensable to personal, family, and business activity (taxes on land).

- The public interest or general welfare, represented by the use of roads in such public activities as national defense, police and fire protection, access to schools, and conservation of natural resources (appropriations from general funds).

- The interest of the motor-vehicle user in providing facilities upon which the private automobile may be used in recreational, social, and personal business activities and the commercial vehicle may be operated in gainful pursuits (motorvehicle user taxes).

The fact that the owners and occupants of adjacent and nearby property received special benefits from highway improvements had long been recognized by the common practice of imposing special assessments for such improvement. Benefits to property throughout a given area were recognized in taxes upon property in general, and the general property tax was also recognized as representing community benefits as well as those directly assignable to the land.

The fact that the benefit principle was firmly imbedded in the earlier period of highway financing probably paved the way for the adoption of motorvehicle registration fees and gasoline taxes as means of taxing the motor-vehicle owner for benefits received. Thus, the gasoline tax, during the period when it was being eagerly adopted by State after State, was commonly described as a "metered tax," and one State, New Hampshire, continued to call its gasoline tax the "road toll."

The further fact that the rapidly developing use of motor vehicles was bringing about the necessity for greater and greater highway expenditures was also a very potent factor in popularizing the imposition of

After WW II it was evident that greater highway expenditures would be needed to cope with the valume of traffic. Highway taxation had to be determined on an equitable assignment of tax responsibility among beneficiary groups in proportion to the benefits received. user taxes. Thus the concepts that underlie the later investigations of the highway tax problem had a natural evolution in the history of highway development.

The central problem of highway taxation was one of determining an equitable assignment of tax responsibility among various beneficiary groups in proportion to the benefits received or highway costs occasioned by each of these groups. The problem divided itself into two parts: (1) The allocation of the highway tax burden among the major classes of beneficiaries of highway expenditures and (2) once the equitable portion assignable to motor-vehicle users was determined, the allocation of the motor-vehicle user share among vehicles of different sizes, weights, and classes of use. A number of methods with supporting concepts were devised for making these determinations and were used by many States for revising their tax schedules.

\section{Vehicle Registrations and Fuel Consumption}

Largely because of the effects of motor fuel rationing, motor vehicle registrations declined only 13 percent during World War II, compared with decreases of 37 and 33 percent, respectively, in travel and fuel consumption. Until the 1940's the rate of growth in fuel consumption per vehicle closely paralleled the rate in total fuel consumption. But after 1946, the rate per vehicle rose more slowly than that of total consumption, because of the growing density of motor vehicle ownership. While ownership of more than one car increases the total miles of driving, the increase is not proportionate to the number of vehicles owned. Thus, a household with one car averaging 12,000 miles of driving annually does not double that mileage by buying a second car but may increase it to perhaps 15,000 or 18,000 miles. Fuel consumption in 1946 averaged about 746 gallons per vehicle per year. ${ }^{5}$

\section{New Directions in Borrowing}

The venerable custom of borrowing money and paying interest on it has its motivation in the simple economic fact that money in hand always has more value than an equal amount in prospect. The existence of a net advantage to be derived from the use of funds now rather than in the future is the criterion justifying public borrowing.

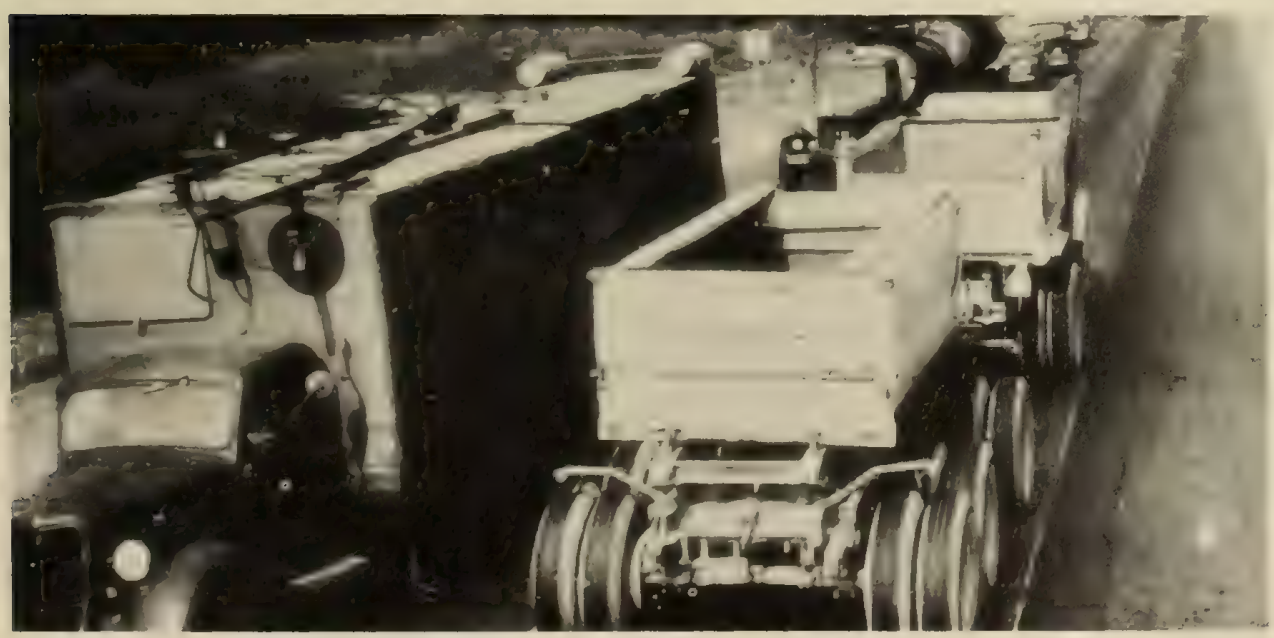


The most favorable condition for credit financing is that of a truly accelerated program contemplating a relatively short period of abnormally high capital outlay, during which the highway plant progresses rapidly toward a condition of adequacy. A subsequent lull in construction activity, during which the need for replacements accumulates very slowly, provides the opportunity for retirement of the bonds.

Conditions following the end of the war were ripe for such a program. The need for greatly increased expenditures to permit reaching a standard of adequacy was recognized in most States. The demands for highway capital funds for financing particular urgently needed facilities or statewide "catch-up" programs encouraged the circumvention of constitutional barriers to State-created debt, either by the more direct but less frequent method of amendment or referendum or by the speedier and, hence, more popular device of the nonguaranteed bond that does not have recourse to the full taxing power of the issuing government and does not require approval of the electorate.

Because they command higher interest rates, nonguaranteed bonds almost always carry with them a higher cost to the public. But the additional cost may be a justifiable premium to pay for avoiding the consequences and delays of seeking voter approval.

During the 5-year period 1946-1950, the States, including special State authorities and commissions, issued over $\$ 1$ billion in highway bonds (not including refunding issues); the counties and other rural local units issued $\$ 429$ million; and the cities and other incorporated places issued $\$ 635$ million. The combined total was $\$ 2.2$ billion of a total outstanding debt at the end of 1950 of about $\$ 4.5$ billion.

The debt issued during this period tended to be concentrated along the Eastern Seaboard, where so much of the population, industry, and heavy traffic volume were also concentrated. These States accounted for 80 percent of the total.

The toll road movement was the most dramatic development in highway financing, particularly in credit financing, in the years immediately following World War II. The success of the Pennsylvania Turnpike with the public, despite its war-induced financial difficulties, stimulated a boom in toll road construction. These roads proved to be feasible where the traffic potential was high and where the parallel free roads were either in poor condition as to grades, curves, or surfaces or where they were inadequate to serve the traffic in the corridor.

The growth in toll road bond financing in the period 1946-1951 was striking. To the $\$ 54$ million of toll road bonds outstanding at the beginning of the period, issues totaling $\$ 449$ million were added. $\mathrm{Re}$ demptions during the period were a slim $\$ 12$ million, leaving \$491 million outstanding at the end of 1951.

The postwar period was one of variety and experimentation in the credit financing of highways, and by no means all of the toll roads were financed by the issue of revenue bonds payable solely from the earnings of the facility. The first fully self-supporting issue of toll road revenue bonds was marketed in 1946 by the Maine Turnpike Authority. Elsewhere, general obligation bonds were sometimes issued, and the building of the 15-mile New Hampshire Turnpike was financed from the proceeds of 90-day renewable notes purchased by Boston banks. By this device of short-term financing, not extensively employed by the States in financing highway capital expenditures, the State of New Hampshire was able to save in interest expense by drawing down funds only as needed.

\section{Bridge Tolls}

In general, the Federal Government continued to look upon toll financing with disfavor. In the late 1940 's, a Federal statute was enacted to encourage the removal of bridge tolls. The General Bridge Act of 1946 required that, within 20 years of construction or acquisition, tolls be removed from all bridges subject to the Act (i.e., interstate bridges). Bridges wholly inside a State or those between the United States and foreign countries were not covered by this legislation.

In 1948 the Act was amended to extend the period for removing tolls to 30 years. Meantime, the 1937 law authorizing the use of Federal funds to free toll bridges on the Federal-aid system expired. During the time it was in force (1937-1947), nearly $\$ 9$ million had been spent to free 30 bridges in five States.

While the number of toll facilities owned by counties and local governments is relatively small, in the 1940's toll charges provided a greater portion of the income from county and local imposts upon highway users than any other single impost. Most of the income derived from these toll charges was spent for highway purposes, chiefly maintenance and operation of the facilities and retirement of the debt incurred when they were built.

\section{The Federal Role in Borrowing}

In the wake of the rapid development of toll roads, the Federal Government had not abandoned its belief in toll-free highways. Accordingly, a section of the Federal Aid Highway Act of 1950 (section 122, title 23 , U.S. Code) provided that any State or local government that issued bonds and used the proceeds to accelerate construction of toll-free facilities on the Federal-aid Interstate or Primary Systems or on extensions of Federal-aid systems within urban areas might apply authorized Federal funds to retire such bonds. Federal funds might not be claimed for the Federal-Aid Secondary System, either in reimbursement of interest payments or for bond proceeds expended on that system.

The Act made the following stipulations:

- The proceeds of the bonds qualifying under the law must have actually been expended in the construction of Federal-aid systems.

- The construction must have been completed in accordance with plans and specifications approved in advance by the Bureau of Public Roads.

- Payments could not exceed the pro rata Federal share specified by law.

- Payments must be made from funds authorized by the Congress.

That this provision was useful to the States in accelerating highway programs was shown by the fact that at the end of December 1961 bond-financed programs totaled nearly $\$ 395$ million, of which the Federal-fund share was more than $\$ 253$ million. 
This bridge was designed and built with the emphasis on concern for the natural environment. The task was accomplished by using prestressed concrete and minor disturbance to the rock outcroppings and boulders, thus producing an economical, as well as an esthetically pleasing bridge.

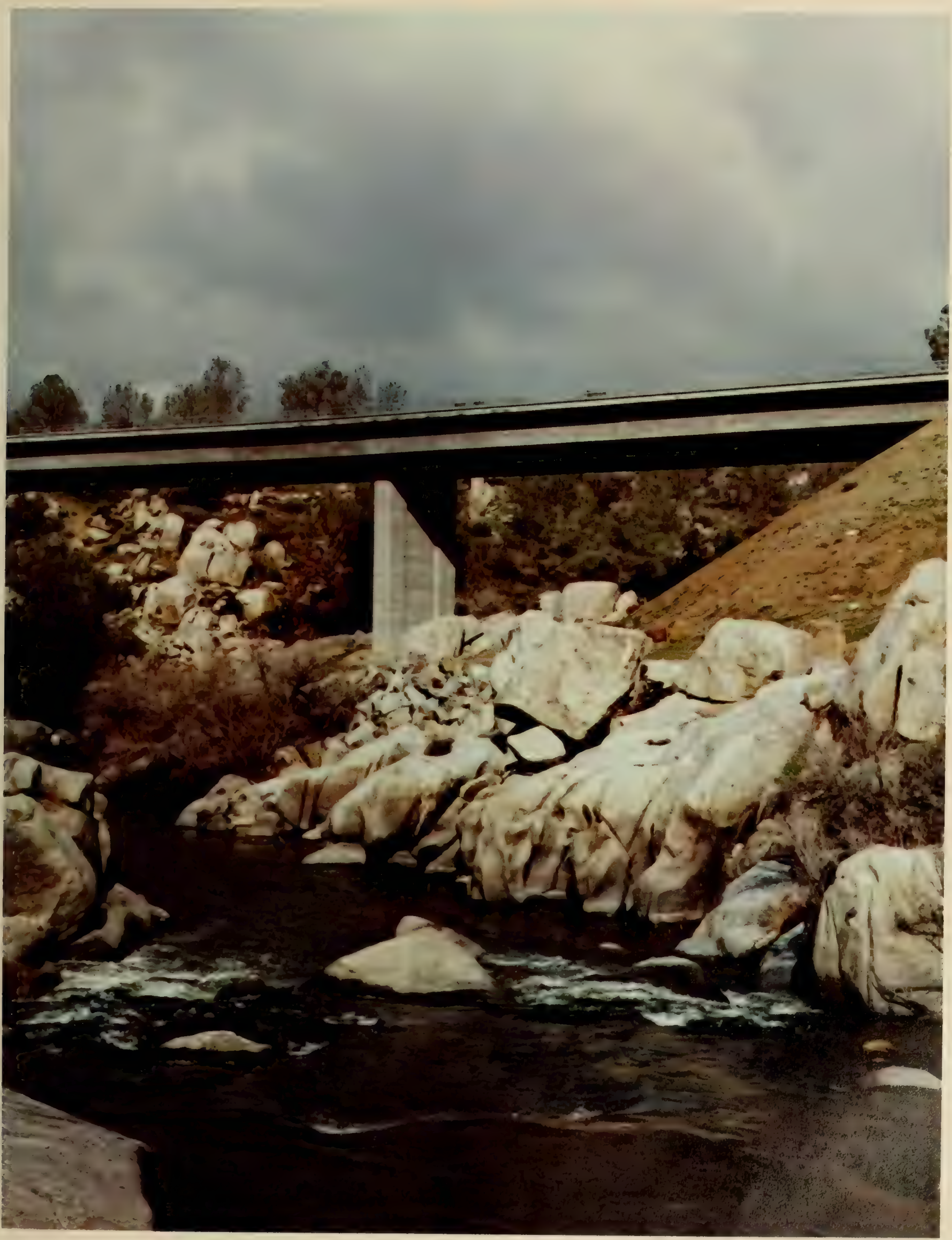


This program was in no sense a Federal lending device; rather, it had the effect of postponing reimbursement of the Federal share of authorized Federalaid projects. It had two advantages to the States:

- Programs involving Federal-aid work could be planned and financed in advance of the availability of Federal funds.

- Federal funds might be claimed at times and in amounts determined by the maturity schedule of the bond issue, reducing the demand for current State tax revenue for debt service during the time the bonds were maturing.

\section{Financial Status in 1951}

By 1951, the postwar pattern of highway financing was well established, except for the changes to come with the Federal-Aid Highway Act of 1956. The States were providing nearly two-thirds of the funds (exclusive of borrowings) applied to the highway program (about $\$ 2.7$ billion), and motor-vehicle user taxes, including tolls, accounted for about 97 percent of these funds.

Contributions from Federal general funds were $\$ 492$ million. This amount was about $\$ 60$ million less than was available from this source in 1941, but the 1941 amount had come largely from special unemployment relief appropriations rather than from regular sources of highway aid.

Funds provided by rural and urban local governments had recovered to approximately the level of 1931: \$483 million in local revenues of the rural governments and $\$ 585$ million in local municipal revenues.

Bond issues for road and street purposes during 1951 totaled $\$ 794$ million, of which $\$ 535$ million was State borrowings. Beginning in 1948, the States resorted to heavy borrowing to expedite their accelerated highway improvement programs.

By 1951, the program for catching up on deferred maintenance and capital outlay was well underway. Total capital outlay on all systems, which bottomed out at $\$ 362$ million in 1944 , had reached a level of $\$ 2.5$ billion and was climbing rapidly. Maintenance expenditures had recovered from a wartime low of $\$ 640$ million to a total of $\$ 1.6$ billion in 1951. Total highway expenditures were $\$ 4.6$ billion.

\section{Federal-Aid Funds and the 1956 Highway Legislation}

Between 1944 and 1956, Federal legislation dictated few major policy changes. The first Interstate System construction was specifically authorized in the Federal-Aid Highway Act of 1952, which provided for apportionment of $\$ 25$ million on the basis of a $50-50$ Federal-State matching ratio in each of the fiscal years 1954 and 1955 . These authorizations were increased to $\$ 175$ million each year for fiscal 1956 and 1957 by the Federal-Aid Highway Act of 1954, which also raised the Federal share of project costs to 60 percent.

The twin 1956 Acts-the Federal-Aid Highway Act and the Highway Revenue Act-are a major landmark in the highway history of the United States. This legislation broke with tradition and established some new principles:
- It authorized and provided for financing an entire highway network, now designated the National System of Interstate and Defense Hghways.

- It departed from the traditional 50-50 sharing of project costs and the fixed formula for apportionment.

- It established a Highway Trust Fund fed from the proceeds of Federal excise taxes on motorvehicle users, which thus directly linked to highway expenditures.

The Highway Revenue Act of 1956 continued the biennial authorizations of Federal-aid primary, secondary, and urban highways (popularly termed the $A B C$ program). But the policy of authorizing Federal aid to the States for highways for 1 - to 3 -year periods was augmented by one of authorizing funds for a long-range program to complete the Interstate Highway System.

A total of $\$ 27$ billion was authorized for the Interstate System, to be apportioned on the basis of $90-10$ percent Federal-State shares of project costs. For the first 3 years of the program, apportionments among the States were to be made on the basis of total population (one-half). After this, the funds were to be apportioned according to the proportion that the estimated cost in each State bore to the total cost of completing the entire System.

It was recognized that some States might be willing and able, with current revenue or bond proceeds, to build their portions of the Interstate System faster than the annual Federal-aid apportionment would permit. The 1956 Act therefore provided for "advance" construction by arranging for later reimbursement to the State for the Federal share of the project costs from apportionments of succeeding years. Federal aid was also made available for the cost of relocating utilities displaced by federally aided highway construction.

In linking Federal excise taxes on highway users and Federal aid for highways, this Act sought to accomplish three objectives: To finance the long-range Federal-aid program, to provide the revenue wholly from user-tax revenues, and to preserve the program on a pay-as-you-go basis. Although automotive excise taxes of one type or another have been levied by the Federal Government since 1917, except for the period 1928-1932, no part of the proceeds of these taxes was earmarked for highways before 1956 . Before that date, Federal aid for highways was appropriated from the General Fund of the Treasury and was not related to the income from taxes on motor vehicles or their operation.

In the Highway Revenue Act of 1956, Congress provided revenues for a program of highway expenditures on the Interstate and other Federal-aid highway systems. The mechanism by which this was done was to create a Highway Trust Fund into which were directed the proceeds of certain existing excise taxes on motor vehicles and automotive products and certain additional taxes imposed by the Act itself.

In particular, the Federal gasoline tax was increased from 2 to 3 cents and became the principal source of revenue of the Highway Trust Fund. In order to provide more revenues, certain changes were 
made by the Federal-Aid Highway Act of 1959, including an increase in the motor-fuel tax from 3 to 4 cents a gallon.

The creation of the Highway Trust Fund resulted in the direction of the greater part of the Federal automotive tax proceeds into that fund but not all of them. Remaining as General Fund revenues were the proceeds of the 10-percent Federal excise tax on automobiles and motorcycles and the 8-percent tax on parts and accessories. There is also a tax of 6 cents per gallon on lubricating oil. Since only about 60 percent of the lubricating oil is estimated to be consumed in highway vehicles, this tax was ordinarily not as closely associated with motor vehicles and their use as are the taxes on motor vehicles, tires and tread rubber, and motor fuels.

Although nearly all of the income of the Highway Trust Fund was derived from excise taxes paid by highway users, certain amounts were derived from nonhighway sources. The largest such amounts were receipts from taxes paid on gasoline used in aircraft, motorboats, and industrial use, but in this case 2 of the 4 cents per gallon tax, if claimed, was subject to refund to the taxpayer. The proceeds of the tax on tires used off the highway (5 cents per pound) was also placed in the Trust Fund, as was the small amount of income obtained from automotive excise taxes paid by the Department of Defense on behalf of highway-type vehicles used entirely in off-highway service. Although such vehicles were exempt from motor-fuel taxes, payment of taxes on the purchase of trucks, buses, trailers, tires, and inner tubes was required.

Because Federal-aid expenditures for highways were now directly related to the income from certain highway user taxes, the equity of tax payments in relation to benefits and the highway costs occasioned by various types of vehicles had to be considered. The 1956 Act, therefore, called for a highway cost allocation study similar to those conducted by the States but on a nationwide basis in order to bring about "an equitable distribution of the tax burden among various classes of persons using the Federalaid highways or otherwise deriving benefit from such highways."

US-169 northeast of Paola, Kan., is a modern two-lane highway built on right-of-way acquired for a four-lane expressway. A second pair of lanes can be added in a few years when the traffic volume warrants it.

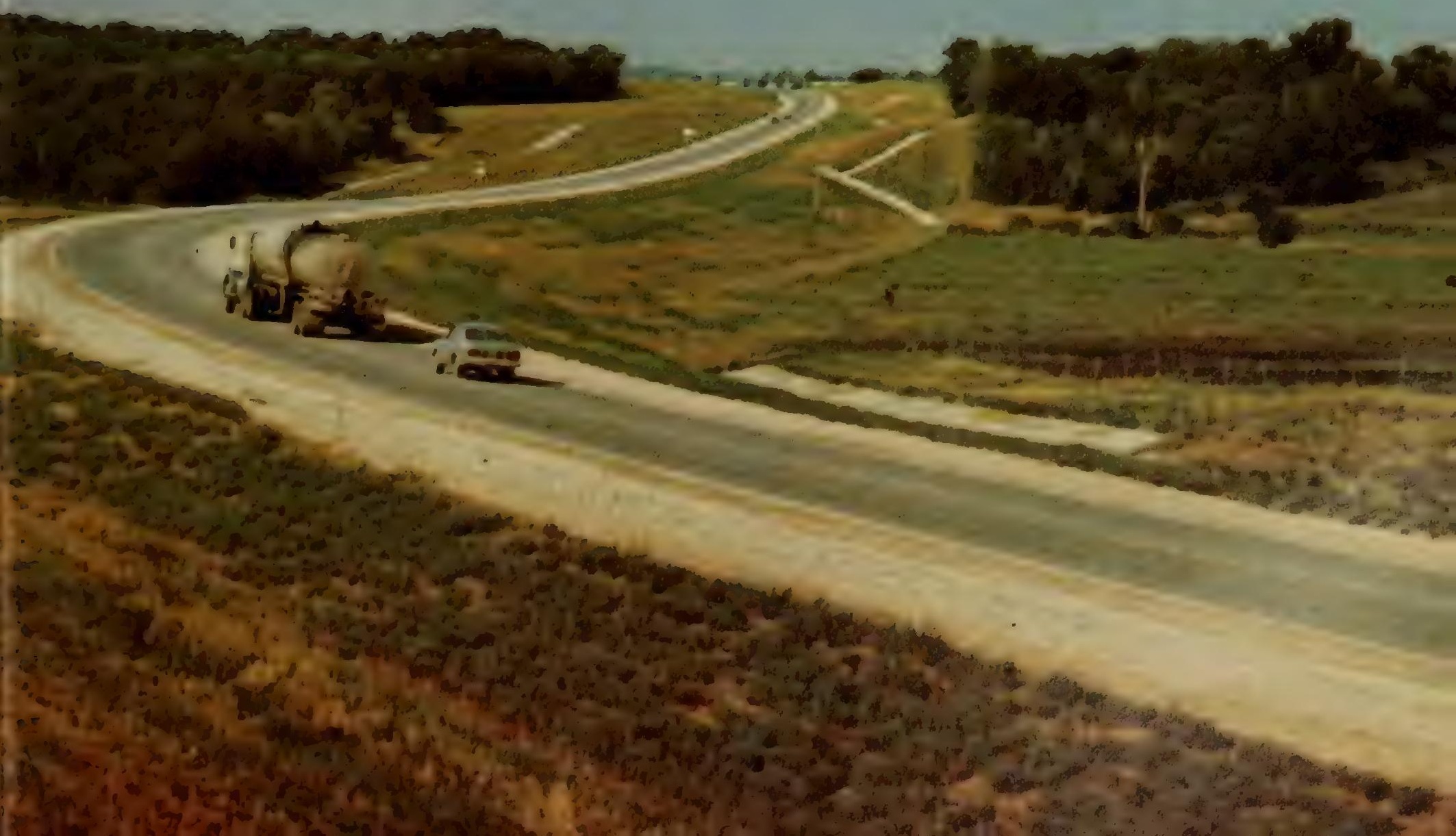


By the end of the 1957 fiscal year, approximately $\$ 1.5$ billion had been deposited in the Trust Fund, of which $\$ 3$ million came from interest earned on investments and the remainder from Federal automotive excise taxes. From this total, nearly $\$ 966$ million was disbursed for work on the Interstate and $A B C$ programs, but there was a balance of obligations of apportioned highway funds of nearly $\$ 2$ billion.

The 1956 Act also marked the first exercise of Federal limitations on commercial vehicle sizes and weights. It established maximum width and weight limitations on the Interstate Highway System to protect the Federal investment in this system and to prevent overstressing of bridges for safety purposes.

\section{Toll Roads and the Interstate System}

Inclusion of toll facilities on the Interstate System has been a major issue since the accelerated program was authorized in 1956. Of the 40,000 miles of highways approved for the System in the early 1950 's, 1,100 were toll facilities. A 1955 report by the President's Advisory Committee on a National Highway Program indicated that about 5,000 miles of toll roads planned, being constructed, or in actual operation in 23 States would either parallel or coincide with the proposed Interstate Highway System.

The Highway Act of 1956 adopted a Bureau of Public Roads' recommendation for incorporating toll roads into the Interstate Highway System. The prohibition against the use of Federal funds for constructing toll facilities was modified only to the extent of permitting their use on the approaches to toll roads, with two provisos:

- If the only use of the access road was to serve as an approach to a toll road, the toll road must be made toll free upon retirement of the outstanding debt.

- Satisfactory alternate free routes for bypassing the toll sections must be available.

Seven toll facilities have received Interstate funds on condition that the tolls be removed upon retirement of the debt:

Indiana Toll Road
Northern Illinois Toll Highway
Kentucky Turnpike*
Maine Turnpike
New York Thruway
Ohio Turnpike
Richmond-Petersburg Turnpike

Because of the legal complexities and contractual requirements under which the various toll facilities were established, a feasible means of freeing those on the Interstate Highway System remains one of the paramount unresolved issues. Many of the toll facilities operating as part of the Interstate System have outstanding debt secured by toll revenues with redemption dates beyond the year 2000 . In a number of cases, statutory provisions require tolls on such facilities to be collected indefinitely, beyond the time when the toll-secured debt is retired.

\footnotetext{
* Tolls were removed from the Kentucky Turnpike on
} June $30,1975$.
In some cases, debt proceeds and revenues related to both highway (including Interstate) and nonhighway facilities have been commingled and are not readily identifiable. Toll revenues are primarily used for operating the toll facilities and retiring the outstanding indebtedness but are also used in some instances for other public services (more often in the case of toll bridges than toll roads). Thus, the loss of revenue for other purposes has to be taken into account.

Since 1956, the Federal Highway Administration has refused to approve the location of free routes on the Interstate System in at least three cases where the routes would parallel toll facilities determined to be adequate for traffic needs until 1975, where the financial structure of the toll facilities was in danger of being adversely affected.

\section{Bond Financing in the 1950's}

Toll revenue bond financing was employed by 29 of the 39 borrowing States during the decade of the 1950 's, and in six States-California, Illinois, Indiana, Oklahoma, Texas, and Virginia-it was the only major type of bond financing used. Although revenue bond financing occupied a position of prominence, road-user tax bonds and other limited obligations evidenced a most significant increase. The seven Northern and Eastern States that issued \$200 million or more of general and limited obligation bonds accounted for nearly two-thirds of all such bonds issued.

Municipal highway debt showed a much faster rate of growth than that of the counties and other rural local governments. If the debt outstanding at the beginning of 1950 is assigned a value of 100 , the comparative volume of municipal debt outstanding at the end of 1960 would be 215.5 and rural local debt, 148 . The more pervasive demand for credit financing by the municipalities was partly caused by the relatively greater State financial assistance to rural governmental units and also to the rapid growth of metropolitan areas and urban traffic volumes during the 1950 's. General obligation bonds were the predominant type of local issues.

\section{The Public Corporation Device}

Although the device was not new even in the highway field, beginning in the 1940's and continuing through the 1950's, public corporations (authorities) came into extensive use. The features that distinguish the authority device are not always clear-cut. For example, a number of State highway departments - and local governments too-directly finance and operate toll projects. But this is not the primary function of a highway public works department. The term "authority" is generally reserved for (1) those instrumentalities whose primary responsibility is the financing of highway facilities with revenue or limited obligation bonds, for which specific revenues are pledged, and (2) those that do not rely upon general tax support or that themselves have the power to levy taxes.

Between 1940 and 1960, authorities became an economic phenomenon of considerable consequence. During this time, 45 of them were created in the highway field, bringing to 75 the number active on January 1, 1961. 
Of the 19 toll road authorities, 17 sold bonds amounting to $\$ 4$ billion during the 1950 's. This amount was two-thirds of all debt incurred by authorities. One of the two not included among these debt issues in the 1950's-the Turnpike Authority of Kentucky - entered the bond market in 1961 and by early 1962 had sold $\$ 186$ million of Turnpike revenue bonds.

The authority concept flourished because in most instances it proved successful as (1) a means of financing capital projects so as not to conflict with constitutional limitations upon the creation of debt; (2) a flexible instrument to manage "commercial" or self-supporting enterprises; and (3) an effective agency for administering joint governmental projects-international, interstate, or intercommunity.

\section{Economic Effects}

Thomas H. MacDonald commented on the relationship between advances in highway transportation, on the one hand, and economic growth and raised standards of living, on the other, in these words:

We were not a wealthy Nation when we began improving our highways ... . but the roads themselves helped us create a new wealth, in business and industry and land values. ... So it was not our wealth that made our highways possible. Rather, it was our highways that made our wealth possible.

The nature, size, and composition of the Nation's output, the industrial structure within which it is produced, and the distribution of the corresponding income flows, both geographically and among the Nation's families, are all dependent in some degree upon transportation facilities: their availability, location, and adequacy. Population mobility could not have been achieved without them.

The movement of goods and people is reflected in different ways: the movement of goods by truck and trailer, the movement of people by bus transit and private automobile, or the movement and expansion of physical facilities and factories across the land. To the extent that highways have aided in the more efficient allocation of resources through their influence on this mobility, they have changed the pattern of land use and development in the United States.

In the early 1960's, it was estimated that approximately one out of every five individuals moved to another home in any single year, and one-third of these individuals moved to a different county in response to economic and social opportunities. Almost 34 million persons moved in 1960 .

The travel propensities of Americans were, and are, reflected in the number of mobile homes in the United States. The Mobile Home Manufacturer's Association estimated that in 1958 almost 98,000 mobile homes and nearly 31,000 trailers were produced, and that 1.2 million mobile homes in the United States housed some 3.5 million persons.

The emphasis on mobility is also illustrated by the investment of Americans in motor vehicles. In 1961, motor vehicles numbered more than 76 million, an increase of about 190 percent over a 30-year period, during which population increased by about 45 percent. Thus, motor-vehicle ownership had increased at a rate more than four times that of population growth.

\section{Goods Movement by Highway}

Truck use of highways aids productivity in at least two ways: by expanding market areas and by lowering distribution costs. In goods movement, the reduction of unit transport costs is a direct benefit to shippers. Whether these savings are passed on to the consumer or are partially absorbed by shippers or their employees, significant savings are realized by the national economy. Between 1958 and 1968, the ton-miles moved by highway increased by 60 percent, nearly twice the 36 percent increase for rail.

In 1963, panel trucks, station wagons, and pickup trucks constituted nearly 60 percent of the total number of trucks in the United States but carried less than 10 percent of the tonnage. Tractor-semitrailers, on the other hand, represented only 5 percent of the number of trucks but handled 32 percent of the tonnage.

\section{Piggyback Revived}

The fact that no single mode of transportation is capable of moving all kinds of freight with equal efficiency suggests that the roles of the various modes should be more complementary than competitive in many areas. A system enabling each mode of transportation to perform the service for which it has the greatest inherent advantage would contribute to more efficient use of resources, the greatest need of today. The development is as yet in an early stage, since the setting is highly institutionalized and the American transportation industry has always been aggressively competitive.

The highway-rail piggyback service that had been the subject of experimentation in the previous two decades had all but disappeared by the late 1940 's. A revival of efforts to inaugurate piggyback service followed an Interstate Commerce Commission (ICC) ruling in the New Haven case in 1954 that railroads could haul trailers on flat cars (TOFC) under the provisions of rail tariffs without having a motor carrier certificate. As a result, 32 railroads offered TOFC service by January 1, 1955. The number of TOFC/ COFC (container-on-flatcar) rail cars loaded in that year was 168,000 . This was the first significant break through the wall of aggressive intermodal competitiveness that has characterized the American transportation industry.

Piggyback combines the flexibility and low cost of truck pickup and delivery and terminal service with the low cost of rail line-haul operations. Because of its significantly lower costs, it has grown most rapidly in the transport of goods having a high value over medium and long distances.

Diversion to rail from highway freight transportation is most likely to occur along high-traffic corridors between major metropolitan centers, and its magnitude was not sufficient to have much dampening effect on the total volume and growth of truck traffic.

Through the 1950's the frequency of heavy gross vehicle loads, especially for vehicles of 50,000 pounds or more, showed a steady, strong upward trend. From 1950 to 1959 , the frequency of trucks in this weight class increased from 58 to 227 per 1,000 trucks and combinations, loaded and empty, a nearly fourfold gain. New truck registrations by weight class showed 


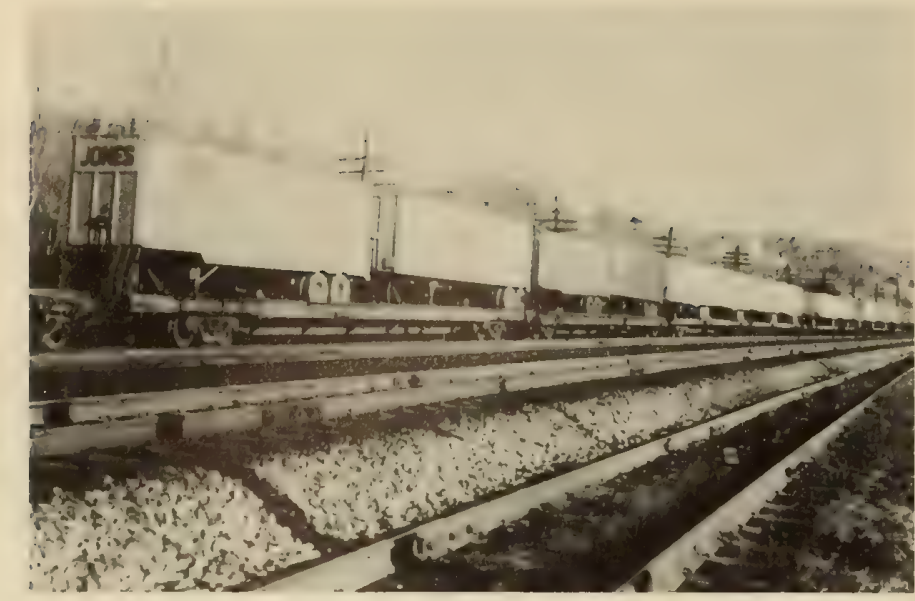

Trailers being transported on flatcars.

a very strong trend in the direction of increasing frequency of heavier trucks and decreasing frequency of medium weight trucks.

Since 1955, an especially heavy public investment has been made in highways, much of it concentrated on high-grade intercity highways designed to carry large volumes of heavy truck traffic. Capital outlay for this purpose by Federal, State, and local governments totaled nearly $\$ 136$ billion between 1955 and 1971 .

By 1970, the mileage of divided highways of four or more lanes with partial or full control of access had increased eightfold since 1956, the first year when highways were so classified. About 80 percent of this increase was on intercity routes. Such controlledaccess highways on the Federal-Aid Primary System increased from somewhat over 4,000 to nearly 41,000 miles, from 2 to nearly 16 percent of the total system mileage.

A 40-ton capacity straddle-lift crane transfers containers from piggyback flatcars to a highway carrier for shipment to destination.

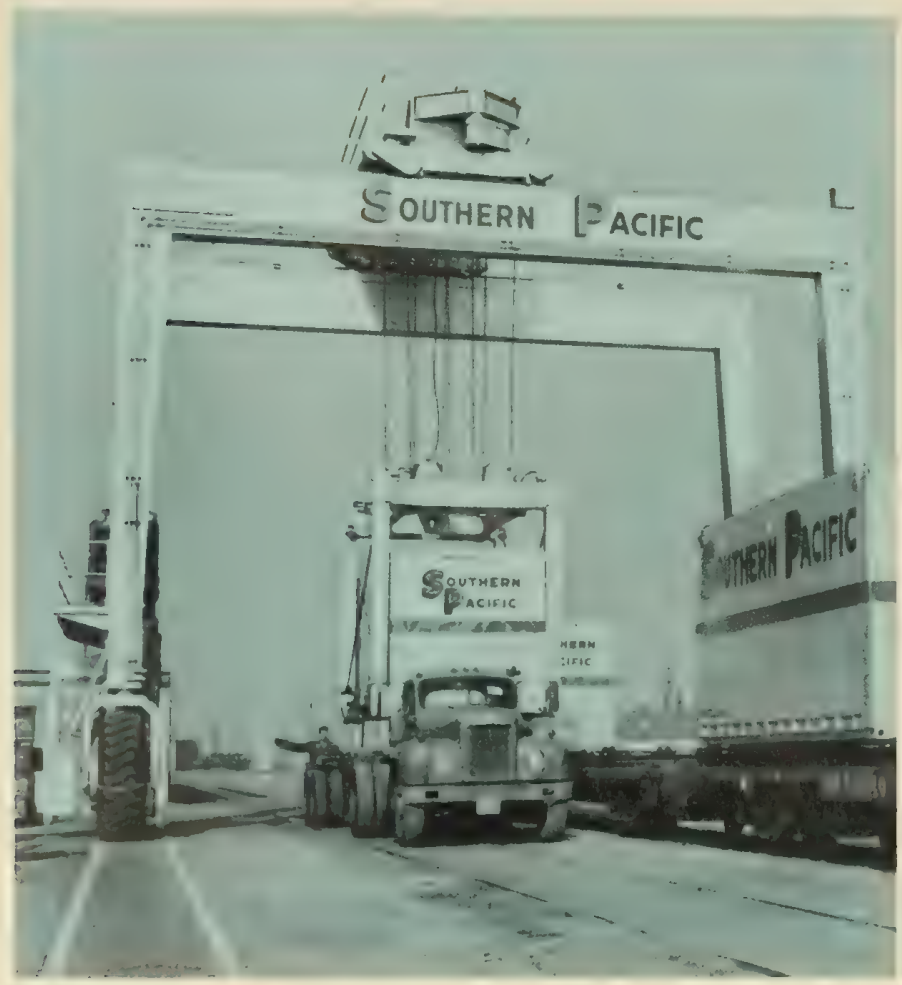

As these high-grade highways have been provided, intercity motor freight transportation has grown rapidly. Truck ton-miles were 89 percent higher in 1971 than in 1955. During the same period, population grew 25 percent. The gross national product (GNP) in constant dollars was up 69 percent and industrial production, 81 percent. The ton-miles accounted for by carriers regulated by the Interstate Commerce Commission more than doubled from 1955 to 1970 , compared with a 73 percent increase for carriers not under regulation. The nonregulated carriers accounted for an increasing share of all intercity freight ton-miles, 9 percent in 1955 compared with 11 percent in 1970.

Urban goods movement is a major element in the economy of the United States and especially in the urban economies. Practically all freight moving in rural areas either originates or terminates within urban areas. Moreover, urban areas are the points of meeting between carriers of different sizes, between regulated and nonregulated carriers, and between different modes of transportation.

The movement of goods in urban areas is performed primarily by trucks, and truck travel in these areas increased during the 1960's even more than passenger car travel: 80 compared with 74 percent. A 1965 study of the tri-State area comprising New York City, New Jersey, and Connecticut indicated that trucks moved over 75 percent of the tonnage and accounted for 97 percent of the value of freight moved.

\section{Trucking and Other Modes}

In the intercity freight market, significant impediments to free market forces are at work determining the relative shares taken by each transportation mode. Airlines and railroads in particular are subject to more pervasive and stringent economic regulations than trucking. In 1970 , only about 41 percent of truck and 7 percent of water ton-miles were regulated.

Nationwide data for 1970 indicate that truck freight expenditures were almost evenly divided between local haul (49.4 percent) and intercity haul (50.6 percent). The intercity hauls usually terminate in urban areas and become part of the urban traffic.

Trucks haul primarily commodities of medium value, but compete strongly with railroads and water carriers for the high value ( $\$ 1,000$ per ton) less-thantruck-load business. Trucks dominate when hauls are less than 400 miles. Yet for individual commodities, the median lengths of haul by rail and truck are rather close.

In 1970, the Nation's estimated total transportation expenditure amounted to over $\$ 181$ billion, 97 percent of which was spent on domestic transportation. Highway-oriented expenditures accounted for 82 percent.

The dominance of highway-oriented modes becomes even more evident in view of the fact that $1970 \mathrm{ex}$ penditures on intercity freight moved by truck $(\$ 20$ billion) were greater than those for the rail, air, water, and pipeline modes combined. Highway passenger travel accounted for 42 percent of total national transportation expenditures. 
The concept of "gross product originating" (GPO) is a useful one for measuring the amount of gross national product (GNP) accounted for by transportation. The GNP equals the sum of GPO across all sectors of the economy. For transportation, the GPO refers to the value added by transportation service.

The estimates for gross product originating in transportation show a decline to 8.9 percent of gross national product in 1970 from 9.1 percent in 1965 , but the sector changes have not been uniform. For example, value added by commercial airlines increased by nearly 84 percent compared with 7 percent for intercity buses. Value added by railroads increased by less than half of 1 percent, whereas trucking increased by a little over 10 percent.

Commercial trucking accounted for about 13 percent of the total value added by transportation in 1970. Private trucking in freight accounted for 17 percent, and nonfreight private trucking for 27 percent. Value added by railroads declined from almost 12 percent to 10 percent of the total transportation GPO.

In 1971, the railroads still remained the principal intercity freight carriers, but their revenue position declined because of the loss of much productive traffic to other modes of transportation. The trucks and the airlines had captured much of their highest class traffic, and the pipelines were carrying a large proportion of the movement of petroleum products.

The Motor Vehicle Manufacturers Association estimated that in 1974 trucks were hauling the following percentages of important products :

\begin{tabular}{|c|c|}
\hline Fruits and vegetables & \\
\hline Cattle and calves & to major \\
\hline Hogs & markets \\
\hline Sheep and lambs & \\
\hline Sand and gravel & \\
\hline Crushed stone & \\
\hline Portland cement & \\
\hline Motor vehicles & \\
\hline Refined petroleum p & ucts \\
\hline
\end{tabular}

The ICC-regulated general freight haulers are the most conspicuous of all for-hire carriers seen on the highways because of the large number of vehicles and combinations used, mainly van trucks with van trailers and tractors with semitrailers and full trailers. Their cargos consist principally of general merchandise, such as food products and manufactured articles.

The operation for small shipments is similar in many respects to former railroad less-than-carload (LCL) freight handling. The shipments are picked up directly from the shipper, taken to a freight terminal for consolidation with other shipments going in the same direction, and loaded into over-the-road vehicles for the journey to the destination terminal, where the procedure is reversed.

\section{Financing Highways in the 1960's and 1970's}

By 1961, the principal change in highway revenues was the infusion of much higher levels of Federal aid, mostly drawn from imposts on highway users as a result of the 1956 Federal Aid Highway Act. The Act of 1961 continued the temporary increase in the

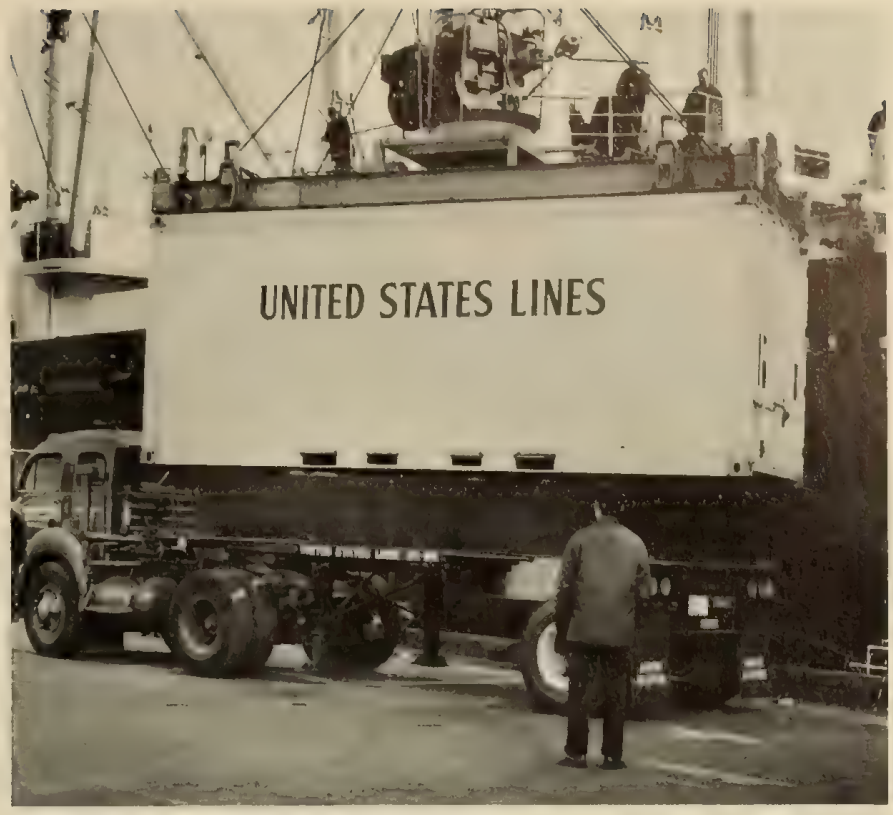

A container being loaded aboard a ship.

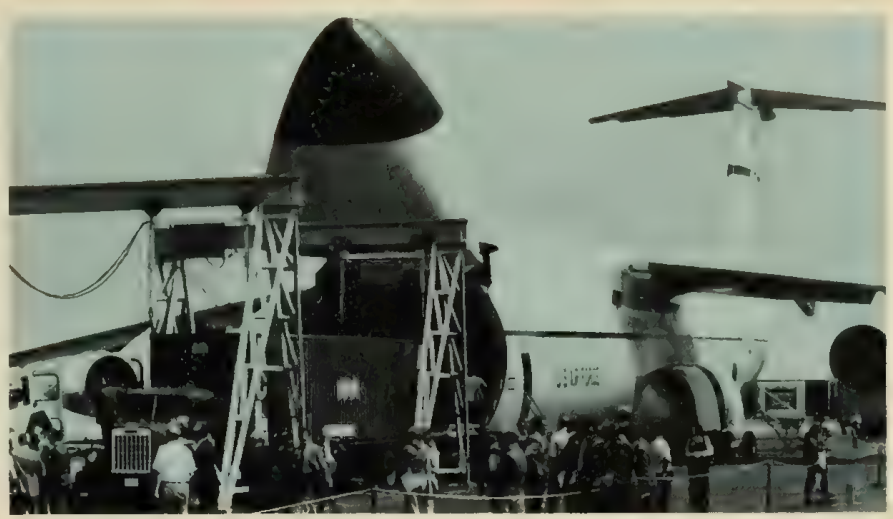

An industry-government project called INTACT (intermodal air cargo test) demonstrates the loading and unloading of intermodal containers on an Air Force Galaxy $(C-5 A)$.

Federal tax on motor fuels from 3 to 4 cents that was enacted in 1959 and due to expire on June 20, 1961. The rate was continued to the expected year of completion of the Interstate System in 1972 and since has been further extended.

Net Federal aid to other governments of $\$ 2.7$ billion in 1961 more than trebled the 1956 figure, and it was increased to $\$ 4.9$ billion in 1973 . All Federal revenue applied to highways rose from $\$ 1$ billion in 1956 to $\$ 7.4$ billion in 1973 .

A demonstration at Colorado Springs, Colo., of a helicopter lifting an intermodal container.

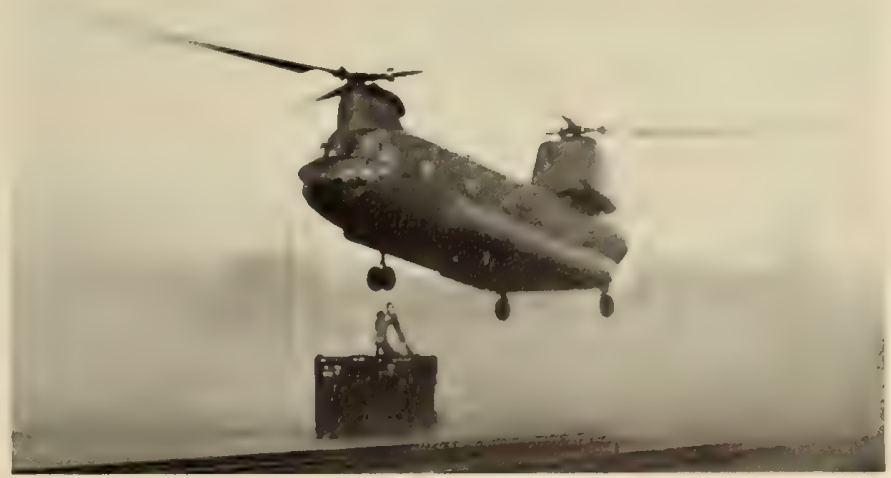


State current income used for roads, most of which came from highway-user taxes, exceeded $\$ 5.5$ billion in 1961 and $\$ 13$ billion in 1973, the 1973 figure being nearly $21 / 2$ times the 1956 level. The net Federal aid received by the States rose dramatically from $\$ 776$ million in 1956 to $\$ 4.5$ billion in 1973.

Income of local governments from all sources to be used for roads and streets grew rapidly after the end of World War II, relatively more rapidly in urban than in rural areas. Net aid to rural governments, largely from the State and Federal Governments, increased from $\$ 675$ million in 1956 to $\$ 844$ million in 1961 to $\$ 1.9$ billion in 1973 . The amounts received by urban governments were at a lower level in 1956 (\$258 million), and rose to $\$ 357$ million in 1961 and almost $\$ 1.4$ billion in 1973 , an increase over the entire period of 371 percent compared with 181 percent for rural units. Revenues from local sources also made significant gains as property tax yields grew and larger sums were made available from general funds. Current revenues of the rural units available for roads rose from $\$ 647$ million in 1956 to $\$ 1.5$ billion in 1973 . For urban governments, the comparable figures were $\$ 881$ million in 1956 and $\$ 2.7$ billion in 1973 .

Expenditures for highway capital improvements responded to the growth in available revenues. State capital outlay (including that for toll facilities) went up from $\$ 3.9$ to $\$ 9.5$ billion between 1956 and 1973 . Before 1965, most of the increase after passage of the Federal Aid Highway Act of 1956 is attributable to the Interstate System. By 1965, Interstate investments stabilized, while non-Interstate expenditures increased from $\$ 3.3$ billion to $\$ 5.6$ billion.

Rural and urban local governments spent nearly the same amount ( $\$ 1$ billion) for capital improvements in 1973. In the case of the rural units, this expenditure represented a 125-percent increase over 1956 , and in the case of the urban units, a 90 -percent increase.

Historically, capital costs have represented the major share of total annual disbursements for highways by all levels of government. But with increasing noncapital demands due to such related requirements as providing for public safety, highway and vehicle law enforcement, higher interest on indebtedness, and increasing requirements for maintenance and operation of the highway plant, by 1975 the proportion of public funds available for capital improvements had declined to less than one-half of the dollars spent.

Inflation has had a serious effect on the Nation's economy. The cost of highway construction has doubled since 1967, and the miles of highway put in place per dollar have shrunk considerably. Total capital outlay of $\$ 13$ billion expended in 1974 is only $\$ 6.5$ billion in terms of constant dollars (1967 base), a figure approximately equal to the constant-dollar value for 1957 .

The Nation's total expenditures for highways have exhibited a pattern of steady growth since the end of World War II, growing from $\$ 1.7$ billion in 1945 to $\$ 4.5$ billion in $1950, \$ 10.8$ billion in 1960 , and $\$ 20.8$ billion in 1970. This rate of growth was 36 percent faster than that of the gross national product (GNP). For 1975 , total highway expenditures were nearly $\$ 26$ billion.
But, if the actual amounts are corrected to remove the effects of inflation, the recent picture of highway finance looks less optimistic. In terms of 1967 dollars, total disbursements for highways by all levels of government peaked in 1971 and have since been declining. Whereas current-dollar disbursements in 1971 were more than twice those of 1960 , the increase in terms of constant dollars was only about one-third. Total disbursements per registered vehicle have declined from \$199 in 1971 to an estimated $\$ 189$ in 1974. In terms of constant dollars, the decline began in 1969 at $\$ 161$ per registered vehicle and dropped to an estimated $\$ 110$ in 1974.

Related to vehicle-miles of travel, disbursements have fluctuated since 1971 and are now on the rise. But expressed in constant dollars, total disbursements per million vehicle-miles of travel have been declining since 1961. Thus, although the amount of travel has greatly increased, expenditures for highway facilities related to this travel have declined.

Before World War II, highway construction represented a more significant share of the gross national product than it has at any time since. In 1939 it equalled 1.72 percent of that year's GNP. The highest postwar percentage was in 1958, when it reached 1.42. For 5-year periods, the average percentages of GNP are as follows:

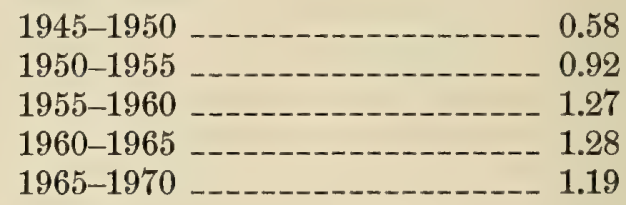

The 1974 highway share of GNP (0.85) was less than half that of 1939 .

It would appear that, while the demand for highway services has been accelerating, it has not been accompanied by a corresponding increase either in the supply or in the quality of highway facilities. The demand for travel, which has grown in recent years, is expected to increase in the future, although at a reduced rate, despite such constraints as increased fuel costs, fuel conservation efforts, and modal shifts from automobile travel to various forms of mass transit. It is possible that the performance of the highway system, which is directly affected by investment, not only is not keeping pace with demand but is actually deteriorating.

\section{Broadening the Highway Program}

The surge of statewide planning activity that began at the close of World War II included planning for urban areas, and the rate of roadbuilding in these areas was greatly accelerated after passage of the 1956 Act. The development of urban transportation from 1960 to 1970 was marked by a 28-percent increase in municipal highway mileage.

Despite the stepped-up population movement to the suburbs that occurred in the postwar period, the central cities of the larger metropolitan areas were still considered to be the focal points of the local transportation network, and growing commuting and other traffic was expected to pour more and more vehicles into these areas. As increased long-distance commuting into, out of, and through central cities produced heavier automobile traffic, the circular action- 


\section{TOTAL RECEIPTS FOR HIGHWAYS, BY GOVERNMENTAL UNITS \\ 1921-1974}

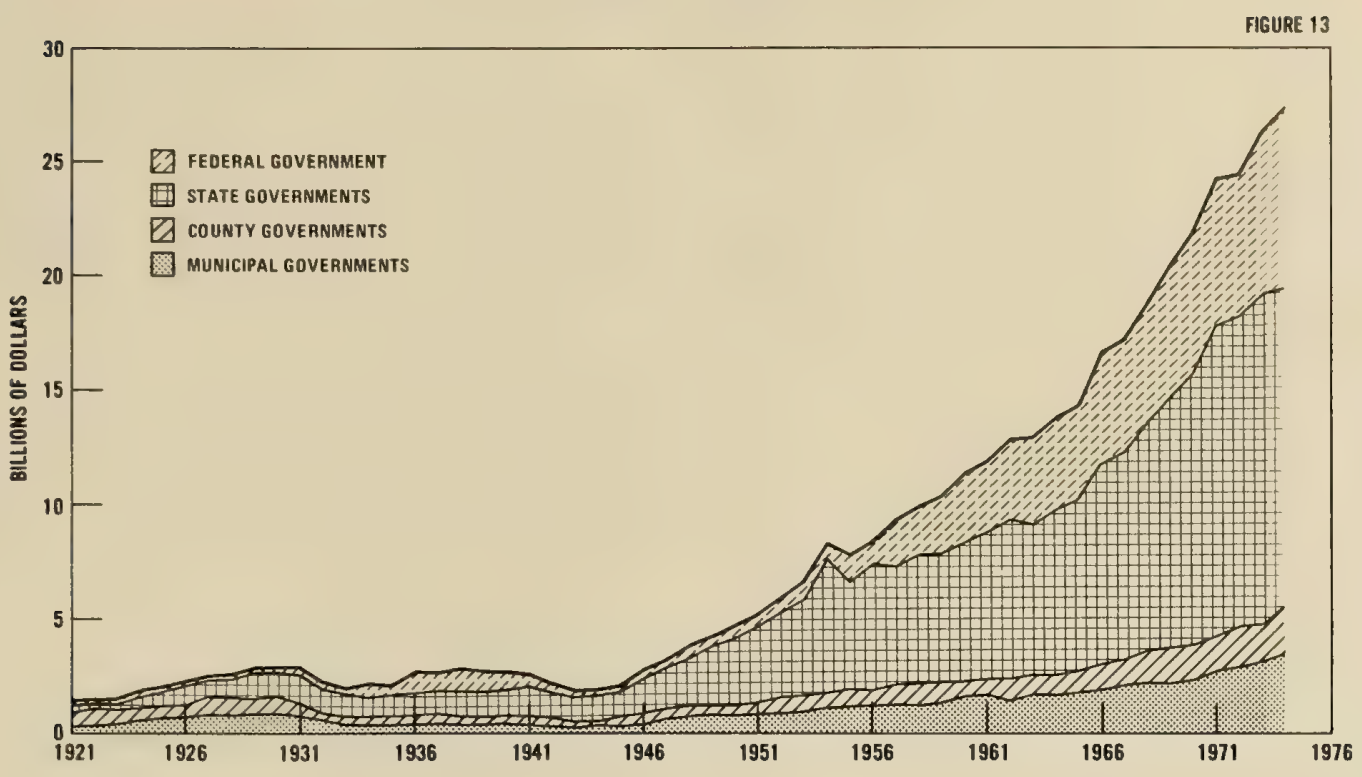

reaction of declining transit patronage and increased fares intensified the downward spiral of those utilities toward insolvency.

Although circumferential and bypass highways were expected to drain off traffic that did not need to go downtown, still large-scale highway building was thought to be required, and plans for it generated little opposition at first. Businessmen and city officials generally encouraged automobile commuting to in-town employment and did not oppose providing daytime storage space for the vehicles.

But as problems of city street congestion led to greater penetration of rural highways into the heart of central cities, more people were affected by the taking of right-of-way and by the construction and opera- tion of highways. Organized opposition to the urban highway improvement program became a major factor in determining the course of Federal and State highway transportation legislation in the 1960's.

A new political activism characterized this period that expressed new needs and priorities that were reflected in Federal legislation between 1962 and 1970 and that broadened the role of the Federal Government in the administration of highway construction programs. The Federal Aid Highway Act of 1962 provided Federal reimbursement to those States that could pay limited relocation allowances to persons and businesses affected by highway construction, and the 1968 Act provided all relocatees with Federal relocation payments.

\section{TOTAL DISBURSEMENTS FOR HIGHWAYS, BY FUNCTION $1921-1974$}

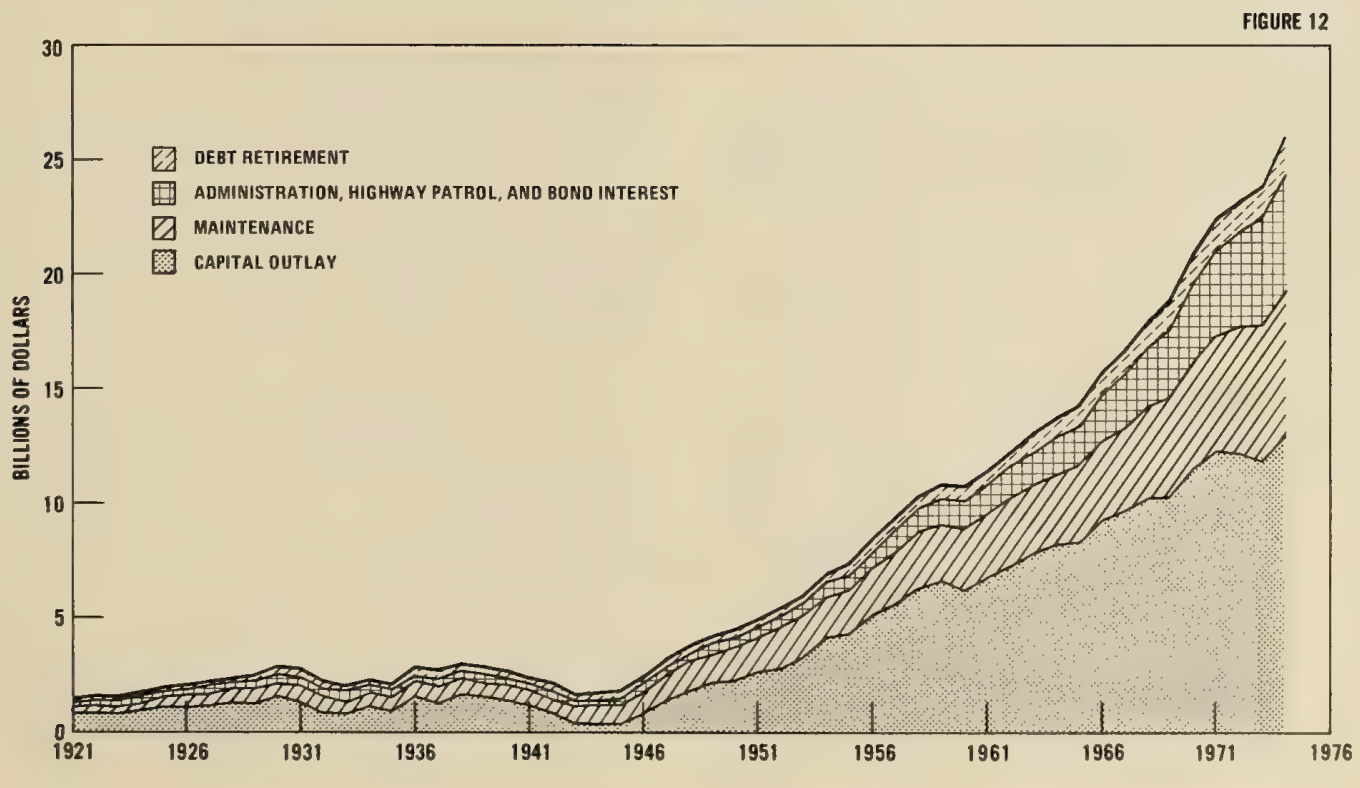


Two new programs were added in 1965 . One was designed to aid the States in the Appalachian region in building main and feeder roads to assist in their economic development. The second was a program of landscaping and scenic enhancement of the Federalaid highway systems, including the control of outdoor advertising and junkyards.

A major development in 1966 was the enactment by the Congress of legislation embracing broad new highway and motor vehicle safety programs. Funds for these programs were to be appropriated from general funds rather than from the Highway Trust Fund.

The 1968 Federal Aid Highway Act established programs known as TOPICS for improving highway traffic operations in urban areas. Specific funds were authorized to provide for making better use of existing highways through the application of traffic engineering techniques. The Act also created a right-ofway revolving fund and authorized additional funds for the Federal-Aid Primary and Secondary System in rural areas. A program was authorized for fringe parking area demonstration, allowing the use of Federal-aid funds to construct parking facilities adjacent to the rights-of-way of Federal-aid highways. Such parking projects became a continuing part of the regular Federal-aid highway program in 1970.

The 1970 Highway Act provided for the establishment of a Federal-Aid Urban System (the D system) in the "urbanized" areas (a census-defined metropoli$\tan$ area for statistical purposes). The Act changed the Federal share of $\mathrm{ABC}$ funds from 50 to 70 percent, effective July 1, 1973, and provided that twothirds of the funds authorized for safety programs for the 1972 and subsequent fiscal years be appropriated from the Trust Fund. The funds for all of these programs formerly came from general funds. The 1970 Act also authorized a program to demonstrate that highways can aid in the development of "growth centers," areas with a high potential for economic growth. This program was changed by the 1973 Act to become a regular part of the Federal-aid highway program.

The 1973 Federal Aid Highway Act introduced several changes in highway policy:

- Highway Trust Fund apportionments could be used for public mass transportation systems, including the purchase of buses, in 1975 and for rail transit facilities in 1976.

- Bicycle facilities and pedestrian walkways could be financed from Federal-aid funds.

- The Trust Fund could be used to pay the cost of parkways located on a Federal-aid system.

- The Trust Fund would henceforth support the entire cost of highway and motor vehicle safety programs.

During 1972, no apportionment of Federal-aid highway funds was made, because the Federal Aid Highway Act was not passed until 1973. But during $1973, \$ 4,743$ million of Federal-aid funds were apportioned to the States for fiscal year 1974 as follows:
Apportionment
(Millions of
Dollars)

2,544
671
376
752

280
97
23
Interstate
Rural primary
Rural secondary
Urban
Urban extensions:
Primary and secondary systems
Priority primary routes
Metropolitan planning funds

A new program for constructing, reconstructing, and improving roads that are not located on any Federal-aid system was launched under provisions of the Federal Aid Highway Amendments of 1974. The $\$ 200$ million made available for this program was distributed according to a formula based on such factors as land area, rural population, and off-system road mileage.

Since the mid-1960's, the Office of Management and Budget of the Executive Office of the President has deferred portions of Federal aid for highways, which may have constrained the total program level. But there is no conclusive evidence that the States would have maintained their 100-percent-State programs at the recorded levels during this period if full Federalaid authorizations were available.

On February 11, 1975, President Ford released an additional $\$ 2$ billion of impounded Federal-aid funds for the 1975 fiscal year in order to stimulate employment. In April of the same year, Congress ended the deferral of the remaining funds, permitting State obligation of greater sums from the unobligated balances of their apportioned and allocated funds.

Further, Congress passed and the President approved a measure allowing the temporary suspension of the Federal-aid matching requirement and removed restrictions on the transferability among non-Interstate program funds. These measures resulted in the obligation of $\$ 7.6$ billion of Federal-aid highway funds in fiscal year 1975, the highest level of obligation in the history of the Federal-aid program.

\section{Indicators of Highway Growth-the Long Term}

The use of the roads as indicated by vehicle registrations, fuel consumption, and travel has increased substantially in the last half century. Registered motor vehicles totaled 3.6 million in 1916 and about 125 million-one vehicle for every 1.7 inhabitants-in 1973. Put another way, the 1973 total represents an average of nearly two vehicles for every one of the Nation's 67 million households. The increase in vehicle registrations has far outstripped the rate of population growth.

In 1916 approximately 3 million automobiles and 250,000 trucks and buses were registered, i.e., about 14 passenger cars to every truck or bus. In 1973 , the registrations had risen to 102 million automobiles, 23 million trucks, and 426,000 buses. This is equivalent to about 4 automobiles for every truck and 240 for each bus. Preliminary data for 1974 indicate that the number of registered vehicles has reached nearly 130 million, with passenger cars about 105 million, trucks numbering about 25 million, and buses in the neighborhood of 445,000 . 
It should be noted that the number of motor vehicles registered is not the same as the number in service at any given time, but it is a reasonable approximation. Registrations tend to exceed the number of vehicles in service for a number of reasons:

- Registrations are cumulative throughout the year. Vehicles registered in January may not be in service in December.

- Vehicles moved by the owner from one State to another may be registered in both States during that year.

- Vehicles scrapped during the year are not deleted from the registrations of that year.

Estimating the number of vehicles in use is becoming increasingly difficult as the States change from a fixed date beginning the registration year to some anniversary month, such as the birth month of the owner or the month of purchase of the vehicle.

Beginning with 1936, nationwide estimates of motor vehicle travel, classified by vehicle type and road system, became available for the first time. Over the 37 -year period between that year and 1973 , no significant increase in the use of passenger cars is indicated by the estimates of average annual travel. But when the density of automobile ownership is considered, multicar ownership is shown to have kept average travel per vehicle down, while average travel per household increased significantly. From 5.25 persons per vehicle in 1936 ( 0.7 passenger cars per household), the density of ownership increased to only 2.06 persons per vehicle (1.5 automobiles per household) in 1973. While fuel consumption per automobile increased by about one-third during the period, fuel consumption per household nearly tripled.

In 1973 , the average annual travel of an individual truck was 11,500 miles, a small increase over 1936, when a truck averaged 10,000 miles. Single-unit trucks averaged 9,900 miles per truck per year, while the average for combinations was nearly 47,000 miles.

Between 1916 and 1973, trends in total motor fuel consumption and travel have roughly paralleled each other, and, as might be expected, both have related rather closely to the trend in motor vehicle registrations. By 1973, annual fuel consumption per vehicle had risen to only about 890 gallons from 750 in 1946 and 800 in 1966 .

The upward creep of average automobile operating speed that took place between 1947 and 1972 has implications for fuel consumption and is indicative of the improvement in highways that has occurred over the years. Speed increased from 45 to 62 miles per hour on main rural highways. Stated another way, only 30 percent of the passenger cars observed in 1945 were traveling more than 50 miles an hour, but by 1972 nearly 90 percent were doing so.

Today, after almost 60 years' experience with Federal aid to and State management of major highways, primary responsibility for about 75 percent of the Nation's highway mileage rests with about 35,000 units of government below the level of the States (excluding the District of Columbia). But, with some notable exceptions, the roads under county and local jurisdiction, for the most part, carry relatively light traffic accounting for a small portion of the total.

In contrast, the 36,300 miles of the Interstate System open to traffic on January 1, 1975, constituting less than 1 percent of the total miles of roads and streets, are carrying about 16 percent of the nationwide total highway traffic. Adding the 6,200 miles of highway carrying the traffic where the System is incomplete, the percentage of total traffic carried by Interstate routes is 19 percent of the total carried by all highways.

The coming of the Interstate Highway System took the steam out of the toll road movement, and today most of the major toll roads carry Interstate routes over a considerable portion of their length, though Federal Interstate funds were not used to build the sections for which tolls are charged. There were 56 public toll roads in operation in 1973, with net toll mileage of a little over 4,000 miles.

Over the 57-year period between 1916 and 1973, road and street mileages in the contiguous United States increased nearly 36 percent, from approximately 3 million to a little less than 4 million. While this increase can be attributed partly to improved mileage inventories, most of it came from new construction.

Changes in rural road mileage, on the one hand, and municipal mileage, on the other, resulted from transfers of rural roads to urban, as cities grew and the Nation's population became predominantly urban. Whereas rural road mileage increased by about 29 percent $(700,000$ miles $)$, municipal mileage grew by about 80 percent ( 300,000 miles).

With all the participating units of government drawing as heavily as possible upon all other available sources of income, the task of developing our modern highway network would have been impossible had it not been for the ability of certain governmental units to tap a lucrative source of revenuethe motor vehicle. It is to this source of revenue, as much as to any other single factor, that the United States owes the extent and quality of its highway systems.

\section{REFERENCES}

\footnotetext{
${ }^{1}$ Early History in American Road Building, AASHO-THE First Fifty Years, 1914-1964 (American Association of State Highway Officials, Washington, D.C., 1965) p. 32.

${ }^{2}$ C. Hayden, The History of Federal-Aid Highway Legislation (unpublished work in the Federal Highway Administration) p. 4.

${ }^{3}$ Federal Highway administration, Highway Statistics SUMMARY To 1965 (U.S. Dept. of Transportation, Washington, D.C., 1967), p. 23.

${ }^{4}$ W. Evans, A Legislative, Program Eligibility and Policy Review of Federal Highway Programs, unpublished part of a support study for the 1974 NATIONAL HIGHWAY NEEDS STUDY (Federal Highway Administration, Washington, D.C., 1973), p. 6.

${ }^{5}$ Federal Highway Administration, Press Release, Table MF-221 (U.S. Dept. of Transportation, Washington, D.C.) Jan, 13, 1976.

${ }^{6}$ Bureau of Public Roads, Highway and Economic and Sociat Chasge (U.S. Dept. of Commerce, Washington, D.C., 1964), p. 1.
} 


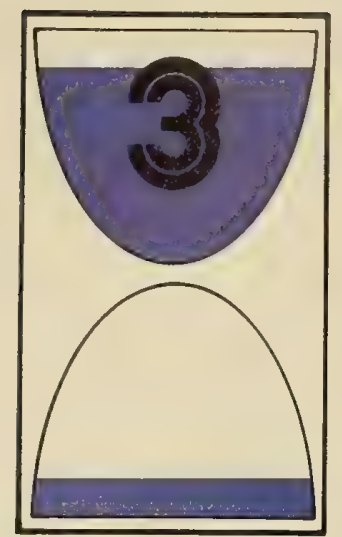

\section{Planning}

\section{Whai Do We Mean-Highway Planning?}

Everyone plans. One may spend hours and days planning a vacation trip abroad. A housewife plans constantly-from the trip to the store for the week's supply of groceries to the time to put the vegetables on the stove for dinner. Engineers locate and design a section of road and portray their results by a construction plan. And perhaps the ultimate example is the successful result of planning to land a man on the moon and return him to earth.

Highway planning, however, is different. In most cases the individual, or even a huge organization such as the National Aeronautical and Space Administration, is planning something he or it expects to do. The ultimate result of highway planning, more recently broadened to be called highway transportation planning, is the development of a highway system to provide for the movement of vehicles-vehicles not under the control of the planner but of the great number of individuals who drive them. Highway transportation is mostly, up to 96 percent, people driving themselves or transporting their goods in their own vehicles. The highway planner plans a system and the engineer builds and maintains it, but they do not provide highway transportation. A railroad company provides transportation; an airline provides transportation; a transit company provides transportation; but the highway agency provides for transportation.
From another viewpoint, the question sometimes is raised as to whether we in the United States do any highway planning. It is reasoned that there were over $2,350,000$ miles of rural roads and city streets at the time of the advent of the automobile, so what we have been doing for some 75 years is highway improvement planning. Literally that is nearly true, for most of the mileage added has been in the expanding suburban areas, with little planning, at least by highway planners, and most of the planning has been directed toward upgrading the early roads on or close to their original locations. Notable exceptions are seen in the Interstate System, which surely is a system planned by highway planners for highway transportation, and in the great undeveloped State of Alaska where new routes are being laid out to permit development of its natural resources. So compared to the many underdeveloped countries, the United States has in effect been doing not highway planning, but highway improvement planning.

Even in view of these qualifications, however, for the purposes of this chapter, the term highway planning will be used in a generic sense and will include whatever is done by the highway planners in facilitating highway transportation, coordinating it with other modes, and helping make it compatible with social and community values, whether the community be the smallest town, a metropolitan area, or the entire Nation. 


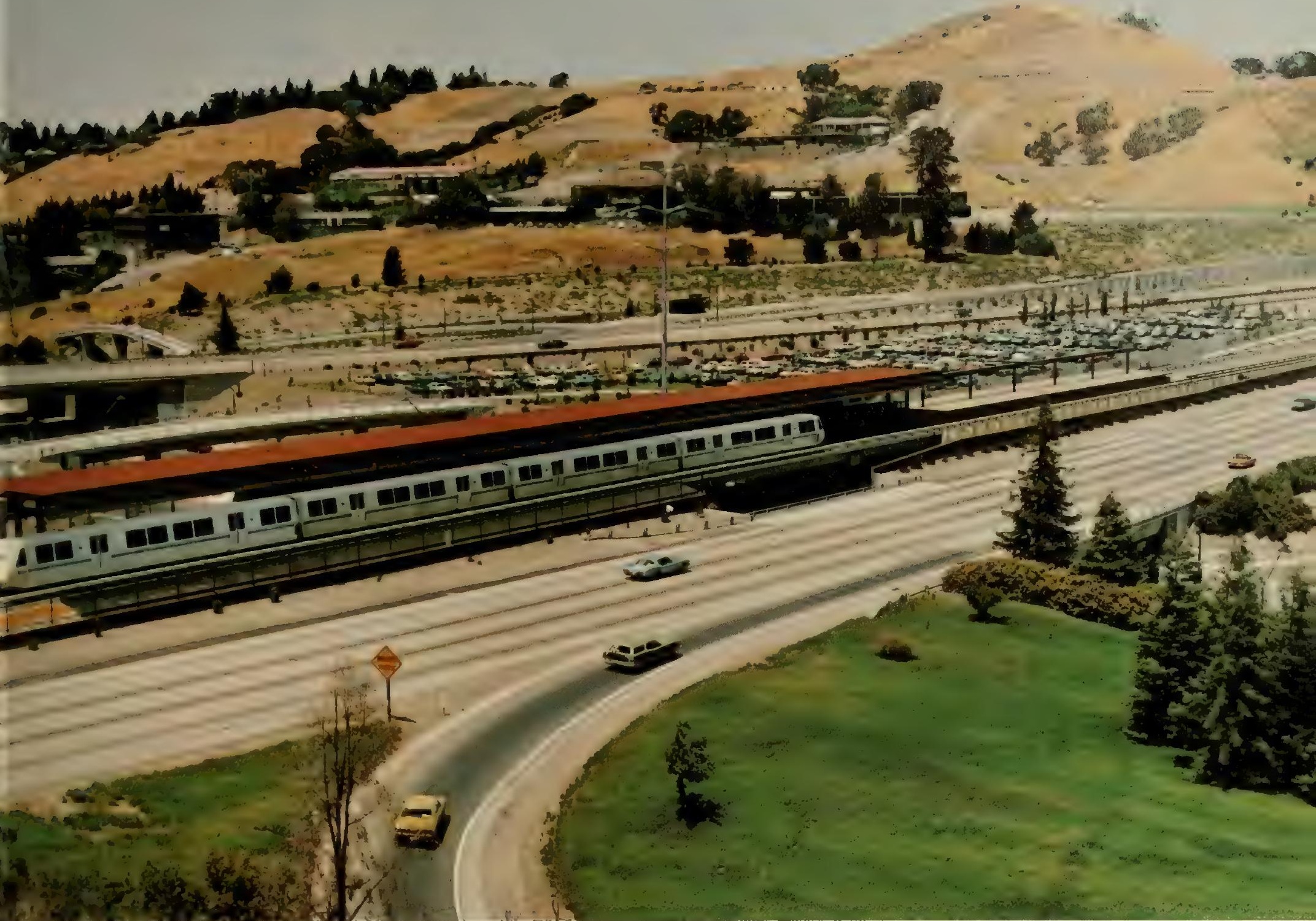

The coordination between the California DOT and the Bay Area Rapid Transit District, from planning through construction of over 11 miles of rail and highway facilities, saved the taxpayers millions of dollars, caused a minimum of disruption to the communities, and made the best use of the land by evaluating shared social values and esthetics for the benefit of all.

\section{Early Highway Planning}

This discussion of highway planning will be devoted primarily to the period beginning in 1934, the year of the passage of the Hayden-Cartwright Act (Senator Carl Hayden of Arizona and Representative Wilburn Cartwright of Oklahoma) that made highway planning possible on an organized and formal basis. Yet planning obviously was an essential feature of highway development even in colonial days.

Before the railroads put a temporary end to highway development, roads were definitely planned to meet such specific needs as connecting principal cities and opening new territory to development or for military purposes. The birth of highway transportation as we know it probably can be dated as 1893 , when J. Frank Duryea first drove his gasoline buggy on the streets of Springfield, Massachusetts. Roads until then were being improved generally in short sections radiating from towns and railroad shipping points and were primarily for the movement of farm products. The availability of the automobile, first usable only in towns and cities and as "pleasure" vehicles, soon brought demands for improvement of larger sections, and especially in the eastern States, connecting the towns with one another.

It was this demand for connecting or trunk roads that brought about the first real differences among highway users, and what might be called the first highway planning - whether to concentrate on the trunk roads or continue to extend the radius of the farm-to-market roads. The question was settled early in the small eastern States in favor of the former rather than the farmer. In 1903 Rhode Island adopted a definite system of State highways for construction by the State Board of Public Roads. A similar proposal in Connecticut in 1901 was finally enacted in 1913, while Maryland in 1908 adopted an intercounty seat trunkline system, the first to be placed under State control for both construction and main- 
tenance. Similar actions in the central and western States followed, only slowly, however, where towns were farther apart and service to farms generally more important than trunkline roads.

Again, as noted in earlier chapters, pressure developing from farm groups, city "pleasure" vehicle owners and, almost strangely, the League of American Wheelman led the Congress in 1916 to authorize funds for the improvement of rural post roads.

Two outstanding features of the 1916 Federal Aid Road Act were the basis of apportionment of Federal funds and the requirement that the States must have or establish a State highway department adequately equipped to receive and administer the funds. The apportionment formula prevented any "pork barrel" distribution of funds by the Federal agency (but not necessarily at State level). The requirement of a State agency through which funds would be applied to road improvement was with the intent of bringing about the progressive development of a connected system of roads. These provisions were included as a result of the experience of the Office of Road Inquiry and several of the States that had already designated State highway systems. At that time, however, the Congress was not ready to accept as a requirement that all States must have State highway systems.

The importance of the system concept still ranked high in the thinking of the Office of Public Roads, however, and in reaching toward this concept, the Secretary of Agriculture required all States to submit programs of improvements proposed over the 5 years of the original authorization of Federal-aid funds for highways and also to file with the Office of Public Roads a "tentative" system on which the improvements would be made. So to this small degree, planning was already in evidence.

Hardly had the program gotten underway when came World War I. To read at this time a recitation of the effect of the war on the highway program is to recall how well these same words could have been used in describing the effect of World War II on the highway program of that period. In a speech before the American Society of Civil Engineers, Mr. MacDonald said:*

The Federal-aid work had scarcely begun, however, when the world war intervened and practically put a stop to all operations; and the war did a number of other things to the existing improved roads which, however disastrous they may have appeared at the time, have turned out to blessings in disguise. At the outset the construction and maintenance of highways were declared to constitute a non-essential industry. As a consequence new construction, except as required for the immediate service of the army, was greatly curtailed. Maintenance also was greatly hampered by the difficulty of obtaining the necessary materials and the scarcity and high wages of labor. At the same time there was released upon roads generally inadequate to stand it an unprecedented traffic of heavy motor trucks. To this experience and the heavy damage which followed we owe the development of most of the sound principles and policies which now govern the improvement of highways.

* This quotation and much of the material for the early history of highway planning are drawn primarily from papers of Chief MacDonald and Mr. H. S. Fairbank.

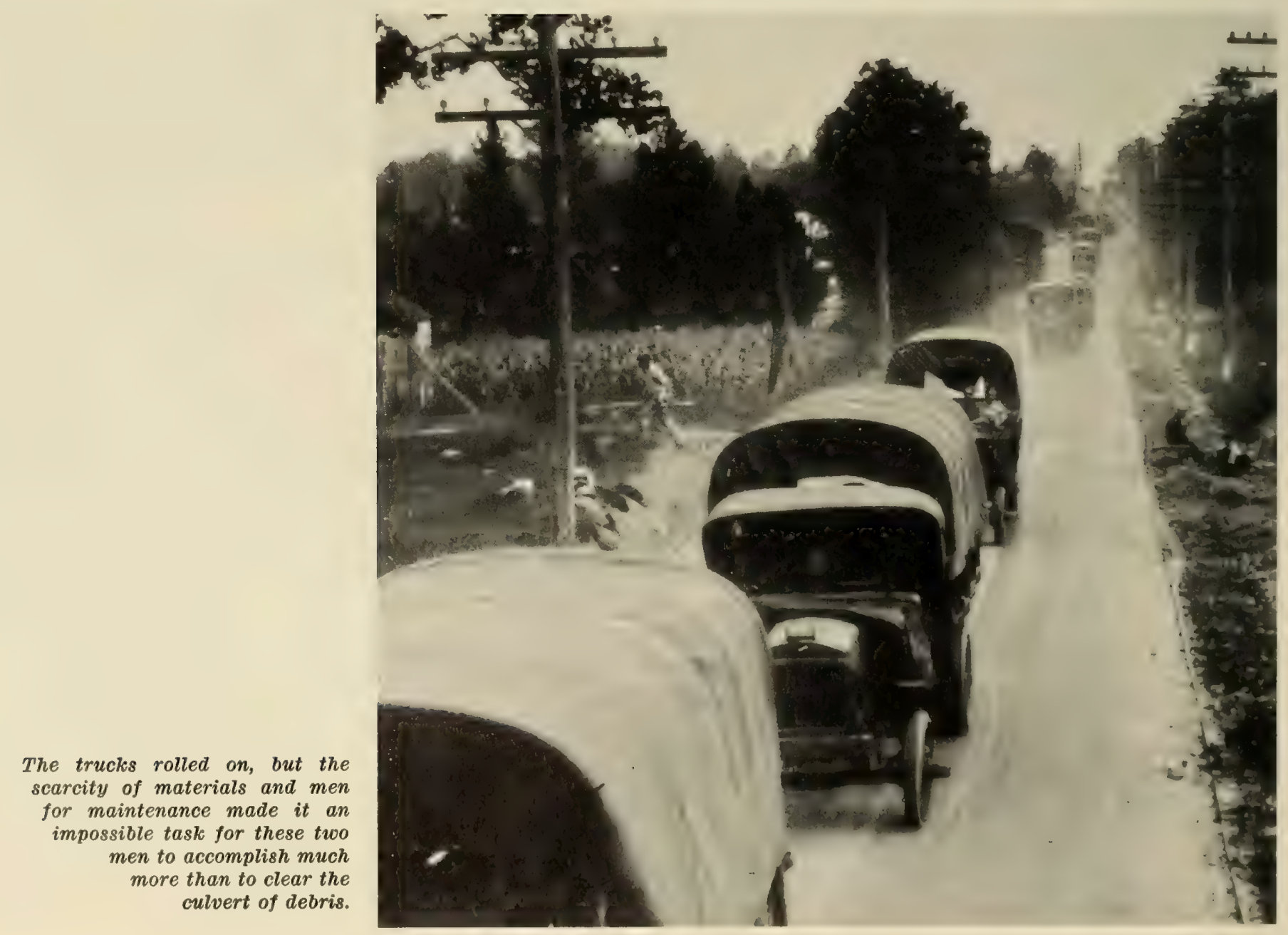


The first result was a strong reaction against the use of heavy motor trucks. There were large numbers of people who, forgetting that a road is of service only in so far as it accommodates the need for economical transportation, demand that the manufacture and operation of vehicles too heavy for the existing roads be prohibited. As few of the roads were designed to carry motor truck traffic, to have taken this course would have amounted to the throttling of a new development in transportation before it had a chance to demonstrate its utility, and it was rightly opposed with great energy by the manufacturers of motor vehicles. The latter, on the other hand, took a position at the opposite extreme from which they demanded the right to manufacture and sell vehicles of large capacity and heavy weight, without regard to the strength of the roads, on the theory that the greater the capacity of the vehicle the smaller would be the cost of operation per unit of capacity. The slogan was, 'build the roads to carry loads,' and this was met by the opposite party with the equally dogmatic demand that the loads should be limited to the capacity of the existing roads.

The issue thus joined, the principals to the controversyhighway officials on the one side and the manufacturers on the other-wisely agreed to submit their differences to the test of mutual discussion; and out of the series of conferences which ensued there came an agreement upon certain fundamental facts and principles which have served as the basis for a harmonious cooperation of the two groups, and which now constitute the foundations of highway improvement policy in all States. ${ }^{1}$

The wartime experience was felt in another way also. It was during this period that an intrepid team drove a truck from Detroit to Washington to demonstrate the value to the military of motor transport. This journey, almost an expedition in those days, represents the birth of a new concept of mobility. It demonstrated the value of a connected system of highways. As much as any other factor, it brought about what is now recognized as the most significant feature of Federal aid to highways, the requirement that funds be expended only on a Federal-aid system recommended by the States and approved by the Secretary of Agriculture, the Department within which the Bureau of Public Roads was then located.

This requirement was set forth in the 1921 Federal Highway Act, and reflected the acceptance of the earlier views as to the essentiality of concentrating highway expenditures on a limited system, then set at 7 percent of the total highway mileage of each State. The Act also recognized another national purpose for Federal aid - to serve possible military needs. While later it came to be accepted that the highway system's military value lay more in aiding in the movement of the materials and products of war industries than in the movement of strictly military vehicles, this Act inspired the selection, by cooperative action of the Bureau of Public Roads and the War Department, of a system of routes of military importance to be included in the Federal-aid system. This system, ultimately portrayed in the "Pershing Map" (General Pershing accepted the responsibility for this effort) served as the basis for the so-called "strategic network" on which Federal-aid funds were to be concentrated during World War II. Thus, the 1921 Act opened the door to another planning effortthe selection of principal highway systems, statewide and national.
World War I also opened the door to another planning area, economic planning. The "harmonious cooperation" of roadbuilders and truck manufacturers had led to the adoption of a limit of $71 / 2$ tons as the capacity of vehicles for future production, a figure deemed fair to both (the user being omitted from consideration, evidently). Again quoting Chief MacDonald :

... It was recognized clearly for the first time that the cost of highway transportation is made up of the cost of the highways and the cost of operating the vehicles over the highways, and it was agreed that the common purpose of the public highway officials, vehicle manufacturers and operators should be to reduce the total cost of transportation rather than one or the other of the elemental costs. It could be proved that the number of largecapacity trucks already using some of the highways, principally those radiating from and connecting the larger cities-had already grown to the point where the combined savings in operating cost would more than balance the greater cost of providing highway service for them. As to those highways there could be little doubt of the wisdom and economy of building a type of surface adequate for the heavy truck traffic. Other roads, similarly located with respect to cities, had not yet developed a sufficient amount of the heavy traffic to repay the additional cost of the stronger construction, but it was not difficult to foresee that such a condition would develop in the future. On the majority of the roads however, the development of traffic of sufficient weight to justify the higher types of construction was very remote; and it was apparent that the one-time prevailing condition of uniformity of traffic on all roads had been definitely broken down. Instead, a new and much different condition had arisen under which the main inter-city roads were found to be carrying traffic far in excess of the much greater mileage of local roads.

Under the new condition the economic justification for the improvement of the main roads lay to a far greater extent than formerly in the reduction of transportation costs and to a lesser degree in the effect upon the value of property. The main roads had become through traffic arteries, as distinguished from the more numerous local roads which continued to be of value primarily through the service they render in giving access to the land. ${ }^{2}$

From the point of view of highway planning, one other important feature emerged from the war and early postwar experience-the matter of highway finance. Recognition that State highways accommodated most through traffic and that the level of their improvement should be based on total transportation cost gave responsibility for financing the improvement logically to users, to be supported by motor-vehicle license fees and excise taxes and the motor-fuel taxes then beginning to come into more widespread acceptance. Local roads primarily serving farms were considered to be the responsibility of property owners served, with the financing coming primarily from real estate taxes, either on the property served or on the entire community.

The experience gained during the first decade following the 1916 Act pointed the direction highway planning would take. The earliest efforts were in the area of traffic counting. Observations included not only the numbers of vehicles, but their classification (passenger cars and trucks of various sizes) to aid in road design and State of registration to provide some gage of lengths of trips and the proportion of travel that was interstate in character as a measure of the propriety of Federal aid. The findings of these surveys coupled with results of the physical research being undertaken, described in Chapter 4, gave 


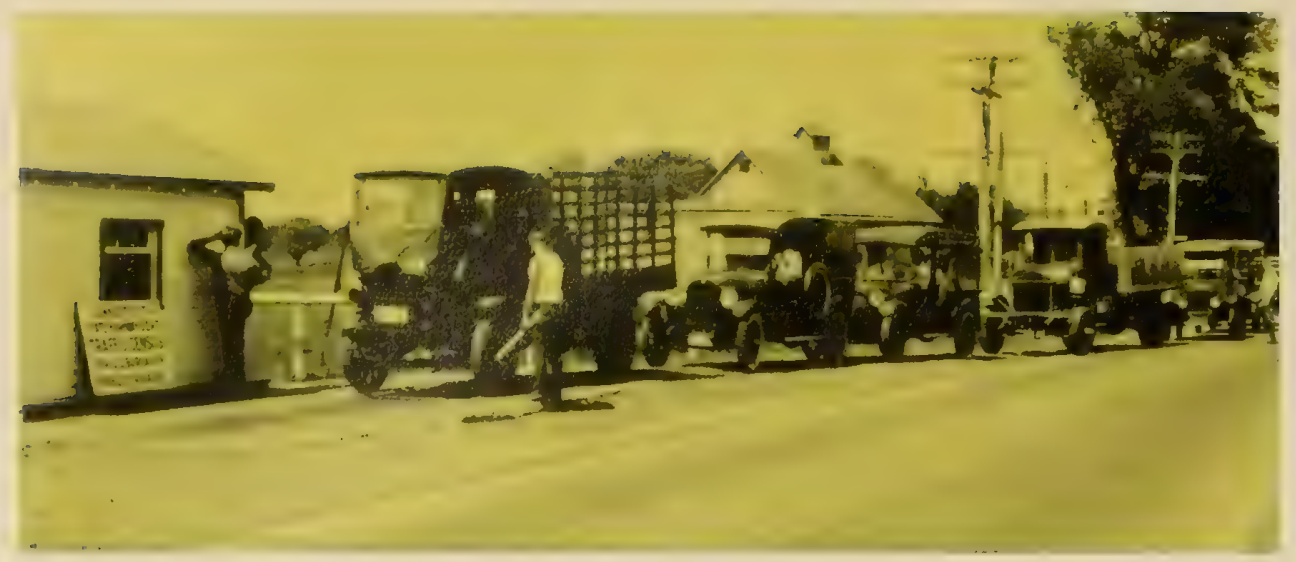

Connecticut conducted this traffic census during the period

September 1922-1923.

the means to get on with the early economic studies perceived to be so important in decisions with respect to degree of improvement to be provided and to the appropriate sharing of the costs.

Traffic counting is not modern phenomenon, dating back at least to the Romans. But modern traffic volume counting began not too long after the beginning of the automobile era. Certainly by the early 1920's many States and cities were making at least sporadic traffic counts. Maine, for example, as early as 1916 began counting traffic for one week each year at 58 stations and was one of the first States to make a statewide survey (in 1924) for the purpose of developing the State highway system. California has a long history of counting at hundreds of stations for one day each summer, using maintenance crews, a practice continued well after the automatic traffic counter had come into general use.

Concern was not limited to rural areas, for Cook County in Illinois, with the Bureau of Public Roads cooperating, conducted a traffic survey in 1924 and used the results to develop a constructive program. Ohio, following generally the Maine method, carried out a full year statewide survey in 1925. The first metropolitan area traffic counting, also with Bureau of Public Roads cooperation, was conducted in the Cleveland area in 1927.

With this background, the Bureau of Public Roads entered into agreements with several States in the late 1920 's for cooperative traffic surveys, the Bureau usually supplying the supervision and the States the counting personnel. The New England States were among the early participants in these cooperative studies, presumably because of their relatively higher traffic volumes, but the most ambitious survey of this period involved the 11 western States* in a simultaneous program. Here the Bureau joined with the States in providing field supervision and, in the Washington Office, did much of the analysis and forecasting of traffic volumes. Efforts to move on from the traffic volumes forecast route by route to recommended programs to meet the traffic demands proved to be considerably less than successful, however, primarily because of uncertainties in forecasting (the use of motor-fuel consumption as a good indicator of traffic growth was still in trial stage) and inadequate knowledge of the capacities and condition of existing roadways.

*Washington, Oregon, California, Montana, Idaho, Nevada, Wyoming, Utah, Arizona, Colorado, and New Mexico.

\section{The Highway Planning Surveys}

With the growing recognition of the need for more facts about highway program accomplishments to date and to establish a basis for estimating the direction and financial magnitude of future programs, the $\mathrm{Bu}$ reau of Public Roads and some States had been considering the possibility of a broad data collection effort. Their deliberations bore fruit by the inclusion in the 1934 Federal-Aid Highway Act of the following wording:

Sec. 11. With the approval of the Secretary of Agriculture, not to exceed $1 \frac{1}{2}$ per centum of the amount apportioned for any year to any State . . . may be used for surveys, plans, and engineering investigations of projects for future construction in such State, either on the Federal-aid highway system and extensions thereof or on secondary or feeder roads.

Though the word "planning" does not appear in this section, it is the basic and still controlling legislation that authorizes the ongoing highway (or nowtermed highway transportation) planning process. The percentage figure has remained the same, but the "may" has been changed to "shall." In addition, an optional $1 / 2$ percent of all funds, except Interstate, has been made available for planning and research purposes. To avoid the appearance of directing how a State shall expend its own funds, with the change from "may" to "shall" was added the provision "with or without State matching." While in the early years one State or another did not match Federal aid, these were the exceptions and now all States at least fully match, and many "over match," Federal-aid planning funds, indicating the essentiality of the planning function.

But to get to the avoidance of the word "planning," the reason lay in the fact that the word had come into disrepute in many sections of the country, and even in Washington, due no doubt to the increasing centralization of authority in Washington as the country was still struggling to emerge from the Depression. So the words "surveys, plans, and engineering investigations of projects for future construction" were in effect a euphemism for the word "planning." While some States tried to interpret the wording as authorizing the funds for preliminary surveys and preparation of construction plans, the intent of those supporting the legislation and of the Public Works Committees of the Congress was clear, and Chief MacDonald yielded at no time to the use of the funds for anything less than the broad planning process envisioned by the Bureau. 
The 1934 Act contained another provision of immense importance to the rural residents, an importance probably not fully appreciated at the time. In the paragraph authorizing appropriations appeared the words :

Provided further, That not less than 25 per centum of the apportionment to any State shall be applied to second. ary or feeder roads, including farm to market roads, rural free delivery mail roads, and public-school bus routes ...

As in the 1916 Act, there was no requirement for the designation of a system, the authorization being simply for roads of particular classifications with no limit as to mileage. The Congress did not until years later specifically authorize or require the designation of a secondary system, for the authorizations regularly continued were for "secondary or feeder roads." The Defense Highway Act of 1941, however, evidently assuming that the roads had formed a system, authorized the extension of the Federal-aid system and the Secondary Road System to include all roads on the strategic network to permit the application of Federal-aid highway funds for their improvement. It was not until the Federal-Aid Highway Act of 1944 that the Congress "Provided, That these funds shall be expended on a system of such roads selected by the State highway departments in cooperation with the county supervisors, county commissioners, or other appropriate local road officials and the Commissioner of Public Roads." Nevertheless, with the experience of 1916 to 1921 still fresh in mind, the Bureau of Public Roads administratively determined that the States must designate systems on which the secondary funds might be programed, initially setting the mileage limit at 10 percent of the rural highway mileage. The 1944 Act in effect confirmed this early administrative decision and at the same time acceded to the growing pressure from local officials to have a say in the selection of routes to be improved with secondary funds.

It was under these conditions in 1934 and 1935, with highway planning formalized by legislation, that H. S. Fairbank began planning for planning. Fairbank, who impressed all who knew him as a brilliant man, a man of broad vision, the most fluent writer of Public Roads' history, was an engineer and a scholar, yet a practical man. He was indeed the "father" of highway planning. He personally sketched out the data collection and analytical processes, leaving only the details to be worked out by his subordinates (whom he preferred to think of as colleagues). And through the early years he wrote and spoke strongly and often in behalf of the planning concept and in encouraging not only its adoption but its use in policy, administrative, and engineering decisions.

Fairbank made it clear that the early work was not planning but the collection and analysis of data to be used in planning, and the agreements between the States and the Bureau were for the purpose of conducting highway planning surveys of three broad types-road inventory, traffic, and financial and road use. As a parenthetical note, it is when one advances from data collection and analysis to forecasting the future that one advances from surveying to planning.
The inventory phase involved driving over every mile of rural highway, recording its width, type, and condition; on the more important routes the geometric features such as curves, grades and sight distances; all farms, residences, businesses, industrial plants, schools, hospitals, and any other cultural feature that the roads must serve. All the information was to be recorded on inch-to-the-mile county maps, and the data tabulated in a variety of ways for analytical use.

The traffic surveys were built on the cooperative traffic surveys described earlier but underwent considerable improvement in method as automatic traffic counting equipment, a better understanding of road design requirements, and improved statistical procedures became available. Basically they involved intensive traffic volume counting on main routes, less intensive counting on secondary roads and spot checks on lightly traveled local roads. At all stations, vehicles were classified as to type, and on the main roads a sampling of commercial vehicles was weighed on portable scales, their cargoes classified, their origins and destinations ascertained, and their tare weights recorded where known. Origins and destinations of passenger cars were also sampled. All these data were to be tabulated in various ways and shown on appropriate maps. They served to show the service highways were providing, the vehicle miles of travel and ton miles of goods and products moved, the lengths and purposes of trips, and average and peak hour volumes for design purposes. When coupled with the road inventory data, they showed the adequacy of the existing roads to provide for the movement of traffic and to serve the needs of rural land use, particularly farms. They permitted estimates of the cost of bringing road conditions up to a standard regarded as suitable for current traffic and, to the extent it could be forecast, future traffic.

The third general area involved the recording of expenditures and revenues for highways and all other purposes from all units of government, including special districts, to ascertain the degree to which user and other taxes were being applied to road purposes by the individual units and, more generally, by the various levels of government. These studies would show the degree to which the main roads were in fact supported by the users as the theorists then thought appropriate, and the local roads by property or general taxes. Today it is recognized that it is only at the extremes that the theory can fully operate

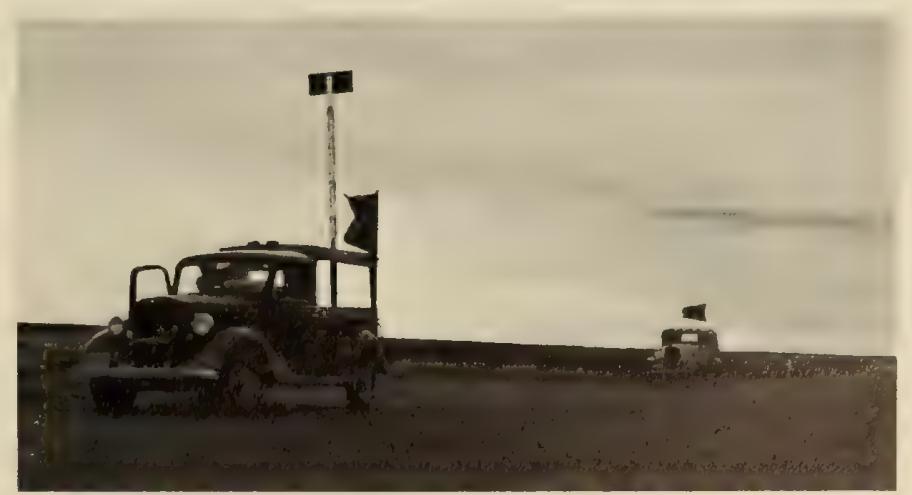

Measuring sight distances and curvature on existing highways to get data to be used in planning. 


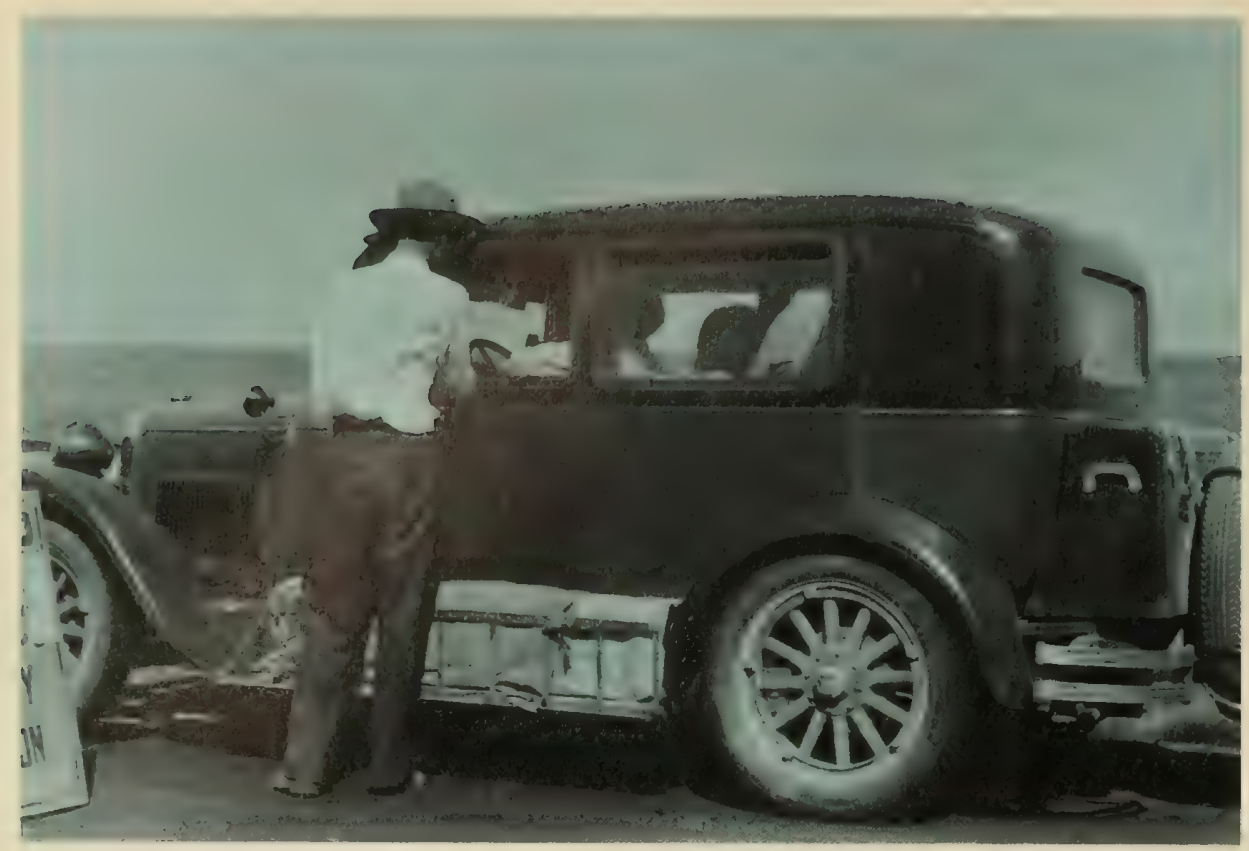

New Mexico participated in an ambitious traffic survey in 1930 with 10 other States.

- freeways as a user responsibility and the dead end road or street as a land service or community responsibility - with the great mass of roads in between deserving some support from each source since all such roads serve both purposes. In 1934, however, there were no facts at all on which even to estimate the propriety of highway finance of the day. In addition, the financial survey included road-use studies which determined from a sample of owners of vehicles in places of various sizes the usage they made of roads in the different systems. This might show, for example, the use of rural roads by urban residents compared to the use of city streets by rural residents, to the end of appraising the propriety of the allocation of funds collected by various levels of government to the several road systems. Also included in the financial surveys were road life studies, which permitted estimates of the physical life of the roads constituting the highway "plant."

Obviously, carrying out Fairbank's bold plan would be an enormous task requiring much manpower, and it might well not have been begun had not at least three significant items conjoined.

First, the country was still deep in the Depression. "Make work" programs were being sought, and funds for highway improvements were being made available as works relief programs. One and one-half percent of these funds added to similar percentages of regular funds then made available under the Hayden-Cartwright Act provided substantial funding from highway sources.

Second, the works relief funds for white-collar projects offered Work Projects Administration (WPA) officials the opportunity to place many needy people in jobs.

Third, the surfacing of the Federal-aid systems in most States was well along toward completion, and administrators were feeling pressures to extend road improvements to the less important roads. The 1934 Act gave them this opportunity, but by requiring that the States select a secondary system, the need for the planning survey was obvious. In fact, Fairbank sug- gested that providing facts on which to select the secondary system would be a main object of the effort. But at the same time Fairbank bore down heavily on the idea that roads were never "completed" but must be maintained, surfaces replaced, and the whole system upgraded to meet new demands of a growing traffic. And the planning surveys were to provide the data that would permit planning this continuing process.

So with the need for this new concept-planningconstantly emphasized by the Bureau, with the procedures formulated, and with funding and manpower at hand, work was begun. The first State to get underway was Pennsylvania in September 1935, closely followed by Ohio in October of that year, and other States joining in quickly thereafter.

With this planning survey process new and not uncomplicated, it was expected that the Bureau of Public Roads would be able to help the States by sending people experienced in the earlier cooperative traffic surveys to assist in starting the field work, anticipating that States would accept the new concept but slowly, perhaps five or six States in a year. But once begun, States followed one another in quick succession, some appreciating the need and the opportunity to meet it, and others influenced by the growing number of other States undertaking the work. In fact officials of one State remarked that "We heard that [State name omitted by choice] was starting one of these planning surveys and so we thought we should have one too, whatever it is." But for whatever reason, by September 1936, only a year after the first survey was launched, 38 States had come into agreement with the Bureau and actually started field work. The schedules varied considerably. Fairbank had envisioned completing the field work in one year (the traffic survey required that long anyway to cover seasonal variations) and spending another year in analysis. Some States did virtually complete all the field work in a year, but more commonly the several phases were spread over a longer period, and in no case was the analysis completed in 
a year. Even with the stretched-out approach, however, a great deal of manpower was involved. In Ohio, for example, over 600 men were in the field within 2 months after the work got underway, some occupied for a full year and others a shorter time. There probably never was a tabulation of the total number of people employed in the early work, but it seems safe to say that at the height of the field work at least 15,000 men were given employment, almost all from the relief rolls or the ranks of the unemployed. Thus, leaving out the benefits of the planning surveys to highway administration, the work represented a major accomplishment in the constructive expenditure of work relief funds in a period of great distress in the country.

But this sudden acceptance of highway planning had a considerable impact on the Bureau of Public Roads as well, for on it fell the task of aiding the States in launching and supervising the work. The few Bureau people who had worked on the cooperative traffic surveys hardly provided a nucleus from which to start. So the Bureau set up a training program for highway planning supervisors, drawing not only from the Washington staff, but recruiting from the field offices and the forest and park programs as well. The response was good, mostly from the younger and perhaps more imaginative employees, many from graduates of the ongoing Bureau's junior engineer training program. With word of the training program getting around, States also began sending prospective supervisors to take the training courses. While the number "processed" through the training program was probably never tabulated, what is more important the program marked the creation of a new discipline-highway planning-the scope and importance of which surely could not have been foreseen at that time.

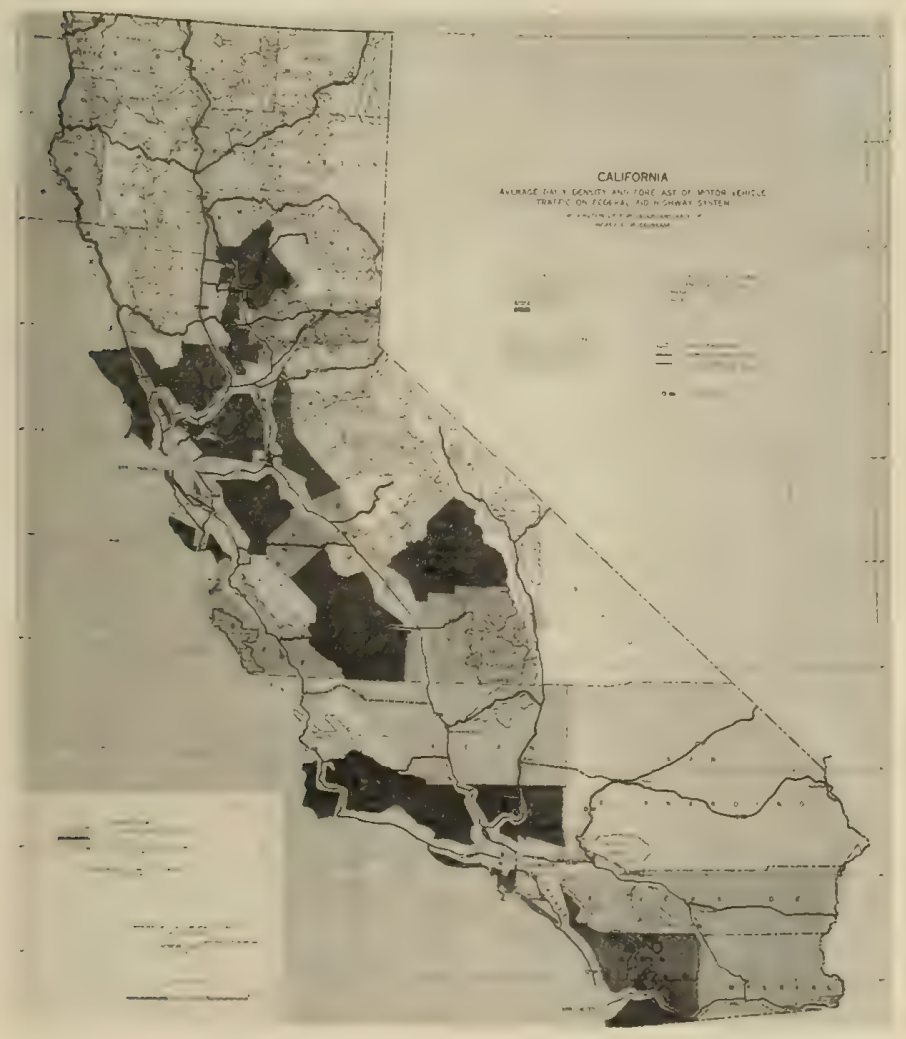

One of the maps prepared as a result of the 1930 western trafic survey.
Thus were launched the highway planning surveys, and simply keeping them on course during their early years was a major concern of the Bureau. Data collection procedures were steadily improved, and the many problems that developed in tabulating, reconciling, and summarizing data were met and solved. But the harder part was in moving from summaries of data to reports and from reports to administrative and policy decisions. It was to this aspect that Fairbank wrote and spoke so frequently in the years before World War II.

Perhaps his most preceptive writing was in the area of taxation, for he foresaw financing as the most critical problem of the future. In the "depression psychology" of the era, in which the official views held that the country had reached its pinnacle of development, that there would be permanent unemployment and our problem would be the equitable distribution of limited resources, neither he nor anyone else could foresee the great upsurge in the economy and even more in highway transportation that in 1956 made relatively easy the financing of the Interstate System-the greatest public works program in history.

\section{Planning the Inferstate System}

While the States were absorbed in collecting and analyzing highway planning data, and Fairbank particularly saw the need to develop a "climate" in the States that would encourage them to carry on from the easier stage of surveying to the more difficult one of planning, the Bureau of Public Roads almost immediately had need to use the data for planning. Early in 1937 President Roosevelt called Chief MacDonald into his office and handed him a map of the United States on which he (the President) had drawn three lines east and west and three north and south across the country. He reasoned that with the increasing use of the automobile the need for more and better highways for long distance travel would be needed, and suggested that the six routes he had sketched on the map might be built and financed through the collection of tolls. And he asked Chief MacDonald to study the possibility. Again, such a program would not only benefit the motor vehicle user but constitute a desirable public works program to provide employment. It can be said that this map is the lineal ancestor of the Interstate System, truly a document of first importance in highway history.

Returning from the White House, Chief MacDonald handed the map to Mr. Fairbank and asked him to get on with the study. Thus, began the first assembly of detailed information on traffic flow on a national basis, possible only because of the rapid progress by the States on the highway planning surveys. While data were still not available for all States, enough States had progressed far enough to supply the data needed for a reasonable appraisal of the feasibility of the President's suggestion. As a first step, a traffic flow map of the United States was prepared, finished in January 1938 and later updated to January 1939 and refined as more States could supply data. For the first time a picture of travel on all main routes was available. 


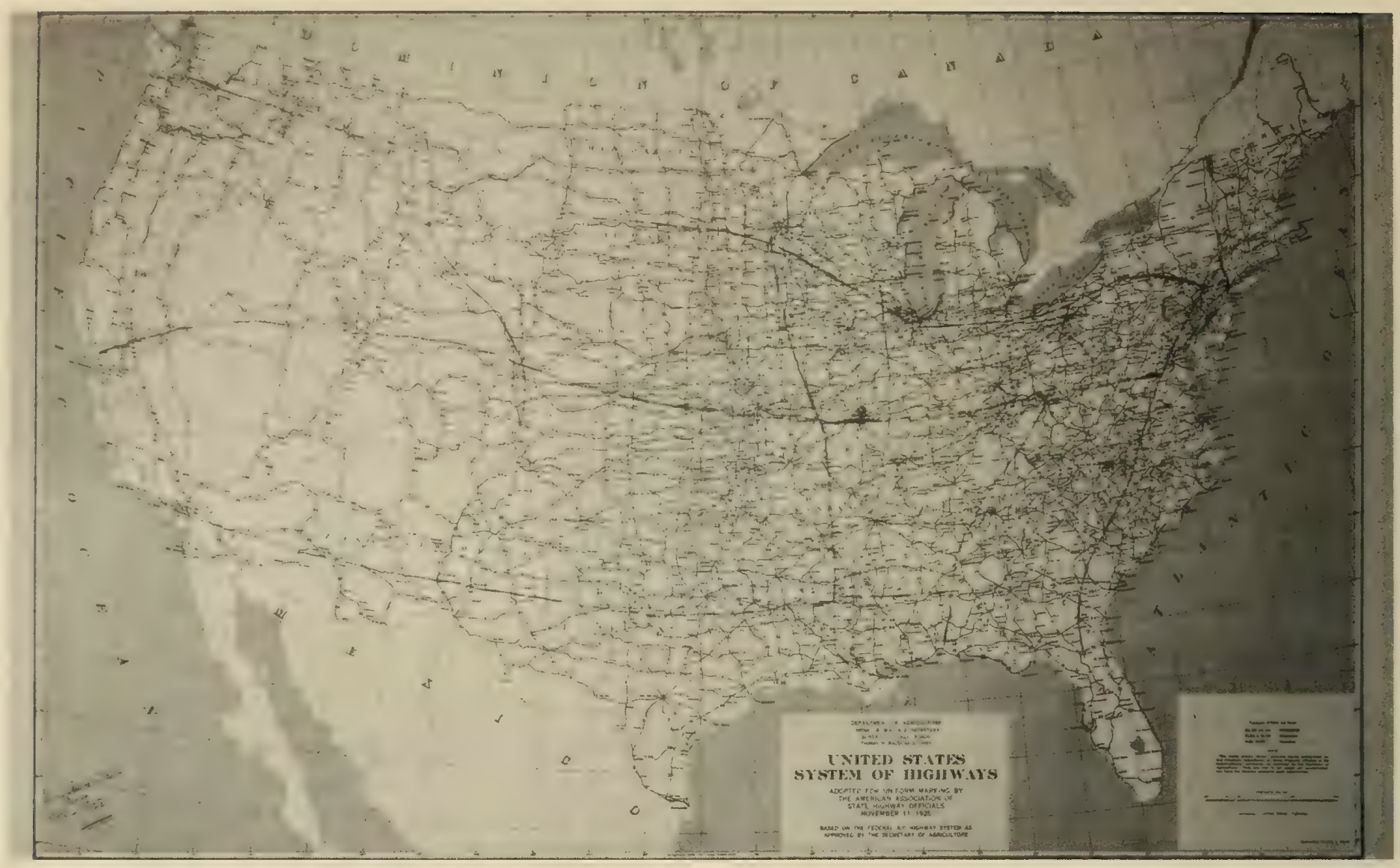

Although the map of the original six routes cannot be found, this map was authenticated in 1951 by Mr. Fairbank as having also been drawn by President Roosevelt and sent to the Bureau in 1938 to indicate the routes on which modern express highways should be built. This map shows three lines east and west and five north and south.

This map showed in striking manner the buildup of traffic near the cities and the relatively low volumes between them. This visual picture was reinforced by results of the origin-destination studies already completed in several States, which showed the small percentage of long trips and how the volumes even on the longer stretched between cities were made up largely of successions of short trips. The small amount of really long distance travel-transcontinental-is shown in the report of the study Toll Roads and Free Roads $s^{s}$ by a map indicating the origins and destinations of traffic crossing a cordon line running through the States of Idaho, Nevada, and Arizona. Here on all the main routes crossing this line only 300 vehicles in an average day were traveling from the Pacific coast States to the Atlantic seaboard States, indicating that transcontinental travel was almost negligible. Only 20 trips from the west coast reached Florida, a figure interestingly close to a finding of 23 trips that were destined to the west coast from Florida, as shown by a similar cordon on the Florida border. Figures such as these gave early evidence that long distance travel would not be sufficient to justify the financing through tolls of the six suggested routes. But it was surmised that certain sections might be self-liquidating. So the investigation proceeded to ascertain the most desirable location of the six routes from the points of view of attracting travel and feasibility of construction and to estimate their costs and probable toll revenues.
The six routes totaled 14,336 miles in length, divided into 75 sections for estimates of cost and potential revenue. Section lengths ranged from just over 30 miles to one-Spokane, Washington, to Fargo, North Dakota-extending 1,160 miles. Mile-by-mile estimates were made of construction, maintenance, operating and debt service costs, aggregated by sections and matched against estimated toll revenues, assuming that travel by 1960 would be 2.5 times the 1937 figure. The comparison confirmed the early surmise; the revenue for the period 1945 (when the system would be completed) to 1960 equaled less than 40 percent of the cost for the entire system and the report concluded the toll system was not feasible. Yet one section, Jersey City to New Haven, showed revenues equaling 104 percent of the cost and adjoining sections from Washington to Portland, Maine, near enough to the break-even point to indicate feasibility of the entire length. Other feasible sections were found running east from Chicago and in southern California.

While the report's conclusion was unfavorable to the toll concept, the detailed study led to a finding that a master plan for highways in the United States called for appropriate action by the Federal and State governments for "the construction of a special, tentatively defined system of direct interrregional highways, with all necessary connections through and around cities, designed to meet the requirements of the national defense in time of war and the needs of a growing peacetime traffic of longer range." With the "abundant data" supplied by the States from the 


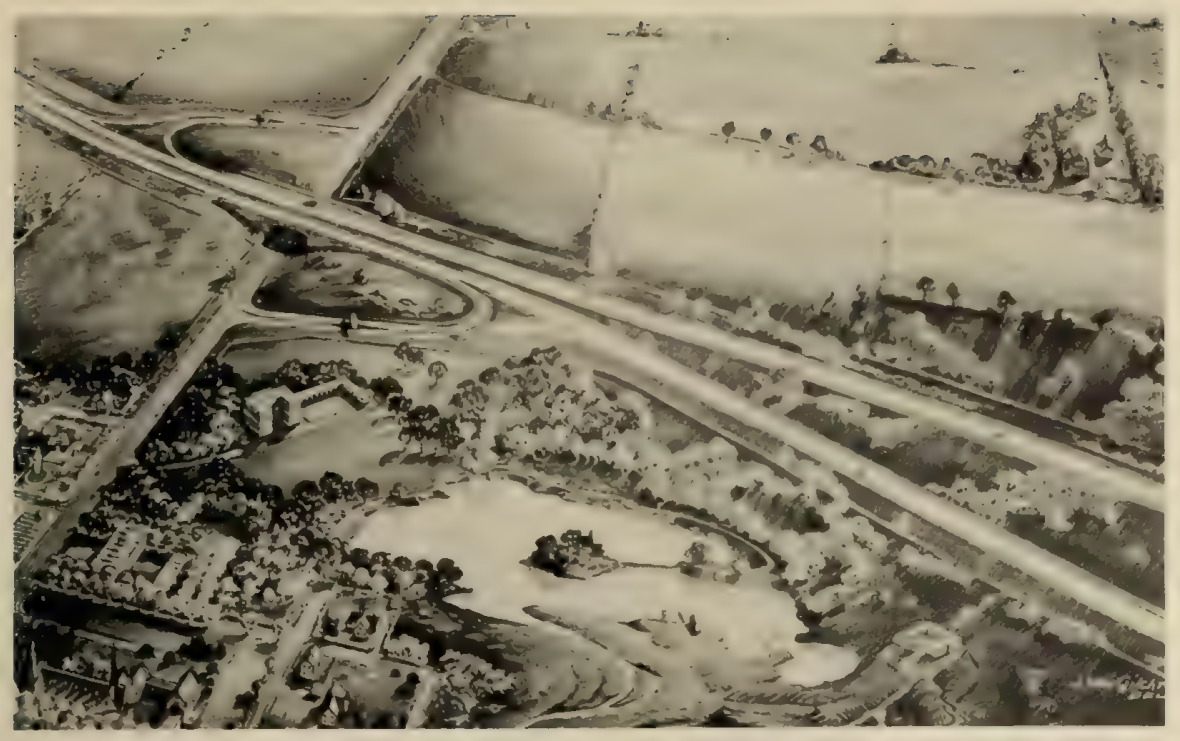

This drawing of a typical grade separation, access roads, and toll booths for a 4-lane road was included in the toll road study.

This sketch of a proposed express highway and bypass route around Baltimore was a part of the master plan for free highway development in the toll road study.

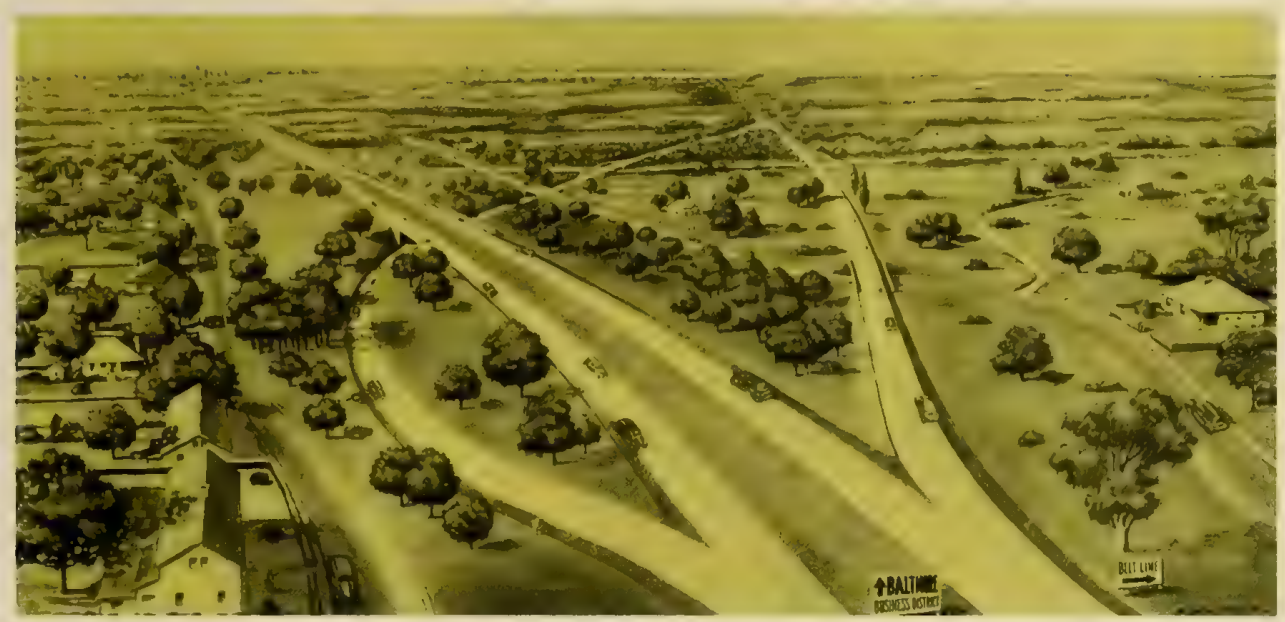

planning surveys, the report examined the desirability of a longer system not for toll-paying traffic but for general use, totaling 26,700 miles and serving all principal cities and regions of the country, and found it ". . now desirable by law to establish this or a closely similar System as the Primary Highway System of the United States." Much of the justification of this system lay in its service to the cities, and indeed, the report devoted many pages to a suggested plan for highways in an urban area, Fairbank using his home city, Baltimore, as an example. Thus was suggested the two major new directions Federal highway aid would take in the years ahead-the Interstate System and acceptance of responsibility of the Federal Government and the States in the areas of urban transportation.

Aware of the study being made by the direction of the President, the Congress to show its support for the investigation (and perhaps to insure that it would receive the report) included in the Federal-Aid Highway Act of 1938 the following provision:

The Chief of the Bureau of Public Roads is hereby directed to investigate and make a report of his findings and recommend to the Congress not later than February 1 , 1939, with respect to the feasibility of building, and cost of, superhighways not exceeding three in number, running in a general direction from the eastern to the western portion of the United States, and not exceeding three in number, running in a general direction from the northern to southern portion of the United States, including the feasibility of a toll system on such roads.
Approved on June 8, 1938, the Congress gave the Bureau only 8 months to complete the investigation and report, thus recognizing it was well on the way to completion at the time. The report was transmitted to the Congress by the President on April 27, 1939.

The 1939 report soon had an impact. In April 1941 President Roosevelt appointed the National Interregional Highway Committee "to investigate the need for a limited system of national highways to improve the facilities now available for interregional transportation, ... and [later became a study for] the possibility of utilizing some of the manpower and industrial capacity expected to be available at the end of the war." ${ }^{4}$ While there is no documentation to support it, it seems fair to assume that the action by the President stemmed from representations originating within the Bureau of Public Roads.

The Committee first met in June 1941 and immediately laid plans for a major study to be carried out by the staff of the Bureau of Public Roads. The Committee also enlisted the cooperation of the State highway departments. Subsequently Public Law 146, approved July 13, 1943 (an amendment to the Defense Highway Act of 1941) again alined the Legislative Branch with the Executive Branch of the Federal Government by authorizing and directing Commissioner MacDonald to study and report on the needs for interregional highways. 
While both Toll Roads and Free Roads and Interregional Highways, the title of this second major report, were prepared under the direction of $\mathrm{H}$. S. Fairbank by the staff of the Bureau of Public Roads and with the substantial assistance of the State highway departments, there was a significant difference. Toll Roads and Free Roads was a Bureau of Public Roads product; Interregional Highways was the product of the National Interregional Highway Committee and submitted to President Roosevelt as such. He in turn transmitted the report to the Congress to meet its requirement of Commissioner MacDonald.

The composition of the Committee is particularly important. Invited by the President to serve on the Committee (all of whom accepted) were three men from the highway field-Commissioner MacDonald, G. Donald Kennedy from Michigan who was incoming President of the American Association of State Highway Officials, and Charles H. Purcell, State Highway Engineer from California; two were from the city planning field-Harland Bartholemew, prominent city planner from St. Louis and Rexford Guy Tugwell, Chairman of the New York City Planning Commission; rounding out the Committee were Frederic A. Delano, Chairman of the National Resources Planning Board and a political leader, and Bibb Graves, former Governor of Alabama. The Committee elected Mr. MacDonald as chairman, and he in turn appointed Mr. Fairbank as secretary.

The composition of the Committee clearly shows the importance then attached to the city and its problems in developing a framework for national highway development. The Committee met repeatedly, and while the words of Interregional Highways were distinctly Fairbank's, the principles expounded were those discussed and agreed upon by the Committee and which received its unanimous approval.

This was indeed a comprehensive study, beginning with the meeting of the Committee in June 1941 and extending until the submittal of the report on January 1,1944 . The system finally recommended was selected by the Committee after examination of several other systems, greater or less in mileage, as best meeting the requirements laid down by the President and the Congress. The report was transmitted to the Congress on January 12, 1944, and the designation of the system, identified as the National System of Interstate Highways, was authorized by the Congress in the Federal-Aid Highway Act of that year. After much study and discussion, the routes of the system as proposed by the several States, substantially as recommended by the Committee, were approved by the Federal Works Administrator in August 1947. But it was not until the passage of the Federal-Aid Highway Act of 1956 that work on the system began in earnest.

Without doubt Interregional Highways was and remains the most significant document in the history of highways in the United States. Several characteristics of the report make it particularly significant.

First is the composition of the Committee that produced it. The report was the product of highway officials and planners with broad interests working together.
Second, the system was not selected simply on the basis of its traffic usage. It was recognized from the beginning that the purpose of the system was to provide for highway transportation to serve the economic and social needs of the Nation. Systems were devised to serve the Nation's agricultural production, its mineral production, its forest products, its manufacturing centers and, of course, its population centers and defense establishments. Without the help of computers, all these factors were laboriously shown by shading county by county on maps, or by similar devices, and the different systems "eyeballed" through the areas of heaviest shading or largest circles. It was not until the final choice of the recommended routes was made by the Committee that traffic volumes to be expected were brought into the picture, and then only to be used as a means to estimate costs and relative economic benefits.

Third, the importance of the system within the cities was given much attention, with a major portion of the report devoted to "Locating the Interregional Routes in Urban Areas." Here principles of route location, still sound today, were proposed and illustrated. A paragraph from this report of 30 years ago is worth quoting. It reads as follows:

In choosing these locations for the arterial routes, however, it should be recognized that the undeveloped lands which lie so favorably for highway purposes also present opportunities equally favorable for other purposes of city planning. Properly preserved and developed, they can become the needed parks and playgrounds for residents of adjacent populated areas. Alternatively, they can be developed as new residential communities in the modern manner, unhampered by previous commitment to the traditional rectangular street plan. It is highly desirable, therefore, that the location and plan of the new highways in these areas shall be developed in harmonious relation with other appropriate uses of the now vacant land. Wherever possible, plans for all uses of the land should be jointly developed and acquisition for all purposes of public uses should proceed simultaneously. ${ }^{6}$

Fourth, the need for coordination with other modes was emphasized with the words "However, it is at the cities ... that the closest attention should be paid to the possibilities of common location, and also to such location of the highways as will best and most conveniently serve to promote their use in proper coordination with other transportation means." 6

Fifth, the Committee recognized clearly the limitations of the system. To quote again,

Obviously, it is not possible by any limited highway system, whatever the relative importance of its constituent routes, to serve all the needs of the Nation's traffic. Nor is it reasonable to assume that in and near the cities the routes included in such a limited system will if improved, provide a complete solution to the serious problem of city traffic congestion. ... In this connection the Committee has been restricted in its choice because the President directed it to select an interregional rather than a local system, and to consider national above local needs. . it is important, both locally and nationally, to recognize this recommended system .... as that system and those routes which best and most directly join region with region and major city with major city. ${ }^{\text {? }}$

Sixth, the Committee recognized the need for full cooperation at all levels of government (still to be fully attained, it seems) by the words ". . . the particular locations of those routes [must] be agreed upon in common by Federal, State, and municipal authorities who will share the responsibility for arterial high- 
way improvement, that the desirable standards for that improvement may be established and commonly accepted. . . ." 8

Finally, the Committee reiterated the recommendation of "Toll Roads and Free Roads" for the creation of a Federal Land Authority, with powers of excess condemnation to aid in recoupment of increases in land values resulting from construction of the system. It also recommended creation of similar authorities in the States, with the thought that a Federal-aid plan might be developed to finance immediate acquisition of land and to permit amortization of the costs by State and local authorities over a long period of time. ${ }^{9}$

It is perhaps of interest that President Roosevelt in transmitting the report to the Congress added in his own words to the transmittal letter prepared in Public Roads the following paragraph:

As a matter of fact, while the courts of the different States have varied in their interpretations, the principle of excess condemnation is coming into wider use both here and in other countries. I always remember the instance of the farmer who was asked to sell a narrow right-of-way through his farm for a main connecting highway. From an engineering point of view it would have been as feasible to build the new highway across the dirt road that ran in front of his house and barn. Actually the owner received from a jury an amount equal to the whole value of the farm. The road was built. The owner of the land thereby acquired two new frontages. He sold lots on one frontage for the former value of his farm. A year or two later he sold the other frontage for the farm value of his farm. The result was that he still had his house and barn and 90 percent of his original acreage, and in addition he had received in cash three times the value of what the whole place was worth in the first instance. ${ }^{10}$

This recitation of what was in fact the early period in urban highway planning is simply to demonstrate that highway officials at that time were ready to join with those in other disciplines who could help in developing the Nation's needed transportation system, and that the principles then established are still valid. What has been done since has been built on this solid foundation, and is no less a sound structure for continued extension and growth of national, State, and urban transportation from here on.

\section{Planning in Wartime}

While, of course, not even suspected at the time, the Federal-Aid Highway Act of 1940 authorized the last apportionments for the regular Federal-aid highway program to be made until toward the end of World War II. The next Federal-aid act was entitled the Defense Highway Act of 1941, approved on November 19, 1941, less than 3 weeks before Pearl Harbor. While the country was not yet at war, the possibility of United States' involvement was recognized in the year preceeding to be sufficient, at least in the highway program, to give life to the adage "In time of peace, prepare for war." The Defense Highway Act in effect placed the road program on a war footing, too little and too late perhaps, but at least a start.

The effect of war preparations, and later the war itself, was felt in two principal ways, first in the need to reconstitute the States' highway programs to concentrate on road improvements important, and later essential, to the war effort, and second to carry on the restructured program in the face of material shortages, loss of key personnel to the military services, and reduced road user revenues at State level. The Congress responded to these problems to some degree, at least, by authorizing 75 percent instead of 50 percent participation in projects on the strategic network and acceptance of the full cost of providing access to military establishments and essential industrial plants. In the area of critical material shortages, the Bureau of Public Roads developed working relationships with the succession of agencies responsible for allocating critical materials to try to gain for the States the authorizations to draw from the available supplies enough material to meet the need on the most essential projects.

It was a period of great distress, of course, with States seeing their road systems deteriorating under the burden of heavy wartime loads. Materials were allocated on the basis of priorities established by the War Production Board, and it is safe to say that the proof of need in the highway sphere could not have been established without the data available or collected as needed by the statewide highway planning surveys.

Priorities were granted after a project by project review, centralized in Washington, under which each application was examined in detail, and its essentiality rated not only against other highway and transportation needs, but against needs in other areas-housing, manufacturing, farming, and in fact every activity. Precise information on the number of war connected trips over proposed projects, the volumes of goods and war material to be moved, the residences of employees, and many other facts related to the use of the proposed projects had to be assembled, analyzed and funneled to Washington. There the Bureau of Public Roads could begin the torturous process of gaining an allocation of the required steel, rubber, cement, asphalt or other critical material. Suffice it to say that with the highway planning survey data, enough cases could be supported to prevent a breakdown in highway transportation.

As Fairbank once remarked, if in time of peace, prepare for war, then in all logic in time of war one should prepare for peace. And whether it may have been that the long duration of the war could not have been foreseen, preparations for peace indeed began early in the war. The fact that work went steadily forward on preparation of the Interregional Highways report was itself an indication of the long-range view of planning for postwar needs. This effort absorbed a large share of the planning resources of the Bureau of Public Roads not directly involved in the war effort planning.

Another aspect of postwar preparation came in an amendment to the Defense Highway Act, approved on July 13, 1943, that permitted the States to use any funds still remaining from the apportionment under the 1940 Federal-Aid Highway Act not only for the "engineering and economic investigations" authorized in 1934, but also for the preparation of plans, specifications, and estimates (PS\&E). The purpose here was to keep the process of collection of essential data going and also to provide a reservoir of "plans on the shelf" to permit immediate start of highway construction once the emergency ended. This latter provision illustrated that the "depression psychology" of the 
1930 's was not entirely dispelled from official thinking even by the exigencies of war. The view then held, and reflected even in Interregional Highways, was that the return of the troops after the war and the sudden cessation of war industry would, without advance preparations, produce massive unemployment and perhaps even a depression such as followed World War I. No one could foresee that the pent-up demand for consumer goods, so long missing or in short supply, and the desire for new products on the market as a result of advances in technology associated with war production would take years to satisfy. And this same psychology, parenthetically, probably accounted for the persistent underestimating of traffic growth for several years after the war.

Another area of preparation for peace during war is seen in the growing concern for the problems of urban transportation. The predominantly short range of highway trips and the buildup of traffic in and near the cities disclosed in the studies for Toll Roads and Free Roads were emphasized and further quantified by the early studies of the National Interregional Highway Committee. These findings led Fairbank to repeatedly urge State highway officials and other groups to recognize the urban problems they soon would be facing and to gain the cooperation of city officials in an approach to what he saw as a mutual responsibility. Beyond that he saw the need for gaining an understanding of urban transportation needs and characteristics paralleling what the highway planning surveys were producing for the rural areas. And he called on his staff to devise appropriate study procedures.

Obviously many of the techniques fully satisfactory in rural areas could not be applied in cities. Procedures for counting traffic and determining origins and destinations of trips in rural areas could not simply be transferred to the networks of closely spaced city streets. While traffic volumes on rural roads where traffic had little choice of route were indicative of improvement needs, volumes on city streets, with traffic having almost infinite choices of routes, had little significance. Traffic often followed the improvement program, shifting from one street to another as the relative capacity or riding quality shifted with the construction and maintenance programs. What was needed was information that would reveal the composition of traffic as shown by the portions that were through trips as contrasted with the longer-range trips within the area and the shortrange neighborhood trips, and trips not only by motor vehicle but by transit as well. Generally these were all being accommodated on the same streets, and the need was obvious for street systems that would permit separation of trips with their disparate interests and permit the design of the different elements of the system to be compatible with the type of service they would provide. Origins, destinations and purposes of trips were required, and stopping even a small sample of vehicles to interview the drivers, as could easily be done in rural areas, could hardly be practicable on busy city streets. Beyond that, the closely spaced network would permit easy avoidance of an interview station. And interviewing transit passengers presented new and not easy problems.
After exploring a variety of methods, some theoretically and some on the ground, with little prospect for satisfying results, the home-interview method was accepted as a possible approach. George Gallup was having considerable success in his early opinion polls. His method involved interviewing the right number, as determined statistically, of representative members of the different occupational groups comprising the total population, such as doctors, plumbers, teachers, housewives, laborers and even unemployed. This approach offered serious problems in attempting to adapt it on a scale necessary to a transportation survey. Fortunately the Bureau of the Census at that time was exploring means of reducing the costs of its complete censuses by the use of sampling methods. It was its view that by preselected geographic samples, say one house in ten, a representative sample of occupational groups would be obtained. That approach would also provide a geographic spread of interviews for origins and destinations of trips needed in travel studies. So the Bureau of the Census, while exploring for their own purposes and finding in the highway field a companion interest, agreed to assist by joining in assaying the statistical soundness of the samples and to assist in supervising one or two early studies so selected. Thus was born the home-interview approach, the basis of today's urban transportation planning process. While still in wartime, 1944, the first home-interview studies to ascertain urban travel habits were launched (not without some trepidation to be sure) nearly simultaneously in Tulsa, Oklahoma and Little Rock, Arkansas. Certainly the State and city officials deserve a great deal of credit in agreeing to undertake such a novel program on the basis of assertions of belief by three Washington Office representatives that the approach would work! But work it did, and from there it grew.

\section{The Federal-Aid Highway Act of 1944}

All these preparations for peace in time of war, mostly in the planning area, led to the Federal-Aid Highway Act of 1944. With all the Federal-aid acts since 1916, it is difficult and probably not useful to try to single out one or a few that are the most significant. The 1916 Act, the first, was organic legislation that got it all started. The 1921 Act stands out by introducing the system concept. More recently the 1956 Act, setting up the Highway Trust Fund and authorizing funds to complete the Interstate System, must be one of the most significant. But none can stand out above the 1944 Act as "landmark" legislation.

First, it authorized apportionments for a 3-year period beginning at the termination of the war emergency or at the concurrent resolution of the two houses of Congress, and it authorized a large amount ( $\$ 1.5$ billion).

Second, it authorized funds specifically for expenditure on the "Federal-aid highway system in urban areas," not for a Federal-aid urban system. (Originally the routes were "extensions" of the rural Federal-aid or Federal-aid secondary routes, and later "portions" of those routes.)

Third, it required the selection of a Federal-aid secondary system for which secondary funds were earmarked. 
Fourth, it divided the funds as follows: 45 percent for the Federal-aid system (it was not yet designated as the "primary" system, and the 45 percent could be expended on rural or urban portions at the States' election); 30 percent for the secondary system; and 25 percent for the routes in urban areas. This $45: 30: 25$ ratio was to prevail until 1973 .

Fifth, it authorized the designation of the National System of Interstate Highways, following almost exactly the recommendations of the National Interregional Highway Committee. The system was to be "... so located as to connect by routes, as direct as practicable, the principal metropolitan areas, cities, and industrial centers, to serve the national defense, and to connect at suitable border points with routes of continental importance in the Dominion of Canada and the Republic of Mexico...." (Although it was later to become an issue, nowhere did the Congress indicate that the system should be expected to accommodate purely local traffic, such as urban commuting movement.)

Sixth, it provided that on any highway or street thereafter constructed with Federal aid "... the location, form, and character of informational, regulatory, and warning signs, curb and pavement or other markings, and traffic signals installed or placed by any public authority, or other agency, shall be subject to the approval of the State highway department with the concurrence of the Public Roads Administration...."

Seventh, it added to the authorization of the $11 / 2$ percent highway planning funds the words "and for highway research necessary in connection therewith." It was the view of the Public Roads Administration that research in the structure and geometrics of the highway was proceeding well under State financing or with Public Roads administrative funds, but that not enough effort was being applied to research in the areas of economics and administration. Once research in these areas became established, the restriction was lifted by subsequent legislation, but through the late forties and the fifties Commissioner MacDonald stood firm against the use of any $1 \frac{1}{2}$ percent funds for the generally more favorably viewed physical research.

Indeed the Federal-Aid Highway Act of 1944 stands as landmark legislation; and most of its forward looking provisions stemmed directly from the highway planning efforts so strongly advocated and ably administered by Fairbank and MacDonald. It was a mandate for the future.

\section{Planning in the Postwar Period}

\section{Statewide Highway Planning}

During the war, highways were officially regarded as expendable, and they were pretty well spent. The most noticeable resulting deficiencies were probably on the State primary systems, and even though Federal-aid funds authorized in the 1944 Act were available, it was soon apparent that funds at both State and Federal levels would not be adequate to stay even with growing needs, to say nothing of recouping the wartime losses. Traffic volumes were greatly depressed by gasoline rationing and the suspension of passenger car production during the war, dropping to about half their 1941 level in 1943 and 1944. It was generally expected that traffic would recover, but slowly, and that time would be on the side of the

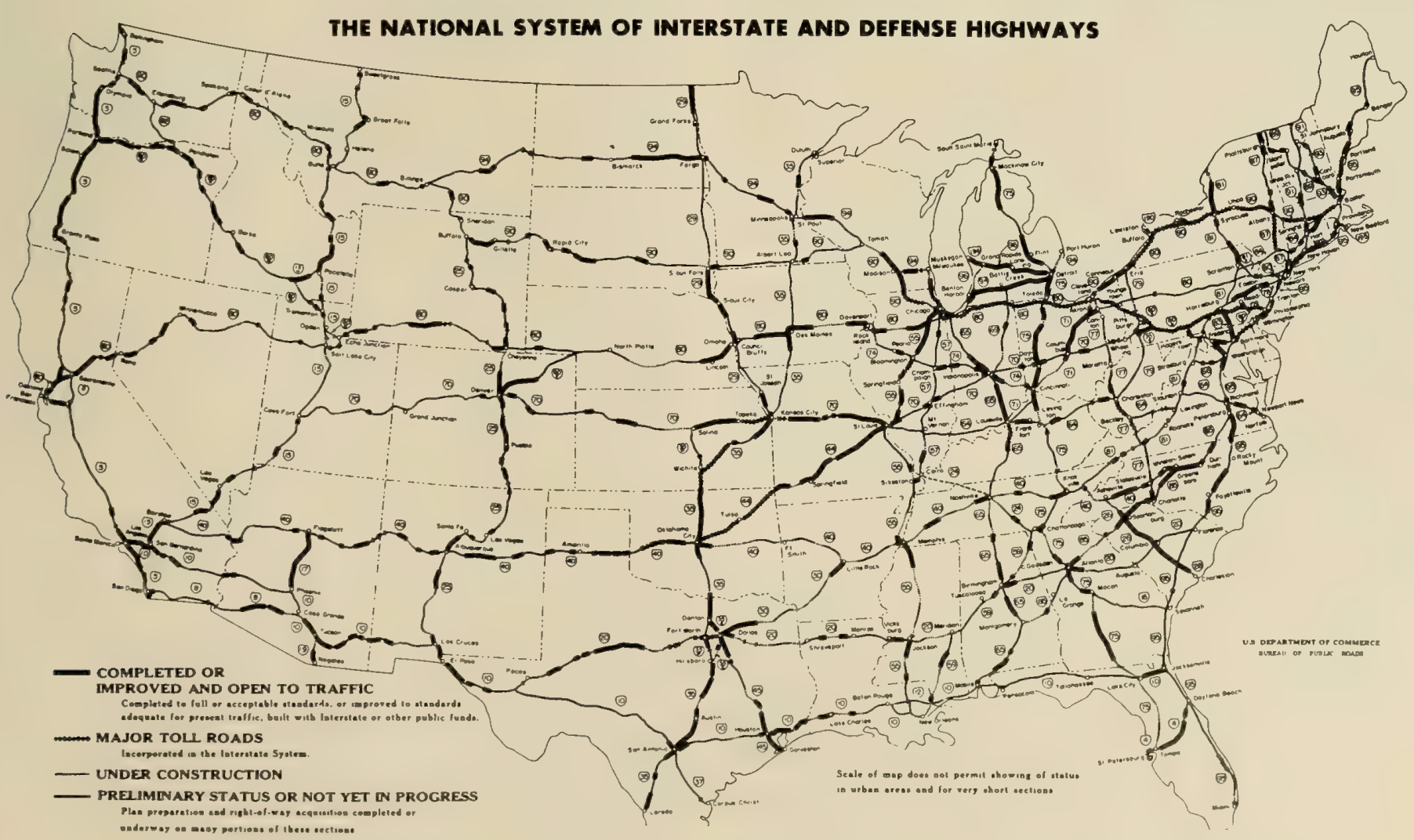

The Interstate System is the only completely planned highway system in the United States. 
highway officials in organizing their catch-up programs. But this was not to be. Traffic volumes recovering from their 1943 low point reached the 1941 level again in 1946, not somewhere around 1960 as perhaps wishful thinking had forecast. By 1948 they had reached the prewar trend line, having thus completely recovered in only 5 years, and the volumes continued to push vigorously upward, following almost exactly the equally unexpected surging economic growth.

To try to establish with the State legislatures the need for more funds, many highway officials reasoned that if highway planning facts were convincing to the War Production Board in allocation of critical materials, they might be equally convincing to State legislators as evidence of highway needs in their own States. Some States did use the data to develop programs for bringing the State highway systems back to reasonable service levels, hopeful of receiving legislative approval and necessary funding. But invariably they met disappointment. The programs were thought to be self-serving, that State highway needs were emphasized at the expense of county and local roads; or that they gave insufficient attention to the needs of the cities; or that the needs were overstated; or that the program would require increased tax rates. Out of this confusing and often frustrating situation came the statewide highway needs studies. The first in California, completed in 1946, set the stage for what might be called an era of such studies.

California's postwar highway problems were perhaps the most severe of any State, stemming largely from the huge population increases during and immediately following the war. Responding to the challenge, the State legislature enacted the CollierBurns Act, so named for its authors Senator Collier and Assemblyman Burns, the chairmen of the respective highway committees. The Act laid down conditions perceived as needed for a successful survey of highway deficiencies and which became virtually "principles" that were generally adopted by other States as they followed California's lead.

The first "principle" the Act specified was the establishment of a legislative commission to whom the report was to be made and which could observe the procedures and conduct of the work, thereby assuring consideration of the report by the legislature.

Second, it provided for a survey of all roads and streets, not just the State highway system, so no level of government could feel that its needs were ignored.

Third, it called for the survey to be conducted by engineers from outside the State to avoid any possible inference of favoring one system or one government level over another.

Fourth, it called for a classification and grouping into systems of all roads and streets according to their functions, toward the end of assigning to the appropriate government levels the responsibility for administering and financing the improvement programs on the different systems.

Fifth, it called for estimates of cost and recommendations of programs to bring the entire network up to desirable standards.
In seeking "outside" engineering assistance, California came into agreement with the Automotive Safety Foundation (ASF). This nonprofit foundation, sponsored by the automotive and associated industries, such as oil and rubber, had been organized to work with public and other private agencies toward the improvement of highway safety. Its principal purpose was to serve as a rallying point for activity in the field of highway and traffic safety and, through educational programs, sponsorship of conferences and meetings, and financial support of projects, to mobilize resources for a concerted attack on the accident problem. It had become convinced that improvement in the engineering of the highway, not simply to produce safer designs but to relate the design standards to the function and capacity requirements of the routes, would constitute an important element in its program. In this position the Foundation received the strong endorsement of the Public Roads Administration and with the Foundation's President, Pyke Johnson, and Commissioner MacDonald lending their strong and steady personal support, technical and financial resources from public and private sectors were deftly marshalled in an attack on specific aspects of the overall problems. Thus, the Automotive Safety Foundation, through its engineering division organized under G. Donald Kennedy, formerly Highway Commissioner of Michigan (the only elected Commissioner among the State highway administrators), undertook to serve as the engineering consultant for the California survey. This first effort led to increasing ASF involvement in highway needs studies over many years to come.

The engineers did not conduct the surveys. Basic data came from the highway planning surveys or, where more data were needed, they were collected by the States, counties or cities as required. The engineers, with the aid of technical committees representing the various levels of government, developed standards against which street and highway adequacy might be judged. Cost estimates were prepared for needed improvements to attain the agreed upon standards, estimates of revenue were made, and from the mass of data, construction programs were prepared. Usually alternatives were proposed to show the governmental units responsible for the various systems what would be required to "catch up" with needs in periods of 10,15 or 20 years, so the State legislature and other governing bodies could choose how rapidly they might or could bring their roads and streets to adequacy. Through the whole process, the legislative commission could observe the work as it progressed, and, thus, both political and technical leaders had had a part in the preparation of the report.

Here perhaps a word on the meaning of "highway needs" is in order. The phrase has become a part of our vocabulary, as shown by legislation at both Federal and State levels. The term is unfortunate perhaps in that it may lead to criticism that what has been proposed is not to satisfy "needs" but "desires," and the forecast of "needs" is a self-fulfilling forecast in that if a highway is built it will be used, and thus the "need" demonstrated. Actually in the highway needs studies, two sets of standards were generally used, one called "tolerable" and the other "desirable." 
The needs study might accept as not needing improvement sections that were barely adequate for current traffic or meeting "tolerable" standards. But when any section was found to be below that level and was recommended for construction, the design was based on what would be required to meet traffic volumes of 20 years beyond the expected date of construction, with all desirable safety and environmental factors included-the "desirable" standard.

What really is done is to establish a "level of service" that would in effect be a measure of the quality of traffic flow-speed, comfort and safety all included. The higher the design standard, the higher the level or quality of service, but also the higher the cost. Thus, the criterion becomes the degree to which the desirable level of service can be attained, limited generally by finances but sometimes, as in urban areas, by physical or environmental factors as well. The level of service to be used as a goal can and, in fact, generally must be the subject of some trade-offs between desirable and tolerable service. That is the way in which "need" should be interpreted in the needs studies. It is the amount of mobility and safety that the public is willing to buy, given the potential traffic volumes, and the costs in money, environmental impact, and nonuser social and economic factors involved. Once the technical and administrative or political leaders concerned have agreed upon the level of service that is appropriate for the routes or systems to be studied under the particular conditions involved, the cost estimate is simply the cost to achieve it. Question as to whether it is to satisfy a "need" or a "desire" disappears, for the target generally lies somewhere in between.

Through the next decade, from the publication of the report for California in 1946 up to the launching of the Interstate program by the 1956 Act, the Foundation assisted 19 States in conducting their needs studies, not all as complete as in California but all using the same format with respect to the request by the State legislature for the study and the committee structure involving both technical and political leaders. Of course in all, dependence for facts fell on the highway planning surveys.

Despite the visible success in the early studies, interest was slow in building up in many States, and the pressures to overcome the immediate problems of the warworn highways were enough to give many States reasons for not worrying about long-range plans or programs. Attention even to keeping the planning data up to date lagged. In this atmosphere Fairbank pressed even harder to bring to the States the importance of planning ahead. In one speech, for example, he closed with these words:

It is a remarkable fact that motor vehicle manufacturers, by a concerted action to improve, and more exactly define the designed capacity of, their vehicles, and through the recent invaluable assistance of the Automotive Safety Foundation, of which they are the principal support, should be taking, as they are, a leading part in bringing about the needed multilateral cooperation toward many of the objectives of highway transportation planning as here defined.

Such cooperation and broad planning is being achieved State by State, one after another. The results that have issued from it in California, the even more gratifying results soon to appear in Michigan are certain to inspire similar effort in many States.
The Public Roads Administration is willing and anxious to take its part. It was for this use, exactly, that the highway planning surveys were conceived; to these ends every item of the recommended outline of needed fact gathering was directed. A recent General Administrative Memorandum (No. 319, issued September 24, 1947) renews our promise of cooperation, and repeats an earlier suggestion of the manner in which information, that can be well assembled only by the highway planning surveys, can be addressed to the ends of highway transportation planning.

The State highway departments cannot, if they would, avoid the responsibility of major contribution to such planning effort when it is undertaken, as surely, soon or late it will be, in every State. The State highway planning surveys will be the expected source of most of the facts required in that planning.

May I, in closing, suggest to the head of each State highway department here attending, that he take a fresh look at his highway planning survey after the approaching holidays; that, patiently, for it will require patience, he read the full text of General Administrative Memorandum No. 319; and, facing toward the west from whence a new wind is blowing, decide for himself, whether he is going to be ready, as the inevitable occasion will require, to fulfill the requirements of this thing called highway transportation planning."1

With the steady pressure of surging traffic growth, the continued urging from Washington, and the success of the early needs studies carried on with the aid of the Automotive Safety Foundation, 35 States had followed California's lead by 1959 in preparing for their future. Not all studies covered all aspects of the problem, other consultants entered the field, and in some States repeat studies were carried out to measure the effectiveness of programs adopted as a result of the original studies or to up date the earlier recommendations in light of unanticipated changes of conditions, notably the rate of traffic growth. With the attention given to the highway needs studies, the use of statewide highway planning data had come into its own in the decade after the war and established highway planning as an essential function of the highway departments.

\section{Urban Transportation Planning}

The postwar decade saw wide expansion of the urban transportation planning process that, as noted earlier, emerged in Tulsa and Little Rock in 1944. The methods were unique, untried, and the cost of data collection high. The figure of 10 cents per capita originally estimated proved to be far too low, but even so it represented amounts well beyond any figures that had been thought of as the cost of an urban traffic survey.

Even as the data collection process was new, so too were new analytical procedures required. The origins and destinations of trips for a representative day were recorded in the sample households and expanded on the basis of the sample size to represent the total travel for the entire area. Recognizing that the particular route of travel was determined by the layout of the street network and the capacity and condition of the streets, no attempt was made to trace the actual routes, but rather to show on a map the direct line between origin and destination. With the sample households grouped into zones of similar characteristics, or sometimes simply geographically delimited, all trips between each zone and each other zone were shown by bands of varying widths. These bands 


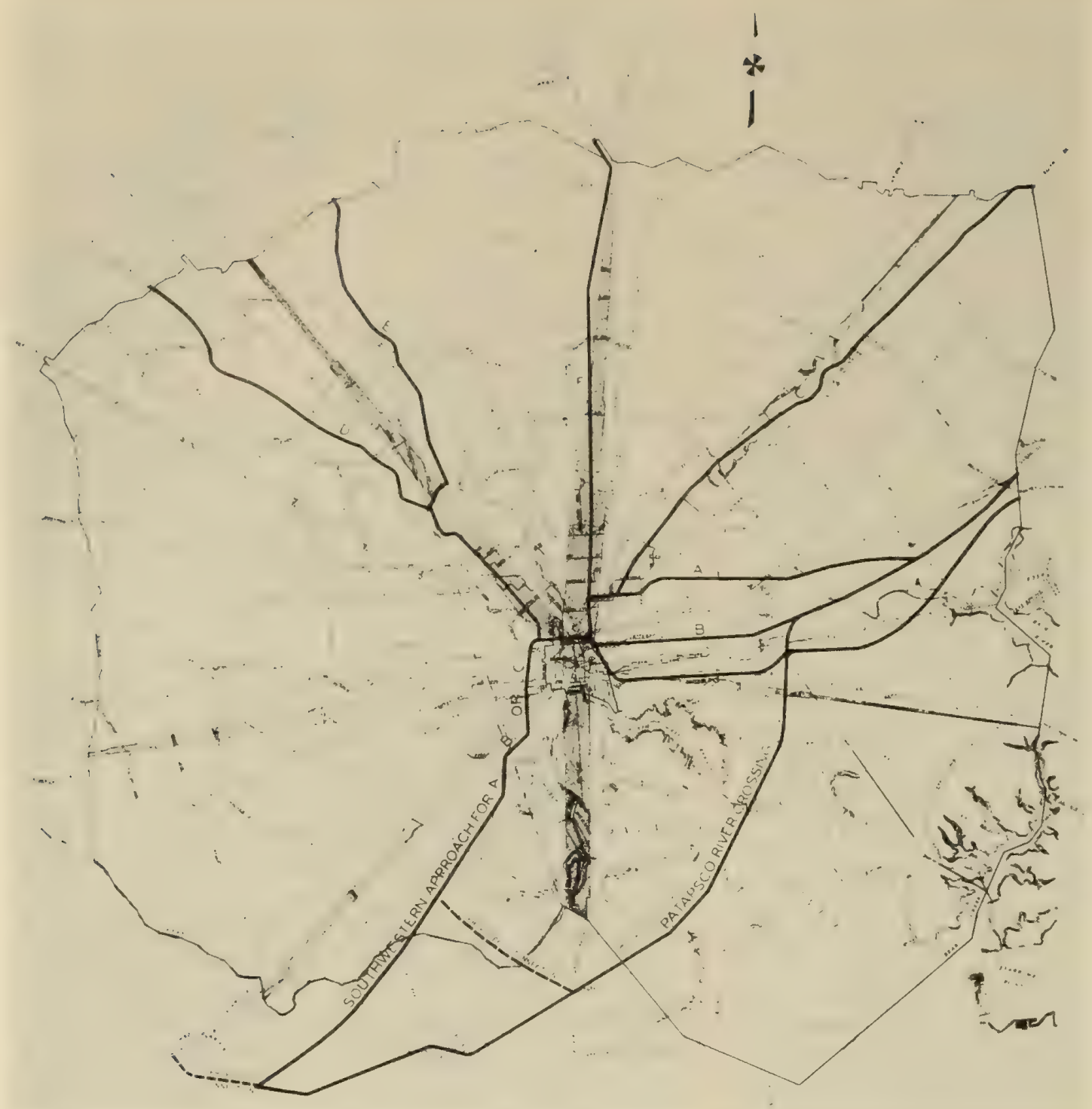

This map shows the major "desire lines" that resulted from a transportation study made in Baltimore in 1938.

came to be known as "desire lines," showing the desired paths of all trips, either by private vehicle or transit in the area. The heaviest bands then gave indication of the desirable location of arterial routes (whether or not feasible) and the traffic volumes the trips would produce. As a check on the accuracy of the survey, the number of trips crossing a natural screen line, such as a river, as shown by the desire lines could be compared with actual vehicle counts. Generally a high accuracy was found, often over 90 percent agreement, but where the sample produced too few trips (seldom did the interviews produce too many) the screen line counts provided a basis for adjustment.

It is important to recall what was recognized thenthat the process was a survey. It did not produce a plan nor even the future volumes for design purposes. The only way to estimate future travel was to assume that if the planners expected the population to increase by say 50 percent, then 50 percent should be added to all current origins and destinations. It was known that that wasn't right, for certainly population or industry would grow more in some zones than in others, but it was better than not increasing them at all, which some planners were then urging. It became apparent early in the game that a relationship existed between the use of the land and the travel it produced or attracted-and that it could be measured. But means to use this relationship in developing plans for the future were rudimentary at best. The earliest effort to apply this approach was probably in San Juan, Puerto Rico, where the travel to and from the existing airport was transferred to the expected location of a new airport in developing a freeway plan.

It remained for the development of the computer to permit exploitation of the land use-transportation relationship, given its first major test in Detroit. This new computer technology marked the turning from surveying to planning. But the application of the new technology could not have occurred without the resources of the highway department's $11 / 2$ percent HPR funds being made available. And it could not have been implemented without conversion of the land use inventories and projections, then usually shown on maps by zones of different colors, from a qualitative to a quantitative basis. It was necessary to know the trip producing characteristics of each type of land use. It was important to know not that 
a zone was industrial, but what kind of industry was there, for a shoe factory would produce far different numbers of trips than a steel mill, for example. And in residential zones income levels were important because they were a factor in numbers of trips and choice of modes. This in turn induced the highway departments and interested cooperating cities to bring into the planning process, up until then carried on largely by engineers, professionals from other disciplines-such as planning, geography, mathematics, and sociology-better equipped by training to deal with the factors of urban growth, to which transportation facilities must be related.

This tremendous breakthrough in planning, a development which put land use and general planning as well as transportation planning on a quantitative basis, can be attributed to three factors, each essential-the introduction of the computer, the availability of resources never before within reach of planners, and the bringing into the planning process, in many cases with responsibility for the direction of the work, of professionals from other than the engineering discipline. But these factors themselves would not have produced the result had it not been for strong urging of the Public Roads Administration and the technical advances developed by its staff and the willingness of many of the State highway departments and interested cities to participate in this major pioneering effort. And it also required a liberal interpretation of what is a highway purpose, for the use of highway funds both at Federal and State level are restricted by law to expenditures for highway purposes. Highway officials had one ally, however, and a strong one, in the Bureau of the Budget, which informally urged leaning as far as possible in the financing of land use and general planning. The logic, of course, is that one can hardly produce a transportation plan without a land use plan reflecting the form of city or region the local citizens will probably have if not necessarily what they desire, and it was on this basis that highway officials, sometimes with justifiable concern as to its legality, agreed to finance considerably more than what might be narrowly construed as highway planning. In plain fact, land use from the beginning of the modern planning process, has been accepted as the base from which urban transportation planning must start. And perhaps more recently but no less strongly accepted is the fact that transportation can be an important factor in determining land use. The two are interrelated.

In the matter of financing of the land use portion of the process, tribute must be paid to the Housing. and Home Finance Agency (HHFA) and its officials which, as the "701" planning assistance funds became available, joined in the effort as full partners at the Federal level. The cordial and effective cooperation of the staffs of HHFA and the Public Roads Administration and the direction of much of the 701 money to the cooperative (sometimes called hyphenated) land use-transportation planning process must rank well up with the highway contribution in the success of the process.

While highway departments were placing major emphasis on planning arterial routes in urban areas, city street congestion was steadily worsening. Arterial highway improvements even though planned were not appearing because of lack of funds, and it became increasingly obvious that even when built they would still leave heavy congestion on city streets, particularly in the downtown areas. The fact that the highway departments' efforts seemed to be resulting in plans but not programs was leading to expressions of quite divergent philosophies. Many city officials, particularly traffic engineers and public works directors, began urging de-emphasis on freeways and concentration on traffic engineering type of improvements and minor construction programs as an immediate aid to lessening congestion. Highway officials, at least in some cases, held the view that such localized improvements were stopgap at best, and that urban officials should give greater attention to getting on with what the highway officials saw as the essential long-range improvements. It was in this atmosphere that the National Committee on Urban Transportation (NCUT) was created in 1954, initiated and sponsored by the Automotive Safety Foundation. Its purpose was "to help cities do a better job of transportation planning through systematic collection and analysis of basic facts .... [to] afford the public the best possible transportation service at the least possible cost ... and ... aid in accomplishing desirable goals of urban renewal and sound suburban growth." 12

The list of organizations which formally named representatives to constitute the National Committee is impressive in its inclusion of virtually every association concerned with transportation in the urban area. The list is as follows:

The American Municipal Association

The American Public Works Association

The International City Managers' Association

The National Institute of Municipal Law Officers

The American Society of Planning Officials

The Municipal Finance Officers Association

The Canadian Federation of Mayors and Municipalities

The National Association of County Officials

The Bureau of Public Roads

Among the consultants to the Committee were Ralph Bartelsmeyer, then Chief Highway Engineer of Illinois, who represented the American Association of State Highway Officials, and George Anderson, Vice President of the American Transit Association. Ben West, Mayor of Nashville was the first chairman of the Committee, later succeeded by Glenn Richards, Commissioner of Public Works of Detroit.

The assembly of this Committee not only exemplified the ability of the Foundation to marshall resources to bear on a specific problem, but also marked the beginning of the cooperative approach to urban transportation problems.

The Committee enlisted a great many experts in various areas of urban transportation to prepare a series of technical manuals covering all phases of data collection and processing, as well as recommendations for developing the plan, carrying out the plan and improving transportation administration. A count of the members of the subcommittees and their consultants and advisors adds up to 142, all recognized experts or leaders in their respective fields. It was an unparalleled volunteer effort, from 1954 through to the publication of the book Better Trans- 
portation for Your City by the Public Administration Service in 1958. This guide and the 17 procedural manuals became "best sellers," for the Public Administration Service and went through several printings. The guide and manuals formed the basis for Action Program of Urban Transportation Planning which is discussed later.

It was during the preparation of the NCUT guide and manuals that the divergent philosophies of urban transportation improvement began to merge. In the Committee's early deliberations, strong representations were made that the planning effort by the States, then often termed the "Bureau Method," was too expensive and produced no data for localized traffic engineering improvement. There was considerable sentiment that the Committee take a firm stand in recommending diversion of effort from the long-range to the shortrange studies and planning. Finally it was recognized that it would be most unwise to look on the two approaches as competitive and that the city interests should join with the States in total studies, long and short range. This decision solidified the Committee's attack on the problem, and the product of its work soon brought the Public Roads Administration into the activity as a financial sponsor along with the Automotive Safety Foundation. And upon its completion, the program proposed by the Committee was endorsed by the Bureau of Public Roads, and by the Joint Committee on Highways that had by then been named by the American Municipal Association and the American Association of State Highway Officials. The Bureau also found that "In general, the studies embraced in the program, if included in the statewide highway planning survey of any state ... are eligible for financing assistance from federal-aid highway funds apportioned to the states. ..." 13

Thus, this volunteer effort not only produced technical documents of lasting importance, but sparked a significant gain in Federal-State-local relationships and opened a channel for Federal aid to cities in solving their local transportation problems. And, incidentally, the Committee having completed its work in 1958, voluntarily disbanded, not a commonplace occurrence in Washington.

\section{Planning in the Washington Office}

The increasing activity in the area of highway needs studies and the urban travel habit surveys placed a considerable burden on the Washington Office of the Bureau of Public Roads. Although a Federal planning engineer was located in each State and in each field region, their responsibilities were primarily administrative. Most of the technical assistance and reviews of the ongoing planning activities in the States came from Washington, especially where innovative methods and pilot projects preceded the more general adoption of new procedures or investigation of new areas. Even so, much effort went into advancing the art of planning, or as later more explicitly defined to satisfy the accounting office, research in the planning method.

The highway needs study procedures offers one example. The accepted procedure in the State studies was to estimate the deficiencies in the highway system route by route as they existed at the time of the survey and as they were expected to appear as traffic continued to grow and roads continued to wear out or become inadequate in capacity. Then the year by year requirements to overcome these deficiencies were accumulated to show the total need by systems or for the entire State.

Even before the highway planning surveys were organized, work was being done under agreement between the Bureau of Public Roads and the Iowa State University on what were called road life studies. This study accepted that just as the average life of human beings, or public utility installations, or railroad ties could be forecast by actuarial methods, so too could the life of road surfaces. Plotting the curve of the actual lives of road surfaces from the time of placement until they were retired from service by reconstruction or for other reasons, including different surface types, would give characteristic curves based on actual experience. In many States bond issue financing provided funds for a large mileage of road to be built in a very short period, all or most of which would have to be rebuilt or otherwise taken from service at some future time. Provision must be made for this replacement cost, and by matching the curve of retirements after, say, 10 years since construction with a curve that had been developed by experience of similar surfaces over, say, a 30-year period, the replacement needs, year by year, could be forecast. This forecast did not reveal which particular sections would be retired, but it would give a reasonable estimate of the total replacement program to be anticipated in any year for financial planning. The success of this approach led to its adoption as a part of the highway planning survey package in all States. Replacement of a road surface on the same location did not retire the whole value of the original investment, however. The right-of-way and probably much of the grading and drainage, still were usable, perhaps depreciated but still an asset. So it was reasoned that a curve of investment life, similar to the road surface's structural life, could also be viewed on an actuarial basis. While there was, then at least, no statistical relationship between investment in the system and demands upon it as shown by traffic volumes accommodated, it was further reasoned that the depreciated investments in the highway plant should keep pace with traffic growth. This view was fully supported by the facts in the decade of the thirties when the curve of traffic growth and the curve of the value of the depreciated investment did almost exactly coincide. Indeed, it has been reasoned and may well be true that our highway systems in that period came nearer to meeting the demands of the traffic of its time than at any period before or since, for it was in this decade that public works programs were strongly financed as unemployment relief projects to the great benefit of the highway systems. With highway construction virtually stopped during the war, investment had barely recovered to its 1940 level by 1950 , while traffic had grown by 50 percent. These curves showed at a glance, by their vertical separation, how far the investment fell below the need-50 percent. And by their horizontal separation, they showed how far behind traffic the investment lagged in years -9 years, at the projected rate, to catch up even to 1950 needs, to say nothing about recovering lost ground. 
When this approach was tested in a number of States in which the needed investment by years to achieve the accepted level of service had been calculated by accumulating the route-by-route needs, the agreement in the total figures was indeed remarkable. The investment life approach could not replace the detailed survey, for it could not be directed toward particular routes or sections necessary to program construction expenditures. But it gave a check on the detailed engineering method and also provided a simple, easily understood means of keeping abreast of progress year by year as the highway program proceeded.

In somewhat the reverse of the highway needs situation, traffic volume forecasting was usually approached on an areawide basis. The classic procedure was to estimate population, motor vehicle ownership per capita, and annual miles per vehicle over the years and from these estimates calculate the total vehicle miles of travel to be expected. In the "depression psychology" still persisting, estimates in all three elements generally were too pessimistic, with the multiplication of all three producing far too low estimates of traffic on which to base future highway needs calculations. In one case of a highway needs study, the level estimated for 10 years ahead had been reached before the report was printed. In exploring this situation to try to find a more realistic basis for forecasting, it was discovered that, for the decade of the thirties, traffic had been growing at almost the same rate as the national economy and that, once the aberrations of the war were behind us, parallel growth was resumed. On the strength of that finding, in 1950 it was suggested by E. H. Holmes, Chief of the Highway Transport Branch of BPR, that this relationship was entirely logical and that in planning ahead it would be unwise to anticipate a growth rate below that of the last two decades -4 percent per year compounded. (This rate of growth would see traffic double in 171/2 years; it did double in 161/2.) This forecast was greeted with skepticism, to put it mildly, perhaps not because of doubts as to the relationship, but more by doubts that that rate of economic growth could continue. It was not until 1954 that the Bureau of Public Roads formally accepted the soundness of this relationship and raised its sights accordingly. Actually over the past two decades, the gross national product has been growing at about 3 percent annually while traffic has continued its 4 percent rate, presumably as our economy shifts from an industrial to a service oriented society and with a generally higher economic level.

But even the more realistic approach to traffic growth forecasting on an areawide basis was of little help in estimating probable volumes on specific routes. With the aid of selected States, origin and destination studies were carried on before and after major route improvements were made, and studies were made comparing parallel routes, such as toll roads and parallel existing routes. These studies disclosed that the traffic on the new routes could be segregated into four groups: trips "diverted" from other routes by the higher level of service; trips "generated" simply because the new routes offered a convenience not previously available; "development" trips resulting from new development along the routes; and finally, some trips simply resulting from "general traffic growth." While subsequent research has refined this approach, estimates using these four general divisions of composition of the traffic stream were generally the basis on which the States estimated needs, route by route, required for the important studies to be conducted in 1954 and 1955.

These were examples of developing and improving planning techniques through research. During this period, great advances were made in processing, analyzing and interpreting data collected in the urban travel habit studies. As noted earlier, with the data processing equipment then available, the survey method was validated in the early studies. Travel could be accurately reproduced through home interviews. But to project travel into the future, the relationships between travel and land use had to be established, and as also noted, it took the computer and the introduction of new disciplines into the process to do it.

What emerged from this effort were a series of relationships, called models in computer terminology, that first showed the trips that might be expected from a zone of known land use to other zones of known land uses, as determined from the actual travel in the area. Then with the number of trips from each zone to each other zone calculated, another series of models to permit the "assigning" of the trips to the links of an existing or proposed network of routes, either highway or transit, was developed. The first series of models employed economic and social factors available by zones from census records, such as occupation, income level, and number in the family and their ages. The second included physical factors such as the purpose, time and distance of trips by various routings, costs of parking if that were involved, cost of travel by transit, and other factors to predict the mode and probable route of travel. The intensive work in this area led to a computer program "package" of models that permitted the estimation of trips and their routing with satisfying (to some, surprising) accuracy. In application of these models to estimate future travel and transportation facility needs, future land use had to be estimated. Research showed that computer simulation could also be used to predict the probable use of land, basing the models largely on theory and testing them against actual changes in land use as the urban areas expanded. In that success it may be said that the quantitative approach had been brought to urban planning by the transportation planners. The use of these models, in combination, can show what transportation facilities are required to provide a desired level of service for a given land use; they will also show what density of land use may be allowed if a desired level of transportation service on a given transportation network is to be maintained. These models, refined as they have been over the years, can appraise the effect of land use on transportation, as well as the reverse, the effect of transportation on land use. They can show how to achieve balance between transportation and other development. 


\section{Edward H. "Ted" Holmes}

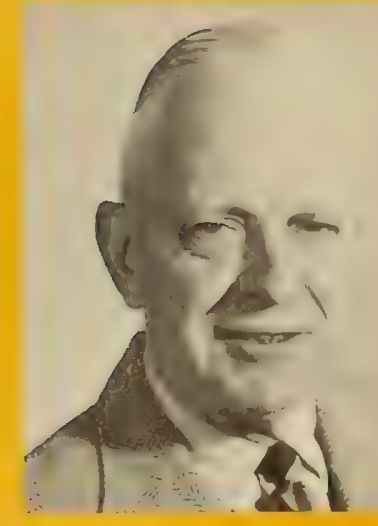

In 1906, Ted Holmes was born in Kingston, Massachusetts, close by to Plymouth. By the time he was 10, the Federal-Aid Road Act of 1916 had become the first national Federal-aid program. Holmes knew nothing of it at the time, nor did he realize that he later would join the Bureau of Public Roads in what would become an intimate partnership lasting 40 years. The value of that merger is still reflected in the quality of highway programs both in the United States and abroad.

Holmes graduated with a degree in civil engineering from the Massachusetts Institute of Technology in 1928. Having spent a surnmer as a student engineer making time studies for the Bureau of Public Roads, he returned to the Bureau after graduation as a trainee, the launching pad for most BPR engineers. Holmes once remarked that at this point he probably envisioned his future as that of a highway contractor or superintendent.

That vision changed, however, when he was chosen in 1929 for a fellowship in the new field of traffic engineering at Harvard University, from which he graduated with a master's degree in 1930. From that time on, Ted Holmes was to devote his entire career to highway research and planning.

From his earliest endeavors, he pioneered in the development of workable solutions for both short- and long-range demands. His early efforts in the Bureau of Public Roads included the planning, adaptation, and design of equipment and scientific techniques to measure the traffic characteristics essential to sound traffic planning, design and engineering. The now common practice of counting traffic with pneumatic detectors was just one of the revolutionary steps that stemmed from these studies. In the mid-1930's he had a major role in establishing the Federal-aid statewide highway planning surveys which provided an appropriate foundation for the continuing Federal and State highway programs.

Among his goals were the pursuit, development and encouragement of a supporting staff. Individually and collectively, those men were or became outstanding experts in their fields. This was due in principal measure to Holmes' ability to forge effective teams from talented individuals and to give each one an opportunity to reach his potential.

Holmes' direction and counsel were invaluable throughout the many years when highway research and planning served as the keystone of the Nation's highway transportation programs. Through the 1940's and 1950 's, he guided the development of the urban factual surveys and analyses of traffic and urban development. These later evolved into a scientific linking of transportation to land use which is now known internationally as the "3 C" (comprehensive, continuing, cooperative) State-local planning process. This innovation in urban transportation planning, perhaps the most notable of all Ted Holmes' many contributions, was subsequently extended to statewide planning. The key to the success of that endeavor was the development of a high degree of cooperation among Federal, State, and local officials that perhaps reached its high point with the Williamsburg Conference in 1965 , which he chaired.

Holmes' efforts covered many diverse subjects related to transport. Among these was his discovery of a significant parallel between trends in vehicle mileage (VMT) and the Gross National Product. In a speech in 1950, he advised his audience that they should expect an increase in traffic over the next 15 years of at least 4 percent annually. Although at the time this forecast met with almost universal doubt, in 1965 the average rate had been 4.1 percent. Not all forecasters have been that fortunate! 
Many of the great landmark reports to Congress bore his mark, among them the Interregional Highways report of 1944 and a series of national needs studies. They formed the framework for the National System of Interstate and Defense Highways and the balance of the Federal-aid system and, as such, are basic to the knowledge of the history of national highway development in the United States.

Thomas H. MacDonald, long the Commissioner of Public Roads, commented before his retirement in 1953: "At no time in the last 25 years has there been a report from Research which did not have the stamp of genius in it." As understudy to H. S. Fairbank, Deputy Commissioner of Research, Holmes' thoughts permeated all research activities. For example, for years he guided the applied research and development of new planning policy procedures. These were implemented in the Federal-aid highway program, which provided continual stimulation for the physical, economic, and resource development of the Nation.

In 1956 Holmes became Director of Research for the Bureau of Public Roads. As such he fostered the development of the National Cooperative Highway Research Program within the Highway Research Board. He also deserves credit for many activities between various levels of government affecting the Nation's highway transport program. Examples include his leadership in determining appropriate sizes and weights of commercial vehicles and a rational allocation of highway costs between users and nonusers.

When Research and Planning were divided into separate offices in 1962, Ted Holmes decided to go with Planning as its Director because, as he later remarked, he saw there "the greater opportunity for improving our transportation and our society." In 1967 he assumed the responsibility of Director of Policy Planning for the Federal Highway Administration in the new Department of Transportation and, with the reorganization of the FHWA, became Associate Administrator for Planning.

Perhaps a fitting description of Ted Holmes is that of an "imagineer"-one who is able to link creative talent, engineering judgment, and administrative finesse. His has always been an inquiring mind, restless, seeking solutions soundly anchored in analysis of relevant facts, yet always cognizant and respectful of opinions differing from his own. To his associates, he always pressed one significant point-"How well we carry on our work will be judged not by this generation, but by those future generations to follow."

His writings lace the literature of traffic engineering, highway and transportation research, and planning. His "Man in California, 1980's" paper, as so many others, reflects the range and brilliance of his thought. Following his retirement from Federal service in 1971, he undertook a study of urban transportation planning for the International Road Federation. His 1974 report, The Coordination of Urban Development and the Planning and Development of Transportation Facilities, is a basic source document on urban transportation and development planning practices in selected major countries around the world.

Holmes' accomplishments have been recognized in many quarters. Some of the principal honors he has earned include the Department of Commerce Meritorious Service Award, presented in 1950, and the Department's gold medal for Exceptional Service in 1962. He was presented the Roy W. Crum Award for distinguished service by the Highway Research Board in 1958. He received, in 1968, the Thomas H. MacDonald Award "For Outstanding Service in Highway Engineering," from the American Association of State Highway Officials, and in 1970, the Theodore M. Matson Award for Outstanding Contributions to Traffic Engineering. At the close of his official service to the Department of Transportation in 1971, Secretary John A. Volpe presented Mr. Holmes with the Department's Silver Medal for Meritorious Achievement in a retirement ceremony attended by several hundred of his friends and colleagues from government and many private organizations in the Washington area. 
Mr. Holmes has also received acclaim from abroad. In 1965 he was honored with an invitation to deliver the Sixth Reese Jeffreys Triennial Lecture, Looking 25 Years Ahead in Highway Development in the United States, to the Town Planning Institute, London, England. He was also invited to be the principal speaker at the Australian Road Research Board Conference in 1972 and at the South African Institution of Civil Engineers in 1973.

Ted Holmes is home again in Kingston, Massachusetts, hard by Plymouth. He lives there with his wife of 40 years, the former Elizabeth Boynton of San Francisco. The Holmeses have two sons, Joseph and David, who still reside in the Washington, D.C. area.

Greatly respected and honored in all his fields and activities, Ted Holmes is a highly knowledgeable, yet modest, man with almost limitless energy, practical sense, good humor, and rare analytical talent. $\mathrm{He}$ has also been a leader with exceptional foresight and a unique capability for understanding people and for organization and management. As Senator Jennings Randolph stated in the Congressional Record, "He performed a major role in improving the lot of his fellow men by helping to provide the highway facilities a mobile society demands. He has left an indelible mark on the Nation's highway program." 


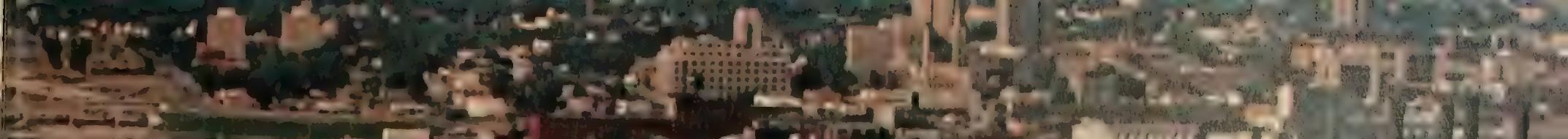

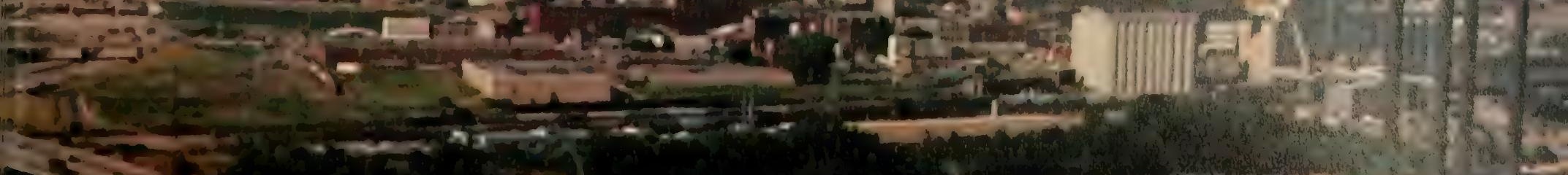
$x_{1}$

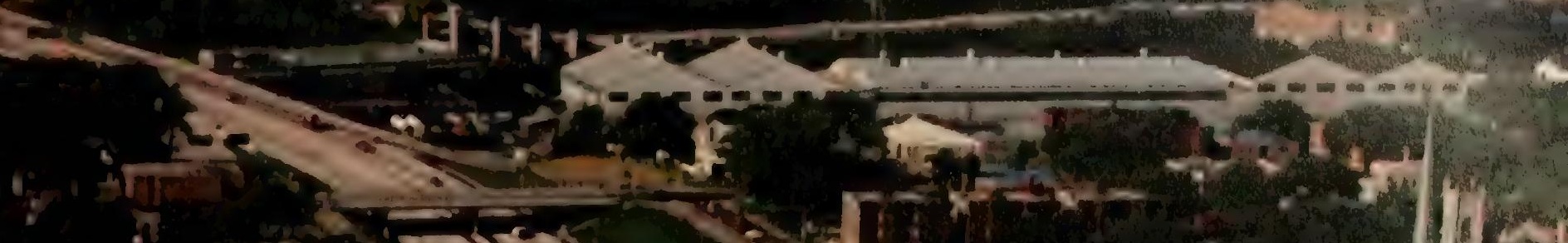

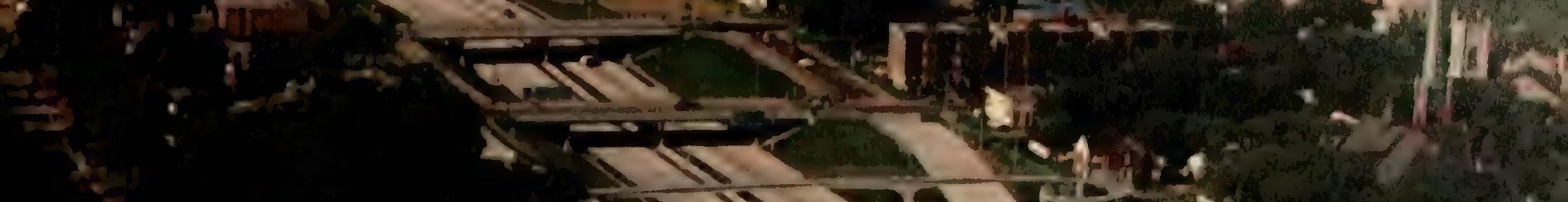

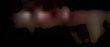

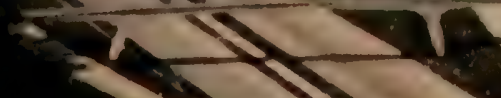

$4 x$

25

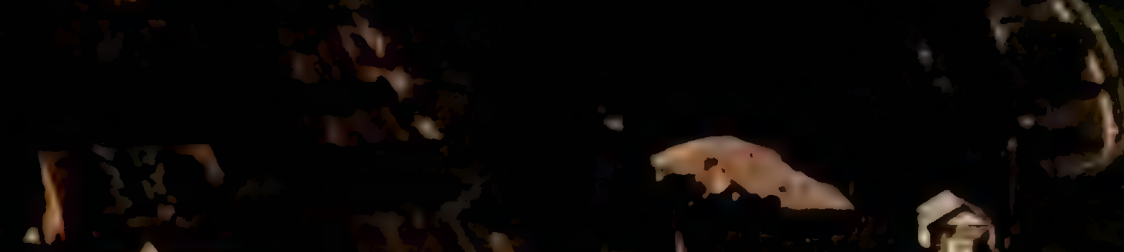

(1)<smiles>C#CCC#CCCCC</smiles>

c
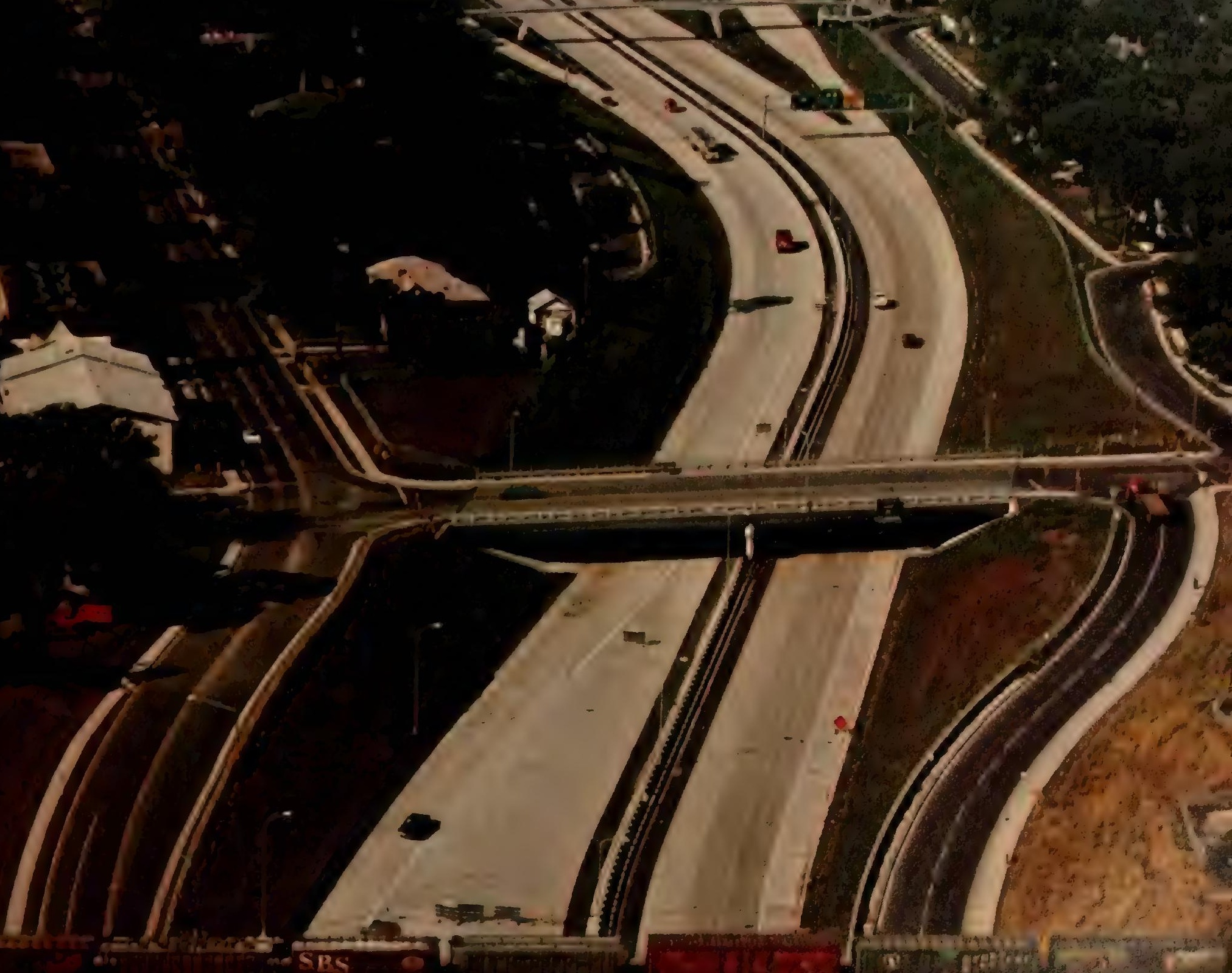


\section{Reports to Congress}

Since 1938, responding to the direction of the Congress for reports on various aspects of the highway problem was sufficiently demanding almost to be called a regular activity in itself. While not all reports were prepared by the planning staff, planning data, available or collected as necessary, were involved in all.

In response to Section 2 of the Federal-Aid Highway Act of 1948, the Commissioner was directed to report on the "current conditions and deficiencies" of the Interstate System that had been finally designated only on August 2 of the previous year. The report Highway Needs of the National Defense ${ }^{14}$ showed graphically the use made of the highway system during the war, still fresh in memory. It covered military traffic on the highways, and even a safe emergency landing of an airplane on the highway. It gave examples of heavy traffic service for employees of industrial plants. One plant was opened on a road on which the average traffic of 700 vehicles was swelled to 14,000 when the plant reached full production. It described many examples of accidents resulting from inadequate highways and unsafe bridges.
But especially, it documented not only the great increase in truck movement, but the greatly increased loads on the average truck. Motor truck vehicle mileage more than doubled during the war years, and the axle loads exceeding 18,000 pounds increased from 12 per thousand trucks prewar to nearly 70 per thousand trucks in 1945. With this twelvefold increase in heavy axle loads, it is small wonder that the highways emerged from the war badly battered. What was made abundantly clear was that under the circumstances of World War II, the use of the highways for military vehicles was very little indeed compared to highway use for moving employees to and from warplants and military establishments and for the movement of goods and manufactured products for the war effort. That in fact the highway became literally a part of the assembly line is most strikingly illustrated by the movement by truck of airplane fuselages from Michigan to Texas for final assembly. The actual experiences of war demonstrated the sound judgment of military and highway officials, when recommending the routes of the Interstate System in 1941, that the greatest value of the system to the military would lie in its part in keeping war industry at maximum production levels.

War production could be undertaken anywhere. This PT boat was on its way to seo from an inland "shipyard."

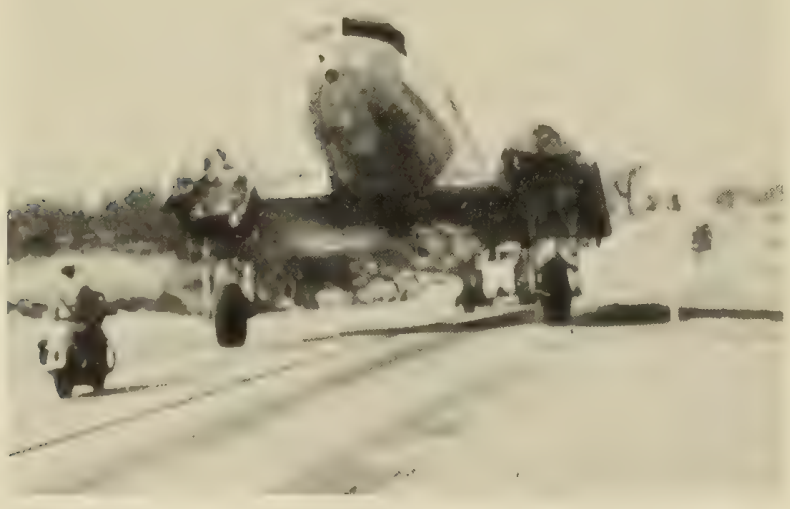

This damaged WW II transport plane, having made an emergency landing on the highway, was towed to the nearest airport. The wings were removed for safe transport along the route.

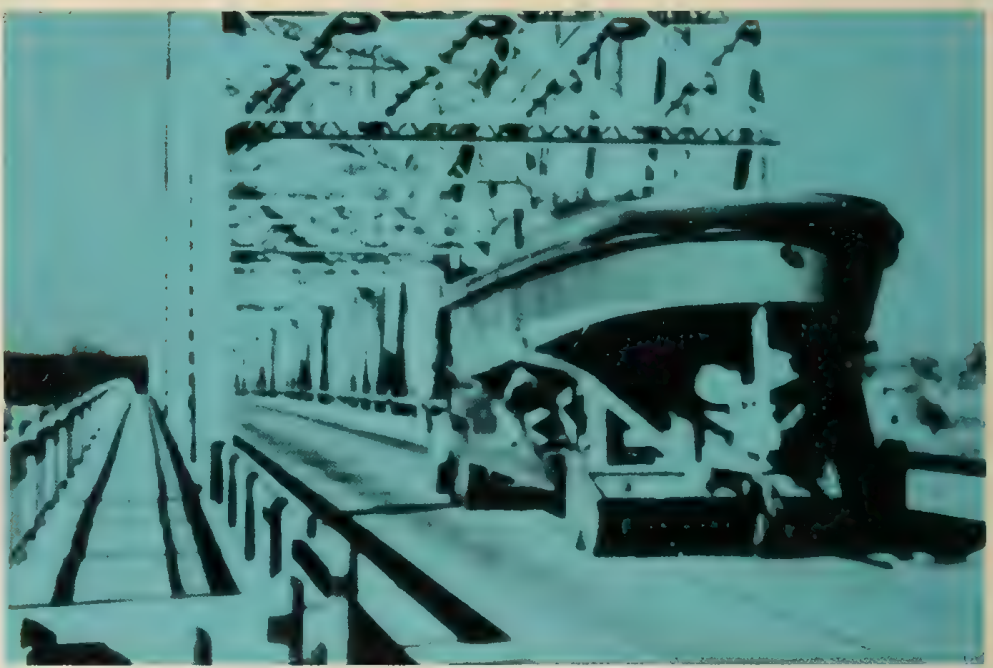

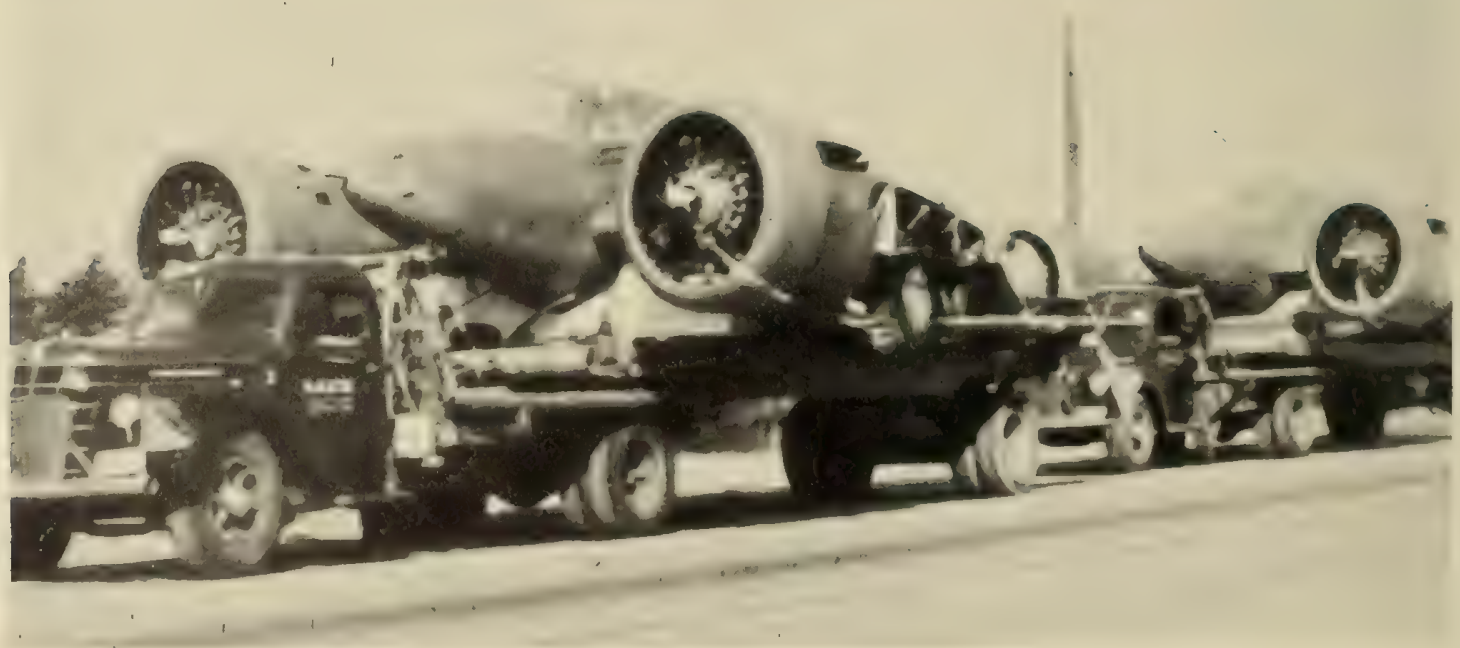


The Interstate System was examined mile by mile for the first time since its designation to measure its deficiencies. Inadequate widths, excessive grades and curvatures, short sight distances and especially weak or narrow bridges and narrow tunnels were recorded, and estimates made to bring all deficient sections, using the standards recommended for the Interstate System in Interregional Highways, up to adequacy for 1948 traffic.

Just why the study estimated the cost to meet the requirements of 1948 traffic while recognizing the continuing increase in traffic volumes and truck weights is not stated, but perhaps because the Congress gave no specific year in the future to which to direct the estimate. In any event, the estimate totaled $\$ 11.2$ billion, about half to correct deficiencies in rural areas and half in cities of population above 5,000. In estimating the cost at 1948 price levels, it was noted that prices might well decline in the years ahead, again reflecting the still persisting "depression psychology." The report further recommended that the system be brought to adequacy in no more than 20 years, which indicated an annual program of not less than $\$ 500$ million. And then in 1968 it would be adequate only for 1948 traffic. But this proposed program, seemingly a "too little-too late" endeavor, must be viewed in light of the fact that at that time improvements by the States on the Interstate System were totaling only about $\$ 75$ million annually, and the report recommended nearly a sevenfold program increase. It further recommended that a much more rapid improvement program would be reflected in economic and social benefits as well as meeting defense needs more quickly and proposed consideration of advancing the rate of construction by a bond issue. And it definitely proposed that the Federal participation in projects on the Interstate System should be raised above the 50 percent State-Federal matching figure. Other recommendations proposed a revolving fund for emergency construction not only for military emergencies, but for civil disasters as well, and authorization to acquire and stockpile critical materials.

While the authorizations for regular Federal aid were increasing somewhat in each biennial act (the Congress had by then indicated an informal linkage between authorization level and the revenue from the Federal motor-fuel tax), no specific provision was made by the Congress for accelerating work on the Interstate System until $\$ 25$ million was authorized for each year 1952 and 1953. In the 1954 Act a somewhat more liberal provision was made by authorizing $\$ 175$ million for that year and 1955. It apportioned the funds somewhat differently, half on the basis of primary system apportionments and the other half on the basis of State population. In addition it changed the matching ratio to 60 percent Federal, 40 percent State. So if Commissioner MacDonald's recommendation of $\$ 500$ million annual authorization, made in 1949 , now seems low, it took the Congress 5 years to come up to one-third of that level.

There were probably two reasons, at least, for the apparent reluctance of Congress to press ahead on improving the Interstate System. First the States, with limited funds (the highway needs studies had yet to yield much fruit) and with deficiencies on all roads, were reluctant to apply funds to the Interstate System on which the design standards were much higher than on other roads and where much less mileage per dollar could be produced. In fact, many States were strongly opposed to the "high" standards. The other reason was the general pressure for more attention to secondary and farm-to-market roads, with the rural strength in State legislatures and in the Congress always evident.

The second reason is given visibility by a letter of May 27, 1949, from the Committee on Public Works of the Senate to Commissioner MacDonald, asking for a report on the condition of rural local roads. This report The Local Rural Road Problem was submitted to Congress in January 1950 and offered little support for the advocates of more aid for local roads.

Calling on the road inventory and traffic volume and classification data from the highway planning surveys, detailed studies were made of rural road service in all States. Such items as the extent of road surfacing; the distances of rural residents from allweather roads; the road usage (from the road use studies) of rural roads by farmers and other rural residents; the average traffic volumes; the adequacy of schoolbus and mail delivery routes; the motor vehicle ownership; and the social functions permitted by the road system were studied.

With the aid of State and county engineers, estimates were made of the cost to bring the entire network up to acceptable standards. And finally the question of highway finance and administration were studied.

In capsule summary, it was found that funds allocated to local rural roads in 1947 amounted to $\$ 834,976,000-4$ percent from Federal sources, 56 percent from State sources and 40 percent from local sources. Local support had dropped steadily to that level from 81 percent in 1927 , with reason to believe the trend toward increasing support from the higher government levels would continue. Against this amount of available funds was an estimate of annual construction, maintenance and administrative costs of $\$ 894$ million to reach adequacy for the entire network in 20 years. The gap between revenue and program costs in 1947 was only $\$ 60$ million with evidence that the revenue was steadily increasing. In the same year that $\$ 835$ million was being applied to local roads, the amount applied to all State primary and secondary roads was only about $\$ 1.4$ billion.

The report concluded local rural roads were not only in good shape relative to roads in the other system, they were in good shape in absolute terms in that funds in sight were sufficient to put the whole system in acceptable condition. The report also concluded that local road administration was generally inefficient because the many small units were unable to own and operate suitable equipment or to retain competent engineering staffs, and it recommended consolidation of local units and close cooperation between State, county and local officials in carrying on the county and local road programs.

If the Congress and the State legislatures were apathetic with respect to improving the Interstate System, the automobile driving public was not. If better roads were not to be provided through the usual procedures, other means were sought, and the 
means proved to be the second toll era in the United States. The Pennsylvania Turnpike, opened just before the war, proved to be a great boom to military convoy and general truck movement during the war period, if less beneficial to the bond holders. After the war when the upsurge of traffic brought in more than ample revenue, pressures for toll roads appeared in other States. The Pennsylvania Turnpike's success was accepted with some reservation because of the peculiarly favorable contrast with the existing routes, for the Turnpike tunneled through several ridges that the old road had to climb, utilizing the tunnels of a railroad line never actually completed. But the New Jersey Turnpike, opened in its full length in 1952 with no advantages of terrain, proved to be a bonanza and thereafter the toll road movement swept through State after State.

The toll road movement not only produced roads; it sparked an interest in Congress that had not been ignited by the reports of 1944 or 1948 . In the Federal-Aid Highway Act of 1954, under section 13 the "Secretary of Commerce [was] authorized and directed to make ... a study of the costs of completing the several systems of highways in the several States and of the progress and feasibility of toll roads with particular attention to the possible effects of such toll roads upon the Federal-aid highway programs ..." The report, to be submitted by February 1, 1955, actually was prepared in two parts. The toll road portion was transmitted on April 14, 1955, still a remarkably short time considering that the Act was not approved until May 6, 1954. For those States in which needs studies had been completed, the information required for the report was not too difficult, but for those States which had not developed needs studies, a heavy workload was imposed.

Looking first at the toll road study transmitted in the report entitled Progress and Feasibility of Toll Roads and Their Relation to the Federal-Aid Program, ${ }^{15}$ it found conditions far different than those in the late thirties when Toll Roads and Free Roads was prepared. Traffic volumes had increased, of course, not only in magnitude, but in relation to the adequacy of the road systems with its lagging improvement programs. And 16 years later there was actual toll road experience to go on.

With these favorable conditions, analyses were made, for which some data already had been collected, to show the characteristics of the traffic using the toll roads. The origins and destinations of trips, their purposes, the time and distances involved in the use of toll roads in comparison with alternate free routes, the tolls paid, and the proportion of travel on the existing roads that was diverted to the toll route indicate the types of information used in the analyses. Factors developed from these analyses were applied to all sections of the Interstate System and other routes believed by the States to have toll potential to estimate probable use of toll roads and the revenue the traffic would produce compared with the costs of maintaining, operating and amortizing the investment in the toll facilities. Any proposed toll sections that showed revenues over the amortization period equaling $1 \frac{1}{2}$ times the total cost were considered feasible of toll financing. (The investment bankers of the time insisted on a "coverage" of 1.5 . In the Toll Roads and Free Roads study, toll financing was assumed to be justified when the revenue and cost were equal to a "coverage" of 1.0. Thus, the 1954 study was conservative and in line with current practice.)

With the changes over the 16 years, however, 6,700 miles were found to be feasible of toll financing compared to the few hundred that might have been selfliquidating in 1938. All but 200 miles were found to be on the lines of the Interstate System, attesting again to its prime importance. Should it be desired to pool revenues from different routes, as did some States such as Pennsylvania, with the stronger one helping to carry those not quite feasible, additional mileage not measured in the study could have been included in the total.

At the time of the 1954 study, 1,239 miles of toll road were open and 1,382 miles under construction. In addition 3,314 miles had been authorized and another 2,253 miles proposed, exceeding somewhat, in their total of 8,188 miles, the 6,700 miles estimated to be feasible in the study.

Looking back to the 1938 study, it is of interest that every one of the toll roads in use or under construction in 1954 that lay along one of the six routes studied in 1938 was on a section of those routes then found to be among the highest in feasibility. While the magnitudes had changed over the 16 -year period, the relative positions had not. This change again exemplifies the psychological effect of the Depression. The 1938 report noted that nearly everyone who could afford a car owned one, that their average incomes were low and that they could ill afford to take long trips, to say nothing of paying tolls. That position was buttressed by the road use studies showing that only 1 percent of trips exceeded 100 miles in length. (Even so they were important, for they produced 25 percent of the vehicle miles.)

But 1954 was a boom period. Cars were better, incomes higher and rising and the new toll roads were giving opportunity for more long trips. (More recent figures show that the percentage of trips of over 100 miles has doubled, indicating that freeways, toll or free, have opened a new market for the highway product, and expanded the horizons of American society.)

With 6,700 miles estimated as feasible of toll financing, more if "pooling" within a State were permitted and perhaps still more if "pooling" on a regional or national basis were accepted, one may wonder why the report did not recommend at least some measure of toll financing in the face of such unmet highway needs and the good public acceptance of toll roads. This question was argued intensely in the Bureau of Public Roads, but in the end it was decided not to recommend any change in the 1921 provision "That all highways constructed or reconstructed under the provisions of this act shall be free of tolls of all kinds."

Partly it is likely that the Bureau did not wish to depart from such a long-standing provision without some indication of congressional interest; and partly it was the strong belief that a toll-financed system was not desirable. It was reasoned that toll roads, 
generally with widely spaced entrance and exit points, would not accommodate the predominant short trips, and that the States would have to provide duplicate facilities or at least continue to maintain the existing ones. It was further reasoned that toll collection could not fit well into the urban scene, and there lay at least half the cost and far more than half the problem of the Interstate program. It was reasoned that tolls simply added to user cost and that a free system in the long run would be cheaper and more effective. And it was also reasoned that some States, as a matter of policy, did not favor toll financing (California as the prime example), and it would be unfair to have a national system part toll and part free. The collecting and pooling of tolls on a national basis for partial support of the system, even though so doing would result in a very direct user charge, was not seriously considered. Thus, Recommendation No. 1 of the 1954 report was that "The present law forbidding the collection of tolls on highways constructed with Federalaid funds should be continued."

Recommendation No. 2, however, offered somewhat of a compromise in allowing the inclusion of toll roads in the Interstate System provided adequate roads of another Federal-aid system allowed for continuous travel without traversing the toll sections.
This provision recognized the ridiculous situation that would result if a State must parallel an existing toll road with another road built to Interstate standards in order to provide a complete freeway system. Yet it did provide for continuity of travel on free Federalaid roads should the traveler make that his choice. Adoption of this recommendation moreover would remove the ambiguity resulting from question as to whether the law prohibited the collection of tolls on any "highway" to which Federal-aid funds were applied, or only to specific projects on such a highway.

At any rate the report was extremely timely. The second toll road era had been in a boom period, and might well have continued were it not for congressional action to greatly increase the Interstate program. With hundreds of millions of dollars at stake, the Interstate program was almost on dead center. Highway administrators could hardly program projects on sections where a toll road was under construction, nor could toll road authorities do so if there were a prospect of approval of a major increase in Interstate funding by Congress.

What the Congress faced in meeting the challenge was conveyed in the second study required by the 1954 Act, Needs of the Highway Systems, 1955-84, which was transmitted March 25, 1955. ${ }^{16}$ The highway, open to traffic in 1956, completes the plan.

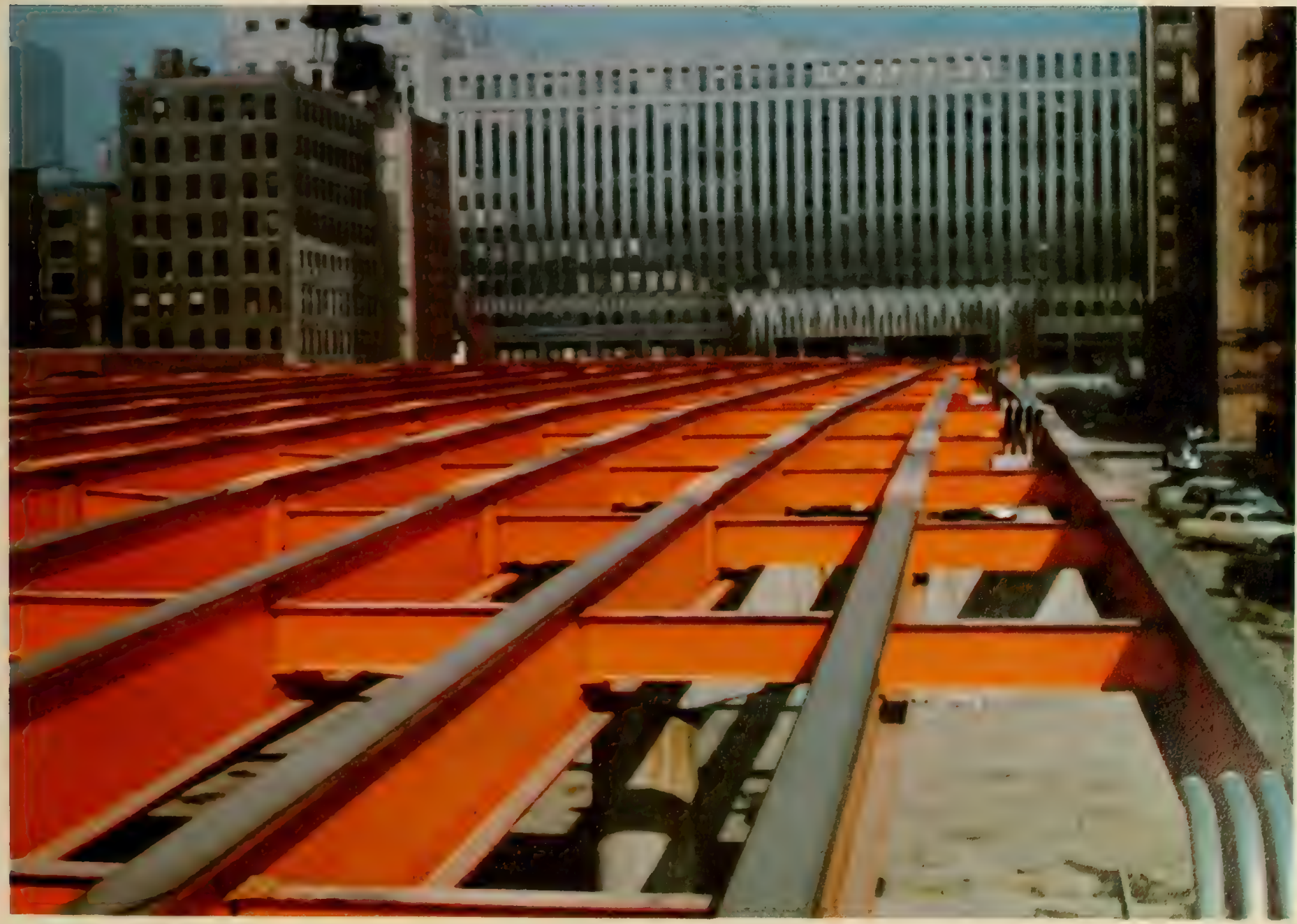


In the 1944 report recommending the designation of the Interstate System, no attempt was made to estimate its cost, simply because of insufficient information or experience at that time. In 1948 the cost of improving the Interstate System was estimated at about $\$ 11$ billion, roughly half rural and half urban. Under that proposal, the system in 1968 would have been brought to adequacy for 1948 traffic. In 1950 an estimate was made of the cost of bringing the local rural roads to a state of adequacy. But now for the first time the Congress called for an estimate of the cost of "completing" all systems of roads and streets. And for the first time the estimate could be made with a reasonably realistic projection of the rate of traffic growth based on the experience of the first postwar decade (although even this projection proved to be low). To interpret Congress meaning of "completing" and believing that considerable urgency was now being expressed, it was decided that the plan would call for completing the Interstate System by 1964 and all others by 1974, 10 to 20 years respectively. It was further decided to plan the Interstate System to be adequate in 1964 for 1974 traffic and the others adequate for the current traffic at the time of completion. As in present highway needs studies, the concept of "tolerable" and "desirable" standards was used for the systems other than Interstate, that is accepting sections that would still be adequate at the proposed date of completion of the system, but constructing any that would be inadequate to standards for adequacy for 20 years beyond the assumed date of construction. Construction programs to accomplish these ends were grouped into 5 -year periods.

With the conditions spelled out, the States were once again called on for a massive data collection, compilation, and analysis task, seeking the aid of the cities and counties to assist in the areas of their interest. It could be expected that States that had built a considerable mileage of high-standard, controlledaccess, divided highways could make realistic estimates of cost, but many such standards were difficult to visualize, and some States having no legal right to control access saw no reason to estimate on that basis. Even so, however, the cost to complete the Interstate System was estimated at $\$ 23.2$ billion, and for the first 10 years' program for all other systems $\$ 78.6$ billion, for a total cost for the 10-year period a "staggering" sum of $\$ 101.8$ billion. In the next 20 years new construction and some reconstruction on all systems would add $\$ 114.4$ billion more, for a total construction cost over the 30-year period of $\$ 216.2$ billion.

As noted earlier, $\$ 216$ billion can hardly be regarded as a "need." It is simply the result of the addition of the best estimates that could be made of the cost of achieving the level of service accepted as the basis of the estimate of "completing" the system to that standard.

With no realistic chance of meeting all the "needs" on all the systems, however, the $\$ 101$ billion figure for the 10-year program (roughly $1 / 4$ for the Interstate System which represented only 1 percent of the total highway mileage) focused attention of the cost and urgency of getting on with this most important of all the systems. The report was to have its effect.

\section{The 1956 Federal-Aid Highway Act}

Although the steps leading to the launching of the Interstate program are described in Chapter 9, consideration of some aspects of the manner in which the planning efforts were used in reaching the final decision seems in order, even at the risk of some repetition. While the most immediate use of results of the 1954 study was in connection with legislation relating to the Interstate System, that report was by no means the single, or even the most important, factor in the ultimate congressional action. It did, however, provide the basic information on which two other major attacks on the highway problem were based.

The first factor was the appointment of a committee of the Governors Conference to study the highway program, no doubt to some degree at least inspired by representations from their highway administrators. This committee had easy access, of course, to the results of the needs studies the States were making in response to requirements of the 1954 Federal-Aid Highway Act.

Paralleling this move, action again became evident in the White House, with the appointment by President Eisenhower of the Advisory Committee on a National Highway Program, not only recognizing the deficiencies of the highway system, but emphasizing again the national responsibility for highway transportation. This committee, appointed in September 1954, quickly became known as the Clay Committee, for President Eisenhower named General Lucius D. Clay as its chairman. General Clay had become acutely aware of transportation problems by virtue of having had responsibility for creating and operating the successful Berlin Airlift but a few years earlier.

Thus, once again, a presidentially appointed committee was charged with consideration of the Nation's highway needs. In contrast to the National Interregional Highway Committee created 13 years earlier, which was a planning committee, the Clay Committee was an action committee. The Interregional Highway Committee spent 3 years in a massive data assembly and analysis program culminating in a plan, but only in the most general recommendations for its implementation through a program. The Clay Committee, in a period of little more than 3 months, in effect recommended an action program to implement the earlier committee's plan. But both depended almost entirely on planning data assembled, as a result of acts of Congress, by the cooperating efforts of the Bureau of Public Roads and the State highway departments.

The composition of the Clay Committee evidenced this contrast. The Interregional Highway Committee, as described earlier, was heavily "planning" oriented. The Clay Committee, in addition to its chairman, included Stephen I. Bechtel, head of a large and successful contracting organization; David Beck, president of the Teamsters Union; S. Sloan Colt, a member of a New York investment banking firm; and William A. Roberts, president of a company manufacturing large construction machinery. With these sharp differences in background and outlook influenced by the difference in the Committee's charge, there was one important similarity. In each case the secretary was provided by the Bureau of 
Public Roads-H. S. Fairbank for the Interregional Highway Committee and Francis C. Turner, then Assistant to Commissioner duPont (later to be Federal Highway Administrator), for the Clay Committee. And in each case, through the secretary, came demands on the Public Roads staff for more data or data compiled or summarized in different ways, the pace deliberate in the case of the earlier committee and feverish in the case of the latter.

In developing its recommendations, the Committee not only had the massive array of data already mentioned, but sought the advice and aid of a group of technical experts representing professional groups and associations of users and of the officials of other levels of government. It also received offerings from 22 national associations in hearings covering several days in the fall of 1954. Significant in its recommendations were the recognition of the problem and an estimate of the programs needed to meet it that pretty much corroborated the conclusions of other groups thinking about the same matters. What stood out as markedly different was the proposal for financing the program. Accepting, as did others generally, that the cost should be met by user taxes, it proposed accelerating the program by resorting to a bond issue. And it proposed the establishment of a new and separate Federal corporation to administer the program, the actual construction of which would still be the responsibility of the States and the Bureau of Public Roads.

That the proposal for financing the program was unique should not have been unexpected. For one thing, even in the face of obvious highway needs over many years, adequate funding had not been authorized by conventional methods. For another, the investment banking influence within the Committee, and the fact that Francis V. duPont, then Commissioner of Public Roads, was experienced in the financial world and one not reluctant to break with tradition, argued that since conventional methods had not worked, a different and possibly more dramatic approach might succeed. In any event, the Clay Committee's report to the President was transmitted with his strong endorsement to the Congress on February 22, 1955, a month ahead of the report called for by Congress in the 1954 Act. And soon after the "Administration bill," incorporating the recommendations of the Committee, went from the White House to the Congress.

The Clay Committee's report for the reasons described in Chapter 9 did not receive favorable acceptance in the Congress. But without doubt it did provide the spark that ignited congressional action, and the ultimate authorization of the greatest public works program in history can be attributed more to Commissioner duPont and the Clay Committee than to any other single factor.

Recognizing the upswinging public demand for improving highway transportation, brought into focus by the Clay Committee's work and its attendant publicity, the Roads Subcommittee (of the Senate Committee on Public Works), under Senator Albert Gore from Tennessee, began hearings early in February. Senator Gore's hearings were more extensive and more penetrating than any hearing previously held on the highway program. Every interested group was heard, and the Subcommittee went deeply into all facets of the problem, constantly calling for data on one subject after another, and questioning critically all the material supplied. Commissioner duPont assigned Frank Turner to act as liaison with the Public Works Committee, and he participated in virtually all its meetings, open or in executive session. Regularly he called the Bureau at the noon recess to say that the Committee wanted certain information "for this afternoon's session" and again in late afternoon to say that the Committee "needs this information by tomorrow morning." Many Public Roads people worked well into many nights to meet these requests!

Eventually came the "Gore bill" authorizing the needed expanded program and calling for its administration by a commission separated from the Department of Commerce. In a very informal session after the hearings, Senator Gore remarked that at the start of the hearings he had been opposed to heavy participation with Federal funds in a program that he then saw as primarily for the benefit of the States, but that the mass of evidence had "turned him around 360 degrees." Commissioner duPont observed that that could only mean that he was back where he started! But Senator Gore replied that, of course, he meant 180 degrees, for he'd turned completely in the opposite direction. It was in this good-humored atmosphere that the lengthy hearings ended, with the legislative and executive branches together and in harmony. It was planning data that "turned the Senator around."

The Senate hearings caused some ruffled feelings at the other end of the Capitol, for there it was maintained that highway legislation traditionally originated on the House side and that by jumping into hearings so early, the Senate had usurped the responsibility of the House. So perhaps not to be outdone, the House, not taking the evidence produced by the Gore Subcommittee, held its own and nearly equally lengthy hearings later in the session. And ultimately it, too, proposed a bill, also for a greatly expanded program with heavy Federal participation, but following more conventional lines of administration.

Thus, toward the very end of the session with three alternatives and with apparently some confusion in signals between the White House and the "Hill," the proposed program, so heavily supported by the public, went down, not so much by defeat as by default.

The highway interests were dejected. It was reasoned that the $2 \mathrm{~d}$ session of the 79th Congress would be in an election year and that there was little prospect of enactment or approval of a big money bill in 1956. The program, it was reasoned, would have to await the new Congress in 1957. But the seers evidently reckoned without the public, for when Congress reconvened in 1956, pressure to get on with the highway program was obvious and heavy. The representatives had heard from their constituents during their stay at home between sessions. As described in Chapter 9, the Committee on Public Works and the Committee on Ways and Means collaborated in providing the two-titled Act of 1956. The Interstate program conceived by President Roosevelt, planned by the Interregional Highway Committee, galvanized by the Clay Committee, and finally shaped by the Congress, was about to be realized. 


\section{Planning After 1956-Statewide and National}

\section{Reimbursement for Toll Roads}

Among the many and far-reaching effects of the 1956 Act, none was felt more immediately than its impact on toll road construction. The modern toll road era ended abruptly. With the promise of adequate funding coming primarily from Federal rather than State user taxes for early improvement of most of the mileage feasible of toll financing, justification for that method no longer existed. This toll road era, in contrast to the early era, ended not in disaster and bankruptcy, but in a substantial, and still financially sound, contribution to the Nation's highway transportation needs.

The Congress gave serious consideration to the problems that would arise if most of the toll road mileage were incorporated, as anticipated, into the system. There was much pressure from the user groups to make them free of tolls, but that raised questions as to how the bonds could be retired far ahead of maturity, even should the bond holders agree. The toll road authorities were hardly favorable to going out of business so quickly after they had launched their mostly successful ventures. As a matter of national policy, there was inequity in users of the Interstate System having to pay tolls in some States but not in others, as discussed earlier in the 1955 report to Congress. But what was perhaps not generally nor fully recognized, the 1956 Act did not provide for constructing the Interstate System but for completing it. It was expected that routes or sections already adequate, or that could be made so, for 1975 traffic under the Interstate standards would be included in the System. Any Federal-aid projects in this category would have received Federal aid anyway, even if at the $50-50$ or the later $60-40$ ratio, but the toll roads had no Federal aid nor State road-user funds applied to their construction. Nevertheless States such as Pennsylvania and New York, with large percentages of their Interstate System already completed by the toll road authorities, felt short changed in relation to States in which small mileage met the Interstate standards and, thus, were scheduled to receive relatively larger amounts of " $90-10$ " money.

In this atmosphere the Congress, by Section 114 of the 1956 Act, called for a report to be made by the Secretary of Commerce, in cooperation with the State highway departments and other agencies as required to aid the Congress," ... to determine whether or not the Federal Government should equitably reimburse any State for a portion of a highway which is on the Interstate System, whether toll or free, the construction of which has been completed subsequent to August 2, 1947, or which is either in actual use or under construction by contract, for completion, awarded not later than June 30, 1957 . .."

The American Association of State Highway Officials, appointed a committee to work with the Bureau of Public Roads in planning the study, and all States provided the needed information. The findings, resulting from the summarization of voluminous data, could be briefly expressed.
In short, the study disclosed that 10,859 miles met the requirement for inclusion in the System, either fully meeting the standards for 1975 traffic or being suitable for upgrading to meet the standards. Less than 2,000 miles were found to be fully adequate, however. Included in the total were 1,950 miles of toll roads in 26 States and 8,909 miles of free roads in 47 States.

The cost of the improvements that had been made within the 10-year period specified (representing the time between the approval of the Interstate System and the effective beginning of the Trust Fund financing) was estimated at $\$ 6.09$ billion, $\$ 2.59$ billion for toll roads and $\$ 3.50$ billion for free roads. The depreciated value was also calculated, the depreciation being very little since the roads were so recently built. Right-of-way was assumed not to depreciate in value; grading and drainage was assumed to depreciate at a rate of 1 percent per year (a life of 100 years), struetures at 2 percent, and pavement at 3 percent. On this basis the depreciated value became $\$ 5.92$ billion, $\$ 2.52$ billion for toll roads and $\$ 3.40$ billion for free roads.

The Congress faced something of a dilemma when receiving the report in January 1958. To decide to reimburse would be to reverse its decision of 1956 to provide for the "completion" of the System, and instead, accept 90 percent of its total cost, including sections already built. Probably the practical problem of finding $\$ 6$ billion overrode any feeling of "inequity," however, and the decision was to defer consideration until later in the program. That time has not yet come, and one can wonder whether it will.

\section{The Continuing Needs Studies}

Congress in 1954, in calling for the report on Needs of the Highway Systems, 1955-1984, set in motion what proved to be nearly continuous examination of the physical and financial problems in the highway transportation area and the development of plans for the years ahead. The report listed the highway needs for all roads and streets over the 30-year period at $\$ 216$ billion. This figure, later under changing conditions found to be at least 50 percent too low, was still a staggering amount and one patently out of reach. The first result of the study was reflected in the 1956 Act. Title I, The Federal-Aid Highway Act, authorized the program to complete the Interstate System, the authorizations extending through 1969, 13 years ahead. In the same Act the so-called ABC program for primary, secondary, and urban roads was authorized for 3 years, through 1959, instead of for the customary biennium. Thus in this way the Congress picked out of the whole package of needs on all systems, the Interstate System as the most urgent, and provided for it authorizations unprecedented both in length of time and amount.

That the Congress did not overlook the broader needs situation, however, is seen in Title II, The Highway Revenue Act of 1956, that imposed the higher tax schedules to finance the program enacted in Title I. As noted before, it was the joint consideration of highway needs by the Committee on Public Works and the Committee on Ways and Means in 1956, also unprecedented, that cleared the way for 
passage of the legislation. But the Ways and Means Committee did not stop there. Under section 210, it authorized and directed the Secretary of Commerce, in cooperation with the State highway departments to make an investigation and report to give the Congress ". . . information on the basis of which it may determine what taxes should be imposed by the United States, and in what amounts, in order to assure, insofar as practicable, an equitable distribution of the tax burden among the various classes of persons using the Federal-aid highways or otherwise deriving benefits from such highways." Moreover, it specifically directed that the study should be coordinated with the AASHO Road Test, and with other research activities of the Bureau, and it authorized funds "as may be necessary" to carry out the investigation.

The final report was due in 1959 but was delayed until 1961, and even then, the conclusions were based on preliminary performance equations derived by the Road Test staff from the still unfinished AASHO Road Test specifically for the section 210 study. A supplementary report was made to Congress in 1965 once the final equations were available, although the differences between the final and preliminary equations were so slight as to make unnecessary any revision of the " 210 " study conclusions. In all, the series of reports, including four progress reports, occupied 940 pages in printed form. ${ }^{17}$

The "210" report surely equaled in stature the reports on transportation of earlier years, the Eastman Report and the Report of the Board of Investigation and Research, but in its narrower scope and with much more data available, it far exceeded them in accuracy and precision of the information on which to base highway policy.

By the time the 1959 Federal-Aid Highway Act was passed, the more precise engineering estimates of the cost of completing the Interstate System had shown an increase in cost from the $\$ 27$ billion of the 1956 Act, based on the 1954 planning estimate, to $\$ 41$ billion. Accompanying the FederalAid Highway Act was an amendment to Title II, the Highway Revenue Act, to provide the added funds then seen as needed. Lacking the expected results of the " 210 " study, the motor-fuel taxes were increased one cent per gallon above the levels set in 1956 as a temporary measure. By 1961 the Congress had received the " 210 " report entitled Highway Cost Allocation Study, with its estimates of the cost responsibility of the various classes of vehicles based on the preliminary equations from the AASHO Road Test. The Ways and Means Committee, accepting the cost responsibility as calculated by the "incremental method" and still striving to finance the completion of the System by 1972, recommended continuing the temporary increase in the tax on fuel, made other adjustments of minor nature and, more significantly, increased the tax on trucks from $\$ 1.50$ to $\$ 3.00$ per year for each 1,000 pounds over 26,000 pounds in gross weight. (This in effect applied to all trucks with more than 2 axles and all tractor truck semitrailers and full trailers.) With the continued higher fuel tax, applicable to all vehicles, the result was that passenger cars were taxed at just about the rate to cover their cost responsibility and in line with the benefits they were receiving from the program. The tax on the heaviest trucks, on the other hand, despite the large increase in their weight tax, did not come up to the level of the cost they occasioned, but exceeded somewhat the calculable benefits they were receiving. The decision on the truck taxes seemingly was consistent with the wording of section 210 in the 1956 Act which called under paragraph (b) (2) for a determination of the "proportionate share" of the highway costs and paragraph (b) (3) for the benefit of the "use" of the highways by the vehicles of the various classes. The curve of taxes in relation to gross weights resulting from the Committee action lay just about midway between the curves of costs and benefits, and perhaps surprisingly, evoked no great objection from the trucking industry. (One reason that the industry was not unwilling to accept the higher taxes was the strongly implied commitment by the Congress that once sufficient mileage of the Interstate System was open to traffic, the size and weight limits imposed for the first time in Federal legislation in the 1956 Act would be relaxed to the degree the higher design standards would permit. Subsequent legislation to effectuate this understanding failed of passage, however, until the Federal-Aid Highway Amendments of 1974 when modest increases in axle weights and gross vehicle weights were allowed.) It might be noted also that section 210 of the 1956 Act called for a determination of direct or indirect benefits other than from the use of the highways. While the " 210 " report clearly showed such benefits, the Congress decided to assess the entire cost of the program on the users. The user rates set in 1961 still apply, soundly derived from the results of the AASHO Road Test. While the AASHO Road Test was undertaken to aid in highway pavement design, the first use of its results was in connection with highway economics and finance, and that use alone may well have justified its cost.

\section{The Functional Classification Study}

But it became obvious that planning for highways, at least after completion of the Interstate System if not earlier, must be undertaken, planning not only for programs to meet the upcoming needs, but to finance them. One of the striking facts to come out of the 1954 estimate of cost of completing the several highway systems, updated by the section 210 study, was the inadequacy of the Secondary System in relation to the rural Primary System and urban portions of the Primary and Secondary Systems. Also revealed was the disparity among the States as to the mileage of the Federal-Aid Secondary System, varying from as little as 6 percent of the rural highway mileage in one State to 39 percent in another. Obviously the concept of what should constitute a Federal-aid secondary route needed definition. While the national total had little significance except to illustrate the problem, it is of interest that the estimate of highway needs prepared in connection with the 210 study showed the needs from 1956 to 1971 on the Federal-aid primary routes, other than Interstate, in relation to the needs on the Federal-aid secondary roads under State control (about what the 1944 Act called principal secondary and feeder roads) to be in the ratio of $43.5: 17.6$, compared to the authorization ratio of $45: 30$ then still in effect. Obviously two aspects needed investigations. 


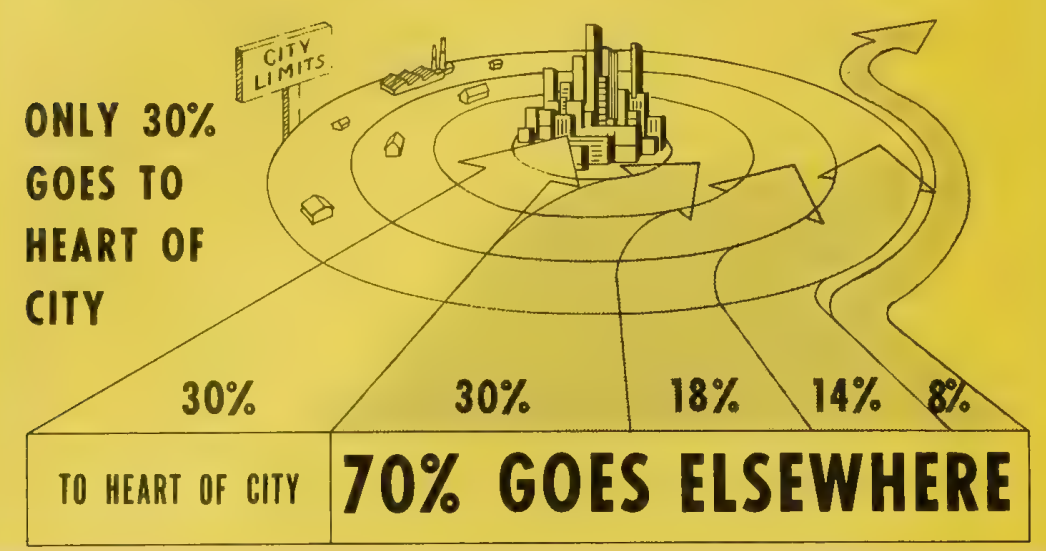

In 1960 intercity travel studies showed this basic travel pattern.

First the roads to be included in the Federal-aid system should be designated under a functional classification definition applicable to all States, and second the general level of Federal aid for rural secondary roads in relation to that for other systems, particularly in the urban area, needed review. It could be considered a restudy and perhaps a restatement of purpose of the Federal-aid secondary program after its 20-year history.

These thoughts and others were brought to the attention of the States by Federal Highway Administrator Rex Whitton in a 1963 speech. He outlined some of the problems and sketched the planning effort that would be required to analyze them and hopefully reach a concensus on how to meet them. AASHO authorized a high-level committee to cooperate with the Bureau of Public Roads to carry out the necessary studies and develop appropriate recommendations to be presented in a report to the Congress.

The Cooperating Committee, as it was designated, met with its Bureau counterparts in the spring of 1964 and agreed upon a format for the study. It was to be the most intensive study of highway needs yet undertaken, covering all roads and streets. The most significant new aspect was functional classification, with roads and streets segregated in three broad classes-arterial, collector, and local. Freeways would be a special category of the arterial group. The classification would be determined route by route by its estimated future traffic, not simply by volume alone but by the character of the traffic, trip length being an important determinant. This basis of classification had been used in a preliminary way in an earlier study by AASHO and the National Association of County Officials (NACO) in a review of rural highway needs, but little experience was available as a guide to urban street classification and none at all in areas yet to be urbanized. Since the period to be covered extended from 1972 to 1990 and with the rapidly increasing urbanization of the country, this latter situation presented a considerable problem. Fortunately, however, the urban transportation studies had by then progressed sufficiently in about 100 cities to permit the development of models that would show, on the basis of area and population, the number of lane-miles of streets needed in each category. So where the urban studies would not permit detailed estimates, at least gross figures could be produced by resorting to the models. With facts thus assembled, estimates could be made of the desirable extent of systems on a functional basis that could be compared with the systems then designated as "administrative" systems. (The study eventually confirmed that the Primary Systems in most States were well selected, but that as anticipated, the Secondary Systems as administratively designated in many States were badly distorted.)

On the basis of the agreed upon format, the Bureau staff, with advice from the Committee as needed, prepared the necessary manuals, and approval to begin the study came in the summer of 1964. The target date for the report to Congress was set as January 1967.

Then began a cooperative approach to data collection on a national basis, heretofore unequaled in the transportation field. The National League of Cities and the National Association of Counties formally designated members to form a joint committee with AASHO to oversee the work of data collection and analysis. At its first meeting in early 1965 , one member remarked that it was significant that for the first time officially designated representatives of State, county, and city governments had convened in a formal meeting. It was further significant that it met in the offices of the Bureau of Public Roads. It reflected intergovernmental cooperation in fact, not just in theory. While ultimately an important product emerged from this initial meeting, its bright promise was never fully realized.

It was during the period of this study that several factors appeared to complicate, delay, and confuse the planning of highway programs after 1972 , the scheduled date of completion of the Interstate program. It might be said that prior to this study, highways had been planned in isolation. While the major planning studies, particularly in urban areas, recognized the need for coordination between highway and other modes of transportation and took those 
modes into consideration, the highway program as authorized by the Congress had gone ahead as an independent program. It was during this period that questions began to be raised as to whether there should be "alternatives" to the highway program. Transit interests began to speak with a stronger voice in the Congress, as evidenced by the establishment in 1964 of the Urban Transportation Administration in the Housing and Home Finance Agency (in 1965 this Agency became a part of the Department of Housing and Urban Development (HUD)). The larger cities began to see their overall needs for transportation, and even for streets and highways, diverging from the programs envisioned by the States.

As noted earlier, each of the major reports on highway needs-1939, 1944, and 1955-had been initiated by the executive branch, but each had the added strength of being carried on by the paralleling direction of an act of Congress. So too in the 1964 study was the paralleling action initiated by the Public Works Committee of the House, which passed unanimously a bill calling for a report on the highway needs of the Nation to be submitted in January 1967, the target date of the AASHO study of which the Committee was well aware. That bill died in the Senate, which reasoned that the organic legislation required annual reports by the Bureau of Public Roads anyway, so no specific legislation was needed. The following year, 1965, Representative George H. Fallon, then Chairman of the House Public Works Committee, introduced a somewhat similar bill, which finally emerged as a Joint Resolution, S.J. Res. 81, instructing the Secretary of Commerce, acting through the Bureau of Public Roads, to ". . . report to Congress in January, 1968, and in January of every second year thereafter, his estimate of the future highway needs of the Nation." Thus, it appeared that the way was cleared for the cooperative studies to continue by the traditional coordinated direction of the legislative and executive branches of the Federal Government. The highway program, it was assumed, would continue to be an independently authorized, although cooperatively developed, program.

If the Congress accepted that the program planned cooperatively could best be authorized independently, that view was not necessarily accepted by the executive branch. The Bureau of the Budget, through which all reports to Congress involving Federal funds in any amount then must pass, as early as 1961 when the " 210 " report was being reviewed, reasoned that any emphasis on the nonuser benefits might encourage the application of general funds rather than exclusively road-user funds to support the program and that to do so would be in the direction of unbalancing the Federal budget. This position was taken even though the Congress in authorizing the study had specifically called for an investigation of benefits to other than highway users.

Meanwhile as the plans for the study moved ahead, it became apparent that with the massive data collection and analyses required for the functional classification of all roads and streets in all jurisdictions, completion of a report by 1967 was out of the question. Yet, with the final apportionments for the Interstate program to be made in 1969 to meet the scheduled completion date, there was real urgency to provide facts to the Congress to serve as a basis for the postInterstate program because extensive hearings and a searching review of highway needs comparable to that of 1955 and 1956 were anticipated. The AASHO Cooperating Committee, renamed by then the Committee on the Continuing Highway Program, concluded that the Congress must be furnished at least gross estimates of foreseeable needs as soon as possible and decided to ask the States to provide estimates not on the basis of functional systems to be designated as a result of the study, but on the basis of the current administrative systems. This estimate would be furnished as an "introductory" or "preliminary" report to give scale to the magnitude of the needed program, with refinements, once the functional classification could be completed. On the basis of this decision, ratified by the AASHO executive committee in Atlanta at the annual meeting in 1964, new manuals were prepared and work moved quickly ahead on the truncated study. This was followed by the much more deliberate and complex work of functional classification and related studies of other aspects of future needs, including such elements as the greater attention to safety and environmental considerations and bases for apportionment of funds not only among the systems, but among the States and local jurisdictions. This decision was made fully workable by the passage of S.J. Res. 81 a few months later. As a result, it became possible to furnish information to the Congress on different aspects of the upcoming problems on a continuing and timely basis at the biennial intervals specified in the resolution rather than in a massive single report comparable to the 1961 Highway Cost Allocation Study (the 210 study).

Highway planning at statewide and national levels seemed to be launched on a course that would lead to regular reporting to the Congress of needs for highway transportation, determined cooperatively by Federal, State and local officials, keeping abreast of changing technology in all transportation modes and of changing social and economic conditions. Most importantly, the study efforts provided the groundwork and guidelines for the broader studies embracing all modes of transportation that would be undertaken in the future.

\section{The Movement Toward Transportation Studies}

Before the 1968 report had been completed, another change at the Federal level further complicated the longstanding relationship between the Bureau of Public Roads, the Congress, and the State highway departments-the establishment of the Department of Transportation. Later the relationships were to become still more complex as departments of transportation were created in many States, a factor having an especially trying effect on the Bureau's longtime partner, the American Association of State Highway Officials, which eventually absorbed or was absorbed by the State DOT officials as the name of the organization was changed to the American Association of State Highway and Transportation Officials. The cordial relations between the Bureau, the States, and the Congress of earlier, simpler times was lost, perhaps never to be regained. 
Arnong the functions included in the new Department were those of the Bureau of Public Roads, which together with a new National Highway Safety Bureau formed the Federal Highway Administration; of the Federal Aviation Agency, formerly an independent agency, which became the Federal Aviation Administration; of the Urban Mass Transportation Administration, transferred bodily from the Department of Housing and Urban Development; and the functions of a new unit, the Federal Railroad Administration. All these were termed "modal" administrations headed by "modal" administrators. The purpose was, of course, to bring about better coordination of the Federal effort in the different modes under a national transportation policy to be developed by the Secretary. The first incumbent of that office was Allen Boyd, formerly Under Secretary for Transportation in the Department of Commerce, and with the change in administration in 1969, he was succeeded by John Volpe, formerly Federal Highway Administrator and, at that time, Governor of Massachusetts. Both men were qualified by solid experience in transportation and in administration.

While the assembly of transportation functions in a single department of the executive branch was a forward step, coordination of programs could hardly be fully effective so long as three different congressional committees on each end of the Capitol retained jurisdiction over the different functional areas. And to complicate coordination still more, three administrations were "modal" in fact, aviation, railroads, and highways. But urban mass transportation was not modal at all, but geographic and functional in its area of responsibility.

In the planning area, still another complicating factor was the establishment within the Federal Highway Administration of the Office of Policy Planning. This office was not to take any functions from the Bureau of Public Roads' Office of Planning, but to work with other modal administrations, with the Secretary's staff, and with other agencies such as the Bureau of the Budget in general policy matters. One function was shepherding reports, such as the 1968 Highway Needs Report, to Congress through the approval channels within the Department and the Bureau of the Budget. The office was also expected to consider and propose long-range policy and action programs in the areas of highways and highway safety, but for various reasons, principally inability to staff the office adequately, it never quite reached its anticipated potential. The major efforts in planning remained, as intended, within the Bureau. Subsequently a reorganization under Secretary Volpe brought the functions together, as Francis Turner, who served as Director of Public Roads under Lowell Bridwell, the first Federal Highway Administrator under the Secretary of Transportation, succeeded Bridwell with the change in administration. The new Office of Planning was organized in two suboffices each under a director, one called Policy Planning that dealt generally with long-range planning and relationships with other government agencies and the Congress, and one called Highway Planning that dealt primarily with the cooperative planning and programing activities of the States and local jurisdic- tions. It was within the Office of Highway Planning that research and development in the planning method produced the striking advances in transportation planning, particularly at metropolitan scale, but also extended the statewide and national scale as well.

Even with all these complicating factors, the 1968 National Highway Needs Report ${ }^{18}$ was transmitted to Congress by Secretary Boyd, the report having been approved by the Bureau of the Budget on January 31, 1968, meeting the requirements of S.J. Res. 81. In line with the AASHO decision, it included a gross estimate of costs, as estimated by the State highway departments, of bringing the administrative systems up to standards agreed upon by the joint AMA-AASHO-NACO* committees and the Federal agencies, including the Bureau of the Budget. By emphasizing that the estimate was that of the State highway departments, Federal endorsement was avoided, and perhaps with justification, considering that the cost of improvements needed to meet the accepted standards totaled $\$ 294$ billion for the 20-year period 1965 to 1985 . There was concern that the sheer magnitude of the estimate, without similar estimates of 20-year needs in other modes, might induce such substantial increase in Federal authorizations for highways that other modes might suffer, relatively at least, if not absolutely.

The $\$ 294$ billion figure was indeed a staggering figure, although not so startling when considered on the basis of cost per vehicle-miles of travel as later studies reported, and it stood in sharp contrast to the cost estimated by the States in the 1954 study of $\$ 216$ billion for the 30-year period of 1955 to 1984 . The difference reflected higher design standards, higher urban costs brought about by the unanticipated urbanization of the country, higher unit construction prices, and just the added costs occasioned by delays in meeting current needs as they developed.

In general terms the report outlined a desirable direction of future policy as follows:

1. Continuing assistance to the States for improving the efficiency and safety of the highway system in both rural and urban areas. (Studies would be necessary to redefine the Federal-aid systems and enable sound economic analyses to reveal how and where the investment of Federal funds would be most beneficial in terms of national objectives; general economic and social benefits; and transportation service to people and commerce.)

2. Greater stress than in the past on the improvement of urban transportation and the development of transportation plans calculated to raise the quality and satisfaction of urban life.

3. Additional emphasis on the coordination of highways with other modes of transport, both intra- and interurban, to ensure the optimum provision of the best features of all modes and continuing emphasis on making the highway a salutary influence on the environment, both in rural and urban areas.

* American Municipal Association-American Association of State Highway Officials-National Association of County Officials. 


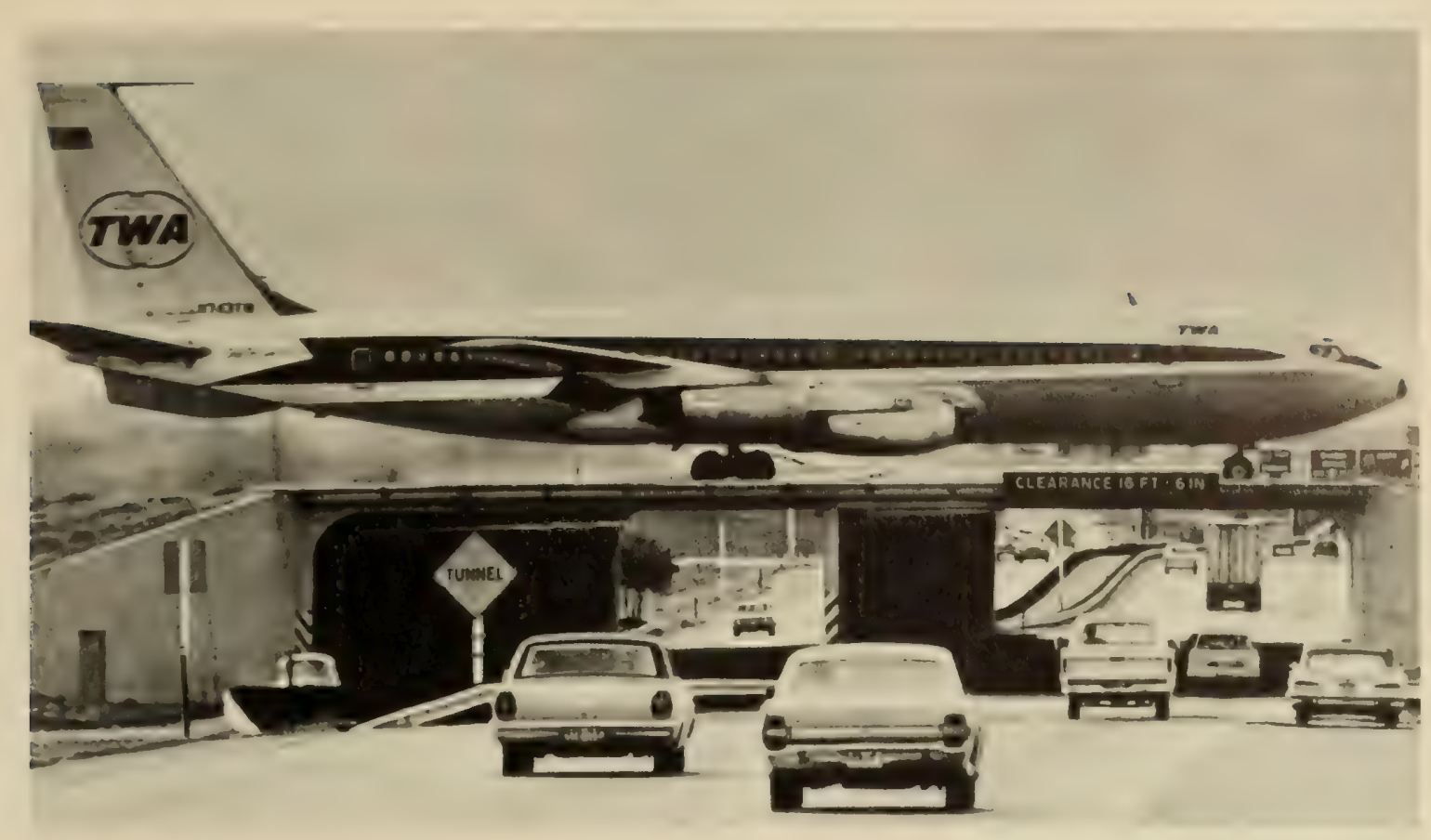

Land and air transportation cross paths at Stapleton International Airport over Interstate 70 in Denver, Colo.

More specifically the 1968 National Highway Needs Report discussed the need for a functional classification study and gave considerable attention to transportation needs in urban areas, quite reminiscent of similar discussions in the reports of 1939 and 1944. It also explored in a limited way the problems of developing highway or other transportation programs at metropolitan scale and suggested specifically that the planning agencies responsible for the urban transportation planning process in those areas be required to develop 5-year construction programs based on the planning data. Under the proposal, the State highway department could include in its program for any area only projects included in the 5-year program. It would not be required to program any projects in the area, but it could not program projects in the area that were not in the 5-year program. This proposal was calculated to insure that any improvements carried out by a highway department in a metropolitan area would be in harmony with the needs of the area. At the same time, the metropolitan officials could not infringe on the responsibility of the State highway department in developing its statewide programs. Hopefully this would reduce the areas of disagreements between the States and local and neighborhood interests within the metropolitan areas, already, in an increasing number of cases, becoming irritating if not actually destructive of implementation of long-range plans.

This proposal was the first attempt at the Federal level to bring metropolitan area officials directly into the programing of projects, and was entirely consistent with section 9 of the Federal-Aid Highway Act of 1962, in which the Congress in establishing the " $3 \mathrm{C}$ " (continuing, cooperative, comprehensive) process directed that "... the Secretary shall cooperate with the States... in the development of long-range highway plans and programs..." By that time the planning process was well in hand but little, virtually nothing in fact, was being done cooperatively with respect to programs.

The Congress received the report and published it as a "Committee Print," not giving it the stature of the previous reports that were published as House Documents. The only specific action it took with respect to the report, however, was to affirm what the States and the Bureau of Public Roads already had in progress, the functional classification of all roads and streets. Section 17 of the Federal-Aid Highway Act of 1968 stated :

The Secretary of Transportation shall, in the report to Congress required to be submitted by January 1970 .. include the results of a systematic nationwide functional highway classification study to be made in cooperation with the State highway departments and local governments ... desirable as one of the bases for realigning Federal highway programs to better meet future needs and priorities.

This section, by specifically including local governments in the planning, in effect required exactly what A.SSHO and the Bureau of Public Roads had undertaken in establishing the Cooperative Committee in 1964 and which by then was well along toward a conclusion. The provision in the Act assured that the information as assembled by the States and local governments would reach the Congress.

Review of the major studies during the 30 years following the 1939 report and the subsequent actions of Congress show clearly that the significant changes in policy followed careful review of deliberate planning studies by the Congress. While Federal Highway Administrator Bridwell chose to separate the function called policy planning from program planning, the planning that had been carried on under the HaydenCartwright Act of 1934, in retrospect, was in itself policy planning, although conceived more to aid in developing sound construction and financial programs in the State, the results when assembled on a neutral 
basis gave Congress the facts on which to base its policy decisions. Of course, times were simpler and the program then could be considered almost in isolation. In more recent years urbanization, environmental considerations, competition among modes, and other factors have complicated planning and action, and with the greatly enlarged programs, the stakes are much higher. However, review of the Federalaid highway acts from about 1968 onward shows clear evidence that the Congress has been responding to outside pressures to an increasing degree and relying less on the product of planning. Perhaps the committees tend to disregard the results of planning, or perhaps planning does not or cannot respond to the accelerated pace of current life. Whatever the reason, planning seems to have played a smaller part in guiding the highway program in the last few years than in earlier decades. While advances were made in planning at the metropolitan level, particularly in the area of intermodal coordination (at the direction of Congress and with added funding for that specific purpose), similar insistence on broad planning as a prelude to national decisionmaking seems to be in abeyance.

It is difficult to know when history should end, as it merges gradually into contemporary life, and when reporting begins. In this chapter, the purpose was to describe how the planning process developed and how the results of the planning aided or led to policy decisions and action programs. But in view of the confusion with respect to both policy and action at the Federal level in the last 5- or 6-year period, and without the damping effect of time to permit viewing recent, almost contemporary, actions in reasonable perspective, it seems presumptuous to try to attach historic significance to recent actions. True, the Congress has had the benefit of the periodic reports it directed to be made, and in the past few years, it has also directed the executive branch to make many special studies and has generally taken some action as a result. But most often these studies applied to special problems of a particular State or area, to proposals advanced by special interest groups, or to fringe or minor aspects of broader programs. While a recitation of the impact on planning of some of these actions is of interest in revealing the course of Federal action, it is simply that-a recitation, not an account of history.

\section{The 1970 Highway Needs Study}

The 1970 Highway Needs Report was transmitted to Congress in January 1970. This report listed, State-by-State, all road and street mileage classified in two ways, by administrative system and by functional systems, the latter as best it could be determined by general criteria in the time available. As expected, the comparison showed reasonably good coincidence between the Federal-Aid Primary System and the system of principal arterials in the rural areas of 113,000 miles so classified, 104,000 miles being on the Federal-Aid Primary System. Of the mileage not on the Primary System, 5,400 miles were on the Federal-Aid Secondary System and 3,600 miles were not on either, indicating the desirability of some revisions upward of those routes in system hierarchy.
On the other hand, some 21,000 miles of collector routes, at best candidates for secondary status, were on the Federal-Aid Primary System, and 75,000 miles of strictly local routes had been included administratively in a Federal-aid system, 74,400 miles on the Secondary and 600 miles inexplicably on the Primary Systems.

More detailed review of the figures would show the disparity between functional and administrative classification to be far greater in some States than in others-as noted earlier, the rural Federal-Aid Secondary System as a percentage of all rural roads in the State ranged from 6 to 39 percent. This disparity simply resulted from State policies of selecting the most heavily traveled routes not on the Primary System (and some no doubt qualifying for that System) and improving them to high standards. Other States preferred to spread their secondary funds as widely as possible. This situation, 35 years after the first authorization of secondary funds, was a far cry from the role of secondary road construction envisioned by Fairbank and MacDonald when they proposed holding the system to 10 percent of the rural mileage. With no clear support from Congress for a limitation on system mileage, the Bureau of Public Roads adopted a policy of approving most of what the States requested in system additions, holding the additions hopefully to a mileage to give "program latitude" rather than requiring more specific criteria. But after 35 years some hard rethinking appeared to be in order.

Although disparity in rural classification existed, that in the urban areas was far more pronounced, accounted for by the fact that Federal aid in urban areas was still limited to projects on extensions of rural Federal-aid primary or secondary routes. As should be expected, while 32,000 miles of urban arterials were on the Federal-Aid Primary System and 22,000 on the Secondary System, some 40,000 miles were not on either. This situation was the result of the concept of authorizing Federal aid in urban areas only for segments of statewide systems that lay geographically in those areas. Even that concept was a considerable advance from the original total prohibition of any Federal aid within urban areas of over 2,500 population. The Congress had never previously viewed Federal aid as appropriate for improving an arterial system for local urban travel.

\section{The Movement to Support Urban Needs}

The Congress by the 1968 Act, responding to continued urging to give greater support to urban needs, authorized a new program, the Urban Area Traffic Operations Improvement Program. This program quickly became known as the TOPICS program, an accronym for Traffic Operations Program to Improve Capacity and Safety. It recognized that extension of the freeway system into urban areas had relieved traffic congestion on many arterials but, by the location and design of interchanges, had imposed heavier volumes on other arterials or city streets on which cities were not prepared to finance improvements. Congress also recognized that generally the traffic operations systems in urban areas were not receiving 
the full advantage of modern traffic engineering techniques, due primarily to lack of funds. To alleviate these conditions, $\$ 200$ million was authorized for each of fiscal years 1970 and 1971, with the normal matching rates. And the Act required that projects to be included in the program be based on the results of the " $3 \mathrm{C}$ " process.

The TOPICS program was slow in getting started, and complaints were heard that the requirement for relation to the nature and cost of the projects. $\mathrm{Be}-$ studies prescribed by the Act was too exacting in yond that, the " $3 \mathrm{C}$ " process applied to urbanized areas (those with populations of 50,000 or more), and the
TOPICS program was applicable to all urban areas, so many new studies had to be undertaken. Subsequently, the authorizing legislation was amended to require the application of the " $3 \mathrm{C}$ " process only to projects within the urbanized areas.

By 1970 urban pressures had become still heavier, and calls for Federal aid for public transportation in the larger cities were becoming louder and stronger. Many voices urged diverting funds from the Highway Trust Fund to aid mass transportation, particularly rail rapid transit where capital costs were so high. Congress responded in small measure through the Federal-Aid Highway Act of 1970 in two specific

This is South Street in Pittsfield, Mass., which has been improved under the TOPICS program. Items eligible for such funding include construction of the islands and smoother alinement, installation of signals and lights, pavement markings for left and right turns and crosswalks, and channelization for turning traffic, all of which improve trafic flow and safety.

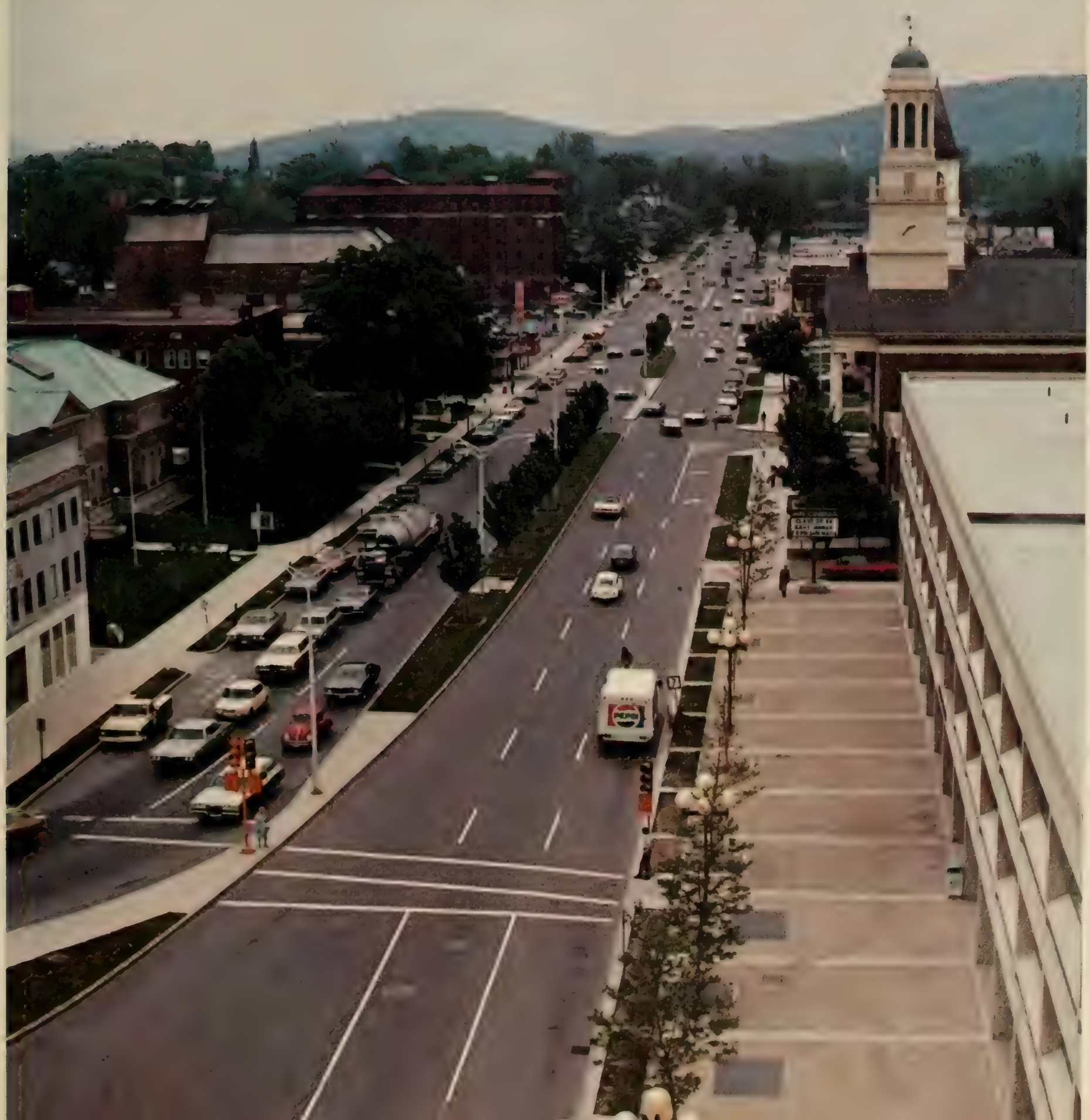


ways-authorization of a new system, the FederalAid Urban System, and of expenditures of funds on exclusive bus lanes.

The authorization of the Urban System presumably was attributable, at least in part, to the findings of the 1970 Highway Needs Study, which focused attention on the disparity between functional and administrative systems in urban areas, as well as to the increasing demands of city officials for more Federal aid. The study in effect confirmed their position. Thus the new system concept was established. The Federal-Aid Primary and Secondary Systems would still extend into and through urban areas to form a connected statewide network. The Urban System would, in urbanized areas, serve the heaviest corridors and major centers of activity to aid intra-city movement. No route on the Urban System could be on another Federal-aid system, and each route must connect with another route on the Urban System or one of the other Federal-aid systems. And the System must be selected by the appropriate local officials and the State highway departments in cooperation (the local officials appeared first, it may be noted) and on the basis of the " $3 \mathrm{C}$ " process.

That this step in recognition of urban street and highway needs was taken rather gingerly is seen in the funding authorized for the different programs. Funds were continued for the fiscal years 1972 and 1973 at its same level as for 1970 and 1971 for the "ABC" program, and with the traditional 45-30 distribution between them. The $\$ 1.1$ billion authorization was divided 45 percent for projects on the Primary System, and 30 percent for those on the Secondary System, each available for either rural or urban portions. The remaining 25 percent was available only for sections on either system within urban areas. In addition, $\$ 100$ million was authorized for each year for the new Urban System, but as an offset, the authorization for TOPICS was reduced from $\$ 200$ million to $\$ 100$ million. As another apparent offset to this foot-in-the-door approach to aiding urban areas, $\$ 125$ million was authorized for projects on the Federal-Aid Primary and Secondary Systems only outside urban areas, 60 percent on the Primary and 40 percent on the Secondary Systems. Finally 50 percent of the authorization for Federal-aid primary and secondary funds for use in urban areas could be applied to the Urban System.

The other significant departure from tradition was seen in section 111 of the 1970 Act which authorized the use of Federal-aid funds for the construction of exclusive or preferential bus lanes, and for facilities such as bus loading areas, shelters, and fringe or corridor parking areas to serve bus or other mass transportation passengers. This action gave specific authorization to a program for encouraging the greater use of buses, an idea that had been urged for several years by the Bureau of Public Roads. ${ }^{19}$ Administratively the Bureau of Public Roads had held that it would be appropriate to reserve a lane for the exclusive use of buses if so doing permitted the movement of more passengers than would result from its general use by all vehicles. Despite Bureau, and later Federal Highway Administration, urging, few State highway departments had been sympathetic to this approach to aiding urban public transportation, California and Wisconsin being notable exceptions.

By the time the Federal-Aid Highway Act of 1973 was approved on August 13 of that year, the 4-system hierarchy, initiated in the 1970 Act, had become firmly established, and authorizations were made in terms of the new concept. With the Interstate System funds authorized under earlier legislation, the old $\mathrm{ABC}$ 45-30-25 relationship was finally dropped, and authorizations made separately for the Federal-aid highway rural, Federal-aid secondary rural, and Federal-aid urban programs. The annual amounts for the last 2 years, 1975 and 1976, of the 3-year authorization, built up slightly from 1973 , were $\$ 700$ million for primary rural, $\$ 400$ million for secondary rural, and $\$ 800$ million for urban. In addition $\$ 300$ million was authorized for extensions of the Federal-Aid Primary and Secondary Systems within urban areas.

Other provisions of the 1973 Act showed more positive concern over the urban program. The authority to construct highway facilities for public bus transportation was extended to include participation in the purchase of buses, and after July 1, 1975, for the construction of fixed-rail facilities and the purchase of rolling stock from Federal-aid urban funds. No new authorization of funds was provided, however, and to benefit from such applications of funds, a city must have the project included in the program of the State highway department.

A more significant departure, however, permitted a State, at the request of local officials and when found to be in accordance with the results of the " $3 \mathrm{C}$ " process, to delete Interstate System links and apply the amount of funds thus saved to a nonhighway public transportation system. The funds involved would not come from the Highway Trust Fund, however, but would be drawn in the same amount from general funds.

Another provision authorized $\$ 50$ million for each of 3 years for a "special urban high density traffic program," for the construction of highways, not more than 10 miles in length, connecting to the Interstate System, if conforming to the results of the " $3 \mathrm{C}$ " process, in areas of high population density and heavy traffic congestion that will serve the urgent needs of commercial, industrial, airport, or national defense installations.

Still another section of the 1973 Act redefined the manner of selecting the Urban System by requiring not that it be selected by local officials and the State highway departments in cooperation, but by "... the appropriate local officials ... with the concurrence of the State highway departments ...," thus moving a step beyond the 1970 Act in enlarging the authority of the local officials. The System still must be in conformity with the " $3 \mathrm{C}$ " process, however, which is a cooperative process.

These provisions and others relating to special interests or matters of local concern cannot help but leave the impression that the Congress was acting more on the basis of accommodating different groups or interests in program details or in minor expansion of traditional boundaries of highway policy than on the basis of long-range plan or policy goals. That 
the periodic needs studies were not without their influence, however, is seen in the provision in section 148 of the 1973 Act that called upon the States to designate three Federal-aid systems. The first was to be the Federal-Aid Primary System, including extensions into and through urban areas. The second was to be the Federal-Aid Secondary System, now to be confined to rural areas. And the third was to be the Federal-Aid Urban System in all urbanized areas and in smaller urban areas that the State highway department might want to designate. The systems were to be designated on the basis of their functional use as anticipated in 1980, which necessitated perceptive planning of routes by function in areas yet to be urbanized or developed in other ways. All the system designations were to be effective after June 30, 1976.

In a requirement for earlier action, another section of the 1973 Act called for the designation of "Priority Primary Routes." These routes were to be high traffic sections to supplement the Interstate System by "... furnishing needed adequate traffic collector and distributor facilities ..." These routes were to be selected by the State highway departments in "consultation" (not cooperation) with appropriate local officials. The States were to make an initial selection of such routes and estimate and report to Congress by July 1974 their cost. Without specific mileage limitation, this provision was as open-ended as the initial authorization of the Federal-Aid Secondary System. But funds increasing from $\$ 100$ million in 1974 to $\$ 300$ in 1976 were authorized.

Perhaps the most significant policy statement of this or other recent acts was the "Declaration of Policy" under section 107. This section declared that ". . . since the Interstate System is now in the final phase of completion it shall be the national policy that increased emphasis be placed on construction and reconstruction of the other Federal-aid systems ... in order to bring all of the Federal-aid systems up to standards and to increase the safety of these systems to the maximum extent." This policy declaration presumably would curtail, and hopefully end, the bitby-bit extensions of the Interstate System. The Interstate System upon its completion, delayed and in some areas curtailed as it was, will be fulfilling admirably, even beyond expectations as to its traffic services and economic benefits, the concept laid down by Congress in 1944. It was in anticipation of this that AASHO and Public Roads began the postInterstate studies in 1964, studies that reached fruition, at least in part, by this provision nearly a decade later.

\section{Statewide Highway Planning}

At State level following passage of the Federal-Aid Highway Act of 1956, planning efforts began rapid expansion. The planning entailed in the early stages of the Interstate program, particularly in the urban areas, a greatly enlarged scope of responsibility -in addition to the amount of work involved, its broadened planning to encompass financial and economic areas and increasingly, the consideration of social and environmental aspects of the highway programs. Fortunately, because planning funds available were a fixed percentage of the apportionments, the in- creased amounts apportioned for construction under the 1956 Act meant substantial increases in planning funds. Certainly no other general planning or transportation planning program ever was so strongly funded in relation to current planning needs. Even though in the early years of the post-1956 period funds quite amply met the needs, as more and more elements were added to the planning responsibility, this relative affluence soon disappeared.

All States accepted as a matter of course the necessity for keeping planning data current, and many utilized the facts collected in response to studies called for by Congress as a basis for developing statewide plans and programs embracing all road systems. Many reviewed their system designations, and some repeated their earlier statewide needs studies. More attention was paid to long-range programing and efforts were made to provide analytical bases for project annual improvement needs for the 10- and 20-year program periods.

Many States adopted the "sufficiency rating" approach, which rated each road section on the basis of its traffic capacity, structural adequacy, and safety. This approach was based partly on planning data, but more on visual observation of current conditions by an annual inventory. It resulted in a listing of projects on the basis of their current adequacy, or "sufficiency," as opposed to the longer range "deficiencies," more commonly reported in the broader needs studies. Knowing the funds to be available for a coming year, a State could develop a construction program simply by going down the list of sections starting with the one currently least sufficient until the available funds were all committed. While this was perhaps not planning, in that it emphasized only current conditions, it was a useful administrative tool because it permitted the highway department to demonstrate to the public that its current program was directed toward correcting the most severe deficiencies, as determined on an objective rating scale. $\mathrm{Ob}$ jections to this approach were that it did not reveal the real future needs, but simply provided an orderly way to distribute currently available funds.

Other States, after the completion of the AASHO Road Test in Illinois, made efforts to adapt to their programing procedures the methods used by the road test staff to determine when a section had been so badly damaged as to justify its being retired from further testing, or in short, failed. The method employed a profilometer or a roughometer to measure periodically the deterioration in riding quality, section by section. These readings did more than provide an objective basis for deciding that a section had failed. It was found in analysis that the trends in current riding quality measurements, called the "present serviceability rating," could also be used as a reliable prediction of when failure would occur. It offered, in effect, a different approach to the life expectancy of pavements by an analytical rather than by the earlier actuarial approach and section by section rather than simply by pavement types. Some States reasoned that similar trends of serviceability ratings could show when particular sections of routes on their highway systems would need replacement, and saw in that approach a means not only of antici- 
pating annual program needs for several years ahead, but possibly another approach to developing longrange plans - a synthesis approach-and with cooperation from the Bureau of Public Roads explored the area with some success. One of the early applications of this approach was made by the New York Thruway Authority in estimating its long-range major maintenance and replacement programs.

By various approaches individual States were successful in developing and keeping reasonably current long-range plans and, to a less satisfactory degree, medium and short-range programs, generally based on objective planning processes. States probably were then and now are better able than the national government to develop transportation policies objectively.

Increasingly States are gearing their transportation policies and plans to general land use development policies. Connecticut and Wisconsin offer early examples of transportation considerations as a key element in implementing desirable land use policies, with the highway departments, and more recently in some cases transportation departments, joining with other State departments in developing the long-range goals and policies. Wisconsin also offers an early example of forecasting transportation needs by a sophisticated simulation model developed as an outgrowth of the urban transportation models expanded to statewide scope. Illinois was another State entering early into the use of statewide simulation models. Increasingly States are coming to accept the futility of attempting any longer to develop a highway policy in isolation from other modes of transportation, or to develop a transportation policy except as an integral element of an overall land use development policy, a view the Congress has yet to accept.

At the beginning of this chapter, the question was raised as to whether in the United States any highway planning was carried on or whether what is called highway planning more realistically is highway improvement planning. Alaska was cited as an exception. It so happened that an opportunity to illustrate this distinction came with the Alaska Highway Study.

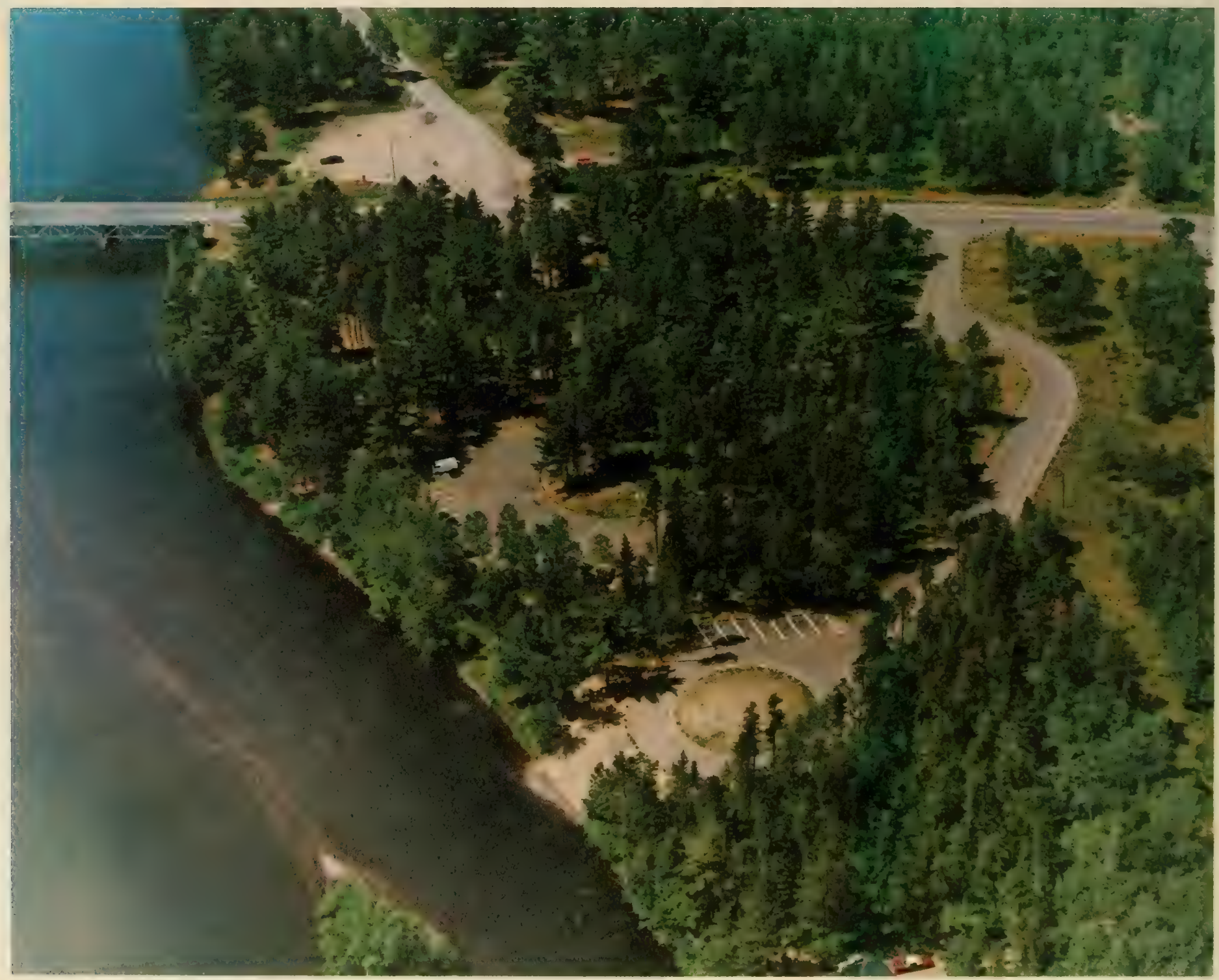

In the early 1930's, engineers planned to make the St. Croix River a part of a proposed Lake Superior-Mississippi River canal. However, in 1968 Congress made the Upper St. Croix part of the national system of wild and scenic rivers. Later the Wisconsin Division of Highways developed a wayside and canoe landing along State highway 35 and negotiated scenic easements to assure that a 200-foot strip along the river and the highway will remain in its natural state. 
Under section 13 of the Federal-Aid Highway Act of 1962, the Secretary of Commerce was authorized, in cooperation with the State of Alaska, to make a study of the adequacy of the Federal-aid highway system, to make specific recommendations for construction of roads through undeveloped areas, and to recommend a feasible program, including the sharing of cost responsibilities, for implementing the recommendations. Although the Act authorized funds, no funds were appropriated in that year, so the study could not be undertaken until $\$ 400,000$, half the original authorization, were appropriated in 1963. Through the Bureau of Public Roads, two consultants were employed, qualified by experience in economic and engineering areas and by previous work in Alaska. Their report, completed early in 1966, was forwarded to Congress in May of that year.

Briefly the consultants found that the current Federal-aid systems, primary and secondary, adequately served the population in Alaska, in fact more nearly meeting desirable standards than in any of the "lower 48" States. It could be anticipated that the entire system could be brought up to desirable standards within 16 years with the continuation of the current rate of authorizations. As to highway needs in undeveloped areas, the consultants found virtually none. Although it was recognized that natural resources would be developed, what specific resources in what specific areas would warrant development could not be forecast. Thus, the consultants concluded that a small amount of funds should be available to draw upon when and if a potential resource development prospect appeared.

What Alaska needed most was assistance in funding maintenance. Extraordinary maintenance problems existed because of snow and cold, and the use of Federal aid for maintenance was, as elsewhere, prohibited by law. Because of its great area, Alaska received a large amount of Federal aid in relation to other States. Alaska's matching ratio, because of the preponderance of land in public holding, was about 5 percent State and 95 percent Federal, relatively little State matching in contrast to other States. However, with small population and few vehicles, even with relatively high road-user taxes, virtually all highway revenue was required to match Federal aid, and maintenance had to be financed from general funds.

The reasoning, perhaps unexpected, with respect to the place of the highway in resource development, was interesting and could well be an example for those promoting development in other areas. Alaska is tremendously rich in natural resources, but little was then economically feasible for development due to its remoteness from population centers and its dependence upon highway transportation. Its timber resources are close to tidewater. At the time of the study, oil production was close to or in tidewater. Exploration of the vast potential of the North Slope would not be brought on simply by the existence of a highway, although if other factors made its exploration feasible( as now has occurred), a highway to permit pipeline construction and maintenance would be a necessity. Similarly the Rampart Dam, when and if justified, would require a highway connection, but building a highway to the site would hardly initiate its construction. Tourism, a growing factor of the economy despite high prices and the great distance from population centers, would require no new highway development, for most of its scenic features, its glaciers and mountain peaks, and its hunting and fishing areas are within easy reach of the present system. And there is no way to judge whether any of the widely scattered mineral resources would be feasible for development simply as a result of highway improvement. Thus, the recommendation of a small "drawing account" for development roads should resource development in unanticipated locations be found feasible.

The consultants proposed three alternates. The first would authorize additional appropriations from general funds to aid the State in maintenance and in constructing tertiary non-Federal-aid system development roads where and when opportunity appeared. The second would allow the use of regular Federalaid funds for tertiary road construction. Both alternates would provide also for improvement in the ferry system, as the "marine highway" system is economically more desirable than attempting to provide land transportation between certain points, such as connecting Juneau, the capital, to other parts of the State. The third alternate simply would authorize the use of a portion of regular Federal-aid funds for maintenance. All three alternates contemplated special authorizations for a 5-year period.

The Department of Commerce rejected the first alternate as not complying "with the President's guidelines for budgetary ceilings and fiscal management." It recommended the acceptance of the second and third alternates. Agreement could not be reached within the Administration, which held that to make special concession to Alaska was inconsistent with a policy of equal treatment to all States and that authority to use Federal-aid funds on nonsystem roads or for improving the ferry system was not appropriate. It was also held by some that the 10 percent of construction funds for maintenance was excessive, but perhaps any construction funds unutilized might be used for maintenance, only at a rate declining from all of that amount in the first year to none after 5 years.

Finally when no agreement could be reached within the Administration, Congress brought pressure to produce the report which led the Secretary of Commerce to transmit the report in May 1966 with his recommendations unchanged, but included in the report a letter to him from the Bureau of the Budget explaining its disagreement.

The controversy proved quite academic, however, by the Federal-Aid Highway Act of 1966, which was enacted 4 months later. The Congress accepted the evidence of need as described in the report by authorizing Federal-aid funds for development roads, and increasing the amount of "construction and maintenance" by $\$ 14$ million annually for a 5 -year period, 1968 through 1972, to be appropriated from general funds, not the Highway Trust Fund. 


\section{Planning In Urban Areas After 1956}

While the 1956 Act ushered in a new era in highway transportation with major emphasis on completing the Interstate System, its effect was but little less on the problems of the urban areas. Funds had been available, even if in relatively small amounts, for expenditure only in urban areas since 1944. Many State highway departments had engaged in the urban transportation studies with the cooperation of the cities. But the States were few indeed that had accepted the role they ultimately must in working with the cities to aid in solving their transportation problems. While many States sought the cities' advice and cooperation in connection with programs in urban areas, their concern generally (and quite naturally) was more with getting the highway through the city in an acceptable manner than in contributing to a solution of the city's internal transportation problems. For the next decade the problems of the States in carrying on the Federal-aid program in urban areas were far more severe in the areas of organization and administration than in the technical or even financial areas. But if the States were not prepared to work together with the cities, the cities were no better prepared to join with the States in a full, cooperative manner.
Early in 1957, sensing well the problems that would arise, Pyke Johnson, President of the Automotive Safety Foundation, following the role it often played of getting people with common interests together, arranged to meet with the Executive Secretary of the American Association of State Highway Officials, Alfred E. Johnson, and Patrick Healy, Executive Director of the American Municipal Association, in the Office of the Commissioner of Public Roads, C. D. Curtiss. In short order it was agreed that a top-level committee, seven from each association, would be formed to explore the State-city problems and to act as a catalyst in working toward solutions. Confirming their representatives' action, AASHO named its President, its Executive Secretary, the Director of Planning of the Bureau of Public Roads and four other key chief administrative officers. The AMA named its President and six other top mayors or city engineers to the committee, known as the AMAAASHO Committee on Highways. Public Roads provided the committee secretary.

The gap between the two groups at the first meeting was clearly evident, although a good rapport was established. One incident illustrates the differences. The AMA group asked the AASHO representatives

The Grand Avenue Overpass makes a graceful split to avoid the Albuquerque Convention

Center and, at the same time, provides

space for off-street parking.

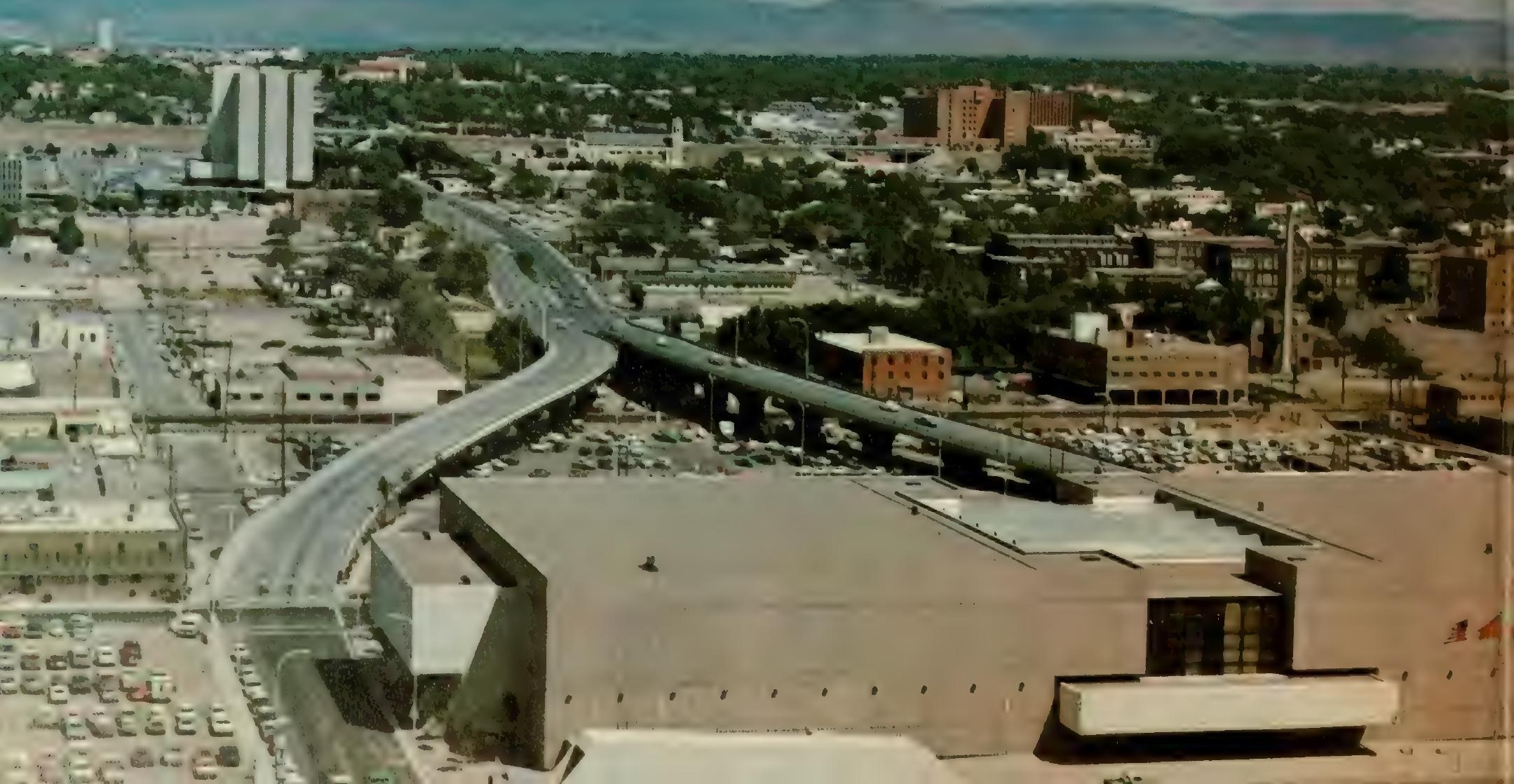


to recommend that the States each organize an "urban division" to give undivided attention to urban problems, paralleling the secondary roads division each State had set up in response to an earlier provision of the Federal-aid highway legislation. The AASHO group demurred and the proposal was again introduced at the next meeting. But instead of being accepted, it was settled by a statement by Jasper Womack, Chief Highway Engineer of California. Cutting through all the verbiage, he observed that the urban problems had become so widespread in California that he might say that the whole Division of Highways was an urban division, and that there was no way in which one particular unit could deal with all facets of State-city relations, that the whole department must be involved. General acceptance of that view cleared the air and led to a mutual understanding and a truly cooperative spirit that persisted for many years.

\section{The First National Conference on Highways and Urban Development}

One of the first activities in which the Committee was engaged was the cosponsoring, along with the Highway Research Board, of the first National Conference on Highways and Urban Development. At that time the Automotive Safety Foundation was supporting the staff activity of the Highway Research Board Committee on Urban Research (later to become the Urban Research Department of the Board under the chairmanship of Pyke Johnson, by then retired from the Automotive Safety Foundation). Through this Committee, the Foundation provided financial support and technical assistance for the Conference.

The AMA-AASHO Committee made sure that key highway and city officials would participate. The HRB Committee arranged for participation by key transit officials, planners, and other professionals and appropriate leaders from the business and academic communities. The Executive Director of AASHO agreed to serve as General Chairman, and ran the Conference with a firm hand. In October 1958 the first National Conference on Highways and Urban Development was held at Sagamore, a conference center operated by Syracuse University.

Had there been any doubt as to the sincerity with which the conferees would go about their task, it was quickly dispelled in the situation in which they found themselves-living, eating, and working together for a full week in the total isolation of the Adirondack Mountains.

In his foreword to the Report, Chairman Johnson says,

The frank discussions of basic issues produced many useful guidelines for developing sound cooperative plans and for expediting action. Recognizing the great interest in this subject throughout the country, the Conference felt that these constructive ideas should be given the widest possible circulation as an aid to the many officials and civic leaders who have the responsibility of moving the highway program and for coordinated, planned urban development but who were not privileged to attend the Sagamore Conference. ${ }^{20}$
In the early stages of the discussions, parochial views were expressed and professional jealousy was sometimes apparent, but after all views were fully aired,

The Conference agreed that the final choice among possible alternatives in highway location and design should be guided by a 'grand accounting' of costs and benefits. Advantages and disadvantages of each alternative - in terms respectively of the highway user and the community-should be added up and evaluated, in comparison with the total cost entailed. ${ }^{21}$

Even as of 1958, thoughful highway and city officials found themselves together on the need for a "grand accounting" and on the need for considering "community values." Probably no one present, however, had any notion of the difficulty of measuring the community costs and benefits.

Agreement on principles was not difficult. Highway officials urged that their departments "should be staffed with personnel experienced in urban problems" and that "State Highway Departments, in cooperation with the local governments, should develop a tentative program of urban highway improvement for a period of at least five years in advance . .." 22

This latter step was agreed to by the highway engineers present only after considerable discussion because of the unfortunate experience of some that programs announced in advance led to land speculation and skyrocketing costs of right-of-way acquisition. It was finally accepted as a concession that must be made if the cities were to be able to gear their programs to those of the States.

The State representatives agreed that the departments "should consult with local authorities on a continuing basis in highway planning" and, what was probably far more significant than then realized, that "it would be helpful to send engineers to seminars in city planning." ${ }_{23}$

On their part, the city officials and planners accepted their responsibility for developing "tools and plans which can be of inestimable value in planning the urban highway program." 24 These tools included a land use plan, transportation plan, capital improvement program zoning ordinance, subdivision regulations, and others. It was agreed that some of the purposes such tools could serve were:

Zoning and subdivision controls can help achieve economy in road development and protect the service values of the facilities after they are built ... City planners need to develop and use factual material to support suggested controls for orderly community development as related to highways. However, the community must stand behind and support these controls to obtain such benefits and economies. ${ }^{25}$

(It is fair to ask whether the planners and elected city officials have even now succeeded or made real effort to meet this responsibility, accepted by their representatives.)

It was noted that

Urban planning can aid in determining the scale and character of the highway program by providing highway officials with estimates of urban growth and development likely to take place in a metropolitan area in the next two decades or more. If new highways are to accomplish their purpose and not become obsolete soon after completion, their planning must take into consideration the patterns of community growth, as well as the urbanizing influence of the highway itself. ${ }^{20}$ 
The conference concluded on an optimistic note. The conferees, perhaps for the first time, had obtained a good knowledge of the total problem and were resolved to do their agreed upon parts to solve it. The question, of course, remained as to how to impart to other officials and professionals and civic leaders the understanding reached, the principles accepted, and the responsibilities that must be assumed.

The first requirement of dissemination was the publication of a report of the meeting, and this the Automotive Safety Foundation handled in admirable fashion, with the report "Guidelines for Action" receiving wide distribution and general acclaim. More important, however, was the followup to get the guidelines put to use. Because of the high caliber of the conferees and their stature in their own organizations, channels to provide for this followup were available and open. Among the 55 participants were included four highway officials who had served or were to be the heads of their respective State highway departments. Two of the mayors had served or were to serve as presidents of AMA, and several other participants held or were to hold office as presidents of their respective national professional organizationsplanners, traffic engineers and public works directors, for example. Their participation in the conference and their endorsement of the findings were important, especially to members of their own groups.

\section{An Action Program}

The urban travel habit studies described earlier were by then being carried on in most large cities. Major efforts in research in ongoing studies in Detroit, Chicago and Philadelphia, for example, were breaking new ground in techniques for relating transportation demand to land use and developing models for predicting future land use to serve as a basis for plans for future transportation facilities. But the great bulk of the cities in the medium population group were not active in preparing for their future transportation needs.

It was in this atmosphere that the AMA-AASHO Committee continued to work through their parent organizations to stimulate greater effort and a higher degree of coordination between State and local officials. Appearances of speakers at one another's meetings helped, as did releases describing advances in technology and improved administrative and organizational approaches. It was ultimately concluded by the Committee, however, that a more specific attack must be organized, and at its meeting in Kansas City in January 1962, adopted the "Action Program."

This program as developed by the Committee called for a series of regional meetings to which all State highway departments and all cities would be invited to send representatives. At these meetings the cooperative planning process would be described, the sources of funds to undertake the studies outlined, and the availability of technical assistance noted. Through the regional engineers of the Bureau of Public Roads, each State in the region was asked to select in advance of the meeting for that region a "pilot city," generally in the population range of 50,000 to 250,000 , for it was felt that most of the larger cities were already engaged in the cooperative process. The pilot city would then serve as an example for officials of other cities in the State, where they might observe how the process was carried out with the hope of their undertaking similar work in their own areas.

The program as developed by the AMA-AASHO Committee was quickly endorsed by their respective parent organizations, and by the National Association of County Officials (NACO) which was invited to join with the AMA and AASHO as a sponsor. The program, known thereafter as the AMA-AASHONACO Action Program was launched in May 1962 with the first regional meeting in Chicago. As was the case in all regional meetings, the regional engineer and all division engineers of the Bureau of Public Roads participated by direction of Rex Whitton, then Federal Highway Administrator. The chief administrative officer from each State highway department, along with staff personnel, attended. Mayors or other representatives from many cities were there, along with a number of county officials. Staff members of the Bureau of Public Roads and the American Municipal Association helped organize that and the other conferences. Representatives of the Housing and Home Finance Agency (HHFA) took part in this and all other conferences to explain how "701" planning assistance funds* could be made available to the cities to aid them in meeting their share of the cost of the cooperative endeavor.

The series extended into June 1963 before the entire country was covered. During this period, over 1,500 State and local officials were brought face-to-face with planning, many for the first time. But during the series came the 1962 Federal-Aid Highway Act, which changed somewhat the emphasis of the series of meetings. Instead of encouraging a voluntary effort, the purpose became one of explaining the requirements of Section 9 of the Act, now known as Section 134 of title 23.

There was no change in principle, however, nor in the approach to the problem as a result of the 1962 Act. Prior to that it was emphasized to the participants that while the program was being described by Federal officials, it was "your" program, one developed and officially endorsed by "your" organizations. The Federal role was to describe and help demonstrate how the program could help to give technical assistance and to aid in the funding.

The 1962 Act was not a new congressionally conceived requirement, but rather an endorsement of a process already being proved effective in many areas. The Act simply required its extension to all urban areas of 50,000 or more population. The language of the Act bears this out in the first and last of the three sentences that comprise section 9. The first sentence reads as follows:

It is declared to be in the national interest to encourage and promote the development of transportation systems, embracing various modes of transport, in a manner that will serve the States and local communities effectively and efficiently.

*rants to State and local governments for planning coordinated transportation systems authorized by the Housing Act of 1961 ( 75 Stat 149,170 ). 


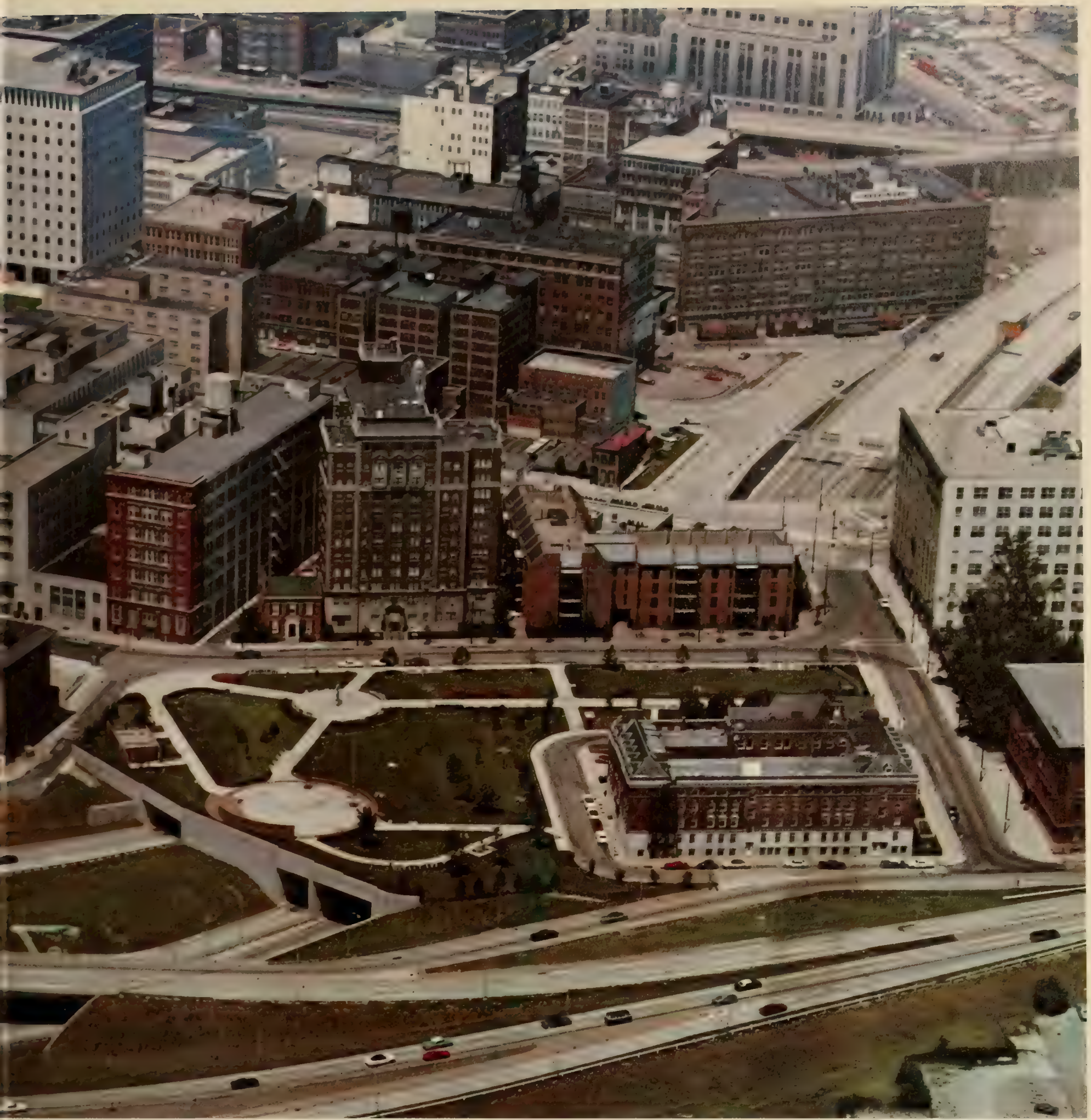

Cincinnati's 1948 Master Plan included certain specifo expressway recommendations. Exhaustive studies were made on this section of $I-\gamma 1$ to preserve the historic Iytle Park area. Two 3-lane tunnels for ramp traffic plus special lighting, ventilation, and flood and fire protection were all included. These tunnels also provide a base for restoring Lytle Park and the private development of a multimillion dollar apartment complex.

That is exactly why the Action Program had been undertaken. It is exactly what was recommended at Sagamore 4 years earlier.

Then the third sentence reads:

After July 1, 1965 the Secretary shall not approve... any program of projects in any urban area of more than 50,000 population unless he finds that such projects are based on a continuing comprehensive transportation planning process carried on cooperatively by the States and local communities in accordance with the objectives stated in this section. 
And how to meet that requirement was exactly the procedures that were being described in the regional meetings, although initially the requirement, of course, was not contemplated. At the meetings subsequent to the passage of the 1962 Act, it was pointed out that no Federal planning is involved, nor in fact is any planning required if no projects are to be programed in a given urban area. But if the States did expect to program projects, they could do so only on the basis of planning adequately performed by the States and local communities themselves. This section said it all in a few words. It put congressional muscle behind an ongoing effort-to make a requirement of a program generally being carried on that had been developing effectively but too slowly on a voluntary basis.

\section{The Hershey Conference on Freeways in the Urban Setting}

The year 1962 saw also the setting of another benchmark, the Hershey Conference on Freeways in the Urban Setting. By that time the Interstate program had progressed far enough to make generally apparent the impact it could have on urban areas. Criticism was being heard of the appearance of the highway, particularly of its overhead structures, and of the way in which it blended or failed to blend into the neighborhoods it traversed. While it was regarded beforehand as primarily an engineering conference, it had planners as participants and its product was an important planning factor. As expressed in the Foreword of the report:

The Highway program being carried out under the Federal-Aid Highway Act of 1956 constitutes the largest form of federal assistance to urban development. The state highway administrators charged with responsibility for this program, and the federal agencies involved, are aware of the significant role freeways will play in making the city an attractive and desirable place to live and work. This conference was called to solicit positive contributions of the professional groups who share with local, state and federal officials the concern that freeways be of widest possible benefit to the city. ${ }^{27}$

In the Background Statement, it was noted that "Since Sagamore, very substantial progress has been made in cooperative efforts between state highway departments and local officials in the planning of highways and land use in urban areas." After commenting on specific areas of progress since Sagamore, it was observed that ". . . the concept that urban highway systems should be planned in conjunction with comprehensive community planning is now generally and widely accepted." 28

The sponsors of the conference were the Bureau of Public Roads, the Housing and Home Finance Agency and the Automotive Safety Foundation, which again provided financial support and staff help in organizing and reporting upon the conference. They set up a Steering Committee representing:

The American Institute of Architects

The American Institute of Planners

The American Municipal Association

The American Society of Civil Engineers

The American Society of Landscape Architects

The Automotive Safety Foundation

The Bureau of Public Roads

The Housing and Home Finance Agency
With the heavy representation of professional groups, the Hershey effort in the freeway design field closely paralleled the earlier successful approach of the National Committee on Urban Transportation in the more general area of overall urban transportation.

Among the professional groups, the architects were most promimently represented, although other professions and professionals of other disciplines who were there as representatives of official agencies provided a good cross section of the technical, as distinguished from the administrative, participants in urban highway development. Unfortunately, the highway field was not well represented.

The early discussions were revealing of strong biases held by some of the participants. Some architects protested that the highway engineers invited them into the act only to provide a "cosmetic" treatment to structures beyond salvation as to appearance. They were critical of highway standards, especially of curvature, which they said demanded unnecessary and undesirable destruction of the fabric of the city. On their part, highway engineers protested that architects commissioned to design structures too often produced costly designs difficult to construct simply to produce unnecessarily refined esthetic effects.

Nevertheless, the conferees by the conclusion of the meeting came together on a series of findings and recommendations. Among the findings, perhaps the most important was:

Freeways cannot be planned independently of the areas through which they pass. The planning concept should extend to the entire sector of the city within the environs of the freeway. The impact of the freeways must be considered in terms not merely of limiting adverse effects but also of achieving positive opportunities for appreciation of value, for development of new land uses, and for changing land use through urban renewal and redevelopment. ${ }^{29}$

Following on the findings came a series of recommendations, sound then and still sound, for unfortunately most of them remain still to be carried out. Among them, three stand out. They were:

There is a fundamental need for teamwork in freeway planning and design. This means teamwork during the preliminary planning phase between the state highway departments who have responsibility for the planning and development of highways, and the municipal agencies responsible for the planning and development of the city. It also means teamwork during the design phase among highway engineers, architects, city planners, landscape architects and other specialists.

Effective participation in design by these professions means participation from the very beginning when the first choices as to location, roadway alignments, right-ofway cross sections and structures are being studied. The full realization of the contribution of the design professions cannot be obtained unless this is done.

More effective programs for informing the public and obtaining community participation in freeway development must be undertaken by state highway departments and local governments. A freeway program cannot obtain in any other way the community concensus necessary to its successful execution. Members of the design professions and other specialists may render valuable assistance by indicating their concurrence with the design and planning objectives presented to the public by the highway officials. ${ }^{30}$

That problems would arise in implementing the findings of the conference evidently was anticipated as noted in recommendation number 7 , which recog- 
nized the limited talent and experience needed to cope with the problem and recommended educational and inservice training programs. In recommendation 8 , it recognized the complexity of the urban problem, and the "... imperfect and incomplete knowledge of the desires and needs of families who live in cities and the mechanics of the functioning of urban complexes" and recommended larger and more intensive research into all aspects of urban design and urban living. But perhaps the most fundamental reason that progress was (and still is) difficult is seen in recommendation 9, the import of which is well expressed in its first sentence: "The necessity for compromise among conflicting philosophies and design objectives often must be recognized in urban and freeway design." $" 31$

A complex viaduct, crossing several streets and rail lines, serves as an entrance way to Eugene, Oreg. However, the local street system remains intact, and attractive park areas provide neighborhood contacts for pedestrians.

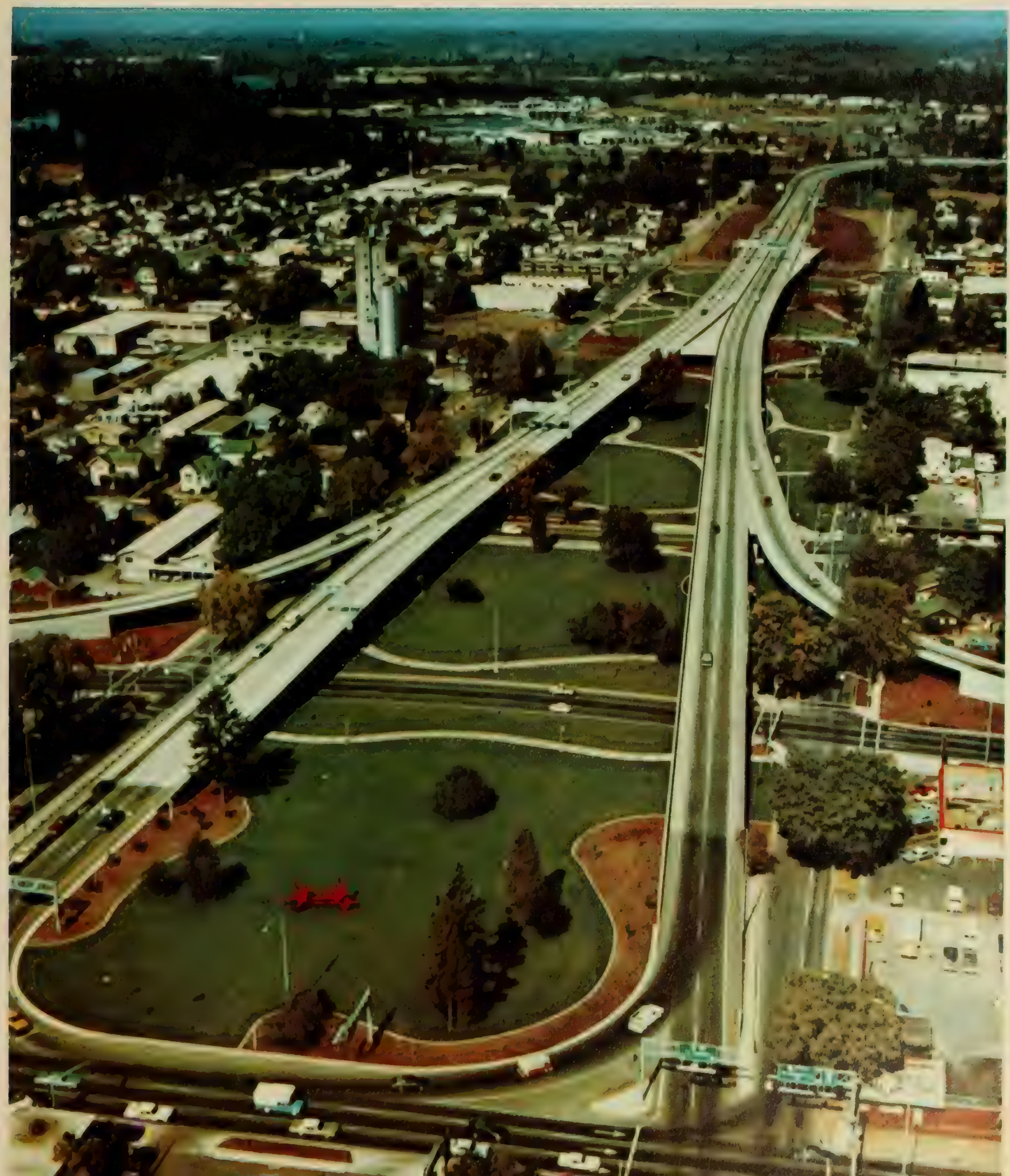


There was little followup of the Hershey Conference. The findings and recommendations were sound and far-reaching, the report was well prepared and widely distributed. But there was no group with muscle to get behind the promotion of the results of Hershey as did the AMA-AASHO Committee in the case of Sagamore. And the professional groups, the predominant participants at Hershey could, even had they tried, have had little impact on the official agencies, State or local, unless they were receptive.

Transition into the "post-' 62 " period was not difficult. Passage of the Act, of course, brought immediate acceleration of planning effort by the States, for the effective date of the application of the réquirements of the Act, July 1, 1965, was less than 3 years from the date of its enactment. The first step in implementing the Act was to spell out the planning requirements that it placed on the States and the local communities. The wording of the Act, that its intent was to encourage the development of long-range plans and programs, made clear that the cooperation between the State highway departments and the local communities must be evidenced by agreement between the highway departments and those in the local communities who had responsibility, the elected officials, for committing those communities to a program. This interpretation left many city planners unhappy, for they had generally been responsible to planning commissions which were often independent of the local elected officials. But they generally had no commitment authority. How the States were to come into agreement with the multitude of local jurisdictions in the larger areas presented real problems, but the means, differing in one way or another, were reached in all areas.

As to the technical requirements for a planning process adequate to meet the intent of the Act, the Bureau of Public Roads turned to the AMA-AASHO Committee as representatives of the State and local communities for advice and assistance. The Committee designated a small task group to work with the Bureau, and after much deliberation and testing among knowledgable people in both associations, a BPR Instructional Memorandum was distributed in March 1963. Because of the thoroughgoing writing and rewriting of this memorandum, it still stands with only minor modifications, as the basic urban transportation planning document. ${ }^{32}$ It is perhaps not amiss to recall that it provided specifically that attention be given to social and community value factors-preservation, enhancement, and extension of parks and open space, preservation of historic buildings and sites, avoidance of disruption of neighborhoods, and appearance of the facility both from the viewpoints of its users and its neighbors-all items brought out at the Hershey Conference.

The need for rapid expansion of the planning process across the Nation led to the employment of consultants for the basic data collection and processing in many areas. And it required the rapid formation of policy committees or groups by other names, representing the States and the local communities in each urban area, complicated by the fact that many urban areas extended across State lines. As a result most of the policy direction was by ad hoc groups, hopefully to be superseded by more permanent organizations.

The Second National Conference on Highways and Urban Development

Under these circumstances, the most remarkable achievement in planning ever seen in this country was developed. Along with the development of the machinery to administer the process came striking advances in technology and in data processing equipment that produced a degree of sophistication in planning techniques that perhaps outran the ability to administer it. By 1965 all but a handful of the then 233 urbanized areas had qualified to meet the terms of the Act. It was against this backdrop that the Second National Conference on Highways and Urban Development was held in December 1965 in Williamsburg, Virginia.

The Williamsburg Conference was the direct result of the concern within the AMA-AASHO Committee that plans, then in the formulation stage, be converted into programs and the recognition that the issue of evaluating social and community values and relating transportation plans and programs to them had not been met. At its meeting in November 1964, the Committee agreed to hold a conference to review the state-of-the-art and recommend courses of action for the future and to invite the National Association of County Officials to join the other two groups as an official sponsor. The Federal Highway Administrator expressed strong support for the idea and instructed the Director of Planning of the Bureau of Public Roads to find the necessary funds. This he did, half within his own budget and half from the Automotive Safety Foundation, which once again not only provided financial support but also the near full-time assignment of the Assistant to the President to aid in organizing the conference and producing the report. The objectives of the Conference as spelled out by the sponsors were as follows:

To identify community values, goals, and objectives; and to explore how development of transportation systems can serve to enhance values and aid in reaching goals and objectives.

To evaluate and recommend alternative arrangements for the organization, administration, and financing of the cooperative continuing transportation planning function within multi-jurisdictional areas.

To recommend methods and procedures for converting cooperatively developed plans for interrelated systems of transportation in urban areas into improvement programs of state, county, and municipal governments. ${ }^{33}$

The Conference was particularly significant in the degree to which the official agencies assumed responsibility for its conduct. The Steering Committee comprised the executive directors of the three Associations-A. E. Johnson for AASHO, Patrick Healy for AMA (now National League of Cities) and Bernard Hillenbrand for NACO. The Bureau of Public Roads provided the Chairman of the Steering Committee (and of the Conference itself) in the person of the Director of Planning of BPR and the Committee secretary. ASF provided the Conference secretary. Each executive director presided over one of the three full-day working sessions.

Of the 74 participants, nearly half were there as official designees of the sponsoring association. The others constituted a good cross section of other profes- 
sionals from the fields of planning, architecture, landscape architecture, research, law and the transportation industries. Concerned Federal agencies were represented by high-level staff members. The directors of the planning studies thought to be the most successful were invited and contributed heavily. Among the highway officials were six who served at one time or another as presidents of AASHO and three others who were heads of their departments. Similar highlevel participation came from the other sponsors. The Federal Highway Administration and the Urban Renewal Administrator filled places on the program.

At Williamsburg there were still some parochial views expressed, and fairly sharp differences came out between participants as to the intent and effect of policies or practices of one or another of the agencies represented. But in general the atmosphere from the beginning was one of seeking means to cooperate in developing urban transportation facilities to benefit the whole community, users and nonusers alike.

A full day's discussion was devoted to the progress of urban transportation planning, emphasizing its technical gains and its financing problems. Another day was devoted to the broad problem of establishing community goals and objectives and determining social values, with successful examples in a few instances described. And another day was devoted to administration, not only of planning and development of plans, but of implementation, both of the transportation programs and of land use controls.

From this review of the state-of-the-art, it could be fairly concluded that tremendous gains in planning techniques had been accomplished and that the importance of close coordination between land use and transportation had been universally accepted. Examples of successful processes embracing both transportation and land use planning over the widest range of population and area boundaries showed that the needed technical processes and administrative machinery could be organized. In these areas it was clearly evident that they generally followed along the lines foreseen as needed at Sagamore. But more than that, the gains in the need for and ability to cooperate among States and their local subdivisions had become equally apparent.

The one area in which little progress had been made, it would seem, was in land use controls. While universally recognized that no transportation system geared to a land use plan could effectively serve land uses unless they developed in adherence to the plan, the assurance of implementation of a land use plan seemed no nearer that at Sagamore. In this area the following measures were proposed to the Conference:

We must define the governmental level at which landuse issues are to be decided.

We must devise positive, rather than negative, controls by which definitive allocations, or even prohibitions, of land use can be made.

We need powers by which public agencies can buy and hold land for future use in accordance with short and long-range derelopment plans legally established and in the public interest."

The Conference concluded that:

Local governments in urban regions should develop workable administrative mechanisms, such as associations of local governments, through which (a) the continuing, coordinated planning process can be carried out in cooperation with Federal and State agencies on a regional basis; and (b) regional plans can be effectively implemented. $^{35}$

In the deliberations and conclusions of the Conference no doubt was left that transportation plans must take into account social and community values, recognizing that as of that time there was no accepted basis for integrating them into the economic analyses customarily made of various alternatives. Again, research was indicated to be needed. But one important point emerged without question-transportation itself is a community value.

And in the conclusions, it was fully accepted that means to bring the decisionmakers into the planning process and to keep the public informed as the planning and programing progressed must be achieved. Words of the recommendation in this area were these:

Urban planning agencies should work actively to achieve (a) public understanding of the planning efforts, and (b) participation of decision-making agencies at appropriate points in the planning process. ${ }^{28}$

While it was accepted that citizens should be kept advised of the planning as it progressed, the conferees evidently saw no reason to bring the oitizens into the decisionmaking process, accepting that it was to make decisions that the local officials were elected.

The Williamsburg Report, like its predecessors, was an excellent statement of sound accomplishment and mutual understanding and was likewise given wide distribution. But it carried a stronger official endorsement than any that went before. It was an officially sponsored Conference, and that alone gave it more than usual stature. Beyond that the sponsoring associations made a point of urging their members to be guided by it. The executive director of AASHO noted in his letter transmitting copies of the report to the chief administrative officers of the member departments that "We hope that you will take advantage of reviewing this Report to indoctrinate your Department on the importance of our urban responsibilities and the magnitude of our urban challenges ..." The Federal Highway Administrator in transmitting copies of the report to the Bureau's field organization stated that:

The Williamsburg Resolves, buttressed by the accompanying text of the report, display an impressive area of agreement among the representatives of the several levels of government and the professionals of the different disciplines . . By this memorandum I am placing the Bureau unequivocally in support of the principles enunciated in this report, and I shall expect all our offices to be guided by them.

\section{Problems of Implementing the Conference Recommendations}

It has been said that the Williamsburg Conference marked the high-water mark of urban transportation planning. Without judging the merits of this view, it did mark the high point in efforts of the professionals and associations of officials to join together in a common approach to the problems they had by then fully agreed were mutual. It highlighted a "decade of cooperation." Following that there seems to have been a decline in real cooperation, and competitive forces both within and without the transportation 
The need for coordinating programs for the different modes of transportation was spelled out in Toll Roads and Free Roads and in Interregional Highways, was recommended at every conference, and likewise was made a requirement in planning in the 1962 Act.

Much of the initiative in all this was taken by highway officials, but they received willing cooperation from the associations of city and county officials and the support of professional and public agencies outside the official circles. Notably, the Automotive Safety Foundation, supported by the so-called highway industry, provided financial support for the three major conferences as well as for many research and promotional activities in the broad areas of improving urban transportation and enlisted public support for sound programs.

The need for keeping the public informed was recognized at Sagamore, and at Williamsburg the conferees urged greater citizen participation in developing plans and programs.

Yet, 10 years after Williamsburg, transportation problems in many urban areas are no nearer solution then in 1965. In fact, unrestrained development in a large number of urban areas, without corresponding improvements in the total transportation systems, have made their solutions even more remote. In retrospect a number of reasons can be seen why the urban transportation planning effort leveled off or even slipped backward, only having to be revised later and broadened by direction at the national level by both the legislative and executive branches. The effect of any one of the several reasons can hardly be segregated because of their interrelationship both in nature and over time. Each contributed to keeping planning and the use of planning data in either policy or programing pretty much off balance, even though, in tracing the impact of any one reason separately, might not seem to indicate that it alone should have been unduly influential.

Funding had to be a major factor in the difficulty of continuing the effectiveness of planning in the urban areas. The data collection required for the initial phases of the urban transportation process (the " $3 \mathrm{C}$ " process), called for in all urbanized areas by the Federal-Aid Highway Act of 1962, was costly, exhausting any $1 \frac{1}{2}$ percent funds not required for other planning functions, and in many States, requiring considerable "over matching" by the States. While the costs of the continuing phases were far less on an annual basis, they were substantial. The development of simulation models and the computer program packages to implement them required only keeping basic data current by sampling methods and not complete resurveys, but even that was not inexpensive. Funding of the urban studies was also hurt by the decrease in "701" planning assistance funds from the Department of Housing and Urban Development. Under earlier policies of the Housing and Home Finance Agency, "701" funds available for general urban planning were directed heavily to aid the cities to carry on their shares of the cooperative process. With the establishment of HUD, the policies changed, and emphasis on long-range physical planning shifted to short-range socially oriented planning, thus, placing virtually the entire burden of Federal participation not only in transportation planning, but in general land use planning as well, on the Federal Highway Administration.

Other demands on planning funds were also increasing, however, particularly to finance the statewide surveys of highway needs begun by the joint action of the Bureau of Public Roads and the States and placed on a continuing basis by Congress. Other new programs imposed more and more responsibility on the process as the Congress underlined the essentiality of planning data to serve as a basis of State and urban programs. In 1968 the TOPICS program required that projects must be based on the "3C" process, as did the fringe parking program also authorized by the 1968 Act. The process must provide the basis for the selection of the Federal-Aid Urban System authorized by the 1970 Act, and aid to bus public transportation could be provided only if the routes and special urban high density traffic program, authorized in 1973 , were on routes approved by the "3C" process. While not specifically related to the " $3 \mathrm{C}$ " process, amendment of the basic provisions of the 1934 Hayden-Cartwright Act expanded the area eligible for use of the $11 / 2$ percent funds by adding a phrase to permit their use for planning of local public transportation systems, which under the earlier language also included planning for their financing.

While such expressions of confidence in the planning process developed by voluntary cooperative effort two decades earlier were heartening, the imposition of these and other added functions made the effective conduct not only of the added responsibilities but of the more basic requirements of statewide planning increasingly difficult simply because of inadequacy of funding. It was not until 1973, however, that Congress increased the $11 / 2$ percent limitation on Federal participation in planning by authorizing an additional $1 / 2$ percent to aid transportation planning in metropolitan areas. Apportioned on the basis of urbanized area population and required to be matched by the States, the funds must be "passed through" by the States ". . . to the metropolitan planning organizations designated by the State as responsible for carrying [on the " $3 \mathrm{C}$ " process]." By this authorization, additional funds were made available for metropolitan transportation planning, but still under the general responsibility of the States, not turned over carte blanche to the metropolitan areas. Attempts by those most concerned with planning over the previous years to increase the $1 \frac{1}{2}$ percent funds, never advanced to Congress by the Bureau, were finally successful only after their inadequacy became painfully apparent.

Coupled with inadequacies of funds was the lack of real concern for planning, especially in the urban areas, by some States, and similar indifference on the part of many cities. Changes in administration in local governments brought into office new officials who were not even aware of the cooperative process in which their jurisdictions were involved by formal agreement. Many State highway departments were not adequately staffed with professionals from disciplines other than engineering to conduct the urban planning process. Over one-third of the States resorted to consultants to complete the initial phases of the planning process in order to meet the July 1, 1965, deadline set by Congress in the 1962 Act. Having 
thus met the requirement to permit programing of projects in the urbanized areas, their interest flagged, and without staff to keep data and analysis current, the product of the planning became less and less adequate as a basis for programing.

Not to overemphasize the negative, a majority of the States, especially those with the largest cities, maintained and even strengthened their interest, and in cooperation with the Bureau of Public Roads, universities, and other agencies, advanced the technology of planning to a highly sophisticated level, so much so that the process may well have outrun the ability to utilize it fully in administration. But despite the advances in some States, a sufficient number allowed the process to become dormant or lag so badly as to bring into question whether the requirement that the process be continuing cooperative, and comprehensive, one or another or all three, were being met. Ultimately the Federal Highway Administration found it necessary to require that the Division Engineer in each State certify annually that the planning process in each urbanzied area satisfactorily met the requirement of the 1962 Act as a basis for programing projects in those areas.

Some of the problems with respect to the planning process were the result of its success. It became widely accepted throughout all the States, as its merits were proved under actual test. It became accepted in other countries as well, as their planners observed its operation in this country, or as American consultants made their experiences available to them. Some countries literally adopted the entire process bodily. But in the enthusiasm of those who developed and were applying the process so successfully, it perhaps became oversold. It had its limitations. The process as it developed could ascertain the relationship between transportation and land use and forecast the number of trips in an area, their origins and destinations, the mode of travel that would be used. It could "assign" trips to specific routes and estimate traffic volumes with accuracy. But it was developed on a metropolitan or "coarse-grained" scale. The sampling techniques and the simulation models were fully adequate to estimate future traffic volumes on freeways and major arterial streets, for example, or on a heavily traveled transit line, but they were not sufficiently "fine-grained" to permit showing turning movements at a particular intersection or volumes on particular ramps of an interchange. It was perfectly proper and hiohly desirable for the Congress, in authorizing the TOPICS program, ${ }^{*}$ for example, to require that projects be based on the planning process. But what the Congress perhaps did not appreciate, and what many States certainly did not, was that the process as then in operation was not the "be-all" and "end-all" in planning, and could not provide data needed to plan minor street improvements or traffic signal timing as TOPICS required. Some State highway officials found it hard to accept that the process, so expensively organized and conducted, could not supply the simple facts needed for TOPICS. All that was needed, of course, was to expand the " $3 \mathrm{C}$ " process to treat local situations, using tested,

* Section 135 of the Federal-Aid Highway Act of 1968 made the Traffic Operations Program for Improvement of Capacity and Safety (TOPICS) a continuing program. more conventional methods, and this was done. But the requirement to do so resulted in some disenchantment, temporarily at least, in some areas.

\section{The Future of Urban Transportation Planning}

The Bureau of Public Roads and others, fully aware of the limitations of the process, once the basic job of getting planning on an acceptable basis in all urbanized areas was substantially accomplished, began exploring methods of adapting the simulations procedure to broader use. Looking toward the finergrained traffic data needs, a "micro-assignment" procedure was developed to meet the needs of localized traffic analyses, and in the other direction, intensive effort by Bureau staff led to the development of a multiregional approach to urban transportation problems at policy, rather than planning and programing, levels.

This latter approach called TRANS, an acronym for Transportation Resources Allocation Study, made it possible to examine the effect on transportation needs of alternate land development policies and the dollar costs and benefits, direct and indirect, of various transportation alternatives to the extent pertinent factors could be expressed in monetary terms. In addition, it provided means for including "noncostable" items such as the impact of the alternatives on social and environmental areas to the extent their effects can be measured, but only in nonmonetary terms. The model is applicable to all urban areas aggregated on a national scale, or on a statewide scale, or down to the larger metropolitan areas. Its purpose, as described by two of the Bureau staff most deeply involved in its development, was:

The determination of long-range government priorities, policies, and programs is a complex process which blends hard politics with occasional naive idealism, trades off narrow interests against the common good ... It remains the responsibility of transportation planners ... to maintain a firm philosophical and functional commitment to provide policy formulators and decision-makers with a continuous flow of information and an objective capability for digesting and evaluating this information. The TRANS-urban approach must be viewed in this context. It is not an automatic policy making tool. It is intended solely as a mechanism that can provide rational information that was perhaps not previously available. ${ }^{37}$

This concise statement applies not only to the mechanical process that was developed. It defines the role of the planner as one in which he must supply usable objective data to the political leader, the decisionmaker, and it calls on the decisionmaker to use it.

The planning process has indeed become a highly sophisticated process, developed by dedicated professionals drawn from a variety of disciplines whose product was made possible only by computer technology. Applicable to all modes and to general planning as well, its development was financed virtually entirely by road-user funds. It is unequaled in any other planning area. Yet it can be effective only to the extent policymakers understand its products and accept the objective data it presents as a basis for their decisions.

Beyond the question of the mechanics or general applicability of the planning process in engineering analyses, the difficulty in gaining public acceptance of plans and programs developed from planning facts 
seems to cast doubts on the process itself. Planning and development of a freeway system must be at metropolitan scale, and the metropolitan system must be accepted as an integral element of a statewide highway network. A rapid transit line and even major arterial route development are facilities of regional importance and must be planned and developed at that scale. Yet their impact, both desirable and undesirable, is felt at a very local scale. While residents of a neighborhood or even a larger community may strongly favor a freeway system, they object to its location in their own neighborhood or community, and even rail rapid transit proposals share this same problem. Differences between local and regional goals can hardly be unexpected, but the highway program brought them into sharp focus. The highway program also gave those with ecology concerns, often at all costs, an opportunity to focus their efforts. The only answer seemed to be to bring the citizens more directly into the planning process.

The Congress first recognized the need to give citizens the opportunity to comment on proposed highway projects in the Federal-Aid Highway Act of 1956, but for diametrically the opposite reason for what is now fundamental to project acceptance. At that time citizens and travel-oriented businesses in small towns feared the loss of business if the Interstate System, with its required control of access and widely spaced interchanges, were to bypass their communities. $\mathbf{R e}$ sponding to these groups, the 1956 Act, under section 116 , declared that as a matter of policy:

Any State highway department which submits plans for a Federal-aid highway project involving the bypassing of, or going through, any city, town, or village, either incorporated or unincorporated, shall certify to the Commissioner of Public Roads that it has had public hearings, or has afforded the opportunity for such hearings, and has considered the economic effects of such a location. Provided, that if such hearings have been held, a copy of the transcript of said hearings shall be submitted to the Commissioner of Public Roads, together with the certification.

From this start grew the public hearing process, with all its inadequacies, dissatisfactions and problems. As it developed, it may have caused more problems than it solved, and it is still a troubled area. Early, most highway departments looked on the public hearing as an unfortunate added step in project approval and went into the hearing intent on defending their decisions against criticism. Later, as the requirements were extended ultimately to cover nearly all Federalaid projects, States increasingly attempted to make the hearing a constructive step, often in difficult cases employing consultants to develop various alternatives for consideration at the hearing, although only recently recognizing that one alternative should be to do nothing. The assumption that a project was to be built and that citizen suggestions might help decide which alternative was most suitable met with little favor among groups which wanted only one thingto be left alone. Criticism developed over the tendency to make only engineering and economic analyses (after all, the law only required consideration of economic effects) and ignored social and environmental factors.

As time went on, the requirement for two public hearings, a location hearing and a design hearing, was introduced, and in the Federal-Aid Highway Act of 1968, the Congress, responding to mounting dissatisfaction with the highway program in many urban areas, amended the language of the 1956 Act by striking out the words "economic effects of such a location" and substituting the words "economic and social effects of such a location, its impact on the environment, and its consistency with the goals and objectives of such urban planning as has been promulgated by the community." This change clearly brought the hearing process directly into the planning area, where previously it had been regarded generally as an engineering function. It imposed a further load on the " $3 \mathrm{C}$ " process, but it moved the process to closer liaison with engineering.

This change still did not suffice as a means of reconciling divergent views as to the highway program, and in the Federal-Aid Highway Act of 1970, the Congress further required that the certification by the State regarding the public hearing must be accompanied by a report of the consideration given to the economic, social, and environmental effects of any of the alternatives that were brought up at the hearing. It must be assumed that representations had been made to the Congress that the States paid insufficient attention to suggestions made at the hearings.

During the consideration of this amendment, the Committee on Public Works explored with the Federal Highway Administration the desirability of requiring a third public hearing, preceding the location and design hearing probably to be called the planning hearing, at which more basic questions would be discussed and hopefully an agreement reached that a highway improvement in the particular corridor or area indeed was necessary. Concern over what such a hearing process would involve led to the counter suggestion that FHWA would devise a strategy by which there could be meaningful input by citizens into the planning process. To this the Committee agreed and the requirement for the third hearing was not pursued.

Thereupon it became incumbent on FHWA to develop guidelines to bring this about. Examination of hearing transcripts and of other means some States had used to reach agreement with local groups and communities showed many examples (ranging from modification of Interstate project design to not having a village street), of changes stemming from the hearing process. Conferences, organized by the Highway Research Board and other agencies, reviewed examples of effective citizen participation and of the problems of achieving it. Primarily, it had to be concluded, citizen participation was most effective when it was handled on a person-to-person basis, a highly subjective approach. The problem FHWA faced was trying to institutionalize such a subjective procedure.

The result was that the first step involved little more than advising the State that the citizens must be brought into the planning process, and gave them examples of some successful devices to do that.

This first step was followed by a more formal requirement in 1973 responding to section 136 of the Federal-Aid Highway Act of 1970 under which each State was called upon to develop an "Action Plan" to ensure that proposed highway projects are based upon a balancing of the adverse economic, social, and environmental effects and the cost of eliminating or 


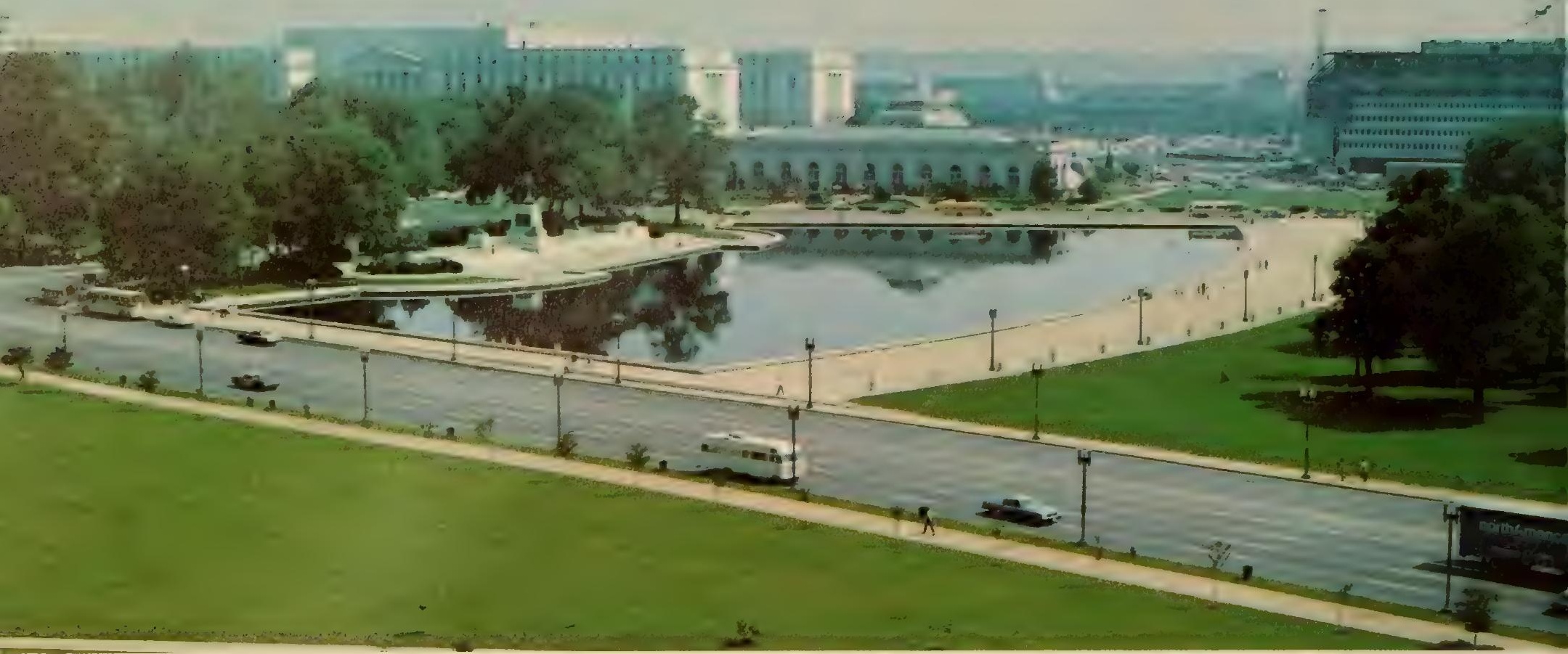

I-95 runs beneath this reflecting pool two blocks west of the Capitol in Washington, D.C. Air-right Federal buildings at each end of the tunnel enclose the ventilation equipment. The tunnel concept permitted the new Mall plan to retain this pool and the proposed Ceremonial Drive along its western edge.

minimizing such effects against the need for fast, safe, and efficient transportation. The guidelines and the State Action Plans are discussed in detail in Chapter 5.

Obviously this section of the 1970 Act put public hearings deeply into the planning process. As the Action Plans were being received in the Federal Highway Administration during 1974, the manner in which the States responded to the congressional intent would become apparent.

It has been noted repeatedly in this chapter that most urban transportation planning, and a considerable amount of general urban planning, had been financed with highway funds. It was also noted that prior to the establishment of the Department of Housing and Urban Development the "701" funds that had been heavily directed to aiding the cities in their cooperation with the States, primarily for developing the land use plan, were redirected more toward shortrange social goals. When aid to public transportation was initiated by Congress, administration of it was placed in the Urban Transportation Administration then under HUD. No UTA funds were available for the sort of planning carried out under the " $3 \mathrm{C}$ " process that might be called transportation system planning, although funds could be used for project planning, the type of work called project design in highway terms and which can be financed from construction funds. Projects could not be approved, however, unless they were found to be consistent with an acceptable city or metropolitan plan such as had been largely financed under the " 701 " funds. This finding, or certification of acceptability, was made within HUD but not within the UTA. Subsequently, when the Department of Transportation was established in 1967 and UMTA was brought in July 1, 1968, project approval became the responsibility of DOT, yet certification of acceptability under the approved city or metropolitan plan still remained in HUD and any lingering hope of "701" fund assistance in system planning disappeared. Responsibility for administering a rapidly and substantially expanding public transportation improvement program fell upon an Administration badly understaffed, with no field organization and no funds for system planning.

To the Federal Highway Administration, it was apparent that the same basic data, the same land use transportation relationships, the same modal-split models applicable to highway planning were either directly applicable or easily adaptable to transit planning. It offered the facilities of the established " $3 \mathrm{C}$ " processes in every urbanized area to aid transit system planning and its field offices and its division planning engineers to act as a field arm of UMTA. These efforts met with only mild success, for over the years transit interests had regarded "their mode" as competitive with highways, and starved for Federal aid in comparison with the affluence of the highway mode with what they saw as heavy Federal "subsidies," particularly the 90-10 Interstate program. Conversion of thinking of modes as competitive rather than as complementary and of administration as antagonistic rather than cooperative was not easy, but gradually was accomplished with strong urging on the part of both FHWA and UMTA Administrators, Turner and Villarreal. Instructions and memorandums signed by both Administrators were issued, joint research projects set up, joint committees organized, and actual exchanges of personnel instituted. During this process, UMTA's basic legislation was modified to permit use of funds in a manner similar to the $11 / 2$ percent planning funds, and the administrative budget increased to allow at least the beginnings of a field organization. A full partnership in attacking urban transportation problems had evolved, and at least in 
one area the purpose of assembling Federal transportation responsibilities under one roof was being realized. A somewhat similar situation existed in the Federal Aviation Administration.

With the growing cooperation evident at the Washington level, the Department of Transportation began extending the policy to the field. In 1970 a memorandum from the Federal Highway Administrator to the Secretary of Transportation recommended a program to be tried in three regions, which by then had been made coextensive for all Administrations, in developing the planning program. Under this experiment, approval of the planning program in any of the three areas, FHWA, UMTA, and FAA, would be approved by the regional modal administrator only when all three were correlated. Regional representatives of each Administration would meet to consider the programs advanced for approval by the State or local jurisdictions, and if necessary discuss them further with their counterparts, to assure that the individual programs were complementary and not overlapping. Hopefully a single planning agency, such as the one developed cooperatively to meet the requirements of the " $3 \mathrm{C}$ " process, would carry on most if not all the transportation planning up to about project design stage (to use highway terms), with the Federal share of the cost apportioned appropriately among the three Administrations.

The trial program was to extend over a period of a year, but within months after its initiation the Secretary ordered it to be extended to all regions and made a permanent procedure. Thus at least in transportation planning, coordination was achieved on paper, and increasingly in practice. By 1973 the procedure had become known as the Unified Work Program and all planning under the agreement must be performed by a single planning agency. The policy established by Congress in 1962 applicable to the highway program had now, by decision of the executive branch, been made applicable to all modes.

In 40 years planning, not even called that in the beginning because of prejudice against the word, has advanced from highway improvement planning to broad, sophisticated transportation planning, advancing in its theory and techniques even more than the technology of any of the modes it plans. Unified at State and local level by requirements of the Congress and Federal executive departments and expanded in scope by acts of Congress as new demands appeared, it is a powerful tool in metropolitan planning, not only in transportation, but in general planning as well. Congress has forced the disparate transportation elements in metropolitan planning to come together at local level. It has provided for coordination of modal administrations within the executive branch.

But much remains to be done at the metropolitan level in planning transportation and land uses as interrelated elements if the overall plan is to be an accomplished fact. Local and metropolitan transportation policies can be based on sound planning, even though currently there is little assurance that adequate land use controls or transportation programs will necessarily ensure that transportation and land use, however carefully planned, will achieve or retain balance. States increasingly are coordinating trans- portation planning and programing through departments of transportation, but only a few are relating them to approved statewide land use or development plans or even policies. At the Federal level there is no national development plan or policy to which a transportation plan or policy can be related. Indeed, much remains to be done.

\section{REFERENCES}

${ }^{1}$ History and Development of Road Building in the United States, address by T. H. MacDonald before the Annual Convention of the Amercian Society of Civil Engineers, pp. 44-45.

${ }^{2} I d$., pp. $47,48$.

${ }^{3} \mathrm{H}$, Doc. 272, 76th Cong., 1st Sess.

H. Doc. 379, 78th Cong., 2d Sess., Message from the President to the Congress, p. III.

${ }^{5} I d .$, pp. 62, 64.

'Id., p. 66.

${ }^{7} I d .$, pp. 4, 5.

${ }^{8} I d .$, p. 3.

${ }^{9} I d .$, p. 87.

${ }^{10} I d$, p. iv.

${ }^{11}$ What is This Thing Called Planning?, address by $H$. Fairbank before the Sixth Annual Meeting of the Southeastern Association of State Highway Officials, Miami, Dec. 8, 1947, pp. 6,7 .

${ }^{12}$ National Committee on Urban Transportation, Better Transportation for Your City (Public Administration Service, 1958) p. XI.

${ }^{13} \mathrm{Id}$.

${ }^{14}$ H. Doc. 249, 81st Cong., 1st Sess.

${ }^{15}$ H. Doc. 139, 84th Cong., 1st Sess.

${ }^{16}$ H. Doc. 120, 84th Cong., 1st Sess.

${ }^{17}$ H. Doc. 106, 85th Cong., 1st Sess.; H. Doc. 344, 85th Cong., $2 d$ Sess. ; H. Doc. 91, 86th Cong., 1st Sess.; H. Doc. 355, 86th Cong., $2 d$ Sess. ; H. Doc. 54, 87th Cong., 1st Sess. ; H. Doc. 72, 87th Cong., 1st Sess.; H. Doc. 124, 89th Cong., 2d Sess.

${ }^{18}$ House Comm. on Public Works, 1968 National Highway Needs Report, 90th Cong., 2d Sess. (Comm. Print 90-22).

19 Transit and Federal Highways, address by E. H. Holmes before the Engineers Club of St. Louis, Apr. 23, 1964, presented on behalf of Federal Highway Administrator Rex M. Whitton.

${ }^{20}$ The Sagamore Conference on Highways and Urban Development Report, (Syracuse University), Oct. 5-9, 1958, Forward.

${ }^{21} I d$., p. 9.

${ }^{22} I d .$, p. 14.

${ }^{23} I d .$, p. 14.

${ }^{24} I d .$, p. 14.

${ }^{25} I d .$, p. 15.

${ }^{28} I d .$, p. 15.

"The Hershey Conference on Freeways in the Urban Setting Report, (Automotive Safety Foundation), Hershey, Pa., June 1962, Foreward.

${ }^{28} I d$., Background.

${ }^{29} I d$., Findings.

${ }^{30}$ Id., Recommendations.

${ }^{31} I d$., Recommendations.

${ }^{32}$ FHWa Federat-Aid Highway Program Manual, Vol. 4, Ch. 4, Sec. 2.

${ }^{33}$ Hrghways and Urban Development, Report on the Second National Conference, Williamsburg, Va., Dec. 12-16, 1965, p. ii.

${ }^{34} I d .$, p. 33.

${ }^{\mathrm{ss}} I d$., p. v.

${ }^{36} I d .$, p. v.

${ }^{a t}$ An Approach to Multi-Regionat Urban Transportatron Policy Planning, a paper presented before the Highway Research Board by H. Kassoff and D. S. Gendell, Jan. 1971. 


\section{Research}

Research was one of the principal missions of the first national highway program in the United States and is, in fact, the oldest continuous Federal highway activity. The scope of federally conducted or assisted research encompasses all of the Federal highway programs and every facet of highway transportationas a national resource and as a principal force in the social and economic well-being of the people and Government.

\section{Early History}

The history of highway research in the Federal Government began with the establishment of the Office of Road Inquiry (ORI) in the Department of Agriculture in 1893. Prior to that date, there had been numerous investigations and experiments, but they were primarily scattered and isolated events. With the creation of the ORI, whose primary mission was to investigate the best methods of roadmaking and to assist in disseminating this information, a formal, organized research program began. In 1894, the ORI issued 9 bulletins on such subjects as State laws, roadbuilding materials, and railroad rates for hauling those materials.

Demonstration trains, originally known as "Good Roads Trains," traveled throughout many parts of the Nation in the 1890 's. These trains were fitted with construction and roadbuilding machinery and equipment as well as section models of macadam and other types of road construction.

States, local authorities, railroad companies and the manufacturers of earth-handling and roadbuilding machinery also cooperated in building short sections of quality roads to demonstrate good roadbuilding practices. The emphasis was on drainage, surface courses, and maintenance. Local materials and manpower were used under the general supervision of Federal engineers. Sometimes on "Good Roads Day," as many as 500 local farmers would take a walking tour of a demonstration section being constructed. In 1910, the annual report of the Office of Public Roads reported that 55 object lesson and experimental roads had been completed during the fiscal year. ${ }^{1}$

Although information on specific research activities in the early 1900's is rather fragmentary, the most substantial continuing effort was testing large numbers of samples of highway materials, including aggregate, cement, soil, asphalt, and tar. A Federal laboratory was established in 1900 for mechanical and chemical investigation of these materials. The results of the tests were analyzed to obtain a general overview of the characteristics of available materials and their suitability for roadbuilding purposes. Samples were sent in from all areas of the country and were tested free of charge until 1924, when it was announced that materials would no longer be tested for the general public. In the early years, the laboratory developed important tests to help improve bituminous construction.

In addition, statistical and economic evaluations were made in 1910 of the effect of road improvements on communities. Some work was also undertaken on coatings and coverings for iron and steel corrosion. In 1911 there were some object lesson projects on culverts, and a bulletin was published on highway bridges. 


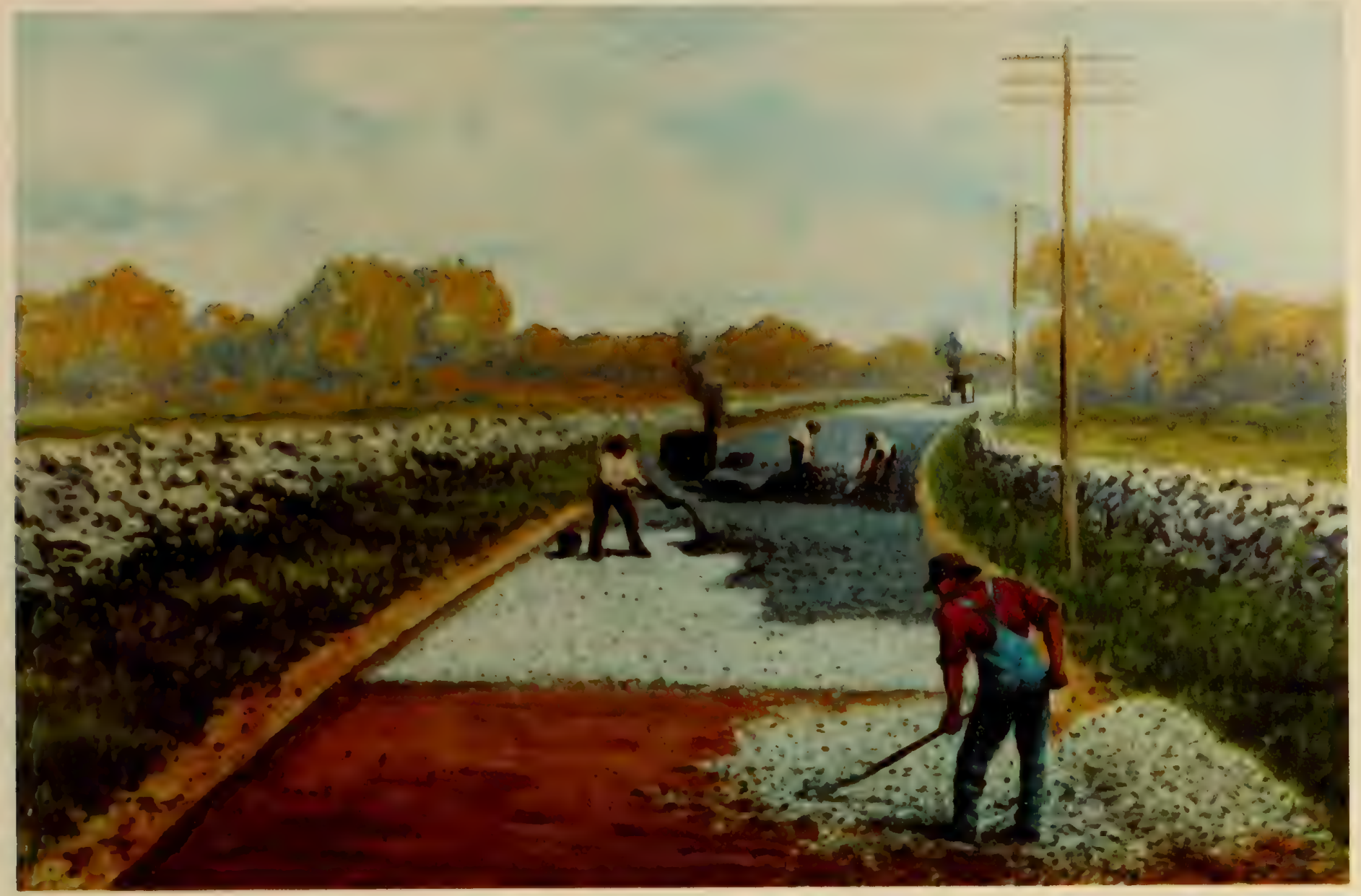

From the beginning, the office of Public Roads included $a$ group of men to develop new techniques through experiment and research. Historically, this activity has involved a strong element of "let's try it and find out" as illustrated in this early bituminous macadam pavement experiment. Today's broad

Rather than attempting to outline here a large number of technical advances, several broad historical milestones can be summarized. (1) The research mission of the Federal agency was clearly established, and, later, Federal funds were specifically earmarked for research. (2) A major research journal, Public Roads, was founded. (3) The cooperative and jointparticipation concept with the States and industry was established. (4) The initial concentration on material and surfaces was rapidly expanded into areas such as structures, economic consequences, and the impact of traffic and trucks.

\section{Federal Aid for Research}

\section{Federal Administrative Resources}

The first sustained fiscal support for highway research was authorized by section 21 of the Federal Highway Act of 1921. The foundation for the Federal-aid State highway planning and research program was laid with the enactment of the HaydenCartwright Act of 1934 .

Section 11 of the Hayden-Cartwright Act specified "With the approval of the Secretary of Agriculture, not to exceed $11 / 2$ per centum of the amount appor- program of research and development dealing with problems of safety, traffic management, environmental protection, materials, structures, and maintenance uses modern, scientific techniques in searching for solutions.

tioned for any year to any State ... may be used for surveys, plans, and engineering investigations. . .." Under this authorization, some States, with the delegated approval of the Bureau of Public Roads, initiated research activities, mostly in the area of physica materials of the highway.

The Federal-Aid Highway Act of 1944 contained for the first time the term "research" in addition to planning. Thus, the States at their option and with the approval of Public Roads could use a portion of the $11 / 2$ percent planning funds for research. Funds not used for planning or research could revert to the construction program. With the enactment of the Federal-Aid Highway Act of 1962, the 11/2 percent funds were restricted as of fiscal year 1964 to research and planning purposes only. If they were not used during their availability period, these funds would lapse.

To further encourage the States to increase their research and planning efforts, the 1962 Highway Act authorized, beginning with fiscal year 1964, the use of an additional one-half of 1 percent of sums apportioned for each fiscal year for planning and research, but this was optional. The initiative to conduct such efforts rests with the State highway departments. 


\section{Prevost Hubbard}

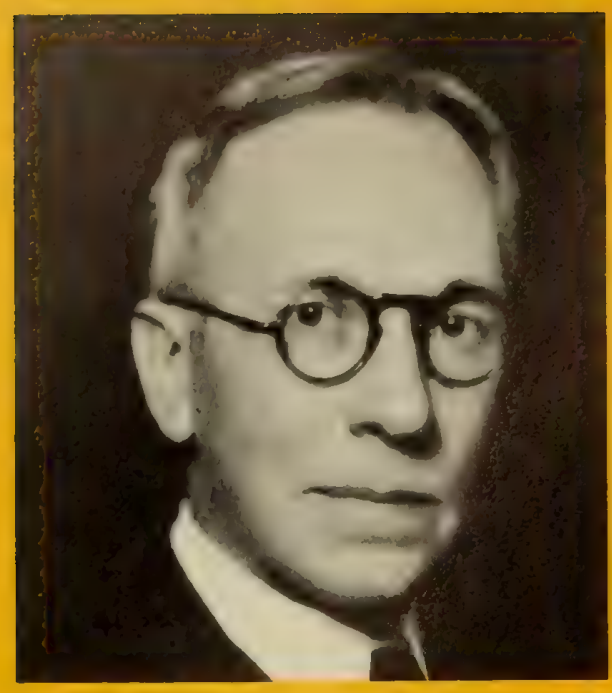

There were many professional men who made major contributions to the development of America's roads. One such man was a scientist named Prevost Hubbard. Between 1905 and 1919 he developed for the Office of Public Roads methods for testing and specifying bituminous pavement materials which eventually became standards of the highway construction industry and the foundation of modern materials technology.

Hubbard, born in 1881, was educated at George Washington University in Washington, D.C. He joined OPR in 1905 as the agency's first laboratory chemist to help sort out and develop standards for the wide variety of petroleum based products then being experimented with as surfacing agents for highways.

He became active in the American Society for Testing Materials and spearheaded, with Logan Waller Page, Committee H (now Committee D-4 on Road and Paving Materials). He served as secretary of the Committee from 1909 to 1946.

In 1919 Hubbard joined the Asphalt Institute, first known as the Asphalt Association, to direct a research and development program sponsored by the petroleum industry. The Institute's laboratory had its beginning in the basement of Hubbard's home in White Plains, New York. One of the first accomplishments under his leadership was the development of Medium Curing Cutback Asphalt, a liquid form of asphalt, later used extensively in the construction of low-cost, lowvolume, all-weather pavements.

During the early 1920's an intensive effort was made to reduce the number of specifications in effect in the United States. The asphalt industry, under the direction of Hubbard, in cooperation with the States and Bureau of Public Roads, was successful in reducing the grades of asphalt cement in use from 88 to 9 and asphalt joint sealers from 14 to 4. Similarly, Hubbard's cooperative efforts during the 1930 's led to the successful reduction of the number of grades of liquid asphalts used by 33 States from 125 to 18.

The latter study included an extensive testing program of most liquid asphalts produced in the United States. J. T. Pauls of the Bureau of Public Roads commented on the study in a progress report in 1932:

Representatives of the Bureau of Public Roads and Mr. Hubbard of the Asphalt [Institute] stressed the fact that they believed in the adequacy of the proposed cooperative tests for the testing of liquid asphaltic products and felt that many tests now being used by the States were unnecessary and unsatisfactory.

Hubbard went on to develop methods for testing the design of paving mixtures. With the assistance of F. C. Field of the Asphalt Institute, Hubbard invented the Hubbard-Field Stability Test, which became the first widely accepted test to measure the strength of asphalt paving mixtures.

He died in 1971 at the age of 90. A year later Committee D-4 on Road and Paving Materials established the "Prevost Hubbard Award" in recognition of his outstanding service to the Committee and to the field of bituminous road and paving materials. 


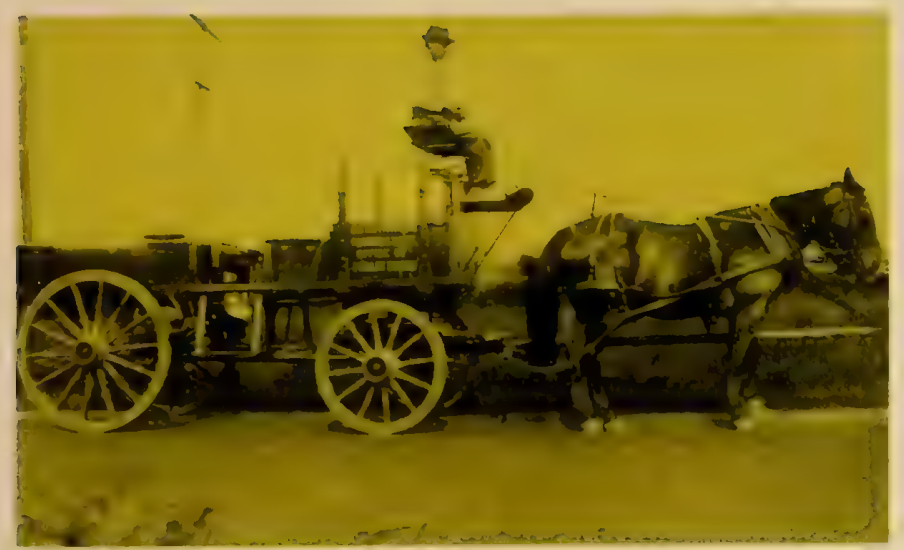

This is a 1915 traction dynamometer mounted on a wagon, used to measure the force required to pull the vehicle over the road against the friction of the wheels in contact with the road.

The Federal-Aid Highway Amendments Act of 1963 expanded the law to include development under the research and planning section. The Act specified that the $11 / 2$ percent funds would be available, among other purposes, ". . . for research and development, necessary in connection with the planning, design, construction, and maintenance of highways and highway systems. ..." The intent of Congress was that development would be an integral part of the overall research and development program and that this provision would stimulate the States to play a more active role in the development phase. ${ }^{2}$

\section{Public Roads Magazine}

The Federal Aid Road Act of 1916 authorized a 5-year road program which had barely begun when the United States entered the European war. Looking forward to the resumption of the road program after the war, Director Logan W. Page of the Office of Public Roads and Rural Engineering (OPRRE) foresaw the need for a journal devoted to the publication "... of the results of researches, experiments and studies of those connected with this Office, and of highway officials of the various States..."; and also ". . . for the dissemination of such information as the officials of the various States may desire to spread for the benefit of their contemporaries." ${ }^{3}$

The first issue of the new publication, named Public Roads, appeared May 1918. It provided the State highway officials with a welcome forum for the discussion of current problems. The first issue brought the industry up-to-date by summarizing motor vehicle licensing laws and fees for registration and operators' licenses. This wartime issue also urged highway builders to conserve scarce fuel by proper attention to the firing of boilers and the careful use of steam in road machines and in quarrying. An entire issue (June 1918) was devoted to the catastrophic road breakups caused by heavy trucking during the 1918 spring thaw. The May 1919 issue dealt with the social and economic benefits of using convict labor on the public roads. When the Government distributed the huge surpluses of military equipment to the States, Public Roads ran articles on how to take care of the equipment and convert it to civilian highway use.
Public Roads published the resolutions adopted by the American Association of State Highway Officials (AASHO) at its annual meetings of December 1918, 1919, and 1920, and also the papers read at those conventions. In effect, it was the official journal of AASHO until that organization launched its own publication, American Highways, in 1922.

Within a year of its first issue, Public Roads was an important voice of the young highway industry, with a long waiting list of would-be subscribers. In fiscal year 1920, the authorized monthly circulation was raised to 4,500 copies, but hundreds of requests for the magazine had to be refused. Budgetary cuts reduced the circulation to 4,000 copies per month for fiscal year 1921, and, without explanation, publication was suspended altogether after the December 1921 issue. The suspension drew an immediate protest from the American Road Builders' Association, AASHO, and other organizations interested in roads and also ". . . many expressions of regret not only from its engineer subscribers, but also from the nontechnical administrative heads of county highway activities to whom it had been helpful. Not the least gratifying of such expressions were those which came entirely without solicitation from the editors of other technical engineering journals." 4

Public Roads resumed publication in March 1924, with the return of better times. However, the magazine was no longer a forum for the administrative and technical problems of the States, this function having been assumed by American Highways after Public Roads ceased publication. Instead, the new Public Roads was exclusively a house research journal, and all of its contributors were engineers, scientists, and economists of the Bureau of Public Roads. As the Bureau's research activities expanded, Public Roads published papers dealing with every aspect of highway research-finance and taxation, the economics of transport systems, the properties of soil and road materials, the management of construction operations by contractors, the characteristics of highway traffic, the strength of road slabs, and many others.

Public Roads was the original publisher of many landmark papers in highway research. Most notable of these was "Highway Capacity: Practical Applications of Research" by O. K. Normann and W. P. Walker (Public Roads, October, December 1949). Another paper, "Interrelationship of Load, Road and Subgrade" by C. Hogentogler and C. Terzaghi (Public Roads, May 1929) laid the foundations of subgrade soil classification and marked a turning point in studies of subgrade soils.

The highway researchers of the twenties, thirties, and forties were breaking new ground. Often progress in a particular field of research depended on the invention of new instruments to measure what had never been measured before. A continuous stream of such instruments issued from the Bureau of Public Roads' instrument laboratory for nearly 40 yearsthe Goldbeck Pressure Cell for measuring pressures under pavements; the electric-eye and road-tube traffic counters; the Benkelman Beam for measuring minute deflections in pavements under load; and many others. Information about most of these devices first reached the scientific world through the pages of Public Roads. 
Publication has continued without interruption from March 1924 down to the present, although the frequency of issues has varied widely. Through the years, Public Roads again expanded to include articles on highway research and development from sources outside of the Bureau of Public Roads. Throughout its long history, Public Roads has maintained a high standard of scientific accuracy and literary clarity and, taken as a whole, is a remarkable chronology of the development of highway engineering and economics in the motor age.

\section{Federal-State-Industry Cooperation}

The historic association between Federal highway researchers and their counterparts in the States is considered unique in Federal Government programs, past and present. Over the years, all of the States have conducted research in cooperation with Public Roads and contributed in countless ways to the program described here. One other important accomplishment in this longstanding Federal-State partnership has been the establishment of strong, viable research staffs, facilities, and programs in the States.

Another successful research relationship was established between Federal and State highway agencies and interested outside groups, including other Government agencies, the academic community and associations, national organizations, professional societies, and industry groups. These various bodies have aided in identifying needs and in planning research to fill those needs. They have assisted in the conduct of studies with time, manpower, funds, and consultation and have taken an integral part in the development and implementation of results.

One organization which has played a major role in coordinating modern highway research and disseminating the results is the Transportation Research Board (TRB), or, as it was known for half a century, the Highway Research Board (HRB). It was organized in 1920 as an agency of the National Research Council in the National Academy of Sciences. Its purpose was to " "assist in outlining a comprehensive national program of highway research and coordinating activities thereunder; organize committees for specific problems; deal with ways and means; and act in a general advisory capacity." " 5 In recognition of the increasing emphasis on the "systems" or balanced

The Maryland State Roads Commission testing laboratory in 1929.

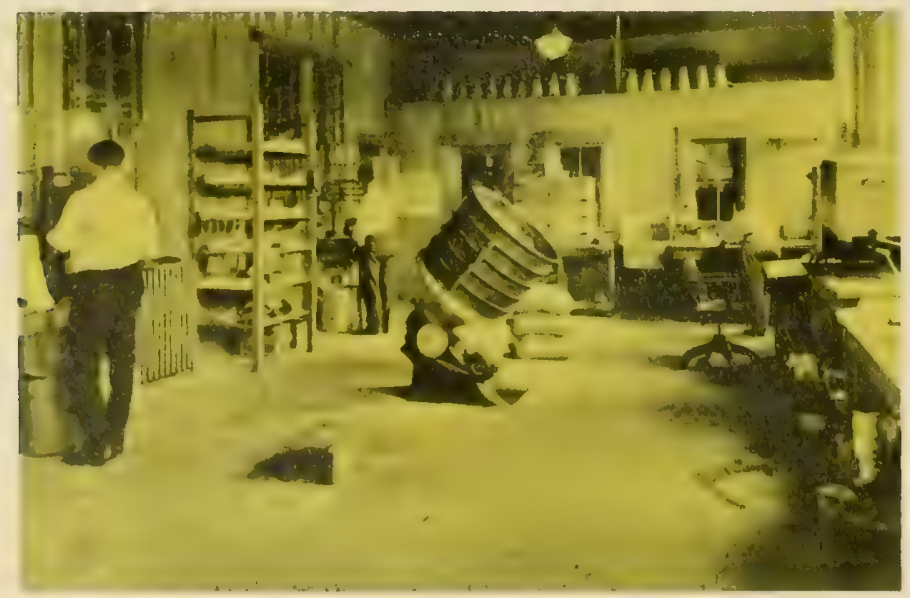

approach to transportation problems, the TRB in recent years has modified its scope to include the development of other modes of transportation as they interact with highways. A more detailed discussion of the TRB and its relationship to the Federal Highway Administration research efforts can be found in Chapter 1 of Part II.

In the last two decades, considerable cooperative research has also been undertaken on an international scale. A notable example is the continued involvement of Public Roads in a number of research committees of the Organization for Economic Cooperation and Development (OECD). Their efforts have been particularly directed toward research for safer highway design and improved traffic operations. Since 1964 Public Roads has also worked with the International Road Federation in the collection and dissemination of information through a worldwide annual inventory of research and development activities.

\section{Construction Materials and Structures}

In the early period of highway construction in this country, an understanding of the physical behavior of the major materials was developed primarily by trial and error, which led to the development of criteria and tests based, to a great extent, on empirical relationships. Much of the early research work consisted of testing large numbers of samples of highway materials to determine the essential characteristics of available materials and their suitability for roadbuilding purposes. Developments with different materials varied somewhat in time, but in general during the 1920 's and early 1930 's, the technology with respect to soils, asphalts and other bituminous materials, cement and concrete, and pavements, bridges, and other structures was developed.

\section{Soils}

In the very early stages of the roadbuilding industry, little of a scientific nature was known about soils as road materials other than that clay soils were sticky and sadly lacking in vehicle support when wet; and that very sandy soils, while having fair performance when wet, were highly unsatisfactory when dry. Thus, the first effective modification of soils for unpaved roads consisted of adding sand to clayed soils and clay to excessively sandy soils in a more or less

Taking soil samples for field subgrade soil studies.

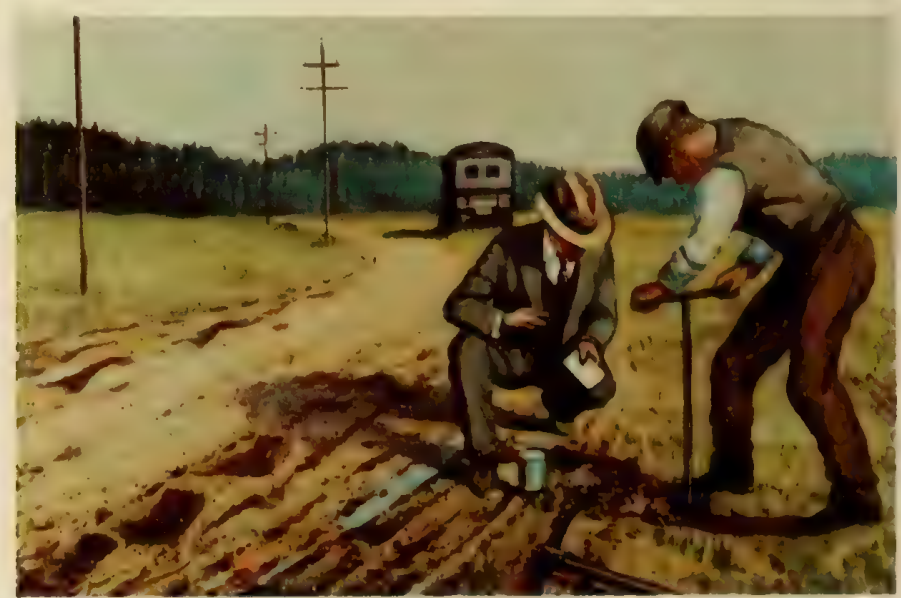


"cut-and-try" system. However, the variable results obtained by casual blending soon made it apparent that more than eyeball engineering was needed in dealing with soils and developing their potential as road material.

Most of the experiments up until 1920 were concerned with dust prevention and road surface preservation. Then, in 1920, the Bureau of Public Roads began investigations "to obtain accurate scientific information regarding the characteristics of soils which affect their bearing value." ${ }^{6}$ At about the same time, several State highway departments established soiltesting units and each attacked the problem in its own way. However, through exchange of information at conferences and through American Society for Testing and Materials (ASTM), AASHO, and HRB, a soil classification system and standard soils tests were developed.

\section{Soil Constants}

One significant milestone was the development, during the latter part of the 1920 's, of tests to measure certain key characteristics of the various soil types and their blends. These were the so-called soil constants which included the liquid limit, plastic limit, and plasticity index, the latter being calculated from the other two. ${ }^{\top}$ These constants, which identify the moisture retention and flow characteristics of a particular soil, have become indispensable criteria for evaluating and predicting the performance of a given soil as a pavement foundation and for use as a control tool to facilitate the blending of inherently unsatisfactory soils to produce acceptable foundations.

Research in the late 1920's also disclosed that other soil properties, in addition to plasticity, affect the performance of soils in road foundations. It became apparent that the wide range of soil types should be classified on the basis of measurable characteristics, such as fineness and chemical composition, to provide highway engineers a working soil language. Based on data obtained by testing thousands of soil samples and observation of behavior of soils under field conditions, the Public Roads' soil classification system

This nuclear moisture-density gage was developed in the late 1950 's to instantly test subgrade compaction without the need to take samples and complete a laboratory analysis.

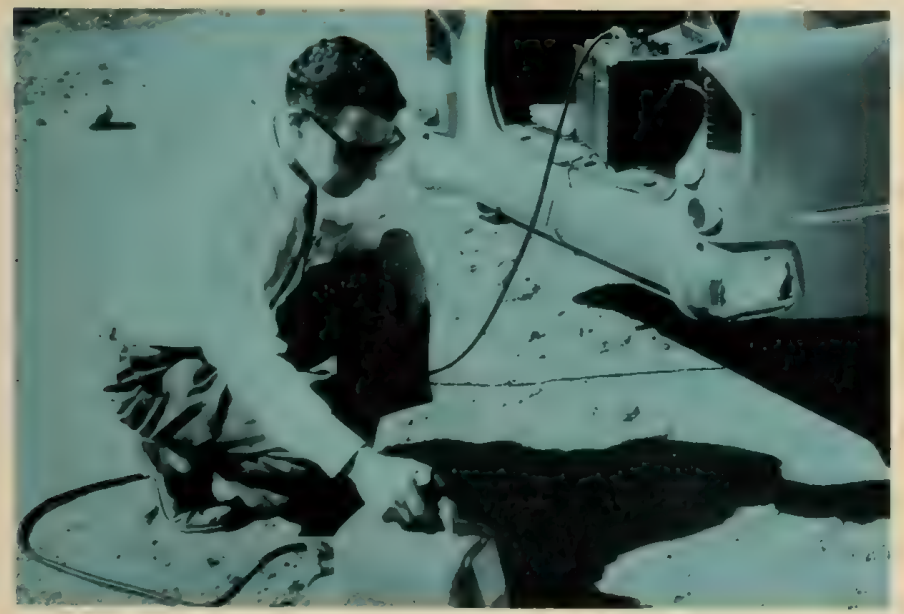

was developed and first published in 1929. The best soil for use in road foundations and earth structures was classified $\mathbf{A}-1$. The series continued through seven more main groups, the poorest being $\mathbf{A}-8$. This system, with appropriate revisions, later became the ASTM and AASHO standards.

Continuing soils research included studies of resistance to frost heaving in cold climates (frost susceptibility) and consolidation or settlement characteristics of soils. It was determined that frost heave was greatest in silty soils and that the best remedy was to remove and replace the silt with coarser grained materials, such as gravel, to a depth at which frost action was not detrimental. Under the guidance of Dr. Charles Terzaghi of the Massachusetts Institute of Technology, serving as consultant to Public Roads, apparatus for measuring the consolidation characteristics of soils was also developed in the late 1920 's, and the test data were used to determine the rate and amount of settlement of highly compressible soils.

Occasional highway surface failures where the quality of the foundation soil was considered to be good indicated insufficient compaction during construction. To provide adequate compaction control, a test method for determining the moisture-density relations of soils for earth dams was adapted to highway earthwork in the mid-1930's. Thereafter, compaction specifications for highway embankments, subgrades and soil-aggregate base courses required that the material have a proper amount of moisture when compacted so that a target density could be reached.

\section{Soil Stabilization}

Significant progress was made in soil stabilization during the 1930's. Research showed that soils for use in pavement subgrades could be improved by the addition of portland cement, lime or bitumen, and that calcium and sodium chlorides were effective dust palliatives. During World War II, the Soils Laboratory collaborated with the Engineer Board, Fort Belvoir, Virginia, in the evaluation of chemicals for

This is a circa 1935 electrical resistivity test along the George Washington Memorial Parkway in Virginia. An electric current is passed through steel rods to measure ground resistance. This geophysical method is used to locate subsurface rock formations.

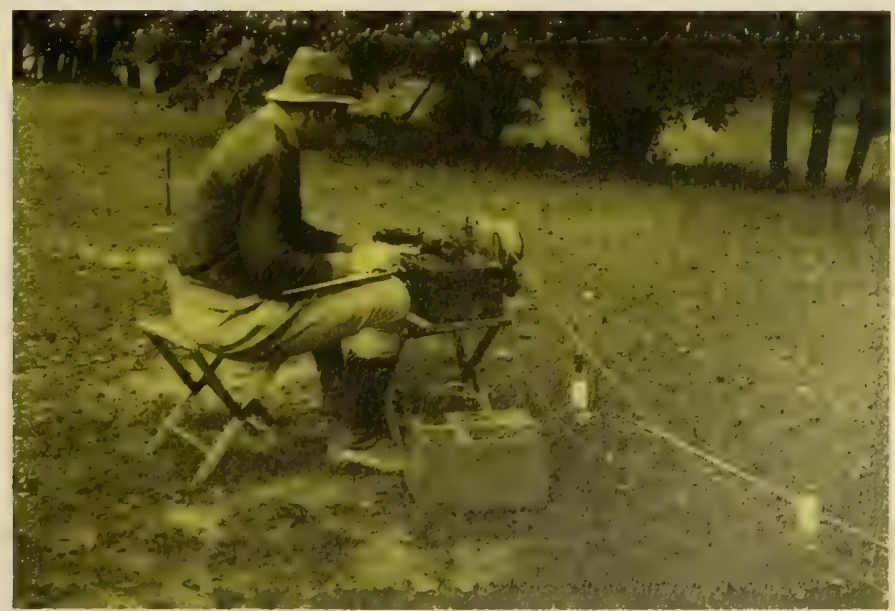


soil stabilization. Beginning in 1954, and continuing until about 1970, the Bureau in cooperation with the chemical industry evaluated about 50 chemicals for soil stabilization. A few were found to be marginally useful, but none were economically competitive with portland cement or lime for subgrades.

\section{Remote Sensing}

Throughout modern highway history, there has been a continuing search for a rapid, effective way to explore conditions on or beneath the ground without actual excavation or ground surveys. Beginning about 1932, Public Roads promoted the development and use of remote sensing methods for obtaining information on soil and ground conditions in place. The "cumulative-curve" method of presenting electrical resistivity data was developed and adapted to determine depth to bedrock, delineate sand-gravel deposits and thickness of portland cement concrete pavement. Also, aerial photographic interpretation principles were adapted to engineering-soil and materials mapping. Cooperative work between BPR field offices and other agencies (U.S. Geological Survey, National Aeronautics and Space Administration (NASA), the University of Michigan and Purdue University) in 1960-1967 demonstrated that color aerial photography was a good way to evaluate soil and terrain. Widespread use of these methods has followed. The development and evaluation of ground and aerial remote sensing methods for obtaining information on terrain and environmental features continued into the 1970 's.

\section{Bituminous Materials}

Over the years, Public Roads has played a predominant role in the development of asphalt technology and test methods for bituminous materials. In 1903 it cooperated with the American Society for Testing Materials in organizing a committee on road and paving materials to develop essential standard test methods and material specifications.

The BPR tried various tests on bituminous materials to determine their physical and chemical properties and their suitability for use in road construction. Conclusions on which properties were significant in relation to performance and on the best methods for testing materials were disseminated in a series of Department of Agriculture bulletins, beginning in 1911, which included the methods in use by the Office of Public Roads at that time, and provided a progression of guidelines for procedures in the use of bituminous materials. Many of the early ASTM and AASHO standards for material and test method specifications, which are used in highway construction, were derived from this series. The latest edition, now called Standard Specifications and Methods of Tests for Highway Materials, was published by AASHO in 1974.

Beginning in the 1920's and continuing through the mid-1960's, most of the research effort in the bituminous area was concerned with studies of properties of asphalts and tars produced in the United States, and the relation of such properties to the performance of pavements. Often such studies resulted in the adoption of new specification requirements.

One of the most significant developments was the simplification of specifications for liquid asphalts and asphalt cements. A survey of penetration grade asphalts in 1923 showed that 88 different specifications for these materials were being used in the United States. A joint conference of representatives of Public Roads and users and producers of asphalt recommended that only nine grades were sufficient to provide the necessary materials. Those nine grades were adopted by national groups and most of the States. Subsequently, the number of grades has been reduced to five.

In 1930 a similar survey showed that there were 119 different tests, including all variations, being used in specifications for acceptable grades of liquid asphaltic materials in the United States. ${ }^{8}$ After a cooperative study of the materials being produced and a series of conferences throughout the United States sponsored by Public Roads, the Asphalt Institute, and the petroleum industry, 13 grades were adopted by most States and national groups. In most cases, the reduced number of grades for both penetration grade and liquid asphalts were adequate to fill the needs for pavement construction and resulted in considerable economic benefit to the user and producer of the materials.

\section{Development of the Thin-Film Oven Test}

The control of the hardening of asphalt in hotplant mixing and in mixtures in service has been of major concern to the engineer and chemist since asphalt was first used. In 1940 the Public Roads Administration developed a laboratory test that would predict the amount of hardening of asphalt in hotplant mix construction. This became known as the "Thin-Film Oven Test" and has been adopted as a standard specification test by ASTM, AASHO, and essentially all State highway departments. This test was also adopted by several foreign countries to measure and control asphalt hardening.

\section{Development of the Immersion-Compression Test}

The effect of moisture on asphalt paving mixtures, macadams and surface treatments has been one of the primary causes of pavement distress or early failure. Tests were available to measure the effect of moisture on different aggregates coated with asphalt, but a test was needed to measure the effect of water on complete compacted mixtures representative of those used in construction. To meet this need, the immersion-compression test was developed, based on a laboratory study made by the Bureau in 1942. The test produced valuable information on the susceptibility of asphalt mixtures to loss in strength by water action. ${ }^{9}$ The immersion-compression test has been adopted as a standard by ASTM, AASHO, and many State highway departments and has been a valuable tool for investigating the cause of distressed pavements. 


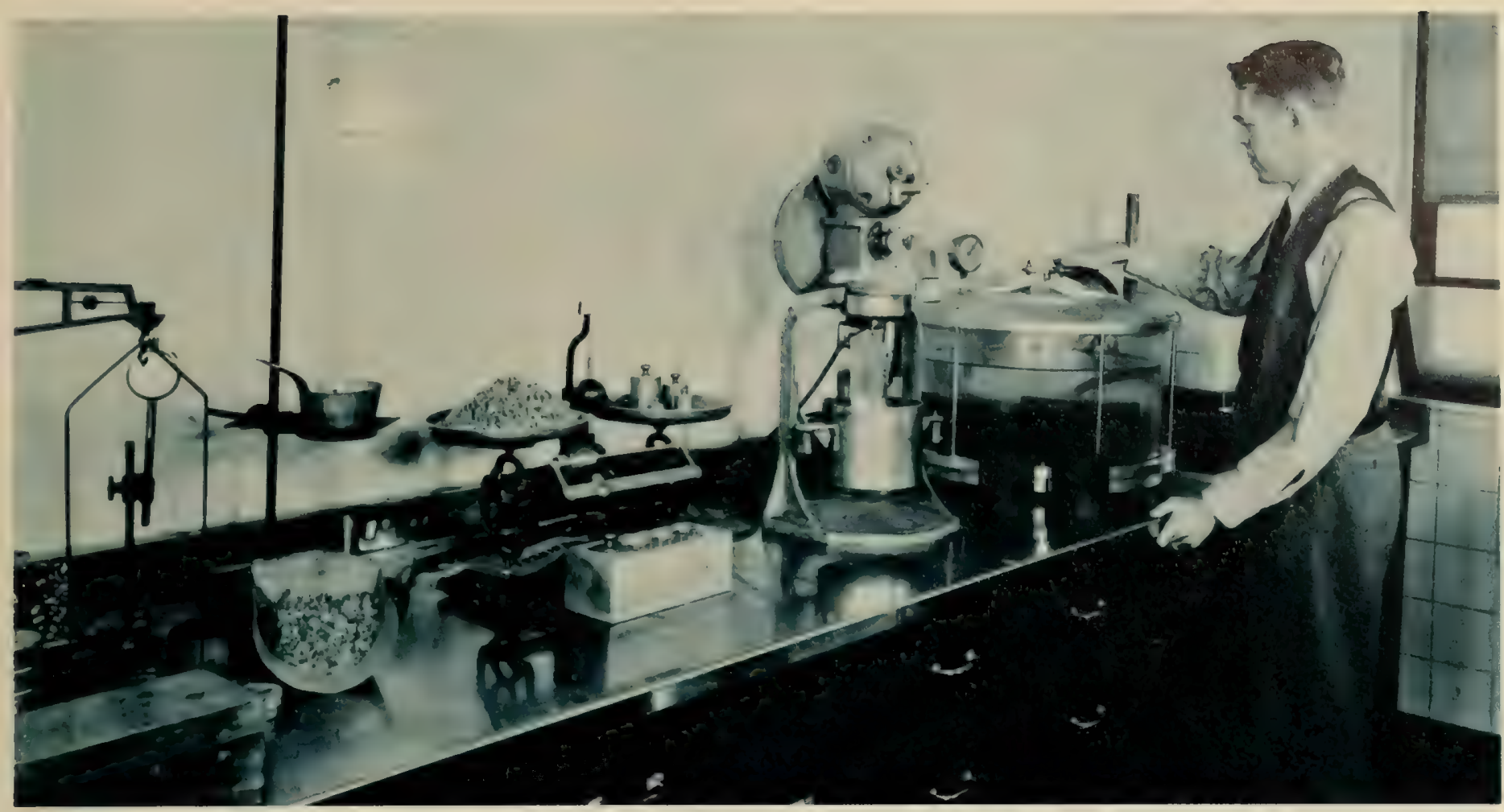

\section{Cement and Concrete Materials}

The name "portland cement" comes from an "artificial" cement patented by Joseph Aspdin in England in 1824. Aspdin kept his process a secret, although many others tried to duplicate this product. In 1845 , I. C. Johnson developed a product based on high temperature calcination that was essentially "portland cement" as we know it today. Portland cement was first manufactured in the United States in $1871 .^{10}$

Concrete technology was in its early development at the beginning of the 20th century. Today's refined knowledge of concrete design and utilization is the product of a number of organizations, such as Lewis Institute, American Concrete Institute, American Society for Testing and Materials, Portland Cement Association, State highway departments, and the Bureau of Public Roads. In particular, BPR played an important role in developing knowledge of the relationship of concrete's various components to concrete strengths and other characteristics and in developing better tests and specifications for the product. In addition, BPR performed studies which established the quantitative relation between some aggregates and the alkali content of cements and determined the value of fly ash in concrete to control the damaging alkali aggregate reactions as well as serve as a replacement for part of the cement. Other research assessed the sulfate resistance of various concretes and the relation of such resistance to cement composition. Air entraining agents to prevent freezethaw damage were also evaluated.

As the science of manufacturing portland cement developed and more knowledge of the effect of special compositions was gained, specialty cements such as "high-early-strength portland cement" or "sulfate resistant" cements began to appear on the market. This led to the adoption by ASTM and AASHO around 1940 of five types of standard cements.
Bituminous mixtures being prepared in the Public Roads Administration research lab for immersion-compression tests to ascertain durability of materials for highway construction in 1948.

The development of standard cement tests was an important part of Public Roads' research in the late 1920 's and early 1930's. Difficulties arose when discrepancies were found in the results of tests run by different testing laboratories around the country whose function was to verify that highway construction materials met their required specifications and also to test samples of completed highways. This problem led to the establishment, in 1929, of the

Research engineer scans slice of concrete with microscope to determine size and distribution of air voids, important in the durability of concrete, especially under the action of freezing temperatures.

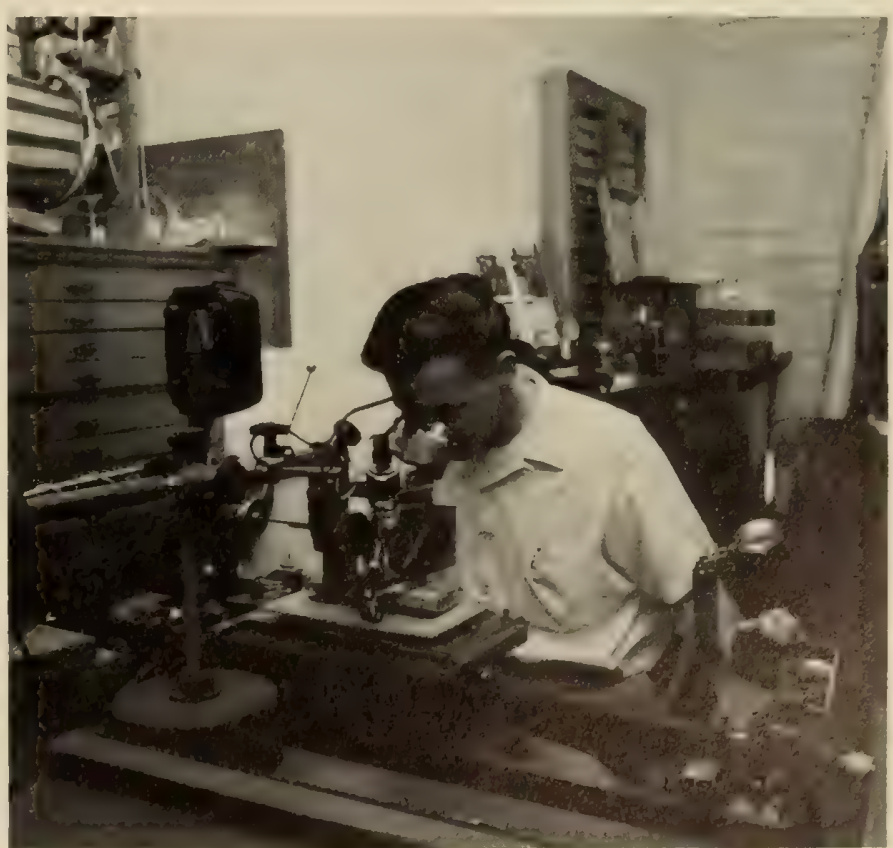


Cement Reference Laboratory (CRL) at the National Bureau of Standards. It was an ASTM sponsored activity actively supported by Public Roads from its inception. The CRL's duty was to determine whether the laboratories' equipment was in order and to observe whether the proper techniques were being used in making the tests.*

\section{Aggregates for Construction}

The simplification, standardization, and uniform application of aggregate gradations has been a major effort since 1936. This work led to the early adoption of a simplified practice of specifying sizes of coarse aggregate for concrete. In 1962 Public Roads encouraged the States and other agencies to adopt simplified procedures for aggregates used in bituminous construction. The recommendations included the development and adoption of standard aggregate sizes, standard sieves, and a standard method of reporting gradations. Public Roads also developed a new gradation chart that showed desired combinations of aggregate sizes in graphical form. Since fewer blends were required, all customers could be supplied from only a few stockpiles and producer costs are minimized. This chart is now in wide use for evaluating aggregates in bituminous paving mixtures.

In 1928 studies were made of concrete containing rounded gravel coarse aggregate versus the angular material produced by crushing ledge stone or largesize waterworn gravel. This research determined that crushed stone is generally preferred for paving work because of the superior strength of the resulting concrete.

* In 1960 the CRL was expanded into the Cement and Concrete Reference Laboratory (CCRL).

Concrete slabs are subjected to daily applications of deicing agents, such as calcium chloride, to determine the durability of the concrete or the effectiveness of various protective treatments.

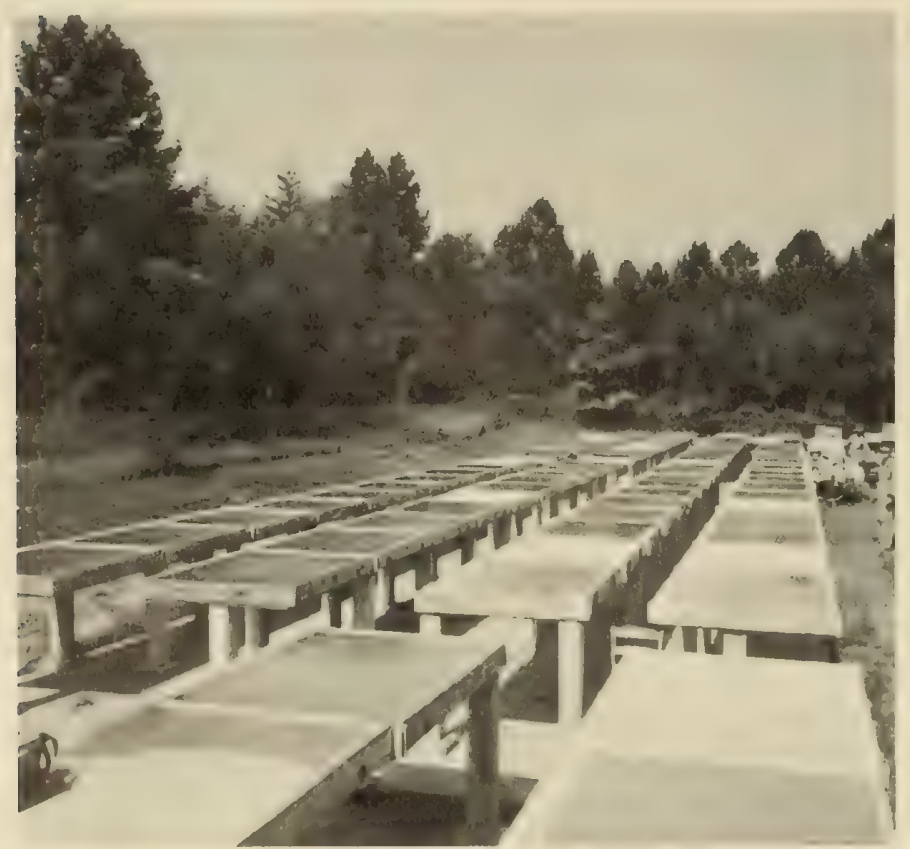

Research on concrete freezing and thawing was also being conducted at this time. Public Roads research led to the development of new concrete specifications requiring denser and more durable types of coarse aggregate. Other research in this area included the development of air-entrainment techniques and the establishment of a list of acceptable air-entrainment admixtures. Air entrainment is a process that puts air bubbles in the cement to relieve the stresses caused by freezing water. Later, Public Roads assisted in the development of ASTM and AASHO specifications and guidelines for air-entraining agents.

\section{Coating Materials}

Beginning in the 1920 's, Public Roads became concerned with the need for improved field performance of such common highway coating materials as paints and galvanizing for metals for guardrails, more durable materials for culverts, and more lasting and visible paint for lane markings and directional highway signs. A special chemical unit was established to conduct research in this area.

A significant result of this effort was the development in the late 1940 's of a modified anticorrosion paint primer for the bridge steel being shipped to the Philippines for rebuilding its war-damaged highway network. The standard red lead-linseed oil primer then in use was found to be badly scratched and significantly stripped from the steel after its arrival in the Philippines. To compound the problem, the exposed steel also corroded rapidly when stored under the humid Philippine conditions. Studies showed that a pigment combination of red lead and iron oxide, as well as a combined base of linseed oil and alkyd resin, would provide adequate corrosion protection and would be tough enough so that shipment damage and deterioration in storage was minimal. ${ }^{11}$ The specification developed has since become an AASHO standard used by a number of State highway departments.

Another development in coating materials was an abrasion-resistant paint system for highway structures. Exceptionally high wind velocities combined with wind-borne ice and soil particles in the Alaskan Copper River Delta produced almost immediate and extensive abrasive damage to the standard bridge paint system in use. Laboratory and field research by Public Roads and the Alaska Department of Highways were completed in 1965 and demonstrated that rubber-based coating systems offered superior abrasive resistance to these destructive forces. ${ }^{12}$

Because traffic paints do not last long in heavy traffic, there has been a continuing interest in developing better and more economical lane marking material. This has led to three distinctly new and rather revolutionary types of lane markers. In general, the new materials have been developed by industry with evaluations performed by State highway departments and technical assistance and funding help from Public Roads.

The new materials are:

- Prefabricated plastic striping which is supplied either as short rectangular segments or in rolls like paper towels and applied to the road surface with permanent cement. 
- Thermoplastic striping applied hot by either extrusion or spraying and capable of self-adhesion to the road surface. The stripe has good visibility and excellent life characteristics.

- Plastic dots reflectorized to have high visibility in rainy weather and protected by steel or other housings or base plates, the unit being firmly cemented to the pavement surface. These devices are being designed to have a very low profile, and the cement now available holds them so firmly to the pavement surface that they are not readily torn loose by street sweepers or even by snowplows.

Each of these lane-marking developments is somewhat more expensive in the initial installation than conventional painted striping, but the initial extra cost is often offset several times over by the greatly extended life, which has proved to be as much as ten times that of painted stripes.

\section{New Analytical Techniques}

During the late 1940's and early 1950's Public Roads pioneered in the application of sophisticated instruments to help solve materials problems. Infrared spectroscopy was developed to identify the nature and understand the behavior of chemical admixtures for concrete, mineral composition of aggregates, and other highway materials. An infrared spectrophotometer was acquired in the late 1950's and was successfully applied to analyzing, classifying, and regulating the use of certain admixtures for concrete, such as water reducers, hardening retarders, and airentraining chemicals. These materials were of such complex chemical nature that they had defied earlier less sophisticated methods.

\section{Pavement Research}

In 1908, Director Page reported on 13 experimental road sections on main roads connecting New York and Boston. These experiments resulted in the successful upgrading and restoration of deteriorated travel surfaces with various water-gas and coal tar products used primarily as dust palliatives. Additional reports by Page during the period 1909 through 1918 covered numerous experiments involving dust

Infrared spectrophotometric analysis can identify substances present in such materials as paints, concrete admixtures, coatings, rubber, etc., by determining the frequency at which radia. tion is absorbed by the substance.

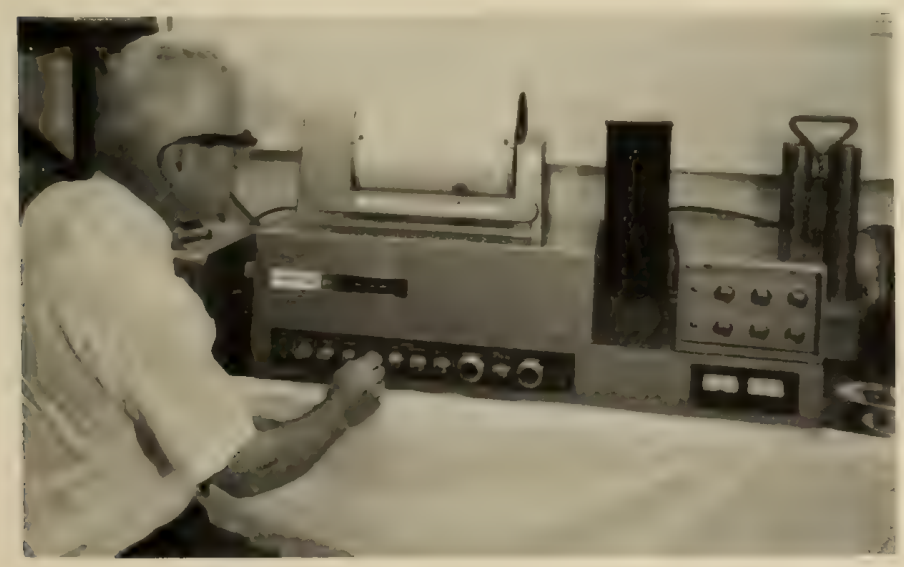

prevention and road preservation. These early treatments did much to make automobile travel faster and more pleasant and were relatively inexpensive for a single application. However, since they required frequent renewal, the total cost was appreciable, and they finally had to be abandoned.

In the early 1930 's, a gradual transition took place from dust control treatments to surface treatments, using tars and asphalts and better mineral cover. Also, during this period and continuing into the 1950 's, many miles of penetration and waterbround macadam pavements were built. These roads served growing highway needs very successfully, and considerable mileage has survived to the present time. Concurrent with the development of more substantial surface treatments, primarily in the east and the south, many central and western States experimented with and developed effective procedures for the type of pavement known as bituminous road mix.

In this period, Public Roads research was very active in coordinating field studies of roads in service with laboratory research on materials. In the 1930 's, for example, studies in Colorado and Wyoming demonstrated the need for sealing or "surface treating" road-mixed surfacings. As a result, bituminous seal coating became a fairly regular procedure. Another example was a study of bituminous concrete roads in Ohio which demonstrated the general serviceability of this paving.

\section{Concrete Pavement Research}

Many articles were published documenting the Bureau of Public Roads' research on portland cement concrete pavements. Among the earliest was a study in 1919 on the behavior of concrete slabs. The measured curling and warping movements of the slab were evaluated, in addition to the effect of wheel loading, and a thickness design formula based on the corner break was developed. This was followed in 1923 by Dr. H. M. Westergaard's theoretical analysis of slabs on an elastic medium. There followed a period of detailed studies by Bureau of Public Roads' researchers lasting until 1936 to verify and expand his results into a comprehensive design procedure, published as The Structural Design for Conorete Pavements, which has remained the basic guide for a decade or more.

Experimental roads continued to be built to test new concepts in concrete pavement. In 1921, the Bureau of Public Roads built the first experimental continuously reinforced concrete pavement near Washington, D.C., where many of the basic principles related to that type of pavement were developed. ${ }^{13}$ In 1937 the Bureau, in cooperation with the Indiana State Highway Department at Stilesville, began an extended field test of continuously reinforced concrete pavement, which now comprises a significant portion of the Interstate System mileage. The BPR also worked with industry in 1957 to produce the first U.S. prestressed concrete highway pavement, and, subsequently, built a 3,200-foot experimental section of pavement at Dulles International Airport in 1971. ${ }^{14}$ This concept too is gaining widespread acceptance. 


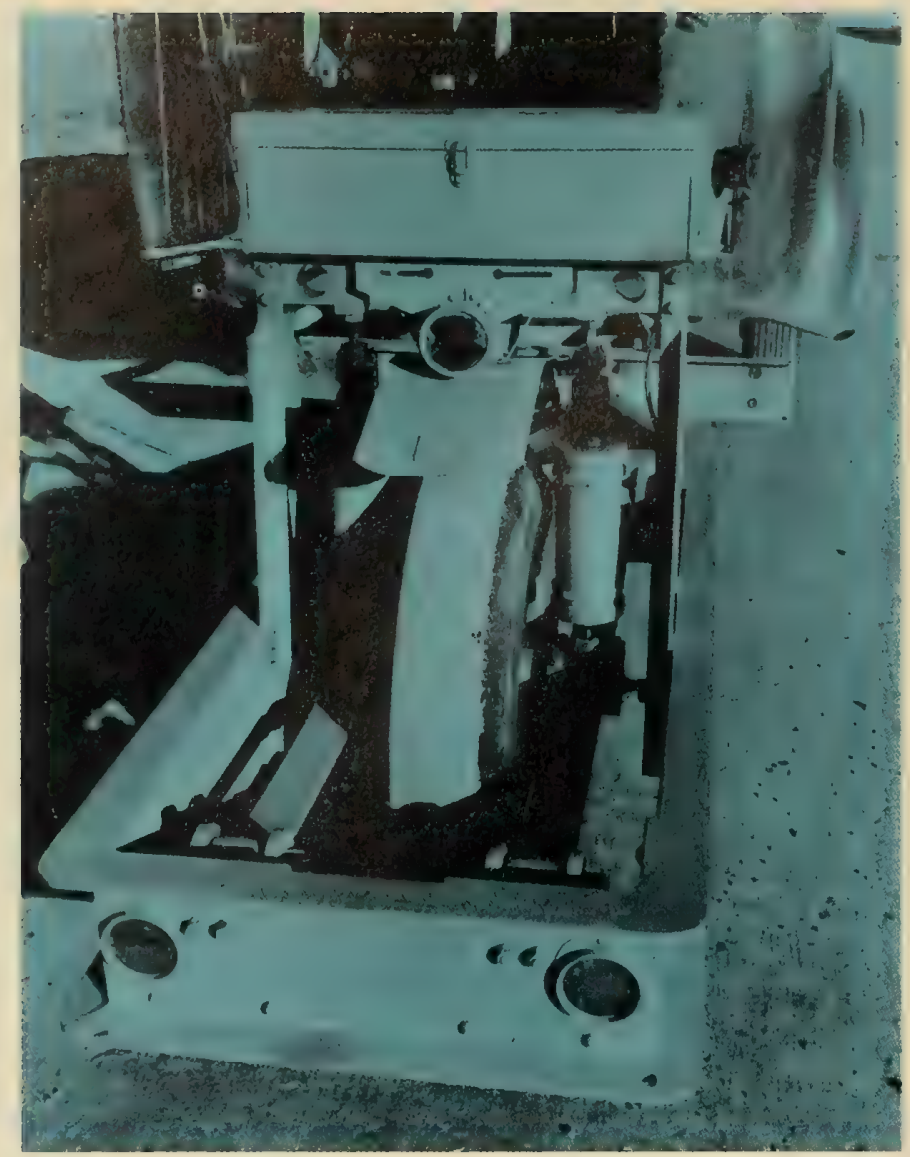

The Bureau of Public Roads roughometer measures the roughness of the pavement in units of vertical spring motion per unit of distance the wheel travels.

Research was also performed on reinforcing materials for concrete pavement. Bond studies in 1926 or steel reinforcing bars of various shapes and types of deformation included pullout tests to evaluate the contribution of the different types of bar deformation to the load-carrying capability of concrete slabs. The superior performance of several specific types of bars was established. In addition, results in 1958 of an extensive laboratory study of the performance of load transfer dowels in concrete pavement joints had an immediate effect in pavement design. Recommended dowel bar lengths and diameters for effective load

Taking deflection measurements with the Benkelman Beam to determine pavement displacement when a load is applied.

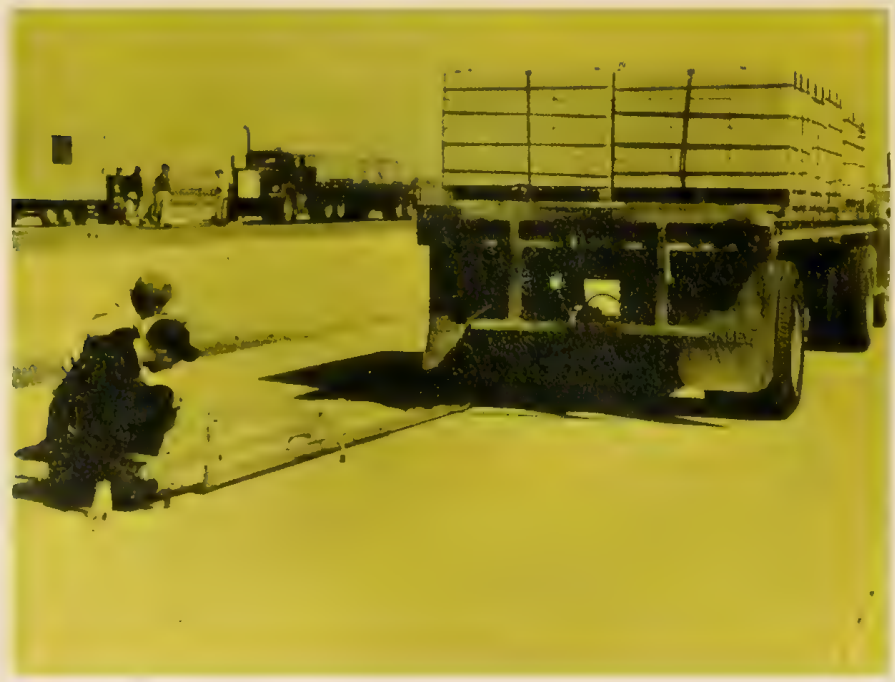

transfer were widely adopted and are still in use today.

The Bureau of Public Roads was an early leader in efforts to provide a means of obtaining quantitative measures of pavement roughness. The result was a compact single-wheel trailer that measured and recorded the roughness of the wheel path in units of vertical spring motion per unit of distance traveled. With this device, commonly known as the BPR roughometer, it became possible to easily rate the roughness of both new and old pavements. The term "present serviceability index" as a function of roughness was used to express the results in numerical terms. This index was used to specify the degree of roughness for design standards and in rating construction.

Among other items of special equipment designed by Public Roads engineers was a device to measure the vertical displacement of pavement, both elastic and permanent, caused by static and moving wheel loads of various intensities and at different distances from the point of load application. With these displacement data, it was possible to make design analyses for better subgrades and pavements. This ingenious device, named the Benkelman Beam for its inventor, received nationwide attention and was duplicated by many State highway departments.

In addition to tests on roads in their normal condition, studies were made in the 1920's to determine the impact forces of wheel loads generated by an "artificial" bump. One study was on a ramp 30 inches long with a drop-off varying from $1 \frac{1}{2}$ to 3 inches. These tests demonstrated the superiority of pneumatic tires versus solid rubber tires. Partly as a result, solid rubber tires were rapidly phased out in the late 1920 's.

\section{Service Lives}

Highways do wear out. Because they wear out, highway programs must include continuous resurfacing and reconstruction operations to maintain highways in a usable and safe condition. Accordingly, a knowledge of service lives of highway pavements is essential.

Testing impact of vehicle wheels on pavement.

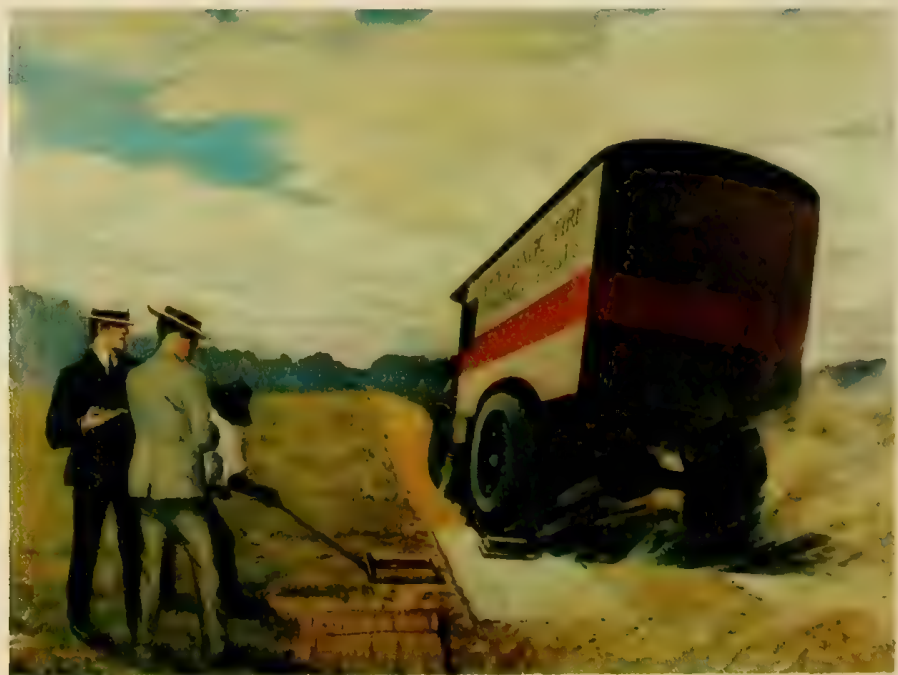




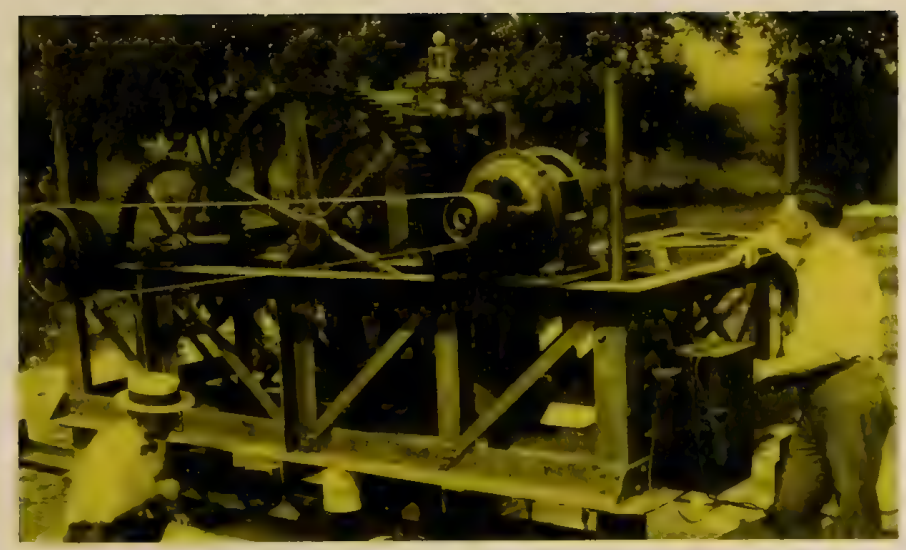

This machine was used in 1922 to test the impact of solid rubber tires on test pavement sections. By raising the wheel and suddenly dropping it at impact forces comparable to truck traffic on the roads, comparative pavement design strengths could be determined.

Research in the field began in 1935 when road life studies were incorporated as part of the statewide planning surveys. At one time or another nearly all States cooperated in this research by providing the basic data which were analyzed by Public Roads staff. Although the purpose of the surveys was to determine average service life of road surfaces, the data also provided the means for obtaining construction costs, salvage values of retired roadway elements, and service lives of structures, gradings, and rightsof-way.

Based on an analysis of the records of surfaces and roadway elements previously constructed and depreciated, it is now possible to estimate the amount and cost of replacement of these elements. For example, the results of a study completed in 1971 indicated that of the total miles of roads remaining in service in 1968, 60 percent will be retired in 10 years and 87 percent in 20 years. ${ }^{15}$ Such information is essential to determine construction and reconstruction programs and corresponding revenue needs of a future period.

\section{Bridge Research}

Early highway bridge research was conducted in response to the need to shape the AASHO standard specifications for highway bridges, which were gradually developed between the formation of the AASHO Bridge Committee in 1921 and the first printing of the standards in 1931. Subjects of early bridge research studies included the expanded use of welding and high-strength bolting for connections in steel structures, the widespread acceptance of continuous composite bridge design and new techniques of construction, such as orthotropic deck design and cablestayed girder bridges. Other important developments were specifications covering the fatigue life of steel and the widespread adoption of new high-strength structural steels for bridges.

A unique aspect of early structural research activity resulted from the catastrophic failure of the Tacoma Narrows Suspension Bridge in the State of Washington on November 7, 1940, due to flutter induced by high winds. Under the auspices of the Advisory Board on the Investigation of Suspension
Bridges, formed in September 1942, a wind tunnel large enough to accommodate a scale model of the entire Narrows Bridge was designed and built at the University of Washington. This tunnel was used to make exhaustive studies of the causes and possible remedies for such a failure. After extensive redesign utilizing the findings of that study, the Narrows Bridge was rebuilt and has since served well without excessive vibration or other evidence of distress. One feature of the redesign was a slotted or grid type of deck which largely relieved the vertical component of wind streams impinging on the bridge.

The extensive investigations which followed the collapse of the Narrows Bridge led to the construction in 1950 at the Fairbank Highway Research Station of the George S. Vincent Memorial Wind Tunnel, where model studies on the effects of winds on highway structures were conducted. Models of many of the major suspension bridges throughout the United States and abroad have been investigated for aerodynamic stability in this wind tunnel.

One of the subjects of those studies was the Golden Gate Bridge. Excessive wind-induced vertical oscillations at a maximum amplitude of 13 feet had occurred while the Narrows Bridge investigation was still underway, causing great official and public concern. Consequently, section-model studies of the bridge were performed in the Vincent wind tunnel. Some structural stiffening of the suspended portions of the bridge, as well as the introduction of slots in the deck to reduce the vertical component of the wind force, proved effective, as in the case of the redesigned Narrows Bridge, in remedying the excessive oscillation.

A great deal of research was also initiated on all of the common bridge construction steels in order to learn more about their sensitivity to brittle fracture. Once this research began to produce results, tentative toughness specifications for bridge steels, using the Charpy V-Notch impact specimen as a control, called for tougher steel with increased steel strength and thickness. These requirements were adopted by the AASHTO Bridge and Materials Committees for inclusion in the 1974 interim specifications.

Aerodynamic studies of suspension bridges are conducted in the George S. Vincent wind tunnel. A precise model of a portion of the bridge deck is mounted on springs that match the stiffness of the actual cable system with instrumentation to measure the oscillations produced by the wind stream.

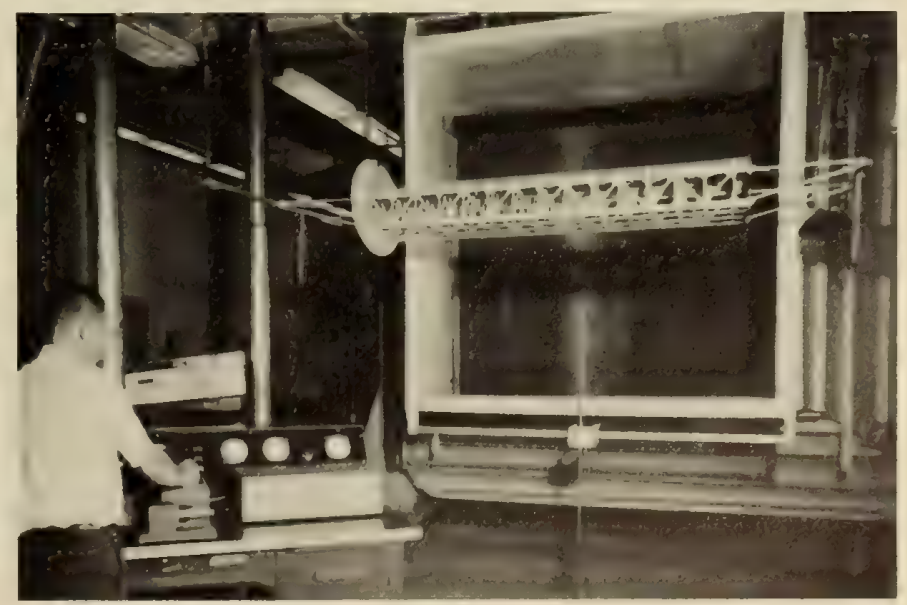




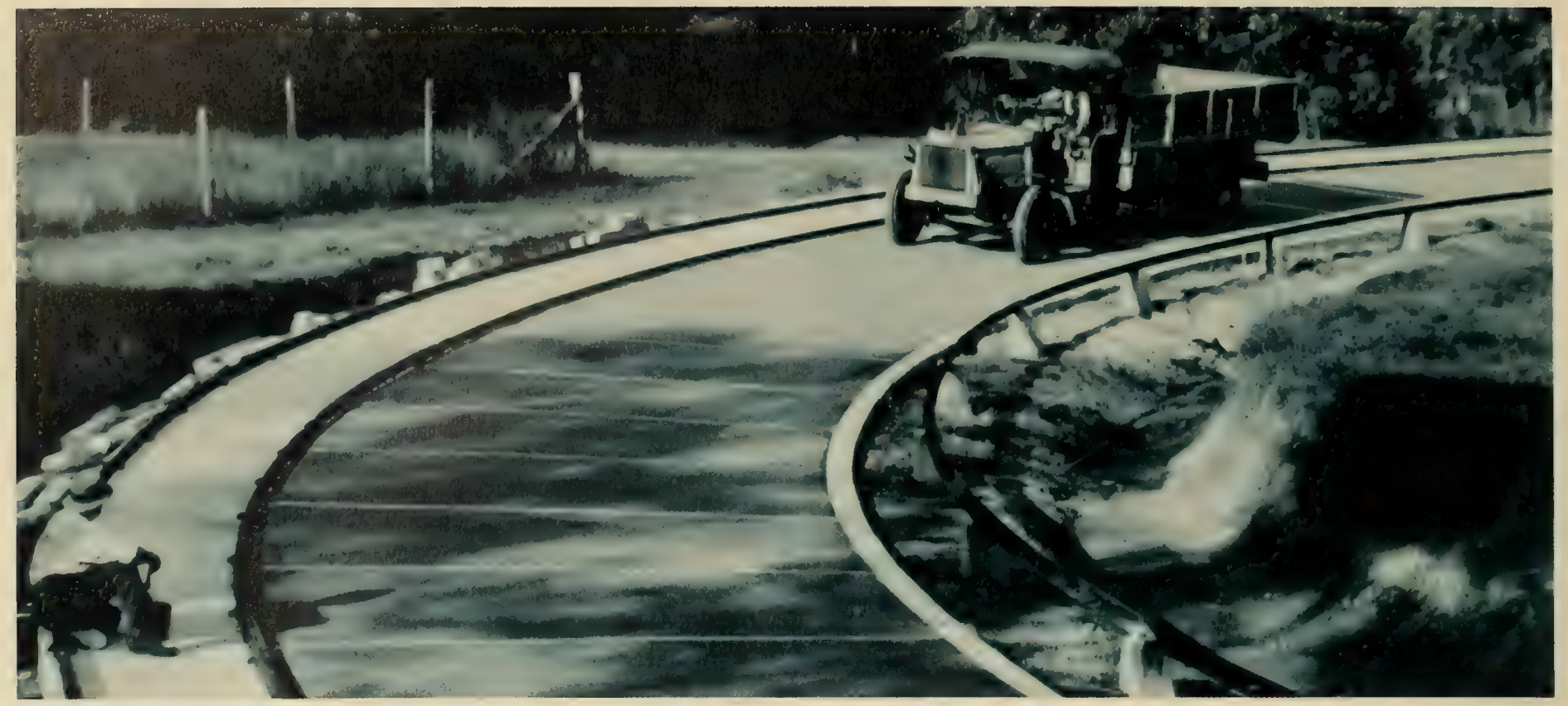

One of the circular test tracks built in Arlington, Va., for measuring the impact forces of various wheel loads on pavements.

\section{New Structural Concepts}

In the early 1950 's, the use of prestressed concrete structural members in this country was hastened by the many research studies dedicated to the solution of problems arising in connection with the adoption of this new structural concept. As a result, the use of prestressed concrete bridges advanced rapidly in the United States, achieving predominance as a construction material in many sections of the country. Similarly, an intensive program of structural research led to the widespread acceptance of the use of highstrength bolting of steel structural connections, an improvement over the previous exclusive dependence on riveting.
Public Roads studied a number of full-scale bridge loadings in cooperation with the various State highway departments beginning with the Yadkin River Bridge Test in 1928. And in 1950, Public Roads instrumentation and assistance were made available to any State highway department requesting assistance. As a result of these studies and the road tests, which included bridges, a significant contribution was made over the years to the improved fatigue design of steel structures. Out of these studies came a better understanding of such theoretical concepts as the effects of structural fatigue on load distribution between members and the effect of incorporating new materials, such as high-strength reinforcing steel or

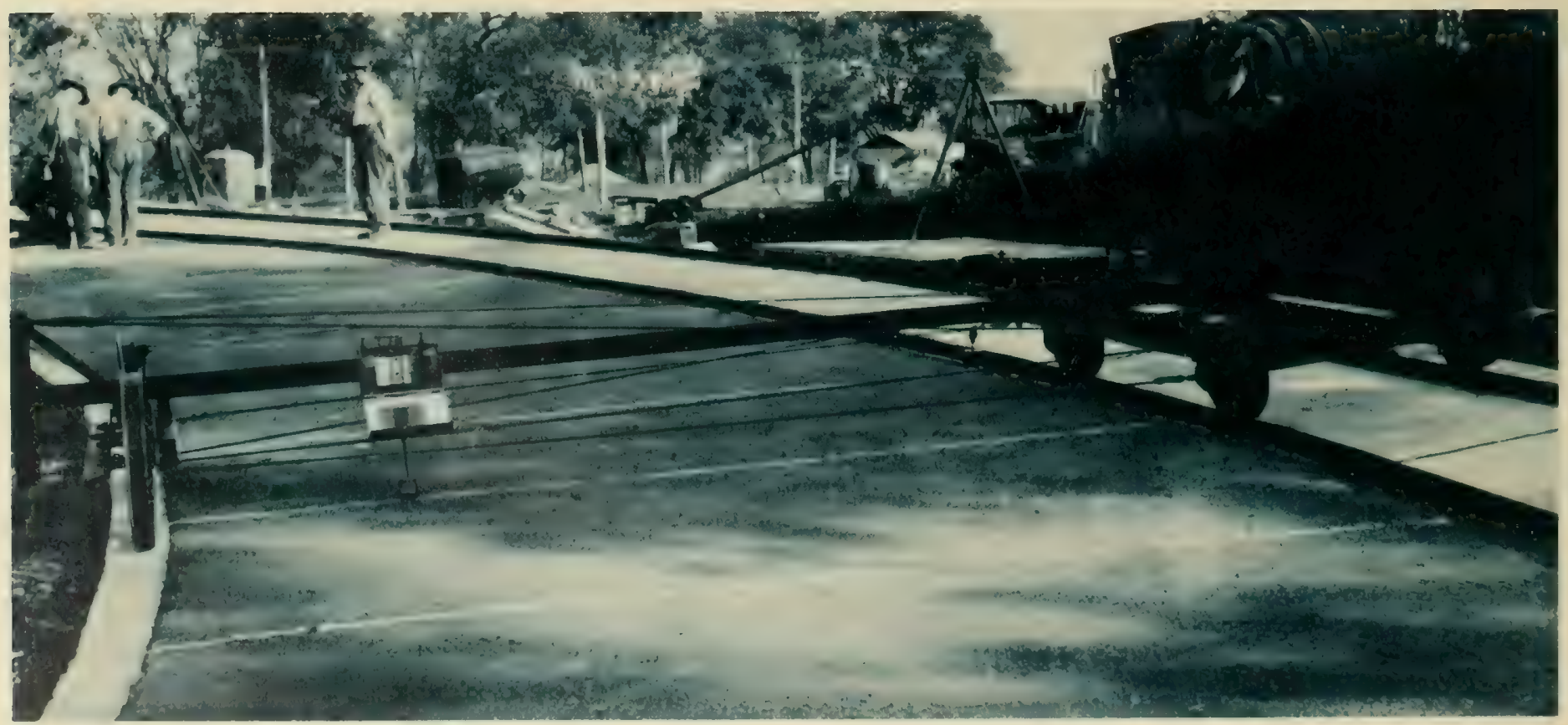


lightweight concrete, on the performance of concrete highway bridges.

With the beginning of the Interstate System came the need for fitting bridges to much more restrictive and sophisticated geometrics to provide for the needs of high-speed traffic in congested areas while maintaining structural esthetics and economy. Straight span members were no longer always adequate for the needs, and the understandings of the structural design of curved members was limited. Research undertaken, both in the form of multi-State pooled-fund laboratory and analytical studies and the extensive use of cooperative Federal-State field studies, helped fill this urgent and critical need for improved curved girder design technology. As a result of this research, bridges today are designed and built with curved alinement and warped decks in a manner unheard of two decades ago.

\section{Road Tests}

Following World War I, a prime objective of the State and Federal highway program was to reconstruct the surfaces and pavements of main highways which had received widespread damage from the greatly increased traffic of heavy trucks with solid rubber-tired wheels. The light surfaces, designed for horsedrawn or other light vehicles, failed under the impact of the heavier vehicles. Road test data were needed to determine the supporting capability of the various subgrade soils, the stresses induced in rigid and flexible pavements by the impact of motor vehicles, the effects of expansion and contraction of road surfaces caused by variations in temperature, the wear of traffic upon pavement surfaces, the distribution of loads upon bridges, and many other factors. To solve some of these problems, the Bureau of Public Roads and the States initiated a series of road tests.

The Bates test road and test vehicles.

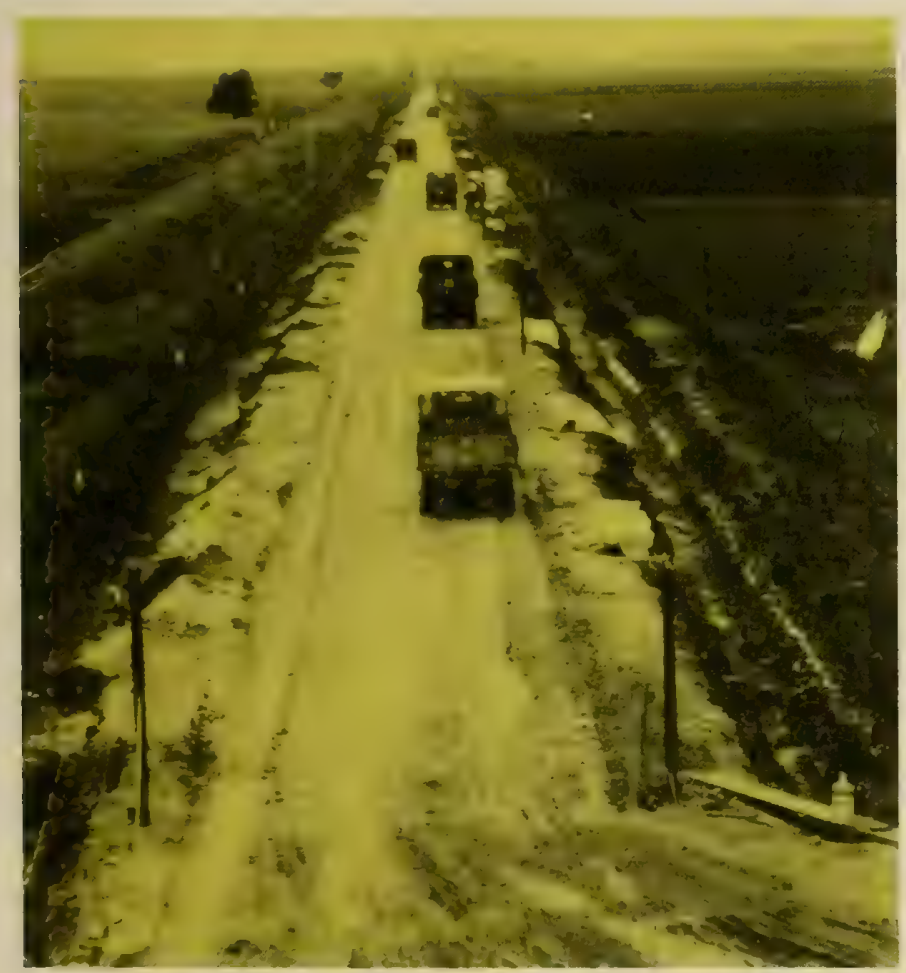

The Arlington Road Test. The first road test was initiated in 1918 at BPR's Experimental Farm in Arlington, Virginia, to measure qualitatively the impact forces of various wheel loads. The tests, conducted with Army trucks equipped with solid rubber tires, were on concrete, brick and bituminous slabs on circular tracks. The early tests indicated the major effect of wheel impact forces and led to further studies with more refined measuring instruments and the inclusion of pneumatic tires.

The Bates Road Test. For the Bates Road Test, the Illinois Division of Highways constructed 68 test sections, including six types of pavement on 2 miles of road and, with the assistance of BPR engineers, conducted tests on them from 1920 to 1923. Trucks were operated with controlled wheel loads that were progressively increased from 2,500 to 13,000 pounds. The test data gave the pavement type and thickness required for a specified loading and showed the need for control of wheel loads. A direct result of this study was the use of a thickened edge concrete pavement.

The Pittsburg Road Test. Between 1921 and 1922, another road test was conducted in Pittsburg, California, to determine the efficiency of both reinforced and plain concrete pavements of variable thickness and designs on certain types of subgrade soil. The test was conducted by the Columbia Steel Company on an elliptical track 560 feet in length containing 13 concrete pavement test sections. Much new information was learned, particularly concerning the effectiveness of longitudinal joints in preventing longitudinal cracking.

The combined findings from these three contemporary road test studies led to major advances in pavement design practices. The relations were determined between concentrated wheel loads and the thickness of several common types of pavement, which were directly usable on new highway plans. From the range of wheel loads studied, highway officials were able for the first time to reach agreement on the use of a 9,000-pound maximum value as the economic standard for highway pavement designs. More directly evident to the public was the abrupt phasing out of solid-rubber tires on trucks because of their high impact destruction on all types of pavements. Within a few years after 1926 the use of pneumatic tires became universal. Also, these studies made evident the need for amplified research on soil support values to attain better pavements.

The Hybla Valley Road Test. From 1944 to 1954 a series of studies on flexible pavements was conducted on the Hybla Valley test track in Alexandria, Virginia, by BPR in cooperation with the Asphalt Institute and HRB. A 2,000-foot oval track for full size vehicles was built with selected soil foundation and paved with asphaltic concrete. Using newly developed measuring equipment, data were obtained on the vertical displacements of the pavements from both static and moving wheel loads of varying intensities.

A significant finding from these tests was that there is considerable elastic movement within a nonrigid pavement structure under load. A great deal was also learned about instrumentation and field measurement procedures which greatly aided later test road studies. 
Road Test One-Md. In 1949 the Interregional Council on Highway Transportation originated a test road study on a 1.1-mile section of highway south of La Plata, Maryland. The study and report was a cooperative effort of 11 eastern States, the District of Columbia, Public Roads, truck manufacturers, the petroleum industry, the Department of Defense and HRB. The objective was to obtain data, for use both in vehicle weight regulations and in pavement design, on the relative effect of four different axle loads on the existing concrete pavement (four lanes), then in excellent condition.

Test trucks with 8,000- and 22,400-pound single axle loads were operated on adjacent lanes and trucks with 32,000 - and 44,800-pound tandem axle loads operated on the other pair of lanes. Nearly 240,000 single axle truck passes were made and about half as many of the tandem axle.

The data on the progressive pavement deterioration, evidenced by cracking, internal structure failure, and joint depression, showed that damage was proportionate to axle loads. Significant data also were reported concerning soil support features and stresses at various points in the pavement slab.

WASHO Road Test. In 1951 the Western Association of State Highway Officials (WASHO) set up a test road to obtain data for use in establishing load limits and in designing flexible pavements. Cooperating in this test were 11 western States, truck and truck trailer manufacturers and three petroleum companies. The Highway Research Board supervised the construction and testing to determine the effects of four-axle loads on selected designs of flexible pavement. The Bureau of Public Roads assisted with funds, personnel, instrumentation, photography, supplies and equipment. This test was run from 1952 to 1954 at a site near Malad, Idaho.

Two four-lane test loops, each with 1,900-foot tangents, were constructed with five pavement structural sections ranging in depth from 6 to 22 inches on each tangent. On one loop the pavements were subjected to 18,000- and 22,000-pound single axle loads and on the other 32,000- and 40,000-pound tandem axle loads. The lighter loads were operated on the inner lanes. About 240,000 truck passes were recorded on each of the loops.

The test data yielded significant relations of stresses within and failures of the several flexible pavement design sections as the truck loadings progressed. Some of the general findings were:

- The 4-inch asphaltic concrete top course was markedly superior to the 2-inch.

- The heavier axle loads resulted in considerably more distress.

- A paved shoulder contributed to the pavement support.

- Greatest distress occurred in the spring and least in the fall.

- Distress from the tandem axle was equivalent to that of a single axle of about two-thirds of the tandem weight.

The AASHO Road Test. After the WASHO Road Test, the American Association of State Highway Officials (AASHO) in agreement with the Bureau of Public Roads decided to conduct a comprehensive national test to obtain data on all significant variables. In 1955, AASHO sponsored and requested the Highway Research Board to direct this test. The purpose was to study the performance of pavement and bridge structures of known characteristics under moving loads of known magnitude and frequency. Portland cement concrete and asphaltic pavements, as well as certain types of bridges, were included in the specially constructed test facility.

This $\$ 27$ million project, located near Ottawa, Illinois, was financed by the highway departments of the 48 States, Hawaii, the District of Columbia, and Puerto Rico. Financial support was also provided by the Bureau of Public Roads, the Automobile Manufacturers Association, the petroleum industry, and the American Institute of Steel Construction. The Department of Defense furnished the heavy vehicles and drivers for their test run operations. In addition, there were many services and contributions by the automotive, petroleum, tire, cement, and steel industries.

Traffic on loops during the AASHO road test.

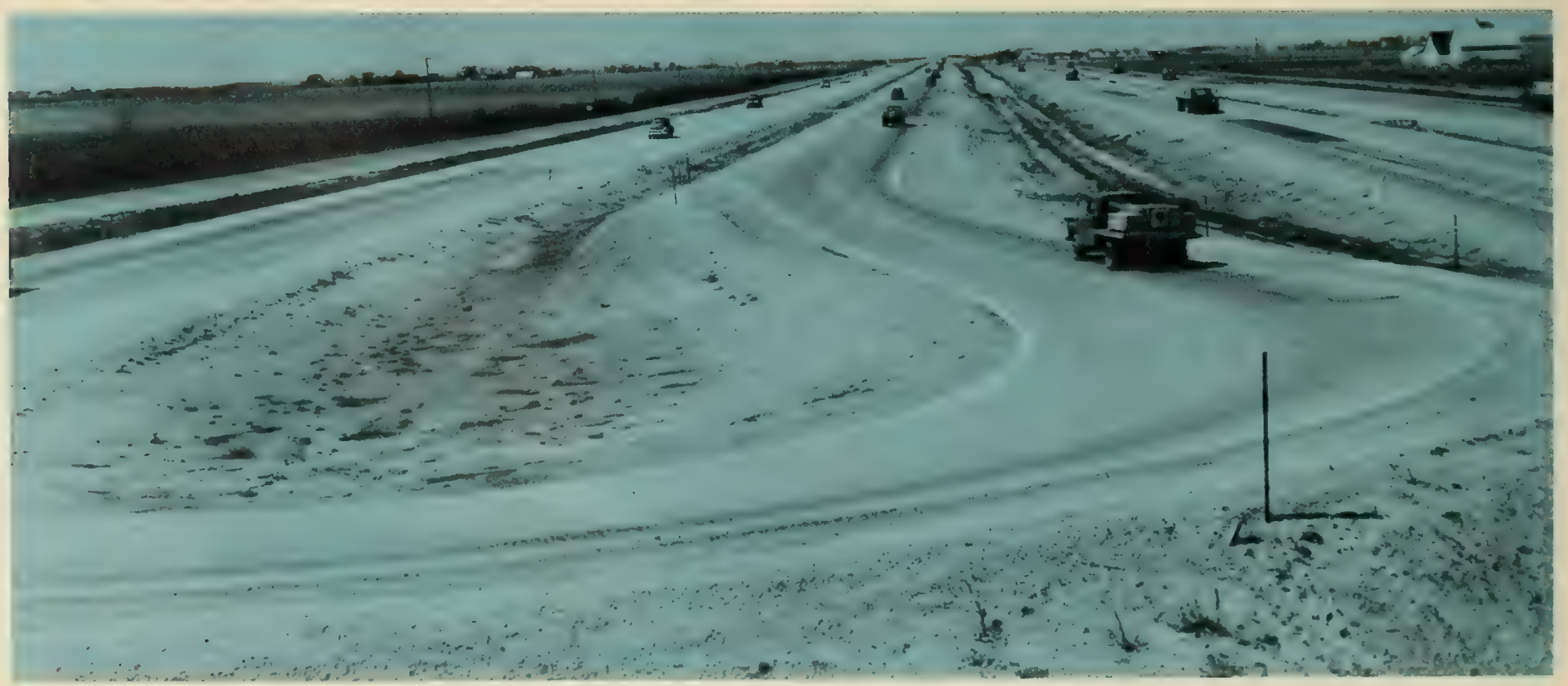


The test road consisted of about 7 miles of two-lane pavements, half of concrete and half bituminous. The roadways included 16 short-span bridges. There were 836 separate test sections located in six loops which varied in length from 2,000 to 6,600 feet. The test sections had selected factorial combinations of surface, base, and subbase thicknesses. Axle loads differed on each loop and varied from 2,000-pound single to 48,000-pound tandem; truck trailer units were included. Full-scale tests started in November 1958 and terminated in November 1960. A total of 1,114,000 axle loads had been applied to the pavements and bridges surviving at the last date.

The project produced a reservoir of facts long needed for the development of a more refined and scientific design of pavements and short bridges.*

The test data well established the desired relations of pavement structural designs (component thicknesses) and loadings (magnitude and frequency of axle loads). These findings were developed in the form of equations and graphs that showed the effects of particular variables on pavement performance. These soon were incorporated by AASHO and others into pavement design guides and manuals. The concept and use of a "serviceability index" to define pavement performance was a major item. And the data on equivalencies of single- and tandem-axle loads for the same pavement performance was a high-use product. Also important were: a method to predict pavement performance from measurements of deflections and strains; and data on the reduction of surface skid resistance.

\footnotetext{
* The extensive technical data and findings are recorded in seven Highway Research Board Special Reports Series 61, and Special Report 73.
}

The test bridge findings largely verified design predictions of deflection and strain. The dynamic studies resulted in the formulation of new theoretical concepts for analytical evaluation of stresses and deflections from moving vehicles.

\section{Construction and Maintenance}

\section{Production Costs}

The construction of highways in the early stages of our country's development involved mostly hand labor and draft horse or mule power. Formal organization and production efficiency were items unheard of, and the pace of construction depended, for the most part, on the forcefulness and ingenuity of the foreman. Later, as mechanized methods started to supplement the man and mule power method, the need for systematic organization increased. Early Public Roads activities in this area concentrated mostly on object lessons gained in test road construction.

In the early 1920's, the Production Cost Study Program was initiated by the Bureau to assist the highway industry in analyzing its various operations regarding time utilization and operational efficiency of equipment used in construction. This program, led by 'T. Warren Allen, served two purposes: (1) To assist the contractor by direct time-motion studies on their operations, expressed in terms of production rates and costs, pointing out observed inefficiencies and measures as to how he might improve on his operations; and (2) to train junior engineers in Public Roads by direct exposure to the practicalities of construction equipment operations and the overall process of building a highway. This program continued until 1936.

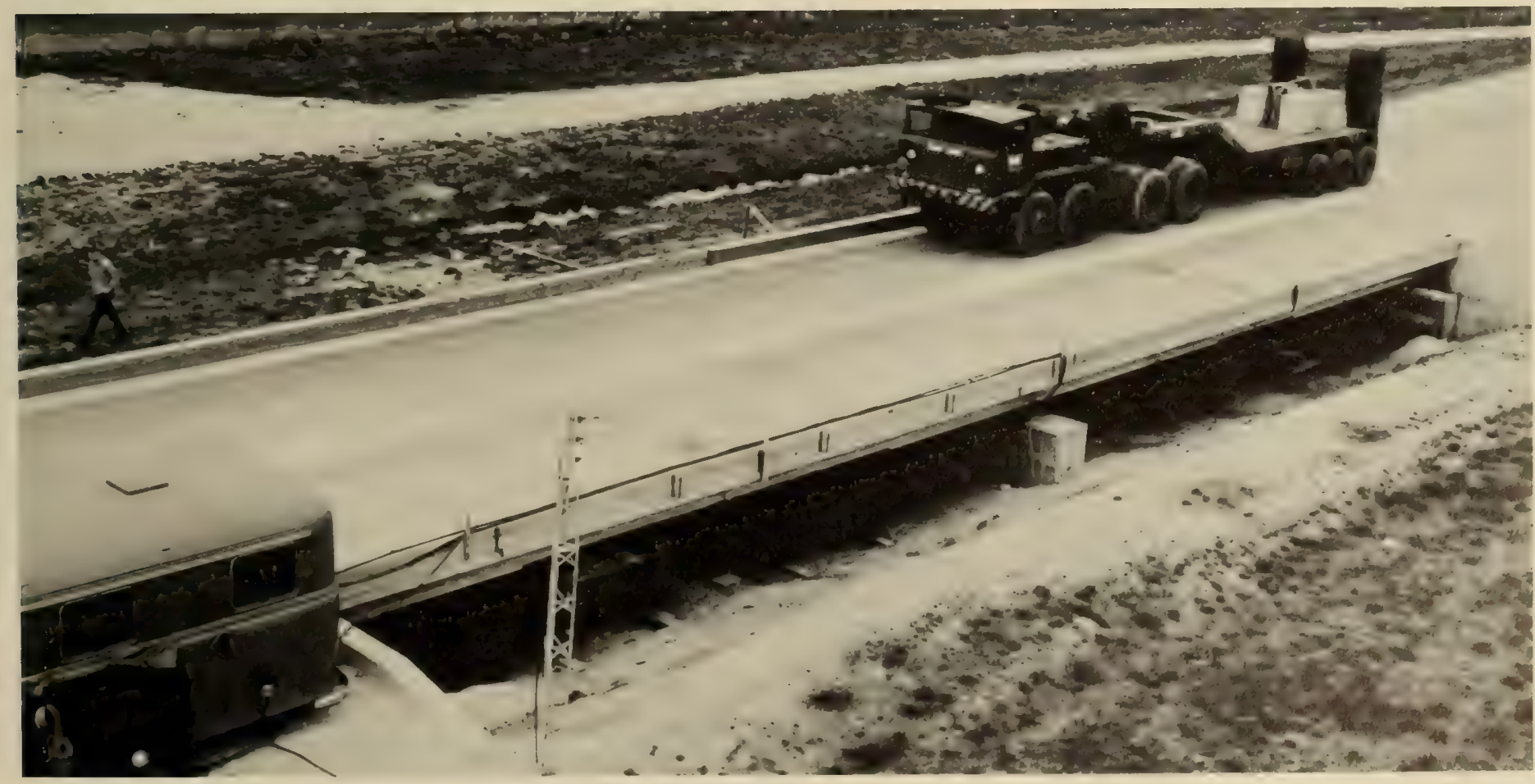


Because of personnel shortage during the war emergency, the program was dormant for 10 years and was reinstituted in 1946. By then the highway construction and maintenance industry, with its far flung operations reaching into every corner of the country, was using thousands of major equipment units and millions of dollars worth of material each year. Economical and efficient use of this equipment, manpower and materials was of concern to every segment of the industry in order to stretch the highway dollar to meet the need for more and better roads and yet assure the competitive contractor a reasonable profit.

During the next 20 years, production time and motion studies were made on over 400 projects. Over 40 information reports were issued prior to 1960 by Public Roads and the Highway Research Board on performance, time utilization, and costs pertaining to equipment employed on highway construction and maintenance work. In addition to routine production studies on maintenance and construction operations, the program was directed also into other areas to gather information on a particular facet of construction. In 1952, a year-long comprehensive study was made with the objective of developing comparative data regarding net cost to the public of construction work performed by contract and by State forces in North Carolina.

These cost studies were later expanded to obtain data on economics of detours versus carrying traffic through construction and on economics of specifying a single cold feed bin versus multiple bins for hot-mix production. Other cost studies were made on various types of bridge construction and grading and paving work to develop comparative man- and equipmenthour unit cost data. Teams also studied such areas as: (1) Determining relationship between mixing time and productivity for dual drum pavers and for central mix plants, (2) mechanics of aggregate drying in hot-mix plants, (3) optimum rolling pattern on hot-mix construction, (4) benefits of blending material prior to loading the concrete mixer, (5) evaluating a newly developed nuclear gage for determining density of bituminous pavements, (6) evaluating time lapse movies technique for studying construction, and (7) demonstrating the need for surge bins. Also, a

Michigan was the site for a winter driving test to determine safe speeds and handling of heavy vehicles on ice and snow, including negotiating turns and curves.

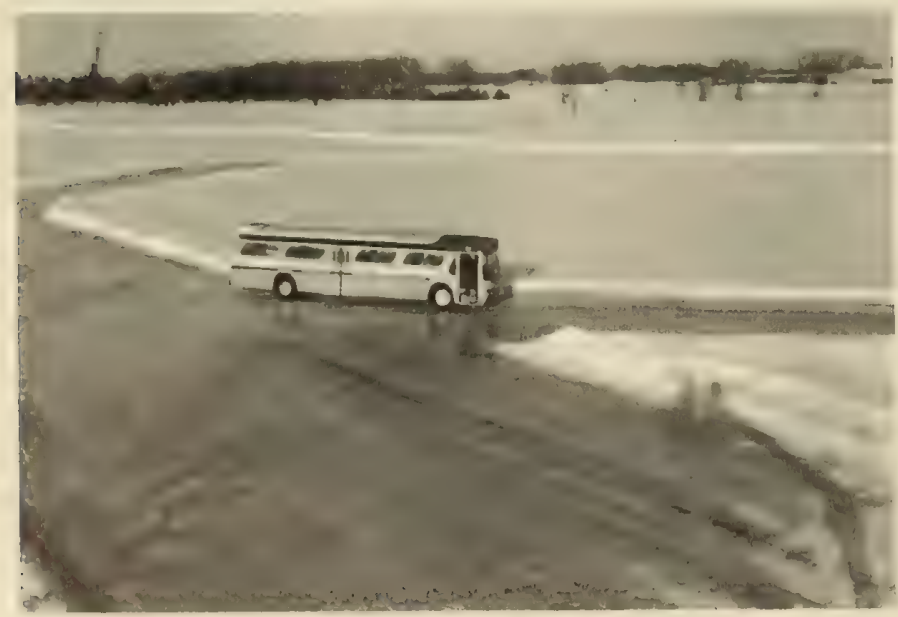

series of short-term and long-term pilot maintenance equipment and operations studies were conducted to pinpoint areas needing better organization and training.

This program was again terminated in 1966. The Federal Highway Administration resumed this program in 1971 on a more limited scale. The benefits that accrued from the early pre-World War II and the later post-World War II programs were widely reflected in many positive improvements in productivity. It can be said that they were a major factor, directly and indirectly, in the constant evolution leading to automation of construction, control, and operation.

\section{Maintenance Management}

Even though research on highway materials and construction processes had an influence on highway maintenance and, in part, directly applied in maintenance operations, the separate study of management of maintenance operations differs substantially from the other areas of highway research. These investigations involved a considerable number of States, and their results have affected all States.

Highway maintenance has experienced many changes through the years, most of which were based on intuition and practical considerations rather than factual knowledge and scientific management principles. There were some limited-scope highway maintenance management studies through the 1940 's, but these did not constitute a significant serious research program.

A 1950 joint study with the Connecticut State Highway Department developed facts concerning the performance of labor and equipment and appraised management problems. Subsequently, about 20 other small studies were conducted by the States during the 1950 's. The results were not singularly significant, but indicated a common need for better management. In 1959, a major study by the State of Iowa, in cooperation with Public Roads, developed a comprehensive system for producing facts and analyzing management aspects. This report received considerable publicity and the study's system was adopted in various ways by many highway maintenance organizations.

During the 1960 's, emerging conditions that required a refined maintenance management role included the new Interstate System, the need for higher levels of maintenance, a rapid change in technology, and labor and budget problems. As a result, maintenance management became much more prominent in both research and practice.

Research to improve maintenance management was greatly expanded to meet these challenges. Between 1960 and 1970, about half of the State highway organizations conducted maintenance management studies. There was considerable cross-fertilization between these studies, and they covered a very wide range of elements, from equipment development and roadside practice to statewide planning and economic investigations. In these studies, a number of major management consultants were involved as well as State universities. The results led to major improvements in maintenance operations throughout the United States, and more refined studies are in progress. 


\section{Traffic and Safety}

\section{Capacity and Design}

In response to Chief MacDonald's concern, research was directed in the 1920 's into three major areas: (1) Road construction and maintenance, (2) the economics of road operation, and (3) the economic value of highways to a community. Although elements of highway capacity and design were mentioned, it was W. K. Hatt, Director of the Highway Research Committee of the National Research Council, who in 1921 raised the following questions: "What is the capacity of a road of a given width for any particular type of vehicle as expressed in vehicles per hour, ton-miles per year, etc.? What is the appropriate unit for expressing traffic for various purposes?" 16

\section{Research on Highway Geometrics}

In March 1925, Public Roads first reported a number of significant facts concerning the lateral distribution of traffic. These factors included the effect of road width, curves, shoulder conditions, grades, surface crown, and other physical features. Observers recorded the positions of tires in relation to lines painted across the pavement at 1 -foot intervals. The results indicated that 18 feet was the minimum pavement width which would permit passenger cars and trucks to pass in safety and with a reasonable amount of clearance. Speeds were not considered in this study.

Four years later, in 1929, when equipment for measuring speeds became more reliable, it was found that the safe passing of "rapidly" moving automobiles and trucks required a surface width of at least 20 feet for two-lane rural highways.

Since 1929, researchers have progressively provided the basic information required to set design standards and operational controls for main roads and freeways. In December 1944, one of the recommendations of a BPR study of the effect of roadway width on traffic operations was that lane widths should be 12 feet for safety and comfort of traffic operations. The AASHO soon adopted this width as a standard for primary highways in the United States. Within a short time this standard was also adopted in many foreign countries. Vehicle widths remain about the same today, and this lane width remains the basic standard.

\section{Horizontal and Vertical Curves}

An early design policy statement that is still current says that "In the design of highway curves it is necessary to establish the proper relation between design speed and curvature and also their joint relations with superelevation. While these relations stem from laws of mechanies, the actual values for use in design depend upon practical limits and factors determined more or less empirically over the range of variables involved." ${ }_{17}$ A series of studies have been made to relate the speed of operation on highways to the horizontal and vertical alinement. One of the earliest studies on the effect of speeds on geometric design was conducted in 1929. Even though the legal speed limits in the 1920 's were 35 to 45 miles per hour, A. Bruce, in his article "The Effect of Increased Speed of Vehicles on the Design of Highways," concluded that there was need for easier curves, greater superelevation of curves, more extensive vertical curves, and greater sight distance on both horizontal and vertical curves.

In 1953 a comprehensive study of driver behavior on vertical and horizontal curves was completed by Public Roads in cooperation with the New York Department of Public Works that showed that the percentage of drivers exceeding a safe speed for the curve radius increased greatly on the sharper curves. The combination of curves over 5 degrees (radius less than 1,200 feet) and grades in excess of 5 percent also were found to result in an especially high accident rate on conventional rural highways.

A comprehensive study of "Driver Performance on Horizontal Curves" was conducted during 1951-1954 in cooperation with five States at 35 horizontal curves. The separate studies were on two-lane, two-directional roads. Among the more important conclusions were the following:

- Drivers did not change their speeds after entering a horizontal curve.

- The existing superelevation had no effect on speeds.

- Operating speeds and the radius of curve are linearly related.

- The curve radius had a greater effect on speeds than sight distance. ${ }^{18}$

In 1969 data in NCHRP* Report 68 on the application of vehicle operating characteristics to geometric design substantially verified these results.

\section{Highway Capacity}

Highway capacity has been the subject of careful and painstaking study for nearly six decades. A rational and practical method for the determination of highway capacity was essential for the sound economic and functional design of new highways and for the many existing roads and streets which must continue in use for extended periods of time. Basically, highway capacity concerns the effectiveness of various highways to serve traffic and involves the many elements of highway design, speeds, vehicle and driver performance, and traffic control. In recent years, due to the development of refined traffic study methods, instrumentation and equipment, substantial amounts of reliable field data have been used to develop new insights into problems of and solutions to traffic operations.

In 1934 the BPR set up and took a dominant part in a coordinated series of studies to obtain the basic data on highway capacity. This widespread effort included studies on: methods of counting traffic;

\footnotetext{
* National Cooperative Highway Research Program.
} 


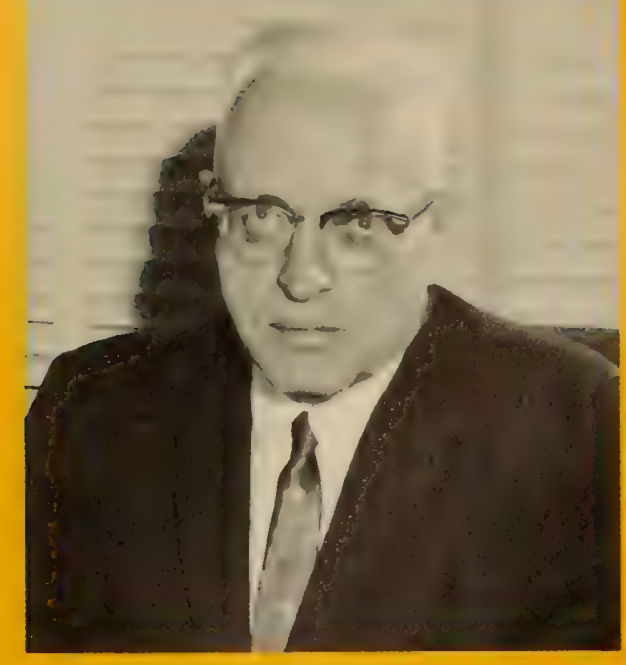

In a career foreshortened by his untimely death at age 57, Olav Koch Normann's contributions to safe and efficient highway travel could be matched by few others in a full lifetime of effort. Endowed with a rare combination of brilliance of mind, skill of hand, and enormous physical strength and endurance, $\mathrm{O}$. K. Normann set a pace that few could follow. He was a leader in many fields but became best known as the 'father' of the world's knowledge in the area of highway capacity.

Normann was born in Kansas City, Missouri, on October 1, 1906, and earned his Bachelor's degree in Civil Engineering at the University of Minnesota in 1928. Immediately entering the Bureau of Public Roads as a junior engineer in its training programme, Normann began the career that kept him in the Bureau until his death.

His inquisitive mind led him early into the field of research, and in 1935 he moved into the field of geometric design and highway capacity.

The approach he followed would probably now be called operations research or system analysis in today's more sophisticated language. Then it was recognized simply as the only logical way to approach the problem. It accepted the movement of traffic as a dynamic system involving the vehicle, the driver, and the road. Organizing studies in each of these segments, Normann himself synthesized the separate results into principles derived from actual experiment on the road and in the traffic stream to reflect the countless possible combinations of the individual and collective actions of drivers and differing vehicle performance and roadway design elements.

This approach might not have been so successful had it not been backed by Normann's own broad talents. As an analyst, he had an uncanny ability to detect trends and relations within masses of data that customary statistical methods did not seem to reveal. While taking full advantage of modern data processing and analysis techniques, he did not forsake simple graphical and other methods that on more than one occasion proved out after the more complex methods failed.

It was this depth of investigation that showed clearly, as research progressed, what specific facts were lacking or where data in different form would have helped. Here another of Normann's talents, mechanical skill, came to the fore, for seldom, it seems, was there available the apparatus or equipment needed to measure particular facets of driver behaviour or vehicle performance. Not only could Normann specify what was needed-he could design and construct it, sometimes with the design only in his mind, not on paper.

The impact of Normann's early research and writing led to his selection as Chairman of the Highway Capacity Committee of the Highway Research Board when it was first organized in 1944. His selection as chairman was unique, for at that time, as a general policy of the Bureau of Public Roads, its employees could serve as members or as secretaries of Board committees, but never as chairmen. Normann's accomplishments were so predominant in the field, however, that there could be no sensible alternative to disregarding the policy in his case.

Years of work by the committee members, aided by heavy contributions of data obtained by the Bureau of Public Roads and many state highway departments and city traffic engineering organizations, led to the publication of the Highway Capacity Manual in 1950. Much of the willing support of this committee can be attributed not only to the desire of various agencies to cooperate in the Board's activities, but also to the personal regard individuals in these organizations felt for Normann, the man, not just the chairman. Published with some early reservations as to the breadth of interest it would attract, more than 26,000 English language copies have been sold, and the manual has been translated into nine other languages. 
Disbanded upon publication of the manual, the committee was subsequently reorganized by the Highway Research Board in 1953, again with $\mathrm{O}$. K. Normann as its chairman. Again, there could have been no other sensible choice. The committee was charged with extending and updating the original manual, and at an appropriate time, presenting a revised version for publication. The new manual was nearing completion when death took the chairman. It will be his monument.

Although perhaps most widely known for his work in highway capacity, Normann's research led him into all facets of geometric design of highways, and many of today's standards of curvature, sight distance, gradients, lane widths, and intersection design are traceable directly to his efforts. Again, it was his understanding of the highway as but one element of a system that enabled him to design his experiments so as to produce results of immediate applicability. Important as he regarded the adequate reporting of research results, he felt their greatest value lay in prompt application.

As his technical field broadened, he was called upon, as is often the case, to shoulder increasing administrative duties. He advanced steadily through positions of heavier responsibility, until at the time of his death, he was serving as Deputy Director for Research of the Office of Research and Development in the Bureau of Public Roads. Despite the burden of administrative duties, his interest in technical matters in no way slackened and he seemed to regard the administrative functions as merely added, not different, responsibilities. In effect, he did two jobs, each in his characteristically thorough and exacting way-something he could do because of his energy and physical endurance, but which evoked mixed feelings of admiration and despair among those whom he hopefully expected to keep pace.

He was always a part of his community and accepted civic responsibilities with the same energy and enthusiasm that marked his professional life. He was active in and served as president of his Civic Association, and as chairman of Better Government Committee of his county's federation of civic associations.

In all aspects of life, not merely in his professional area, Normann was a confirmed skeptic. In his view, there must be some better way to do it, whatever it might be, than the way it was traditionally being done. Little with which he was connected failed to show some evidence of innovation before its completion-a healthy attribute in research, but not always so desirable in other fields, such as, for example, home building. Many are the anecdotes which will live long in retelling among his vast circle of friends that stemmed from Normann's innovations, and from his amazing resourcefulness in turning apparent setbacks and failures into advances and success.

Through his highway work he became widely known around the world. Many engineers from other countries, in travelling through the United States, benefited by technical discussion and enjoyed his warm hospitality. Along with his activity in the United States he had the unique opportunity to direct the changeover from left-hand to righthand driving in Panama during World War II. He conducted a training course in highway capacity in Madrid in 1961 and was one of a small group of United States highway engineers who were given an extensive tour through Russia in that same year.

In his professional field, he was active in the Institute of Traffic Engineers, and served as a member of its Board of Direction from 1959 to 1961 , as well as President of the Washington Section, ITE, in 1956 to 1957 .

Among the many testimonials and honours he received were the Department of Commerce Silver Medal for Meritorious Service in 1960, and the Theodore M. Matson Memorial Award in recognition of the advancement of the science of traffic engineering in 1957. A unique feature of the latter award is that he was the first recipient. 
Normann was deeply appreciative of these awards, and sincerely felt undeserving. But a little-known gesture only a few months before his death meant more to him than any other. As chairman of the Highway Capacity Committee as it was reconstituted in 1953, his role had not been easy. The committee included in its membership men of brilliance, but whose brilliance was in some cases matched by their strong wills. As the work on the new manual was nearing completion, some issues became increasingly difficult to resolve, some philosophies were at wide variance with others, and schisms within the committee threatened. Eventually agreement was reached, but few knew of Normann's concern over what he construed as disharmony for which he felt somehow responsible, and perhaps even a lack of confidence of the committee in its chairman. His doubts and fears were relieved, however, during the 1964 meeting of the Highway Research Board when his committee members, in a carefully staged luncheon, presented him with a very fine watch bearing the engraving 'to Mr. Capacity'. Such tributes are not uncommon upon completion of assignments or retirement from office, but how often does a committee make such a heartfelt expression of appreciation to a chairman who is continuing in office?

No one is indispensable, but $\mathrm{O}$. K. Normann came close to being irreplaceable.

Reprinted with permission from Australian Road Research, Vol. 2, No. 1, September 1964. 
lateral placement of vehicles; distances for passing; speeds of vehicles; spacing of vehicles in the traffic stream; and hill-climbing abilities of larger vehicles. Improved measuring instruments and methods for analyzing the large volume of data were also developed.

The Bureau immediately applied these early results in design and construction programs. One direct application was the analysis of data on transverse positions of vehicles on bridges to assist in the establishment of standards for bridge widths. The basic relations found between vehicle speeds and spacings with varying volumes of commercial traffic and under various alinement conditions have been used and have aided in estimating the likelihood of congestion in tunnels and on bridges.

These early studies in principles of highway capacity were developed and later expanded by $\mathrm{O}$. K. Normann, the "Mr. Capacity" of highway research. He established that the practical or working capacity of a highway is a relative value, being the number of vehicles that a highway can carry without restricting the speed or movement of vehicles to an extent that drivers find intolerable. He also determined that the minimum spacing the average driver allows between his vehicle and a vehicle ahead varies for different highway conditions, as well as the different speeds, and that the theoretical or possible capacities vary accordingly.

A major milestone was the determination of possible capacities, which are still used by design, traffic, and operating engineers today. On analyses of the data assembled by 1941, Normann concluded that "The possible capacities are about 2,000 vehicles per hour for both lanes of a 2-lane highway, 4,000 vehicles per hour for two lanes of a 4-lane highway, and up to 3,600 vehicles per hour for the best 3-lane highways." 19 The first edition of the Highway Capacity Manual, published in 1950, and the latest edition, published in 1965 , provide the identical capacity values for two- and four-lane highways. The value for three-lane, two-way highways has been increased only slightly to 4,000 vehicles per hour in the latest edition.

Both manuals have been widely used, the first having been translated into nine languages. These successively refined evaluations proved to be major tools for engineers developing the details of current highway programs. With them, designers were able to determine the number of traffic lanes and other geometric features that should be provided to accommodate the predicted volumes and types of vehicles in operation at practical speeds on a given highway.

Continuing research in the 1940 's regarding characteristics of individual drivers showed that "persons traveling long distances drive faster and generally have newer cars than local travelers; young persons drive somewhat faster than older persons; men drive somewhat faster than women; and the newer vehicles are driven faster than older vehicles." 20 Two important conclusions were developed from this series of studies: (1) Highways built to accommodate a high percentage of drivers traveling on long trips should, therefore, be designed for higher speeds than highways on which trips are predominantly short, and (2) there is no justification for a design of high- ways to accommodate speeds in excess of 70 miles per hour under any condition. For about two decades 70 miles per hour has been the advocated upper design speed for the Interstate System and other main highways.

\section{Truck Performance}

Data obtained and procedures developed in the analysis of passing practices in the late 1930's have resulted in guidelines for proper design of two-lane, two-way highways, including the principles of stopping and passing sight distances. Also, the more fundamental data then developed from the hillclimbing or gradeability studies are still in use today in solving problems of highway design and traffic regulation. A basic conclusion of the gradeability study was that for motor trucks even to approach reasonable speeds on grades, grades must be reduced to 3 percent or less. Where such grades are not practical, these data led to the concept of an additional uphill or climbing lane on highways carrying substantial numbers of heavy trucks.

The desirability of design with grades as flat as practical was recognized in the 1954 AASHO design policy guides. The 1956 Interstate standards named maximum design grades of 3,4 , and 5 percent (except in rugged terrain) for design speeds of 70,60 , and 50 m.p.h., respectively.

In 1948, a major study was conducted on the fuel consumption of trucks in relation to their weight and power. Cooperating in the study were vehicle manufacturing and operating groups, the Department of the Army, the Pennsylvania Department of Highways, the Pennsylvania Turnpike Commission, and the Bureau of Public Roads. Important findings developed then, and still in use today, for commercial vehicles were: (1) On any highway section, gasoline consumption and travel time vary in a definite manner with the rate of rise and fall on the highway; (2) gasoline consumption was definitely related to the gross weight and the travel time to the weight-power ratio of the vehicle; and (3) the results were applicable to paved highways and gasoline-powered vehicles in any part of the country. ${ }^{21}$

This automatic traffic recorder was installed on US 240 in Maryland in 1938. It used photoelectric cells to project two beams across the road, and when a vehicle broke the two beams simultaneously, a cumulative count was recorded on a tape.

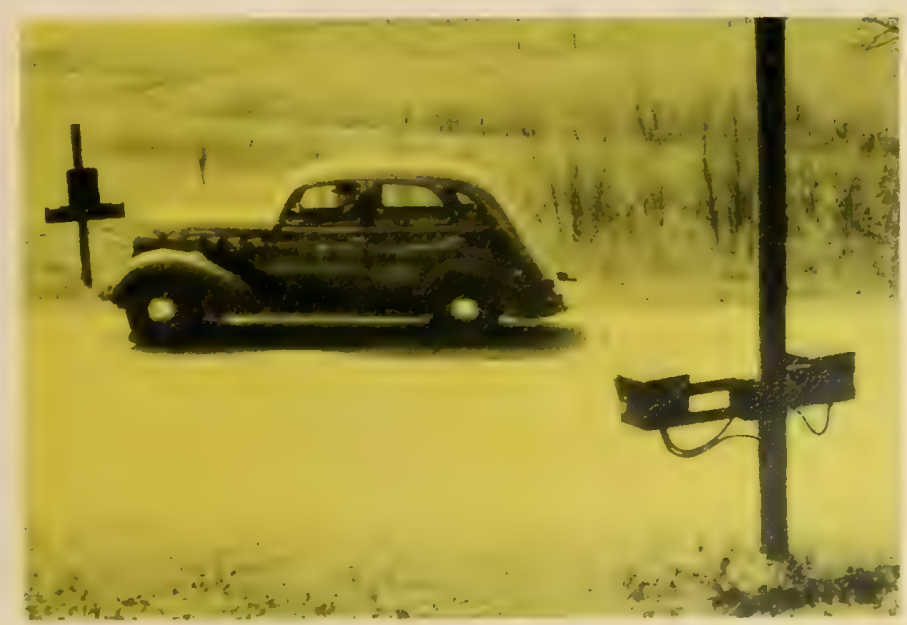




\section{Stopping Distance}

Braking performance of motor vehicles is another important area which the Public Roads researchers have been studying for over three decades. The braking ability of all types of motor vehicles is an essential factor in the safe and efficient movement of traffic on our highways. The sight distance needed for stopping is one of the important geometric design elements.

In 1941, the Public Roads Administration started a broad program of brake performance studies of motor vehicles in everyday traffic. The Advisory Committee on Motor Vehicle Brake Research was formed to direct and guide the program. This was the beginning of a series of studies conducted at 7- to 10-year intervals, the latest of which was completed in 1974. The objectives of these studies were to: (1) Establish a better understanding of the features of vehicle braking performance; (2) determine what levels of brake performance can reasonably be met by vehicles in service; (3) determine the essential elements of reasonable brake regulations; and (4) determine practical means of enforcing brake regulations.

\section{Military Highway Transport}

Most highway research was initiated to provide basic information for the development of street and highway design and traffic operations for civilian traffic. Much of this information has been applicable also to military traffic movements, but military convoys required special study. In the spring of 1940, a study to determine the effect of certain highway conditions on the operation of military convoys was conducted by BPR at the request of the Department of the Army.

Ruote 82 in Connecticut winds its way down hill, but note, that there are two lanes for up-hill traffic, allowing slower traffic such as trucks, to use the outer lane and faster traffic to pass on the inner lane.

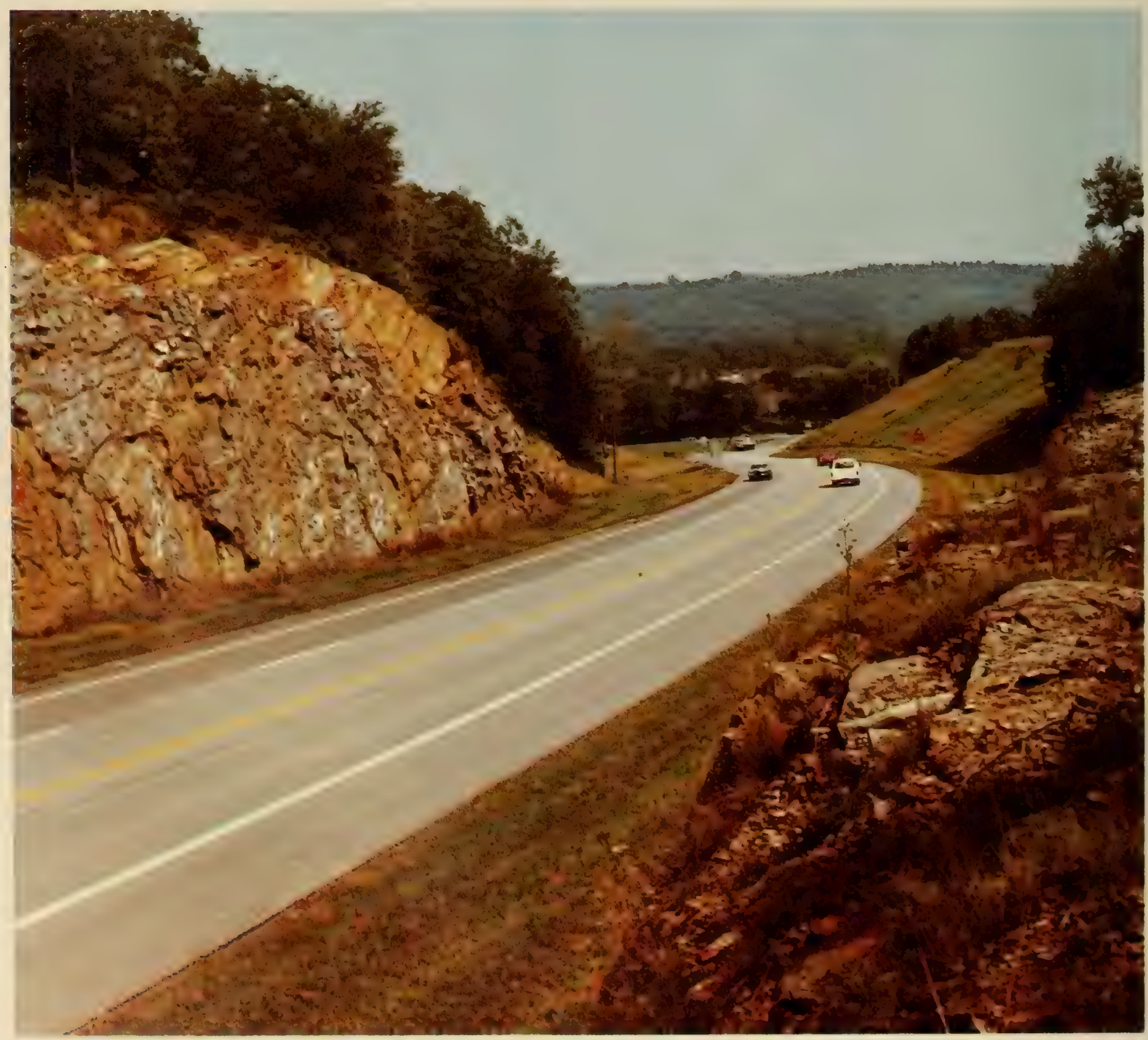


This study dealt with the effect of alinement, grade, and pavement type and condition on convoy operations. It involved an analysis of the individual speeds of all convoy vehicles and the longitudinal spacings between them. It was found that grades were the only highway feature that materially affected the speed of the military convoys. Highway grades of no more than 6 percent, and preferably 5 percent, would allow practically all military vehicles to maintain speeds of 25 miles per hour as long as the road surfaces were dry and solid. These data help produce better controls for military convoy operations.

\section{Traffic Control Devices}

Units along a highway that regulate or advise the vehicle operators are broadly known as traffic control devices. Presently they consist of traffic signals, signs, pavement markings and other markers or delineations along the roadway. The earliest forms were milestones and notched trees. With the advent of the automobile, signing and markings became prevalent in the early 1900's on principal highways in and around the larger cities. Most of these early devices were developed by innovative people based primarily on their imagination and ingenuity.

The U.S. literature until the mid 1920 's is practically void of records of research on devices used to control traffic. Instead, a unit was conceived, installed, observed and conclusions drawn for future guidance. Naming, numbering, and marking of roads began with motorist clubs, chambers of commerce, women's clubs and, to some extent, the States. Being individually initiated, the overall result was a colorful chaos. To bring order out of this chaos and thus help to speed the traveler upon his way, the American Association of State Highway Officials agreed in 1925 that the main roads of the country should be marked with standardized information and direction signs. A 1927 manual, developed by a joint board of Federal and State highway officials, published sign details and the numbering system of U.S. highways. This incorporated the numbering system adopted in 1925 for

In the late 1920's, a uniform route numbering system for U.S. highways was adopted, and these routes were identified with a distinctive shield design.

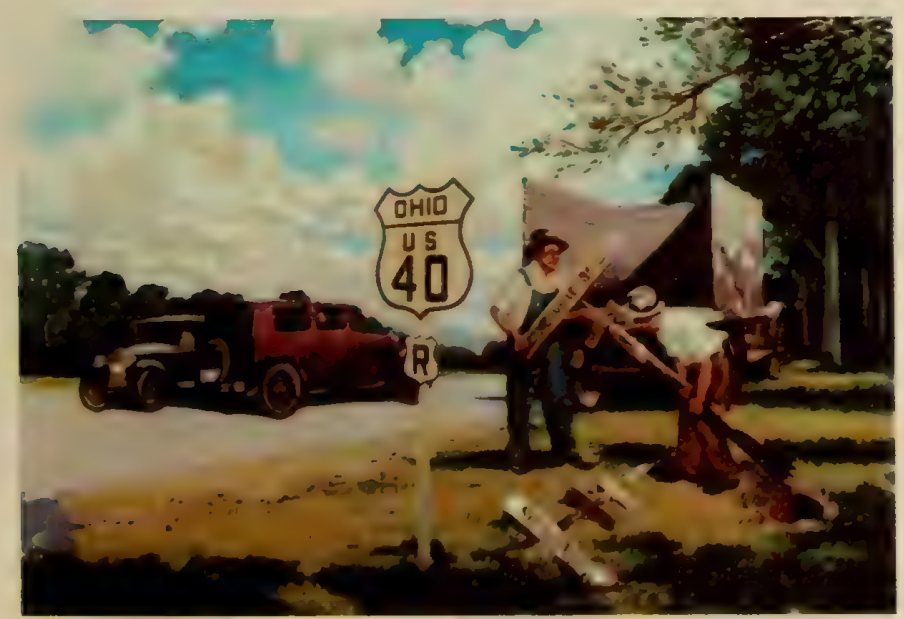

the Federal-aid highway system, which is still in effect.

The various control devices now used for traffic management were mostly developed through private industrial research. However, as early as 1934 the Bureau of Public Roads had begun a series of intersection studies to determine the delay caused by different control methods. A report in that year showed that for an intersection having a total volume of 2,000 vehicles per hour, operation without any mechanical control incurred the least delay to traffic. "Of all the control methods [studied], officer control permitted the fastest movement of traffic, closely followed by the shortest fixed-time control, and traffic-actuated control." 22 This study not only set the pattern for much future research in this area, but also established methods and procedures for the conduct of studies of the effect of traffic control devices on the safety and efficiency of traffic operations.

The first national rural manual on traffic control signs was issued by AASHO in 1927, and the Manual on Street Traffic Signs, Signals and Markings (urban) was issued in 1930 by the National Conference on Street and Highway Safety. These first efforts at national standards gave details on sign shape, color, legend and mountings. While colors were prescribed, data were lacking as to their suitability. To fill this need, the Bureau of Public Roads undertook a study, completed in September 1933, on the visibility and legibility of several alternative color combinations of signs visible by day and by night, with and without reflector buttons. This study showed that the black on yellow combination was more effective than either black on white or white on black. It also determined for the first time the effectiveness of reflecting buttons in various sizes and spacings. ${ }^{23}$

The first combined rural-urban Manual on Uniform Traffic Control Devices for Streets and Highways was issued in 1935. With each new edition of the Manual, revisions were made based on research conducted by Public Roads, State highway departments, universities, cities, industries, and others. For example, in the 1955 Manual the stop sign was changed from black on yellow to white on red, a standard in use today. This came about as a result of research tests which demonstrated that motorists observe the red sign more effectively than the yellow. ${ }^{24}$

The Interstate manual adopted by AASHO and approved by the Bureau of Public Roads in 1958 for signing and pavement marking of the Interstate System was the result of recommendations based on their joint engineering and psychological research. The use of lowercase lettering became widespread after research indicated that these letters are more easily read by the average driver. There was diversity of opinion on the color and reflectorization of directional signs. A research project was undertaken by Public Roads in 1957, which gave substantial support for the final selection of green as the approved color for directional sign background on the Interstate System. ${ }^{25}$ 
The general advantages of pavement markings were recognized after their first use in 1911, and they were included in the early manuals to some extent. However, it was not until 1947 that the effectiveness of centerlines, particularly on two-lane, two-way roads, was confirmed through research. The result of studies at 12 locations in seven States showed that centerline markings provided a general improvement in the transverse positioning of vehicles, that vehicles were driven closer to their proper position on the roadway, and that they encroached on the left lane much less frequently where there was a centerline. ${ }^{26}$

Edge lines were added as a standard device in the current Manual on Uniform Traffic Control Devices for Streets and Highways (1971) and are in universal use. Their effectiveness was determined through a comprehensive study of driver behavior as related to pavement edge markings, conducted by BPR in 1957 in Louisiana and the western States. This study showed that edge lines were very effective aids in confining traffic in the normal travel lane and in reducing partial shoulder use.

\section{Freeway Control Systems}

By the late 1950's a substantial number of freeways had been developed in most of our larger cities. As a result of increasing traffic on them, peak-hour congestion became a major problem. Research studies showed congestion during the morning and evening peak travel periods could be greatly reduced by the use of traffic surveillance and addition of further controls. The application of the latest developments in electronic and other technological equipment served to increase operational efficiency and safety.

The Bureau of Public Roads, in cooperation with a number of State highway departments, spearheaded the research and development in this area and has promoted the practical results of its studies. The first project was initiated in 1960 on John C. Lodge Freeway in Detroit. The second one was initiated in

Demonstration moving merge control systems have been used since about 1969 on freeway entrance ramps to help ramp drivers enter a freeway in situations where it would be difficult to determine adequate gaps in the freeway traffic. This is an artist's concept of the moving greenband system, just one type under consideration.

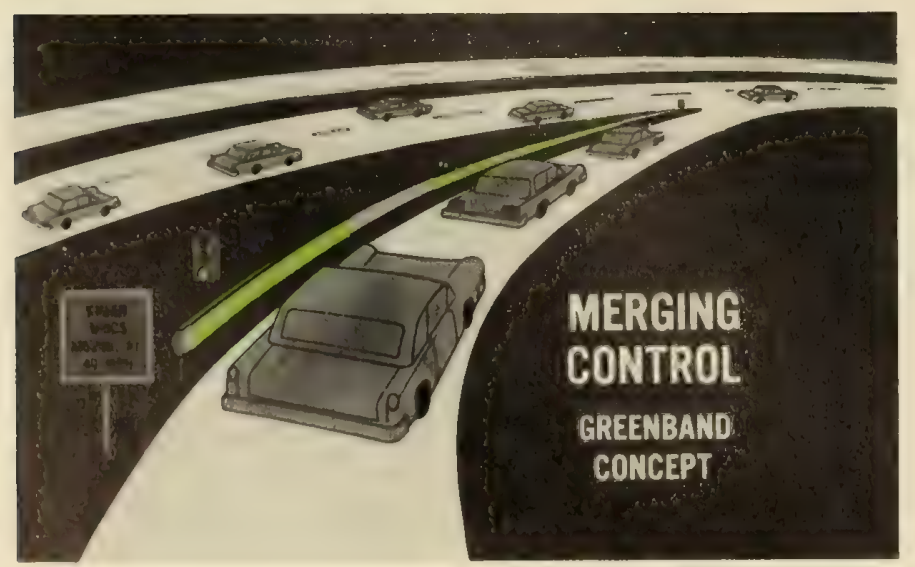

1961 on the Eisenhower Expressway in Chicago and the third in 1964 on the Gulf Freeway in Houston, Texas. After 1965, a large number of States started installing freeway surveillance and control systems, the most extensive of which was the 42-mile loop pilot project in Los Angeles.

In the late 1960's, Public Roads continued to expand and refine the technology of freeway operations by undertaking a major travel corridor control investigation in Dallas. This research was a major effort to explore the total corridor concept, including the freeway, service road, arterial street, and surrounding system. Public transportation, bus operations, roadside communications and park-and-ride were modern-day additions to the effort. Public Roads sponsored many other freeway operations studies, among them the improved control of diamond interchanges.

The concepts of integrated surveillance and control are equally important to urban nonfreeway systems. Traffic signals, intersections, and individual aspects have been mentioned. In the late 1960's, Public Roads stimulated and assisted in "systems" approaches to control traffic for the whole of a certain urban area. One significant output has been the computerized concept of arterial traffic control. Another major project was an urban traffic control research laboratory operating on certain streets in Washington, D.C., which was still active in 1975 . This study has had many influences in the broad area of "software" for urban systems, ranging from preprogramed to instantaneous timing. Another major component was an integrated bus priority system. As meaningful results from these studies have become available, nearly all of the States have applied the new technology to other locations.

\section{Lighting}

During the late 1930's when driver behavior, highway capacity, and traffic control were under intensive study, considerable research was devoted to the effect of highway lighting on traffic operations and safety. For several years prior to this time, illuminating engineers had studied means of reducing nighttime accidents, which were proportionally higher then those in the daytime. There were only a few hundred miles of rural highways that were lighted, many of which were temporary installations to demonstrate and experiment with the safety aspects of lighting.

In 1939, the Public Roads Administration and the Ohio Department of Highways concentrated their research efforts on the effect of lighting on the lateral position, passing practices, headways, and speeds of vehicles on rural highways. The results showed that the behavior of drivers operating at night without overhead light differed measurably from that in daytime, but that under artificial light they conformed very nearly to their behavior in the daytime. This indicated the advantage of highway lighting for certain speed-volume-geometric highway conditions. ${ }^{27}$ 
By the late 1950 's, an increasing number of miles of freeways were being put into operation. Because very little was known about freeway lighting with respect to driver behavior and safety, the Bureau and the Connecticut State Highway Department undertook in 1959 a comprehensive field study on the effect of illumination and delineation. Nine different conditions of illumination and delineation were studied. No significant difference with respect to vehicle speeds, lateral position, and clearances between vehicles under the nine study conditions were noted. In general, it appeared that some benefit resulted from full-level illumination in the deceleration area and that even greater benefit occurred when illumination was combined with roadside delineation. Since then HRB has reported a number of similar studies which generally corroborate the original findings. As a result of these research conclusions, recent lighting installations have been largely located at interchanges and other points of conflict or decision.

The photolog system is a sequential set of photographs, usually taken at one-hundreth mile increments and recorded on a continuous film strip, of the highway and its immediate environment. Each photograph normally provides the viewer with the date it was made, the route, milepoint, and direction of travel, but it can include other data as well. Photologging was developed more or less on the "let's try it and find out" method by research and operations engineers. Today it is an operational tool in some 40 states. The varied uses to which photologs may be applied include evaluating the adequacy of traffic control devices, providing information for project design, identifying and evaluating high accident locations, acquiring planning inventory data and supplying data for research studies.
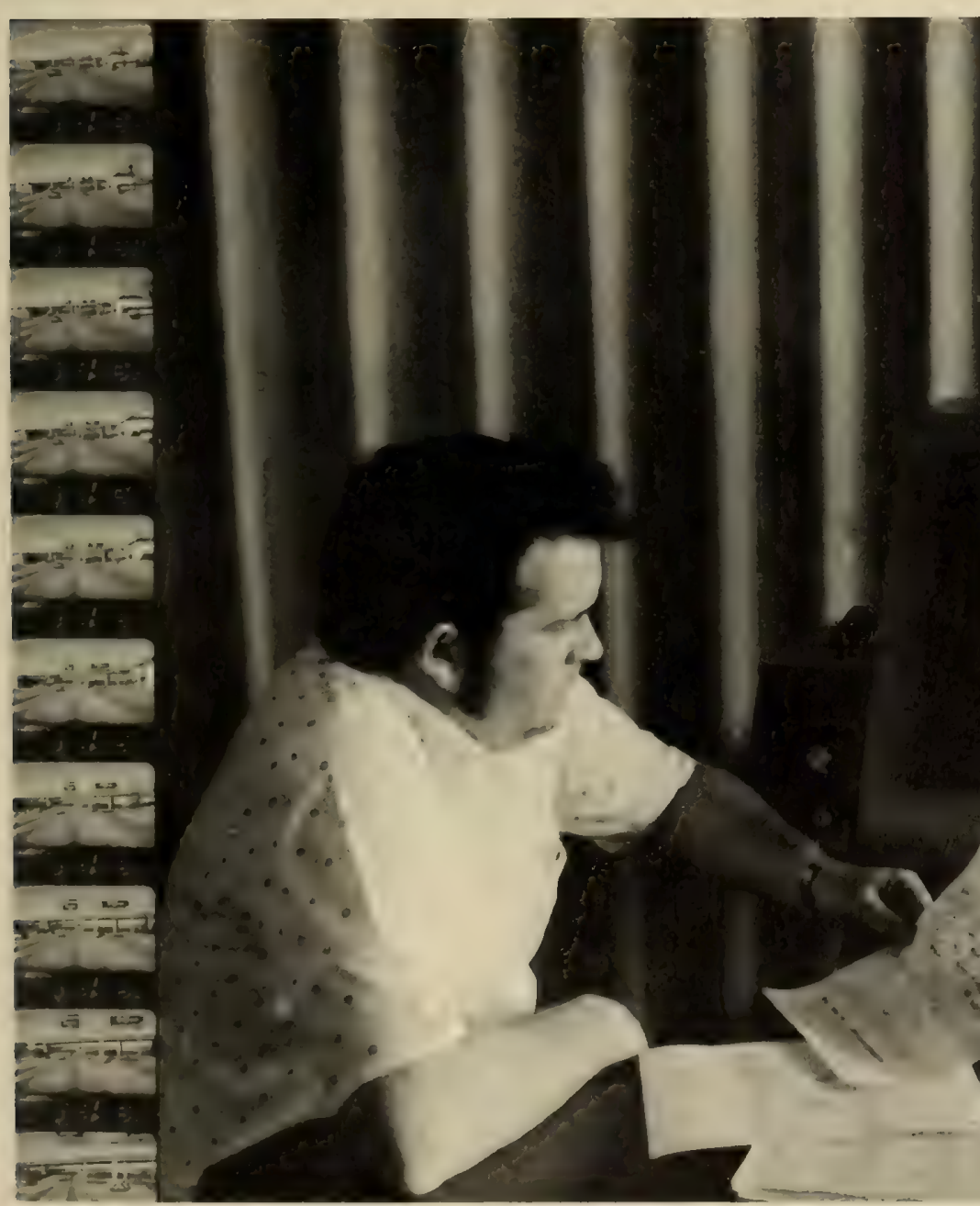

The basic principle of highway safety, as summarized by Thomas H. MacDonald in 1949 in Public Roads magazine, is that maximum safety is provided by designing, building and operating the highway and vehicle to fit the driver's known capabilities and limitations. This concept recognizes the tremendous variation in age, ability, experience, skill and physical and mental condition of tens of millions of drivers. It prescribes that the highway and the vehicle should accommodate the maximum amount of this variation and assist the maximum number of drivers in their task. It has been the foundation for nearly all useful and productive research in highway safety.

Since the 1930 's, many studies have provided the bases for safer design criteria for highways and vehicles. The highway safety research has included onhighway experiments and observational studies of passing practices, lane position, braking and acceleration capability, grade-climbing ability, and other aspects of driver behavior and vehicle performance.

\section{Control of Access}

Research studies over the past several decades have shown that the most effective way to facilitate the driver's task is to provide him with a highway having full control of access. Such a highway, best exemplified by the Interstate Highway System, prohibits 
access from abutting property, thus eliminating many of the roadside conflicts which confront the driver. Crossroads are grade separated, eliminating angle collisions occurring at intersections. Wide medians eliminate head-on collisions, and carefully planned interchanges with long speed change lanes minimize rear end and turning collisions. Research undertaken in the early 1950 's demonstrated that full control of access reduces accidents, injuries and fatalities by 50 percent or more. ${ }^{28}$

Control of access also has safety benefits on twolane highways. A study on a two-lane rural highway with average daily traffic of about 8,000 vehicles showed that, if the number of at-grade intersections and roadside business driveways per mile were increased a hundredfold, the expected accident rate would increase approximately 14 times. $^{29}$

\section{Roadside Safely}

One of the major accident types is the single vehicle run-off-the-road accident. Often the vehicle strikes an object such as a tree, rock, sign, or guardrail, resulting in injury or death to the vehicle's occupants. Although studies designed to relieve this problem began in the 1920 's, the most significant advances have occurred in the recent past.

In December 1966 a short-range Public Roads research program was established for quick-payoff concepts and devices to substantially reduce the severity of single vehicle collisions with fixed roadside structural obstacles. The primary objective of this program was the development of devices that would protect vehicle occupants against severe injury during impact with rigid gore structures, bridge piers, sign bridge supports, and open areas between twin bridges. The studies emphasized the use of existing technology in such fields as impact absorption barriers, new and improved types of redirectional barriers, vehicle entrapment devices, cable supported structures, and improved computer simulation techniques. The impact acceptance criterion was tentatively set at a maximum deceleration limit corresponding to a 10 foot stopping distance from 60 miles per hour for passenger vehicles, a survivable situation for shoulder and lap-belted vehicle occupants.

Several types of impact attenuators, or crash cushions, were successfully developed and tested. These include the steel drum barrier (an assemblage of empty 55-gallon drums), a water cushion (an array of waterfilled vinyl cells), and clusters of sand-filled plastic drums. More than 3,000 such devices have been installed on the highways to date, with evidence that they are extremely effective in reducing severity of single vehicle collisions.

The overall concept and application of breakaway sign supports were also developed primarily during the past 10 years. Research efforts began with the inception of multi-State, pooled-fund studies of the breakaway sign and luminaire support concept. The research included full-scale field experiments and crash testing of vehicles into prototype breakaway sign supports. In addition, much work was also developed or verified through the use of computer simulation and theoretical studies. Private industry also joined in this effort and produced a number of breakaway concepts.

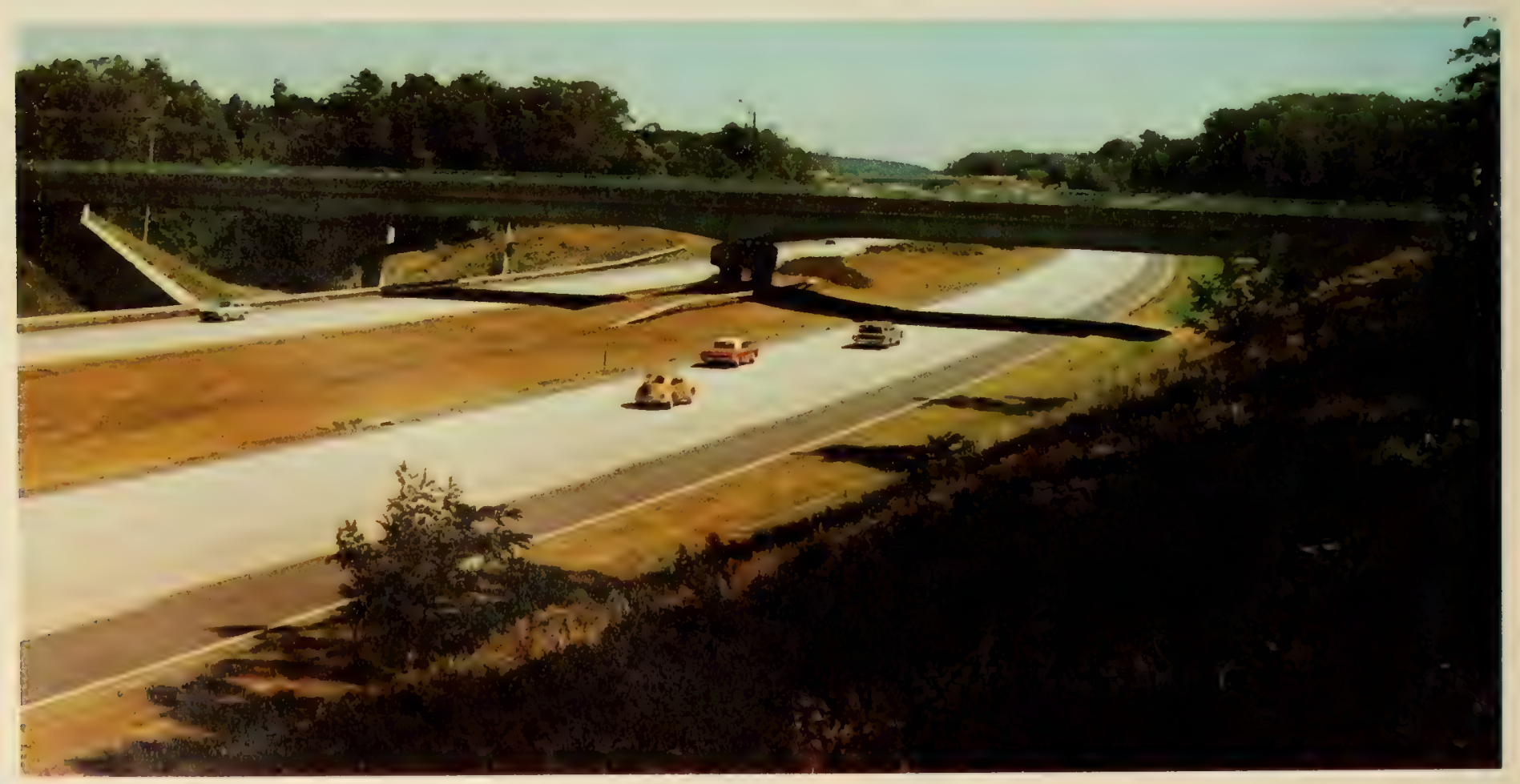




\section{Reducing Skid Accidents}

Skid accidents, which result from slippery pavements, especially when wet, are of such severity that they have received considerable attention in research and safety programs for more than four decades. Major skid factors include: water-on-pavement conditions, tires and their treads, pavement surface characteristics, aggregates and mixes used, pavement age and surface wear, speeds and vehicle operations, and highway geometrics. There have been many contributing research studies on individual factors and their various combinations, but the complex interactions involved have inhibited easy and low-cost solutions.

In the late 1920's Iowa State College began measuring road skid resistance with a towed trailer. Extension of these studies were reported in 1934 ; this proved to be a milestone report on the theory of skidding and means for measuring. Within the next few years many States, universities, industries and other groups were engaged in related research. Both field measurements and laboratory studies on aggregates, mixes, their polishing features, and means for measurement were under study. The Hybla Valley and other test roads included these features. In the 1950's hydroplaning was identified as one of the skid conditions of much concern on airports as well as roads. Also the first steps toward grooving of concrete pavements were being made to reduce slipperiness.

Skid prevention attained nationwide attention and emphasis at an important international conference in Charlottesville, Virginia, in 1958. This conference dealt with many new research and development studies to attain better skid resistance and served to redirect the research that has continued since then. Because of the magnitude and severity of the prob- lems in recent years, FHWA has instituted a large scale research project under its federally coordinated program. It deals with friction requirements, pavement materials and surfaces, accident and cost effectiveness studies, and a national program to standardize the skid measurement process.

Early results from the research have provided: (1) Three regional test centers and the calibration of dozens of State skid trailers; (2) a standard twowheel test trailer and testing procedure; (3) guidelines to design appropriate variable message signs under adverse weather conditions; and (4) improved laboratory methods to select skid-resistant materials.

\section{The Accident Prone Driver}

Accident research studies have often been deficient because of limited data and the difficulties in obtaining the data. Despite these limitations, key accident studies have provided much useful information that has dispelled certain myths and provided support for research and practical day-to-day programs.

One such myth prevalent during the 1940's and 1950 's that has been exploded is that of the so-called "accident prone driver." A study in 1962-63, showed that ". . . in any one year 0.5 percent of the drivers have two or more reported accidents and that they account for 13.9 percent of all accidents." 30 The accident prone concept suggested that these drivers be removed from the road, thereby reducing accidents by 13.9 percent. Such a conclusion, however, was erroneous. Nearly all of those who were "accident repeaters" in any one year became so by chance alone; the research revealed that 87 percent of the so-called accident repeaters would not have even one reportable accident the second year.

This trailer measures pavement skid resistance. A prescribed film of water is spread on the pavement junk prior to brake application. Instruments on the trailer measure wheel motion and traction during the entire braking cycle.

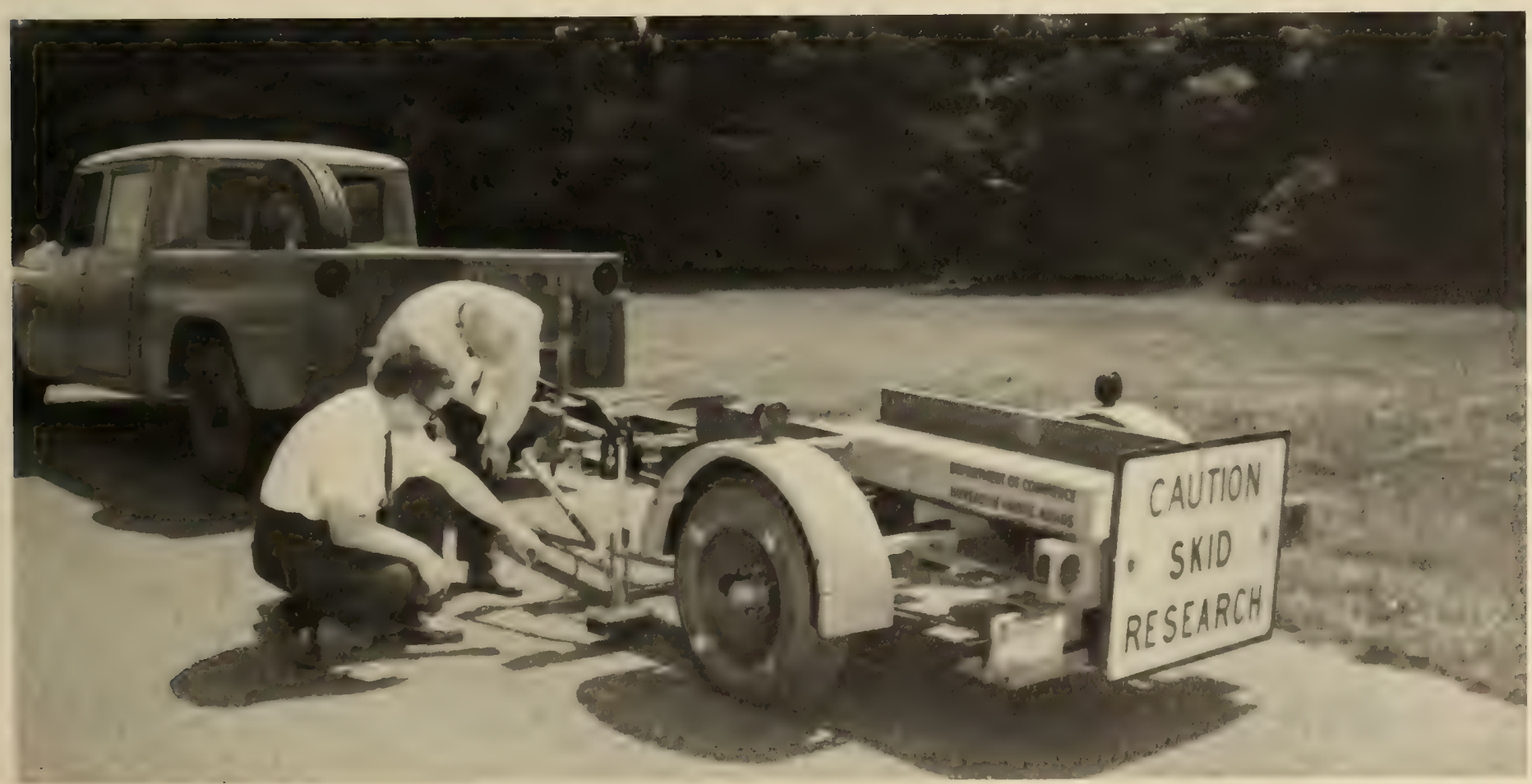


Speed and Accidents

For many years, highway professionals have known that highway safety could best be achieved by minimizing traffic turbulence and speed variance. Cooperative research by the Bureau of Public Roads and several State highway departments in the late 1950's and 1960's verified these views. Both two- and fourlane main rural highways without control of access, as well as urban and rural freeways, exhibited the lowest accident involvement rate for vehicles operating near the average speed for all traffic. For vehicles traveling at both lower and higher speeds, the involvement rate increased sharply. For example, at speeds 15 miles per hour below the average speed on Interstate highways, the accident involvement rate was five times as great as for vehicles operating at the average speed. When an accident occurred, the severity increased with speed, particularly at travel speeds above 60 miles per hour. The chance of being killed in an accident was found to be about four times as great at travel speeds of 73 miles per hour or higher than at 60 miles per hour. ${ }^{31}$ These findings have been particularly useful in stimulating official and public awareness of the effects of speed.

\section{Driver and Vehicle Characteristics}

In addition to speed, studies showed that other characteristics for groups of drivers and vehicles were directly related to accidents on two- and fourlane main rural highways without control of access. Included were age, sex, and residence of driver; type, age, and horsepower of vehicle; and the seat location of individuals within passenger cars.

It was found that local drivers tend to have higher accident involvement rates than out-of-county drivers, particularly at night, and that drivers of passenger cars with low horsepower have higher involvement rates than drivers of cars with higher horsepower, regardless of several other variables studied, including travel speed..$^{32}$

\section{Highway Safety Study}

In the late 1950's in response to a congressional requirement, a comprehensive study of highway safety was undertaken by the Bureau of Public Roads. The report included a discussion of the traffic accident problem and its setting, review of the highway transportation system, evaluation of current highway safety activities, and a brief description of an adequate highway safety program. Results of this study were used to expand the Federal role in highway safety, including creation of a special National Highway Safety Bureau in the Federal Highway Administration, and eventually creation of the National Highway Traffic Safety Administration. Also, a nationwide computerized system was developed for identifying drivers with suspended or revoked licenses attempting to obtain drivers' licenses in other States.

\section{Other Safety Research}

Other important studies have delineated the cost of traffic accidents in considerable detail, permitting development of useful benefit-cost analyses of various safety problems. Studies related to sizes and weights of trucks in connection with the speed study mentioned earlier have been useful in justifying a combined reduction in speed to 55 miles per hour to save fuel and lives coupled with a 10 percent increase in allowable axle and gross weight limits on the Interstate System to further save fuel and reduce freight haulage costs.

Since 1970 research studies have provided methods for designing improved guardrails, median barriers and bridge rails, criteria for safer roadsides, improved highway lighting, improved traffic signal configurations, warrants for enhancing safety at rail-highway grade crossings, use of earth heat to melt snow, crack detectors for bridges, and driver aids in fog. Also, there has been increased attention to pedestrian and bicycle safety, including the development of bicycle safe grate inlets for city streets, wide dissemination of a bikeway state-of-the-art and evaluation of several pedestrian countermeasures.
The in-motion vehicle weighing and measuring system obtains a description of the traffic traversing the area-number of vehicles, speed and classification (car or truck). Then the weight and dimension subsystems add a complete description of the truck portion of the traffic, including height, width, length, axle spacing and weights, vehicle type, loading, etc. Installations such as this are being used in Texas and as demonstrations in several other States.

\section{IN-MOTION VEHICLE WEIGHING AND MEASURING SYSTEM}

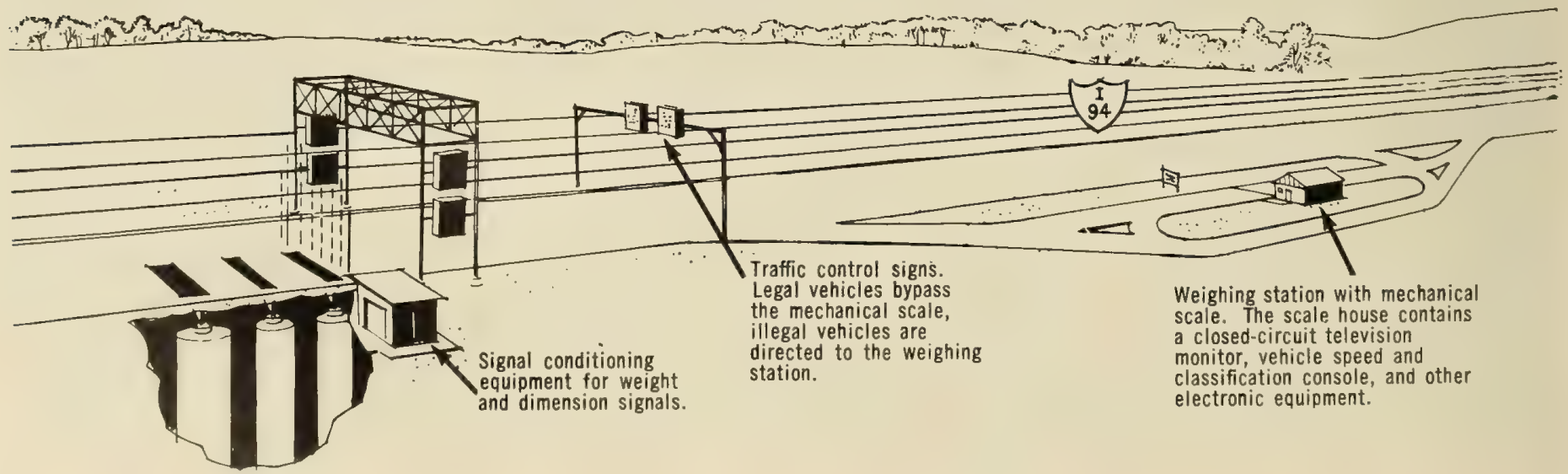




\section{Human Facfors Engineering}

During World War II, behavioral scientists pooled their talents to help military systems engineers develop vehicle operating systems to be used by military trainees with little or no engineering or scientific training. Fitting machines and environments to man's capabilities and limitations resulted in the emergence of new disciplines known as engineering psychology or human engineering. The relationship between highway design and operational techniques became a major concern of the BPR's research program.

In the 1950's a few engineering psychologists began to translate the findings of classical experimental psychology to tasks that confronted motorists operating their automobiles between towns and cities. They also attempted to determine the basic skills required of drivers. The early models of driver behavior are now recognized to be overly simplistic, but they alerted traffic engineers and other road authorities to the fact that most people using highways differ from highway designers and traffic engineers in their perception of the driving situation.

The 1950 's were characterized by three major approaches for incorporating driver characteristics into highway designs and traffic operations techniques. The first was an attempt to scale the difficulty of specific types of driving situations by measuring driver stress. The second was performance oriented research characterized by measurement of the driving patterns of large numbers of drivers on a variety of road environments and was an extension of studies undertaken by the Bureau of Public Roads in the 1930 's and 1940's. The third was epidemiological research, aimed at establishing patterns of responses of drivers which would permit officials to improve their selection techniques or develop remedial training programs. Incorporation of driving behavior into highway design and operational techniques was a major concern of the BPR's research program.

Behavior research in the 1960 's began to mature. A programmatic approach to determining driver capabilities and limitations was begun in the late 1950 's when a team of behavior scientists began to conduct sophisticated analyses of the perceptual environment faced by motorists traversing high-speed roadways on potential collision courses with other vehicles and obstacles. Fundamental work on road tracking, speed sensing, car following, overtaking and passing, object avoidance, sign reading, and path finding were performed jointly in BPR, several universities and by private contractors. Most notable among the collective agencies was the portion of a program of automated or semiautomatic vehicular control conducted by Ohio State University's Industrial Engineering Department.

In the mid-1960's, fundamental work aimed at delineating driving skills abated in favor of development of driving aids systems to assist motorists. Several such systems were identified to overcome high accident situations and basic limitations of motorists; developmental research study of them continues. Some of the traffic control and information systems were:

- A passing aid system to assist drivers in overtaking and passing on two- and three-lane highways.
- A merge control system to assist drivers in making complex decisions at freeway entrance ramps.

- An experimental route guidance system for assisting motorists in finding their way to unfamiliar destinations.

The knowledge developed through these programs and efforts of behavioral scientists have been integrated into modern highway design and traffic engineering.

\section{Environmental Factors}

\section{Hydraulics and Hydrology}

Hydraulics and hydrology, simply stated, are sciences developed to control the deleterious effects of water. There is adequate evidence that ancient cultures constructed amazingly elaborate conduits, aqueducts and other drainage structures to control the flow of water. In the early development of rail transportation, bridges and culverts were certainly an integral part of the design. With the advent of the automobile and accelerated highway construction programs, drainage and water problems became more critical. Bridge damage, washouts, and flooded roadways became intolerable, and paved surfaces required good drainage to reduce hazardous conditions for the movement of traffic and to prevent pavement failures.

Progress in the control of water flow and drainage was slow, and in the early days, designs were based on judgment without uniform policy guidelines or well-developed engineering technology. It was common to size highway drainage structures by using a formula developed by Professor Talbot of the University of Illinois for the design of railroad structures being built in the western States in the 1890's. That formula was the first attempt to provide a rational approach to drainage design; it was crude but an improvement over previous methods. However, it is interesting to note that in 1961, despite the fact that by then more sophisticated techniques had been developed, a survey by the American Society of Civil Engineers concerning drainage practice showed 12 States still using Talbot's formula.

In the early 1920 's, David Yarnell pioneered in experimental hydraulic research with his study on the flow of water through culverts based on extensive full-scale tests conducted at the University of Iowa. Unfortunately the report covered only culverts flowing full. Most culverts do not flow full, and the factors affecting them are significantly different. Yarnell went on with experiments on flow resistance caused by pile trestles and flowover embankments. His work on rainfall intensity-frequency relations was published by the U.S. Department of Agriculture in the mid-1930's and for many years was widely used across the country in determining the rainfall rate to apply in the use of the rational method of estimating runoff.

Highway engineers had also been concerned about erosion of highway ditches and slopes, but it took the demonstration projects of the Soil Conservation Service in the late 1930's to show how flattening of slopes and rapid establishment of sod could control erosion. About the same time the Soil Conservation Service also began setting up experimental watershed stations in several locations to study rainfall-runoff relationships as affected by land use practices. 
During Trorld War II, the Public Roads Administration became responsible for constructing satellite airfields and found that data on rainfall and runoff were inadequate. Using rainfall simulators provided and operated by the Soil Conservation Service, a series of experiments on overland flow was conducted on paved and grass surfaces. The data analyzed and reported by Public Roads in 1944 enabled engineers to estimate for the first time flows over overland routes. This paper has become a standard reference on the subject.

After World War II greater interest developed in the application of hydraulic engineering principles to highway design. One of the first applications of the overland flow equations was in the design of a storm drain system in Chicago. From this, Tholin and Kiefer developed the "Chicago Hydrograph Method" which involved routing runoff through the drainage system.

The Public Roads Administration developed a highway engineering drainage manual. The manual provided step-by-step instructions, together with numerous nomographs and charts based on research data, to facilitate the solution of hydraulic equations for design of culverts, open channels, and storm drains. The manual was widely used in draft form by the States in their highway programs and on most of the toll roads because it provided uniform and improved drainage design techniques. It was never formally published and has since been superseded by the series of Hydraulic Engineering Circulars published by BPR beginning in 1960. The original manual and the Circulars have been used as text for training courses and design practices throughout the United States and abroad.

Following a series of disastrous floods, the Iowa State Highway Commission began a research project in 1948 at the University of Iowa to investigate scour around bridge piers. Scour is the severe erosion of firm supporting soils around bridge piers and is the principal factor in the failure of bridges. The results of that investigation enabled bridge designers to estimate the probable depth of scour during floods and provide adequate supports.

A formal hydraulics research program was instituted by Public Roads in 1949 in recognition of the need for systematic study of hydraulics and hydrology as an integral part of highway engineering. The agency conducted in-house research principally in the field of hydrology (analyses of runoff data); supervised contract research at a number of university and Government laboratories; and monitored research undertaken in several States.

In the 1950's major research was continued on bridge scour at the University of Iowa; culvert design was studied at the National Bureau of Standards; backwater caused by bridges was studied at Colorado State University; head, or energy, losses in storm drain junctions were studied at the University of Missouri; resistance losses in concrete pipe were studied at the University of Minnesota; and urban stormwater runoff was studied at the Johns Hopkins University. All of the research was undertaken as a result of expressed needs evolving from field experience. All reports provided design data and methods readily used by highway designers.

Another field of research begun in the 1950's in a few States was the Cooperative Highway Program of the U.S. Geological Survey for measurement and analysis of runoff from small watersheds, preferably for at least 10 years in each State. The objective was to estimate the magnitude and frequency of peak flows from watersheds generally under 25 square miles in area. The program has grown to include at present about 30 States with an annual total expenditure of about $\$ 1$ million.
To protect this cut slope from erosion during highway construction, the first section of the cut already has new grass growing. The second section has been seeded and mulched, while earthwork is still in progress on the third section.

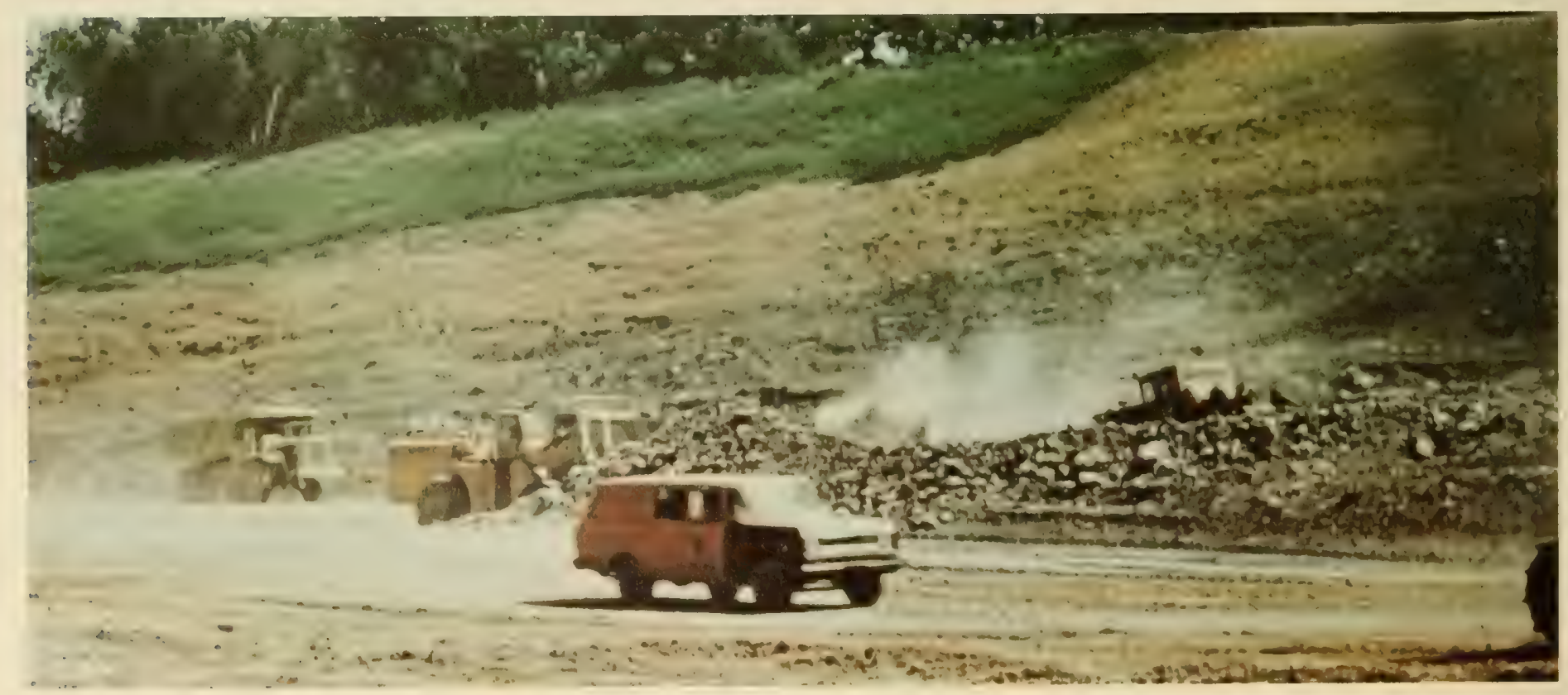


In succeeding years hydraulic research for the Federal Highway Administration has been conducted on hydraulic roughness of corrugated metal pipes by the U.S. Waterways Experiment Station, on use of riprap* to minimize scour at culvert outlets, on unsteady flow in a pipe at Colorado State University, and on design of riprap lining for open channels at the University of Minnesota, not to mention numerous smaller studies undertaken elsewhere, usually in cooperation with a State highway department.

\section{Roadside Development}

One of the earliest publications to identify the elements of and the need for improved road environments was by Louis C. Haupt in $18910^{33}$ His theme was that good roadside development is a move toward better roads. Little further attention was given to this subject until the early 1930's when AASHO and HRB organized their first roadside committees; at that time only 10 States were represented. Even then, where roadside improvement was performed, it was done years after the highway was constructed.

Finally, however, the research and development work of the committees, with support from the $\mathrm{Bu}$ reau of Public Roads, received progressively greater attention, and for some 20 years adequate roadside treatment has been a recognized part of design and construction. Roadside development research has covered such areas as erosion, esthetics, rest areas, resource conservation, planting and vegetation management.

The large number of studies and reports in this area of research was oriented mostly to local problems and conditions. A 1972 study showed that roadside development efforts still seem to be very much a local matter. Efforts to broaden this activity on a national scale have thus far met with little success.

\section{Vegetation Management}

A major part of roadside development is vegetation management. For 50 years, most of the work was directed toward the prevention of erosion. While erosion control is still a primary goal, for more than a decade the Federal Highway Administration and most States have recognized other values in vegetation. Research was directed to the selection of proper vegetation to encourage the establishment of certain species of wildlife. In addition, the esthetic value of vegetation is recognized for its potential in maintaining balance between the highway and the natural environment.

During the 1920 's and 1930 's, maintenance of roadside vegetation was usually done by hand. Although research had greatly improved mowing equipment and techniques by 1960 , breakthroughs in the use of herbicides greatly altered roadside maintenance techniques. As this work progressed, however, concern over the long-term effect of herbicides created new interest in development of dwarf ground covers.

\footnotetext{
* Riprap is a laver, facing or protective mound of stones, concrete, or other material, randomly placed to prevent erosion, scour or sloughing of a structure or embankment.
}

Today, with rising maintenance costs and public concern for our environment, the need is recognized for a highly refined roadside development program. Research and implementation efforts by FHWA, State agencies and others are focused on reduced mowing, refinement of herbicide technology, and the development and selection of vegetation that will reduce maintenance costs and enhance the overall environment.

\section{Recent Environmental Research}

In the past 10 years, two areas of interest have been receiving considerable attention: (1) Firm criteria for esthetic enhancement of the view from the highway are evolving from key studies and are having a major impact on new highway design and upgrading of existing roads, and (2) the need to protect the wildlife environment has opened a broad vista of studies addressing the compatibility of small and large game, birds and fish with the highway environment.

Work on erosion control, roadside vegetation, management transportation economics, and hydrology were the forerunners of today's environmental research. This was highlighted by the establishment of a formal research program in environmental design and control. In response to the National Environmental Policy Act of 1969, the research is directed to understanding the interaction between highways and the environment and developing technology to protect the environment.

Since 1970 this research has dealt with a wide range of environmental elements including air, noise and water quality; social and economic effects; roadside rest areas; sewage treatment; vegetation management; esthetics; water runoff; de-icing chemicals; spills of hazardous materials; erosion control; and wildlife.

In summary, roadside development has progressed during the past 50 years from a somewhat haphazard approach to a highly sophisticated and comprehensive science.

\section{Nationally Coordinated Programs}

In the early 1960 's several significant events led to dramatic changes in the concept and activity of highway research. Enlarged research and development legislative authority was enacted in 1962 and made effective beginning with fiscal year 1964. There were growing problems for highway transportation along with population growth, urban concentration, and changing national priorities and goals.

One major legislative change was the requirement that $1 \frac{1}{2}$ percent highway planning and research (HPR) funds must be used for planning and research purposes. No longer was there an option of using this money for construction. This requirement ensured the strength and vitality of federally aided planning and research programs in the States. Another event was the organizational separation of planning and research in the Bureau of Public Roads late in 1961. Research and development finally became a formal separate program in the Bureau. 
At the same time, there was high interest and strong urging from scientists and technologists in the Department of Commerce and elsewhere to push the Bureau of Public Roads beyond its historic materials and physical research and undertake so-called "soft" research in operations, human factors, systems analysis, safety, society and the environment. Research programing and management could no longer be a loose collection of a number of separate, isolated, totally unrelated studies. The problems were too complex and the resources too small. Comprehensive, integrated and balanced research was the only answer.

Starting in 1963, a multidisciplined task force reviewed a wide range of problems and opportunities for solution in the human, physical, environmental and public policy fields. This culminated in the creation of "A National Program of Research and Development for Highway Transportation," which officially began in 1965 .

If the National Program could be summed up in three words, they would be coordination, concentration and flexibility. The Federal Highway Administrator called it a program to coordinate and concentrate our efforts on the most urgent problems with flexibility, responsiveness and recognition of local and regional problems. ${ }^{34}$ The program consisted of detailed work plans and problem statements for each; it served as a stimulus and guide for R\&D efforts to develop and apply solutions rapidly.

The National Program was directed to three issues of highest concern-highway safety, urban transportation, and reduction in the costs of construction and maintenance. These issues were important because of the considerable human losses and $\$ 10$ billion annual costs of accidents; the increasing problems of congestion, pollution and adverse socioeconomic impacts; and the critical need to optimize technological processes and cost.

In 1970 when the National Program was 5 years old, FHWA initiated a new, nationally designed and coordinated program for highway research and development called the Federally Coordinated Program of Research and Development in Highway Transportation (FCP). The FCP was specially designed to meet the needs of the customer-highway program managers and operating personnel in State and local agencies as well as the general public. It was also designed to be particularly responsive to urgent new problems in the environment, energy and resource conservation, utilization of waste, the integration of multitransportation goals, and increasing the efficiency of the present system.

\section{Research Into Practice}

For a number of years, there had been a strong movement throughout the highway community to expand and strengthen the practical utilization of research. The problems of highway transportation were becoming too large, and it seemed that too little was being accomplished in putting the information gained from research to work.

Both AASHO and FHWA acted in the late 1960's to formalize implementation. It was suggested that each State name a high-level implementation coordinator and each FHWA region organize an implemen- tation committee. Both of these suggestions were carried out, but a national program still did not develop. It seems that plans, procedures and resources were lacking. There still was no formal national focus. Skilled promotion was needed to gain managerial support, to overcome inertia and reluctance to change, and to secure the essential ingredients of public acceptance.

In response to this need, FHWA in 1970 created a separate Office of Development. Thus a formal, substantial program was begun and within a couple of years, the resources, plans, procedures and programs were prepared. Development/implementation has become a full and substantial partner in the business of "research to practice."

\section{REFERENCES}

\author{
${ }^{1}$ Bureau of Public Roads Annual Report, 1910, p. 769. \\ ${ }^{2}$ Federal-Aid Highway Act Amendments of 1963, S.R. 552, \\ 88th Cong., 1st Sess., p. 6. \\ ${ }^{3}$ L. Page, Salutatory, Public Roads, Vol. 1, No. 1, May 1918,
} p. 3.

${ }^{4}$ Bureau of Public Roads Annual Report, 1922, p. 36.

${ }^{5}$ Ideas and Actions: A History of the Highway Research BoARD, 1920-1970 (Highway Research Board, Washington, D.C., $1970)$ p. 29.

${ }^{6}$ Subgrade Investigations Begun by Bureau of Public Roads, Public Roads, Vol. 2, No. 24, Apr. 1920, p. 29.

${ }^{7}$ A. WIntermeyer, Adaptation of Atterberg Plasticity Tests for Subgrade Soils, Public Roads, Vol. 7, No. 5, Jul. 1926, pp. 119-122.

${ }^{8}$ E. KELLY \& P. HUBBARD, Rationalization and Simplification of Test Requirements for Liquid Asphaltic Materials, Pubic Roads, Vol. 13, No. 6, Aug. 1932, p. 89.

' J. Pauls \& H. Rex, A Test for Determining the Effect of Water on Bituminous Mixtures, Public Roads, Vol. 24, No. 5, Jul.-Aug.-Sept. 1945, pp. 115-129.

${ }^{10} \mathrm{R}$. Bogue, Chemistry of Portland Cement (Reinhold Publishing Corp., New York, 1947) pp. 10-14.

${ }^{11} \mathrm{~W}$. Halstead, The Behavior of Red Lead-Iron Oxide Primers When Exposed Directly to Weathering, Public Roads, Vol. 29, No. 9, Aug. 1957, p. 213.

${ }^{12}$ B. ChaIKEN, Abrasion Resistance of Bridge Paints for Use in Alaska-Field and Laboratory Tests Evaluated, PUBLIC RoADs, Vol. 33, No. 10, Oct. 1965, p. 201.

${ }^{13} \mathrm{~J}$. PAULS, Reinforcing and the Subgrade as Factors in the Design of Concrete Pavements, Public Roads, Vol. 5, No. 8, Oct. 1924, pp. 1-9.

${ }^{14}$ Prestressed Concrete Pavement Demonstration at Dulles International Airport, Public Roads, Vol. 37, No. 1, Jun. 1972, pp. $16-21$.

${ }^{15}$ I. Convi \& J. Houghton, Service Lives of Highway Pavements-A Reappraisal, Public Roads, Vol. 36, No. 9, Aug. 1971 , p. 192.

${ }^{16}$ W. Hatt, The Field of Highway Research, Public Roads, Vol. 4, No. 5, Sept. 1921, p. 17.

${ }^{17}$ Policy On Geometric Design of Rural Highways (American Association of State Highway Officials, Washington, D.C., $1965)$ p. 152.

${ }^{18}$ A. Taragin, Driver Performance on Horizontal Curves, Public Roads, Vol. 28, No. 2, Jun. 1954, pp. 27, 28.

${ }^{19} \mathrm{O}$. K. Normann, Highway Capacity, Proceedixgs, 21st Annual Meeting, Vol. 21 (Highway Research Board, Washington, D.C., 1941) p. 379 .

${ }^{20}$ Public Roads Administration, Highway Practice in the United States of America (Federal Works Agency, Washington, D.C., 1949) p. 65.

${ }^{21}$ C. SaAl, Thme axd Gasoline Consumption in Motor Truck Operatios, Research Report 9-A (Highway Research Board, Washington, D.C., 1950) p. 16. 
${ }^{22}$ E. Holdies, The Effect of Control Methods on Traffic Flow, Pubic Roads, Vol. 14, No. 12, Feb. 1934, p. 240.

${ }^{23}$ F. MrLls, The Comparative Visibility of Standard Luminous and Nonluminous Highway Signs, P'ublic Rodds, Vol. 14, No. 7, Sept. 1933, p. 111.

${ }^{24} \mathrm{G}$. Sessions, Traffic Devices: Historical Aspects Thereof (Institute of Traffic Engineers, Washington, D.C., 1971) p. 121.

${ }^{25} I d$, p. 123.

${ }^{28}$ A. TARagIN, The Effect of Driver Behavior of Center Lines on Two-Lane Roads, I'rocenorxgs, 27th Annual Meeting, Vol. 27 (Highway Research Board, Washington, D.C., 1947) p. 273.

${ }^{27}$ W. WAXKer, Effects of Highway Lighting on Driver Behavior, Public Roads, Vol. 21, No. 10, Dec. 1940, p. 187.

${ }^{29}$ C. Prisk, How Access Control Affects Accident Experience, Public Roads, Vol, 29, No. 11, Dec. 1957, p. 266.
29 J. Cirilio, R. Beattr, S. Dietz, S. Kaufman \& J. Yates,

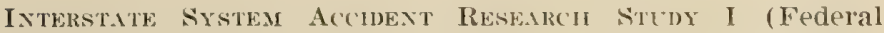
Highway Administration, Washington, D.C., 1970) p. I-1.

${ }^{30}$ D. Solomon, Highway Safety Myths, North Carolrsa Symposium ON Highway SAfety, Vol. 2 (the University of North Carolina Highway Safety Research Centex, Chapel Hill, 1972 ) p. 41.

${ }^{31}$ D. Solomon, Accidents ON Main Rural Highways (Federal Highway Administration, Washington, D.C., Reprinted $1974)$ p. 12.

${ }^{32}$ The Federal Role in Highway Safety, H. Doc. 93, 86th Cong., 1st Sess., pp. 71-83.

${ }^{33}$ Roadsiog Developanes-Evaluation of Research, NCHRI Report No. 137 (Highway Research Board, Washington, D.C., 1972) p. 45.

${ }^{34}$ R. Whitton, Preface to A Nationat. Program of Research Axd DEvelommext For IIgIIWAY TRANSportatrox (Bureau of Public Roads, Washington, D.C., 1965) p. 11. 


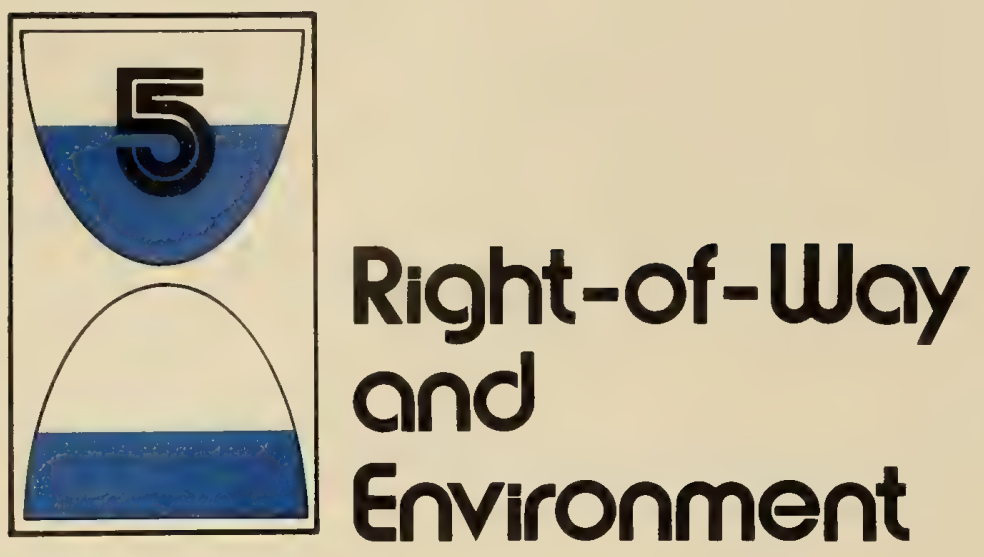

Historically, right-of-way acquisition for a new highway or improving an existing highway meant selecting the location or alinement based upon costbenefit factors of the highway and then acquiring the most economical and effective alternative without much consideration given to the socio-economic impact on those along the proposed route or the community as a whole. Occasionally land was reserved for public thoroughfares, but usually the landowner discovered that if the State or county wished to take his land for a highway, he had little recourse but to give in, sometimes receiving fair market value for the property. Since route selection and land acquisition for the highway was entirely the responsibility of the State and local authorities, the Federal Government took no part in this phase of the Federal-aid highway program.

It was not until World War II that it became expedient for the Federal Government to become involved in the acquisition of rights-of-way to provide highways for the national defense. But the anguish and hardships to the landowners in the path of the highway continued unabated.

About 1950 when more highways were being built on entirely new locations, it became apparent that sociological and economic impacts on communities must become a principal factor in the location selection process.

When the 1956 Federal-Aid Highway Act was signed into law, the push for completion of the Interstate System, mostly on new locations, brought the entire country's attention to social, economic and environmental factors related to highways. In the 1960's the public became quite vocal about its concerns, and Congress, too, became aware that highway construction could have adverse as well as advantageous impact upon all individuals. Congress acted with legislation to alleviate personal hardships and environmental detriment caused by highway and other Federal-aid programs.

\section{Right-of-Way}

As with other aspects of the highway program, the authority for right-of-way acquisition is assigned with due regard for the distribution of powers between the Federal and State governments. Thus, the major responsibilities for initiation and execution have been left to the States and their political subdivisions.

Although organized quite similarly in many respects, systems of highway administration in the various States vary considerably. The resultant diversity of systems renders difficult any attempt to outline their individual characteristics as applied to right-of-way acquisition. Therefore, only the aspects of right-of-way administration common to most jurisdictions will be considered in this chapter. Special emphasis is given to the evolution and dissemination of right-of-way policies and procedures which are developed and administered by the Federal Government, especially in the area of Federal-aid highways. 


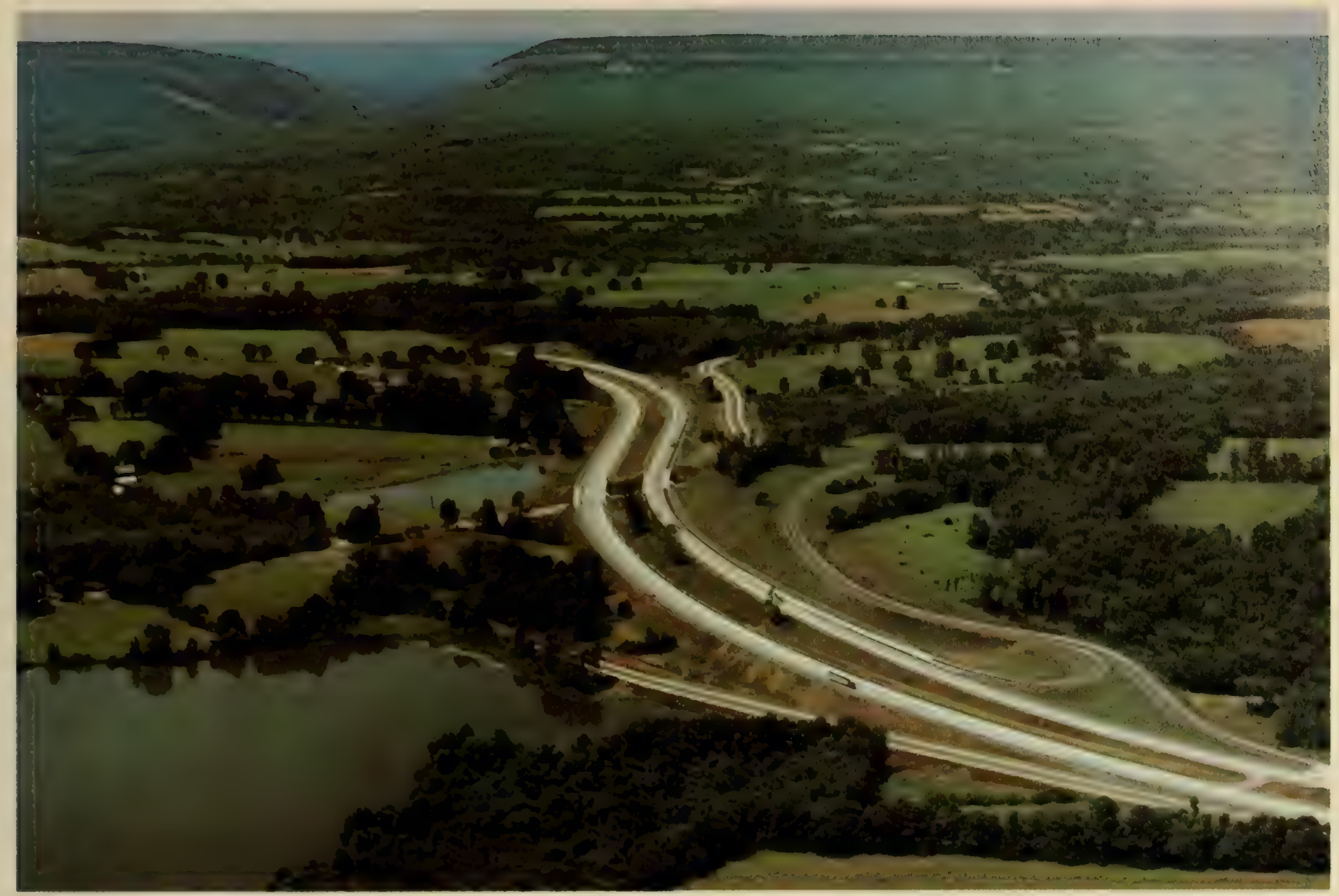

The development of the Interstate System helped focus national attention on the social, economic and environmental factors of building highways. I-80 winds gracefully through the Delaware Valley Gap,

which is part of the National Park System in New Jersey.

\section{The Legal Establishment of Right-of-Way}

The establishment of highways is primarily under the control of the State legislature, subject to constitutional limitations and restrictions. Except as so restricted, the legislative power is practically unlimited. The legislature may establish highways, but State highway departments, cities, counties or other political subdivisions of the State are usually empowered to locate, design, purchase right-of-way for, construct, and maintain highways and to carry out related highway functions.

Right-of-way for a designated highway may be acquired in one of three ways, or a combination of them: by donation, by purchase at the fair market value of the property taken plus damages to any remainders not taken, or by exercise of the power of eminent domain. Eminent domain, the lawful expropriation of property, is an inherent and necessary attribute of sovereignty, existing independently of constitutional provisions although subject to regulation. In order to justify the taking of land for a highway, there must exist a public necessity for the proposed road, and it must be of public utility or convenience. The road need not, however, be an absolute necessity; it is legally sufficient if it is required for public convenience or advantage.

The determination of the necessity for the proposed road is considered a legislative, rather than a judicial question, and the determination is usually made by administrative officials. Such action, however, is lim- ited by certain common principles, among which is that property cannot be taken without due process of law through condemnation proceedings and that property cannot be taken without the payment of just compensation based on fair market value.

\section{Early Background}

Within the United States, right-of-way for overland transportation started with the forest trails along the earth's natural contours. The trails first were followed on foot, then they became paths over which beasts of burden and ox carts could also move. At this stage, no concern was given to the acquisition of right-of-way, for the only consideration was the fastest route in getting from one place to another.

In most instances, the right of the public to maintain and use these roads was not established formally, it was simply assumed. However, as the population and the corresponding private ownership of property increased, and as overland transportation became increasingly important for commerce, communications, and conquest, right-of-way had to be established on a more formal basis to ensure the continued use of these and future overland routes.

In the latter part of the 1700 's and early 1800 's, many privately chartered turnpike companies were authorized to acquire rights-of-way for the turnpikes. Little difficulty was experienced in acquiring the needed rights-of-way. These companies eventually suffered financial difficulties from the competition by 


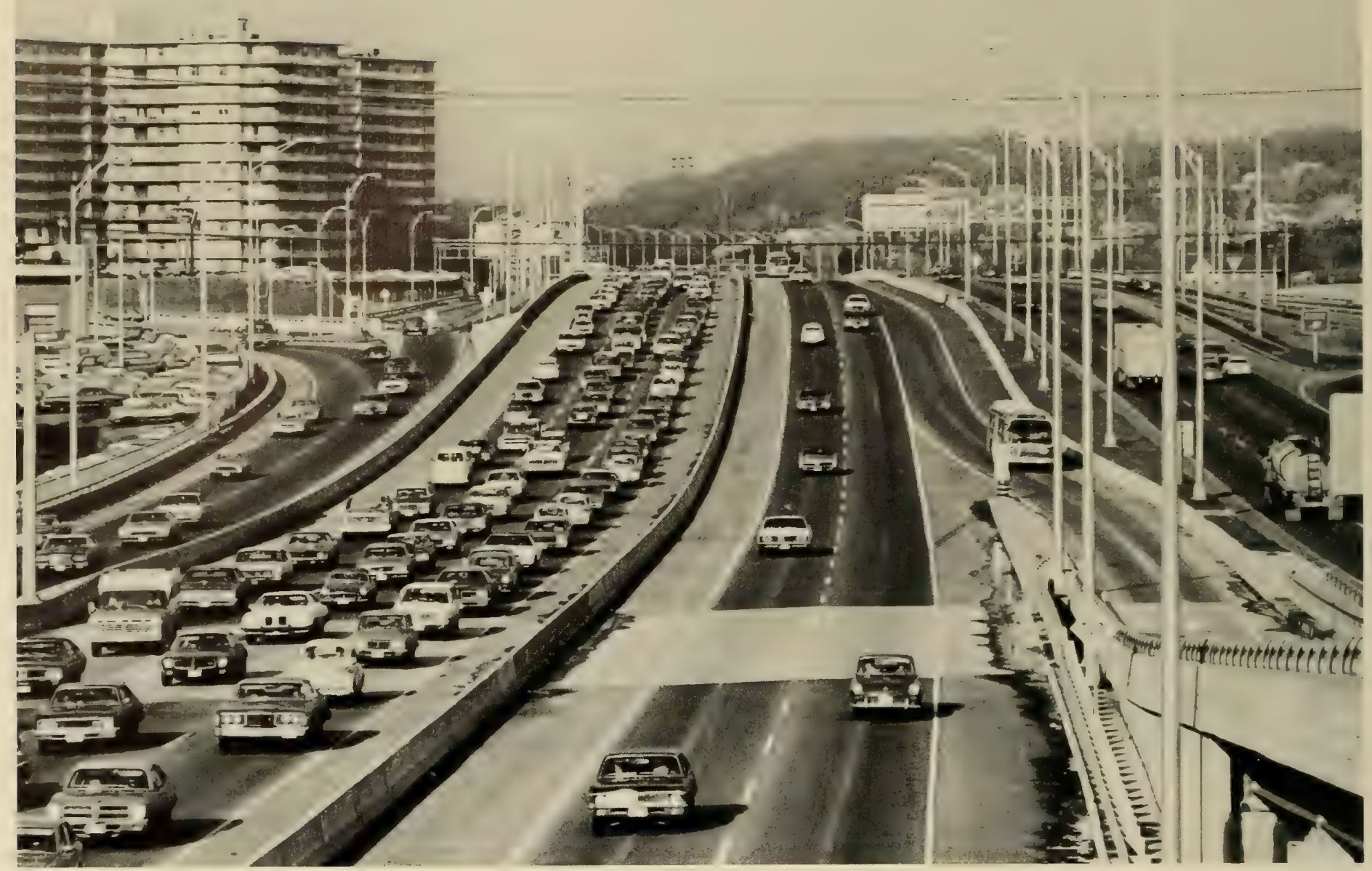

Shirley Highway (I-95) in Virginia has reversible bus and carpool lanes in the median to improve traffic movement during Washington, D.C., rush hours.

canals and railroads, and after a short time, most were abandoned or turned over to local public agencies who acquired the highway right-of-way in the process. By the middle of the 19th century, most highways were being constructed by local and special agencies of the States through which they passed, with, in some instances, slight assistance from the Federal Government.* But the formal acquisition of deeded right-of-way evolved as a gradual process.

In the early stages of State highway building, highways were built primarily to give access to farms, homes, and businesses. They were truly "land service roads," and rights-of-way usually were donated by property owners or by others eager to get road improvements in their communities. In many instances, the landowner helped build the road through direct labor or assessments. There was no question as to the

* In 1802 Congress passed the first semblance of Federalaid legislation in an act for the admission of the State of Ohio, which included a provision for 5 percent of the net proceeds of the sales of public lands in the State to be devoted to the construction of public roads. This type of provision was later extended to other States. In the next 90 years, Congress enacted literally hundreds of laws appropriating funds for roads for military and other purposes, including roads providing communication with new settlements. The aggregate amount appropriated by Congress up to 1893 for the construction of roads and bridges is reported to have been in excess of $\$ 17$ million. ${ }^{3}$ landowner's right of access to the road since denying him access would have defeated the purpose of the road.

Many States adopted the policy of requiring the local political subdivisions to furnish right-of-way for State highways as a contributing share in the cost of the facility. This practice, however, was gradually abandoned except for local roads when the cost of acquiring rights-of-way became too heavy a burden on local agencies or political subdivisions. It then became the general practice for the State highway department to acquire the major portion of State rights-of-way, especially for the arterial highways.

The land ordinance of 1785 provided for the rectangular system of surveying land. Under the system, 30 of the present States** were subdivided into townships 6 miles square, each containing 36 sections 1-mile square. $^{3} \quad$ These land lines, in many instances, became the boundaries between farms and, thus, were the lines of least resistance for local roads. Normally, each property owner donated 33 feet on his side of the section line, resulting in a right-of-way of one chain or 66 feet wide.

** Alabama, Arizona, Arkansas, California, Colorado, Florida, Idaho, Illinois, Indiana, Iowa, Kansas, Louisiana, Michigan, Minnesota, Mississippi, Missouri, Montana, Nebraska, Nevada, New Mexico, North Dakota, Oklahoma, Ohio, Oregon, South Dakota, Utah, Washington, Wisconsin, Wyoming, and Alaska. 
In the Great Plains and Far West, many counties took advantage of the Act of July 26, 1866 (13 Stat 253) in which Congress granted a free right-of-way for public roads over unreserved public lands by declaring all section lines in the county to be public roads and, thus, reserving the right-of-way before the lands became private property. The Legislature of Dakota Territory passed an act (43 USCA 266) making all section lines public roads 66 feet wide to the extent it was physically possible to build roads on these lines.

The first continuing involvement of the Federal Government in the Nation's highway construction program came with the original Federal Aid Road Act of 1916. This Act contained a definition of the term "construction" in broad general terms which did not specifically authorize or exclude Federal participation in right-of-way costs. However, the Federal Highway Act of 1921 expressly excluded Federal participation in such costs by redefining the term "construction" to except "costs of rights-of-way." The effect of this definition was to bar right-of-way costs from Federal participation for a number of years. The 1921 Act did, however, provide that rights-of-way might be granted to the States across public lands or reservations of the United States for any highway or forest road or as a source of materials for the construction or maintenance of any such facility.

In 1938, Chief MacDonald expressed, in general terms, BPR's thinking on right-of-way and clearly forecast the transportation needs of the future. In a speech before the 24th Annual AASHO meeting, he stated:

"The new special motor roads in the Netherlands include in the design two separated roadways for motor traffic, a bicycle pared path on one side, a wide pedestrian path also pared on the other, and at some distance remored, local roads adequately surfaced for land service and animal traffic. Here is a conception of a highway service that, complete in its component parts, may be used safely by all normal types of traffic, which quality should be reflected in many miles of highways in this country in the future. It may be urged that some of these types of traffic do not exist now in numbers to justify special provision for them, a valid objection as to the immediate need; but it is not the important point. The essential feature is the provision now for the land necessary for the development of each traffic facility when it is necessary. As our country matures and becomes more congested in population, we shall have the need for a combination of these or comparable highway facilities." "4

In anticipation of its involvement in right-of-way acquisition, the Bureau of Public Roads, in that same year, initiated a program of research involving highway right-of-way acquisition and development.

During the latter half of the 1930-40 decade, a number of bills were introduced in Congress proposing the authorization of Federal participation in right-of-way costs. Some of these bills even proposed to permit Federal acquisition of necessary lands for right-of-way purposes. None, however, received favorable consideration. During the period prior to World War II, acquiring land necessary for a highway was often thought of as a chore which would ultimately have to be taken care of but which could be postponed until after all other steps in the planning and programing of the work had been taken. A deviation from the established policy of no Federal participation in right-of-way costs did come in the Federal Aid Highway Act of 1940 which permitted Federal participation in the cost "of necessary new or additional rights-of-way" in the Territory of Hawaii under certain specified conditions related to the national defense. The Public Roads Administration was authorized to pay all or any part of the costs of specified projects, including the cost of right-ofway.

It was common practice to proceed with other preliminaries, including the preparation of plans, specifications, and estimates of construction items, before beginning the preparation of plats, descriptions, title evidence and appraisals of the individual parcels of land required for right-of-way. Only after all other preparatory work was completed did the agency begin to acquire the right-of-way, often under pressure to meet construction schedules fixed without giving adequate consideration to the time necessarily involved in all land transactions. The result was often the last minute acquisition of rights-of-way without the necessary basic data having been assembled. Because of the delays that followed, there were complaints that construction was constantly being held up because of the antiquated and cumbersome procedures pursued in securing the land.

This complacent prewar attitude and approach to the right-of-way problem existed at all levels of government. It was manifest both in the judicial and legislative branches as well as in the administrative units having jurisdiction over highway construction and maintenance activities. Federal funds could not participate in right-of-way costs, and the PRA took a legally required "hands off" position. However, as time passed, it became apparent that the Federal Government could not continue to tolerate the lack of proper acquisition procedures which existed in many jurisdictions as they related to the Federal-aid highway program.

\section{Active Federal Assistance in Right-of-Way Acquisition}

Congress made its first major departure from the policy of not participating in right-of-way costs with the Defense Highway Act of 1941. It authorized 100 percent Federal reimbursement for right-of-way costs on defense access roads and the payment of threefourths of such costs on strategic network projects. It also authorized the Federal Government, itself, to acquire any new or additional lands that might be required for such purposes. Under this authority, many parcels of land were acquired by the PRA throughout a number of States. PRA also issued General Administrative Memorandum 149 in 1942 as a guide for States acquiring rights-of-way that would be subject to Federal reimbursement under this Act.

Twenty-seven years after the passage of the Federal Aid Road Act in 1916, Congress gave recognition to right-of-way as a necessary requisite to peacetime highway construction with passage of Public Law 146 by the 78th Congress on July 13, 1943. This Act redefined the term "construction" to include the cost of rights-of-way, thus permitting Federal participation in its funding. The following year the Federal Aid Highway Act of 1944 again included the cost of rights-of-way in the definition of the cost of construction. However, the Federal share of right-of-way 
costs was restricted to one-third of such costs plus certain increases in the public land States. For projects eliminating hazards at railway-highway grade crossings, 50 percent of the right-of-way and property damage costs were reimbursable from Federal funds. Because of the difference in the Federal participating ratios between right-of-way costs and other construction costs established by the 1944 Act, it was necessary to differentiate between what was a right-of-way and what was a construction item. Since construction costs were established by competitive bidding, it was often simpler to document eligible construction costs than right-of-way costs for Federal participation. Because of this and since the States received a fixed apportionment of money, which if not used for rightof-way participation would be available for construction, most of the States did not take advantage of their ability to claim Federal reimbursement for right-of-way costs. They elected to use their Federal allotments for construction costs which were more easily substantiated.

PRA was very careful in analyzing the costs to be sure that proper reimbursement from Federal funds was made. This caused confusion and difficulty until the distinction in matching ratios was removed. However, it was not until the passage of the Federal Aid Highway Act of 1950 that the Federal share of rightof-way costs was increased to 50 percent-the same ratio then permitted for construction costs and thereby eliminated the necessity for strict delineation of costs between right-of-way and construction.

The Federal Aid Highway Act of 1954 increased the Federal participation ratio in all costs to 60 percent on projects located on the Interstate System and the 1956 Act raised this ratio to 90 percent. The participating ratio for right-of-way costs on regular Federal-aid projects and on railroad grade crossing protection projects remained at 50 percent. However, the Federal Aid Highway Act of 1970 increased the ratio on regular Federal-aid projects to 70 percent beginning in fiscal year 1974. In summary, the present Federal participating ratios in right-of-way costs are:
Railroad Grade Crossing Projects
50 percent
Regular Federal-Aid Projects
70 percent
Interstate System Projects
90 percent

\section{Staffing Changes With Increased Federal Involvement}

Staffing requirements of the State highway departments and the Bureau of Public Roads were related to passage of highway legislation.

In the years when right-of-way was obtained without Federal participation, it was often acquired by local authorities. At the State highway department level, this activity had been handled as merely a part of the overall duties of the engineering staffs in the highway departments. Thus, few adequate State right-of-way organizations were in existence.

In the headquarters office of the Bureau of Public Roads, first right-of-way matters were handled in the Solicitor's Office by a single attorney. After passage of the 1943 and 1944 Acts when Federal funds became available for right-of-way cost reimbursement, an appraiser and another attorney were added to the staff in the Bureau. The right-of-way staff was then ele- vated to branch status. A new directive governing Federal participation in right-of-way costs was issued in 1953 which required that right-of-way costs be fully documented if Federal funds were desired. The small branch in BPR was sufficient, since only a few States were willing to go to the extra work necessary to secure Federal participation in their right-of-way costs. As mentioned above, if a State were able to use all of its Federal-aid apportionment for highway construction work, there was no loss if Federal funds were not claimed for right-of-way. So there was no necessity for the States to build up their own rightof-way organizations.

With the passage of the Federal Aid Highway Act of 1956, the full impact of Federal participation in right-of-way costs was felt by the States. Interstate funds were apportioned on the basis of the cost to complete the System in each State. Therefore, each State had to claim right-of-way costs in order to obtain all the Federal funds available for its Interstate program. With Federal funds assured for right-ofway costs on the Interstate System and as highway programs moved into urban areas where right-of-way problems were complex, it was inevitable that the right-of-way organizations and procedures of both the States and BPR had to be strengthened.

By May 1957, the right-of-way staff in the BPR headquarters was expanded and raised to division level. In 1962, a separate Office of Right-of-Way and Location was formed. BPR developed and issued expanded policy and procedure memorandums governing the Federal-aid right-of-way program and established right-of-way staffs in each State and in all regional offices to provide close and continuing contact between the States and BPR. In 1963 BPR established its own right-of-way training program to assure a continuing supply of properly educated and trained personnel for right-of-way work. Thus, procedures and staff were created to assure prompt solution of problems, and controls and records were instituted to assure the eligibility for Federal aid of costs incurred by the States in the acquisition of rights-of-way.

As for the States, in 1956 two States did not have right-of-way staffs at all, and in many others rightof-way activities came under some other division. At the urging of BPR and with much assistance from AASHO, all States have made a steady improvement over the years in their right-of-way organizations by better coordination between design and right-of-way and by the establishment of advance acquisition divisions, training units, property management sections, appraisal and review appraisal groups, relocation units, environmental specialty sections, etc. The State highway departments are now effectively using rightof-way personnel from the inception of a project to its conclusion. Such practices have brought about savings of millions of dollars.

\section{Federal Reimbursement Requirements}

The Federal Highway Act of 1921 provided that the State highway departments be suitably equipped and organized to discharge their duties. With the passage of the 1956 Federal-Aid Highway Act, the Bureau of Public Roads, in order to fully ascertain 
the capabilities of the State highway departments in right-of-way acquisition matters, required that each State highway department submit a formal statement covering its right-of-way organization, policies, and procedures. The statement was required to be updated and revised as changes occurred.

By accepting the State's procedures, Public Roads assumed the responsibility to assure that each State would conduct its operations in accordance with its formal statement and that the State's personnel were competent and reliable. FHIT A continues to review State property acquisitions to assure conformance with Federal rules and regulations governing reimbursements for expenditures made by the State.

With minor exceptions, such as negotiations for lands from national parks and forests and other Federal areas, FHWA does not acquire lands or interest in lands for the construction of Federal-aid highways except in connection with the Interstate System, and then only when it has been determined that the State is either unable to acquire the necessary lands or interests in lands or is unable to acquire them with sufficient promptness. For example, from 1956 until about 1962, Iowa, Idaho and several other States did not have the legal authority to acquire property for right-of-way until a court hearing had been held to determine final payment. Until final payment had been made to the property owner, construction could not proceed. This provision in the State laws delayed Interstate construction several months at the very least and sometimes caused a delay until the next construction season. In cases of this nature, the Bureau of Public Roads acquired the property to permit timely construction schedules.

\section{Appraisal and Appraisal Review}

In the early years of highway construction, rightof-way was acquired by donation or by "horse trading" practices with little thought to a value appraisal of the lands to be acquired. Later, appraisals were used, but there were often a simple opinion of value without written support.

Under such circumstances, the property owner was to a degree dependent on the whims of the appraiser, whose personal opinions could too easily affect the amount of his estimate. Since these value opinions usually were prepared by local men familiar with land values in the general area, they usually were surprisingly accurate. However, such unsupported opinions of value could not be accepted for Federal participation and more sophisticated procedures were required.

Close coordination between design and right-of-way blends this section of I-90 on the Mississippi River in Minnesotawith its buildings, terraces, plantings and parking areas-compatibly with its surroundings.

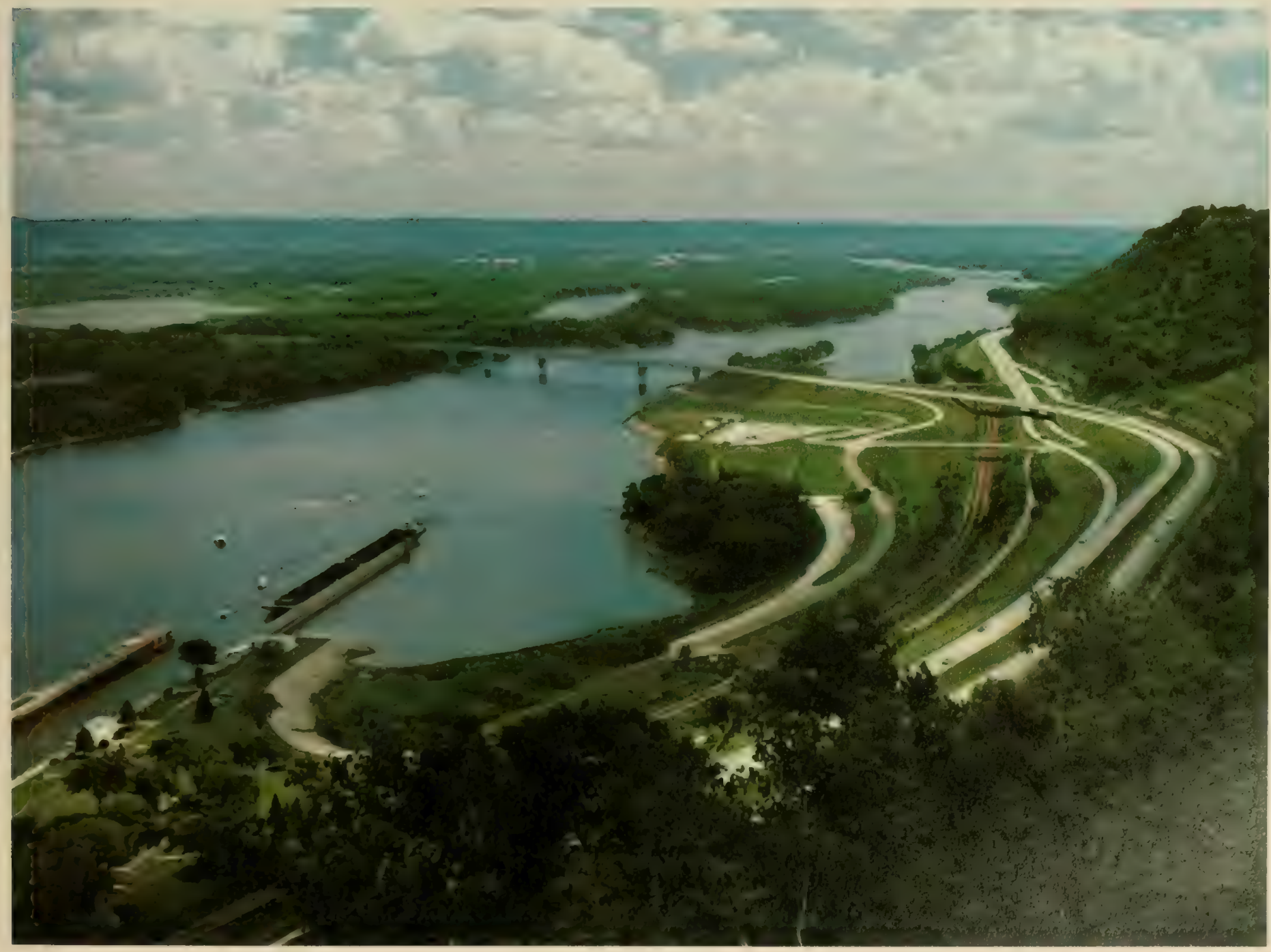


The States or their political subdivisions had, of course, for many years been acquiring right-of-way for highway projects without Federal participation. Although procedures, and particularly documentation, in many States were inadequate, considerable knowledge had been acquired about how to take private property for public use, and how to appraise "just compensation" for it. In addition, the courts were conversant with eminent domain procedures because such processes had been used in cases of railroad and utility right-of-way condemnations which established precedents and opinions. Thus, it was prior to Federal participation that the "market value" concept came into use as a means of determining "just compensation." Likewise, the "before and after" approach in appraising damages came into use and the term "a willing buyer and a willing seller" was discussed in many court opinions.

The acquisition of right-of-way has been, and continues to be, a process of evolution brought about by the experiences of men and the wisdom of trial judges in acquiring private property for public use. When the Federal Government became involved in reimbursing the States for right-of-way costs, the BPR adopted, as the foundation of its right-of-way program, standards established by courts in eminent domain cases and procedures evolved in acquisition programs of other agencies. One of the first procedures, still in use today, involved sound prenegotiation appraisal requirements where the fair market value of land to be acquired was established and the damages to the remaining property were determined prior to negotiations or institution of condemnation proceedings. These appraisals had to conform to established appraisal principles and techniques; be independent judgments as to the value of the property; and be prepared without collaboration between the various appraisers.

To assure that the States' appraisals are properly prepared and documented, FHWA requires that a responsible reviewing appraiser in the State right-ofway division review each appraisal. Basically, it is the duty of the reviewing appraiser to assemble, review, analyze, and correlate all appraisal data into a final estimate of value and damages that will fairly compensate a landowner for his real property being acquired. The reviewing appraiser's estimate of value is offered in writing to the property owner on the first negotiating visit where price is discussed.

Prior to the establishment of prenegotiation appraisals, it was noted that in one State the acquisition cost was always in the exact amount of the appraisal. Upon investigation, it was found that the State was working out an agreement with the property owner and then sending an appraiser out to make an appraisal supporting the settlement. An educational program prevented a continuation of this procedure and resulted in the property owners receiving the full appraised fair market value of their property.

The property owner has no role in the selection of the appraisers for the acquiring agency. $\mathrm{He}$ is free, however, to secure his own appraisals to guide him in making his decision in subsequent negotiations. The property owner is not always aware that sentiment or long family tenure is of no use in determining the value of his property. He will not receive more for his property just because it has been in the family for generations. Comparing the price offered with the price someone else received also is hazardous since no two situations are exactly the same.

At the outset, the appraisers of land needed for highways were often without training and experience. The situation is entirely different today. The acquiring agencies employ appraisers who have been well trained in their field through college courses and training courses conducted by appraisal organizations or the acquiring agencies themselves.

\section{Negotiations}

During the formative years (1941-1956) of rightof-way acquisition procedures, negotiations for rightsof-way often were conducted by the person who appraised the property. Usually, this person would make a fair appraisal of the property being purchased. He would then call on the property owner and after some discussion make a verbal offer of some amount less than his appraisal. In these years many property owners were not knowledgeable about real estate transactions. If the owner accepted the offer, the acquiring agency "saved" the difference between the appraisal and the offer, but the owner was actually deprived of money that really belonged to him. If the owner objected to the low offer, the appraiser/ negotiator would "horse trade" up to, or perhaps exceed, the amount of his appraisal. Under this system, the knowledgeable person may have received more than that to which he was entitled.

To help correct this inequity, BPR late in 1956 required that appraisal and negotiation functions be separated. The appraiser would appraise the fair market value, the reviewing appraiser would review all appraisals and approve the amount to be offered the property owner, a trained and qualified negotiator would visit the property owner, explain the highway improvement and the need for the property, and present in writing the amount approved by the reviewing appraiser as the full fair market value of the property to be purchased. The negotiator would not have authority to increase the amount of the written offer.

Under certain prescribed conditions, the chief administrative officer, or other officials of the highway department having final authority over right-of-way matters, may make an administrative determination whether a settlement should be attempted at an amount above that previously offered the property owner. When a settlement is made on the basis of an administrative determination and such a settlement varies from the State review appraiser's determination of value, the file must contain a statement setting forth the reason for the settlement.

In a few instances, a property owner refusing to settle by negotiation has taken a case into court and received a verdict less than the amount offered by the acquiring agency. He then wanted to go back to the amount offered. However, the acquiring agency was bound by the court decision and could not pay more than the court award. 
Acquiring agencies make an effort to be extremely fair with the property owner and, if there is a doubt, to resolve it in his favor. The acquiring agency normally will not go beyond the reasonable fair market value. Occasionally there are cases where there is an honest difference of opinion as to value, and in these instances, it is desirable to let a court decide the question.

It is recognized that sometimes there are hardships resulting from taking property for which no just compensation can be made. As a case in point, an elderly couple had owned their home for many years. The wife had been blind for a number of those years, but because she knew the community, she could visit her friends, the stores, and other facilities within a several-block radius unaccompanied. The family agreed that the offer made for this home was, in fact, generous, but moving the blind woman to a new neighborhood was of genuine concern. Though the couple had to move, here was a hardship for which just compensation could not be legally paid.

In many cases, however, the situation of a family that has to be relocated ends up for the better because of strict regulations requiring health and safety features. In a southern State, a man, his wife and 11 children, ranging in age from 6 months to 16 years, lived in a three-room structure that the husband had built. There were no plumbing facilities, and a fireplace provided the only heat. The husband was disabled and unemployed. The family subsisted largely on a $\$ 1,980$ yearly allowance for aid to dependent children.

The highway agency successfully relocated the family to another house superior to their former dwelling. The relocation officer was also instrumental in obtaining such necessities for the family as a stove, refrigerator, beds, bedding, furniture, and even clothing. In this case, the relocation officer provided much more than the strictly legal role required in the relocation process, which is discussed later in this chapter.

As a result of the requirement for sound, supported appraisals, appraisal review and independent negotiations, professionalism in the land acquisition organizations at all levels of government has been assured. As will be seen later in this chapter, the present Uniform Relocation Assistance and Real Property Acquisition Policies Act of 1970 follows, to a great extent, the procedures advocated and developed by the BPR throughout the years. BPR's early directives required the States to adopt acquisition practices which met the same basic goals that the Act later embodied.

\section{Disposition of Improvements}

How best to dispose of buildings and appurtenances purchased with land needed for highway rights-ofway is another important question involved in the right-of-way operations. Originally the disposition of improvements on the acquired right-of-way often was handled in an informal manner with no uniformity of treatment. A common form of disposition was to include the buildings in the prime construction contract as a clearing item and let the contractor dispose of them as he wished. This was permitted under a BPR right-of-way directive issued in 1956 . At times, however, the contractor would sell the im- provements to the former owner or others for a considerable amount and at the same time receive payment from the State for removing them from the right-ofway.

Since the contractor had no authority to operate outside the right-of-way, a building that was only partially within the right-of-way was often partially demolished leaving the remainder standing on the private property. This resulted in situations that were costly to the private property owner to correct.

To correct these situations, under current procedures, the owner of improvements and appurtenances on lands being acquired for right-of-way is allowed the option of retaining them at a retention value predetermined by the State through a comparative process with improvements sold at public sale. If the owner does not wish to retain the improvements, the acquiring agency will take title and sell them under competitive conditions. The objective is to dispose of the improvements by the method that will reflect the greatest amount of credit to the project consistent with equitable treatment for the former owner. Only under unusual circumstances should they be included in the construction contract as a clearing item. Where leadtime is sufficient, acquired properties are leased for private use on a short-term basis until the land is needed for construction of the highway.

\section{Property in Public Ownership}

Property in public ownership needed for highway purposes is treated differently. Originally BPR did not permit Federal participation in the cost of land already in public ownership. However, participation was permitted in the removal, readjustment, repair, or restoration of facilities made necessary as a result of the construction of the highway project. A later policy permitted Federal participation on the basis of the appraisal of the property taken and the resulting damages incurred. However, it proved to be difficult to determine the fair market value of public property, such as a school, firehouse, library, etc., that is not commonly bought and sold in the open market. In many instances, the local government was subject to additional burdensome costs of replacing the public facilities, since the old buildings could and would have served their purposes for many years.

Presently, when the State highway department makes a request and can legally incur costs for the functional replacement of real property and improvements in public ownership, Federal funds may participate in the costs if the functional replacement is determined to be in the overall public interest. The costs are those necessary to replace the land and improvements being acquired with a similar needed facility having the same use. Usually, the present buildings are old and out-of-date and the materials with which they are constructed are often not available. The new buildings may be constructed with modern materials and are required to be constructed in accordance with present day local laws, building codes, and reasonable prevailing standards in the area for similar facilities. If the owning agency has suitable land on which the new facility can be constructed, payment may be made for the land taken for highway purposes. If the owning agency does not have the land, a replacement site may be purchased. 


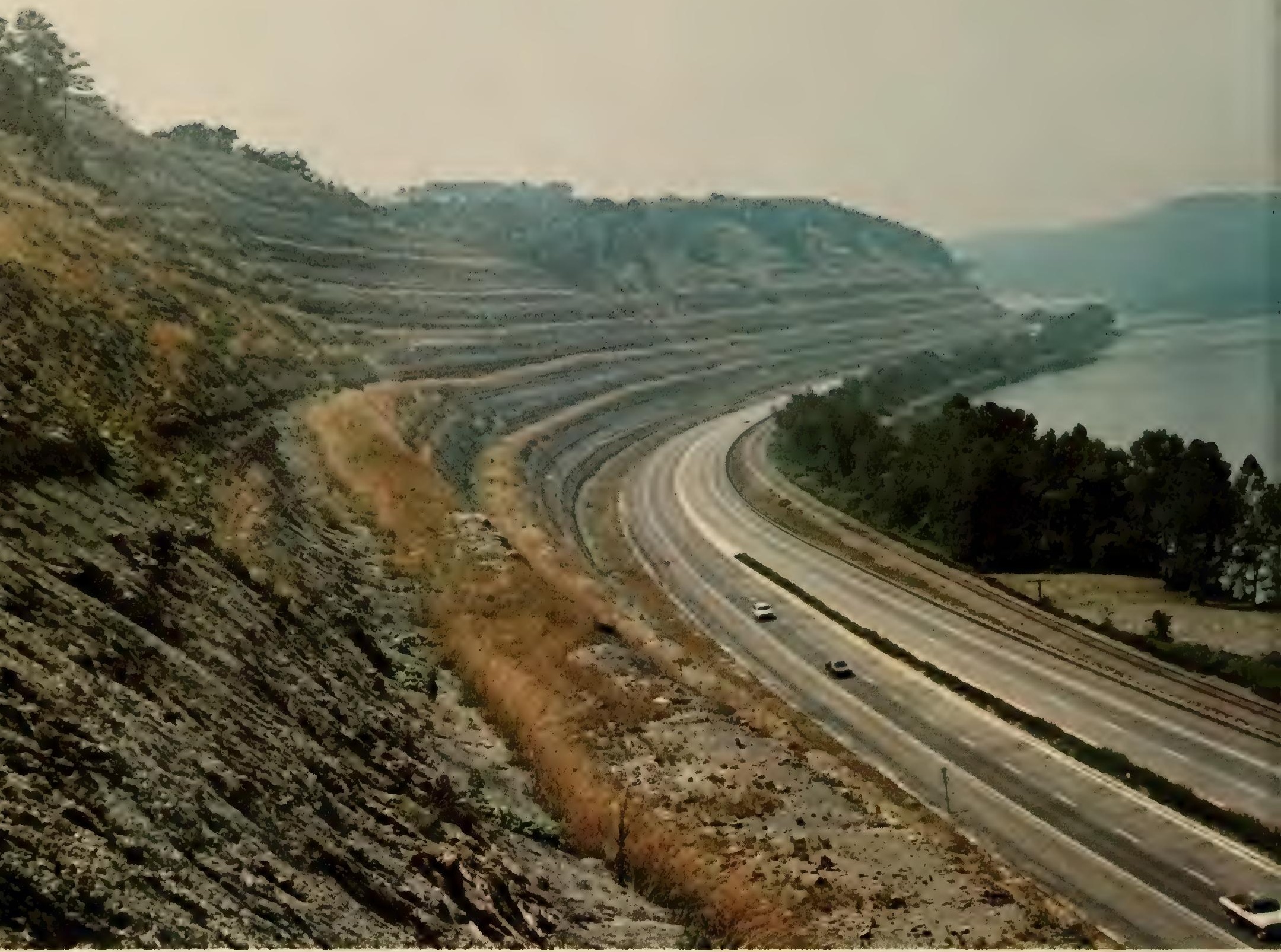

In order to widen Route 2 along the Ohio River, the West Virginia Department of Highways specified presplitting and benching of Round Hill. This project involved excavation of more than 5 million cubic yards of earth.

\section{Advance Acquisition and Revolving Fund}

As the highway program continued to expand, one major problem was insufficiency of leadtime for the acquisition of rights-of-way. As soon as construction plans were completed, right-of-way personnel were under constant pressure to acquire the right-of-way so that the construction work could be advertised for bids.

In order to encourage early acquisition of right-ofway, BPR issued a directive in July 1956 providing that a State could be authorized to acquire right-ofway with its own funds and that later, when sufficient Federal funds were available, reimbursement for the Federal share of costs could be made back to the date of authorization to proceed. Previously, it had been customary for Federal funds to be available at the time right-of-way acquisition was authorized.

The full requirements for land cannot be determined until the exact location of the highway is known and the final design is nearly completed. In January 1958, BPR issued a directive providing that right-of-way acquisition could begin when the State had indicated on maps or drawings the proposed general location of the highway together with the approximate limits of the right-of-way and they were acceptable to BPR. Federal funds could participate in the right-of-way costs incurred at this early stage, but before final reimbursement was made for the right-of-way, the accounts had to be adjusted so that Federal funds were finally used only for the land area that was incorporated within the final right-of-way widths.

Further right-of-way developments have made necessary the discontinuance of the above two procedures. The first was in effect for about 20 years, and the second for about 10 years. For the periods of time the procedures were in effect, they helped acquire rights-of-way expeditiously.

When right-of-way was acquired in advance, the BPR and the State executed a project agreement specifying that construction on the right-of-way would be accomplished within a reasonable period of 
time after acquisition. The Federal-Aid Highway Act of 1956 provided for actual construction of a road on the right-of-way within 5 years. In 1959 , the time period was extended to 7 years, in 1973 to 10 years, and in 1976 Congress provided that the period could be extended beyond 10 years to whatever additional period was reasonable.

In the Federal-Aid Highway Act of 1968, Congress established a right-of-way revolving fund for loans to State highway departments to purchase right-ofway for future highway construction on any of the Federal-aid systems. No interest is to be charged. The money can be used to pay both the State and Federal shares of right-of-way acquisition, property management costs, and for moving or relocation expenses of persons, businesses and farms. Actual construction on the right-of-way shall be commenced not less than 2 years (and as amended by later legislation) nor more than 10 years following the end of the fiscal year in which the cash advance is made unless a shorter or longer period is provided by FHWA.

Some advantages resulting from using the revolving fund are:

- Additional leadtime for relocation of persons and businesses.

- Reduction of cost by purchasing land ahead of rising prices.

- Forestalling proposed private development on land within the proposed right-of-way.

- Acquisition of "hardship" parcels where the owner would suffer if purchase of his property were delayed.

Acquisition in advance was restricted by Congress in the National Environmental Policy Act of 1969. Procedures developed under the Act provide for consideration of environmental aspects and approval of the highway location before right-of-way purchases can be started, except in bona fide hardship cases. Prior to this Act, parcels could be purchased if they were in the probable limits of the proposed highway.

The size of the fund serves also as a restriction on its use. Congress authorized a total of only $\$ 300$ million. However, administratively, about $\$ 50$ million a year were provided to FHWA. One of the reasons for these financial limitations is that the fund is to revolve. First a State borrows the money from the fund for right-of-way acquisition on a specific project. Sometime during the 2-year to 10-year period the right-of-way is acquired, construction plans are completed, and the construction project is ready to be advertised for bids. At this point in time, the State must pay back 100 percent of its loan without interest. For the right-of-way purchased, the State must provide its matching share from its own revenues while the Federal share will be paid from the current fiscal year highway funds for the project. The money paid back to the revolving fund can then be loaned out again to another State (or to the same State) for another project and the whole process is repeated.

\section{Uniform Real Property Acquisition Policy}

With the entry in 1962 of BPR and the State highway departments into the field of relocation assistance and payments, the problems incident to a multiplicity of laws and procedures applicable to right-of-way acquisition were increased. It was possible for a number of Federal and State agencies to be operating in the same community at the same time, each under its own individual laws and directives. Such a situation resulted in considerable differences in acquisition procedures and in relocation assistance and payments provided. This lack of uniformity, in many cases, resulted in inequities to individuals.

As a case in point, there were two garment manufacturers across the street from each other. Their businesses, buildings and equipment were comparable. Under the then-existing Federal highway legislation, the business whose property was being acquired for highway purposes could be reimbursed the maximum of $\$ 3,000$ for moving expenses. The other owner whose business was being taken for an urban renewal project could receive up to $\$ 25,000$ for moving. The owner whose property was being acquired for highway purposes was understandably upset at the difference in treatment.

To assure consistent treatment to owners by the many Federal programs and to promote public confidence in Federal land acquisition practices, Congress enacted the Uniform Relocation Assistance and Real Property Acquisition Policies Act of 1970. This Act was applicable to all Federal agencies and established a uniform policy on land acquisition practices for their guidance.

FHWA, to implement this Act, issued policy directives which are being followed by the individual State highway departments and makes periodic reviews to assure that the intent of the Act is being carried out.

\section{Relocation}

\section{Relocation Assistance and Payments}

As more and more property became essential for the construction of the Interstate System and other highways, it became apparent that the "fair market value" concept as a basis for payment to the property owner did not completely reimburse him for his costs and required some persons to suffer disproportionate injuries. The cost of moving personal property, locating substitute housing, making adjustments to new quarters, utility deposits and fees, damages to property moved, higher rental payments, etc., were not a part of fair market value and often worked an extreme hardship on those whose property was being acquired or who were forced to move from rental premises. In the Federal-Aid Highway Act of 1962, Congress required that the State highway departments provide relocation advisory assistance to individuals and families displaced by acquisition or clearance of right-of-way for any Federal-aid highway. That Act also permitted BPR to reimburse, as part of the cost of construction, such relocation payments as the State highway departments might make to persons for their moving expenses from the property. While the relocation advisory assistance services were mandatory, the relocation payments were not. The payment feature was entirely dependent upon State law, but few States actually provided monetary reimbursement to people forced to move. 
As the need for a national payment program for relocation became increasingly urgent, Congress included in the 1968 Act the first mandatory payment program for people who must relocate because of Federal-aid highway construction. The legislation established provisions to assist individuals, families, businesses and nonprofit organizations in avoiding the human and economic shock that can result from involuntary displacement. The purpose of the new law was twofold: (1) To aid the national goal of providing every citizen with decent, safe and sanitary housing, and (2) to reduce the inequities of a strict application of the fair market value concept to Federal-aid highway right-of-way acquisitions.

Principal provisions of the law were that:

- Each individual or family displaced must receive a scheduled moving expense and dislocation allowance or actual moving expenses.

- Businesses, farms and nonprofit organizations must receive their actual moving expenses or a lump sum payment based on an established formula in lieu of actual moving expenses. Payment was also permitted when they discontinued their operations because of displacement.

- Owner occupants could receive a payment above fair market value for their homes to assure theix ability to obtain decent, safe and sanitary replacement housing at least comparable to the homes taken with designated upper limits. Decent, safe and sanitary housing standards were established by FHWA.

- Tenants could receive a payment to enable them to rent comparable rental housing or purchase replacement housing within a specified upper limit.

- Each State highway department was required to provide relocation advisory service to those being displaced.

\section{Last Resort Housing}

While the relocation advisory assistance and payments required by the 1968 Highway Act were a needed addition to the fair market value payments, they did not take care of the situations where decent, safe and sanitary replacement housing simply was not available. In some communities, decent, safe and sanitary housing is nearly impossible to find within the economic means of those being displaced. Therefore, the Federal-Aid Highway Act of 1970 author-

During right-of-way acquisition, sometimes moving a house intact is a part of the relocation agreement.

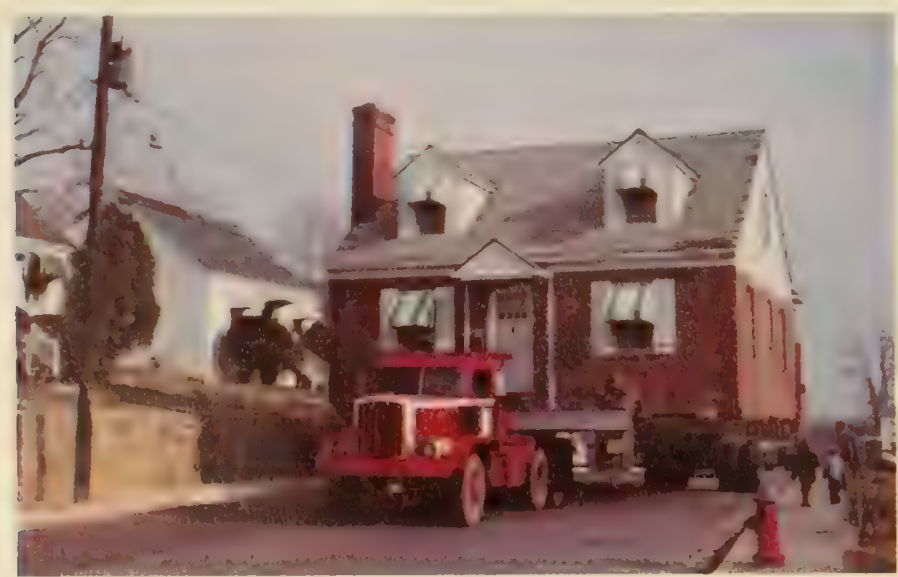

ized, as part of the cost of highway construction, the inclusion of the construction of existing housing to serve as replacement housing. Through this "last resort housing," the highway agency could release a tied-up project by rehabilitating or constructing homes or apartments for the displaced persons. Thus, no person would be required to move from his dwelling unless replacement housing was available.

The 1970 Highway Act also provided that the displaced dwelling owner could be compensated for any increased interest costs that such owner was required to pay for financing the acquisition of his new dwelling.

The precedents established in the Federal-Aid Highway Act of 1968 and the additional emphasis supplied by the FHWA and the highway industry during the hearings on the 1970 Highway Act greatly influenced the Congress to enact the Uniform Relocation Assistance and Real Property Acquisition Policies Act of 1970. The 1970 Uniform Act, which nullified the relocation requirements of previous highway acts as well as those of other Federal legislation, authorized last resort housing when:

- An adequate supply of comparable decent, safe and sanitary replacement housing is not available for those persons to be displaced (either from public housing agencies or private enterprise).

- Comparable decent, safe and sanitary replacement housing cannot be purchased for the maximum payment of $\$ 15,000$ in addition to the purchase price of the displaced person's present dwelling.

- Comparable decent, safe and sanitary housing cannot be rented over a 4-year period for the maximum payment of $\$ 4,000$ in addition to the rent presently being paid.

\section{Current Status of Relocation Procedures}

In addition to making decent, safe and sanitary housing available to all those displaced, the relocation program has, in general, not only been instrumental in assisting those persons required to move to improve the quality of their housing and standard of living, but has also been instrumental in assisting many tenants to become homeowners.

The replacement housing payments and additional benefits, plus the authority to provide replacement housing as a last resort, facilitates the move, minimizes the hardship, and assists in the improvement of the quality of life for most persons involuntarily displaced.

The magnitude of the relocation program is revealed by the reports received from the States. In fiscal year 1975 , the Federal-aid highway program relocated 21,162 persons from 8,605 dwelling units. The average moving cost payment was $\$ 410$ per claim. In addition, 2,186 businesses were displaced at an average moving most of $\$ 4,544 ; 116$ farms at an average moving cost of $\$ 1,075$; and 103 nonprofit organizations at an average moving cost of $\$ 916$.

Of the total number of people displaced in fiscal year 1975,44 percent were owners and 56 percent were tenants. Of the 21,162 people displaced, 24 percent were minorities. About 70 percent of the residential units acquired represented housing over $\$ 6,000$ in value or renting for over $\$ 60$ per month. 


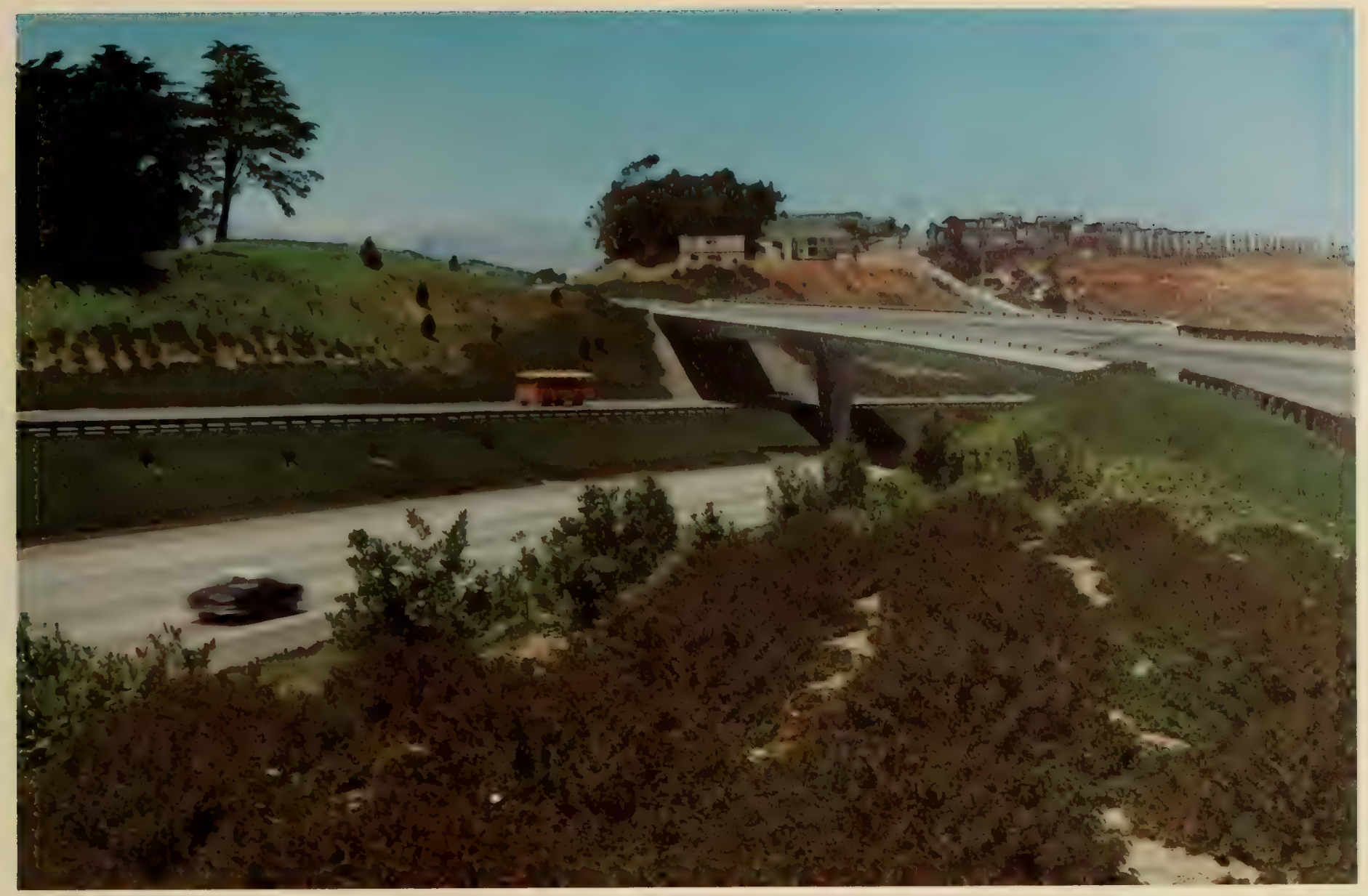

The motorist's viewpoint was one of the design factors in the planning and construction of Junipero Serra Freeway in San Bruno, California. A long range landscaping program was carefully planned for the entire route. Trees within the right-of-way were either preserved or transplanted.

Replacement housing payments to owners averaged, nationally, $\$ 4,755$ and to tenants $\$ 1,137$. The moving cost payments and replacement housing payments were supplementary to the payments made for the property taken under the "fair market value" concept and represent the expanding concept of preventing, to the extent possible, hardships upon the individuals who are relocated because of the construction of a highway.

\section{Location}

A phase of highway construction which is closely related to right-of-way is highway location. During the early years of highway development, the emphasis was almost exclusively on the engineering features of such location. Unless the highway was solely a land service facility, the highway agency attempted to find the most direct lines between the points that they wanted to serve and to develop the most economical way, in engineering terms, of building adequate roads along these direct lines. They sought easy grades, the shortest possible river crossings, and generally adopted the lowest priced adequate solution that could be found. This resulted in many hardships to the property owners for, too often, little consideration was given to their needs and the needs of the community as a whole. A trial attorney once remarked that it appeared to him that the engineers' procedure was first to find a farmer's water supply and then make that the centerline of the highway. While this judgment is harsh, it is clear all too often that a little consideration of right-of-way costs and damages at the location stage could have materially lowered the cost of right-of-way and of the total highway project.

It has been understood that right-of-way personnel should not determine the location of a highway. That has always been an engineering determination. However, the engineer should have input from the rightof-way man as to property costs and damages to assist him in making his engineering determination. As an example of this, a highway preliminary location ran through the middle of an airstrip. The right-of-way man estimated damages at nearly $\$ 400,000$. A restudy was made, and a slight realinement resulted in taking only a portion off one end of the airstrip. The damages were reduced to well under $\$ 100,000$. In addition, construction costs on the new location were several thousand dollars less than they would have been on the original location.

Another situation involved a very minor acquisition from an iceplant which would have resulted in a major claim for damages because of having to relocate and rearrange the freezing apparatus. A restudy resulted in a slight relocation that avoided taking any portion of the iceplant. 
Beginning about 1950 and rapidly developing in importance since that time, sociological and economic impacts on communities have become the principal and often overriding factors in the location selection process. This has been particularly true in the more densely settled areas of the country. People who in the past wanted a highway in order to have a way to get places suddenly did not want that same highway reconstructed near their residences to attract and better serve large noisy volumes of traffic in which they had no particular interest. Over the last few years, esthetic values have become more and more important, and this emphasis, of course, has culminated in the current determination to preserve and enhance the environment.

The highway location problems now are to find those places to build the roads that will provide an adequate highway facility for the particular traffic to be served and, at the same time, cause a minimal disruption of families, a minimum disturbance of the landscape, and the least adverse effect on such things as established school districts, church parishes, park areas and historical sites. The FHWA's role in location is largely to make certain that State highway departments have placed in proper relationship the various engineering, social, and environmental elements of highway location.

\section{The Environment}

\section{Pollution in the Horse and Buggy Era}

"King Mud" was the environmental problem that most concerned the early traveler. Farmer and villager, horseman and wagoner, to all of them, the mud of the roadway was an unwelcome but frequent companion. Large towns might be isolated for days after a heavy rain. Horses floundering up to their bellies in thick mud were a common sight, and the farmer, unable to get his produce to markets that were empty, was confronted with spoilage and loss of income. The better roads were found primarily in the major cities, where carriages and wagons of many different kinds were in daily use. As the number of conveyances increased, so did the number of horses that pulled them, and as the horses multiplied, they began to be denounced as polluters of the environment in harsh terms similar to those applied to automobiles today.

Nineteenth century urban life generally moved at the pace of horsedrawn transportation. Evidence of the horse could not be missed. It was seen in the piles of manure littering the streets, attracting swarms of flies and creating a stench, and in the numerous livery stables that let loose an odor that could only mean "horse." 5 The city streets were usually the repository for overworked, mistreated horses that died making their rounds. Atlantic Monthly, in an 1866 article described Broadway as clogged with "dead horses and vehicular entanglements." The carcasses arded another dimension to the smells and the swarms of flies. In 1880, New York City removed some 15,000 dead horses from its streets, and Chicago carted away nearly 10,000 horses as late as 1912. ${ }^{6}$

Because of this problem, the cities constantly feared epidemics of cholera, smallpox, yellow fever, or typhoid. Medical authorities blamed the spread of these diseases on filth in the atmosphere and believed that the horse was the chief offender. In 1752, Boston authorities voted funds to clean the streets to avoid smallpox infection, and in 1795 during the yellow fever season, they asked neighboring farmers to collect manure from the streets, free of charge. ${ }^{7}$ Even in 1908, Appleton's Magazine, in an article "The Horse v. Health," blamed most of the sanitary and economic problems of cities on the horse. The article calculated that the horse problem cost New York City some $\$ 100$ million each year. ${ }^{8}$

However, disease was not the only hazard caused by the horse. Even in the 1700 's, noise pollution was already becoming a problem in the cities. The clopping and clanking of horses' iron shoes and the irontired wheels of carts and wagons made ear-shattering sounds on cobblestone pavements. Boston, in 1747, banned traffic from a major street so that noise would not disturb the sessions of the General Court. Later Benjamin Franklin noted the " thundering of coaches, chariots, chaises, waggons, drays, and the whole fraternity of noise" that offended the ears of Philadelphians. A New York ordinance in 1785 banned teams and wagons with iron-shod wheels from the streets, and as late as the 1890 's, an article in Scientific American referred to the sounds of traffic on busy New York streets as making conversation difficult. ${ }^{9}$

The solution to these problems, critics agreed, was the horseless carriage. As the motor car and the truck began to replace the horse, benefits were clearly seen. Streets were cleaner, pollution from manure was diminished, the number of flies dropped, goods were transported more cheaply and more efficiently, and traffic moved faster. By the early part of this century, the advantages of the motor vehicle over the horse were accepted in nearly every quarter.

\section{The Conquest of Mud and Dust}

While the motor vehicle gradually diminished the problem of sanitation, it was beginning to show some of its own disadvantages. Mud in the rainy periods and dust in dry continued to plague the traveler through the close of the 19th century and well into the 20 th, and the automobile seemed to only exasperate this problem.

Dust, although a minor factor, still bothered anyone riding, driving or walking on or near a highway. "The dust raised by an automobile, when running at a rate of less than twenty miles an hour, is not any worse than that raised by many wagons, but when this limit is exceeded, the automobile becomes the dust nuisance.'" 10

Many methods were used to try to control the mud and dust problem. Sprinkling roads with crude oil or absorbent salts, while effective, was considered too expensive, and water was recommended to provide " 'a better, smoother and more dustless surface than we now enjoy." 11

Martin Dodge, Director of the Office of Public Road Inquiries, reported on an experimental road project in the District of Columbia in 1900. This project, the Queens Chapel Road in the District of Columbia, was selected for a controlled oiling application for dust control. The annual report stated: "This road was treated several weeks ago and so far as we are now able to judge the new system is a suc- 
cess as a dust settler.... It is claimed by some that the application of erude oil will make a surface impervious to water and consequently free from frost and mud. If this be the case, oil will supersede gravel and stone in the improvement of country roads." 12

With the various types of surfaces becoming available at the turn of the century, there was much discussion as to the merit of each. Some of the criteria usually taken into consideration were smoothness of ride, durability, ease of repair, cost, etc. However, though very much in a minority, there were those who argued for and developed experiments on the health factors of various surfaces.

\section{The Beginnings of Roadside Beautification}

Other early concerns with environmental effects of highways were basically limited to beautification, and that apparently was not a high priority issue with roadbuilders. "The effort to promote the beautifying of the highways by planting of shade trees has not received the recognition and attention that it deserves," noted a speaker at the turn of the century. "A wellshaded road makes the work of the heavily laden team easier, and greatly enhances the delight of the man who is traveling for pleasure," he remarked, appealing to the wealthy to supply the funds to carry out "embellishment" of roadways. ${ }^{13}$

In 1909 the Office of Public Roads issued Farmers" Bulletin No. 338 in which roadside development along macadam roads was discussed as follows:

No matter how smooth and well constructed the traveled road may be, if the roadsides are not cared for, the highway as a whole will not give a good impression. All rubbish should be removed; the excavations should be filled and embankments smoothed and planted with grass whererer it will grow. Unsightly brush should be cut and grubbed out. Sometimes, however, the brush and small trees, if suitably trimmed, add to the attractiveness of the roadside.

All trees that are ornamental or which have value as shade trees should be preserved and protected, unless they grow so close together as to make a dense shade... Care in the selection of the kinds of trees best suited to the locality is important. ${ }^{19}$

By 1915 highway development had progressed to a degree that more environmental factors were being considered. Some of these factors were enumerated

Gray birch trees were planted along this Massachusetts highway in 1928 to improve its appearance and to shade the highway.

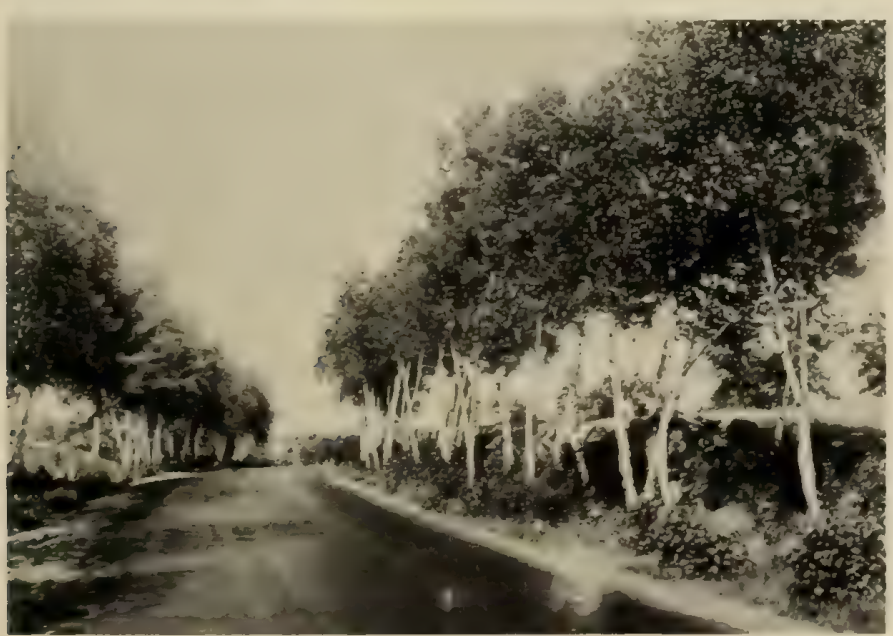

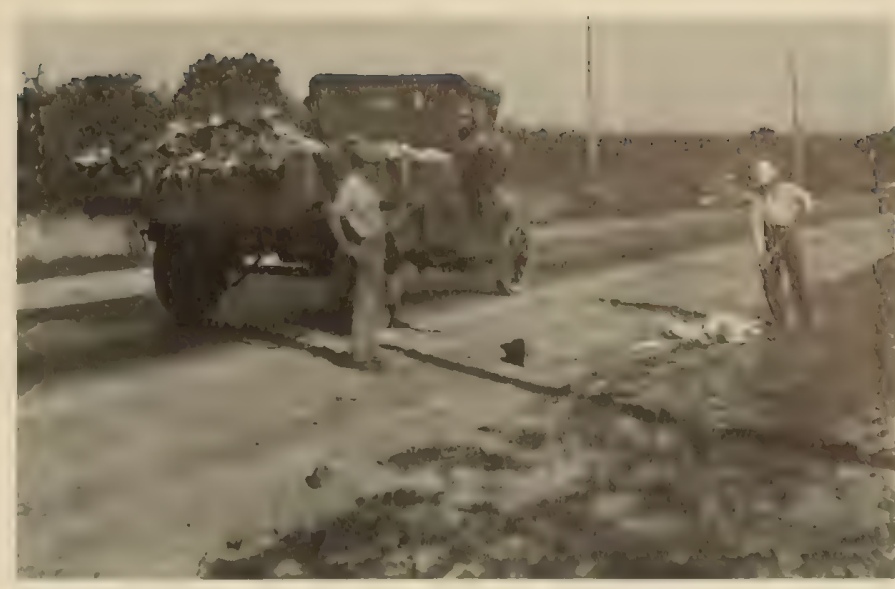

Highway litter removal was of concern in Delaware as early as 1927 .

in OPR Farmer's' Bulletin No. 505. In an article entitled Benefits of Improved Roads, the following items of social advantages were listed: (1) Improvement of schools, (2) improvement of rural delivery service, (3) improvement of social conditions.

The esthetic value of roads well built and clean is sometimes reluctantly conceded or even denied by individuals. It is noticeable, however, that along improved roads there is a visible tendency for farmers to improve the appearance of their homes and their outbuildings. . . The improved road not only has an esthetic value in itself, but it is potent in awakening the dwellers along its borders to a sense of esthetic values in farm buildings and home surroundings.

Social activities in rural communities need all the encouragement and stimulus that can reasonably be given. All social activities take time and energy, and the countryroad condition therefore is a prime consideration to enable farmers and their families to afford time for social intercourse..$^{15}$

Over the ensuing two decades, engineers periodically pointed to the esthetic advantages of tree planting. In 1920 a State highway commissioner called for the adoption in his State of the slogan "scenic betterment," while at the same time warning against the destruction of roadside beauty by billboards. ${ }^{16}$ In 1929, after describing in detail his State's program, another official insisted that "the business of roadside beautification" be made permanent. "It can never be finished" he concluded. ${ }^{17}$ In an article in 1930, titled "Uncle Sam Considers Roadsides," Chief MacDonald stated:

Planting shade trees along highways is a necessary complement to surfacing of roadways, the Bureau believes. A number of States had started, with their own resources, improvement of roadsides before passage of the amendment of the Federal Highway Act, authorizing Federal participation in planting shade trees along highways in the Federal-aid system. Recognizing that the first duty of the State Highway Departments is to surface highways, the Bureau does not wish to force States to resort to Federal aid in tree-planting nor to lead States to begin tree-planting until they are ready for it. But it will use its influence to bring about adoption of suitable prorisions in all States to enable this work to be done.

Correlated with roadside beautification is the problem of ridding the main traveled highways of the blatant commercial advertising signs. While the Bureau has no authority to correct what often proves a menace to safe driving, it has done what it could toward eliminating the billboards by developing popular sentiment against them. It is on the main traveled highways of the country that the billboards are concentrated. ${ }^{18}$ 
Recognizing the lure of pleasure driving, some States could see roadways as integral parts of the parks they were beginning to build. One of the earliest efforts in this direction was New York City's Central Park, opened in 1862, with an excellent system of roadways for horsedrawn vehicles. ${ }^{19}$ One of the earliest parks with boulevards to be completed as a total system was constructed in Kansas City, Missouri, with the original designs dating back to $1893 .^{20}$

New York's Bronx River Parkway was the first parkway in the Westchester County system, a system that in 1925 pioneered the limited access scenic road. ${ }^{21}$

In 1928 the Bureau of Public Roads made its entry into construction of national parkways. With a mandate to complete a highway from Washington, D.C., to Mount Vernon in Virginia, the Bureau, using knowledge gained in observing the development of the Westchester County parkway system, attacked the problem of coordinating design, location, landscaping and construction into a finished parkway that would befit an approach to the home of our First President. This, the Mount Vernon Memorial Parkway, was the first major project to which the Bureau assigned a full-time landscape architect. From the construction of this project, a new awareness of the relationship of landscaping to construction, design, and maintenance was established at the Federal level.

In 1932 the American Association of State Highway Officials joined with the Highway Research Board in the appointment of a Joint Committee on Roadside Development. During the next 8 years, the Joint
Committee prepared and published a number of reports. By 1940 it was felt that the field had enlarged to the point of justifying some degree of specialization. Accordingly, the Joint Committee was replaced by a committee appointed by HRB to continue research activities and a committee appointed by AASHO to concentrate on administrative issues.

As a means of exchanging ideas on all aspects of roadside development, the Ohio Department of Highways and the Department of Landscape Architecture of Ohio State University began sponsoring in 1941 an annual Short Course on Roadside Development which has developed over the years into a national conference. The proceedings of the conference are published each year to disseminate the latest information.

With increasing interest in the subject, Congress proceeded to include in the Federal-Aid Highway Act of 1938 approval for the use of construction funds to cover tcosts of roadside and landscape development. This measure established a new standard for Federal assistance in meeting costs beyond those incurred for purely engineering needs. As a result, many roadside development activities were carired out. Nevertheless, the provisions were permissive only, and since the funds came from amounts otherwise earmarked for construction, there was a reluctance by a number of States to allocate moneys to roadside development at the expense of badly needed new highways. It was not until the Highway Beautification Act of 1965 provided separate funding for roadside development that States really took advantage of this permissive legislation.

A junkyard along the Baltimore-Washington Expressway in Anne Arundel County is effectively screened with wood slats and with vines planted along the fence.

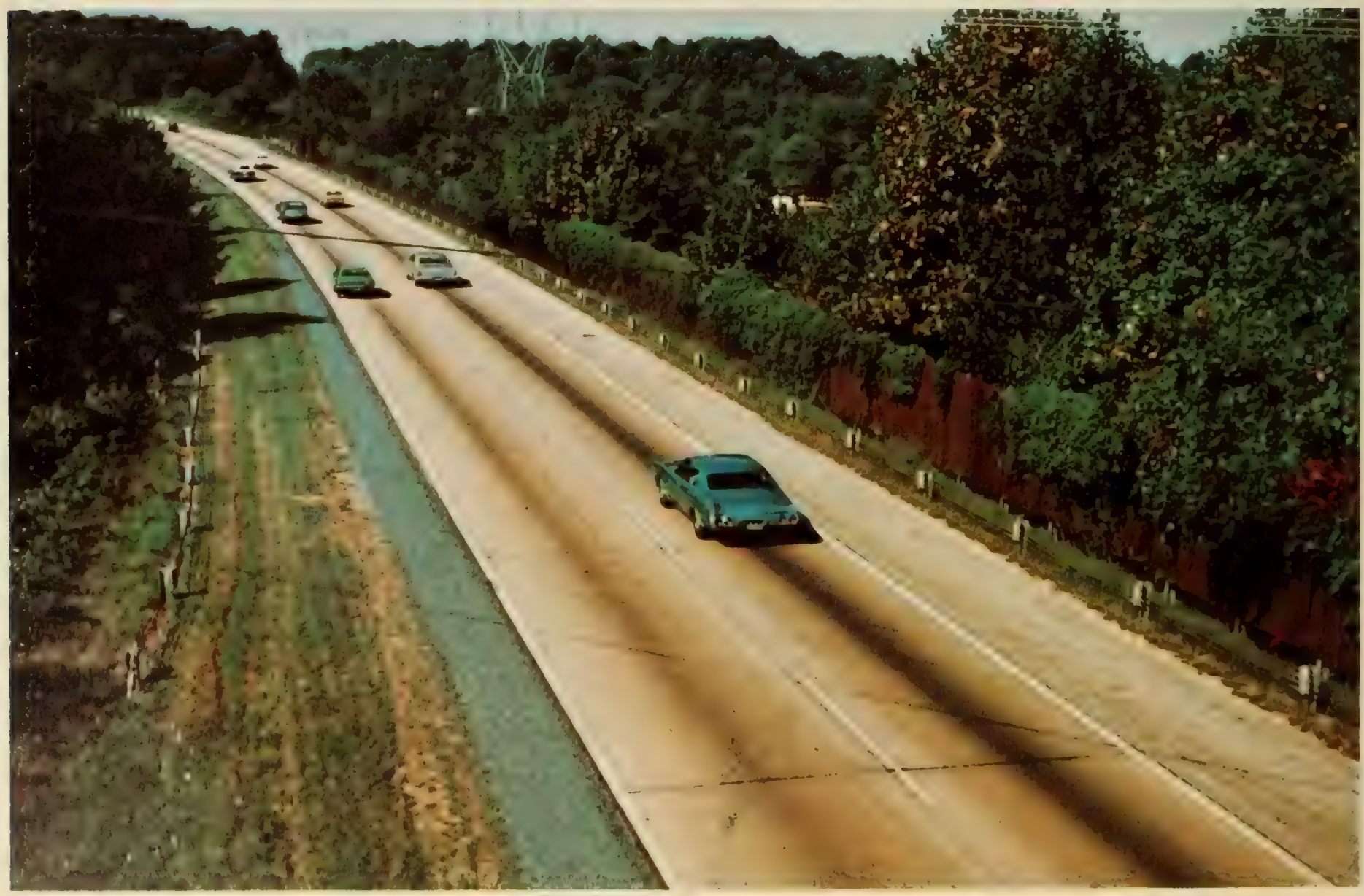




\section{Scenic Enhancement Programs}

Roadside development programs were normally limited to areas within right-of-way lines to improve appearance and safety, to provide amenities for the traveling public, to facilitate maintenance, and to control runoff and erosion. Development of private land on the other side of these lines might greatly affect the capacity or the safety of the highway or the view seen by the motorist, but normally this development could only be controlled through such measures as zoning, and this was considered, by State highway officials, to be the province of local governments.

Gradually, however, it was realized that highway agencies had a legitimate interest in what took place on the other side of right-of-way lines. A paper presented at the $1940 \mathrm{~A}$ S SHO convention, for example, advocated empowering State highway departments to apply roadside zoning along major arteries. ${ }^{22}$ Nothing came of that recommendation, but Congress did, in the 1940 Highway Act, authorize the use of up to 3 percent of apportioned Federal funds, without State matching, for the purchase of land beyond normal right-of-way lines to preserve natural beauty. As with roadside development, funds used for such purchases came from amounts otherwise available for construction, and only limited use was made of this authorization. Again, separate funding for this program was also provided later by the Highway Beautification Act of 1965 .

\section{Parkways and Scenic Roads}

During the 1920 's and 1930 's, a few new roads were built with major attention to enhancing the pleasure of driving. These included parkways constructed by State and county agencies, national parkways, and a number of scenic roads in national forests. World War II brought a stop to these programs. After the war, work resumed on scenic roads in national forests, and several State-sponsored scenic road programs were initiated, notably in California and Wisconsin. A few new parkways were built, but aside from these, the parkway program never really developed again. Parkways became increasingly expensive and the prohibition of truck traffic-one of the characteristics of parkways-was a factor in its loss of popularity. While parkways were not barred from inclusion in the Federal-aid program, the Bureau of Public Roads had reservations about making Federal-aid funds available for highways from which trucks were banned.

Bureau personnel did, however, participate in a comprehensive reoprt proposing an extensive program of parkways and scenic roads which was prepared for the President's Council on Recreation and Natural Beauty by the Department of Commerce and released in $1966 .{ }^{23}$

\section{Highway Beautification Act}

One of the high points in this country's efforts to improve the appearance of highways has been the Highway Beautification Act of 1965. Basically it authorized a threefold program:

- Outdoor Advertising Control. Certain types of signs adjacent to primary and Interstate highways were to be removed, and States were required to adopt legislation, if necessary, controlling new signs. Compensation was to be mandatory and
Federal aid was to be available for 75 percent of the costs. States failing to comply were to be subject to a 10 percent loss of Federal highway aid. There were certain important limitations in the Act: on-premise signs were excluded; control extended only 660-feet from the highway right-ofway; signs in commercial or industrial areas could be controlled but not eliminated; and Federal-aid secondary highways were not covered.*

- Junkyard Control. Certain existing junkyards along Interstate or primary highways were to be removed or screened, and States were to adopt legislation, if necessary, controlling new junkyards. Federal assistance was to be available for 75 percent of the cost of the program. States failing to comply were to be subject to a 10 percent loss of Federal highway aid. Again, there were important limitations: control extended only 1,000 feet from the highway right-of-way and Federalaid secondary highways were not covered.

- Scenic Enhancement. Alternative financing from general funds without State matching funds was established for the scenic enhancement and roadside development programs previously authorized. In addition, scenic easements were authorized and funds could be used not only for new projects, but also for existing highways on the Federal-aid system.

Progress under the Highway Beautification Act was at first quite slow, due perhaps to lack of moneys. Within the last 5 years, however, appropriations have increased and considerable progress has been made. All States, for example, have now adopted the required control legislation for outdoor advertising and junkyards.

\section{An Expanding Environmental Perspective}

Although highway administrators had long considered the advantages and disadvantages of road locations and design features, recognition of the various adverse impacts of the highway have only fairly recently been expanded and quantified. There are a number of reasons for this lack of eariler awareness. Most important, perhaps, was the fact that prior to the mid-1950's few entirely new major highways were built. Efforts were focused upon the improvement of existing routes. Surfaces were paved or repaved, lanes were widened or added, and curves or grades were smoothed. Occasionally short stretches of road were realined or additional rights-of-way were needed for other improvements, but generally the original alinement was preserved and little, if any, additional land was acquired.

Properties which, in the 1950 's, were located next to major highways with heavy traffic flows were not placed in this situation suddenly or unexpectedly. The highways had evolved from unpaved country roads in stages over a period of years. During any one stage, traffic increased steadily, but gradually, year-by-year. The final impact may have been substantial, but since it was imposed bit-by-bit, there was time for adjustment and usually little, if any, protest. In addition, many adjacent properties became suitable for roadside commercial uses and land values

\footnotetext{
* The 660-foot limitation was removed by the Federal-Aid Highway Amendment of 1974.
} 
increased accordingly. In such instances, owners regarded the improvement of the highway and the growth of traffic as an asset rather than a nuisance.

Much of the Federal-aid program took place in rural or undeveloped areas - urban projects were not eligible prior to the mid-1930's, and it was not until the 1944 Highway Act that a continuing program for Federal assistance to urban projects was established. Many of the adverse impacts of highways upon the environment were, of course, minimal in rural or undeveloped areas. Generally speaking, neither noise nor air pollution were significant problems either in the early years. The ecology of the areas traversed may have been affected, but it has only been in recent years, with the general recognition of the interdependent nature of the biosphere, that there has been serious recognition of this possibility.

A matter of priorities also shaped the perspective of these years. In 1920, there were 8 million passenger cars, but by 1930 the number had expanded to 23 million and in 1940, to 27 million cars. This rapid expansion loosened the restraints of fixed transit systems, and suburbia, with access provided by the automobile, became a way of life for millions. Little attention was being paid to the possible adverse effects of cars and trucks on the environment, for the emphasis was on building or improving the roads and building them faster to meet the burgeoning demand.

The socio-economic and political dislocations of the thirties and forties also diverted attention from the environmental effects of highways. The Depression of the 1930's resulted in the encouragement of highway construction as a means of relieving unemployment, with little thought given to possible side effects. Similarly, during World War II, highway construction was devoted to projects needed to support the war effort, no matter what their environmental consequences.
The Bureau of Public Roads did, however, take a step in the instigation of an environmental concern in the early 1950 's. W. J. Keller, BPR Division Engineer in New Mexico, felt a program had to be developed to preserve a record of our past that was being lost through highway construction. He envisioned a program for identifying archeological and paleontological sites prior to road construction. Keller visualized a three-way partnership-the BPR, the State highway department and the Museum of New Mexico. Because of the working relationship developed, the Museum recovered many items during 7 years of operation at 89 sites. More important to the Nation, Congress granted specific authority in the 1956 Federal-aid highway legislation with respect to archeological and paleontological salvage.

An economic issue affecting urban merchants was the first general intimation that highway projects could yield environmental problems as well as benefits. In improving existing highways, the major flow of through traffic was channeled along the main shopping streets of towns and cities. The merchants viewed the cars passing their stores as carrying potential customers and were pleased when the numbers of cars increased. From the standpoint of the motorist and the highway engineer, however, shopping districts were frequently bottlenecks causing congestion and delays. Due to existing development, street widening to relieve the congestion was usually out of the question, and, thus, the obvious solution became a new highway bypassing built-up areas.

Proposed bypasses were often bitterly resisted by central-city merchants fearing substantial losses in business by the diversion of traffic from downtown streets. Highway builders argued that most through traffic had no interest in shopping and that its presence on business district streets simply interfered with local traffic which did desire to shop. The resulting con-

U.S. Route 48 winds through western Maryland, not far from the trail followed by General Braddock in the French and Indian War. Freeflowing alinement, wide medians and independently sited roadways blend well with the picturesque and historic countryside.

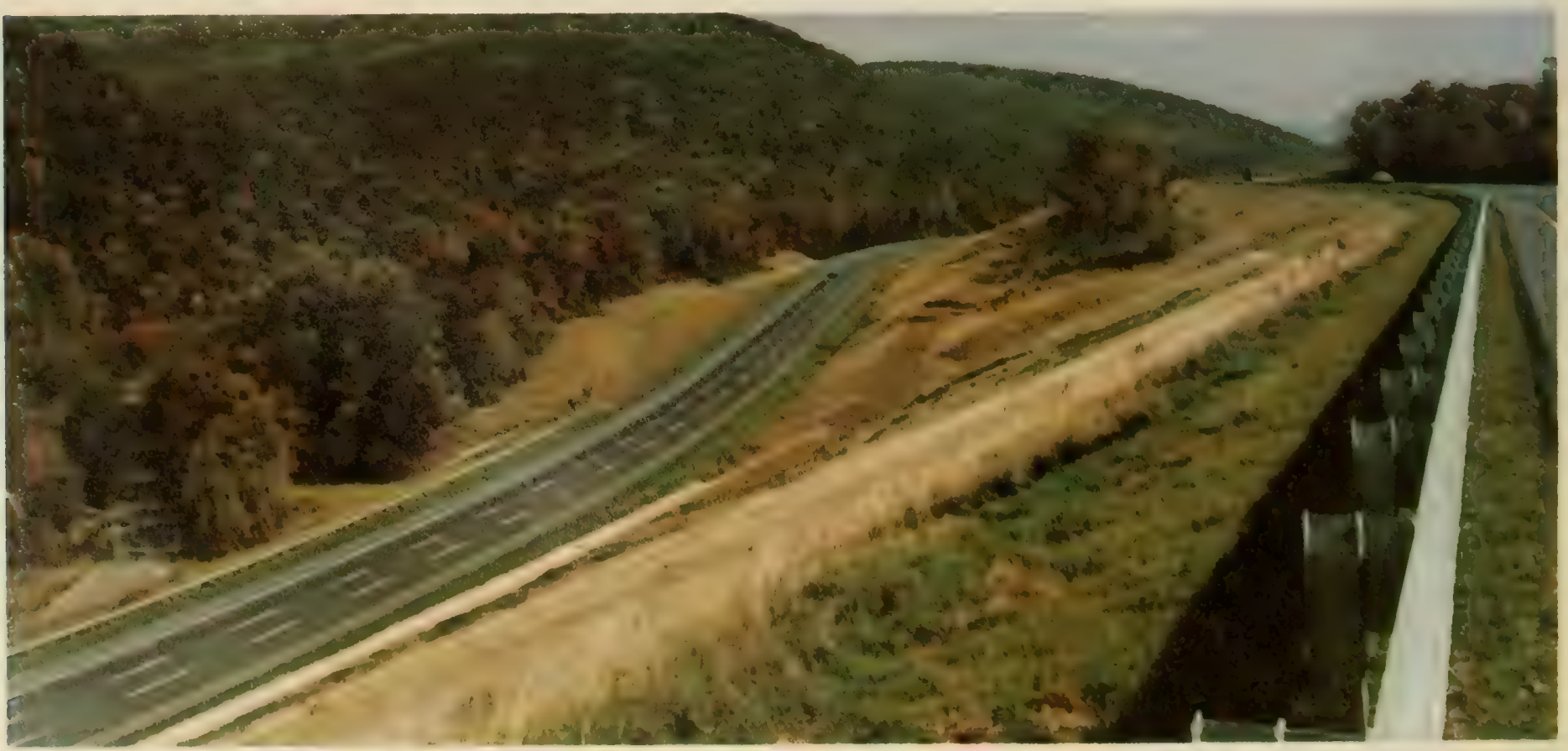


troversies led, in many cases to economic surveys and studies designed to ascertain what the facts actually were. Typically these studies showed mixed results; some businesses suffered from the diversion of through traffic, some benefitted, and some were little affected.

This issue, which first surfaced in the years just prior to World War II, reached a peak during the 1950 's, and then gradually disappeared. Traffic volumes became so large that it was very apparent that they could no longer be carried on existing urban arteries.

A number of other developments, starting in the mid-1950's, served to focus attention on the effects that highways might have on adjacent areas. Prominent among these was the increasing reliance upon freeways for the safe and efficent handling of major traffic flows. In developed areas, controlled access and other characteristics of freeways were extremely difficult to achieve by upgrading existing highways. New freeways, therefore, were nearly always constructed along new alinements, and thus, their impacts upon adjacent areas were imposed suddenly and without time for adjustment.

Many of the new freeways in the Interstate and other programs were located in or near the large urban areas where traffic demand was the heaviest. These were also the areas where the possibilities for displacement from homes and businesses were the greatest and where such adverse effects as noise and air pollution were most keenly felt.

An awareness of the hazards caused by vehicular emissions and poor air quality, in general, also basically developed only in the last 10 to 15 years. The density of smog over a number of large urban areas warning of future dangers dramatically brought a heightened environmental consciousness to the people at large and increased the demands for corrective action.

\section{Responses to Environmental Awareness}

Increased awareness of the environmental effects of highways has led to a variety of responses by Congress, by the FHWA, and in some instances by other agenices or organizations. Some of the congressional actions have been additions or amendments to basic highway legislation, but others, such as the National Environmental Policy Act of 1969 (NEPA), apply to a wide range of Federal programs, including highways.

\section{Public Hearings}

Largely as a result of the bypass controversy, Congress, in the 1950 Federal-Aid Highway Act, required State highway departments to hold public hearings for all projects bypassing cities or towns. In 1956 this requirement was enlarged by requiring public hearings (or the opportunity for hearings afforded) for routes going through cities or towns as well as those bypassing cities or towns. Two years later, in the Federal-Aid Highway Act of 1958, the public hearing requirement was applied to Interstate projects. In effect, public hearings are now necessary for all major projects and for projects of any size which have generated public interest or controversy.

In 1969 the FHWA released new detailed provisions requiring that two hearings (or the opportunity for them) be held for each important project, one at the location stage and the other at the design stage. Later, in 1974, however, this two-hearing requirement was modified. New regulations permit a State to omit one of the hearings providing its Action Plan* spells out acceptable alternative procedures for accomplishing the same objectives.

* Action Plans are discussed later in this chapter.

Erosion control during construction is aided by these silt fence installations along the Natchez Trace Parkway. Other methods used are temporary riprap at culvert inlets, plastic sheeting to carry cross drainage, and brush barriers

in conjunction with filter fabric on embankments.

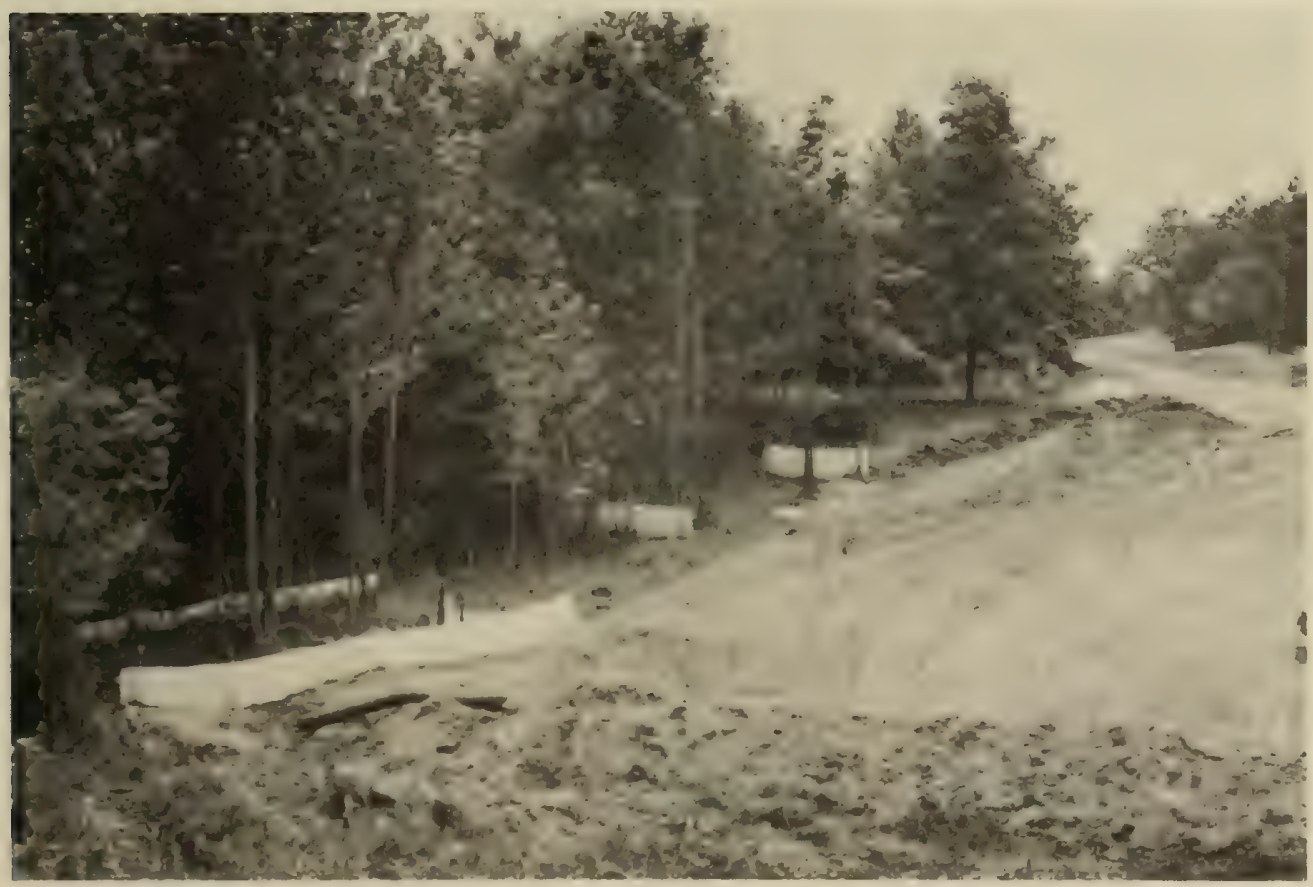


Consideration of Social, Economic, and Environmental Factors

In addition to holding public hearings, Congress, in 1950 and 1956, required that consideration be given to the economic effects of routes bypassing or going through urban areas. In the 1968 highway legislation, it specified that social and environmental effects of such projects be considered and be consistent with "the goals and objectives of such urban planning as have been promulgated by the community."

Meanwhile, BPR recognized pressures for increased evaluation of alternative alinements during the route location process and for more attention to social, economic, and environmental factors. Accordingly, in 1964 the Bureau issued a directive emphasizing the need for full consideration of all reasonable alternative alinements and listing approximately 20 social, economic, and environmental factors to be studied and evaluated, if applicable, in the process of investigating alternatives.
Interdisciplinary Studies and Joint Development Perspective

As the importance of environmental considerations became increasingly apparent during the 1960's, BPR was receptive to innovative approaches to achieve greater compatibility between highways and adjacent land uses. These efforts have taken several forms:

- Special studies of critical segments of highways, usually on the Interstate System, have been undertaken by interdisciplinary groups, sometimes referred to as design concept teams. Such studies focused not only on the design of the highway, but also on the planning or replanning of the adjacent areas.* This type of study is still being made, but the trend has been towards the utilization of in-house professional skills or established planning agencies rather than the creation of a one-time team of outside experts.

* An excellent discussion on this subject is presented in Urban Highway Design Teams, published by the Highway Users Federation for Safety and Mobility.

A downtown mini-mall joint development project in Twin Falls, Idaho.

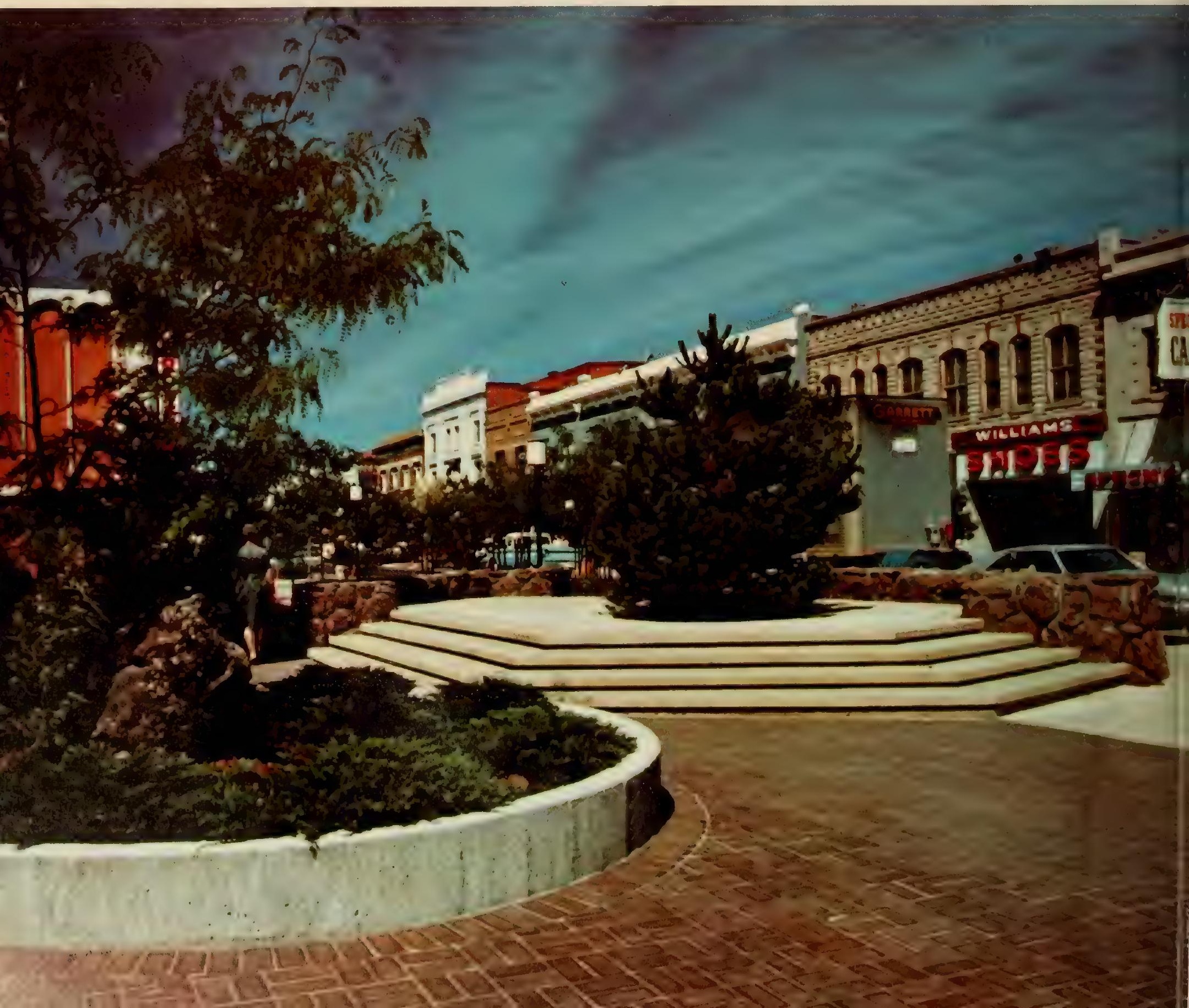


- Joint development of highway rights-of-way has been encouraged so as to accommodate other uses which, by their nature or design, could be rendered compatible with the highway. Such uses might be located over or under the highway or, right-of-way lines permitting, beside the highway. Joint development projects frequently provide for parking facilities, parks, and recreation areas; other uses have included buildings, both public and private, and mass transportation facilities, such as rail rapid transit lines.

- Trails within highway rights-of-way form a special category of joint development. Within the last few years, there has been greatly increased interest in bicycling as a healthy form of recreation, an economical transportation mode, and a significant means of conserving energy. In 1971, the FHWA issued a notice urging States to give favorable consideration to the inclusion of bicycle or hiking trails within highway rights-of-way

The location of I-66 in Virginia was altered to save historic Beverly's Mill near Middleburg.

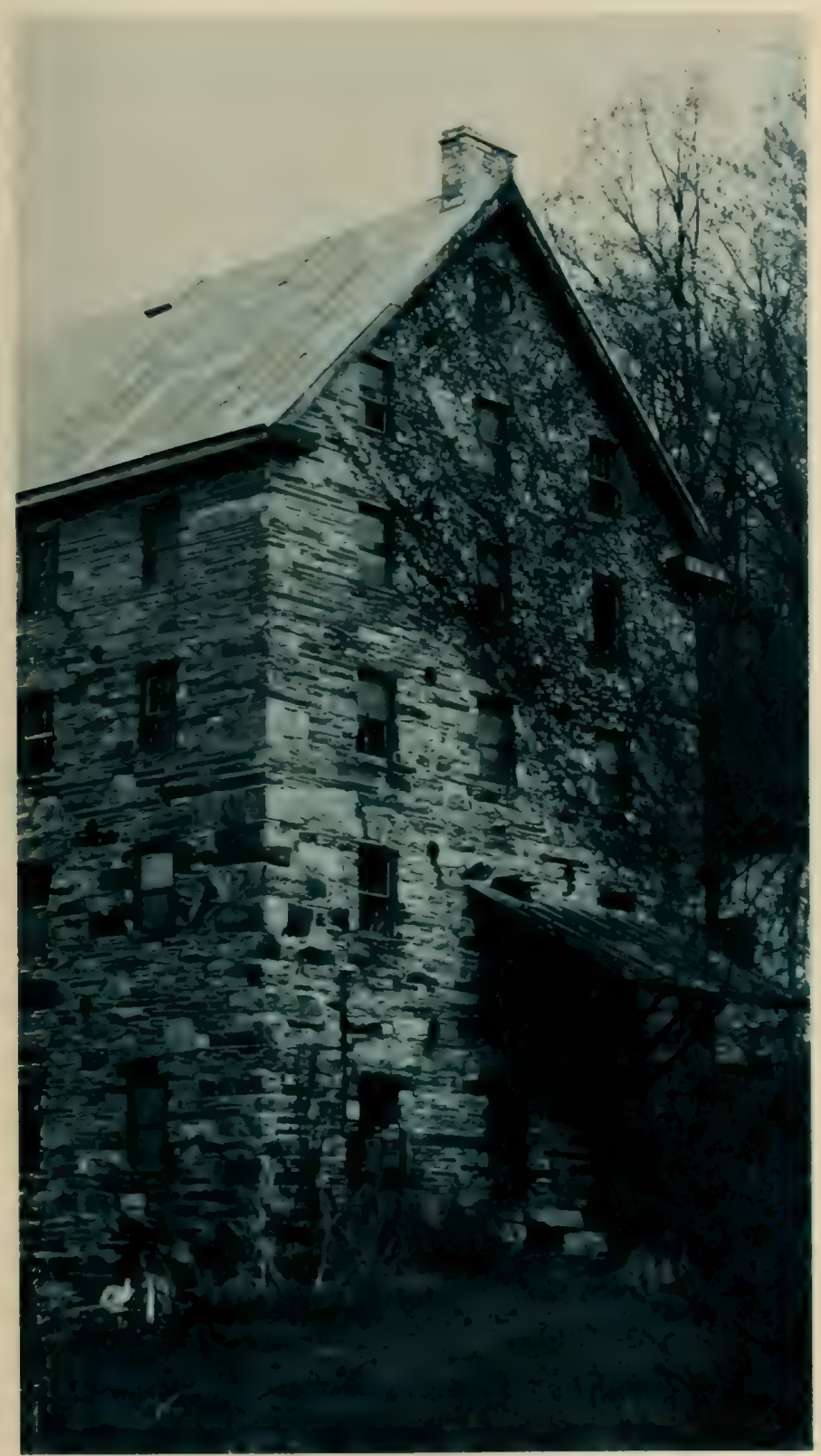

under appropriate conditions. Two years later this notice was expanded and indicated that Federal highway funds could be used in the cost of trails included in highway projects.

During 1973 Congress carried this program one step further by authorizing in the highway legislation the use of Federal funds, otherwise available to States for highway purposes, for the provision of separate bikeways or walkways up to a total of $\$ 40$ million per year.

- In 1965, the Federal Highway Administrator brought together a group of eight distinguished professionals - representing engineers, architects, landscape architects, and planners - and requested that they prepare a set of guidelines for the planning and design of urban expressways. The product of their work was The Freeway in the City, issued in May 1968. The report contained many unusual and innovative proposals and represented the most advanced thinking of its time on the problem of fitting a freeway into an urban setting.

\section{Protection for Parks, Recreation Areas, Wildlife and Waterfowl Refuges, and Historic Sites}

Lands in parks, recreation areas, wildlife and waterfowl refuges, and historic sites have particular environmental significance. Preservation has emerged as a conscious consideration in public works programs and in the public's mind only in the last two decades. Preservation had always been a latent concern in good engineering practice.

One of the first movements for historic preservation came about in the 19th century when Miss Ann Pamela Cunningham and her Mount Vernon Ladies Association decided to preserve General George Washington's home, Mount Vernon. This was and still is today a purely private effort.

The current phase of preservation that is discerned today is the environmental approach. Historic preservation was conceived as a facet of the physical environment to be reflected in its total view. Historic districts and restrictive zoning came about. Incorporating sympathetic modern transportation facilities in these areas has presented the highway engineer with many challenges.

As historic preservation has developed, legislative mandates have helped define its direction and goals and often presented interesting parallels with the highway program. In 1906, the Antiquities Act was passed which gave the Secretary of the Department of the Interior responsibility for prehistoric and historic sites on Federal lands. In 1916, the year of the first highway act, the National Park Service Act was passed which included preservation of historic parks. In 1935, the Historic Sites Act announced a national policy to preserve for public use historic resources. This Act was the culmination of the associative value and inherent architectural merit phases of the preservation movement and exists today in the National Historic Landmark Program. 
As the environmental phase of preservation was developing, a legislative interlude occurred. Not until 1966 was the environmental phase recognized in the National Historic Preservation Act which called for a national inventory of historic resources (including historic districts) whose value could be national, State or local in significance. Also, these sites were extended a protective umbrella that required special planning consideration for historic resources affected by Federal public works projects. This same year the Department of Transportation Act was passed including paragraph $4(\mathrm{f})$ which reflected national concern for historic sites and mandated that lands from historic sites, public parks, recreation areas, etc., were to be protected. This provision has been incorporated into section 138 of title 23, U.S.C. Highways, as follows:

... the Secretary shall not approve any program or project which requires the use of any publicly owned land from a public park, recreation area, or wildlife and waterfowl refuge of national, State, or local significance... or any land from an historic site of national, State, or local significance... unless (1) there is no feasible and prudent alternative to the use of such land, and (2) such program includes all possible planning to minimize harm....*

Since 1966 there have been several more policy refinements. In 1969, the National Environmental Policy Act set forth a national policy in this area which includes historic resources. In 1971 Presidential Executive Order No. 11593 put the Executive Department deeply into the environmental phase of the historic preservation movement. Most recently has been the 1974 Archeological and Historic Preservation Act which has liberalized funding requirements for Federal agencies to spend moneys on preservation activities.

\footnotetext{
* This language is quite similar to that used in section 4 (f) of the 1966 Department of Transportation Act, and this requirement has since been identified as section 4 (f). Sponsors of projects coming within the bounds of section 4 (f) are required to demonstrate compliance with its requirements to the satisfaction of DOT.
}

\section{Other Federal Environmental Requirements and the} Highways

There are now numerous Federal environmental laws and regulations relating to a wide range of Federal or Federal-aid programs, of which the Federalaid highway program is only one. To the extent that highway projects are affected, they must and do comply. The more significant of these measures are:

- A-95 Notification Procedure. Named after Circular A-95 issued by the Bureau of the Budget (now the Office of Management and Budget) originally in 1969, this procedure requires applicants for Federal assistance for many types of projects to provide advance notice and plans to State or metropolitan area clearinghouses. The clearinghouses inform interested State and local agencies which, in turn, have the opportunity to comment. Submitted comments must accompany the application for Federal assistance.

- Historic Preservation Act (1966). Any project impinging upon a historic site placed on the National Register must be referred to the Advisory Council on Historic Preservation for its review and comment. (This requirement relating to historic sites is in addition to the requirements imposed by section $4(f)$.)

- National Environmental Policy Act of 1969. This law, as its name indicates, is first and foremost a statement of policy designed to ". . . encourage productive and enjoyable harmony between man and his environment; to promote efforts which will prevent or eliminate damage to the environment and biosphere and stimulate the health and welfare of man; to enrich the understanding of the ecological systems and natural resources important to the Nation; and to establish a Council on Environmental Quality."

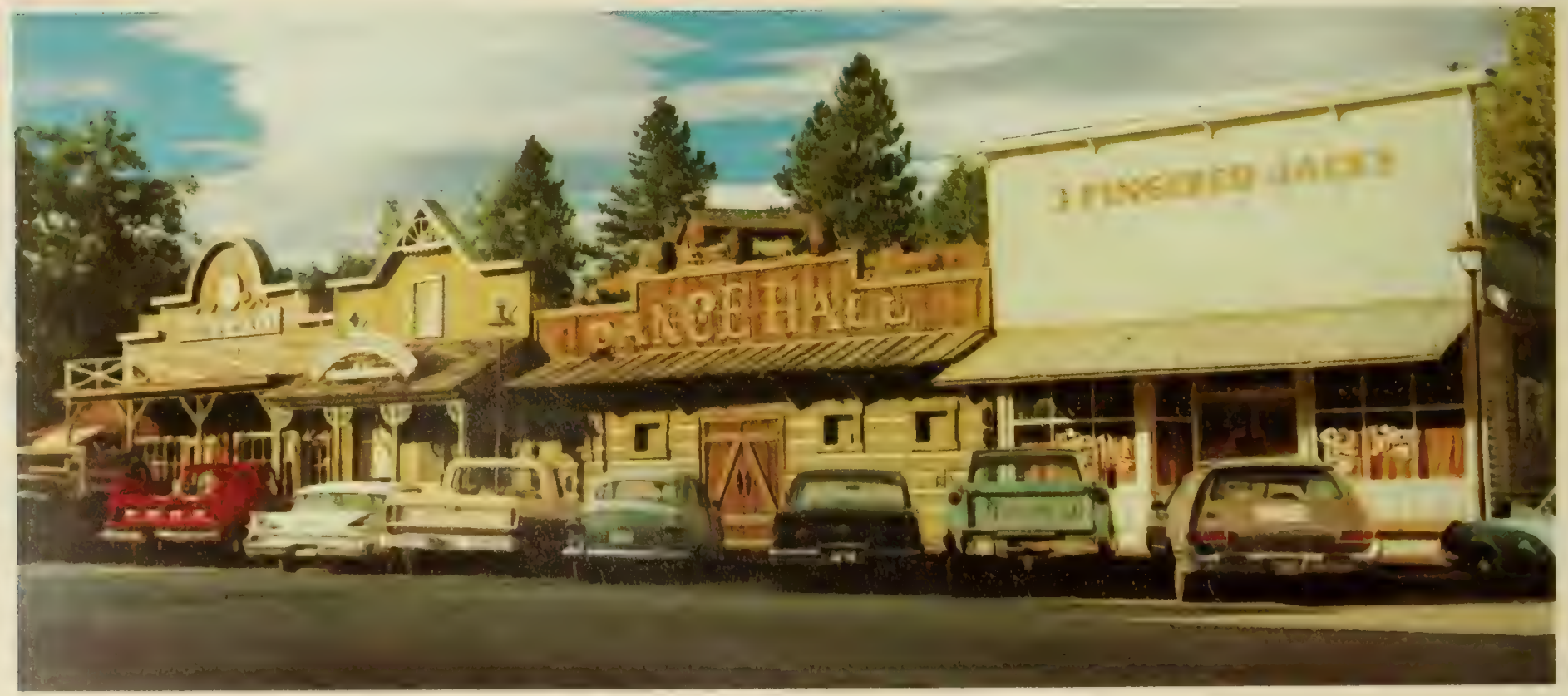


The National Environmental Policy Act (NEPA) undertakes two substantive actions. First, it establishes the Council on Environmental Quality (CEQ). This three-man group is responsible for monitoring progress, or lack thereof, in the environmental field, for advising the President, and for making recommendations on future actions or programs which it believes should be adopted. Secondly, NEPA requires for each legislative proposal or other Federal action "significantly affecting the quality of the human environment" a detailed statement covering:

"(i) the environmental impact of the proposed action, "(ii) any adverse environmental effects which cannot be avoided should the proposal be implemented,

"(iii) alternatives to the proposed action,

"(iv) the relationship between local short-term uses of man's environment and the maintenance and enhancement of long-term productivity, and

"(v) any irreversible and irretrievable commitments of resources which would be involved in the proposed action should it be implemented."

These statements, known as environmental impact statements (EIS's), must be prepared for all Federalaid projects, including highways, meeting the test of "significantly affecting the quality of the human environment." Their preparation is a two-stage operation: draft EIS's are circulated to all concerned agencies and the public for review and comment; final EIS's then incorporate comments and indicate their disposition. Since passage of NEPA, approximately half of all EIS's prepared stem from highway projects.

All three of these requirements are similar in approach in that none of them authorizes the direct alteration or stopping of a project. All rely upon the wide dissemination of information and the opportunity for comments by others to influence the decisionmaking process and to prevent or mitigate environmental damage. Each has the incidental, but important, effect of helping to identify pertinent social, economic, and environmental considerations.

A fish ladder alongside $I-84$ in Connecticut aids the migration of fish while enhancing the natural environment.

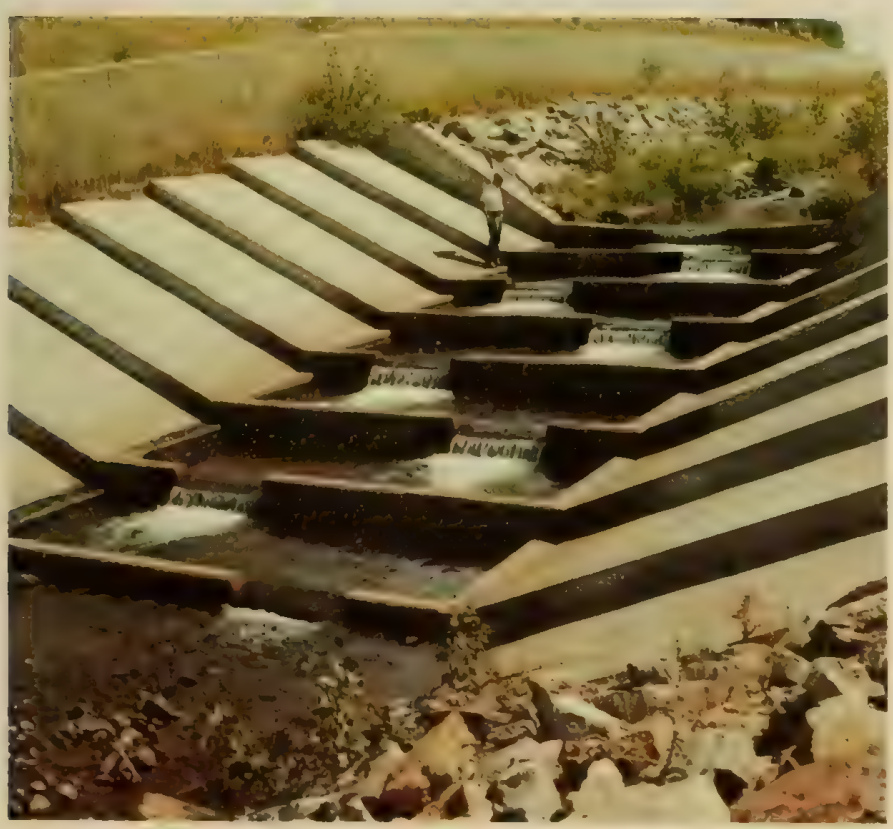

Process Guidelines and Action Plans Approach to Environmental Protection

In 1970 Congress decided that previous efforts by it and by the FHW $\mathrm{A}$ to assure adequate consideration of the envirommental aspects of highways should be reinforced. Therefore, the 1970 Federal-Aid Highway Act added three related measures dealing with environmental considerations in general, noise standards, and air quality.

In dealing with general environmental considerations, the Department of Transportation was called upon to prepare and issue guidelines to assure (a) that possible social, economic, and environmental effects of proposed highway projects are fully considered and (b) that final decisions on highway projects are made in the best overall public interest, taking into account the need for fast, safe, and efficient transportation and the costs of eliminating or minimizing adverse effects.

The resulting guidelines, known as the "Process Guidelines," are aimed at influencing the methods by which highway projects are developed rather than by attempting detailed supervision or control of plans or projects.

The Process Guidelines, officially issued in September 1972, require each State highway agency to prepare an Action Plan spelling out the organizational arrangement, the assignment of responsibilities, and the procedures to be followed in developing projects in conformity with congressional intent. The Guidelines outline issues which must be addressed, of which the following are particularly important:

- Identification of social, economic and environmental effects, including, especially, the incidence of such effects upon specific groups and interests.

- Consideration of alternative courses of action, including, to the extent appropriate, alternative locations, alternative types of scales of highway improvements, other transportation modes, and the option of no new construction (often referred to as the "no build" alternative).

- Systematic interdisciplinary approach, including the need for consideration and evaluation of the social, economic, and environmental effects of highway projects by a wide range of professional skills.

- Involvement of other agencies and the pubtic, including the widespread dissemination of information and the active solicitation of comments and views during all stages of project development.

While coverage of the topics included in the Guidelines is required, the manner in which these subjects are addressed is left to the States, and thus, each State has considerable freedom in adjusting its Action Plan to its own needs and conditions.

As of May 23, 1975, 52 of a possible 53 State Action Plans were completed and approved,* and while it is too early to make definite judgment on their longrange effectiveness, an FHWA report to Congress in 1974 concluded, "It is impossible to read the Action Plans so far approved without being struck by their thoroughness and sincerity. These Action Plans dis-

\footnotetext{
* The total number of 53 Action Plans includes 50 States, Puerto Rico, the District of Columbia, and the FHWA Offices of Federal Highway Projects.
} 
play a willingness to experiment with the new techniques and approaches, a strong intent to solicit comments and to disseminate widely all relevant information, and a determination to conduct an open administration of the highway program. Not all of the Action Plans reviewed are equally strong in all of their responses to the Process Guidelines, but the general level of discussion is remarkably high." ${ }^{24}$

\section{Noise Standards}

The second of the 1970 environmental actions by Congress was a requirement calling for the preparation and promulgation of "standards for highway noise levels compatible with different land uses" to be applied to future Federal-aid projects. In responses to this mandate, FHWA published noise standards in 1972 .

The standards established design noise levels for various land uses and activities. These values are compared with predicted future noise levels expected from new highway projects to determine noise impacts and the possible need for noise abatement measures. Consideration of shifts in route alinement or grade, the provision of buffer zones, the installation of noise barriers, or (in limited cases) the noise insulation of public-use institutional buildings are evaluated on all such projects to the extent that opportunities to abate noise reasonably exist.

The Federal-Aid Highway Act of 1973 authorized Federal-aid funds for noise abatement measures on existing Federal-aid highways.

Two important aspects of the highway noise problem lie outside the authority of the FHWA. The first is the noise emanating from the vehicle itself. Effective control here is dependent upon additional legislation affecting the manufacture, maintenance, and operation of motor vehicles. The second concerns the imposition of controls over the development of lands adjacent to highways to reflect actual or anticipated noise levels. FHWA's noise regulations instruct highway officials to advise local governments of expected noise levels for new projects. In addition, the FHWA has issued an advisory manual on the subject. ${ }^{25}$

\section{Air Quality Guidelines}

The third 1970 environmental action directed by Congress was the preparation and promulgation of guidelines to assure that future highways are consistent with state implementation plans to meet the National Ambient Air Quality Standards established as a result of the 1970 Clean Air Act.

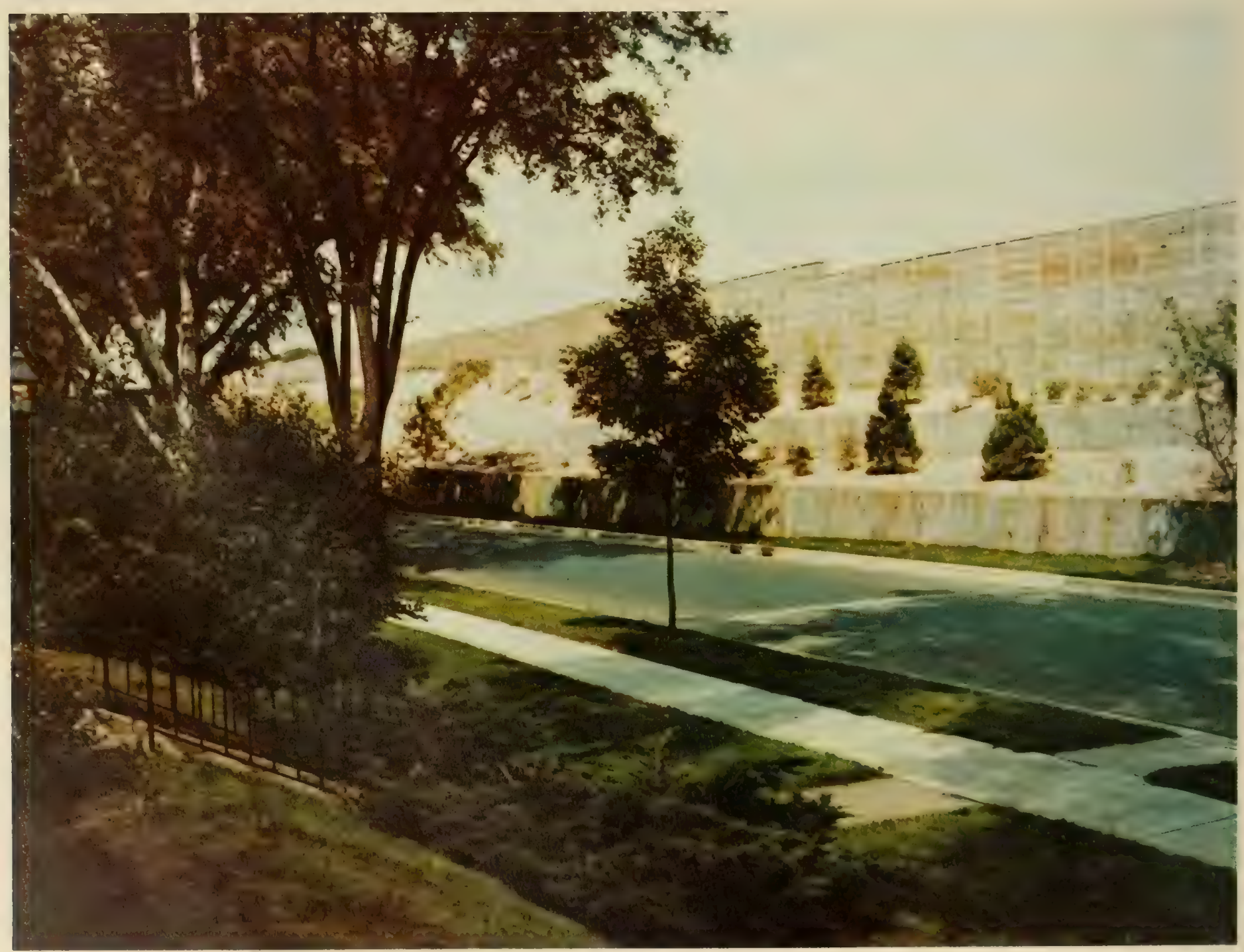


Air Quality Guidelines prepared on the premise that transportation planning and air quality planning are interdependent and that neither should proceed without full consideration of the other were issued in final form by the FHWA in 1974. The Guidelines instruct highway officials responsible for urban transportation planning in areas subject to the $3 \mathrm{C}$ process* to confer with the appropriate air pollution control agencies; annually solicit comments on the consistency of transportation plans with approved State Implementation Plans for attainment and maintenance of air quality; and determine consistency of transportation plans with State Implementation Plans. Other provisions in the Guidelines are intended to ensure adequate coverage of air quality considerations in EIS's.

Achieving applicable air quality standards in some urban areas will undoubtedly be very difficult. For the more troublesome air quality problem areas, the Environmental Protection Agency (EPA) has required transportation control plans designed to reduce the volume of pollutants by such methods as improving the flow of traffic, improvements in mass transportation, bans on parking, and encouraging carpooling.

* Section 134 of title 23, U.S.C.
Of the various responses to the many environmental problems, only a few set forth specific rules for application to individual projects. Section 4 (f) of the Department of Transportation Act is one such instance. Given the availability of a "feasible and prudent alternative," land from public parks or certain related uses cannot be used for a Federal-aid highway project.

The Noise Standards issued by the FHWA are also based upon a project approach. When predicted noise levels for a project exceed specified design noise levels for various land uses and activities, then noise control measures are to be undertaken. If strict adherence to the Standards are demonstratively unreasonable, there are provisions for flexibility or exceptions.

Like noise, air quality is subject to quantitative analysis, and it might, therefore, be assumed that it would be equally susceptible to a project approach. Because so little is known about the subject of air quality conditions and the elements involved are so varied, project rules have not been established with the same degree of specificity as the Noise Standards. The Air Quailty Guidelines are, therefore, aimed at processes and procedures to assure consistency between highway plans and State air quality plans.

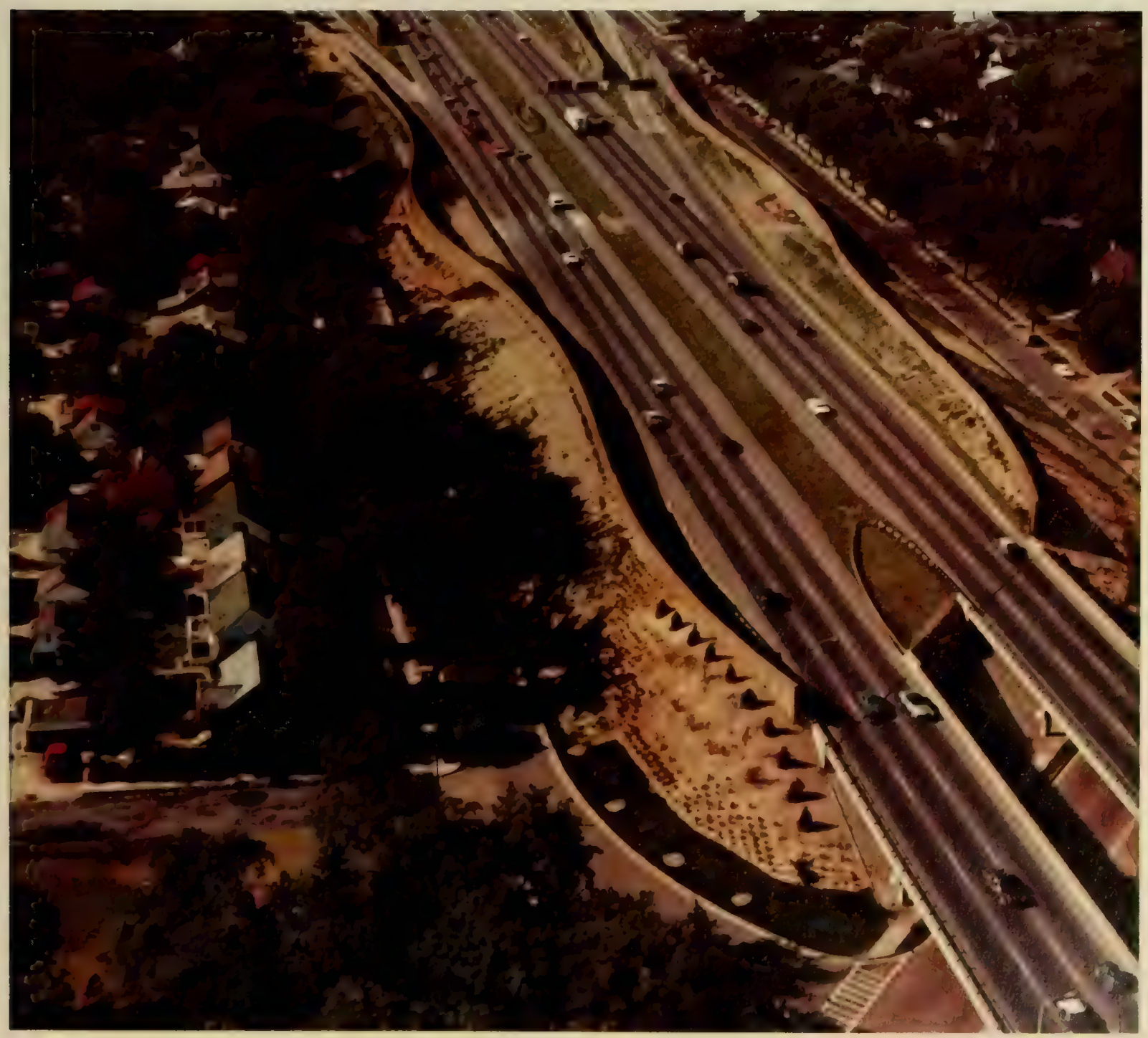




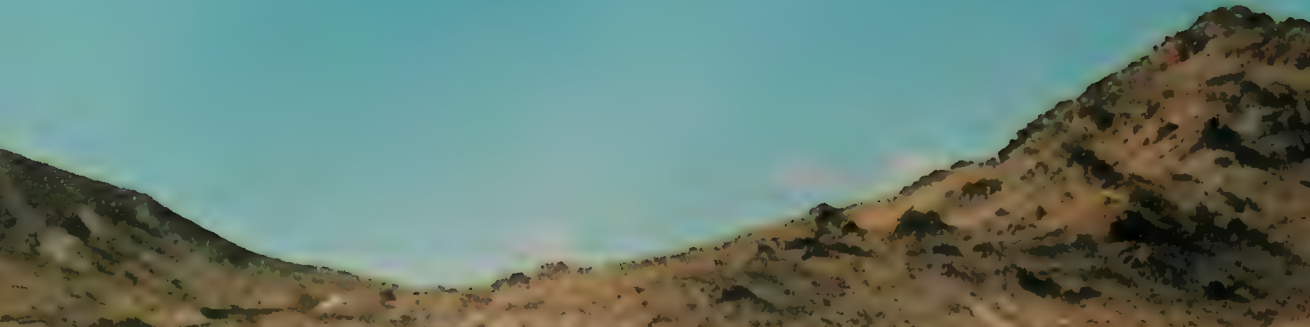

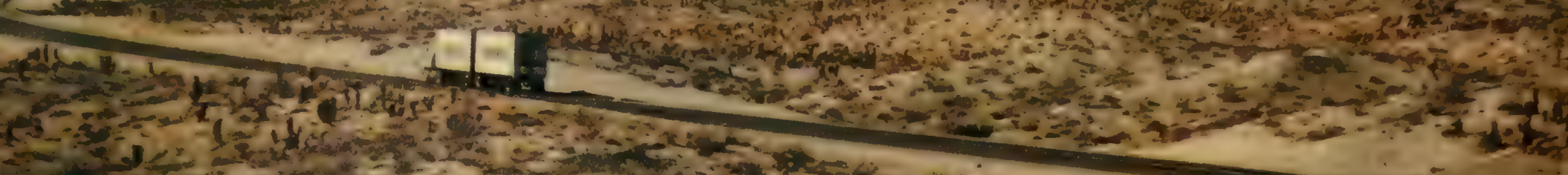

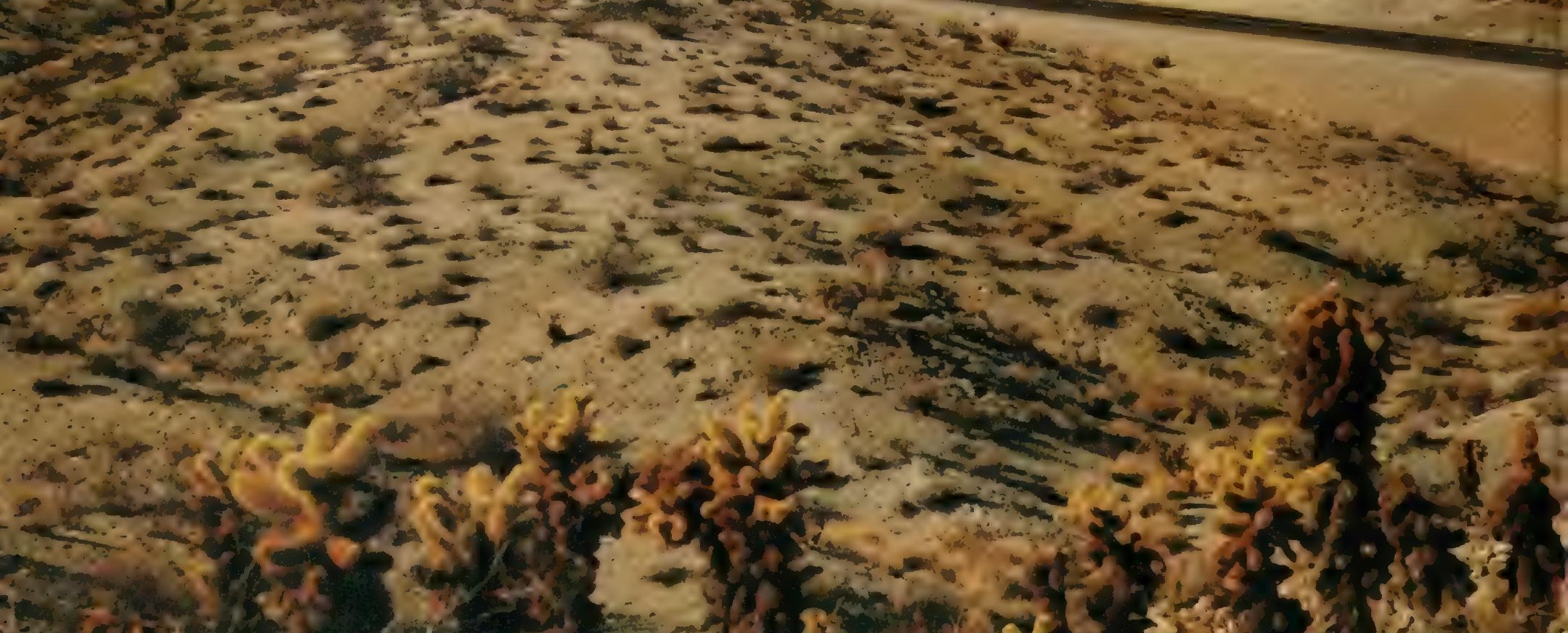

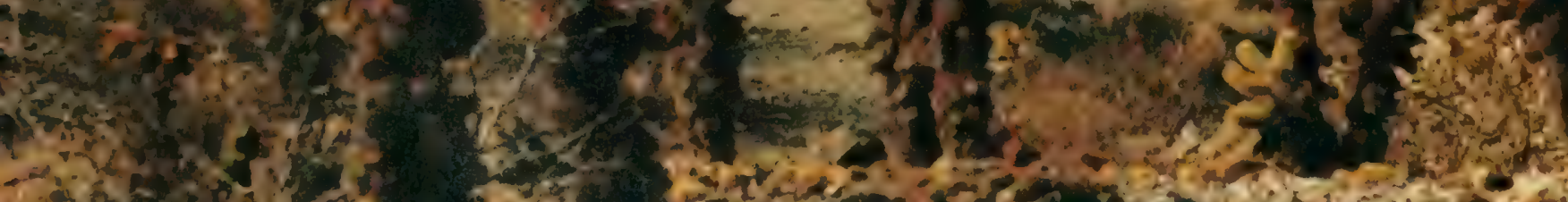

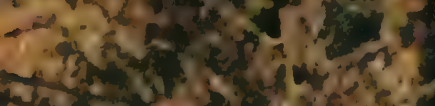

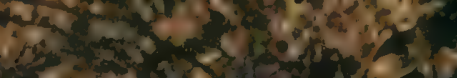

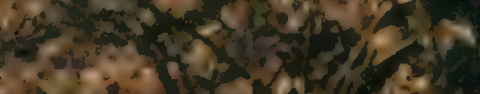

Lise

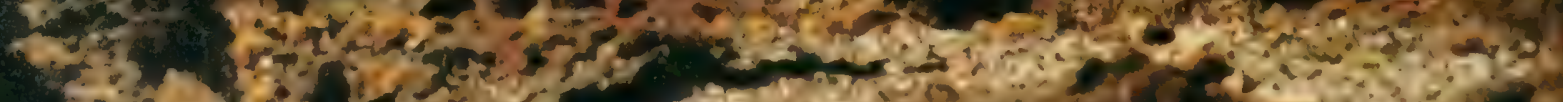
S.

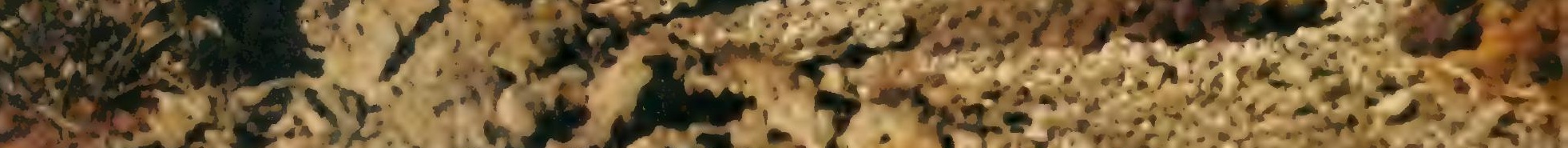

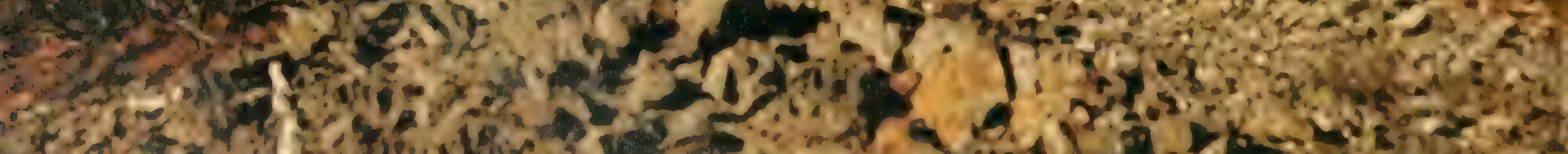

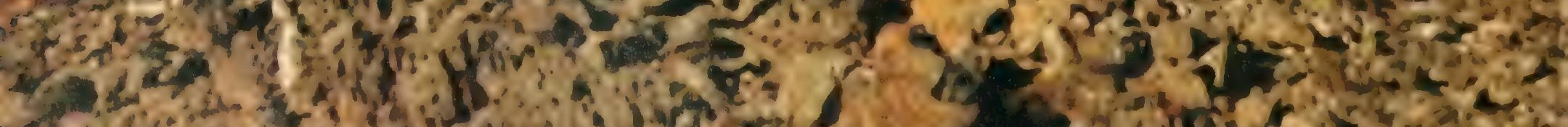

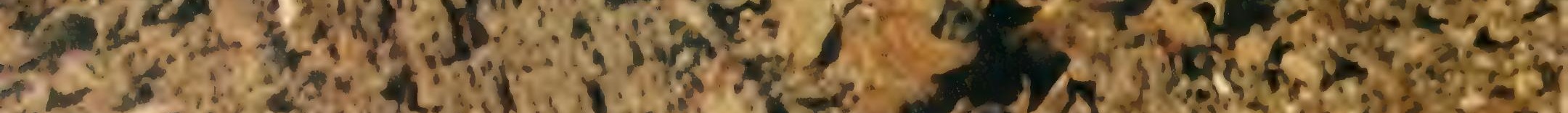

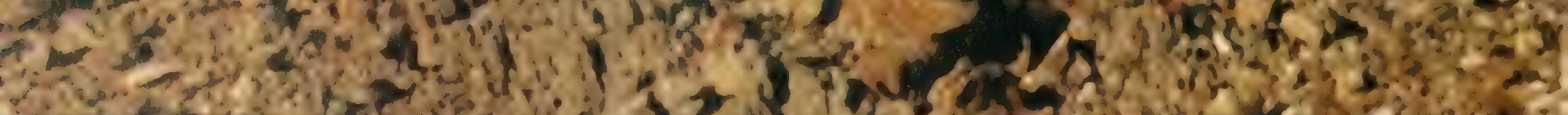
?

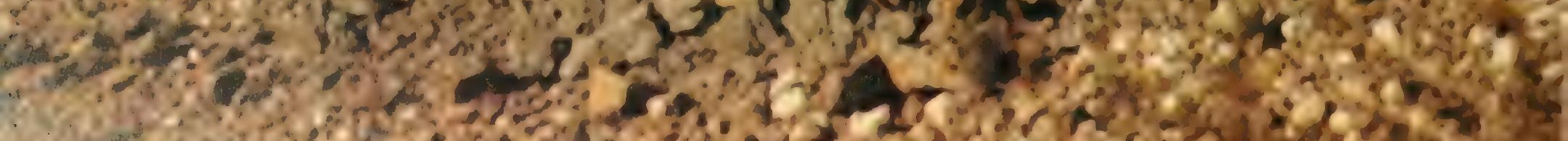
6. 
The other environmental responses, while varied in their approaches and methods, are alike in certain respects. They do not, for one thing, attempt to impose regulations or standards aimed at individual projects, presumably reflecting a concensus that any such effort would be cumbersome or otherwise impracticable. They are oriented, rather, to procedures, organization, and personnel in the expectation that the right processes will lead to the right decisions on individual projects.

Virtually all of these process-oriented responses are based upon one or more of a small group of fundamental principles:

- The need for identification and evaluation of all significant factors.

- The importance of wide participation in the highway development process by other agencies, offcials, and disciplines and by the general public.

- The value of careful consideration of all feasible alternatives, including, where appropriate, other modes and the option of not proceeding with the project in question.

- The need for widespread dissemination of information to other agenices and to the public.

The application of these principles will not directly solve environmental problems. But taken together, they establish a process which goes a long way to assuring maximum compatibility between highways and the environment.

\section{Conclusion}

In the development of the highway system of this Nation, the original motivating factor in the roadbuilding was to be able to move quickly from one point to another. All too often in the early years, the detrimental sociological and environmental impacts that occurred as a result of highway construction were ignored or treated only when it became obvious or hazardous, as in the case of the health problems raised by horses.

The development of an awareness of the sociological and environmental aspects of roadbuilding was a gradual, evolutionary process. The separation of State and Federal functions allowed the development of this awareness and of the tools to correct the situation. But the Federal-State partnership evolved such programs as appraisal, appraisal review, negotiation, relocation assistance and payment, replacement housing, highway beautification, environmental protection, joint use of highway rights-of-way, and many more.

There are yet many problems which affect man's total environment that have to be solved. However, mechanisms have been created in the interrelated, yet independent, nature of the Federal-State partnership and in the establishment of independent offices of right-of-way and environment to assure that these concerns receive their full consideration in the building of a highway. The existence of these mechanisms do not guarantee the successful solution to all the problems affecting man's total environment. However, their existence does provide a well-founded hope and does go a long way in assuring that the creation of the highway system and the well-being of our total environment will exist compatibly.

\section{REFERENCES}

${ }^{1} \mathrm{~S}$. BоoтH, The History of Federal-Aid Legislation for Highways, AASHO-THE FIRST FifTY YeARs, 1914-1964 (American Association of State Highway Officials, Washington, D.C., 1965) p. 151.

${ }^{2}$ W. Rayner, Elementary Surveying, Vol. I, $2 d$ ed. (Van Nostrand Company, Inc., New York, 1946) p. 278.

${ }^{3} I d$.

' Contrasting United States and European Practices In Road Development, address by T. H. MacDonald before the 24th Annual Meeting of the American Association of State Highway Officials, Dallas, Tex., Dec. 5, 1938, Papers, 1937-39, pp. $12,13$.

'J. A. TARr, Urban Pollution-Many Long Years Ago, AMERican Heritage, Vol. XXII, No. 6, Oct. 1971, p. 66.

${ }^{6} I d .$, p. 68.

${ }^{7} I d .$, p. 67.

${ }^{8}$ Id., p. 69.

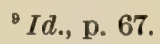

${ }^{10}$ What New York State is Doing, Good Roads Magazine, N.S. Vol. IX, No. 2, Feb. 1908, p. 59.

${ }^{11} I d$.

${ }^{12}$ Bureau of Public Roads Annual Report, 1900, p. 287.

${ }^{13} \mathrm{M}$. Dickinson, The Beautifying and Endowment of Highways, Good Roads Magazine, Vol. IV, No. 8, Aug. 1903, p. 324.

${ }^{14}$ A. Fletcher, Macadam Roads, Farmers' Bulletin, 338 (U.S. Dept. of Agriculture, Washington, D.C. 1909) p. 21.

${ }^{15}$ Office of Public Roads, Benefits of Improved Roads, Farmers' Bulletin 505 (U.S. Dept. of Agriculture, Washington, D.C. 1915) p. 20.

${ }^{16} \mathrm{~J}$. HAzLEWOOD, Making Highways Ornamental and Useful, Public Roads, Vol. 2, Nos. 21-22, Jan.-Feb. 1920, pp. 14-16.

${ }^{17} \mathrm{~J}$. TAYLOR, Roadside Plan and Progress in Massachusetts, Public Roads, Vol. 10, No. 6, Aug. 1929, p. 109.

${ }^{18}$ T. H. MacDonald, Uncle Sam Considers Roadsides, AMERican Crvic Annua, Vol. II (American Civic Association, Inc., Washington, D.C. 1930) pp. 164, 165.

${ }^{10}$ D. C. Smith, Urban Parks and Roads (Highway Users Federation for Safety and Mobility, Washington, D.C. 1971) pp. 7,8 .

\section{${ }^{20} I d$., p. 21.}

${ }^{21}$ W. Bugge \& W. SNow, The Complete Highway, THE HighWAY AND THE LANDSCAPE (Rutgers Univeristy Press, New Brunswick, N.J. 1959) p. 10.

${ }^{22} \mathrm{H}$. Coons, Control of Roadside Exploitation, Convention Group Meetings, Papers and Discussions (American Association of State Highway Officials, Washington, D.C., 1940) p. 40 .

${ }^{23}$ U.S. Dept. of Commerce, A Proposed Program for Scenic Roads and Parkways (GPO, Washington, D.C., 1966) pp. 2-4.

${ }^{24}$ Federal Highway administration, Progress Report on Implementation of Process Guidelines (U.S. Dept. of Transportation, Washington, D.C., 1974) p. 15.

${ }^{25}$ Federal Highway Administration, The Audirte LandScape: A Manual for Highway NoIse and Land Use (U.S. Dept. of Transportation, Washington, D.C., 1974). 


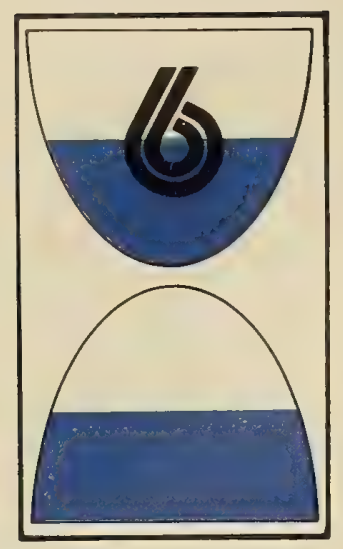

Design

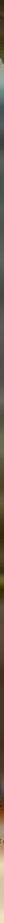

U.S. 422 in rural Pennsylvania. The curvilinear alinement and roadside treatment have resulted in a design incorporating utility, beauty, and economy of maintenance. 
Highway design is the art of anticipating the roadway requirements of motor vehicle traffic and of satisfying these requirements in the preparation of construction plans. It involves the selection of dimensional values for geometric features such as widths, radii of curvature, rates of cross section slopes and longitudinal gradients; the determination of the requirements for the roadway structure (pavement and base courses) and for the bridges, drainage and other structures; the preservation and restoration of ground cover and plant growths; the safety and efficiency of traffic operations, including all forms of traffic control devices; and the melding of the highway's alinement and gradient with the landscape in a manner least disturbing to the natural environment. Engineering analyses during the highway design must attain an acceptable balance between the broad controls of economic limitations, land space usage and environmental and social considerations.

The roads existing during the early years of the automobile were not designed for motor vehicle usage; they were simply wagon roads. For many years after the automobile came into wide use, these same roads were adapted to automobile travel with little or no change in location, alinement or geometrics. Even after the automobile became commonplace, a number of years, or even decades, were to elapse before highways were constructed to meet the unique requirements of motor vehicle traffic.

The transitional period from horsedrawn to motor vehicle traffic occurred at a time when railroad transportation was approaching maturity. Trains shared with the automobile one distinguishing characteristic when compared with horsedrawn vehicles-both trav. eled at a faster speed. It was natural, then, that when travel speed became recognizable as a factor in highway design, the leaders in this art turned to the practicing railroad designers for guidance in determining alinement design details to satisfy the requirements of the higher speeds of motor vehicles.

While building upon these bases of knowledge, highway designers were often in a dilemma as to which features of wagon roads should be retained, modified, or rejected, which characteristics of railroad practice should be incorporated, and what new concepts were needed to satisfy the peculiar qualities of automobile traffic. Resolution of these matters was often the subject of heated debate with the answers frequently being dictated by economics.

From the standpoint of highway design, the automobile era logically falls into four fairly distinct periods: (1) 1900-1920: the preemptory period during which the motor vehicle usurped the wagon road in its contemporary state of improvement; (2) 1920 1930: the uplifting period during which existing roads were adapted to motor vehicular use, largely by shaping the cross section, draining and surfacing; (3) 1930-1940: the period of stabilization in the design of conventional highway during which the dynamics of motor vehicle traffic were recognized as a major force to be dealt with; and (4) 1940-1976: the era of the freeway.

It is significant that throughout the brief period of development of the modern highway system there has been a lag of a decade or more between the time of recognition of a new design principle, or a standardization of a dimensional value, or the advocacy of a concept, and the time that results of these advances in design begin to show in completed highways. For example, a discovery or determination in 1910 that highway curves should be superelevated to offset centrifugal force found little application until after 1920 when the extensive program of surfacing high ways came into full swing.

The categorization of the four design periods reflects the period of application of design principles, rather than the period of their discovery. Each of these periods is discussed in terms of the design characteristics in vogue at the time and of the factors that influenced these characteristics.

\section{Twilight of the Wagon Road: 1900-1920}

The automobile came on the scene at a time when roadbuilding was undergoing a renaissance after 50 years of neglect. The better rural roads of the mid19 th century were waterbound macadam, 12 to 15 feet wide - a width that was adequate for two loaded wagons to pass each other with the horses at a walk. To. shed water quickly, these roads were crowned on both the straight sections and the curves, and the crown, 6 to 8 inches higher in the center, was steep enough to make driving at the sides uncomfortable. Consequently all traffic ran in the middle, taking to the righthand side of the road only to pass other vehicles.

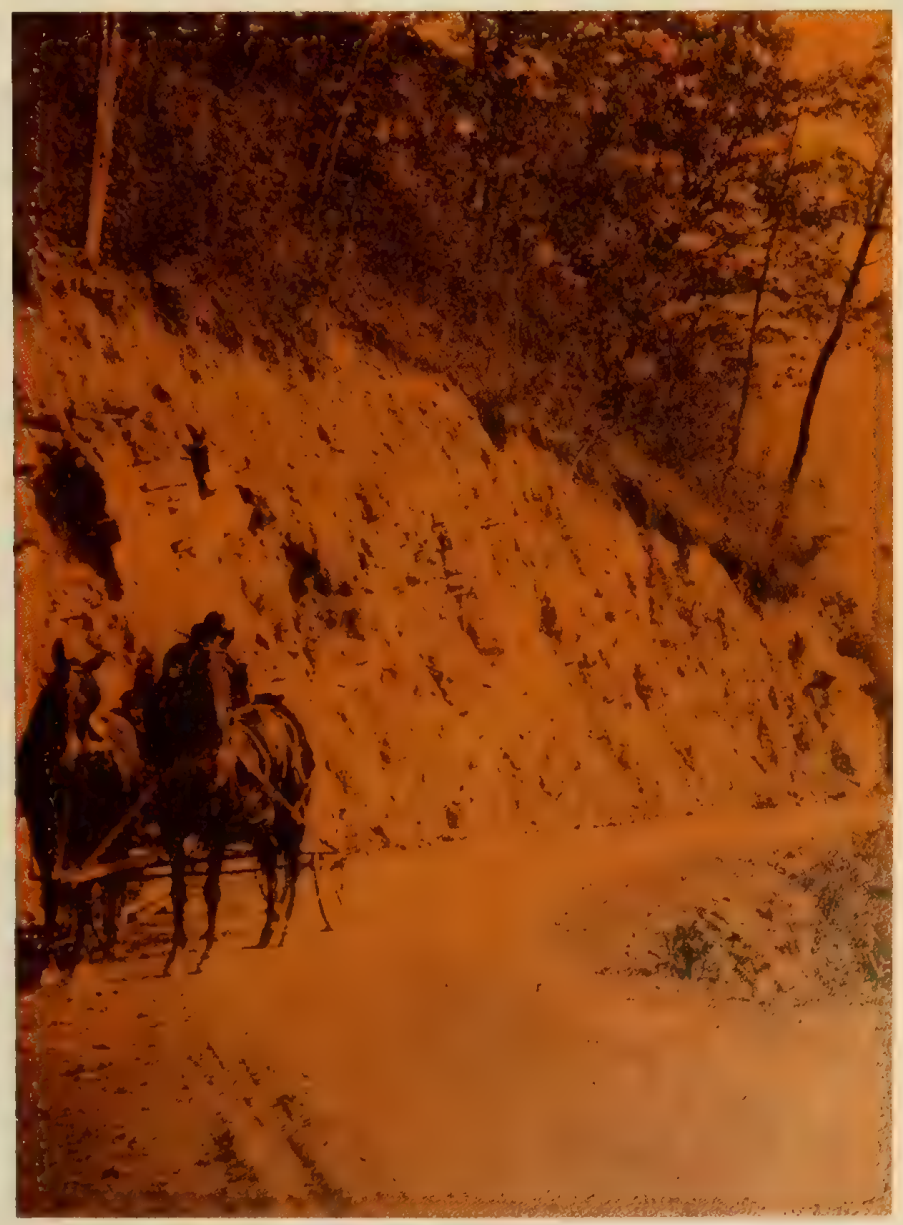

In 1913, even mountain roads such as this earth road in Wise County, Va., had relatively flat grades to accommodate horsedrawn vehicles. 
Wagon roads outside of cities were usually unsurfaced except for the more heavily traveled trunk routes. Highways carrying heavy tonnages of freight were surfaced with broken stone, gravel, or waterbound macadam. The National Road, for example, which was constructed westward from Cumberland, Maryland, in the early years of the 19th century, had a 20-foot surface consisting of a 12 -inch bottom course and a 6-inch top course of broken stone. This was far superior to the typical highway of that period.

In addition to macadam, broken stone, and gravel, other road surface materials used with varying success were brick, asphalt, wooden planks, sand-clay and granite blocks.

The basic principles for constructing all forms of surfaces as they are known today had been discovered and put into limited practice before 1910. Except for streets in the larger metropolitan areas and major routes of commerce, most road surfaces were in a rather primitive state of improvement at that time and were to remain so for several years to come.

These roads were built for horsedrawn steel-tired traffic traveling at a top speed of 8 miles per hour. In recognition of the limited capability of animaldrawn conveyances to ascend grades, gradients seldom exceeded 5 percent, and this resulted in rather crooked locations carefully selected to avoid steep grades, closely fitted to the terrain, with small cuts and fills to save grading costs. Side slopes in both cuts and fills were as steep as the natural materials would allow, usually $11 / 2$ feet horizontal to 1 foot vertical.

In the era of animal power, 105 feet was a generous radius for horizontal curves. This would enable a four-horse team and wagon having a total length of 50 feet to round a curve without leaving a 12 -foot travelled way. For two-horse rigs with wider roads, the radius could be even shorter. Vertical curves were seldom used; the vertical angle between two 5 percent grades was only about 6 degrees, and this was hardly enough of a peak or valley to cause discomfort to anyone in a vehicle traveling at 4 or 5 miles per hour.

The wagon roads were inconspicuous and, from economic necessity, "rested lightly on the land." However, it is doubtful that their builders considered this fact as an esthetic advantage for their work or, for that matter, that they gave much thought to the appearance of the road itself. In a few eastern States, notably Massachusetts and Maryland, trees were planted along the roads, but these had a practical purpose in addition to creating visual beauty. Their shade reduced the dusting and disintegration which followed when waterbound macadam surfaces dried too rapidly.

\section{Early Location Methods}

The railroads pioneered good location methods in the early 20th century. Under the spur of competition among themselves and being relatively unhampered by manmade obstacles, the railroads began to seek locations with flatter gradients than previously accepted in the interest of greater loads and less fuel consumption. For such exacting requirements, the old method of location by which the locator went into the field, selected the route by direct observation, and set the stakes as he went along was no longer adequate in any but the most level country. The locator could be aware of only what was in the range of his vision; a better location might lie over the next hill, but he could not see it. A method had to be devised that would permit the locator to examine a wider and longer sweep of country, and to meet this need, a new method of location evolved. This is called the "topographic method" to distinguish it from the old "direct method."

Instead of staking the centerline directly on the ground, the locator surveyed a preliminary line, or "baseline," as a base for a strip topographic map. After completing 4 or 5 miles of topography, the locator spread his maps on a long table, and he looked down upon them as if he were an observer in a balloon. Instead of seeing only a hill in front of him he saw the country in a miniature far ahead. His vision was not obstructed by trees, and he was not annoyed by insects or the weather. $\mathrm{He}$ easily perceived the vital features, or "controls," which determined the best location for the centerline that would conform with the railroad's geometric standards.

By scaling the horizontal distances between points where his projected centerline intersected the contours of the map, the locator obtained a profile which he could analyze for gradients and earthwork balance. If this profile was unsatisfactory, he could draw another paper projection, scale a new profile, and make a new analysis. Only when he was satisfied that he had the best location did he transfer the paper projection to the ground as his final staked location for the centerline of the railroad.

It was to be many years before the art of highway location and design was to attain such a high degree of sophistication. Until about 1930, the railroad method of alinement and profile was generally considered the ultimate in design for highways as well.

\section{The Impact of the Automobile on the Early Roads}

Prior to and during the first decade of the 20th century, the automobile had a negligible effect on the design and construction of highways. It was looked upon as an interloper which had to adapt itself to existing streets and highways. If adjustment was necessary, it was encumbent upon the vehicle manufacturer and the operator to make such adjustment. It was considered no more inconvenient for a motorist on a rural highway to slow to 6 or 8 miles per hour for a right-angled curve than for him to do so at an urban street intersection. If climatic conditions were unfavorable for motoring, the traveler merely substituted the horse for the auto. In northern latitudes, roads were so frequently impassable for automobiles during the winter months that cars were customarily placed on jacks in the late autumn and remained there until after the spring thaws in order to preserve the tires.

Despite enactment of the 1916 Federal Aid Road Act, the harsh impact of the automobile on the highway system was felt very strongly in the second decade of the century, and this was particularly true of the roadway surface. The automobile was extremely damaging to macadam and gravel roads, which essentially were held together by the interlocking of stone 


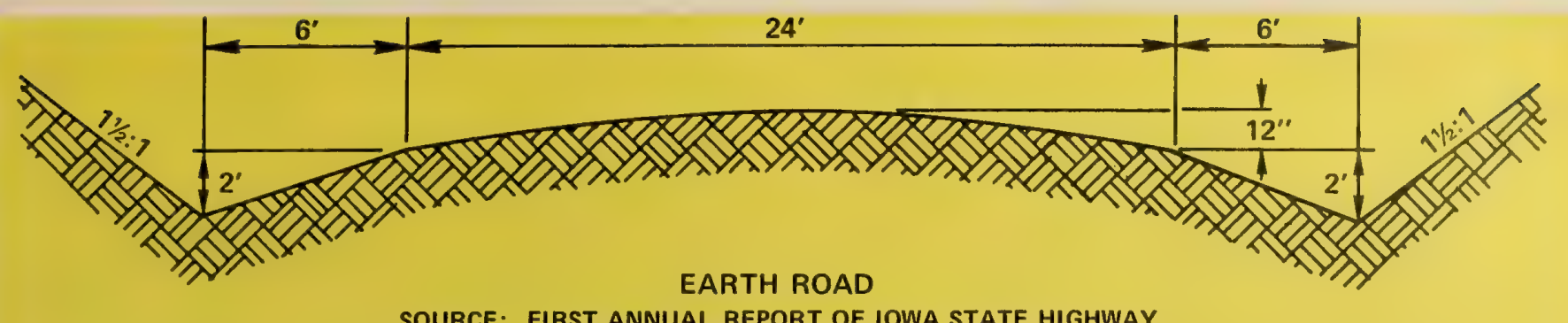

SOURCE: FIRST ANNUAL REPORT OF IOWA STATE HIGHWAY COMMISSION 1913-1914

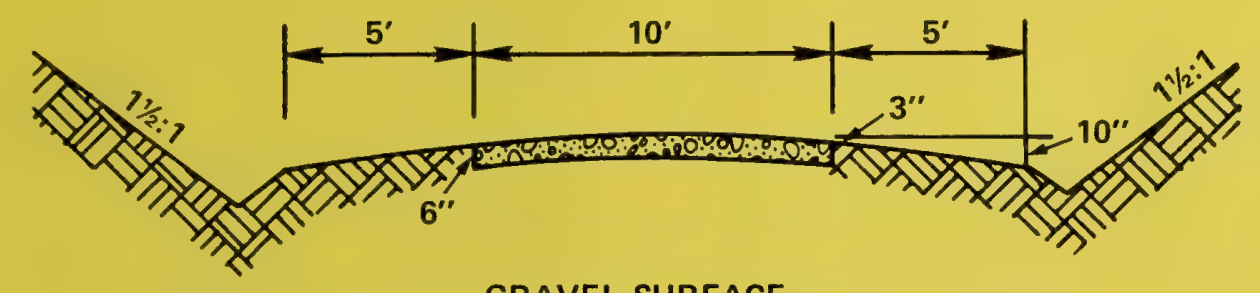

GRAVEL SURFACE

SOURCE: SECOND BIENNIAL REPORT ARKANSAS STATE HIGHWAY COMMISSION 1916

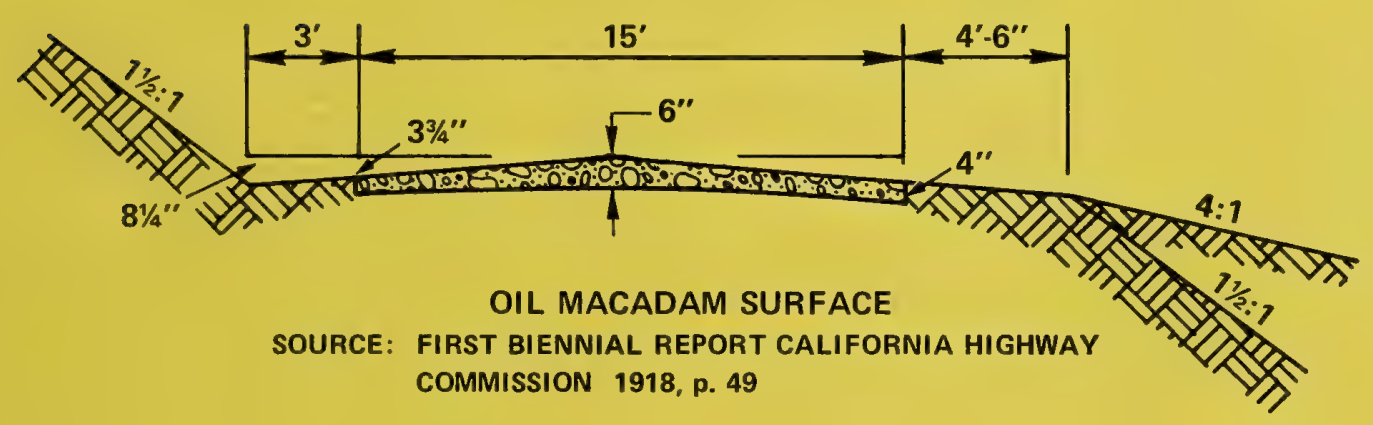

TYPICAL SECTIONS 1900-1920

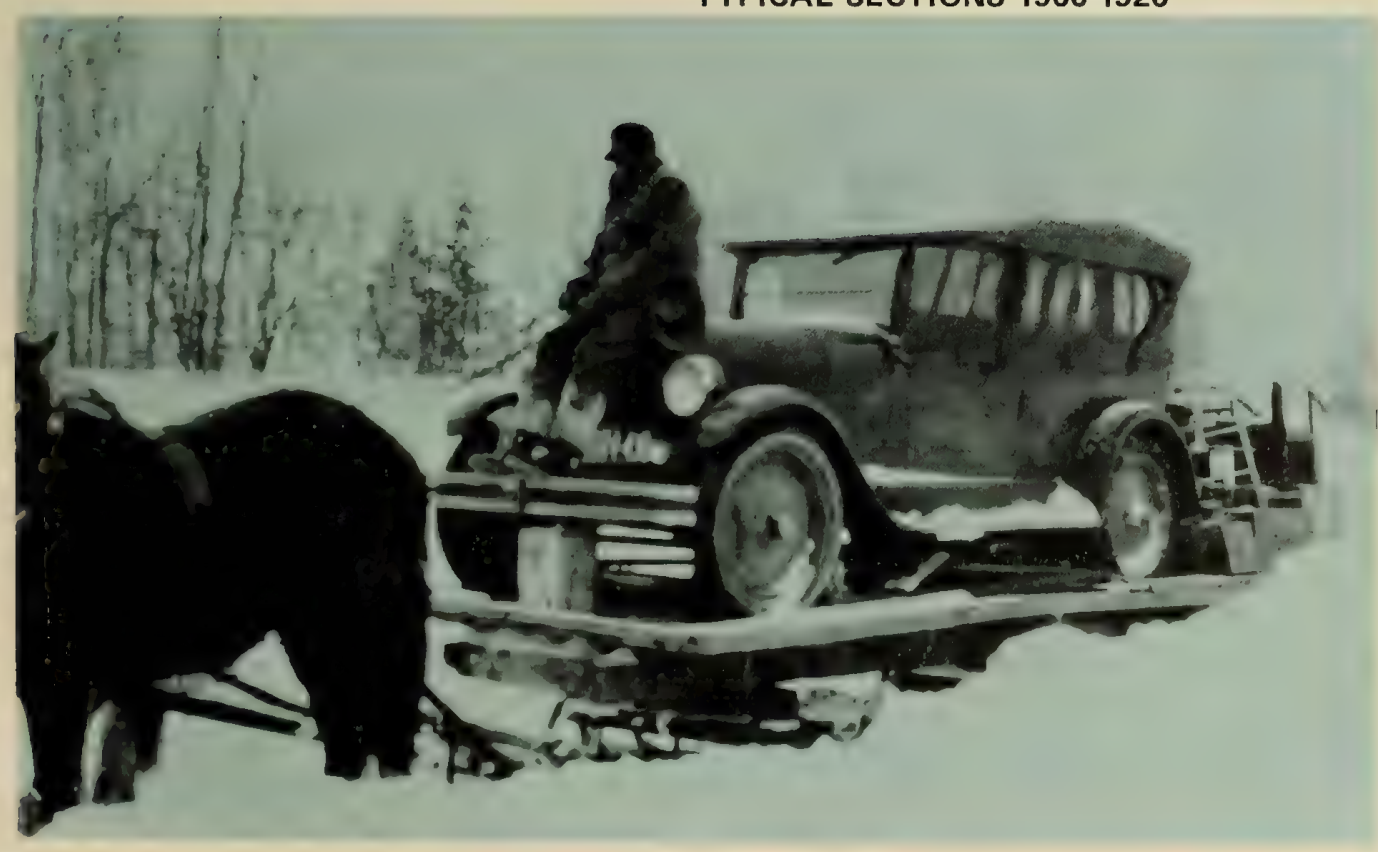

When roads became impassable, some motorists fell back on the services of more

traditional transportation. 
fragments and the cementing power of stone dust and clay. The tread patterns of pneumatic tires tended to suck the finer particles to the surface where they were caught in the turbulent air currents created by the car's rapid movement. The result was a huge cloud of dust, stifling to the motorist and abhorrent to the property owner, but even worse was the devastating effect on the road surface. Waterbound macadam was soon reduced to a residual layer of loose coarse material filled with potholes. On roads of native clay, the surface became a dust layer 2 inches or more in depth during the dry season and as fine as powdered talc. A sudden shower would turn such a layer of dust into a thin blanket of mud as slippery as wet ice; a prolonged rain would convert it to a bottomless quagmire.

Another unexpected effect was greatly increased wear on the inside of curves and the loosening and shifting of surfacing materials from the inner to the outer side of the roadway on curves. Rather than slowing to a speed commensurate with the radius of the curve, drivers instinctively hugged the inside of the curve, even to the extent of encroaching upon the ditch slope, in order to lengthen the effective radius and to take advantage of the "banking" afforded by the ditch slope.

In the case of curves to the left, this meant crossing into the opposing lane, since the normal, high crown was customarily carried around curves. As a consequence of resistance to lateral acceleration, loose surfacing materials were thrown to the outer side of the curves, resulting in a curve of longer radius that became somewhat superelevated by traffic, rather than by design and construction.

The impact of the automobile on the early roads was not all on the negative side. In the case of gradient, for example, automobiles and trucks were capable of ascending any grade suitable for horsedrawn traffic. If the surface provided sufficient traction, grades up to 6 or 8 percent posed no serious problem for skilled operators who had mastered the art of down-shifting to a lower gear. One feature of vehicular design that was the cause of considerable consternation to many. drivers ascending hills was the location of the gas tank with respect to the carburetor. Many vehicles, including the most popular make of the era, relied upon gravity flow of fuel from a tank beneath the driver's seat to the engine's carburetor located only 2 or 3 inches lower than the bottom of the tank. It was not uncommon to stall on a grade for lack of gas, even with a tank partly filled. There is no evidence that these experiences altered the design of highways, however.

By the year 1920, many State highway departments were recognizing the inadequacies of the design features of wagon roads, but aside from a very limited mileage of added pavement during the period 19001920, advances in design 'were very limited. It is questionable whether rural roads in many of the States up to this time were actually designed. Rather, they came into being through the gradual improvement of trails, and their shape and dimensions depended more on the skill and judgment of a maintenance man riding a split log drag than upon a professional design engineer guided by a set of design standards.

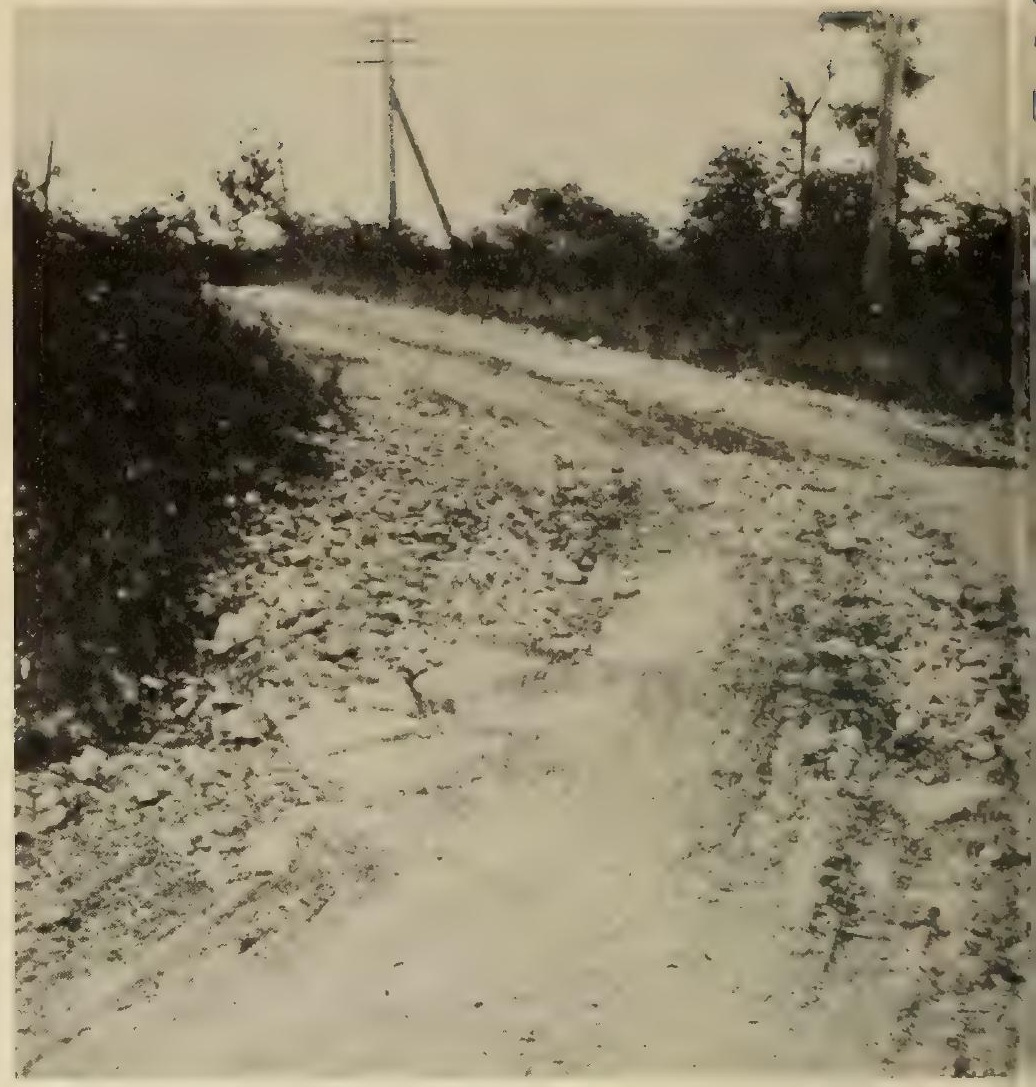

By the early 1900's the National Road, a superior highway for its time, needed improvement. This is a section of the road near Hancock, Md., before construction.

In a report prepared by the highway commissioner of one of the States in 1915, county officials were advised:

Many of the counties ... have the remains of roads... built during the early part of the nineteenth century ... The old roads of this age still stand as monuments to the ability and farsightedness of our forefathers ... The roads of that day were arteries of commerce. Later they gave way to the railroads and roadbuilding became a forgotten and lost science. Any man who could nap rock was a roadbuilder.

With the coming of the automobile and the motor truck the road is again the artery of commerce. Interest has been revived. We are beginning to appreciate the State highways and turnpikes built nearly one hundred years ago. We find them hard to improve on, even with present day methods. We can build a better surface, but we can't build a better subgrade. . .

- a road once built is rarely changed, provided it is built according to certain laws which are as old as the hills themselves. So insist that your road be properly drained, well located, taking advantage of every topographic condition. No grade should exceed a rise of $5^{\prime}$ in $100^{\prime}$, and lastly that you keep and take sufficient right of way to allow for ditches and any increase in width your road may require in the years to come ... The right of way, roadbed and drainage openings are permanent. The surface, regardless of what it is, will sooner or later have to be replaced. ${ }^{1}$

At about the same time, a neighboring State reported that 90 percent of the roads within its boundaries were earth roads and added, prophetically, that they were likely to remain earth roads for a great many years. ${ }^{2}$ In 1933,18 years later, less than 14 percent of the total road mileage in that State was reported as surfaced. ${ }^{3}$ Despite the fact that over 13,000 miles had been paved in the interim, there had been little gain percentagewise because of expansion in the highway network. 


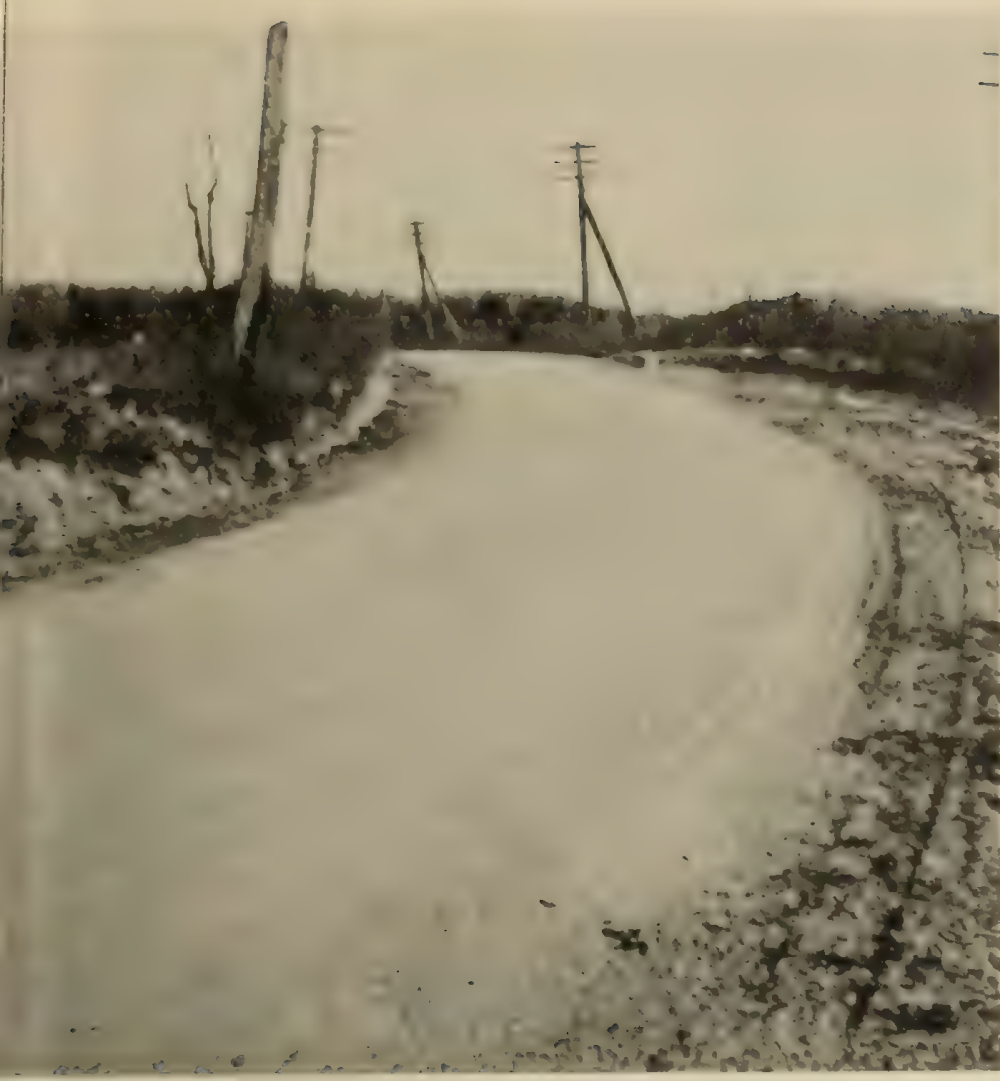

The same section of road after construction.

Nationwide, the mileage of high type pavements on rural highways in 1920 was negligible in relation to the total miles of highway, although substantial gains had been made in gravel surfacing up to that time. Regretably, however, much of the rural pavement in place at the beginning of World War I was destroyed by heavy trucking in pursuance of the war effort.

\section{Dawn of the Motor Highway: 1920-1930}

The period 1920-1930 may be characterized as a period of trial and error in adapting an assortment of roads laid out for use by horses and wagons to the use of automobiles and trucks. While the highway system continued to expand during this period, particularly in the agricultural belt of the Plains States, the nature of the added highways was generally the same as the earlier wagon roads with perhaps the addition of an all-weather surface, frequently gravel or sand-clay. Except for roads in the New England and North Atlantic States and in portions of the Pacific States. few rural roads in 1920 were surfaced with anything better than sand-clay or gravel. If one were careful in selecting his route, he could travel from New York City to Washington, D.C., on paved highways. From Washington to Richmond, however, the best route was one-third longer than the most direct one and included 99 miles of gravel surface rather than a paved surface. From Chicago to Milwaukee, according to a prominent guidebook of the day, the entire 92 miles was paved with concrete or macadam "except for one very rough mile." Going south from Chicago, the route to Lafayette, Indiana, consisted of 98 miles of gravel, 26 miles of macadam, and 16 miles of dirt. The entire 102-mile route from Atlanta to Macon, Georgia, consisted of sand-clay roads." With these segments of interstate highways in the conditions described, it requires little imagination to visualize the condition of the lesser important routes. Clearly, the most pressing need was for allweather surfacing, and this was the course that the roadbuilding program followed.

\section{Geometric Design Feafures}

While most highway authorities were conscious of a need to modify the highway cross section and alinement to meet the requirements of motorized traffic, there was little precedent upon which to base judgments of immediate design requirements, or worse, for predicting those of the future. Highway engineers had much in common with one self-made automotive engineer of this period who has been quoted to the effect that, "If its in a book its out of date." 5 *

Elements recognized as warranting special consideration because of higher vehicular speed included sight distance, curvature, and superelevation. Variables taken into account because of the volume and character of traffic were pavement width and structural needs. The manner of satisfying these requirements varied not only between States, but within States. Minnesota, for example, found that, "Abrupt narrow curves have contributed their share to fatal accidents . . . which it is expected will be relieved by... [a] requirement for a clear sight distance of 200 feet on all State roads with widening and banking on curves." 6 In 1921 it was the practice in Illinois, as another example, to eliminate right-angled turns "whenever possible," and where such turns were necessary, a minimum radius of 500 feet was used. Moreover, "All curves which have a radius of less than 6,000 feet are super-elevated . . " " The speed upon which the superelevation was based was the legal speed limit which, in 1921, was 25 m.p.h. This was increased to 35 m.p.h. in 1928, with a maximum superelevation of 1 inch per foot for curves with radii of less than 1,000 feet. $^{8}$ The State of California, among others, had earlier considered the matter of superelevation and, in 1917, had reached a compromise decision to apply superelevation to concrete pavements on mountain roads only. The rate of superelevation to be applied varied from a maximum of $3 / 4$ inch per foot for curves having a radius of 75 feet or less to $1 / 8$ inch per foot for radii within the range of 225 to 300 feet. $^{9}$ A few States used spiral transitions, but the practice was not widespread. Obviously, most decisions in the matter of roadway geometry were arbitrarily made and had little scientific support.

Perhaps the element that varied most widely was the width of surfacing. In Kentucky, for example, during the years just before and after 1920, contracts were awarded for pavements ranging from 9 to 20 feet in width, with 14 feet predominating. ${ }^{10}$ Most bridges had either 12- or 16-foot roadways. In Illinois during the same period, concrete and brick pavements were 10,15 , and 18 feet wide. ${ }^{11}$ It was common practice at about this time to construct pavements with sufficient width to accommodate only a single lane of traffic. There was some disagreement as to whether the best position for such a pavement was in the center of the roadbed or at the right-hand side

* The engineer was Childe Harold Wills, at the time an employee of the Ford Motor Company and later producer of the Wills St. Claire Automobile. 
going to the market center. One critic claimed that the center was the most desirable position because it was better looking, was more easily drained, and was safer to traffic. ${ }^{12}$

The dilemma as to the most suitable position for single-lane pavements was soon resolved - the rate of traffic growth was so rapid that single-lane pavements were short lived and such construction was uneconomical. Consequently, this type construction was discontinued. The Federal Highway Act of 1921 doubtless spurred this action. This legislation required, for the first time, that the wearing surfaces on Federal-aid highways be at least 18 feet wide.

With the discontinuance of single-lane construction, practically all subsequent paving between 1920 and 1930 was of two-lane width, ranging from 14 to 20 feet. Pavements wider than two lanes were rarely needed. The experience in Maryland may be typical. In 1920 the concrete roads were constructed 15 feet wide, 6 inches in depth at the edges and 8 inches in depth at the center, resulting in a crown of 2 inches. This same type construction was used in 1921. In
1922 the Commission thought it desirable to reduce the crown and adopted a section $61 / 2$ inches in depth at the edges and $71 / 2$ inches in the center. This construction method was used in 1922 and 1923. At that time, however, concrete was finished by hand, and some difficulty was experienced in getting a smooth road with only a 1-inch crown. In 1924 the Commission went back to building a 2 -inch crown, still using a 15-foot width, 6 inches in depth at the edges and 8 inches at the center. This type construction continued to the end of 1927 . In 1928 the thickened edge was adopted, and the standard width of roadway was increased to 16 feet with a depth of 9 inches at the edges and 6.3 inches at the center and was the method still used in $1930 .^{13}$

In contrast, Illinois during this period was building concrete pavements 18 feet wide (in some cases 20 feet) on a roadway 30 feet wide. In 1926 Illinois constructed its first four-lane highway. ${ }^{14}$ Lanes 10 feet or more in width were rare anywhere in the country.

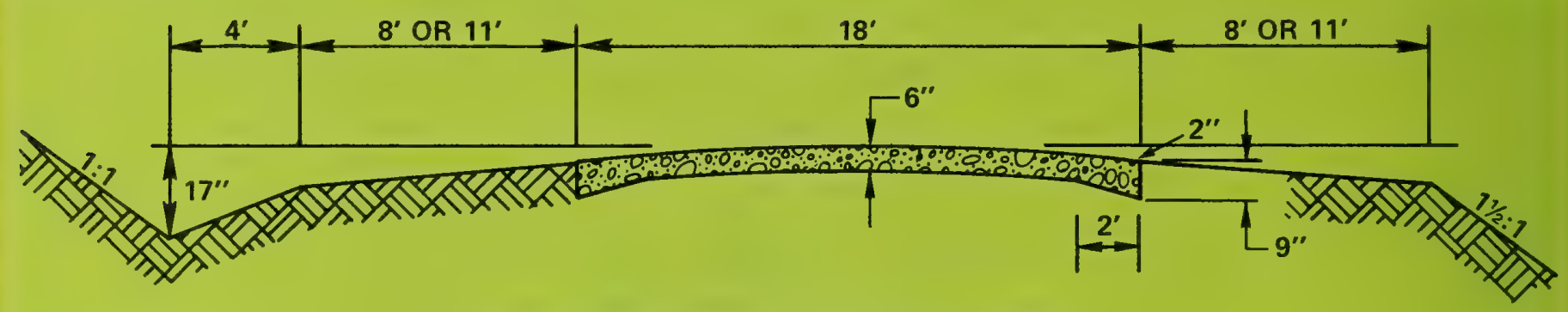

PORTLAND CEMENT CONCRETE PAVEMENT

SOURCE: ANNUAL REPORT ILLINOIS DIVISION OF HIGHWAYS 1927

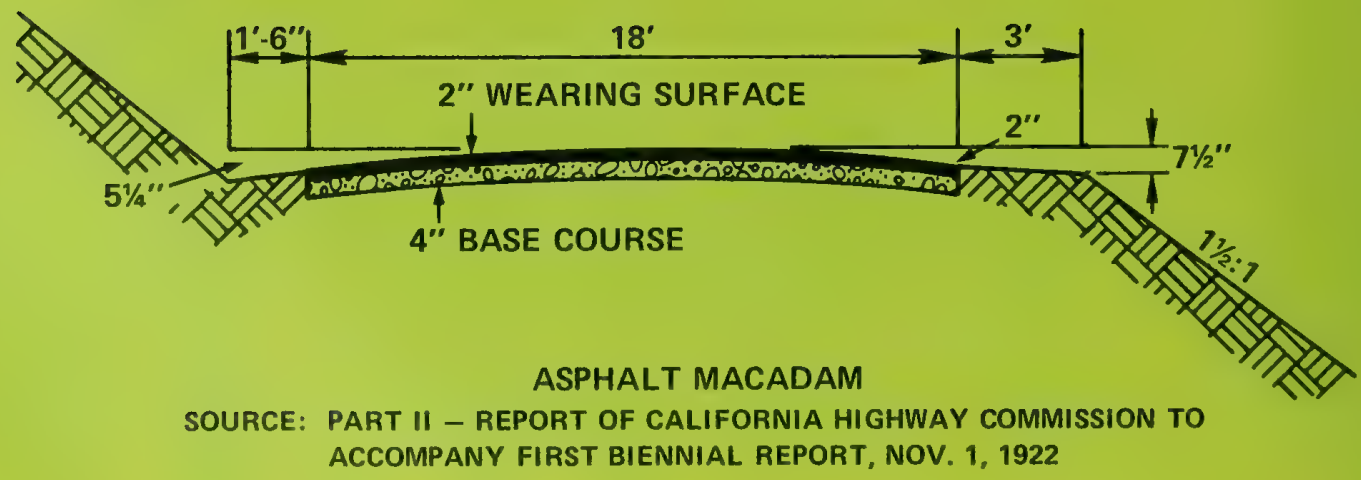

TYPICAL SECTIONS 1920-1930 


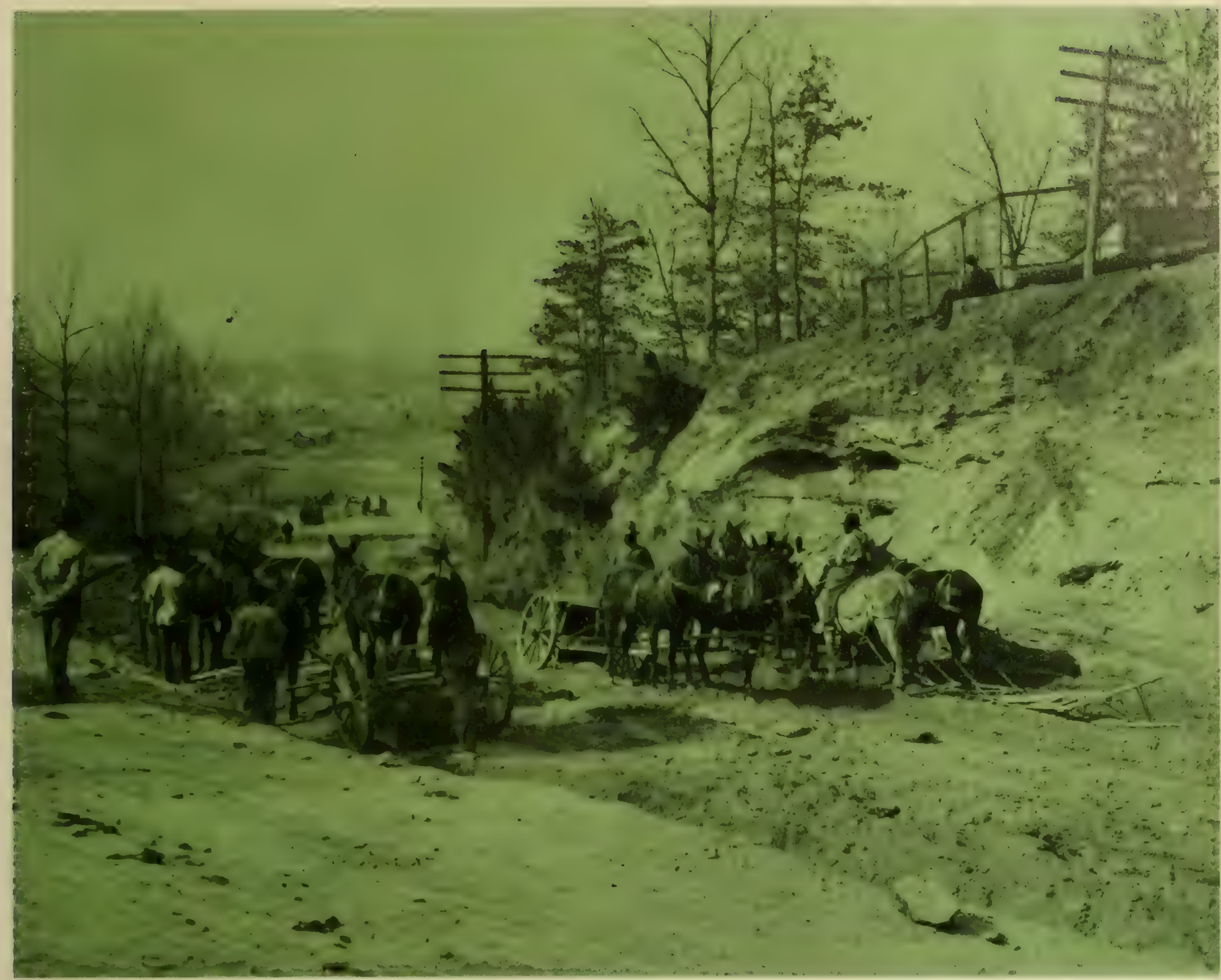

Horsedrawn equipment making a cut and raising levee across Souwashy Creek Bottom near Meridian, Miss.

Except where the terrain was flat, the rolling profile and widening alinement of the wagon road era continued. Although location and design engineers recognized the desirability of gentle curvature and uniform grades, much of the design was dictated by economics and the limitations of grading equipment. Grading was performed largely with animal-drawn equipment; hence heavy cuts and fills and direct alinement were avoided in favor of sidehill locations. Power shovels were in common use for rock excavation and sidehill casting, but the narrow cuts and fills of the period were too confining for efficient use of motorized hauling units, which were also poorly adapted to operating on newly placed embankments. For the year 1920, Minnesota reported that equipment actually engaged in highway construction included 2,693 scrapers (wheel, slip, or Fresno), 36 steam shovels and 6,212 horses and mules, together with 466 motor trucks recently acquired as war surplus materials. ${ }^{15}$ In Illinois in 1924, a recordbreaking year for construction in that State, 11,700 men and 3,000 teams were employed, a "team" consisting of two or more animals. The day of mechanization was still in the future.
Roadbuilders then, as always, were realists. They were in a race with time to pave as many miles as possible with available funds. Office seekers made extravagant promises for getting the voters out of the mud. The report of one highway department in 1924 boasts that of the 4,671 miles of hard surfaced roads then existent in the State, 75 percent were completed during the 4-year tenure of the encumbent governor. ${ }^{16}$ One result of this frenzied effort to add miles of pavement was that many design features, later found to be hazardous, were incorporated into the highway system before a background of experience could be developed.

Every section of newly paved highway seemed to have its "deadman's curve." Vehicular brakes were generally poor, as was lighting equipment. Many trucks using the highways in the late twenties were still equipped with acetylene or kerosene lamps, and their speeds were limited by mechanical engine governors to 15 to 18 m.p.h. A good number of horsedrawn vehicles continued to use the public highways. Passenger car speeds increased rapidly in keeping with highway and automotive improvements. In 1920 most States had a 25 m.p.h. speed limit for rural highways. By 1930 the speed limit most frequently 


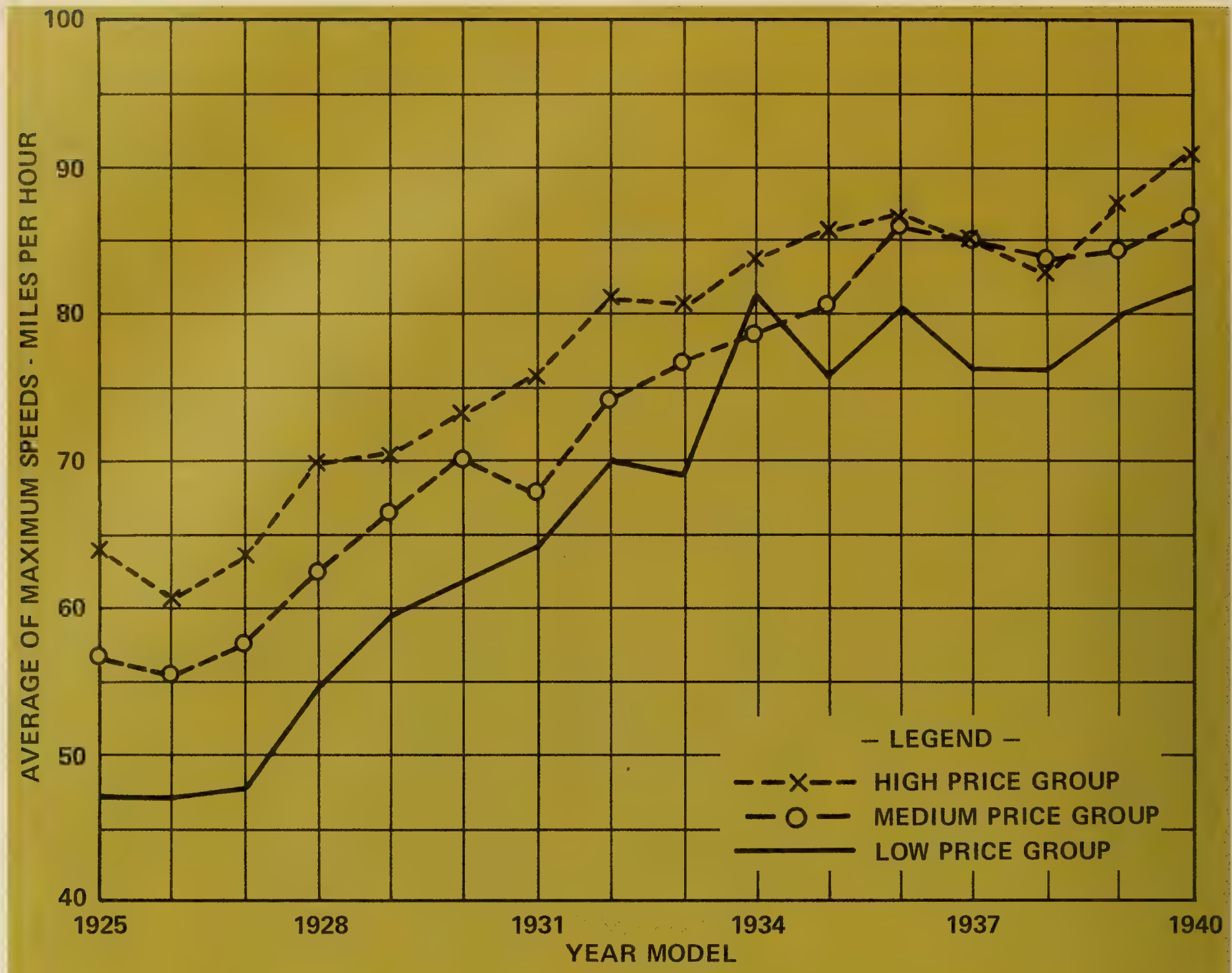

\section{AVERAGE TOP SPEEDS OF AMERICAN STOCK CARS IN HIGH, MEDIUM AND LOW PRICE RANGES BY YEAR MODELS.}

\section{SOURCE: "HIGHWAY PRACTICE IN THE USA", BUREAU OF PUBLIC ROADS, 1948, p. 65}

encountered was 35 , with a few States having limits of 40 or 45 m.p.h. No highway, regardless of how designed, could be properly fitted to the needs of such a conglomeration of vehicles and regulations. Not surprisingly, deaths and injuries soared.

There were also signs of pessimism in some quarters as to the ability to cope with the unbridled growth in motor vehicle usage through highway construction alone. Taking note of the heavy weekend demands being placed on improved highways, one State highway commission noted in 1926 :

It seems quite clear to the commission that the regulation of traffic is the first step toward adequate use of the highways. Indeed, the number of vehicles placed upon the highways each year is proportionately greater than the miles of highway which are added. The conditions of traveling, instead of becoming better, are becoming worse, due to congestion on these roads, and the entire solution does not seem to lie in the building of more roads, but rather in the regulation of traffic that goes over them.

This philosophy was to find expression many times over in the years ahead. Traffic, however, continued to increase in volume.
Partly as a result of the wide disparity in design practices between the States, a new form of leadership in the art of highway design began to assert itself toward the end of this period. This was the Committee on Standards of the American Association of State Highway Officials (AASHO), which had been formed in 1914. Initially, AASHO's Committee on Standards confined itself to disseminating information on design to its members, but in 1928 it proposed that the Association adopt "standards of practice" to guide the member States in technical matters in which some uniformity from State to State was urgently needed. The resulting first standards, 1928, prescribed:

- That whenever practicable, shoulders shall have a standard width of not less than 8 feet.

- That on pavements, 10 feet shall be considered as the standard width for each traffic lane.

- That the crown of a two-lane concrete pavement shall be 1 inch.

- That no part of a concrete pavement shall have a thickness of less than 6 inches. ${ }^{18}$ 
The AASHO Committee on Standards and its offspring, the Committee on Planning and Design Policies, were destined to have a profound effect in stabilizing highway design by recognizing and advocating the best and most economical practices of the various highway departments and in promoting the results of research efforts that were soon to be undertaken.

\section{Advent of Aerial Surveying}

Another development of the decade, 1920-1930, was the initial use of aerial surveys in highway location. Mention has been made of the "topographic method" pioneered by the railroads for selecting the most suitable alinement from among a number of alternatives. Initially the topographic method did not meet with much favor among highway builders for several reasons: (1) Alinement and profile were not as critical for highways as for railroads; (2) the method was slower and more costly than the conventional or direct method; and (3) most highway projects consisted of improving an existing or established route, which might be either a trail, a well traveled artery, or something in between. The penalty for using the direct method was the production of an inferior, unsafe highway.
When aerial photography became available on a commercial scale, it offered a means of overcoming the greatest objection to the topographic method of location, namely, heavy expense in time and manpower in making field surveys and preparing maps. The highway profession was quick to recognize the potential of aerial survey methods. An example of its use described briefly in the 1927 Aircraft Yearbook:

The Bureau of Public Roads of the Department of Agriculture has used the airplane in making of mosaics to show the route of a proposed road and to ascertain over what territory the proposed road will travel. The Army Air Corps has provided the equipment and personnel, and the Bureau has provided the films and paid the cost of operation.

During the past year aerial survey has been made of a proposed new highway from Washington to Mt. Vernon, Va. The survey showed the old road as well as the territory over which the new road would have to be laid. Surveys have been made in Connecticut along the coast line, and again between Boston and New York in the vicinity of the Boston Post Road, in an endeavor to find a new automobile route to take care of the crowded travel on the old Boston Post Road. ${ }^{10}$

The article concluded that the saving in time and money on these and other projects was very satisfactory, and future use of this means of mapping and surveying was contemplated. This was a very conservative prediction.

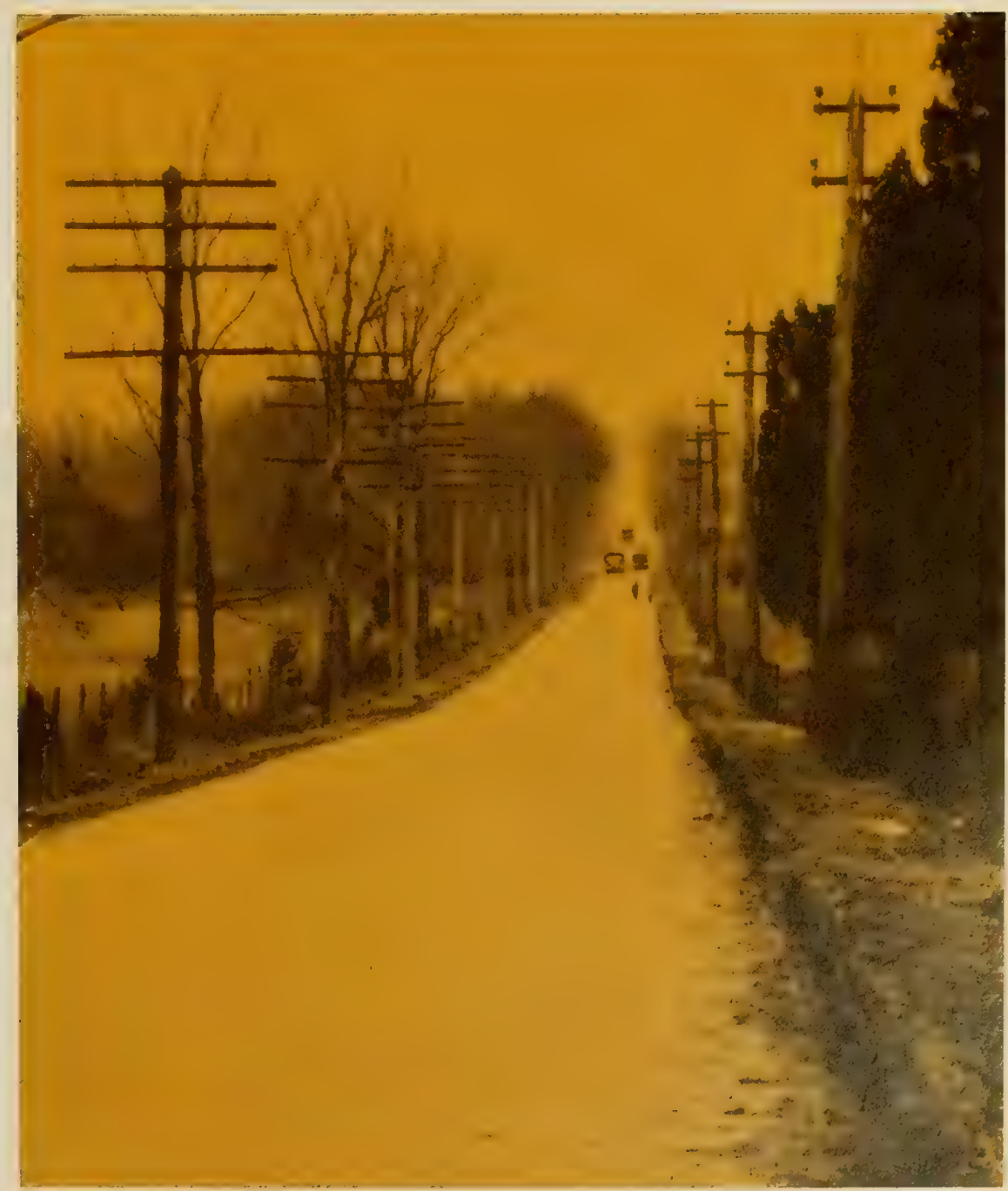




\section{Stabilization in Design Practices: 1930-1940}

The period 1930-1940 was one of discovery, as well as of stabilization. On the debit side, administrators were dismayed to discover that many highways paved during the previous decade, in the expectation they would last a lifetime, were already obsolete. There were several reasons for this-the alinement was not suited to current speeds, sight distances were too short, pavements and shoulders were too narrow, and traffic volume had simply outgrown the capacities of many two-lane roads. Moreover, the seemingly unlimited capacity of multilane roads near cities was being rapidly depleted as a result of uncontrolled access. Pavements were deteriorating because of the frequency of heavy axle loads. Trucks were seriously interfering with the free movement of passenger cars where there were long steep grades.

On the plus side, the most outstanding discovery, or more properly, achievement, was the recognition that most problems could be resolved through a coordinated research effort coupled with an organized program to exchange knowledge and information gained in the various States.

A coordinated research program was given a strong boost by the U.S. Congress in 1934 through passage of the Hayden-Cartwright Act. This Act authorized the use of up to $11 / 2$ percent of Federal-aid highway funds for planning and research.

Secondly, distilling the results of experience and research and promoting the best in design practices commensurate with economic benefits found expression through the AASHO Committee on Planning and Design Policies.

\section{Design Policies}

In February 1937 a proposal was approved by AASHO to establish a special committee consisting of three key officials from the Bureau of Public Roads (BPR) and 12 outstanding design engineers from the States. This committee was named the Committee on Administrative Design Policies. It was subsequently renamed the Committee on Planning and Design Policies, and membership was increased to include 20 members from the States with BPR furnishing a single member, a nonvoting secretary. A unique feature of the committee working process was the provision of a small force of experts assigned by BPR to devote full time, if necessary, to the work of the Committee.

The Committee's mode of operation was to outline a general program of work, after which the BPR task force gathered and evaluated all the known information on each subject. If there were gaps in the existing knowledge, the BPR engineers identified them for further study. Eventually the staff prepared a tentative discussion, with indicated design controls, guide values and other conclusions for that subject. This was then criticized, evaluated, and supplemented by the Committee members and reworked until a policy acceptable to them was produced. The resulting policy was submitted through the Committee on Standards to the AASHO Executive Committee for ballot by the several States; with a two-thirds favorable vote, it became an approved policy, and also, in effect, the national design policy of the United States on that particular subject.
The Committee soon developed design policy brochures on seven projects: (1) Highway classifications; (2) sight distance; (3) marking and signing nopassing zones; (4) highway types; (5) intersections at grade; (6) rotary intersections; and (7) grade separations. These booklets have considerable historical significance since, together, they are the fundamental structure upon which all subsequent geometric design policy for highways has been based.

A Policy on Highway Classification, 1938-offered a method of classifying highways to indicate the service expected of them. Three factors were considered in the classification: (1) Traffic volume, (2) character of traffic, and (3) design speed.

"Traffic volume" represented the number of vehicles per hour and was defined as the average of the probable maximum hourly traffic of several peak days. Prior to this time, it had been common practice to consider traffic on a daily basis if, in fact, it was considered at all in geometric design. In later years, research was to permit a degree of refinement, and the 30th highest hourly volume of the design year became the criterion of traffic volume classification for design purposes.

"Character of traffic" was used to denote the relative number, or percentage, of trucks and buses in the traffic stream in order that allowance could be made for them in design and operation of highways. Three categories were utilized: "P" for traffic composed entirely of passenger cars or types of trucks which did not impede smooth traffic operation; " $T$ " for traffic in which the percentage of trucks likely to use the highway was such that movements of passenger cars would be interfered with and, consequently, should be given detailed considerations; and "M" for mixed traffic where the percentage of trucks was between that for "T" and "P." While the classification was necessarily vague, it did serve a useful purpose in recognizing that truck traffic was an essential factor that must be dealt with. This classification stood for many years and was discontinued only after a means was devised in 1950 for converting truck volumes into equivalent passenger car volumes.

The "assumed design speed" was used for correlating the design features of a length of highway that affect, or are affected by, the speed of operation. For this purpose, assumed design speed was chosen as being representative of the maximum approximately uniform speed that probably would be adopted by the faster group of drivers, exclusive of the reckless few, that would use the highway. Speed classifications of $30,40,50,60$ and 70 miles per hour were agreed upon, and guidance was offered as to conditions under which each might be appropriate.

Adoption of speed as a design criterion was in recognition of the fallacy of the previously held belief that drivers could be relied upon to detect sharp curvature and short sight distances sufficiently well to adjust their speed to conditions. The false assumption that drivers would reduce their speed to as low as 15 or 20 miles per hour at curves was a major cause for high accident rates and the early obsolescense of many highways paved prior to 1930. The design speed concept was truly a landmark innovation in highway engineering. ${ }^{20}$ 


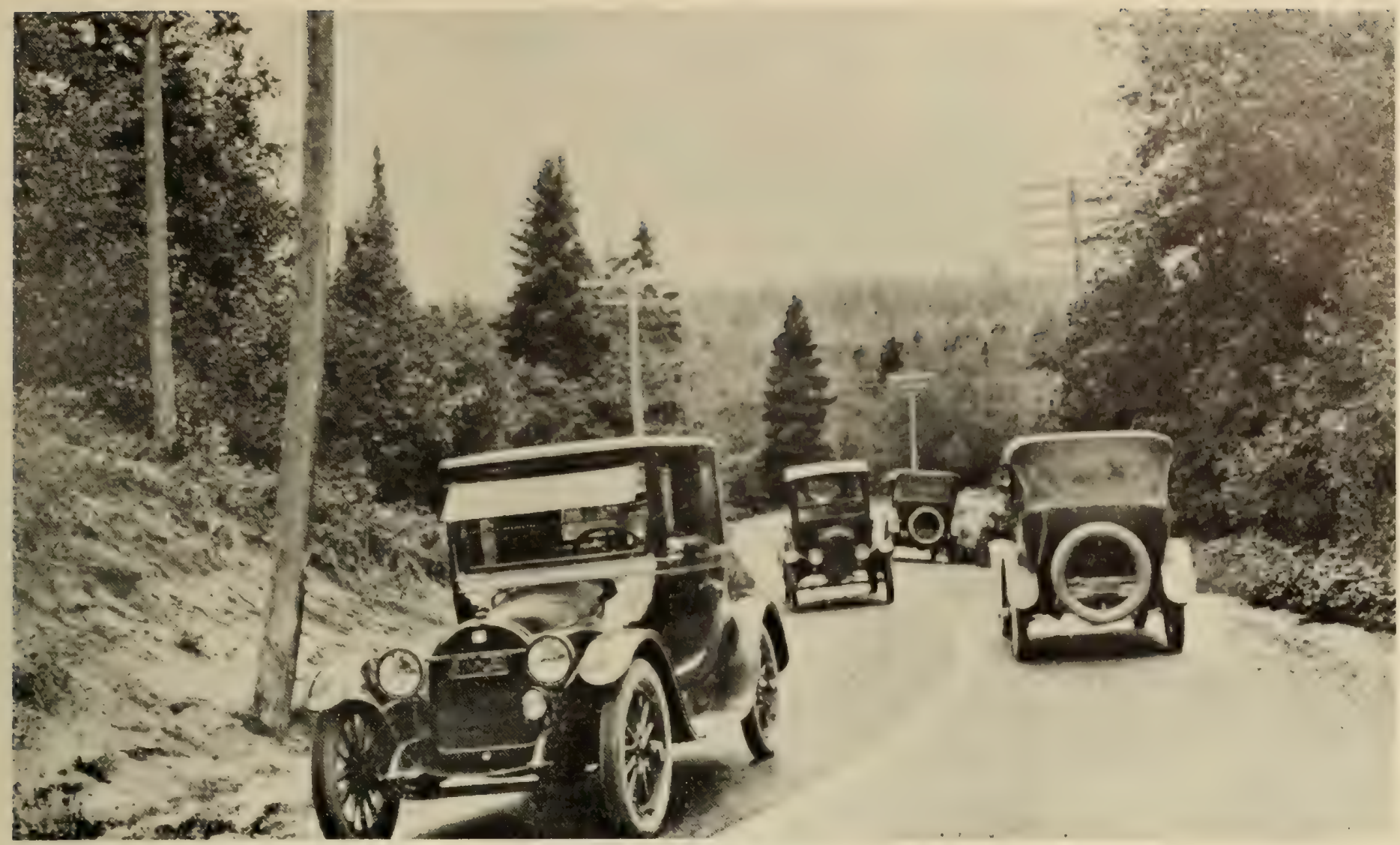

Center markings on curves aided motorists on this highway in 1921, but short sight distances made passing dangerous.

A Policy on Sight Distance for Highways, 1940 provided a scientific approach to answering the controversial question as to the length of sight distance that should be provided to assure safety at curves and crests and also for overtaking and passing slower vehicles on two- and three-lane highways.

In the absence of research results, which were to become available a few years later, certain assumptions were necessary in deriving the values. It is a credit to the Committee that the assumptions were remarkably accurate. In one of the first applications of the design speed concept, the derived minimum sight distance values for stopping ranged from 200 feet for an assumed design speed of 30 m.p.h. to 600 feet for a design speed of $70 \mathrm{~m}$.p.h. It was further postulated that this distance should be measured on a line from the driver's eye 4.5 feet above the surface to a hypothetical object 4 inches above the pavement. ${ }^{21}$ There was considerable conjecture as to the height of the object. Logic would dictate that visibility of the road surface itself would provide the ultimate in safety, but provision of the required sight distance to the road surface would necessitate extremely long vertical curves at hill crests and would, therefore, be very costly. A standing or slow moving vehicle would be the type of obstacle most likely to be encountered on a highway and a height of 2 feet, representative of the height of tail lights for a typical vehicle, was favored by some Committee members. Obstacles a foot or so in height, even though encountered only infrequently on highways, could result in serious accidents if struck by cars and, consequently, such minimum heights were rejected on the grounds of being unsafe. The 4-inch dimension finally agreed upon represented a compromise between economics of construction and severity of hazard. (Both dimensions, height of eye and height of object, were reevaluated in 1961 and, because of reduced height of vehicle, were changed to 3.75 feet for height of eye and 6 inches as a compromise value for height of object.)

Passing sight distances were derived by dividing the passing maneuvers into several component parts and developing time-space relationships for each. Desirable distances, as well as absolute minimums, were developed. For two-lane roads, the "desirable" values ranged from 600 feet for a design speed of 30 m.p.h. to 3,200 feet for a speed of 70 m.p.h. The sight line was from the driver's eye, assumed to be 4.5 feet above the road surface, to the top of an oncoming car, also assumed to be 4.5 feet in height. ${ }^{22}$ Both dimensions were changed to 3.75 feet in 1961 in recognition of changes in vehicle design.

The three-lane highway, like the single-lane highway of 20 years earlier, enjoyed a comparatively short period of popularity, and sight distances for such highways, as well as for two-lane highways, were discussed in this policy. Very few three-lane projects were constructed before 1930 or after 1940. It was soon learned that, while they did provide greater capacity than two-lane roads, the added increment was not great. With the rapid increase in traffic, they were soon taxed to capacity. Moreover, they did not lend themselves to conversion to multilane divided highways. Of greatest concern, however, was their poor accident experience. One reason for this 


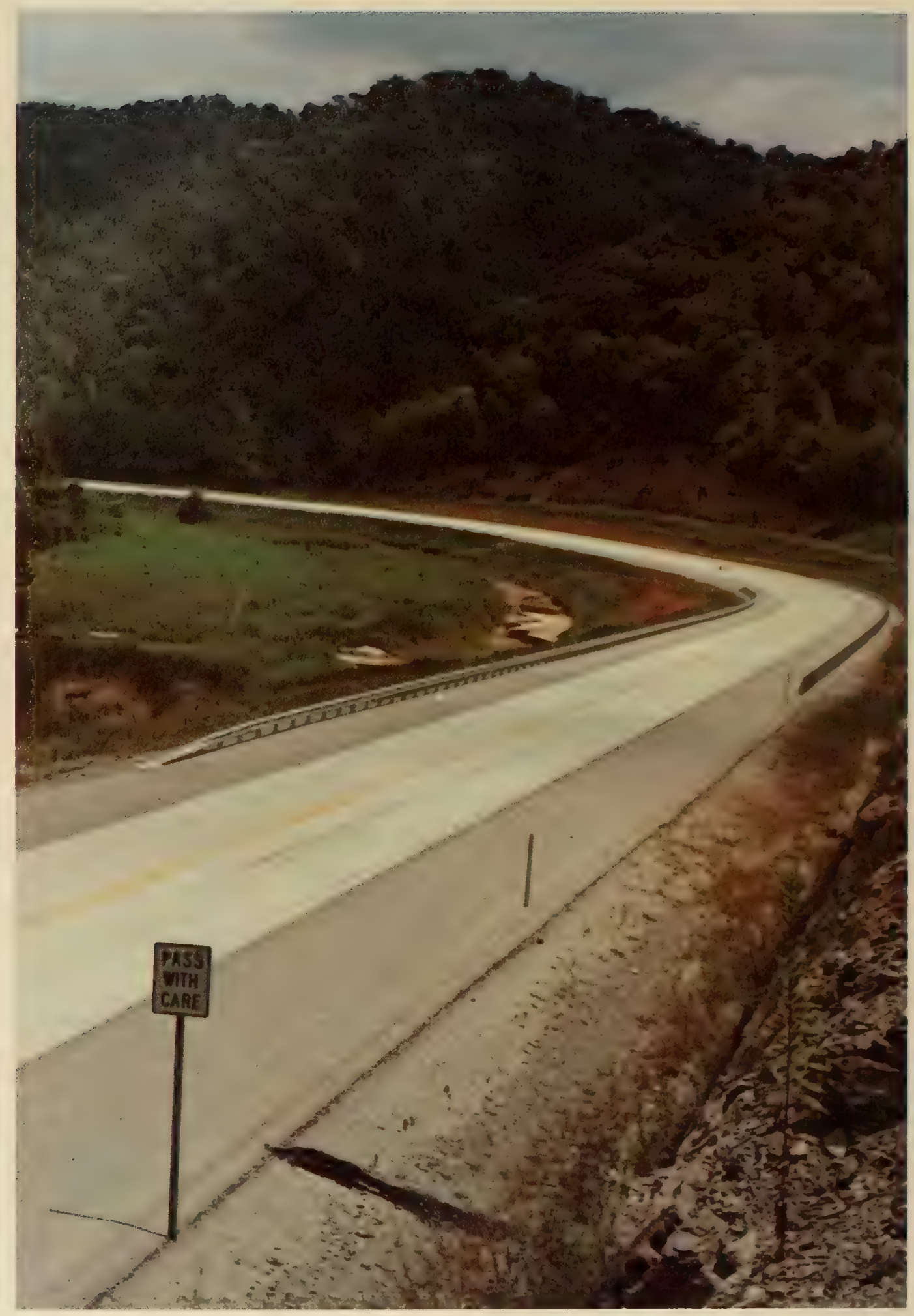

Kentucky's Daniel Boone Parkway exhibits modern design features such as sweeping curves with adequate sight distances and gentle grades.

was that sight distances were frequently too short for passing. The AASHO policy sought to overcome this deficiency in future construction by furnishing derived values for needed passing sight distances on three-lane roads. "Desirable minimum" values ranged from 900 feet for 50 m.p.h. to 1,700 feet for 70 m.p.h.

Another reason for the poor accident experience on three-lane roads was the lack of uniformity and the haphazard manner in which they were marked to regulate overtaking and passing during the early years of their use. A recognized need for improvement in this department led to development of the next of the several policies.
A Policy on Criteria for Marking and Signing NoPassing Zones on Two- and Three-Lane Roads, 1940advocated a uniform system of marking two- and three-lane roads to restrict passing where sight distances were less than certain values as listed for various design speeds. The types of stripes and signs for marking no-passing zones were the province of another AASHO committee, but the recommendations of that committee were included in the policy. Since this feature was more closely related to operation than design, this subject received no further attention by the Committee on Planning and Design Policies but, instead, was handled thereafter by the National Joint Committee on Uniform Traffic Control Devices. 
A Policy on Highway Types (Geometric), 1940-outlined the distinctions between the two-, three-, and four-lane highway types and divided highways. It dealt primarily with pavement widths and factors of driver behavior and highway design that affect width. The policy related the traffic volume, the character of traffic ("P," " $M$ " or "T"), and design speed to the minimum width of pavement that should be provided. For two-lane roads, the minimum width of surfacing varied from 16 feet for the lowest classification upward to 24 feet. (Single-lane roads were acceptable for volumes below five vehicles per hour.) Turning paths were developed for three design vehicles-a passenger car, a truck, and a tractor-semitrailer.

The Committee lamented the absence of better highway capacity information that would permit delineation between the traffic warrants for two-, three-, and four-lane pavements. Because of the intervention of World War II and for other reasons, such information would not become available for another 10 years, although the basic research was already well advanced.

The policy discussed median design for divided highways at considerable length, as well as curbs, sidewalks, guardrails and shoulders. Shoulders 8 to 10 feet wide, clear of all obstructions, were recommended. ${ }^{23}$
A Poticy on Intersections at Grade, 1940-treated the subject in great detail, utilizing turning paths for a design passenger car and a design truck. Design requirements were developed for various types of intersections from a simple crossing to the more elaborate types of channelized intersections with relatively high-speed turning roadways and speed change lanes. Innovations included three-centered compound curves for the pavement edge at turns, minimum radii for separate turning roadways as related to design speed, pavement widths for such roadways, and sight distance requirements at intersections not controlled by signals. Vehicle dimensions have changed since this policy was prepared, but in all other respects the concepts have stood the test of time with little need for modification.

A Policy on Rotary Intersections was not completed until 1941. During the period 1930-1940, rotary intersections were thought to be a considerable improvement over conventional intersections, so much so that they were often constructed as substitutes for gradeseparated interchanges. Events were to prove that, like the three-lane road, their effective life was usually rather short because of their limited capacity and the rapid rate of traffic growth.

The policy provided guidance in selecting various design dimensions such as radius of the central island, roadway widths, and lengths of weaving sections as related to design speed.

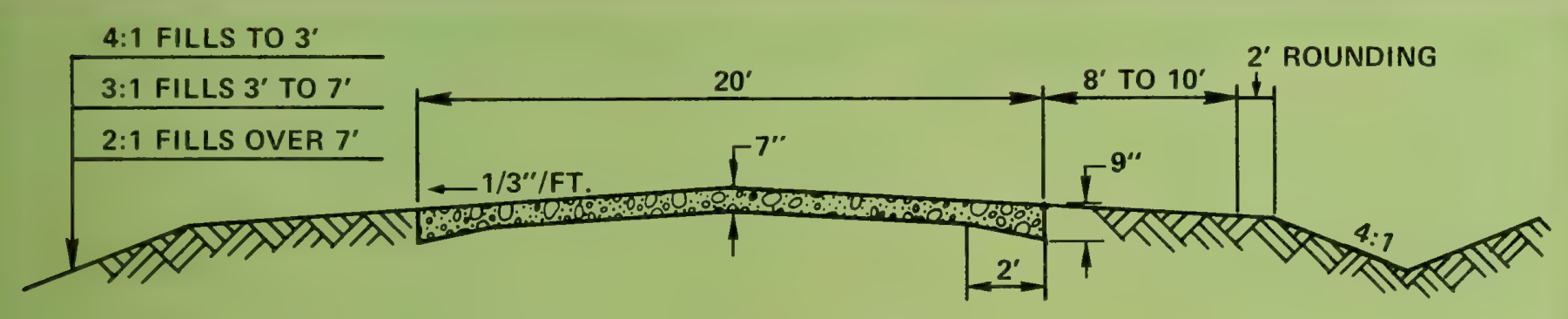

\author{
PORTLAND CEMENT CONCRETE PAVEMENT \\ SOURCE: TENTH BIENNIAL REPORT OF STATE HIGHWAY COMMISSION \\ OF MISSOURI 1936
}

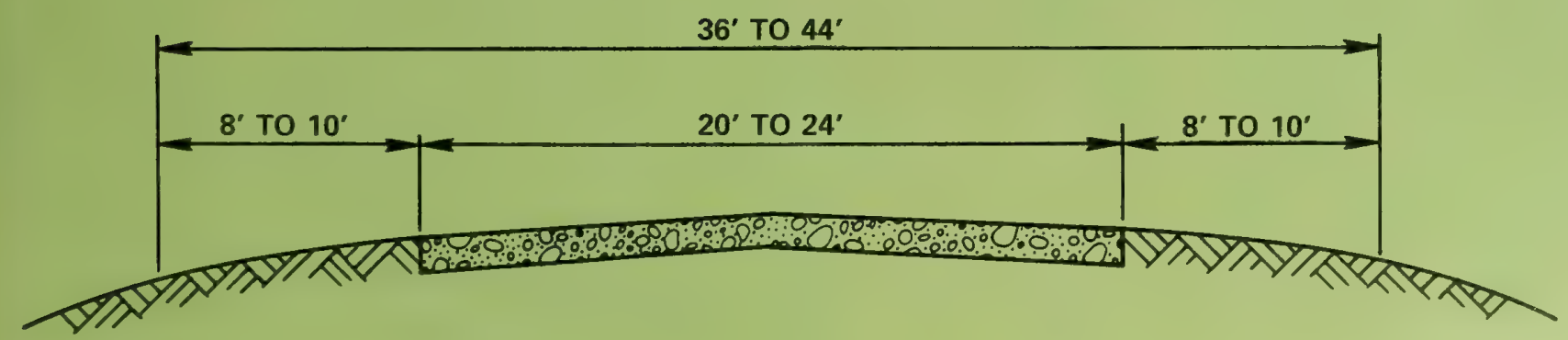

TYPICAL 2-LANE HIGHWAY (GEOMETRIC)

SOURCE: A POLICY ON HIGHWAY TYPES (GEOMETRIC), AASHO 1940 
A Policy on Grade Separations for Intersecting Highways was the logical sequel to the two policies on intersections. It was the final one of the seven geometric design policies, and it was completed in 1944.

The title of this policy is somewhat misleading because it treated not only the separating structure, but actually covered in great detail the design of grade separated traffic interchanges. Design data were grouped in three categories: (1) Structures and approaches, (2) ramp arrangements, and (3) ramp design.

One important design element not treated in detail by these several design policies was the relation between curvature, superelevation, and design speed.

\section{Curves}

By 1930 most States were superelevating all curves except those of very long radius; however, there was little uniformity as to superelevation rates, just as there was little consistency in minimum radii for curves. Empirical controls were generally applied, with maximum cross slopes of about 10 percent.

A BPR study in 1920 focused attention on the necessity of a tire-pavement friction factor for superelevation design and also noted that a spiral curve or transition length was needed at each end of a curve section for the change from normal pavement crown to a superelevated section. ${ }^{24}$

One of several conclusions resulting from a long series of studies on tire-parement skidding relationships conducted by the Iowa State University was that the maximum permissible speed as used in designing curves should not exceed that for which a useful side-friction coefficient of 0.30 was required to counteract centrifugal force. This conclusion was reached in $1934 . .^{25}$

In 1935, the BPR collected data from drivers across the country operating their own vehicles on curves of known radius and superelevation by asking them to report the speed at which they began to feel a side pitch outward. Analysis of these data resulted in a new design premise that safe operation on curves would be attained when the superelevation was sufficient to counteract centrifugal force for threequarters of the expected speed, relying on side friction to supply the remaining horizontal resistance up to a maximum side friction factor of +0.16 at 60 m.p.h. ${ }^{26}$ The speed concerned was advocated to be the "assumed design speed," which was to be used as a basis for coordination of all alinement and geometric design values. The side friction factor to be used in calculating the minimum radius or the maximum rate superelevation did not enjoy the same degree of finality as the speed criteria, although the values used were apparently on the safe side. Research is continuing at the present time in an endeavor to discover pavement materials and construction methods to improve the skid resistant qualities of pavements.

In 1937 the BPR completed a highway curve design manual (later published as Transition Curves for Highways, 1940) embodying the above proposals. The manual presented data for $10 \mathrm{~m}$.p.h. increments in design speed for all curve design features-curve radii, superelevation, curve widening and transition (spiral) curves. These concepts and design details were greatly needed and soon gained wide use, thus stabilizing, to a large extent, curve design practices throughout the country and nullifying for the time being any necessity for the AASHO Committee to concentrate its efforts on this subject.

\section{Gradients}

Common logic has always dictated that, from the traveler's point of view, the most desirable route between two points is the one that is straightest and has the least rise and fall. In the days of wagon roadbuilding, circuity and indirection of alinement often had to be substituted for directness in order to obtain a suitable profile. The wagon roads were later converted to motor highways, frequently with little change in alinement and grade despite the fact that automobiles and trucks could negotiate grades steeper than the 4 to 6 percent commonly used for horsedrawn vehicles. This was done in the interest of economy, although the roadbuilders would have preferred a better alinement.

As the highway network expanded and more roads were built on new locations, particularly during the late 1920's and the 1930's, advantages were taken of the better gradeability of motor vehicles, and grades as steep as 9 percent were used sometimes to provide a straight alinement. Design with long tangents became commonplace and road distances were shortened by hundreds of miles in the aggregate. A BPR summary of practice in 1929 stated:

On main-line highways it is customary to adopt a maximum grade of 5 percent in gently rolling country and 7 percent in rough country, but it is no longer considered good practice to resort to sharp currature in order to aroid grades steeper than 7 percent. If local conditions permit either a 7 percent grade with a sharp curve or a short 9 percent grade with a wider curve, the latter design is thought to be the better practice because it is safer for modern motor traffic. ${ }^{2 \pi}$

In the rolling terrain commonly encountered in the midwest and far west where roads were developed on section line locations, this type of design resulted in many hundreds of miles of "roller coaster" highway profiles. Design of profiles with frequent grades over 5 percent tended to minimize earthwork quantities, with only shallow cuts and fills. As traffic volumes, speeds, and truck loadings increased, the deficiencies of short sight distances and high-downgrade speeds proved that this type of profile was somewhat hazardous.

The alternative was a profile design of a railroad grade type, that is, long, easy grades with long flat vertical curves in conjunction with long horizontal tangents connected by gentle curves. Prior to 1930 , any extensive mileage of such highway construction would have been out of the question because of the large earthwork quantities and attendant high costs.

The rapid mechanization of earthmoving equipment that began in the early 1930's revolutionized construction methods and made feasible the construction of highways of a type that had heretofore existed only in the fanciful minds of design engineers. Tractordrawn self-loading scrapers with capacities of 12 cubic yards came upon the scene for the first time. Pneumatic tires had been improved to such an extent that they could be used on heavy trucks, thus affording sufficient flotation to operate on newly placed 


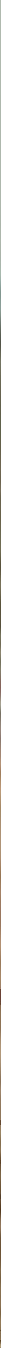

Connecticut's route 11 preserves the natural rock formations and vegetation by varying the width of the median.

embankments and made long hauls a routine operation. The roadbed of the then-modern highway, even though it was only two lanes in width, afforded sufficient room for turning and maneuvering. When compared with unit construction costs for the earlier years, earthwork became the best bargain in the entire roadbuilding operation.

The trends toward steeper gradients was arrested, if not reversed, by these developments. However, it was not until 1950 or later that a consensus was arrived at and anything approaching standardization of maximum grades was developed by AASHO.

\section{Design Effects on the Environment}

Highway construction inevitably left scars upon the landscape. These were not particularly objectionable until the era of heavy cuts and fills and relatively wide roadbeds that accompanied the design concepts of the 1930's. Most State highway departments had programs for roadside development prior to that time, some as early as 1912. These programs consisted largely of planting trees and shrubs. These were reasonably successful prior to 1930 but were not adequate for the true automobile road. As one writer described the situation in 1936 :

The quite common belief that the adoption and execution of a mere beautification program for our highways satisfies even the most obvious requirements and potentialities of roadside development is both incorrect and disheartening. We must sadly admit that much of our present so-called roadside improvement is little more than a landscape hair-cut or perhaps a horticultural manicure.
What is now most needed is to set up a better type of organization with engineering and landscape departments properly coordinated and working in harmony. ${ }^{28}$

This advice was heeded, at least in part, but the demands for more miles of paved highways and for widening and straightening existing ones continued to take the lion's share of the highway dollar. Much credit is due the National Park Service for their insistence upon the incorporation of esthetic quality in the design of national parkways. An outstanding example of the good results that could be produced by the joint efforts of landscape architects and highway design engineers may be found in the Mount Vernon Memorial Highway which was designed and constructed by the Bureau of Public Roads for the Park Service during the period 1929-1932.

Credit is also due to the membership of two committees within the highway fraternity - the Committee on Roadside Development of the American Association of State Highway Officials and a similarly named group in the Highway Research Board. Initially in 1932, these two groups were established as a joint committee but were separated in 1939 under their parent organizations. The term "complete highway" was coined by these committees to describe succinctly the importance of blending into a highway the fundamental elements of design, construction, and maintenance. The complete highway had to incorporate utility, safety, beauty, and economy to satisfy this very sound concept. 
Highway beautification was also given a boost by the National Recovery Act of 1933, which included among its objectives the landscaping, with Public Works funds, of a moderate mileage of main roadsides. The rules and regulations governing the use of these funds required that at least one-half of 1 percent of each State's apportionment should be devoted to this type of improvement. Thus, a total of approximately $\$ 2$ million was set aside for pioneering work which had for its ideal the conversion of unsightly roadsides into attractive areas bordering roadways made safe for those traveling upon them.

The Federal-Aid Highway Act of 1940 was a further landmark in legislation in support of better looking and safer roadsides. Section 11 of this act authorized the use of Federal funds for ". . . such roadside and landscape development, including such sanitary and other facilities as may be deemed reasonably necessary to provide for the suitable accommodation of the public ... and ... likewise ... the purchase of . . . adjacent strips of land of limited width and primary importance for the preservation of the natural beauty through which highways are constructed ..." The Highway Beautification Act of 1965 further liberalized the use of Federal funds for roadside improvements, such as control of outdoor advertising and the control of roadside junkyards.

\section{Practical Applications}

Returning for a moment to the Mount Vernon Memorial Highway, one reason for its attractive appearance was its gentle sinuous alinement; there were no long tangents and no abrupt, short radius curves. Yet, the highway formed a reasonably direct route between termini. It was the antithesis of the type of alinement that was evolving for conventional two-lane highways which, by their very nature, necessitated that vehicles encroach upon the opposing lane of traffic in order to overtake and pass slower vehicles. Straight alinement with good sight distances was thus a requisite of a good, safe two-lane road.

By way of contrast, the Mount Vernon highway was a four-lane highway on which faster cars could overtake and pass slower ones without having to encroach on the lane for oncoming traffic. Thus, passing sight distance was not important. The curves on the Mount Vernon highway were of longer radius than those generally used on two-lane roads, and there was no necessity for the motorist to vary his speed in traversing the entire length of the route. One curve has been said to be over 2 miles long. All curves were provided with spiral transitions.

This departure from conventional curve design was achieved through the use of a flexible spline of the type used in ship design, and this was one of the early applications of the method. A prerequisite of this method of location and design is a topographic map of fairly large scale and of sufficient width to include all alternative locations for the selected routes. As has been mentioned, aerial photographs were very helpful in this regard, and this project was one of the first to use this technique. The methods for determining elevations from the two-dimensional photographs were crude and lacked precision, and there were other problems to be overcome, but the benefits of seeing the vegetation, the drainage courses, the configurations of the ground, and the land uses as they appeared in nature were tremendous.

Rapid strides were to be made in photographic techniques and in the development of equipment for interpreting and photogrammetrically plotting topography by use of contours on topographic maps entirely adequate for precise highway location and design. Improvements were to continue. Looking ahead, the Federal-Aid Highway Act of 1956 authorized "the use of photogrammetric methods in mapping, and the utilization of commercial enterprise for such services." By 1960, the accuracy and practicality of aerial survey methods were so well recognized that contractors were willing to accept payment for earthwork computed on the basis of cross sections measured photogrammetrically using aerial photographs taken before and after the construction work was performed.

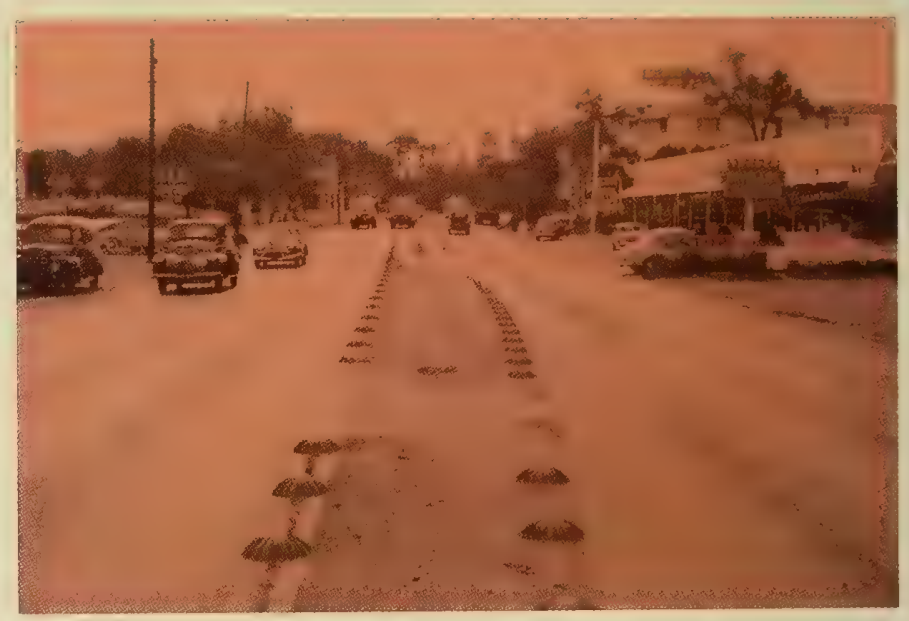

An arterial highway of the $1940^{\prime}$ 's with uncontrolled access. An early form of channelization helped traffic movements, but the danger from cars backing out onto the highway still remained.

At the same time that new techniques were being discovered or improved, new concepts and principles were being recognized. One of these, soon to be exploited, was the principle of control of access. It would be difficult to say when the first public highway was planned with the express intent of excluding abutting property owners from access to the road for the purpose of protecting and preserving the operational character of the highway. One of the earliest examples of a controlled access highway is the Bronx River Parkway in New York. It was designed about 1914 and completed approximately 10 years later. It has been said that this project was conceived as an attempt to protect the historical old Bronx River, but as studies developed, it was found that protection was feasible only if the land on both sides were purchased in fee. Once the land was purchased, it appeared desirable to use it for park purposes and then for a parkway to relieve the congestion on the heavily traveled north-south streets in the area. Regardless of whether this controlled access parkway came into being by accident or whether by intent, it stood for half a century as a lasting proof of the value of controlled access. Whereas other roads of much higher standard built decades later have since become obsolete because of roadside interference, the original Bronx River Parkway retained all of its beauty and 
utility until the pressures of continued traffic growth necessitated reconstruction during the 1960's. Much of this beauty was retained in the reconstruction process.

The example set by the Bronx River Parkway and other early controlled access highways went largely unnoticed for many years, mainly because one of the primary functions of highways at that time was to serve the abutting property, not to isolate the road user.

During the period 1930-1940, highway designers became aware of the adverse effect that unregulated access could have upon highway traffic service. Strip commercial development in the vicinity of towns and cities was particularly troublesome. Vehicles turning into and out of roadside businesses created congestion and caused accidents. A few far-sighted individuals recognized the principle of control of access that had been pretty much dormant throughout the 1920's. Interest was not limited to the United States. In 1933, the first spade of earth was turned on a new system of highways for the German Reich. These autobahnen, with full control of access and designed for speeds up to 120 miles per hour, were destined to exert considerable influence on American design criteria.

The roadbuilders in the United States demonstrated, however, that they were not dependent on the German engineers for leadership in designing and constructing freeways. Between 1934 and 1940 the Merritt Parkway was constructed, extending the parkway and controlled access features of the Westchester County, New York, parkway system across Connecticut. During its first full year of operation, it handled an average of 20,000 cars per day.
The need for a traffic artery capable of handling similar traffic volumes between Los Angeles and Pasadena led to the start of the six-lane Arroyo Seca Freeway in 1938. It had two 35-foot roadways with a 6 -foot curbed median.

The Pennsylvania Turnpike, completed in 1940 from Irwin to Carlisle as a toll facility, was the first rural freeway of notable length in this country. It was a four-lane divided highway, except for several tunnels through mountains where the width was narrowed to two lanes. Noteworthy features in the design standards were gentle alinement and relatively flat gradients suitable for high-speed travel despite the rugged terrain traversed by portions of the route. Also, consistent with anticipated high-speed travel was a design requirement for speed change lanes 1,200 feet long at points of access.

These and the several other freeways in use by 1940 met with immediate acceptance by the motoring public. The freeway era was born.

\section{The Era of the Freeway: 1940-1976}

\section{Design Standards}

Concentrated thought and effort toward a nationwide system of controlled access highways, both urban and rural, began to gather momentum about 1940 . However, it would be totally erroneous to leave the impression that no further advances were made in the design of conventional highways after that date. It is generally true that the advances were in the nature of refinements of the basic concepts and principles enunciated in AASHO's seven published design policies. These refinements generally took the form of more generous dimensions in such elements as pave-

The Merritt Parkway near Darien, Conn.

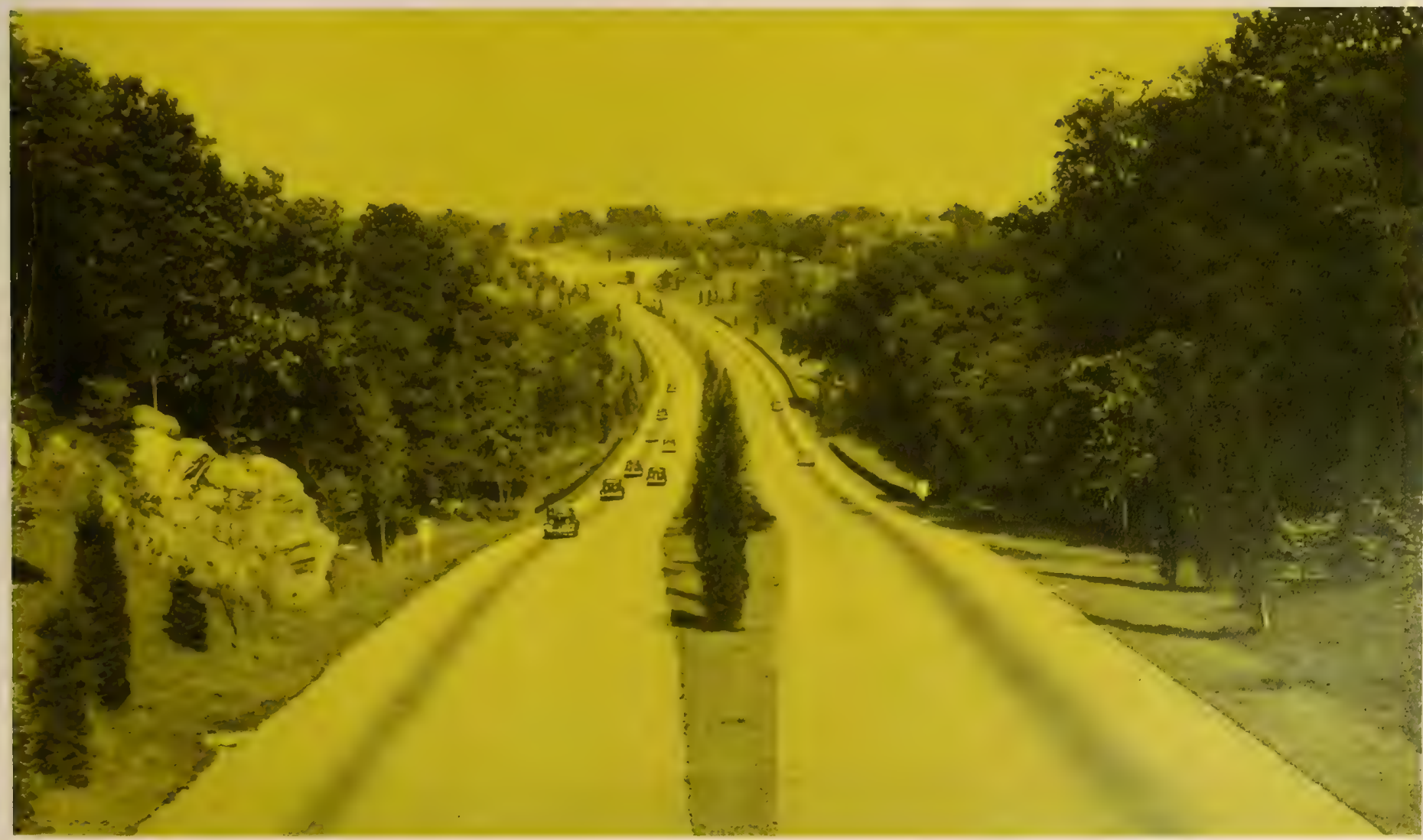




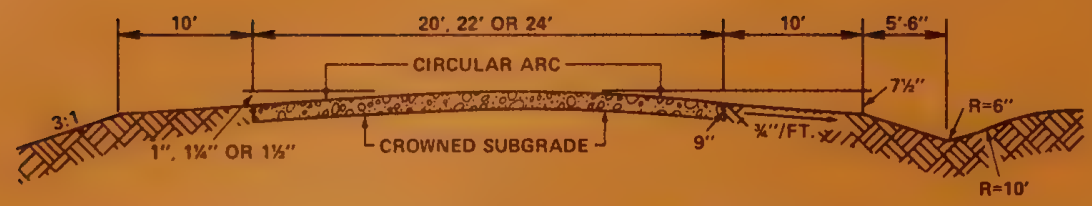

PORTLAND CEMENT CONCRETE PAVEMENT, NORMAL TRAFFIC

SOURCE: ANNUAL REPORT ILLINOIS DIVISION OF HIGHWAYS 1942

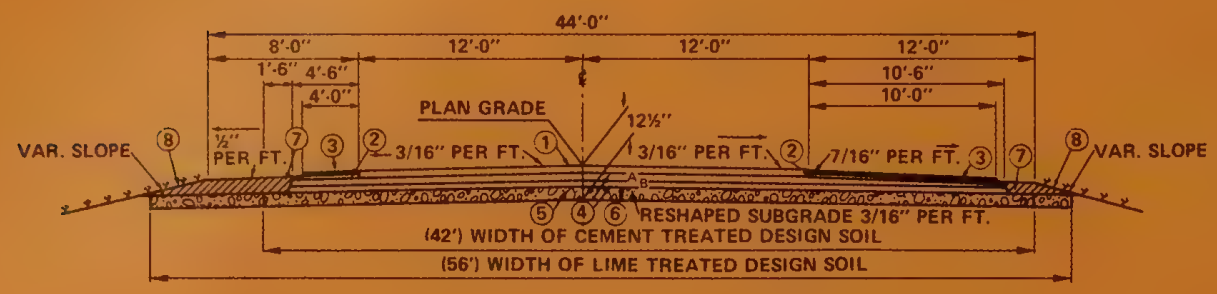

TYPICAL SECTION MAIN FACILITY

TYPICAL SECTION MAIN FACILITY
RT. OR LT. LANE IN DIRECTION OF TRAFFIC

(1) 4" HOT BITUMINOUS PAVEMENT

(2) 3" \& VARIABLE HOT BITUMINOUS PAVEMENT

(3) DOUBLE BITUMINOUS SUAFACE TREATMENT

(4) $8 \% "$ " PLANT MIX BITUMINOUS BASE COURSE

(A) 4\%" TO BE PLACED IN 1 2\%" COUASE AND 1 2 2" COURSE

(B) 4" COURSE MAY BE PLACED IN ONE OR MORE COURSES AS NECESSARY TO MEET THE REQUIREMENTS OF CONTRACT

(5) CEMENT TREATED OR LIME TREATED DESIGN SOIL

6) BITUMINOUS PRIME COAT (CURING SEAL)

(7) VARIABLE DEPTH GRANULAR MATERIAL

(8) $+\$$ INDICATES EROSION CONTROL TREATMENT

FLEXIBLE PAVEMENT-Interstate Highway 1975 SOURCE: INTERSTATE COST STUDY, MISSISSIPP|

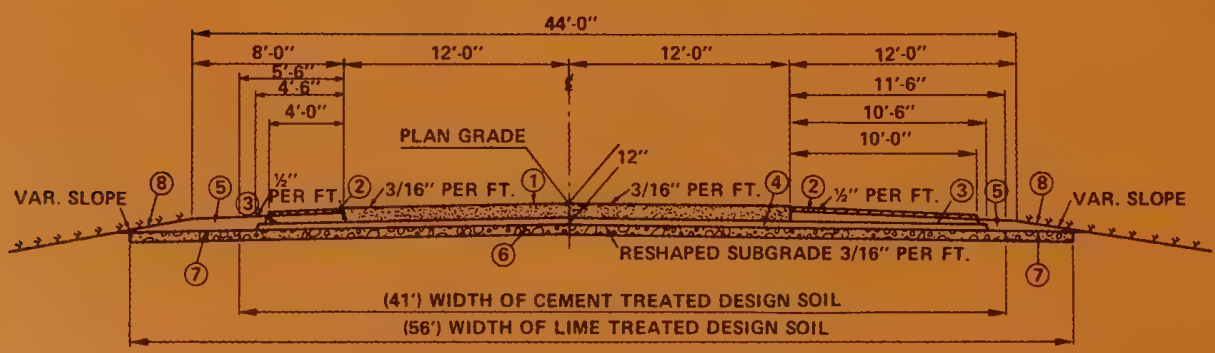

TYPICAL SECTION MAIN FACILITY

RT. OR LT. LANE IN DIRECTION OF TRAFFIC

(1) $8^{\prime \prime}$ CONTINUOUSLY REINFORCED CONCRETE PAVEMENT

(2) DOUBLE BITUMINOUS SURFACE TREATMENT

(3) $7 "$ VARIABLE DEPTH PLANT MIX BITUMINOUS BASE

(4) 4" PLANT MIX BITUMINOUS BASE (TO BE PLACED IN ONE OR MORE COURSES AS NECESSARY TO MEET THE REOUIREMENTS OF CONTRACT

(5) VARIABLE DEPTH GRANULAR MATERIAL.

(6) CEMENT TREATED OR LIME TREATED DESIGN SOIL

(7) BITUMINOUS PRIME COAT (CURING SEAL)

(8) $\longleftarrow \because \because \geq$ INOICATES EROSION CONTROL TREATMENT

RIGID PAVEMENT-interstate Highway 1975

SOURCE: INTERSTATE COST STUDY, MISSISSIPPI

TYPICAL SECTIONS 1940-1975 
ment and shoulder widths, wider bridges, and flatter slopes with better rounding at intersections of slope planes. The need for a more open type of design was occasioned, in part, by the continued increase in travel speeds, but in most cases, these liberal practices were as much a result of a greater flow of money into the highway coffers as to any sudden awareness of need for more generous dimensions. It would be difficult to say which is cause and which is effect-increases in speed or improvements in design standards-but historically they have gone hand in hand.

AASHO prepared concise, abbreviated design standards for the several classes of highways, starting with those for primary highways in 1941. Design and construction standards for secondary and feeder roads and for the Interstate System were published in 1945. These have since been expanded and upgraded, as necessary, for the three general categories of roads. The classification terminology has been changed somewhat with the passage of time.*

These standards have since been approved by the Federal Highway Administrator for application on Federal-aid highways and are the specific controls for the design of such highways. Many States have also adopted them in their exact form for application on highways that are off the Federal-aid systems. Other States have promulgated standards of their own for application on their various classes of State highways. Where found to be in reasonable conformity with AASHO standards, these have been approved by the Federal Highway Administrator for use on the Federal-aid systems.

Getting AASHO standards approved has not always been accomplished without dissension and debate. When a pavement width of 24 feet was proposed for heavily traveled two-lane roads in 1941, for example, some officials, accustomed to building lanes only 9 or 10 feet wide and having been stung by the bad accident experience on three-lane roads, were fearful that drivers would mistake the 24 -foot roadway for a three-lane road. Other States were deeply concerned by the added costs for higher standards.

\section{Rural Design Policies}

Highway design policies are general procedures and controls which are less specific than design standards, often with a range of acceptable values, and which are officially adopted or accepted for application in the design of highways. In 1950, the seven separately published design policies were reprinted and bound as a single volume under the title, Poticies on Geometric Highway Design. Parenthetically, the final one of the policies, published in 1944, dealt with interchanges and grade separations and should properly be identified with freeway development to a greater extent than with conventional highways. The policies were updated and republished in 1954 as $A$ Policy on Geometric Design of Rural Highways, the "Blue Book." This publication broadened considerably the earlier work, largely as a result of research efforts in

\footnotetext{
* Current rersions prepared by the Committee on Planning and Design Policies are Geometric Design Standards for the National System of Interstate and Defense Highways-1967. Geometric Design Standards for Highways Other Than Freeways-1969; and Geometric Design Guide for Local Roads and Streets-1970.
}

the field of traffic operation. The Highway Capacity Manual, published by the Highway Research Board in 1950 , supplied material on the relation between highway capacity and roadway characteristics. This information was incorporated in the 1954 rural design policy and has been invaluable in aiding the designer to better fit the highway to traffic requirements.

The results of studies of truck speeds on grades as related to motive power and load carried also became available after 1940 and were used in selecting values for control gradients for the design of the several classes of highways in different types of terrain. One solution to the problem created by slow moving trucks on grades was the provision of an added lane in the uphill direction for use by trucks. These have become known as "climbing lanes." Criteria for climbing lanes were included in the 1954 policy.

The 1954 design policy also enlarged upon the design speed concept and included tables showing the relation between design speed, degree of curvature, rate of superelevation, and needed length of spiral transition. The subjects of freeway design and interchange geometrics were discussed to the extent that the state-of-the-art permitted.

In 1965 the rural design policy was again brought up to date and republished under the same title.

\section{A Need to Expand the Highway Network}

As efforts to improve and expand the highway network continued, it became increasingly apparent to highway administrators and lawmakers alike that portions of the predominantly two-lane rural system of highways were becoming severely strained by the ever increasing traffic burden. Urban arterials were becoming choked by intensified commercial development coupled with rapid traffic growth. Inadequacies in the form of low travel speeds, low capacities, and high accident rates were clearly evident to those at even the highest level of government. At the same time, there was an awareness that transportation within cities was a national matter rather than a local problem. As a means of defining the scope of the problem and of developing remedial measures, President Roosevelt, on April 14, 1941, appointed the National Interregional Highway Committee to ". . . investigate the need for a limited system of national highways to improve the facilities now available for interregional transportation, and to advise ... as to the desirable character of such improvement. . . ." ${ }^{29}$

The product of the Committee's efforts was the celebrated report Interregional Highways, submitted to the President on January 5, 1944. The ultimate accomplishment was the incorporation in the FederalAid Highway Act of 1944 of a provision for designating a national system of highways and a further provision for the expenditure of Federal-aid highway funds in urban areas.

Highlights of some of the recommendations of the report as to locating and designing the system were:

- The system would be both urban and rural in extent.

- Roadways and structures would be designed to serve vehicles of the types and numbers to be expected 20 years from the date of construction.

- Intersections with crossroads and railroads would be separated in grade. 


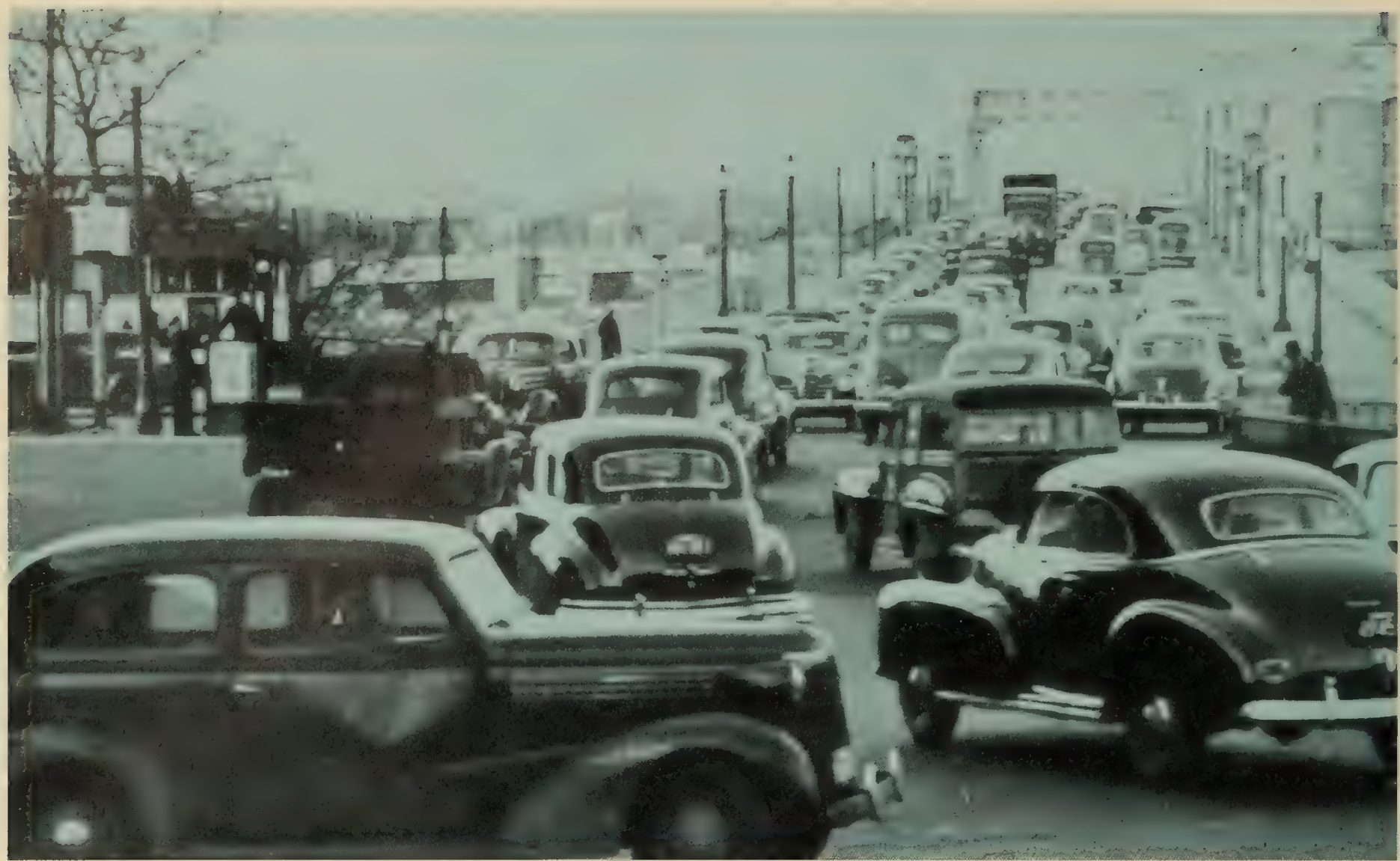

Traffic jam at intersection of U.S. routes 3 and 20 in Boston, Mass., in the early 1940's.

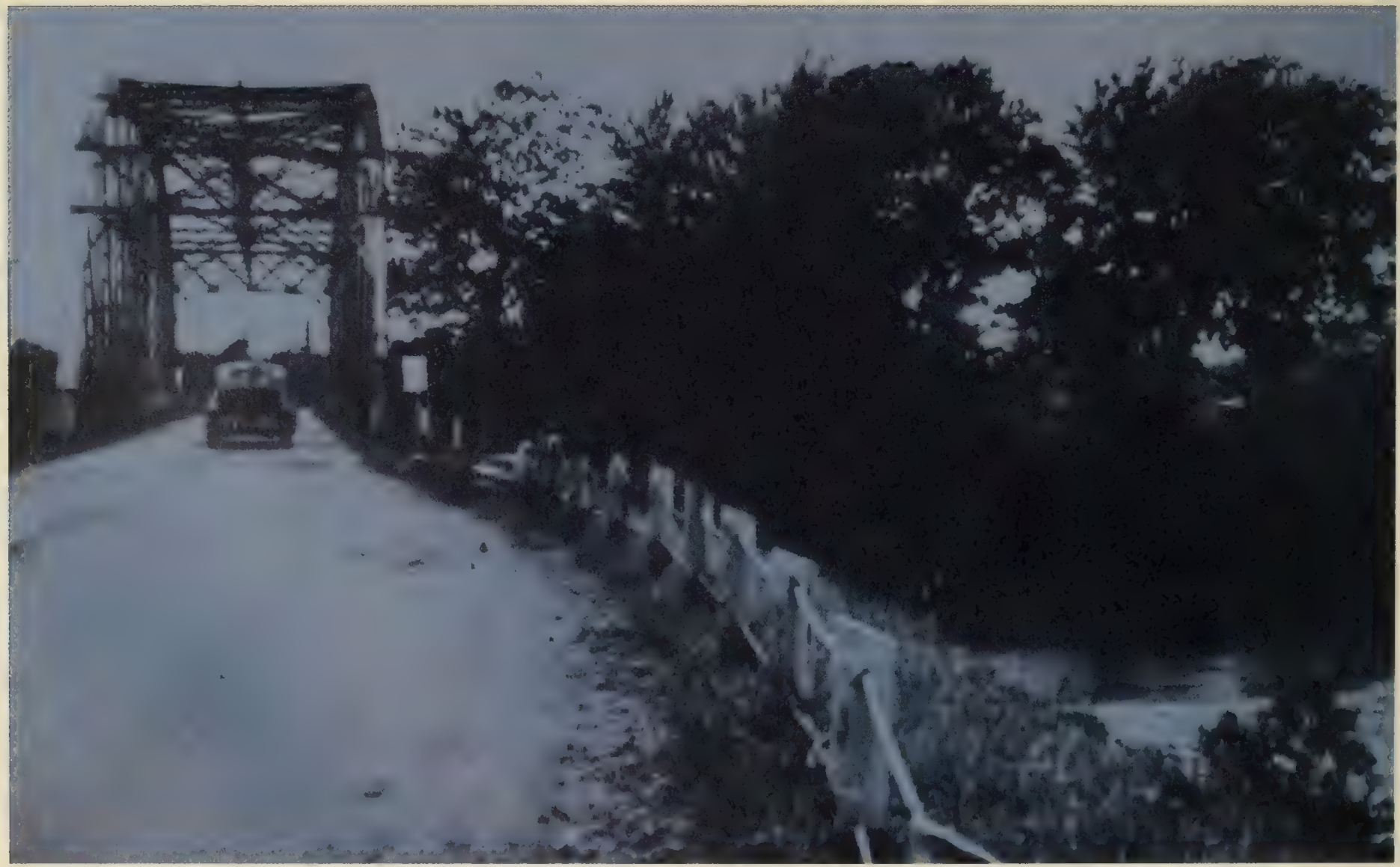


- Rural sections would be designed for safe travel at a speed of 75 m.p.h. in flat topography; urban sections for 50 m.p.h.

- Traffic lanes would be 12 feet wide.

- Shoulders would be 10 feet wide except in mountainous topography.

- Embankments 10 feet or less in height would have side slopes no steeper than 1 foot vertically to 4 feet horizontally.

- The roadway width on bridges would be at least 6 feet greater than the width of the pavement of the approach roadway; on short bridges the roadway width would be as great as the width of approach roadway, including shoulders.

There were many other details for the design and construction of the system, including such items as signs and markings, lighting and landscaping. $\mathbf{A}$ discussion of the principles of landscape design occupied three and one-half pages of the report. It was a complete text within itself.

The design criteria contained in the report were recommendations only. The 1944 legislation authorizing the designation of the National System of Interstate Highways made no reference to the standards to be used in the design and construction of that System. This was to come later.

Enabling legislation for financing and constructing the System was enacted in 1956. This legislation contained the unique provision that the standards for the System would be those approved by the Secretary of Commerce ". . . in cooperation with the State highway departments." Thus, the continuance of the voluntary cooperative efforts of the States and the Bureau of Public Roads in formulating standards for the other highway systems for the past 20 years was firmly assured and made applicable to the Interstate System.

AASHO responded to the requirement of the law by adopting standards for the System within 3 weeks after passage of the Act. Many of the recommendations of the 1944 Interregional Highways found expression in these standards, which were approved by the Secretary of Commerce in accordance with the law.

\section{Urban Design Policies}

The Committee on Planning and Design Policies was well aware, as it always had been, that bare-bone standards are not enough to assure the design of a safe, utilitarian highway that is esthetically pleasing and economical to construct and maintain. They recognized a need for a more casual and philosophical discussion of the principles of freeway location and design. The Committee was also confronted with the challenge of developing guidelines for the utilization of Federal-aid funds in the construction or improvement of city streets and highways.

The Committee chose to combine these objectives and to develop a policy on urban arterial highways, which would, of course, include freeways as well as conventional arterial surface streets. This effort culminated in the publication, in 1957, of A Policy on
Arterial Highways in Urban Areas, the "Red Book." When work began on this policy, there were few freeways in existence, and experience in their design and operation was limited. Nevertheless, the vision and foresight of the Committee members was sufficient to result in a thorough and comprehensive text on this subject, as well as on the more conventional types of streets and urban highways. The discussion of interchange types and configurations was particularly exhaustive.

Experience in the application of the 1957 urban design policy was generally favorable, but after a period of years, operational deficiencies began to develop in many urban freeways built in accordance with the 1957 doctrine. In large measure, these deficiencies were attributable to traffic loads far in excess of those that were anticipated at the design stages. Nevertheless, many of the operational problems would have been alleviated had some of the dimensional values and configurations been more generous. Accordingly, the policy was updated and republished in 1973 as A Policy on Design of Arterial Highways and Urban Streets. In the process of revision, new sections were added on urban transportation planning and on arterial route location.

Design standards and guidelines have undergone only minor modification and upgrading since adoption of the first editions of the two geometric design policies, rural in 1954 and urban in 1957 . Such changes as have been made are attributable to two principal factors: (1) Travel speeds have continued to climb, necessitating adjustments for all design features, and (2) vehicular silhouettes have been lowered, requiring flatter highway profiles to provide the necessary sight distances for avoidance of accidents.

Clearances to roadside obstacles and the moderately flat side slopes that were entirely adequate for the travel speeds prevalent before the mid-1950's were found deficient when measured against the speeds and other operational practices of the seventies, as is apparent from an examination of speed trends on main rural highways. Consequently, more liberal dimensions have been incorporated in the standards and above minimum design is the rule rather than the exception.

It may be truthfully said that throughout the history of highway design development, the highway user, in the collective sense, has dictated the character of the highway by his manner of operation on it and by the extent of his willingness to pay, through road user imposts, for roads that would sustain that type of operation. It remained for the design engineer, working in concert with the research engineer, the landscape architect, and the economist, to determine the type of operation demanded by the vehicle operator (now and in the future), the design characteristics of a highway system that would safely support that type of operation without being unnecessarily extravagant, and the probable revenues that would be available. It would not be a gross exaggeration to say that every highway project has represented a compromise between the ideal in design characteristics on the one hand and economic reality on the other. This is likely to remain the case in the future. 


\section{Design For Safely}

While not always indicated separately, safety in highway vehicle operations has been an important objective of highway design since the beginning of the highway development programs. The identification by the 1920 's of the need for clear stopping distances, for widths to pass without major pullover, and for usable curve radii led to early efforts to determine and incorporate such appropriate features in the next highway improvements. With reasonable rapidity, the design engineers accepted the identified highway safety needs, developed newer design controls reflecting them and put them to use. In retrospect over the last 50 years, it should be said that designers never were able to catch up with nor were the construction programs able to provide the highways needed for the rapidly changing vehicles, volumes, speeds, travel habits and driver attitudes. The history of highway design control development shows a progressive series of adjustments that reflect the concerns for highway safety evolving from the latest experiences and accident data. The same process continues today.

There is space here only to indicate a few examples of design controls and practices that were pointed toward better safety. In 1938-1944 initial design policies of AASHO had many such items. The 1941 primary standards preamble urged that in using the design values, "unquestioned adequacy rather than strict economy should be the criterion." " 30 The overall concept of design for expected volumes, for the character of traffic and for an assumed design speed was a major effort for highway safety. The enumerated values and controls for lane width, shoulders, use of a dividing median, pavement crown, curve radius and superelevation, minimum sight distance, safety passing sections, guardrails where roadway slopes were steep, appropriate intersection details and layouts, and for grade separations with interchange ramps all embody features patterned for safe vehicle operations. The 1954 rural design policy book refined these and provided additional details; advocacy of controlled access design was a major addition. The 1965 revision expanded treatment of these details, primarily in the realm of the higher volume and higher speed operations which were then being experienced. Both of these editions keyed into the separately developing standards for the several types of traffic control devices which have a high safety orientation. Both the 1957 and the 1973 urban highway policy books reflected design features needed for the higher volumes and greater land space restrictions in urban areas. They particularly stressed the design details of grade separations, interchange patterns, frontage roads, and practical geometrics relative to expressways and freeways.
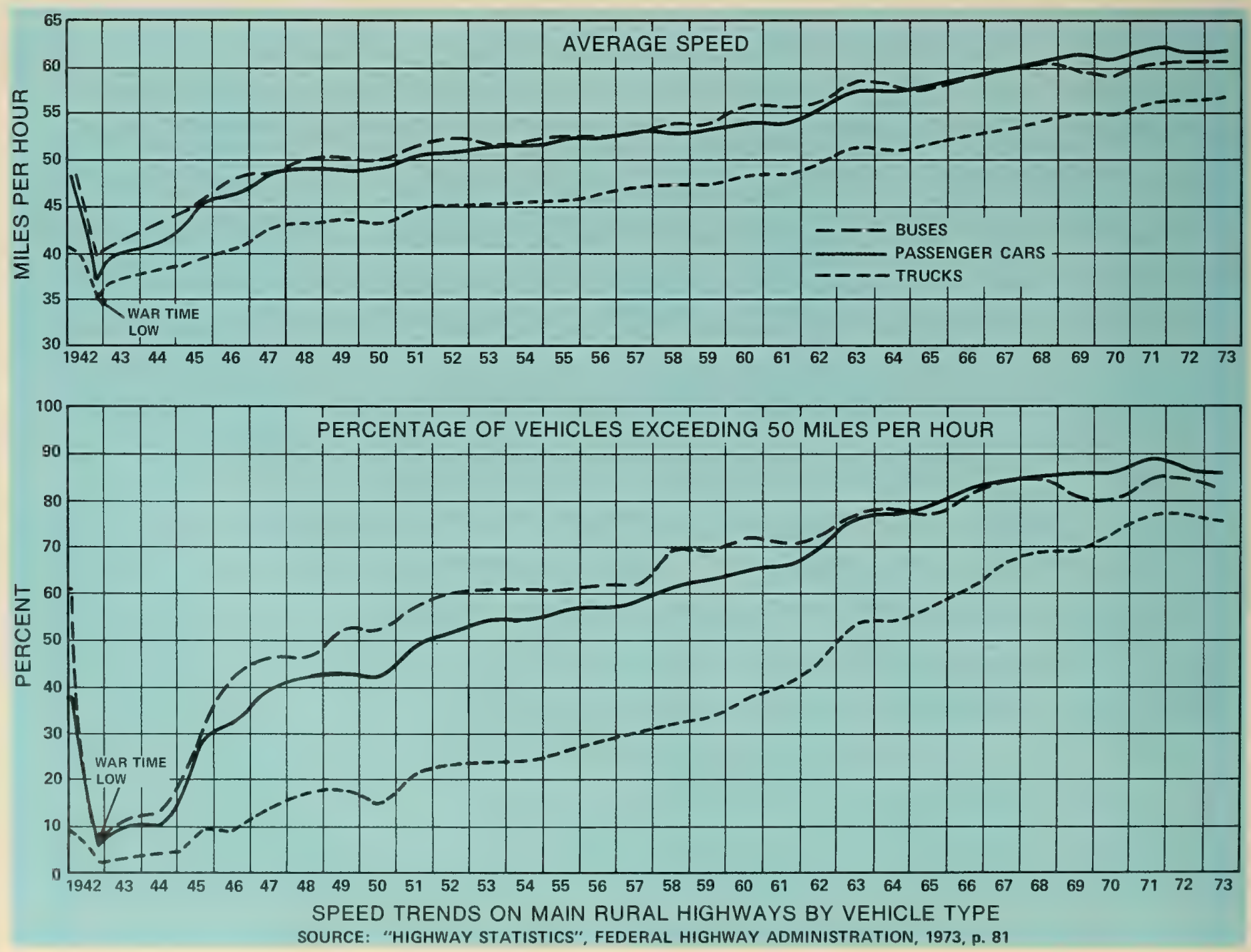


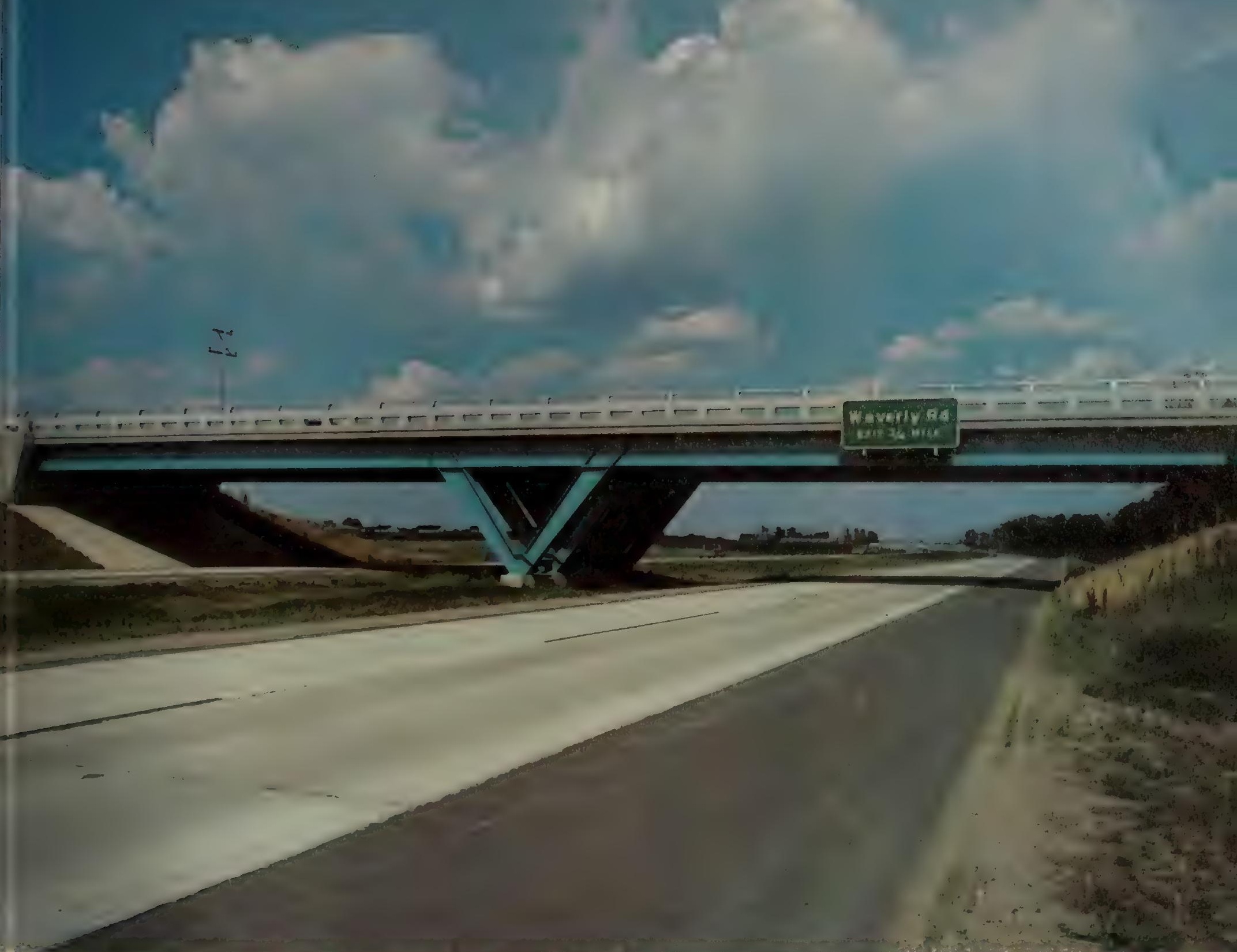

The Snow Road Bridge over I-496 near Lansing, Mich., is an example of modern safety design. Slanted back slopes and the absence of side piers on either end make safe vehicle recovery possible.

The 1956 Interstate standards made a further breakthrough in stating positive requirements for design with full access control throughout that System and for use of higher realm geometric design values as needed for operations at speeds of $60 \mathrm{~m} . \mathrm{p} . \mathrm{h}$. and above.

During 1959 and again in 1966, a special AASHO Safety Committee conducted a nationwide survey of highways which resulted in published reports enumerating design details to provide greater safety. The second of these, Highway Design and Operational Practices Related to Highway Safety, 1967, soon known as the "Yellow Book," included recommendations on the current highway design and practices to attain a higher degree of safety in both State and local agency actions. Responding, Federal policy directives called for utilization of the report recommendations on all project plans designed for a speed of 50 m.p.h. or more and a corrective program to apply the findings on existing highways. The report was updated and reissued in 1974 with the same title.
One of the newly advocated features from these studies was the "clear roadside" concept, which by 1966 had been started in a few States. During the early 1960 's, it became evident through accident analyses that about one-third of all accidents were single vehicle, run-off-the-pavement types, a high proportion of which proved to be of high severity on collisions with an object on the roadside, such as a rock, large tree, or steep cut slope. Some of these objects were highway elements such as culvert headwalls, rigid sign posts, lighting standards, bridge piers, etc. Better design and correction programs for safety were needed to provide traversible roadsides of a width well beyond the shoulder that was free of all formidable objects and reasonably flat and rounded so that off-roadway drivers would have a chance to recover control of their vehicles. Actions taken included lengthening culverts and overcrossings, moving sign supports or using the breakaway type, eliminating protruding drainage inlets, flattening and rounding roadway slopes, and providing tested-types of crash cushions at bridge abutments and between diverging 
highways and guardrails in front of essential roadside objects and as central barriers in narrow medians. Main highways of new design now are being developed in this manner and corrections made to the extent practical on existing highways. The cost effectiveness of some of these features remains moot on low and intermediate volume highways and further studies are continuing for their more widespread application.

\section{Traffic Control Devices}

Traffic control devices are the several elements provided on highways to advise, guide, warn, regulate or otherwise inform the vehicle drivers. The basic types of devices are signs, pavement markings, roadside delineators and traffic signals. The 1971 Manual on Uniform Traffic Control Devices was approved by the Federal Highway Administrator as the national standard for all highways open to public travel. This Manual presents essential standards for design, location, installation and operation of all forms of traffic control devices and is the culmination of over 50 years of progressive development of the devices and national standards for their detailed and uniform use.

The history of these developments can be briefly reviewed in two stages. First are the series of individual and scattered instances to conceive and use some form of device. Second are the organized efforts to develop and attain acceptance of standards for national uniformity.

\section{Early Traffic Controls}

In 1745 stone markers were placed between Trenton and Perth Amboy on the principal highway between New York and Philadelphia. They were installed at 2-mile intervals and at intersections with other public roads. A public subscription was made to pay for them. In 1763 the Boston Post Road similarly was marked with mileposts.

The Pennsylvania State authorizing act in 1792 for the Philadelphia to Lancaster turnpike included requirements for mileposts and directional signs.
By 1902 some cautious automobile touring had begun, and the adventurers were losing their way. Often there were no signs at all, or where there had been signs, many had toppled over and been broken or faded beyond readability. As early as 1905 , extensive signpost work was performed by the Buffalo Automobile Club in New York State. In the next few years, auto clubs across the country undertook the task of a basic directional signing on the principal highways within their areas. Despite their local efforts, there were no national or long route installations.

In 1913 the Lincoln Memorial Highway Association was organized and funds collected toward promotion and construction of a central east-west highway across the country. While the construction phase largely became promotional assistance to the State highway agencies, the Association shortly put into effect an entire route marking along existing roads. Painted red, white and blue band markings and symbols were placed on utility poles, clearly designating the chosen route. This example generated widespread activity by many motorist and local clubs to similarly, but distinctively, mark a selected and named route and foster its improvement. By the 1920's, there were some 250 name routes, each with characteristic color bands marked on roadside poles. In some cases, several such routes overlapped, resulting in totem poles of multicolors. These color bands and symbols were gradually replaced by route numbers as the States installed signs designating them.

The widespread use of stone mileposts did not begin until the early 1920 's when mileposts appeared on the roads of a few States in the form of concrete marker posts. Gradually the mileposts began to be replaced by signs indicating mileages to places ahead to aid travelers. The rapid expansion and drastic changes in our Nation's highway system beginning about 1910 were reflected in significant modifications in highway markings. The realinement and abandonment of roads, together with construction of new highways, made many of the old mileage signs virtually useless, and they were gradually replaced by signs displaying point-to-point distances and route numbers based

The Automobile Club of Maryland posting directional and mileage signs.

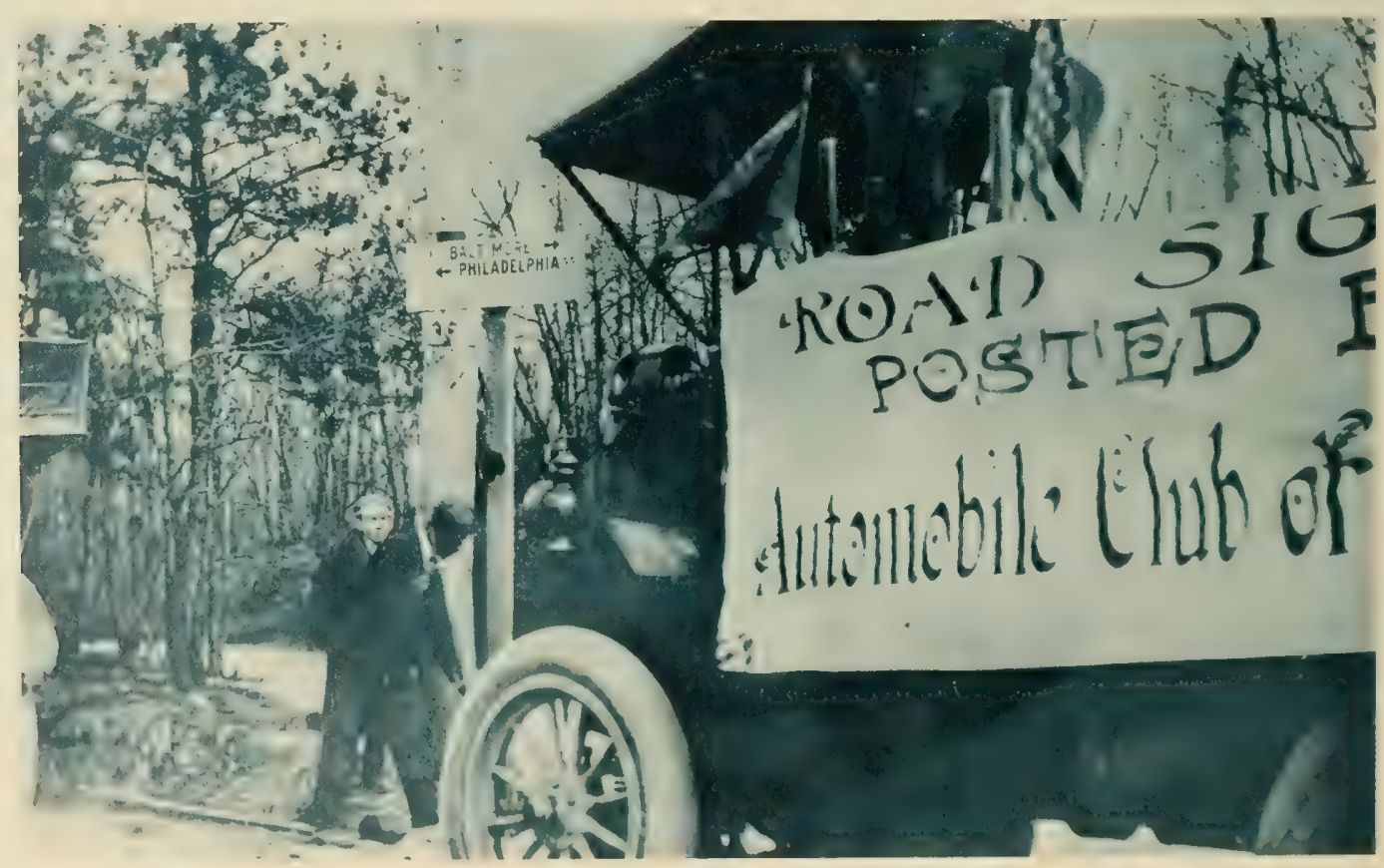




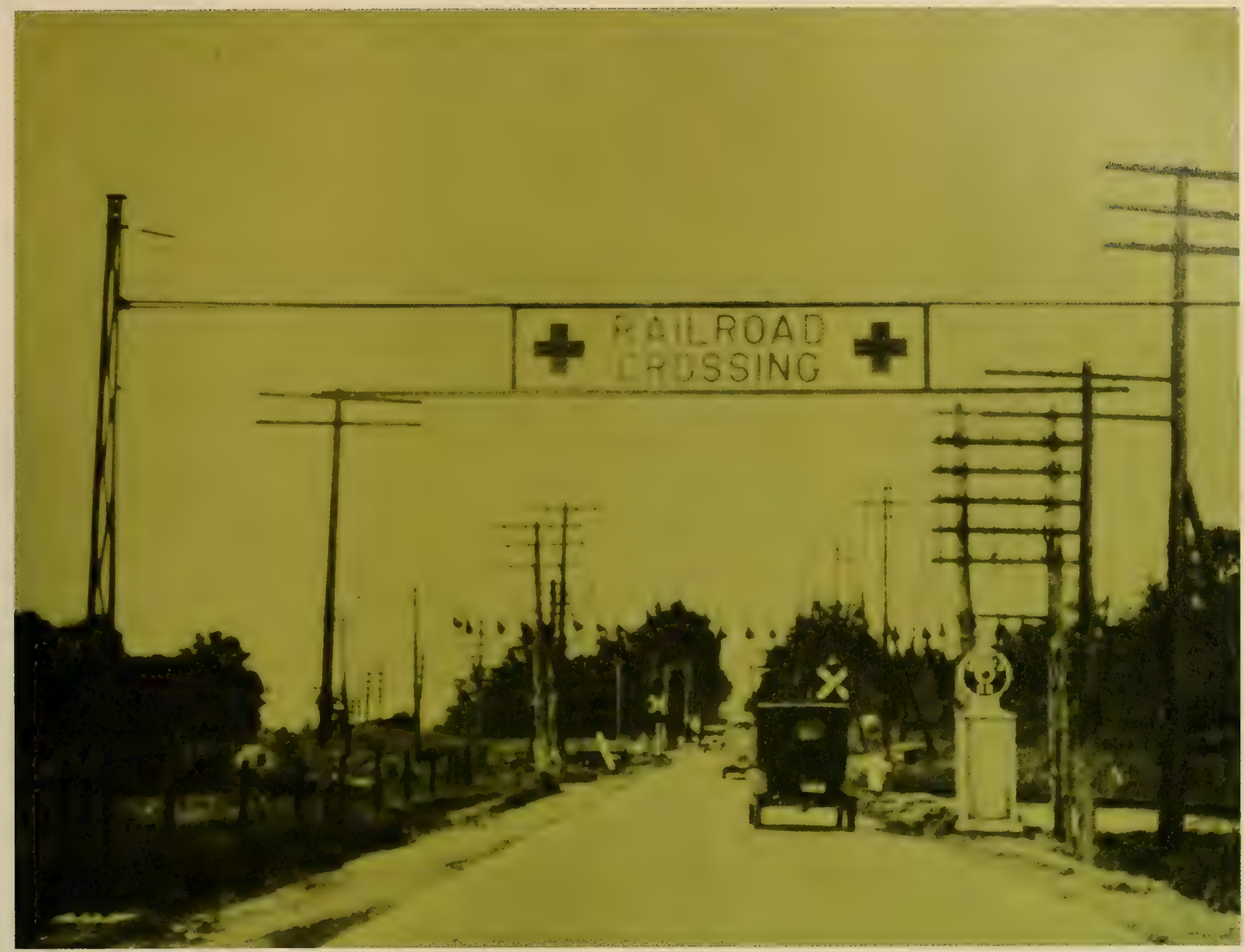

An early railroad crossing warning.

upon uniform statewide highway numbering systems. In addition, travelers were greatly aided by the widespread production and distribution of tourist maps that made use of readily identifiable landmarks, as well as route markers and signs. This increased availability of other devices for the guidance of travelers resulted in a marked decline in the use of mileposts, except in a few States and on turnpikes.

Immediately after World War I, as the States engaged in a greatly speeded-up road development program, it became apparent that a simplified and adequate marking system was a necessity. In 1918, Wisconsin decided that proper names could not be applied to an extensive network of highways and so developed the route marker and the numbering method of designating its highways and for directing travel over them. The shape selected for its route marker signs was a triangle with the apex down, using black and white colors. The triangle showed "State trunk highway," the route number and the State name. Also Wisconsin placed directional and distance signs for the trunk system and for lesser roads ${ }^{31}$

In 1921 Minnesota established its trunk highway system and promptly installed full-scale marking and signing. Minnesota adopted a star shaped design, with lemon yellow and black colors for all official route signs on the system and suggested white and black for signs placed by other jurisdictions. ${ }^{32}$
In 1911 the road commissioner in Wayne County, Michigan, ordered that a white line be painted down the center of every bridge and curve under his authority. Later, he carried the idea to its logical conclusion and painted the centerline along all the highways. The obvious benefits of the centerline strip were eventually realized, and the striping spread to all highway agencies. ${ }^{33}$

In 1915, a Detroit police official designed the first stop sign. When the first installation proved effective, the city promptly allocated funds to make six major streets through thoroughfares, by placing stop signs on intersecting streets. ${ }^{34}$

Traffic signals were developing in this same decade, first with the hand operated semaphores, then a motorized version that was patented in 1910. The first use of electric traffic signals was during the period 1912 to 1914 with Cleveland, Salt Lake City, and St. Paul all claiming their use to be the first. ${ }^{35}$ In 1920 , the first three-colored traffic signal light to control street and highway traffic was installed in Detroit. ${ }^{36}$ The first four-way three-color signal was installed in Detroit in $1920 .^{37}$

The first traffic control tower, located within an intersection, was set up in 1917, at a main Detroit crossroad. ${ }^{38}$ Similar towers also were used about the same time in New York City. 


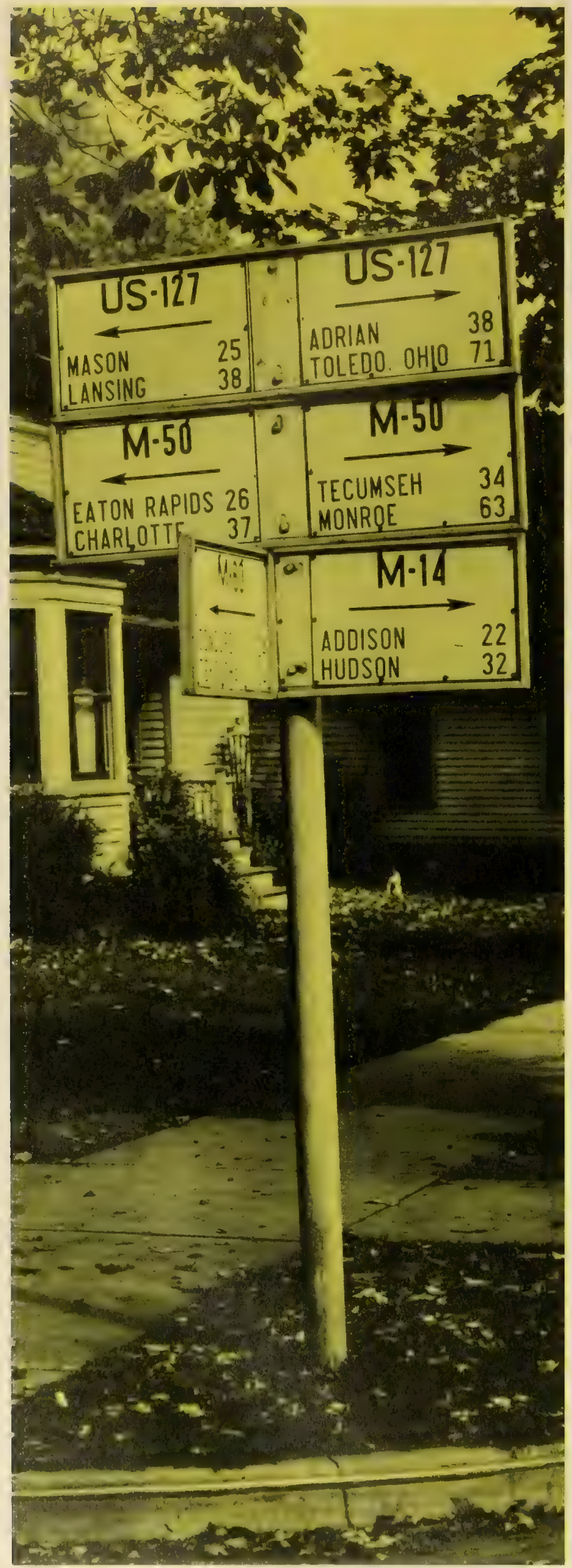

These route and mileage markers aided travelers passing through Jackson, Wich.

\section{Uniformity Through Standards}

Late in 1922, three State highway department officials from Minnesota, Wisconsin, and Indiana joined in a trip through several States to try to work out some basis for uniformity in the signing and marking of their highways. The trio's findings were reported at the 1923 meeting of the Mississippi Valley Association of State Highway Departments. That body agreed on them as a uniform signing and marking plan for the member States and passed its recommendations on to AASHO. Two years later the system of signs and markers became the basis for the first national standards. ${ }^{39}$

The Mississippi Valley Association established distinctive shapes for the several classes of signs, namely, a circular railroad crossing sign, an octagonal stop sign, a diamond-shaped slow sign, and a distinct route marker to be individually designed by each State. All of these signs were to have a white background with black lettering and border. With the exception of the route markers and the rectangular information sign, all were to be two feet square or 2 feet across. Within a year Wisconsin, Minnesota, Indiana, and Michigan were installing signs on their State systems largely in harmony with the Association plan, and other States in the Association were making plans to do so promptly. A Minnesota Highway Department Manual of Markers and Signs was completed in April 1923.

The report of the National Conference on Street and Highway Safety in 1924 by its Committee on Construction and Engineering stated that:

Proper signs and signals are essential to the safe movement of traffic on any street or highway. . . Signs should be uniform for a given purpose throughout the United States. ... It can be assumed that the Federalaid signs ... will be uniform in every state and will point the way to state and county highway authorities to follow the same standards. . . A All signs should be simple, with the least amount of wording necessary to make them readily understood, depending mainly on distinctive shapes, symbols and colors. ${ }^{40}$

The Conference report recommended that color indications, which would not be used for any other purpose, should be red for "stop"; green for "proceed"; yellow for "caution" at curves; some special cautionary color indications should be used at crossroads; white letters or symbols should be used on the red or green background, and black on the yellow. Distance and direction signs should be black and white.

Other recommendations were:

Railroad crossings remaining at grade should be safeguarded in every reasonable way. Standard warning signs and pavement markings should be used to mark the approaches to all public railroad crossings.

Rural highways should be marked with a white center line on curves, at and near hill crests, at irregular intersections, and at any other points where safety requires that motorists keep strictly to the right. No parking even off the traveled roadway should be permitted opposite these white lines. White center lines should not be used on straight level sections of highway or street except at highway, street or railroad crossings. Black center lines on straight sections of highways are desirable.

Pedestrian lanes should be marked on the pavement at busy intersections.

Objects near the roadway, such as curbs, poles, fences and rock surfaces, should be painted white. Obstructions, such as columns and curbs, at the centers of underpass, should be striped diagonally black and white.41 


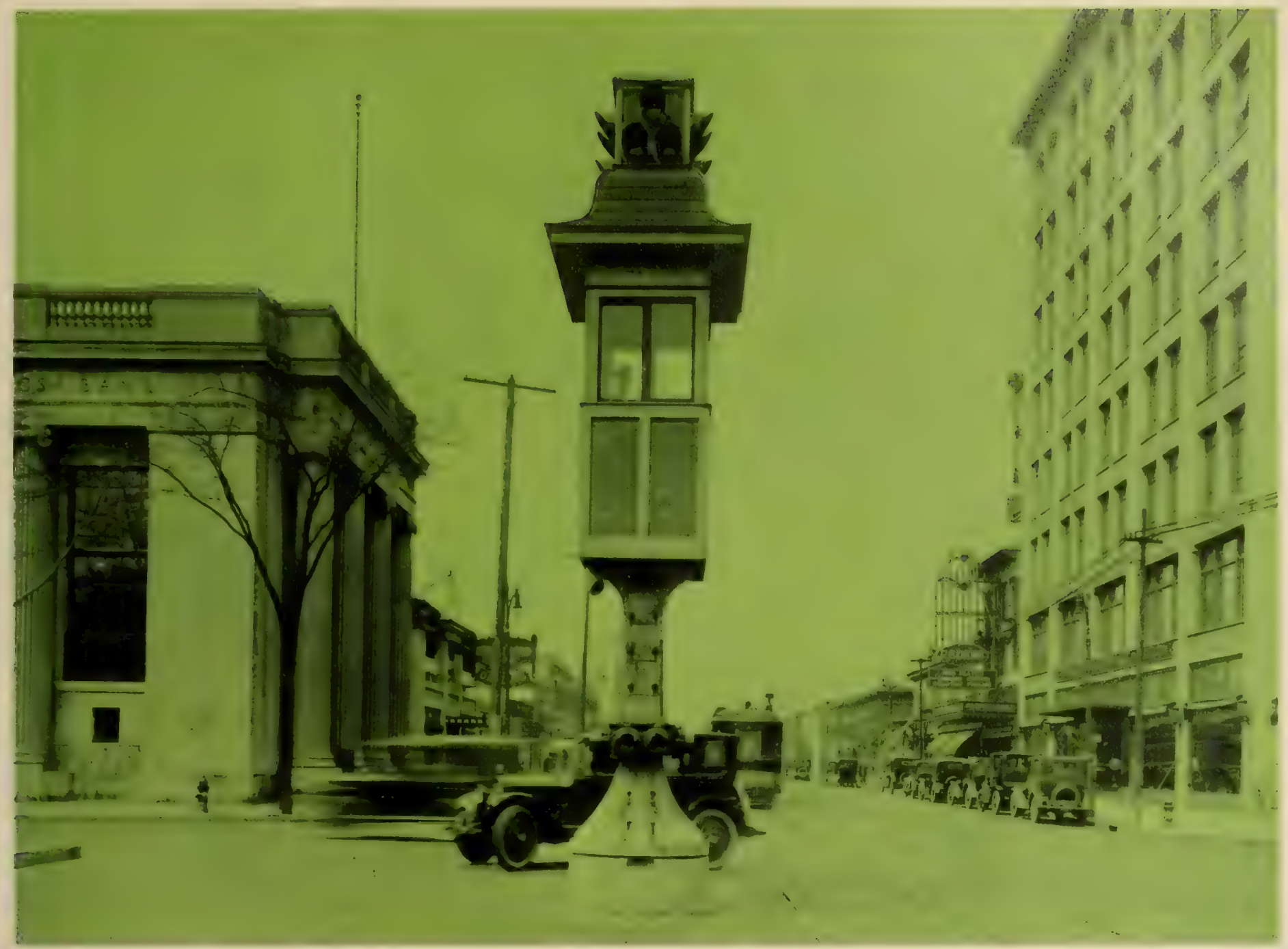

By 1922, fourteen towers of this type had been installed at main intersections in Detroit, Mich.
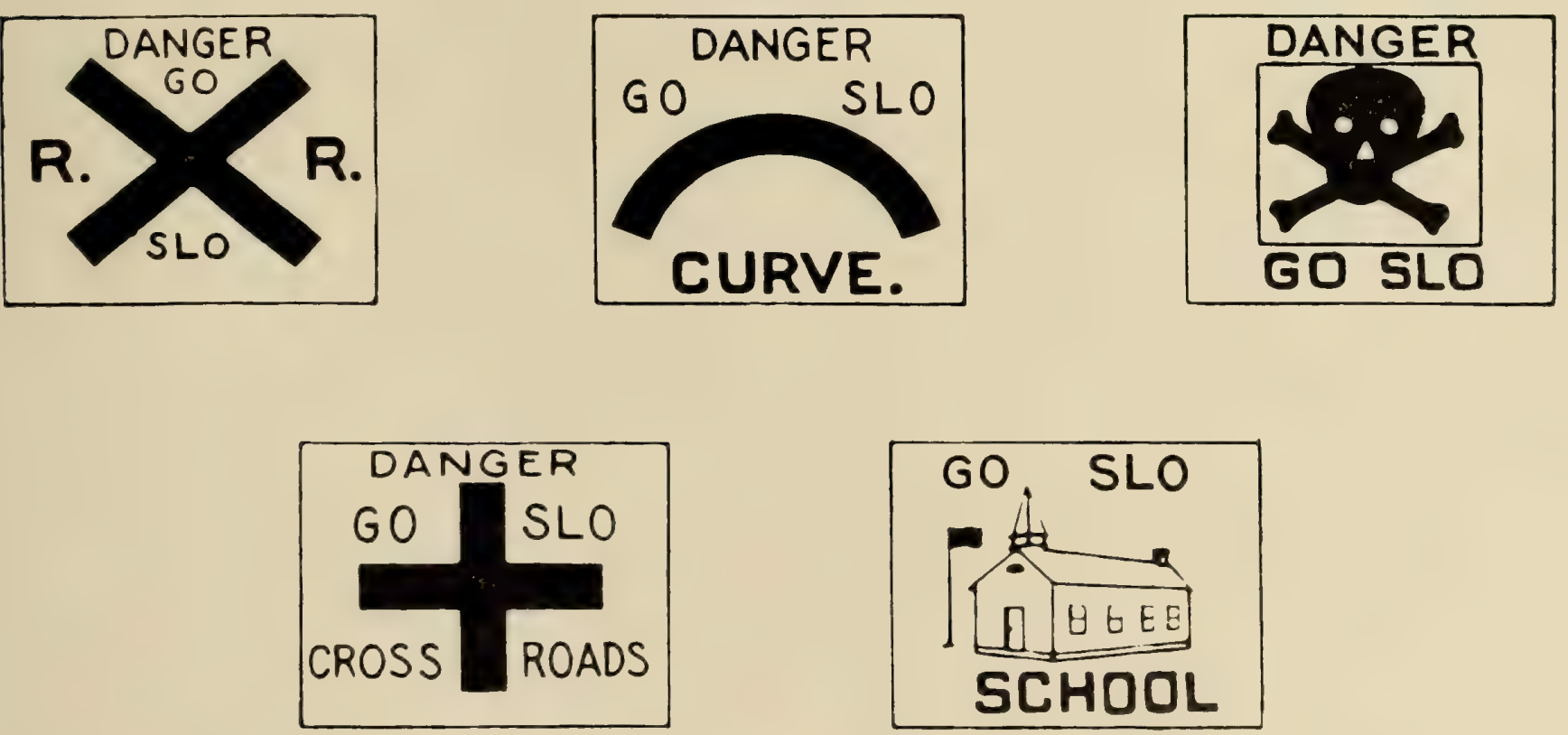

STANDARD DANGER SIGNS - 1919 
At the annual meeting of AASHO in 1924, its Subcommittee on Traffic Control and Safety presented recommendations for standard signs and markings based largely on the work of the Mississippi Valley Association, but incorporating at least one new feature, a color code to distinguish the several types of signs. Acting on an AASHO resolution, the Secretary of Agriculture appointed a Joint Board on Interstate Highways in March 1925 with 21 members from State highway departments and 3 from the Bureau of Public Roads. In October, the Board made its report covering the proposed interstate highway network, the route numbering system, and a comprehensive set of sign designs. The system devised for numbering the interstate network of highways (now called the U.S. Numbered Highways) used even numbers for east and west roads and odd numbers for north and south roads. Long distance routes which might be connected entirely, or nearly so, across the country were given multiple numbers of 10 . The principal north and south routes were given numbers such as $1,5,11,15$. Other numbered routes could be used for shorter lines between the main designated routes.

The Joint Board sign standards followed closely the 1924 Conference recommendations with the addition of the now familiar "U.S. shield" marker for the new network. A yellow background was adopted for all caution and danger message signs, including the stop sign. There were no recommendations on Iuminous or reflectorized signs.

The Joint Board report was submitted to the Secretary of Agriculture and approved by him November 8,1925 . It was accepted at the annual A ASHO meeting a few days later and subsequently adopted by letter ballot of the State highway departments.

During the following year, AASHO developed detailed sign standards and published the first edition (1927) of the Manual and Specifications for the Manufacture, Display, and Erection of U.S. Standard Road Markers and Signs. This Manual set forth the design and use of each type of sign and illustrated most of the approved signs. It listed a series of working drawings of standard signs and alphabets that had been prepared for distribution by the Bureau of Public Roads. Also, it contained detailed specifications for materials and manufacturing of various types of wood and metal signs. This 1927 Manual was the first national rural manual on traffic control signs and markings. A 1929 second edition authorized the use of a luminous element mounted below a standard sign on the same post or on a separate mounting in advance of the standard sign framed with a background of the same shape and color as the standard sign that it supplemented. A 1931 revised edition added a number of new signs, including a new design for junction markers.

Two years after the 1927 AASHO Manual, other officials gathered for urban sign standardization. The National Conference on Street and Highway Safety, recognizing the need for greater uniformity in street

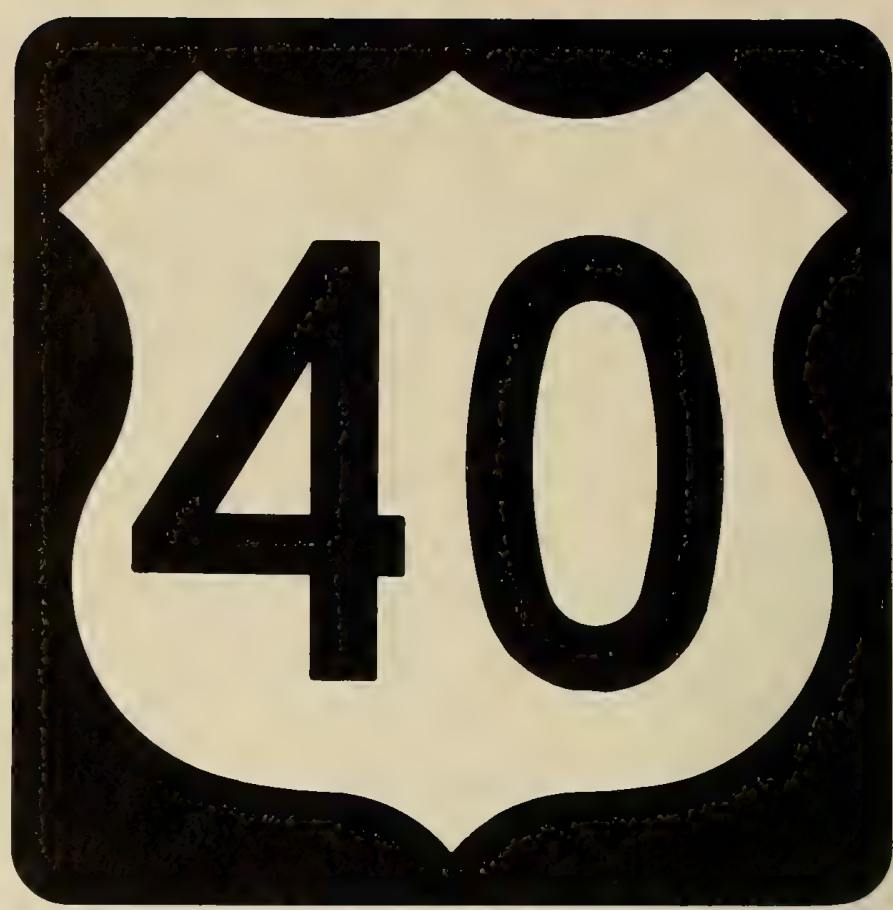

The standardized U.S. route shield.

traffic signs, signals, and markings, accepted an offer of the American Engineering Council to make a national survey of existing conditions and to prepare a recommended practice. The resulting report accepted most of the AASHO Sign Manual standards, but with some exceptions and qualifications. The recommended "stop" sign was to have a yellow background, but the letters were to be red. Eighteen inches was to be the standard outside dimension instead of 24 inches because the generally slower speeds in cities did not require large signs for visibility and the smaller signs would occupy less space. Parking regulation signs and other signs applicable to city use were added. These parking signs were to be 12 by 18 inches with a white background. Red letters were to be used on "no parking" signs, and green letters where limited time parking was permitted. Pedestrian restrictions were to be shown in blue letters on a white background, and other restrictions in black on white.

The urban recommendations also included subjects not dealt with by AASHO, such as traffic signals, pavement markings and safety zones. The signal recommendations included terms, systems, control types, colors, specifications, beacons, and "wigwag" and flashing light train signals. The marking recommendations included pavement lines, railroads, identification, curve lines, words, pavement inserts, paint, buttons, and markings on vertical elements such as obstructions and railroad gates.

The Council's report was submitted and approved by the Third National Conference on Street and Highway Safety in 1930 . Then there were in existence two national manuals, one for rural use and one for municipal use, with some significant differences between them. It was apparent to all that a single manual covering all traffic control devices would be desirable. 
Soon a Joint Committee on Uniform Traffic Control Devices was established, represented by A $\Lambda$ SHO for the rural manual and the National Conference for the urban manual. At the first meeting of the Committee, it was agreed that certain details should be thoroughly investigated before completing the joint sign manual. A project to investigate visibility and legibility of several alternative color combinations by day and night, with and without reflector buttons, was arranged with the Bureau of Standards by the Bureau of Public Roads. The Bureau of Public Roads also made delay studies at traffic control signals. With these and other data, Committee compromise adjustments were worked out and a combined manual was developed. The new manual was approved by the Secretary of Agriculture as the standard code for application on Federal-aid highways; it was published in 1935 as the Manual on Uniform Trafico Control Devices for Streets and Highways (MUTCD).

The new Manual dealt comprehensively with the whole field of traffic control devices. Signs were divided into three classifications-regulatory, warning, and guide. The stop sign retained the yellow background and red letters were accepted as an alternative to the black letters. The railroad crossing sign was a crossbuck to closely resemble the standard railroad advance warning sign. The Manual included new self-evident symbols to indicate crossroads, $\mathrm{Y}$ and $\mathrm{T}$ intersections and side roads. The section on traffic signals supplied long needed guidance on the number, meaning, and arrangement of signal lenses. Green was specified for go, yellow for caution, and red for stop. The Manual provided that each signal should have three lenses since the function of the yellow light could not be attained with a signal having only two lenses.

In 1938 the Joint Committee reexamined the Manual and recommended numerous updating revisions, and a supplement was issued in February 1939.

As one of the aftermaths of the Pearl Harbor attack on December 7, 1941, problems of wartime traffic loomed, especially the altogether new possibility of having to move traffic under blackout conditions. The Joint Committee was revived, this time including the Institute of Traffic Engineers as a member. The "War Emergency Edition" of the Manual, published at the end of 1942, was a condensed version of the previous edition, modified only to deal with blackouts and make certain wartime concessions, such as permissive use of white pavement markings instead of yellow because of material shortages.

In 1944 the Joint Committee agreed that the Manual must be entirely rewritten to include the needs of changed conditions. In 1948, after a wide review, the final draft was approved by the Joint Committee's three sponsoring organizations and by the American Standards Association. That year, also, the National Committee on Uniform Traffic Laws and Ordinances was made a member of the Joint Committee replacing the National Conference on Streets and Highway Safety.
Some of the more significant changes in the 1948 Manual were: a diamond-shaped sign was prescribed for all warning signs (except the circle for the railroad crossing); a new intersection route turn symbol sign was provided; a new "advisory speed" sign was included for use with any warning signs; and the growing need for larger signs was recognized and some of the minimum sizes were increased.

A major change and innovation was made in the next Joint Committee Manual revision of 1955. The stop sign was changed from black on yellow to white on red. The yield sign came into being in the now familiar equilateral triangle with one point downward and used black lettering on yellow as were other warning signs.

In 1955 the MUTCD did not include material for the signing and marking of freeways. The National Joint Committee on Uniform Traffic Control Devices began drafting an extensive addition to the existing manual in 1956 to cover expressway signs as called for by the 1956 Federal-Aid Highway Act. Also in 1956, the American Association of State Highway Officials set up a subcommittee of its traffic committee to develop an Interstate Manual that would "incorporate the best experience from all the higher type toll roads and freeways." The resulting Manual was adopted by AASHO in 1958. In February 1958, the Manual for Signing and Pavement Marking of the National System of Interstate and Defense Highways was approved by the Bureau of Public Roads. A second edition of the Interstate Manual was published in 1961 and a slightly revised edition in 1962.

In the meantime, to provide broader representation, the Joint Committee, in 1960, had enlarged its membership to include the National Association of County Officials (now the National Association of Counties) and the American Municipal Association (now the National League of Cities). The Joint Committee published a new MUTCD in 1961, drawing heavily on the AASHO Interstate Manual for expressway and freeway signing. The new Manual had many refinements, changes in emphasis, and new applications of engineering and psychological research and experience in operations of the substantial mileage of high-speed limited access highways, particularly of toll roads. New features included the use of lowercase letters and green background on freeway directional signs, reflectorization or illumination for the background of overhead signs, and reflectorization of all pavement markings that have application at night. The 1961 MUTCD also included, for the first time, an extensive special treatment of traffic control devices for highway construction and maintenance operations and a group of special signs for emergency civil defense applications. Standards for traffic signals were modernized to keep up with technical advances in that field.

The 1966 Highway Safety Act provided for the first time that specific Federal safety funds be spent by local governments as a step toward reducing the number of accidents. The existing devices on all highways and streets were to be continually reviewed and upgraded. The Federal-aid requirement for uni- 


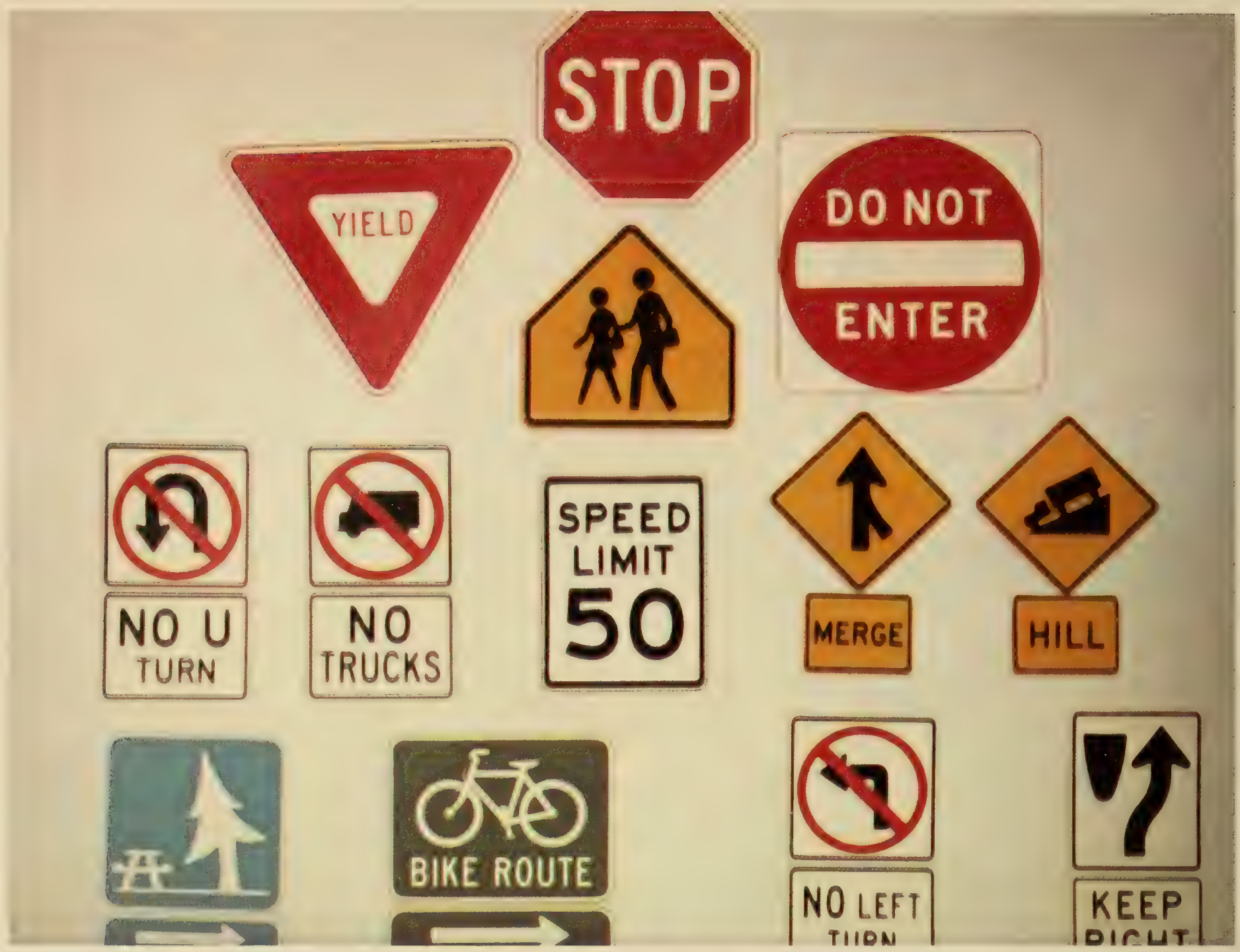

New signs, 1971. Many of the signs combine international symbols and word equivalents.

form traffic control standards was extended to apply to all streets and highways. The Act provided funds for the improvements, which would ultimately place the Nation under one set of traffic control standards.

Using the Joint Committee as an advisory board, a new updated revision of the MUTCD was prepared by the FHWA staff. Issued as the 1971 Manual on Uniform Traffc Control Devices for Streets and Highways, it is now the national standard for all highways open to public travel.

The 1971 MUTCD incorporates significant changes in the wider use of symbols, which are international in character, on both regulatory and warning signs. A separate part covers traffic controls for school areas. A pennant shaped "no passing zone" sign and pentagon shaped school signs were added. For construction and maintenance work, the colors for the warning signs were changed to orange. In the pavement marking area, yellow was added as the color to delineate the separation of traffic flowing in opposite directions. Traffic signal updating included recommending a 12-inch signal face instead of 8-inch for arrows. It emphasizes that engineering study always is an important part of the application of detail standards.

\section{Surfacing and Paving the Highways}

\section{Development of Pavement Design}

The history of the development of highway pavements in the United States to the present stage is a series of incidents that are widespread both in time and place. Once roads advanced beyond the footpaths and horse trails, their improvements into paved highways were successive developmental efforts to match the available manpower, funds and natural resources against the changing needs of the types and extent of vehicular traffic for each area's expanding commerce.

The first "macadam" surface in this country was constructed in 1823 between Hagerstown and Boonsboro, Maryland. Rocks were broken by hand so as not to exceed 6 ounces in weight or to fail to pass a 2-inch ring. The material was laid in three separate strata, the finished surface being 15 inches deep at the center and 12 inches at each edge. The surface was 20 feet wide. ${ }^{42}$

In the forested sections, plank roads were dominant for a period. The first plank road in the United States was opened to traffic in 1846 in Syracuse, New York. Advocates of plank roads made extravagant 
claims as to their superiority over macadam, and lumber being available, thousands of miles were built in many States during the following decade. In a few years, the public discerned that the life of any road is limited by the lasting qualities of the material of which it is built. It took about 10 years for the wooden planks to rot away, and the plank road era ended rather abruptly. ${ }^{43}$

Dust palliatives were applied on gravel and macadam road surfaces as early as 1898. Tar and asphalt were used as protective surface coatings and later as binders.

Bituminous pavements were constructed in Washington, D.C., and New York City as early as about 1870.4 Bituminous macadam experiments began in Boston in 1906, and a 1-mile section was constructed there in $1907 . .^{45}$

Recovering from the ravages of the Civil War, the South needed a road surface that could be built and maintained at a small cost from local materials in general abundance. Sand-clay surfacing, because it was lower in cost, adequate for light traffic, less dusty and noisy, and more resilient than macadam, was the logical answer to the road problems of the South Atlantic and Gulf States in 1885 . It was used widely in these areas.

The first brick pavement on a rural road was placed near Cleveland, Ohio, in 1893. The roadway was 32 feet wide, but the brick pavement, 8 feet wide, was placed near one side of the roadway, leaving the remaining width unsurfaced. ${ }^{46}$

Mention has been made of early macadam, brick, and bituminous surfaces and pavements on rural roads. By the 1890's the heavy-load hauling demands in the large cities had led to construction of heavy street pavement sections of the types which had shown good stability. The horsedrawn drays hauling heavy loads on steel-rimmed wheels had pulverized all but the hardest pavement surfaces. Consequently, the main streets of the large cities were built very heavily and surfaced with granite blocks or hard paving bricks. Concrete bases were used on some. The minor business streets and residential streets were commonly of macadam or gravel. Asphalt paving, begun in the early 1870 's, was immediately popular because of its smoothness, silence, lack of dust, and ease of cleaning. By the 1890 's, many of the city streets were asphalt surfaced to gain these advantages.

Credit for first surfacing a rural public road with portland cement concrete is conceded to Wayne County, Michigan, where a 1-mile section was built in 1909. The pavement was laid in two courses, 18 feet wide and having a total depth of $61 / 2$ inches. The first course was made of $1-21 / 2-5$ mix of portland cement, sand and limestone 4 inches deep and the second course of a 1-2-3 mix of portland cement, sand and crushed cobblestone $2 \frac{1}{2}$ inches deep. It was laid in 25 -foot sections. ${ }^{47}$

The heavy truck traffic during World War I inflicted widespread damage upon surfaces built during the preceding generations to carry horsedrawn vehicles. After the war, there was a public clamor for improved roads, at once and everywhere. Responsible engineers agreed that they lacked the essential information required for the design and construction of a nationwide system of paved highways as envisioned by the framers of the 1916 Federal Aid Road Act. This led to the formulation and carrying out of the continuing and extensive series of engineering research studies by the State highway departments, Bureau of Public Roads and related industry. The Highway Research Board, created in 1920, served to nationally correlate and disseminate the ensuing results of the studies, delving into the proper relationship between highway loads, road surfaces, and subgrades. The system of soil classification and analysis was developed, together with data on the many detailed characteristics of aggregates, materials and mixes under the varied field conditions and traffic loads. Traffic counting and weighing facilities were set up, and the procedures for predicting traffic volumes and loadings were developed and put into use in the late 1930 's.

As the numbers, sizes, weights and speeds of vehicles increased, highway officials struggled to provide pavements with adequate structural strength to meet the demands of traffic. Practices of highway design, construction and maintenance were progressively revised upward. Some of these revisions were the result of practical experience and some were based on results of engineering research. In the 1920 's, many highway engineers recognized that the supporting ability required in the pavement structure of roads was determined principally by the axle loads of the vehicles. There was also general recognition of the need for more factual information on all of the pavement and soil elements.

\section{Design Road Tests}

Beginning in 1920, several research projects using specially constructed test tracks produced significant advances in the science of pavement design and construction. In 1920, the Bureau of Public Roads expedited its field tests on the large circular track containing different pavement sections at Arlington, Virginia. Experimental roads were constructed in 1921 by the Columbia Steel Company cooperating with the California Highway Commission at Pittsburg east of San Francisco. The Bureau of Public Roads intensified its laboratory tests and initiated a countrywide field study of subgrade soils. Universities became beehives of research activity. One major effort to obtain such information was the Bates Experimental Road, a test conducted by the Illinois Division of Highways in 1922 and 1923 near Springfield, Illinois, on a $21 / 2$-mile roadway divided into 63 test sections of varied materials and design. ${ }^{48}$ The test vehicles were trucks with solid rubber tires on which wheel loads were increased from 2,500 to 13,000 pounds as the testing progressed.

Within a few years, there were four principal types of findings: (1) Subgrade soil tests were developed which, together with traffic studies and other information, became valuable aids in pavement design. (2) The destructive impact of the solid rubber tire was isolated and overcome by the introduction of the softer pneumatic tire. (3) Agreement was reached on the 9,000-pound wheel load as a logical basis upon which to plan a long-term paving program. (4) The thickened edge design of rigid pavements was adopted. These findings soon brought about the adoption of laws regulating vehicle weights. 
The Baltimore-Washington Boulevard was greatly damaged by World War I truck traffic

$B y 1930$, the same stretch of road had been resurfaced with bituminous concrete and widened by the construction of two

10-foot concrete shoulders.
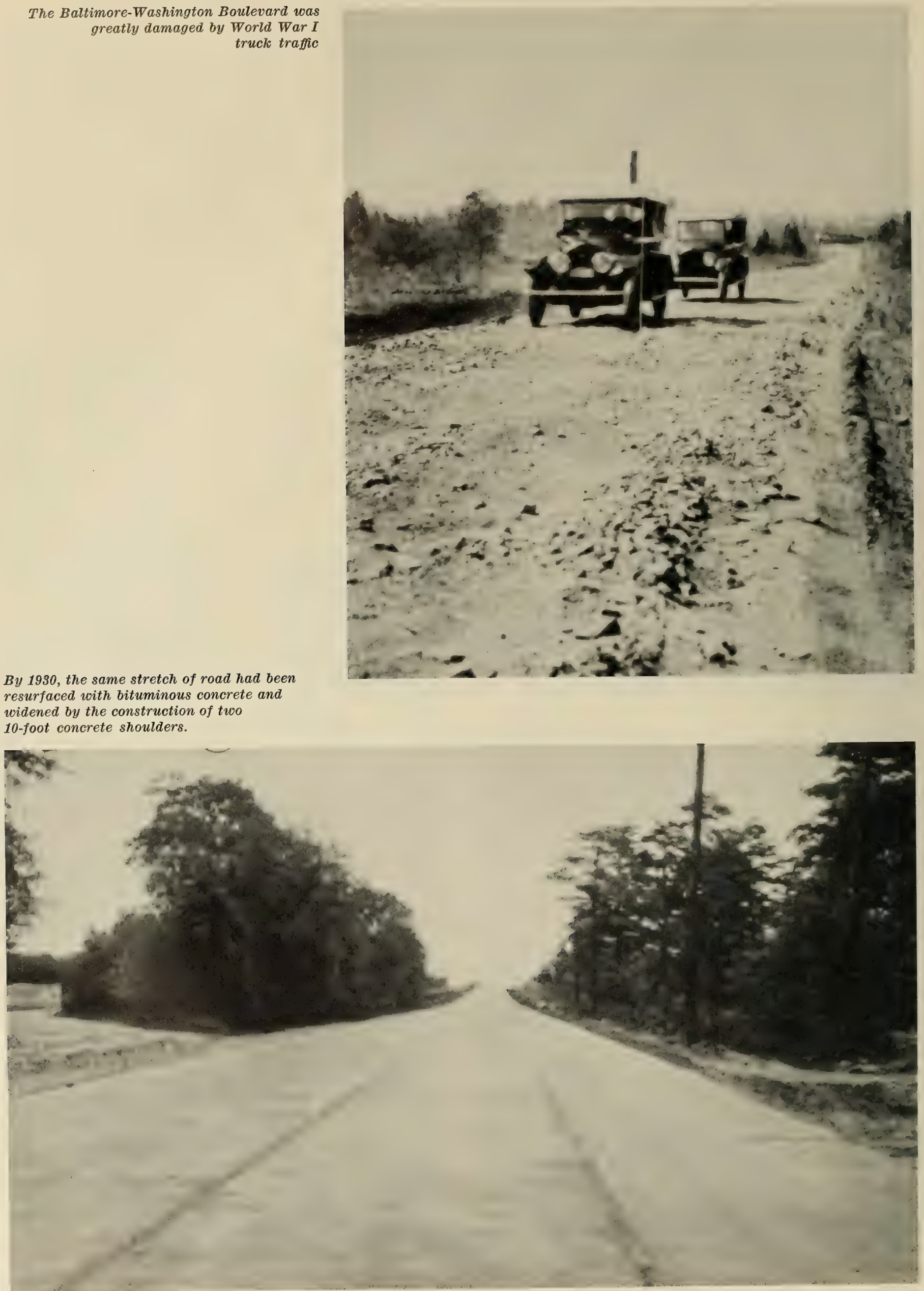


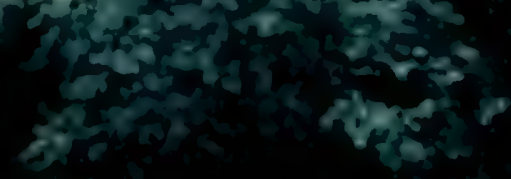

ats.
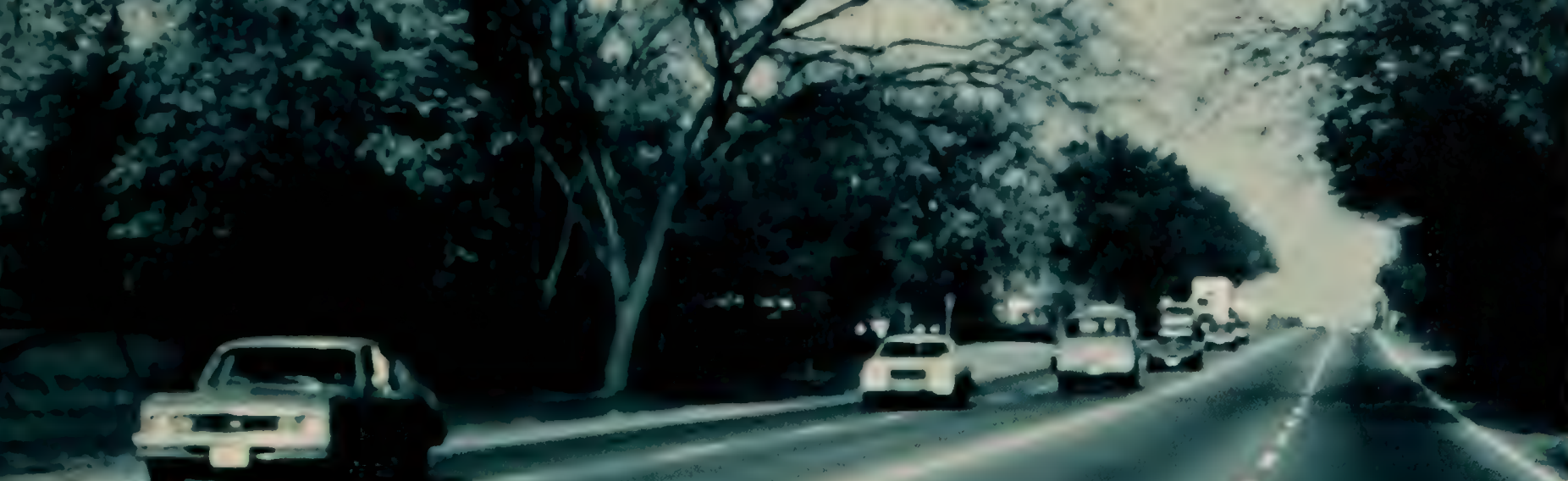

$$
\text { , } x
$$
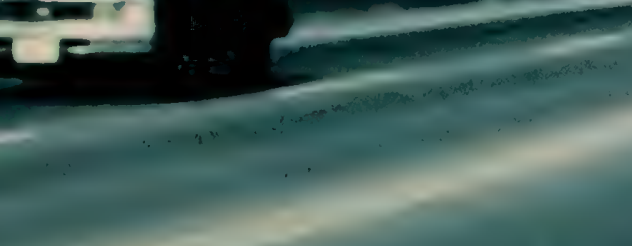
Aware of the need for uniformity of State motor vehicle weight regulations, the Governors Conference, in 1949, requested a study of the matter. This study resulted in a rigid pavement test road being established in Maryland, with participation by 11 State highway departments, the District of Columbia, the Bureau of Public Roads, auto manufacturers and the petroleum industry. The purpose of the testing program was to determine the relative effects of various axle loads and configurations on distress of rigid pavement. The findings supplied extensive data on the factors to be used in the design of rigid pavements. ${ }^{49}$ Especially significant were those factors regarding support material characteristics.

The Western Association of State Highway Officials constructed a test road in Idaho in 1951 to aid in establishing load limits and to develop rational design methods for flexible pavements. A number of specially designed and constructed bituminous pavements were carefully observed under the repeated application of a number of selected heavy axle loads. The findings provided significant information on the materials and soil parameters for designing flexible pavements, especially in the western States where soil conditions are similar. Also the surfaced shoulder was found to contribute to the pavement structural stability. ${ }^{50}$

In 1955, the American Association of State Highway Officials undertook the AASHO Road Test at a selected site near Ottawa, Illinois, with the Highway Research Board accepting the responsibility of administering the project. Various heavy truck loads were operated on specially constructed pavement sections of both rigid and flexible types until they reached a failure stage. A vast amount of data was collected and analyzed, providing engineering facts for highway design and construction nationwide. In addition, the test findings were aimed at determining maximum desirable weights of vehicles to be operated on Federal-aid highways, including the Interstate System, and determining an equitable distribution of the tax burden among various classes of persons using Federal-aid highways.

The findings of the AASHO Road Test were summarized and prepared in the form of design equations and graphs and made available to the States in 1962 , but it was not until 1973 that the data was updated and published by AASHO as Interim Guide for the Design of Rigid Pavement Structures. The equations and graphs incorporated the research data for design factors such as traffic, soil support and material strengths. The guide today represents the major current data available for broad application in designing pavements and is used by the Federal Highway Administration to measure the adequacy of the States' proposed pavement designs for use on Federal-aid highways.

Present day pavements consist of layers of bituminous materials or portland cement concrete, plain or reinforced, with thicknesses ranging up to 10 inches; in some instances, unusually high truck loadings call for even greater thicknesses. Most pavements today include a subbase which is a stratum of material 4 to 20 inches thick between the pavement and natural subgrade. This subbase is a granular material sometimes treated for stabilization with either cement or asphalt. Design criteria, which account for soil support values, material strength characteristics and traffic, are used to determine the thickness of the pavement subbase.

\section{Highway Development Record}

The records of the development of roads and streets in the United States show a progressive increase in the total mileage and a continued conversion from the lower to higher surfacing and pavement types. The actual rate of development and change reflects not only the increase in funding for public highways to serve the rising traffic needs, but also the findings from research studies on surface materials, aggregates, reinforcements, mixes, construction and maintenance.

In 1904 there were about 2.35 million miles of public streets and highways. From 1910 to 1920 the total increased rapidly to about 3.2 million miles in all stages of improvement, ranging from primitive trails to highly improved urban thoroughfares. In 1920, 425,000 miles had some form of surfacing. Since 1950 the total mileage has increased consistently to the 1973 total of 3.8 million miles. The urban mileage has been expanding somewhat more rapidly than the rural mileage, particularly since 1950 .

About 90 percent of the total road mileage was not surfaced in 1904. During the total mileage expansion in the teens, the nonsurfaced mileage actually increased, but the construction programs resulted in a gradual proportional decrease to about 80 percent in 1925. Since then the nonsurfaced mileage has decreased rapidly to about 20 percent in 1973 .

Since about 1920 the total surfaced mileage has been increasing steadily to the 1973 total of 3.17 million miles. The gravel surfacing type has been dominant. Since about 1935 the rate of surfacing urban highways has been somewhat more rapid than that for the rural mileage.

The mileage of rural gravel-type surfaces (soil, slag, gravel and stone) increased regularly to about 1960. Since 1962 this type has been decreasing. It should be noted that the increase in gravel mileage up to 1960 was over and above the mileage that was upgraded to higher surface types. From 1935 to 1955 the rural gravel improved mileage was from 3 to 4 times that of the low bituminous mileage. The record on urban gravel mileage shows little change from 1941 to 1973 , with a continuing total of 70,000 to 80,000 miles.

The low bituminous* rural mileage jumped substantially during the 1930 's and increased steadily until the late 1960 's, when it leveled off. In the urban areas, the low bituminous mileage continually increased.

The high bituminous** rural mileage followed the upward trend of low bituminous type, with totals only about half to two-thirds that of the lower type. The decided increase about 1950 corresponds with the decrease in the low bituminous type. This type continued the upward trend the last few years, as distinct from the low bituminous mileage.

\footnotetext{
* Having a combined surface and base thickness less than 7 inches and/or low load-bearing capacity.

** Having a combined surface and base thickness 7 inches or more and/or a high load-bearing capacity.
} 


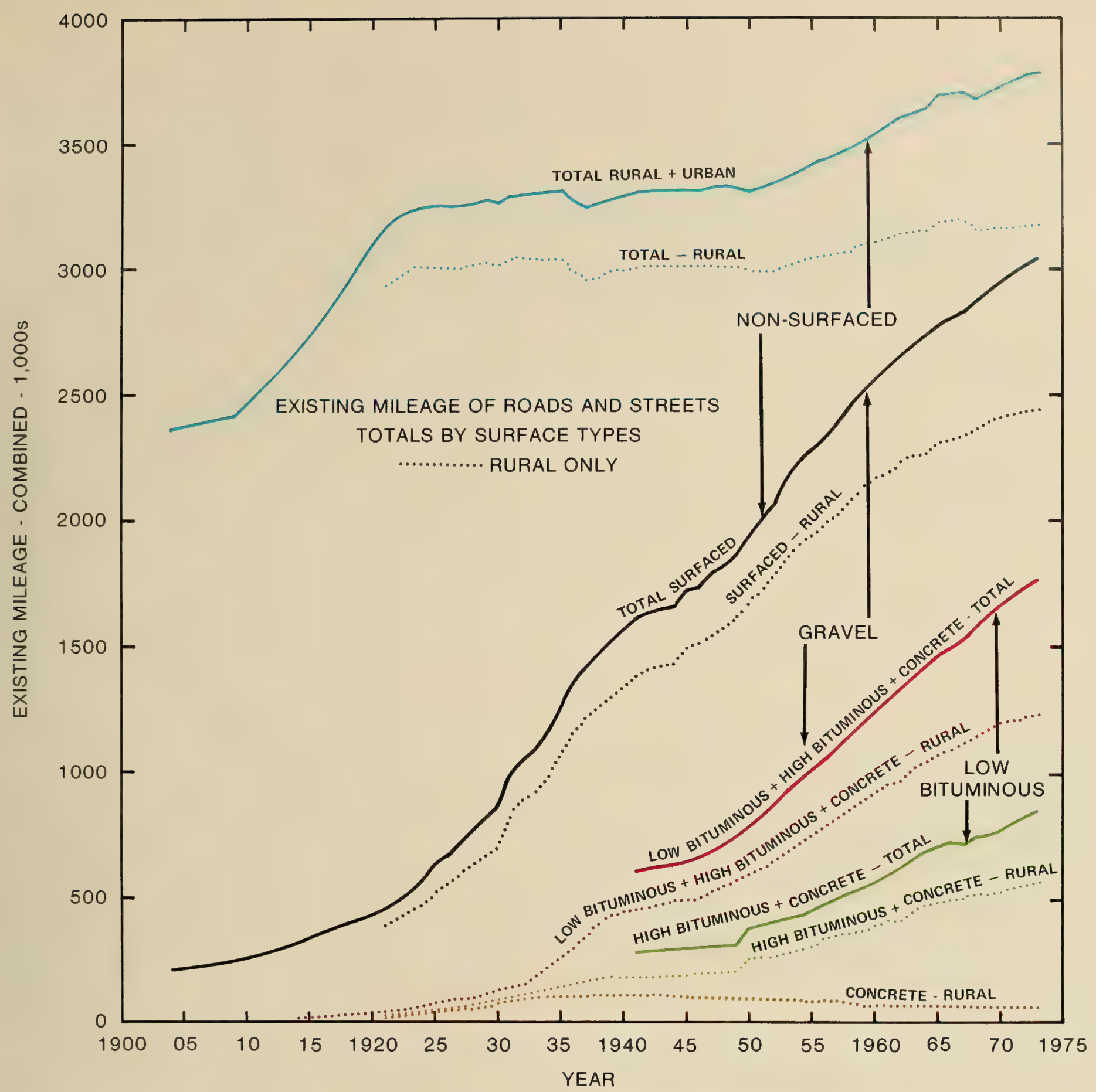

SOURCE: "HIGHWAY STATISTICS," ANNUAL PUBLICATIONS 1945- 1973.

The mileage record of the concrete type differs considerably from the other types. For the rural mileage during the 1920's and early 1930 's, the total exceeded that of both bituminous types. The existing rural concrete pavement mileage increased until 1935 , leveled off for some 10 years, and since has decreased.

The mileage decrease for rural concrete pavements reflects the conversion of sections of that type of pavement to the high bituminous type when an overlay was placed as a maintenance step. The existing urban concrete mileage for the last 16 years shows no increase, the mileage being only half or less those of bituminous pavements. The overlay conversion effect doubtless applies here also.
Proportionally, there has been substantially higher type development of road and street mileage in the urban area. The percentages of the 1973 mileages for the various types were:

$$
\text { (1,000's) }
$$

Percentage by Type:

Nonsurfaced

surfaced :

Gravel

Low Bituminous

High Bituminous

Concrete

Total Surfaced
State Highway

Total Rural Urban Systems

$3,807 \quad 3,176 \quad 631 \quad 764$

$\begin{array}{llll}20 & 23 & 4 & 3\end{array}$

$\begin{array}{llll}34 & 38 & 11 & 8\end{array}$

$\begin{array}{llll}24 & 21 & 40 & 33\end{array}$

$\begin{array}{llll}19 & 16 & 36 & 48\end{array}$

$\begin{array}{llll}3 & 2 & 9 & 8\end{array}$ 


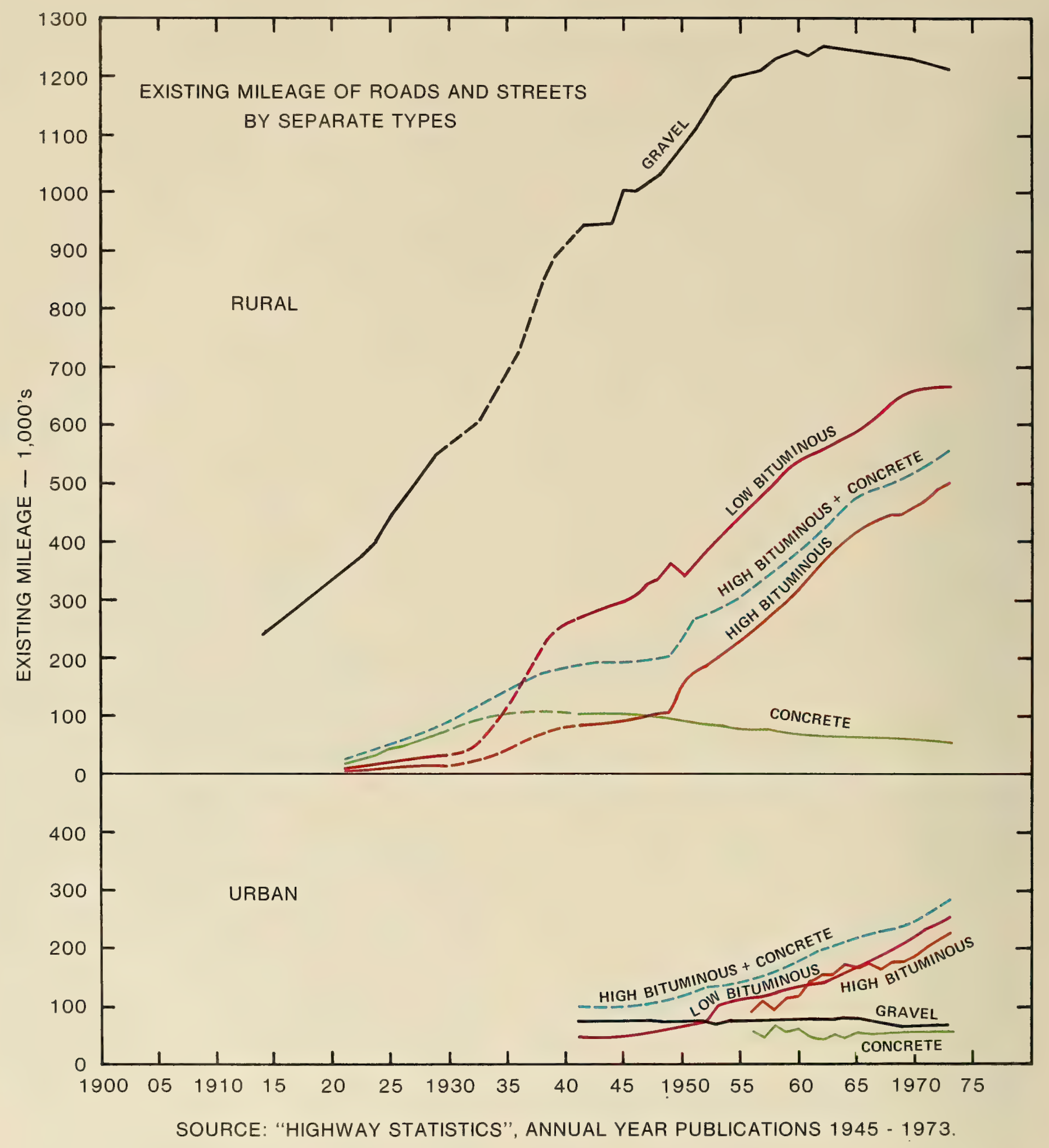




\section{REFERENCES}

'Second Biennial Report of the Departanent of Public Roads Made to the Governor and General Assemblx of KENTCCKY-Nov. 1, 1913 to Nov. 1, 1915 (The State Journal Co., Frankfort, $\mathrm{Ky} ., 1915)$ pp. 35, 36.

2 Fifth Report of the Ilimois State Highway DepartMENT For THE YEARS 1913, 1914, 1915, 1916 (Illinois State Journal Co., Springfield, IIl., 1917) p. 135.

${ }^{3}$ Sixteenth AnNual Report of the Division of HighWAYs-Jan. 1, 1933 to Dec. 31, 1933 (Illinois Department of Public Works and Buildings, Springfield, Ill., 1933) p. 10.

- Official Automobile Blue Book, various volumes for the year 1920 (Automobile Blue Book Publishing Co., New York).

${ }^{5}$ M. DUERKSEN, The Story of Abner Doble and His Magnificent Steam Cars, CARS \& PARTS, Jan. 1975, p. 102.

${ }^{6}$ Report of the State Highwax Commission of Munnesota, 1915-1916, (Mar. 1, 1917) p. 18.

${ }^{7}$ Fourth Annual Report of the Division of HighwaysJul. 1, 1920 to Dec. 31, 1921 (Illinois Department of Public Works and Buildings, Springfield, Ill., 1922) p. 9.

${ }^{8}$ Eleienth AnNual Report of the Division of HighwaysJan. 1, 1928 to Dec. 31, 1928 (Illinois Department of Public Works and Buildings, Springfield, IIl, 1929) p. 25.

- First Biennial Report of the California Highway ComMission, 1917-1918 (State Printing Office, Sacramento, Calif., 1919) p. 51.

${ }^{10}$ Biennial Reports of the State Highway Commission, CoMmonwealth of Kentucky, various years from 1915 to 1921 (The State Journal Co., Frankfort, Ky.).

${ }^{11}$ ANNuAl Reports of the Division of Highways, various years from 1915 to 1921 (Illinois Department of Public Works and Buildings, Springfield, Ill.).

${ }^{12} I d$.

${ }^{13}$ Report of the State Road Commission of Marylaind For the YEARS 1927, 1928, 1929 and 1930 (Baltimore, Md., Oct. 1, 1930) p. 85 .

"ANNual Reports of THE Dryision of Highways, various years from 1921 to 1930 (Illinois Department of Public Works and Buildings, Springfield, Ill.).

${ }^{15}$ Report of the Commissioner of Highways of Minnesota For 1920 (Mar. 1, 1921) p. 4.

${ }^{16}$ Seventh Annual Report of the Division of HighwaysJan. 1, 1924 to Dec. 31, 1924 (Illinois Department of Public Works and Buildings, Springfield, Ill,, 1925) p. 1.

${ }^{27}$ Seventeenth, Eighteenth and Nineteenth Annual Reports of the State Highway Commisston For the Years 1924, 1925 and 1926 to the General Assembly of Maryland (Baltimore, Md., Jan. 1927) p. 12.

${ }^{18}$ Standards Approved by the American Association of State Highway Officials During the Year 1928, American Highways, Vol. 7, No. 4, Oct. 1928, p. 21.

10 AIrcraft YEARBooK, 1927 (Aeronautical Chamber of Commerce of America, Inc., New York, 1927) pp. 96, 97.

${ }^{20}$ A Policy ON Highway Classification (American Association of State Highway Officials, Washington, D.C., 1940) pp. 1, 2, 7, 8 .

${ }^{21}$ A Poldcy ON Sight Distance For Highways (American Association of State Highway Officials, Washington, D.C., 1940) pp. 4, 17
${ }^{22} I d .$, p. 15.

${ }^{23}$ A Policy ON Highway Types (Geometric) (American Association of State Highway Officials, Washington, D.C., 1940 ) pp. 65-69.

${ }^{24}$ A. LuEdKe \& J. HARrison, Superelevation and Easement as Applied to Highway Curves, Public Roads, Vol. 3, No. 31 , Nov. 1920 , pp. 3-12.

${ }^{25}$ R. MoXER, Further Skidding Tests With Particular Reference to Curves, Proceedings, 14th Annual Meeting, Vol. 14 (Highway Research Board, Washington, D.C., 1934) p. 129.

${ }^{26}$ J. BARNet, Safe Side Friction Factors and Superelevation Design, Proceedings, 16th Annual Meeting, Vol. 16 (Highway Research Board, Washington, D.C., 1936) pp. 72, 73.

${ }^{27}$ A. BRuce, The Effect of Increased speed of Vehicles on the Design of Highways, Public Roads, Vol. 10, No. 1, Mar. 1929 , pp. 15,16

${ }^{28} \mathrm{H}$. KEISEY, The Future of Roadside Development in Massachusetts, (Address delivered at the annual meeting of the Massachusetts Forest and Park Association in Boston, Mass., Feb. 6, 1936) pp. 1, 2.

${ }^{29}$ Interkegional Highways, H. Doc. 379, 78th Cong., $2 d$ Sess., p. III.

${ }^{30}$ A Policy On Design Standards (American Association of State Highway Officials, Washington, D.C., 1941) p. 5.

${ }^{31}$ Traffic Devices: Historical Aspects Thereof (Institute of Traffic Engineers, Washington, D.C., 1971) p. 81.

${ }^{32}$ Id., p. 82.

${ }^{\mathrm{a}}$ Id., p .103.

${ }^{34}$ C. Borth, Mankind ON THE Move (Automotive Safety Foundation, Washington, D.C., 1969) p. 204.

${ }^{35}$ ITE, supra, note 31 , p. 24.

${ }^{36} I d .$, p. 35.

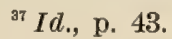

${ }^{38} I d .$, p. 35.

${ }^{39} I d$., pp. $82-84$.

${ }^{40}$ Report of First National Conference ON Street and Highway Safety, Washington, D.C., Dec. 15-16, 1924, p. 21.

${ }^{41} I d .$, p. 26.

42 A. Rose, Historic American Hrghways-Public Roads OF THE PAST (American Association of State Highway officials, Washington, D.C., 1953) pp. 52, 53.

${ }^{43} I d .$, p. 70.

${ }^{44}$ Fundamentals of Asphalt Paving (The Ohio Oil Company, 1949) pp. 18, 19.

${ }^{45}$ A. Rose, supra, note 42 , p. 105.

${ }^{40}$ Id., p. 97.

47 Third Annual Report of the Board of County Road Commissioners of WAyne County to THE BoARd of SuPERyisors of WAyne County-From Sept. 16, 1908 to Sept. 30, 1909 , p. 23.

${ }^{48}$ C. Older, Official Conclusions From the Bates Road, PUBLIC Works, Vol. 54, No. 1, Jan. 1923, p. 13.

${ }^{49}$ Final Report ON Road Test ONe-Mo.: Effect of Controlled Truck Axle Loadings ON Concrete Pavement, Special Report 4 (Highway Research Board, Washington, D.C., 1952) pp. 7-11.

${ }^{50}$ The Washo Road Test-Part 2, Test Data, Analyses, ANd Findings, Special Report 22 (Highway Research Board, Washington, D.C., 1955) pp. 4, 5. 


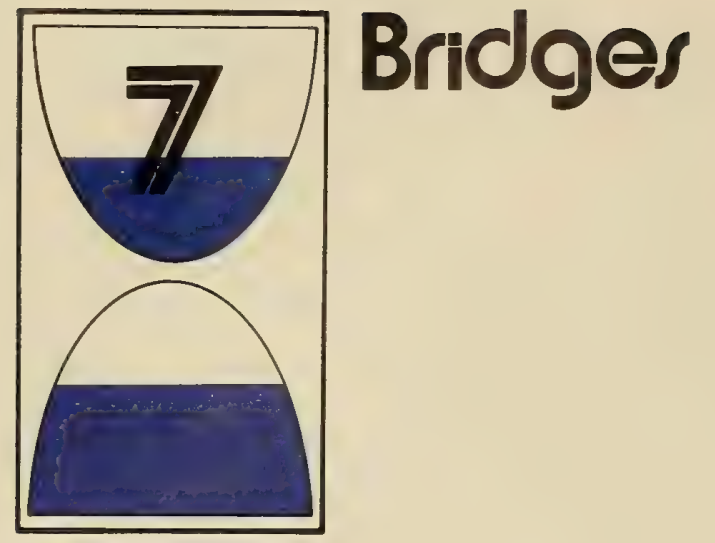

Pre-1776 Bridges

History teaches that all sciences and arts, including bridge design and construction, benefit from the innovations, successes and failures of the past. This presupposes a tradition of learning not always available to the American colonists. The first bridges in this country were often built by untrained persons inexperienced with the difficulties and problems of constructing a bridge of adequate strength and reasonable durability. Instead, they substituted determination, native ingenuity, and more determination.

Economics and material availability generally limited the colonial bridges to timber or stone construction with timber being predominant. This was largely due to the greater time and labor required to quarry and transport stone. From this lowly beginning, the complex design, construction and material sciences have developed.

The existing bridges in the American colonies in 1776 were few and minor in size. At that time, all major cities and most towns and villages were located on navigable waterways, since the waterways offered the most practical transportation between populated areas. Barges, boats, canoes and fords were mainly used where roads crossed the waterways. As the population centers developed, some timber bridges were built over adjacent narrow waterways by local authorities to facilitate access by travelers and commercial goods.

Generally, the bridges had log beam spans and were limited to the length of timber available from local trees. Abutments at the stream banks were timber mud sills, wooden cribs, or dry stone masonry where stone was available. Where more than one span was required, timber pile bents, wooden cribs or wooden mud sills were used for piers in the stream bed. The cribs were usually braced and filled with rock or compacted earth. The life of these bridges was usually short due to the rapid deterioration of the timber and the washing out of the foundation structures. Some floating bridges were constructed, usually of large logs fastened together.

It is interesting to note that the Concord Bridge, at which the homespun New England "Horatius" fired "the shot heard round the world," was a timber beam and pile bent structure very similar to the Sublician Bridge defended by his Roman prototype nearly 2,000 years before.

Since the waterways were the main and pre-existing arteries of travel and commerce, any bridges built over navigable waterways required openings and clearances adequate for the passage of the waterway traffic, whether sailing ships, barges, canoes or $\log$ rafts. Where the horizontal and vertical clearances of fixed spans were not adequate for such passage, 


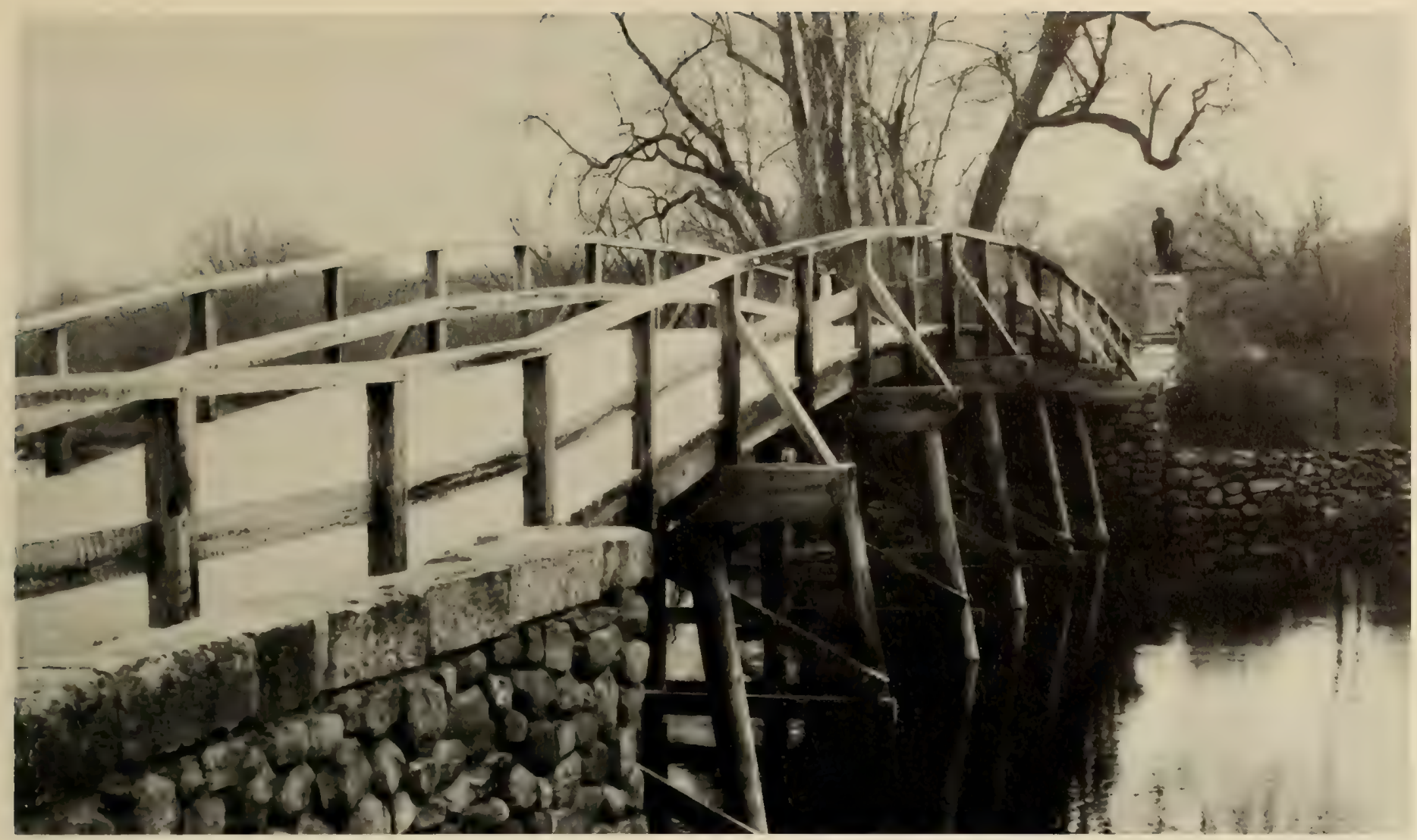

Reproduction of historic timber beam and pile bent bridge at the original site in Concord, Mass.

movable spans were used. These were most likely single or double leaf bascules (hinged sections) operated manually. Floating bridges were provided with sections that could be hinged or pulled out of place to permit the passage of waterway traffic. ${ }^{1}$

Some short span stone arches were built, mainly in the colonies north of the Potomac River.

\section{Timber Bridges 1776-1916}

King-post or queen-post trusses (actually simple braced beams) were in early use for short spans. However, the very common pier washouts experienced by multispan beam bridges, plus the increasing knowledge of the society in general, led to the development of timber trussed arches that could span wide rivers. A New England millwright named Timothy Palmer built a series of patented trussed arches very like one of those illustrated in Palladio's Treatise on Architecture (1570). The best known was the 244-foot span across the Piscataqua River near Portsmouth, New Hampshire, built in $1794 .^{2}$ The roadways were supported on the lower chords of the structure, resulting in steep grades ascending to the center from each end of the spans. These bridges being true arches, provision was made for their horizontal thrust to be transferred to the substructure.

Besides Timothy Palmer, two other men, Louis Wernwag and Theodore Burr, stand out as the first professional bridge builders in the United States. These men shared several things in common-they were, of course, contemporaries, their structures were all highly indeterminate combinations of trusses and arches, and they most likely did not have the theoreti-

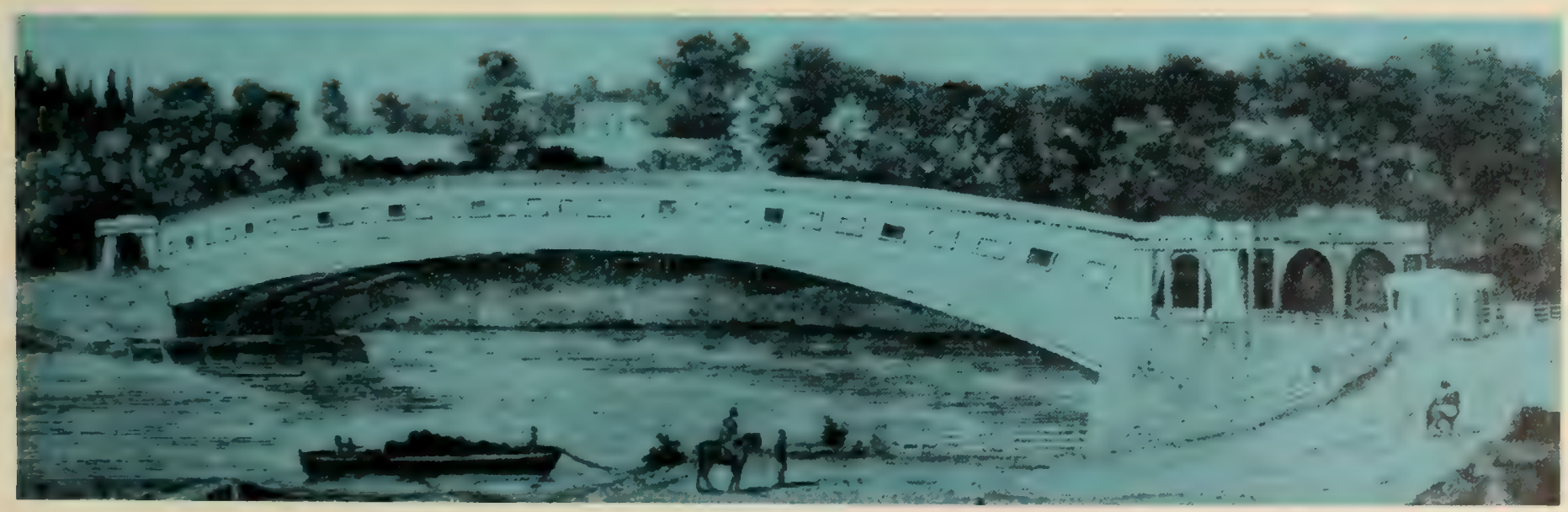

The Upper Ferry Bridge over the Schuylkill River, Philadelphia, Pa., was a covered timber trussed arch created by Lewis Wernwag in 1805. 


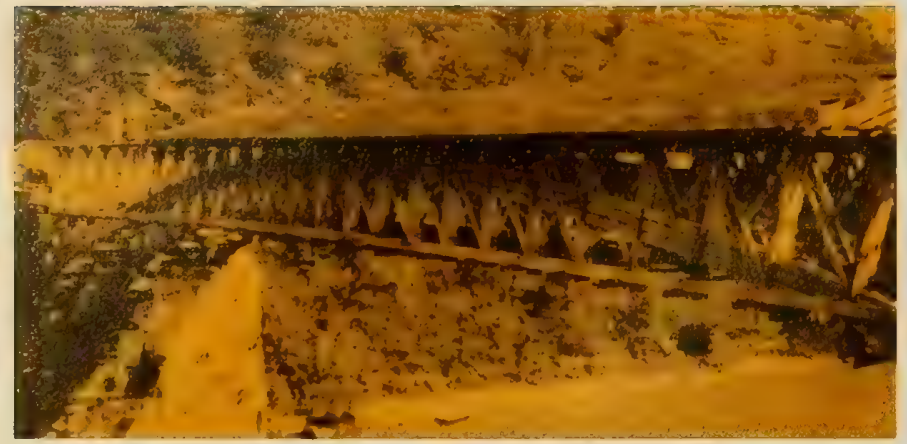

Camp Nelson covered arch-truss over the Kentucky River during razing in 1939. The three trussed 240-foot span bridge was built by Wernwag in 1838 and closed to traffic in 1926.

cal knowledge to analyze such structures. They were virtually carpenters building bridges in accordance with their own experience or that related by others, and they were among the group that produced the distinctly American bridge characteristic, the covered bridge. Their pieturesque practice was, of course, a sound and practical measure that extended the life of the wooden structure immeasurably.

The first of many covered bridges in America was built in 1800 by Palmer at Middle Ferry, Philadelphia, Pennsylvania. ${ }^{3}$ The covering protected the bridge members from decay to the extent that a properly maintained bridge would give many years of service. The Waterford Bridge over the Hudson River, a covered wood truss bridge built by Theodore Burr in 1803-4, had a service life of 105 years (it was destroyed by fire in 1909). ${ }^{4}$

The steep roadway grades of the trussed arches were objectionable, and by the beginning of the 19th century, a combination truss and arch was developed with the roadway supported by the lower chords and having only a slight longitudinal camber. The height or rise of the timber arch was about equal to the depth of the truss, with the arch fastened to the truss web members at all intersections. The Susquehanna River bridge at McCall's Ferry, Pennsylvania, built in 1814-15 by Theodore Burr, contained a truss-arch with a 367-foot span said to be the longest then built in America. ${ }^{5}$ Burr's bridge represented a small, but significant, change - the arch was added to the truss.

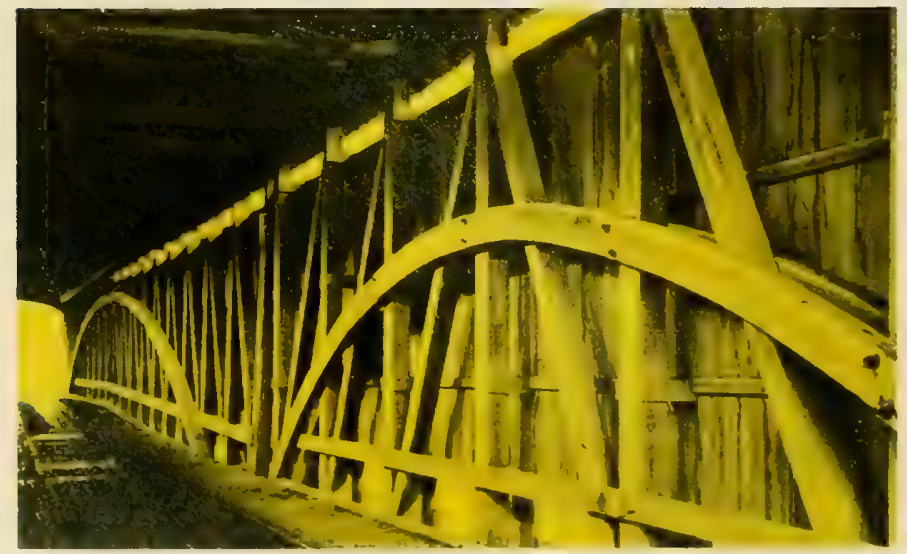

Inside view of typical Indiana covered bridge, built in 1900, showing arch-truss details.

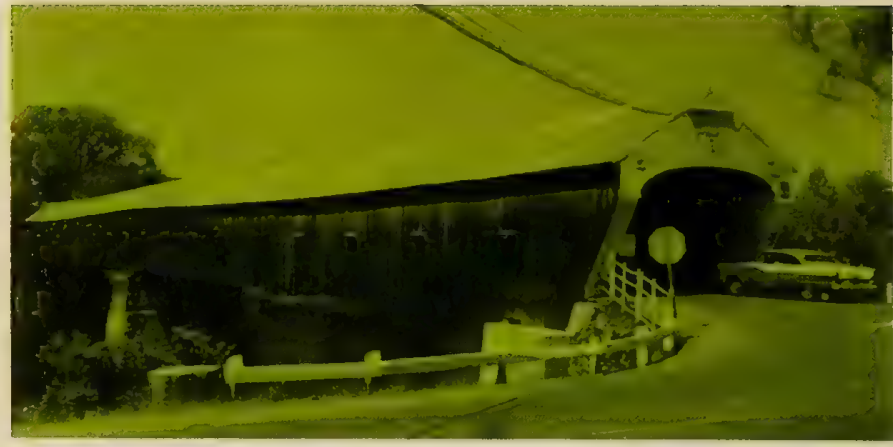

Covered timber truss bridge over the Connecticut River between Cornish, N.H., and Windsor, Vt. Built in 1866, this 460-foot long, two-span Town truss structure is said to be the longest timber briage remaining in this country.

In 1820, Ithiel Town patented a timber lattice truss, although lattice trusses had been built in Vermont as early as $1813,{ }^{6}$ and in 1829 Colonel Stephen H. Long developed a panel truss with double diagonals, similar to a Howe truss. ${ }^{7}$ These trusses could stand by themselves, and arches were not necessary. Thus, the truss bridge appeared in a recognizable modern form.

The web members, diagonals and verticals of the earlier trussed arches and truss-arches were made of timber. Some of the later web systems used iron rods for tension verticals, diagonals and counters in the web system. There were many other variations of the truss besides those mentioned. Due to intensive promotion, the various types were identified by the name of the developer. When iron and steel trusses were developed, the timber truss designations were given to the corresponding geometric metal trusses, i.e., Howe, Pratt, Fink, etc. Connections of members were made by bearings of timber, forgings, iron bolts and spikes, mortises and tenons, and hardwood dowels.

The layout and relative position of the trusses and arches, the proportioning of the members, the methods of support of the floor system, and type and magnitude of the connections were determined by the experience and preference of the builder. There was no published method of stress analysis available to the builders for proportioning members and connections until Squire Whipple's publication in 1847, An Essay on Bridge Building, and Herman Haupt's General Theory of Bridge Construction in $1851,{ }^{8}$ although it appears that Colonel Long may have used mathematical theory in the design of his bridges. ${ }^{9}$

While the timber bridge had evolved into an almost determinate, fully utilitarian structure, it was not free of problems. Covering the truss with a roof and siding had retarded deterioration, but there were still many failures of covered timber trusses due to lack of maintenance, fires, floods, overloads, and inadequate design. Nonetheless, the covered bridge era might have lasted until the coming of the automobile were it not for a combination of events that led bridge designing into the modern era. The newly developed truss and the fledgling analytic methods found themselves a new client, the railroad. Trains being unable to ford even small streams or tolerate the sinuous alinement and steep grades used by pedestrians and wagon traffic, a great many bridges were needed, and not only more bridges, but stronger and more durable ones. This accelerated the growth of design technology. 
As far as durability was concerned, early attempts at increasing the life of timber in contact with earth and water achieved little success. Methods used included dipping, soaking or brushing the timber with creosote or salts, such as zinc chloride or mercuric chloride. These methods were ineffective due to the lack of penetration and leaching out of water soluble preservatives.

While the railroads were especially desirous of finding a satisfactory method of prolonging the life of the great number of ties and timber structures on their systems, it was not until 1865 that the first pressure creosote treatment plant was constructed at Somerset, Massachusetts, primarily to treat timber track ties. ${ }^{10}$ Other plants were constructed soon thereafter for treatment of ties, piles and timber.

With the advent of timber treatment plants to supply the railroads, treated timber piles and lumber became available for use on highway structures, but by then the use of metal in trusses was becoming more common.

The general use of timber trusses for highway bridges continued to the 1880 's, but gradually decreased until by 1916, there were practically none. However, such construction has continued in isolated areas where timber was readily available and in scenic areas as tourist attractions.

\section{Cast-Iron, Wrought-Iron and Composite Wood Bridges and Metal Bridges}

The use of iron for incidental connecting parts was introduced early in the construction of timber bridges since it facilitated construction, improved the rigidity of the structure and reduced maintenance problems. Wernwag used iron rods for the light web diagonal of his Upper Ferry Bridge, popularly named the "Colossus," in 1806."

Soon after the railroad era started in 1827 , bridge engineers realized that the timber truss-arch bridges were not serving satisfactorily under the speed and weight of railroad traffic and sought various methods to introduce iron members into the truss arch. Such structures were called combination bridges.

One of the early combination bridges was a through timber truss-iron arch bridge, a 133-foot span, carrying the Pennsylvania Central Railroad over a canal. The bridge was so constructed that the timber truss would receive the load from the ties, transfer it to the arch, and provide lateral support for the arch ribs which were the main load carrying members. However, should the arch fail, the truss was adequate for the full load. The engineer, possibly at the owner's request, tested the completed structure by passing a 23-ton locomotive over it several times. ${ }^{12}$

In 1840, William Howe patented the "Howe" truss. This was a true truss with timber chords and compression diagonals but with iron bars for the vertical hangers. Iron members had been used before, but they had always played a minor role.

His patent also permitted prefabrication of parts, permitting manufacture away from the site. The ability to tighten up the hanger, via an adjustable nut should it become loose, was an added benefit. The parallel chord and $\mathbf{X}$ diagonal pattern soon became a familiar part of the countryside since the Howe truss was the most common of all timber trusses. However, this truss represented high tide for the timber truss and for the carpenter bridge builders, of whom Howe was the last well-known one. What had already happened in Europe was happening in America. Stress and strength were about to join stability as the criteria in bridge building.

The stone arch had been the main bridge type for nearly 2,000 years. A masonry arch, if stable enough to stand, was adequate for any conceivable load. For this reason, stress analysis had been unnecessary. With the advent of timber (and metal) beams and trusses, it could no longer be assumed that the bridge's existence was proof of its strength. The possibility of overload and failure due to overload now existed, especially with the heavier loads of the locomotive.

The timber trusses and combination timber-metal trusses still suffered from the difficulty in joining timber-the tensile strength of the joint was always less than the strength of the timber member. This made these trusses especially susceptible to falling apart at the joints. On March 4, 1840, a Town lattice truss over Catskill Creek, New York, came apart dropping a train of boxcars into the water, resulting in the Nation's first railroad bridge fatality. ${ }^{13}$ The need for a metal bridge had arrived.

Other methods were used in replacing wood with iron in the arches of truss-arch railway bridges. While limited construction of short-span combination trusses with timber compression and wrought iron or steel tension members continued until the end of the 19th century, it steadily decreased.

The engineer's first choice for a bridge metal was cast iron, and 1836 saw the first cast-iron bridge in this country, an 80-foot arch span, built over Dunlap Creek in Brownsville, Pennsylvania, by the U.S. Corps of Engineers. ${ }^{14}$ Shortly afterward, in 1840, the first iron trusses came into existence when two highway bridges were built over the Erie Canal by Earl Trumbull and Squire Whipple. Trumbull's truss spanned 80 feet and had a wooden floor system. It featured a parabolic bottom chord of wrought iron bars. Squire Whipple's 72-foot bridge was the first example of the famous Whipple bowstring truss, so called because of its curved upper and horizontal bottom chord. The tension members were wrought iron and the compression members were cast iron. ${ }^{15}$ While most of Whipple's bowstring trusses have vanished, there are still some examples of his other design, the trapezoidal truss, in service.

In 1844, 4 years after the first two iron bridges, Thomas and Caleb Pratt patented the Pratt truss. This parallel chord truss with tension diagonals and compression verticals in the web system was well suited for metal trusses and, together with its many modifications, became the most popular type of truss for short and intermediate span trusses to the present day. Among its better known variations are the Baltimore, Parker, Pegram, Pennsylvania and Petit trusses. ${ }^{16}$ 


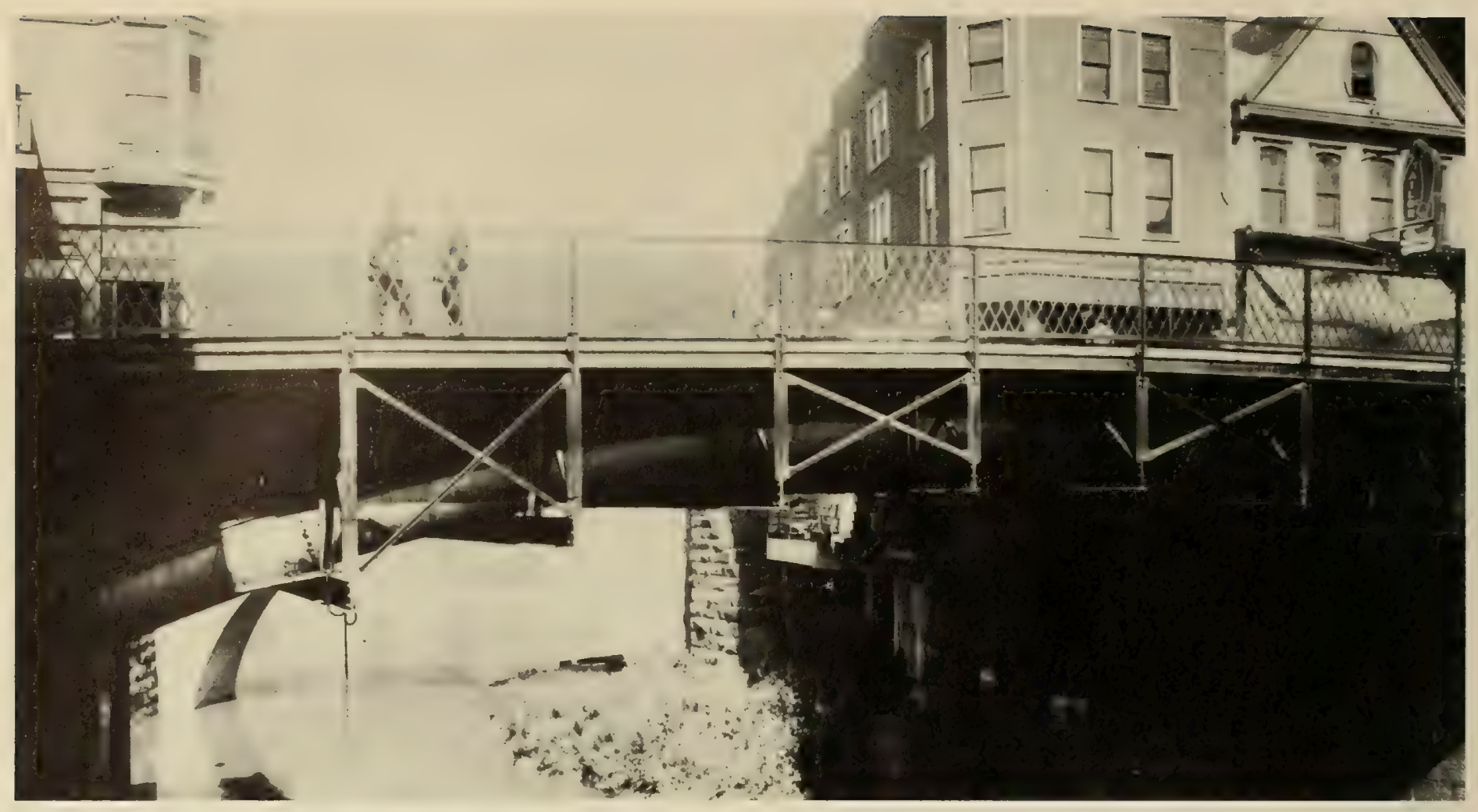

First cast-iron bridge in the United States, over Dunlap Creek at Brownsville, Pa.

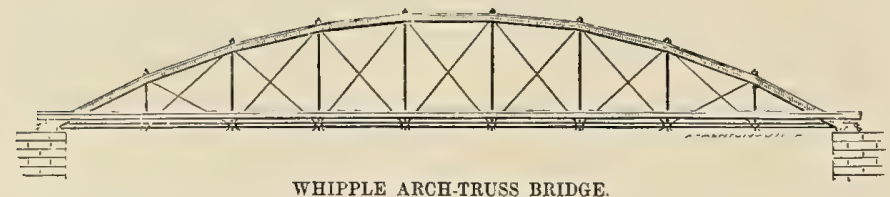

WHIPPLE ARCH-TRUSS BRIDGE.

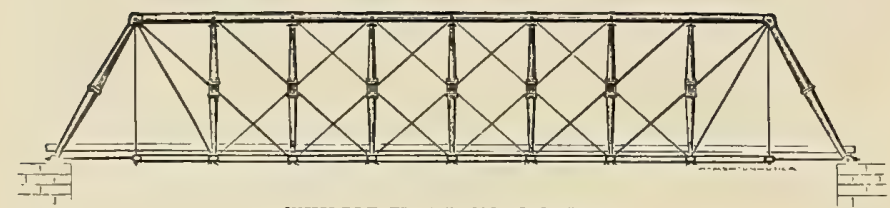

WIIIPPLE TR.IPL:ZOINAL BRTDGE

The second cast-iron arch in this country, completed in 1860, was the Meigs Bridge over Rock Creek in Washington, D.C.* Like the Dunlap Creek Bridge, it was also built by the Corps of Engineers. Its two cast-iron pipe arches supported the deck of the highway bridge and carried the water supply of the city over the creek. The 51-inch outside diameter pipes spanned 200 feet. The bridge deck and supports were removed in 1916 and a new bridge was constructed over and independent of the pipes still carrying water. ${ }^{17}$

Ironically, the chief factor in the decline of the cast-iron bridge was its success. The increased use of wrought iron and cast iron for bridges, rails and other related uses caused a boom in the iron industry and created an incentive to develop new processes for producing iron and steel.

* Not to he confused with the Meigs Stone Arch over Cabin John Creek in Maryland which was also built under the supervision of Capt. Montgomery C. Meigs when he was with the U.S. Army Corps of Enginecrs.

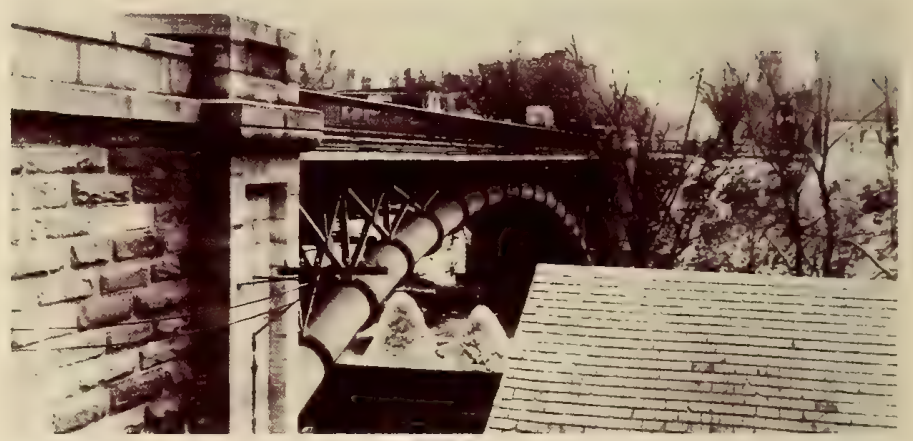

The original Meigs Bridge over Rock Creek in Washington, D.C., built in 1860 by the U.S. Corps of Engineers.

Although the Bessemer converter and open-hearth furnace made the steel bridge inevitable, several bridge failures also increased distrust of iron bridges. The most notable was a failure of an iron Howe truss at Ashtabula, Ohio, which took 65 lives in 1876, the worst rail disaster in America so far. Surprisingly, many highway bridges also failed, despite their relatively light live loads. This was due to the pressures for economy put upon county officials who lacked technical expertise and fly-by-night bridge salesmen and promoters, who, sometimes involved in political and business corruption, provided cheap and inadequately designed structures.

From the 1850 's, companies were formed primarily for constructing patented truss bridges, either under their own patents or as licensees. There being very few bridge engineers with a working knowledge of stress analysis and truss design in the early years of iron superstructures, these "bridge companies" became firmly established. Bids let for short- and mediumlength span truss bridges allowed the bidder to fur- 


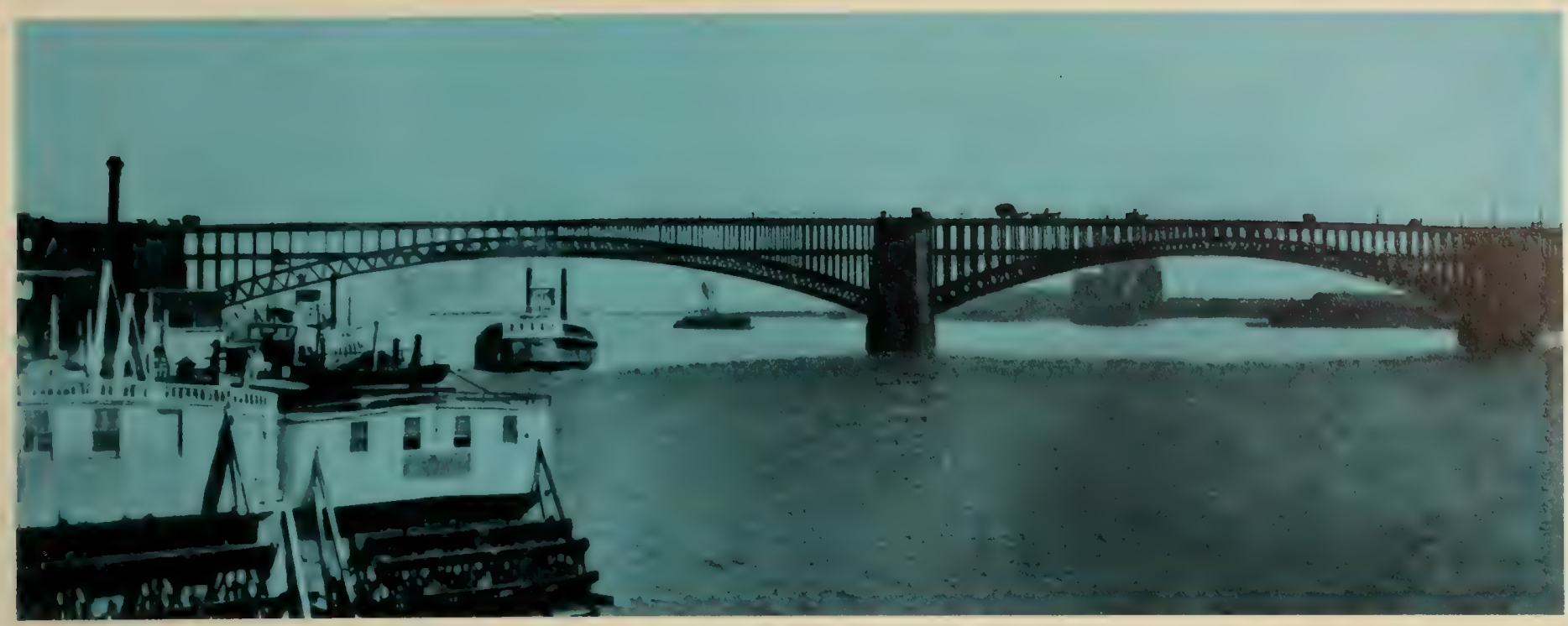

The Eads Bridge over the Mississippi River was opened to traffic in 1874. Alloy steel was used for the first time in this country for the member's of the three arches of this double deck bridge.

nish the superstructure to his own plans. While many safe and satisfactory bridges were obtained by this procedure, there were also many unsatisfactory bridges. In some cases, the companies furnished weak or inadequate bridges to compensate for underbidding or to make excessive profits.

Due perhaps to a combination of poor engineering, poor material, and fraud, the numerous failures of iron and combination bridges brought about the complete abandonment of cast iron and led to the acceptance of wrought iron and steel, the flowering of modern truss design, and the rise of the civil engineer.

The first American all steel spans built were the five main spans of the Missouri River Bridge at Glasgow, Missouri. Bessemer steel was used for the 315-foot long trusses. The remaining trusses and trestle work were made of wrought iron.

However, the Glasgow trusses lagged by 10 years the first extensive use of structural steel in a bridge. It was in 1868 that construction commenced on the first of the two "great bridges" of American history, * the Eads Bridge across the Mississippi at St. Louis, Missouri.

Until 1855, the "Father of Waters" had never been spanned. Thirteen years later, James Eads, a hero of the Civil War, began building three alloy-steel arches of 502-, 520-, and 502-foot spans, respectively, across the river. This bridge is noteworthy for another reason: The first use of pneumatic caissons in the United States and, sadly, the first death from the "bends" or "caisson disease." (In all, 13 died.) It is interesting that Captain Eads had never built a bridge before. ${ }^{38}$ Despite the magnificence of the Eads Bridge, which is still in use, the future of the steel bridge was with the plate girder and the truss.

After Squire Whipple's essays on bridge building, the increasing knowledgability of the engineer led to further refinements in the metal truss as iron yielded to steel. Among the changes were the use of bridge rollers and the perfecting of the pinned connection.

"The second of the "great bridges" in America-the BrookIyn Bridge-is discussed under Suspension Bridges.
The improved metallurgy permitted the evolution of machined steel pins from the old iron trunnions and the use of the now famous eyebar tension member. The eyebar became the trademark of the American truss bridge in the latter half of the 19th century. In this area, the American engineers deviated from European practice, which was turning to the more rigid riveted gusset plate connections. The economy and determinacy of the pinned truss was well suited to the American bridge engineer's interest in structural analysis. While the riveted joint was finally accepted, the practice of using deeper trusses and longer panels was retained this side of the Atlantic.

Interest in determinate structures led to the use of cantilever bridges. Eventually, cantilevers were so widespread that Europeans referred to them as the "American" bridge.

In 1876, Charles Smith built the first such bridge over the Kentucky River for the Cincinnati Southern Railway with three 375-foot spans. Other long span cantilever bridges were the Monongahela River Bridge at Pittsburgh, Pennsylvania, built in 1904 with a maximum span length of 812 feet, and the Queensborough cantilever designed by Gustav Lindenthal in 1909 in New York City. Its maximum span was 1,182 feet. $^{19}$

The use of plate girder bridges for short spans began during the Civil War. While these spans were limited to moderate length by the size and length of the wrought-iron plates and shapes then being rolled, longer spans were built as the available size of

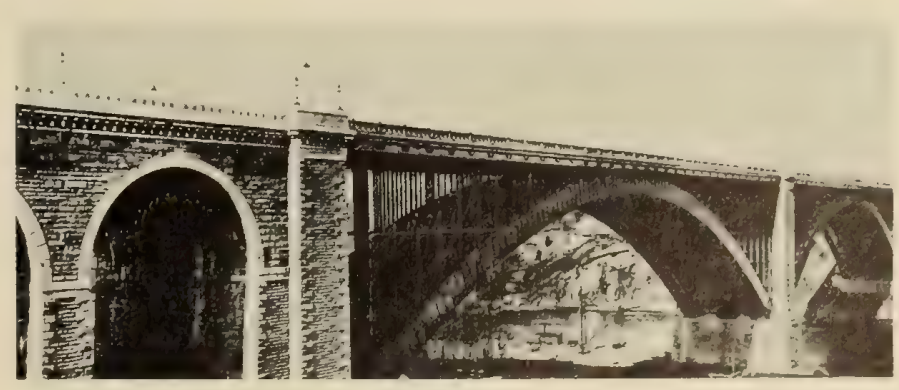

The Washington Street Bridge over the Harlem River in New York City. 


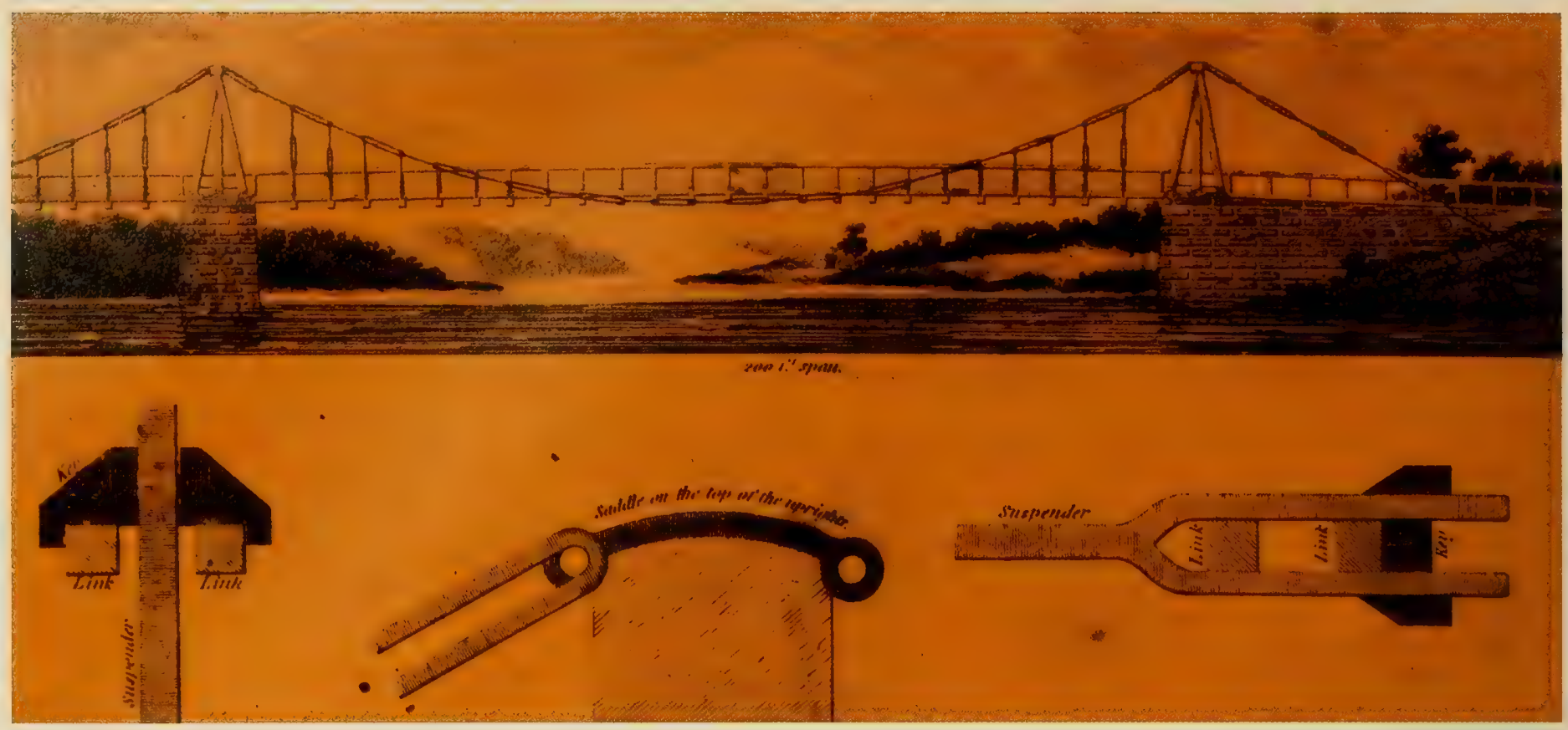

Details of a 200-foot Finley chain link suspension bridge.

wrought-iron and steel plates increased. The first American railroad girder bridge with a 100 -foot span was built in 1887. Just 7 years later, a 182-foot span was constructed, a major span even by today's standards. The use of wrought-iron and steel I-beams for short spans was initiated by the rolling of deeper beams.

Still, early plate girder highway bridges were limited to short spans because of the inconvenience and cost of transporting and erecting long members except when the bridge site was near railroad transportation. ${ }^{20}$ Thus, long spans still belonged to the truss, the suspension span, and the arch.

The first American plate girder arch bridge was the Washington Street Bridge over the Harlem River in New York City, built in 1886-88. It had two 510foot arch spans with plate girders 13 feet deep. ${ }^{21}$

By the early 1870 's, the size of I-beams rolled was large enough to use for stringers in the floor systems of short paneled truss bridges. This, together with the development of plate girders for floor beams, led to the general discontinuance of the use of wooden stringers by 1875 . However, wooden stringers were used on short- and medium-length spans until 1890 and later. ${ }^{22}$ During the period 1874 to 1890 , the maximum depth of American rolled I-beams increased from $101 / 2$ inches to 20 inches.

\section{Suspension Bridges}

This most fascinating of all bridges first appeared in America in 1801 when Judge James Finley built a 70-foot chain link suspension bridge over Jacobs Creek near Greensburg, Pennsylvania. The chains were made from 1 inch square wrought-iron bars. The links varied from 5 to 10 feet in length so as to match the distance between floor beams. The timber floor system was stiff enough to distribute live loads to several hangers and to resist deformation, undula-

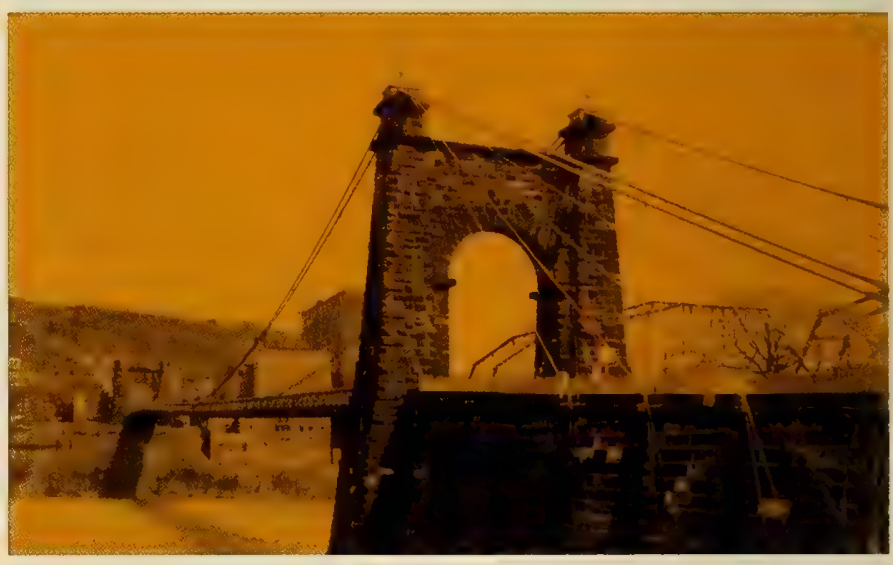

Suspension bridge built by Charles Ellet in 1849 over the Ohio River at Wheeling, W. Va.

tions and vibrations from the live load and wind loads. The bridge failed under a six-horse team in 1825 but was repaired. A number of bridges were built under the direction of Judge Finley or his licensees. The maximum span lengths were probably about 150 feet. The cable supports were usually timber towers on stone masonry piers. A suspension bridge at Lehigh Gap, Pennsylvania, apparently the last Finley type in use, was replaced by a modern structure in $1933 .{ }^{23}$

One of the largest of the chain link structures was the Point Bridge over the Monongahela River at Pittsburgh, Pennsylvania. Built in $1875-77$, it was a stiffened chain suspension span 800 feet long. The main and backstay chains were of wrought-iron link bars 20 feet 6 inches long. ${ }^{24}$

The first highway bridge in America with wire suspension cables was designed by Charles Ellet and completed in 1842. It replaced Wernwag's wooden trussed-arch Upper Ferry Bridge over the Schuylkill River at Philadelphia.. ${ }^{25}$ As would be the case for all American suspension bridges until the Brooklyn 


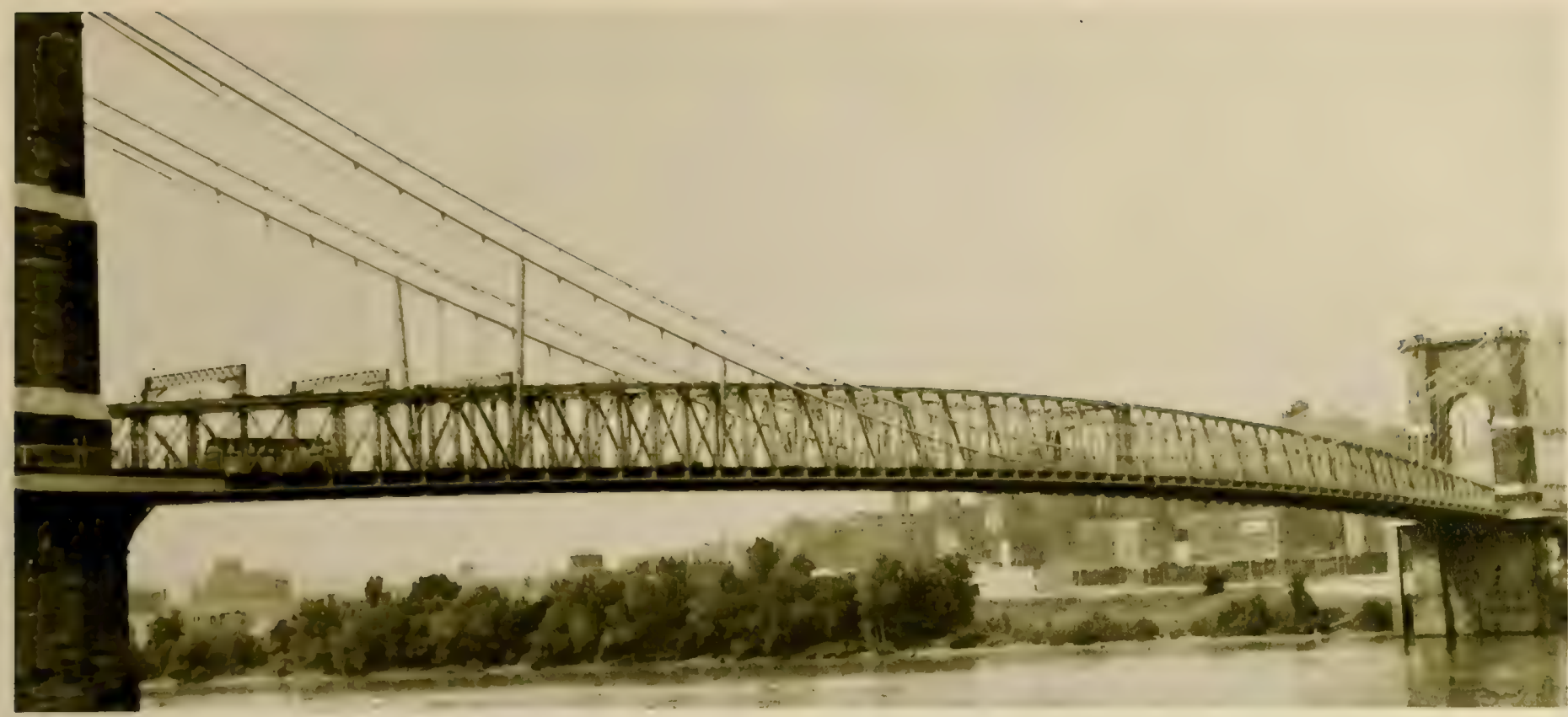

Roebling opened this suspension bridge over the Ohio River between Cincinnati, Ohio, and Covington, Ky., in 1866.

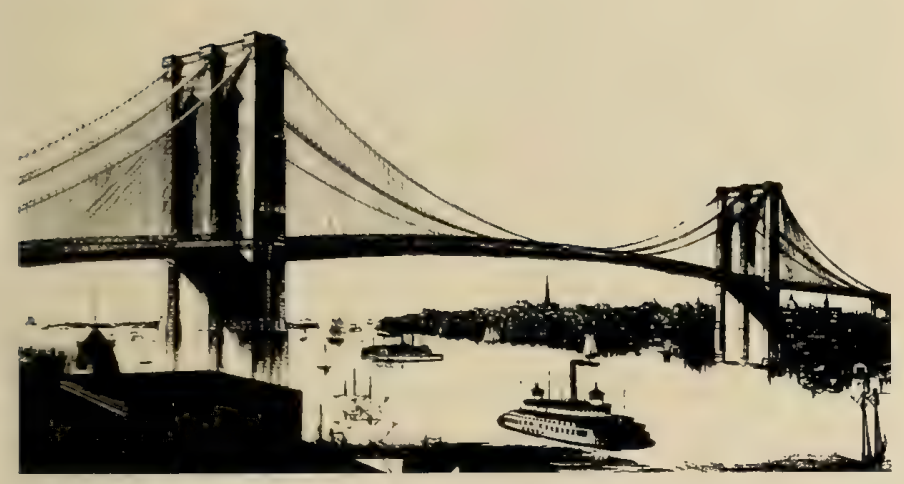

The Brooklyn Bridge over the East River in New York City.

Bridge, drawn wrought-iron wires were used for the cables.

Subsequent to 1840 , several wrought-iron wire bridges were built in America by Charles Ellet, John A. Roebling, Thomas M. Griffith, Edward W. Serrell and others. However, the suspension bridge was still in its infancy. It began to come of age in 1849 when Ellet spanned the Ohio at Wheeling, Virginia, with a 1,010-foot suspension span. When completed, this was the longest bridge span in the world. While it was damaged by wind in 1854 , the bridge was repaired and is still in service. ${ }^{26}$

John Roebling had built nine suspension bridges by 1855 , one of which was the 821 -foot span combination highway-railroad bridge over the Niagara Falls rapids, a bridge most engineers thought doomed to failure. When Mr. Ellet's temporary suspension bridge was built at the site in 1848, the rope for pulling the first cable across the river was pulled across by a cord flown over the gorge by a boy with his kite. $^{27}$ In December 1866, Roebling opened his recordbreaking Ohio River suspension span at Cin- cinnati. This structure, 1,057 feet between towers, is also still in use. ${ }^{28}$ During the flood of 1937, this was the only highway bridge open across the Ohio between the Mississippi River and Sciotoville, Ohio.

There were at least two factors that Roebling had considered in his bridges: the quality and protection of the cable and the bracing of the structure against aerodynamic loadings. Attention to these problems, plus the other design aspects, made his bridges successes.

These major bridges, although unprecedented achievements, were only the prototype for his crowning task, the second "great bridge" of America: the Brooklyn Bridge over the East River. This bridge, its 1,595-foot main span 50 percent longer than the previous record span at Cincinnati, linked Brooklyn and Manhattan and made New York's expansion possible. It was also the first bridge to use galvanized steel cable.

Building the East River bridge was probably the most dramatic verse in the saga of bridges. Its creator, John Roebling, died of tetanus as a result of an accident during the early stages of construction. His son, Colonel Washington Roebling, who had survived the battle of Gettysburg, was crippled by the "bends" and had to direct operations through his wife, Emily. But in 1883, 14 years after construction started, man had conquered the East River and signaled the beginning of the great age of bridge building. ${ }^{29}$

Two other notable suspension bridges were built over the East River at New York City around the turn of the century. The Williamsburg Bridge, built in 1903, has a 1,600-foot main span. The main span of the Manhattan Bridge, built in 1909, while 130 feet shorter, yet is considered by many as the most graceful cable arc of any of New York's bridges. 
The rising tempo of bridge building may be noted from the fact that the Williamsburg Bridge, although 5 feet longer than the Brooklyn Bridge, was just a long bridge. The long-span title had gone across the seas to the Firth of Forth's 1,700-foot cantilever span in 1890 .

\section{Movable Bridges}

Bridges with movable spans to accommodate water traffic also date back to colonial times. The early timber bridges were opened and closed by the only available power-manpower. As a rule, they were either bascule (draw) spans or swing spans which rotated to open the channel to marine traffic. This, of course, meant that only short span openings could be used. Fortunately, the pace of life, as well as of river traffic, was sufficiently slow so that lengthy bridge opening times could be tolerated.

Some early spans were a wooden drawbridge between Boston and Charlestown over the Charles River, built in $1785-86,{ }^{30}$ and the Haverhill Bridge over the Merrimack River at Haverhill, Massachusetts, built in 1794 with a wooden bascule drawspan. The 30 -foot drawspan was raised by means of levers elevated on a post on each side of the draw. ${ }^{31}$ The Tiverton Bridge over a tidal inlet near Howland Ferry, between Portsmouth and Tiverton, Rhode Island, built in 1795 , contained a sliding drawspan. ${ }^{32}$

The advent of the railroads and steam-powered boats made the span weights heavier and the opening time of the movable spans more critical. Fortunately, as wrought iron, and then steel, became the material for the bridge members, steam became the motive power for opening railroad and main highway movable bridges over busy waterways. For minor waterway crossings and during power failures, movable spans were still opened manually.

As the larger rivers and tidal estuaries became more frequently bridged and river craft became wider and longer, wider channel openings were required, necessitating longer spans for movable bridges. Of the movable bridges constructed during the last half of the 19th century, two were notable. The first was

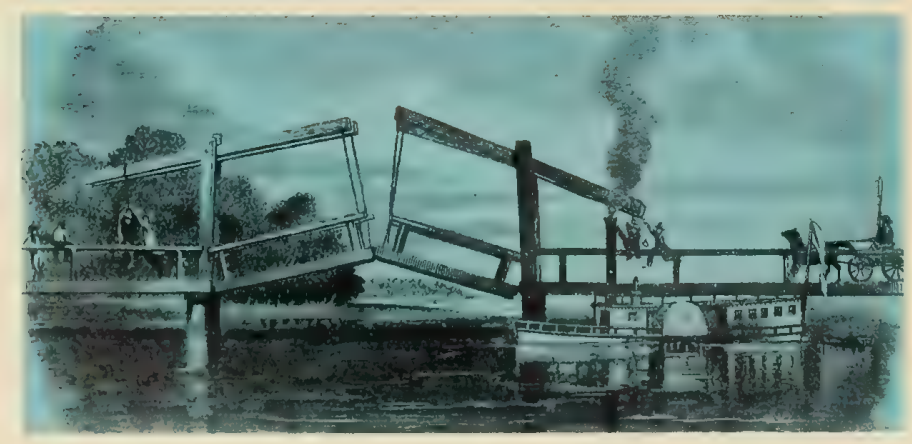

This sketch of a manpower-operated bascule on the Pongo River Bridge in Virginia probably exaggerates the difficulties of such operations. From the Harpers New Monthly May 1858. a railroad bridge located between Rock Island, Illinois, and Davenport, Iowa, providing a swing span with two 120-foot channel openings. Built in 1854-56, it was the second bridge to cross the Mississippi River. ${ }^{33}$ The other was the Utica Lift Drawbridge, a 60 -foot $\mathrm{x} 18$-foot movable deck, suspended by rods from the lower chord panel points of an overhead fixed truss. The vertical lift was 11.5 feet. Opening time, using preset weights, took 10 seconds. This was one of several unusual vertical lift bridges which Squire Whipple designed and built over the Erie Canal in New York in the 1870's. ${ }^{34}$

The development of modern movable bridge spans started in Chicago when the channels of the Chicago River and related waterways were improved at the turn of the century. Many of the existing movable bridges were manually powered swing spans, with center piers obstructing channels. These were replaced with bascule and vertical lift spans. This era was begun by two famous bridges. The Halsted Street Lift Bridge over the Chicago River in Chicago, Illinois, 1894, lifted a 130-foot truss span with a 34-foot roadway and two 7 -foot sidewalks using steampower. Maximum vertical clearance was 155 feet above low water. Two light longitudinal, laterally braced, trusses connected the tops of the towers. The design of this bridge introduced another famous name in bridge engineering, J. A. L. Waddell. ${ }^{35}$ The other bridge, the Van Buren Street Bridge also over the Chicago River, was opened in 1895. This 115foot span, double leaf of the Scherzer type, was the first rolling lift bridge. ${ }^{36}$

From then on there was a series of new movable bridge types: the simple trunnion, or Chicago, ${ }^{*}$ and Strauss bascules, the Rall rolling lift, ${ }^{* *}$ and various vertical lifts. The swing span, despite its economy and minimal power requirements, fell into relative disuse since it required a pier in the middle of the stream and blocked the channel more during opening and closing operations.

* So named because it was developed by the city of Chicago bridge office.

** Rolling lifts were really bascules turning on a large roller quadrant instead of a trunnion or axle.

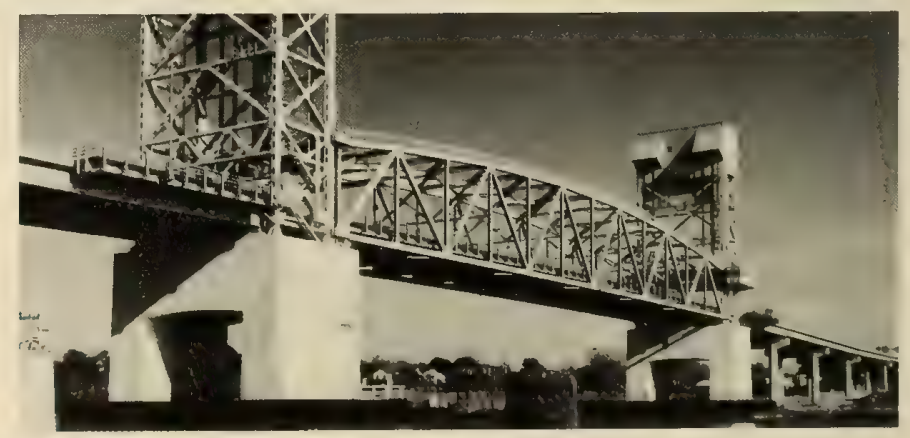

Vertical lift bridge over the Cape Fear River at Wilmington, N.C. The 400-foot lift span has a vertical clearance above mean high water of 65 feet in the closed position and 125 feet in the open position. 


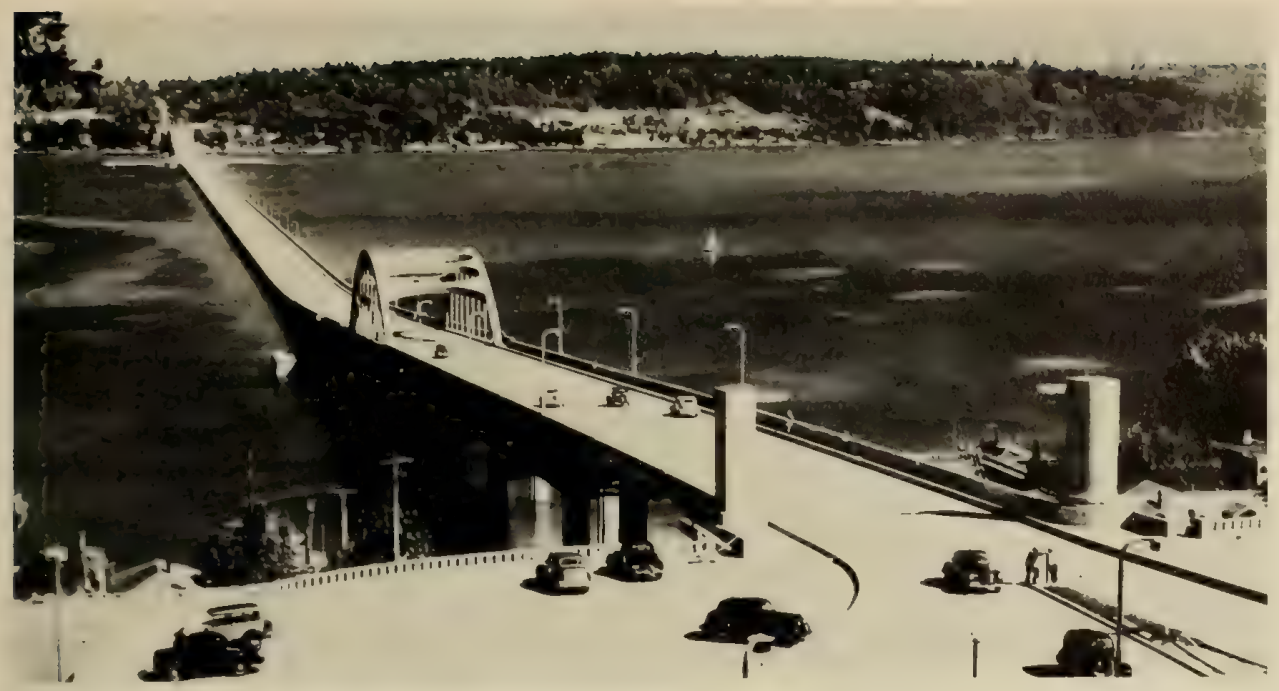

Lake Washington Pontoon Bridge, Seattle, Wash., is a concrete pontoon briage completed in 1940. The floating portion consists of 25 units 350 feet long, together with retracting sections to provide a 200-foot opening for large vessels. Passage for small boats is provided near each shore under truss spans. The pontoons are fixed laterally by long steel cables fastened to submerged concrete anchors.

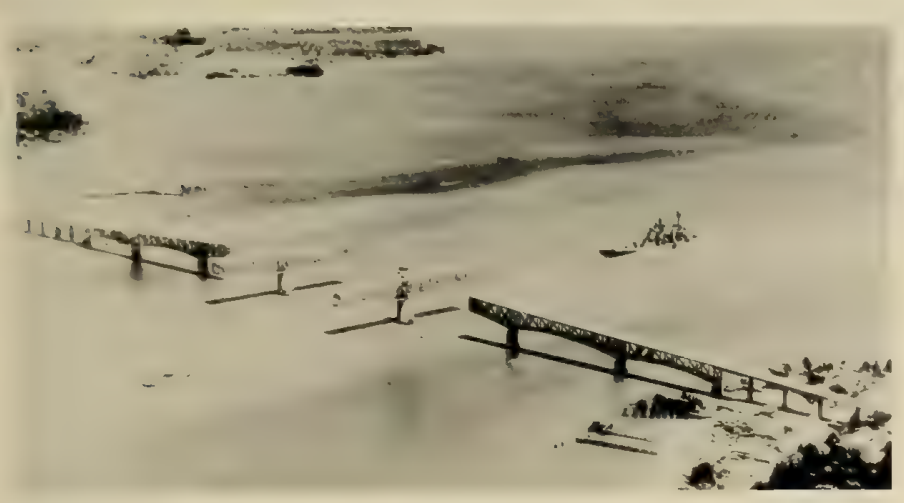

The George P. Coleman Memorial Bridge over the York River near Yorktown, Va. The double 500-foot swing spans are the largest tandem swing spans in the world.

The great size of today's structures, which evolved from the short span crossings of the Charles River and Merrimack River, is due to the growth in technical knowledge, experience, better steels, steam and electric power, and a near perfect use of the old-fashioned counterweight.

\section{Stone Arches}

Stone arches have not been a major element in highway bridge construction in this country. However, numerous short-span stone arches have been built in areas where stone and skilled masons were readily available. These bridges are frequently seen alongside present highways where they have been left for their historic and scenic value when highway alinement, width, or grade was improved. Long- and short-span stone bridges have been built in parks and large cities to be compatible with their surroundings.

One of the most notable stone arches was built during the Civil War as a combination aqueduct and road. The 220-foot filled spandrel Meigs Arch, which carries Washington, D.C.'s water supply and MacArthur Boulevard over Cabin John Creek in Cabin John, Maryland, was the longest span of its type when built. It is still in service despite its narrow roadway. ${ }^{37}$

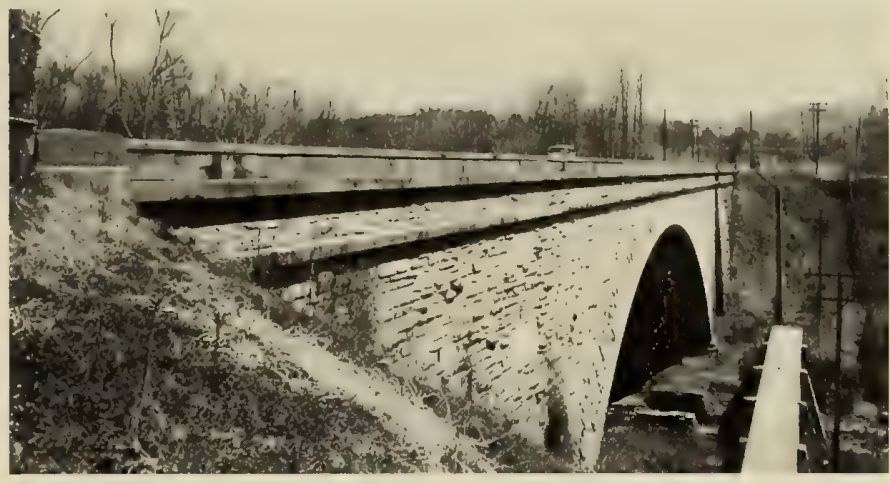

Cabin John Bridge over Cabin John Creek in Montgomery County, Md. The aqueduct for the Washington, D.C., water supply is in the spandrel fill under the roadway.

Where stone was readily available, stone arches of nominal spans and stone arch culverts were frequently used in railroad construction before metal superstructures were developed and accepted. Some of the noteworthy stone railroad bridges still in existence are:

- Carrollton Viaduct over Gynn's Falls on the Baltimore and Ohio Railroad, near Baltimore, Maryland, was built in 1829 of granite ashlar masonry. The center span is 80 feet and the overall length is 297 feet. $^{38}$

- Thomas Viaduct over Patapsco Creek on the Baltimore and Ohio Railroad, near Relay Station, Maryland, was built in 1835 of granite ashlar masonry and is 612 feet long and has eight fullcentered arch spans. ${ }^{39}$

- Starrucca Viaduct over Starrucca Creek (a tributary of the Susquehanna River) on the New York and Erie Railroad, was built in 1847-48 with stone masonry made of stone quarried locally. The viaduct is 1,040 feet long with a maximum height of 110 feet above the creek. ${ }^{40}$

- The Morgan Bulkeley Bridge was constructed across the Connecticut River between Hartford and East Hartford with funds raised by subscription from all the towns around the area in 1905 . This beautiful structure of pink granite has 11 elliptic arches, the largest being 119 feet long. In 1962, it was widened to carry Interstate 84. 


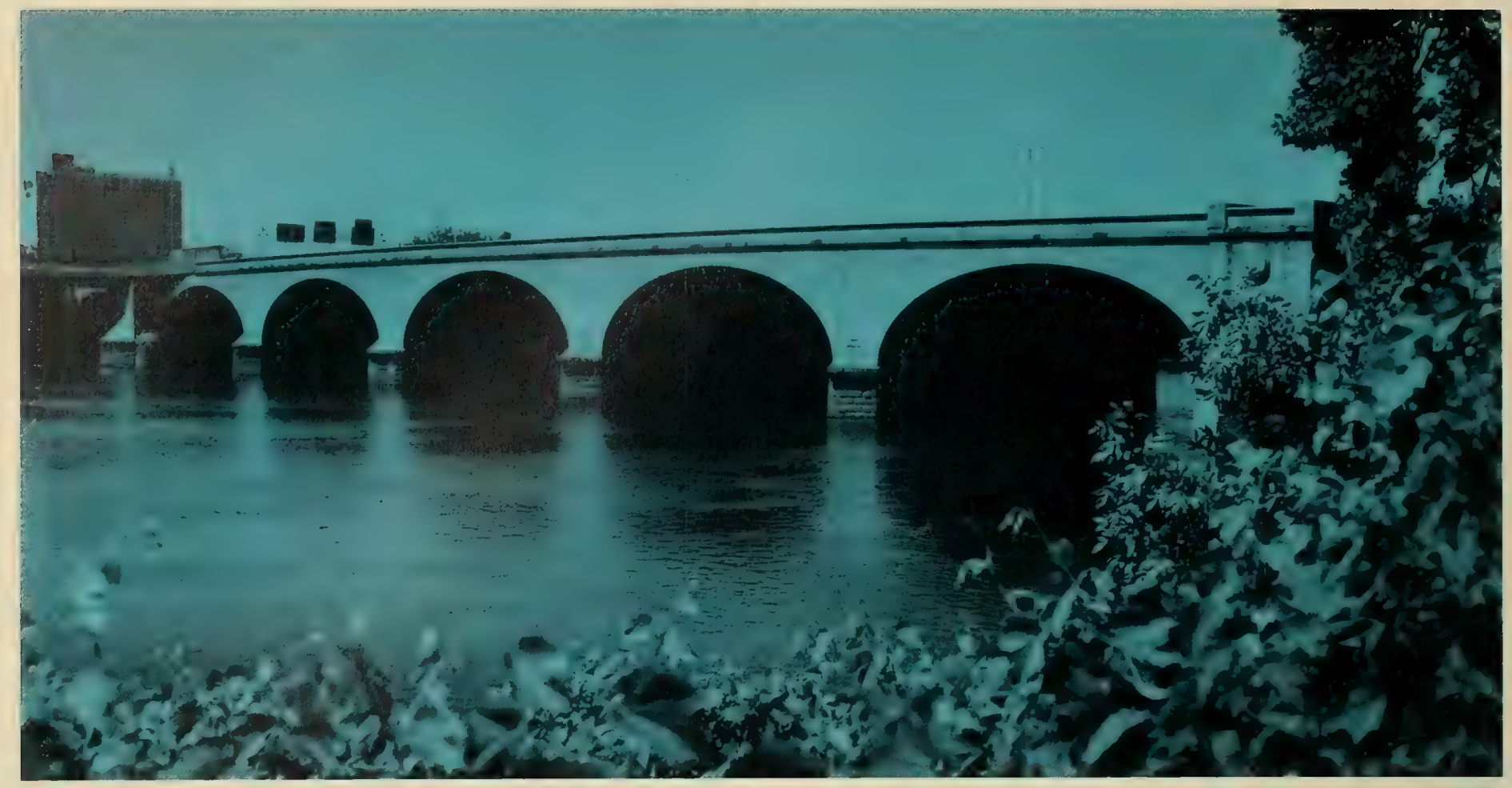

The Morgan Bulkeley Bridge over the Connecticut River at Hartford, Conn.

\section{Reinforced Concrete Bridges}

Although concrete bridges are part of the modern era, the early use of concrete was limited. Natural cement entered into bridge construction as mortar for stone masonry and for unreinforced concrete footings and substructures as early as 1850. Although many cement users switched to the more uniform and superior portland cement after its first manufacture in this country at Allentown, Pennsylvania, in 1871, natural cement has continued to be used to a lesser extent even to this day.

The Clefridge pedestrian underpass was built of concrete in Prospect Park, Brooklyn, New York, in 1871. This structure, said to be the earliest concrete arch constructed in America, is an arch that follows the design of stone arches and has a radius. of 10 feet. ${ }^{41}$

The first reinforced concrete building in this country was built by W. E. Ward in New York State in 1875, and the first reinforced concrete bridge in this country was a 20-foot span built in Golden Gate Park, San Francisco, California, in 1889.42 43

Other early reinforced concrete bridges were the Eden Park Bridge, Cincinnati, Ohio, a 70 -foot arch span built in 1894-95; the five-span arches over the Kansas River at Topeka, Kansas, built in 1896 with a maximum span of 125 feet and a total length of 539 feet; and the 36-foot span stone-faced reinforced concrete arch built according to the Melan method near Rock Rapids, Iowa, in 1894. This latter bridge was moved to a roadside park when the bridge was replaced in $1964 .{ }^{44} 45$

The first 10 years of the 20th century saw a phenomenal growth in the use of concrete structures on both the highway and railroad systems. Many longspan concrete arch bridges with either plain or reinforced arches were built in populated places, probably because of the architectural improvement over the truss and trestle bridges of the time. The use of reinforced concrete for deck girders, culverts, slabs for steel truss and girder spans, and bridge abutments and piers soon became commonplace. Of special importance was the use of reinforced concrete slabs, still in use today, for bridge decks instead of timber, steel, or cast iron.

\section{Construction to 1916}

Through the years, the methods, materials and equipment for bridge construction had developed and improved with experience and invention. Steampowered equipment had supplanted men and horses for heavy lifting and excavation. Deep foundation excavation in open cofferdams, cellular cofferdams, open caissons and pneumatic caissons had been developed and successfully used. Steam piston and pulsometer pumps had supplanted the chain and ship pumps of colonial days for draining foundation excavations. Improved timber sheet piling,* such as the Wakefield type, and steel sheet piling were developed which resulted in relatively watertight cofferdams.

Many steel fabricating shops had become established with power equipment for handling and fabricating the steel bridge members. Power shears, punches and drills were employed. Heavy hydraulic and pneumatic riveters were developed for driving tight rivets. Relatively efficient and structually satisfactory standards for riveted and pinned connections and other structural details had been developed and were in use, by 1916 .

Efficient and safe methods had also been developed for erection of steel superstructures. Steam-powered cranes, derricks and gin poles** were available for

\footnotetext{
* Designed to interlock, forming a wall or sheet to resist lateral pressures.

** Hoisting devices.
} 
lifting heavy members. Relatively light pneumatic riveting guns were developed for driving field rivets so that only small and minor structures had handriveted or bolted connections.

Most important of all, these construction improvements were documented in the literature, and engineers and technicians well versed in their application were available for bridge construction.

About 1870 engineers began developing shear and moment analyses to determine stresses for structural design. Before that, structures were "proof loaded" before acceptance, that is, highway bridges were subjected to carts loaded with pig iron or stone, while railroad bridges were subjected to two locomotives in tandem. While this primarily tested the quality of workmanship and protected against the most gross errors, it did not provide for overloads or fatigue failure. These proof-load requirements persisted in the specifications until the turn of the century.

However, engineers were aware that the proof-load was no substitute for a rational design and, as their knowledge grew, began to write design specifications. Whipple had already recommended a design load of 100 pounds per square foot, equivalent to the whole roadway area covered with men. ${ }^{46}$ In 1875 , as a result of a series of bridge failures, an American Society of Civil Engineers committee recommended live loading values for both railway and highway bridges. For highway bridges, loads varying from 40 to 100 pounds per square foot were given, depending on span and type of usage. ${ }^{47}$ While railroad and "bridge companies" issued their own specifications for highway bridges, a concerted effort for a specification of national scope had to await the Operating Committee on Bridges and Structures of the American Association of State Highway Officials in the 1920's.

In 1910, the Office of Public Roads established a Division of Highway Bridges and Culverts. This new division, upon request from a State or local authority, assisted in bridge design and construction and reviewed and advised on bridge plans and specifications prepared by States, local authorities or bridge companies. It also prepared and published bulletins on highway bridge and culvert design and construction, including typical plans for reinforced concrete culverts, abutments and piers and discussions on the use and design of steel truss and plate girder bridges.

In 1913, the Office of Public Roads issued Circular No. 11, Typical Specifications for the Fabrication and Erection of Steel Highway Bridges. This circular specified a live loading of interurban electric cars or a 15-ton road roller plus a uniform live load on the portion of the bridge deck not occupied by the roller.

\section{The Era of Great Bridges}

It was said earlier that the opening of the Eads and Brooklyn Bridges was the beginning of the great bridge building era. As noted, it continued slowly with the Williamsburg and Manhattan Bridges.

The Hell Gate Railroad Bridge in New York City, built in 1916, and designed by Gustav Lindenthal, spanned $9771 / 2$ feet between support pins and was the longest and heaviest arch in the world. When it was built, it was considered an engineering marvel because of the location conditions and the long span. It was to have a profound effect on steel arch design.
At almost the same time, the long-span continuous truss had finally come to America in the form of two continuous spans of 775 feet over the Ohio River at Sciotoville, Ohio. (Strictly speaking, a continuous truss had been used in the approaches to an earlier structure, but Sciotoville was the first use of it for main river spans.) Coincidentally, the longest simple span truss, 720 feet, was built over the Mississippi at Metropolis, Illinois. Both of these were railroad bridges.

Not long after, a major cantilever truss with two cantilever spans of 1,100 feet, designed by David B. Steinman, crossed the Carquinez Straits near San Francisco, California.

The long-span records continued to fall through the 1920's and 1930's. Detroit's Ambassador Bridge, 1,850foot suspension span surpassed the Quebec cantilever's 1,800 feet. In 1931, Othmar Amman's arch over the Kill van Kull between Staten Island,New York, and Bayonne, New Jersey, set a new arch record of 1,652 feet.

In that same year (1931), the George Washington Bridge was opened. This bridge across the Hudson River in New York City reached 3,500 feet between towers. At one bound, it had virtually doubled the Ambassador's span. Not only that, but it was one of the strongest bridges ever built, with the greatest capacity-eight highway traffic lanes on the upper deck and provision for future rapid transit below (ultimately six highway lanes were added instead) when the stiffening trusses would be added. While the increase in technical knowledge was one factor, the most important reason behind this great leap in span length was, as Roebling had realized years before, the great improvement in the quality of the steel wire.

Since then, the George Washington Bridge has been surpassed several times in span but not yet in strength and capacity. The three longest spans are the 4,200foot center span of the Golden Gate in San Francisco (1937), the 4,260-foot span of the Verrazano-Narrows (1965) in New York City and also an Amman design, and the 3,800-foot center span of the Mackinac Straits Bridge which joins Michigan's upper and lower peninsulas.

The George Washington Bridge. The upper roadway has eight traffic lanes; a lower deck with six lanes was added later.

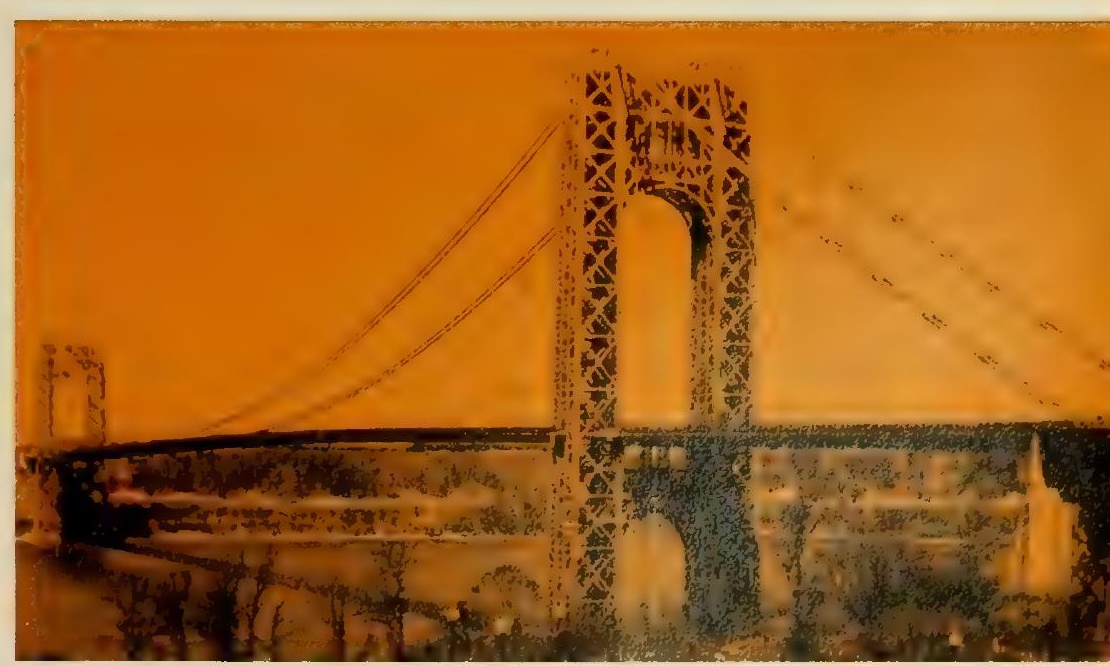




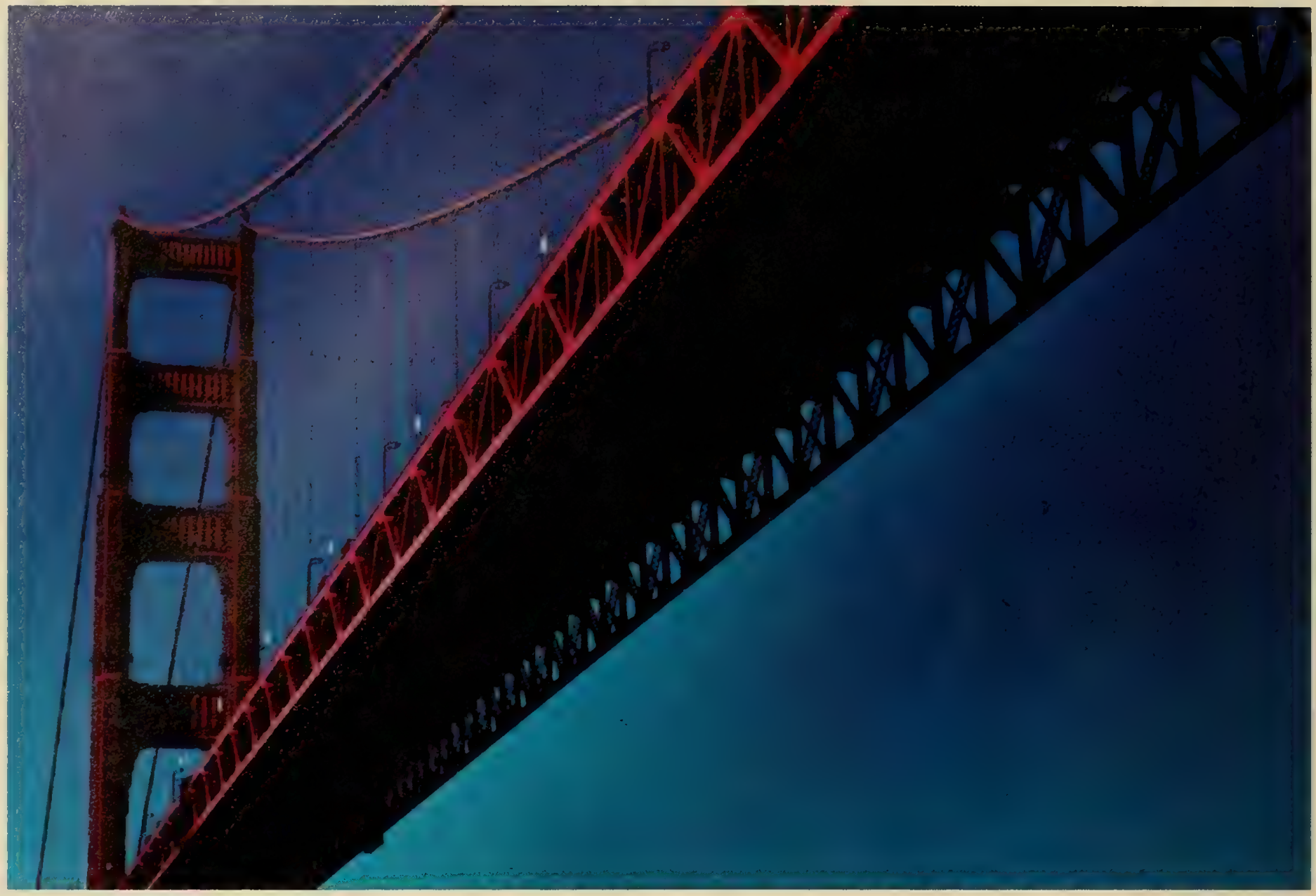

San Francisco's Golden Gate Bridge.

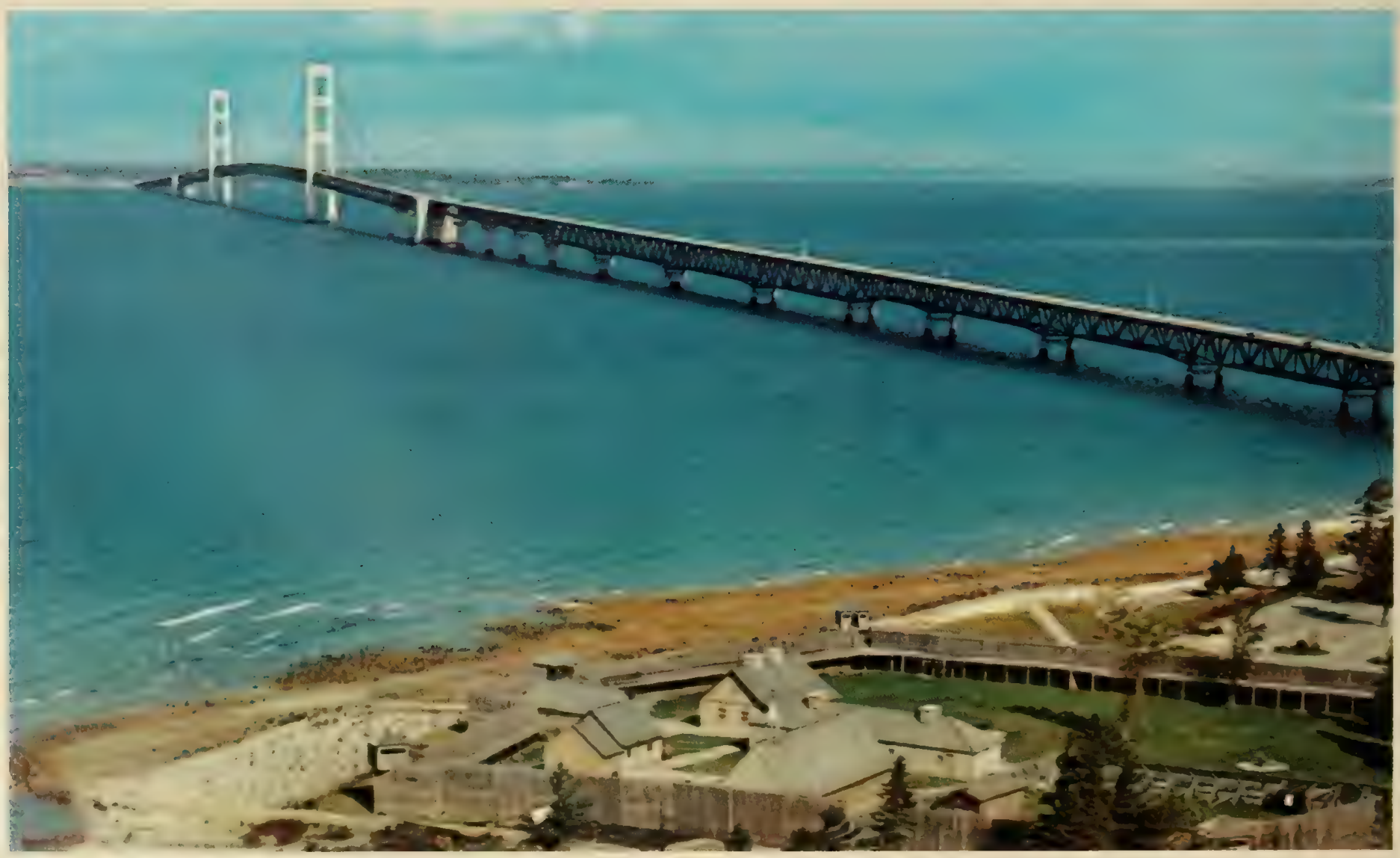

The Mackinac Bridge over the Straits of Mackinac, where Lakes Huron and Michigan meet. Completed in 195\%, this bridge is nearly five miles long. 
During the 1930 's, many other noted long suspension bridges were built, among them two beautiful spans, the Bronx-Whitestone in New York City and the Oakland Bay Bridge, and that fateful structure, the Tacoma Narrows Bridge over Puget Sound in Washington.

The Tacoma Narrows Bridge, like the Whitestone, was built with a plate girder instead of a stiffening truss. In addition, although 2,800 feet between towers, the cables were only 39 feet apart. Just over 4 months after being opened, it failed, literally twisting itself to pieces. The shallow stiffening girder, combined with the light dead load of the relatively narrow bridge, was unable to resist the aerodynamic forces that developed because of the steady winds of Puget Sound. This failure led to considerable research and improvement of future structures, such as the Mackinac and Verrazano-Narrows Bridges, as well as stiffening of existing bridges. Since the Whitestone Bridge showed signs of serious oscillation, a half truss was added to the top of the original girder. It is noteworthy that the George Washington, despite the absence of a stiffening truss, showed few symptoms of instability, possibly due to its great weight and width, as well as to the less constant wind patterns of New York Harbor.

Current technology seems to make it less necessary to build record spans. However, even today, a new steel arch with a record span of 1,700 feet is under construction at the New River Gorge in West Virginia.

These "great bridges" were all toll facilities built by bond issues rather than Federal-aid financing. After enactment of the Federal Aid Road Act of 1916, the Division of Highway Bridges and Culverts, established in 1910, became the Bridge Division of Public Roads. The immediate task of this Division was to set standards for design and construction of bridges to be constructed under the 1916 Act. Under the Act, roadway and bridge planning became a cooperative undertaking with the States initiating, planning, designing and constructing the projects and the Bureau of Public Roads (BPR) advising, approving, committing Federal-aid matching funds for satisfactory plans and specifications and paying such funds upon successful final inspection of the completed projects.

This cooperation was facilitated by the formation, in 1921, of the Operating Committee on Bridges and Structures of AASHO, known popularly as the AASHO Bridge Committee, which was composed of the bridge engineer of each State highway department and a designated bridge engineer from Public Roads.

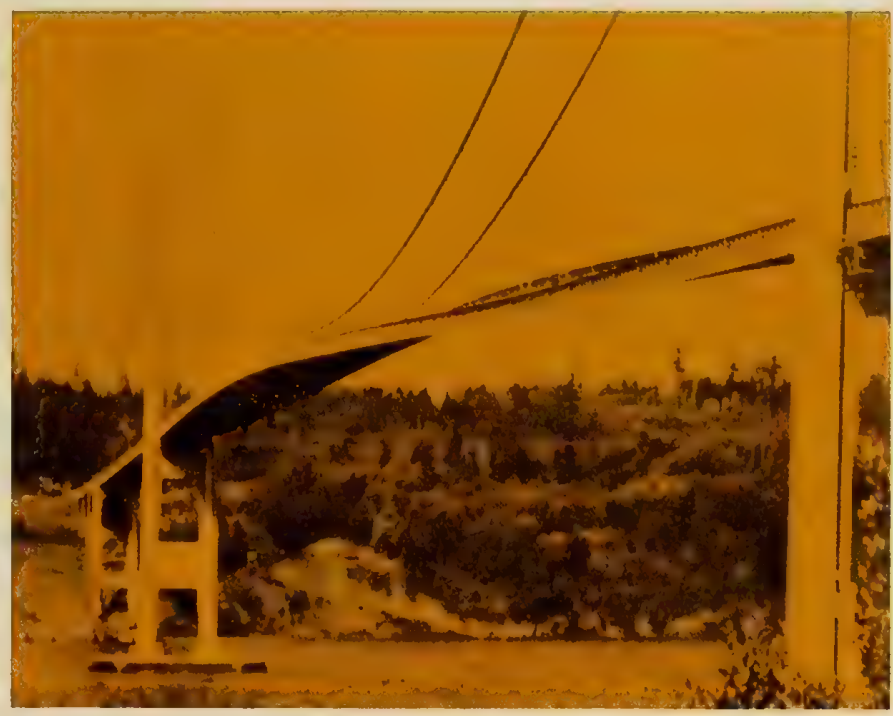

The Tacoma Narrows Bridge, showing oscillation 1 hour before its collapse.

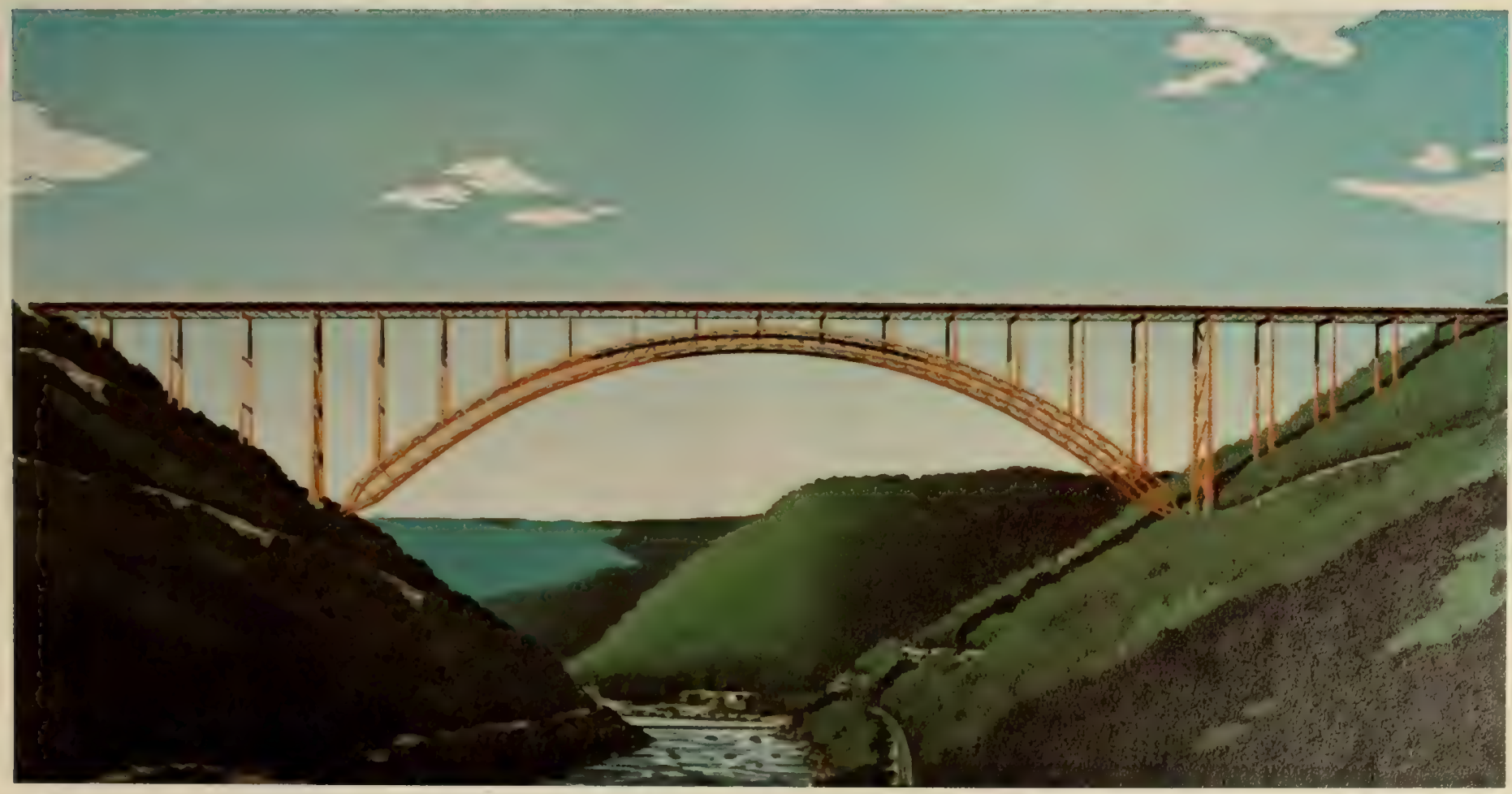

Architect's drawing of the New River Gorge Bridge in West Virginia. The hinged arch has a span of 1,700 feet, the longest of its kind in the world. Construction began in 1973. 
The AASHO Bridge Committee's continuing function was to develop policies and specifications for design and construction of highway bridges. Public Roads bridge engineers served as chairman of the AASHO Bridge Committee from 1921 until 1953 and as secretary from then until the present time.

The AASHO Bridge Committee gradually developed the bridge specifications and issued the first printed edition of the AASHO Standard Specifications for Highway Bridges in 1931. These "Standard Specifications" were not just specifications, but served as a standard or guide for the preparation of State specifications and for reference by bridge engineers. They combined design criteria and policies with detailed specification guidelines. Primarily, "Standard Specifications" set forth minimum requirements which were consistent with the current practices. The same objectives prevail in the current edition.

A notable innovation in the specifications was the use of a truck system of live load instead of road rollers. The loadings, designated as $\mathrm{H}-20, \mathrm{H}-15$, and $\mathrm{H}-10$, specified basic two-axle design trucks of 20,15 , and 10 tons, respectively. The $\mathrm{H}$-truck loading was a basic truck in each lane of the bridge, preceded and followed by a train of trucks each weighing $3 / 4$ as much as the basic truck. An equivalent "lane loading," consisting of a concentrated load plus a uniformly distributed load for each lane of loaded structure, was provided.

During the "great bridge" era between 1900 and World War II, there was a phenomenal increase in the number and size of lesser bridges as well as a growth in technical knowledge. The biggest new development was reinforced concrete. The short-span timber bridges were being displaced by concrete slab or concrete I-beam bridges. The reinforced concrete box culvert also became common. But aside from this, most of the growth consisted of further developments and refinements of existing bridge types. Riveted joints in steel trusses replaced the earlier pin connected joints, and stiffer and more substantial truss members developed. Steel rolled beam and built-up "plate girder" structures became common. The small arch brige changed from stone to concrete and began to grow in span length. Wider bridge roadways were being used.

There were three new, or at least different, developments that were significant beginning in the 1920 's. The first was the construction of a "parkway system" in Westchester County. This progressive county began building roads with some control of access and separation of cross traffic. This kind of road meant bridges wherever traffic was to be separated, even where there was no river to be crossed. Usually, these grade separation structures were not very large but did need eye appeal. The result was the rebirth of the stone arch (or stone-faced at least) and its variation, the rigid frame. The Westchester Parkway used many stone-faced reinforced concrete arches and frames for the Bronx River, Cross County, Saw Mill, and Taconic Parkways. Arthur Hayden was the bridge engineer at Westchester, and his book on the Rigid Frame Bridge has become a classic. The parkway and freeway concept spread to Connecticut where the Merritt and Wilbur Cross Parkways were built, again with emphasis on esthetics. Every bridge on the Merritt Parkway is different. This road is still one of the most delightful and scenic in the United States.

The second development was the almost exponential increase in engineering theory and application. While there were many whose studies made these new frames and arches possible, there was one outstanding contribution. In 1932 Professor Hardy Cross of the University of Illinois presented the method of moment distribution for determining the moments and shears in continuous beams, arches, and frames in a paper to the American Society of Civil Engineers. Prior to this time, the design of continuous frames was a tedious, intricate and time consuming process which discouraged the use of indeterminate structures. Moment distribution came at a very favorable timeat the beginning of the widespread use of highway grade separation structures for which rigid frames were especially appropriate.

The third significant factor was the growth of Federal interest and activity in the highway field. Public Roads was still a relatively small agency, but it helped the States through the transition to heavier automobile loadings. While the designated Federal-aid system at the start of the Federal-aid program was in most States essentially a system of county roads located and designed for preautomobile traffic, the quality of bridges increased dramatically during the 1920 's because of the cooperation of the States and Public Roads, increased experience, and improved criteria, specifications and guides. The example of the improved highways and bridges created a demand for similar improvements on other State highways. In general, bridges on the Federal-aid system in this period were of short to medium spans and of moderate cost. The Federal-aid allocation and the State highway funds were not sufficient to finance high cost structures and at the same time to construct other highway facilities in the State. Consequently, high cost bridges and tunnels were frequently built by bridge or tunnel authorities or private interests as toll facilities.

During these years, the AASHO Bridge Committee continued to develop the bridge design specifications. Basic two- and three-axle truck design loads were substituted for the truck train loading in 1941, leav-

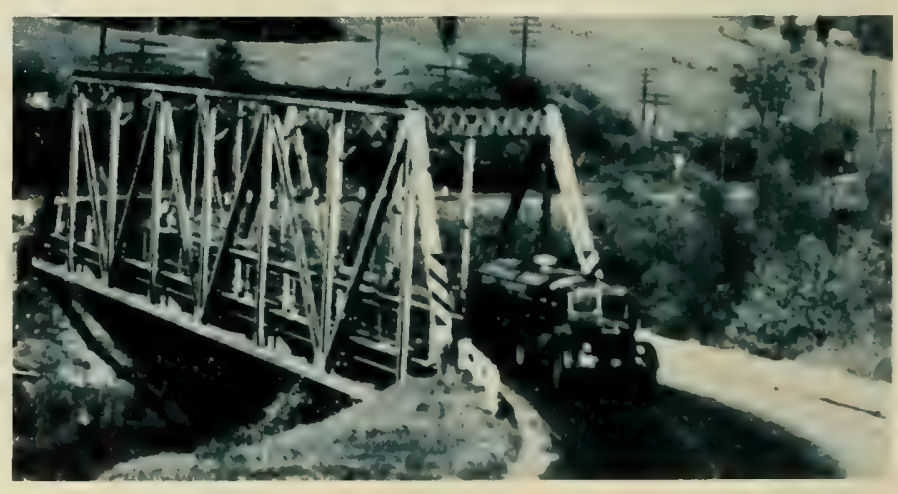

On U.S. route 5 in Vermont, large vehicles were forced to straddle the pavement centerline in crossing this narrow bridge with its sharp-curved approaches. 


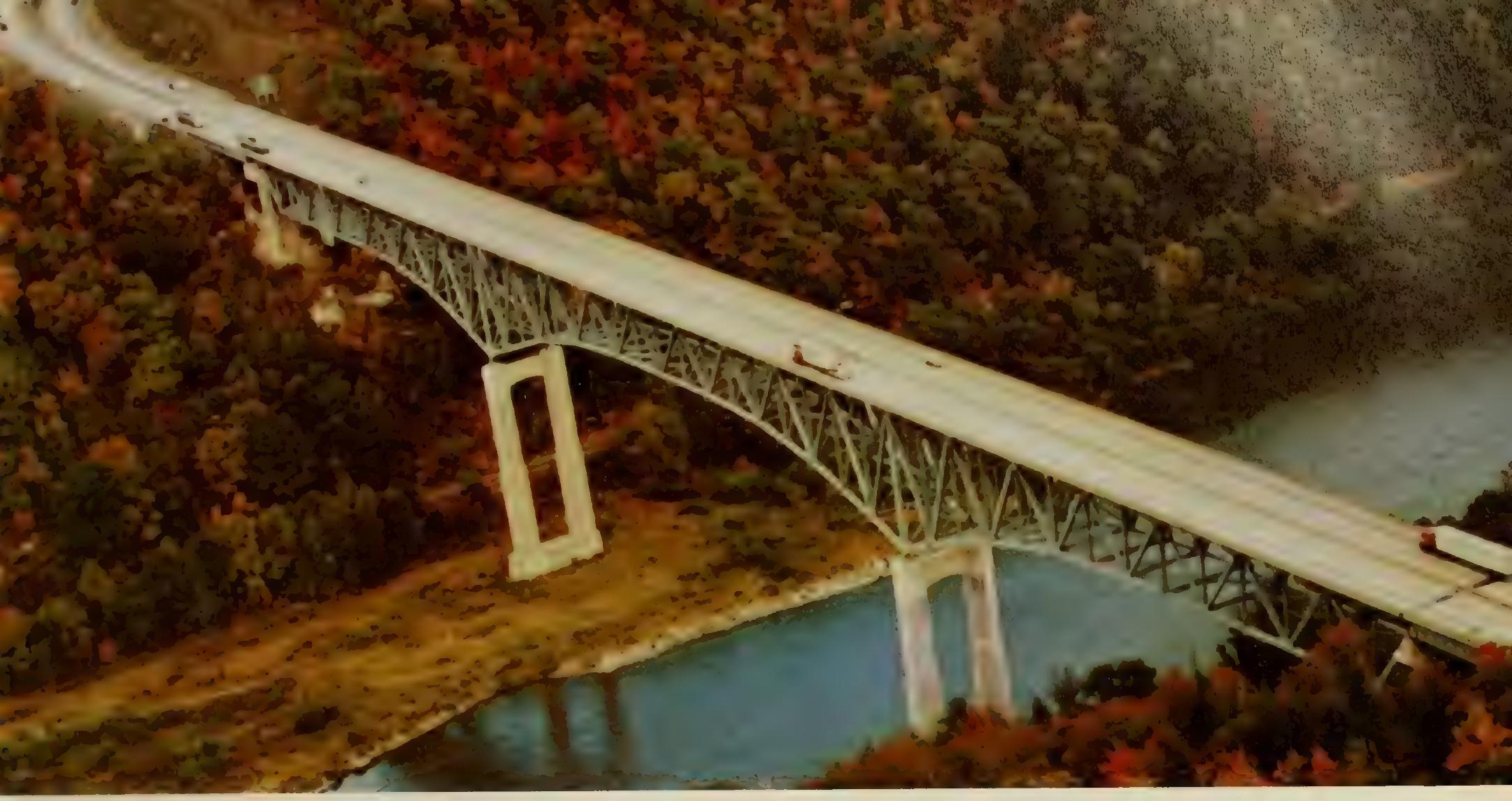

This continuous steel truss bridge over the Allegheny River on I-80 in Pennsylvania was completed in 1968. The 68foot wide concrete deck easily accommodates four lanes of traffic and a concrete median barrier.

ing the concentrated truck loading for short span designs and the conventionalized lane loading for longer span designs.

The design formulas for concrete floor slabs were revised in the 1941 and the 1961 editions of the AASHO Bridge Specifications to conform to the results of slab tests.

Now revised editions of the specifications continued to be developed and issued at 4- or 5-year intervals up to the present day. The revisions keep the specifications up-to-date on new design concepts, safety policies, use and development of materials and construction practices. The AASHO Bridge Specifications have become a valuable addition to the bridge building profession, serving as guides to State highway departments, cities, counties and foreign countries in the design of adequate but economical structures of all types.

A new design concept evolved during the 1930'sthat bridge alinement should conform to the overall alinement of the highway. Previously, bridges, which cost much more per unit of length than roadways, were generally located for minimum cost reasons, with little regard to approach road curvature. The new concept has resulted in much safer approach alinements.

\section{Developments After World War II}

The Federal-Aid Highway Act of 1944 authorized the National System of Interstate Highways. Initial standards for construction of the Interstate System were developed jointly by Public Roads and AASHO in 1945. The high standards for the Interstate System to meet present and future traffic needs also necessitated changes in the character of highway bridges. Standards for traffic capacity, load capacity, safety and appearance of structures were given careful study in order to provide for the safe and free movement of vehicles over and through bridges.

The field of the bridge engineer was broadened because of the number of large bridges required over waterways and because of the greatly increased number of grade separations.

Bridge railings were studied and led to the use of rail curbs and streamlined railings. Full width roadways (surface and shoulders) were advocated for safety on short bridges, and deck type rather than through type bridges were emphasized. Particular attention was given to horizontal clearance at underpasses, with greater clearances to sidewalls and center piers than had been customary.

Design with continuous spans was advocated. In anticipation of the increased use of three-span continuous reinforced concrete structures for urban and Interstate bridges, Public Roads prepared a report, 


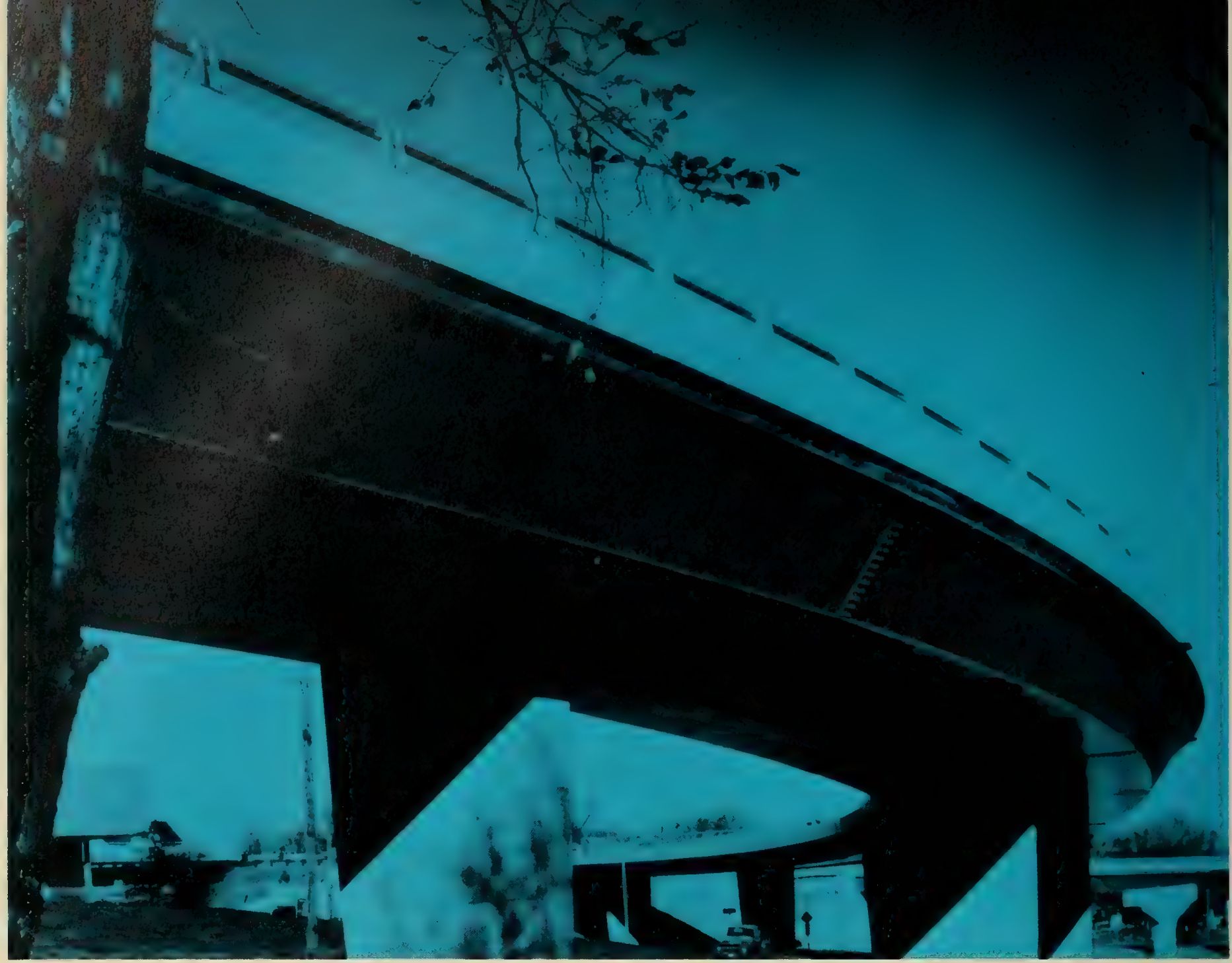

I-480 exit ramp in Omaha, Nebr. This was one of the first major interchanges where curved composite steel box girders were used.

Computing Moments for Continuous Concrete Bridges, including design procedures and moment charts, which was published in the January-February-March 1944 issue of Public Roads.

While the use of AASHO H20 loading was quite general, the new and heavier H20-S16 loading was adopted for bridges on routes that would probably be included in the Interstate System. There was a general trend toward the use of heavier loading design of bridges on all highway systems.

With the toll turnpike era starting again after the war, good architectural treatment of structures was encouraged, especially where improvement could be made without substantial increase in cost. Consulting engineers and architects were retained for design of these toll road structures and for other major bridges on the Federal-aid system.

In the 10 years following World War II, the march of new developments in the bridge field resumed. One of the most widespread was the use of composite steel beam bridges, which enabled the deck slab to work with the steel beams as a main load-carrying member.

Another development was the use of welded bridges. Welded steel bridges, except for minor details, had not been permitted on the Federal-aid system until after World War II because of the lack of toughness (and resultant welding inadequacy) of most structural steel used for bridges. At first, welding on bridge members was limited to welding flange cover plates to beams and web to flange connections on plate girders. At BPR's urging, steel producers developed a weldable steel for bridges which had sufficient chemical controls to produce a tougher steel. The American Society of Testing and Materials (ASTM) adopted the Specification for Structural Steel for Welding (A373) in 1954. ASTM A373 steel was supplanted in 1960 by ASTM A36 steel which had the same toughness with a higher yield point. The availability of these steels rapidly expanded the scope and volume of welded structures and eliminated the riveted plate girder save for very large bridges and railroad structures. More versatile designs and economy of weight were obtained with welded designs.

At about the same time, high strength bolts were developed for use in place of rivets in the connection of structural members. These bolts, tightened to their proof load, clamp the plates tightly together and transfer the stress in joints by friction rather than by bearing and shear on the bolt.

However, the most significant development of this period was the use of prestressed concrete in which highly stressed steel wires introduced compressive forces into the concrete to offset the tensile stresses 


\section{The National System of Interstate and Defense Highways}

The Federal-Aid Highway Act of 1956 provided for construction of the 41,000-mile Interstate System with an accompanying source of funding. This System, which was to be a modern, safe, limited access, divided highway, set highway and bridge design engineers to work developing ideas for facilities which would be adequate for estimated future needs. The tremendous number of structures required to maintain access control encouraged continuous study of structure types and construction methods. Coincident with this was the dawn of the computer age. The capability of these electronic machines to perform lengthy mathematical operations permitted more refined anal- ysis of increasingly complex structures in less time. Just as moment distribution gave impetus to continuous frame analysis, the computer made indeterminate analysis commonplace. The elimination of the computational drudgery brought a return to more basic and theoretical solutions and away from the approximation methods of the second quarter of the century. The computer also created new approaches, such as the finite element method.

The numerous large and complex grade separation structures and extensive urban viaducts led to many bridge developments in designing for improved architectural treatments and economy. Deck structures were generally used with girders curved to follow the alinement of the roadway. Box girder design tech-

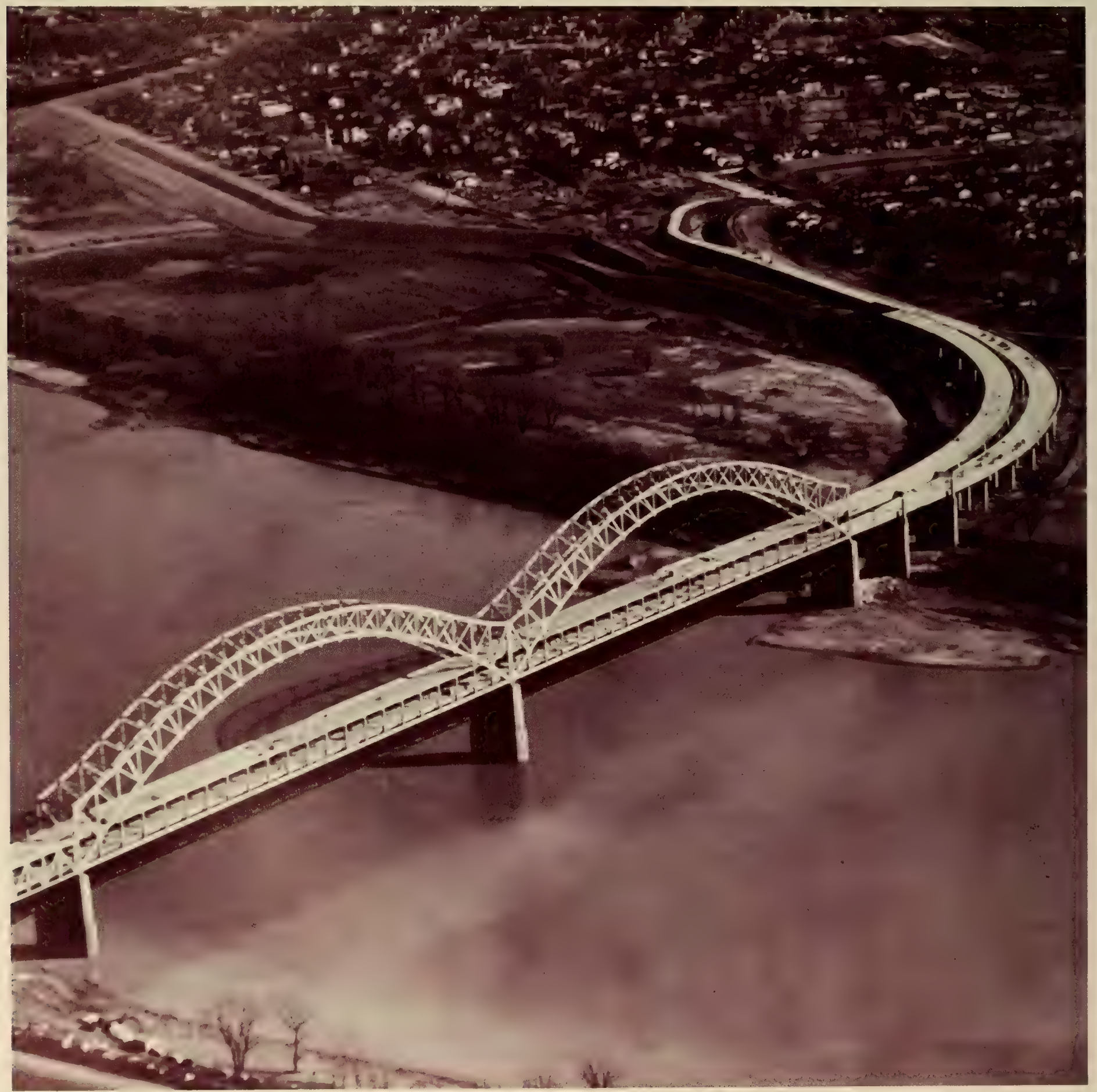

High strength steels were used for the welded arch truss members of the Sherman-Minton Bridge over the Ohio River on I-64 between Louisville, Ky., and New Albany, Ind. 
Completed in 1973, the Sitka Harbor Bridge in Sitka, Alaska, is the first cable-stayed highway bridge in the United States. The cable-stayed welded steel box girder design was selected

to make the structure as visually unobstructive as possible from Sitka and Castle Hill, the site of Baranof Castle, from which the Russians governed Alaska prior to $186 \%$, when it became a U.S. territory.
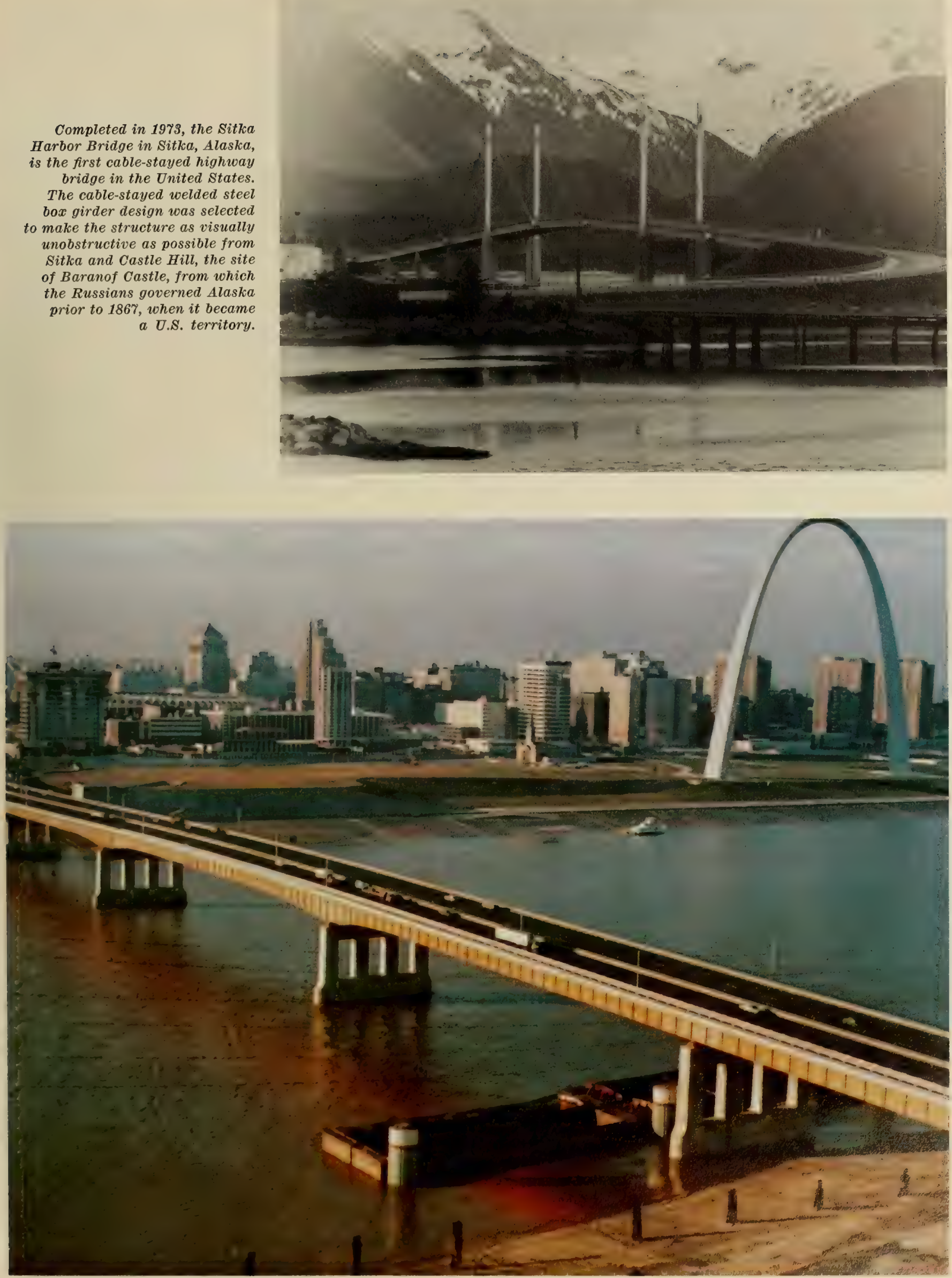

The Poplar Street Brilge orer the JLississippi Rirer at St. Louis, Mo 


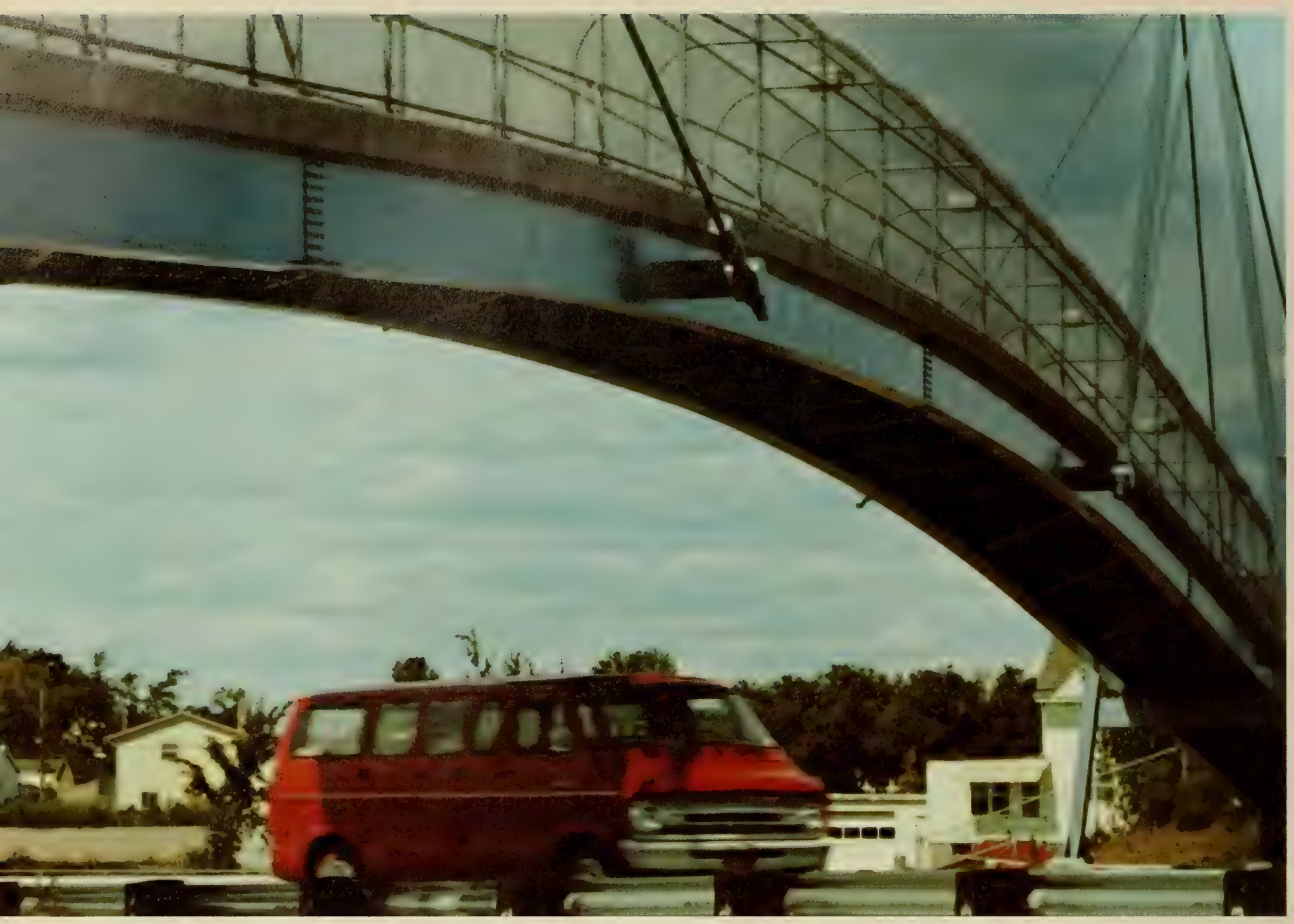

This pedestrian bridge over U.S. 41 in Menomonee Falls, Wis., was the first cable-stayed girder bridge in the United States.

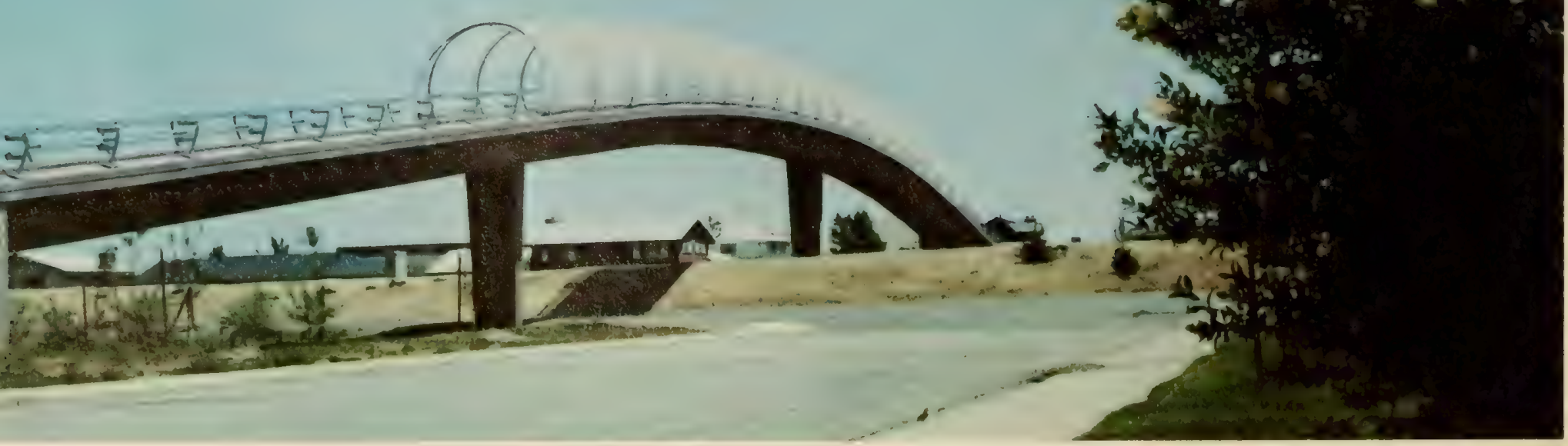


niques were developed for the longer spans. Reinforced concrete box girders and composite structural steel box girders were constructed to conform to the sinuous and undulating lines of the ramps and viaducts. Without the computer many of these structures could hardly have been analyzed and designed realistically or economically.

As happens so often, a breakthrough in one area seems to lead to one in another area. Prestressed concrete has already been mentioned. New structural steels were also developed to permit larger, more heavily stressed bridges. In 1959 and 1960, a new high-strength low-alloy structural steel for riveted construction, ASTM A440, and a companion steel for welded construction, ASTM A441, were produced to supersede the then-standard silicon steel.

In 1961 , a temporary specification for a 90,000 100,000 pounds per square inch yield strength steel for long-span bridges was approved by Public Roads for use on Federal-aid projects. After 3 years, an ASTM specification for this steel, High-YieldStrength, Quenched and Tempered Alloy Steel Plate, Suitable for Welding, ASTM A514, was issued, and the temporary specification was discontinued. This same procedure was followed in 1966 with the highstrength columbium and vanadium steels. ASTM issued a specification for the steel, A572, without notch toughness (impact testing to insure steel will resist fatigue cracking) requirements. BPR accepted the ASTM specification for use on Federal-aid projects with welded steel only if a special provision covering notch toughness was included in the project specification. This was done, but the use of the special provisions was discontinued in 1974 when ASTM included notch toughness tests for all structural steels.

The use of curved bridges produced other problems besides design, e.g., the great amount of scrap metal resulting from cutting the flanges to the curve. This required development of new fabrication methods whereby members were fabricated straight and then heated and bent to the desired curvatures, thereby eliminating the waste.

To achieve better quality control in welding bridge members, nondestructive testing by radiography, magnetic particle and ultrasonic testing were developed by Public Roads bridge engineers. Ultrasonic testing of welded groove joints was found to be a faster, more sensitive and cheaper method of locating weld defects than the methods previously used.

Among the many long-span bridges built on the Interstate System to cross wide waterways, the Poplar Street Bridge over the Mississippi River at St. Louis is one of the most notable structures. A truss or arch span was not acceptable since it was considered that its bulk would detract from the nearby Gateway Arch and the Eads Bridge. The 8-lane bridge, constructed in the mid-1960's with a 600 -foot center span, is the Nation's longest box girder bridge and the first large structure in the United States to use orthotropic design. Orthotropic design, developed in Europe, consists of main girders and a stiffened steel plate deck welded together so as to act jointly in supporting the structure. The stiffened plate deck serves a fourfold purpose as bridge deck, stringers, and an upper flange for both the floor beams and the main girders, reducing the dead load of the structure.
Pedestrian crossings of freeways became necessary in some locations to avoid undue division of established neighborhoods. Topography and personal safety of pedestrians generally dictate the design of overpasses. Protection for the traffic below from objects dropped or thrown from pedestrian crossings led to the use of enclosures or high fences of closely meshed wires on the overpasses. Many unique and attractive structures have been developed for these overpasses.

\section{Bridge Research}

The AASHO Road Test near Ottawa, Illinois, discussed in Chapters 4 and 6 , is a good example of Federal-State cooperation on research. Public Roads bridge engineers designed and prepared the plans for the 18 bridges in the program. The bridges were designed with high working loads so that fatigue failures could be expected. There were 18 steel and/or concrete beam spans representing contemporary practices.

At the conclusion of the regular test traffic in December 1960, 7 of the 11 surviving bridges were subjected to accelerated fatigue tests, and two were tested to failure by increased vehicle loads. The mass of test-to-failure data on the behavior of the bridges under repeated loading has proved to be of major assistance in subsequent studies for developing specifications and design revisions.

Seven years later, full size welded plate girders were fatigue tested at Lehigh University under the sponsorship of the Welding Research Council. Analyses of the results of these tests resulted in design and specification changes for welded and riveted plate girders and confirmed the integrity of properly designed and constructed welded girders.

Since the late 1920's, research and development has been greatly broadened in the nonstructural areas, such as hydraulics. While bridges and culverts have been used for centuries to cross streams and rivers, the structural elements of these crossings have attracted most of the attention of engineers with less attention given to the bridge's capacity to accommodate floods, except for very large bridges over major rivers. Progress in highway hydraulics and drainage was slow, and in the early days, designs were frequently based on judgment without well developed engineering technology or adequate rainfall data. Drainage structures, including bridges, were commonly sized by using empirical formulas developed in the 19th century.

Progressive engineers had long recognized the shortcomings of drainage design and had stressed the importance of estimating the magnitude and frequency of flood flows and the risk of damage. The lack of hydrologic data and the dearth of information on hydraulics of highway structures made it difficult to develop policy and design procedures.

Research on hydraulics and hydrology started in the 1920-1930 era, mainly encouraged by Public Roads and other agencies of the Department of Agriculture, and after World War II, extensive development in the application of hydraulic engineering principles to highway design began in Public Roads. During the 


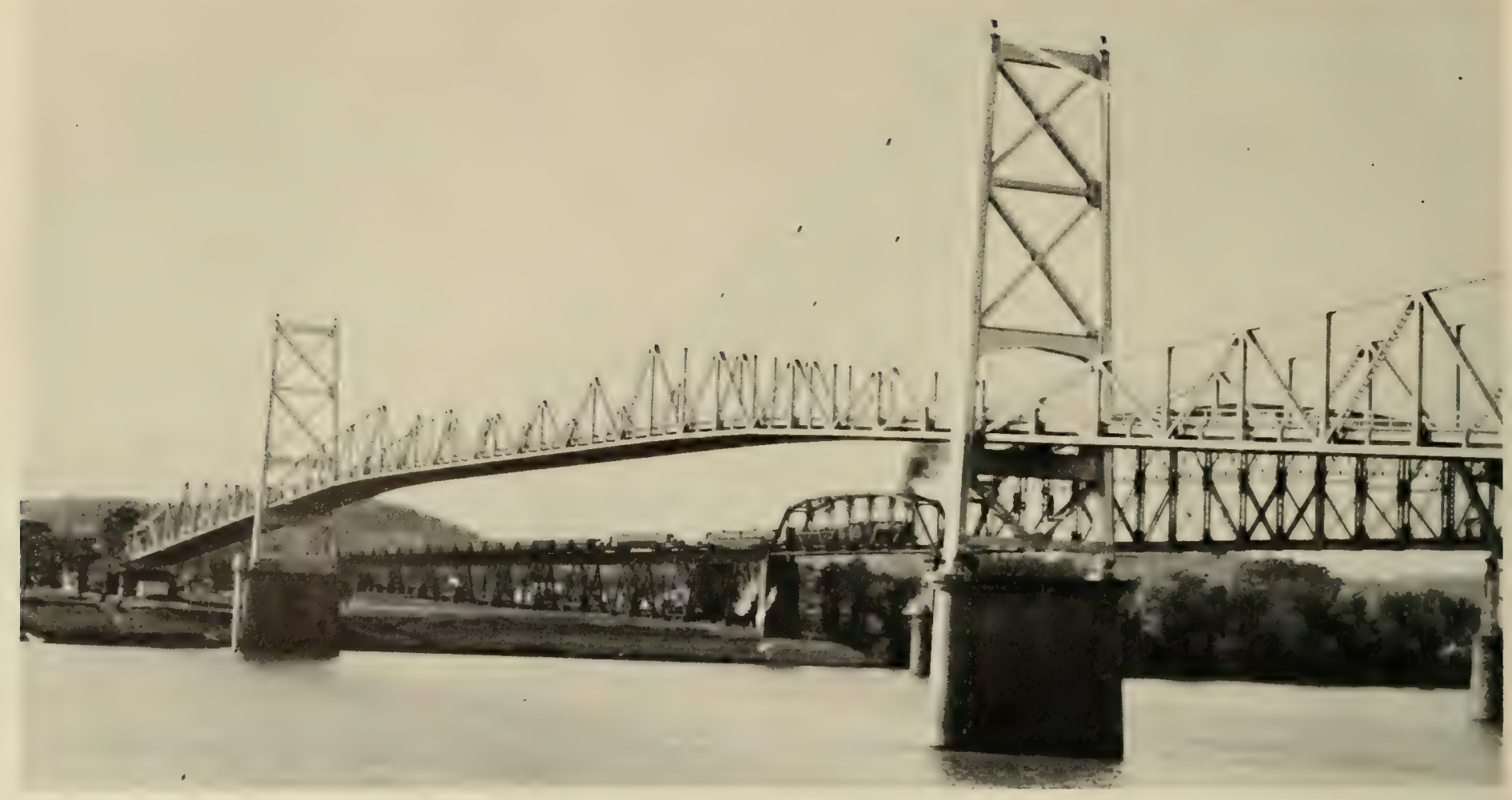

The infamous Silver Bridge over the Ohio River at Point Pleasant, W. Va.

1950 's, an extensive program of research on the hydraulics of culverts, bridges, and storm sewers was undertaken, largely by contract with various universities and other Federal agencies.

In 1959 a Hydraulic Branch was established in the Public Roads Bridge Division. The functions of this Branch were to initiate and participate in hydraulic research, to disseminate the practical application of hydraulic design to bridge engineers and to review hydraulic features of Federal-aid structures. Studies were also made on stream pollution from highway and bridge construction and guidelines were issued on reduction of such pollution.

One of the most important contributions in this area was BPR's Hydraulic Engineering Circulars and Hydraulic Design Series Bulletins. These publications, still in use, provide practical methods for applying research results to designs and are widely used by Federal, State and consulting engineers.

Other areas of bridge related research and development included safety measures, with particular emphasis on:

- Elimination or neutralization of hazardous fixed objects along the roadside including bridge piers, abutments, parapets, and culvert headwalls.

- Strengthening of bridge guardrail designs and the new concept of a strong beam (rail) with a weak post that would yield partially and redirect the errant vehicle safely back to the road.

- Breakaway sign supports and lighting poles that break when hit by a vehicle, thereby reducing the injury to vehicle and occupants on collision. In collisions, the vehicle usually passes under the sign or pole before it falls. These concepts were developed at Texas A\&M through State and Federal funding.
- Gore* protection devices to protect out-of-control vehicles at the diverging point of ramp exits and branching roadways. These rapidly reduce the speed of an out-of-control vehicle by the absorption of energy by using springs, crushing of drums, displacement of water or sand or related methods.

- New criteria for design of sign supports, including new recommedations for certain aluminum alloy design stresses, accepted and published by AASHO in 1961.

\section{The Scene Today}

The State transportation agencies, the Federal Highway Administration, the highway industry and research groups have achieved a finely tuned, cooperative highway program. It is difficult to say that any one group is responsible for new developments, since each concerned group has played a part. This is the way it has been with the latest developments in bridge design, ultimate strength design (USD) for concrete and load factor design for steel. The Bureau of Public Roads supported these developments vigorously and was in the forefront of this movement when it published the Strength and Serviceability Criteria-Reinforced Concrete Bridge Members-Ultimate Design in 1966. This helped bring the bridge specifications up to the American Concrete Institute (ACI) Building Code Requirements for Reinforced Concrete which had adopted USD in 1963. A Tentative Criteria for Load Factor Design of Steel Highway Bridges, with

\footnotetext{
* The elongated triangular area where one-way roadways begin to separate.
} 
commentary, was developed and circulated by the American Iron and Steel Institute in 1968. This criteria for steel design was similar to the strength and serviceability criteria for USD in that the designs are based on yield conditions and load factors. Basically, these methods represent a departure from designing a structure for service loads with an overall safety factor. Under USD and load factor design, magnification of individual safety factors are applied to the various types of loads. The magnified loads are then totaled and used to proportion a member assumed to be in a state of incipent yielding. These methods, with additional controls for overload, excessive cracking, deflection, vibration, and permanent set and for fatigue of material at working loads, have been incorporated in the AASHTO Bridge Design Specification criteria.

Comparisons of costs have shown an initial economy in material costs for both steel and concrete members proportioned by these methods over those proportioned by working stress design, especially for long spans.

The events chronicled here, aside from a few setbacks, have been a series of successes. One failure should be recorded to alert the bridge engineer frater- nity that these is more to be learned about materials and fatigue structures. On the evening of December 15, 1967, a 39-year old eyebar suspension bridge quivered slightly and then collapsed, carrying 46 persons to their deaths in the icy Ohio River. This catastrophic failure of the Silver Bridge at Point Pleasant, West Virginia, shocked the Nation.

An extensive investigation, including mechanical and chemical tests of the failed structure, showed that the failure was initiated by fracture of an eyebar in the suspension chain. It was further determined that a small corrosion pit on the pin hole face of the eyebar started a small crack and that the crack reached critical size under the joint action of stress-corrosion and fatigue.

The disturbing part about the Silver Bridge failure was the contributing causes listed as:

- In 1927 when the bridge was designed, the phenomena of stress corrosion and fatigue were not known to occur in the classes of bridge material used under conditions of exposure normally encountered in rural areas.

- The location of the flaw was inaccessible to visual inspection.

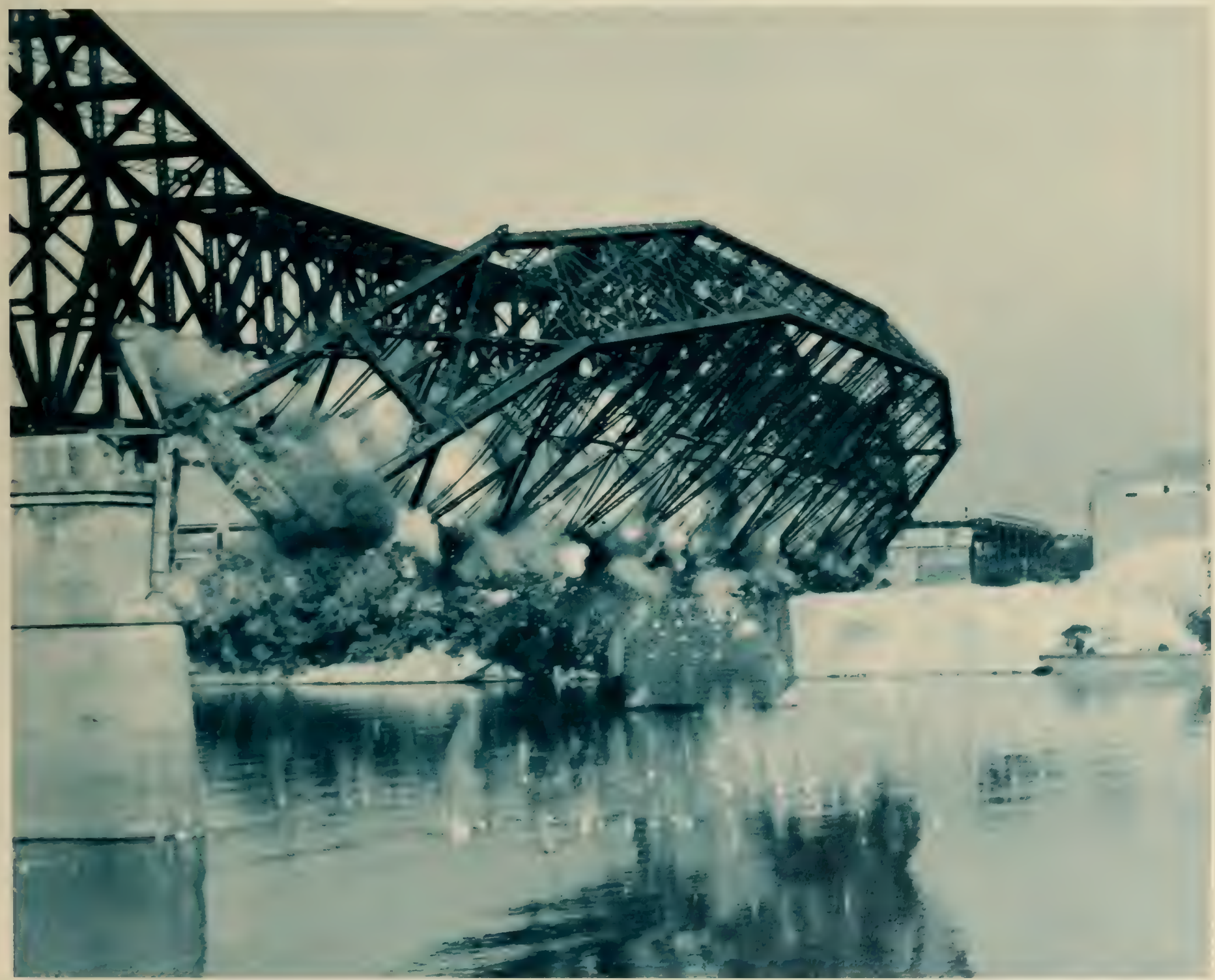

The C\&O Bridge over the Ohio River between Cincinnati, Ohio, and Covington, Ky., was removed by explosives after inspection revealed it was unsafe for highway traffic. The replacement bridge was opened to highway traffic in 1974. 
- The flaw could not have been detected by any inspection method known to the state-of-the-art today without disassembly of the eyebar.

These revelations led to a program of immediate bridge inspections and bridge inventories directed by a committtee formed at the direction of the President. As a result of this committee's actions, new inspection equipment is being developed and purchased and sophisticated devices are being employed for inspecting bridge members and for determining scour at bridge piers. Bridges deemed unsafe are being closed to traffic, and bridges are being reappraised as to load capacities.

The 1968 Federal-Aid Highway Act mandated national bridge inspection standards for the Federal-aid systems. These standards establish inspection qualifications and require biennial inspections. All States are required to maintain written inspection reports and a current inventory of all bridges on the Federalaid systems.

The 1968 Act also required that an inspector training program for employees of the Federal and State governments be established and be kept current with new and improved techniques. In the Federal-Aid Highway Act of 1970, a bridge replacement program was required to replace substandard bridges over waterways and topographic barriers. This program is now in full swing. Many of the most deficient bridges have been or are being replaced. There are thousands of bridges on the Federal-aid system that are posted as having limited capability of carrying truck traffic. It is presently estimated that replacement cost would be approximately $\$ 2.3$ billion.

The 60 years since the first Federal-aid act have been a challenge to the bridge engineer. The first goal was to set a plan of cooperation and encouragement between Federal and State organizations in developing bridge standards, then to devise a comprehensive and workable program for planning, designing, approving and inspecting Federal-aid bridges to meet the current and predictable future needs of traffic. With no early background for predicting traffic growth and facing an unprecedented increase in vehicle volumes, speed and weight, increased higher standards for width, alinement and strength of bridges were required, and many existing bridges became obsolete.

Continuous and careful attention to new developments was necessary to maintain current criteria and specifications for bridge planning and design. The first 60 years' pursuits and accomplishments leave a background of experience and knowledge for continued accomplishmment of future comprehensive programs.

\section{Highway Tunnels}

As was the case in Europe, tunneling activity in this country began with the mining industry, followed by canal tunnel construction, then the railroads and finally highways. Most of the early canal and railroad tunnel work was done in Pennsylvania, but California holds several important "firsts" for highway tunnels.
By stretching the definition of a highway tunnel to include tunnels constructed for horsedrawn traffic before the automobile came into general use, probably the oldest highway tunnel in the United States is located in California. Built during the 1870's, the tunnel pierces a high rock cliff on the Pacific Ocean about 6 miles south of San Francisco. Complete and accurate records concerning this tunnel are lacking, but historians speculate that the bore was built to permit local ranchers easy access to San Francisco along the beaches. ${ }^{48} 49$

The first tunnel of substantial length constructed to accommodate automobile traffic is also located in California. Completed in 1901, the Third Street Tunnel passes through Bunker Hill in downtown Los Angeles. Interestingly, the contractor made an unsuccessful attempt to use a tunnel boring machine on the project. ${ }^{50}$

The pioneer spirit and Yankee ingenuity of American tunnel builders was perhaps most evident in the 1920 's. During this era, some of the most famous highway tunnels in the United States were built. Early in the 1920's a comprehensive research program developed the fundamental data for vehicular tunnel ventilation. The research was conducted in connection with the design of the Holland Tunnel. ${ }^{51}$ Passing under the Hudson River between New Jersey and New York, the Holland Tunnel was the first major subaqueous vehicular tunnel in the United States. It was opened to traffic in 1927 . Three years earlier the Liberty Tunnels were completed in Pittsburgh, Pennsylvania, and, at 5,800 feet, were the longest highway tunnels in the country at that time. ${ }^{52}$ About the same time, the Posey Tube under the estuary between Oakland and Alameda, California, was nearing completion. When opened to traffic in 1928, the Posey Tube became the first highway tunnel in the world to be built by the "trench method." ${ }_{53}$ An American innovation, the trench method consists of sinking prefabricated tunnel sections into a prepared trench on the riverbed. A total of 13 highway tunnels have been built by the trench method, the latest being the Wallace Tunnel on Interstate 10 in Mobile, Alabama, opened to traffic in 1973.

The decade of the 1930's saw most of the tunnel construction being concentrated in the western States. Many of these tunnels were located on the new access routes into the national parks. Probably the most notable accomplishment during the 1930 's was the Yerba Buena Island Tunnel connecting the San Francisco-Oakland Bay Bridges in California. Completed in 1937, it remains the only double-deck highway tunnel in the country.

Immediately following World War II, tunnel construction activity quickened, and in 1950 another record was established. The Brooklyn-Battery Tunnel under the East River in New York City became the longest highway tunnel in the country-a distinction it still holds today.

Since the early 1960 's, the bulk of U.S. highway tunnel construction has been within the Interstate System. To date 15 major tunnels have been completed on the Interstate, 4 are under construction and 13 others are under design. These facilities are designed to safely handle high-speed traffic, a far cry from that narrow passage carved through a cliff on a California beach. 


\section{REFERENCES}

${ }^{1}$ L. EdDARds, A RECord of History and Evolution of EarLy American Bridges (University Press, Orono, Maine, 1959) pp. 47,48 .

'Id., p. 197.

${ }^{3} I d$., p. 40.

Id., pp. 49, 50.

${ }^{8} I d$., p. 50.

Id., p. 56.

"Id., p. 61.

${ }^{8} I d$., pp. $80,82$.

${ }^{\circ} I d$., p. 63.

${ }^{10} \mathrm{G}$. Hunt, A Century of Engineering in Wood Preservation, Proceedings of Wood Symposium, September 3-13, 1952 (Timber Engineering Co., Washington, D.C., 1952) p. 66.

${ }^{11}$ J. GIes, Bridges and Men (Doubleday, Garden City, N.Y., 1963) p. 107.

${ }^{12}$ H. Haupt, Generat Theory of Brtoge Construction (D. Appleton and Co., New York, 1853) pp. 243-247.

${ }^{13} \mathrm{~J}$. GIEs, supra, note 11, p. 112.

${ }^{14}$ L. EDWARDS, supra, note 1, p. 75.

${ }^{15} I d$., p. 71 .

${ }^{16} I d$., p. 74.

${ }^{17} I d$., p. 76

${ }^{18} \mathrm{~J}$. GIEs, supra, note 11, pp. 155-177.

${ }^{10}$ A. Reichmann, The History of Bridge Development, JourNAL OF the Western Socrety of Engineers Special Edition75 Years of Engineering Achievements In the Midwest, Dec. 1944, pp. 60,61

${ }^{20}$ L. EDwARDs, supra, note 1, pp. 125, 126.

${ }^{21} I d$., p. 204.

${ }^{22} I d$., p. 122.

${ }^{23} I d$., pp. 41-44.

${ }^{3} I d$., pp. 202, 203.

${ }^{25} I d .$, pp. $162,163$.

${ }^{28} I d$., pp. 88-90.

${ }^{27} I d .$, p. 167.
${ }^{28} I d$., p. 90.

${ }^{29} I d$., pp. 199, 200.

${ }^{30} I d$., p. 190.

${ }^{31} I d$., p. 194.

${ }^{32} I d$., p. 198.

${ }^{33} I d$., p. 197.

${ }^{3}$ O. Hovey, Movable Bridges, Vol. I (John Wiley and Sons, New York, 1926) pp. 146-149.

${ }^{35} I d .$, pp. 151, 152.

${ }^{36}$ L. EDWARDS, supra, note 1, pp. 203, 204.

${ }^{37} I d$., p. 191.

${ }^{38} I d$.

${ }^{39} I d .$, p. 198.

${ }^{40} I d$.

${ }^{41} I d$., p. 200.

${ }^{42}$ F. Turneaure \& E. Maurer, Principles of Reinforced Concrete Construcrion (John Wiley and Sons, New York, 1911) p. 2.

${ }^{43}$ L. Edwards, supra, note 1, p. 137.

${ }^{44} I d$.

${ }^{45}$ A. Reichmann, supra, note 19, p. 64 .

${ }^{46}$ L. Edwards, supra, note 1, p. 140.

${ }^{47} I d$., pp. 144, 145.

${ }^{49}$ E. Drew, First Highway Tunnel, California Highways and Public Works, Vol. 35, Nos. 5-6, May-Jun. 1956, pp. 12, 13.

${ }^{49} \mathrm{~F}$. STANGer, An Interesting Historical Letter, California Hrghways and Public Works, Vol. 35, Nos. 9-10, Sept.-Oct. 1956, p. 37.

${ }^{50} \mathrm{~J}$. Quinton, The Third Street Concrete and Brick-Lined Tunnel, Los Angeles, Cal., Engineering News, Vol. XLVI, No. 3, Jul. 18, 1901, pp. 34-37.

${ }^{51}$ Studies and Methods Adopted for Ventilating the Holland Vehicular Tunnels, Engineering News-Record, Vol. 98, No. 23, Jun. 9, 1927, pp. 934-939.

${ }^{52}$ Pioneer Highway Tunnels Modernized for Service, ENGINeEring News-Record, Vol. 131, No. 9, Aug. 26, 1943, p. 68.

${ }^{63}$ T. Merriman \& $T$. Wiggrn, American Civil Engineers' HANDBOoK, 5th Ed. (John Wiley and Sons, New York, 1949) p. 1647 . 


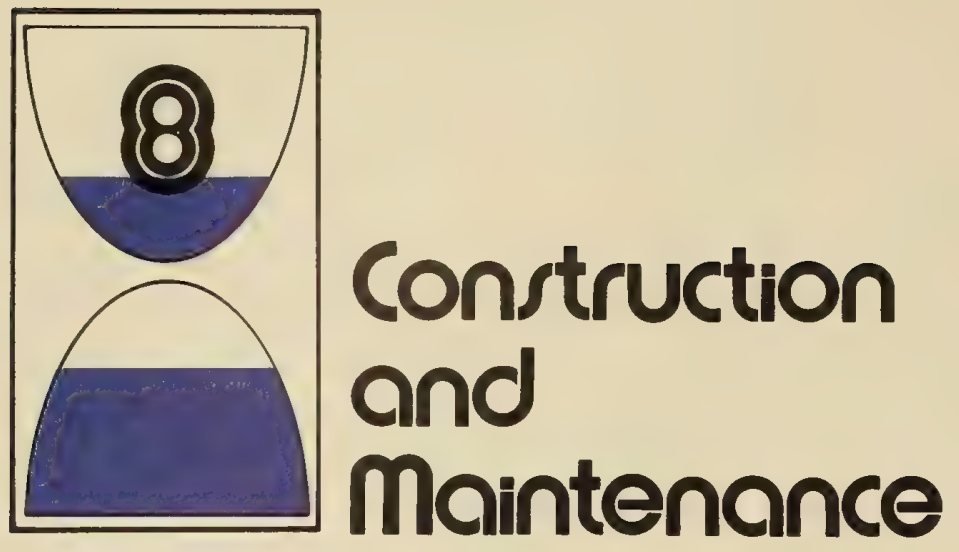

In the late 1800 's, with the growth of the cities, the demand for better roads increased. The need to move farm produce from the fields to the city in a steady, dependable manner grew with the increasing city population. Yet, only about 150,000 miles of the rural roads were surfaced, while the vast majority was of rutted, packed earth that became unusable with inclement weather. In describing the prevalent condition of the roads in this country, General Roy Stone said, "In many parts of the United States the roads are torn up with the outcoming frost in the spring, soaked with autumn rains, frozen into ridges in winter, and buried in the dust in the summer, making four regular seasons of bad roads, besides innumerable brief 'spells.'" 1

Roadbuilding and maintenance, in the latter 19th century, was still primarily accomplished by the statute labor system using horsedrawn slip scrapers and teams and wagons. The road grader, first introduced in 1878, consisted of a steel blade hung beneath

Early grading operations were performed with pick, shovel, and animal-drawn equipment.

This muledrawn slip scraper hauled very little earth compared to more modern devices.

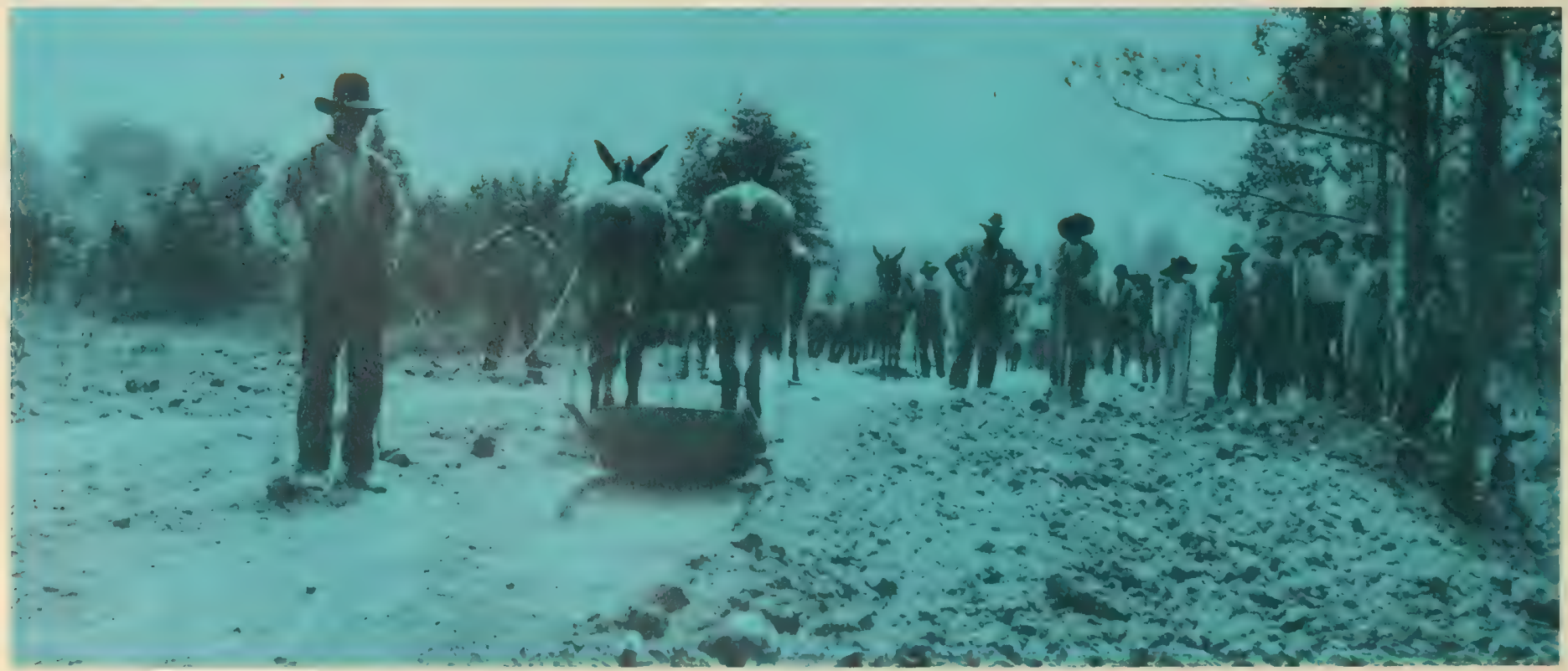




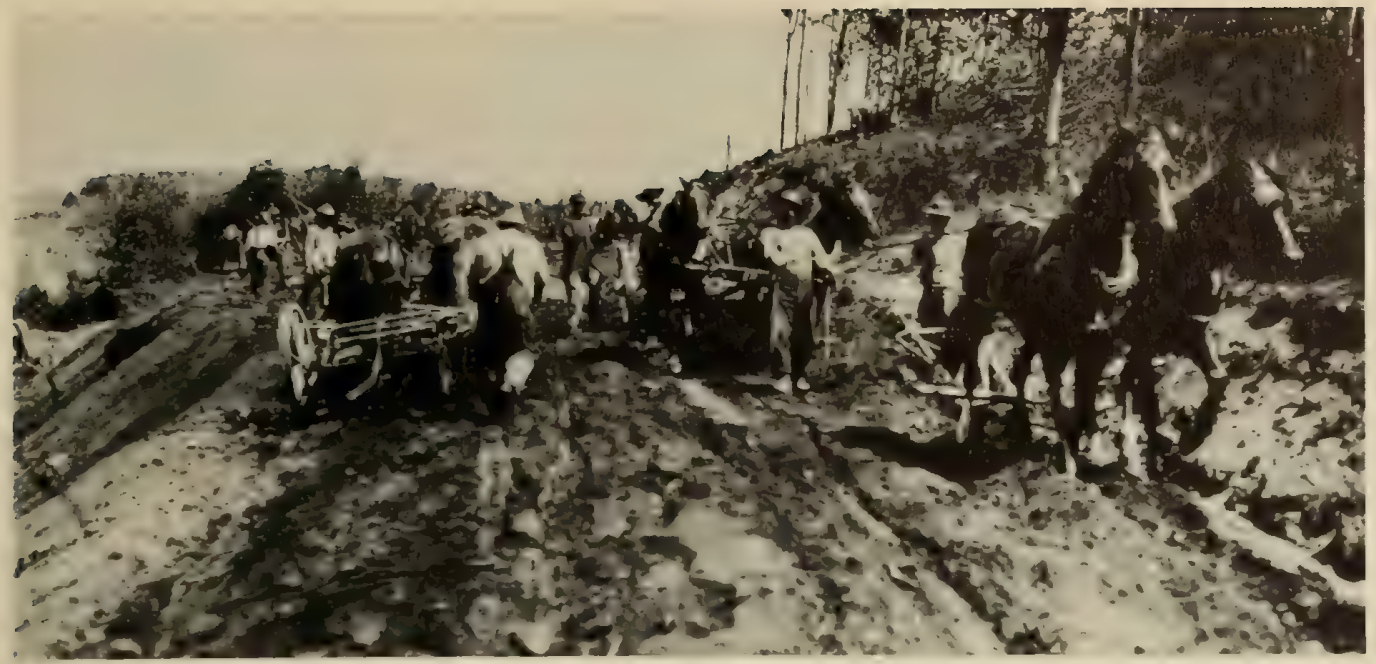

Grading a new location at a washout in 1914. At right a man uses a plow to form a ditch, others drive horsedrawn wheel scrapers.

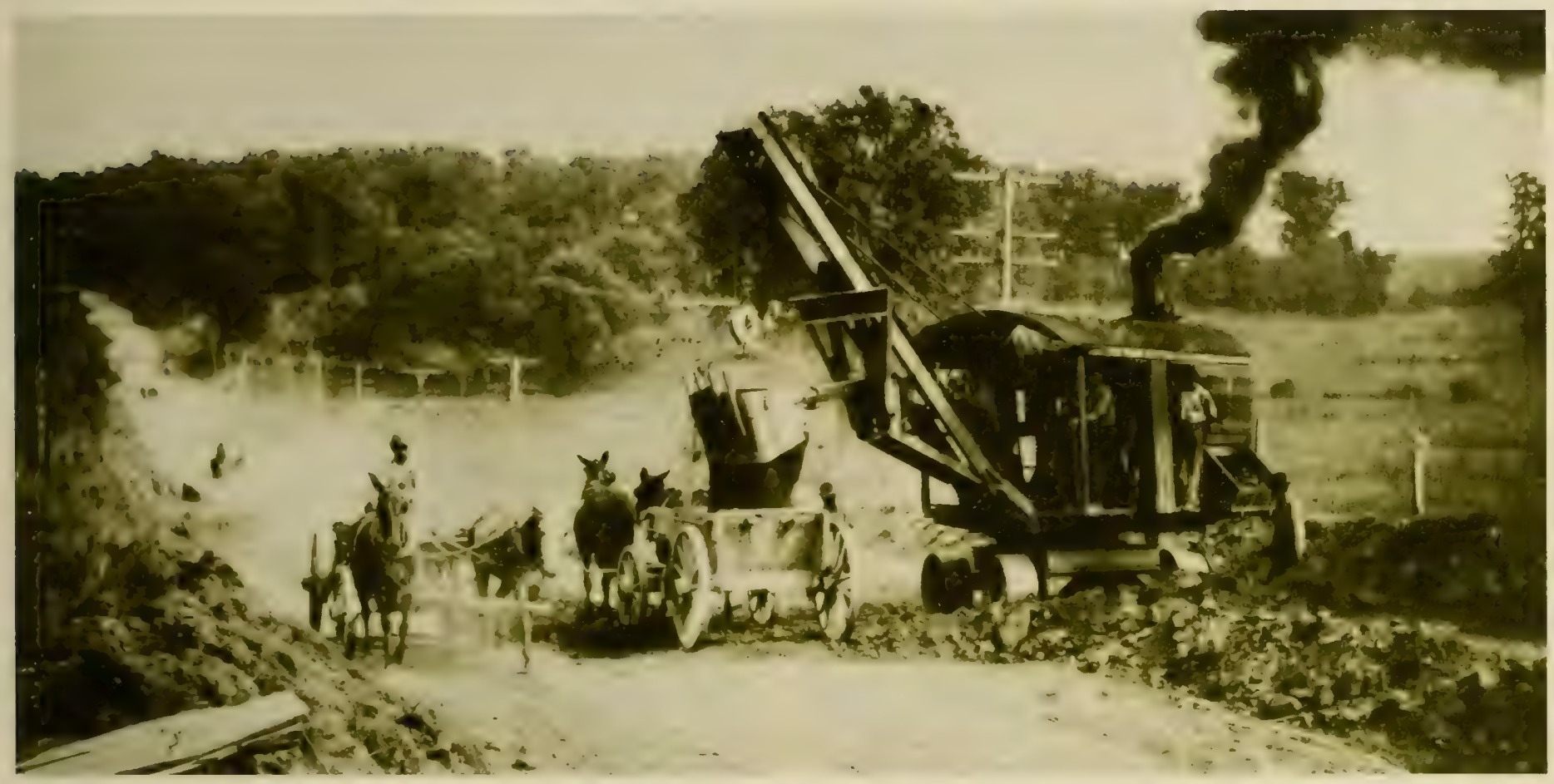

Steam shovels were used for excavation work in the early 1900's, but dump wagons were still horsedrawn. Bottom dump wagons, shown here, were especially useful for dumping heavy, sticky material.

a wooden wagon. But changes were starting to take place. The Office of Road Inquiry, established in 1893, sent engineers to various parts of the country to construct object lesson roads in order to demonstrate that year-round good roads were possible and to show the proper roadbuilding methods to achieve them. In machinery, the steam shovel and steam roller were already in limited use but the new steam tractor, with its broad iron wheels, foreshadowed the retirement of the horse and mule from the road construction scene.

\section{0 to 1916-The Beginning of Federal-Aid Construction}

After the turn of the century, there were some very significant happenings which had quite an influence on the future of road construction. The Office of Public Roads (OPR) engineers continued to teach others how to build and maintain good roads under the object lesson roads program while also studying and investigating new methods themselves. The small Federal laboratory in the OPR developed tests for aggregates and other materials and made important contributions toward overcoming defects in early bituminous construction. Public Roads engineers determined and published typical specifications for highway construction, the first of which was in 1913 concerning the fabrication and erection of steel highway bridges.

With the coming of the automobile, the macadam and earth roads caused quite a dust nuisance in dry weather. However, it was also about this time that people realized that oil could be used as a road material. It was found that a road covered with oil would be free from dust in the dry season, yet hard and firm in the wet season. This led the way to early experiments with tar and bituminous material to improve road surfaces. ${ }^{2}$ 
In 1905, coal tar and crude oil were experimentally applied to recompacted macadam streets in Jackson, Tennessee. After nearly a year of observation, it showed that the coal tar had penetrated from 1 to 2 inches and maintained a hard smooth surface. However, the light crude oil used showed little permanent results. The heavier crudes showed nearly the same results as coal tar. Late in 1906, coal tar was used by Rhode Island on a short section of the New York to Boston trunk highway in Charlestown in much the same method as building an ordinary macadam road. After the subgrade had been thoroughly rolled, the number one stone (11/4-inch to $21 / 4$-inch diameter) was spread to a depth of 6 inches and rolled to 4 inches. Heated tar was then sprinkled on the first course with dippers. The number two stone $(11 / 2$-inch to $11 / 4$-inch diameter) was next mixed by hand with hot tar and spread to a depth of 3 inches on the first course and rolled to 2 inches. A thin coat of fine stone (passing $1 / 2$-inch ring) was then spread on the surface and rolled into the number two course to fill up the voids and provide a smooth surface-11/4 gallons of the tar per square yard were used in all. As this method provided a stable hard surface, it was advocated by State engineers for use on first class highways. ${ }^{3}$

Use of portland cement concrete pavement also was beginning to grow, as the steel drum tilting mixer came into use. The first rural concrete pavement, however, was not constructed until 1909 in Wayne County, Michigan.

In terms of new equipment and techniques, steel forms were being produced for concrete work and the gasoline engine came to construction work as the power unit for hoisting and excavation equipment, spelling doom for the steam engine. The diesel engine was also being developed and crawler tracks were being tried on tractors and cranes. A wooden-boomed excavator was rigged with a drag bucket in 1903, making this the forerunner of the drag-line. By 1907 , a sheepsfoot roller was in use on embankment work on West Coast road construction. A rock crusher and elevator was mounted on a four-wheel truck in 1910 to become the first portable crushing and screening plant. ${ }^{4}$
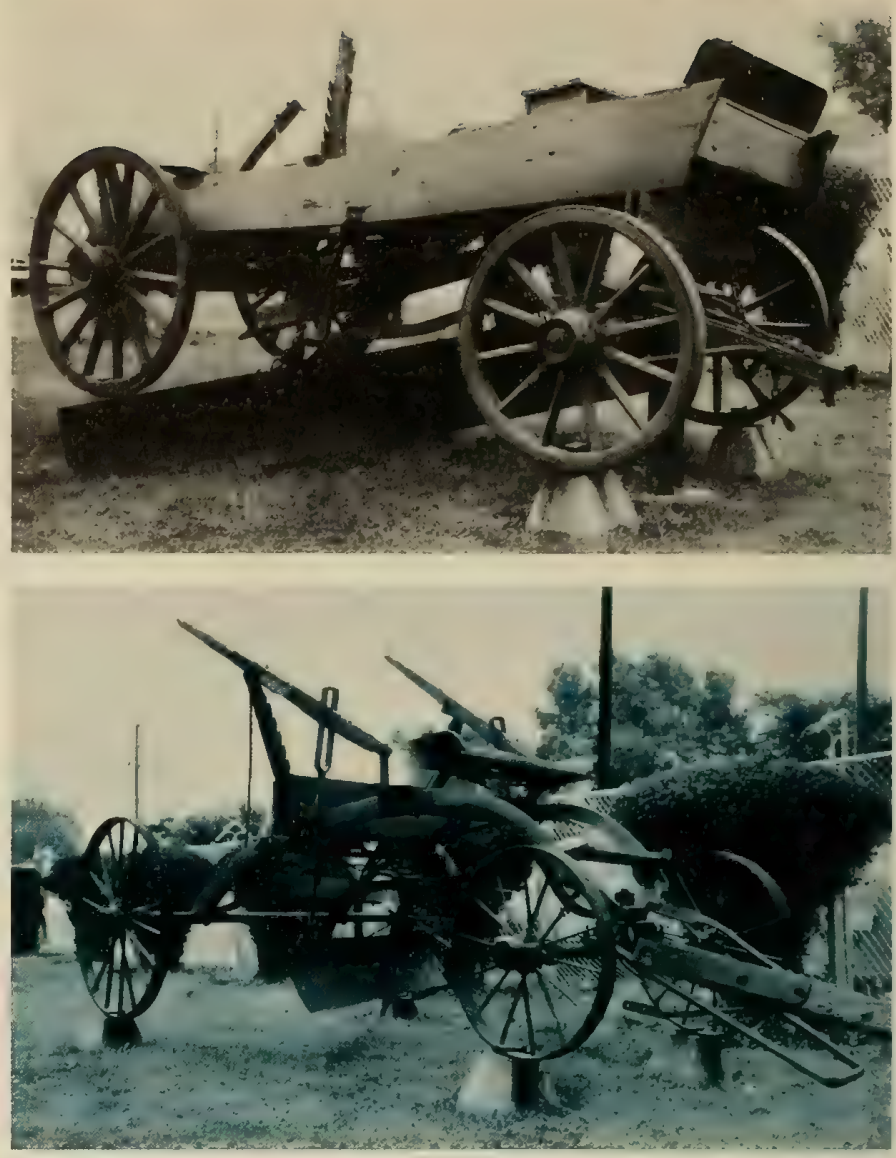

First graders ever used on highway construction work. Fixed with adjustable blades to provide the desired slope and section, graders were suited for fine grading and shaping.

Even though the first Federal Aid Road Act was not passed until 1916, in 1912, the Congress authorized funds for the improvement of post roads with the appropriation of $\$ 500,000$, to be expended in rebuilding and upgrading roads used in the rural free delivery of mails.

The first of these road projects to be built was in Lauderdale County, Alabama, where approximately 30 miles of road was graded and surfaced with gravel at a total cost of nearly $\$ 28,000$. One-third of the cost was paid with Federal funds and the remainder

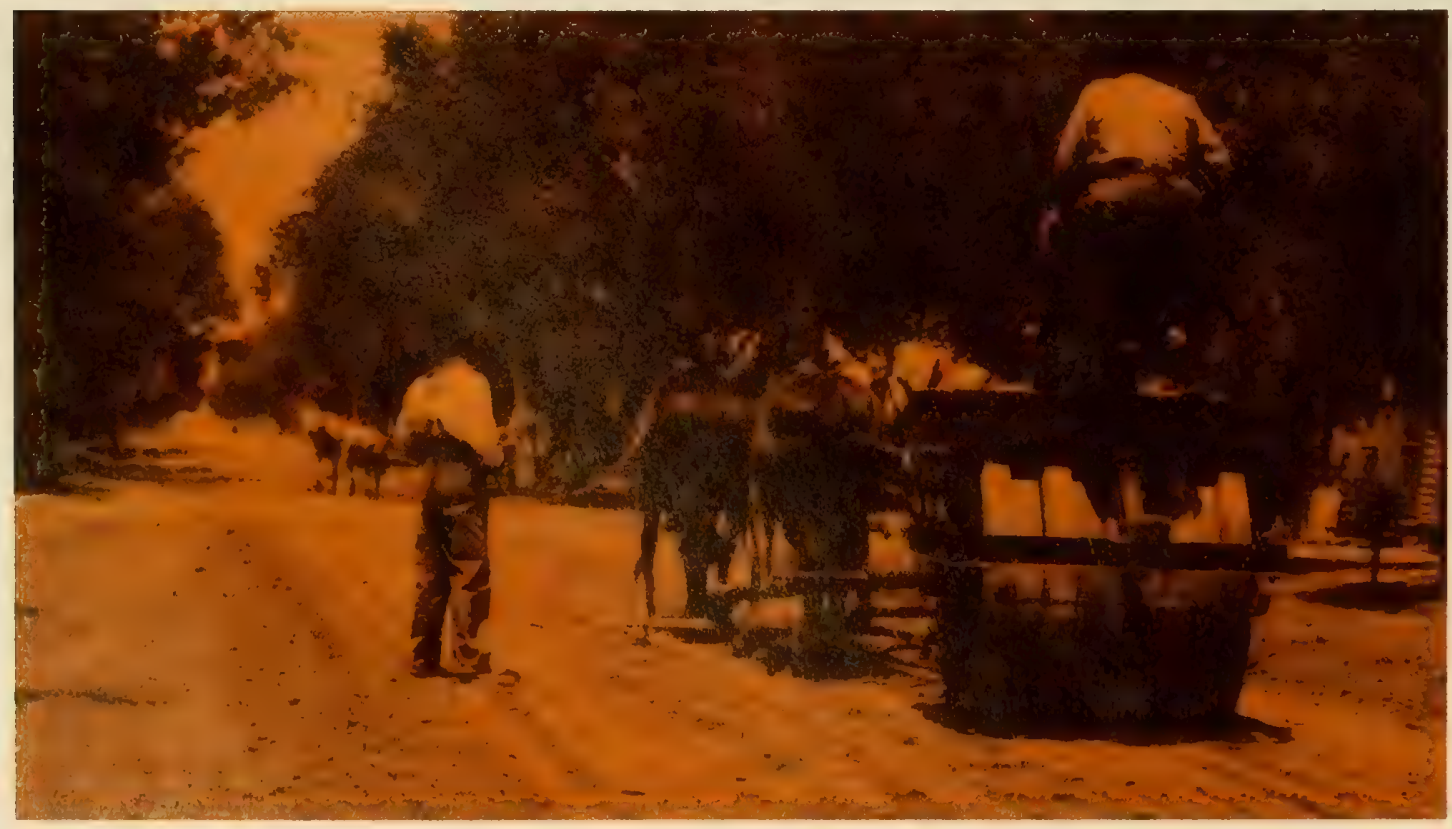

An early roller compacting a roadbed. 
The Office of Public Roads and the American Highway Association sponsored this road improvement in Dunn, N.C., in 1914, the first use of a drag in the county.

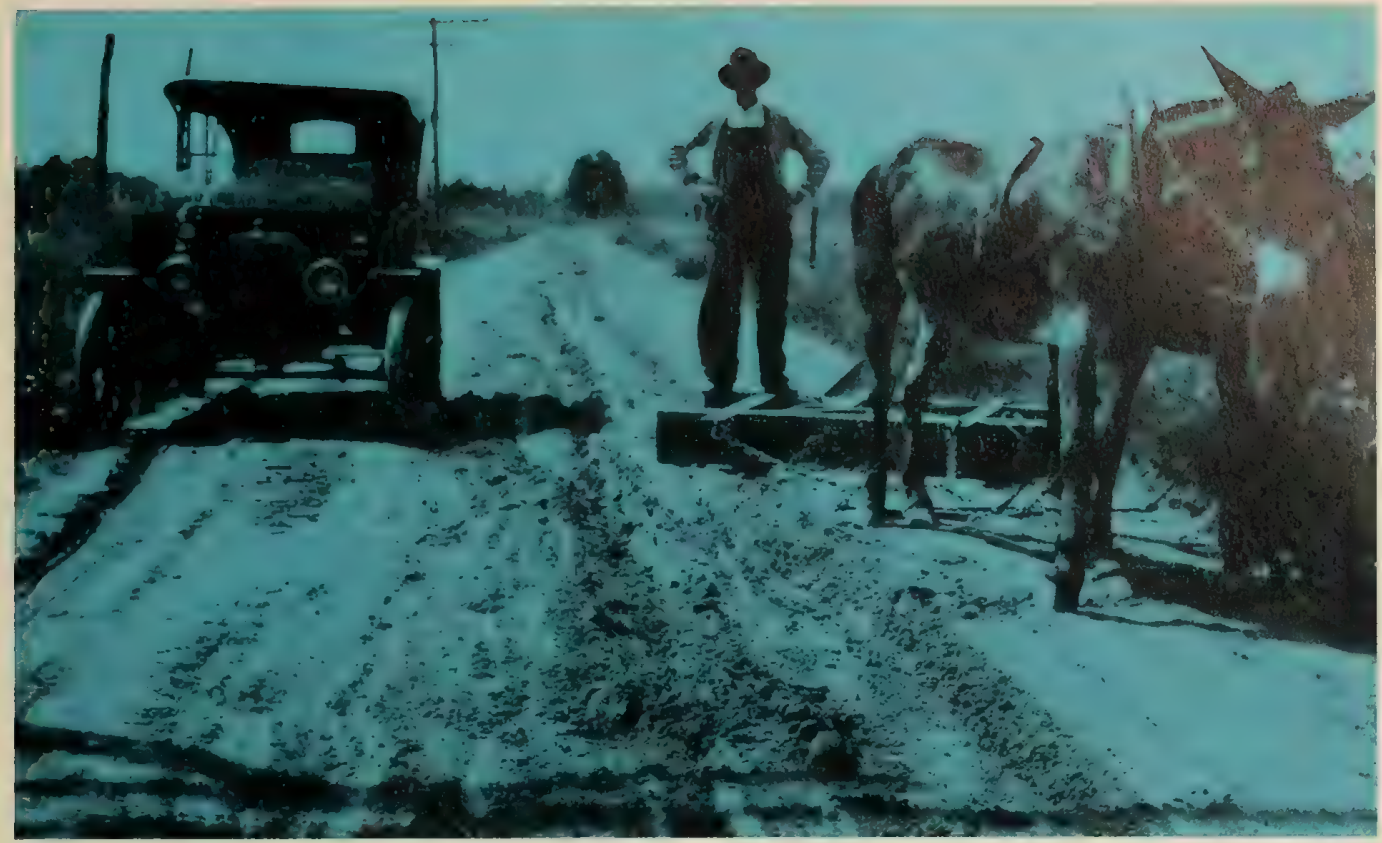

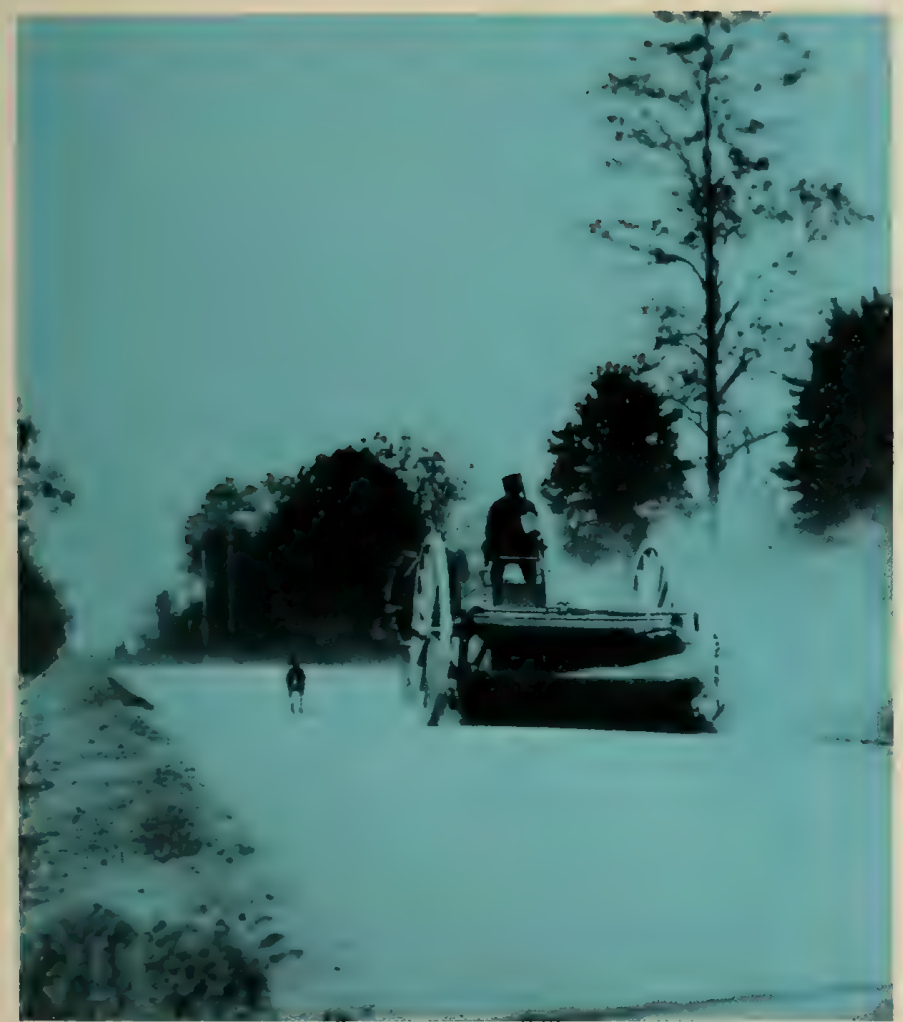

4 horsedrawn sweeper cleans the surface of a macadam road in preparation for bitumen application. It rid the surface of dust and loose material so that the bitumen would form a positive bond between the cover aggregate and the macadam layer.

with State funds. Under this post road program, each of the 48 States was to be allotted $\$ 10,000$ and the remaining $\$ 20,000$ was to be used for administrative expenses and contingencies. It was estimated that an average of $\$ 600$ per mile would be spent on this improvement whereby about 50 miles would be completed by each State with their total joint fund of $\$ 30,000 .^{5}$

It is likely that these roads were built by contract, rather than statute labor as in the past, thus, recognizing the importance of the new road technology. However, though there was probably a change in the labor system, the roads must surely have been built by hand with pick and shovel and by horsedrawn slips and scrapers. The gravel surfacing material was no doubt hauled by teams and wagons. Though many new types of equipment were being developed or modified and improved, construction equipment advertising was in its infancy and so there was often a lack of widespread knowledge of the development. In other cases, if the equipment were known, often the contractors were not ready to accept it or could not afford it. Therefore, during this time, the older methods of road construction often prevailed long past the development of new machinery and techniques.

In this era of post road building, $\$ 1.8$ million of State and Federal-aid funds was spent in the construction of 425 miles of roads-certainly not a very impressive accomplishment compared to present roadbuilding, but one that meant a great deal at the time. A further advantage of the 1912 Act was that the betterment of these post roads was a good training ground for the engineers of the Office of Public Roads, and this experience was to prove valuable in the administration of the Federal Aid Road Act of 1916.

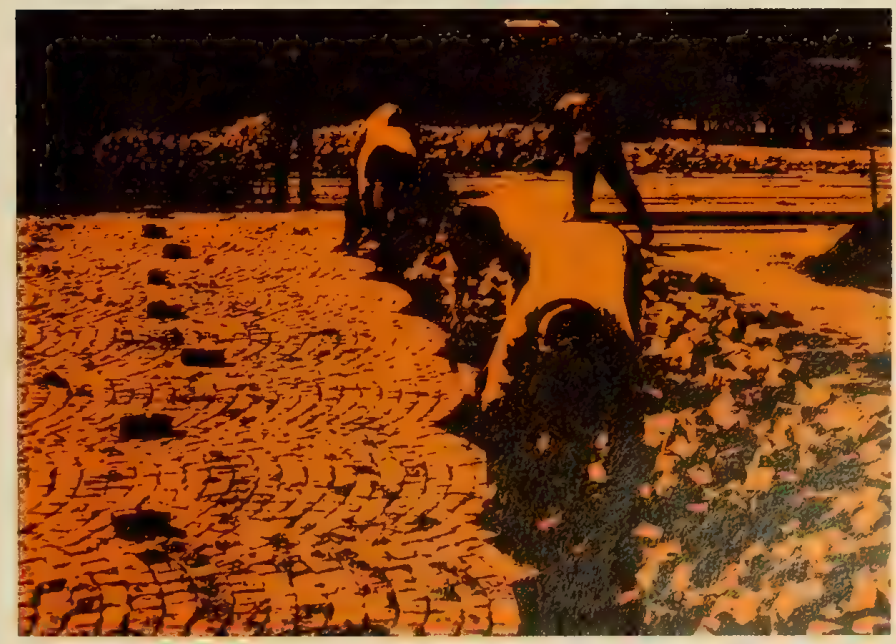

Laying block pavement in Washington, D.C., in 1917. 


\section{6 to 1926: The Start of the Federal-State Joint Highway Effort}

Evidence of the success of the small previous Federal-aid program for post road construction surely contributed to the passing of the Federal Aid Road Act of 1916 which provided for the improvement of any rural road over which the mails were carried.

One of the central features of this Act, in terms of the future, was the requirement that the States must have a highway department capable of designing, constructing, and maintaining the designated roads in order to share in the appropriation. Immediately this brought about the creation of highway departments in those States not meeting this requirement. Other provisions of the Act gave the States the authority, subject to Federal approval, to select the roads to be improved and the nature of the improvement, plus the responsibility of supervising the construction and the obligation to maintain the completed projects. $^{6}$

\section{A Need for Maintenance}

With Federal funds assured for highway construction, the door was open to considerable activity in roadbuilding. By 1918, a feeling of well being was the mood of the day. In the 1918 fiscal year alone, 6,249 miles of Federal-aid roads had been or were being surfaced. ${ }^{7}$ New surface treatments were being utilized, and equipment technology was advancing to make work easier and more productive. However, the development of heavy trucks and their usage during World War I brought this mood quickly to an end. Roads that were suitable for travel by passenger cars rapidly deteriorated as they were subjected to the loads imposed by 5- and 10-ton trucks. Prevost Hubbard, the chief chemist and expert on bituminous pavements for BPR described the situation in Public Roads:

Hundreds of miles of roads failed under the heavy motor-truck traffic within a comparatively few weeks or months. Roads with bituminous surfaces, bituminous macadam roads, and bituminous concrete roads all failed

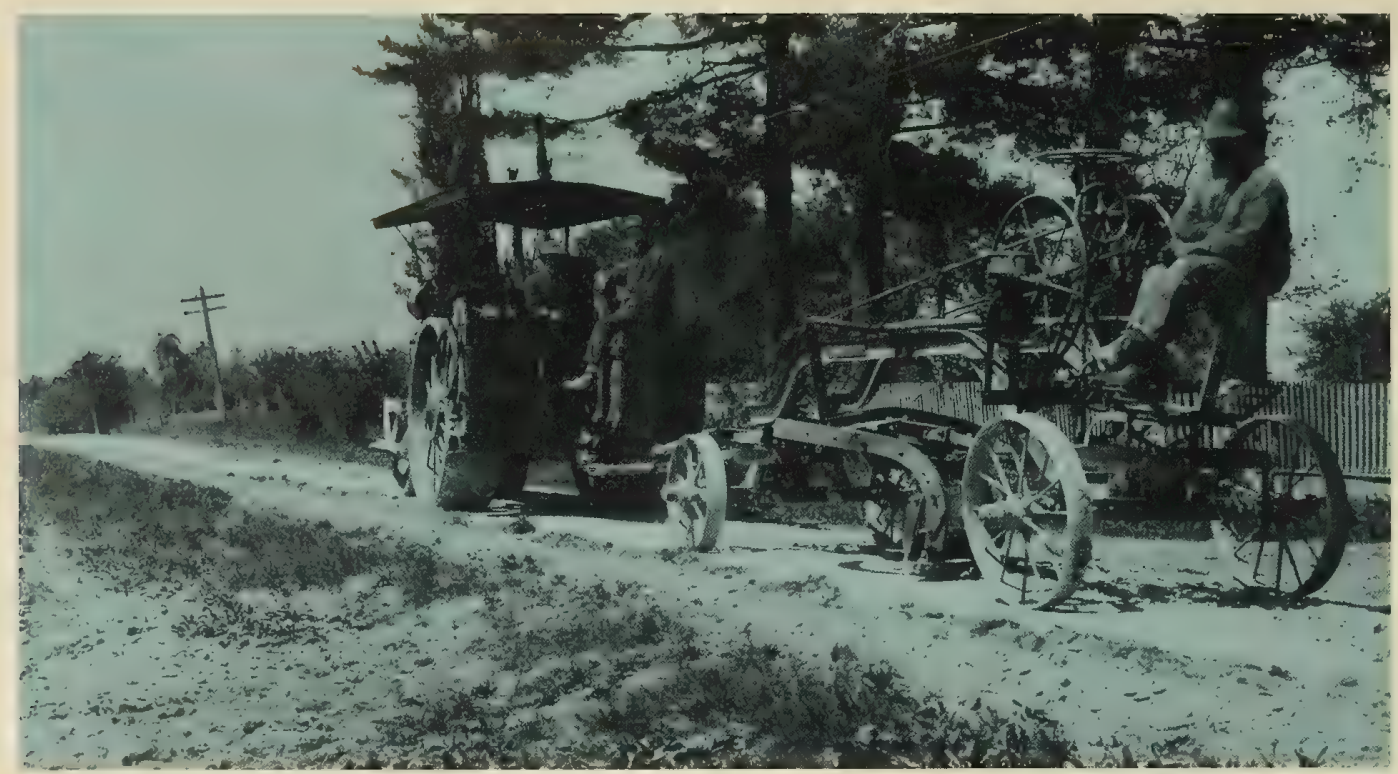

A steam roller provides motive power for a scarifier on an Indiana road in 1916. Scarifiers were used to loosen the material on the top layer of the road. The surface was then graded and compacted.

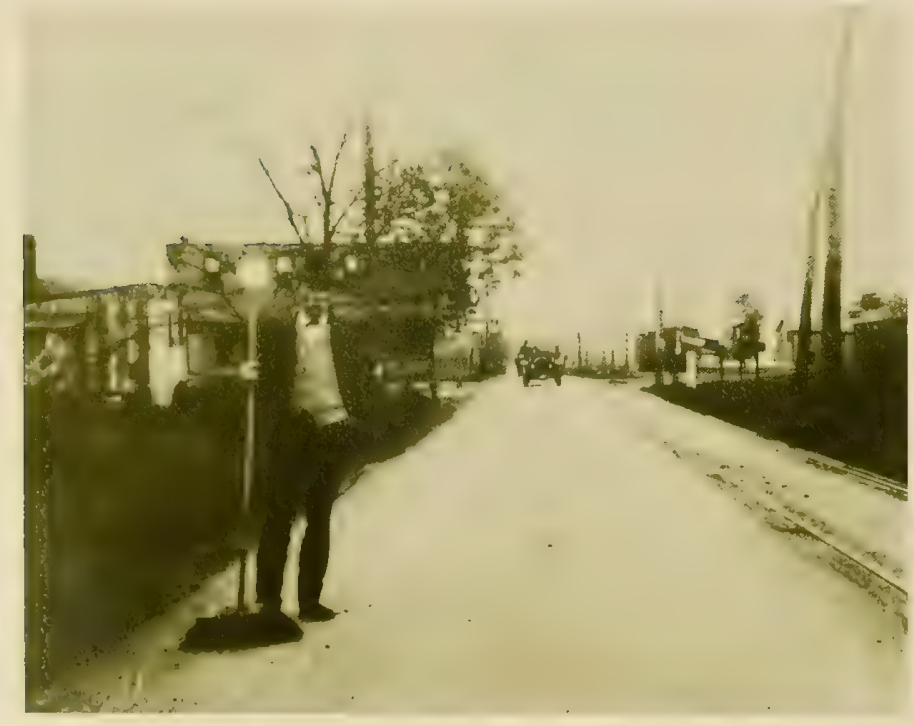

In the early 1900's, some counties and eities hired full-time caretalcers to perform the maintenance functions previously done by statute labor. This man was one of 95 carctakers for a Pennsylvania county who received $\$ 50$ per month to maintain from 3 to 5 miles of road. alike, together with other types used in State and county work. These failures were not only sudden but complete, and almost overnight an excellent surface might become impassable. ... A very large proportion of the failures have been characterized by an almost simultaneous destruction of the entire road structure, and not merely the disintegration of the wearing course or pavement proper. ${ }^{8}$

The Bureau of Public Roads conducted extensive research on this subject and concluded that possible solutions to this problem required: (1) Stronger road surfaces and better drainage, with special attention to sub-drainage, and (2) continual adequate maintenance.

The Bureau recommended during this same period that really economic and efficient maintenance could be secured only by: (1) Patrols assigned to definite sections for which they would be responsible for all ordinary routine work, and (2) well-equipped and organized gangs or crews continuously employed throughout the season to perform all work which could not be economically performed by the patrol alone. ${ }^{9} \quad$ These recommendations became the basis for the structure of most of the State maintenance organizations. 

to heat tar as a surfacing for dustless macadam.
A homemade tar kettle used

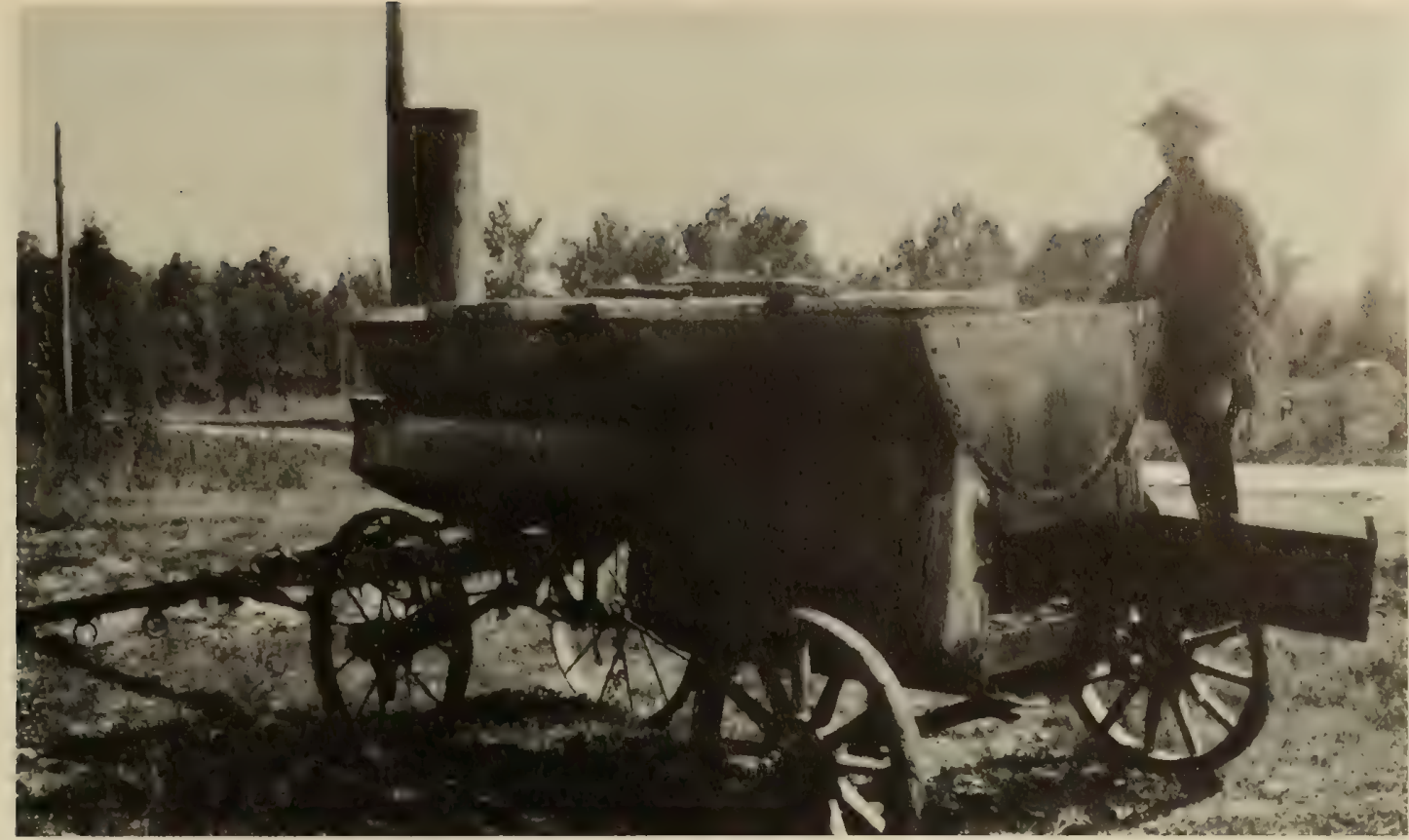

The 1921 Federal Highway Act reinforced the construction and maintenance provisions of the 1916 Act by requiring the States to maintain the highway constructed under the program and specifying actions to be taken if this were not done. Section 14 of the Act required that where a State failed to maintain any road constructed as a Federal-aid highway project, the Secretary of Agriculture was to serve notice to that State. If the State did not repair the project within 90 days, the Secretary was to make the repairs by contract or Federal force account work and charge the cost against the Federal funds allotted to the State. No additional Federal-aid highway projects were to be approved for that State until the maintenance conditions were made satisfactory. When the Federal Government was reimbursed for the maintenance performed, the funds were paid into the Federal highway fund for reapportionment among all the States for the construction of roads. The Secretary could then approve further projects for that State.

\section{Construction Partners}

Unlike earlier roadbuilding procedures, such as statute labor or force account, by 1918, nearly all of the road construction work was done by contract. The State highway departments, after getting the approval from the BPR on their highway programs, project plans, specifications, and estimates of cost (PS\&E), advertised for bids on the proposed work. After studying the bids received and selecting a contractor, a construction contract was awarded by the State highway department with the concurrence of the BPR. Copies of all contract documents, as well as plans and specifications, were forwarded to the BPR Washington office for review and analysis. This evaluation was to insure full compliance with Federal laws and regulations in order to avoid difficulties in paying the Federal share of the cost and to keep up with new materials and methods of construction de-

Application of bitumen on a macadam road in 1912. The man in the center foreground is sprinkling aggregate onto the freshly poured surface. Today mechanized spreaders perform the same task.

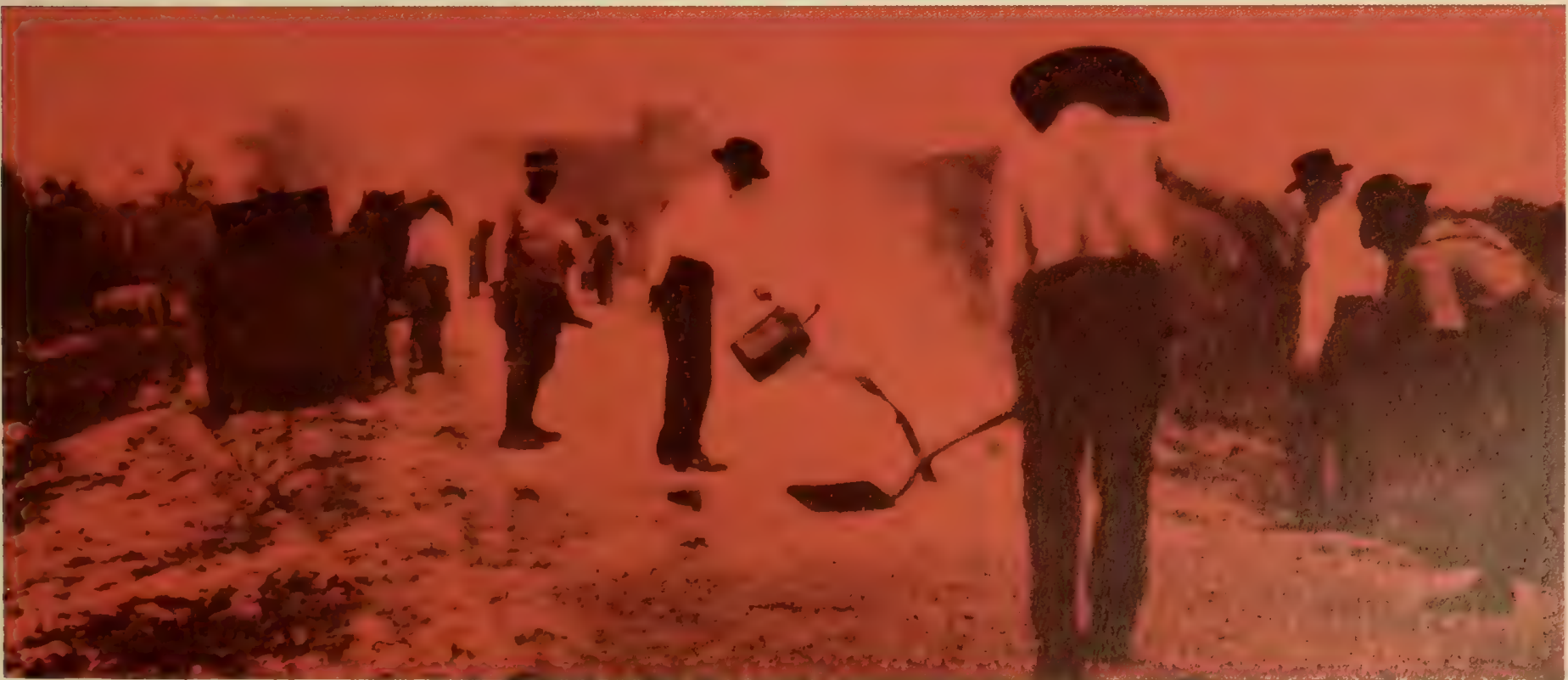


veloped by the various States. The information was passed on to the other States for their mutual benefit. All of the construction work was supervised and inspected by State engineers. Public roads field engineers made periodic inspections to assure compliance with the approved PS\&E. All changes in the plans or extra work that became necessary during the life of contracts were reviewed by BPR. A final review and inspection of all engineering features of the completed project was made by BPR before payment of the final reimbursement for the Federal share of the work done.

In the early twenties, the average length of Federalaid projects was just over 5 miles, and the average cost per project was roughly $\$ 85,000$. The average

This road was surfaced using the penetration method. Aggregate was spread on the roadbed first and the bitumen pourer on top.

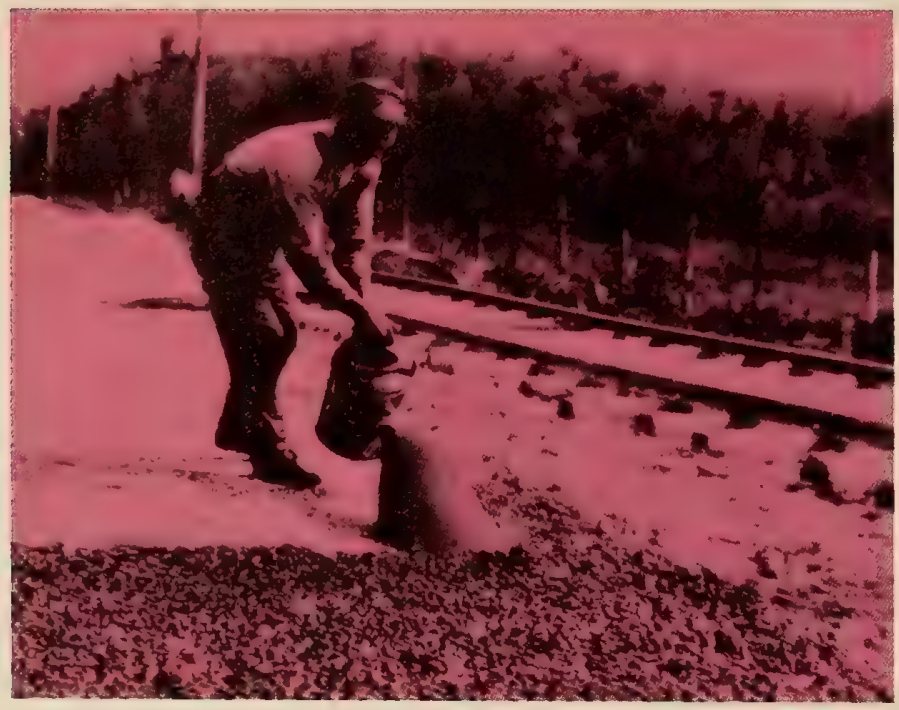

cost per mile was about $\$ 17,000$. Of the roads completed during this period, about 25 percent were paved, and the rest were surfaced with gravel, sandclay, or other select material. On the paved roads, about 65 percent was spent on surfacing, 20 percent on grading and nearly 15 percent on structures. The Federal share of these projects was approximately 50 percent.

The unit prices for the various items of road construction, such as excavation, concrete pavement and structural concrete, were, in general, more expensive in the twenties than they were in the thirties. Of course, this was partly due to the Depression of the 1930 's, but it was also due to the development of equipment to replace more expensive hand methods. This enabled roadbuilders to move more earth and pour more concrete for the same amount of money in the thirties than they could in the twenties.

The cost data were compiled on all projects and forwarded to the BPR Washington office for analysis to determine the trends in highway construction cost for various types of construction. This information has proven to be of such general interest through the years that it has become the basis of a quarterly index, showing the relative movement of highway construction costs over a period of years. ${ }^{10}$

During the early twenties, important advances and experiments were made in all phases of management techniques and standardization development in the construction and maintenance of roadways. This work by the BPR and private organizations increased the capability to produce cheaper, more efficient, quality roads.

A steam roller rolls a second coat of bitumen with chips on a macadam street in 1922. First a coat of bitumen was spread, then a layer of large stones, followed by another coat of bitumen, and, finally, a layer of smaller stones to fill in the voids.

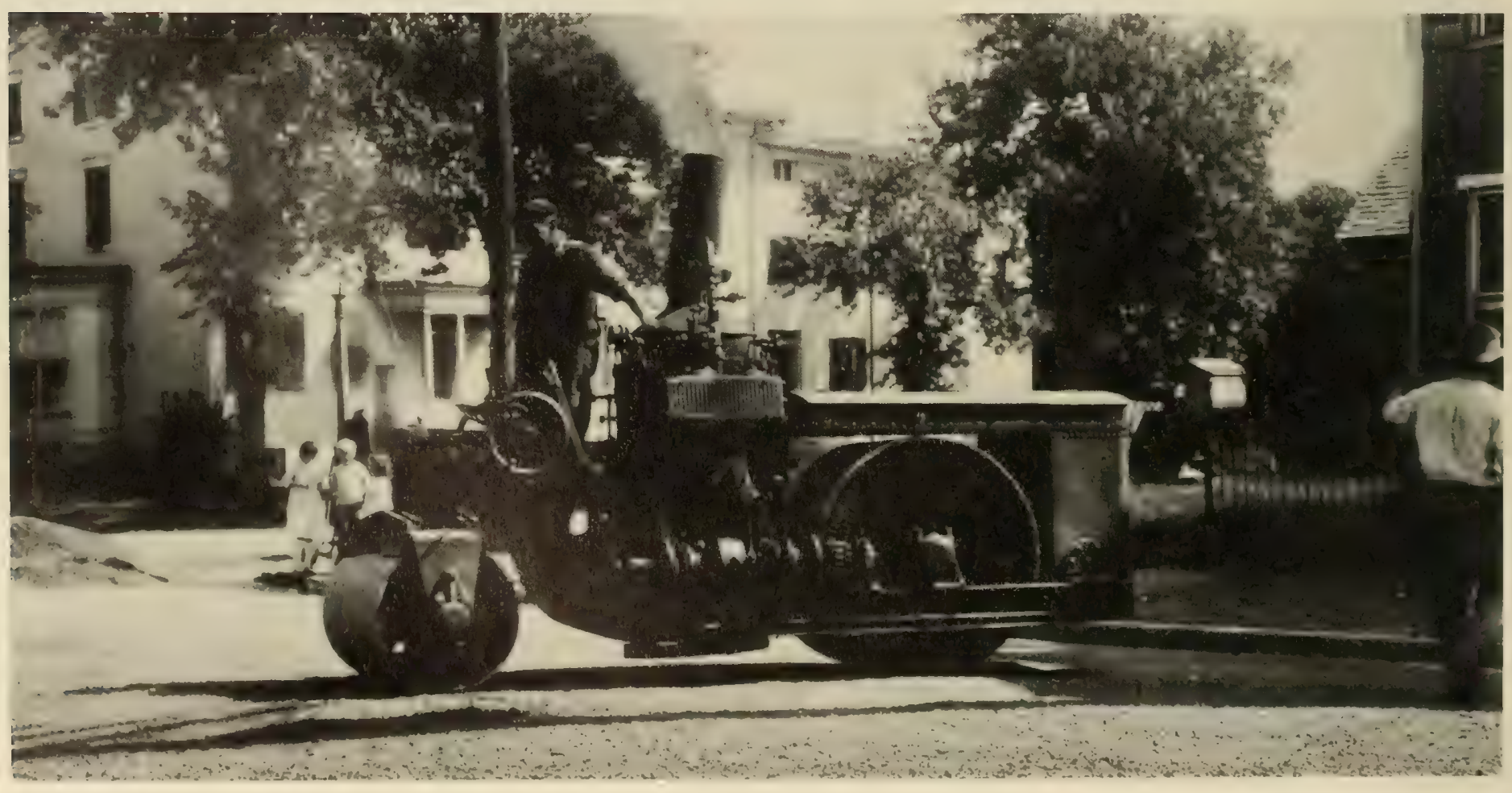




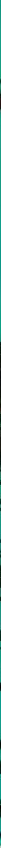

$B y$ the 1920's, crawler tractors were pulling scrapers and other equipment. This tractor could pull 5 scrapers at once, enabling these men to excavate and move material more efficiently.

An important program started by the BPR during this period was the "Production Cost Studies," a management tool to promote efficient road construction operations. These studies on earth moving and concrete pavement construction produced practical applications. From the results of these studies, savings of from 25 to 35 percent were possible in earthwork by selecting the right number of appropriate pieces of equipment best suited to the particular job. The process applied to the concrete paving operations showed that production losses were mainly the result of the failure to provide appropriate hauling equipment in number and character to maintain the capacity of the concrete mixer. By careful elimination of such losses, astonishing increases of from 25 to 100 percent were made by Public Roads engineers in the output of working paving organizations. The most gratifying result, however, was the success that some contractors attained in nearly doubling their output by employing similar methods, and thereby permitting them to drastically reduce their next bids on concrete pavement items. ${ }^{11}$

Another important development in earthwork was the ability to compact soil embankments. Early experiments showed that the amount of moisture in soil had a great influence on the degree of compaction that could be attained. This, of course, led to the use of moisture control methods of compaction and the development of the "Proctor" method of testing the compaction of soil embankments, a method which later became standard on highway embankments throughout the country.

The Public Roads engineers were actively working with various State highway departments and universities in cooperative investigations to develop suitable cheap roadway surfacing materials. At the University of Georgia, tests were underway on sand- clay. In Iowa and South Dakota tests were being run on methods of stabilization of soils with cement and lime. South Carolina was experimenting with bituminous applications to preserve earth roads. Investigations continued in Iowa on the tractive resistance of various types of highway surfaces. In Kansas, tests were being conducted to measure tire wear on various surfaces. In addition, the Bureau also was continuously making routine examinations of highway materials and coordinating the work of a large number of State and commercial laboratories making tests for the acceptance of materials on Federal-aid projects. The result of this work was a general improvement of all laboratories with the corresponding benefit to both Federal-aid and State highway construction projects. $^{12}$

A tractor-pulled grader maintaining a gravel-surfaced road in Iinnesota. Self-propellerl motor graders were introlluerl in the early 1920's but were not widely used until much later.

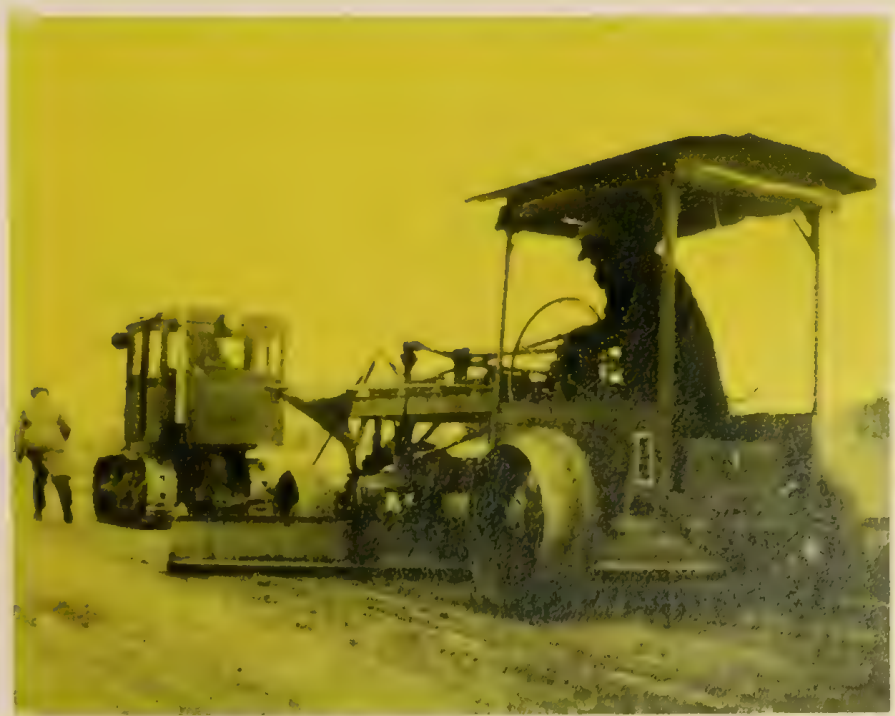




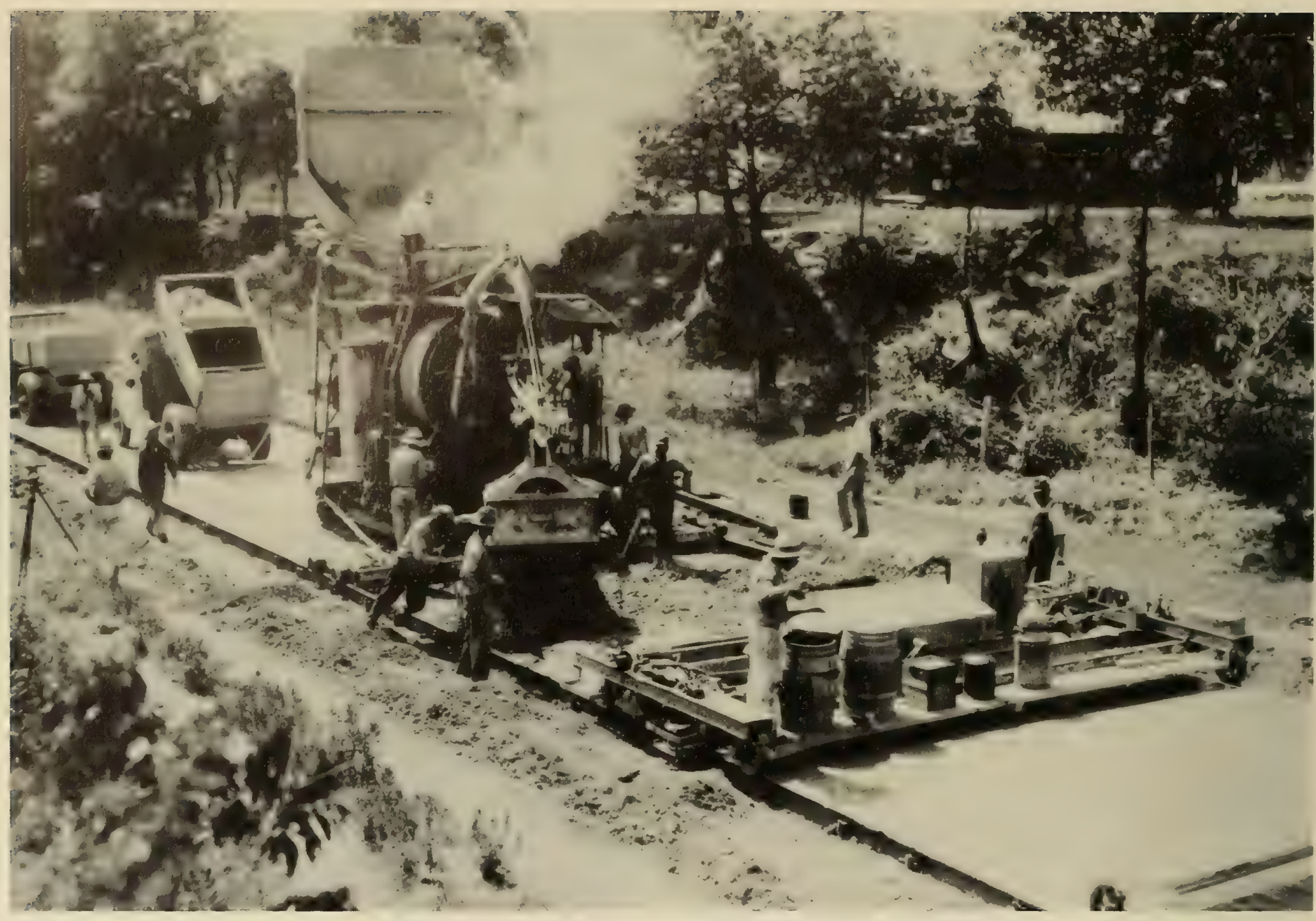

A paving train near Memphis, Tenn., in 1929. Steel forms were set ahead of time on the subgrade to hold the concrete in place.

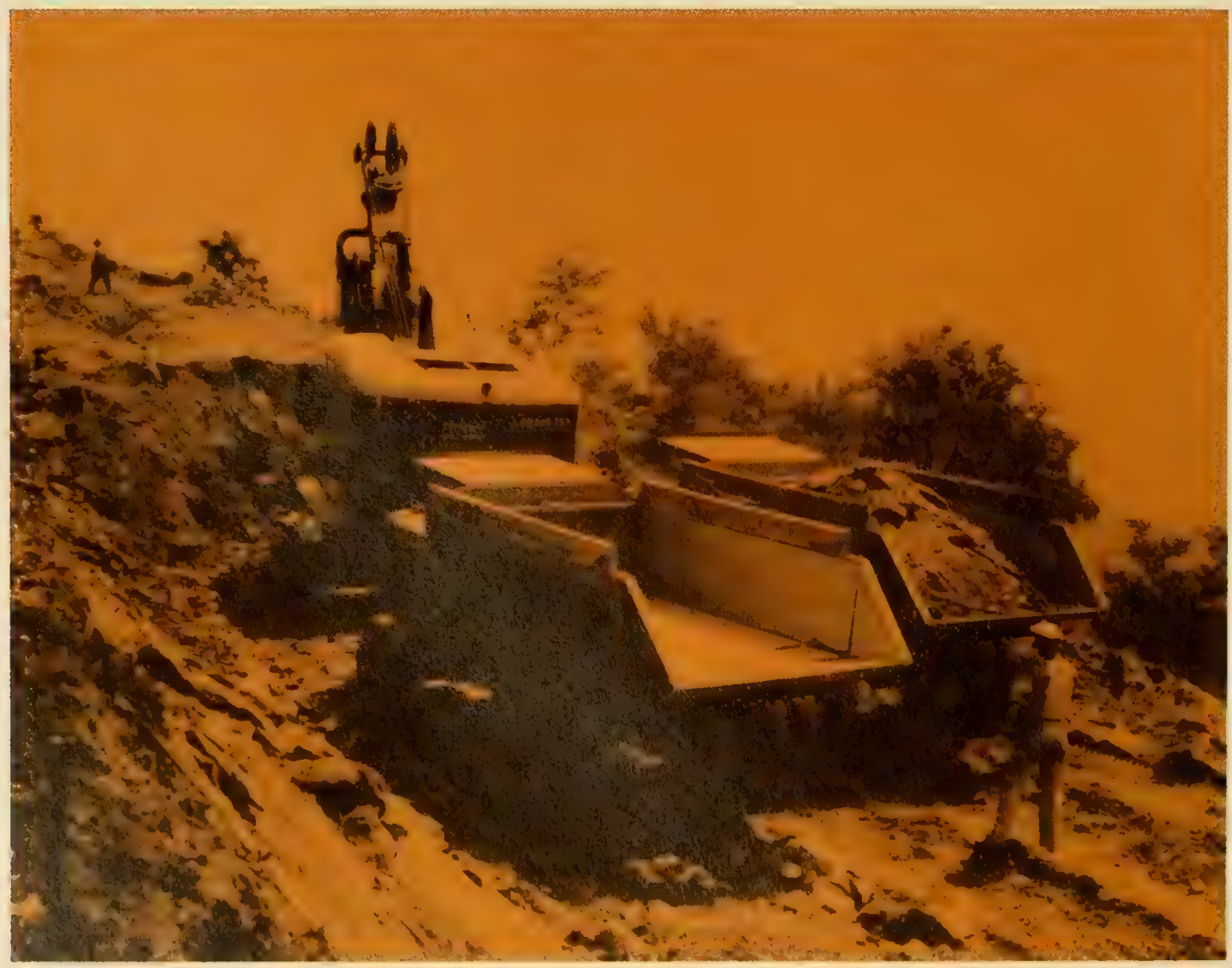

Excavation work on the Blue Ridge Parkway in 1936. In the background men arill holes for explosives used to break up rock, while a diesel-powered shovel loads earth into dump trucks. 


\section{The Swing to Power Equipment}

Equipment for highway construction was undergoing some tremendous changes during the period 1916-26. The steam shovel was being replaced with gasoline engine-powered excavators. The lines of horsedrawn wagons were disappearing as dump trucks were taking their places. Crawler tractors pulling rotary scrapers were replacing horse or muledrawn fresnos and drag scrapers. Monstrous early models of the self-propelled scrapers were being developed in the early 1920 's. ${ }^{13}$ A manual hoisting bulldozer blade was put on a crawler tractor in 1923, and by 1925 hydraulic controls were in use on the bulldozer blades.

The self-propelled motor grader was introduced in the early 1920's, but it did not get widespread use until much later. By 1922, an all-welded tractor drawn scraper with a 6 -cubic yard capacity was in use and by 1924 electric handsaws were put to use in construction. The steam crusher was being replaced with gasoline engine models with revolving screens and belt conveyors, and in 1923 a completely portable crushing and screening plant was placed on the market. ${ }^{14}$

Paving equipment was also coming into more use. In 1919, a bituminous distributor was introduced to help improve the quality and uniformity of penetration asphalt pavements; 1920 brought batching plants (volumetric) for concrete aggregates, eliminating a large amount of hand shovel and wheelbarrow work. In 1923, a traveling concrete mixer was introduced on pavement projects. An old issue of Engineering News-Record contains a detailed description of the construction of a concrete pavement in 1918:

The rough grading was done entirely by machine: meaning a pull-type grader equipped with a scarifier. Fine grading was done by hand. A concrete mixer rode between wooden forms, with volumetric proportioning of the mix. The concrete was struck off and tamped with an iron-shod wooden templet, finished with a wood float and a coarse wire stable broom. The concrete gang (23 men) averaged 500 feet of 9 -foot wide, 8 -inch thick pavement per 9-hour day. ${ }^{15}$

\section{6 to 1944 -Building More and Better Roads}

The Federal-aid system of building roads was well established by this time. Construction followed the same basic procedure with the State highway departments selecting, designing and constructing their own projects by contract, all with the approval of the Bureau of Public Roads and with partial funding from Federal appropriations.

Pressure from the general public was increasing to "get the farmer out of the mud"; and the consolidated school system required the improvement of many miles of roads in order to facilitate the busing of more children to the wider dispersed schools. To get more miles improved with the funds available, many of the highways were built as "stage" construction so that the road could be brought up to a higher type later with additional improvement as traffic volumes grew and the weight and speed of vehicles increased.

The 1930's witnessed an important advance-the introduction of the diesel engine on tractors. This diesel-powered tractor teamed with a 5-cubic yard capacity scraper moved approximately 16,000 yards of earth in 14 days.

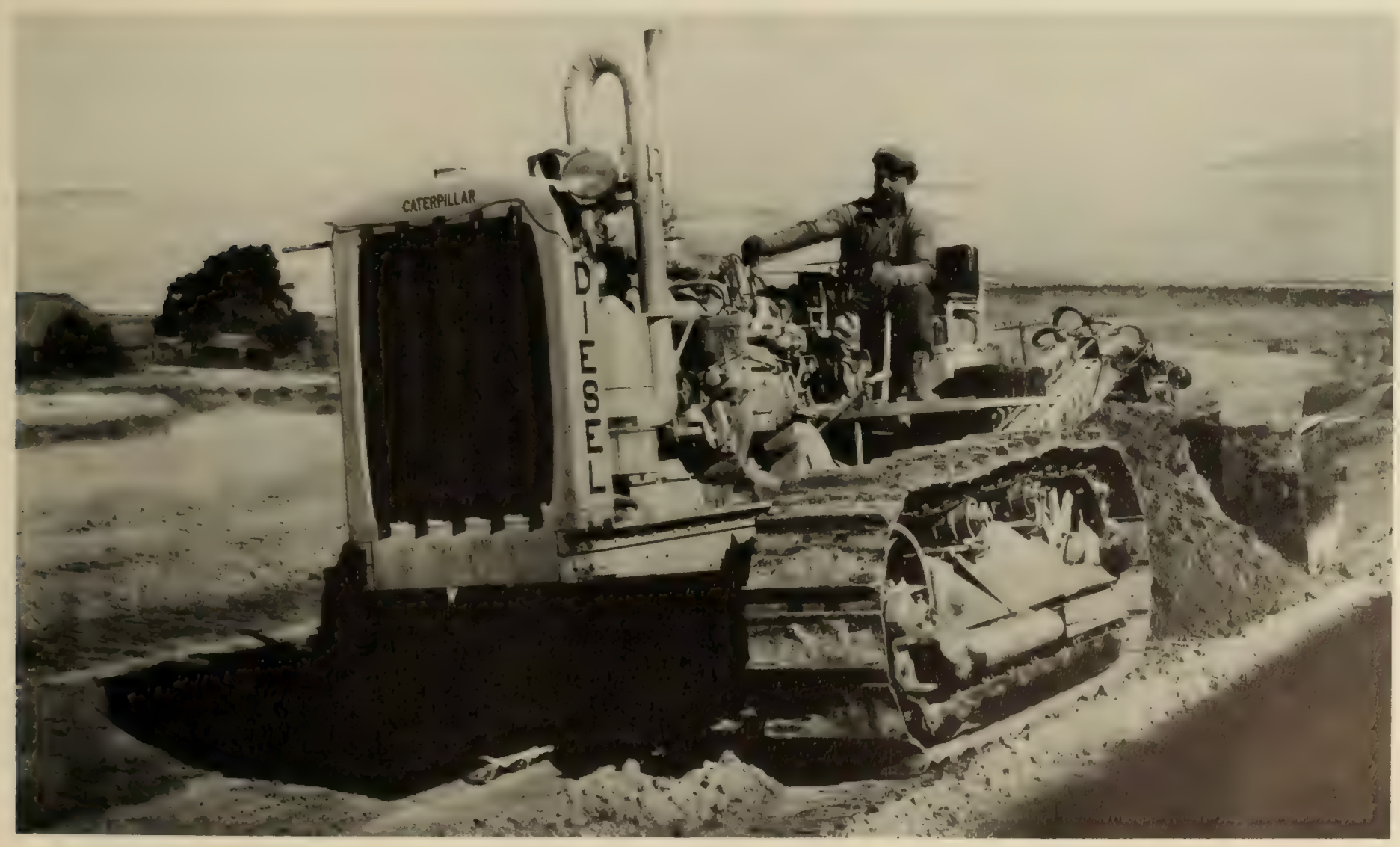


Stage construction was also used for other reasons. Some road projects were let to contract for the grading work alone, or perhaps the drainage work and grading work, leaving the surfacing work to be done by later contracts. This permitted the newly graded embankments to settle for a couple of years before placing surfacing materials. It was advantageous to let nature compact these embankments over a period of time because many States still did not use effective compaction procedures in their grading work. This also permitted the natural stabilizing of any slips and slides that might occur in the generally steep back slopes which were employed at that time in roadway excavation.

Between 1926 and 1944, BPR and the American Association of State Highway Officials (AASHO) worked with various associations in the highway industry toward the common goal of building more and better highways. For example, the Portland Cement Association (PCA) contributed financially to the establishment in 1929 of the Cement Reference Laboratory by the National Bureau of Standards in cooperation with the American Society for Testing and Materials (ASTM). The PCA was also instrumental in the development of soil cement for low-cost surfacing. ${ }^{16}$ AASHO published the first edition of their materials books in 1931, and then in 1940 and 1942 they published their Standard Specifications for Concrete Pavement and Bituminous Surface Treatment, respectively. In the 1920 's and early 1930 's, the Asphalt Institute, in cooperation with the BPR and various other public agencies, standardized asphalt cements and liquid asphalt products, thus, greatly reducing the number of grades and thereby facilitating the writing of asphalt specifications. Also, the Asphalt Institute in cooperation with the American Farm Bureau Federation was instrumental in initiating a program of paving farm-to-market roads. Like the capillaries of one's blood system, these feeder

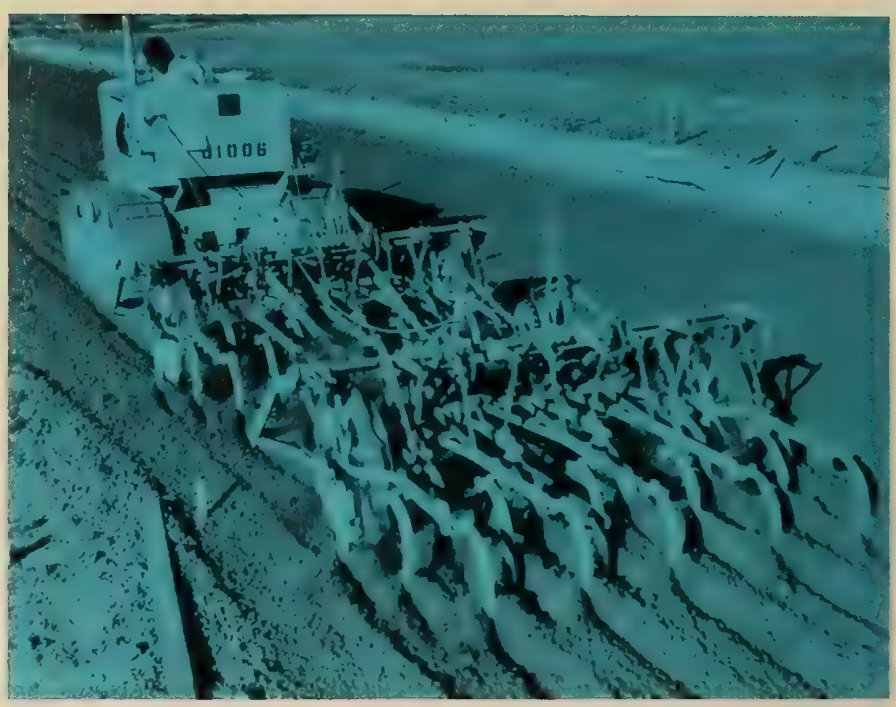

Constructing a stabilized soil road. A scarifier prepares road for the mixing of soil and cement.

roads played an important role in the transportation system of today. ${ }^{17}$ In cooperation with public highway authorities, all of the industry associations, in one way or another, were major contributors to the tremendous development of highway construction during this period.

\section{Modernization of Roadbuilding}

Probably the two most important advances in modernizing construction equipment during the 1920's and 1930's were: (1) The introduction of the diesel engine on tractors and graders in 1931, and (2) the development of large pneumatic tires which were used on scrapers as early as 1932, and on dump trucks in 1934, making it easier to operate on soft ground off the highway.

In the 1940's self-powered equipment for onsite material stabilization was developed. T'his machine mixed soil and cement and added water to create a stabilized base.

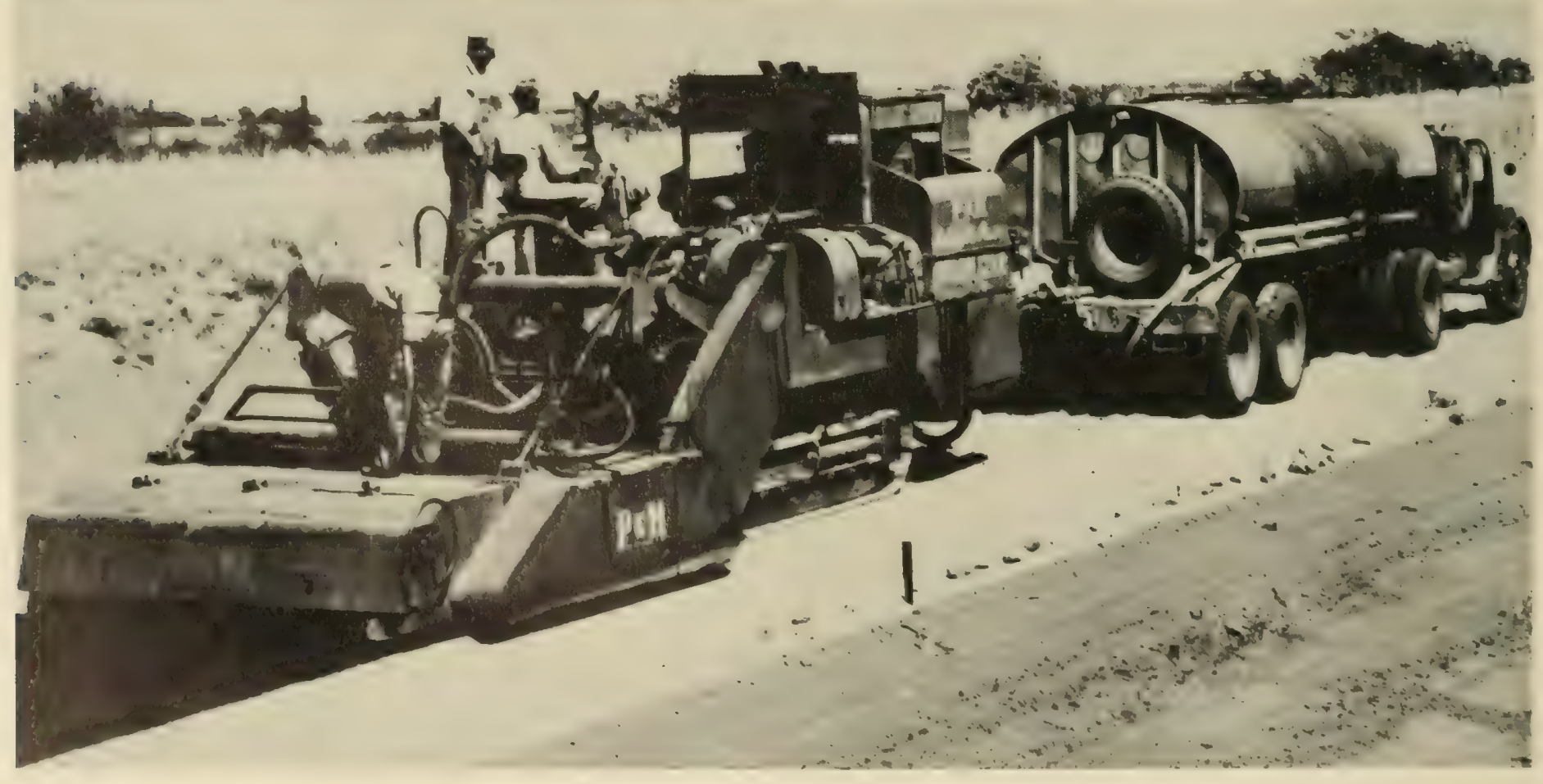


In other developments of construction equipment, the front apron was first placed on scrapers in 1933, making a 12-cubic yard load possible. Hydraulic controls were placed on power shovels in 1937, then in 1938 the self-propelled scrapers made it possible to move earth at a much faster pace. The compaction of earth was also keeping pace as the ballastable rollers were introduced in 1936. Paving equipment was being revolutionized as the traveling concrete paver, introduced in 1926, made use of the skip lever to activate the water measurement and the timing of the mix. In 1932, the dual-drum traveling paver helped to increase production of concrete for pavements. Internal vibrators for portland cement concrete were patented in the United States in 1935 and soon used widely to assist in the consolidation of concrete in the forms. Bituminous paving equipment was being developed as the road mix machine was introduced in 1929, and the bituminous paver placed on the market in 1932. This equipment provided more rapid construction of improved asphalt pavement at lower cost. ${ }^{18}$

\section{Silver Lining of the Depression Cloud}

As can be seen, many of these developments took place during the Depression years, when so many industries were virtually shut down because of the national economic situation. The highway industry was probably one of the industries that was least injured by the Depression. By using highway work as one of the "make work" projects of this period, the National Recovery Act brought employment close to the homes of the unemployed. It was estimated that for every person directly employed on road work, there were two others employed in the manufacture and transportation of road materials and equipment. ${ }^{19}$

Thus, while being used as one of the "tools" to fight the unemployment of the Depression, an added benefit was that the highway industry grew in capacity and was ready for the program of interregional highways that was recommended by the report Toll Roads and Free Roads in 1939. The program discussed in the report became the basis for the plan of the National System of Interstate and Defense Highways as we know it today.

\section{World War II Disrupts the Highways}

The Interstate program had to be postponed, however, as the country plunged into World War II. The Nation's roads took a hard beating during the war years, as construction and maintenance were slowed considerably. The road work accomplished was largely composed of correction of critical deficiencies on main highways essential to war transportation.

All noncritical highway work was deferred, and the use of critical materials was reduced to a minimum. New construction was largely confined to access roads to new military installations, defense plants, ports and the like. World War II left its imprint on the highways. Many miles of the oldest highways, already worn and obsolete and scheduled for replacement, were kept in service. This situation, already bad, was accentuated by the wear and tear of continuous streams of war traffic. Thus, the mileage of roads no longer adequate for the traffic carried and difficult to maintain in service, grew in size throughout the war.

Due to the loss of personnel by State highway departments to the military forces and defense plants and the unavailability of new equipment, spare parts, tires and fuel, it was necessary for most States to sharply reduce their maintenance activities. ${ }^{20}$ The quality of maintenance suffered. Only routine surface maintenance, resurfacing, and resealing were intensified to preserve the existing surface, whatever type it happened to be. Operations to maintain shoulders, clean ditches and culverts and mow the weeds were performed only as time, manpower, and equipment allowed. ${ }^{21}$

\section{4 to 1964-The Push For More Production}

As the war in Europe neared an end, Congress passed the Federal Aid Highway Act of 1944. This was a far-reaching piece of legislation. It authorized $\$ 500$ million for each of the first 3 postwar years; it authorized, for the first time, the use of Federal-aid highway funds in urban areas; it provided authorization for the construction of a Secondary Road System; and it directed the designation of a National System of Interstate Highways. The funds authorized in this legislation made possible an expanded and

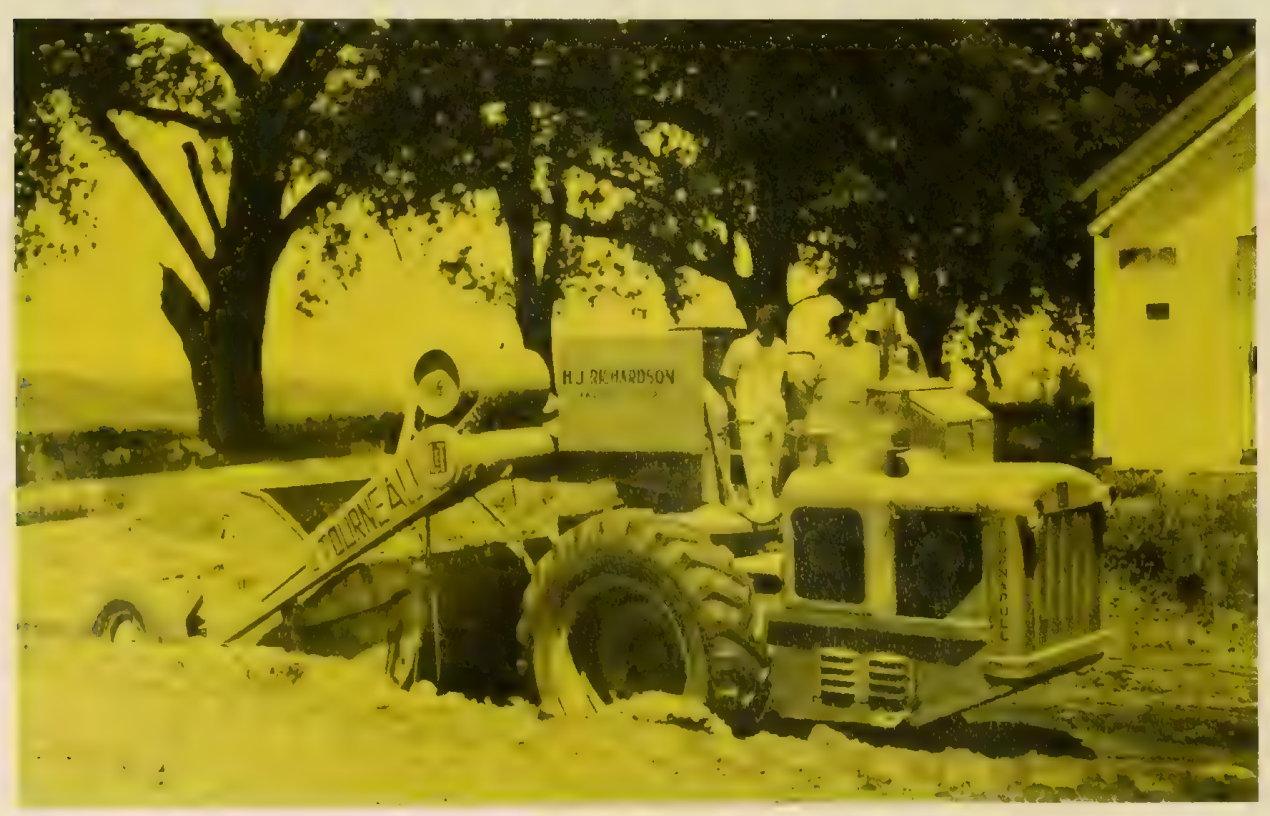




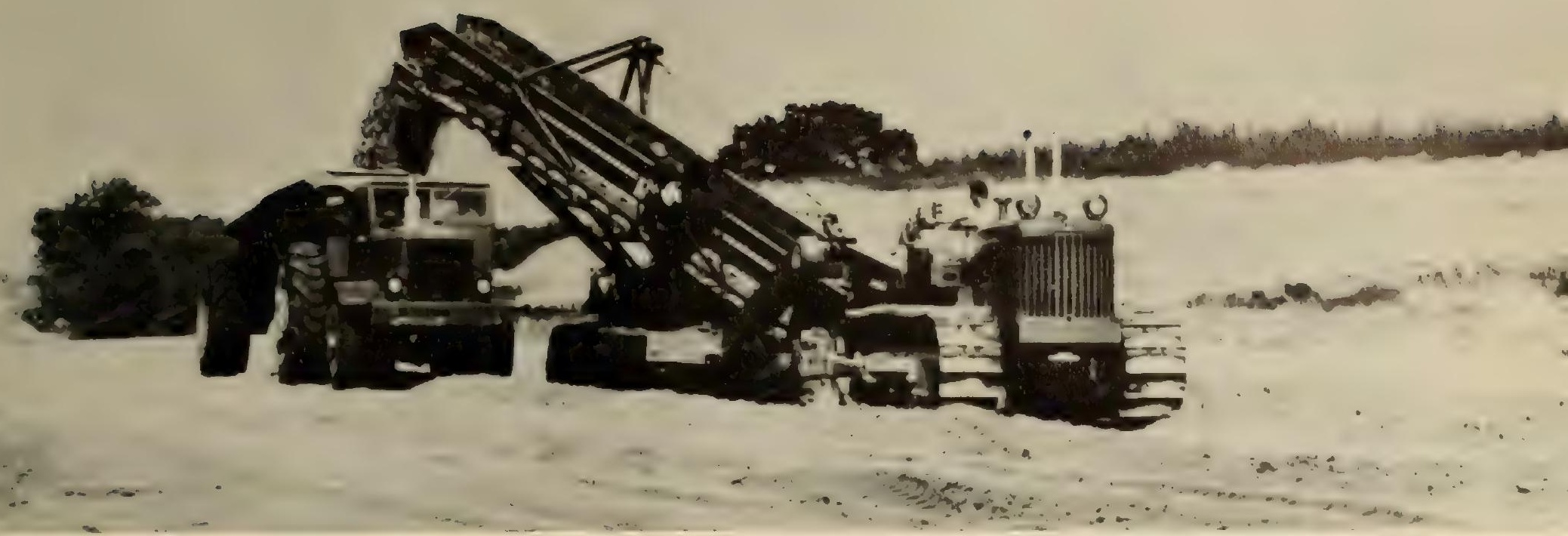

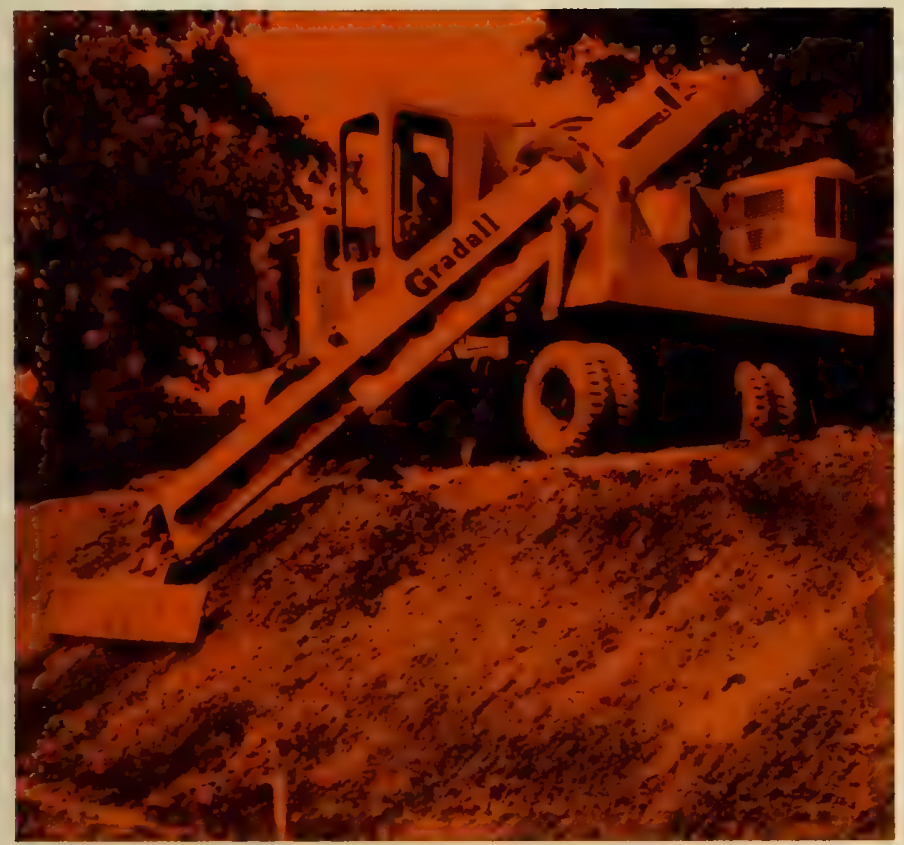

This grader was designed to be as flexible as the human wrist. The blade shown here is especially useful for fine grading on slopes and ditches; a bucket blade is used for excavation work.

essential program of construction and reconstruction of highways which had borne the burden of heavy wartime traffic with a minimum of maintenance or betterment activity.

This period of 1944-64 was one of greatly expanded highway activity. Public Roads worked closely with the AASHO, the Highway Research Board (HRB), and the various industry associations, especially in the areas of coordination of construction practices, research, and the development of standard specifications.

In 1948, AASHO published its Policy on Maintenance of Roadway Surfaces (revised in 1961). Then in 1949, AASHO came out with its Manual of Highway Construction Practices and Methods. These two publications were a great help in distributing information to the States so that all could benefit from the successes that some States were having in their construction and maintenance procedures.
An elevating grader picks up material and conveys it to a waiting truck.

In 1960, AASHO published its guide on project procedures, and in 1963, it published the first Guide Specifications for Highway Construction, which became the national standard for highway construction specifications.

During this period, there were also tremendous advances in the productivity of highway construction. One of the big advances was the development, in 1945, of self-powered equipment for onsite material stabilization, which greatly increased the productivity and control of stabilized bases and subbase courses. The rubber-tired bulldozer, first placed on the market in 1947 , and the vibrating roller, introduced in 1948, proved to be very successful. In rock excavation, the new carbide insert on rock bits was a tremendous help in lengthening the life of these bits. The application of hydrostatic drive to construction equipment was also being developed. In earthwork, as well as all phases of construction as a whole, the equipment manufacturers were continuously developing heavier and more powerful units to obtain more production at less unit cost for a better quality highway. ${ }^{22}$

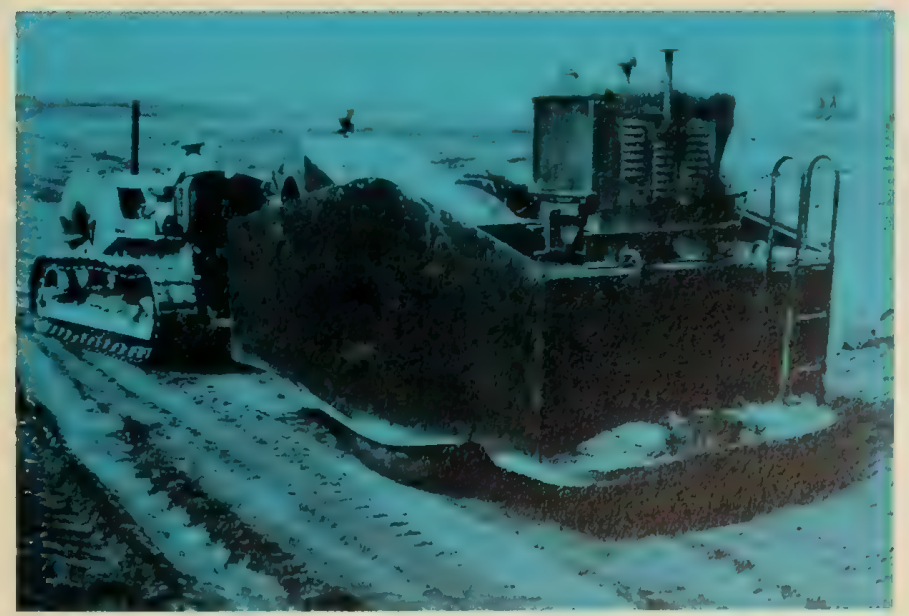

Compartion is important in preprering a firm hishuren foumlution. This compactor has pneumatic-tired, vibrating rollers which are particularly effective in compacting granular soils. 


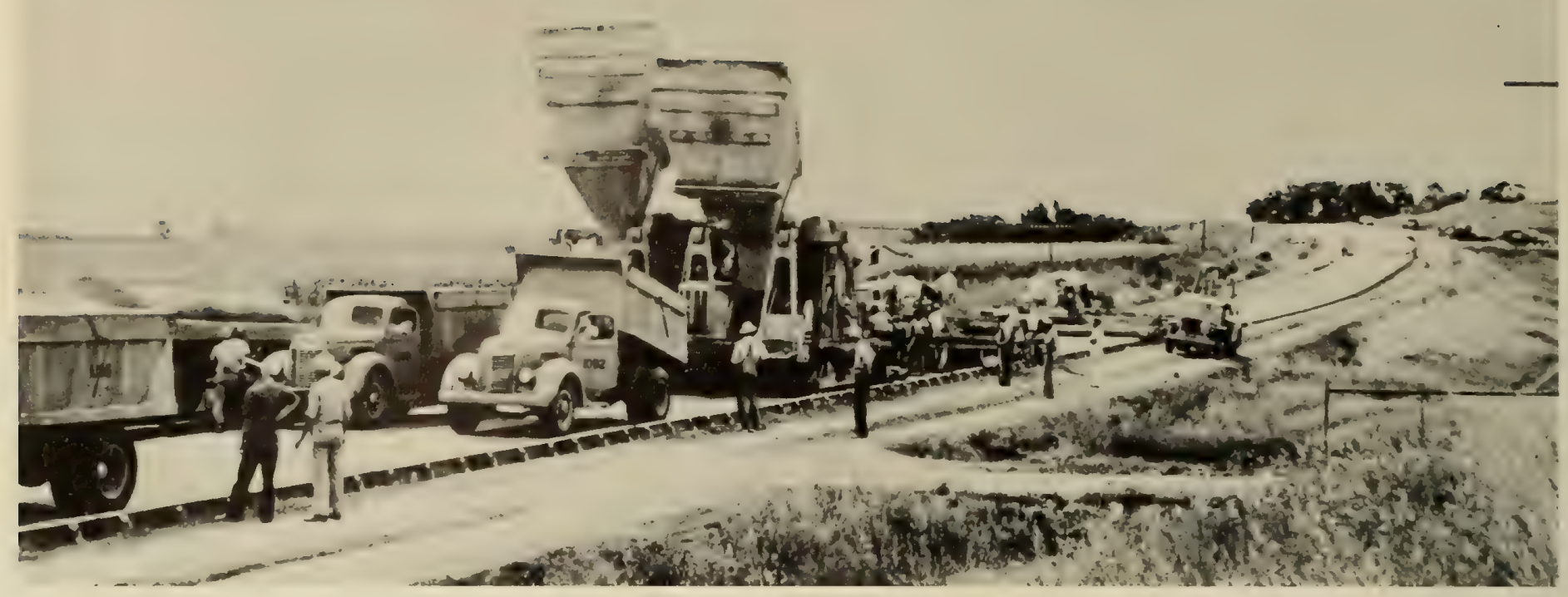

A paving train in Iowa in 1949 utilized dry batches dumped in to two twin-batch traveling mixers.

For this paving operation, concerte was hauled from a central mix plant and poured into the spreader from a side dump (bin).

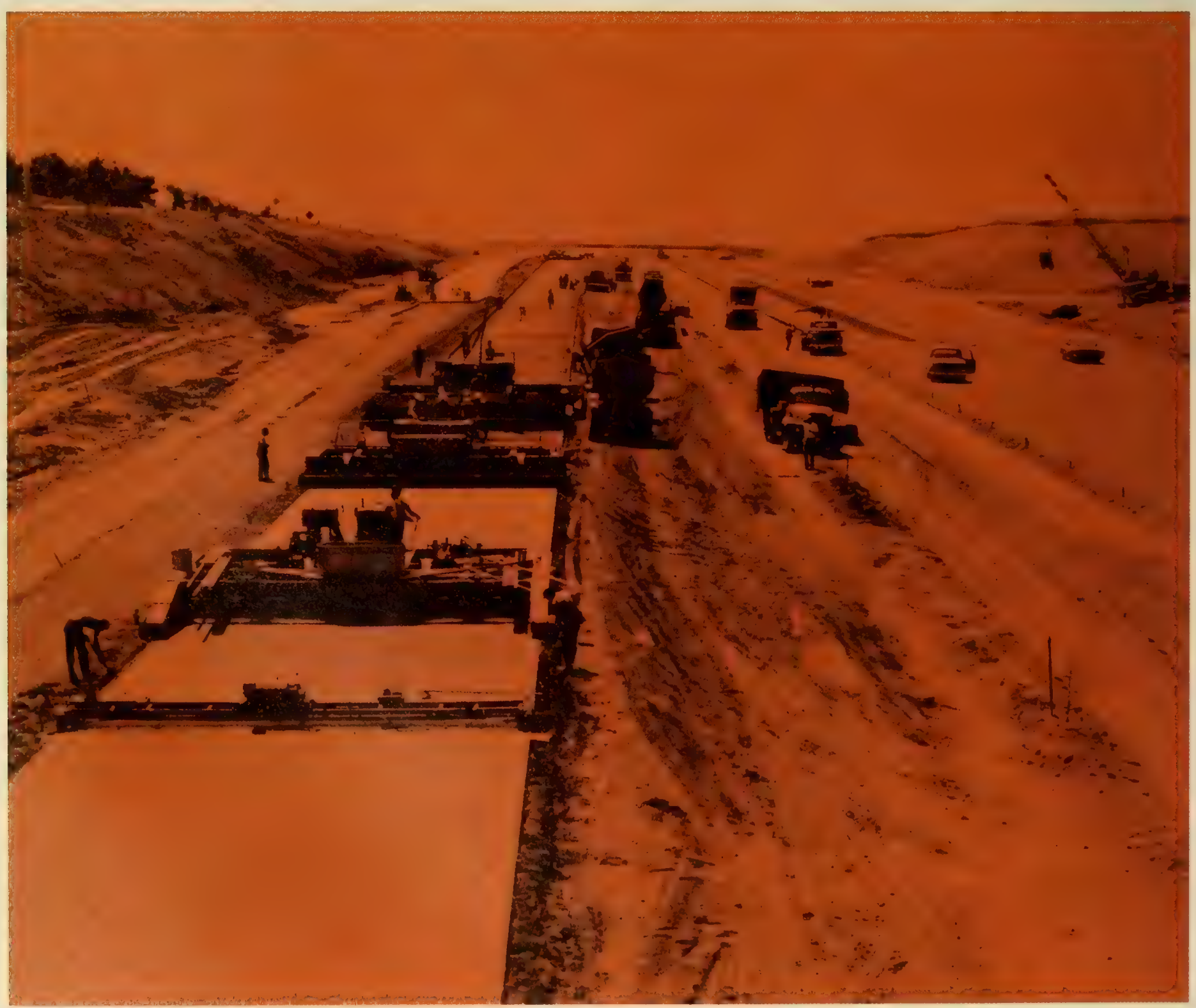


The array of road construction equipment that was available at this time was huge and diverse, but every unit was developed in an orderly fashion to fill a definite need.

Significant advances in paving equipment were started. In 1955, electronic controls were put into use in concrete batch plants, simplifying and giving better control over batching. The triple-drum concrete paver, which could produce 125 batches per hour compared to 87 batches for the dual-drum, was introduced in 1959. Central-plant mixing with hauling by agitator trucks was used on large concrete paving projects. Transit mixers were widely used in urban paving and bridge work. Slipform pavers became widely accepted on highway work. Spreading and finishing equipment were developed to do a faster, better job. The use of central-plant mixing and slipform paving methods made possible some astonishing achievements in concrete pavement. Some road contractors reached the production rate of paving more
In 1958, there were over 12,000 Federal-aid highway projects awarded at a total cost of about $\$ 3.5$ billion to build or improve nearly 34,000 miles of roads. In 1964, approximately 7,000 Federal-aid projects were awarded at a total value of about $\$ 4$ billion, corresponding to 18,300 miles of roads. The average size contract in 1958 was almost $\$ 300,000$ and in 1964 was about $\$ 560,000$-nearly doubled-while the total annual miles dropped. Obviously the trend was to shorter, more costly projects. In general, the longer rural, less costly Interstate projects were built first with the more costly and shorter urban projects following.

The high degree of mechanization of highway construction activity enabled construction labor to increase production greatly while reducing the number of man-hours required per mile of highway construction. The cost of highway construction over the years, in fact, has risen quite slowly as compared to the cost of labor and materials.

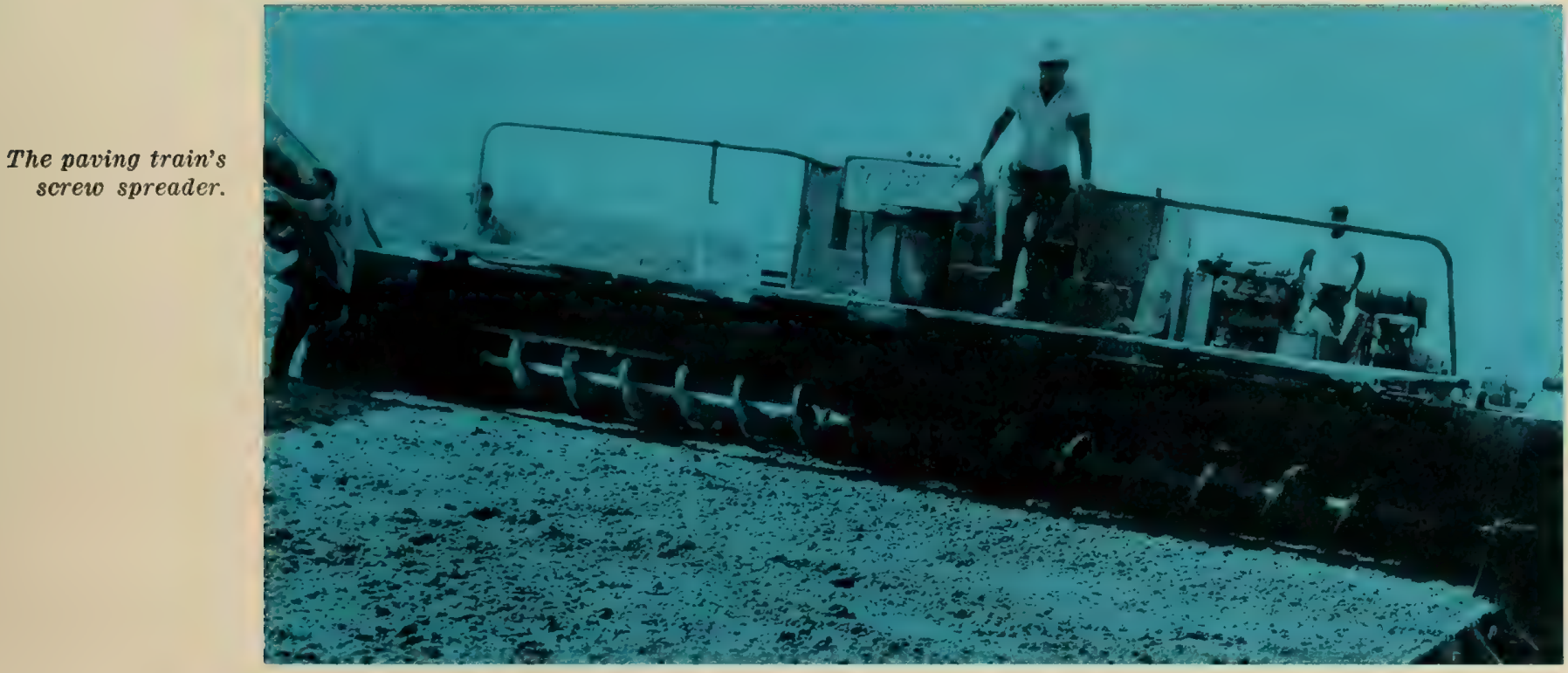

than a mile per day of 24 -foot wide, 9-inch thick portland cement concrete pavement with this type modern equipment. This led to the "Mile-A-Day Club," sponsored by the American Concrete Paving Association. In 1973, one contractor set a new record by paving 4.7 miles of 8 -inch thick, 24 -foot wide concrete pavement in a 23 -hour period-14,853 cubic yards of concrete.

In the early sixties, automatic slope and grade controls for asphalt paver screeds were developed. Rolling equipment for bituminous pavements showed little apparent change over the years, but in reality improvements were developed for these machines during this period which made them faster, more productive, and easier to operate.

Other innovative developments included a helicopter designed to hoist and haul a 6-ton payload for construction work in inaccessible areas, and a vibratory sonic pile driver that could drive and pull piling at a small fraction of the time needed with conventional equipment.

\section{4 to 1974-An Increased Emphasis on Social Goals}

By 1964 the Interstate program was in full swing. While highway mileage accomplishment for the Interstate was still the main goal, attention was focusing on other aspects such as highway safety, highway beautification, and consideration of wildlife and recreation areas, as well as historic sites. Environmentalists and ecologists were instrumental in keeping environmental concerns, potentially affected by construction, at a high level of consciousness among highway builders. New construction procedures were developed whereby detailed programs were implemented in order to reduce to a minimum the soil erosion during the construction process, and several States were investigating improved methods of sediment control for future highway construction use.

Studies were undertaken to investigate new equipment and other means to control noise and air pollu- 


\section{U.S. DEPARTMENT OF TRANSPORTATION \\ FEDERAL HIGHWAY ADMINISTRATION}

\section{HIGHWAY CONSTRUCTION COST AND LABOR USAGE TRENDS}

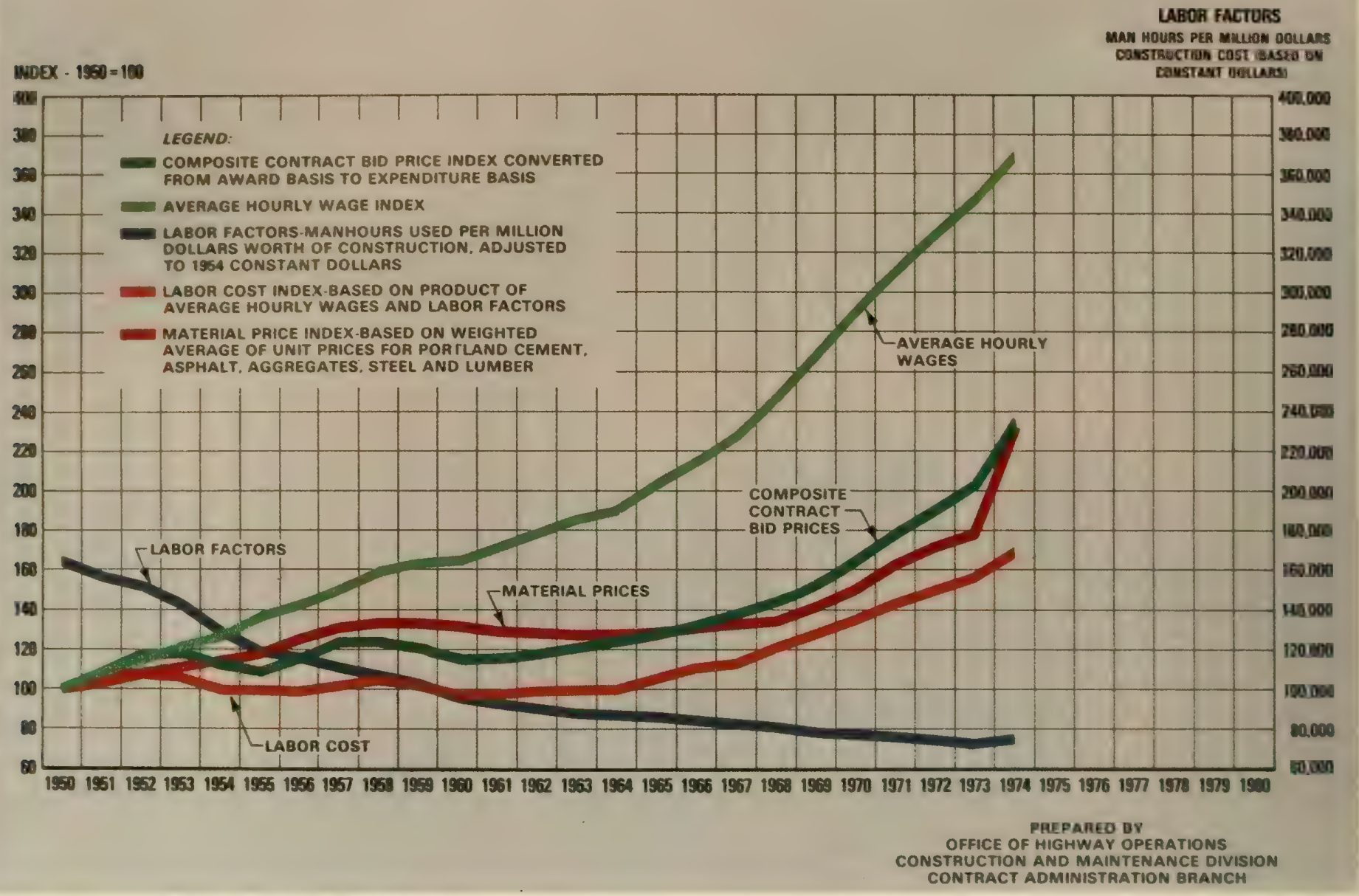

tion during the construction process. The dryer-drum process for hot-mix asphalt plants and better mufflers for heavy equipment were developed in an effort to reduce or eliminate these types of pollution.

There was an increased emphasis on highway safety. New safety devices were built into new highways, such as sign posts that broke upon impact, safer guardrails, and crash cushions which absorbed the shock of a collision with fixed structural elements.

Activities on construction projects were also changing. Construction contractors in some States were being required to furnish completely equipped laboratories and do their own surveying and layout staking, jobs which had previously been done by State highway departments. More States were using aerial photography and new data processing procedures to speed up monthly estimates.

The highway construction industry developed a greater awareness of public need and good public relations. Soil erosion prevention and other environmental and ecological aspects became integral parts of construction practices. Ways were studied to help the construction labor force also. Where possible, activities such as winter concreting techniques were developed to help extend the construction season and to give workers more yearly income, and occupational safety measures were adopted to improve the working conditions for the construction work force.

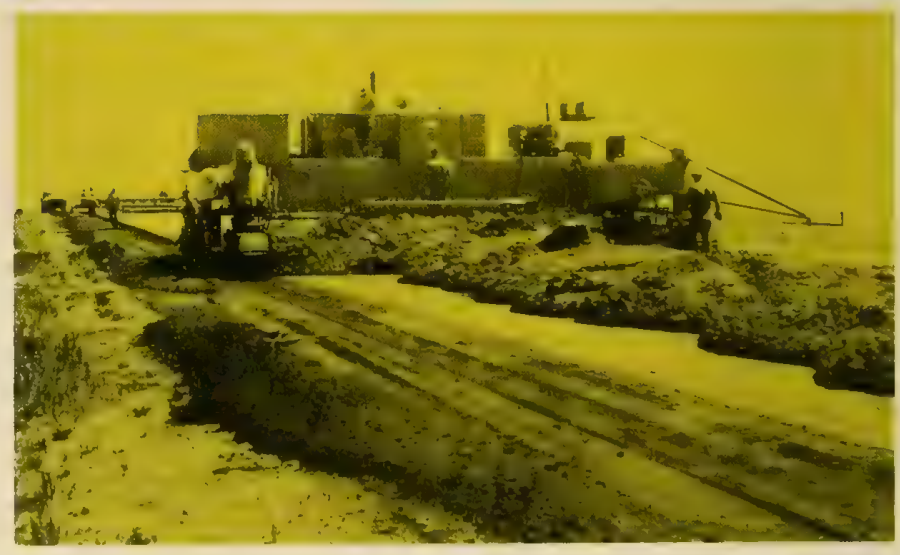

A slip form paver eliminates the need for setting steel forms, since the forms move along with the paving machine. A relatively stiff concrete is used so that, by the time the machine passes on, the concrete will hold its shape. 
Bridge deck construction has become increasingly mechanized. This finishing machine permits the use of stiffer concrete and produces a smooth deck surface.

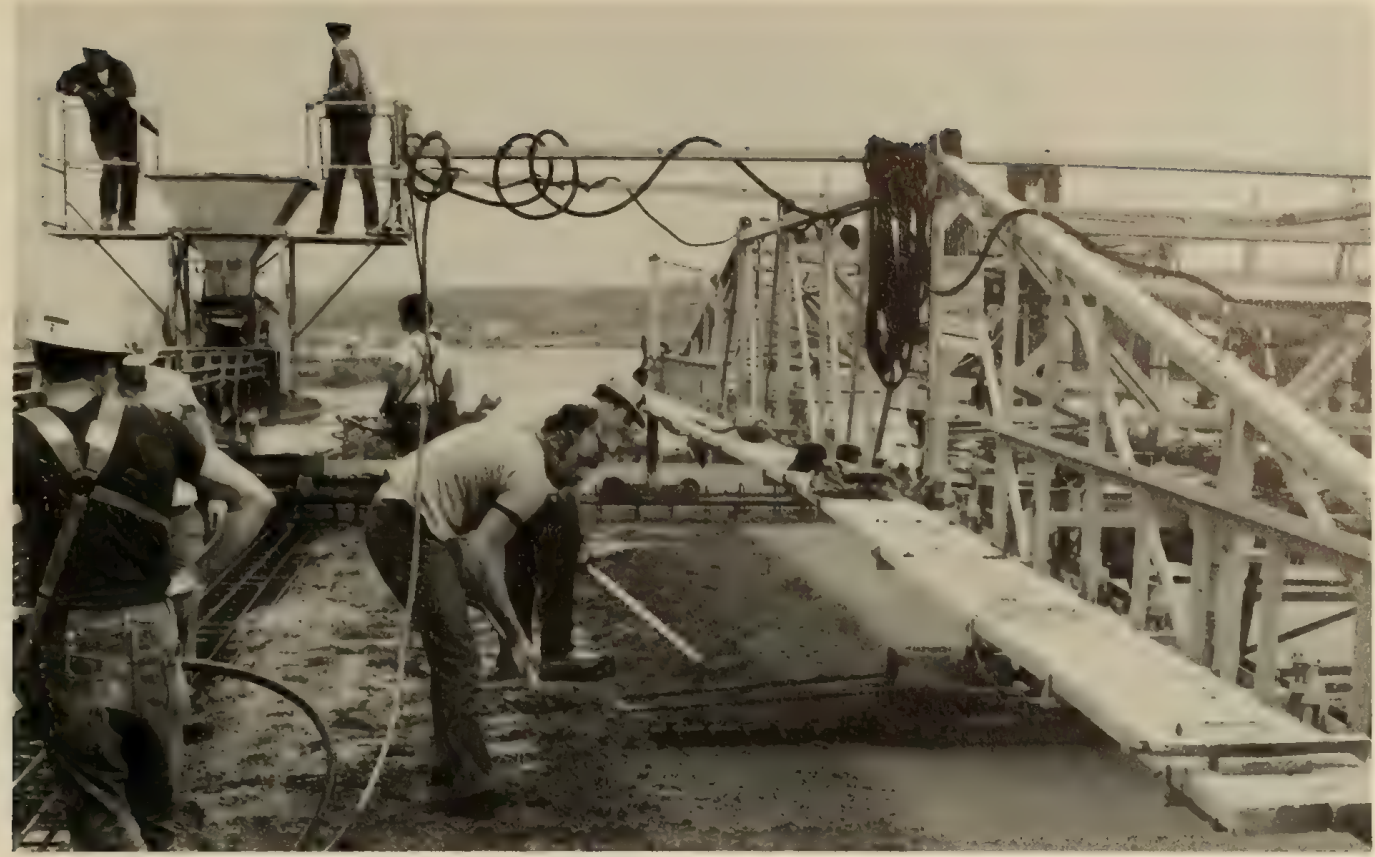

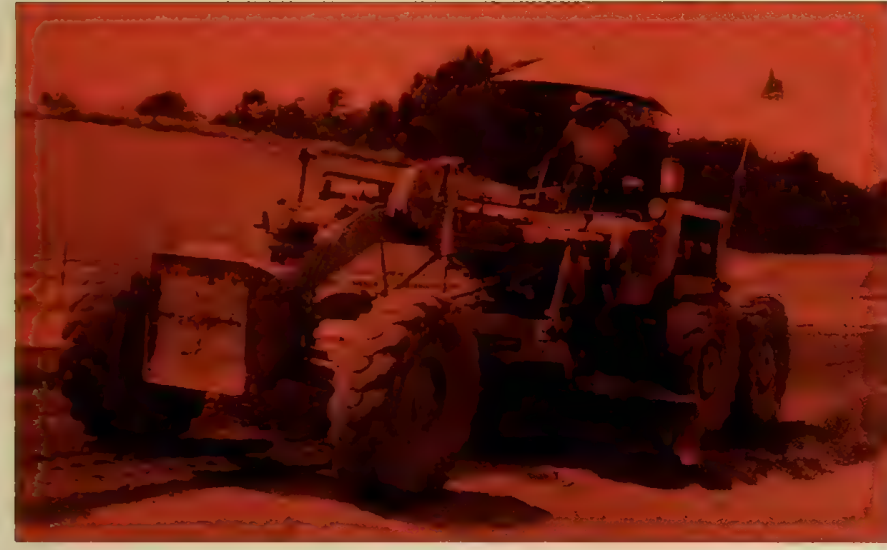

Grading equipment had greatly improved by the 60's and ro's. This motor grader is not only self-propelled, but also has enough power to push a scraper.

\section{Conflict for Space Brings New Maintenance Era}

As highway facilities became more and more congested and more people with their respective vehicles were fighting for this precious space on the streets and highways, the public began to resent the highway worker with his equipment taking up space on the public right-of-way, even if it did have to be maintained. The cry was: "Can't you find some other time to do that; you can't block the road at this time of day." So a new emphasis was placed on road maintenance. Maintenance organizations were subjected to numerous external pressures which caused severe internal stresses. Because a maintenance management science had not been developed as fast as the technological improvements or sociological needs, the existing management was not able to cope with the problems of reporting systems, work methods and procedures, performance in terms of quality, quantity and productivity, and planning and scheduling work. An organized formal research program was expanded considerably during this period, with studies covering a wide variety of subjects.
In Virginia between 1963 and 1965, a Federal-aid study was designed to cover nearly every aspect of maintenance management. It involved the collection of data concerning performance of labor and equipment; development and testing of various work methods; establishment of quality, quantity and performance standards; development and testing of a new reporting system; development and testing of a budgeting system; and development and testing of training materials. Other simultaneous studies were in progress which zeroed in on various aspects of maintenance management.

The basic components of maintenance management systems derived from these studies have been accepted by approximately 30 highway maintenance organizations. Such a system enables a highway department to prepare a performance budget showing specific maintenance activities and the resources in personnel, materials and equipment required to carry them out. On this basis, the highway department can develop long-range plans for maintenance operations and evaluate performance of the various field organizational units. This, in turn, indicates where additional

Scraper being pushed by two tractors. Push-loading speeds up the process of loading and hauling heavy materials.

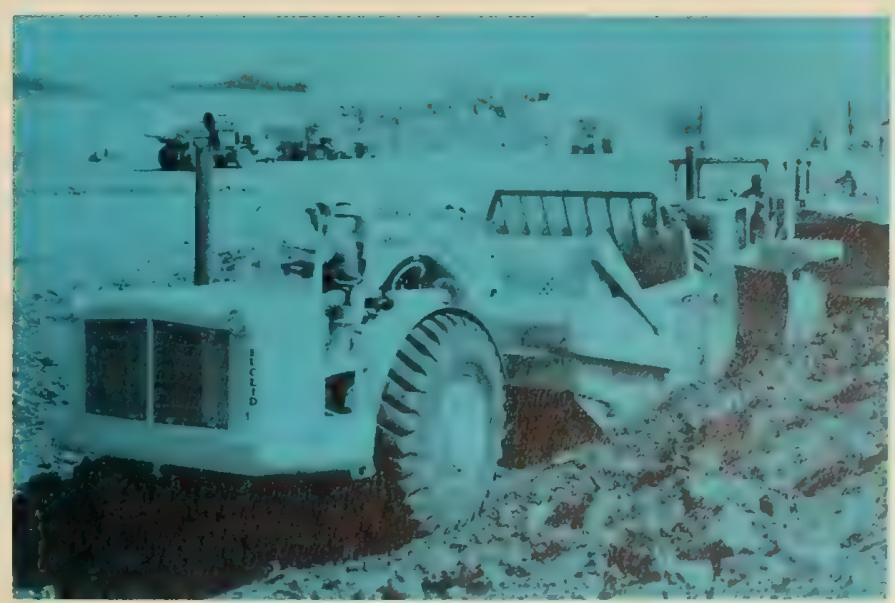




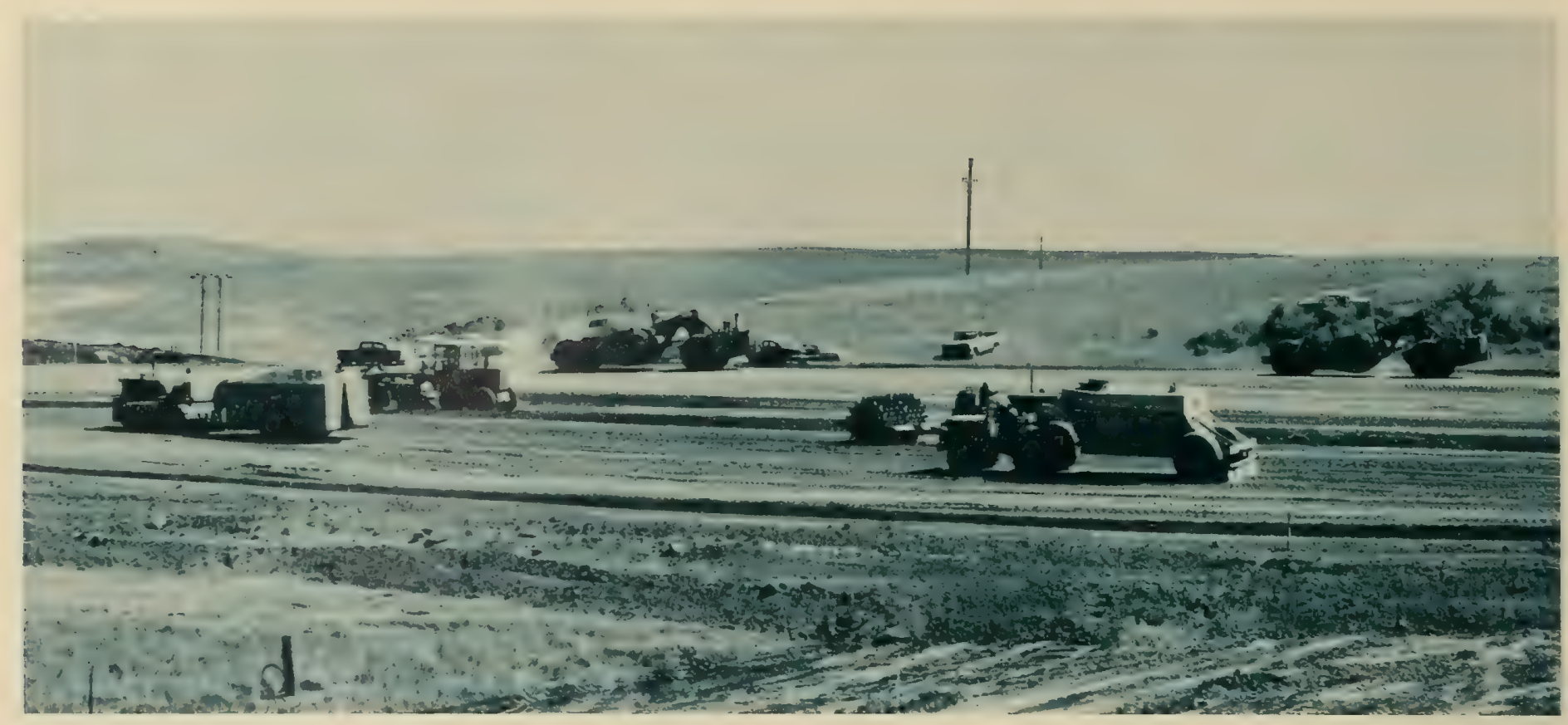

Grading operations on Interstate 94 in North Dakota.

After a water distribution truck moistens the soil,

sheeps foot and ballastable rollers compact it.

training is needed. Furthermore, such a system provides the manager with the information needed to insure that equipment is being used efficiently and effectively, and to aid him in selecting the best unit for the work to be done.

Since 1971 the Federal Highway Administration, when requested, has assisted State organizations interested in discussing the basic components of a maintenance management program. State highway maintenance organizations that have implemented a maintenance management system are presently reviewing management practices in equipment management and capital outlay programs and are establishing district and area boundaries for related maintenance programs.

\section{Advances in Equipment and Techniques}

Construction industry associations were instrumental, as in previous periods, in the development of new equipment in such areas as tamping and vibrating rollers to speed up compaction of embankments and base courses. The use of nuclear devices for testing compaction on soil and base courses became more widespread as these devices made this type of testing much faster. Large screw augers were being used more frequently for structure foundation excavation. New equipment developed for subsurface investigation made it possible for more precise bidding on excavation work, because the contractor could depend on more accurate subsurface information.

The laser beam has become a very useful tool for engineers in establishing line and grade for pipe laying, eliminating the need for off-set lines and batter boards. New methods of making pipe and specialized equipment for cleaning pipe have also come into use during this period.

New methods for handling concrete, such as concrete pumps and new deck finishing equipment, have marle bridge work nore productive and enabled contractors to produce safer, smoother riding bridge roadways. Stay-in-place steel forms for concrete bridge decks were developed and thereby eliminated the need for the removal of the forms, an often hazardous and difficult operation.

Precast concrete units such as culverts and barricades came to be widely used, also.

Spreading and finishing equipment for pavements were developed into quite sophisticated machines that eliminated much of the hand work. New types of equipment for texturing and grooving concrete pavement surfaces came into use to help provide more skid resistance.

Large automatically controlled, central-mix plants were quite extensively used in concrete pavement work in this period from 1964 to 1974 . Some States permitted asphalt plants to operate without screens, using variable speed belts and multiple cold feed bins for gradation control. Also, some asphalt plants were equipped with surge storage, which allowed them to produce asphaltic concrete continuously without having to stop the plant to wait for haul trucks. The development of practical electronic systems for automatic grade controls, which used sensing devices to follow a string-line or guide-wire, was very important.

Significant advances in equipment in nearly every field of use were seen during this period in an effort by the industry, as a whole, to obtain faster, more efficient production with less "down time."

Many advances have been made in developing new materials and techniques for highway construction. A new technique of presplitting faces of road back slopes before blasting for excavation gave a much more even back slope in rock cuts. Various treatments, such as lime and water-proof membranes, were put into use to help overcome the problems of swelling soils. Even though they had been in use for many years, synthetic aggregates were seeing more use in highway work during this period. New types of coatings for structural steel and culvert pipe, as well as pipe jointing materials, were being produced. 
Additives for concrete that controlled the set for better workability and that produced more durable structures were being further developed. Even so, concrete bridge decks were beginning to show signs of early deterioration, caused by salt used as a de-icing agent penetrating the concrete and destroying the reinforcing steel. This brought about specialized construction methods for the protection of bridge decks, such as the use of epoxy coated or galvanized reinforcing steel and waterproof mastics or membranes.

During the years from 1967-1974, highway builders were finding an increasing scarcity of key highway construction materials, such as cement, steel, asphalt, and paint, which accelerated the search for alternate materials. Gasoline and diesel oil for the big rigs also became scarce, especially during the oil embargo late in 1973 and early 1974. The use of some waste materials in highway construction helped stretch existing supplies somewhat. For example, some States started using fly ash as a substitute for some of the cement in concrete mixes. Some experimented with rubber from old automobile tires to modify asphalt in hot mixes.

Now the United States has become a Nation bound together by an extensive ribbon of efficient wellmaintained, quality streets and highways. Where once the horse and wagon slowly plowed through muddy roadways, millions of cars and trucks swiftly carry people, goods, and sexvices to every corner of this country, impacting the social and economic wellbeing of every community. The ability to steadily obtain more production and an improved quality of construction and maintenance of this Nation's streets and highways while still preserving a reasonably level cost is due to the combination of the many factors of the construction and maintenance system as it has developed. Some of these factors, which have been discussed, are the competitive bidding mechanism, the improved managerial methods, a dependable public financing, the advancing technology, and the motive force of the State and Federal Governments in desiring to meet the needs of the Nation and her people.

However, though the capability and motivation were present, the success of this effort required the excellent cooperative spirit that existed among the Federal Highway Administration and its predecessors, the State highway departments, and the industry associations. Without this partnership, there would not be the sound construction industry or the effective highway network that we have today.

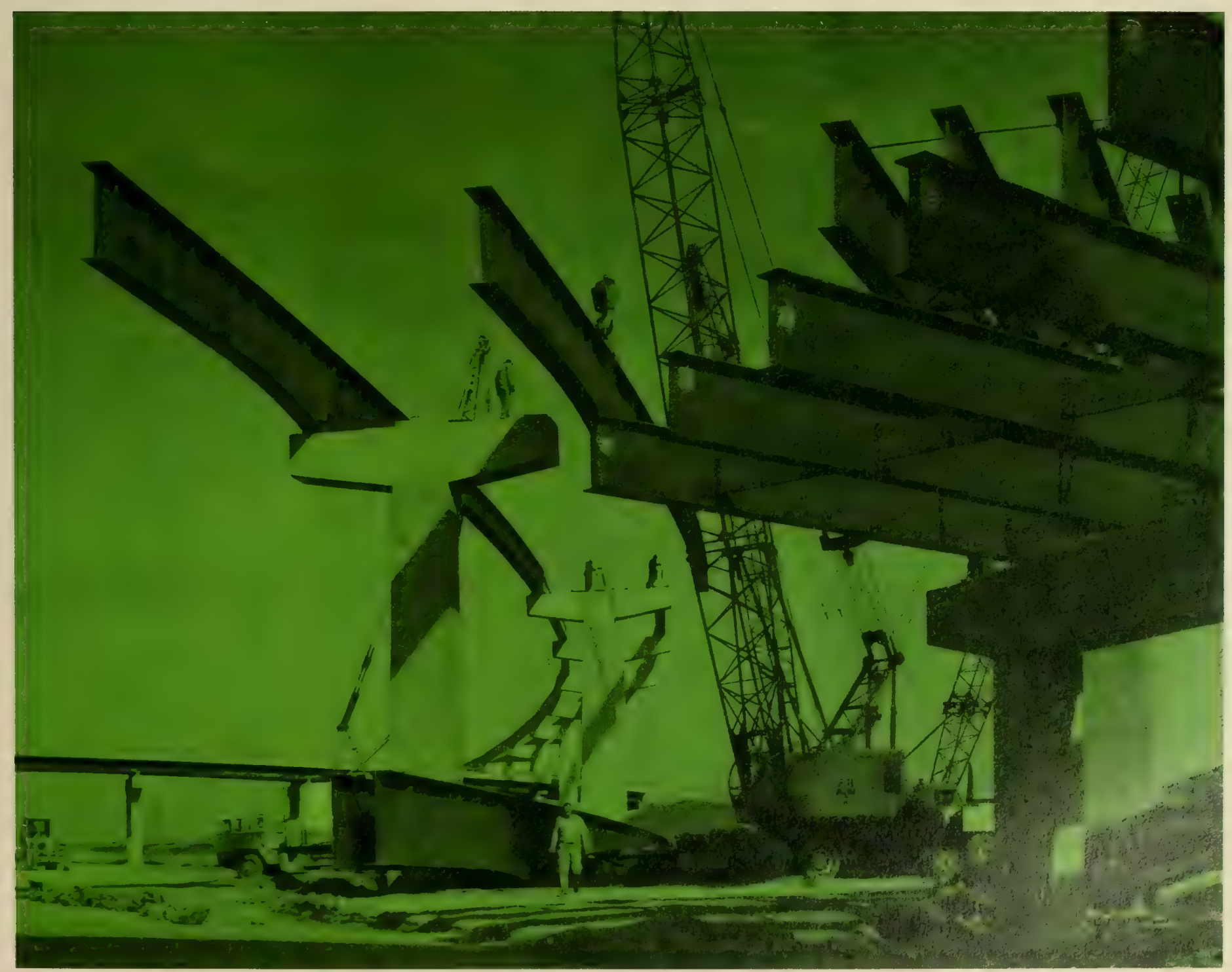




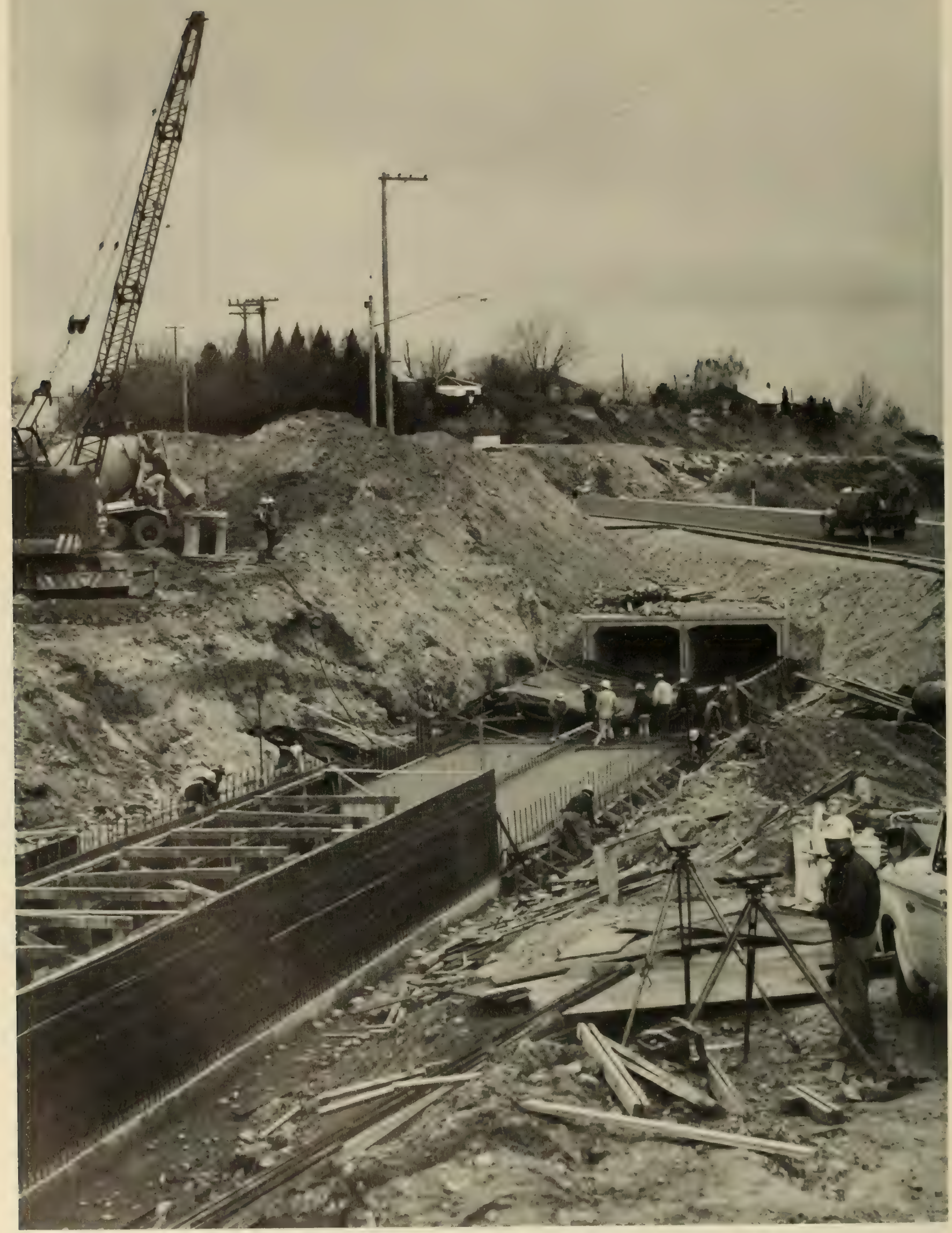




\section{REFERENCES}

${ }^{1}$ A. C. Rose, Historic American Highways-Public Roans of THE PAST, (American Association of State Highway Officials, Washington, D.C., 1953) p. 100.

"Id., p. 101.

${ }^{3} I d .$, pp. 103-105.

"G. Galli, 100 Years of Construction Nevs-Events That shaped the F'uture, Exgineerixg News-Record, Vol. 192, No. 18, Apr. 30, 1974, p. 455.

${ }^{5}$ A. C. Rose, supra, note 1, p. 108.

${ }^{6}$ Public Roads Administration, The Public Roads AdmixISTRATION AND ITS Works (Federal Works Agency, Washington, D.C., Revised Nov. 1946) p. 3.

${ }^{7}$ Bureau of Public Roads Annual Report, 1918, p. 5.

${ }^{8}$ P. HubBard, Efficiency of Bituminous Surfaces and Pavements Under Motor Truck Traffic, Public Roads, Vol. 1, No. 10, Feb. 1919, p. 25.

- A. P. Anderson, Modern Road Bunlding and Maintenance (Hercules Powder Co., 1921), pp. 33, 103.

${ }^{10}$ PRA, supra, note 6, pp. 25-27.

${ }^{11}$ Bureau of Public Roads Annual Report, 1926, p. 32.
${ }^{12} I d, \mathrm{pp} .34-35$.

${ }^{3}$ Crvil Engineering Department and the Transportation Fingineerixg Center of the OHo State University, ProCeedings of the Sixteenth ANNual OHIo Highway EngiNeerixg Conference (Columbus, Ohio, Apr. 2-4, 1962), pp. $13-14$.

${ }^{14} \mathrm{G}$. Galli, supra, note 4, p. 455.

${ }^{15}$ Ohio State Univeksity, supra, note 13, p. 27.

${ }^{16} 50$ th Anniversary of PCA, Civil Engineering, Vol. 36, No. 3, Mar. 1966, pp. 32-42.

${ }_{17}$ The Asphait INSTITUTE-What IT Is AND What IT Does, Information Series 110, (The Asphalt Institute, College I'ark, Md., Jun. 1973).

${ }^{18}$ G. Galdi, supra, note 4, pp. 455, 456.

${ }^{10}$ Bureau of Public Roads Annual Report, 1931, pp. 1-7.

${ }^{20}$ Southeastern Associatiox of State Highway Officiars, I'roceedings (Chattanooga, Tenn., 1943) p. 75.

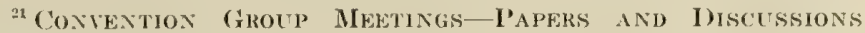
(St. Louis, Missouri, Dec. 1942), (American Association of State Highway Officials, Washington, D.C.) p. 76.

${ }^{22}$ G. Galli, supra, note 4, pp. 455-459. 


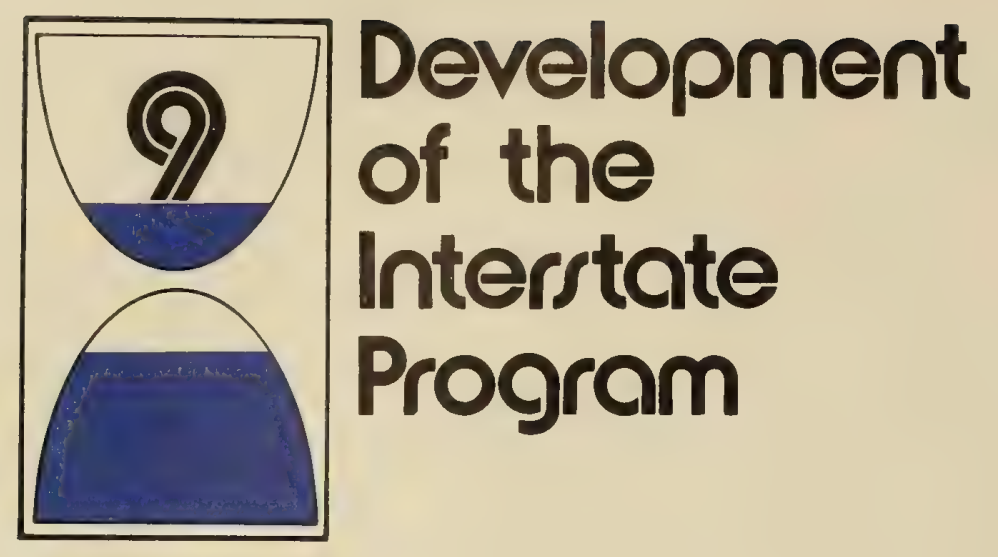

The National System of Interstate and Defense Highways, more commonly known as the Interstate Highway System, is a 42,500 -mile network of freeways, spanning the Nation and linking together and serving more than 90 percent of all cities of over 50,000 population and thousands of smaller cities and towns. The System comprises little more than 1 percent of the Nation's road and street mileage, but when completed, it is expected to carry about 25 percent of all traffic.

While the Interstate System is a national system connecting all States, it is a part of the State highway system in each of the States in which it is located. Federal highway funds, derived from highway-user taxes, are used together with appropriate State funding for the construction of the Interstate System, but the "ownership" is with the States, and the entire burden of maintenance, administration, and regulation falls upon the States and localities.

The Interstate System, now nearing completion, is being constructed by a State-Federal partnership. The State highway departments and the Department of Defense assisted in the designation of the System's routes. The States select and design the projects to be built each year; the necessary right-of-way is acquired by the States under State law, and the States

award and manage the construction contracts-all subject to the review and approval of the Federal Highway Administration. The Federal share of the total system cost, now estimated at $\$ 89$ billion, is 90 percent, and States' shares are 10 percent.

\section{The Birth of the Interstate System}

\section{Initial Consideration}

The origin of the Interstate Highway System can be related specifically to a formal report made to Congress in 1939. Before that, a few scattered parkways and urban arterials were already demonstrating the virtues of controlled access highways with gradeseparated interchanges. There had been earlier dreams of a transcontinental network of superhighways, although these were usually conceived of as bypassing all cities and serving only those who wanted to make long trips.

In the 1930's there was mounting evidence of future traffic congestion on the country's main travel arteries; but at the same time a prolonged period of economic depression made normal public financing of highway improvement a difficult matter. There was a sudden revival of interest, after almost a century, in toll road financing, and toll roads were built in several of the major traffic corridors. 


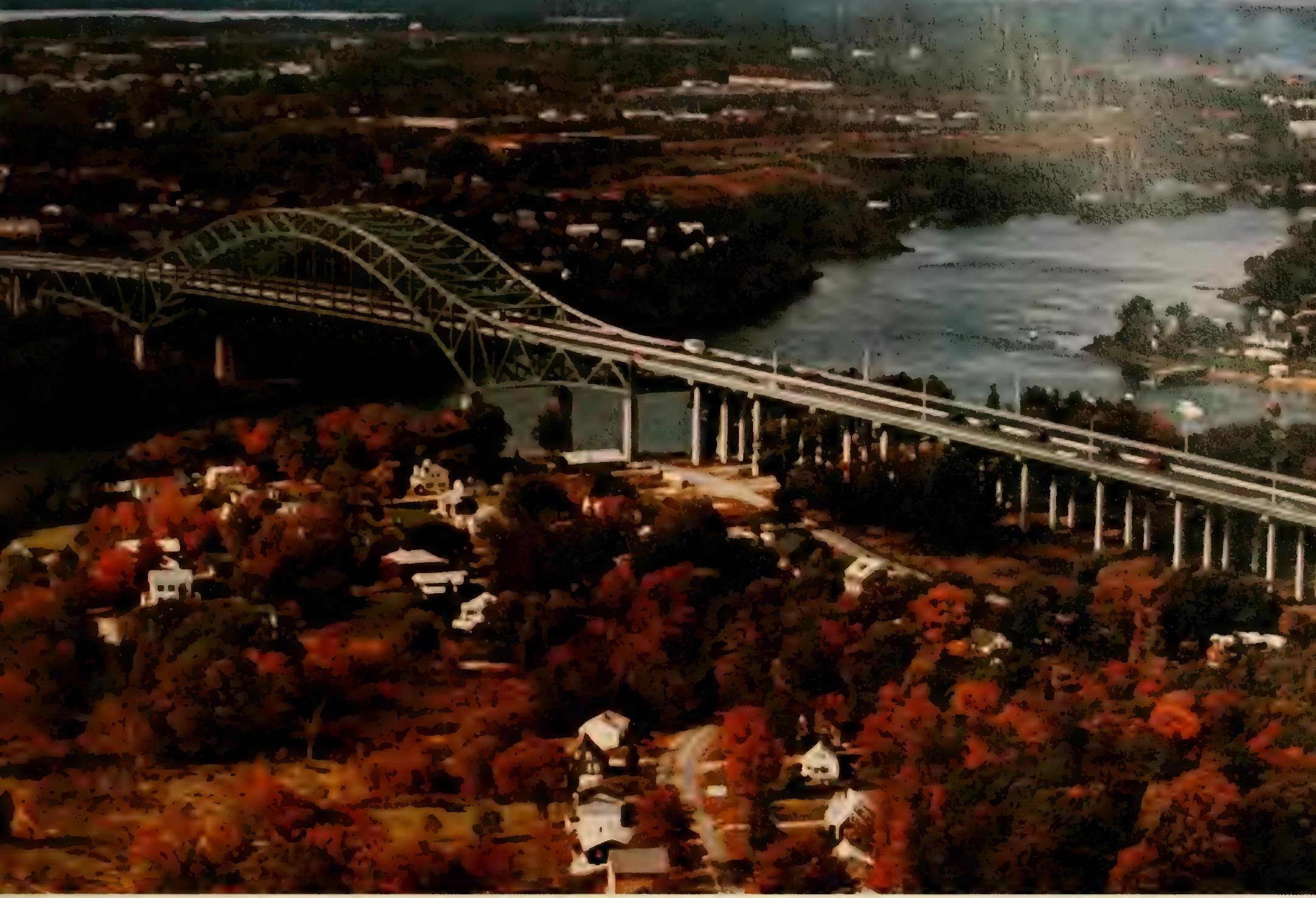

The Piscataqua River Bridge on Interstate 95 literally joins the States of Maine and New Hampshire. It fits gracefully into its environment and provides convenience, safety, and savings in travel time for the motorist.

The Federal-aid legislation in 1934 had authorized the use of Federal-aid highway funds for planning purposes, and continuing statewide highway planning surveys were initiated in 1935 under the guidance and leadership of the Bureau of Public Roads. From these studies came a wealth of factual information which, for the first time, permitted some definition and measurement of highway transportation and its problems and made possible highway planning based on knowledge rather than guesswork.

\section{A Study of Toll Roads Versus Free Roads}

With this data to draw on, the Congress in 1938 requested the Bureau of Public Roads to study the feasibility of a toll financed system of three east-west and three north-south superhighways. The resulting comprehensive study made by Public Roads in cooperation with the State highway departments was reported to Congress in 1939 in the landmark publication Toll Roads and Free Roads.

This study demonstrated that the suggested 14,000mile toll road system would be far from self-supporting. Seeking more than a negative recommendation, the study explored and documented the need for a system of interregional superhighways, with connections through and around cities. A 26,700-mile nontoll network was proposed, with the recommendation that the Federal Government share the construction cost at more than the traditional 50 percent Federalaid rate.

\section{The Interregional Highways Study}

To pursue this concept, President Franklin D. Roosevelt appointed a National Interregional Highway Committee in 1941. Thomas H. MacDonald, Commissioner of Public Roads, became the Committee's chairman; its secretary was Herbert S. Fairbank, Deputy Commissioner for Research in the Public Roads Administration.

Through them, the resources and assistance of the Public Roads Administration and the States were made available to the Interregional Highway Committee. Then, in 1943, in the midst of World War II, Congress requested Public Roads to make a study of the need for a nationwide expressway system. The Committee and Public Roads presented their report, Interregional Highways, to Congress in 1944. 
The study considered systems of several sizes, testing each by a variety of criteria, and recommended as optimum a rural network of 33,900 miles. The need for an additional 5,000 miles of auxiliary urban routes was foreseen, bringing the total proposed system to about 39,000 miles, of which one-fifth would be in urban areas.

High standards of geometric design with full control of access were recommended. No overall cost estimate for the system was made. It was suggested that postwar expenditures for its construction should be $\$ 750$ million a year, two-thirds of it on the urban sections.

\section{Designation of the System}

Acting on the basis of the 1939 and 1944 reports, the Congress in the Federal-Aid Highway Act of 1944 directed the designation of a National System of Interstate Highways limited to 40,000 miles and ". . . so located as to connect by routes, as direct as practicable, the principal metropolitan areas, cities, and industrial centers, to serve the national defense, and to connect at suitable border points with routes of continental importance..."

The Act provided that the routes of the Nationa] System of Interstate Highways be selected by joint action of the State highway department of each State and the adjoining States, with the approval of the Public Roads Administration and were to be incorporated in the Federal-Aid Primary System if not already included in it.

In response to a request from PRA, the States proposed routes for inclusion in the System. Criteria for selection included service to cities and rural population, to manufacturing and agricultural production, to concentrations of motor-vehicle ownership and traffic, and to national defense. Additional criteria in urban areas included consideration of need for through and circumferential routes and their relation to land use, urban planning, and civil defense.

Considerable discussion ensued between the States and the Department of Defense. On August 2, 1947, selection of the general locations of the main routes of the Interstate System was announced. They totaled 37,700 miles, including 2,900 in urban areas. The remaining mileage within the 40,000-mile limit was reserved for auxiliary urban routes.

Again on the recommendation of and in consultation with the States and the Department of Defense, the general locations of 2,300 miles of urban circumferential and distributing routes were designated on September 15, 1955.

This well designed interchange in Morris County, N.J., maintains much of the original topography while smoothly blending the heavy traffic of I-80 and 287 with that of U.S. 46. It provides long acceleration and deceleration lanes and wide shoulders for safe emergency stops.

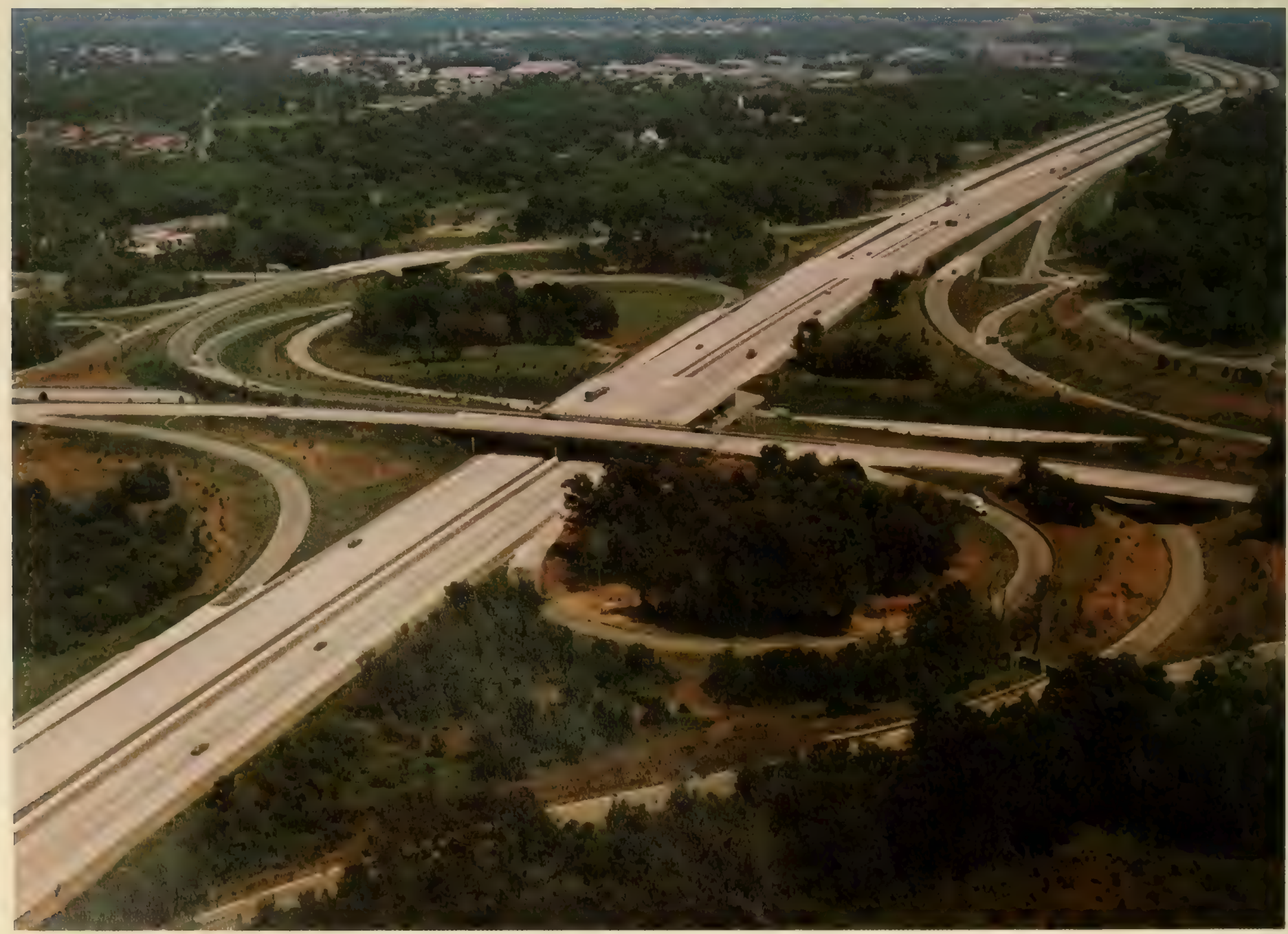




\section{Early System Construction}

Progress in the designation of the routes on the System had been slow. So was progress in construction. Congress authorized a sizable postwar Federalaid highway program, but for the fiscal years 1946-53 no specific amounts were earmarked for the Interstate System.

In what now seems a token gesture, the FederalAid Highway Act of 1952 did authorize $\$ 25$ million for the Interstate System for each of the fiscal years 1954 and 1955 , to be matched on the traditional $50-50$ Federal-State cost sharing basis. The Federal-Aid Highway Act of 1954 authorized $\$ 175$ million for the Interstate for each of the fiscal years 1956 and 1957, with the matching ratio changed to a 60 -percent Federal share. These 1954-57 funds were apportioned among the States by formulas used for apportioning regular Primary System funds, taking into account the area, population, and postal route mileage in each State.

During the first postwar decade, of course, a good deal of the regular Federal-aid highway funds were used on the Interstate System-some 27 percent of the Primary and 45 percent of the Urban Federal-aid funds authorized for fiscal years 1946-56-however, this level of construction funding fell far short of meeting System traffic requirements or design standards.

\section{Highway Needs Studies}

\section{National Defense}

Although some work progressed, traffic needs on the System increased at a faster rate than construction. The Congress, in 1948, requested PRA to study the status of the System and to comment on the relation of highways to the national defense. The ensuing study, made in cooperation with the State highway departments, was reported to Congress in 1949 in the document Highway Needs of the National Defense. It demonstrated the critical deficiencies of the Interstate routes and estimated the cost of needed improvements at $\$ 11.3$ billion; 47 percent of the suggested improvements lay in urban areas.

There were some recognized deficiencies in the estimate. It did not include the 2,300 miles of urban auxiliary routes, which were then yet to be designated. It was realized that designs should be based on traffic needs of the future, but it was found impracticable to make such forecasts, so deficiencies of existing highways were measured against existing traffic.

There were other flaws, easily seen in hindsight. It was then considered that a good deal of the System could be developed by reconstruction of or widening existing highways, which later proved impractical on many route segments. And subsequent substantial construction price increases were unanticipated.

\section{Highway Systems}

The next few years brought a welter of discussion and studies of the problem. Protracted hearings of the Subcommittee on Roads of the House of Representatives in 1953, published as the National Highway Study, dwelt at length on the Interstate System among other subjects.
In a message sent to the Governors Conference on July 12, 1954, President Eisenhower called for "a grand plan for a properly articulated highway system." 1 Later in 1954, a committee of the Governors Conference reported to the President its belief that the national government should assume primary responsibility, with State participation, for financing the Interstate System.

In the Federal-Aid Highway Act of 1954, Congress requested the Bureau of Public Roads to make several extensive studies, in each of which the State highway departments collaborated.

One study was reported in March 1955 in the document Needs of the Highway Systems, 1955-84. Construction needs of the 37,700-mile Interstate System for the years 1955-64, to provide for traffic predicted for 1974 , were estimated to cost $\$ 23.2$ billion, of which 46 percent would be spent in urban areas. Again, the estimate did not cover the 2,300 miles of urban auxiliary routes. Thus, the estimate included essentially the same mileage as the estimate reported in 1949, and at about the same construction unit price levels.

Yet the new cost estimate was double that reported in 1949. This time an attempt was made to forecast future traffic needs; higher standards were used for estimate purposes, including access control throughout; and there was greater awareness of the probable need for extensive location on new right-of-way.

Still, the report itself acknowledged that there was a tendency in State estimates to reflect financial limitations rather than anticipated needs, and additionally a tendency to understate the needs. Further, both this and the earlier estimates were made in a comparatively short time, with limited manpower. A good deal of the estimating was done by map study for route location and use of average quantities and costs per mile.

\section{Feasibility of Toll Roads}

Another study requested by Congress in 1954 was reported in April 1955 in the document Progress and Feasibility of Toll Roads and Their Relation to the Federal-Aid Program. At that time the toll turnpike was vigorously advocated by various promotional groups as the ready solution to highway congestion and financing. This study indicated that 6,700 miles of routes could be successfully financed by tolls, but predicted (reliably) that assurance of public funds for early completion of the Interstate System would soon end widespread interest in toll roads.

The report reaffirmed the desirability of the principle established in the Federal-Aid Road Act of 1916: Roads built with Federal aid should be toll free. But the report did recommend inclusion in the Interstate System of toll roads which met System standards where there were reasonably satisfactory free roads in the corridor permitting traffic to bypass the toll road. This simply recognized that toll roads, built without Federal aid, existed on the lines of the Interstate System and that to duplicate them would be an economic waste.

\section{The Clay Committee Report}

Following up on his message to the Governors Conference in 1954, President Eisenhower appointed an Advisory Committee on a National Highway Program, with General Lucius D. Clay as its chairman. The 

A modified version of the Gore bill was passed by the Senate on May 25, 1955, providing $\$ 7.75$ billion for the Interstate System program, spread over the 5 fiscal years 1957-61, with the Federal share of costs to be 90 percent. Numerous other significant provisions were included in the bill with respect to the Interstate program. There were no provisions for the revenue required.

In the House of Representatives consideration was given to the Administration bill, the Senate-passed bill, and a bill proposed by Representative George $\mathrm{H}$. Fallon. For the Interstate System, Fallon's bill offered $\$ 24$ billion over the 12 years $1957-68$, a 90 percent Federal share of costs, and apportionment among the States in the ratio of the estimated cost of completing the System in each State to the total cost of completion in all the States. The bill proposed increases in Federal motor-fuel and rubber taxes to provide needed revenue.

A modified Fallon bill came before the House in the last days of the session but was defeated. The Administration bill also was defeated. With adjournment of the 1st session of the 84th Congress, the Gore bill, passed by the Senate, remained alive but dormant for the rest of 1955 .

The failure of Congress to enact legislation came as a shock to many. There had been almost universal testimony supporting an expanded highway program. One major difficulty, perhaps, was the diversity of proposals, each vigorously supported or opposed. Questions of toll financing, credit financing, and current-revenue financing were hotly argued. Almost every highway beneficiary group expressed willingness to pay its fair share of the cost-according to its own method of calculation. Some groups objected to any tax increases. There was one further possible reason why legislation was not enacted in 1955 . The public, still relatively uninformed on the issues, had yet to raise a concerted voice.

\section{6-Year of Action}

Congress returned to the problem early in 1956. User groups seemed more amenable to compromise; the public was better informed, aroused, and strong for action. The Federal corporation and the bond financing plan were dead issues, and the Administration endorsed the pay-as-you-go principle.

In this receptive atmosphere the House Roads Subcommittee and the House Ways and Means Committee separately undertook to develop the program features and the finance provisions for Federal-aid highway legislation. Many provisions of the 1955 bills were adopted. A joint committee bill was approved by the House on April 27, 1956.

Shortly thereafter the Senate Public Works Committee replaced the program features of the House bill with a modified version of the 1955 Gore bill; and the Senate Finance Committee modified the House bill's finance provisions. The revised bill was approved by the Senate, with some amendments, on May 29.

Senate-House conferees developed a compromise bill on June 25 and on the next day both the Senate and the House approved it by overwhelming votes. On June 29, 1956, President Eisenhower signed the bill into law.

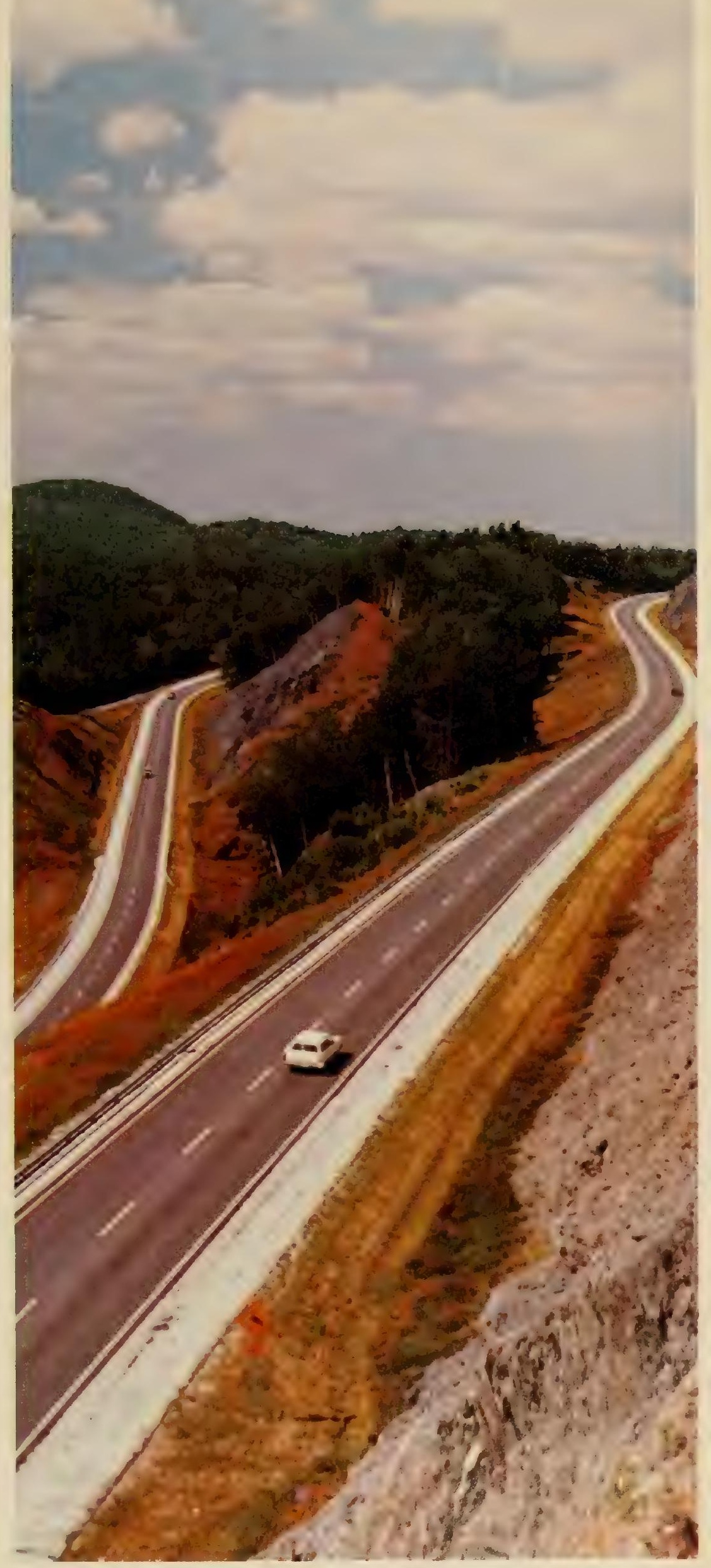

This portion of I-91 near Fairlee, $V t$., is located on independent alinements to preserve the natural terrain characteristics and the beauty of the area. 


\section{The Federal-Aid Act Highway of 1956}

\section{General Provisions}

The legislation, so painstakingly developed, is commonly called the Federal-Aid Highway Act of 1956 , but officially this is the name of Title $I$ of twin acts; it contains the program features. The other twin is Title II, the Highway Revenue Act of 1956, which covers the financing provisions.

In recognition of its importance to the national defense, the System's name was expanded to National System of Interstate and Defense Highways. The length limitation for the System was increased from 40,000 to 41,000 miles. (Later, in the Federal-Aid Highway Act of 1968, an additional 1,500 miles of Interstate System was authorized-bringing the total system length to 42,500 miles.)

The Act prescribed that standards for the Interstate System should be adopted by the Secretary of Commerce in cooperation with the State highway departments; that they should be adequate to accommodate the traffic forecast for 1975 (modified in later legislation) and that they be applied uniformly throughout the States. To preserve the operating efficiency and safety of this System, access ramps at interchanges on Interstate highways were to be limited to those provided in the original project plans, except as changes may be approved by the Secretary.

In authorizing Interstate funds, the 1956 Act significantly departed from the traditional biennial authorization pattern. For the first time, an accelerated program to complete a highway system was authorized. The Act authorized a total of $\$ 25$ billion over the period 1957-69 as the Federal share of this construction program.

The Act also established a new method of apportioning Interstate funds among the States, changing after the first 3 years from a formula based on mileage, area, and population to an apportionment factor for each State computed from the ratio of the cost of completing the System in each State to the total cost of completing the System in all States. It further provided for a series of cost estimates to establish these values on a current basis as construction of the System progressed in the years that followed.

The Federal share of Interstate project costs was set at 90 percent, except in States with large areas of Federal public land where the Federal share is increased proportionally up to a limit of 95 percent.

Title II-the Highway Revenue Act of 1956-established the Highway Trust Fund and assigned specific motor-vehicle user taxes to this fund for the payment of highway construction costs. The Act also provided that the highway program must be conducted on a "pay-as-you-go" basis, requiring that Trust Fund revenues be adequate to meet all needs without drawing on the General Fund of the Treasury which had previously supported the Federal-aid highway program.

\section{Interstate Use Restrictions}

The 1956 Act barred service stations and other commercial establishments from location on or access within the Interstate System right-of-way on the grounds that highway users should not be subjected to monopoly and so that highway-oriented business could engage in free competition. It is probable, also, that many State highway departments were unenthusiastic about undertaking the franchise system, with its attendant problems, which is common on toll roads. Service at businesses located on intersecting roads is not difficult for Interstate travelers to obtain, since interchanges occur much more frequently and there is less inconvenience in leaving and re-entering than on toll roads.

In a positive direction, the Act permitted use of airspace above or below Interstate highways for parking purposes (a provision subsequently broadened to allow any public or private use that will not impair the highway).

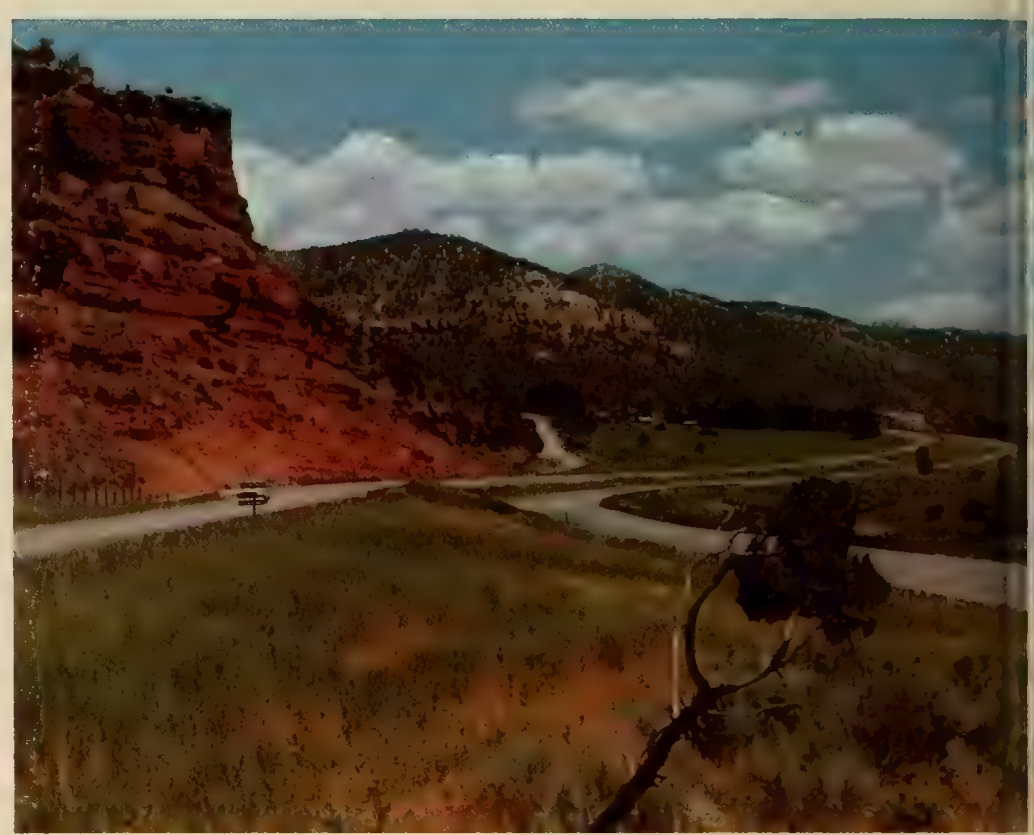

Gently curving I-70 in the Eagle River Valley of Colorado provides the motorist with new vistas of the countryside with each turn. The weathering-steel guardrail blends with its surroundings. Flat slopes, designed for safety, are quickly regaining vegetation because of the topsoil salvaged during early stages of the construction.

Congressional belief that Interstate highways built with 90 percent Federal funds should have some Federal protection against very heavy loads led to a provision in the Act on vehicle weight and width limitations. The limits were essentially those of the then-current policy of the American Association of State Highway Officials, or alternatively those legally permitted in a State on July 1, 1956, whichever were greater. The law did not actually prescribe Federal limitations per se, but accomplished its objective by providing that no Federal-aid apportionment would be made to any State that permitted vehicles on the Interstate System of greater size or weight.

\section{Route Location}

To some extent, Congress entered into problems of route location. The 1956 Act proposed that "Insofar as possible in consonance with this objective [prompt completion of the Interstate System], existing highways located on an interstate route shall be used to the extent that such use is practicable, suitable, and feasible, it being the intent that local needs, to the extent practicable, suitable, and feasible, shall be given equal consideration with the needs of interstate commerce." 
This language was intended as permissive modification of the original legislative prescription in the 1944 Act that the system was ". . . to connect by routes, as direct as practicable, the principal metropolitan areas, cities, and industrial centers..." There may also have been concern about the needs of the cities as contrasted with those of cross-country travel, about possible dislocations of homes and businesses, and about the costs of new right-of-way.

Broadening a provision of the Federal-Aid Highway Act of 1950, the 1956 Act required that the State highway departments, in planning a Federal-aid project (Interstate or $\mathrm{ABC}$ ) involving the bypassing of or going through a city or town, must hold, or offer to hold, a public hearing and must consider the economic effects of such a location. (This provision was subsequently expanded to cover rural Interstate projects as well.)

The public hearing has a dual purpose: for the State to present and explain its proposals to the public and for the public to present its views to the State. Decision by popular vote was not intended. Decision by the responsible highway official is properly made by weighing the economic and social costs and benefits to highway users and to the locality, the region, and the Nation, and choosing that solution which produces the greatest overall benefit-often a far from simple task.

\section{Right-of-Way Acquisition}

Acquisition of right-of-way had been recognized as a large, costly, and complicated aspect of the Interstate System program. To ease the problem, the 1956 Act authorized use of apportioned Federal-aid funds for advance acquisition of right-of-way, provided that actual construction followed within a specified period (within 10 years now).

At that time, not all States could legally acquire control of access, and while all could take land by eminent domain, some could not begin construction on the land until the taking process had gone through the courts. The 1956 Act, therefore, provided a means whereby, at the request of a State, the Federal Government could acquire land (and prompt entry to it) or access control for an Interstate project and then convey the title to the State. Some States took advantage of this mechanism; however, most States soon obtained legislation or procedures for obtaining access control and prompt right-of-way entry.

\section{Toll Facilities}

The early consideration of toll road construction for the Interstate System has already been mentioned. The subject received a great deal of attention again in both 1955 and 1956. The decision reached in the 1956 Act was that toll roads, bridges, and tunnels could be included in the Interstate System if they met the System standards and if their inclusion promoted development of an integrated system. The Act reiterated that Federal-aid funds could not be used on toll roads, nor on toll bridges and tunnels except under the special circumstances already covered by Federal-aid legislation.
The Act did provide that Federal-aid Interstate funds could be used on an approach to a toll road incorporated in the System, if the toll road is to become free when the bonds are liquidated and if there is a reasonably satisfactory alternate free route available by which the toll section may be bypassed.

As a result of these provisions, some 2,300 miles of toll facilities (roads, bridges, and tunnels) have since been incorporated in the Interstate System.

A sharp controversy had developed over the question of reimbursement to the States for Interstate projects already built with less than 90-percent Federal aid or with none at all. While both free and toll facilities were involved, the arguments generally centered on the latter. In the 1956 Act, the whole matter was in effect deferred-the law declared the intent of Congress to determine whether or not the States should be reimbursed for work completed between 1947 and 1957, and if so, how, when, and how much; and the Secretary of Commerce was requested to report to Congress on this issue. The report was made in January 1958, but Congress took no action to provide reimbursement for either toll or free road construction.

\section{The Highway Revenue Act of 1956}

The language of Title II was formidable, for in large part it comprised amendments to the Internal Revenue Code. But it was a landmark in Federal highway law since it established, for the first time, a linkage between Federal excise taxes on highway users and Federal aid for highways. It sought to achieve three major objectives: To finance the longrange Federal-aid program, including the funds specifically authorized to complete the Interstate System and an anticipated, but not legislated, escalating $\mathrm{ABC}$ program during the same period; to provide revenue wholly from highway-user tax revenues; and to confine the program to a pay-as-you-go basis.

\section{The Taxes}

The Federal excise taxes earmarked to pay for the Federal share of the highway program and their rates reflected a balance between the need to pay for highways and for other functions of Government and the cost occasioned or the benefit gained by each class of highway beneficiary in forms that were practical of collection. The result of this endeavor by Congress appeared at the time to be a productive and generally equitable tax schedule. Considerable revision was made in later legislation. The taxes included an increase in the tax on motor-vehicle fuel, an increase in the excise tax on the manufacturer's sale price on commercial vehicles (new trucks, buses, and trailers), a new annual use tax on vehicles in excess of 26,000 pounds gross weight, and an increase in the tax on highway vehicle tires.

\section{The Highway Trusł Fund}

Linkage between highway-user tax revenue and Federal aid for highways was formalized in the 1956 Act by creation of the Highway Trust Fund. Into the Fund go the earmarked taxes; out of it are appropriated the Federal-aid funds for payment to the States. 


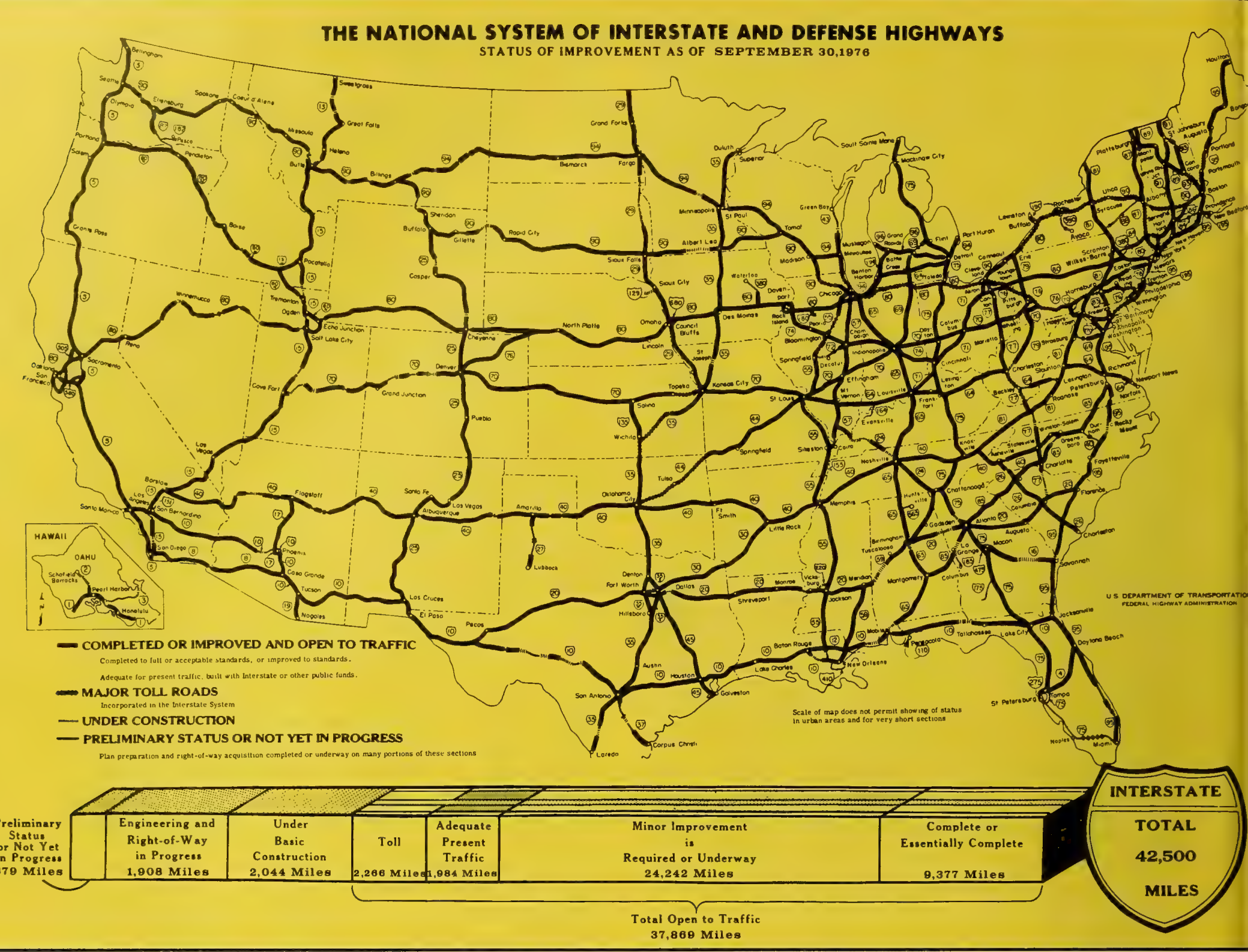

It was recognized that expenditures would exceed income in the early years of the Trust Fund, but this deficit would be overcome by excess revenue in later years. The 1956 Act, therefore, included a provision permitting borrowing or "repayable advances" from the U.S. Treasury. However, this provision was in effect nullified by an amendment requiring pay-asyou-go operation. The amendment (Byrd Amendment) required that if the projected expenditures which would result from a pending apportionment of authorized funds were forecast to exceed projected Trust Fund receipts, then the apportionment was to be appropriately reduced to prevent a deficit.

\section{6-A Landmark Year}

In the 1956 Act, the Congress acknowledged that it was dealing with forecasts of highway needs and of tax revenue and that future legislation might well be needed to bring about proper balancing of receipts and expenditures and of costs and benefits to beneficiaries of highways. Accordingly, it requested the Secretary of Commerce to undertake an extensive investigation which became known as the highway cost allocation study; the final report was completed in January 1961.
The twin 1956 Acts were indeed a major landmark in the highway history of the United States. It was perhaps less than perfect legislation, arrived at after long and sometimes hot debate. Much of it evolved through compromise, aimed at practical solutions.

Nevertheless, the legislation broke with traditions and created some new principles:

- It authorized completion of an entire national highway network-the Interstate System-and provided for its financing (on the basis of costs recognized at that time).

- It required the establishment of, and broadly defined, location and design criteria for the System.

- It departed from the historic 50-50 Federal-State sharing of project costs and the fixed formula method of apportionment.

- It created a linkage between highway-user tax revenue and highway expenditure and established the Highway Trust Fund.

- It began an accelerated highway improvement program which was to bring about a new era in highway transportation in America. 


\section{The Accelerated Program}

\section{The Starting Point}

To the public, the accelerated program for building the Interstate System as announced in 1956 was obviously a big job, but not necessarily complex. Perhaps this thinking derived from the characteristic development of a toll road-a one-route project, all starting from scratch, all on new location, all built in a short period of time, and all under the management of a single agency, with all the money available at the beginning or as needed.

But the Interstate program was being accomplished by 49 States and the District of Columbia (there are no Interstate routes in Alaska), in cooperation with the Federal Bureau of Public Roads. Cities, counties, and towns had a direct interest in how routes were to be (or were not) located to serve them; and while toll roads characteristically approach but do not enter the cities, the Interstate System would, and at the same time would serve large volumes of the local traffic load.

Not all Interstate routes were starting from the same status of development in 1956. Some sections, indeed, were already completed, although these were mostly toll roads. Some others were in varied stages of development-a two-lane highway needing expansion to four lanes; an expressway lacking full control of access or needing additional grade separations or lanes. About four-fifths of the Interstate mileage was destined to be built on new location, but some would follow an existing highway, perhaps using it as one of its separated pairs of directional roadways.

The alinement of I-280 in densely populated northern New Jersey was carefully selected to have a minimal impact on the established neighborhoods and existing traffic patterns.

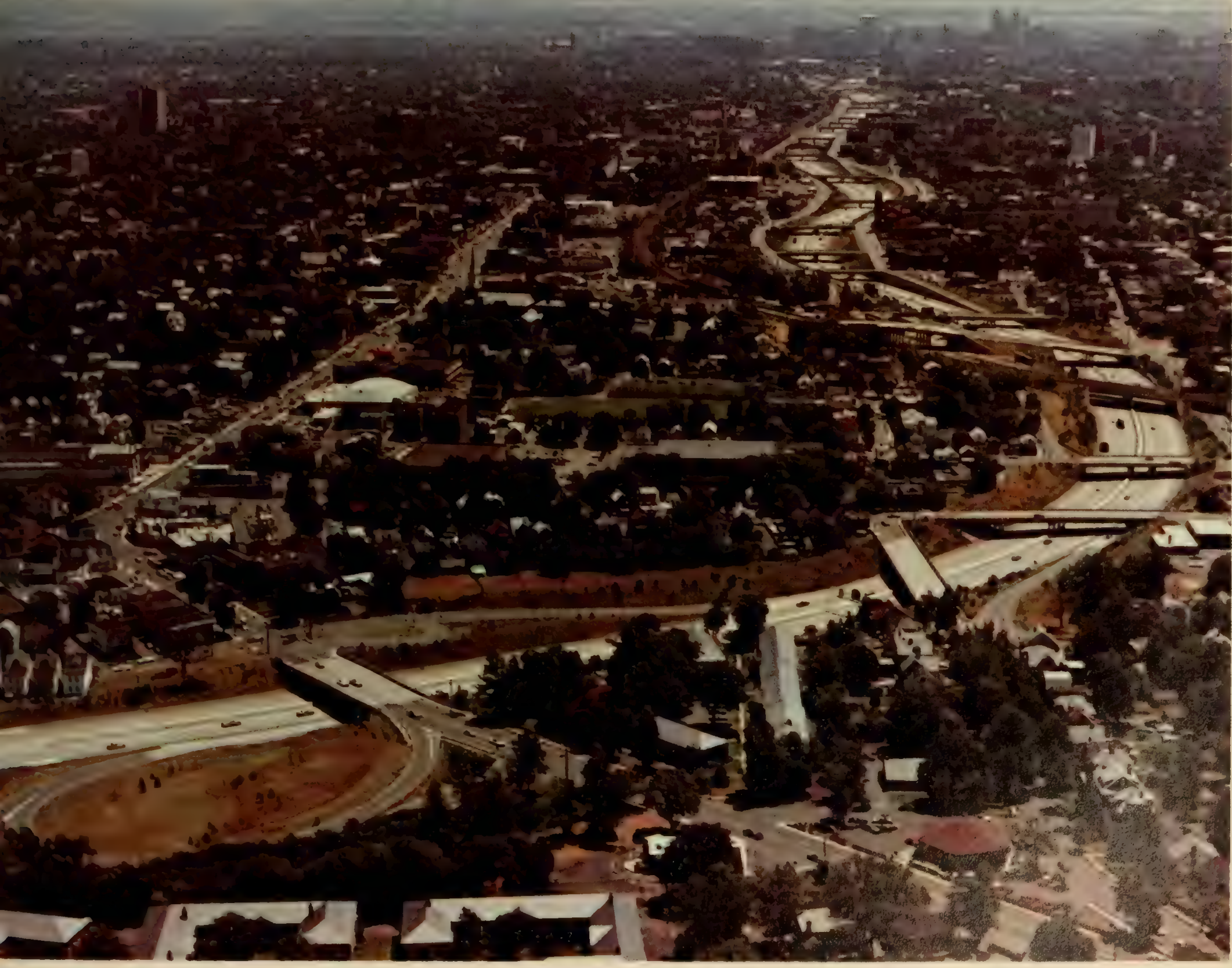


Not all States were starting from the same status in 1956 either, for a variety of reasons. A "shelf" of acceptable project plans was available in some States but not in others. Some State highway departments were able to staff up to the job rapidly while others took much longer; many had previously acquired little or no right-of-way on their own; some had never before designed or built freeways on a large scale.

Interstate projects are complex undertakings, consuming 3 or 4 years from beginning of route location study to final completion-and often much longer in urban areas. In the early years of the program, a large proportion of effort and expenditure was devoted to preliminary engineering and right-of-way acquisition. Construction followed at some later period.

All of this explains why the Interstate System program did not instantly jump into high gear on the morning of June 30, 1956, producing great stretches of completed pavement. It necessarily would be a number of years before any notable mileage was opened to traffic.

\section{Design Standards}

The 1956 Act called for adoption of uniform design standards for the Interstate System in all States. The American Association of State Highway Officials and the Bureau of Public Roads, anticipating the need, began developing geometric standards (those governing curvature, gradient, number and width of lanes, etc.) in May 1956 and by July had completed and adopted a full set of such standards. This rapid accomplishment was possible because the AASHO Committee on Planning and Design Policies had been evolving progressive freeway standards for years and had developed a set of Interstate System standards as early as 1945 .

The major items in the adopted standards included: control of access throughout the System; design adequacy for projected 1975 traffic-later changed (in 1963 Act) to a 20 -year minimum design period from the date of project approval; 12-foot travel lane width; 10-foot minimum shoulder width; elimination of railroad grade crossings; elimination of highway at-grade intersections; design speeds of 50,60 , and 70 m.p.h respectively for mountainous, rolling, or flat terrain conditions; curvatures and gradients consistent with design speeds; separated traffic lanes with variable median widths on a right-of-way adequate in width to accommodate these standards; and minimum widths for highway bridges.

The 1956 design standards were formulated as minimum rather than fixed levels, with the expectation that minimum levels would be used only where higher ones would result in excessive cost. They have served well, and have required but little modification since their adoption.

Reasonable uniformity prescribed through minimum standards seemed fully appropriate for the Interstate System insofar as geometrics were concerned, since these are the features the driver sees and is directly affected by. In contrast, however, structural design features which govern load-carrying capacity and durability are hidden from the driver's eye. Moreover, structural design of a roadway is necessarily largely guided by localized circumstances-physical conditions, availability of materials, and local experience and practice. Consequently "uniformity" in structural design was not prescribed in detail for the Interstate System-only the requirement that design be soundly and justifiably arrived at and be adequate to support anticipated traffic loads.

While these geometric standards complied with the basic requirements of the law at the time of adoption, they were soon found to be inadequate to meet realistic needs for future traffic service. The statutory design year 1975 was changed by Congress in the 1963 Highway Amendment Act to provide a design requirement for traffic service adequate for a 20-year period commencing on the date of plan approval for the initial

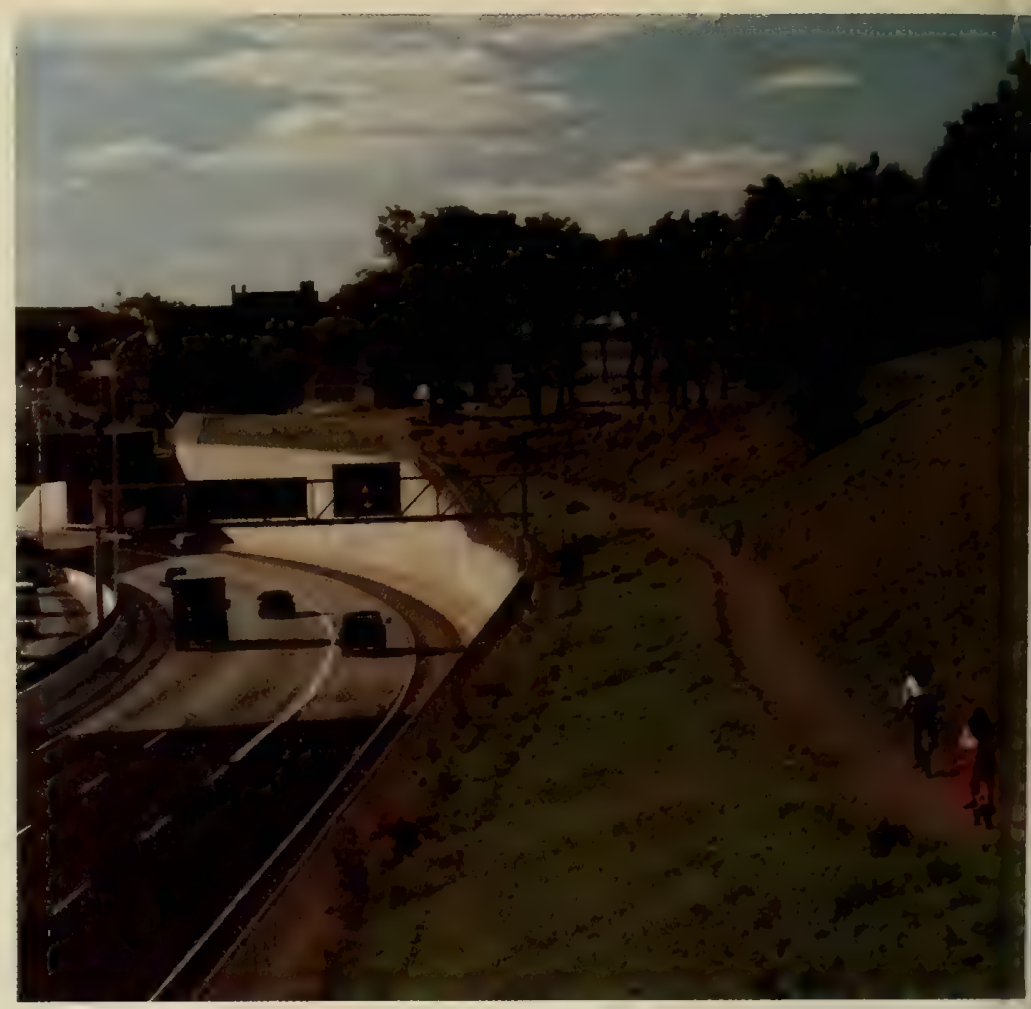

A bicycle path has been built within the right-of-way of I-94 in Minneapolis, Minn., that extends for over half a mile and safely connects two neighborhoods.

construction of the project. The Committee Report stated this action was necessary to prevent premature obsolescence in the System design. And, in 1966, the Congress amended Title 23 to provide that "Such standards shall in all cases provide for at least four lanes of traffic."

\section{Designation of Additional System Mileage}

As noted earlier, the 1944 Federal-Aid Highway Act provided for the designation of an Interstate System not to exceed 40,000 miles, and in August 1947 a System totaling 37,700 miles was designated which included routes through and skirting major cities. The remaining mileage authorized $(2,300$ miles) was designated in September 1955 for additional routes around and through urban areas.

At the time of the initial System designation, there were no detailed location studies and no engineering and economic analyses available for consideration. The locations within each State, therefore, were diagrammetic only, and the estimated mileage of designated System segments was derived from the length of the existing principal highways in the route cor- 
be added to the System within the authorized mileage ridors selected for the System. As more precise data became available, the mileage and location of the designated segments were adjusted accordingly.

Savings in the total System length, resulting from more detailed studies of the related engineering, economic and sociological factors involved in the highway location, permitted added System segments under the original statutory length limitation. In addition, Congress in the Federal-Aid Highway Act of 1956 increased the authorized length of the Interstate System by 1,000 miles. Thus, the Secretary of Commerce, on October 18,1957 , was able to announce an increase of 2,102 miles of Interstate routes that could

\section{Signing and Numbering}

From the very nature of Interstate System traffic, signs on the System need to be highly visible, properly located, clearly understood, and completely uniform. After study of existing practices on expressways and field tests by the Bureau of Public Roads, the American Association of State Highway Officials in 1958 adopted a manual on signing and pavement marking for the Interstate System. The manual prescribed as the Interstate route number marker the now familiar red-white-and-blue shield. Guide signs, primarily for carrying destination information, are uniformly white on green; signs concerning services

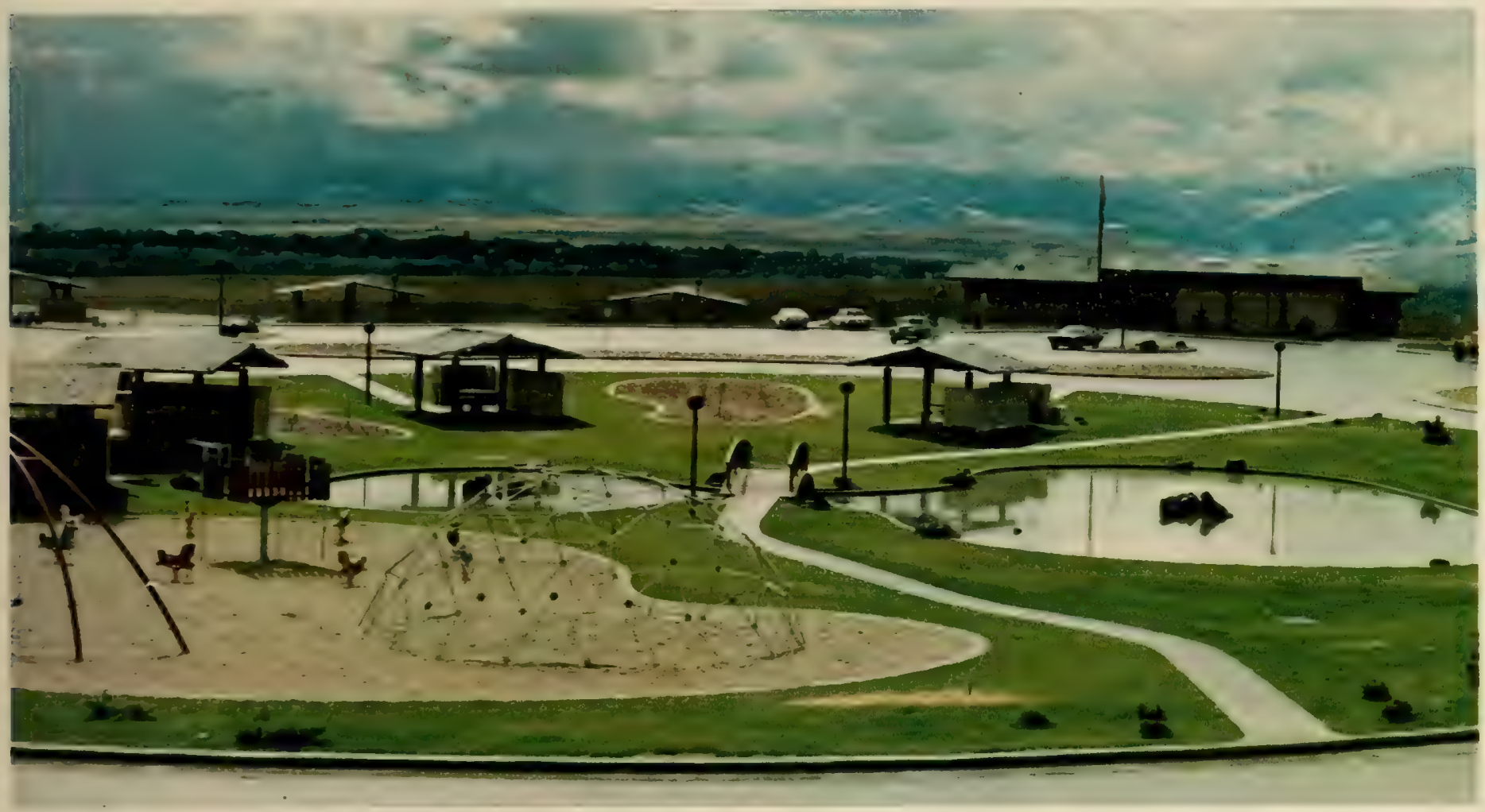

The rest and information area on I-90 near Sheridan, Wyo., provides picnic areas for the family and play areas for children. A choice of a moment beside the delicate ponds or a lovely view of mountains is also available to arrest the traveler's eye.

limit. With these additions, there remained a reserve of 350 miles which was held to cover possible increases in the length of individual route segments as more detailed location studies progressed.

Section 17 of the Hawaii Omnibus Act of 1960 (PL 86-624) included an amendment that removed the limitation that the Interstate System be designated entirely within the continental United States. Under the provisions of this amendment, three routes on the island of Oahu in the State of Hawaii were approved as additions to the System in August 1960, utilizing some of the "reserve" mileage noted above. And in the Federal-Aid Highway Act of 1968, Congress authorized an additional 1,500 miles on the Interstate System. This led to an announcement in December 1968 of the designation of route segments totaling 1,473 miles in length.

Subsequent System adjustments, additions and deletions have resulted in the present status of full commitment of the total 42,500 miles authorized by Congress for the Interstate highways. and rest areas are white on blue. The manual also specified the message sizes and, in general terms, the placement of signs so that uniformity will prevail throughout the System.

The American Association of State Highway Officials also developed a complete numbering system for Interstate routes. Those routes with odd numbers run north-south; those with even numbers run eastwest. Major routes have one- or two-digit numbers, and the long, evenly spaced routes have numbers ending in 5 or 0 . The lowest numbers are in the west and south to avoid conflict locally with the U.S. Route numbers. In urban areas the main route numbers are carried through on the paths of the major traffic streams. Connecting circumferential or loop routes at urban areas have three-digit numbers, using the main route number with an even-number prefix. Radial and spur routes also have three-digit numbers, with an odd-number prefix. 


\section{Toll Roads}

As already noted, the 1956 Act permitted inclusion of toll roads in the Interstate System, although it continued to bar the use of Federal aid for toll road construction or for further improvement of such included routes. On the recommendation of the States, it was announced on August 21, 1957, that 2,102 miles of then existing toll roads in 15 States were being officially included in the System. The only sizable toll section undertaken on the designated Interstate System since 1956 is a 53-mile portion of I-95 in Maryland and Delaware. This segment was completed in 1963 and was constructed following special congressional legislation.

\section{Program Funding}

\section{Initial Authorization Level}

Although Congress in 1944 directed that the Interstate System be designated, it made no provision for special Federal funding for the construction of the System until years later. The 1952 Act included a token Interstate authorization of $\$ 25$ million each for fiscal years 1954 and 1955 and the 1954 Act included $\$ 175$ million for fiscal years 1956 and 1957 . This "beginning" of special Interstate System funding authorization was followed by the creation of the Highway Trust Fund in 1956.

In Section 108 of the 1956 Act the Congress declared it to be essential to the national interest to provide for the early completion of the Interstate System as authorized and designated in accordance with the 1944 Act. Section 108 states it was ". . . the intent of the Congress that the Interstate System be completed as nearly as practicable over a thirteenyear period and that the entire System in all the States be brought to simultaneous completion." There was authorized to be appropriated for fiscal years $1957-69$ a total of $\$ 24.8$ billion of Federal funds, to be matched by the States on a 90-10 Federal-State ratio, for the purpose of expediting the construction, reconstruction or improvement of the Interstate System. This amount combined with the unexpended balance of previous authorizations brought the total of available Federal Interstate authorization to $\$ 25.14$ billion as of June 1956.

It should be noted that up to this time there had been no detailed estimate on a section-by-section basis of the cost of building the Interstate System. The $\$ 25$ billion Federal authorization in the Act was based on the Clay Committee Report, in which the total System cost was stated at $\$ 27$ billion-with a Federal share of $\$ 25$ billion recommended.

The Congress, in the 1956 Act, recognized the changing requirements for the System and the need for up-to-date periodic estimates of the cost of completing the System and required a series of such estimates beginning in 1958 .

\section{Cost Estimate}

The first of the series of periodic estimates of the cost of completing the Interstate System was submitted to the Congress in January 1958. This estimate was prepared by the individual States during calendar year 1957. To provide for uniformity of estimate procedures among the States, an instruction manual was adopted which extended the standards for design and construction of the System.

The unit price level of 1956 construction in each State was selected as a cost base. Units of construction quantities estimated for the System completion in each State were computed against this unit price base for the total cost determination. The estimate total exceeded the authorization level established by Congress 2 years earlier in the 1956 Act.

In submitting this first estimate to Congress, Secretary of Commerce Sinclair Weeks noted:

\begin{abstract}
Although this estimate shows an increase in cost over the amounts authorized by section 108(d) of the 1956 Act, I do not see any need for consideration at the present time of new legislative measures which would add to the income of the highway trust fund. This is the first estimate of a series of five and is made in the early stage of the highway program launched by the 1956 Act. As construction of the Interstate System progresses toward completion and as the amount of remaining work correspondingly decreases, future estimates of cost will be made on a broader basis of experience and these estimates will progressively become more accurate by reflecting actual trends in cost, either upward or downward, that cannot be forecast as well now. Until this additional experience is acquired, consideration of any adjustments in authorization of funds or revenues would be premature. ${ }^{2}$
\end{abstract}

The 1958 estimate included only 38,548 miles of the 41,000-mile System authorized by Congress. This differential resulted from the fact that the 1,000-mile addition to the System, authorized by Congress in 1956, was specifically excluded from the estimate by provisions of the 1956 Act; and the additional 1,102 miles available for allocation October 18, 1957, became available after the cutoff date for preparation of the estimate. The total cost for the 38,548 miles was estimated to be $\$ 37.6$ billion of which $\$ 33.9$ billion was the Federal share, and $\$ 3.7$ billion the States' matching share.

The basic information in the 1958 estimate was supplemented by data presented in hearings conducted before the House Ways and Means Committee in July 1959, at which time preliminary cost data for the remaining 2,452 miles of the 41,000-mile System were reported. The combination of these submittals was an estimate totaling $\$ 41$ billion for 41,000 miles. Of this total the Federal share was estimated to be $\$ 37$ billion. This was the first detailed Interstate cost estimate submitted to the Congress which encompassed the entire System mileage authorized up to that time. No costs were included for State highway planning and research, or for Bureau of Public Roads administration and research. Since both of these activities are charged against Federal Interstate funds, the costs should have been included. This omission was corrected in the 1961 estimate.

\section{Economic Recession and the 1958 Federal-Aid Highway Act}

In 1958 the Nation found itself in the grip of an extended economic recession, and acceleration of the Federal-aid Highway program was considered as one means to hasten recovery. The Federal-Aid Highway Act of 1958 was prepared with this objective in view. Among other provisions, it increased the annual Interstate authorizations of the 1956 Act from $\$ 2.0$ billion 
The plants and vegetation used along I-64 in Greenbrier County, W. Va., were selected to blend with the natural vegetation on the rolling hills of the Greenbrier River Valley.

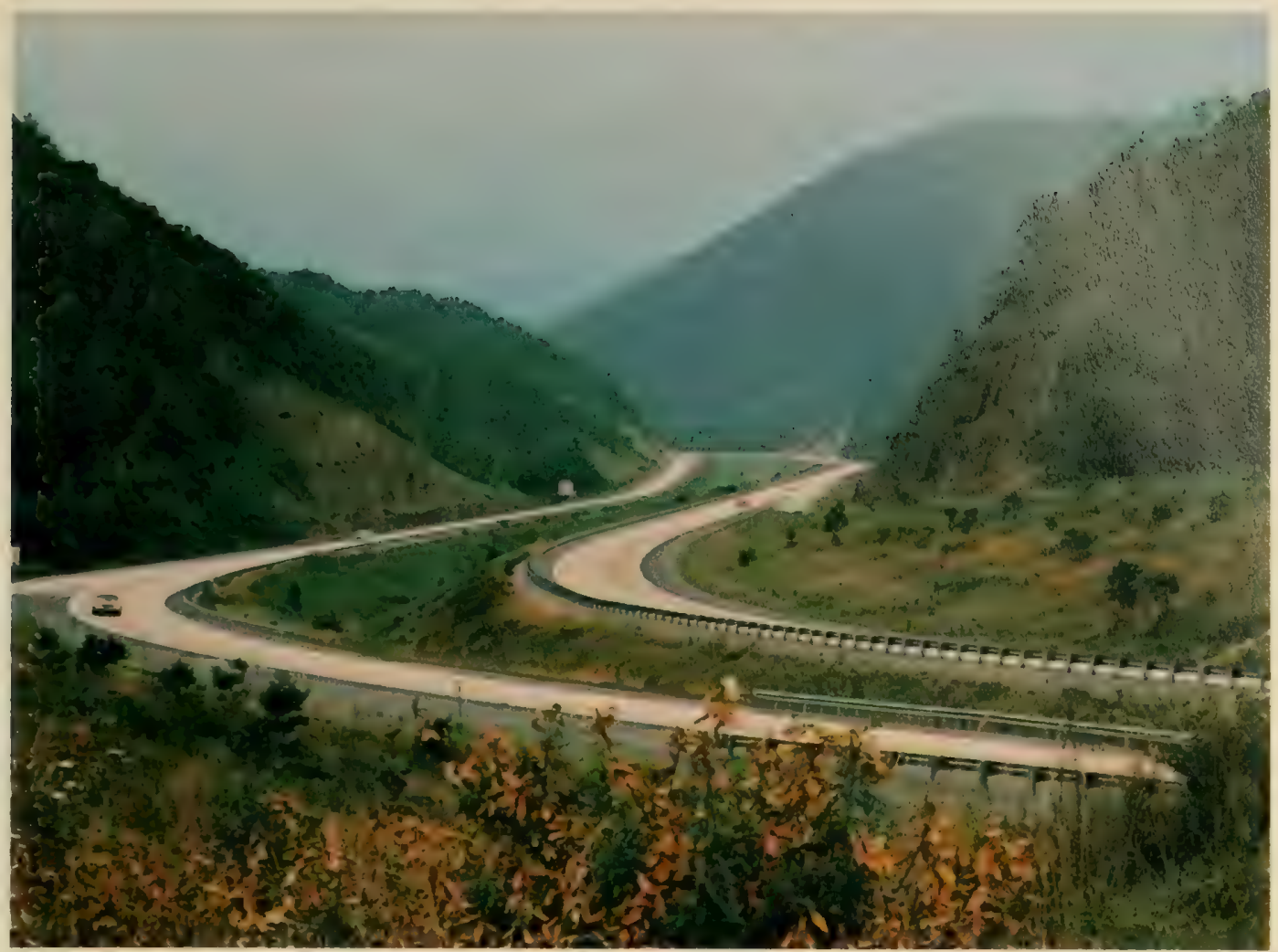

to $\$ 2.2$ billion for fiscal year 1959 , and from $\$ 2.2$ billion to $\$ 2.5$ billion for each of the fiscal years 1960 and 1961. These increases were partially in recognition by the Congress that the Interstate System was going to cost more than had been provided for in the 1956 Act; partially because Congress desired to accelerate progress toward completion of the System; and partially because of the recession in the economy.

More important perhaps than the increases in authorization levels-in its ultimate impact on the program financing-was the provision of the 1958 Act which set aside the pay-as-you-go provision of the 1956 Act for 2 years and directed apportionment to the States of the full amounts authorized for fiscal years 1959 and 1960 , namely, $\$ 2.2$ billion and $\$ 2.5$ billion. This provision in the 1958 Act for expanded and accelerated expenditures was not matched by a commensurate provision for additional Trust Fund revenue.

The net effect was to advance appreciably the time when the Federal-aid program would enter a period during which annual expenditures would exceed Trust Fund revenues. And when the pay-as-you-go amendment again became effective after its 2-year suspension, it was obvious that Federal-aid highway program financing was in need of adjustment.

\section{Temporary Relief}

A report on the study of allocating highway costs and benefits and a new estimate of the cost of completing the Interstate System, both called for by the 1956 Act, were expected to be completed early in 1961 . It was generally assumed that a long-range solution to Federal-aid financing problems should then be undertaken and that, in the meanwhile, temporary relief measures would be sufficient.

Consequently, early in 1959 President Eisenhower proposed a temporary increase of $11 / 2$ cents per gallon in the Federal motor-fuel tax. The Congress, in the Federal-Aid Highway Act of 1959, increased the tax from 3 to 4 cents per gallon for the period from October 1, 1959, to June 30, 1961.

The 1959 Act also reduced the Interstate authorization for fiscal year 1961 to $\$ 2.0$ billion. When the time came to make the apportionment in October 1959, however, the pay-as-you-go provision made it necessary to reduce the apportionment to $\$ 1.8$ billion.

In addition, because of the necessity for correlating the level of anticipated Trust Fund revenues and expenditures, the Bureau of Public Roads in 1959 instituted a program of "reimbursement planning" under which a limit was set quarterly on the rate at which each State could obligate funds to contracts in order to assure that Federal payments of ultimate reimbursement to the States for work accomplished could be made within the limits of the available Trust Fund balance.

\section{The 1961 Estimate}

In 1961 the second estimate of cost of the Interstate System was submitted to the Congress. Again, as in the 1958 estimate, the total cost was $\$ 41$ billion with a Federal share of $\$ 37$ billion.

The unit price base for the 1961 estimate was the average unit price level in each individual State for calendar year 1959. There had been a lowering of construction unit price levels between the 1956 level used in the 1958 estimate and the 1959 level used for the 1961 estimate. With this lowering of construction prices, the construction costs reported in 1961 were reduced. This was offset by including the costs of administration and research and planning, which were omitted from the 1958 report. A comparison of the 1958 estimate and the 1961 estimate is shown in Table 1. 


\begin{tabular}{|c|c|c|c|c|}
\hline \multirow[b]{2}{*}{ Item } & \multicolumn{2}{|c|}{1958} & \multicolumn{2}{|c|}{1961} \\
\hline & $\begin{array}{l}\text { Total } \\
\text { cost }\end{array}$ & $\begin{array}{l}\text { Federal } \\
\text { funds }\end{array}$ & $\begin{array}{l}\text { Total } \\
\text { cost }\end{array}$ & $\begin{array}{l}\text { Federal } \\
\text { funds }\end{array}$ \\
\hline $\begin{array}{l}\text { Interstate System routes included in } 1958 \text { estimates: } \\
1958 \text { estimate }(38,548 \text { miles) } \\
1961 \text { estimate }(38,522 \text { miles) }\end{array}$ & $\$ 37,570$ & $\$ 33,900$ & $\$ 36,848$ & $\$ 33,234$ \\
\hline $\begin{array}{l}\text { Remaining system mileage: } \\
1958 \text { estimate adjusted to include } 1,452 \text { miles, excluding } 1,000 \text {-mile addition } \\
1961 \text { estimate }(1,528 \text { miles), excluding } 950 \text { miles of } 1,000 \text {-mile addition: } \\
\text { Routes designated in } 1957 \text { ( } 952 \text { miles) } \\
\text { Hawaii routes designated in } 1960 \text { ( } 48 \text { miles) } \\
\text { Reserved for specific routes, detailed location not yet established ( } 220 \text { miles) } \\
\text { Held for final measurement (308 miles) }\end{array}$ & -1-1-1- & 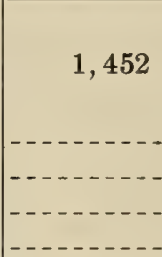 & $\begin{array}{r}1,209 \\
216 \\
220 \\
308\end{array}$ & $\begin{array}{r}1,087 \\
195 \\
198 \\
277\end{array}$ \\
\hline Subtotal & 1,613 & 1,452 & 1,953 & 1,757 \\
\hline $\begin{array}{l}\text { Routes included in } 1,000 \text {-mile addition: } \\
1958 \text { estimate adjusted to include the } 1,000 \text { miles } \\
1961 \text { estimate (950 miles) }\end{array}$ & 1,111 & 1,000 & 449 & 404 \\
\hline $\begin{array}{l}\text { Subtotal, 41, 000-mile system } \\
\text { State highway planning and research } \\
\text { Public Roads administration and research } \\
\text { Contingencies_. }\end{array}$ & 706 & 36,352 & $\begin{array}{r}39,250 \\
574 \\
357 \\
809\end{array}$ & $\begin{array}{r}35,395 \\
511 \\
357 \\
737\end{array}$ \\
\hline Grand total $\ldots$ & $\$ 41,000$ & $\$ 37,000$ & $\$ 41,000$ & $\$ 37,000$ \\
\hline
\end{tabular}

The 1961 estimate report stated that the estimates reflected accurate appraisals of the cost in each State based on 1959 price levels but "do not represent a commitment of funds to the location, design, or cost of individual projects to be undertaken on the Interstate System." 3 The estimates were considered adequate for establishing apportionment factors for distributing Federal funds among the States for the fiscal years 1963, 1964, 1965, and 1966 - the purpose for which Congress intended the estimate-and for the enactment of necessary legislation modifying the level of authorization for construction of the Interstate System and providing the revenue needed to pay for the costs involved.

\section{Highway Cost Allocation Study}

The highway cost allocation study, undertaken pursuant to the 1956 Act, was reported on to Congress in January 1961. Its purpose was to provide Congress with information on which it might make an equitable distribution of the Federal tax burden for the support of the Federal-aid highway program among the various classes of persons using Federal-aid highways or otherwise deriving benefits from them. The need for additional revenue to meet the cost of the Interstate System program had already become evident from the 1958 cost estimate, as substantiated by the 1961 cost estimate.
The highway cost allocation study was unquestionably the most comprehensive and exhaustive study of highway economics ever undertaken. The study findings relative to highway-user benefits of passenger cars and trucks of different weight categories strongly influenced the legislation that was to put Interstate financing back on a sound basis.

\section{The 1961 Federal-Aid Highway Act}

In February 1961 President Kennedy, in a message to Congress, endorsed continuation of the pay-as-yougo principle and support of the Federal-aid highway program wholly by highway-user taxes, for which he recommended certain increases. After extensive study, the Congress rejuvenated the Interstate program by passage of the Federal-Aid Highway Act of 1961 .

Under the 1956 Act, as amended in 1958 and 1959, some $\$ 11.7$ billion of Federal Interstate funds had already been apportioned to the States for fiscal years 1957-62. The 1961 Act revised the remaining authorization schedule to provide $\$ 2.4$ billion for fiscal year $1963, \$ 2.6$ billion for $1964, \$ 2.7$ billion for $1965, \$ 2.8$ billion for 1966, $\$ 2.9$ billion for 1967, $\$ 3.0$ billion each for 1968,1969 , and 1970 , and $\$ 2.885$ billion for 1971 . Thus the total of Federal funds apportioned or authorized was increased to $\$ 37$ billion, the 90 -percent Federal share of the total $\$ 41$ billion Interstate program cost. 


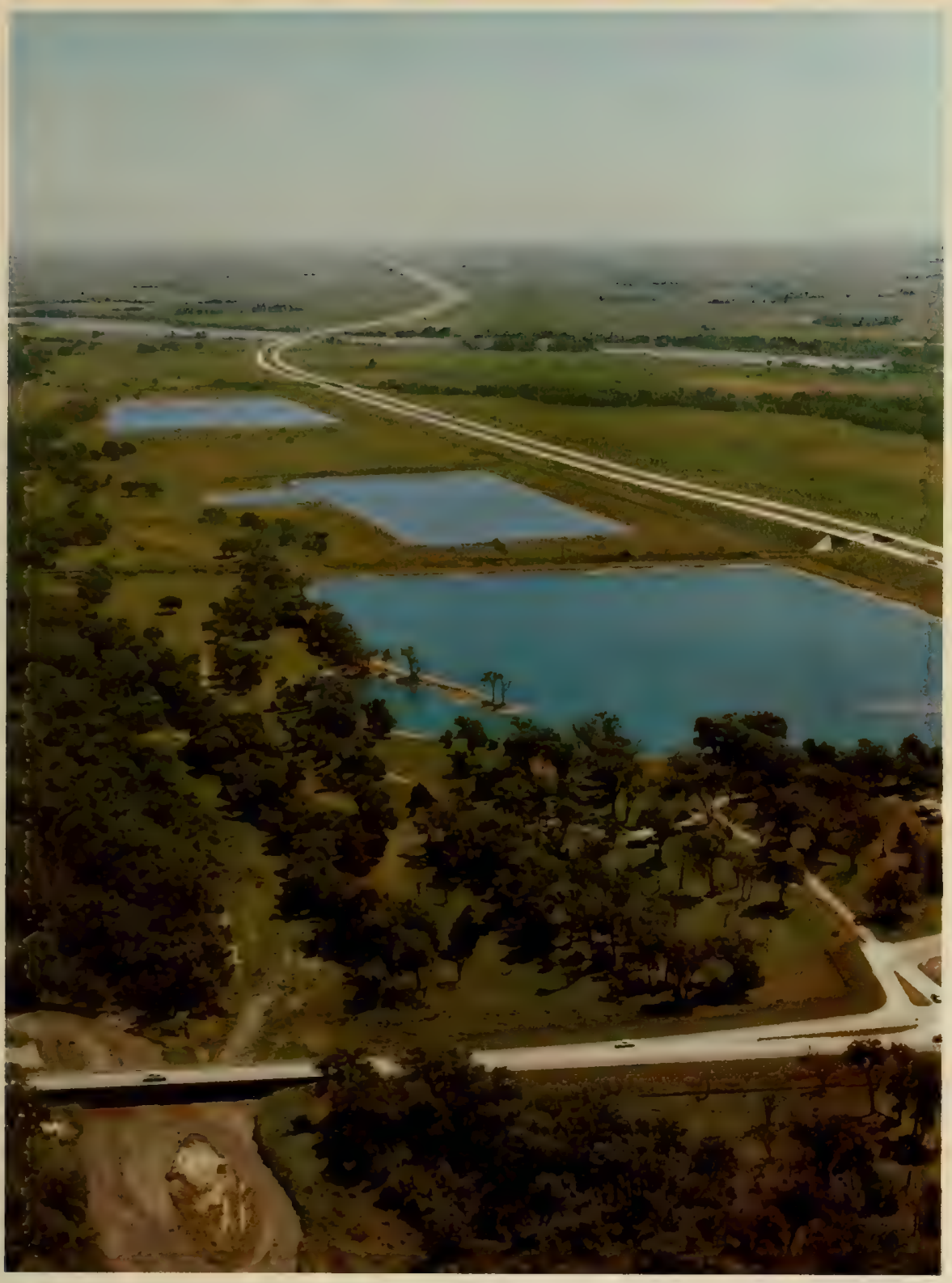

Nebraska's "Chain $O$ ' Lakes" along I-80 resulted from borrow pits used during construction of this part of the highway. These lakes have been landscaped with native grasses and trees and offer the highway user water-oriented recreation and provide wildlife sanctuaries.
To provide the needed financing, the 1961 Act revised the existing schedule of highway-user excise taxes dedicated to the Highway Trust Fund. The motor-fuel tax was continued at 4 cents per gallon until October 1, 1972. For the same period, the tax per pound was increased on highway vehicle tires from 8 to 10 cents, on inner tubes from 9 to 10 cents, and on retread rubber from 3 to 5 cents. The use tax on heavy vehicles, those of over 26,000 pounds gross weight, was increased from $\$ 1.50$ to $\$ 3.00$ per 1,000 pounds per year. All of the 10-percent tax on the manufacturer's sale price of new trucks, buses, and trailers was earmarked to the Trust Fund, instead of only half as had been provided by the 1956 Act.

By this 1961 Act, both the necessary authorizations to complete the Interstate System on the basis of the most recent estimate available and the revenues to pay for the job were provided.

\section{Construction Progress}

Following passage of the 1961 Act and the regular funding of the program which resulted, construction of the System moved forward steadily. "Miles open to traffic" grew in number on virtually a straight-line basis year by year. The States were able to move to construction on most sections of the System without major delay and total progress was limited only by the funding available.

There were problems relating to the location of some segments of the System, generally involving environmental considerations, but these were relatively few in number when considered against the total system concept. Progress in general was excellent.

In 1967, as a Federal budget requirement, the authorized Federal funding was withheld in part. Although the States had available balances of unobligated apportioned funds, they were not permitted to exceed a predetermined level of Federal funding. The result was the beginning of the controversy over "withholding" of funds authorized by the Congress and otherwise legally available.

With obligation ceilings controlling the total level of highway construction after 1967, there was a slackening of the rate at which new sections of the Interstate System were opened to traffic. However, even with these controls, there were in service at the end of 1974 over 36,000 miles of the 42,500 -mile System and another 2,800 miles were under basic construction, 


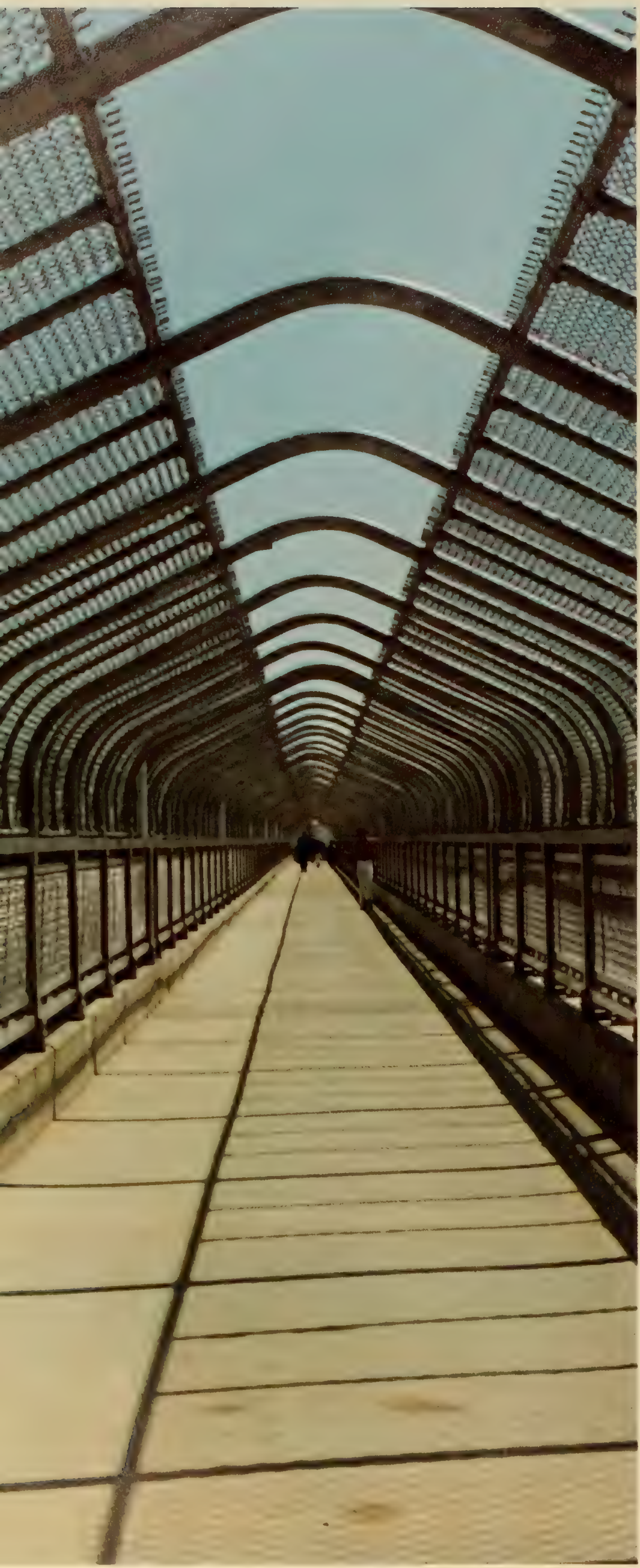

generally on new location. Only about 400 miles, or about 1 percent, of the System remained in a noprogress status at that time.

\section{Increase In System Cost}

With the changes in statutory engineering requirements (20-year traffic projection (1963), minimum design of four lanes (1966), and increased System length by 1,500 miles (1968)) for the Interstate System, there were also legislative requirements enacted by the Congress in recognition of the public need in areas of economic, sociologic, and environmental considerations. Included in this category of legislative requirements were:

- Assistance for relocating families and businesses1962

- Transportation planning requirements in urban areas for joint modes-1962

- Scenic enhancement provisions, spot safety improvement program-1965

- Joint development concept, soil erosion control, preservation of parklands-1966

- Fringe parking facilities, increased relocation assistance, replacement housing-1968

- Exclusive or preferential bus lanes, highway traffic control devices, passenger loading areas to serve bus and other mass transit passengers-1970

- Urban mass transit provisions involving the withdrawal and substitution of certain Interstate routes in large urban areas-1973

The provisions of the 1973 Act have not yet been fully implemented, and the ultimate cost effect of this legislation is not known.

Such changes have a marked effect on the cost of constructing a highway system. This had been expected from the start. The earliest reports to Congress on the need for an interregional highway system stated the "impossibility" of venturing an approximate estimate of the cost of building the entire interregional system to the standards recommended. It was stated that to be of value, such an estimate would have to be predicated on far more exact determination of all variables involved than had been possible to undertake. Further, the Congress was informed that even had such precise determination been attempted, the "usefulness and validity of an estimate of the ultimate cost of a construction program that must inevitably extend over a period of perhaps 20 years and be affected by unpredictable changes in the general economy, in the habits and desires of people, in the character of vehicles, and in other circumstances, would still be highly questionable." 4

With safety for the pedestrian in mind, a 1,082-foot long pedestrian overpass was built over I-95 in Shirlington, $\nabla a$., that safely connects a large apartment complex on the east side of the highway with a large

shopping center on the west. 


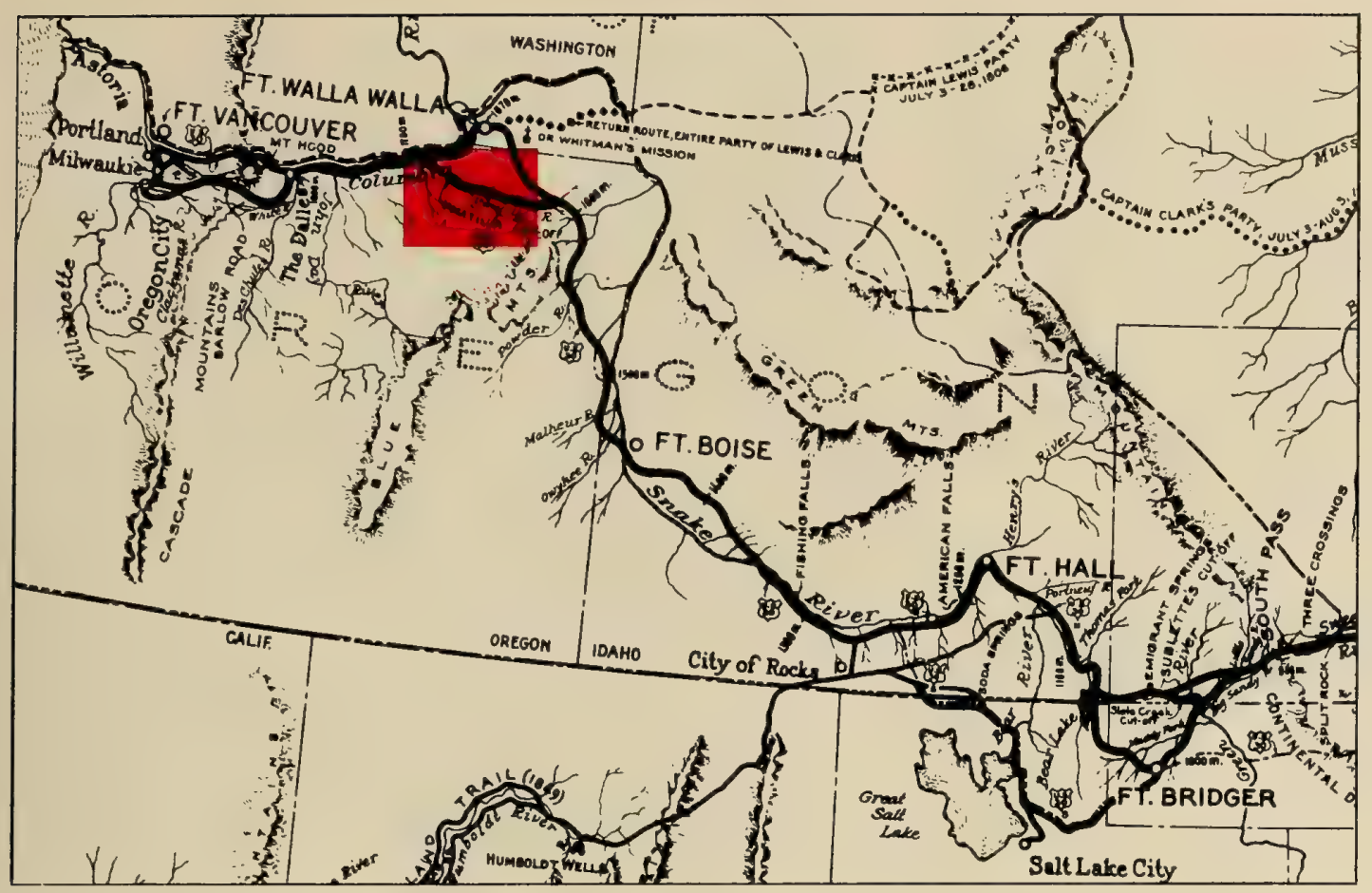

The Oregon Trail as of 1848 .

The eastbound lane of $I-80$, east of Pendleton, Oreg., is built on the site of the Old Oregon Trail and takes the motorist into tortuous, but spectacularly scenic, mountain country. In this area,

the east- and westbound lanes may be more than a mile apart.

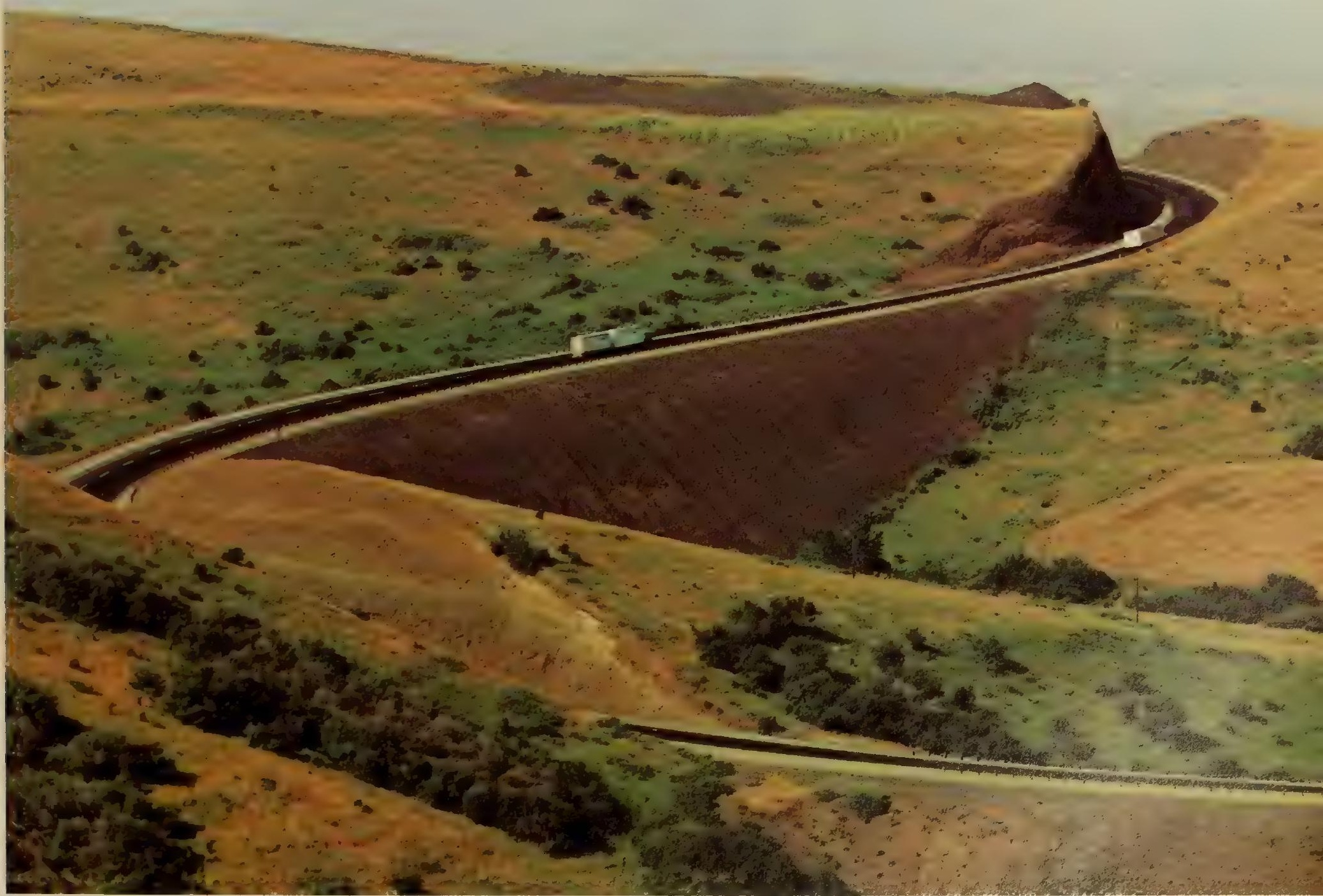


The report continued, "Construction to the standards recommended will certainly be expensive beyond the common experience in building most of the ordinary existing roads and streets, but the merit of the expenditure is to be judged not by such a comparison but rather by the value of the advantages to be gained in traffic facilitation, in reduced costs of vehicle operations, and in lowered accident rates." 5

As noted earlier, the 1958 and 1961 estimates, each totaling $\$ 41$ billion in cost, formed the basis for the 1961 Act. In compliance with statutory requirements, additional cost estimates were submitted to Congress in $1965,1968,1970,1972$, and 1975. Future estimates are to be submitted in January 1977.

In each of the reports to Congress, information was submitted regarding the difference in total costs reported. With the changes in the statutory requirements as to the total system concept and the enactment of new environmental and sociological requirements, it was expected there would be introduced elements of cost not considered in the initial estimates. These increased costs were not "overruns" or "errors" in previous estimates, but were rather, a reflection of changing construction prices and changes in law enacted by Congress in recognition of changing public need, including design changes for mobility, safety, and environmental requirements.

Table 2 categorizes the major influences affecting total costs and shows the cost increase in each category. Some elements of the 1973 highway legislation are yet to be implemented, and the permissive substitution of System segments and cost in urban areas will be reflected in the highway and mass transit construction programs in urban areas. These changes will affect the construction cost on the Interstate System.

TABLE 2-Interstate System cost estimates, increases by cost categories (Millions of dollars)

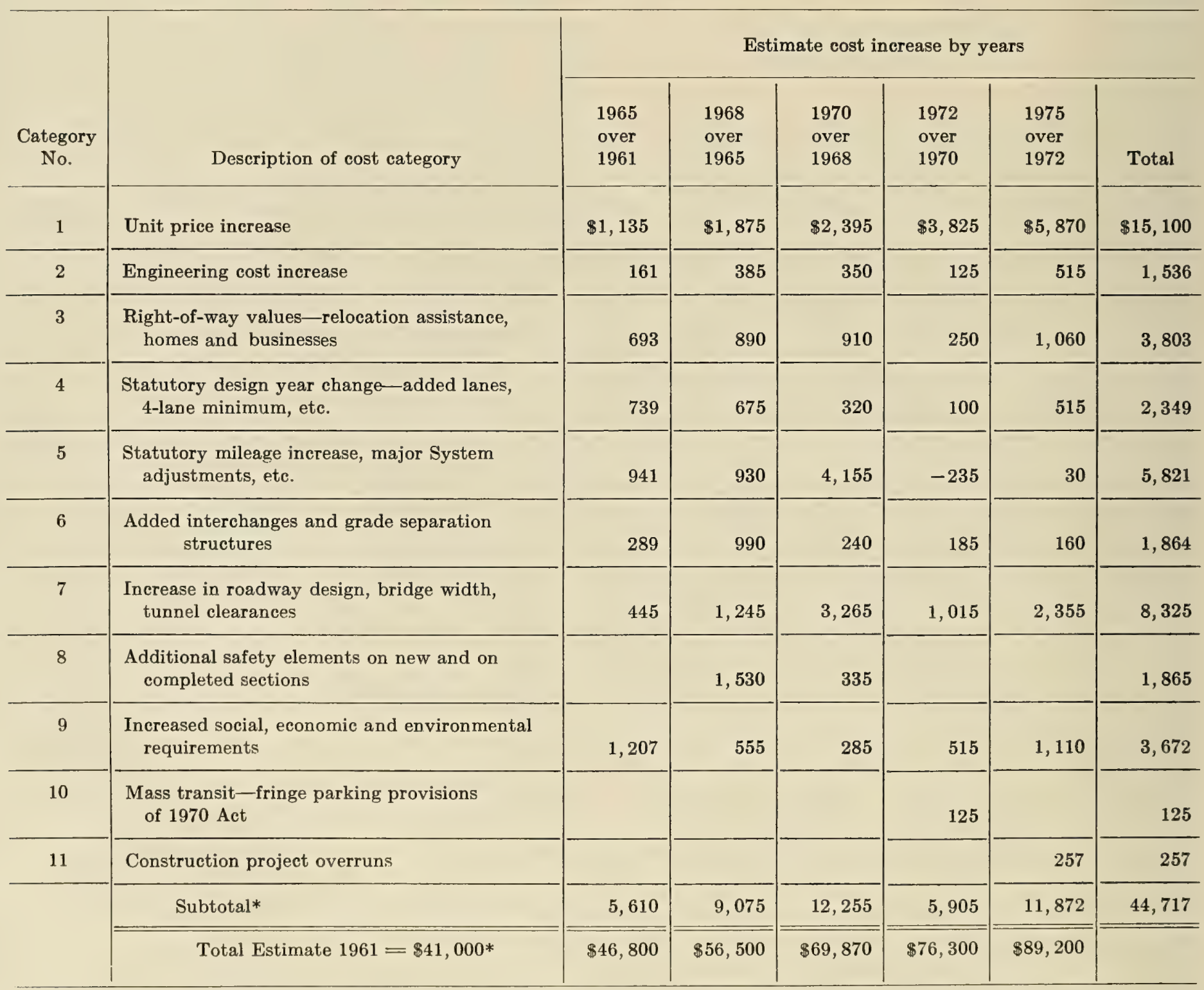

* The arithmetic disparity between the addition of these last two entries is the element of cost involved in categories of State highway planning and research, FHWA administration and research, and in contingency items. These are listed in the reports to Congress. 


\section{Completion of the Interstate System}

The System is nearing completion in rural areas and in most of the urban areas. The benefits derived in the new freedom of movement and safety of travel have been enormous. The movement of people and goods on this System results in a user-benefit ratio of about $\$ 2.90$ for every dollar invested in the construction of the System over its service life period. The differential in operating safety on this highway system, over other highway systems, will result in a saving of an estimated 8,000 lives per year. The System contributes dramatically to the economic development of the areas it serves and, because of the advanced design features involved, will continue to serve this development long after other highways would have become functionally obsolete.

The "finished" System may yet be altered in urban areas as the 1973 Highway Act is implemented and as Congress gives further consideration to the total transportation needs in the large urban areas. However, these adjustments can and will be made without impairment of the total value of the Interstate System to this Nation's economic growth and social well being.
The $\$ 90$ billion level which is approximately the "cost of completion" of this giant public works project is a fair price for the end product. The highway system cannot be compared in service or in cost to the limited facility under consideration when the basic highway legislation was first being formulated. The Nation can well be grateful to the Congress for its wisdom in adjusting highway statutes to meet public interest requirements as the System developed. The end product will be a lasting testimonial to the Congress and to the highway organizations, State and Federal, who were responsible for carrying out the program.

\section{REFERENCES}

${ }^{1}$ Bureau of Public Roads Annual Report, 1954, p. 3.

${ }^{2}$ A Report of Factors for Use In Apportioning Funds For The National System of Interstate and Defense Highways, H. Doc. 300, 85th Cong., 2d Sess., pp. III, IV.

${ }^{3}$ The 1961 Interstate System Cost Estimate, H. Doc. 49, 87th Cong., 1st Sess., p. 13.

${ }^{4}$ Interregional Highways, H. Doc. 379, 78th Cong., 2d Sess., p. 114.

${ }^{5}$ Id. 


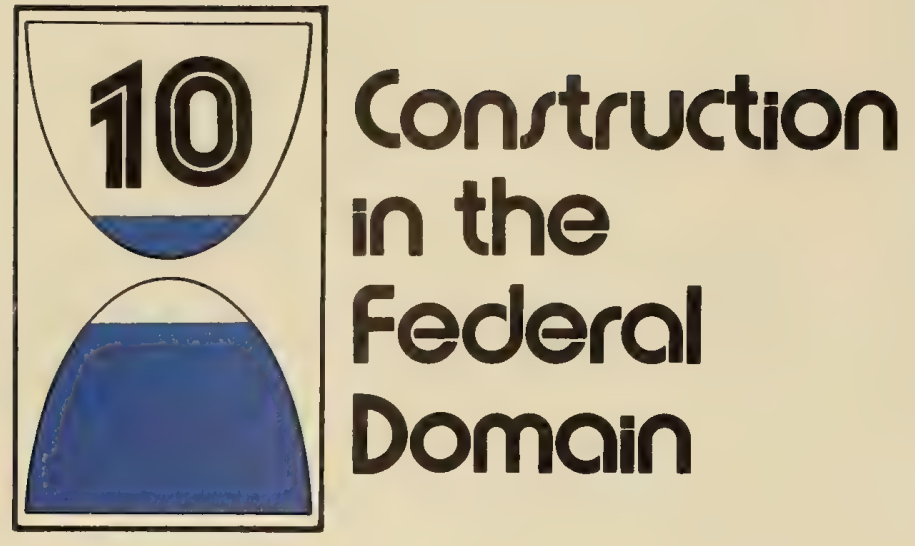

Millions of Americans visit national parks and forests and other Federal recreational areas each year. From this experience, they enrich their lives and gain new appreciation of their national heritage and of the natural beauty of the country. It is difficult today to realize that just a few decades ago the trip that is casually made now by automobile was impossible because there was no transportation system giving citizens access to these areas.

The thrust of western migration across the continent during the first 150 years settled the land and still left vast areas in the public domain. It was from these public land areas that Congress established the first national parks and national forests. Yellowstone National Park, the first national park, was created by act of Congress in $1872 .{ }^{1}$ Other national parks were gradually added and by 1900 , included Yosemite, General Grant, Mt. Rainier, and Sequoia. A rapid expansion of the national parks system followed in succeeding years.

National forests have developed in a similar fashion. The first forest reserves were authorized by Congress in $1891,{ }^{2}$ and again, they were taken from the public domain in the West. The forest reserves were created to perpetuate the country's supply of timber and to ensure a more regular flow of water from streams by preserving the forest floor to prevent too rapid run-off and flooding. In 1905, Congress transferred the forest reserves from the Department of the Interior to the Department of Agriculture, and in 1907, Congress changed the name "forest reserve" to national forest. Like the national parks, the national forests expanded rapidly and today constitute a major resource of this Nation.
The development of both the national parks system and the national forests occurred during the same period as the development of the Nation's highway system. Because the Federal Highway Administration is the "roadbuilder" for the Federal Government, it has been directly engaged in the location, design, and construction of public roads to and through the national parks and forests and other Federal domain areas since 1905 . In spite of extremely limited staff and resources in the early days, the Office of Public Roads constructed a macadam road on the grounds of the Weather Bureau Station in Mount Weather, Virginia; assisted the Forest Service in securing information to be used in the preparation of a manual on trailmaking and maintenance; and gave advice on the construction of wagon roads and trails in forest reserves to facilitate lumbering. One engineer was detailed for a short time in the Yellowstone Reserve during 1906 to investigate and make recommendations for the improvement and maintenance of forest roads and trails. ${ }^{3}$

In 1912 the Agriculture Appropriation Act contained a provision that 10 percent of all moneys received from the national forests during each fiscal year be available at the end of the year for use by the Secretary of Agriculture for the construction and maintenance of roads and trails within the national forests in the States from which such proceeds were derived. This provision was made a continuing appropriation by the Agriculture Appropriation Act of 1913. These laws provided, for the first time, a sustained source of revenue for road improvement purposes in the public domain. 


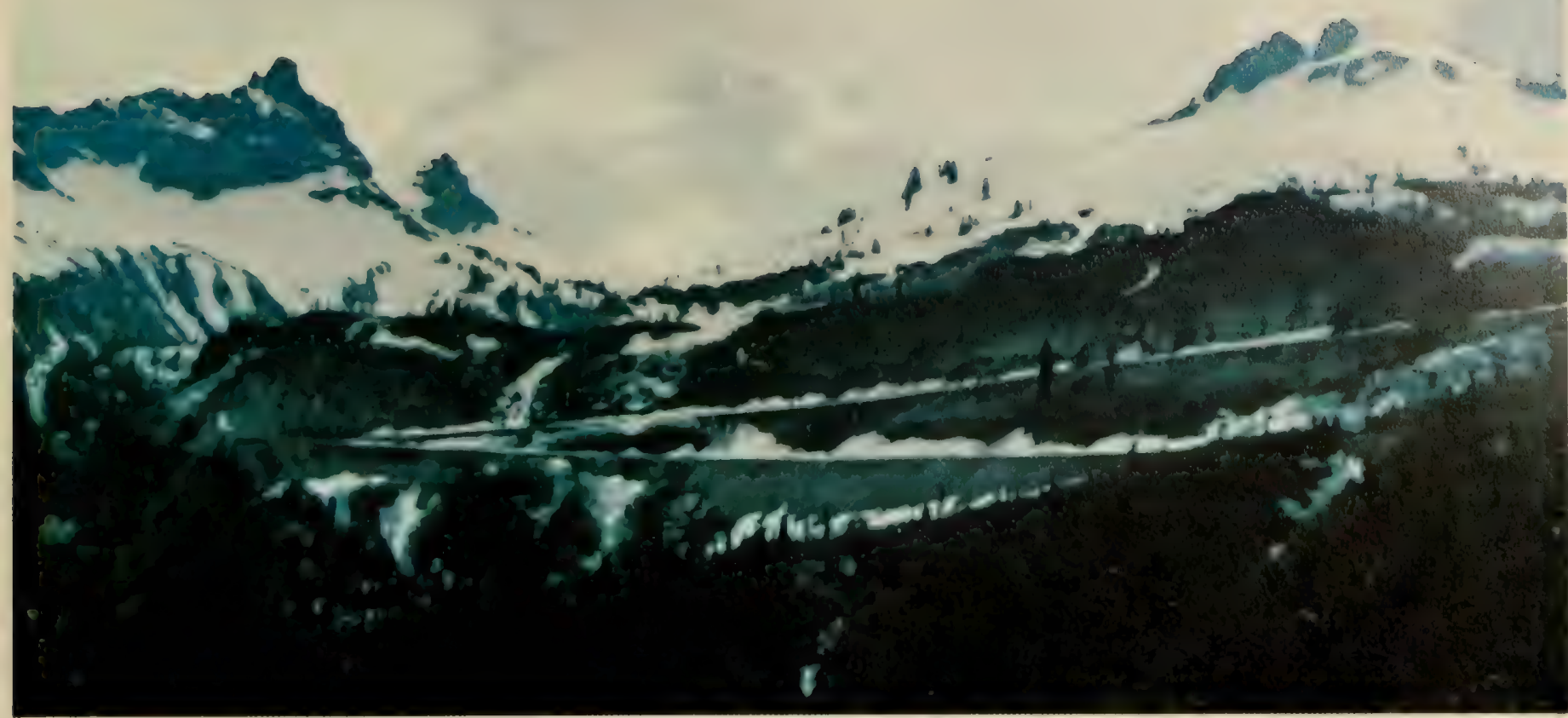

Mount Rainier National Park in the State of Washington was established in 1899. The peak is covered with snow year round.

Because of increased responsibilities for direct road construction activity, a Division of National Park and Forest Roads was created in 1914 in the Office of Public Roads to give advice and to supervise major construction projects in national parks and forests in cooperation with the Department of the Interior and the Forest Service. At that time, improved roads were practically nonexistent throughout the vast areas of the West where the principal national parks and forests were located.

\section{Forest Highways and Development Roads}

By the end of fiscal year 1916, the direct Federal highway construction program was well established. The annual report for that year states that approximately 127 miles of reconnaissance surveys and 350 miles of location surveys were made. Maintenance work had been done on approximately 160 miles. Construction work was in progress on about 170 miles, of which approximately 70 miles were completed during the fiscal year. Of great significance was the construction of the road across Rabbit Ear Pass in the Routt National Forest in Colorado-which opened large sections of country, and the initiation of construction of the Trinity River Road in Trinity County, California, which would eventually provide a year-round highway connection from the upper Sacramento Valley with the coast of Humboldt Bay. Another significant survey that year was on the Mt. Hood Road in Oregon. This road was essential for the comprehensive development of the Oregon $\mathrm{Na}$ tional Forest and in providing a southern outlet for Columbia River highway traffic. ${ }^{4}$

By section 8 of the Federal Aid Road Act of 1916 , the sum of $\$ 1$ million was appropriated for each of the fiscal years 1917 through 1926 for a total of $\$ 10$ million to be available until expended under the supervision of the Secretary of Agriculture for the survey, construction and maintenance of roads, trails and bridges within the national forests. The Act provided that the work would be carried on under cooperative agreements with the State, territory or county authorities on a basis equitable to both parties. The subsequent rules and regulations provided that the cooperating agency would contribute at least 50 percent of the cost of the work and also the entire cost of maintenance. There was thus made available for the construction of so-called "section 8 national forest roads" slightly more than $\$ 2$ million annually.

The Federal Aid Road Act necessitated the establishment of a complete Federal highway engineering organization throughout the country, and in 1917, 10 Districts were established to carry out the responsibilities mandated in the Act.

The Secretary of Agriculture placed with the Bureau of Public Roads the responsibility for all engineering and construction work on the national forest roads and cooperative forest roads to be built under section 8 of the Act. At the same time he placed with the Forest Service the responsibility for the general administrative work necessary in selecting the roads to be constructed, securing cooperation and cooperative funds, arranging the allotment of funds and financing of projects and, in general, harmonizing the scheme of road construction with the requirements of the national forests. ${ }^{\circ}$

Independent of the section 8 funds, the so-called "10 percent fund" was still available to the Forest Service annually for road and trail construction located entirely within the national forest areas. Part of this fund was allotted by the Forest Service for expenditure by the Bureau of Public Roads on survey and road construction work on major projects which usually were also financed with matching funds. The 


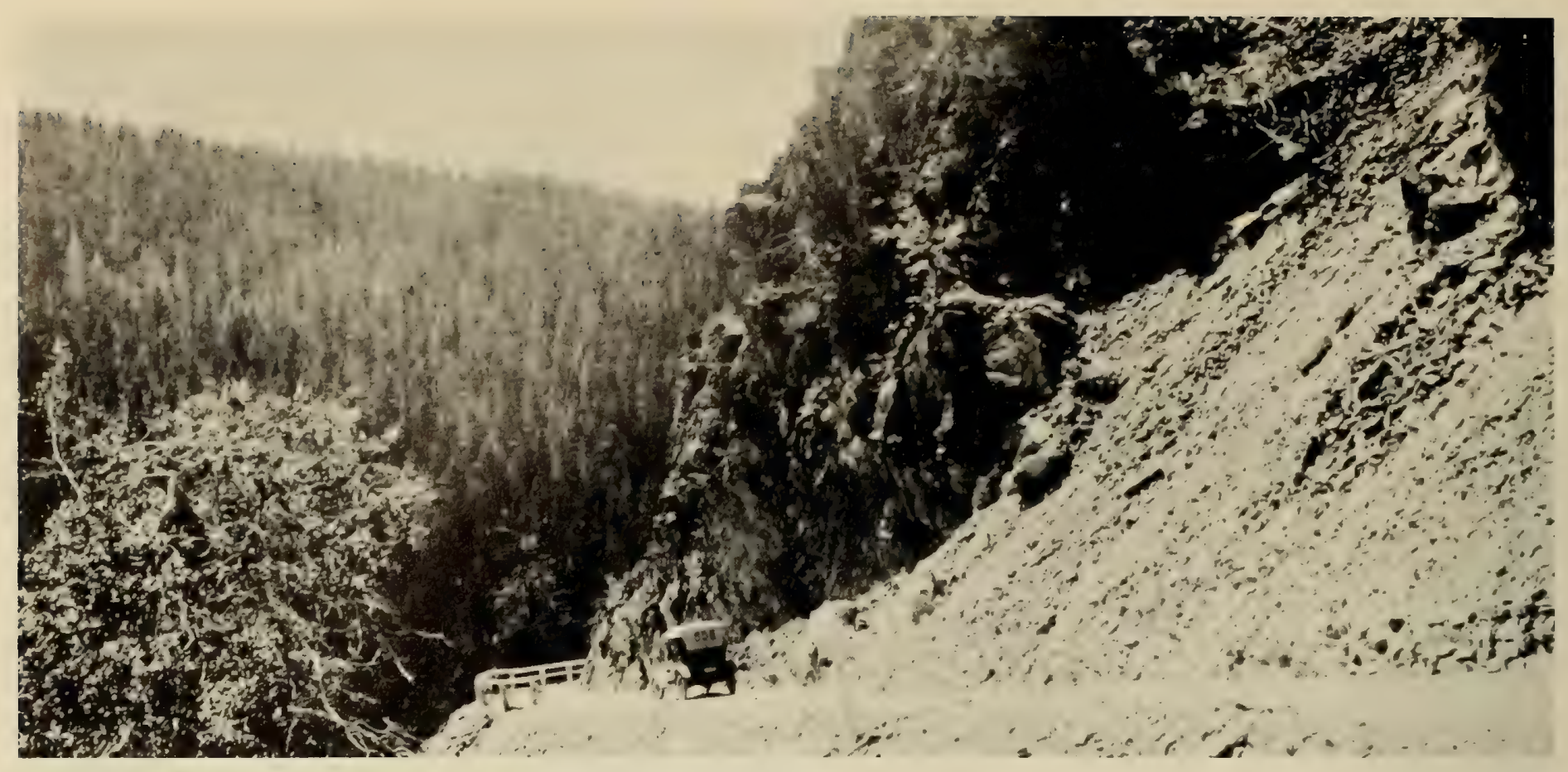

The Bitterroot-Bighole Road in Beaverhead National Forest, Mont., exemplifies the type of forest highway constructed around 1916.

Berthoud Pass crosses the Continental Divide about 60 miles from Denver and was on a line of the main east-west highway in Colorado in 1920. This steam shovel was surplus equipment after $W W$ and allowed considerable savings in time and costs.

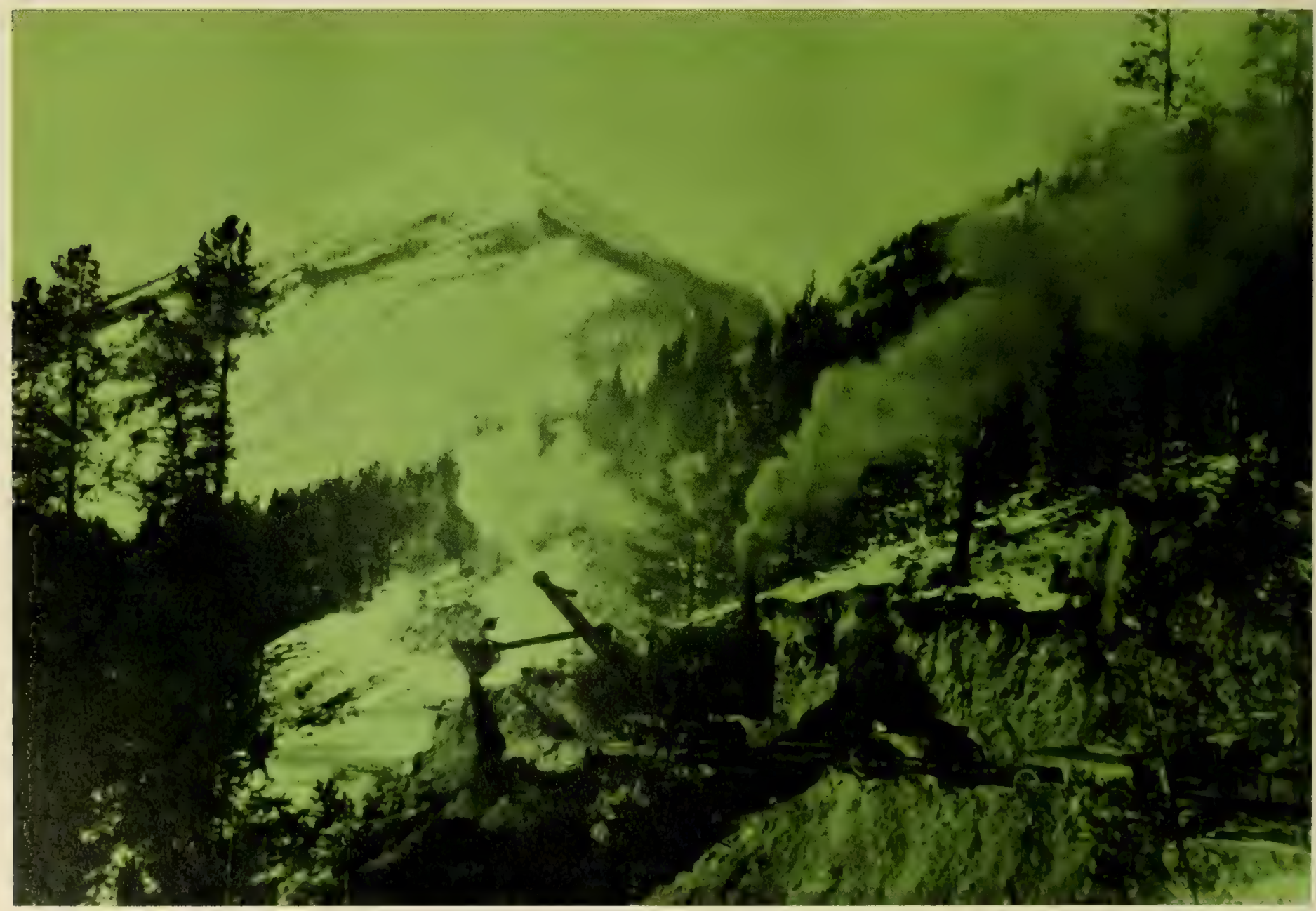


remainder of the 10 percent fund was expended directly by the Forest Service on the construction of trails and other minor road construction and maintenance projects needed for the administration of the forests. Within BPR, the field responsibility for the forest road work was such that each district forester would deal with only one district engineer.

\section{Breaking the Mountain Barrier}

In 1918 the national forests in the West comprised 274,000 square miles, equivalent to the area of the States of California, Oregon, and one-fourth of Washington. ${ }^{6}$ They were, in general, located on the slopes of the Rocky, Cascade, and Sierra Nevada Mountains between Canada and Mexico. They comprised rough and rugged terrain which was an imposing barrier to transcontinental travel. Of greater State and local interest was the fact that the intensive development of agricultural and other resources of the valleys required the improvement of roads adjacent to and through the national forests. It was imperative that mountain barriers within the national forests be conquered if the Great Plains were to be connected to the Pacific by trunk highways and north and south travel provided in the intermountain States. Dr. L. I. Hewes, then General Inspector of BPR, described the importance of forest road work in 1920 as follows:

. . Except to the westerner and the traveler, the idea of altitude may not carry great significance. But the effect of altitude may be realized when it is stated that from the Canadian boundary to Helena, Mont., there has never yet been built a road crossing the Rocky Mountains. Automobilists who visit Glacier National Park cannot drive from Glacier to Bolton, 30 miles away, until the road partly within the Blackfeet Forest along the southern boundary of the park is completed. There is no road in the State of Washington that can be traveled the entire year across the Cascade Mountains between the InlandEmpire and Puget Sound and western Washington populations. The same is true in Oregon. The only all-theyear passable road from the Columbia basin to the coast is down the gorge of the Columbia River; and at the point where the Cascade Range would cross the river a national forest road has just been constructed on the north bank from Stevenson to White Salmon. There are now in process of construction in the 11 Western States more than 20 projects, all of which run over mountain passes at elevations of from 3,000 to 10,000 feet. These particular roads involve some of the most difficult pieces of construction in the entire western road program, and many are connecting links in State highways. The McKenzie Pass Road across the Cascade Mountains between Eugene and Bend in Oregon runs for 3 miles on a mountain top over a fresh lava flow in which not a single plant grows.

Second, every national park in the western one-third of the continent is practically surrounded by national forests, and motorists ean not reach the roads already constructed in the national parks unless the roads through the forests leading to the parks are first constructed.

Glacier National Park in Montana is bordered by the Blackfeet National Forest; the Yellowstone is completely surrounded by six forests, except for a narrow strip along the railroad branch from Livingston. Mount Rainier is completely surrounded; Crater Lake can be approached only through the National forest, although a narrow strip of patented land exists on the southeast; Yosemite is completely surrounded, except for the road to El Porto; and Sequoia lies in the heart of the Sequoia Forest. $^{7}$

In addition to the importance of forest highways to through travel and to community development, they were essential to the conservation and resource development of the national forests themselves. Annually, there was a tremendous loss of timber due to fires since there was no way to fight forest fires in remote areas without access roads. In 1920, heavy timber operations in the national forests were still some years away; however, the need for a forest highway system was evident if both timber and other forest resources, including recreation, were to be developed.

\section{Early Administration}

The Federal Highway Act of 1921 provided a number of elements needed for the administration of the cooperative Federal-aid highway program. Section 23 of this Act substantially increased the funds available for the forest highways and recognized that there were two distinct classes of roads needed in the national forests. The "forest highways," which were in many instances extensions within the forest of the State and local road system, were needed for community use and resource development; in addition, "forest development roads" were needed for the protection, administration and resource development of the national forests themselves. The forest development roads have been a direct responsibility of the Forest Service, and their location, design, and construction supervision has generally been by Forest Service engineers, sometimes with assistance from the Bureau of Public Roads.

The rules and regulations for administration of forest roads and trails, approved by the Secretary of Agriculture on March 11, 1922, provided for the development of a forest highway system through the cooperative effort of the State highway departments, the Bureau of Public Roads and the Forest Service. These regulations also provided for the development by the three agencies of an annual work program defining those projects selected for improvement with forest highway funds. These procedures have worked so well that they have been followed for over 50 years with little change.

By 1921 the importance of forest highways to interstate and regional travel, as well as to the full development of State and local road systems, was fully recognized. At that time, there were approximately 14,000 miles of main State and county roads within the forests still to be constructed, and in addition, it was estimated there were approximately 13,000 miles of forest development roads or service roads needed in the administration of the forests. ${ }^{8}$

To facilitate the construction work in the western States, BPR established the Western Regional Office at San Francisco, California, under the direction of Dr. L. I. Hewes, Deputy Chief Engineer in Charge. The six western districts (with headquarters at Portland, San Francisco, Denver, Missoula, Ogden, and Albuquerque) were placed under the Western Regional Headquarters. These locations were also the headquarters of the corresponding forest districts.

By 1929 there were 14,166 miles on the forest highway system of which 12,015 miles were in the 11 western States, South Dakota and Alaska. Some improvement had been made on 4,091 miles since the beginning of the program. ${ }^{9}$ Total expenditure through fiscal year 1929 was $\$ 77$ million. 


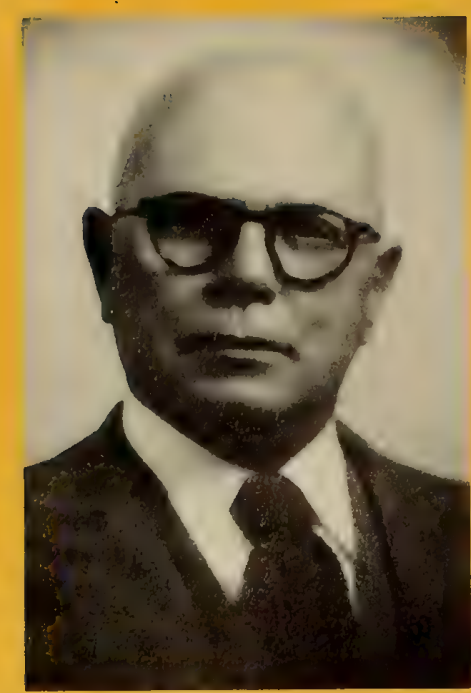

No one man contributed more to the development of the highways of the West than Dr. Laurence Ilsley Hewes. He opened the Western Headquarters Office of the Bureau of Public Roads in 1921 when Washington officials felt that the magnitude of the national forest highways and the expected increased workload resulting from the 1921 Federal Highway Act needed more direct supervision than was possible by having all review authority placed in Washington. In the course of his 29-year tenure, he stimulated and guided highway progress over an area representing one-third of the Nation.

Dr. Hewes was born in New Hampshire. He received a B.S. degree from Dartmouth College in 1898 and a $\mathrm{Ph} . \mathrm{D}$. from Yale University in 1901. He then taught science and mathematies at Rhode Island State College, Yale University and Whitman College, Walla Walla, Washington. In 1911 he was appointed as a Senior Highway Engineer with the Federal Office of Public Roads in Washington, D.C.

In 1920, as General Inspector, he conducted a study of the operations of the California Highway Commission and of its accomplishments under three State highway bond issues. The report was cited as being the most comprehensive study of results obtained through the development of a State highway system that had yet been undertaken. In fact, this report was the initial highway needs study of the type later authorized under Section 11 of the 1934 Hayden-Cartwright Act, which authorized Federal-aid funds to cover the cost of highway planning surveys.

Dr. Hewes was selected in 1921 to administer the Federal-aid highways and the direct Federal highway construction programs in the 11 western States and the Territories of Alaska and Hawaii. He served continuously as chief of the Western Headquarters for almost 30 years.

During that time, Dr. Hewes guided and shaped the highway transportation patterns of the Federal-aid highway system. He assured the connection of Federal-aid road systems in the West with the principal roads of Canada and Mexico and with Federal-aid routes of the States to the east. He directed the construction of thousands of miles of Federal roads and trails through the national forests and parks. $\mathrm{He}$ directed the coordinated efforts of Public Roads and the western States leading to the designation of the city-to-city routes of the National System of Interstate and Defense Highways. $\mathrm{He}$ also directed the activities leading to the designation of the Federal-Aid Secondary Road System and Federal-aid route extensions through the urban areas in the West that were authorized in the 1944 Highway Act.

As an engineer, controller, expediter and manager, Dr. Hewes had an influence on every phase of highway construction. "The problem of keeping a high mountain pass free from winter blockade in Colorado was as fascinating problem to him as repairing flood damage on an Oregon valley road, or the threat of shifting sands to travel in the Imperial Valley," according to a testimonial written after his death.

His interest in keeping the Federal-State partnership active and healthy led him to play a major role in the establishment of the Western Association of State Highway Officials (consisting of the 11 western States, Alaska, Hawaii, Texas, and the Forest Service, Park Service, Land Management and Public Roads agencies). He participated in all of its meetings and in the work of its various committees.

In addition, Dr. Hewes contributed many technical and policy papers dealing with highways. He authored several books on mathematics and highway engineering, the most important of which was American Highway Practice, a standard engineering reference first published in 1942. In collaboration with Professor Clark Oglesby of Stanford University, he published several revised editions.

In 1934 Dr. Hewes was Chairman of the American Delegation to the Seventh International Roads Congress at Munich, Germany. In 1946-47 he was Consulting Engineer to the government of Saudi Arabia. 
Dr. Hewes' chief hobby was his job, but family was a close second. He and Mrs. Hewes, an author of novels for children, raised a family of five. He was also an enthusiastic tennis player and a butterfly collector. He was skilled enough in lepidopterology to have articles on the subject published in National Geographic magazine.

Dr. Hewes was a member of the American Society of Civil Engineers, the American Association for the Advancement of Science, the California Academy of Sciences, the Commonwealth Club of San Francisco, the Cosmos Club of Washington, D.C., and the Sigma Xi honorary fraternity.

Just prior to his death on March 2, 1950, he received the Gold Medal Award of the U.S. Department of Commerce for exceptional service. A year later, the Western Association of State Highway Officials formally approved the establishment of the "Dr. L. I. Hewes Award," to be given annually to a highway engineer from WASHO in recognition of an outstanding contribution to highway development.

"This award," reads the resolution, "will perpetrate the name and achievements of Laurence Ilsley Hewes . . . whose superlative contributions in every phase of highway engineering gave great impetus to Western highway development." 


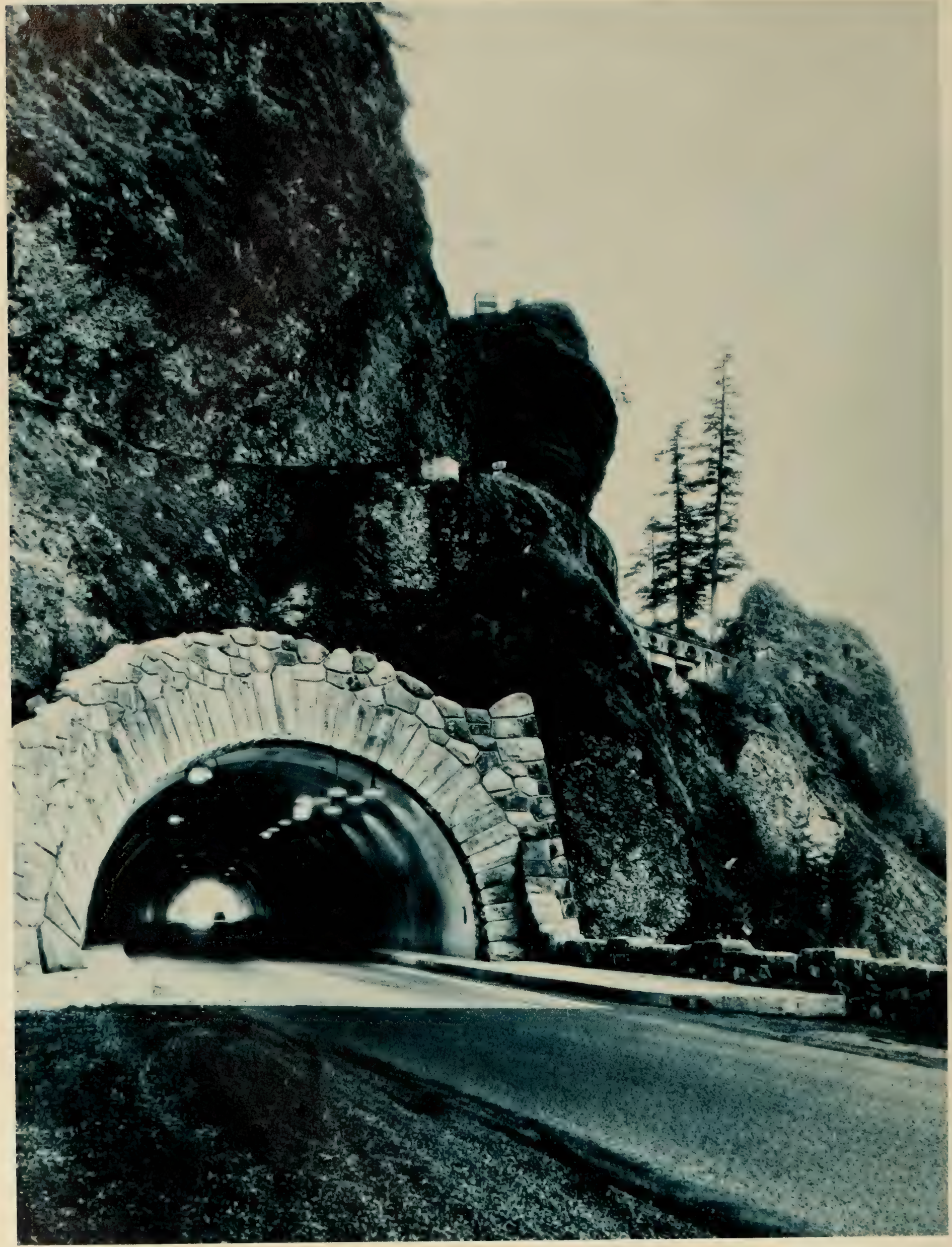




\section{The Growth of a Valuable Resource}

In the 1930's, the Bureau of Public Roads' direct Federal construction program in the Federal domain greatly expanded. The onset of the Great Depression prompted Congress to enact legislation expanding public works construction, including funds for roads and trails in the national forests and national parks.

For example, the regular forest highway fund authorizations under section 23 of the Federal Highway Act during the period 1921-1929 totaled $\$ 58$ million, whereas in the period 1930-1939, these funds totaled $\$ 93$ million. In addition, under the National Industrial Recovery Act of 1933 and several emergency relief and construction acts, $\$ 43$ million in additional funds were authorized and appropriated for forest highways and development roads and trails. Of the total funds, $\$ 95$ million were expended on forest highways and $\$ 40$ million were expended on forest development roads and trails during this period.

By 1940, the original national forest lands had been increased by more than 17 million acres, purchased under the Weeks Act passed by Congress in 1911 and amended in 1924, which authorized the purchase of forest lands to protect the navigability of streams, and to help perpetuate the country's water supply. All the original national forests were taken from the public domain lands in the West. By 1940, there were 2 national forests in Alaska, 1 in Puerto Rico, and 158 in 36 States.

While in 1930 there were only 65 miles of forest highways with a bituminous surface, by 1939 there were about 1,670 miles of surfaced roads that had some form of bituminous surfacing or paving. ${ }^{10}$

The improvement of the Nation's highway transportation system was making the national forest areas increasingly accessible and contributed to their becoming a great national resource. In addition to the production of saw timber, the national forests provided a water source for cities, towns, farm irrigation, and hydroelectric power; grazing land for cattle, sheep and horses; protection for wildlife; mining resources; and recreation areas. In 1931, there were 8 million visits by people who used the national forests for camping and other forms of recreation. ${ }^{11}$ In 1939, 14.5 million people visited the national forests. ${ }^{12}$

\section{Postwar Developments on the Forest Highways}

The Federal-Aid Highway Act of 1944 authorized for each of the first 3 postwar years, $\$ 25$ million for forest highways, $\$ 4.3$ million for highways in national parks, and $\$ 10$ million for parkways. By concurrent resolution of Congress, the first postwar fiscal year was determined to be the 1946 fiscal year.

During the war, timber was cut from commercial stands on such a scale that the supply was nearly exhausted. In developing the postwar national housing program, it became imperative to use the timber resources of the national forests. This resulted in an immediate demand for timber access roads.

At the same time, it was recognized that many forest highways on the Federal-aid and State highway systems constructed in the earlier years needed modernization to provide an adequate level of service for the increasing traffic volume. However, the scarcity of materials and supplies and the high national priority assigned to building houses affected the resumption of the forest highway program.

A directive from the Office of War Mobilization, issued on August 5, 1946, restricted the award of contracts for construction in Federal areas to improvements needed for the production of lumber in order to conserve the use of materials needed for the expanding housing program. The President limited expenditures for forest highways during fiscal year 1946 to $\$ 12.5$ million.

Work on the forest highways on the Federal-Aid Primary Highway System had ceased in 1942, and little had been done to repair surface damage during the war years. Hauling logs and timber had left a deep imprint on many miles of main forest highways.

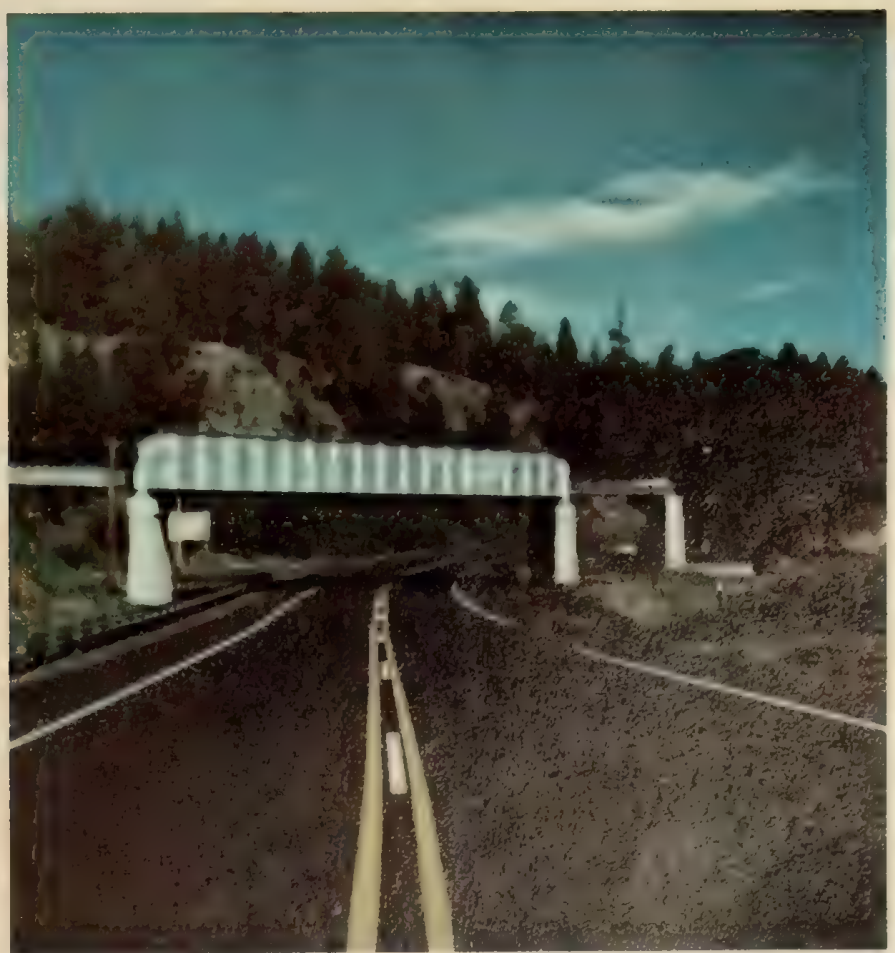

Wind Cave-Deadwood and Sylvan Lake Road in S. Dakota with a new railroad bridge crossing over the forest highway. 
Toward the end of the forties, there was, therefore, increasing pressure from many quarters to modernize these highways to meet the growing traffic demand. The Public Roads Administration, in cooperation with the State highway departments and the Forest Service, undertook a study of the network of forest highways in the western States and Alaska and reported in 1948 that an expenditure of $\$ 40$ million for each of the next 10 years would be required to provide a well balanced and adequate system. ${ }^{13}$

In spite of many problems, in 1949, 232 miles of forest highways were completed at a cost of $\$ 8$ million and projects were under construction at the close of the year on 521 miles, estimated to cost $\$ 24$ million. ${ }^{14}$ Many important forest highway projects were either under construction or programed for improvement.

The direct Federal construction program was growing in size and complexity during the fifties. Forest highways were authorized $\$ 219$ million during this period which was more than twice the amount authorized during the thirties. The amount authorized for forest development roads and trails was $\$ 222$ million compared with $\$ 40$ million during the thirties.

A concerted effort was made during the 1950 's to modernize the forest highways on the Federal-aid highway system that were no longer adequate. A 310 -foot steel arch bridge was constructed across the Snake River in the Teton National Forest in Wyoming, and 26 miles of forest highway was built through the Snake River Canyon, becoming a part of U.S. Route 89. This opened a new route that saved from 50 to 135 miles when traveling from Utah and southeastern Idaho to Jackson Hole, Grand Teton National Park and Yellowstone National Park in Wyoming. This route permits a gradual climb to Jackson, $\mathrm{Wy}_{\text {- }}$ oming (elevation 6,235 feet) instead of going over the summit through Teton Pass at an elevation of 8,450 feet by tortuous mountain road. Because of the difference in elevation, the new route also made a great difference in travel conditions during the winter months.

\section{Highways in the Territory of Alaska}

In addition to the normal forest highway program, the 1950 Federal-Aid Highway Act contained a special forest highway provision of $\$ 3.5$ million each for fiscal years 1951 and 1952 for the construction of new highways in the Tongass National Forest in Alaska. The Bureau had been building forest highways in Alaska since 1919 through an agreement with the Alaska Road Commission in the Department of the Interior. One such project was the Turnagain Arm Highway, connecting Anchorage with Seward and the Kenai Peninsula highway system. In addition, BPR, by mutual agreement with the Alaska Road Commission occasionally performed highway engineering functions throughout Alaska. By 1956, some 400 miles of forest highways at a cost of approximately $\$ 50$ million had been constructed in Alaska by BPR.

The Federal-Aid Highway Act of 1956 extended the Federal-aid highway program to Alaska for the first time, and it transferred all the functions and responsibilities for the Territory's highway program to BPR. Personnel of the Alaska Road Commission were transferred to the existing BPR Alaska at this time, and the direct responsibility for the location, surveys, design, contract administration, construction supervision, and highway maintenance of the 5,356mile highway system placed the Bureau in the position of acting as a State highway department. In 1959, Alaska became a State, and the Alaska Omnibus Act made the State responsible for the Federal-aid highway program on a basis comparable to that of the other States.

\section{A 10-Year Program}

In 1958, Congress directed that a study be made to determine how well the forest highway system was meeting the highway transportation needs of the counties and communities that were within or adjacent to the national forests and that a 10-year program to meet these needs be prepared in cooperation with the Forest Service and the States. The report was submitted to Congress in January 1960. The report noted that:

- The roads of primary importance to the States, counties, and communities which were not designated as forest highways totaled 28,884 miles. Approximately 48 percent of this mileage was on the Federal-aid highway systems as follows:

$$
\begin{array}{lr}
\text { Interstate Highway System } & 360 \\
\text { Primary System } & 2,332 \\
\text { Secondary System } & 11,272 \\
\cline { 2 - 2 } & 13,964
\end{array}
$$

As a comparison, 82 percent, or 19,927 miles out of a total of 24,399 miles, of presently designated forest highways was on a Federal-aid system.

- It would cost approximately $\$ 2.6$ billion to complete construction of all presently designated forest highways to adequate standards.

- A 10-year construction and maintenance program for roads of primary importance but which were not designated forest highways would cost a total of $\$ 803$ million for construction and $\$ 237$ million for maintenance.

- A similar 10-year construction and maintenance program for presently designated forest highways would cost a total of $\$ 1.4$ billion for construction and $\$ 305$ million for maintenance.

The report estimated that the 10-year construction programs, totaling about $\$ 2.2$ billion, "could be financed by continued authorization of Federal foresthighway funds at the presently authorized level of $\$ 33$ million annually, together with the use of all other funds normally expended on forest highways, including Federal-aid funds, State and local matching money, and other State and local funds." 15

The report recommended that, since Federal-aid funds were not eligible for maintenance of highways and, in the past, authorized funds had been fully obligated for construction of forest highways, the approximately $\$ 542$ million estimated for maintenance during the 10-year period should be derived from State and local sources. The report also recommended that the apportionment of funds be continued in the historic manner. ${ }^{16}$

As of January 1960, national forests, or purchase units under the Weeks Act, were located in 41 States and in Puerto Rico. In all of these States, there was 


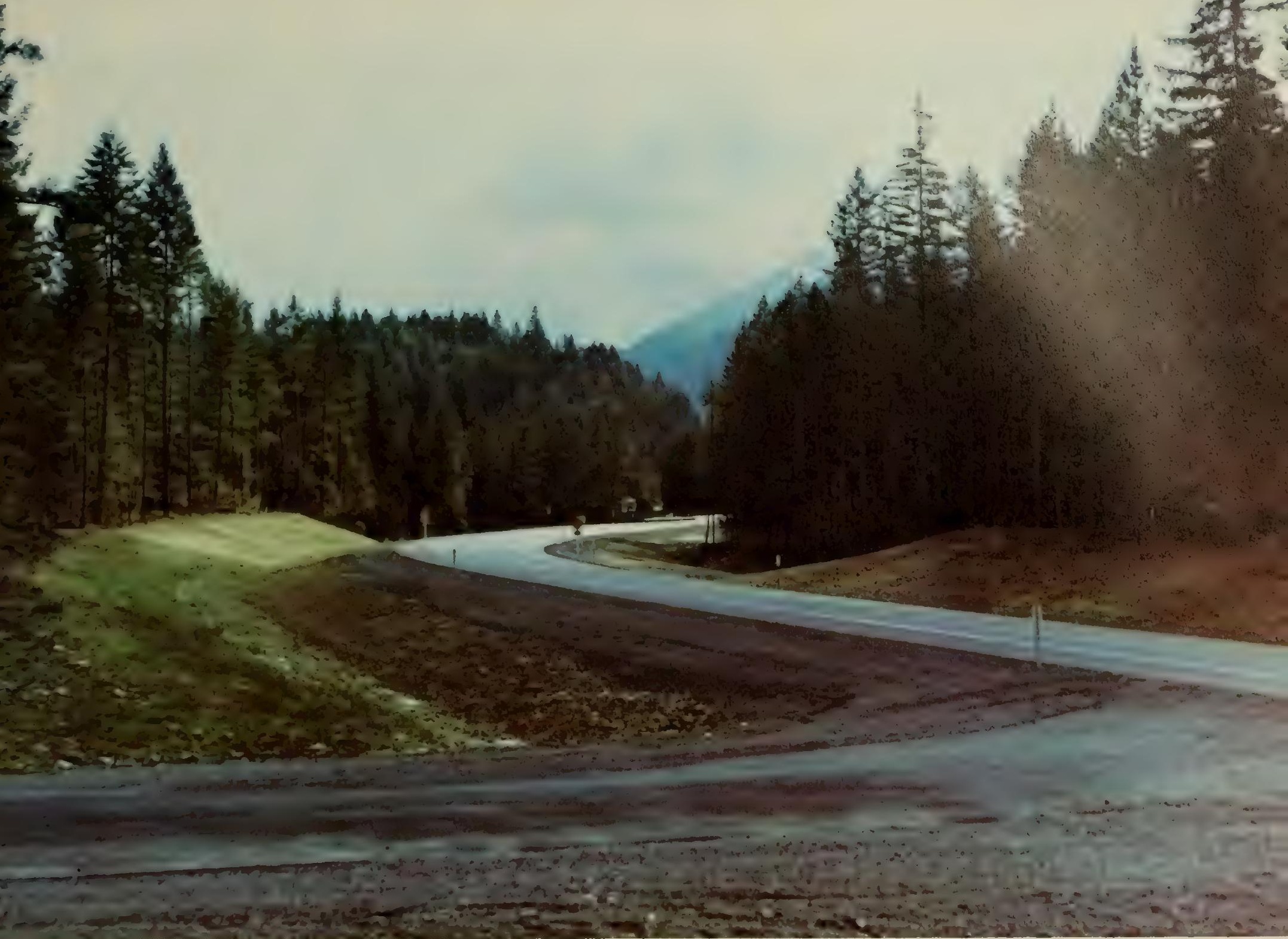

McKenzie Highway (Oreg. FH-22) in Willamette National Forest is a modern design and has numerous safety features.

a designated forest highway system except in North Dakota. Nine other States* had no national forests or purchase units, and, consequently no forest highway system.

Since 1960, the direct Federal highway construction program has continued at about the same program level. Beginning with the Federal-Aid Highway Act of 1958, forest highway funds have been authorized for each of the succeeding years at the level of $\$ 33$ million. Historically, funds for the forest highway system have been authorized and appropriated from the general fund. However, the Federal-Aid Highway Act of 1970 directed that, beginning with the fiscal year 1972, the forest highway funds would come from the Highway Trust Fund. This Act amended the definition of the term "forest highway" to require all forest highways to be on the Federal-aid system. This change eliminated the former Class III forest highway designation which included those highways designated as forest highways which were not on the Federal-aid system.

* Connecticut, Delaware, Hawaii, Kansas, Maryland, Massachusetts, New Jersey, New York, and Rhode Island.

\section{The Hardships of Working on Forest Roads}

The history of the BPR's direct Federal construction program is a record of the work of three generations of highway engineers, many of whom devoted their entire professional careers to this service. By the very nature of the work, they accepted hardship and personal privation for the love and challenge of the work. Arthur E. Loder, Assistant Chief Engineer of BPR in 1918 aptly described their lot.

Much of the work is located at high altitudes where heavy snow remains until late in the spring. The streams carrying away the melting snow remain at flood stage making them difficult to ford until the last of June and in some cases even later. In such places the snow may begin to fall again in September and often stops field work before October. Although the work is located in every climate from the torrid desert, through regions of excessive rainfall and high timberline altitudes to the frozen forests of Alaska, the average season for efficient work is short. Under these conditions work must be organized and rushed as fast as possible while conditions permit.

Although the locating engineer's work, with its interesting problems and the call of mountain and forest, is so fascinating that he is rarely content thereafter to live in the plains, his existence is a busy one and his hardships real. He soon learns to regard as a luxury his bed made by pounding the earth with an ax to remove the 


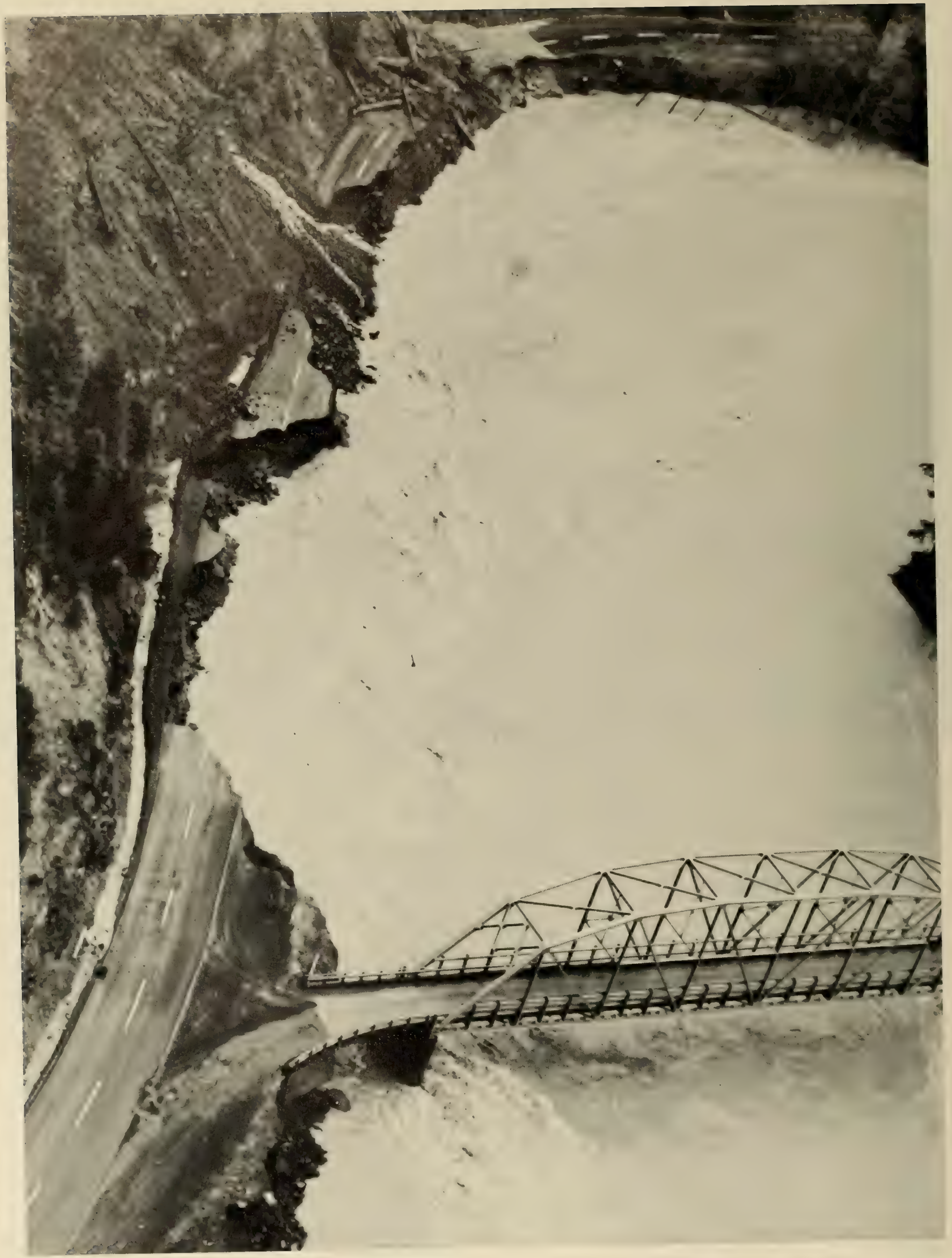

When the Clatames flood stage in 1964, Oregon Forest Highway 55 was destroyed. 


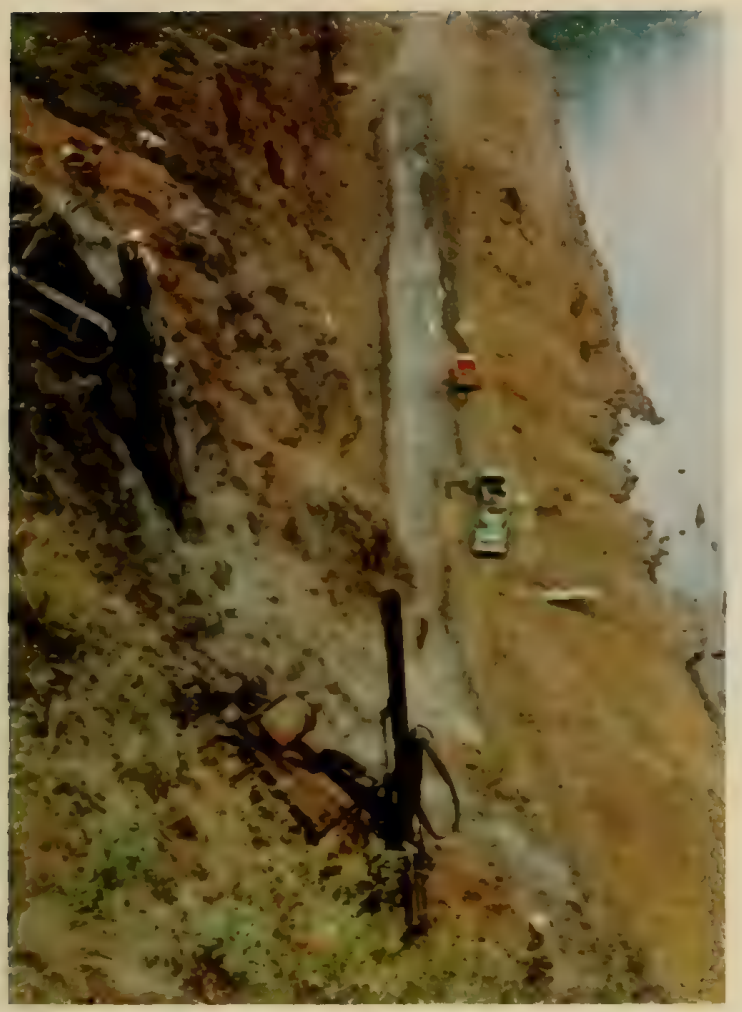

In 1967 repair work was underway on Oreg. FH 55.

The men working on this project took a

quick course in mountain climbing, which

later saved the life of at least one man.

The slope was drilled and small charges of dynamite were set to blast the face of the slope for what is called presplitting of cut slopes. The drills and other equipment had to be high-lined on cables to the top of the slope.
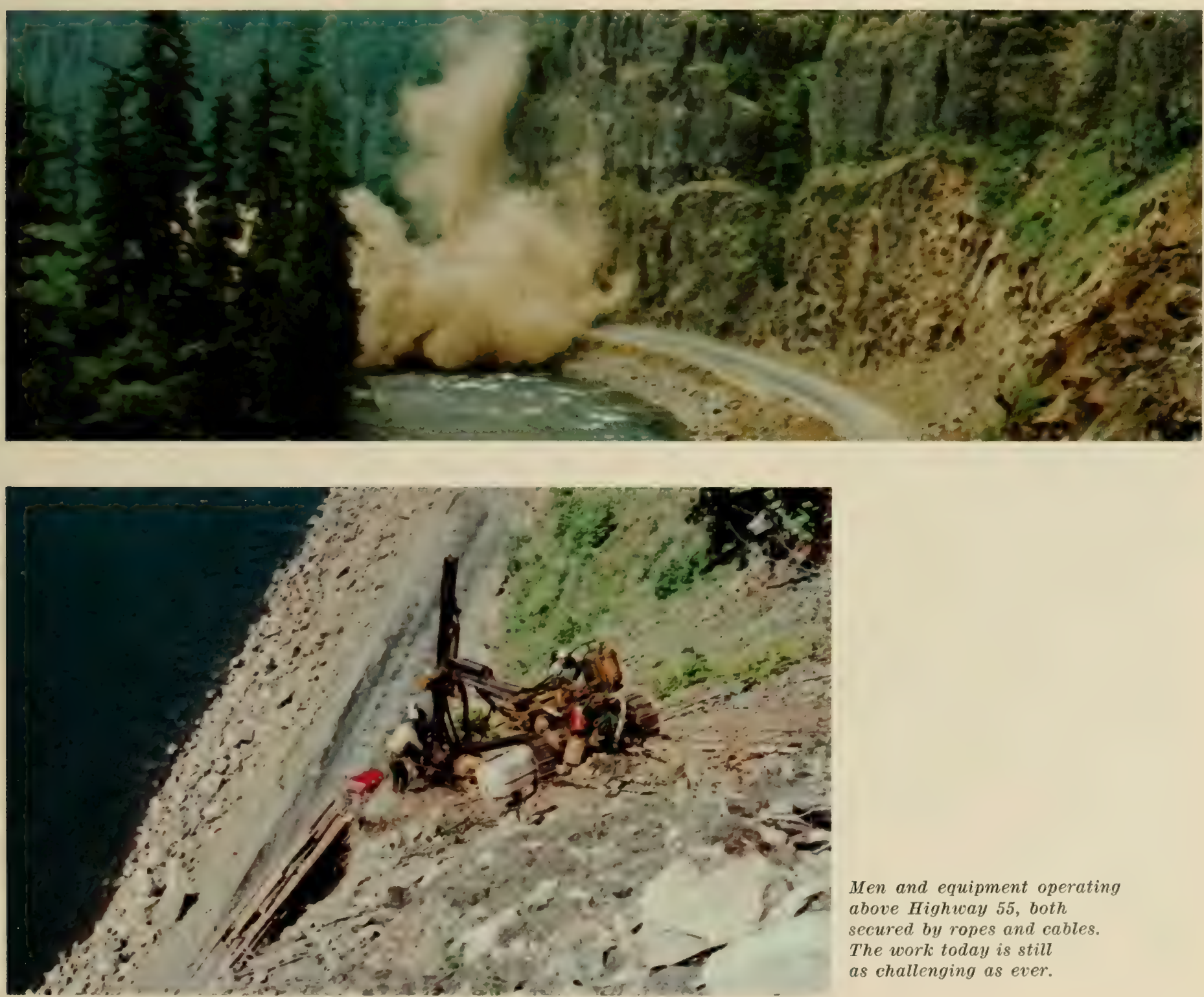

Men and equipment operating above Highway 55, both secured by ropes and cables. The work today is still as challenging as ever. 
stones and roughest projections, and never has difficulty in sleeping without shelter unless the coyotes howl too much. He is also content with his morning bath in an icy stream and never complains of an all day and night hike to find camp, but the romance of the work gives way to the most serious problem of existence when, on a long lonesome reconnaissance a week's travel from base, he wakes in the morning to find that a neighborly bear has visited camp, destroying his light grub pack and making away with the bacon upon which he had relied for subsistence on his return journey. If to this is added the sadness of finding that his horses have slipped their hobbles and disappeared completely, leaving him afoot, hungry, and four days from grub, his misery is complete. When a survey party sets forth with a standard camp, living conditions are usually good. The hardships are more often encountered on the long reconnaissance surveys when an attempt is made to travel with little equipment, depending upon game and good fortune for subsistence. Some sections can be traversed more easily by waiting for snowfall and using snowshoes or skis. In Alaska the dog train is useful. It is not an uncommon experience for the party to bunk in the snow without tent.

Occasionally the survey must be carried along the face of precipitous slopes and rocky cliffs where a misstep or a loosened rock would be disastrous. In such cases long ropes from above suspend the men or protect them from accident. In 1916 one member of a survey party on this work lost his life from a fall of several hundred feet on account of not taking such precaution. ${ }^{17}$

In 1926, the BPR Annual Report described forest highway construction: "For the engineering features involved in their construction and the difficulties overcome these roads are not surpassed in the world."

Today we smoothly cross these same mountain barriers on Interstate highways which are a tribute to 50 years of highway engineering progress pioneered by those engineers who made the first highway locations and carried through the design and construction of the first improved highways across the mountain barriers, tying all parts of our country together with a modern highway transportation system.

\section{National Park Roads and Trails}

The construction of roads in national parks was an essential element of park development. Prior to the establishment of the National Park Service in the Department of the Interior in 1916, improvements within each park appear to have been the responsibility of the park superintendent, and road improvements were at best spasmodic as funds were made available, but some progress was made. Yellowstone National Park was allotted $\$ 15,000$ in 1877 , the first appropriation for roads in a national park. ${ }^{18}$

The U.S. Army Corps of Engineers took over the roadbuilding responsibility in Yellowstone National Park in the summer of 1883 and continued to be responsible for road construction in the Park until 1918. During this period, the basic road system was constructed. General Hiram M. Chittenden, associated with Yellowstone National Park from 1891 to 1893 and from 1899 to 1906 , is credited with having a major influence on the development of the Yellowstone Park loop road system. He was one of the early advocates of building high quality roads in the Park, roads that would sit lightly on the landscape, taking advantage of the terrain by curvilinear alinement. ${ }^{19}$

By the mid-1920's, it was becoming increasingly evident that the activities of the State highway departments, the Bureau of Public Roads, the Forest
Service, and the National Park Service needed to be closely correlated. In most instances, the national parks were practically surrounded by forests, and in almost every case, the approach to the parks was dependent on the construction of a main road through the forests.

In 1924 Congress enacted special legislation (43 Stat. 90 ) for the authorization of road construction in national parks. Following this legislation, BPR and the National Park Service worked out a Memorandum of Agreement on the survey, construction and improvement of roads and trails in the national parks and national monuments. This document and later ones established broad principles for standardizing construction of these highways and joining them with forest roads and trails, State highways, and the Federal-aid system to form an interconnected system of highways. ${ }^{20}$

A statement of policy on roads was made by Director Stephen T. Mather in the National Park Service's annual report of 1924 :

It is not the plan to have the parks gridironed with roads, but in each it is desired to make a good sensible road system so that visitors may have a good chance to enjoy them. At the same time large sections of each park will be kept in a natural wilderness state without piercing feeder roads and will be accessible only by trails by the horseback rider and the hiker. All this has been carefully considered in laying out our road program. Particular attention also will be given to laying out the roads themselves so that they will disturb as little as possible the vegetation, forests, and rocky hillsides through which they are built. ... ${ }^{21}$

\section{See America First}

Under the new park road Act, work was initiated in 1925 on the construction of the transmountain highway in Glacier National Park, Montana. This project was considered one of the most important of the transcontinental highways. It was located between Lake MacDonald and St. Mary Lake and connected these two areas of Glacier National Park via Logan Pass.

By the mid-1920's, a national system of improved highways was beginning to take form, encouraging family vacations by automobile and visits to the national parks and national forests. "See America First" was the slogan. Auto camping was becoming increasingly popular. The first automobiles had been admitted to Yellowstone National Park in $1915,{ }^{22}$ and from 1918 to 1925 approximately 1.6 million private autos entered the national parks. ${ }^{23}$

\section{Locating National Parks in the East}

All but one of the major parks were west of the Mississippi River, while two-thirds of the population lived east. Director Mather wrote in 1923, "I should like to see additional national parks established east of the Mississippi, but just how this can be accomplished is not clear." ${ }^{24}$

While western parks had been created out of the public domain, the only extensive land in public ownership in the East were the number of forest reserves acquired under the provisions of the Weeks Act, which authorized the purchase of land for the protection of forests and the headwaters of streams. It appeared the only practical way national park areas could be acquired would be by donation or by purchasing land with privately donated funds. 
The Transmountain Highway (now called Going-to-the-Sun Highway) under

construction in $192 \%$.
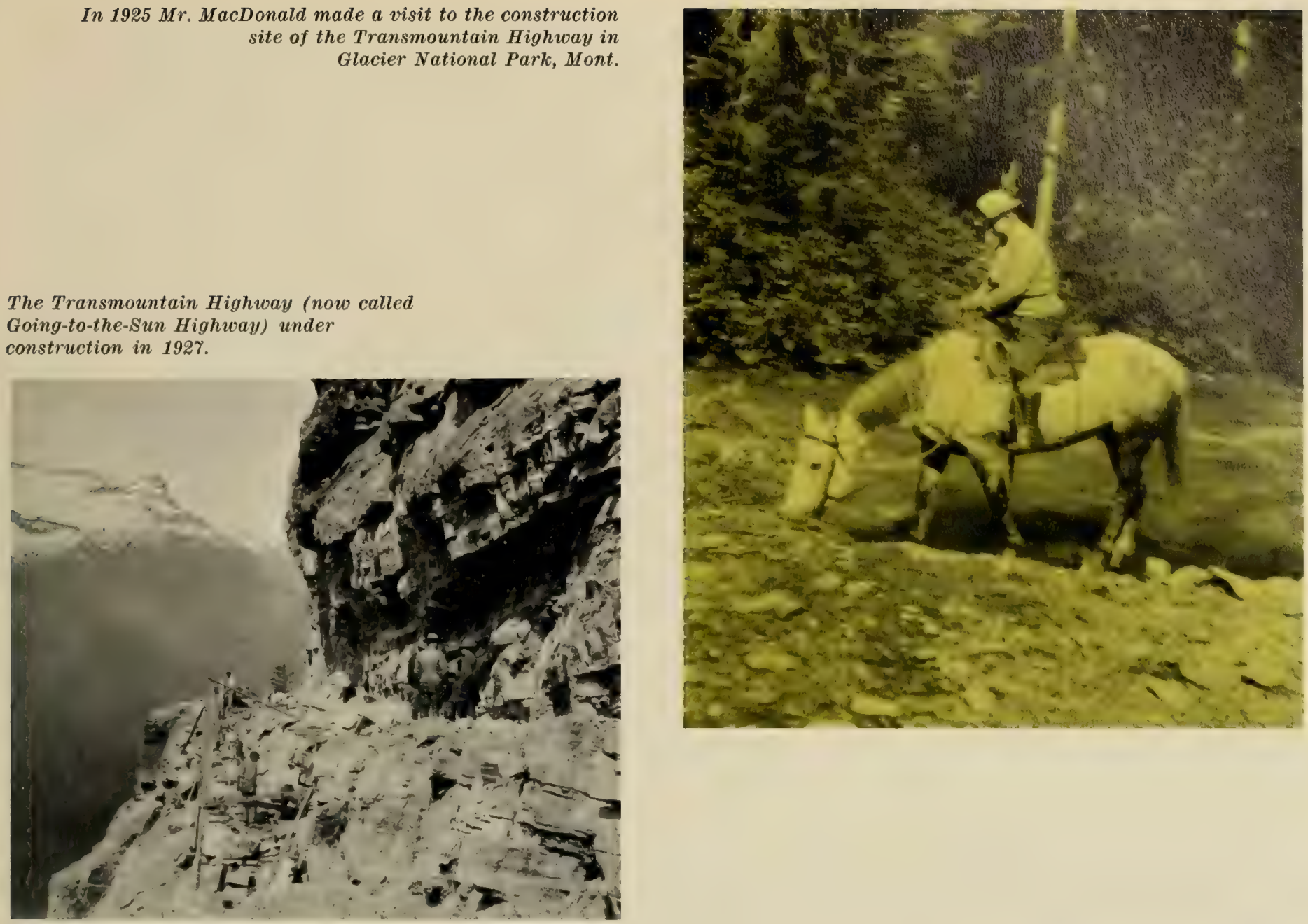

Going-to-the-Sun Highway in 1962 in Glacier National

Park, Mont.

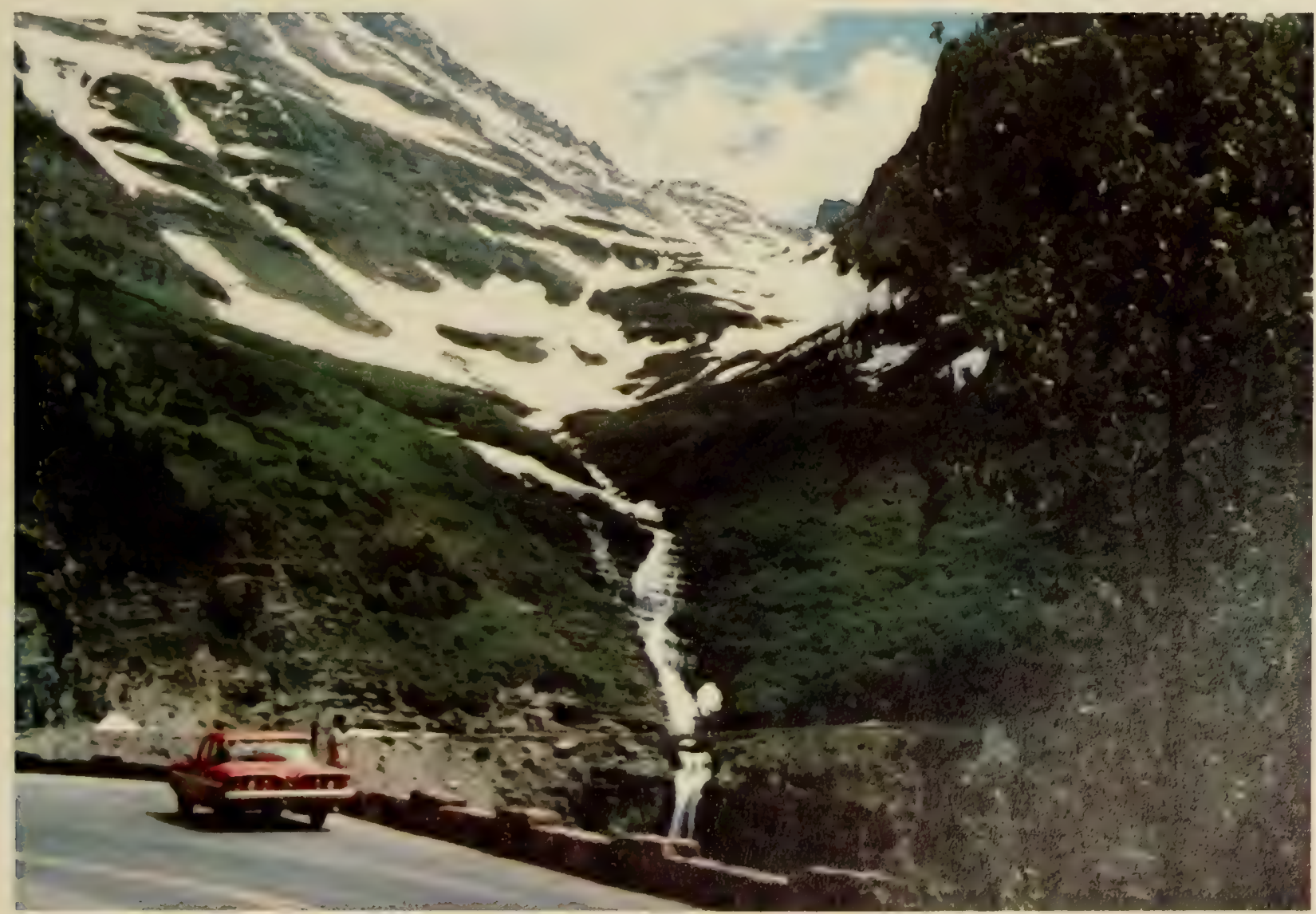


As a result of Director Mather's concerns, Secretary of the Interior Hubert Work, in 1924, established a Southern Appalachian National Park Commission to make an investigation of the southern Appalachian Mountains region and to determine whether there were suitable areas for national parks. The initial committee appointed by the Secretary was composed of public-spirited men who served without compensation. The only funds available for the Commission's use were those provided by private individuals. The Commission devoted much personal time in reconnaissance of the area, meeting with local groups and investigating the feasibility of areas to be recommended for national parks. From these studies, Congress drafted the necessary legislation in 1925 authorizing the securing of lands in the southern Appalachian Mountains for perpetual preservation as national parks.

By 1926 enough public support had been generated so that enabling laws in both the State legislatures and in Congress led to the establishment of the Great Smoky Mountains National Park in North Carolina and Tennessee and the Shenandoah National Park in Virginia. Later the Mammoth Cave National Park was established in Kentucky.

In the Commission's 1924 report to the Secretary of the Interior, the following comment was made on the Blue Ridge area of Virginia that became the Shenandoah National Park:

\footnotetext{
The greatest single feature, however, is a possible skyline drive along the mountain top, following a continuous ridge and looking down westerly on the Shenandoah Valley, some 2,500 to 3,500 feet below, and also commanding a view of the Piedmont Plain stretching easterly to the Washington Monument, which landmark of our National Capital may be seen on a clear day. Few scenic drives in the world could surpass it. ${ }^{25}$
}

It was this vision that led ultimately to the construction of the Skyline Drive in the proposed Shenandoah National Park.

\section{Pioneer Road Construction}

By 1930 the work initiated in 1924 for the National Park Service on the improvement of park roads was a significant part of the total direct Federal construction program. A system of national park roads had been selected for improvement, involving some 1,500 miles of road. The cost of improvement was $\$ 50$ million, and $\$ 22.5$ million had been authorized between 1924 and 1930, of which $\$ 20$ million had been actually appropriated. Of the planned system, 302 miles were already improved at a cost of approximately $\$ 9.2$ million, and construction was underway on 241 miles on which the cost was estimated to be approximately $\$ 9.6$ million. ${ }^{26}$

The initial project in 1924 of surveying the transmountain highway in Glacier National Park and the work on the Zion-Mount Carmel Road illustrate the difficulties to be surmounted in pioneer road construction. The transmountain highway project was only accessible by saddle horses, and in the very early stages of work, the average load for a packhorse was very small. The project was on the west side of the Continental Divide in the Rocky Mountains and was 15.7 miles long. It started at an elevation of 3,537 feet and, for the major portion of its length, climbed along the "Garden Wall" to Logan Pass at an elevation of 6,648 feet. In the upper reaches, the location followed virtually a vertical cliff for long distances.

On the Zion-Mount Carmel Road in Zion National Park, Utah, which was completed in 1930, a tunnel was necessary.

In the 4.6 mile stretch of the Zion Park Road in Upper Pine Creek Canyon, there is more than a mile of tunnel. The tunnel is sufficiently near to the cliff face so that it has been possible to cut openings or galleries through the face from which views of the canyon may be obtained...

Before actual construction work began much had to be done in preparation. A feasible route had to be found by which to climb from the floor of the valley, 1,400 feet in elevation to the park boundary at 4,100 feet. The survey involved weeks of arduous labor, climbing rocky slopes, cutting through dense thickets, hanging from hazardous points, and at all times maintaining an accuracy of measurement which would allow computations to be made closely enough for proper control and close estimate of the work to be done.

In starting the tunnel work, it was necessary to begin at several points along the line and excavate the galleries first and then complete the tunnel between these points. All measurements had to be made from the outside, carried in and projected through the tunnel. Scaffolds were built on the outside of the cliffs, and all supplies and materials were lifted to these galleries. ${ }^{27}$

\section{The National Park System}

On June 10, 1933, President Roosevelt signed an executive order establishing the national park system which was to be administered by the National Park Service. The components of the system were identified in six groupings: (1) The National Capital Parks, comprising the lands reserved by the Federal Government after the founding of the District of Columbia in 1790 on which today are found the Capitol, the White House, the Lincoln and Jefferson Memorials with the connecting mall and park area, the Rock Creek Park authorized in 1890, and other areas and buildings in the Nation's Capital of great historical significance; (2) 21 national memorials; (3) 11 national military parks and 9 national battlefield sites; (4) national cemeteries, including the Gettysburg National Cemetery and 10 other similar cemeteries established at the sites of historic battlefields; (5) 10 national monuments on military reservations; and (6) 21 national monuments on national forest lands. Altogether, there were 137 areas in the national park system. ${ }^{28}$

Between 1933 and 1940, six new national parks were established: the Everglades National Park, Florida, 1934; the Great Smoky Mountains National Park, North Carolina and Tennessee, 1934; the Shenandoah National Park, Virginia, 1935; Big Bend National Park, Texas, 1935; the Olympic National Park, Washington, 1938; and King's Canyon National Park, California, 1940. BPR's activity on park road construction was thus greatly expanded.

As a result of the 1933 executive order, Commissioner MacDonald, in January 1934, established the Eastern Parks and Forests District in Washington, D.C., to provide an organization to undertake the location, design, and construction of park and forest and such other highway work in the eastern section of the United States as might be entrusted to the Bureau. The result of this action was to bring under 


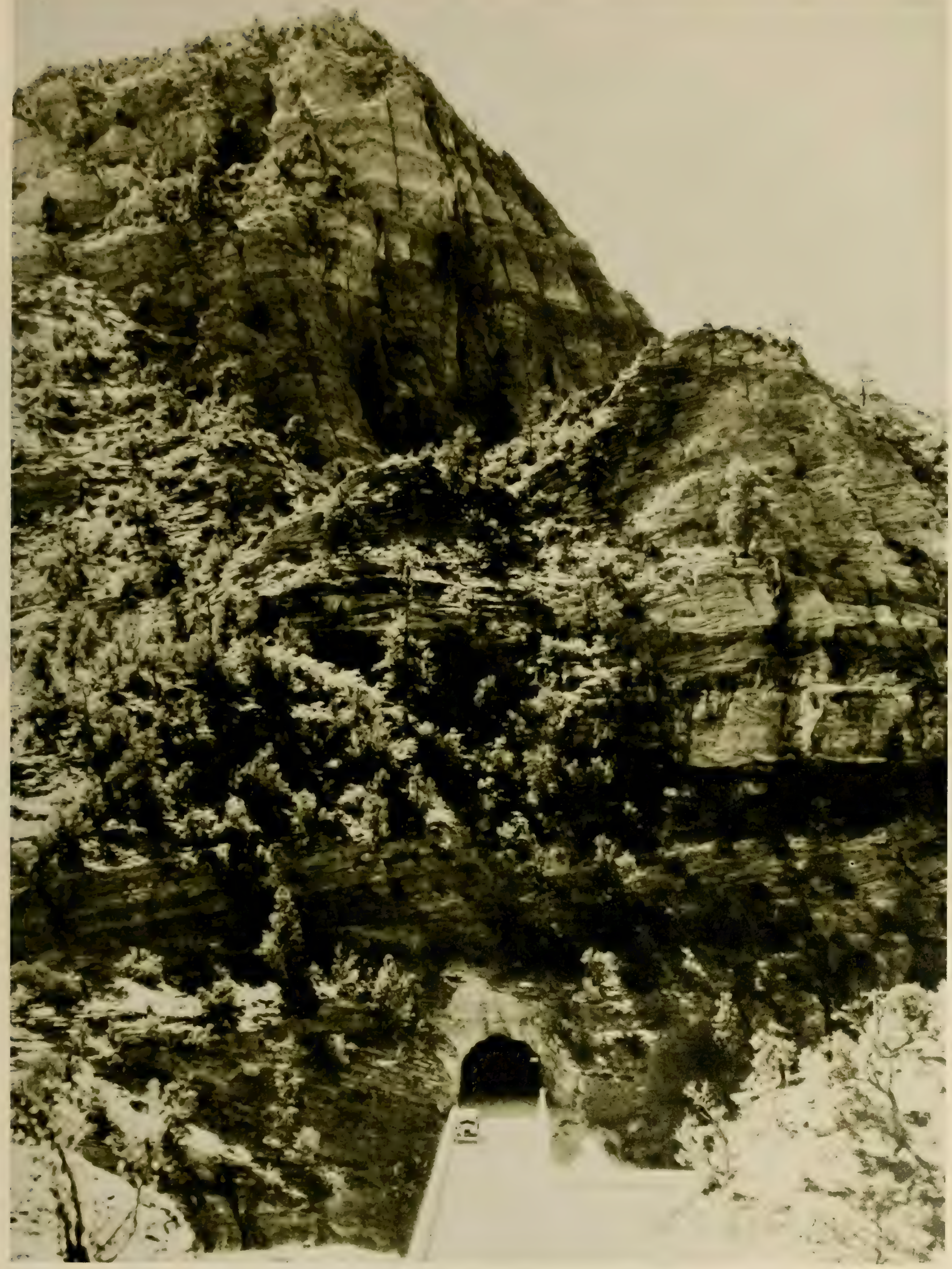




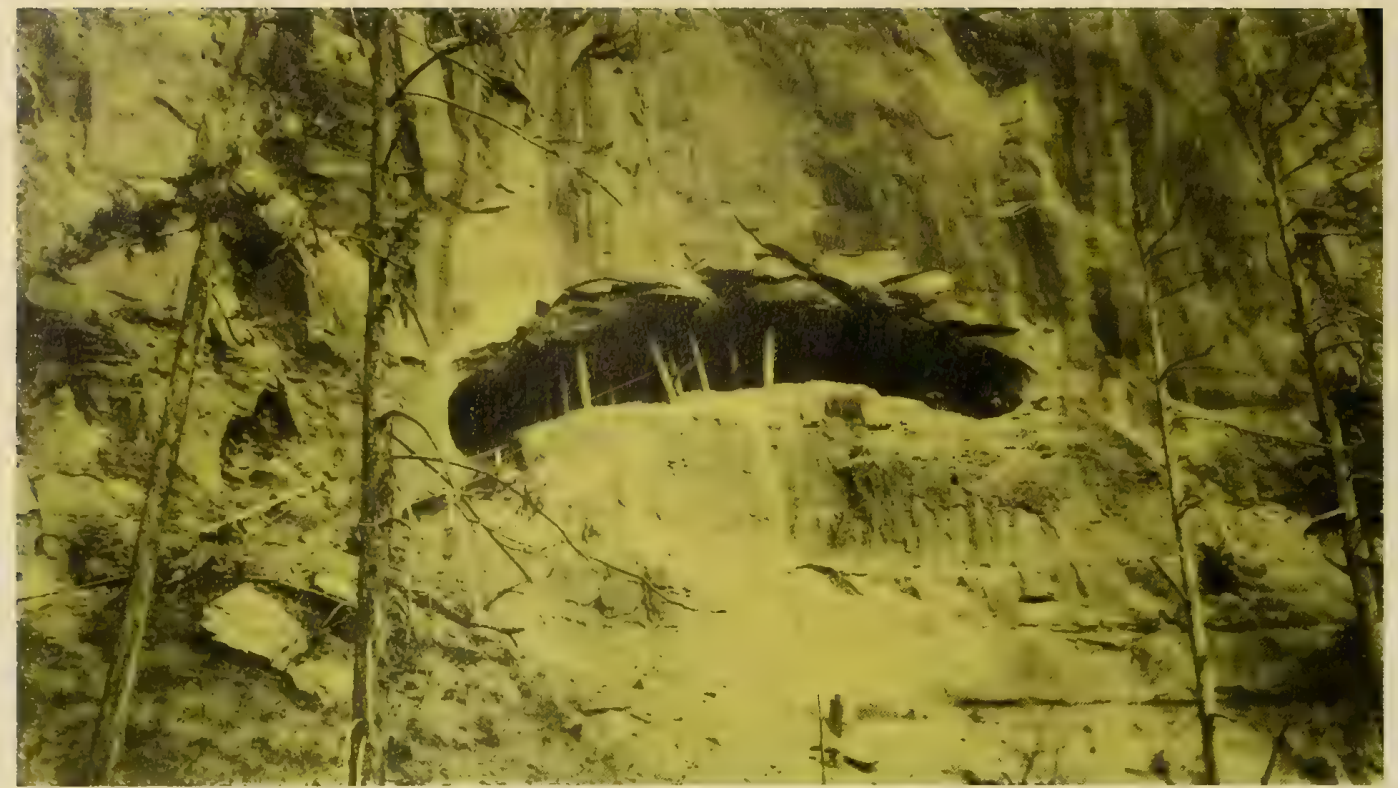

Excavation of gallery No. 1 late in 192\%.

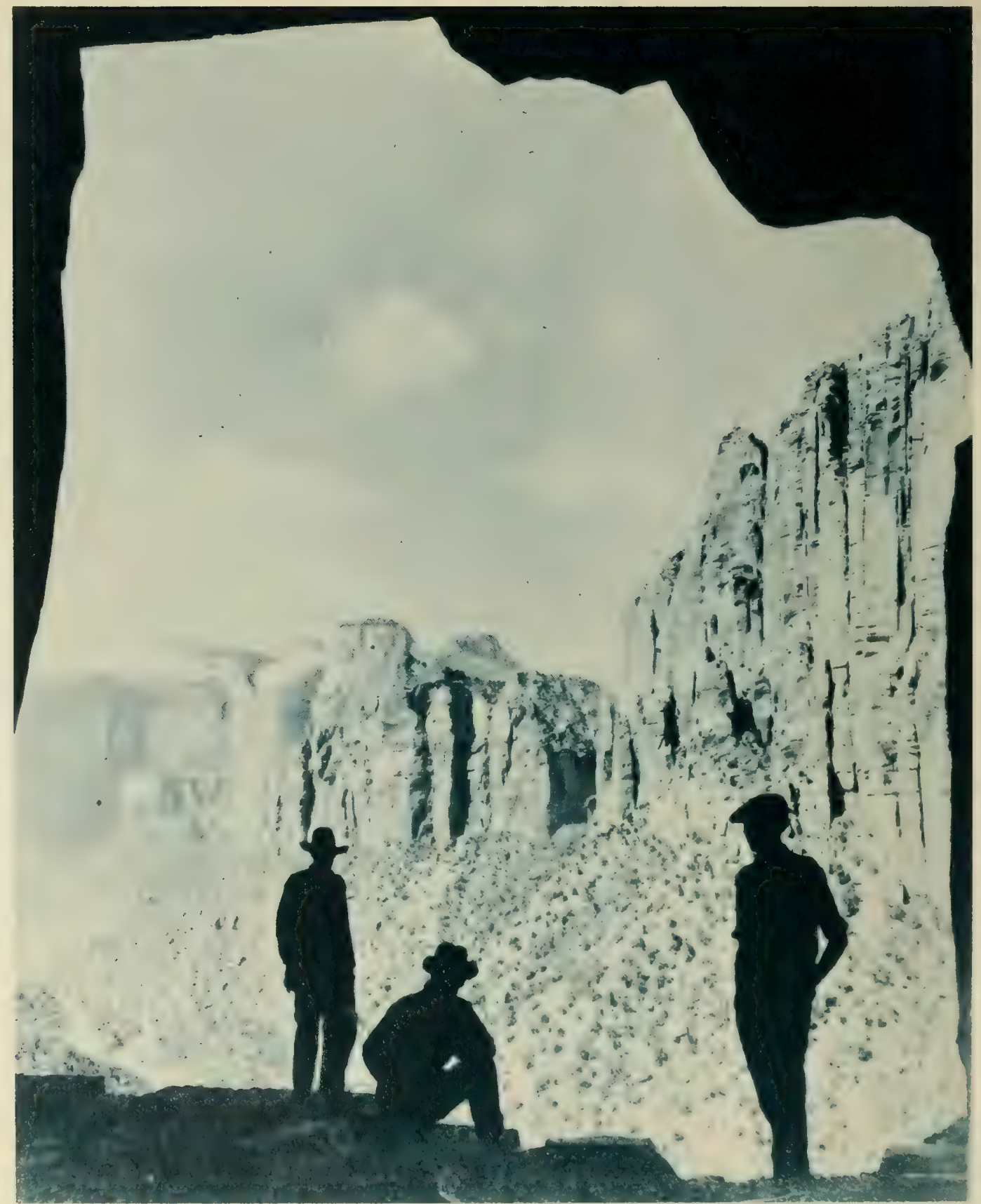




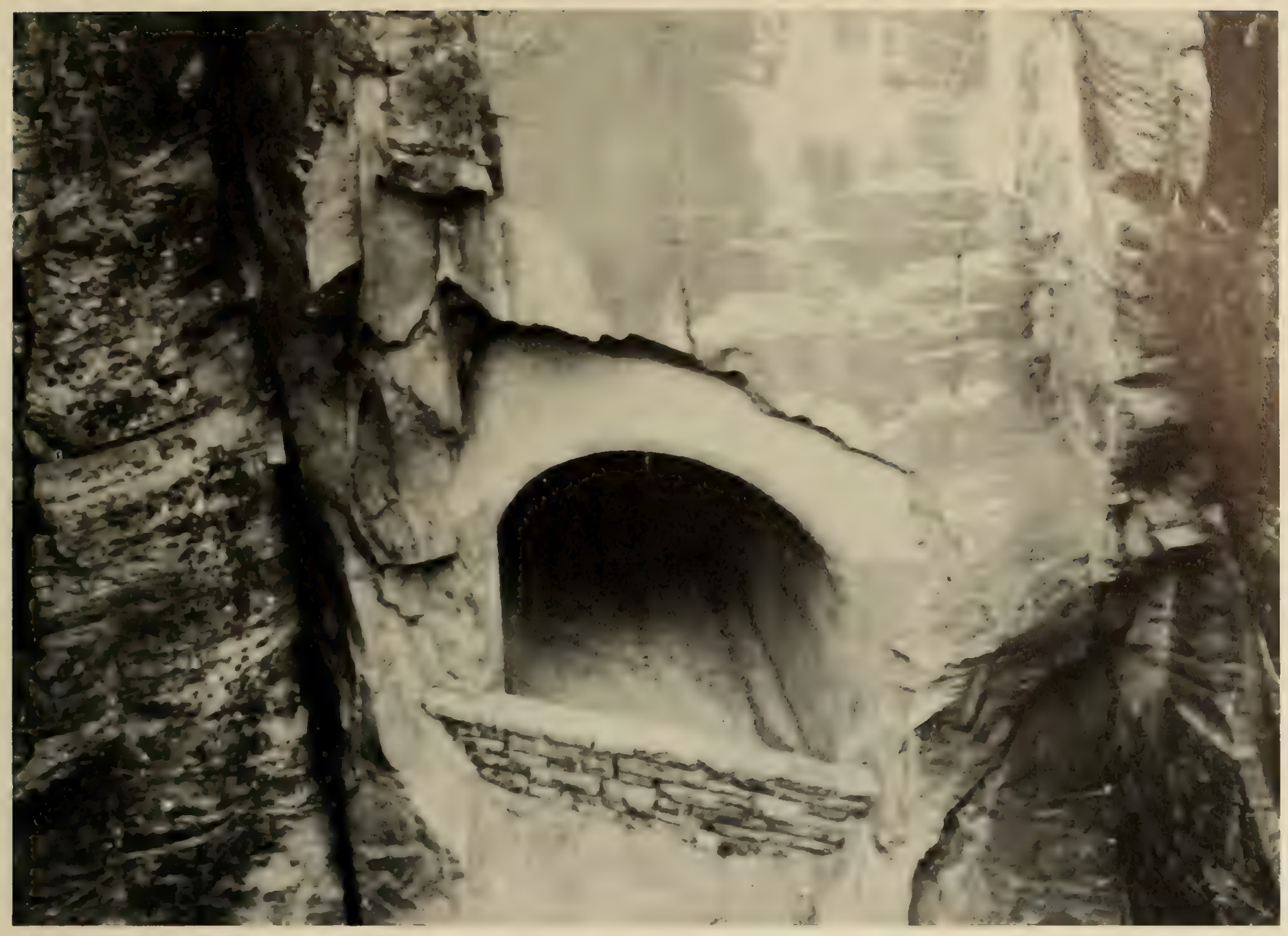

View of the completed gallery No. 4 with reinforced concrete lining from across Pine Creek Canyon.

the new district direct supervision of all the work contemplated or underway in the East. The territory of the region included 30 States east of the Rocky Mountains and the District of Columbia. The work in the western States and Alaska remained as organized in 1921 under a Western Regional Office.

All of the park work was performed under the interagency agreement of 1926 , and by $1939,1,577$ miles of road in or leading to 43 national parks and monuments had been improved on the national park system. ${ }^{29}$ For example, much of the original Yellowstone Park loop road was reconstructed suitable for automobile traffic. The Red Lodge-Cook City approach road to Yellowstone National Park and the Cameron Desert View approach road to Grand Canyon National Park in Arizona were both completed. The Crater Lake National Park loop road in Oregon, portions of the Fall River Highway in the Rocky Mountain National Park, and the Wawona Tunnel project in Yosemite National Park in California were also completed. This tunnel was approximately 4,200 feet in length. The Big Oak Flat Road on which the Wawona Tunnel is located replaced a carriage road built in 1874 which was very narrow with a steep descent into Yosemite Valley. Building a road to acceptable standards to replace the old road called for the best highway engineering skills. The new road, 10 miles in length, included three tunnels, three major bridges, and 2 miles of exceptionally difficult construction. Work was also in progress on the Tioga Pass Road, giving access to Yosemite National Park from points east of the Sierra Nevada Mountains.

\section{Skyline Drive}

Late in 1930, work was begun on the Skyline Drive to provide employment for the inhabitants of the drought-stricken Shenandoah Valley and to open a road in the newly authorized Shenandoah National Park for recreational use.

Today, Skyline Drive extends from the northern boundary of the Shenandoah National Park at the outskirts of Front Royal, Virginia, and then in a southerly direction along the crest of the Blue Ridge Mountains to Jarman's Gap near where U.S. Route 250 crosses the summit of the Blue Ridge Mountains at Rockfish Gap, a distance of approximately 97 miles. In altitude, the Skyline Drive varies from approximately 600 feet at Front Royal to a maximum elevation on the north section of 3,390 feet on the side of Hogback Mountain. 


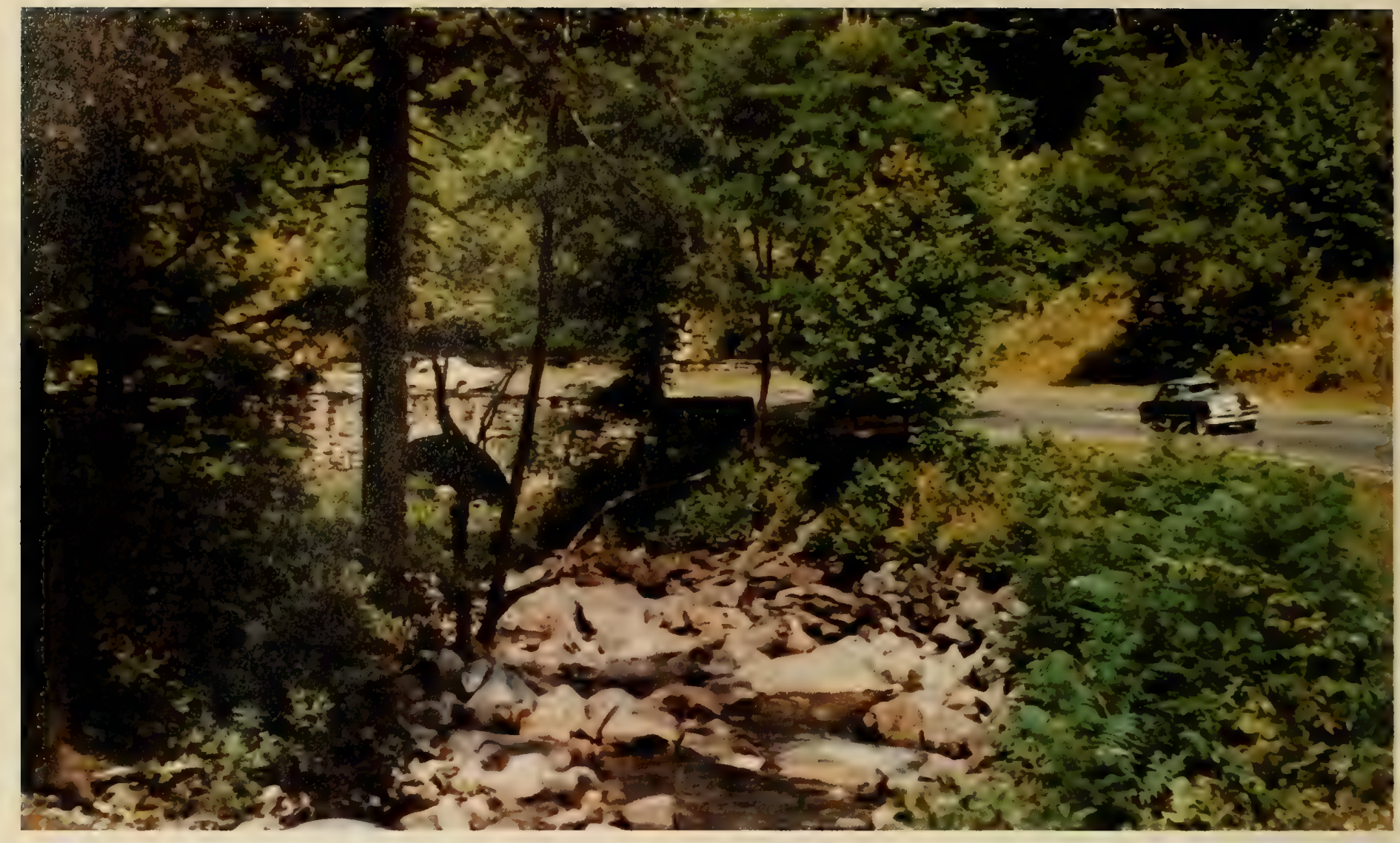

Cole Creek Bridge in the Great Smoky Mountains.

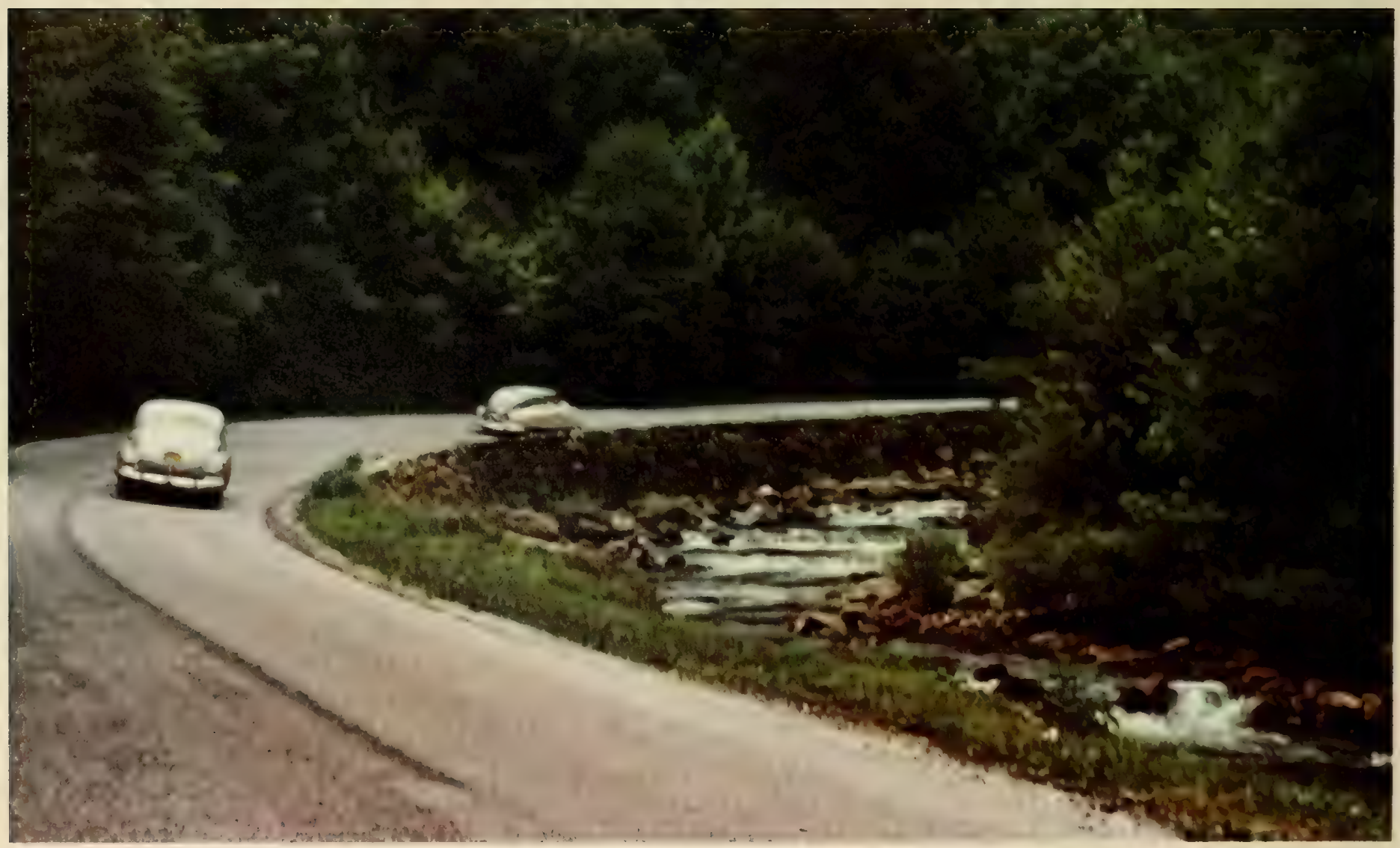




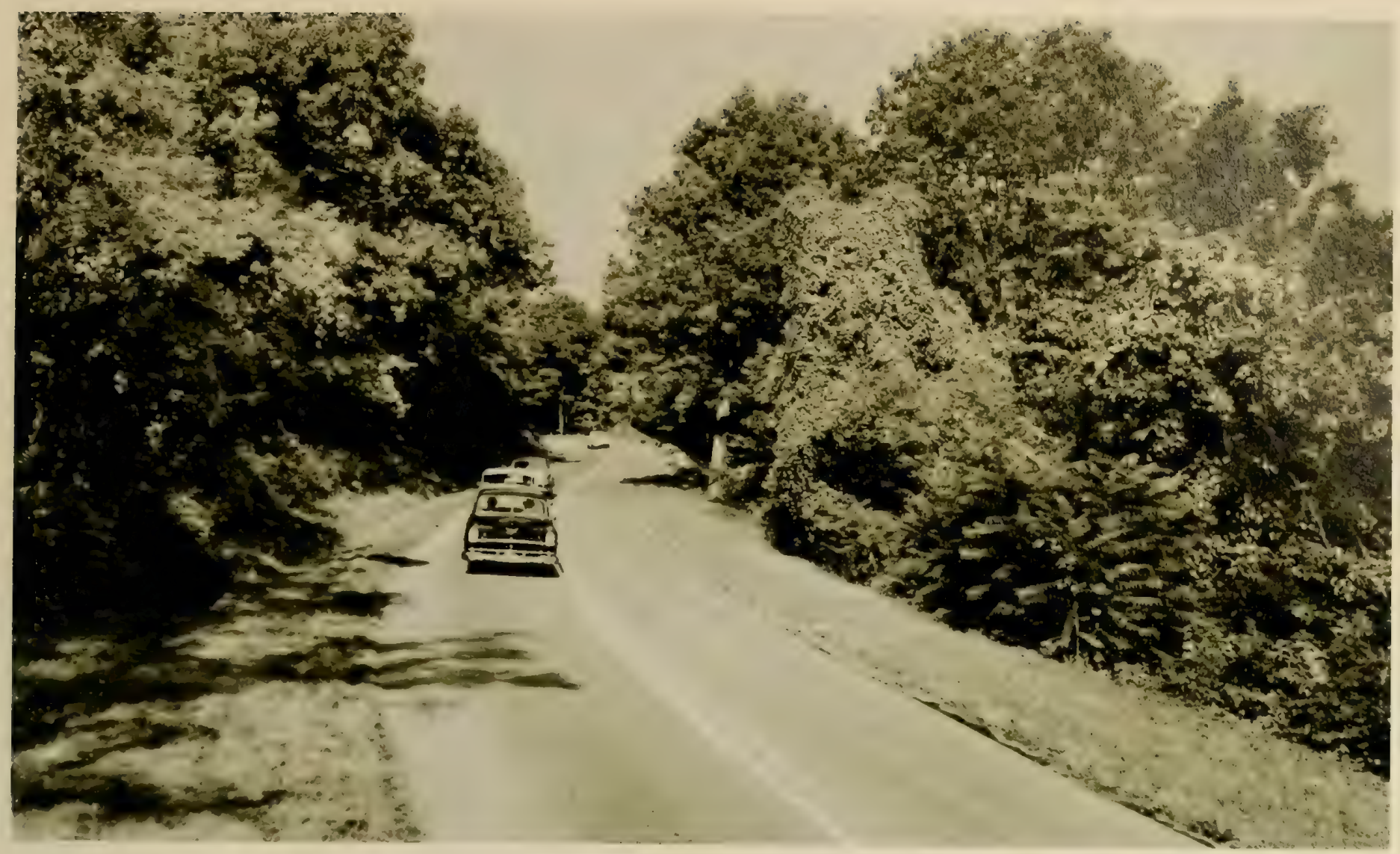

A section of Skyline Drive in the Shenandoah National Park about 9 miles south of Front Royal, Va.

Hand-laid rock embankment at Beacon Hollow Overlook on Skyline Drive.

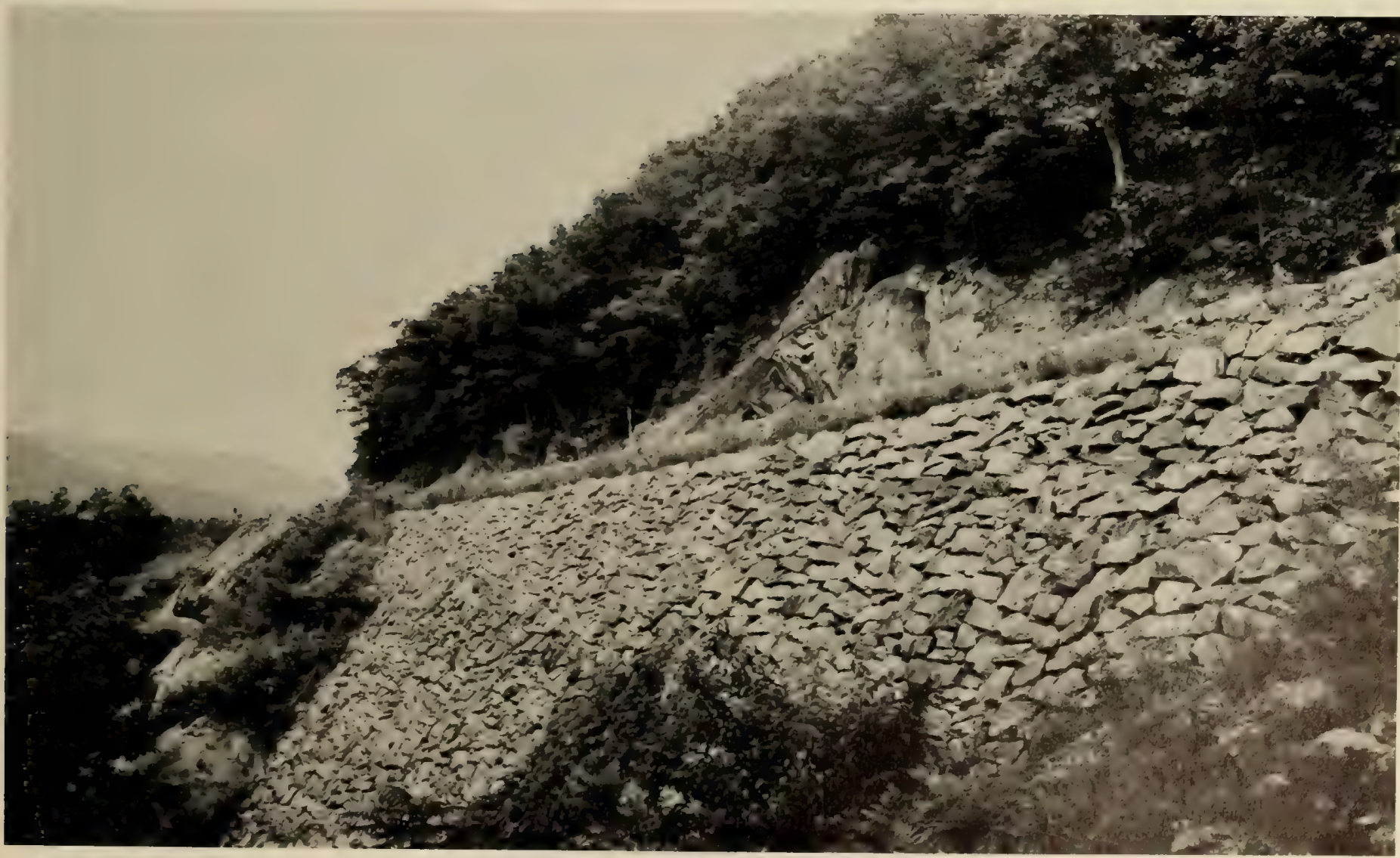




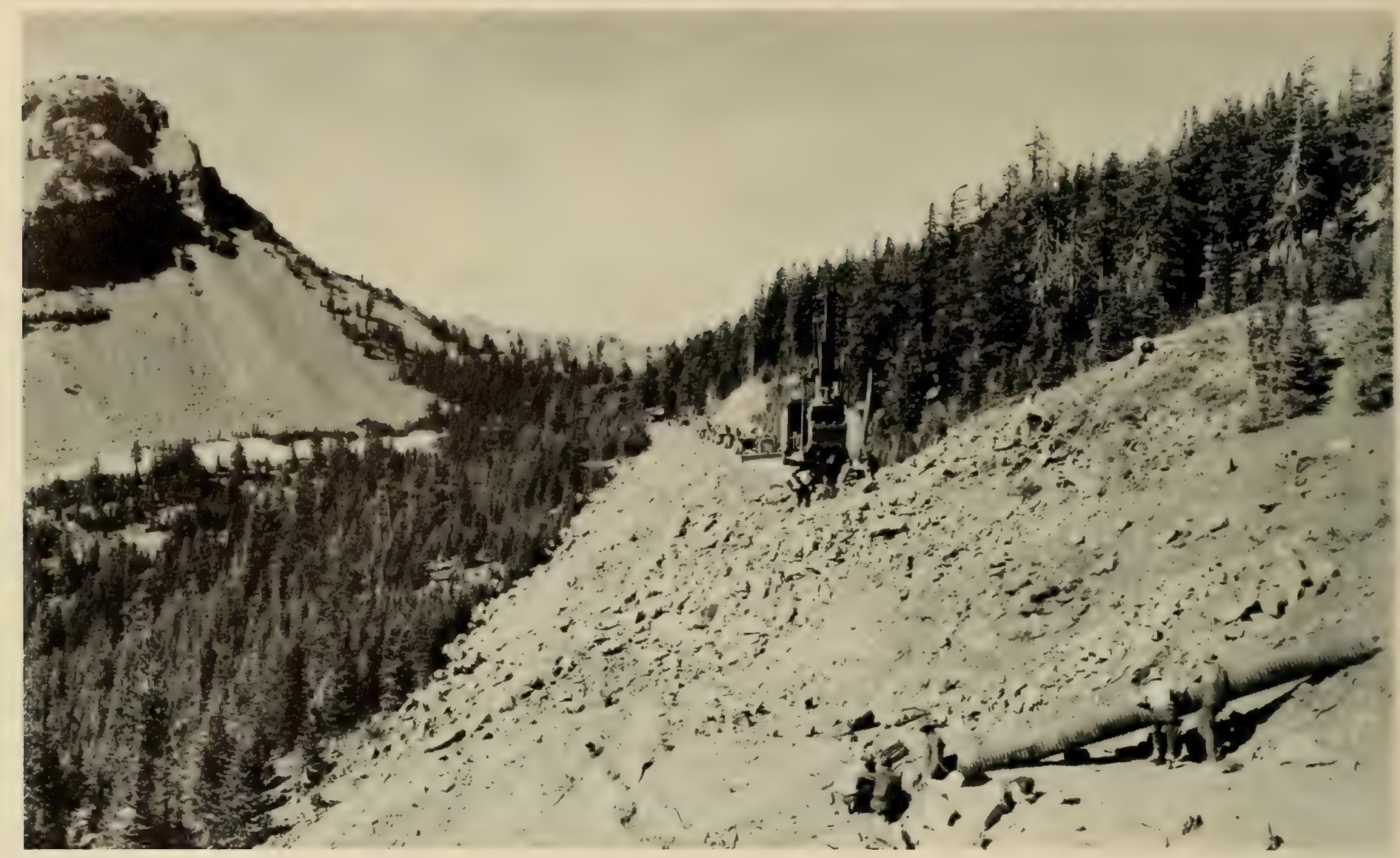

Construction in 1938 of Crater Lake Rim Road switchback along Applegate Peak (at left) in Oregon. Men in foreground are installing a culvert.

Preliminary surveys were started in January 1931 with only 5 months to make surveys, prepare plans, and award contracts for approximately 40 miles of highway. The initial construction work was let under two contracts, a 20-mile section from Thornton Gap to Big Meadows and a 20 -mile section from the Rapidan River via Big Meadows to Swift Run Gap. Both contracts were awarded in the latter part of June 1931.

The Skyline Drive was constructed in three major sections. Part of the first section between Thornton Gap and Swift Run Gap was surfaced by the summer of 1934. Because of the public clamor to use the park road, it was decided to open the Drive on September 15, 1934, between Thornton Gap and Big Meadows. But it soon became impossible to keep tourists off the section from Big Meadows to Swift Run Gap and work was delayed. The surfacing on this part was completed in 1935 .

The northern section between Thornton Gap and Front Royal was placed under contract in 1934, and the final surfacing was completed in time for the dedication of the Park by President Roosevelt in July 1936. The final section of Skyline Drive between Swift Run Gap and Jarman Gap was constructed between 1936 and 1939. ${ }^{30}$

It has been estimated that the grading and base course operations, covering the years 1931 through 1938, provided approximately 2.1 million man-hours of employment and the total construction cost was approximately $\$ 4$ million.
Although begun hurriedly during the Depression to stimulate employment, the blend of this park road into the mountain landscape, providing the most scenic views of the panorama of the foothills of the Blue Ridge Mountains and the plains of Virginia, was no accident. It was the joint effort of the National Park Service landscape architects and the Bureau's highway engineers in carrying out the policy on park roads announced in 1924.

\section{A Master Plan for the National Park System}

Very early the National Park Service had evolved a general development plan or master plan as a guide for the development of each park area in the national park system. The road system plan was an integral part of the overall master park plan and was developed through collaboration of Bureau engineers working closely with the landscape architects and engineers in the National Park Service. It was customary for the road system plan to be approved both by the Director of the National Park Service and the Commissioner of the Bureau of Public Roads. The road system plan provided a means for identifying roadway needs and improvements and allowed for phase construction of park roads and trails.

During the 1940's, much work was accomplished or. the development of the road system plans while the construction program was at a low ebb. However, even though there was a scarcity of materials because of the urgency of the housing program, the mileage on the national park system increased from 1,577 to 1,979 miles. $^{31}$ 


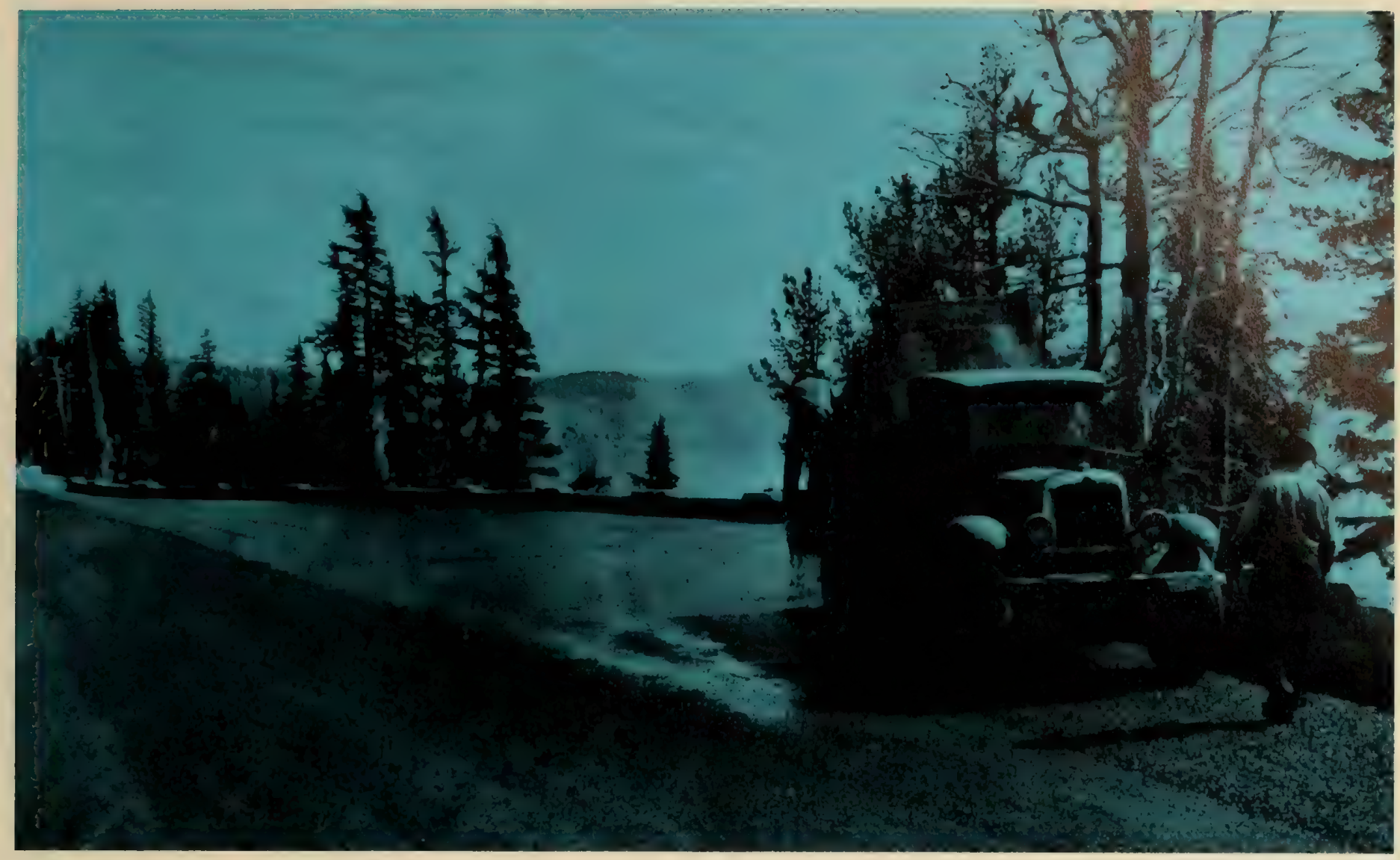

Spreading crushed stone over fresh oil on Crater Lake Rim Road.

\section{Keeping Up With the Vacationers}

After the establishment in 1933 of the national park system, the Bureau of Public Roads was called on to build roads in many of the areas as they were added to the national park system.

The development of the Nation's highway transportation system had also brought a tremendous increase in recreational travel in the years following the close of World War II. Visits to the national park system mounted from a low of 6 million in 1942 to 33 million in 1950 and to 72 million in $1960 .^{32}$

Providing an adequate road system serving each of the national park areas was an essential element of the development of each area. To accommodate the travelers, much work was necessary. For example, during the fifties, the Stevens Canyon Highway in the southeastern part of Mount Rainier National Park in Washington was completed. The Moran-Yellowstone Park approach road, between the Grand Teton $\mathrm{Na}$ tional Park and Yellowstone National Park in Wyoming, was also completed. In the eastern United States, the work included park road construction in the Acadia National Park in Maine, located on beautiful Mount Desert Island, in the Great Smoky Mountains National Park, and in the new Everglades National Park.

The Mission 66 national park 10-year program had as a target date the completion by 1966 of the modernization of the national park system, now comprising 183 separate units. The upgrading of existing park roads and trails, construction of new park roads and construction on the eight national parkways administered by the National Park Service was a major part of this program. Special emphasis was placed on modernizing the Yellowstone National Park road system in anticipation of the celebration of the 100th anniversary of Yellowstone Park in 1972.

One of the last transmountain highways of the West, reminiscent of the early twenties pioneer effort, was the North Cross State Highway in Washington, constructed during the 1960's. After construction was substantially completed, the North Cascades National Park was established. The highway bisects the national park and is its principal access road. Important segments of the highway were designed and constructed as forest highway projects.

Throughout the national park system the unusual terrain features encountered, the necessity to preserve to the maximum extent the natural scene, the fulfillment of park objectives in constructing roads to points of special scenic interest, and to meet the requirements of other park objectives, challenged the best ingenuity of the highway engineer working with the landscape architect.

\section{The Development of Parkways}

A parkway differs from a park road in that the park road is within or leads to a national park or monument and is intended primarily to provide access to the national park without disturbing its beauty. On the other hand, the parkway was developed as a highway primarily for through traffic, excluding commercial vehicles, with full or partial control of access, and usually located either within a park or a parklike setting. 


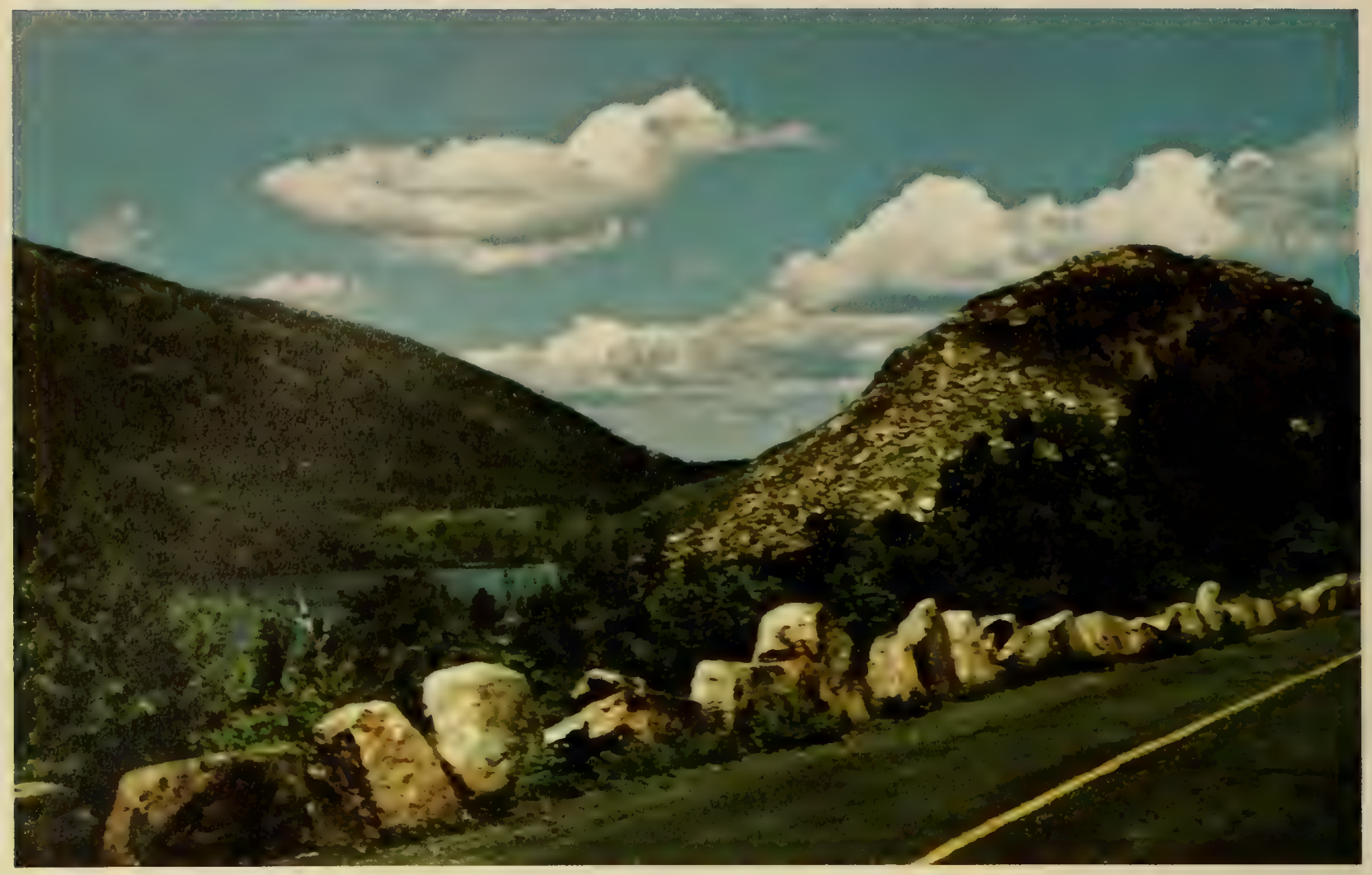

Jordan Pond in the Acadia National Park in Maine.

Early parkways showed the potential of the parkway. The first parkway in the Nation was the Bronx River Parkway completely opened to traffic in 1924. By 1934, 114 miles of parkways existed in the New York City area. These parkways, developed by private authorities to move commuter traffic, generated great interest among highway engineers because of the imaginative design concept. When properly designed, the parkway could serve a twofold purposeit would provide a park and an arterial highway at the same time, and in a manner that would impact favorably upon the surrounding environment.

The design concept was to develop the parkway from the interior outward in such a way as to provide freedom in the determination of the highway location to take maximum advantage of the landscape for scenic vistas and to preserve the parkway environment by suitable planting and screening. The necessity for preserving the arterial highway aspect was also recognized, and access to the parkway was provided only at long intervals. Special attention was given to the development of interesting alinement by long, easy curves fitted to the natural contour of the land, with special emphasis given to the landscaping scheme so that the completed road became a part of the natural countryside. ${ }^{33}$

The concept of national parkways under the authority of the National Park Service came about in 1928 when an act of Congress authorized a highway between Mount Vernon and Arlington Memorial Bridge to commemorate the birth of George Washington. National parkways encompass ribbons of land of scenic interest belonging to the U.S. Government and are authorized by an act of Congress. They are not designed for high-speed point-to-point travel, but they do constitute a through traffic highway.

\section{The Mount Vernon Memorial Parkway}

In December 1924, the 68th Congress, by joint resolution, established the United States Commission for the Celebration of the 200th Anniversary of the Birth of George Washington. In May 1928, the 70th Congress passed a law directing the Bicentennial Commission, acting through and using the services of the Department of Agriculture, to construct a suitable memorial highway to connect Mount Vernon, the home of George Washington, with the south end of the Arlington Memorial Bridge which crosses the Potomac River at the city of Washington. The objective was to have the Mount Vernon Memorial Parkway completed in time for the bicentennial celebration in 1932.

The concept of a highway to Mount Vernon originated with a group of public-spirited citizens organized in 1886 and incorporated by the Virginia Legislature as the Mount Vernon Avenue Association in 1888. An interesting sidelight is that the Virginia Legislature simultaneously, by a joint resolution, transferred to the Association a claim for $\$ 120,000$. (The State had loaned this money to the United States Government in 1790 to be used toward the erection of the public buildings at the permanent seat of government in the United States. The loan was paid in person to President George Washington, and the money was disbursed under his supervision.) The General Assembly empowered the Association to collect and receive the claim and the interest on it from the U.S. Government and to use the funds to construct the proposed memorial avenue to Mount Vernon. ${ }^{34}$ 
No tangible progress was made until the passage of the 1928 Act. The Secretary of Agriculture immediately delegated the duty of surveying and supervising the construction of the highway to the Bureau of Public Roads. Earlier the Bureau had made reconnaissance surveys of two possible locations at the request of the Committee on Roads of the House of Representatives, one an inland route and the other a route along the shore of the Potomac River. With the approval of the Bicentennial Commission, the river route was selected as having the greater scenic and historical advantage, and offering superiority for the development of park areas between the highway and the river. ${ }^{35}$ Surveying and determining the final location were begun on June 15, 1928, and the work was pursued with all possible vigor. The development of the Mount Vernon Memorial Highway was most fortuitous because it provided an opportunity for the BPR to further develop the parkway design concept.

In 1930 Congress enlarged the concept of the Mount Vernon Memorial Parkway to provide for the development of a parkway along the shores of the Potomac all the way up to Great Falls in Virginia and from Fort Washington to Great Falls in Maryland, incorporating the parkway section already under construction as part of the George Washington Memorial Parkway.

The Mount Vernon Memorial Parkway was completed on schedule and was dedicated in a special ceremony in conjunction with the annual meeting of the American Association of State Highway Officials in 1932. This occasion afforded highway engineers a chance to see at firsthand an example of the full development of the parkway concept. Forty-four years

The Mount Vernon Memorial Parkway in Virginia a couple years after it was opened to traffic in 1932.

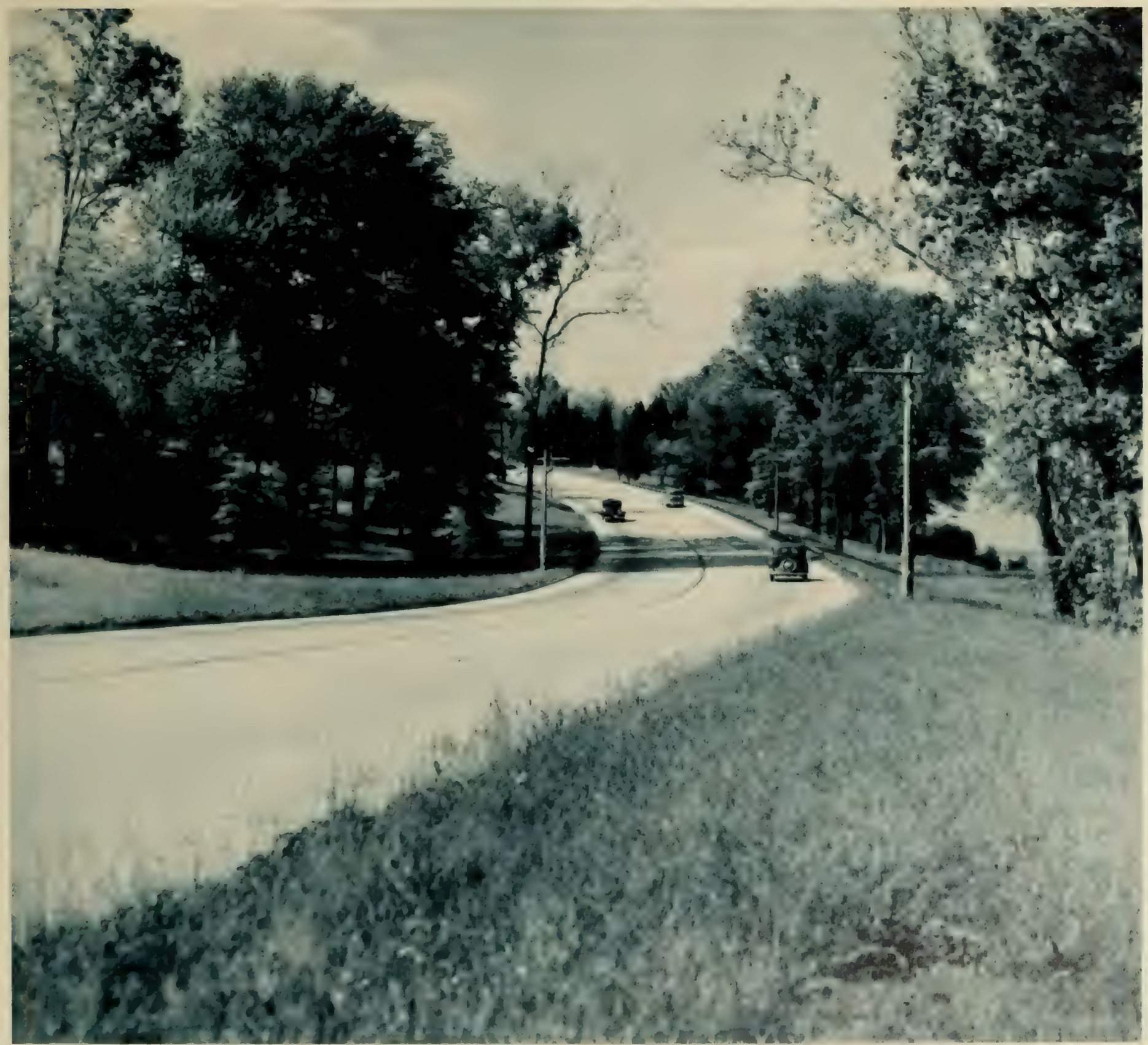





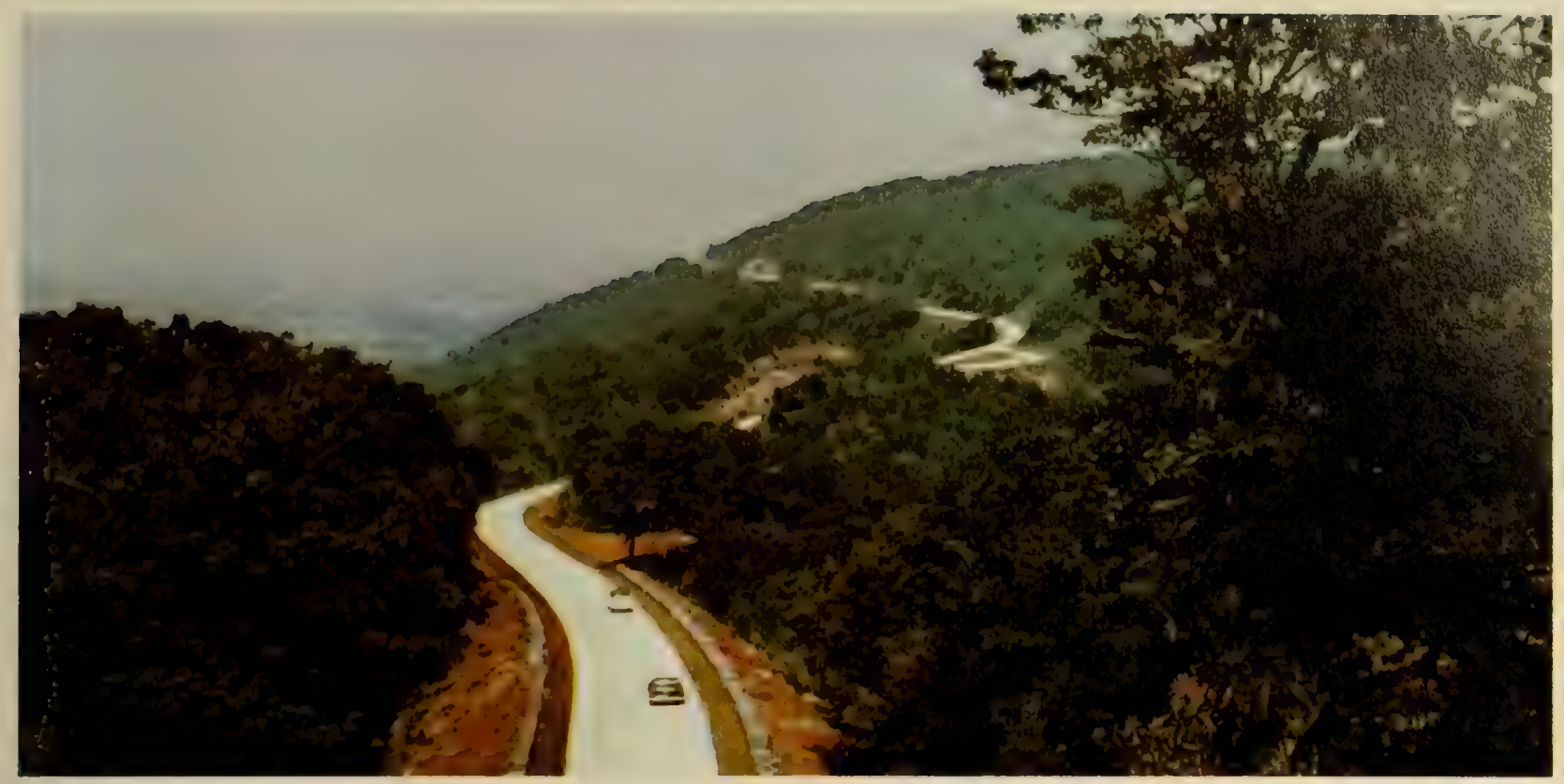

The Blue Ridge Parkway winds along the crest of the mountains.

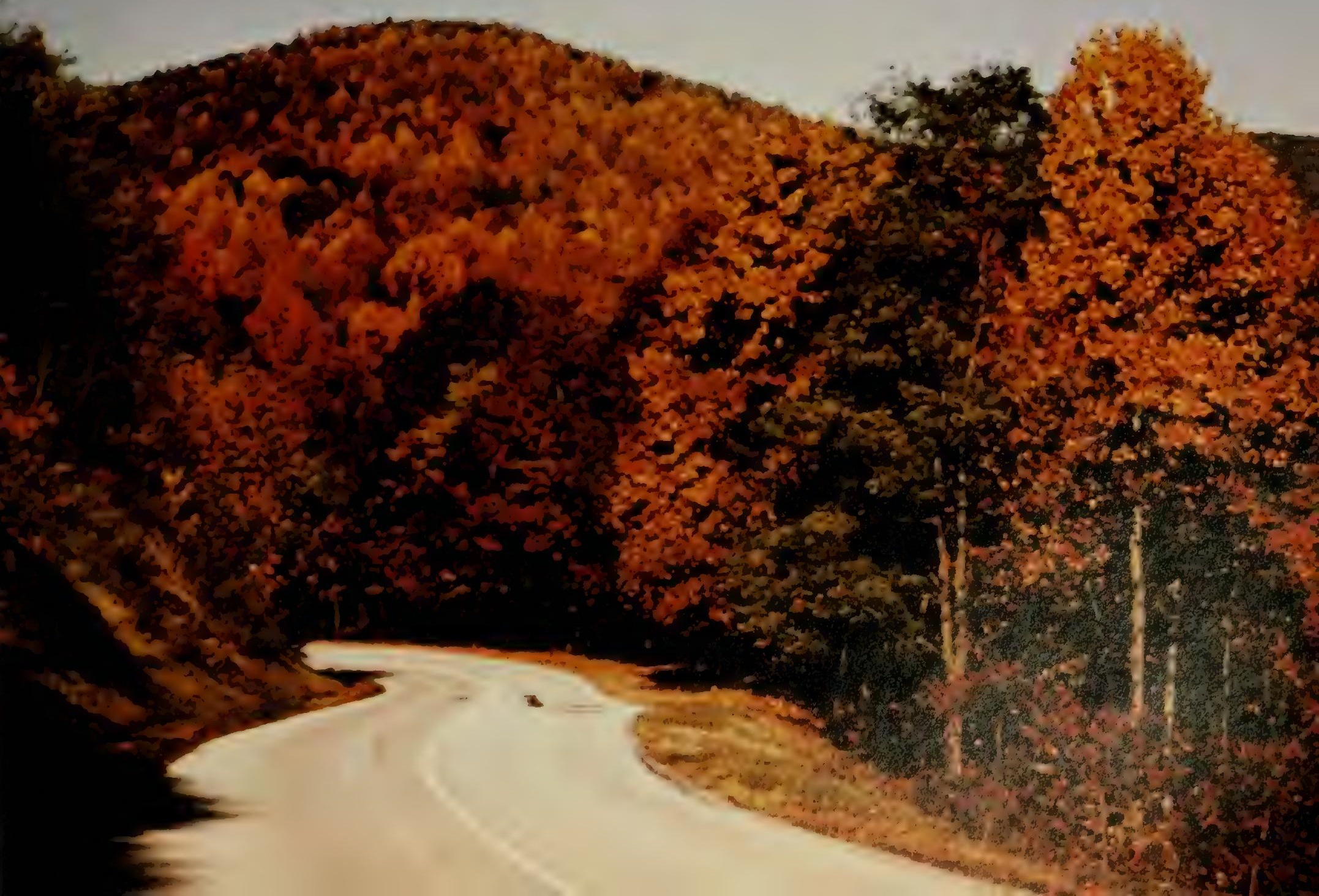



taw Nations permitted construction of a wagon road through their lands. This old Natchez Trace was used by the early pioneers who rafted their produce from the Ohio and Cumberland River valleys via the Ohio and Mississippi Rivers to New Orleans and then returned over the Trace to their homes. ${ }^{40}$ It was also an important military route for General Andrew Jackson's army of Tennessee volunteers during the war of 1812.41 Today the Natchez Trace Parkway extends approximately 455 miles and is about 75 percent completed.

The George Washington Memorial Parkway, the Blue Ridge Parkway, and the Natchez Trace Parkway are covered here to show what is involved in establishing a national parkway. One additional parkway should be mentioned.

In 1930 Congress passed an act establishing a Colonial National Monument of the area which includes Jamestown Island, the 1607 site of the first permanent English settlement, and Yorktown, the scene of the culminating battle of the American Revolution in 1781. The Act also authorized the Secretary of the Interior to examine the feasibility of a parkway through the monument.

The Colonial Parkway, covering 23 miles from Yorktown to Jamestown Island via Williamsburg, Virginia, was opened to traffic in time for the 350th anniversary celebration of the founding of Jamestown.

\section{Defense Access Roads}

During the years of World War II, the normal construction of all highways was stopped, and many employees engaged in this work entered war service. A large contingent of direct Federal construction employees, particularly in the western districts, were assigned to the construction of the Alaska Highway. Others were engaged in the construction of roads to war establishments such as the Indian Head Access Road to the Naval Powder Factory and the military highway to Andrews Air Force Base in Maryland, which was later transferred to the National Park Service and renamed the Suitland Parkway. But aside from the Alaska Highway project, the biggest highway project undertaken during the years of the war was the building of the road system servicing the new War Department building constructed in Arlington, Virginia.

\section{The Pentagon Road Network}

In the summer of 1941, Congress appropriated $\$ 35$ million to be used by the War Department for the construction of a new office building, now known as the Pentagon. The building was to provide office space for 40,000 workers, and in addition, other defense installations were planned in the immediate vicinity. The War Department requested the Federal Works Agency to undertake the layout and design and to supervise the construction of the highway network to service the new War Department building.

The Natchez Trace Parkway in Mississippi.

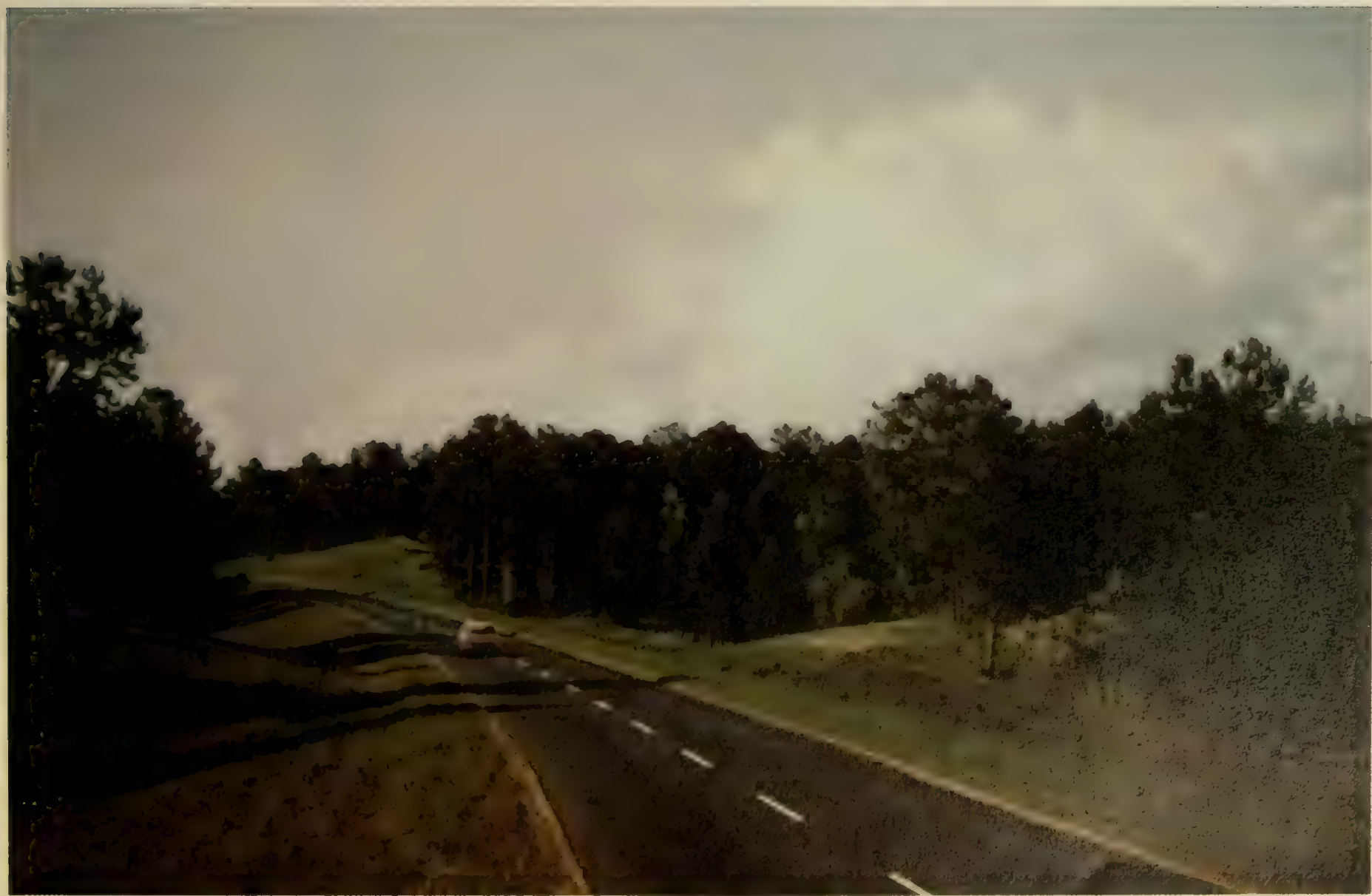


The inadequacy of roads approaching the Potomac River bridges crossing from Virginia to Washington, D.C., had been a matter of increasing concern for many years. For example, in January 1934, Chief MacDonald prepared a report on the situation for the National Capital Parks and Planning Commission. The report proposed a plan for a system of arterial highways to be used as a basis for a progressive program of improvements. Through the years, little was accomplished toward these objectives, and by 1941 the traffic flow across the Memorial, Key, and 14th Street bridges had reached an average daily total of 118,000 vehicles, with an hourly peak flow close to 11,000 vehicles.

The request from the War Department required the best design and planning engineers available. A special design section was established in the Public Roads Administration's headquarters. Engineers were assembled from field offices to work on the largest single design project ever undertaken by Public Roads up to that time.

The design problem was superimposing a new high traffic volume created by the new government office buildings on an already congested road system. The location of the existing bridges across the Potomac River, the proximity of Arlington Cemetery, the necessity of connecting the principal highways, and the requirement that the design be functional as well as esthetically compatible, posed formidable problems.

Coincident with the studies for the Pentagon network, the Virginia Department of Highways conducted studies for a new highway from Woodbridge, Virginia, to Arlington, to bypass Alexandria and connect with the Potomac River bridges. (This highway today is known as the Henry G. Shirley Memorial Highway.)
In September 1942, agreement was reached that the portion of the Shirley Highway from an interchange with Virginia Route 7 to the connection with the Pentagon network would be certified by the War Department as a defense access road project, and the Public Roads Administration was directed to build it. Responsibility for construction of the two projects was assigned to Region 15, Eastern Parks and Forests Roads. The work was completed in $1952 .{ }^{42}$ The Pentagon network today is a part of $\mathrm{I}-95$ and has been reconstructed with some new alinement under the Interstate program.

\section{Access Roads for the Bureau of Land Management}

In 1949 the Interior Department Appropriation Act for 1950 provided for construction of access roads on and to grant lands that had been returned to the Federal Government in the early 1900's. These lands, known as "O \& $\mathrm{C}$ lands," were under the jurisdiction of the Bureau of Land Management (BLM), and in 1950 a Memorandum of Agreement was drawn up between BLM and BPR identifying responsibilities for the work. The Interior Department Appropriation Act for 1951 directed that funds be turned over to BPR.

The $\mathrm{O}$ \& $\mathrm{C}$ lands were originally two separate land grants. The first was the Oregon and California Railroad grant in 1866 for a railroad from Portland to the California border consisting of odd numbered sections on each side of the road location for a 20 -mile wide strip. In 1869 limitations were imposed that the land could be sold only to bona fide settlers and that not more than 160 acres at not more than $\$ 2.50$ per acre could be sold to any one person. However, the conditions of the grant were violated, and in 1915

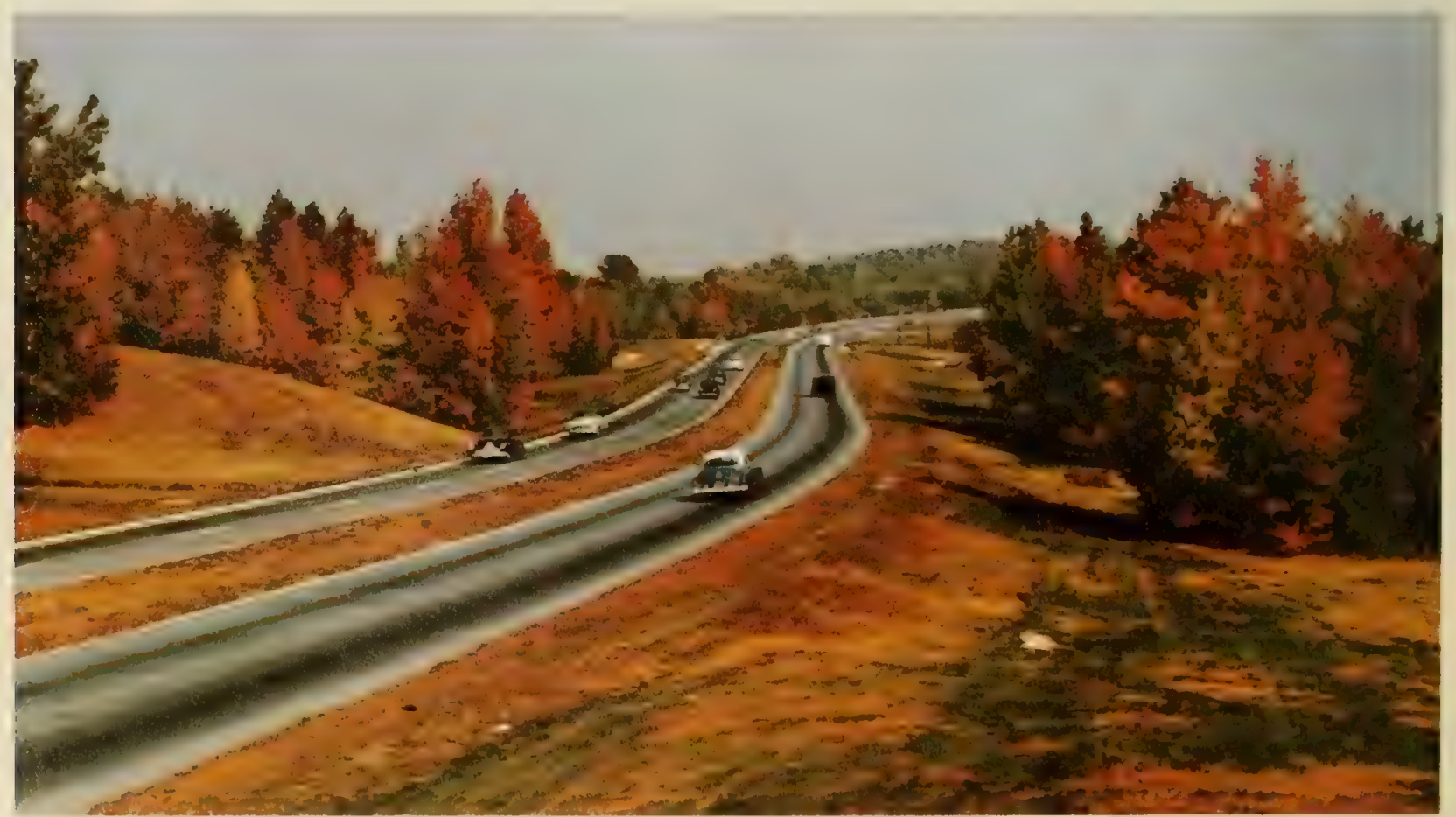




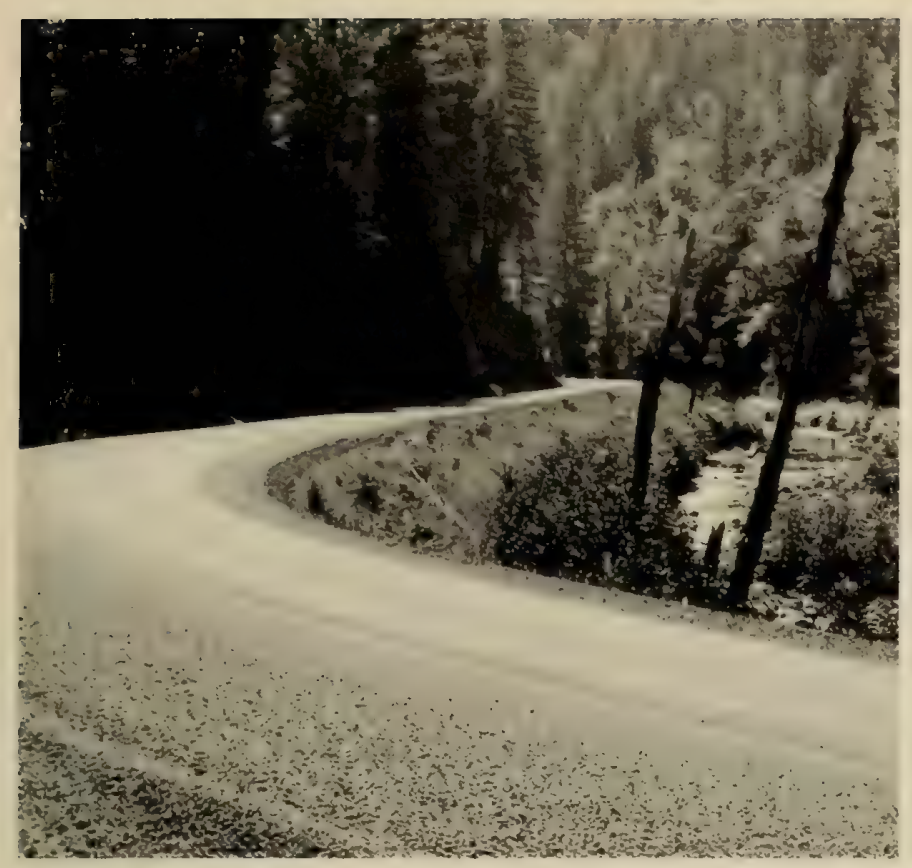

The Nestucca River Road in the Oregon Coast Range was improved in 1967 for use as a timber access road, but it has become an area also used for recreational purposes.

the Supreme Court enjoined the Company from further disposition of lands. About 2.9 million acres were returned to the Federal Government in 1916. The other piece of land was granted in 1868 to the Southern Oregon Company for a wagon road between Coos Bay and Roseburg consisting of three alternate sections per mile in a strip 3 miles on either side of the wagon road location. When this land was returned in 1919 for similar reasons, the Federal Government reclaimed 93,000 acres. $^{43}$

The $\mathrm{O} \& \mathrm{C}$ lands are located in the Coast Range and on the western slope of the Cascades in Oregon and contain very valuable and productive timber lands. At the time of the 1950 agreement, the $\mathrm{O}$ \& $\mathrm{C}$ lands were essentially unroaded and isolated. The roads designed and constructed under BPR supervision made these lands accessible for timber production.

The major impact of the road construction was the improvement in the local economy stimulated by the logging operations. Timber available for sale went from 500 million board feet in 1937 to 1.2 billion board feet presently available, or about 3 percent of the Nation's total production. In addition, receipts for fiscal year 1976 were $\$ 118$ million, of which 50 percent is returned to the 18 counties for such uses as roads, schools, public works, and other needs of the counties. The Treasury Department receives 25 percent of the remainder and BLM uses the other 25 percent to manage the lands. ${ }^{44}$

Funds transferred to BPR for design and construction have ranged from an initial $\$ 550,000$ for fiscal year 1951 to $\$ 11.6$ million for fiscal year 1975 . Since 1954 BPR has also been responsible for the performance of the maintenance work on these roads. To date, BPR has constructed 4,900 miles of one- and two-lane roads on the $\mathrm{O} \& \mathrm{C}$ lands. Although initially developed as timber access roads, most of the roads are open to the public, and recreational use of these roads has increased substantially in recent years.

\section{Demonstration Projects Program}

In 1969 a Demonstration Projects Program was established in Region 15 with the objective of promoting, by demonstration, the application of new technology as it applied to highway location, design, construction, maintenance, and operation. This program was to reestablish one of the most successful programs initiated by the original Office of Road Inquiry in 1897 and carried on as a major program effort for many years thereafter-the construction of "object lesson roads" and the conduct of demonstration programs. This program was established in Region 15 because this office had experienced most every type of highway construction under a wide range of field conditions and because the Region 15 project personnel included competent practicing highway engineers and technicians who could communicate readily with their counterparts in the FHWA headquarters $\mathbf{R}$ and $\mathrm{D}$ and field offices and State transportation agencies.

Since the establishment of the Demonstration Projects Program, many successful demonstration projects have been carried out. Particularly noteworthy was the construction on the grounds of Dulles Airport in 1972 of one of the first prestressed reinforced concrete pavements and the construction of a large parking lot in conjunction with the Transpo '72 exhibition, using a calcium sulphate sludge and fly ash as a base stabilization product.
The Chaco Wash Bridge on the Navajo Indian Reservation in New Mexico was built by agreement for the Bureau of Indian Affairs. Note the rock and wire channel protection in the right foreground.

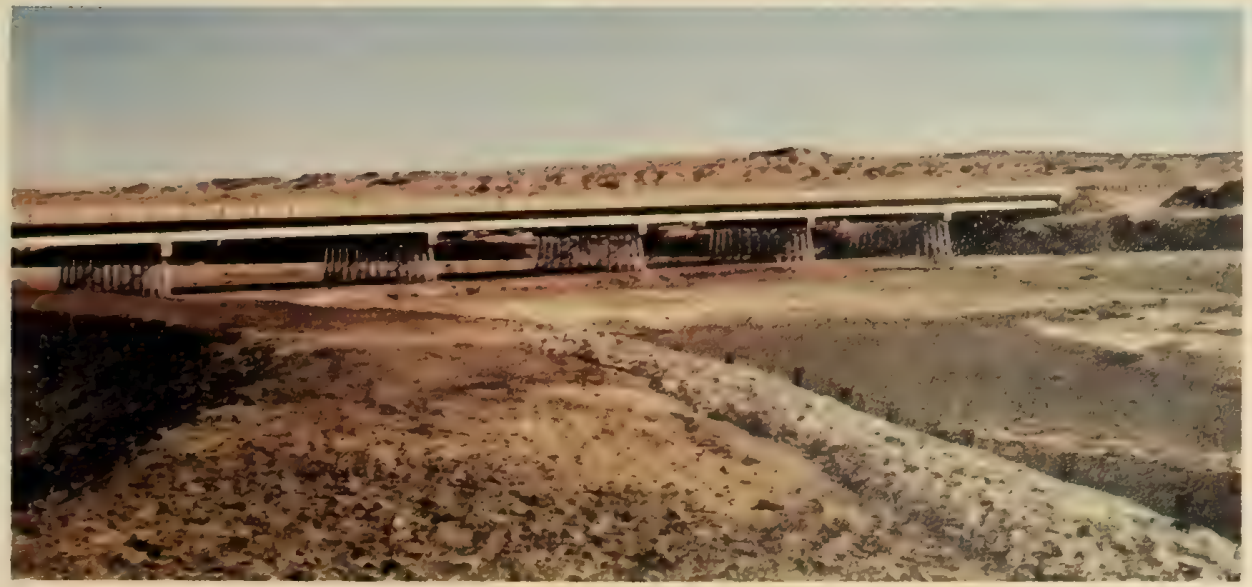




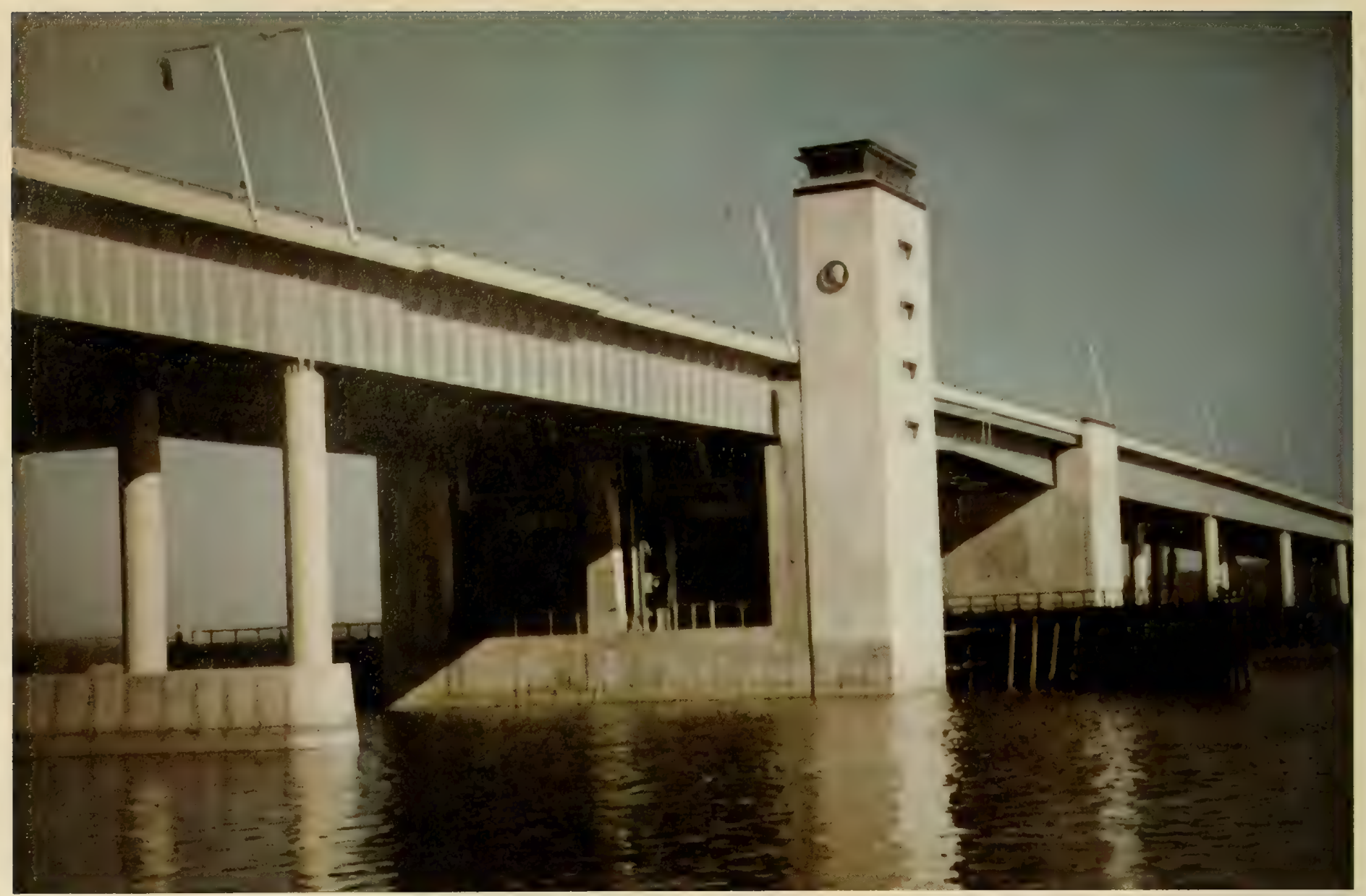

The Woodrow Wilson Memorial Bridge on I-495, the Capital Beltway, crosses the Potomac River south of Washington, D.C.

In 1974-75 a program for detecting the premature deterioration of reinforced concrete highway bridge decks as a result of using deicing salts became available for demonstration. It was a two-part project, the initial project being a series of evaluation techniques to determine the degree of damage already occurring in the bridge deck and the second project demonstrated an electrical method to stop the corrosion of reinforcing steel occurring in the bridge deck.

Erosion along highway rights-of-way, particularly at major drainage structures, has presented the highway engineer with numerous design, construction, and maintenance problems. These problems exist because the construction of a highway system often disrupts, and in many instances alters, natural drainage networks. This disruption and alteration generally results in high velocity flow within highway drainage structures. While this is desirable from the standpoint of carrying large volumes of runoff in relatively small structures, it frequently leads to serious erosion problems. A demonstration project was established to educate and train highway engineers on the proper selection and design of a broad range of flow control devices which serve to dissipate the hydraulic energy.

Two other demonstration projects expected to benefit State agencies in cost-effectiveness planning are the demonstration of noise measurement techniques, equipment systems, data interpretation, and the demonstration of air quality monitoring devices. By the requirements of the 1970 Federal-Aid Highway Act, noise level standards and air quality guidelines were developed. The demonstration projects make known to the State agencies the equipment available to make necessary measurements, techniques for analyzing the data and projecting the impact of planned construction projects, and to assist the States in selecting the equipment suitable to their particular needs based on cost/benefit.

The Demonstration Projects Program attempts to touch on every aspect of concern within the highway industry. In addition to the five projects above, the Demonstration Program included demonstrations on safety (High Performance and Energy Absorbing Bridge Rails), waste materials (Discarded Tires in Highway Construction), conservation of natural resources (Recycling Asphalt Pavements), public education (Highway Photomontage) to translate the technical information of highway planning and design so that the community can become knowledgeably involved, design (Automated Design System), and many other features, concepts and techniques.

The success of any program is its measure of effectiveness in terms of real world results. Just as the object lesson roads of the early days of the Federal Highway Administration broadcast the knowledge available and how to do it with the materials at hand for cost/benefit, so also is the purpose of today's Demonstration Projects Program. The long-range objective of both efforts is a more economical environmentally acceptable transportation system for the good of the country. 


\section{A Program to Enrich the Quality of Life}

In addition to the work performed for the Forest Service, the National Park Service, the War Department, and the Bureau of Land Management, the Federal Highway Administration has standing agreements with the Bureau of Indian Affairs, in the Department of the Interior, and with several other agencies to construct roads on lands under their jurisdictions upon request.

An interesting project developed when, in 1956, Congress directed that the Bureau of Public Roads should build the Woodrow Wilson Memorial Bridge. This 5,900-foot bridge across the Potomac River is a vital link in the Capital Beltway around Washington, D.C. Region 15 supervised the construction of the bridge because the bridge involved three governmental jurisdictions-Virginia, the District of Columbia, and Maryland. The Woodrow Wilson Memorial Bridge was opened to traffic in 1961.

The Federal Highway Administration has, for a continuous span of 70 years, contributed its highway engineering expertise to the planning, location, design, and construction of roads in the Federal domain for other government agencies. The many beautiful highways and parkways constructed under this program are a legacy for future generations to enjoy as they continue to serve the transportation system in the national forests and parks and other Federal domain areas.

In 1973, citizens visited the national forests and national park system areas in record numbers-188 million visitor-days in national forests and 215 million visits to national park system areas. These figures speak for themselves in rating the contribution the direct Federal highway program has made to enriching the quality of life for our Nation.

\section{REFERENCES}

${ }^{1} R$. Lee, Family Tree of the National Park Service (Eastern National Park and Monument Association, Philadelphia, 1972) p. 9.

${ }^{2}$ Public Roads administration, Report to the Committee ON Roads, House of Representatrues, Forest Highway Srstem (Federal Works Agency, Washington, D.C., 1940) p. 2.

'Bureau of Public Roads annuat Report, 1906, p. 23 ; 1907 , p. 21.

'Buread of Public Roads Annual Report, 1916, pp. 5, 6.

"A. LODER, The Location and Building of Roads in the National Forests, Public Roads, Vol. 1, No. 4, Aug. 1918, p. 7.

${ }^{8} I d ., \mathrm{p} .5$.

${ }^{\top}$ L. Hewes, Federal Road Building in the National Forests of the West, Public Roads, Vol. 3, No. 26, Jun. 1920, p. 18.

${ }^{8}$ Bureau of Public Roads annual Report, 1921, p. 20.

- Bureau of Public Roads annual Report, 1929, pp. 37, 38.

${ }^{10}$ Buread of Public Roads Annual Report, 1939, pp. 62, 63.

${ }^{11}$ U.S. Department of Agriculture, ANnual Report of the Forester (GPO, Washington, D.C., 1932) p. 23.

${ }^{12}$ Forest Lands of the United States, S. Doc. 32, 77th Cong., 1st Sess., p. 9.

${ }^{13}$ Bureau of Public Roads Annuat Report, 1948, pp. 24, 35.

${ }^{14}$ Bubeau of Public Roads annual Report, 1949, p. 38.
${ }^{15}$ Bureau of Public Roads, Report ON the Forest HighWay Study Required By Section $3(b)$ of the Federal-Aid Highway ACt of 1958 (Dept. of Commerce, Washington, D.C., 1960) pp. 1, 2.

${ }^{18} I d$., p. 2.

${ }^{17}$ A. LODER, supra, note 5, pp. 11, 12.

${ }^{18}$ B. O'Brien, The Yellowstone National Park Road System: Past, Present and Future (unpublished dissertation, University of Washington, 1965) p. 10.

${ }^{10} I d$., pp. 81, 96-102.

${ }^{20}$ Memorandum of Agreement Between the National Park Service and the Bureau of Public Roads Rerating to the Survey, Construction, and Improvement of Roads and Trails in the National. Parks and National Monuments, Jan.-Feb. 1926.

${ }^{21}$ S. Mather, Report of the Director of the National Park Service, Annual Report of the Department of the Interior, 1924 (GPO, Washington, D.C., 1924) p. 14.

${ }^{28} \mathrm{~B}$. O'Brien, supra, note 18, p. 125.

${ }^{23} \mathrm{~S}$. MATher, Report of the Director of the National Part Service, Annual Report of the Department of the Interior, 1925 (GPO, Washington, D.C., 1925) p. 65.

${ }^{24} \mathrm{~S}$. MATher, Report of the Director of the National Park Service, Annual Report of the Department of the Interior, 1923 (GPO, Washington, D.C., 1923) p. 14.

${ }^{25}$ U.S. Department of THE INTERIoR, Finat REPOR' OF THE Southern Appatachian National Park Commission to the SECRETARY OF THE INTERIOR, June 30, 1931 (GPO, Washington, D.C., 1931) p. 8.

${ }^{26}$ T. MacDonatd, The Bureau of Public Roads and Its WoRk (BPR, Washington, D.C., June 1930) pp. 42, 43.

${ }^{27} I d$., pp. $40-42$.

${ }^{28}$ R. LEE, supra, note 1, pp. 21-35.

${ }^{29} \mathrm{BPR}$, supra, note 10 , pp. 63,64 .

${ }^{30} \mathrm{~B}$. Smith, The Story of the Skyline Drive, The VIrginia Road Butlder, Vol. I, No. 4, Nov. 1945, pp. 11, 12 ; Vol. I, No. 5 , Jan. 1946, pp. 6-8; Vol. I, No. 6, Mar. 1946, pp. 8, 9; Vol. II, No. 1, May-Jun. 1946, pp. 8, 9; Vol. II, No. 2, Jul.-Aug. 1946, pp. 8-11; Vol. II, No. 3, Sept.-Oct. 1946, pp. 10, 11.

${ }^{31}$ Bureau of Public Roads Annual Report, 1949, p. 105.

${ }^{32}$ R. LEE, supra, note 1 , p. 38.

${ }^{33}$ E. JAMES, Parkway Features of Interest to the Highway Engineer, Public Roads, Vol. 10, No. 2, Apr. 1929, pp. 21, 22.

${ }^{34}$ J. Reavis, Mount Vernon Avenue, a National Memorial Highway From Washington to Mount Vernon (Mount Vernon Avenue Association, Washington, D.C., 1888) pp. 4-7.

${ }^{35} \mathrm{R}$. Toms \& J. Johnson, The Design and Construction of the Mount Vernon Memorial Highway, JourNaL OF THE AMERICan Concrete Institute, Vol. 3, No. 8, Apr. 1932. p. 563.

${ }^{38} \mathrm{H}$. Jolley, The BuUe Rtdge Parkway (University of Tennessee Press, Knoxville, 1969) pp. 12, 13.

${ }^{37} \mathrm{H}$. Spelman, Design and Construction Features of the Blue Ridge Parkway, Roads and Streets, Vol. 79, No. 7, Jul. 1936, pp. 27, 28.

${ }^{38} \mathrm{H}$. Spexman, Tunnels and Bridges Solve Diffcult Location Problems on 476-Mile Blue Ridge Parkway, Civil ENgineering, Vol. 17, No. 7, Jul. 1947, p. 20.

${ }^{39}$ Natchez Trace Parkway Survey, S. Doc. No. 148, 76th Cong., 3d Sess., pp. v, 150.

${ }^{40} I d$., pp. 26, 31, 32.

${ }^{41} I d$., pp. 82, 83, 85.

${ }^{42}$ F. Cron, Appendix A, Statement of Historical Reference Relating to the Development of the Pentagon Road System and the Connecting Shirley Memorial Highway, Oct. 24, 1960, unpublished appendix to Pentagon Area Transportation STUdY (BPR, Washington, D.C., 1961).

${ }^{43}$ Information from unpublished material in the Division of Forestry in the Bureau of Land Management, U.S. Department of the Interior.

"Interview with Robert Bainbridge of the Division of Forestry in the Bureau of Land Management, U.S. Department of the Interior. 


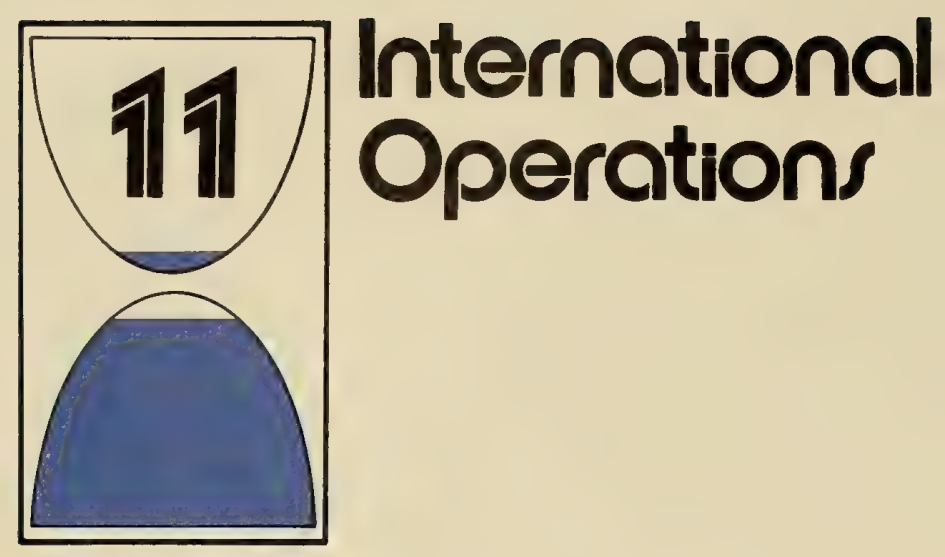

Concurrent with the extensive development of highways in the United States, the Federal Highway Administration and its predecessors have traditionally carried out a number of important projects and operations in the international field. Three of the major international efforts undertaken have been the Alaska Highway, the Inter-American Highway, and a continuing technical assistance program to foreign countries. Also, with transportation research assuming an increasing international importance in recent years, the international exchange of information and the coordinated multinational development of transportation research has become an important function in the research and development programs of the Federal Highway Administration (FHWA).

In its international operations, the FHWA cooperates with major financial and developmental institutions, such as the International Bank for Reconstruction and Development, the Inter-American Development Bank, the Export-Import Bank, the United Nations, the Organization of American States, and the Department of State through its Agency for International Development (AID). In addition, foreign contacts have been established through international technical seminars and technical forums sponsored by such groups as the International Road Federation and basic engineering societies.

Perhaps the two best known projects the FHWA has worked on outside of the United States are the Alaska Highway and the Inter-American Highway. The Alaska Highway was an urgent World War II undertaking, requiring slightly over 2 years to construct, while the Inter-American Highway, begun about 1930 , has only recently been completed with a paved surface. Just south of the southern terminus of the Inter-American Highway, the Darien Gap Highway is now under construction as a final link between North and South America. Neither of these endeavors has been the sole responsibility of the FHWA, but in both instances, the FHWA has been the prime motivator on the technical aspects of the undertaking. The greatest contribution to world transportation has been FHWA's technical assistance programs in many countries around the globe.

\section{Early International Exchanges}

Today it is common to think in terms of global events and places, but near the turn of the 20th century, American engineers were already very much aware of the events and technological advances abroad. With the clamor for roads growing constantly stronger in the 1890 's, the Department of State initiated a project to gather information concerning European road laws and methods of construction. This information was a factor in stimulating the Congress in 1893 to establish in the Department of Agriculture the Office of Road Inquiry.

One of the first published studies of the Office was Cost of Hauling Farm Products in Europe. An international influence can also be seen in the 1901 Annual Report of the Office of Public Road Inquiries (OPRI). In the section on Testing of Road Materials, Director Martin Dodge stated "The importance of laboratory tests on road materials has long been recognized both in this country and in Europe. For over thirty years the national schools of roads and bridges of France have conducted careful tests of all materials used in the construction of National highways. These laboratory tests have been the means of 


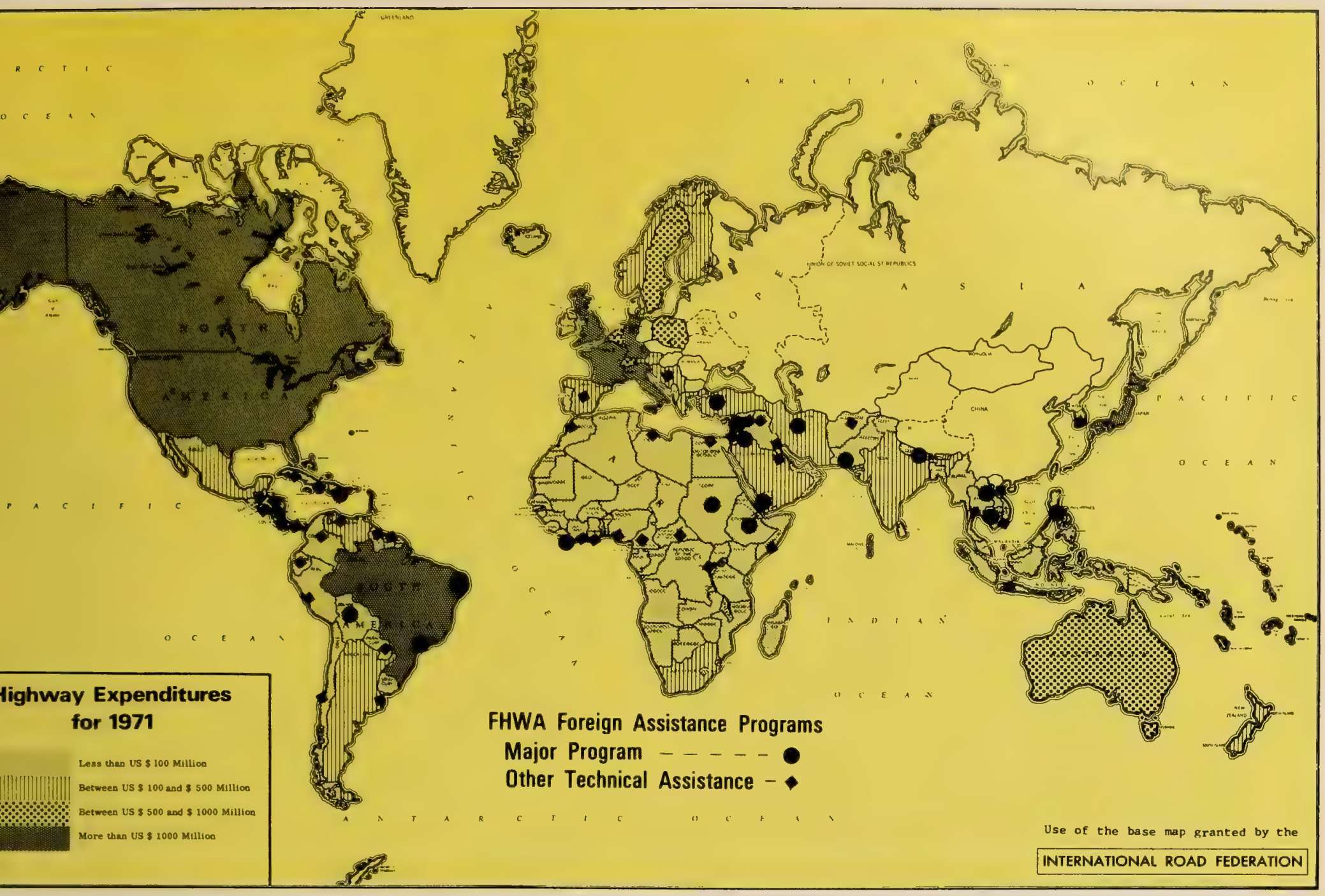

The Federal Highway Administration and its predecessors have sent engineers and technicians throughout the world to help build and maintain roads.

greatly reducing the cost of road construction, and it is a well-known fact that the French roads are the best in the world. ..." 1

The OPRI first participated in an international event in 1900 when the Office built an object lesson road for observation of engineers and officials attending the First International Good Roads Convention at Port Huron, Michigan. "A special feature of the work was that the traction engine was used instead of horses to draw the road machine and dumping wagons, which plan proved very satisfactory. Thus, the traction engine served the treble purpose of furnishing power for the crusher, drawing the road grader, etc., and rolling the road." 2

In 1908 Maurice O. Eldridge, Chief of Records, Office of Public Road Inquiries, submitted a paper on "Cost of Road Building in the United States" for the First International Road Congress in Paris, France. In the same year, a new investigation by OPRI of road construction, maintenance and administration in foreign countries was also in progress. ${ }^{3}$

By 1910 the library of the Office of Public Roads (OPR) was receiving periodicals and reports from the major European countries. In 1911 the library reported ". . . Foreign countries which are issuing reports concerning highway activities have also placed this office on their mailing list in exchange for similar courtesies from us [Public Roads]." 4*

In 1913 the OPR made its first exhibition outside the United States. Financed by a special appropriation from Congress, an exhibit was set up at the International Dry Farming Congress in Lethbridge, Canada. It was also in this year that Congress requested the Department of State to obtain the latest information available concerning 17 items of highway development from some 19 countries of Europe and Asia. When this material was obtained, it was studied by OPR officials and given to Congress for their use in considering legislation.

During the next 8 years, which included World War I, the Office had little foreign exchange of information on peacetime road developments, but U.S. research and development in this area accelerated

* The 1912 Annual Report noted, "The office has also received large collections of city engineer's reports from Australia, Austria, Belgium, British Guiana, Canada, China, Costa Rica, Cuba, Denmark, Ecuador, Egypt, England, France, Germany, India, Ireland, Italy, Jamaica, the Netherlands, Norway, Peru, Romania, Russia, Salvador, Scotland, Straits Settlements, Sweden, Switzerland and the Union of South Africa." 
rapidly. When the Department of Agriculture decided in 1922 to send an exhibition to the Brazilian International Centennial Exposition, the Bureau of Public Roads (BPR) was selected to participate. Its exhibit was a large model of a gravel road in various phases of construction placed in front of a realistic background supplied by an oil painting. For this meeting a special report explaining the work of the Bureau and its exhibit was prepared, translated into Portuguese, and distributed. ${ }^{5}$

Following the successful demonstration at the Brazilian exhibit, Chief MacDonald was appointed as a delegate to attend the first Pan-American Road Congress in Argentina in October 1925. H. H. Rice, Chairman of the U.S. Delegation, clearly defined the reasons for participation in this Congress when he stated:

We feel that our mission is especially important on account of this country's long and costly experience in establishing an adequate system of highways. Those who have been connected with the good roads movement in the United States since its inception have learned many lessons which should be of the greatest value to any other nation in the earlier stages of highway development.

If, by citing our own experiences, we can help our sister nations of the south to avoid the needless waste of time and millions of dollars of money which we were obliged to go through before highway construction had become systematized as it is now in this country, we feel that our return trip to South America will be productive of ... good results....

After his return from this Congress, Chief MacDonald presented a paper titled "Our International Relations as Shown by the Pan-American Congress at Buenos Aires" to the 11th Annual Meeting of AASHO. In concluding his address, Chief MacDonald established what was to be the guiding policy of the Bureau when he stated:

What is here written must be heard for its one purpose-rather two purposes. The first is to stimulate our own imagination and to sustain a more profound faith in this work of highway building. The other is to point one way in which we may be of the greatest service to these other countries. There are many opportunities open to help in the tremendous highway improvement program they must have... There is a definite responsibility upon this generation for the establishment of international relations of enduring character. In the next quarter century these will be of greater importance. The solidarity of the Western Hemisphere and the opportunity for each republic to work out its own destiny under favorable and helpful conditions is the end sought. Without highway improvement of magnificent proportions these conditions are impossible. Mutual sympathy and helpfulness is the spirit of Pan Americanism. It is the finer statesmanship. ${ }^{7}$

Shortly after this, the Bureau appointed a technical advisor to the American Delegation at a Conference on Automobile Circulation held in Paris, France.

In October 1930 the Sixth International Road Congress was held in Washington, D.C., with the Chief of the Bureau of Public Roads serving as Secretary-General of the American Organizing Commission. Engineers from 64 countries attended. The Congress consisted of general discussions and reports of road problems of mutual interest to all engineers.

At about this same time, in line with the policy expressed by Chief MacDonald, the Bureau became actively involved in the design and construction of the Inter-American Highway. But with the increased load of national recovery programs in the mid-1930's, very little attention was given to other overseas operations or exchanges.

In 1938, Chief MacDonald presented a paper at the 24th Annual Meeting of the AASHO titled "Contrasting United States and European Practice in Road Development." $\mathrm{He}$ pointed out significant developments on the European scene, such as the German autobahn, and emphasized the benefits to be gained by the study and application of events and programs undertaken by other political entities. He stressed that "This is not an advocacy that we should or should not be governed by or adopt the policies and methods of other countries; rather that we should intelligently appraise the results of the cycles of time through which the older countries have gone as an invaluable experience from which we can profit sans cost." 8

In 1938, E. W. James, who was deeply involved in the Inter-American Highway, was detailed to Cuba to provide assistance to Cuban engineers in reconstruction of the central highway. By 1939 other requests from Latin-American countries for technical assistance began to come to the Bureau. Under provisions of Public Law No. 545 of the 75th Congress and Public Law No. 63 of the 76th Congress, the Bureau sent engineers to Venezuela, Colombia, and Ecuador for short-term specialized assistance. On May 25, 1939, the Export-Import Bank of Washington officially requested the Secretary of Agriculture to arrange for the assignment of engineers from the Bureau to assist the Bank in connection with the extension of credits for public road construction in Latin America.

\section{Economic Development Becomes the Guiding Force}

With the advent of World War II, PRA engineers became involved in urgent projects in Panama, on the Inter-American Highway, and on the Alaska Highway as part of the defense effort. In addition to these high priority projects, Public Roads engineers in 1943 were detailed to highway projects in Bolivia, Haiti, and Santo Domingo. By the end of the war, these projects had either been completed or were phased down to a peacetime schedule.

However, a new priority on overseas operations had emerged. The United States took on the responsibility to assist in the recovery of our friends and allies from the devastation and economic ruin resulting from the war. Two major programs were soon to be initiated under separate legislation by Congress. The first of these was the reconstruction and rehabilitation of the war-damaged highway system of the Philippines. The second was the development of a highway organization in Turkey capable of the construction and maintenance of an expanding road system to be undertaken as a part of a Mutual Security Program. From 1946 to 1950 these two programs drew heavily upon the manpower and technical backup skill of Public Roads. Over 100 engineers and technicians were sent overseas to work and train local engineers and equipment personnel.

The effect of the U.S. highway operations in the Philippines was probably most clearly and sincerely expressed in a letter written to the Bureau in 1952 by 
Jose Lozada, Chief Engineer of the Philippine Highway Department, in which he said:

Undoubtedly untold material benefits have accrued to the Country in general in the implementation of the Rehabilitation Program. But the benefits derived therefrom by the Bureau of Public Works, particularly the Division of Highways, are in themselves invaluable and immeasurable. The wealth of new knowledge and modern practices in the design, construction and maintenance of highways, unfolded before us by the engineers of the U.S. Bureau of Public Roads on the basis of their past experience, has saved the Philippine Government time, effort and expense in ferreting out suitable highway procedures thru the usual cumbersome and costly channel of 'cut and try' method. ...

With a sound foundation, tempered and tried during those hectic days of implementing the Rehabilitation Program and enriched by constant associations with the U.S. Bureau of Public Roads, the Division of Highways is now much better prepared to shoulder the responsibility of executing the highway building programs of the Philippine Government, especially in connection with the total Economic Mobilization of the Country. ${ }^{\circ}$

During the 1950-1960 period, Bureau overseas operations expanded as the need increased for technical assistance to the developing countries throughout the world. Bureau engineers traveled throughout the world on special assignments undertaken in cooperation with the International Cooperation Administration (ICA), * the Export-Import Bank, and the

* Now known as the Agency for International Development (AID).
International Bank for Reconstruction and Development (IBRD). Major programs during this period were initiated or completed in Ethiopia, Iran, Jordan, Liberia, Turkey, and the Philippines.

From 1960 to 1970 , Bureau technical assistance continued at about the same level with major programs initiated or completed in Laos, Cambodia, Yemen, Brazil, Nepal, Philippines, Bolivia, Dominican Republic, and the Sudan.

During these two decades, all technical assistance programs of the Bureau were characterized by an intensive effort to provide adequate training and selective procurement of equipment to do the job.

Mechanization has been the key to modern road construction on the scale necessary to meet the needs of transport throughout the world. Over $\$ 250$ million worth of equipment and spare parts, destined for highway departments of foreign governments or for construction projects undertaken by the Bureau overseas, have been procured by the Bureau since 1930 . Because timely deliveries of spare parts and servicing of equipment is essential throughout its life, Bureau engineers and administrators elected to utilize the Bureau procurement and contracting office for this service. The Bureau required factory inspection prior to shipping on all major equipment purchases.

In addition to equipment procurement, Bureau engineers designed or assisted foreign engineers in the

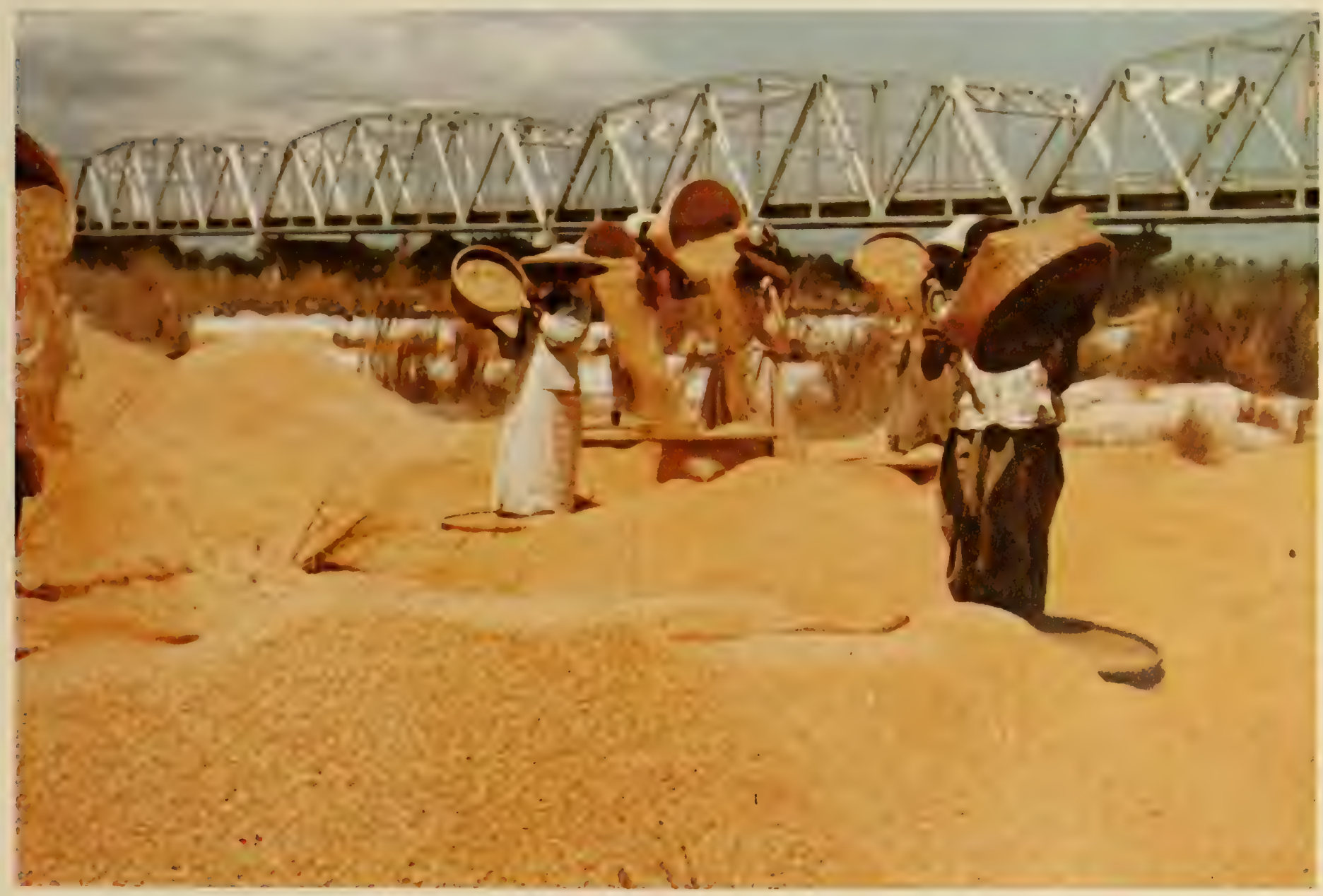


design of many bridges, the superstructures of which were later purchased in the United States. For the Philippines alone, of the approximately 500 bridges erected in the rehabilitation program, over 300 bridges were designed, procured in the United States, shipped, and erected.

By the end of 1969, major programs of FHWA's overseas operations were nearly completed, and an overseas force of over 200 engineers and technicians was reduced to less than 70. From 1970 to 1974, programs consisted of relatively small teams of engineers assigned to Brazil, Argentina, Laos and Kuwait, with specialists being detailed to other countries for specific assignments when requested. Although current technical assistance requirements in many countries have changed to more sophisticated elements of highway and transportation techniques, such as the design and construction of limited access expressways in Kuwait, the need for basic highway assistance still exists in many developing nations.

In total, the Federal Highway Administration and its predecessors have sent engineers and technicians to over 50 countries throughout the world. From the deserts of Sudan and Jordan to the mountains of Nepal and Bolivia, from the jungles of the Amazon and Mindanao to the plateaus of Yemen and Ethiopia, and to the hills of Laos and Cambodia, FHWA engineers and technicians have helped develop local personnel to build and maintain roads, roads that provide much needed access for food, medicines and all of the many other items needed to improve living. In more than eight countries where these engineers have worked, revolutions and open civil warfare have taken place during the life of the projects, but no Bureau employee has been seriously injured. In many instances, the Bureau continued operations during the unrest.

However, a record of the international activities in road construction by the United States is not complete without a discussion of its work on the InterAmerican Highway, the Alaska Highway, and its major technical assistance programs. Whether for the purpose of defense or international aid, it is in these operations that the capabilities of the United States, through its agent, Public Roads, was tested in imaginatively meeting totally different and complex situations, and in the professional competence, toughness, and diplomacy of its personnel. It is also in these operations with foreign countries that major positive impacts were effected as scores of engineers, technicians, and machine operators were trained, and as roads, which facilitated communications, defense, and economic development, were built or repaired. A more detailed examination of these operations presents a glimpse of the diversity and depth of the programs undertaken and the challenges that were met by the Federal Highway Administration and its predecessors as it worked in the international arena.

\section{The Inter-American Highway}

The dream of linking North and South America is an old one. King Charles V of Spain, in the early 1500 's, ordered a road built from Mexico to South America. ${ }^{10}$ However, practical difficulties at that time made this plan impossible. In the 1880 's, Henry Clay publicly proposed a hemispheric route for the purpose of promoting good will and improving social and economic progress. ${ }^{11}$ The idea gained impetus when a proposal was advanced in the U.S. Congress in 1884 for connecting the American continents by means of a Pan-American Railroad. Congress authorized the creation of a special commission to consult with the American Republics about the possibilities of railroad communication between their countries and the United States. As a result, at the First International American Conference held in December 1889 in Washington, D.C., the railroad project received active support. Subsequently the Pan-American Railroad Committee was created and over a period of years worked diligently but unsuccessfully to develop interest in the project.

In 1923, with automotive travel coming of age, the Fifth Conference of American States meeting in Santiago, Chile, recommended the holding of an automobile highway conference, looking toward the construction of a network of roads to facilitate freer passage within and between the various republics of the Americas. This was the start that was needed.

The first Pan-American Highway Congress was held in Buenos Aires in 1925, and it was decided to have the Highway Congress become a permanent activity of the Pan American Union. Three years after this meeting, the Sixth Conference of American States met at Havana, Cuba. This conference authorized the Pan-American Highway Congress to take the actions necessary to obtain financing and technical cooperation for preliminary studies of feasible routes for construction of an Inter-American Highway. The U.S. Congress took action on the idea of an InterAmerican Highway on March 4, 1929 (45 Stat 1697) when a joint resolution was passed authorizing the appropriation of funds for the reconnaissance survey for a road to connect North and South America.

The concept of a Pan-American Highway System, meanwhile, was advanced at the Second Pan-American Highway Congress held in Rio de Janeiro, Brazil, in early October 1929. At this Congress a resolution was adopted stating that each member country should prepare a complete study of its highway system plan in order to meet the needs of intercommunication of its political subdivisions and to provide the most convenient junction with the highway system of the neighboring countries. The governments were also requested to designate, as international highways, those main arteries of transportation which connected or would connect the capitals of the different countries with a view to incorporating them in the PanAmerican Highway System.

Following the Congress in Rio de Janeiro, the Republic of Panama invited all of the countries of Central America, Mexico, and the United States to a conference in Panama City to consider ways and means of furthering the proposed plan for a road survey between the isthmus and the Rio Grande River. On October 7, 1929, this first Inter-American (Regional) Conference was held at the National Palace in Panama City. The representatives* enthusiastically endorsed the proposed survey and took action calling

* From Panama, Costa Rica, the Canal Zone, Nicaragua, Honduras, El Salvador, Guatemala, and the United States. 


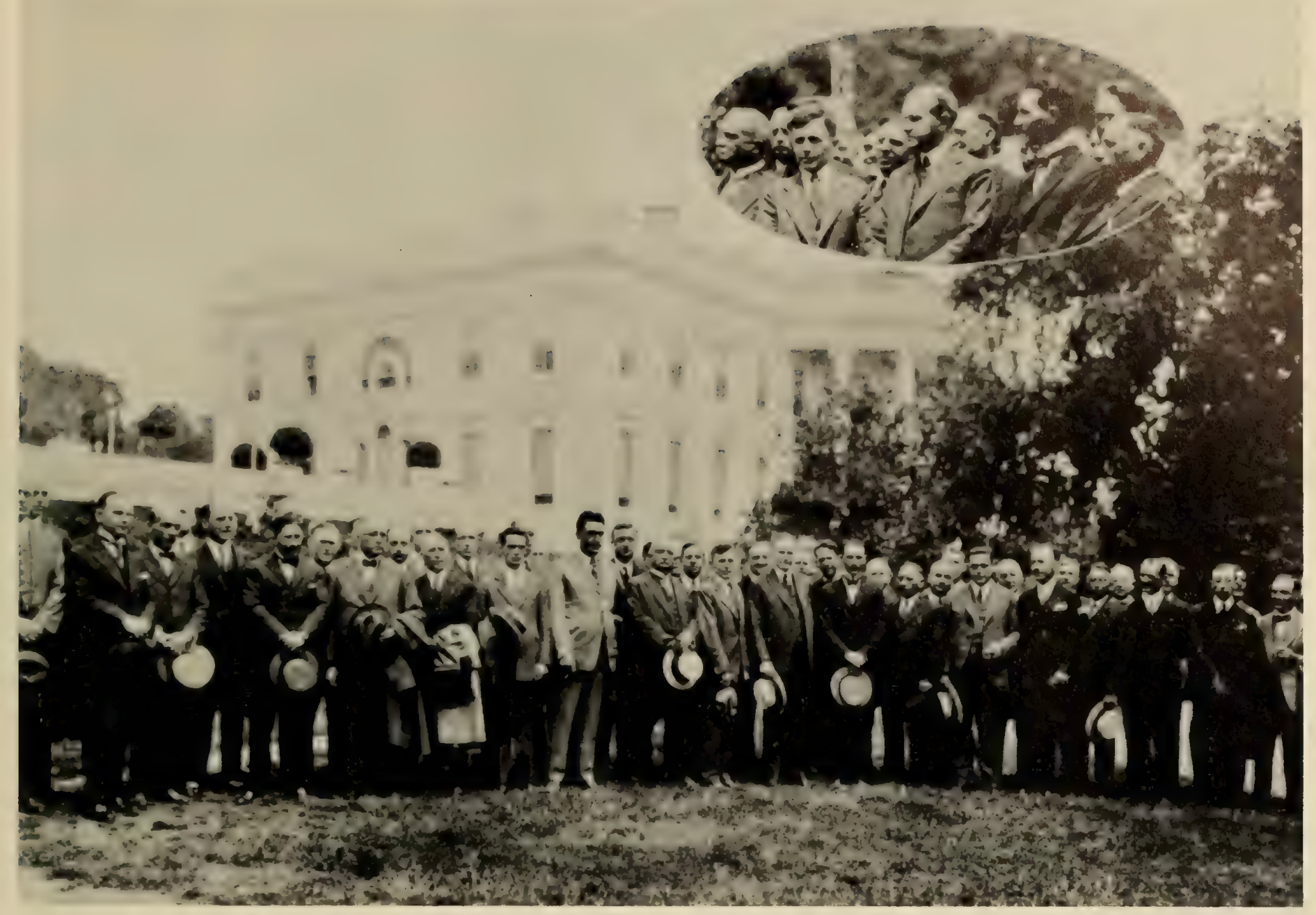

President Calvin Coolidge welcomes the Pan American Highway Commission at the White House in 1924. This group, representing 19 Latin American countries, toured the United States to observe construction progress under the Federal-aid program.

on the several governments to furnish transportation, assistance, maps, existing survey records and other such cooperation that would help in carrying out the required field work. Office space and drafting quarters were provided rent-free by Panama in the National Palace until the conclusion of the field work in May 1933. This was the genesis of the "InterAmerican Highway," a section of the hemispheric Pan-American Highway System.*

As a followup in March 1930, the U.S. Congress appropriated $\$ 50,000$, previously authorized in the joint resolution, "To enable the Secretary of State to cooperate with the several Governments, members of the Pan American Union, when he shall find that any or all of such States having initiated a request or signified a desire to the Pan American Union to cooperate in the reconnaissance surveys to develop the facts and to report to Congress as to the feasibility of possible routes, the probable cost, the economic service and such other information as will be pertinent to the building of an inter-American highway or highways. ..." ${ }^{12}$ The Act specified that all official con-

\footnotetext{
* Although the road from Laredo, Texas, to Panama City is commonly referred to as the Inter-American Highway, the section of road from the southern border of Mexico to Panama constitutes the length in which the U.S. Government, through the BPR (FHWA), has participated.
}

tacts were to be made by the Department of State, and by arrangement with the Department of Agriculture, the Bureau of Public Roads was to conduct the reconnaissance.

By June 21, 1930, an engineering party of BPR engineers had left the United States for Panama, and by July 1,1930, the Office for the Technical Committee of the Commission in Panama was established and located, at the invitation of the Government of Panama, in the National Palace.

By May 1933 the field work was complete, and work began in Washington on the report to be submitted to Congress.

\section{First U.S. Appropriation for Construction}

In 1934 an appropriation of $\$ 5$ million was requested from the U.S. Congress. It was estimated that this amount would be required to construct a passable dirt road which would connect the existing stretches of road and, thus, make the Inter-American Highway a continuous reality. Congress, however, only appropriated $\$ 1$ million which was to be divided between Guatemala, Honduras, Nicaragua, Costa Rica, and Panama for plans and construction of a number of major bridges and the continuation of survey work. The first construction work was to be 


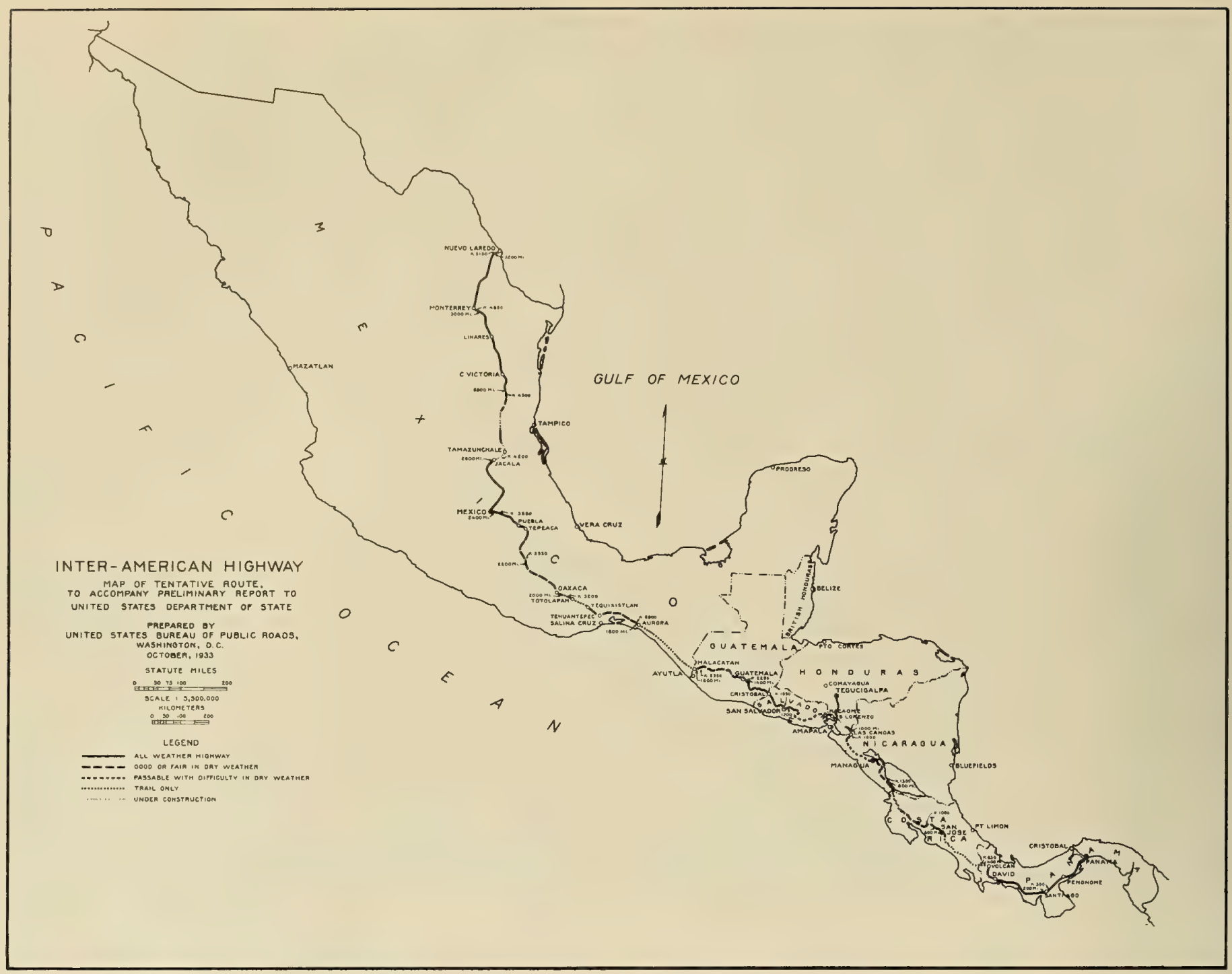

Proposed route of the Inter-American Highway in 1938.

done on a cooperative basis with the United States furnishing the plans, specifications and estimates for the bridges, all the steel and other fabricated materials for the superstructures, mechanical equipment, and transportation of materials and equipment to the work sites. In addition, the United States was to construct the superstructures and furnish all supervision and inspection. Each cooperating country was to furnish all local materials and transportation of these materials, purchase right-of-way, furnish labor needed to construct the bridge foundations and substructures, remove bridge falsework, grade bridge approaches and clean up the job site.

Guatemala, Honduras and Panama quickly agreed on the disposition of their shares for bridge construction. Costa Rica did not wish to use its share of this allotment for bridges but desired, instead, to construct portions of the southern section of the highway in order to open up promising agricultural areas. After lengthy negotiations, it was agreed, in September 1937, that the United States would provide technical assistance, furnish adequate modern equipment and provide culvert materials. The Government of Costa Rica would provide the labor and local materials needed for the work. Because of the difficult terrain, work on these sections progressed slowly over the next few years. With the completion of surveys handled from the Panama office and the initiation of construction in Costa Rica, the Bureau established its headquarters office in San Jose, Costa Rica, in October 1935.

\section{The Threat of War Steps Up Construction}

In 1939 the Commanding General of the Panama Canal requested the PRA to administer the construction of a 61-mile road project from Chorrera to Rio Hato, where an important air defense facility was located. Panama was to undertake the construction with PRA acting principally as monitor. For this project, Congress provided $\$ 1.8$ million to the U.S. Army, and in 1940 Panama received a $\$ 2.5$ million loan from the Export-Import Bank to cover its share of the cost. With the advent of war in 1941 and the military importance of the highway, the U.S. Government took over full financing of the project. With some 45 miles to complete, Public Roads took charge, and by July 1942, just 7 months later, the project was completed. Although this project was originally a military requirement, because of its location and alinement, it was later incorporated into the Inter-American Highway. 


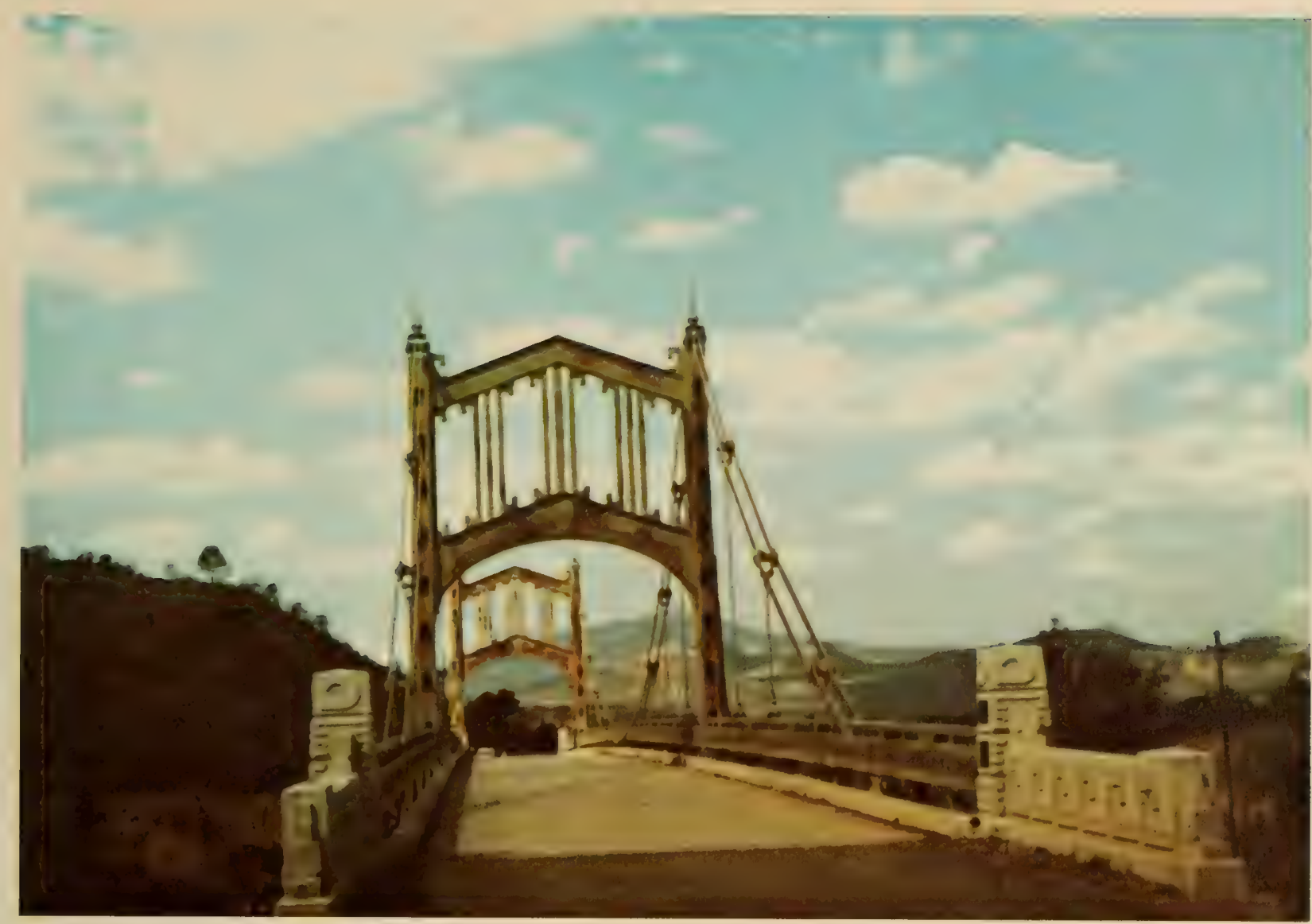

Guatemala constructed this 300-foot bridge over the Tamazulapa River as its first project on the Inter-American Highway.

At the same time, Public Roads was also working with the military on the transisthmus highway, also known as the Boyd-Roosevelt Highway. Work on this project began in 1940, but due to heavy rains and other problems, work did not proceed rapidly. With the Japanese attack on Pearl Harbor, work began on a 20-hour day basis, and by April 1942, a battalion of field artillery was able to move from the Pacific side of the isthmus to the Atlantic side in 3 hours in contrast to the previous 24 hours required by other modes.

Meanwhile, because of the possibility of attacks on the sea routes to Panama, Congress, on December 26, 1941 , authorized expenditure of $\$ 20$ million for construction (55 Stat 196). One-third of the construction cost was to be contributed by the Central American countries and Panama. This established the pattern for $2 / 3^{-1 / 3}$ matching formula which, in general, has been followed ever since. However, Panama, desiring that the road there be built in its entirety with a concrete surface, agreed to contribute the total difference between what would otherwise have been its matching share and the amount necessary to complete the road at the higher cost of the concrete.

First priority in speeding up the construction of missing sections was assigned to completion of the work in Costa Rica. Recognizing the difficulties and cost of construction in the rugged Costa Rica mountain country, Congress appropriated an additional amount of $\$ 12$ million without matching requirements (55 Stat 540). As a result of military studies and events in early 1942, the Secretary of War, on June 6, 1942, authorized the Army Corps of Engineers to initiate necessary surveys and preconstruction work to complete the highway to military needs. Soon after, the Secretary authorized construction to proceed with military funds. The work by the Corps was to be undertaken in cooperation with Public Roads and the respective countries. To complete the project in the shortest possible time, standards were drastically reduced.

In late September 1943, because of changing priorities, the Army Chief of Engineers received orders to begin demobilization of their activities on the highway.

Prior to the commencement of the War Department project, the local governments and Public Roads had completed 696 miles of all-weather road through the Central American Republics south of Mexico. This left 864 miles to be constructed or completed. Of this, approximately 460 miles was to be new construction and 404 miles was to be widening and improving already existing dry-weather roads. When the U.S. Army project was terminated in 1943 , about 58 percent of the project was completed at a cost of approximately $\$ 36$ million, and of the total 864 miles, approximately 600 miles were passable. ${ }^{13}$ Work continued on projects in the respective countries until 1951 when appropriations were expended.*

\footnotetext{
* From December 1941 to December 1946, 333 miles of InterAmerican Highway and 62 miles of the Rama Road were improved under Public Roads programs.
} 


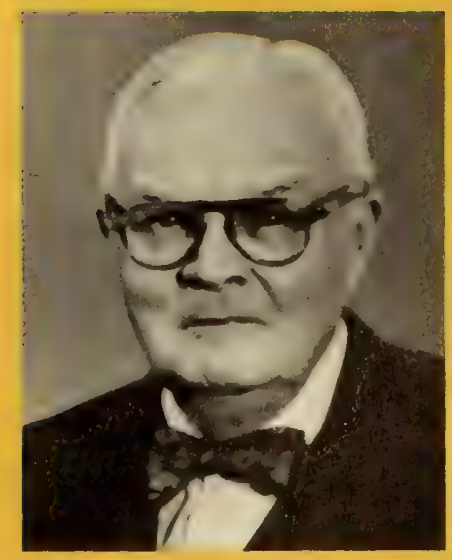

When Edwin Warley James left the Corps of Engineers' New London (Conn.) District Office in 1910 to work for the Office of Public Roads, the fledgling automobile and roadbuilding industry gained a hard working, brilliant engineer and an author and future diplomat.

James, who was to become the "Father of the Inter-American Highway," was born October 17, 1877, in Ossining, N.Y. After he graduated from Phillip's Exeter Academy in 1897, he continued his studies at Harvard University, where he was a 1901 cum laude graduate.

He went to work in a publishing office, but his interest in engineering led him to spend his evenings studying drafting and steel detailing at the Boston Evening Institute. This schooling only increased his desire for greater engineering knowledge, and in 1905 he entered the Massachusetts Institute of Technology where he completed the final 2 years of engineering study. In March of that year he married Ethel Townsend.

After he graduated from MIT, James received an appointment with the Corps of Engineers and 6 months later was on his way to the Philippine Islands as a district engineer. After 2 years of supervising public works projects in the Provinces of Bulacan and Nueva Ecija, he returned to New London.

It was here that he worked on design and surveys for the intracoastal canal. James was now in his early thirties and had a solid background of engineering experience.

When in May 1910 Public Roads needed two experienced engineers, James applied for one of the positions and was accepted.

$\mathrm{He}$ immediately dug into the problems of road construction, and it wasn't long after passage of the Post Road Act of 1912 that Director Page selected and assigned responsibility for administration of the program to James.

Under this Act, experimental roads were built in a number of States with the cooperation of counties and other legislative districts. From this experience, James became fully aware of the many problems encountered with Federal assistance at the operational level.

As a result, he realized that programs funded through the Federal Government could best be administered through State organizations. At every opportunity, he supported this view and when the 1916 Federal Aid Road Act was passed, enough legislators had been convinced to establish a Federal-State relationship - a relationship which has been fundamental in the development of highway systems throughout the United States - to make it part of the law.

After passage of the 1916 Act, James was placed in charge of project implementation. Faced with project submissions and no uniform procedures or criteria, he soon established standards for plan sheets and other information necessary for project review and approval.

It wasn't long before Federal legislation called for selection of a primary highway system, and criteria were required to assure the best route selections to meet the purposes of the law. Once again he accepted the challenge and when Thomas H. MacDonald became the Director in May 1919, he asked James to select a small committee and assist him with the project. Using Post Office maps and Census Bureau information, James and his assistants established a formula that assured them that the routes selected would serve to a maximum extent the greatest needs of the country at the time. This method withstood many controversies and inquiries that flooded the desk of the administrator.

It was quite natural now that the question of route markings and designation would be required for interstate travel. Once again James was called upon to provide a solution. Taking advantage of his experience and the personal relationships developed over the years, he, along with others from the Bureau, was able to get the cooperation from 
States, road associations, and other elements to endorse a plan for U.S. route numbering.

Shortly thereafter as Chief of the Design Division he spearheaded the development of uniform signs and markings. His great interest in traffic control devices was evidenced with his appointment in 1925 as Chairman of the AASHO Committee on Highway Signs, Signals and Markers and the subsequent publication in 1927 of the Mamral and Specifications for the Manufacture, Display and Erection of U.S. Standard Road Markers and Signs prepared under his supervision.

From 1924 to 1943 he served as chairman of the AASHO Committee on Standards. In March 1930 James became Chief of the new Division of Highway Transport.

This Division, under his leadership, brought the Bureau of Public Roads into the newly reorganized field of traffic engineering and the developing fields of highway finance and economics.

For nine years James, as Chief of the Division, supervised the development in the Bureau of this new field of highway transport, including planning surveys, traffic surveys and related studies, coordinating activities with AASHO and the Highway Research Board.

Although occupied with the duties of his new position, he was still able to assume responsibility for undertaking a comprehensive feasibility and reconnaissance study of an Inter-American Highway. The resultant report, Reconnaissance Survey of the Proposed Inter-American Highway from the Republic of Panama to the United States, became the basis of construction of this important international highway.

By 1939 James was deeply involved with construction programs on the Inter-American route as well as foreign assistance programs. He continued with these projects until he retired in 1953.

During the course of his career, he served as Chief Inspector of Post Roads, Chief of the Division of Maintenance, General Inspector, Assistant Chief Engineer, Chief of Design, Chief of Highway Transport, and Chief of the Inter-American Highway Division.

James continually found time to express his thoughts and knowledge in articles prepared for publication in engineering magazines and periodicals. Well over 200 such articles were published, with many of them in Spanish, a language which James spoke fluently.

With his background of work in the Philippines and his knowledge of design, construction and planning, he prepared the book titled Highway Constmuction, Administration, and Finance-1929. The book, prepared especially for the purpose of acquainting Latin American officials and engineers with road practice in the United States, was translated into 17 languages and distributed throughout the world. In 1930 it was selected for the Belgian Award as first prize in a worldwide competition by the International Association of Road Congresses.

With a genuine handshake, sincerity, and directness to the problem, James represented the best in highway engineering that the first half century of the automobile age could produce.

His greatest assets were reflected in his relentless drive to achieve or solve problems in the highway field.

Perhaps the James theory concerning man and the use of his intellect were best expressed in a letter he wrote as he approached his 90 th year.

On his well-worn typewriter he wrote to a friend: "I have never been able to sympathize with the fellow who retires and at once begins to rust out."

During his career he received many awards and citations. Receipt of the Citation for Meritorious Service and Gold Medal Award of the Department of Commerce in 1950 and the Citation and Decoration of Foreign Service (U.S.) in 1944 represented acknowledgement by his government of his devotion to his job.

Needless to say, James was the "amigo" of the highway engineering professionals of Latin America and materially extended the image of the Bureau as an organization dedicated to the art of building roads and, in foreign assistance, of helping those who wished to help themselves. 


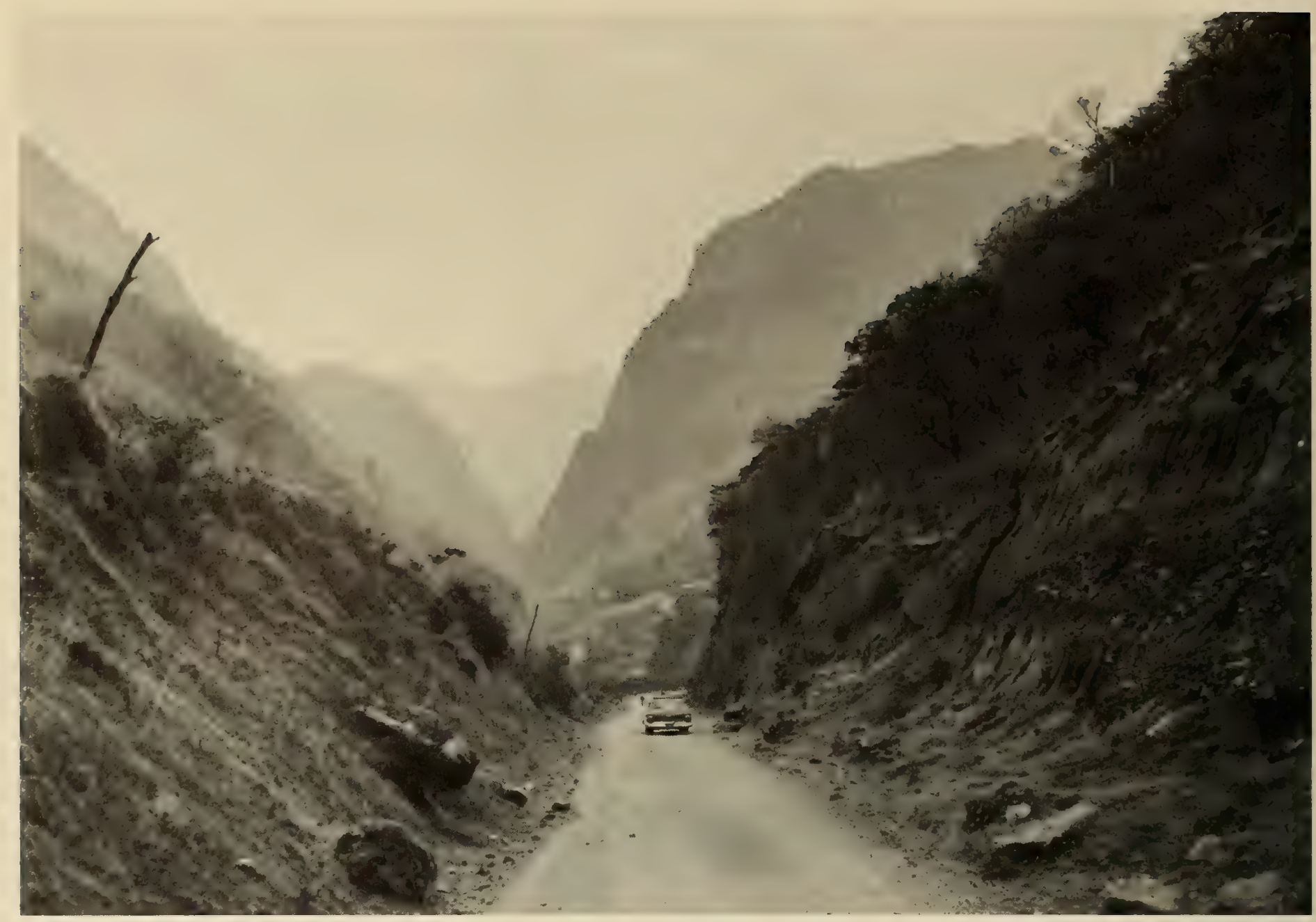

The Selegua Canyon in northern Guatemala as it was in 1959 depicts the rough terrain along the Inter-American Highway.

\section{An All-Weather Road Becomes a Reality}

Impressed with the progress being made on the highway and the cooperative attitude of the participating countries, Congress in the early 1950 's authorized expenditures aggregating $\$ 64$ million in the Public Roads Federal Highway Acts of 1950, 1952, and 1954. Of this total amount, however, there still remained unappropriated at the beginning of the 84th Congress in 1955 the sum of $\$ 49.3$ million.

The most dramatic progress in financing the highway began after President Eisenhower's message to Congress in 1955 urging the early completion of the highway. Congress promptly and overwhelmingly passed the legislation requested by the President and proposed that the highway be finished within 3 years. To this end, the Appropriation Act of June 30, 1955 (69 Stat 233) appropriated $\$ 25.3$ million, a special act of July 1, 1955 (69 Stat 244) appropriated $\$ 24$ million previously authorized and an additional $\$ 25.7$ million, and an act of August 4, 1955 (69 Stat 452) appropriated an additional $\$ 37.7$ million.

Regular appropriations continued during subsequent years, permitting construction to progress in each country with the final gaps of an all-weather road being completed in Guatemala and Costa Rica at about the same time in 1963 . The final paving of the highway was not completed until late 1973 when the difficult mountain section was finally surfaced.
Formal dedication of the Inter-American Highway took place in the form of a motorcade from Panama to Mexico City in April 1963. This motorcade of three buses carried the leading officials from practically every country in the Western Hemisphere. Formal dedication ceremonies were held at each border crossing with Presidents of the neighboring countries often attending. Receptions were held at major cities and enthusiastic greetings were given the travelers throughout the trip.

A current road map of the Central American Republics reveals the significant role of the InterAmerican Highway in the overall socio-economic and highway transportation development within each Republic. Generally located in the more heavily populated areas of the western or Pacific side of the isthmus, the Inter-American Highway, as a main artery, serves to intensify the development in such areas, provides a base for many feeder roads to virtually isolated communities, and in some instances, opens up riches in the interior and eastern sections of these countries. Initially, the opening of certain sections of an early pioneer road were strongly resisted by many farmers who looked upon the road engineers and the small construction crews as invaders. Soon, however, they recognized the benefits that the highway was bringing to them-a ready access to markets, a means for more frequent visits with relatives in the city, and a virtual end to their isolation. 


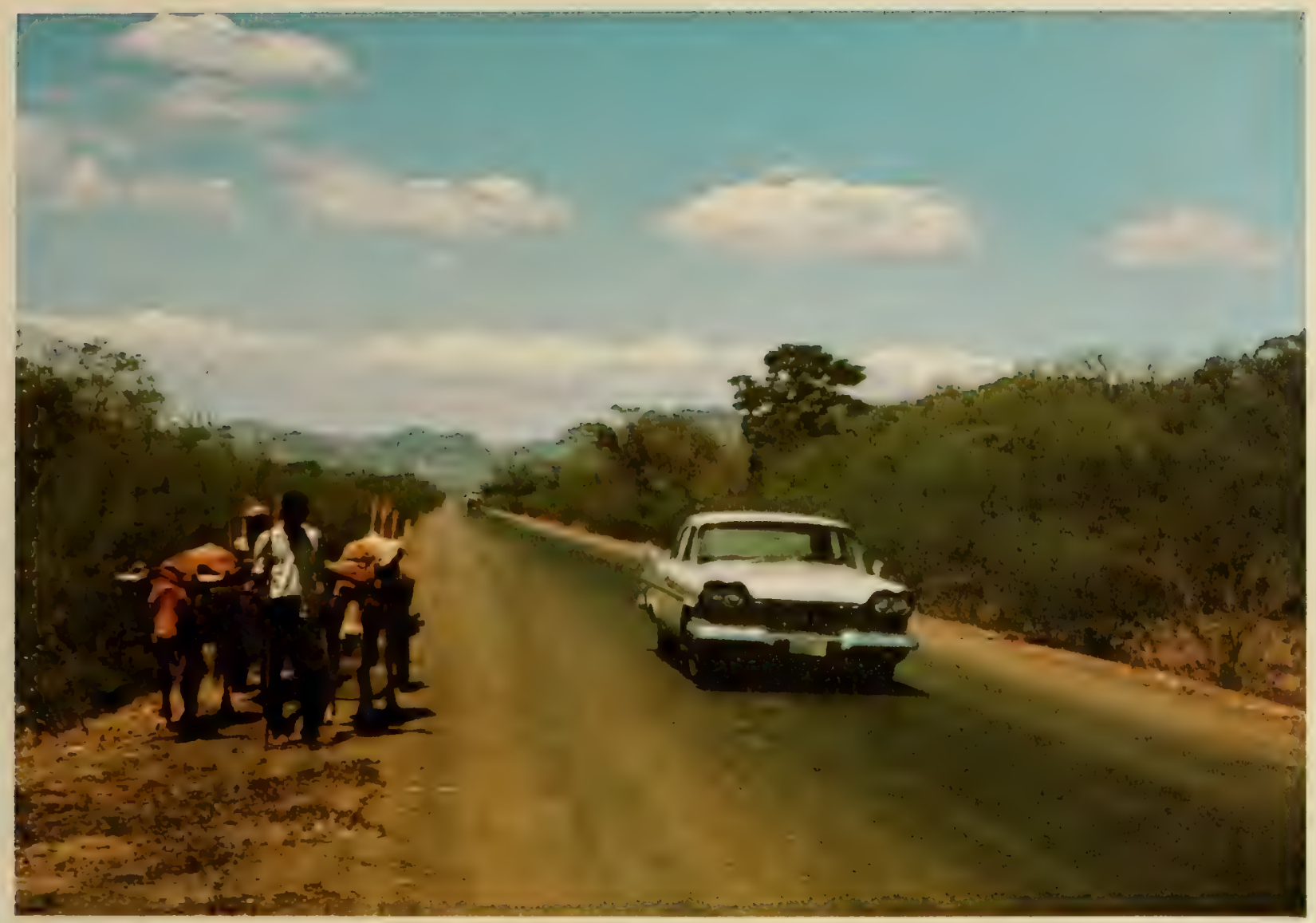

The Inter-American Highway in rural Honduras in 1963.

Thus, the forces of socio-economic development emerged slowly, but strongly, sparked in a small, but very significant, manner by the Inter-American Highway which, later, contributed toward the extensive advances made by the Republics of the isthmus. The Inter-American Highway found its rightful place in the economic history of these countries and in the hierarchy of events that, over the years, led to the establishment of a bond of friendship between them and their partner, the United States of America.

\section{The Darien Gap*}

The Pan-American Highway Congress, meeting in Lima, Peru, in 1951, requested the Organization of American States to urgently create an ad hoc committee of experts to determine the most efficient and expeditious manner for opening to traffic the incomplete stretches of the "longitudinal Pan-American Highway." A committee was established in 1952 to study and develop recommendations by which each country could finance and construct the missing sections of the highway within its borders.

Subsequently, this technical committee, in October 1953, recommended studies in the Darien for the first time. When the Sixth Pan-American Highway Congress, met in July 1954, it recommended that a technical expedition be organized to conduct research and planning surveys in the Darien Region of Panama

* "The vast jungle region adjoining the Republics of Panama and Colombia, known as Darien Province in the first country and as the Department of Choco in the second, bore from its discovery the generic name of DARIEN. This possibly resulted from the name given by the Indians to the torrential river now known as Atrato...." and the adjacent area of Colombia. ${ }^{15}$ Finances for early explorations, administration, and promotion were provided by annual contributions of $\$ 30,000$ each from Colombia and Panama.

In February 1955, the Darien Subcommittee was organized to be made up of technicians designated by each of the Governments of Panama, Colombia, and the United States. The first Darien Subcommittee meeting was held in August 1955 in Panama.

The south or Pacific route was recommended for both countries with a border crossing at Cruce de Espave, but both countries modified this recommendation, making the border point at the landmark known as Palo de las Letras. ${ }^{16}$

With an apparent feasible route for a highway through the Darien having been agreed upon, efforts began to obtain financing for surveys. The Eighth Pan-American Highway Congress in Bogota, Colombia, in May 1960, adopted a financing plan requiring all member countries of the Organization of American States to participate.

By late 1962, the Darien Subcommittee had negotiated contracts with consulting firms from the United States, Panama and Colombia to undertake the surveys and studies of the route. A BPR engineer was assigned to work with the Darien Subcommittee in administering the $\$ 3$ million survey program.

As the surveys progressed in Colombia, it became increasingly evident that the route along the Pacific Coast was impractical; the mountainous terrain, the torrential rains exceeding 400 inches per year, and the length of the route clearly made it unacceptable for an international highway. Thus, at the seventh meet- 


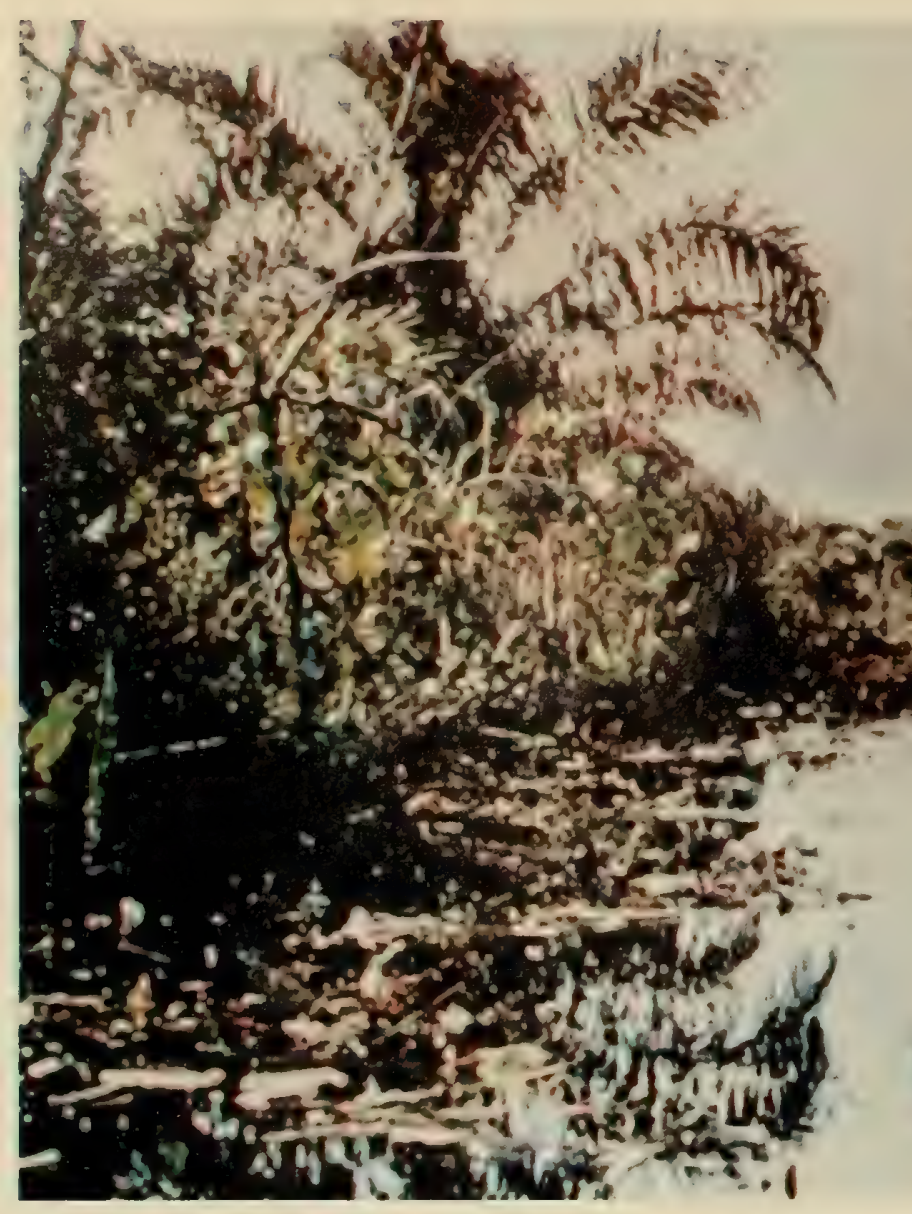

ing of the Permanent Executive Committee of the Pan-American Highway Congress in Mexico City in 1964, permission was obtained for the Bureau of Public Roads to undertake geophysical research studies of the alternate or Atrato route along the Caribbean Coast of Colombia. This route had always been considered impossible because of the extensive Atrato swamps.

Using a helicopter which could land engineers and equipment on the surface of the swamp, field investigations of the preselected routes were made. Visual examination of surface conditions was supplemented by peat sampler penetrations into the swamp.

Once the specific route had been recommended, a geophysical survey was made by using electrical resistivity methods along the route corridor across the swamp. A sufficient number of tests were made to indicate a reasonably stable sand layer could be anticipated at depths of about 20 to 36 feet below the swamp surface to confirm the feasibility that the highway could be built across the Atrato swamp and it would save 205 miles in length, about $\$ 115$ million in cost, and 5 years in construction time.

The Atrato route was approved, and as a result of this breakthrough and tremendous saving, the entire Darien project received international publicity and support from the Organization of American States. The Darien Gap project was selected by the National Society of Professional Engineers as one of the top 10 engineering achievements in 1968.

The U.S. Congress authorized the initiation of construction on the Darien program by an amendment

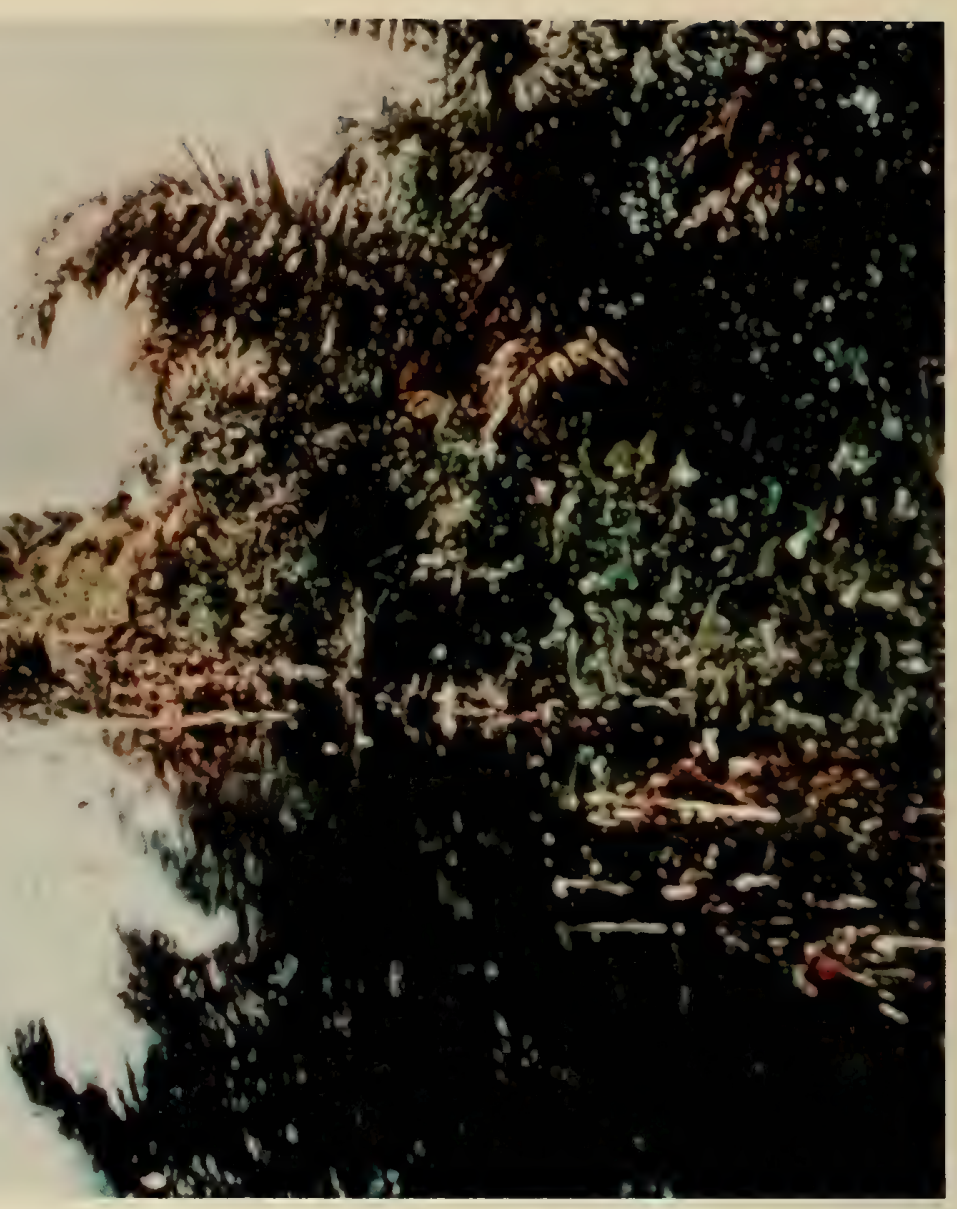

The Darien Gap highway was cut through almost impenetrable swamps adjoining the Republics of Panama and Colombia.

to the 1970 Federal-Aid Highway Act. This amendment provided that funds should be obligated and expended under the same terms, conditions, and requirements with respect to the Darien Gap Highway as were the funds authorized for the Inter-American Highway. The amendment authorized the appropriation of $\$ 100$ million for the Darien Gap program.

Administration of FHWA interests in the project is under the direction of the Region 19 office in the Panama Canal Zone, with field supervision being handled from division offices in both Panama and Colombia. The entire route, except for 14 miles in Colombia, has now been designed or is under contract for final design, with construction well underway in Panama. It is anticipated that by 1982 the vision of many legislators, engineers, and highway administrators for a "land bridge" to connect the Americas may become a reality.

\section{The Alaska Highway}

The Japanese attack on Pearl Harbor on December 7, 1941, and their closely following successes in the Pacific found Alaska, located on the great circle route between the United States and Japan, in a position highly vulnerable to attack.

On January 16, 1942, the President appointed a Cabinet Committee consisting of the Secretaries of Navy, War, and Interior to consider the necessity of and proper route for a highway to Alaska. In February, it was concluded that a highway was necessary and that it should fulfill two major requirements: 
- Furnish a supply route to link up the airfield established in Canada and Alaska by the Canadian Government and the United States Army Air Force.

- Provide an auxiliary overland route to Alaska, relatively secure from attack by the enemy, to supplement sea and air routes and, thus, provide a measure of safety for the armed forces and aircraft ferrying personnel. ${ }^{1 i}$
Many previous studies had been made of the most desirable routing to Alaska, but due to the wartime emergency, military considerations became the prime criteria. The project was approved by President Roosevelt on February 11, 1942, with work on the project authorized to begin at once. Final agreement with Canada was reached on March 18, 1942.

The work to be performed by the United States would begin at Dawson Creek, British Columbia, and

The Alaska Highway stretches from Dawson Creek, British Columbia, to Fairbanks, Alaska.

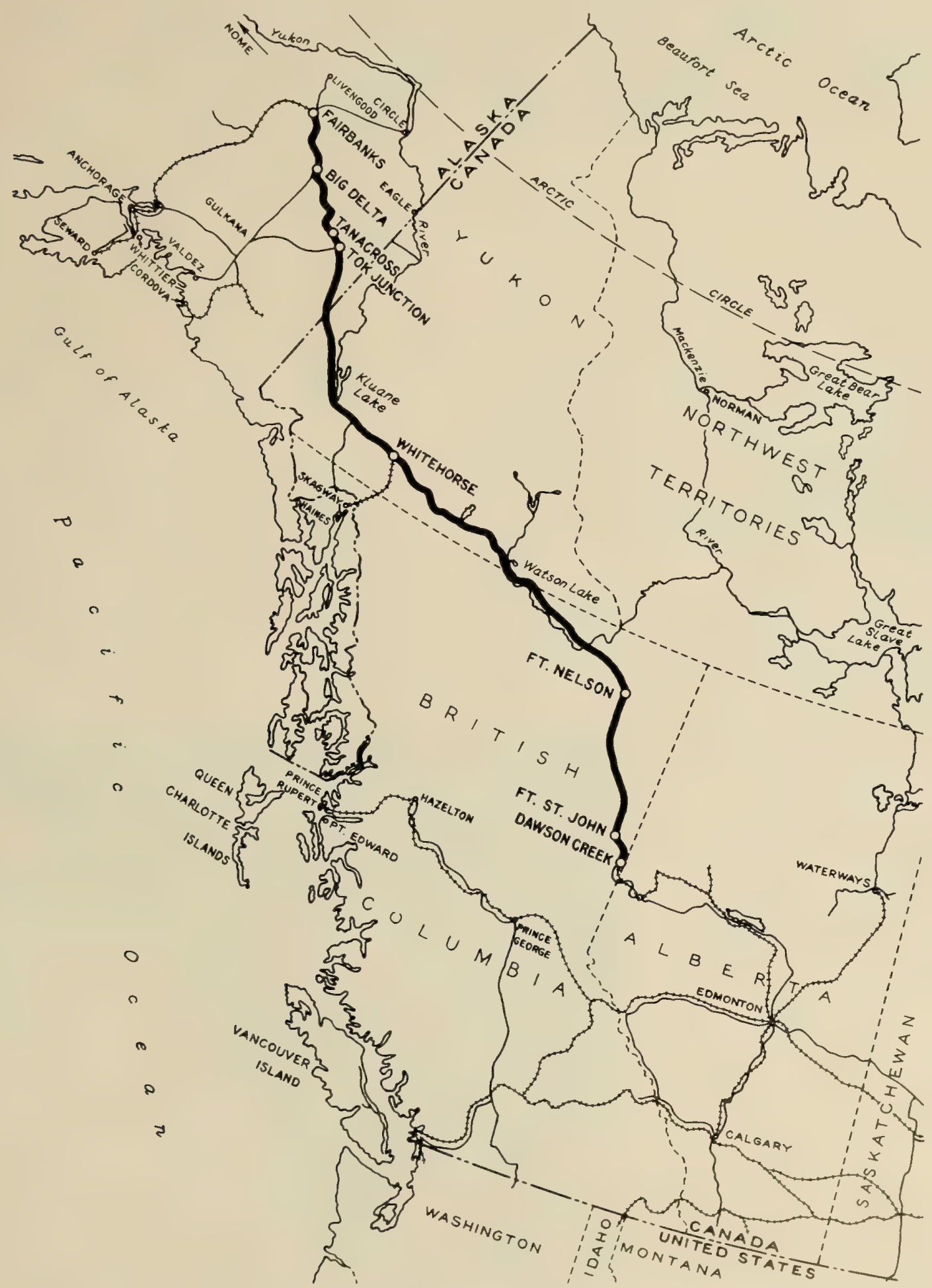


extend northwestward to Big Delta, Alaska, where connections were to be made with existing transportation facilities. The authorization provided for construction of a pioneer road by U.S. Army engineer troops, followed by contractors, furnished and directed by the Public Roads Administration, who would improve the pioneer road to an authorized standard.

Public Roads received instructions from the War Department to build the final highway according to established standard specifications for roads and bridges in national forests and parks. The road was to be two lanes, and surfacing was to be of local materials, with final surfacing to be applied only after earthwork had stabilized. Temporary bridges were to be trestles of local timber. Permanent bridges were to be left to future financing and to the determination of the government authorities charged with operation of the road. The Army sector commanders were to locate the pioneer road with such ultimate standards in mind that would permit maximum use of the alinement for the final road. ${ }^{18}$

As originally conceived, the work of constructing the highway was divided between the engineer troops of the Army and civilian contractors under the direction of Public Roads. In actuality, however, it was a combined effort with overlapping work responsibility, shifts in priorities, and a great deal of truly cooperative effort from the time of the arrival of the first Army troops at Dawson Creek on March 10, 1942, to the removal of all contractor personnel and supervisory engineers of Public Roads at the end of October 1943. As a highway project alone, ignoring military and economic considerations, the route selected was perhaps inferior to one located west of the main range of the Rocky Mountains but because of the war, a completely different set of requirements and priorities was necessary.

With the general route established, decisions had to be made concerning location and design in or across canyons, rivers, mountain passes and muskeg; the weather for work schedules; the use and source of native materials; as well as many other engineering and logistic considerations.

\section{Mobilization}

Immediately upon receiving notice of the impending agreement, the PRA Western Headquarters started a search of the whole West Coast for water transportation. Eventually, transportation to and from the project, both freight and personnel, was handled by a contractor and consisted of a fleet of 4 freighters, 10 tugboats, 5 passenger boats (converted yachts) and 1 manned barge built in 1868, assembled in Lake Union and Lake Washington in Seattle. In addition, early contingents of personnel were carried to Skagway by the Army Transportation Service, classified as either passengers or cargo, depending on order of boarding and location of berth above or below decks.

Simultaneously trucks, tools, and other equipment and materials were gathered from the camps of the Civilian Conservation Corps (CCC) in the northwest for use on the project. These were started north by whatever transport could be obtained. The resources of the Work Projects Administration (WPA) were also tapped for roadbuilding and office equipment. Both of these agencies were being terminated at the time, and the use of surplus equipment was mutually beneficial.

Field headquarters were established in Whitehorse, Yukon Territory, with a subsidiary office at Gulkana, Alaska, and in Ft. St. John, British Columbia, with a subsidiary office at Ft. Nelson on the Liard River. PRA work in the Whitehorse sector did not commence until over a month after activities started on the Ft. St. John end of the project. The first contingent of 12 men from Denver arrived in Ft. St. John on March 14 and 15, and the first troops and PRA personnel reached Skagway, Alaska, early in April, with Public Roads men finally reaching Whitehorse in mid-April.

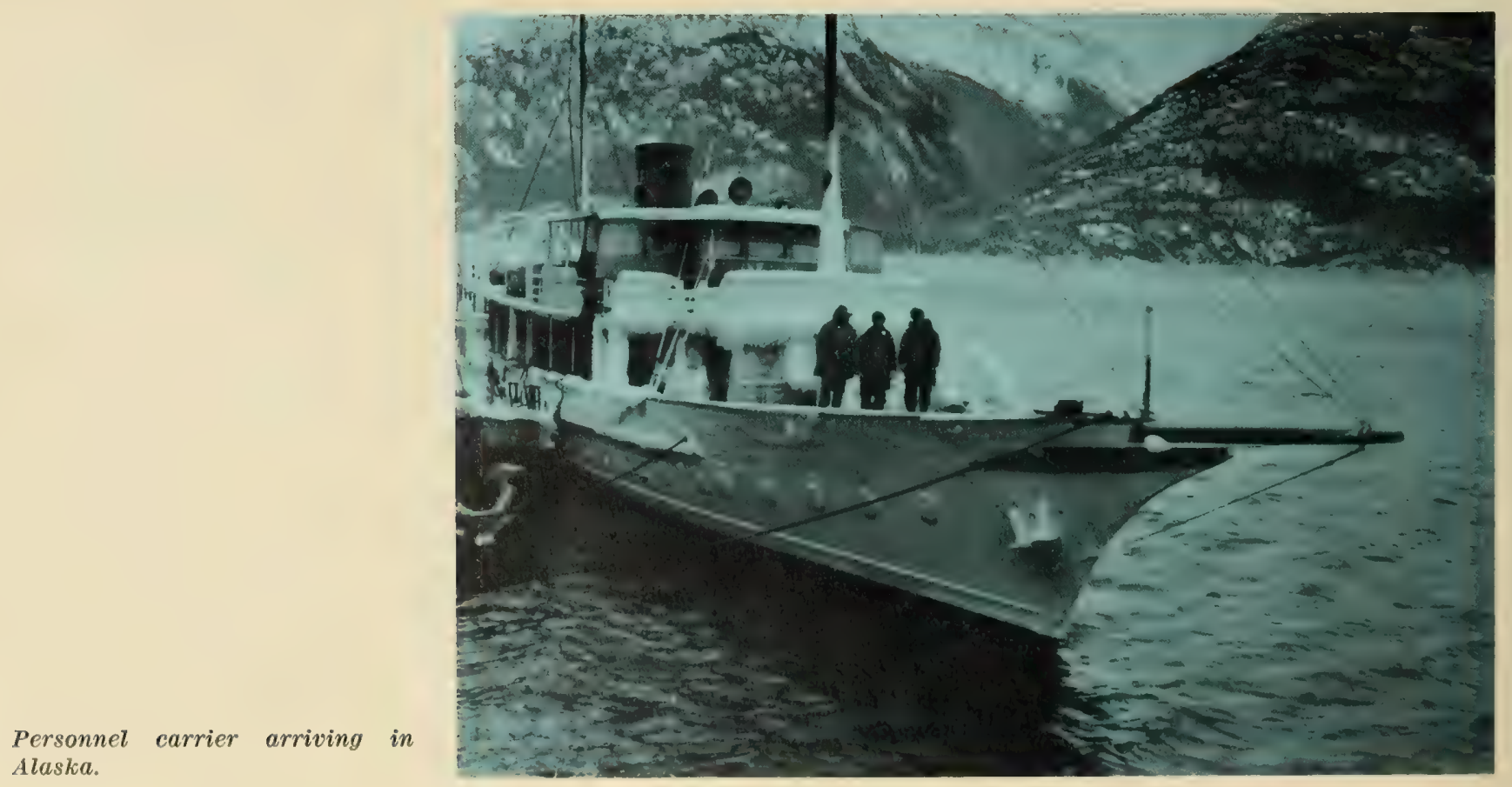




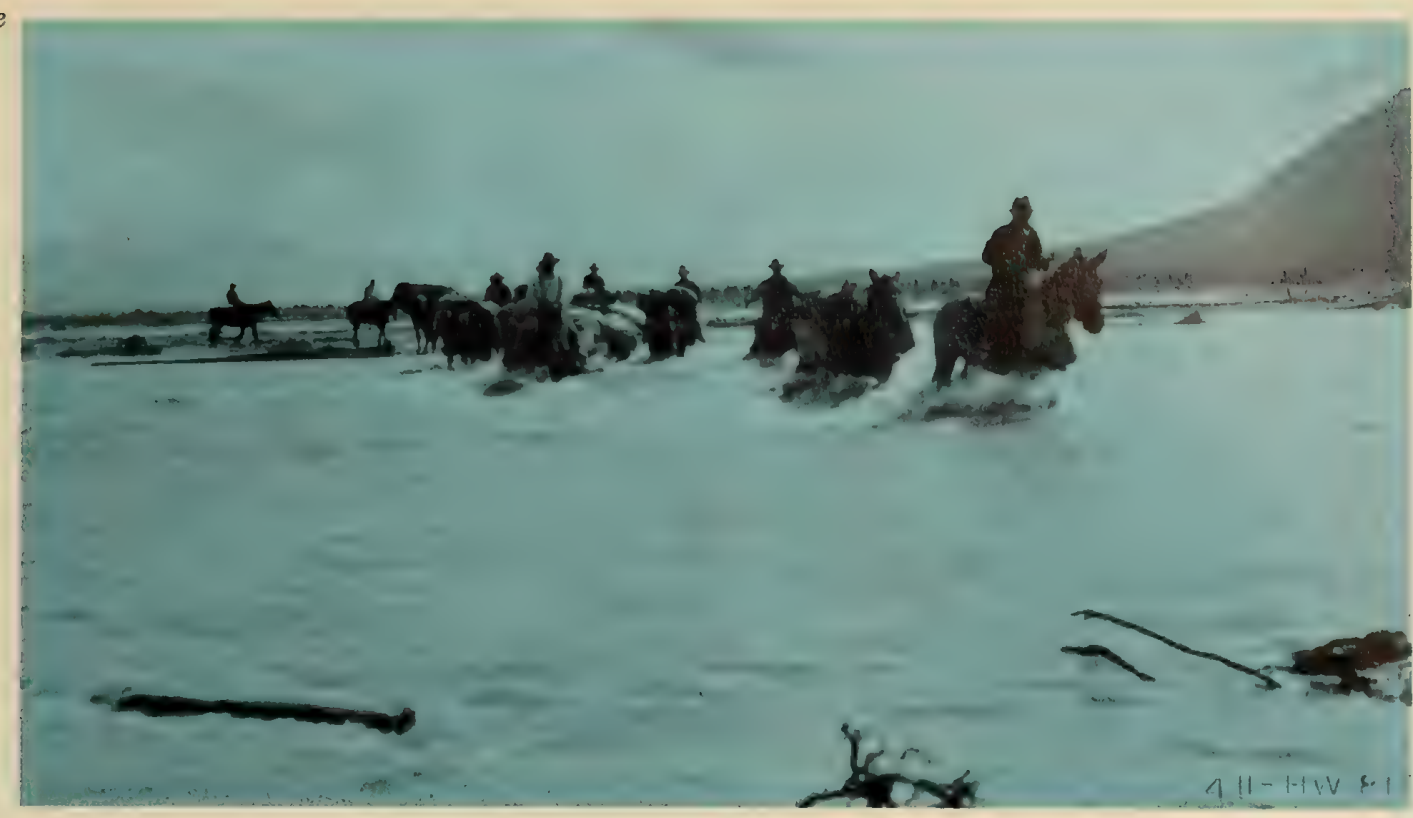

Access to the entire project was limited to three major routes: by rail to Dawson Creek, B.C., by boat to Skagway and then rail to Whitehorse, and by boat to Valdez, Alaska, and then by highway to Gulkana. This restricted access inevitably resulted in serious congestion at all three points. In the spring of 1942 , 600 carloads arrived by rail at Dawson Creek within a period of 5 weeks. At one time 200 carloads were awaiting shipment at Prince Rupert, B.C., for Skagway or Valdez.

The level of activity soon made it apparent to PRA personnel that a project office had to be established close to the scene of action, and in April 1942, a district office was established in Seattle. This office was later moved to Edmonton, Alberta, in January 1943 as contractor operations accelerated.

\section{Reconnaissance and Location}

Initial reconnaissance to establish a preliminary location for the Alaska Highway was conducted by air, on foot, and with pack trains and dog sleds. Aerial reconnaissance was new but invaluable in locating the route from Watson Lake to Whitehorse and crossing the Continental Divide. However, it was necessary to send ground reconnaissance teams on foot or with dog sleds to survey many sections of the highway. When feasible, a winter road was used by surveying parties, but the very nature of a winter road, located through the wettest areas and on frozen rivers in contrast to the requirements for an all-weather route, demanded that the reconnaissance teams do much hiking to locate the route of the proposed road some distance away. When dog sleds were used, usually a couple of engineers, their guides and dog teams would set off for weeks at a time and cover hundreds of miles. Much of this work was performed in temperatures between $-20^{\circ} \mathrm{F}$. and $+40^{\circ} \mathrm{F}$., and with the exception of an occasional trapper's cabin, the men lived in the open under a canvas fly.

When sufficient reconnaissance work had been done, though far from complete, work began on locating the centerline for the pioneer road. Sixty packhorse outfits were organized at the beginning of May 1942, to accompany survey crews working out of Ft. Nelson.
These PRA survey crews began flagging line for the Army clearing crew. In late May, Army and Public Roads location parties moved north from St. John to establish that section of the pioneer road. Aerial photographs of the area ahead were made available to the location engineers in the field camps, enabling them, by use of compass and prominent landmarks, to locate critical "control" points in the route selection. Much of the time, particularly in the Ft. St. John sector, this preliminary line was flagged and blazed just ahead of the bulldozers. In fact, at times the locators expressed fear of being run over by the heavy equipment. In some areas ground reconnaissance was not really completed until after location surveys had started. However, no significant rerunning of surveys was required.

\section{Consfruction, 1942}

The rate of actual construction in 1942 is difficult to conceive, but the fact that practically all of the pioneer road was built in 5 months, and most of it in 4 months, gives an idea of the urgency of the project. The Army involvement in construction of the pioneer road consisted of seven engineer regiments comprising a force of 394 officers and 10,765 enlisted men. ${ }^{19}$

As soon as the Army troops started construction, it was apparent that, without help from the civilian contractors, it would be impossible to complete the access road or keep anything resembling the originally planned schedule. Consequently, work forces began to be merged. By the end of July, contractors were being shifted about and rescheduled all up and down the line to supplement and speed up construction of the pioneer road regardless of prior arrangements.

Army requests for the construction of the Dawson Creek railhead, pipeline, flight strips, and other installations, coupled with a labor and spare parts shortage and increasing equipment breakdowns, compounded to further delay the work despite the closest kind of cooperation. Perseverance prevailed, however, and on October 25 the final breakthrough came at Beaver Creek in the Yukon Territory near the Alaska border. A formal ceremony at Soldiers Sum- 
A ribbon separates Royal $\mathrm{Ca}$ nadian Mounted Police and U.S. Army troops at the dedication of the Alaska Highway in 1942.

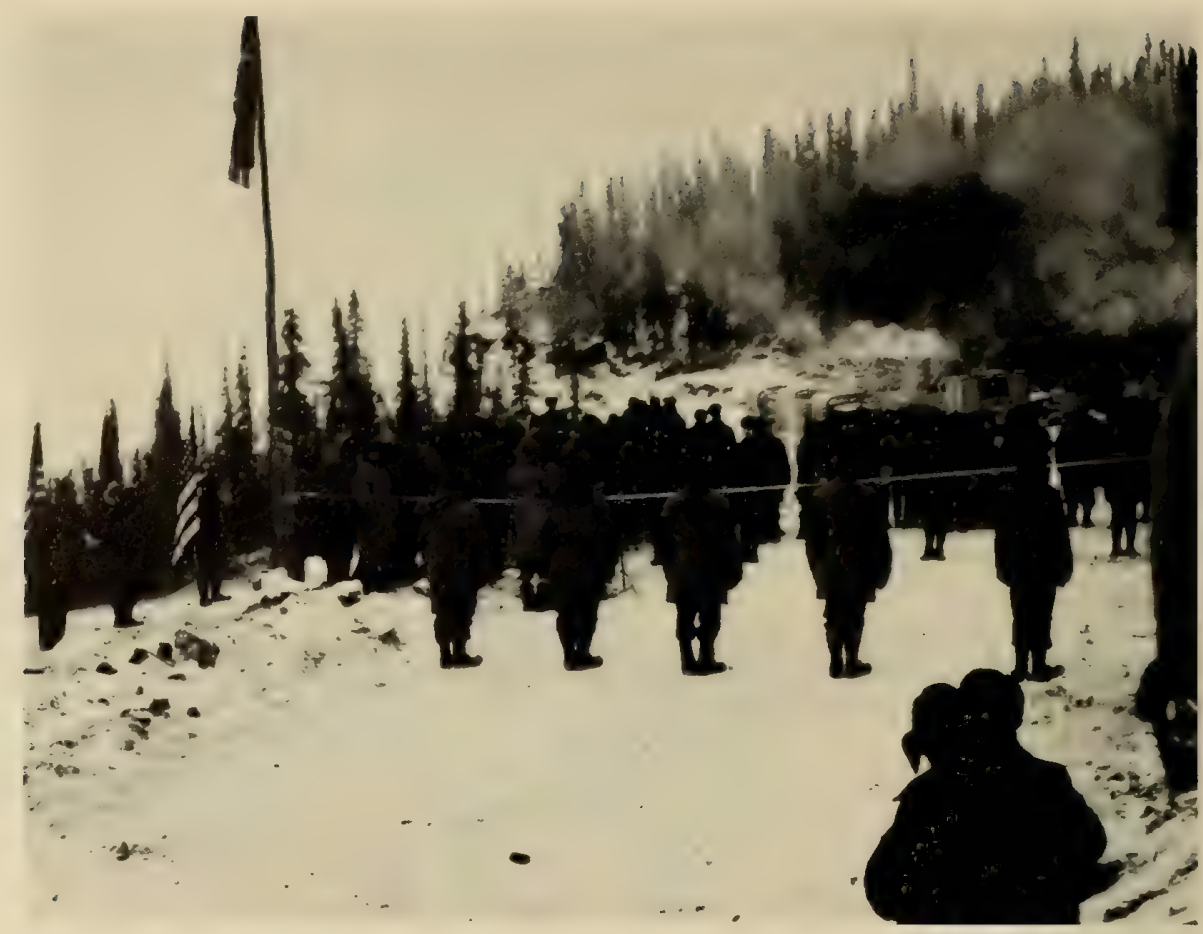

mit, on the south end of Kluane Lake, celebrated the event on November 20, 1942.

\section{Winter, 1942-43}

After the breakthrough at Beaver Creek, much remained to be done to make the truck trail a usable road. The westerly portion presented a dreary prospect, and work continued on into the winter under extreme weather conditions. Record low temperatures were encountered, reaching 72 degrees below zero on the northern sector. Diesel fuel failed to flow from the equipment fuel tanks to the engines, and steel parts broke with increasing frequency. Throughout the project, temporary bridges were "freezing in" and going out when forming ice pulled them apart. However, work continued at a fairly high level during the winter on major structures over the Peace, Sikanni Chief, Muskwa, and Liard Rivers, on rock cuts where possible, and on preparation for the 1943 construction season by repairing equipment and building shops and camps.

Engineering design work in preparation for the following year's construction was carried on throughout the winter, the design for the permanent highway being essentially completed by the beginning of the 1943 season. On April 7, 1943, however, the policies on standards and alinement were radically altered by an Army directive. This directive ordered a substantial lowering of design standards and required that construction of the all-weather route follow the pioneer truck trail to the maximum extent that could provide a usable road. ${ }^{20}$

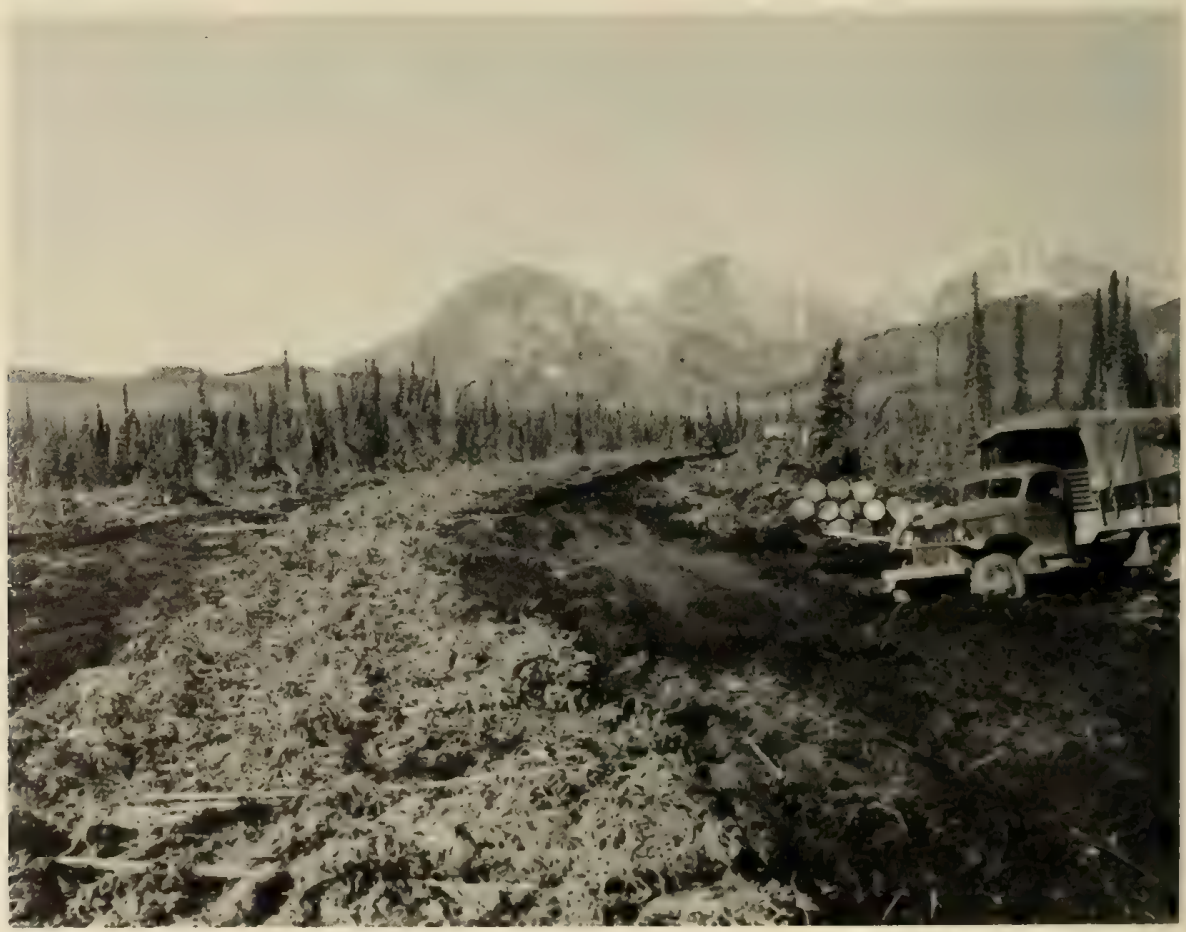




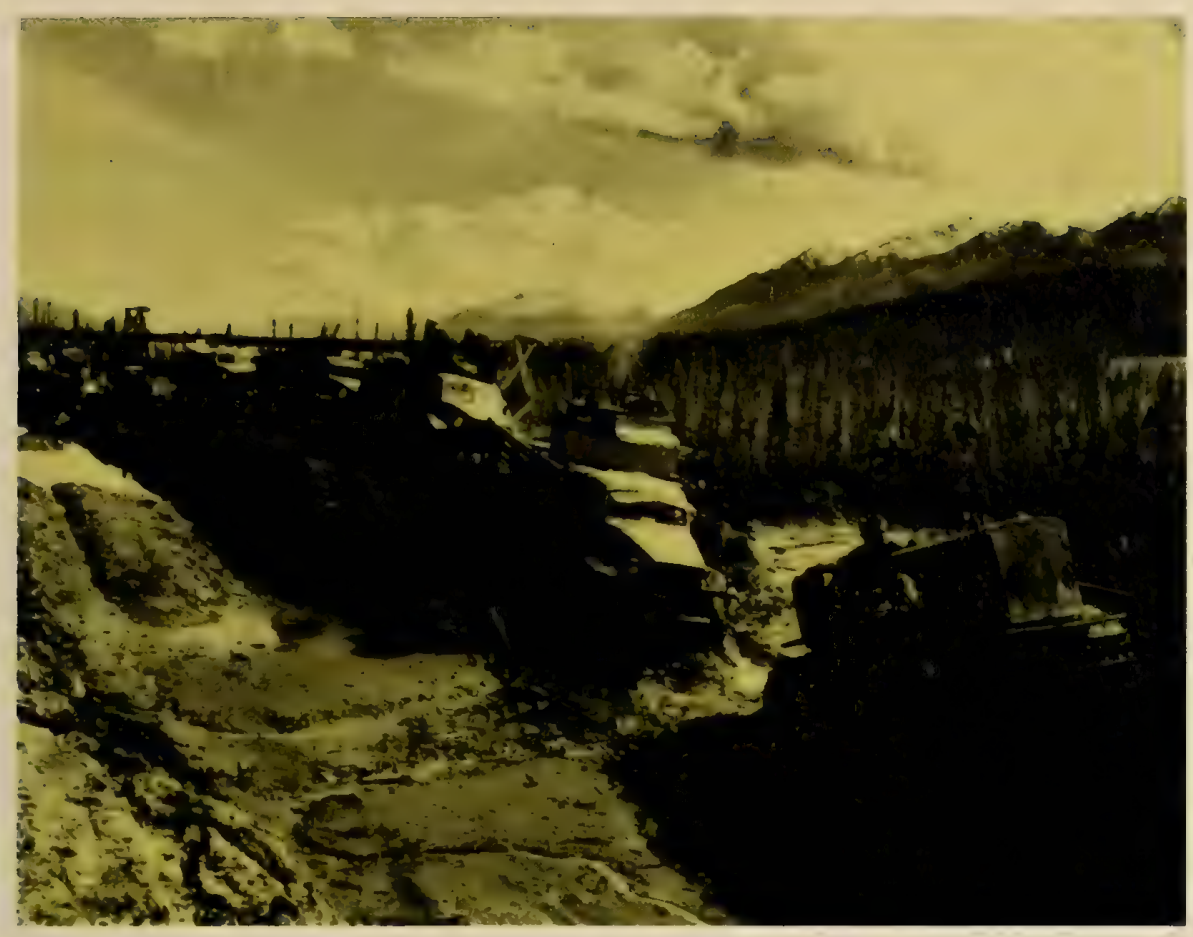

Moving freight along the highway near the AlaskaYukon border was a

hazardous operation in the summer of 1943. The ditch on the left was the original pioneer road.

In retrospect, the first year was one of many problems of logistics, establishment and reestablishment of policy, inconsistencies, and conflict, but also, it was a year in which a spirit of full cooperation and dedication developed in all workers on the job, regardless of status. A truck trail of sorts was built, much of it improved to a usable, all-weather standard, and the construction of a highway in 1943 was made a possibility.

\section{Construction, 1943}

The road, as it evolved at the end of 1943, was constructed almost entirely in that year. However, the original road, resulting from the 1942 effort, must be given full credit for its contribution to the final effort in communication and transport.
The directive changing the standards and alinement caused a substantial shift in emphasis of the 1943 work of the contractors under the direction of Public Roads. As a result, the final road contained a considerable length of indirect mileage, excessively steep grades and substandard alinement. This was an outgrowth of the fact that the original road had been constructed to a large degree along the lines of least resistance, with no appreciable thought given at that time to locating it as a permanent, all-weather, and reasonably safe facility.

The spring breakup during May destroyed a large number of temporary bridges south of Watson Lake, but stockpiled materials enabled rapid replacement. Although this was a temporary setback, over all progress on the project was maintained by a work force

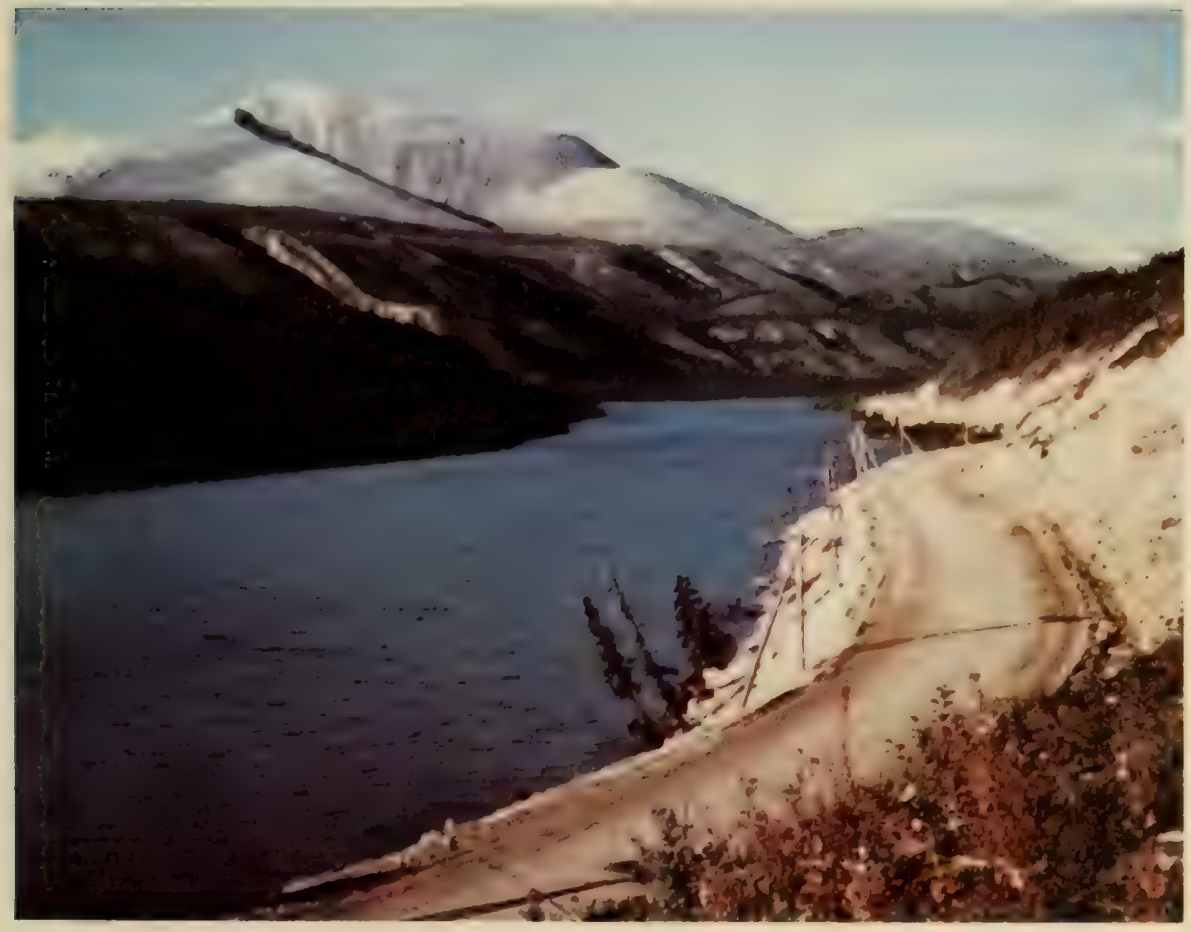

The completed Alaska

Highway as it appeared at Summit Lake in the Rocky Mountains in 1943. 
of over 11,000 men. Throughout June bad weather seriously delayed the construction schedule on the southerly section, including numerous washouts of structures. Despite this, work on the major structures was not seriously impeded and some were put into use.

On June 9 and 10 disaster struck when heavy rains extending 200 miles north and south of Ft. Nelson caused the destruction of 24 temporary bridges. A coordinated effort by all the forces, using stockpiled and salvaged material, resulted in reopening this section for through traffic by July 20, nearly 2 weeks sooner than the most favorable estimates made at the time of the floods.

Even with the temporary loss of six more bridges to high water west of Ft. Nelson early in August, the opening of the Peace River Bridge to one-way traffic August 4, and later that month to two-way traffic, was accomplished. Fortunately, by this time it had become almost routine to replace temporary spans, and 5 days after the washouts traffic was again moving over the sector.

As late as August the 40-mile section near the Alaska-Yukon border was still impassable. Access to the area was possible only by float planes. Finally on October 13 the gap was closed, reopening the road permanently. Followup forces improved it to required standards. By October 31, 99 bridges had been completed, and 34 were either under construction or not yet started. The entire pioneer road was in a usable condition.

At the peak of operations in September 1943, there were 1,850 PRA employees and 14,100 civilian employees of 81 contractors working with 11,107 units of equipment. Except for two companies, the Army engineer regiments had been moved in February 1943 to new assignments elsewhere. As with the pioneer road, the 1,420 miles of final highway was largely built in a 4-month period, with the final overall cost for both the pioneer road and completed highway amounting to $\$ 138,312,166$.

\begin{tabular}{lrrrr}
\multicolumn{4}{c}{ Cost of Alaska Highway } \\
\multicolumn{1}{c}{ Item } & PRA Funds & Army Funds & Total \\
Cost of pioneer road & $\$ 10,196,759$ & $\$ 9,547,826$ & $\$ 19,744,585$ \\
Cost of final type road & $87,205,328$ & $6,874,307$ & $94,079,635$ \\
Other work & $11,615,913$ & & $11,615,913$ \\
Final job inventory & $\mathbf{1 2 , 8 7 2 , 0 3 3}$ & & $12,872,033$ \\
\cline { 2 - 3 } & $\$ 121,890,033$ & $\$ 16,422,133$ & $\$ 138,312,166^{21}$
\end{tabular}

The challenge of administering the civilian program in constructing the Alaska Highway at a time when Bureau personnel were helping to complete the InterAmerican Highway and administering wartime activities on domestic highway systems required a tremendous effort by everyone in the organization. In retrospect, these undertakings confirmed the soundness of Commissioner MacDonald's personnel and administrative policies, the comprehensive training programs of young engineers, especially on field construction projects in the national forests and parks and other Federal lands, and the spirit and pride of all employees in maintaining the professional stature of the Bureau.

\section{Postwar Operations}

\section{The Philippine Program-1946 to 1969}

Public Roads began work in the Philippines in 1946 under authorization contained in Public Law 370, 79th Congress, an Act for the rehabilitation of war damage to the Philippines (usually referred to as the Rehabilitation Act of 1946). The Act authorized Public Roads ". . . after consultation with the Philippine Government, to plan, design, restore, and build,... such roads, essential streets and bridges as may be necessary . . . for national defense and economic rehabilitation and development of the Philippines." It also provided authorization for training engineers of the Philippine Government.

Under this authorization and with a fiscal appropriation of slightly more than $\$ 40$ million, Public Roads assigned three of its highway engineers under F. C. Turner to begin the program.

The program began under difficult conditions. Recruitment of engineers in the States did not proceed readily since many Public Roads engineers had just finished difficult wartime assignments. Housing was practically nonexistent, office facilities limited, and at this time, there was a Pacific shipping strike in progress. For the Philippine Bureau of Public Works, only a few experienced engineers were immediately available.

By September 1947, however, many of the initial problems were overcome and the project was well underway with key positions filled and operating procedures well defined. A highway planning and programing section was established in the Philippine Bureau of Public Works to undertake a complete road and bridge inventory necessary for future economic development. This new section was also responsible for recommendations on the organization of a Philippine Division of Highways separate and distinct from the numerous other operations of the Philippine Bureau of Public Works. The recommendations of the highway planning survey (HPS) were accepted, and in 1948 a Philippine Division of Highways within the Bureau of Public Works was established by executive order.

Under the "Rehab" program administered by the reorganized highway department, approximately 500 bridges and 360 miles of high-type roads and streets were constructed.

The work of the U.S. Division Office under the Rehabilitation Act of 1946 continued through 1951 at which time Public Roads was requested by the International Cooperation Administration (ICA) to remain in the Philippines as highway consultants to the ICA and as advisors to the Philippine Bureau of Public Highways. Public Roads personnel completed the work under the Rehabilitation Act, which had been extended 1 year, and accepted new work authorized by ICA. Funds were provided by ICA with matching funds by the Philippine Government for a program of improvements for a nationwide highway network, construction of development roads (principally on the Island of Mindanao), replacement of temporary wooden bridges, and the development of village and feeder roads. The training program begun in 1948 was continued and was so successful that 


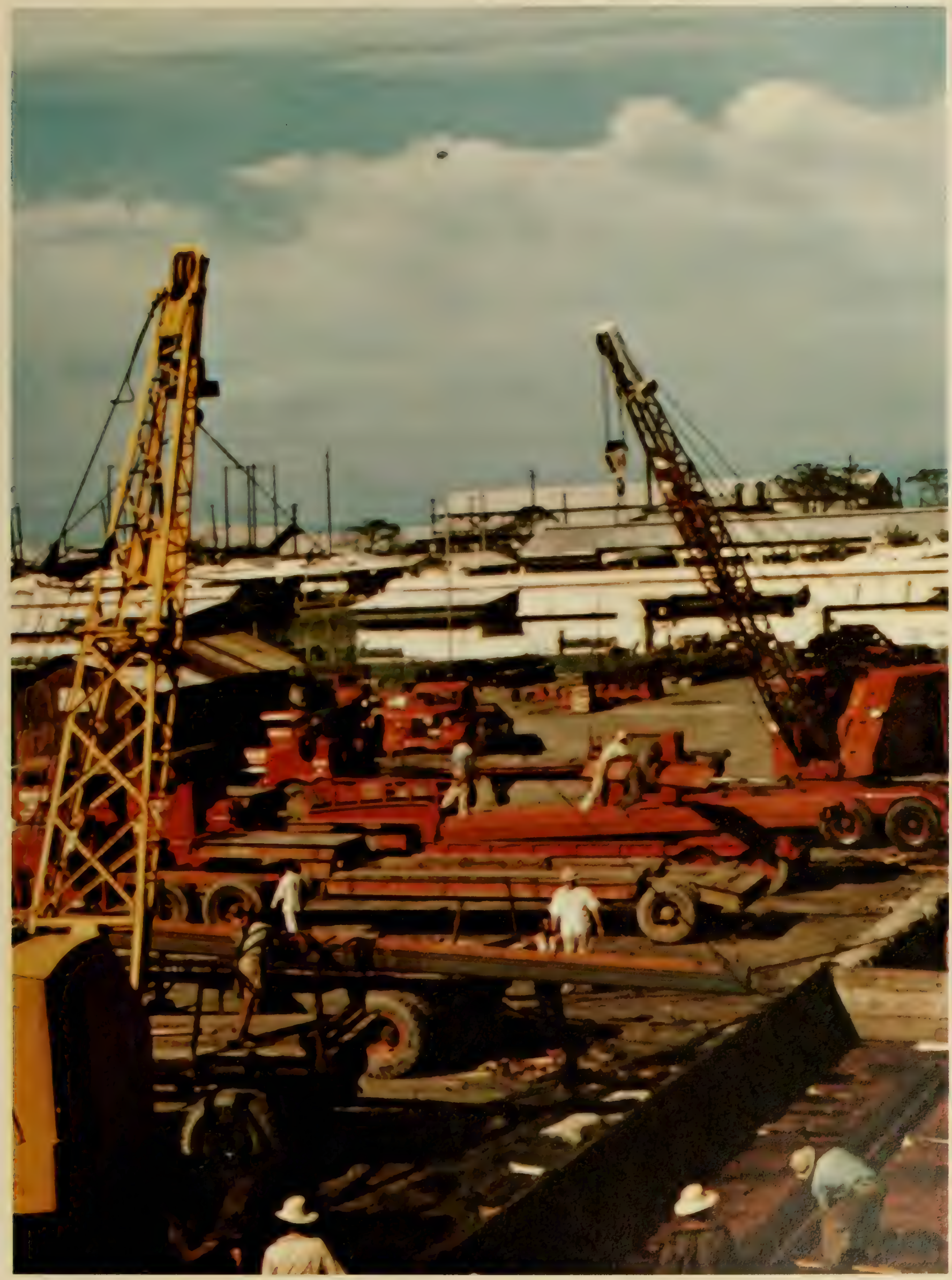




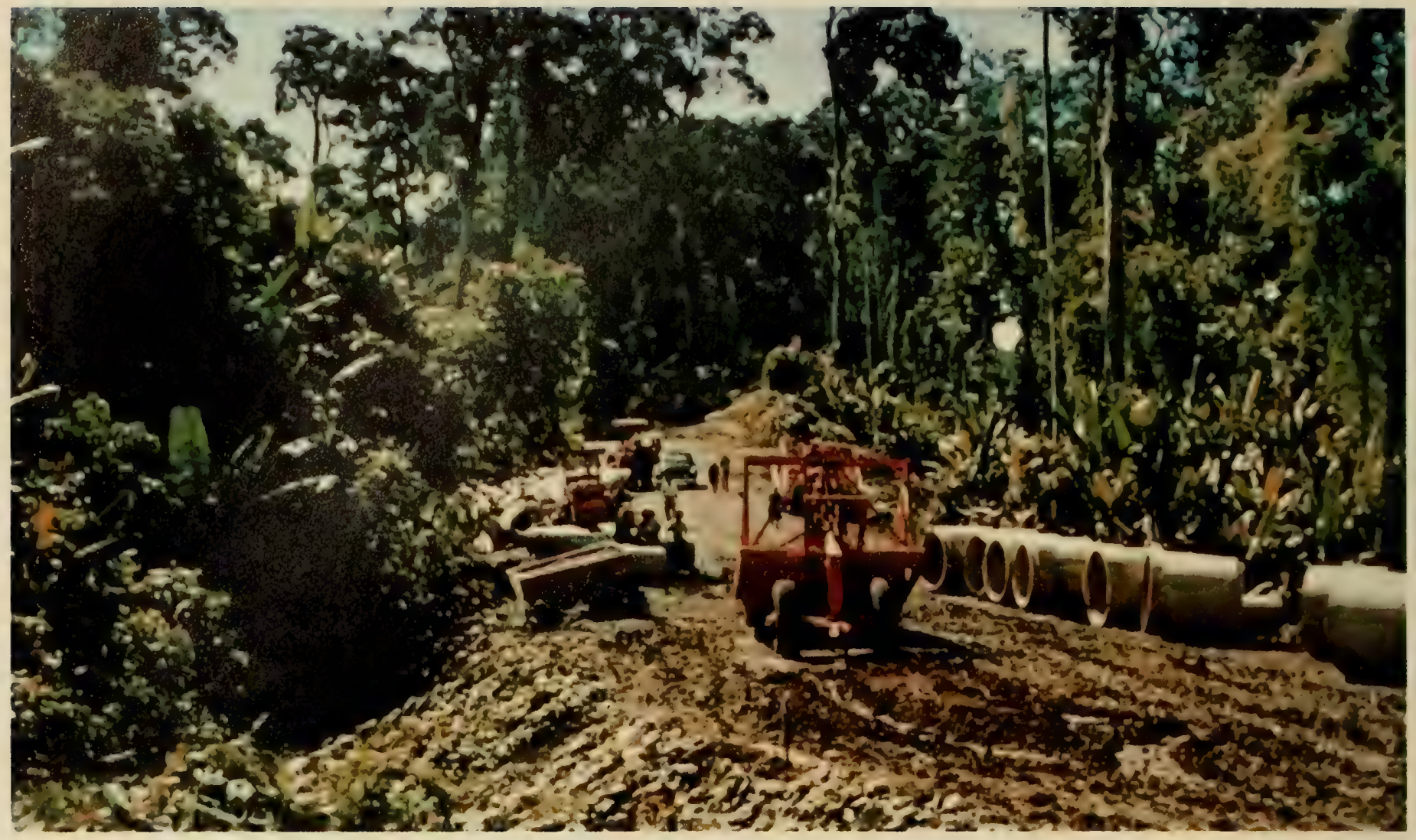

Construction of the Mindanao development road.

Turkish terrain required intensive maintenanee.

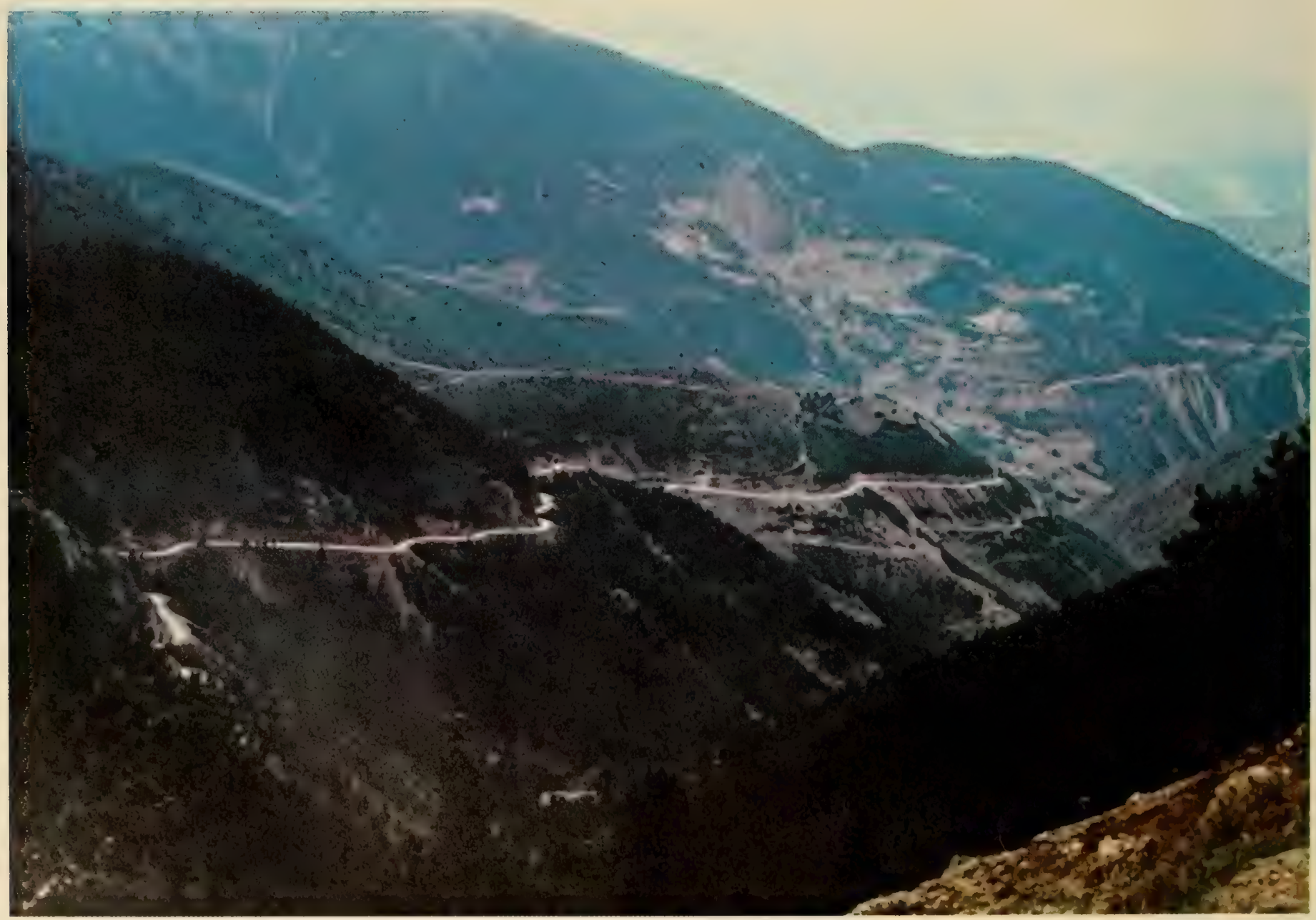


by 1952 the Philippine Bureau of Public Highways was staffed entirely by local engineers and technicians and was recognized as one of the most capable highway organizations in Asia. During 1961 and 1962 the BPR/ICA activities were gradually phased out, and the Bureau Division Office in the Philippines was closed.

Meanwhile, however, negotiations were underway between the Philippine Government and the Development Loan Fund (a U.S. Government lending institution) for a substantial loan for highway purposes. This loan, identified as DLF No. 67, was approved in June 1959 in the amount of $\$ 18.75$ million. The loan agreement specified that the borrower (Philippine Government) make arrangements for the Bureau of Public Roads to act as liaison between the Philippine Government and the lending agency. ${ }^{22}$

After a difficult beginning, the program progressed satisfactorily, and the majority of program activities were completed in September 1969.

\section{The Turkish Program-1947 to 1958}

On May 22, 1947, the 80th Congress enacted Public Law 75, known as the Aid to Greece and Turkey Program. The law included a sum of $\$ 5$ million to Turkey for highway purposes. Originally scheduled to be administered and operated by the U.S. Army, it was shortly found more suitable for the Public Roads Administration (PRA). Thus, on July 12, 1947, the State Department and the PRA signed an agreement in which Public Roads would supervise the highway program in Turkey under the terms of the Act. By the end of 1947, the PRA's staff consisted of is men, engineers and specialists sharing space with their Turkish counterparts for a good opportunity for close working relationships and training. The initial objectives of the administrative and planning advisors were to prepare a report on the status of highway development and to negotiate a formal agreement with the Turkish Government covering the objectives of the cooperative program; establish the obligations to be assumed by each party; formulate the ways of attaining the desired objectives; and arrange the financial requirements for the program. The report was completed, presented to the Turkish Government, and an agreement executed on April 26, 1948. This agreement stated that the Public Roads group would assist the Ministry of Public Works of Turkey in establishing a long-range highway improvement program and in establishing a pattern for highway administration on a national scale.

The initial staffing of the Public Roads group provided the required organizational arrangement for accomplishing the work. Specialists were added to the organizational units as required, but when Turkish personnel were capable of taking over an organizational unit, that unit was dropped from the Public Roads organization. The first division to be transferred to exclusive Turkish administration was the Planning and Programing Division in 1954.

The 11 years of training and working together between BPR and the Turkish personnel bore fruit. When the technical assistance program began in Turkey, BPR personnel could not identify a counterpart in the Turkish organization for many of the divisions such as in Survey and Design or in $\mathrm{Ma}$ terials. Or, if there were counterpart groups, many of the techniques used were not mechanized. Thus, units had to be organized and staffed, and training for counterparts and their sections had to be undertaken. The better graduates from this instruction became instructors for new classes. While the on-thejob instruction was going on, further practical ex-

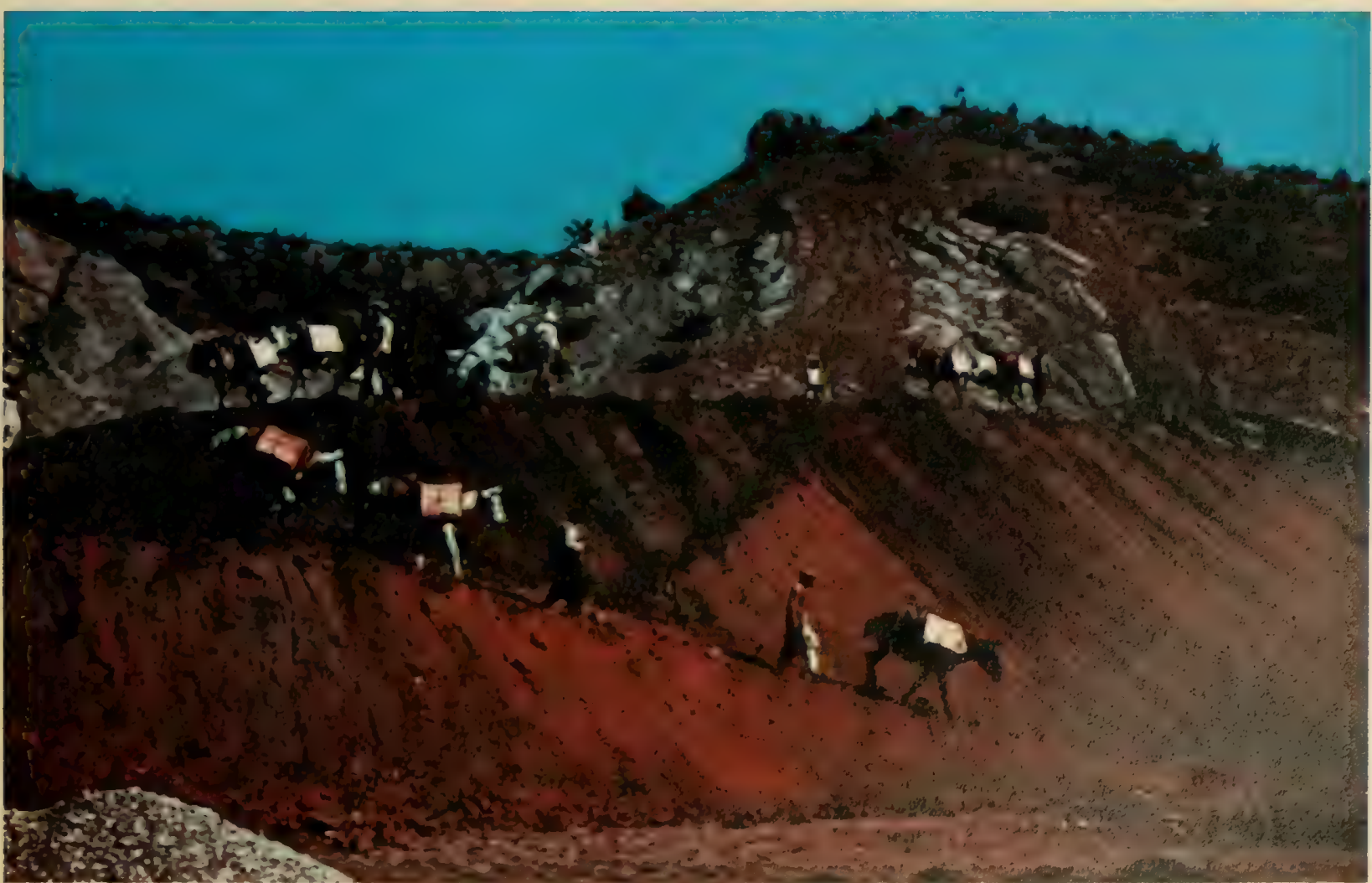


perience was being gained by the Turkish personnel as they built and maintained the highway system.

By far the greatest part of the Bureau's effort was in supplying equipment. The initial aid program provided for shipment to Turkey of equipment, materials, and parts valued at approximately $\$ 4.5 \mathrm{mil}$ lion; subsequent aid programs increased this figure to approximately $\$ 41$ million. Equipment was already arriving in Turkey in December 1947 when the first of the PRA group arrived.

The task of institution building* required innovative measures, especially in training matters. Initially, recruiting local personnel satisfactory as equipment operators proved to be difficult, and to furnish enough operators, the Turkish Army supplied officers and men to the program. This speeded up construction of strategic highways and was considered to be sufficient justification for bringing army personnel into the training program. Prior to starting actual road construction, all operators received training on the new equipment.

The basic program was essentially completed by the mid-1950's, and the last advisor returned to the United States in late 1958. Measured in terms of highway improvement, the mileage of all-weather roads on the Turkish National Road system more than doubled between 1948 and 1958, and on the Provincial System it increased fivefold. In 1960 the Turkish highway department was maintaining 14,450 miles of national roads and 13,182 miles of provincial roads. From 1940 to 1960 , over 800 bridges were built on the national system and more than 400 on the provincial roads. In evaluating the Turkish program, the following assessment was made in a study prepared in 1962 by the Columbia University School of Law :

Financially, the extent of the aid hardly comes up to the level of the aid received by the other sectors and organizations in Turkey. Yet, the outstanding feature of the aid is that in this instance the technical assistance has been rendered directly by the Federal Bureau of Public Roads. Consequently, the technical aspect of the work done has been of the highest level. The fact that the organization was set up and put into operation by the U.S. experts has been the principal factor in the eventual success of the project.

Within a short time, the general Directorate of Highways has evolved into a first-class organization. So much so that today it is in a position to extend technical assistance to certain countries in the Middle East implementing highway-construction programs.

The aid extended to Turkey in connection with her highway program and the results achieved through that aid confirm the fact that, in the case of underdeveloped countries, technical aid is more important than financial and that it should be given priority. ${ }^{23}$

\section{Training Foreign Nationals}

The Federal Highway Administration has always placed strong emphasis on training. The training of young engineers and construction operators in developing the roadbuilding capability in this country proved so significant that an initial emphasis in this

\footnotetext{
* Institution building is assisting in the development of a highway organization equipped with adequate laws and procedures and administered and operated by trained personnel The ultimate desired result of technical assistance is to develop the capability of a country's highway organization to administer, build, and maintain a highway system adequate to develop their economy and improve the standard of living.
}

area was naturally of high priority in all overseas projects also.

The first major applications of overseas training programs were undertaken in the projects in Turkey and the Philippines. Since then institution building through training has been a part of all technical assistance provided by FHWA. Because conditions in each country vary tremendously in facilities, educational level, and other factors, each overseas Division Office has been required to develop training programs specifically to meet the needs of that country.

A deficiency Bureau engineers noted in all overseas programs immediately after World War II was the lack of manuals or procedural guides. In order to overcome this, early in each program, a Bureau advisor assisted his local counterpart in preparing manuals to cover his specific technical field. These manuals were in the local language and were designed to fit conditions within that country. Practically all Bureau technical manuals and some State highway department manuals have been modified and issued in the language of the various countries. Thus, American design standards, planning techniques, material tests and specifications, and equipment practices have been adopted, in various degrees, throughout the world. The use of these manuals by the respective countries for both training and operations has been one of the greatest influences on the growth and development of their highway departments.

Major overseas programs where training was the key element for the successful establishment of a workable highway department were undertaken, in addition to Turkey and the Philippine Republic, in Ethiopia, Iran, and Laos. Less extensive programs were undertaken in Nepal, Lebanon, Sudan, Brazil, Bolivia, Kuwait, Jordan, Dominican Republic, and Cambodia.

While the overseas divisions carried out the greater portion of their training activities onsite, the need to train, in this country, staff engineers and administrators of foreign highway departments was also recognized. Since 1948, the Bureau has welcomed over 10,000 engineers and highway officials for various types of formal training programs.

In 1949 BPR and the Department of State decided to offer to groups of foreign engineers a formal course of lectures, discussions, demonstrations, and field trips. The course included 6 weeks of lectures and discussions in Washington, 2 weeks visiting equipment and automobile plants, and subsequent visits to various State highway departments where field operations and Federal-State cooperation could be observed. This program continued for 4 years, the final course being held in 1952.

By combining a relatively small group of specialists overseas with the extensive backup provided by the FHWA headquarters and field offices working in cooperation with State highway departments, FHWA has contributed much to assist the world in its struggle to expand economic development by opening new areas. Certainly the work of the FHWA around the world, through its use and teaching of American design standards and construction trades, has fulfilled Mr. MacDonald's charge in 1925. It is, indeed, the finer statesmanship. 
REFERENCES

${ }^{1}$ Bureau of Public Roads Annual Report, 1901, p. 243.

${ }^{2}$ Bureau of Public Roads annual Report, 1900, p. 289.

3 Bureau of Public Roads Annual Report, 1908, p. 6.

"Bureau of Public Roads Annual Report, 1911, p. 46.

${ }^{5}$ Bureau of Public Roads, The Bureau of Public Roads And Its Exhibit (U.S. Dept. of Agriculture, Washington, D.C., 1922) pp. 5, 6.

${ }^{-} H$. H. Rice Appointed Chairman of U.S. Delegation to Pan-American Road Congress at Buenos Aires, Good Roads, Vol. 68, No. 7, Aug. 1925, pp. 196, 197

${ }^{7}$ T. MacDonald, Our International Relations as Shown by the Pan-American Road Congress at Buenos Aires, Address delivered at 11th Annual Meeting, American Association of State Highway Officials, Detroit, Mich., Nov. 19, 1925, PAPERs, 1924-25, p. 11.

${ }^{8}$ T. MacDonald, Contrasting United States and European Practices in Road Development, Address delivered at 24 th Annual Meeting, American Association of State Highway Officials, Dallas, Tex., Dec. 5, 1938, PAPERs, 1937-39, pp. 3, 4.

${ }^{2}$ Bureau of Public Roads, Testimonial (Manila Division Office, Manila, 1952), pp. 12, 13.

${ }^{10}$ Staff of The House Comm. ON Public Works, 86 Th Cong., 2d Sis., Report of The Construction Progress ON Inter-American Highway in Central America and Panama (Comm. Print 22) p. 146.

${ }^{11}$ Staff of The House Comm. On Public Works, 88 th Cong., 1st. Sens., The Final Link, Report On The Darien Gap and Progress Toward Completion of The Inter-AmeriCan Highway (Comm. Print 2) p. 3.

${ }^{12}$ Supplemental Appropriations Act of 1930 (46 Stat 115 ).
${ }^{13}$ Staff of The House Comm. ON Roads, The InterAmerican Highway-An Interim Report Pursuant To $H$. Res. 255 (Comm. Print, Dec. 18, 1946) pp. vi, vii, 11.

"Darien Subcommittee, The Darien Gap Project (Darien Gap Subcommittee, Panama, Oct. 1965) p. 1.

${ }^{15}$ Final Act, Sixth Pan-American Highway Congress, July 11-23, 1954 (Comm. on Economic and Social Affairs, Pan American Union, Washington, D.C., 1955) p. 22.

${ }^{16}$ Final Conclusions and Recommendations Regarding Location, Design, and Construction of The Pan-American Highway Through The Darien gap in The Republics of Panama and Colombia (Darien Subcommittee, Panama, 1968) p. 11.

${ }^{17}$ The Alaska Highway, H. Rep. 1705, 79Th Cong., 2p Sass., pp. $9,10$.

${ }^{18}$ Letter to Gen. Clarence L. Sturdevant, Office of the Chief of Engineers, from Thomas H. MacDonald, Commissioner, Public Roads Administration, Mar. 4, 1942, in Construction of The Alaska Highway (Public Roads Admin., Washington, D.C., 1945) pp. 102-105.

${ }^{19}$ H. REP., supra, note 17, p. 14.

${ }^{20}$ Letter to J. S. Bright, Public Roads Administration, from Col. L. D. Worsham, Corps of Engineers, Division Engineer, Apr. 7, 1943, in Construction of The Alaska Highway (Public Roads Admin., Washington, D.C., 1945) pp. 164, 165.

${ }^{21}$ H. REP., supra, note 17, p. 26.

${ }^{22}$ Loan Agreement Between Department of Public Works and Communications, Republic of The Philippines, and The Development Loan Fund, DLF Loan No. 67, June 29, 1959.

${ }^{23}$ Columbia University School of Law, Public InternTIONAL DEVELOPMENT FInancing IN TURKeY (Columbia Univerity Press, New York, 1962) pp. 132, 133.

541 


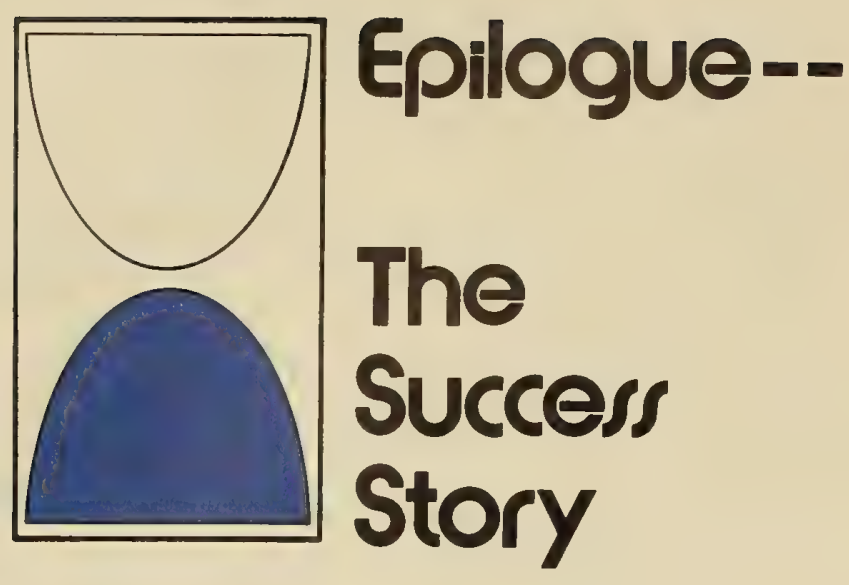

The story of the development of highways and of highway transportation in the United States, as presented here, has been limited largely to the role of the Federal Government in the construction of our Nation's highways under the remarkably successful Federal-aid highway program. As the name indicates, the "Federal-aid" program is one involving joint Federal-State funding and execution of the design and construction of highways on approved systems of interconnected routes in all States. The Federal-State funding varies with the designated system on which the improvement is undertaken, and the States, at their option, may schedule construction without Federal funding and without Federal review.

In the Federal-aid highway program, each of the State highway departments has served as a full and equal partner in that State and merits equal credit for the program accomplishments. This text has recorded the story of the Bureau of Public Roads as one of the partners. The accomplishments of each State highway department in a common and parallel endeavor is a separate story. It has been a truly successful partnership program.

The agency that was to become the Bureau of Public Roads, and ultimately the Federal Highway Administration, was created in 1893 with an initial appropriation of $\$ 10,000$ per year. The activities of the agency were limited to making "inquiries" among State and local units as to road construction and maintenance practices. The initial "staff" was the Special Agent and Engineer, General Roy Stone, and a clerical assistant, and the first year's expenditures totaled less than $\$ 3,000$ of the available appropriation.
Thus, at the outset, frugality in manpower and administrative expenditures, through the years, characterized the performance of the Federal Government's highway agency, by whatever title it was termed under law.

Initially, the interest of the Federal Government in road improvement was minimal, and years passed before the public demand for improved rural mail delivery service resulted in a Federal enactment of financial aid to the States for improvement of selected post roads. Experimentation in road construction methods and in the use of construction materials was the forerunner of today's sophisticated program of construction and research in the highway industry. The post road improvement program led to the Federal-aid highway program and provided valuable experience which was of assistance to the Congress in its framing of the Federal Aid Road Act of 1916the first real Federal-aid highway legislation.

Early efforts toward a system of Federal highways, constructed and maintained by the Federal Government, did not prevail. Rather, there developed an underlying concept of State ownership, State responsibility, and State program initiation, with the Federal agency advising and consulting and with the Federal Government providing financial assistance.

The Federal Aid Road Act of 1916 established the partnership role of the State and Federal Governments in a program of Federal aid for highway construction, and the Federal Highway Act of 1921, together with the Post Office Appropriation Act of 1922, provided a multiyear plan of Federal funding 
for the program-both essential to the continuous program that has endured to the present.

During the time period in which congressional action on the basic highway legislation was evolving, first Logan Waller Page (1905-1918) and then Thomas H. MacDonald (1919-1953) were appointed to be Director of Public Roads and ably developed the Bureau of Public Roads (as it is known to most Americans). Under these two men, the Bureau procedures implemented the basic concept of equal Federal-State partnership roles in carrying out the congressional mandate for Federal assistance in constructing a highway system in the United States. The State had the responsibility to locate and design the proposed highways, to secure the necessary rights-ofway, to advertise and award the proposed construction contracts, and to supervise the construction activity under the contract which followed. The role of the Bureau of Public Roads was that of consultation, advice, review and approval at each of the successive steps as the project developed from its initial proposal to its final contract completion. The State owned and agreed to maintain the highways on which Federalaid moneys were spent.

While the size of the program has increased dramatically-from an authorization level of $\$ 75$ million in 1922 to a program level in excess of $\$ 5$ billion in 1974 the same basic procedures initiated in the beginning years of the program are still followed. This stability of program operation has resulted in widespread confidence in and acceptance of the highway program at local, State and Federal levels, both in and out of the highway program.

The success of the Federal-aid highway program is unquestioned, and the reasons are many. The Congress consistently provided advance authorizations and timely appropriations so that the States, from the beginning, could move with confidence knowing in advance the level of authorization at which they could operate and knowing that appropriated funds would be adequate to provide cash reimbursement for their expenditures. The Congress increased the level of financing as public needs required, and expansion of the scope of program activities has been authorized as special needs for highway transportation became evident. The sage action of Congress in highway legislation has been a most important factor in the success of the Federal-aid highway program.

A second and equally important factor has been the development of strong, competent individual State highway organizations and their interaction with members of the construction industry in implementing the program made possible by the congressional authorizations. The States have developed organizations with the technical and administrative ability to meet the changing program demands, and the construction industry nationwide has kept pace through advancing construction technology and integrity of purpose to meet the growing needs in highway construction procedures.

Recognizing the contributions of Congress, the States, and the construction industry toward the development of highway transportation in the United States, the Bureau of Public Roads, for its part, has implemented and administered the legislation since
1916 and has fostered the successful Federal-State partnership.

In the formative years, the Bureau held a tight rein in guiding development of the program. All approval authority was administered from the central office in Washington, with assistance provided through 10 field district offices to which routine operating responsibility and authority was delegated, and a Regional Office which served as an extension of the Washington Office covering operations of the program in 11 western States in which most of the direct Federal construction work was performed. Strong central office control prevailed over all system approvals, program actions, and project plans and specifications. Construction contract administration was a more local responsibility with review at the field level.

This initial strong central control accomplished a major objective of uniformity in the administration of emerging regulations and procedures among the States, thus establishing Federal-aid programs in each State on a common basis.

Mr. MacDonald developed within the Bureau a spirit of organizational pride in professional excellence of performance combined with a dedication to public service and unquestioned integrity. The ability of the Bureau to attract competent and dedicated personnel through the years stemmed in a large part from the early organizational image. The well ordered, fully professional program was attractive to young engineers who sensed the opportunity to participate in a rewarding program and who normally remained in that service throughout their professional careers.

In the 1940 's a major organizational change established BPR offices in each State, with geographical regional offices designated to serve as intermediary between these State level organizational units and the central office in Washington. The reorganization resulted in closer operating coordination at the State level and the development of staff capability at the regional level, both of which were to be of immense value in the decentralization of program control and delegation of authority which were to follow a few years later.

The increase in the size of the Federal-aid program funding in the postwar years, the expanding Federal interest in urban transportation problems, and the anticipated legislation for separate funding for construction of the Interstate System resulted in major delegation of operating authority in 1953, and in the following 2 years, authority for all program and project approval action was delegated. The submission of project plans to Washington was discontinued as a general requirement. The Washington Office role became that of consultant and arbitrator on project matters and one of leadership in establishing program policy consistent with the total transportation program objectives of the Administration and of Congress. The result was that the Bureau effectively administered a vastly increased program with very little increase in the number of personnel.

Changes in the program have been many, and their impact has been dramatic. The program started as a rural post road improvement program. With the growth of the Nation and of its urban population, the 
program became one of meeting the complex transportation and social problems in urban areas and the needs for intercity and interstate motor vehicle transportation. The changing focus in national highway needs and in national transportation objectives had been anticipated by BPR leaders and had prompted their early efforts in the fields of highway planning and needs studies, highway research sponsorship, highway design and construction, highway traffic operation, and highway transportation economics. This capability to meet the demands of changing national interests with major program changes and with a modest, but flexible, staff is the real success story of the Bureau of Public Roads. It is a story of dedicated and competent public service which has earned the confidence and respect of the American people over a 60-year period. Professional excellence with total integrity has marked that performance from the beginning.

But what about tomorrow? Is it not only natural to expect that this impressive story of accomplishment will continue well into the future?

Engraved on the facade of the National Archives building is the phrase "What is past is prologue." This is certainly true with respect to the long and successful highway building era in America. We cannot contemplate the present without knowledge of the past nor forecast the future in ignorance of either.

The national highway program is in the throes of major change in direction and emphasis. These changes are emanating from complex issues and problems associated with growing questions of government involvement. For instance, the appropriate roles of Federal, State, and local governments in highway construction, operation, and maintenance are being reconsidered. We realize that the Interstate System is going to require a continuing process of resurfacing, restoring, and rehabilitation to maintain the high level of transportation service demanded by the public. This will be quite expensive and probably beyond the financial capability of the States to do it adequately. A program for Federal participation in the upgrading and rehabilitation of the Interstate System has been authorized in the Federal-Aid Highway Act of 1976.

The Federal role in other highway systems-the Primary, Secondary, and Urban Systems-will also be examined closely and debated in the coming months and years. It appears likely that more of the responsibility for planning the construction, maintenance, and operation of these systems will shift away from the Federal and further toward State and local levels of government over time, consistent with the policy of increasing the decisionmaking flexibility of these levels of government to deal with issues of lesser national significance.

During the past 10 years, although the total investment for all highway functions by all levels of government has increased substantially, inflation has eroded the highway dollar so seriously that actual construction activities on highways has in fact decreased. In the same 10-year period, the number of miles of highways in the United States, the number of registered vehicles, and the number of vehicle miles of travel have all increased substantially. These facts indicate that, at best, we have maintained approximately the same level of performance on our highway system during the last 10 years. As more facts are gathered, however, we may learn that the highway system's overall performance has deteriorated. A major issue, then, will be to determine appropriate funding levels to maintain a reasonable performance level on our highways and to provide for those funds fairly and equitably in accordance with the benefits derived by the users of the highway system. Included in this issue is the question of what funding mechanisms can be used to adequately finance the Nation's highway system-for example, shall we retain the Highway Trust Fund or establish a Transportation Trust Fund? Or should we return to general revenue funding for highways? And how will rising State and local funding needs be satisfied? These are questions which will also be debated during the coming months.

More attention will be given in the coming years to upgrading public transportation, including light and heavy rail mass transit and railroad facilities. At the same time, more rigorous analytical procedures will be needed in making such large transportation investment decisions through cost-effectiveness studies and analyses of alternatives. Highway builders, the engineers who developed the highway system that is the envy of the whole world, may be expected to assist in the rehabilitation of the fixed rail systems in the Nation. We may expect that State and Federal highway organizations will become more closely involved in this new major thrust within the transportation family.

A major objective now and in the years to come will be to make better use of the highway facilities we already have. Land and other resources in many areas are becoming scarce, and fuel is becoming more precious. Accordingly, we may expect to see in the future a continuing emphasis on the more efficient utilization of our existing facilities. Better traffic management, auto-restricted zones in our dense urban areas, preferential transit bus and carpool treatments, better utilization of air space and below ground space in rights-of-way-all of these concepts will receive more attention in the coming years, especially in the more densely populated urban areas where efficiency is paramount.

More attention will be given to the conservation of energy and the development of new sources of energy. We will need to discipline ourselves to use less fuel by driving at slower speeds and developing more fuel efficient vehicles. It would be comforting to predict the development of new, clean, infinite sources of energy. After all, the United States did not become a great Nation by saving energy, but by using huge quantities of it. We may again reach a time when we can use all the energy we want without polluting the atmosphere or depleting finite resources, but this day is far off, and in the interim, conservation must be our watchword.

Improved highway safety will continue as a high priority goal. Significant improvement has been realized in very recent years, due in part to the nationwide 55 mile per hour maximum speed limit. Since 1973 , the actual number of fatalities, as well as the fatality rate, have been significantly reduced. But we must continue to improve highway design and 
engineering so that the roads become ever more "forgiving" of errant drivers and vehicles. At the same time, we must continue to make the vehicles themselves more mechanically safe, and we must try to better equip the human beings who operate those vehicles to do so safely.

Past investments in highway improvements have provided a high level of mobility for the general population. In the future we can anticipate greater efforts to provide better mobility for the young, the elderly, and the handicapped who lack ready access to autonobile transportation. In this regard, local elected officials of urbanized areas may elect to use certain apportioned highway funds for public mass transportation projects instead of for highways. Such an effort may be expected to extend to the transportation disadvantaged segment of our population the same opportunities for social, cultural, recreational, and economic benefits enjoyed by the rest of us.

The United States does not have an explicit national land use policy. The uncertainty regarding the nature and direction of changes in land use and settlement patterns is increased by the lack of a concensus regarding desirable growth within and among regions and between urban and nonurban areas. The Federal Highway Administration and the State and local highway organizations have responded to the needs of our growing Nation well in the past. As we look to the future, our efforts must be to provide even greater flexibility of choice to the States and local governments to provide highway services to meet changing population or economic developmental patterns that may emerge or be consciously pursued.

Out of all our past efforts-planning, designing, constructing, bridge building, and organizational efforts at all levels of government-has come a superb system of highways to serve a growing Nation. The challenge now and in the future is to preserve and enhance the performance level of our highways and at the same time promote within a multi-modal transportation family a more flexible and innovative transportation system. Our past performance, in all respects, would indicate that we will be equal to the challenge. We must demonstrate that we are. 


\section{HIGHWAY RELATED LEGISLATION}

The following is a chronological list of national laws which have had a significant impact on the growth and development of the Federal-Aid Highway System.

\section{Title \\ Date Number}

Land Grant to Ohio Act of 1823

Agriculture Appropriation Act of 1894

Agriculture Appropriation Act of 1895

Agriculture Appropriation Act of 1896

Agriculture Appropriation Act of 1897

Agriculture Appropriation Act of 1898

Agriculture Appropriation Act of 1899

Agriculture Appropriation Act of 1900

Agriculture Appropriation Act of 1901

Agriculture Appropriation Act of 1902

Agriculture Appropriation Act of 1903

Agriculture Appropriation Act of 1904

Agriculture Appropriation Act of 1905

Agriculture Appropriation Act of 1906

Agriculture Appropriation Act of 1907

Agriculture Appropriation Act of 1908

Agriculture Appropriation Act of 1909

Agriculture Appropriation Act of 1910

Agriculture Appropriation Act of 1911

Agriculture Appropriation Act of 1912

Post Office Appropriation Act of 1913

Agriculture Appropriation Act of 1914

Agriculture Appropriation Act of 1915

Agriculture Appropriation Act of 1916

Federal Aid Road Act of 1916

Post Office Appropriation Act of 1917

Aug. 8, $1894 \quad 28$ Stat 264

Apr. 25, 189629 Stat 99

Apr. $28,1897 \quad 30$ Stat 1

Mar. 22, $1898 \quad 30$ Stat 30

Mar. 1, $1899 \quad 30$ Stat 47

Mar. 2, $1901 \quad 31$ Stat 22

The full title, date of passage and citation number are given for each reference.

Title

Agriculture Appropriation Act of 1917

Agriculture Appropriation Act of 1918

Mar. 2, $1895 \quad 28$ Stat 727

May 25, $1900 \quad 31$ Stat 191

June 3, $1902 \quad 32$ Stat 286

Mar. 3, $1903 \quad 32$ Stat 1147

Apr. 23, $1904 \quad 33$ Stat 226

Mar. 3, $1905 \quad 33$ Stat 361

June 30, $1906 \quad 34$ Stat 369

Mar. 4, $1907 \quad 34$ Stat 2256

May 23, $1908 \quad 35$ Stat 251

Mar. 4, $1909 \quad 35$ Stat 1039

May $26,1910 \quad 36$ Stat 416

Mar. 4, $1911 \quad 36$ Stat 1235

Aug. 24, $1912 \quad 37$ Stat 551

Mar. 4, $1913 \quad 37$ Stat 828

June 30, 191438 Stat 415

Mar. 4, $1915 \quad 38$ Stat 1088

July 11, 191639 Stat 355

July 28, 191639 Stat 412
Post Office Appropriation Act of 1919

Agriculture Appropriation Act of 1919

Post Office Appropriation Act of 1920

Army Appropriation Act of 1919

Agriculture Appropriation Act of 1920

Wadsworth-Kahn Act of 1920

Agriculture Appropriation Act of 1921

Agriculture Appropriation Act of 1922

Budget and Accounting Act

Federal Highway Act of 1921

Post Office Appropriation Act of 1923

Federal-Aid Highway Amendment of $\mathbf{1 9 2 5}$

Federal-Aid Highway Amendment of 1926

Agriculture Appropriation Act of 1928

Federal-Aid Highway Amendment 1927

Federal-Aid Highway Amendment 1928

Federal-Aid Highway Amendment 1930

George Washington Memorial Parkway Act 1930

Emergency Construction Act of 1930

Federal-Aid Highway Amendment 1931

Emergency Relief and Construction Act 1932

National Industrial Recovery Act

Hayden-Cartwright Act of 1934

Emergency Relief Appropriation Act of 1935

Davis-Bacon Act 1935

Federal-Aid Highway Act Amendment 1937
Date Number

Aug. 11, 191639 Stat 446

Mar. 4, 1917

39 Stat 1134

July 2, 1918

40 Stat 742

Oct. 1,1918

40 Stat 973

Feb. 28, 1919

40 Stat 1189

July 11, $1919 \quad 41$ Stat 105

July 24, 191941 Stat 234

Mar. 15, 192041 Stat 530

May 31, $1920 \quad 41$ Stat 694

Mar. 3, $1921 \quad 41$ Stat 1315

June 10, $1921 \quad 42$ Stat 207

Nov. 9, 192142 Stat 22

June 19, 192242 Stat 660

Feb. 12, $1925 \quad 43$ Stat 889

June 22, $1926 \quad 44$ Stat 760

Jan. 18, 1927 44 Stat 976

Mar. 3, $1927 \quad 44$ Stat 1398

May 21, $1928 \quad 45$ Stat 683

May 5, $1930 \quad 46$ Stat 261

May 29, $1930 \quad 46$ Stat 482

Dec. 20,193046 Stat 1030

Jan. 31, 193146 Stat 1053

July 21, $1932 \quad 47$ Stat 709

June 16, 193348 Stat 195 June 18, 193448 Stat 993

Apr. 8, $1935 \quad 49$ Stat 115

Apr. 30, 193549 Stat 1011

June 16, 193649 Stat 1519 
Title

Federal-Aid Highway Act 1938

Defense Highway Act 1941

Inter-American Highway Act 1941

Defense Highway Act Amendment 1942

Federal-Aid Highway Amendment 1943

Federal-Aid Highway Act 1944

Federal-Aid Highway Amendment 1945

Philippine Rehabilitation Act 1946

Federal-Aid Highway Amendment 1946

Federal-Aid Highway Amendment 1947

Federal-Aid Highway Act 1948

Federal-Aid Highway Act 1950

Budget and Accounting

Procedures Act

Federal-Aid Highway Act 1952

Departments of State, Justice and Commerce Appropriation Act 1954

Federal-Aid Highway Act 1954

Department of Commerce and Related Agencies Appropriation Act 1956

Inter-American Highway Appropriation Act

Supplemental Appropriation Act 1956

Federal-Aid Highway Act of 1956

Highway Revenue Act of 1956

Federal-Aid Highway Act of 1958

Alaska Statehood Act

Alaska Omnibus Act

Federal-Aid Highway Act 1959

Mutual Security Appropriation Act 1960

Federal-Aid Highway Act 1960
Date Number

June 8, $1938 \quad 52$ Stat 633

Nov. 19, 194155 Stat 765

Dec. 26, 194155 Stat 860

July 2, $1942 \quad 56$ Stat 562

July 13, $1943 \quad 57$ Stat 560

Dec. 20, $1944 \quad 58$ Stat 838

July 31, $1945 \quad 59$ Stat 507

Apr. 30, $1946 \quad 60$ Stat 128

July 29, $1946 \quad 60$ Stat 709

June 21, $1947 \quad 61$ Stat 136

June 29, 194862 Stat 1105

Sept. 7, $1950 \quad 64$ Stat 785

Sept. 12, $1950 \quad 64$ Stat 832

June 25, $1952 \quad 66$ Stat 158

Aug. 5, $1953 \quad 67$ Stat 367

May 6, $1954 \quad 68$ Stat 70

June 30, 195569 Stat 226

July 1, $1955 \quad 69$ Stat 244

Aug. 4, $1955 \quad 69$ Stat 450

June $29,1956 \quad 70$ Stat 374

June 29, $1956 \quad 70$ Stat 387

Aug. 7, $1958 \quad 72$ Stat 389

Apr. 16, $1958 \quad 72$ Stat 89

June 25, $1959 \quad 73$ Stat 141

Sept. 21, 195973 Stat 611

Sept. 28, 195973 Stat 717

July 14, $1960 \quad 74$ Stat 522
Title

Date

Number

National Driver Register Service Act

Federal-Aid Highway Act 1961

Federal-Aid Highway Act 1962

Federal-Aid Highway

Amendments Act 1963

Urban Mass Transportation Act 1964

Federal-Aid Highway Act 1964

Government Employees Salary Reform Act of 1964

Federal-Aid Highway Act of 1956 Amendments 1965

Highway Beautification Act of 1965

National Traffic and Motor Vehicle Safety Act 1966

Highway Safety Act 1966

Federal-Aid Highway Act 1966

Historic Preservation Act 1966

Department of Transportation Act 1966

Highway Interstate Systems Modification Act 1968

Federal-Aid Highway Act 1958

National Environmental Policy Act 1969

Clean Air Amendments of 1970

Federal-Aid Highway Act 1970

Highway Safety Act 1970

Uniform Relocation Assistance and Real Property Acquisition Policies Act of 1970

Noise Control Act of 1972

Federal-Aid Highway Act 1973

Emergency Highway Energy Conservation Act 1974

National Mass Transportation Assistance Act 1974

Federal-Aid Highway Amendments of 1974

Federal-Aid Highway Act of 1976
Aug. 14, $1960 \quad 74$ Stat 526

June 29, $1961 \quad 75$ Stat 122

Oct. 23,196276 Stat 1145

Oct. 24,196377 Stat 276

July 9, $1964 \quad 78$ Stat 302

Aug. 13, $1964 \quad 78$ Stat 397

Aug. 14, 196478 Stat 400

Aug. 28, $1965 \quad 79$ Stat 578

Oct. $22,1965 \quad 79$ Stat 1028

Sept. 9, $1966 \quad 80$ Stat 718

Sept. $9,1966 \quad 80$ Stat 731

Sept. 13, 196680 Stat 766

Oct. $15,1966 \quad 80$ Stat 915

Oct. 15, $1966 \quad 80$ Stat 931

Jan. 2, $1968 \quad 81$ Stat 772

Aug: -3, $1968 \quad 82$ Stat 815

Jan. 1, $1970 \quad 83$ Stat 852

Dec. $31,1970 \quad 84$ Stat 1676

Dec. 31, $1970 \quad 84$ Stat 1713

Dec. 31, 197084 Stat 1739

Jan. 2, $1971 \quad 84$ Stat 1894

Oct. $27,1972 \quad 86$ Stat 1234

Aug. 13, 197387 Stat 250

Jan. 2, $1974 \quad 87$ Stat 1046

Nov. 26, $1974 \quad 88$ Stat 1565

Jan. 4, $1975 \quad 88$ Stat 2281

May 5, $1976 \quad 90$ Stat 425 


\section{PICTURE CREDITS}

We gratefully acknowledge all those whose illustrations were used in this book. Many of the color plates, especially in Part I, are paintings in a series of 109 by the late Carl Rakeman (1878-1965), which were completed in the 1930's and 1940's on the theme of American transportation development. Rakeman was an employee of the Bureau of Public Roads who studied at the Corcoran Art School and the Royal Academies of Dusseldorf, Munich and Paris. Among other accomplishments, he helped complete the painted decorations of the U.S. Capitol. Special thanks are also extended to the National Archives and Records

\section{PART I}

\section{CHAPTER 1. THE COLONIAL LEGACY}

Page $4(\mathrm{BR})$ : Winter Trail. Drawing by H. W. Hendley.

Page 5 (BL): Post Rider. Drawing by H. W. Hendley.

Page $7(\mathrm{~T})$ : $\quad$ Rolling Tobacco. Drawing by $\mathrm{H}$. W. Hendley, after H. E. Elliott.

CHAPTER 3. EARLY FEDERAL AID FOR ROADS AND CANALS

Page 18 (B) : Fairview Inn. Courtesy of Culver Pictures, Inc.

\section{CHAPTER 5. THE GOOD ROADS MOVEMENT}

Page 40 (T): The Cherrelyn Horsecar. Courtesy (B) : of E. H. Maloney and Edie Dines.

Page 51 ('T): Bishop Creek. Courtesy of California Division of Highways.

(BR) : Plank Road. Courtesy of California Division of Highways.

Page $52(\mathrm{~T})$ : Sacramento Canyon. Courtesy of California Division of Highways.

\section{CHAPTER 6. DAWN OF THE MOTOR AGE}

Page 55 (BR): 1907 Columbia. Courtesy of Hank Head.

Page $58(\mathrm{~T})$ : The Pasear Highway. Courtesy of the California Division of Highways.

Page 59 (M): $\quad$ Scenes of El Camino Sierra. Courtesy of the California Division of Highways.

Page 60 (T): Challenge of early AAA tours. Courtesy of the Michigan Department of State Highways and Transportation.

\section{CHAPTER 8. THE DRIVE FOR FEDERAL AID}

Page $84(\mathrm{~T})$ : $\quad$ Spring thaw and roads in Michigan. Courtesy of the Michigan
Service, which stored and protected much of the photographic material of the Federal Highway Administration and its predecessor agencies which appears in this history.

The following is a listing by chapter of all those individuals and organizations outside of the Federal Highway Administration who contributed illustrations printed in this book. The abbreviations with the page number of each credit indicate position; i.e., Top (T), Top Left (TL), Top Right (TR), Middle (M), Middle Left (ML), Middle Right (MR), Bottom (B), Bottom Left (BL), Bottom Right (BR).

Department of State Highways and Transportation.

Page 85 (B): $\quad$ State Highway No. 1 (Now I-25) in New Mexico. Courtesy of New Mexico State Highway Department.

\section{CHAPTER 9. PLANNING A HIGHWAY SYSTEM}

Page 93 (B): W. Hicks and Sons General Store, Rockville, Md. (1900). Courtesy of William L. Hicks.

Page $94(T)$ : $\quad$ State highway officials on inspection tour. Courtesy of the Michigan Department of State Highways and Transportation.

Page 95 (MR): McConnellsburg, Pa. Courtesy of the Michigan Department of State Highways and Transportation.

\section{CHAPTER 10. THE HIGHWAY BOOM}

Page $118(\mathrm{~T})$ : Concrete Mixer patching a bad spot on the road. Courtesy of Hank Head.

Page 122 (M) : Maryland State Roads Commission testing laboratory. Courtesy of the Maryland State Roads Commission.

Page $127(\mathrm{~T})$ : First centerline on a rural state highway. Courtesy of the Michigan Department of State Highways and Transportation.

CHAPTER 11. ROADS FOR NATIONAL DEFENSE

Page 151 (B): The Pennsylvania Turnpike. Courtesy of the Pennsylvania Turnpike Commission.

CHAPTER 12. EVENTS LEADING TO ENACTMENT OF THE 1956 FEDERAL AID HIGHWAY ACT

Page $169(\mathrm{~T})$ : Turnpike toll booth. Courtesy of the Pennsylvania Turnpike Commission. 
PART II

CHAPTER 1. ADMINISTRATION OF THE FEDERAL AID PROGRAM

Page 207 (ML) : Old tour bus. Courtesy of the Grey Line, Inc.

Page 207 (BL) : Modern tour bus. Courtesy of the Urban Mass Transit Authority.

Page 210 (MR): Lansing, Michigan street scene. Courtesy of the Michigan Department of State Highways and Transportation.

CHAPTER 2. FINANCE AND ECONOMICS

Page 240 (TL) : 1905 Cadillac. Courtesy of Hank Head.

Page $244(\mathrm{~T})$ : 1922 Superior Motor Coach body. Courtesy of the National Association of Motor Bus Owners.

Page $250(\mathrm{~T})$ : Rio Grande Gorge Bridge near Taos, N.M. Courtesy of the New Mexico State Highway Department.

Page 258 (BL) : 40 ton straddle-lift crane. Courtesy of the Southern Pacific Co.

Page 259 (MR) : Air Force C-5 Galaxy. Courtesy of Tadder/Baltimore.

CHAPTER 3. PLANNING

Page 270 (T): Traffic survey station. Courtesy of the New Mexico Highway Department.

Page 291 (B): Chicago Post Office. Courtesy of H. Dean Fravel.

Page 299 (T): Stapleton International Airport. Courtesy of the Denver Post.

CHAPTER 4. RESEARCH

Page 332 (T): Circular Track in Arlington, Virginia. Courtesy of Carl A. Carpenter.

Page 332 (B): Profilometer. Courtesy of Carl A. Carpenter.

\section{CHAPTER 5. RIGHT-OF-WAY AND ENVIRONMENT}

Page 367 (TR): Highway road crew removing litter. Courtesy of the Delaware Department of Highways.

Page 373 (BL): Beverly's Mill in Middleburg, Virginia. Courtesy of U.S. News and World Report.

CHAPTER 6. DESIGN

Page 383 (BL) : Horse towing an old car in winter. Courtesy of the Michigan Department of State Highways and Transportation.

Page 384 (TR): The National Road near Hancock, Maryland (before construction). Courtesy of the Maryland State Roads Commission.

Page 385 (TL): The National Road near Hancock, Maryland (after construction). Courtesy of the Maryland State Roads Commission.
Page 391 (T): Center marked highway curve, 1921. Courtesy of the Michigan Department of State Highways and Transportation.

Page 396 (MR) : Arterial highway of 1940's. Courtesy of Donald W. Loutzenheiser.

Page 404 (B) : Automobile Club of Maryland posting directional and mileage signs. Courtesy of the Institute of Traffic Engineers.

Page 406 (TL) : Jackson, Miss. route markers. Courtesy of the Institute of Traffic Engineers.

Page $407(\mathrm{~T})$ : Intersection in Detroit, Mich. (1922). Courtesy of the Institute of Traffic Engineers.

Page 412 (T): The Baltimore-Washington Boulevard. Courtesy of the Maryland State Roads Commission.

Page 412 (B): The Baltimore-Washington Boulevard widened in the 1930 's. Courtesy of the Maryland State Roads Commission.

\section{CHAPTER 7. BRIDGES}

Page 419 (T): Covered bridge reproduction near Concord, Massachusetts. Courtesy of the Massachusetts Department of Public Works.

Page 420 (TL) : Camp Nelson Bridge over the Kentucky River. Courtesy of the Kentucky Department of Transportation.

Page 420 (TR): Covered timber bridge over the Connecticut River between Cornish, N.H. and Windsor, Vt. Courtesy of the New Hampshire Department of Public Works and Highways.

Page 420 (BL): Indiana covered bridge (1900). Courtesy of the Indiana Historical Society.

Page $425(\mathrm{~T})$ : Roebling Bridge over the Ohio River between Cincinnati, Ohio, and Covington, Kentucky. Courtesy of the Kentucky Department of Transportation.

Page 426 (BR) : Vertical lift bridge over the Cape Fear River at Wilmington, North Carolina. Courtesy of the North Carolina Department of Transportation.

Page $427(\mathrm{~T})$ : $\quad$ Lake Washington Pontoon Bridge, Seattle, Washington. Courtesy of the Washington Department of Highways.

Page 427 (ML) : George P. Coleman Memorial Bridge. Courtesy of the Virginia Department of Highways and Transportation.

Page $428(\mathrm{~T})$ : The Morgan Bulkeley Bridge. Courtesy of the Connecticut Department of Transportation. 
Page 430 (T): San Francisco's Golden Gate Bridge. Courtesy of $\mathrm{H}$. Dean Fravel.

Page 430 (B): Mackinac Bridge over the Straits of Mackinac. Courtesy of the Michigan Department of State Highways and Transportation.

Page 431 (TR): Tacoma Narrows Bridge. Courtesy of the National Museum of Science and Technology.

Page 431 (B): New River Gorge Bridge in West Virginia. Courtesy of the West Virginia Department of Highways.

Page 433 (T): I-80 Bridge over the Allegheny River. Courtesy of the Pennsylvania Department of Transportation.

Page 434 (T): $\mathrm{I}-480$ exit ramp in Omaha, Nebraska. Courtesy of the Nebraska State Highway Department.

Page 435 (T) : Red Bridge over the Seekonk River. Courtesy of the Rhode Island Department of Transportation.

Page 435 (BR): Mission Valley Bridge in San Diego, California. Courtesy of the California Department of Transportation.

Page 436 (B) : Sitka Harbor Bridge in Sitka, Alaska. Courtesy of the Alaska Department of Highways.

Page 437 (T): Sherman Minton Bridge over the Ohio River. Courtesy of the Kentucky Department of Transportation.

Page 437 (B): Poplar Street Bridge over the Mississippi River. Courtesy of the Illinois Department of Transportation.

Page 438 (T): Pedestrian bridge over U.S. 41 in Menomonee Falls, Wisconsin. Courtesy of the Wisconsin Department of Transportation.
Page 438 (B) : 47th Street Bypass in Boulder, Colorado. Courtesy of the Colorado Department of Highways.

Page 441 (B): Demolition of C \& O Bridge over the Ohio River. Courtesy of the Kentucky Department of Transportation.

\section{CHAPTER 10. CONSTRUCTION AND MAINTENANCE}

Page 487 (T) : Mount Rainer. Courtesy of James L. Obenschain, Sr.

Page 496: Clakamas River flood. Courtesy of the Oregon State Highway Department.

Page 499 (B) : Going-to-the-Sun Highway. Courtesy of James L. Obenschain, Sr.

Page 504 (T) : Cole Creek Bridge. Courtesy of James L. Obenschain, Sr.

Page 504 (B): Creek channel in the Great Smoky Mountains. Courtesy of James L. Obenschain, Sr.

Page 508 (T) : Jordan Pond. Courtesy of James L. Obenschain, Sr.

Page 511 (T) : Blue Ridge Parkway. Courtesy of James L. Obenschain, Sr.

Page 511 (B): Blue Ridge Parkway in the fall. Courtesy of the National Park Service.

Page 512 (T): James River Bridge on the Blue Ridge Parkway. Courtesy of the National Park Service.

Page 514 (B): Suitland Parkway. Courtesy of James L. Obenschain, Sr.

\section{CHAPTER 11. INTERNATIONAL OPERATIONS}

Page 519 (T) : Map of FHWA Foreign Assistance Programs. Courtesy of the International Road Federation.

Page 535 (B): Alaska Highway at Summit Lake. Courtesy of Gail Pinkstaff.

End papers: Fairview Inn on the National Pike. Courtesy of Culver Pictures, Inc. 


\section{INDEX}

Accidents, 115, 127-129, 135, 149, 246, 262, 278, 279, $337,342,344-348,352,391-392,401-403,406,408$, $440,459,460,484,485$

Agricultural Appropriation Act of 1893, 44

Agricultural Appropriation Act of 1894, 200

Agricultural Appropriation Act of 1905,52

Agricultural Appropriation Act of 1928, 138

Agricultural Appropriation Act of 1936, 125

Alaska Highway, 149, 530-536

American Association of State Highway Officials (A.A.S.H.O.), 79, 86, 96, 98, 101-102, 104, 106$108,120,145,148,152,158,163,165-166,172,202$, 207-208, 296-297, 326, 334, 341

American Automobile Association, 60-61, 74, 76, 84-85, 102,106

Army Corps of Engineers, 21, 31, 107, 138, 498

Automobiles, 52, 54-57, 60, 115, 123-124, 147, 154, 162, $238,247,370,382,384,390,411,414$ (also see Registration)

Bankhead Act 1916, 107

Barnett, Joseph, 188-190

Beautification, (see Highway Beautification Act 1965)

Bridwell, Lowell K., 194

Bridges, 19, 240, 331-332, 418-442

Bureau of Public Roads, 102-110, 120-121, 124-126, $129,132,134,137-140,150,156,163,169-173,208-$ $209,214,218,267-268,271,281-282,298,327,330$, $337,339,341,352,368,431,448-451,453-454$

Capper-Cramton Act, 139

Congestion, 115, 154, 165-166, 171, 261, 281, 300, 370, 466

Construction, (see Roads)

Cumberland Road, (see National Road)

Curtiss, Charles D., 172, 193

Defense, (see Roads)

Defense Highway Act 1941, 150, 249, 269, 275

Design, 337-341, 349, 381-382, 384-398, 401, 411, 476

Dodge, Martin, 46-50, 52, 64, 191, 235

Department of Transportation, 297, 298, 318, 319

Department of Transportation Act 1956, 218

Department of Transportation Act 1966, 221

Department of Transportation Act 1974, 372

DuPont, Francis V., 170, 192

Eldridge, Maurice O., 46, 50, 215-216, 519

Emergency Relief \& Construction Act 1932, 124

Emergency Relief Appropriation Act 1935, 125, 130
Environment, 221, 223, 314, 349-352, 366, 378, 396, $459-460$

Expressways, 150, 152, 160, 163, 169, 171, 397-467

Federal-Aid Highway Act 1934, 268-269, 467

Federal-Aid Highway Act 1938, 134, 278, 368

Federal-Aid Highway Act 1940, 249, 275, 369

Federal-Aid Highway Act 1944, 153, 156-158, 214, $249,269,274,276,321,456,468,493$

Federal-Aid Highway Act 1948, 165, 288

Federal-Aid Highway Act, 1950, 165, 221, 252, 258, 494, 528

Federal-Aid Highway Act 1952, 166, 254, 469, 528

Federal-Aid Highway Act 1954, 166, 171, 254, 292, 294, 358, 469, 528

Federal-Aid Highway Act 1956, 159, 174, 222, 228, $234,254,256,259-260,292,303,317,358,362,396$, $472,476-477,494$

Federal-Aid Highway Act 1958, 478-479

Federal-Aid Highway Act 1959, 255, 479

Federal-Aid Highway Act 1961, 259, 481

Federal-Aid Highway Act 1962, 211, 269, 299, 305, $315,321,363$

Federal-Aid Highway Act 1966, 305

Federal-Aid Highway Act 1968, 262, 299, 315, 317, $363,364,442,472,477$

Federal-Aid Highway Act 1970, 223, 237, 262, 315, $317,358,364,376,442,495$

Federal-Aid Highway Act 1973, 202, 262, 302, 377

Federal-Aid Highway Act 1976, 226, 230

Federal Aid Road Act 1916, 83, 86, 93, 100, 103, 108, $113,144,202,204,219,240-242,244$

Federal Aid System, 108-109, 113-114, 116, 125-126, $136,140-142,156,160-161,164-165,167,170$ (also see Roads)

Federal Highway Act 1921, 108-109, 113, 121, 126, $136,138,142,205-206,214,220,242,244,246$, $321,357-358$

Federal Highway Administration, 210, 219, 222, 226, $231,233,236-237,256,298,315,352,359$, et al.

Finance;

bonds, $41,73,89,101-102,114,137,151-152,163-173$, $239,243-244,247,248,252,256,282,431,470-471$;

Federal aid, 198-214, 220, 227-235, 240, 243, 245-247, 253-255, 259-260, 266-267, 270, 273, 282, 289, 431432,470 ;

State aid, 43-44, 50, 57, 64, 76, 155, 199-200, 239, 249,260

taxes, 37-39, 41-42, 50, 57, 74, 84, 114, 118, 122-125, $131,148,157,163-164,166-167,169-173,238,242$, $245,247,250-251,254-255,267,271,295,473$;

tolls, $7-11,14,18,20-23,30,116,136-137,164-167$, $169,244,271,290-291$

Forest Roads, (see Roads) 
Gallatin, Albert, 17

Good Roads Association (see Good Roads Movement)

Good Roads Movement, 41-44, 46-50, 57, 67, 75, 124

Good Roads Train, 48-50, 76

Grade Crossings, 125, 128-130, 136, 159, 165, 246-247, 393-394

Hayden-Cartwright Act of 1934, 124-125, 130, 134, $139,156-157,167,171,247,265,270,321$

Hewes, L. I., 489-491

Highway Access, (see Right-of-Way)

Highway Beautification Act 1965, 367-369

Highway Related Legislation, 546-547

Highway Research Board, (see Research)

Highway Revenue Act 1956, 174, 228, 254, 472-474

Highway Trust Fund, 173, 211, 227-230, 254-256, 262, $276,301,473-475,481$

Historic Preservation, 373-374

Holmes, Edward H., 283-286

Hubbard, Prevost, 117, 322

Inter-American Highway, 139-140, 150, 522-530

International Roads (see Roads)

Interstate (see Roads)

James, Edwin W., 73, 108, 110, 520, 526-527

King Drag Laws, 22

League of American Wheelmen, 42-43, 56, 76

Lincoln Highway Association, 83, 95, 109, 135

Long Distance Roads, (see Roads, Transcontinental)

Maintenance, (see Roads)

Mass Transit, 262, 301-302, 312

McAdam, John L., 12-13, 21, 52, 117-118

MacDonald, Thomas M., 103, 105-107, 108, 113, 114, $121,123,126,135-136,138,142,144,147-148,161$, $170,176-179,192,206-208,233,257,268,271$, $273-274,277,289,367,467,500,520$

Mount Vernon Memorial Highway, 134, 139, 394, 405

National Industrial Recovery Act of 1933, 125, 130, $139,156-157,246-247,493$

National Roads, (see Roads)

National Road, (or National Pike, Cumberland Road), $10,14,16-17,19,21-22,24,26,29,32,109,198-$ $199,201,273,382$

National Good Roads Association, 48-50, (also see Good Roads Movement)

Normann, O. K., 338-341

Object Lesson Roads, 45-48, 64-66, 72-75, 83, 320, 515-516 (also see Good Roads Movement)

Office of Public Roads, 37, 52, 62, 64-69, 72-76, 80, 82-84, 86-87, 89, 235, 240-241, 266, 367, 519

Office of Public Roads and Rural Engineering, 87, 9596, 100-101, 118, 204

Office of Public Road Inquiries, 46-50, 52, 88

Office of Road Inquiry, 44-46
Page, Logan W., 47, 52, 57, 64-65, 67, 72-76, 80, 82-83, $87,89,96,98,101-102,114,117,191,206,323,329$

Parkways, 56, 86, 133-134, 137-139, 154, 159-160, 163, 167-169, 368-369, 396-397, 507-512

Pioneer Freighter, 62, 83

Planning, 264, 265-271, 276-286, 294, 295, 299, 303, $304,306,316-319,351$

Pneumatic Tires, 42, 54, 119, 145, 384, 394, 454

Post Office Appropriation Act 1912, 84, 240

Post Office Appropriation Act 1913, 81, 201

Post Office Appropriation Act 1919, 102, 103, 107

Post Office Appropriation Act 1922, 108

Post Office Appropriation Act 1923, 206, 227

Post Roads, (see Roads)

Public Roads Administration, 142-145, 147-151, 156$158,160-162,165-166,168-169$

Railroads, 13, 14, 23-24, 26, 29-34, 36, 39, 44, 49-50, $76,84,90-93,97-99,113,117,127,145,150,154$, $250,257,259,420$

Registration, 57, 60, 109, 114, 123, 124, 126, 143, 146, $154,161,169,239-242,245,248,251,262,263$

Relocation, 363-365

Right-of-Way, 9，12，20-21，24，37，56-57，87，102, $114-115,117,126,132-137,139,149-150,152-153$, $159-160,163,165,168,199,249,294,354-365,473$

Remote Sensing, 326, 389, 394

Research, 208-210, 277, 320-352, 439

Road Signs, 61, 78, 109-110, 115, 130, 343, 404-410, 477

Roads;

construction, $2,9-13,24-25,37,39,45,47-48,50$, 56-57, 64-67, 87, 89, 98, 100, 104-106, 113-114, $117-118,121,137,147,161,171,324,325-329,332$, $333,335,385,388,394,395,444-464,495,498,519$;

defense, $18-19,24,26,30-31,62,94-100,138,142$ $153,166,241,249,267,275,357,468,469,513,514$, $524,525,531-536$;

Federal aid, 16-24, 26, 44, 47, 80-89, 98, 113-115, 143-147, 155, 157-160, 165-167, 169-173, 295, 296, $300,302,447-448,494,542-545$;

forests, $75,126,137-139,170,242,247,487-507$;

other nations', 139-140, 149-150, 152, 518-536, 539, 540 ;

Interstate, $83,96,102,107-110,116,136-137,152$ $153,156-159,165-166,168-174,211,213,228,230$, $243,249,252,254,256,259-260,263-264,271,273-$ $277,281-292,295-296,303,341,343,345,354,466-$ $485,543-544$;

maintenance, $6,8,12-15,20,30,36-37,41,43-44$, $47,65,68,78,80-81,83,93,95,98,105,118,134$, $147,161-163,165,249,330,331,336,444-464$;

national, 47, 62, 84-85, 95, 101-102, 106, 108, 137, 151, 153, 173;

post, $16,22-23,26,80-87,100-102,106,108,114,201-$ 202,240 ;

rural, $36-37,41,48,50,56-57,64,66,72,80-81$, $85-86,89,102,114-118,128,132,151-152,156-157$, 160-162, 238, 240-241, 262-264, 381-382, 384, 414, 415,468 ;

toll, 8-12, 14, 21, 36, 50, 117, 135-137, 142, 150-152, $165,171,247-248,252,256-257,263,272,274,294$, 466-467, 469 ; 
transcontinental, $62,83,85,101,107-109,113,136$, $138,152-153,272,277,498$;

urban, $34,39,41,47,56,66,103,125,135-136,151-$ $152,154,156-158,160,163,169-172,263$

\section{Safety (see Accidents)}

Settlements, 16, 26, 29, 32, 34

Signs (see Road Signs)

Shirley, Henry G., 106

State Aid (see Finance)

Statute Labor, 7, 10, 12, 36-37, 41, 238

Steamboats, $29-31$

Stone, Roy (General), 44-47, 83, 191, 206, 213, 444

Suburbs, 39, 133, 154

Taxes (see Finance)

Tiemann, Norbert T., 195

Trade, 10-12, 14, 18, 20, 24, 38-39, 44-45, 49, 57, 84-86, $98-100,102,115,121,126,166,247,257-259,274$
Tresaquet, J.P.M., 12, 13, 20, 52, 117

Trucking, 92-95, 97-99, 102, 114, 117-119, 122, 132, $137,145-147,163,169,171,241-242,248,250,257-$ $259,288,295$

Tunnels, 442

Turner, Francis C., 185-187, 195

Turnpikes, 8-16, 22-24, 29-31, 36, 136-137, 150-151, $159,166-169$

Turnpike Companies, 8-13, 15, 22-24, 36

Uniform Relocation Assistance \& Real Property Acquisitions Policy Act 1970, 211, 221, 363-364

Volpe, John A., 193

Wheelmen (see League of American Wheelmen)

Whitton, Rex M., 194

Zane's Trace, 16

מิ U.S. GOVERNMENT PRINTING OFFICE : $1977 \quad 0-230-457$ 





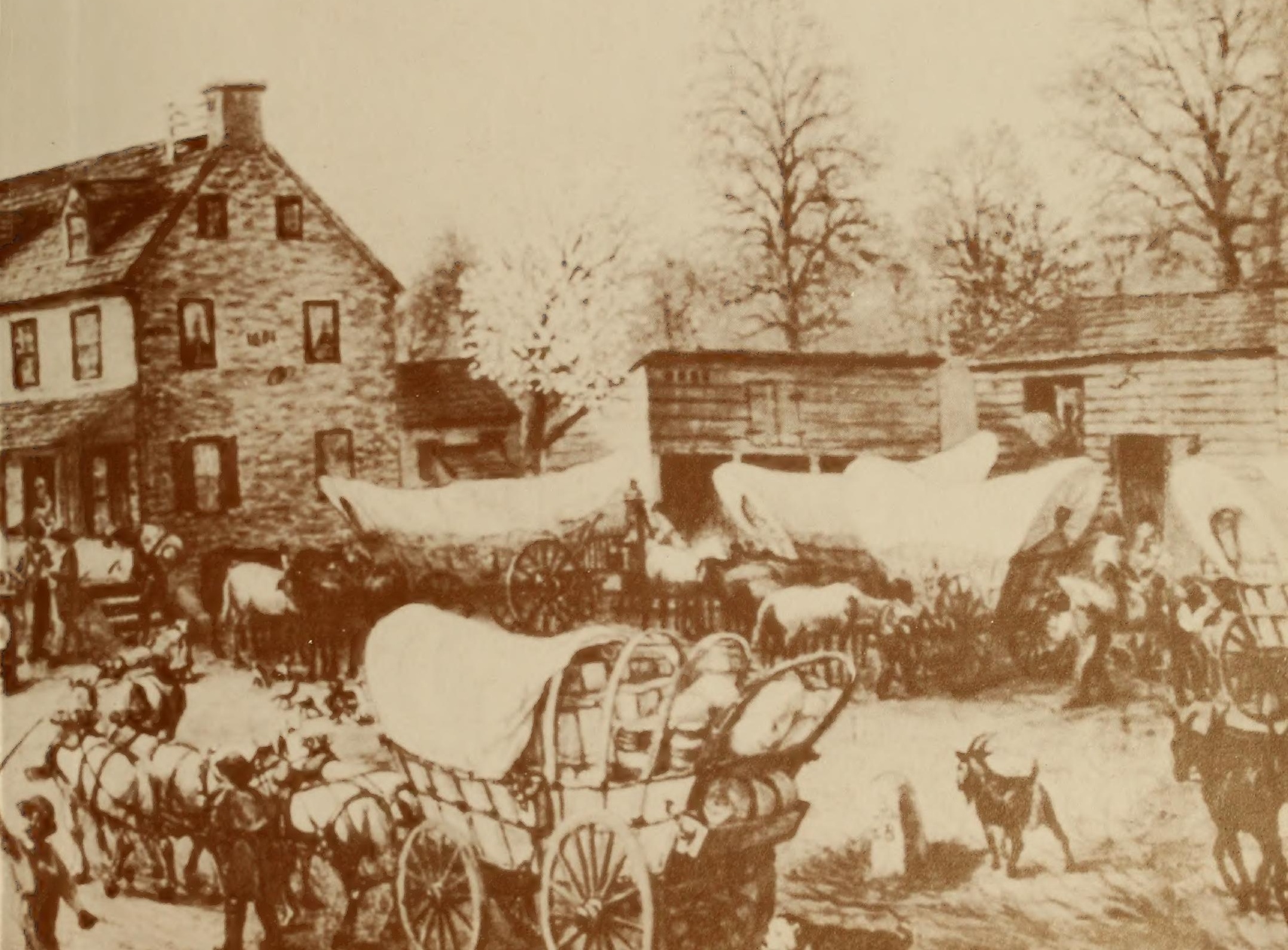


$\theta$ 